\title{
Meletij Smotryćkyj
}

\section{Hrammatiki slavenskija pravilnoe syntagma}

\section{Kirchenslavische Grammatik}

Verlag Otto Sagner München · Berlin · Washington D.C.

Digitalisiert im Rahmen der Kooperation mit dem DFG-Projekt „Digi20“

der Bayerischen Staatsbibliothek, München. OCR-Bearbeitung und Erstellung des eBooks durch den Verlag Otto Sagner:

http://verlag.kubon-sagner.de

() bei Verlag Otto Sagner. Eine Verwertung oder Weitergabe der Texte und Abbildungen, insbesondere durch Vervielfältigung, ist ohne vorherige schriftliche Genehmigung des Verlages unzulässig. 


\section{SPECIMINA PHILOLOGIAE SLAVICAE}

Herausgegeben von

Olexa Horbatsch und Gerd Freidhof

\section{Band 4}

\section{MELETIJ SMOTRYĆKYJ}

\section{HRAMMATIKI SLAVENSKIJA PRAVILNOE SYNTAGMA}

Jevje 1619

Kirchenslavische Grammatik

(Erstausgabe)

Herausgegeben und eingeleitet

$$
\text { von }
$$

Olexa Horbatsch

\section{FRANKFURT AM MAIN}

1974

Auslieferung:

KUBON \& SAGNER, Münctien 
0004758

1.7t (4

Bayerischo stantsbibliothek München 


\section{Die kirchenslavische Grammatik von M. Smotryckkyie}

\section{ihre Quellen und Auswirkungen.}

Als eines der bedeutendsten slavischen grammatischen Werke vor J.Dobrovskýs 'Institutiones linguae Slavicae'(Wien 1822) 1 ) bzw. vor M.V.Lomonosovs 'Россинская грамкатика' (Sankt-Petersburg $1755(1757 /)^{2)}$ wird mit Recht diexkirchenslavische Grammatik angesehen ${ }^{3)}$. Jedoch sowohl bezüglich des Brscheinungsortes (Wilna, Jevje bei Wilna) als auch des Erscheinungsjahres (1618, 1619) sowie der genauen Blätterzahl dieser Grammatik hat es unter Bibliographen verschiedene Meinungen gegeben ${ }^{4)}$; die Unterschiede wurden durch eine differenzierte Gestaltung des Titelblattes in den bislang zugänglichen und bekannt gewordenen BXemplare/der Grammatik hervorgerufen.

Das Problem der auftretenden Unterschiede bei der Angabe des Brscheinungs jahres und -ortes (Jevje 1618 $8^{5}$, 0.0 .1618 , Jevje $1619^{6)}$ ) löst H.Baumann ${ }^{7)}$ aufgrund des Vergleiches des Grammatikexemplars der Jenaer Universitätsbibliothek ${ }^{8)}$ mit den Bxemplaren der Nationalbibliothek Prag 9 ) sowie der Mikrofilmauszüge aus dem (Leningrader) Bxemplar der Bibliothek der Akademie der Wissenschaften der UdSSR und der mitgeteilten Angaben über das Grammatikexemplar der Wiener Osterreichischen Nationalbibliothek ${ }^{10)}$. Br stellt vier Typen dieser Grammatik fest:

1) mit dem Titelblatt, auf dem der Druckort Jevje und das Brscheinungsjahr 1619 stehen (auf der Ruckseite das Wappen des Fürsten Bohdan Oginskij), mit dem Vorwort (auf 3 Blättern) und mit dem anschliebenden zweiten Titelblatt, auf dem das Brscheinungsjahr 1618 ohne Erscheinungsort steht (mit einer unbedruckten Rückseite) - das Bxemplar der Jenaer UB ${ }^{11)}$

2) mit dem Titelblatt, worauf Jevie 1619 steht, einem Wappen auf der Rückseite, den 3 Blättern des Vorwortes, jedoch ohne die Wiederholung des zweiten Titelblattes - die Bxemplare: der Moskauer Lenin-Bibliothek ${ }^{22}$, der Wiener Osterreichischen Nationalbibliothek ${ }^{13}$ und der Krakauer Biblioteka Jagiellonska 14)

3) mit dem zweiten Titelblatt vorne (darauf 1618 und ohne Angabe des Brscheinungsortes unten) und dem anschliebenden Vor wort auf 3 Blättern - das Exemplar der Prager UB (Sign. UK.8. I.23) 15 ) 
4) mit dem zweiten Titelblatt $(\underline{1618}$ 0.0.) aber ohne das Vorwort - vermutlich das Exemplar, das V.M.Undol'skij beschrieben hat ${ }^{16)}$.

Unser Vergleich des Krakauer Bxemplars mit dem Moskauer hat ergeben, dab es noch weitere Varianten dieser Grammatik gibt. Auf Blatt 2290 (in unserem Abdruck S.231-32) wird in правило д. das Beispiel aus der Ostroher Bibel Ame хомепи,.. имвніА TEOA: (S.232, Zeilen 2-3) im Moskauer Grammatikexemplar der Lonin-Bibliothek nach dem Wort Сослагателному: vor anderen Beispielen (Ame ob вparb...) geführt. Unser Abdruck folgt hier dem Krakauer, Prager und Wiener Bxemplar. Da ich keinen Binblick in das Jenaer Exemplar bekommen durfte, kann ich nicht sagen, welcher es von den beiden Varianten angehört. Der Kustode Henpa auf Bl. 1700 (unser Abdruck,S.171) ist mit dem Kustoden Cocrg auf Bl. 168 (unser Abdruck,S.169) in allen drei uns zugänglichen Bxemplaren vertauscht worden. Möglicherweise könnten sich noch weitere Varianten des Buches herausstellen.

Man darf vermuten, daß das Exemplar Undol'skijs (der Typ 4) die früheste Fassung der Grammatik darstellt; die Variante des Typs 3 ist als eine weitere Form des Buches denkbar; die dritte Variante (der Typ 2) stellt eine endgültige Passung dar, auf deren Bögen noch einzelne Korrekturen vorgenommen wurden (eine Variante mit einer solchen Korrektur auf Bl. 1700 stellt das Moskauer Bxemplar dar). Der Typ 1 ist eine Kombination der Typen 2 und 3.

Das Vorwort zur Grammatik (Учителемъ школным' Авторъ: Д:С:и $\mathrm{T}: 3: 3$. ) schreibt M. Weingart zweifelsfrei Smotryćkyj zu (a.a. $0 .$, S.28 und 54), ungeachtet eines anderen Sprachstils als in der Grammatik selbst. Wir hatten hingegen die Vermutung geäuBert ${ }^{17)}$, dab es sich dabei vielleicht um einen anderen Autor oder sogar Autoren (vgl. die Initialien) handelt. Dieses Problem kann jedoch erst nach einem Vergleich der Sprache dieses Vorworts mit der Sprache anderer Schriften Smotryckyjs sowi€ mit den anderen damaligen Vorworttexten gelöst werden. Das darin entworfene Programm des Anfangsunterrichts erinnert 2 . T. an das der westlichen Schulen mit einem Brlernen der lateinischen voces - ähnlich etwa wie sie das Doctrinale (1199) von Alexander von Villa-Dei bietet ${ }^{18)}$.

Maksym (nach dem Bintritt ins Wilnaer Basilianerkloster 106 
Neletij) S m o t $r$ y ć $k$ y j, geboren um 1578 in Smotryč (Westpodolien) als Sohn des kleinadeligen Burgkanzlisten Herasym (später Lehrer und Polemist der Schule zu Ostrih), empfing den Anfangsunterricht in derselben Schule, studierte ab 1601 Philosophie an der Wilnaer Jesuitenakademie, hielt sich 1605-08 als Begleiter des jungen Fürsten Solomireckij an verschiedenen deutschen Universitäten (Breslau, Leipzig, Wittenberg, Nürnberg) auf. AnschlieBend unterrichtete er an der Wilnaer Bruderschaftsschule und verfaBte hier seine Grammatik. Sein Interesse galt nunmehr nur noch der Kirchenpolitik ${ }^{19)} .1633$ starb er in Dermań (Westwolhynien) 20 ).

Seine Grammatik wurde dem damaligen Niveau der lateinischen Grammatiklehre in Polen 21 ) und Deutschland 22 angepaßt. Hier stutzte sie sich auf die bereits bestehenden Grammatiken 'Adelphotes ${ }^{23)}$ und L.Zyzanijs ${ }^{24)}$, die von der traditionellen griechischen und lateinischen Grammatiklehre aus ins Kirchenslavische: fremde Kategorien einfuhrten. Sie enthielt vier Teile: Orthographie, in die man traditionsgemäß Phonetik miteinbezog, "Btymologie",d.h. Morphologie, Syntax mit Elementen der Stilistik und Prosodie (Verskunde). so wie sich Elemente dieser Teile seit den lateinischen grammatischen Traktaten von Diomedes (2.Hälfte des 4.Jns. n.Chr.) ${ }^{25}$ ), Aelius Donatus (4.Jh.) ${ }^{26}$ ) Pris-

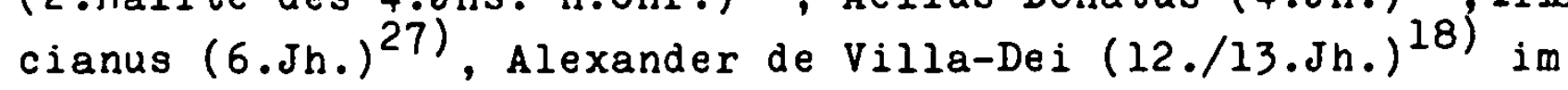
Mittelalter und bei den Humanisten (insb. bei Philipp Melanchthon ${ }^{28}$ ) 1497-1560) sowie Jesuiten (Bmanuel Alvarus-Alvarez') 1526-83) in den lateinischen Schulgrammatiken durchgesetzt hatten. Smotryckyjs Vorbilder bei der Behandlung des ksl. Materials hat am eingehendsten Jevstachij-Ostap Makaruška 30 ) untersucht. Außer den beiden heimischen Grammatiken (L'viv 1591, Wilna 1596) waren es vor allem: 'De octo partibus orationis. Grammatica Gracca'(Erstausgabe: Mediolani 1476) von C.Lascaris, 'Grammaticae Graecae cum Latina congruentis partes II'(ErstausGabe: Basileae 1566) von M.Crusius, 'Grammatica Latina' (Brstausgabe: Haganoae 152228), und 'Syntaxis' ${ }^{31)}$ (Brstausgabe: Hagenoae 1526) von Ph. Melanchthon, 'Ars grammatica' von Aelius Donatus 26$)$ sowie 'Grammaticarum institutionum libri III, 29) von E.Alvarez 32 ). Aus ihnen schöpfte Smotryćkyj allgemeine Do finitionen und Anregungen für die Stoffgliederung sowie manche Regeln. Dabei ist besonders zu beachten, inwieweit die 
westlichen Quellen indirekt oder über die beiden heirischen Grammatiken auf Smotryćkyj eingewirkt hatten.

M. Weingart (a.a.0.,S.21-22) hat diese Ausführungen Nakaruskas akzeptiert. $Z u$ den Quellen, deren Spuren in den Grammatiken aus den JJ. 1591 und 1596 zu beobachten sind, fügte er gen der Ubereinstimmungen in der grammatischen Terminologie noch die handschriftlichen Traktate hinzu: I) 0 осмихь частьх слова ${ }^{33)}$ und 2) Сказанїе извјавліснно о писменех von Konstantin von Kostenec 34 ) entstanden um 1418 35 ).

Unter den möglichen weiteren westlichen Vorbildern Smotryćkyjs wären fernerhin noch zu nennen: 1) die 'Ars grammatica' von Diomedes 25$)$ - insb. seine Ausführungen über die syntaktischstilistischen Figuren (De metaplasmis), 2) das 'Doctrinale' von Alexander de Villa-Dei ${ }^{18}$ ) - insb. bei der Behandlung der Wortfolge ( 0 чинь грамматичесть, S. 233-34), 3) die lateinische Grammatik von Jan Ursin jr.'Methodicae grammaticae libri IV' (nach Linacer), Leopoli 1592 (Cytowska,M.,a.a.0.,S.7781) - insb. seine Binteilung der syntax in syrtaxis regularis

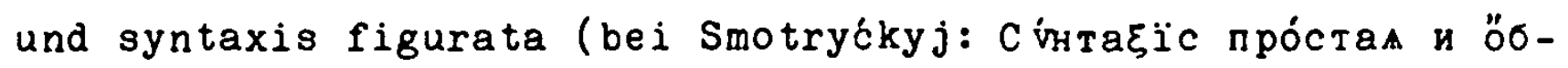
разнал, S.191), 4) die slovenische Grummatik 'Arcticae horulae', Wittenberg $1584^{36}$ ), vor allem als Vorbild einer konsequent durchgeführten verbalen femininen Dualendung (-ve, $\frac{-t e}{37}$ bei A.Bohorič, $-B$ b, $-T$ bei Smotryckyj). Laut L. Tesnière sind im Slovenischen solche verbale fexinine Dualendungen vor wiegend im Süden und Osten (Unterkrain, Oststeiermark) verbreitet und kommen auch bei P.Trubar (duei bote mleili) und J.Dalmatin vor (dvej bodete mlejle). Solche Formen treten selten in bezug auf ein feminines oder neutrales Subjekt im Dual auch in Altkirchenslavischen auf - jedoch nur in der 2 . und 3. Ps. Dualis 38). Bs ist jedoch wenig wahrscheinlich, dab Smctryckyj gerade von dorther und nicht aus einem grammatischen Werk, dem er auf seiner Studienreise durch Deutschland begegnen konnte, die Idee der Differenzierung der grammatischen Genusunter schiede im Dual entlehnt hätte.

Hinsichtlich der Reihenfolge der behandelten Redeteile hit t sich Smotryćkyj an die Reihenfolge der Grammatik von Diomedes bzw. Melanchthon (nomen, pronomen, verbum, participium, adverbium, praepositio, conjunctio, interjectio) und wich somit von der Reihenfolge der Grammatiken 'Adelphotes' und Zyzanijs ab, 
die unter dem BinfluB der griechischen Grammatik von C.Lascaris eine andere Binordnung der Redeteile einführten (articulus, nomen, pronomen, verbum - mit Partizipien innerhalb der jeweiligen Konjugationen und Genera,- praepositio, adverbium, conjunctio) 39 )

Nach der Art der damaligen lateinischen und griechischen Grammatiken führte smotryckyj ein relativ reichhaltiges illus tratives Wortmaterial an. Verglichen jedoch mit der 'Adelphotes'-Grammatik (1591) hat er dabei deutliche Korrekturen durchgeführt, obwohl er aus ihr sowie aus der Grammatik zyzanijs manches Beispiel übernommen hat:

1) allzu 'vulgäre' Beispiele (BOmz 'Laus'), die in der 'Adelphotes'-Grammatik durch ihre griechische Vorlage (die Grammatik von C.Lascaris) bedingt sein durften, sowie die mundartlichen Bntsprechungen der griechischen Dialektformen wurden weggelassen,

2) in einem viel stärkeren Ausmaß wurden bei Substantiven und Adjektiven griechische und lateinische Namen eingefürt (in der 'Adelphotes'-Grammatik wurden sie entsprechend der Lascaris-Vorlage gehalten); dabei sind auch gewisse Korrekturen zu vermerken: a) entsprechend der westlichen humanistischen Mode fuhrte Smotryckyj bei Substantiven hybride griechisch-kir chenslavische (çитаціс, коіновіон, імармени, Віас, Артеміс) bzw. lateinisch-kirchenslavische Paradigmen ein (aviópirac) mit verschiedenen stammesformen und mit ihren ursprünglichen Kasusendungen (c снтақеос, Віанта, avторітати); in Ubereinstimmung mit dieser Tendenz beseitigte er die slavisierten griechischen Namenformen (Jита̇ in 'Adelph.'-Gr.,S.42 - Jитw bei Smotr.,S. 256, 30); andererseits wurde die griechische Ortsm-

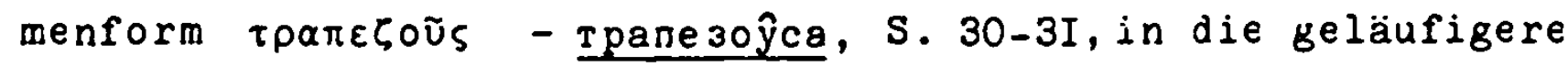
Tpane зу́нтъ, S. 500, von Smotryćkyj umgeändert; b) in der Aussprache und Schreibweise griechischer Namen ist Smotryckyj won der lateinischen bereits eingebürgerten Tradition abgewichen und zu griechischen Ursprungsformen zurückgekehrt (vgl. Димосте́нъ, 'Adelph.',S. 37 - Димосэе́нъ, Smotr.,S. 505),

3) Polonismen der ukrainisch-weiBrussischen Umgangssprache, die sich auf das damalige adelig-bürgerliche Gesellschaftsleben tezogen, wurden unter entsprechenden kirchenslavischen Beispielen genannt (nахӧлї, 70, каштела́на, ста́ростанна, 26); 
ebenso wurden die 'heidnischen' (--азыческіе) bekannten Städtenamen der Dolnischen Adelsrepublik berücksichtigt (Вилно,I60, Iвов 26, Kiев, Краков 232); die heimatlichen Ländernamen wurden in gräzisierten bzw. latinisierten Formen angegeben ( Jïa Bia, 36, Poccia, Jexïa 260).

Zahlreich sind Smotryćkyjs Beispiele in bezug auf die jeweils behandelten Fragen der Rechtschreibung und insbesondere der Morphologie und Syntax. Seine syntaktischen Ausführungen werden öfters mit kirchenslavischen Beispielen illustriert, zu denen $a b$ und $z u$ griechische Parallelen angefüht werden. $2 u$ drei Vierteln handelt es sich dabei um kirchenslavische 2 itate aus der Bibel von $0 \operatorname{trih}^{40)}$ (vgl. S. 258-60) bzw. um 2 itate aus ostkirchlichen Gebeten (Под твоі к. (Marien-Heirmos der Fastensonntage: 0 тебі́ pányer'c4..., 2I26), Troparien und Sticheren. Selten sind es kurze frei erfundene Schulübungssätze (vgl. S.232).

Den Bibeltext zitiert Smotryckyj nicht selten frei mit Kürzungen, Binschübseln und Veränderungen (gegenüber der Bibel von Ostrih), die sich auf Rechtschreibung, Betonung, Morphologie und Syntax beziehen ${ }^{41}$ ). Br paßt ihn überall seinen in der Grammatik festgelegten Rechtschreibungsregeln an. Den Wortakzent verändert er im Sinne der geläufigen damaligen ukrainischen Tradition ${ }^{42)}$; morphologische Endungen korrigiert er entsprechend den Normen seiner Grammatik ${ }^{43}$; er führt das Pronomen exe bei Infinitiven mit Finalsatzfunktionen als eine kirchenslavische Bntsprechung des griechischen Artikels ein ${ }^{44}$, er verändert einzelne Ausdrücke im Text der Bibel von Ostrih, da sie ihm vermutlich aus lokaler kirchlicher Tradition nicht geläufig waren ${ }^{45)}$. Möglicherweise stützten sich seine Korrekturen der Bibel von Ostrih auf eine Kritik der Sprache und des Bibeltextes des Lehrerkreises der Schule von Ostrih, die Smotryckyj besucht hatte. Biner Art Textkritik unterzog diesalbe Bibel auch der damalige ukrainische Lexikograph Pamvo Beryn$\mathrm{da}^{46}$. Finer eingehenden Analyse der Veränderungen des OstrihBibeltextes in der Grammatik Smotryckyjs werde ich anderswo noch einen Aufsatz widmen.

Hervorzuheben ist noch, daß Smotryćkyjs griechische Bibelzitate dem griechischen Codex Sinaiticus (N) sowie der gedruckten Version $S$ (R.Stephani editio tertia,'regia', 'textus 
receptus', Paris 1550) entsprechen ${ }^{47)}$; manchmal tritt dabei die neugriechische Aussprache hervor ${ }^{48}$ ).

In den fehlerhaften nichtetymologischen Schreibungen, die im Grammatiktext auftreten, spiegelt sich die ukrainische (podolisch-wolhynische) Mundart Smotryćkyjs (bzw. der Jevjeer weibrussischen Setzer) wider: ${ }^{49)}$

1) der ukrainische Zusammenfall der etymologischen $\underline{i} l \underline{y}=\underline{y}$ (nach $\underline{\underline{r}}, \underline{e}$ auch weiBrussisch): неácить $22 / /$ неácuтb 230 , тйсаща

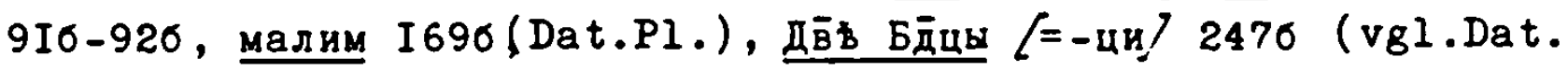
Sg. пїаници 336), вто́римъ I8, рич10 I406// рычю́ I520, ри́бв 2136 , рида́юща 219 , оукриял 230 ;

2) der nordukrainische Zusammenfall der unbetonten $\underline{\underline{\alpha}} \underline{\mathrm{e}}=\underline{\mathrm{e}}$ (in betonten und unbetonten Positionen auch weibrussisch): из-

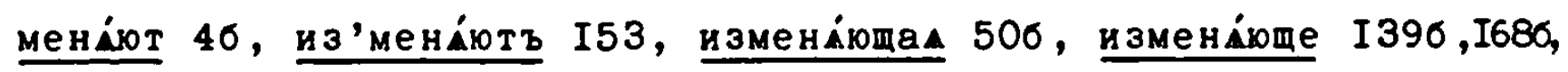
премендотъ $200 / /$ премвне́ну I90, целбу̀ I98, ценюे 2I00, разреша́eI'cA 2I6; weitere Pälle (бerý, rpexb statt бbrỳ, rpbxb 246, rbrecà statt rerecà 246) werden unter den Beispielen für Bktasis und Systole genannt;

3) der nordukrainische Zusammenfall der unbetonten etymologischen $\underline{e l e}=\underline{e}$ : кла́дезь 600 , иглено 2240 ;

4) der ukr. ostpodolisch-wolhynisch-Poliśsaer (und SW-weiB-

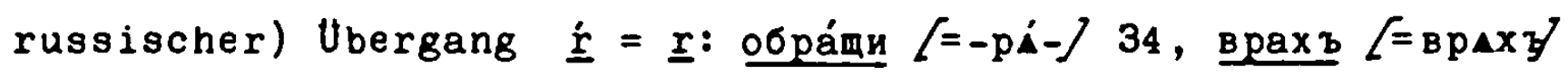
I520; weitere Fälle ( баграни́д $s$ tatt -pa-,246, npa statt npa 2460) werden unter den Beispielen für Systole und Blleipsis geführt;

5) die so-ukr., südpodolisch-Pokut'taer Analogieendungen der 1.Sg.Präs. vom Typ Гнвздю I20, дохдю I720, слезю I20, I520, I720;

6) die Pokuttaer Analogieendungen der 1.Sg.Präs. ohne die 1-Fpenthese: гримо I20,I526,I726, дымі I520, ломю I526, мертвю́ I20, мо́лвю I720, пла́вю I520, скорбюо I20, сла́вю I530, спю I520, терпі் I720, ஐyкí I53;

7) die wolhynisch-podolischen Analogieendungen der passiven Partizipien Prät. vom Typ TBÓpaнuh I506;

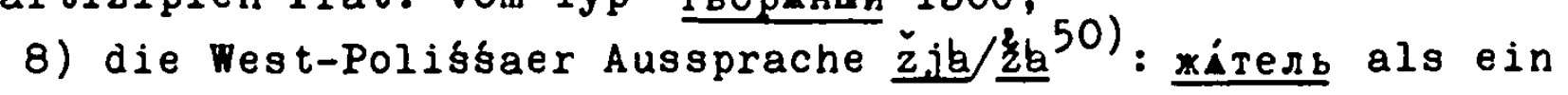
Beispiel für Parenthesis;

9) die ukr. (und weibruss.) mundartliche Verwechslung von xv $\underline{f}$ (хворма, фала 9$)$, die Smotryćkyj bekämpfte ${ }^{51)}$.

Die bei Zyzanij (vgl. unsere Anmerkung 24, S.89-90) allgemein formulierten Grundsätze des Versbaus (nach griechischen 


\section{- VIII -}

Vorbildern) erweiterte Smotryckyj (vermutlich aufgrund der lateinischen Grammatiken von Diomedes und Donatus) um konkrete Beispiele der kirchenslavischen metrischen Verse, die er selber zusammengestellt hatte. Seine Gramatik - eine Art kirchenslavische 'ars major' - wurde 20 Jahre später in Kremjaneć 1538 in gekurzter Form (als eine kirchenslavische 'ars minor') gedruckt und im wesentlichen nur auf Definitionen und Hauptparadigmen begrenzt. Der anonyme Verfasser dieser Kürzung - manvermutet, daß es der Bischof von Lućk Afanasij Puzyna war ${ }^{52)}$ wande sich jedoch in bezug auf die kirchenslavische Metrik von dem Weg Smotryćkyjs ab und hob vorsichtig das Prinzip des polnisch-lateinischen Syllabismus bzw. der Syllabotonik als den geeigneten Weg für den kirchenslavischen Versbau hervor ${ }^{53}$ ).

AuBer den bereits zitierten kritischen Analysen der Brstausgabo der Grammatik Smotryćkyjs (von Je.Nakaruška, M.Weingart ${ }^{54}$ ) u.a.) wäre noch als eine der ersten die Abhandlung von N.Zasadkevič55) zu erwähnen.

Von dem breiten Fcho, das die Grammatik Smotryćkyjs bei Ostund Südslaven sowie bei Rumänen und im Westen bei den Gelehrten, die sich für Kirchenslavisch und Russisch interessierten, gefunden hat, zeugen ihre Abdrucke, Kopien, Ubersetzungen und Umarbeitungen, die in Binzelfällen verspätet bis in die 1.Häfte des 19.Jhs. reichen.

Mit Recht zweifelte M. Weingart (a.a.0.,S. 55, Anmerkung 44) an der Bxistenz einer Ausgabe der Grammatik Smotryckyjs aus dem J. $1629^{56)}$.

Den EinfluB der Grammatik Smotryćkyjs erkennt man an der Binführung der zwei Konjugationen in der Zweitfassung der lateinischsprachigen ukrainischen handschriftlichen Grammatik (1645) von Ivan Uževyč 57 ).

In RuBland wurde die Jevjeer Ausgabe (1619) mit gewissen Är derungen der Deklinatione- und Konjugationsendungen noch vor 1648 abgeschrieben. Bine solche Kopie befand sich 1907 in der Bibliothek des Gerbovec-Klosters (westlich von Bendery) in Bessarabien und wurde von Vasilij Kurdinovskij beschrieben ${ }^{58)}$.

Smotryckyjs Grammatik wurde 1648 in Moskau ohne den Namen des Verfassers, mit einem Traktat von Maksim Grek im Vorwort, mit Veränderungen in der Rechtschreibung und Betonung als auch in der Auffassung von den acht Redeteilen (statt Interjektion 
wwieder Artikel als ein Redeteil im Sinne der griechischen Traddition und der Grammatik L.Zyzanijs), mit russifizierten Dekklinations- und gewissen Konjugationsendungen, mit heiligennnamendeutungen (aus dem Lexikon von P.Berynda $1627^{l}$ ), mit der ggrammatischen Analyse eines Ubungssatzes sowie zweier Gebete

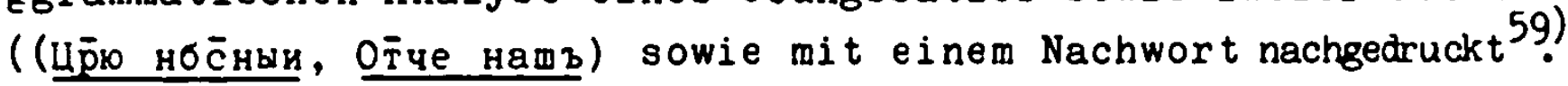

Dieser Grammatikausgabe bediente sich vermutlich der deutsche VVerfasser der 'Grammatica Russica' (Oxford 1696) Heinrich Wilhhelm Ludolf ${ }^{60)}$.

Auf die Moskauer Grammatikausgabe stutzte sich in seiner - Manductio in Grammaticam in Sclavonico Rosseanam seu Moscovitticam' (Stolzenberg bei Danzig 1706) der weiBrussische kalvinnistische Emigrant in Amsterdam Flias Kopijewitz-Il'ja Kopijjevskij61).

Aus der Moskauer Grammatikfassung wurden handschriftliche llateinische Ubersetzungen hergestellt: 1) eine interlineare kbzw. Marginalübersetzung im Bxemplar, das heute in Moskau (aus dder Schule des deutschen Pastors Glück) und im Bxemplar, das theute in der Universitätsbibliothek Halle aufbewahrt wird, 62 ) 22) eine Marginalubersetzung des schwedischen Polyglotten und IDiplomaten J.G. Sparfvenfeldt (1655-1727) heute in Uppsala 63) 33) ein vom Drucktext unabhängiges handschriftliches Grammatikfragment (Rechtschreibung und ein Teil der 'Btymologie') des SStockholmer Staatsarchivs, - das vermutlich aus dem J. 1702 vom kköniglichen Russisch-Dolmetscher Bnok Lillienmarck stammt 64 )

Die Moskauer Grammatikausgabe diente als Quelle für das kircchenslavisch-russische Alphabet- und Paradigmenkompendium 'Bxeemplar characteris Moscovitico-Ruthenici duplicis Biblici et uusualis: (NeiBe/Schlesien 1690) des čechischen Jesuiten Jiři IDavid 65 ).

Die Jevjeer Grammatikausgabe wiederholte mit einem verändert ten und ergänzten Vorwort sowie mit paralleler Zulassung genwisser russischer morphologischer Besonderheiten Feodor Polikarpov-Orlov (Moskau 1721) 66).

Zu der Grammatikausgabe Polikarpovs hat der englische Pasttor Thomas Consett 1727 eine handschriftliche lateinische Uberssetzung angefertigt (heute im Nationalmuseum in Prag), die er dder Berliner Akademie der Wissenschaften zum Druck erfolglos a anbot 67 . 
Aufgrund der Ausgabe Polikarpovs (unter den acht Redeteilen befindet sich auch Interjektion!) stellte der Schüler der Nov goroder Schule Hypodiakon Feodor Maksimov seine 'Граммaтíka славе́нскаа въ кра́ти́ собра́ннаяа' (SPb. 1723) zusammen ${ }^{68)}$.

Auf Smotryćkyjs Grammatik stützten sich z.T. Vasilij B.Adodurov (1709-80) in seinen 'Anfangsgründen der russischen Sprche'(SPb. 1731 69) und Nichail v. Lomonosov (1711-65) in seiner 'Россінская грамматика'(SPb. 1755/1757/) 2)

Aufgrund der Grammatik Smotryćkyjs verfaBte Apollos-Bajbakov Andrej seine 'Грамматика, руководствующая к познанию славено-россияского языка' (Kіеw 1794) 70$)$.

Bedeutend war die Auswirkung der Grammatik Smotryckyjs in den rumänischen Ländern. Die Jevjeer Brstfassung druckte (chne Namen des Verfassers, mit dem Wappen des walachischen Wojewoden Konstantin Basarab sowie mit einer Würdigung des Wojewoden in einem Sechszeiler und im eigenen Vorwort) der in die Walachei zugewanderte georgische Mönch Anfim Tipograf (Antim Ivireanu) in Snagóv $(0.0 ., 1697)$ ab. Das Kišinever Exemplar dieser Ausgabe beschrieb Vasilij Kurdinovskij71). Bingehender wurde diese Ausgabe (nach dem Bxemplar der Bibliothek der Rumänischen Akademie der Wissenschaften in Bukarest) von Diomid Strungaru besprochen ${ }^{72}$ ).

Dieselbe Jevjeer Grammatikausgabe wurde im walachischen Tirgoviste 1655 vom Priestermönch Stefan aus Loved abgeschrieben (vermutlich eine Abschrift seiner Kopie wird im bulgarischen Lom aufbewahrt) ${ }^{73)}$.

Die Polikarpov-Ausgabe der Grammatik druckte der serbische Erzbischof von Karlovci Pavle Nenadović (1699-1768) im walachischen Rimnicul-Vilcea nit gewissen Änderungen des Vorworts $1755 a b^{74)}$.

Von den acht kirchenslavischen handschriftlichen Grammatiken (bzw. ihren Teilen) der Klosterbibliothek zu Neamt aus den 1770er JJ. erweisen sich die meisten als direkte Kopien der Snagover Ausgabe, andere wiederum als auf Smotryćkyj gestützte Umarbeitungen (insb.'O етvмологи', переписаль іеромонах в

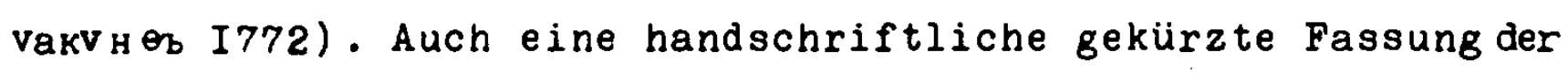
griechisch-kirchenslavischen 'Adelphotes'-Grammatik befindet sich ebendort 75$)$. Ihnen widmen wir eine Abhandlung demnächst.

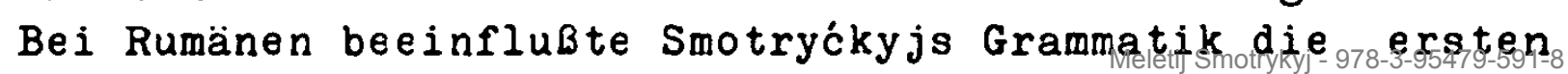


handschriftlichen Grammatiken des Rumänischen: 1) die 'Grammaticà rumineascà' von Dimitrie Bustatie Brasoveanul (Hs. Nr. 583 in der Bibliothek der Rumänischen Ak.d.Wiss.) aus dem J. 1757 (gestützt auf die Snagóver Ausgabe), 2) die 'Grammatică rumineasca' des moldauischen Priestermönchs Macarie Dragomirneanul (Hs. Nr. 102 in der Bibliothek der Rumänischen Ak. d. Wiss.) aus den JJ. 1770-74 (gestuitzt auf die Moskauer Ausgabe 1648). Da sich diese rumänischen Grammatiker auf dasselbe kirchenslavische Vorbild stützten, ist die alte rumänische grammatische Terminologie in der Walachei, Moldau und in Siebenbürgen identisch geworden ${ }^{76}$ ).

Zu den Serben wurde Smotryckyjs Grammatik (in der Ausgabe Polikarpovs) 1726 vom Vojvodinaer russischen Lehrer Maksim Suvorov in 100 Exemplaren gebracht ${ }^{77)}$. Auf Smotryckyj stützten sich in ihren Grammatiken, die für serbische Schulen bestimmt waren: Stefan Vujanovski (um 1743-1829) 'Руково́дство ко правоглаго́ланїо и правописа́нїо (Wien 1793 1,2 , 78) und Avram Mrazović in 'Руково́дство къ славе́нсть грамкаті́д' (Wien $1794^{l}$, Buda $\left.1800^{2}, 3,1811^{4}, 1821,1834\right)^{79)}$ und in 'Руководство къ славенскому правочтенїо и правописанін (Wien $1792^{2}$, Buda $1797^{2}, 1800^{3}$, $\left.1806^{4}\right)^{80)}$ sowie Georgije Zaharijadis in 'Руководство къ славенскон грамматіuв:' (Buda 1830) 81 ) und in 'Славенска грамати$\mathrm{ka} \cdot\left(\right.$ Buda 1832) ${ }^{82)}$. Bine bulgarische handschriftliche Kopie (aus der Mitte des 19.Jhs.) der Grammatik Mrazovićs aus dem J. 1834 beschreibt B.Conev ${ }^{83)}$.

Aus Bulgarien sind bislang einige Kopien der Grammatik Smotryćkyjs aus dem 17.-19.Jh. bekannt: 1) die bereits erwähnte Abschrift des Priestermönchs Stefan aus Loveč, die sich in den 1850er JJ. in den Händen von G.Rakovski und in den 1870er JJ. im Besitz des Lehrers von Lom Nikola Pbrvanov befand ${ }^{73}$ ), 2) eine unkomplette Abschrift (eines Teiles der Morphologie nach der Polikarpov-Ausgabe) aus der 1.Hälfte des 18.Jhs. (ab 1953 in der Bibliothek der Synode der Bulgarischen Orthodoxen Kirche, Sign. 120/1953184), 3) Abschriften der Grammatik Smotryćkyjs sind vermutlich die von B.Conev ${ }^{85)}$ beschriebenen kirchenslavischen Grammatiken der Bibliothek der Bulgarischen Akademie der Wissenschaften und der Nationalbibliothek in Sofia: a) abgeschrieben vom Lehrer N.Michajlovski 1834 in Blona aus einem unbekannten Original, das der Rimniker Ausgabe 
(1755) nahestand und vermutlich von einem A thosmönch nach Blena fur die Ortsklosterschule mitgebracht wurde, b) drei kirchenslavische Grammatiken aus dem J. 1837 aus Ljaskovica ( $\mathrm{Nr}$. 378,379 und 380 in der Nationalbibliothek $2 u$ Sofia) ${ }^{86)}$,

4) eine weitere Abschrift der Grammatik Smotryckyjs aus der Bibliothek 'Iskra' in Kazanlbk erwähnt N.Dilevski ${ }^{87)}$.

Die Smotryckyj-Ausgabe von 1755 (sowie die Umarbeitung von A.Mrazovic und die 'Institutiones...' von J.Dobrovský in der russischen Ubersetzung) benutzte Neofit Rilski ${ }^{88}$ ) bei der $2 u-$ sammenstellung seiner 'Болгарска грамматика'(Kragujevac 183599) Der Grammatik Smotryćkyjs bediente sich auch der Verfasser der 'Грамматика славено-болгарска' (Budapest $1836^{1}, 1845^{2}$ ) Christaki Pavlovič Dupčanin ${ }^{90)}$. Auch in der Umarbeitung von A.Mrazovic wirkte die Grammatik Smotryćkyjs bei den Bulgaren weiter fort. So vermerkt V.Pogorelov ${ }^{91)}$ den BinfluB Mrazovićs auf die 'Писменница на Славянскін-а язнкъ'(Beograd I847) von I van N.Namčilovič Blenčanin.

Binen tiefgreifenden Binfluß übte Smotryckyjs Grammatik von 1619 auf die Normierung der Schriftsprache bei den kroatischen katholischen Glagolitern Dalmatiens aus. Unter dem BinfluB dieser Grammatik und der unierten Ukrainer (Metodij Terleckyjs $u$. a.) korrigierte der kroatische Franziskaner Rafael Levaković (um 1597- um 1649) die Sprache der glagolitischen kirchlichen Drucke in Rom im Geiste ihrer Annäherung an die damalige ukrainisch-weiBrussische Variante des Kirchenslavischen ${ }^{92)}$. Sein Werk setzten im gleichen Geiste Josip Pastrić93) und Matej Karaman (1700-71) ${ }^{94}$ fort. Karamans Altersgenosse und Protegé Matej Sović (um 1700-1774) half inm in Rom bei der ostslavisierten Herausgabe des glagolitischen Missale von 1741; als Lehrer für Kirchenslavisch im römischen Kollegium der Kongregation de propaganda fide ubersetzte er ins Latein (mit gewissen Korrekturen) die Jevjeer Ausgabe der Grammatik Smotryckyjs 'Grammatica Slavonica Meletii Smotriski...', die heute in der UB in Ijubljana (Hs. Nr. 185.1I.C.a/2) aufbewahrt wird95).

Bin Nachdruck der Jevjeer Ausgabe der Grammatik Smotryćkyjs erscheint uns dringend aktuell aus triftigen Gründen: Ihre Fxemplare sind sehr selten ${ }^{96)}$, ihr Bcho - in Form von Abschriften und Umarbeitungen - sehr breit. 
Beim Abdruck wurden die von mir hinzugefügten Ergänzungen und Korrekturen sowie die Pagination in eckige bzw. schräge, die gedruckten aber Randvermerke Smotryckyjs (mit Quellenverweisen) in runde Klammern gesetzt. Die Schriftsatzunterschiede sowie besondere Formen mancher Buchstaben $(\underline{i}, \underline{y}, \underline{3})$ des Originals konnten nicht berücksichtigt werden.

Olexa Horbatsch 
A $n$ m e r k u $n g \in n$

1) We i $n g$ a $r$ t, M.: Dobrovského Institutiones, na vděčnou pamèt jejich stoletého jubilea, I. Cirkevněslovanské mluvnice pr̆ed Dobrovským, II. Rozbor Institucl, Sbornlk Filosofické fakulty University Komenského $v$ Bratislavê, $r$. I, E. 16; r.III, c.38 (12), Bratislava I923-25.

2) 'Rossijskaja grammatika' von M.V.Lomonosov erschien mit dem antedatierten Brscheinungsjahr ' $1755^{\prime}$ tatsächlich erst 17b7.- Vgl. M а к е в a, B. Н.: Истерия создания 'Pоссияскор гояматики' M.B.Ломонесева, Москва-Ленинград I96I, S. 3 und $53-54 .-$ In der Besprechung meiner Abhand lung - Die vier Ausgaben der kirchenslavischen Grammatik von $M$. Smotryćkyj'(Wiesbaden 1964) in Slovo (Zagreb 1964), Bd.14, S. 157, wirft mir B. He r c i g o j a u.a. bei der Datierung ' 1757 ' einen Fehler vor: ' kod O.H. greskom: 1757)' Bs tut mir leid, aber eine 'greska' liegt nicht bei m i r vor... Vgl. noch $J \circ M \circ H \circ c \circ B, M . B .:$ Полное собрание сочинений, т.7: Труды пс филолсгии I739-58 гг., Москга-Jенинград I952, S. 389-578.

3) Бу ли ч, С.К.: Очерк история языкознания в Россия, Т. I.

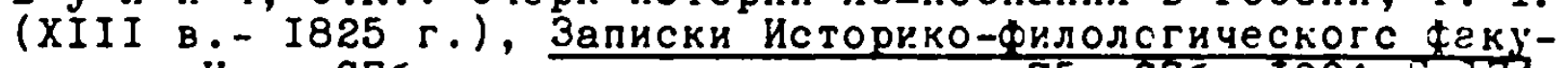
льтета Имп. СПб-ского университета, 4.75, СПб. $1904,5.174-$ -79; я гич, И.В.: История славянской филологии, СПб. I9IO, Nachdruck Leipzig 1967, S. 28-32 u. 908.

4) К а р а т а е в, И.П.: Описание славяно-русских книг напечатанных кирилловскими буквами, т.I: c I49I по I652, Сборник Отделения русского языка и словесности Имп. Акаде-

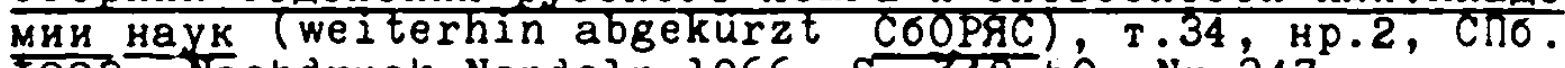
I883, Nachdruck Nendeln 1966, S. 349-50, Nr.247.

5) у н д о $л$ ь ски и, В.М.: Очерк славяно-русской биолиография, с дополнениями А.Ф.Бычксва и А.Викторсва, Москва

6) K а p а т а е в, И.П., а.а.0., S.349, Nr.247.

7) B a $u$ m a $n$, H.: Das Erscheinungsjahr der 'Slawischen Grammatik' M. Smotrickijs, Zeitschrift fur Slawistik (weiterhin $\underline{2 \mathrm{fSl}}$ ), Jg.III, 5, Berlin 1958, S.682-85.

8) B a u m a $n$ n, H.: Slavica in der Universitätsbibliothek Jena: Die 'Slawische Grammatik' des Meletij Smotrickij vor. Jahre 1619, Wissenschaftliche Zeitschrift der Fr.SchillerUniversität Jena, Jg.VI, Jena 1956/37, Gesellschafts- und sprachwissenschaftliche Reihe, $\mathrm{H} .1 / 2, \mathrm{~S} .63-67$.

9) Bbendort, S. 66, Anmerkung 7 .

10) Ebendort, S. 66 , Anmerkung 7 .

11) Laut Beschreibung von $B$ a $u m$ a $n$, H. (vgl. unsere Anmerkung 8); meine briefliche Bitte vom 2l.12.1973 an die UB Jena um einen Mikrofilm oder Fotokopien aus den ersten diesbezuglichen Seiten des Jenaer Grammatikexemplars blieb unbeantwortet.- $\mathrm{E}$ a $u \mathrm{~m}$ a $n \mathrm{n} H$. (vgl. unsere Anmerkung 7, a.a.0., S.683-84) fand das Jenaer Bxemplar (ausgenommen die Unterschiede zwischen dem Typ l und 3) identisch mit dem Prager, das er eingesehen hat. 
112) Der Mikrofilm wurde mir von Herrn Doz.Dr. G.Freidhof freundicherweise zur Verfugung gestellt.

113) Xerokopien entsprechender Seiten verdanke ich der Osterreichischen Nationalbibliothek in Wien.

114) Fotokopien davon verdanke ich Herrn Prof.Dr. P.Zwoliński. Das Titelblatt dieses Exemplars ist samt Vorwort entweder genauestens kopiert oder neu gesetzt worden.

115) Bin Nikrofilm daraus ist mir freundicherweise in Prag angefertigt worden.

116) Vgl. unsere Anmerkung $b$.

117) $H \circ r$ b a $t$ s $c h$, 0 .: Die vier Ausgaben der kirchenslavischen Grammatik von M.Smotryćkyj, Frankfurter Abhandlungen zur Slavistik, Bd.7, Wiesbaden 1964, S. 11 .

118) $R$ e $i c h l$ i $n$ g, D.: Das Doctrinale des Alexander de Villa-Dei. Kritisch-exegetische Ausgabe mit Binleitung, Verzeichnis der Handschriften und Drucke nebst Registern, Monumenta Germaniae Paedagogica, Bd.12, Berlin 1893, Neudruck Leipzig /um 1938/,S. XXXV.

119) N.W e i $n g$ a $r$ t, a.a.0.,S.54, schreibt Smotryckyj auch noch die Abfassung der in Wilna 1621 unter dem Titel

Грамматикв Ал'бо, сложеніе Писмена, хотАщимъса оучити Словеньскато јазька. Млодольтным Отрочатомъ. В Вилни,Року $\bar{a} \bar{x} \bar{\varepsilon}$. (Каратаев, И.П.: Описание...,S.36ל-66,Nr.269) herausgegebenen Schulfibel zu. J.Dobrovský (Institutiones.... Praefatio, S.LVIII, - laut M.Weingart,a.a.0., S.54) fuhrt sic mit dem Brscheinungsjahr 1618 nach dem Exemplar der Oxforder Bodleian Library an.- $\overline{D i e s e}$ Hypothese von $M$. Weingart, die sich nur auf die Bmpfehlung einer Anfängerfibel im Vorwort zu Smotryckyjs Grammatik stützt, könnte erst nach einer vergleichenden Untersuchung früherer und späterer ksl. Schulfibeln (Liviv 1574, Wilna 1596, Mahiloü 1636) angenommen werden. Die Rechtschreibung des von Karataev angefuhrten Fibeltitels stimmt nicht mit den entsprechenden Regeln Smotryckyjs uberein.- Vorsichtig äubert sich im Sinne Weingarts $M$ д д н

Братские пколы укранны и Белорјссии в I6-I7 вв, и их рсль в еоссоединения Укранны с Рессией, Москва I954,S.54.- Die Wilnaer Fibel wurde 1634 in Moskau von Vasilij Burcev mit einem Nachwort nachgedruckt (Каратаев, И.П.: Описание.., S.441-42, Nr.407).

220) В о з н я K, M.: Iстсрія јкраінськоїлітератури, т.II, I, Jьвів I92I, Nachdruck jlavistic rrintings and Reprintings $224 / 2$, The Hague-Paris 1970, S. 223-34 u. 263-73; $\Gamma$ p y-

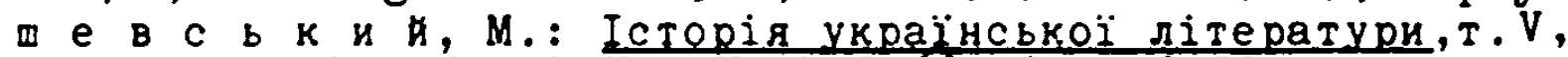
Киї I927, Nachdruck New York I960, s.458-71; I c T o$p$ i $я$ укрE $1967,5.266-71$.

(21) C y t o w s k a, R.: Od Aleksandra do Alwara. (Gramatyki łacińskie w Polsce w 16 w.), Archiwum filologicane, Bd.18, Wrocław-Warszawa-Kraków 1968.

i22) $R$ e i c h l i n g, D., a.a.0.,S.XIII u.ff.; S a $n$ d y s, J.E.: A history of classical scholarship, Bde. I-III, New York 1958, Bd.1,5.607; I.,..163 u. ff.; I s i n g, B.: 
Die Anfänge der volkssprachlichen Grammatik in Deutschland und Böhmgn. Dargestellt am BinfluB der Schrift dee Aelius Donatus De octo partibus orationis ars minor,T.I. Quellen, Berlin 1966; Die Herausbildung der Grammatik der Volkssprachen in Mittel- und Osteuropa. Studien über den BinfluB der lateinischen Flementargrammatik des Aelius Donatus De octo partibus orationis ars minor, Berlin 1970.

23) Adelphotes. Die erste gedruckte griechisch-kirchenslavische Grammatik. Lviv-Lemberg logl, hrsg.u. eingeleitet v. Hor b a t s c h, O., Specimina Philologiae Slavicae, Bd. 2, Frankfurt a.M. 1973, S.XV, Anm. 21 .

24) $Z$ i 2 a $n$ i $i$ L.: Hrammatika Slovenska. Wilna 1596,hrsg. u. eingeleitet v. F $r$ i d hof, G., Specimina Philologiae Slavicae, Bd. l, Frankfurt a.M. 1972.

25) $D i \circ \mathrm{m} e \mathrm{~d} i \mathrm{~s}$ Artis grammaticae libri III, Grammetici Latini, v.I,S. 296-529, hrsg.v. K e i l, H., Leipzig I857, Nachdruck Hildesheim 196I; $D$ i 0 m e d i s Grammatici opus ab Iounne $C$ a e $s$ a $r$ i o ita emendatum, scholiisque illustratum ut nulla porro labes insideat, item $D$ o$n$ a $t$ i De octo orationis partibus, et barbariamo libellus, ab eodem recognitus cum indice, Lipsiae 1541. Bxemplar der UB Ffm. Sign. 15/408.

26) $D$ o n a $t$ i De partibus orationis ars minor. Ars gramma tica, Grammatici Latini, v. IV, S. 353-402, hrsg. v.Keil, H., Leipzig 1864, Nachdruck Hildesheim 1961 .

27) $P r$ i s c i a $n i$ Institutionum grammaticarum libri XVIII, Grammatici Latini,v.II-III, hrsg. v. Her $t z$, M. und Ke i l, H., Leipzig 1855-59, Nachdruck Hildesheim 1961.

28) $\mathrm{l}$ l a $\mathrm{n} / \mathrm{c} \mathrm{h} / \mathrm{t} \mathrm{h} \circ \mathrm{n}$ i s, Philippi: Opera quae supersunt Omnia, v.XX: Reliqua scripta philologica (96.Grammatica Latina, 1522; 97.Syntaxis, 1532; 98.Prosodia, 1526), S.197 -390 , hrsg. v. K.G.Breitschneider u. H.B.Bindseil, Braunschweig 1854, Nachdruck Frankfurt a.M. 1963.

29) A 1 v a r i, F.: Grammaticarum institutionum libri III, 1572; in Polen abgedruckt in Poznan 1577, 1586 und in wilna 1592 - laut $C$ y tow s k a, M.,a.a.0.,S.105, 64 .

30) м а к а у у к а, Є.: Граматика М.Смотрицького, Звіт приватно $і$ генсько $і$ гінназіi Сестео Василіянок у Львов mKiлbHнt ojk I907/8, JьBiв I908,S.1-55 (und Sonderdruck), insb. S.40-50.

31) Daß Smotryćkyj sich der 'Syntaxis' Ph.Melanchthons bedient hat, erkennt man an seinem übersetzten $\mathrm{Z}$ itat aus Bnnius Дру́гъ извъстенъ в' неизв бстны ве́щи познава́ет'са, I9Iб (am Rande: Єннї: Поé:) = Amicus certus in re incerta cernitur. Da aber in der 'Syntaxis' Ph. Melanchthons (vgl. unsere Anm. 28: Spalte 348, De syntaxi nominum, 1. regula) der lateinische Satz ohne Verweis auf Bnnius (im Text selbst!) vorkommt, die Abhandlung von M.Cytowska (a.a.o., S. 45, Fußrote 13) dieses 2 itat aus Melanchthons Text mit dem Verweis '... Bnnius.' führt, so ist es anzunehmen, daB Smotryćkyj dieselbe (polnische) Ausgabe der 'Syntaxis' Melanchthons benutzt hat, aus der Cytowska ihre Fußnote schöpft. Laut Cytowskas chronologischer Tabelle der Grammatiken des 16.Jhs.(a.a.0.,S. 102-03) wärana- 
er Ausgabe Mielanchthons aus dem J. 1526.

32) Vgl. Smotryćkyj (1619): Нькіи Гл̆й два̀ по себї вини́телна прит А́уть, 2II - Alvarez: 4.ordo. Quaedam verba activa post se duos accusandi casus admittunt. (Zitiert nach der Ausgabe Tyrnaviae 1768 im Aufsatz von V.Kurdinovskij in Russkij Filologičeskij Vestnik,Bd.58/1907, S.329).

33) Die Tradition schrieb diese auf den griechisch-byzantinischen grammatischen Traktaten (insb. auf dem von Choiroboskos aus dem Anfang des 14.Jhs. stammenden Werk) aufgebaute Abhandlung dem hl.Johannes aus Damaskus ( $8 . J h$.$) zu,$ wobei seine aksl. Ubersetzung dem bulgarischen Bxarchen Johannes (10.Jh.) zugeschrieben wurde. Vgl. K a $\pi$ a म д 0в и ч, К.Ф.: Иоанн ексарх болгарскй, CПб.I824, Abdruck des Textes auf S.167-73.-V.J a 8 i ć (Рассуждения южнославғнской и русско старины о церковно-славянском языке Исследования по русскому языку, I, 3, СПб. I895, S.326(38), Abdrucx der lexte auf $5.328-42$ hat dieser Legende endgiltig ein Bnde gesetzt.- Bire Abschrift des Traktats, die sich im 16.Jh. in der Bibliothek des Püsten K.Ostrozkyj be sand, wurde in Wilna 1586 abgedruckt (vgl. K a p a $\mathrm{T}$ aе в, И.П.: Описание..., S.232, Nr.113).

34) Abdruck in $Я г$ и ч, И.В.: Pacсуждения..., S.383 (95)-487 (199).- Konstantins BinfluB auf die orthographisch-morphologischen Vorsteilungen Smotryckyjs hat auch rieine Abhandlung 'Die vier Ausgaben...'(S.16) hervorgehoben.

35) История на българскета литературе в 4 тома, I.Староб ългарска литеритура, София I962, S. 317.

36) B o h $\circ r$ i č Adam. Arcticae horulae. Die erste Grammatik der slowenischen Sprache. Wittenberg 1584. Nachdruck von $B$ e $r$ c $i$, B. in: Geschichte, Kultur und Geisteswelt der Slowenen, Bd.IV, 1 ( Text), Munchen 1969, S.102-46, passim. Uber die Sprache der Grammatik vgl. L é $n$ a $r$ d, L.: Rozwoj historyczny gramatyki słoweńskiej, Prace Filologiczne, Bd.8, S.101-248, insb. S.207-48, Warszawa 1916; K o l a$r i c, R_{.}:$Die Sprache in A.Bohorics Arcticae horulae, in: Geschichte, Kultur und Geisteswelt der Slowenen, Bd.IV,2 (Untersuchungen), München 1971, S. 2G-82.

37) $T$ e $s$ n $i$ è $r$, $L$.: Les formes du duei en slovène, Paris 1925, S. 410-11.

38) D i e l s, P.: Altkirchenslavische Grammatik mit einer Auswahl von Texten und einem Wörterbuch, I.Teil: Grammatik, Heidelberg 1932, S.228.- Vgl. 2.Dual.1.: посъласть, Joh.11,3, in: 向 е п к и н, В.: Саввина книга, Памятники старсславянского языка, т.I, 2, СПб. I903, Nachdruck Graz

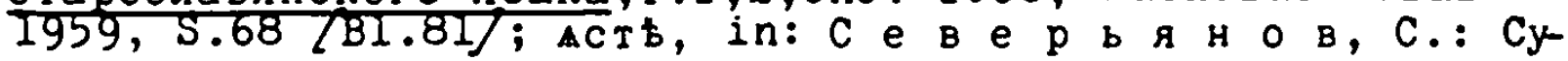
прасльская рукопнсь,т.I, Памятники старославянского языка, T.I I, 1 , CПб. I904, Nachdruck Graz 1956, 5.446, Zeile 7; uriklar: вьроучть, a.a.0.,3.445, Zeile 17 (//ввроунста, Zеle 16 !); текость, идьсть, Мt.28,8, Асть сА, поклонисть сА, N.t. 28;9, Мепкин, B., a.a.0., S.116/Bl.12l/; 3. Dual.n.: видвств очи моі, ebendort, S.136/Bl.139/,Lk.2,30.

39: C y tow s k a, M., a.a.0., S.85-101 (Tabela I).

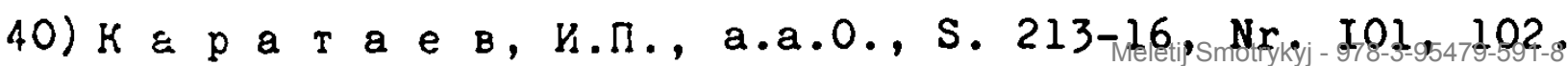


41) ОБ: ДьА.I,6:гй, аще въ льто се оустролеши ирствӥе ійёво;

См. І6б: Гсди аще в' сіе времА оустромети царствї ійлево; ОБ: Чл.ІІ7, 8: Бл̆го есть надыатисА на гё, нежели надьатиса на чйка.

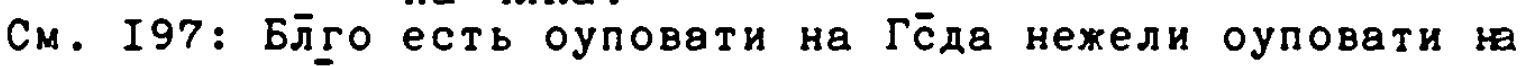
члеква.

ОБ: Лк.2,35: и тебь же самси дйу проидет оружіе,

См. 200: И тебе самын дйу проидетв оружіе.

ОБ: ДьА.2,2: и бысть внезапу с носе шумъ, јако носиму дыханію бурку, і исполни весь докъ идыже баху свдаще.

См. 2I9: Бысть шумз и исполни домъ, идеже баху оученици седаще.

ОБ: Iw.I, 33: над него же оузрити дехъ сходадь, и пребчвающ в на немъ,

См. 227-2276: Над него же оузрипи цих̄a сходаща и пребывающа на нем:

Die Worttrennungen stammen von mir. Die Rechtschreibung

ist vereinfacht worden.

42) ОБ: Мт.II,I3: зако́нъ - См. 2260: за́ковъ.

43) $\mathrm{V}_{\mathrm{g}}$. die verbalen remininen Dualendungen: 0Б: Чл.II8,73:

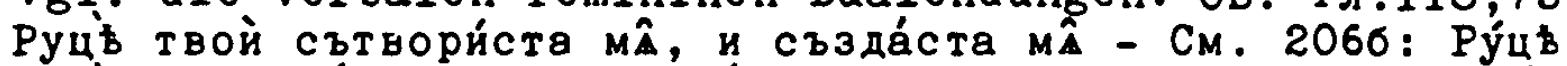

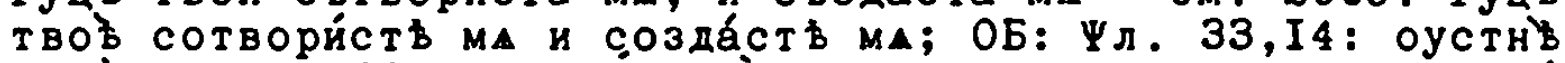
свой - См; 230: оустнб свов; ОБ: Чл; 62,5: о имени твое́мъ въздежу̀ ру́кь моА. - См. 228: о имени́ твое́м' воздвну ру́ць моb:- die Imperativendung: ОБ: MT.25, 28: дади́те - См.2IЗ дадыте.

44) ОБ: Ұл. 25,6: и обиду олта́рв тво́й ги. оусли́⿴囗ти мй глас хваль́ твоё, - См. 2I76: об'иду олтарь твби Гсди ёже оуслйтати мй гла́съ хвалы твое́А:- Vgl. nосh: ОБ 2I70;

45) ОБ: Мт.25,28: тала́нтъ - См.2І30: мнас̧ъ; ОБ: Сирах I3,I7: съ бл̆говврнымъ - См.205: со бл̆гочести́вьм.

46) $Г$ о р 6 а ч, 0.: Памво Беринда як етимолог, Науковия жірник Украінського Вільного університету, т. 6 , Munchen 1956, S.70.

47) $V_{g 1}$. auf $S .2256 \mathrm{Zitate}$ aus: Lk. 2l,33 und Mt. 24,2I -

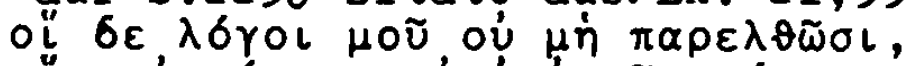

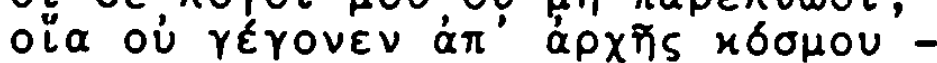

bei $T i s$ c $h$ e $n$ d o r f, C.de: Novum Testamentum Graece.

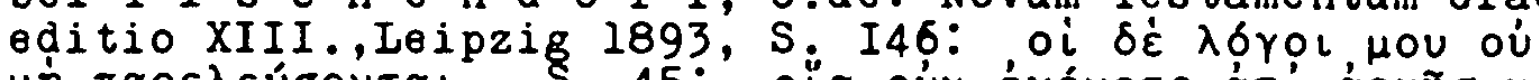

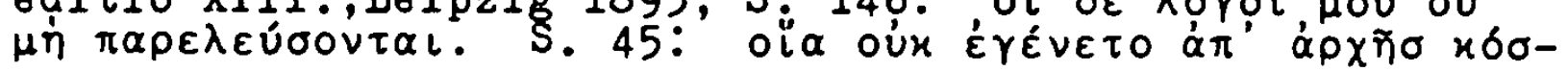
Hov - und die Fußnoten ebendort.

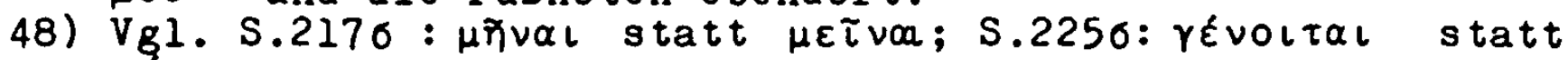

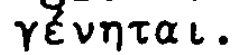

49) AuBerdem ist noch eine Reihe von offensichtlichen Druakfehlern zu verzeichnen: a)'Spiegeldruck': возмньол Eвло) I56, доP (=POД] 2440; b) Silben- und Buchstabenauslassungen: оу/по/требленіи 486 /Зват:..J 77, 0/с/тавихом' 860, прочто/xо/вbca I3IO, c) Silben- und Buchstabenverwechs-

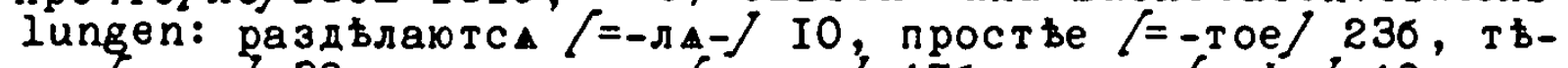

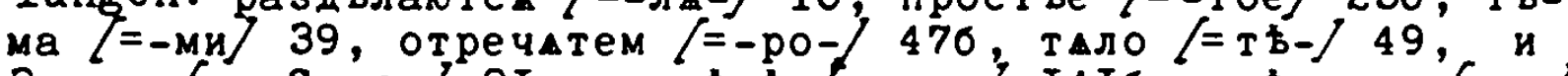

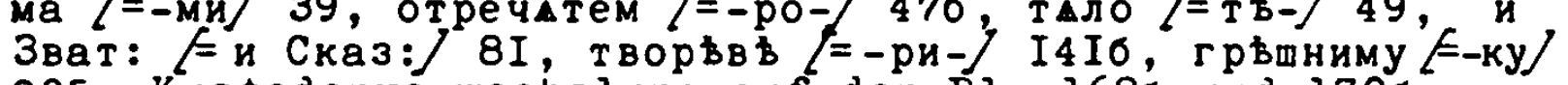
205; Kustodenverwechslung auf den Bl. 1686 und 1706 ; cka-

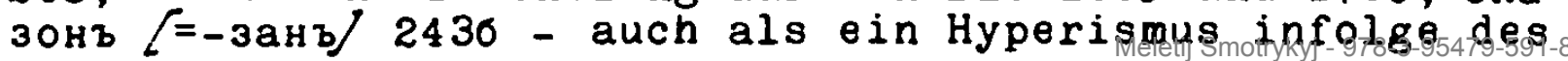


weiBrussischen Zusammenfalls der unbetonten olla denkbar.

50) Г р р а а ч, 0.: Західньополіська говірке села Остромичі кол. повіту Кобринь, Наукові записки Украінського Технічно-Господапського Iнституту, Bd.25, München 1973, 5.4 .

51) $\mathrm{Vgl}$. noch $\mathrm{H} \circ \mathrm{r}$ b a $t \mathrm{~s} \mathrm{c} h$, 0. : Die vier Ausgaben ..., S. 6 u. ff.

52) Я $г$ и ч, И.В.: История..., S.29-30; Б у ли и, С.К.:Очерк., S.175; nach ihnen auch we i $n g$ a $r$, M.,a.a.0.,S.5b; Es gibt auch eine Vermutung, dab ihr Verfasser Kyrylo Trakvilion-S tavroveckyj (gestorben 1646) war, der in den JJ. 1589-92 als Lehrer der Lemberger und ab 1592 (bis zum Anfang des 17.Jhs.) der Wilnaer Bruderschaftsschule wirkte. In Kremjaneć gab es ab 1636 eine Filiale des Kiewer P.Mohyla-Kollegiums.- Vgl. C e p e д граматика, Hama культура, нр.II(I63), S.10, Warszawa 1971. М а $\mathrm{x}$ н о в $е$ ц ліографічнй словник, т.I: Навня украінська література (XI-XYIII ст.ст.), Киів I960, S. 560-64.

53) К а р а т а е в, и.П., а.а.0., S.466, Nr.474; im abgedruckten Nachwort heibt es: "... Поне́xe Славцном нвсть еme оби́чай мврами. вре́мен'ми и степенми стихи составла́ти. Нّко же ви́дим и Пблских стихотео́рцовъ. не мврами, ни́ же сте́пенми (еже Єллином. и Лати́ном оби́чно) но сло́гами во всъх потре́бах вс́ иску́снии стихотво́/p/цы, илй вв́ршопи́сцы. мвру то́кмо сло́говъ въ стисвХъ, и согла́сіе псслвднаго сло́га съблюда́юme оупотреблйютса. Сймъ и Славенстїи тща́телї, любо оучащейс послвду́юmе в' любйихз потре́бу, довлветъ. Здравствй grund eines Mikrofilms vom Bxemplar der Moskauer LeninBibliothek korrigiert.

54) we in g a $r$, M., a.a.0., S. 45, wirft aus Versehen der Grammatik Smotryckyjs vor, dab sie den kirchenslavischen Dativus absolutus nicht erwähnt habe; ein Absatz aber ' 0 дателномъ со гїомъ самостолтелном' ist bei Smotryckej auf BI. 2090 zu lesen.

55) 3 а с а д к е в и ч, Никифор: Мелетий Смотрицкийкак филолог, Киевские университетские Известия, Киев $1875, \mathrm{Nr} .2$, S.130-58, Nr.4, S.348-63; 2.Ausgabe Oдеcca 1883, 204 S.; Bespr. Б у д и л О в и ч, A. in: Журнал Министерствв народного просвещения, ч.228, спб.І883,УІ-УІІІ, S.144-51; und

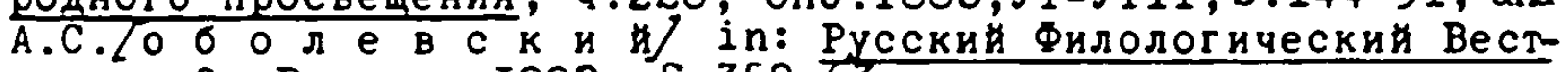
ник, T.9, Варmава I883, S.358-63.

56) К а р а т а е в, И.П., а.а.0.,S. 413, Nr.348.

57) (Б і л О д $і$ д, І.К., К у д р и и ь к и И, Є.М.J Граматика слов янська I.Ужевича, Киів I970; $\Gamma$ о $о$ о а ч, $0 .:$ Рукописна 'Граматыка словенская' I.Ужевича 3 I 643 й I645 pp., Наукові записки Украінського Технічно-Господарського Iнституту, T.I4(I7), München 1967, S. 3-21.

58) К у р д и н о в с к и И, В.: Рукописная церксвнославянская грамматика Гербовецкого монастыря Бессарабской губернии, Еусский Филологический Вестник, т.57, S.389-97, т.58, S. 307-30, Bapmaba 1907 .

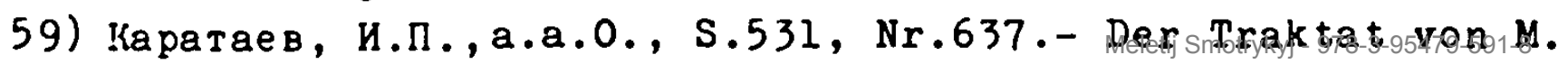


Grek (aus dem Vorwort zur Grammatik) wurde gesondert noch 1782 in Moskau abgedruckt. Vgl. $\Pi$ e T p O B, C.0.: Книги гражданской печати I8 века. (Каталог книг, хранящихся БГосударственной публичной библиотеке УССP), Киев I956, S. 135, Nr. 1309 b2w. S. 225, Nr. 2166.- Vermutlich aufgrund dessen gibt $M$ a $x$ H $\circ$ в merkung 52), S.549, eine sonst unbekannte Ausgabe der Grammatik Smotryćkyjs (Moskau 1782) an.

60) L $u d o$ I $i$ Henrici Wilhelmi: Grammatica Russica, oxford 1696 , edited by $U n$ b e \& a $u n, B .0$. , oxford 1959; Tetzn e r, J.: H.W.Ludolf und RuBland, Veröffentlichung des Instituts fur Slawistik, Nr.6, Dt.A.d.W.2u Berlin, Berlin 1955, S.34, Anm. 7; U n b e $g$ a u n, B.0.: Rus sian grammars before Lomonosov, Oxford Slavonic Papers, $v$. 8, Oxford 1958, S.100-05.

61) $U \mathrm{n}$ b e g a $u$ n, B.0.: Drei russische Grammatiken des 18. Jhs. Nachdruck der Ausgaben von 1706, 1731 und $1730 \mathrm{mit}$ einer Einleitung, Slavische Propyläen, Bd. 55, Munchen 1969, S.VII; d e r s e I b e: Russian grammars ... (unsere Anmerkung 60), S. 10b-09.

62) $S j \ddot{o} b$ e $r$, A.: Two unknown translations of M.Smotrickijs Slavonic grammar, Scando-Slavica, Bd.12, Kopenhagen 1966, S. 124 .

63) Я $г$ и ч, И.В.: История..., S.65.

64) $S$ j ö b e r g, A., a.a.0.,S. 125-28.

65) F lor o v s k i j, A.: Ruská mluvnice českého jesuity 2 r. I690, Slovo a slovesnost, r. 4, Praha 1938, S.239-45; U $n$ b e $g$ a u $n$, B.0.: Kussian grammars ..., s. 99-100.

66) H $\circ \mathrm{r}$ b a $t \mathrm{~s} c \mathrm{~h}$, 0.: Die vier Ausgaben ..., s. 50-6l; Б к $о$ в $а$, T.A., Г у $р$ е в и ч, М.М.: Описание издании напечатанных кириллицен. I689-январь I725 $\mathrm{r}_{.}$, Москва-Jенинград 1958, S. 221-23, Nr.135.

67) $S j o ̈ b$ b g, A., a.a.0.,S.129-31.

68) Б к о в а, Т.A., Г у р е в и ч, М.М.: Описание ..., S. 261-64, Nr. 194 .

69) U n b e g a $u$ n, B.0.: Drei russische Grammatiken ..., S. IX-XII und Potonachdruck; d e $r s e l$ b e: Russian grammars ...., S. 109-13; B a um a $n n, H .:$ Die erste indeutschen Sprache gedruckte Russischgrammatik, Beiträge zur Geschichte der Slawistik, Veröffentlichungen des Instituts fur Slawistik, Nr.30, Dt.A.d.W. zu Berlin, Berlin 1964,S. 183-91.

70) Я $г$ ич, И.В.: История..., S. 31; П е т р В, С.0.: Книги ..., S.18, Nr.90.

71) К у р д и н О в С к и И, В.: Рукописная церковнославянская грамматика Гербовецкого монастыря Бессарабской губернии, Русский Филологический Вестник, Вd. 57, Варшава 1907, S. $389-94$.

72) S t $r$ u g a.r u, D.: Gramatica lui Smotritki si prima gramatică rominească, Romanoslavica, Bd.4, Bucuresti 1960 , S. 289-306.- Diesen aufschlußreichen Spezialaw foatz478-59ge genuber der allgemeinen Notiz vornod Jaglecterin 
S. 908, mit einem Verweis auf den Aufsatz von V.Kurdinovskij) - scheint u.a. H. B a u m a $n$ (in seiner Besprechung meiner Abhandlung 'Die vier Ausgaben...' in der Zeitschrift für Slawistik, Jg.XI,H.1,S. 105, Berlin 1966) zu unterschätzen.

73) S t r u n g a r u, D., a.a.0.,S. 293; д и ле в с к и,н.M. Редки руски книги в български книгохранилища от епохатана възраждането. По случа тристагодишнината на българския препис от 'Славенската' граматика на Мелетй Смотрицки (I655) и двестегодишнината на Римнитко й издание (I755), Български език,Jg.V,H.4, S.319-35, София I955; Д ыле вски и, Н.М.: Грамматика Мелетия Смотрицкого у болгар в эпоху их возрохдения, Тоуды Отдела древне-русской литерагурь, Bd.14, S.461-73, Ленинград 1958.

74) $\mathrm{H} \circ \mathrm{r}$ b a $t$ s $\mathrm{c} h$, 0.: Die vier Ausgaben..., S. 62-63; $M$ i h a i l o v i c, G.: Srpska bibliografija 18 veka, Beograd 1964, S. 44, Nr. 31.

75) Я ц и м и р ск и и, А.И.: Славянские и русские рукописи румынских библиотек, СООРЯС 79, СПб. I905, Nachdruck Nendeln 1961, S. 355-83 (Рублисная библиотека Паисия и его учеников).

76) S t $r$ u $\mathrm{g}$ a $r$ u, D., a.a.0., S. 297-303 und 303-06.

77) U $\mathrm{n}$ b e $g$ a $u n$, B.: Les débuts de la langue littéraire chez les serbes, Travaux publiés par l'Institut d'études slaves, Bd. 15, Paris 1935, S. 30-31.

78) $M i h$ a $i l o v$ i $k$, G.: Srpska bibliografija...,S.244-45, $\mathrm{Nr} .268$ und 269.

79) Bbendort, S. 280-81, Nr.308, S.351-52, $\mathrm{Nr} .395$ und 396; $K$ i $r$ i 1 o v i $k$, D.: Katalog Biblioteke Matice Srpske, I. Srpske knjige 1494-1847, Novi Sad 1950, S. 46, Nr.361; ein Exemplar aus d.J. 1834 besitzt das Slavische Seminar in Frankfurt a.M.

80) $\mathrm{Mi} \mathrm{h}$ a i $\mathrm{l}$ o $\mathrm{v}$ i ć, G., a.a.0., S.231, Nr.254, S.308, Nr. $341, \mathrm{~S} .350-51, \mathrm{Nr} .394$.

81) K i r i l o vi c, D.: Katalog ..., S.76, Nr.649.

82) $\mathrm{N} \circ \mathrm{v}$ a $k \circ \mathrm{v} i$ ć, S.: Srpska biblijografija za noviju književnost. 1741-1867, Beograd 1869, S.165, Nr.821.

83) Ц о не в, Б.: Опис на ръкописите и старопечатните книги на Народната Библиотека в София, София I9I0, 5.418-19, Nr. $377(301)$ : 'Руководство къ славенско граматіцы'.

84) Д ы $л$ е в ск и и, Н.М.: Грамматика..., S.467-70.

85) Ц О н е в, Б.: Славянски ръкописи в Българската Академия, Сборник на Българската Академия на Науките, кн.6 (Клон историко-билологичен и философско-обществен, 4), София I9I6, 5. 78 , Nr.16:'Черковнославянска граматика (препис от I834 г.)'.

86) ц о н е в, Б.: Опис...., S.419-20.- Bin Verweis auf Smotryćkyj fehlt jedoch dabei.

87) Д и ле в ски и, Н.М.: Редки руски книги..., S.335.

88) М и ле т и ч, Л.: Неофит Рилски като ияляог, Училияен 
прєглед, Jg.XI,H.I, София I906, S.1-j3.

89) Погоре лов, В.: Опис на старите печатани овлгарски книги (IE: 2-I877 г.), Соұия I923, ј. 39, Nr.31.

90) Ди ле в ски, Н.M.: Рсдки руски книги..., S.334; П ого $\mathrm{f}$ е $л \circ$ B, B., a.a.0., S.37, Nr.46, S.12l, Nr.112.

91) $\Pi \circ\ulcorner\circ p$ e $л \circ B$, Е., a.a.0., S.143, Nr.139.

92) Naukb krstiunski kratak, 1628; Azbukovidnjak slovinski iž opcenim nacinom psal teric nazivaet se, $1629^{1}, 1697^{2}$; Missal rimskij va èzik slavenskij, 1631; Casoslovb rimskii slavinskimb ězikon.b, 1648; Ispravnik za jereji ispovidnici i za pokornik, 1635 (in lateinischer Schrift 1636).- Uber seine wejteren noch in Handschriften zuruckgelassenen Werke vgl. S i m o vi ć, v.: Levakovic R., Enciklopedija Jugoslavije, Bd.5, S.ว2l-22, Zagreb 1962 (mit Bibliographie). Die bibliographische Beschreibung seiner Drucke bei $\mathrm{K} u-$ $k$ u 1 je vi ć-s a k c i n $s k$ i, I.: Bibliografia jugoslavenska, I: Bibliografia hrvatska, 1 : Tiskane knjige, 2 greb 1860 (Dodatak, Zagreb 1863), S.5, Nr.34, 33, Dodatak. $\mathrm{S} .1, \mathrm{Nr} .1, \mathrm{S.2}, \mathrm{Nr} .8$.

93) Missal rimskij va ězik slovenskij sazdan trudomb Josifa Pastrića, Roma 1706; vgl. K u k u l je vi ć-S a k c i ns k i, I., a.a.0., S.6, Nr.43.

94 ) Bukvaro slavenskij, Rom $1738^{1}, 1753^{2}$; Misal rimski slavenskim ězikomb izdan, Kom 1741; 'eine nicht vollendete handschriftliche kirchenslavische Grammatik; vgl. V.š. (t e fa$n i k J$ : Karaman M., (mit Bibliographie), Enciklopedija Jugoslavije, Bd.b, S.201, Zagreb 1962; $\mathrm{Hi}_{\mathrm{i}} \mathrm{h}$ a i lovic, G.: Srpska bibliografija...,S.21, Nr.16, S.41-42, Nr.28; $k$ u k u l je vi ć-S a k c i n s k i, I.: Bibliografia.., $\mathrm{S} .6, \mathrm{Nr} .44$.

95) M i l č e $t$ i ć, I.: Matije Sovića predgovor 'Slavenskoj gramatici', Starine JAZU, Bd. 35, Zagreb 1916, S.396-425, insb. S. $400 ;$ V.S.lte f a $n$ i ć): Sović M. , (mit Bibliographie), Enciklopedija Jugoslavije, Bd. 7, S.436-37, Zagreb 1968 .

96) Deswegen bedienten sich manche Forscher der wesentlich geänderten Moskauer Ausgabe von 1648 und schrieben die Bigentümlichkeiten dieser Fassung Smotryckyj zu, vgl. K./aч е н О В К и И, М.Т.J: Исторический взглд на грамкатику славянских наречй, Вестник Европы, 4.95, I8I7, июнь, S. 186-208, und in: Tруды боmества л10бителе россияско словесности при Имп. Московском университете, Вd.9,5.17-46, Уо ква I817; B a m ен K O, B.C: Граматика CNотринького. $\mathrm{y}_{K-}$ раінська мова в тколі, Jg.VII, Nr.3, S.27-33, Киї I957. 


\section{Г P A M M A T I K}

Сливе́нскиа пра́вилное С̆́нтагма,

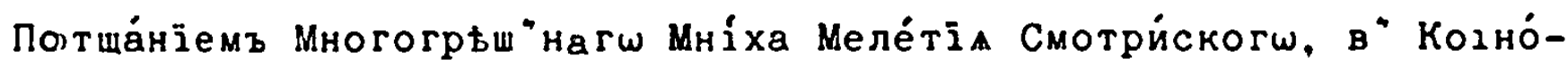
вїи Бра́т“ства Церко́внагш Вйленскагш, прй хра́мє соше́ствїа Прес₹́̃ ное иं прижитое:

Льт́ $\omega^{T}$ воплоще́нí Бŕa Cróвa -ax日i.

Пра́ващу п $^{\complement}$ лскій престо́л" вели́киа Бо́жиа Константїнопо ркве Вселе́нскому Патріа́pct $\Gamma: \omega^{T}$ цу тімоөію. Ви́ленскому же Когнӧвію предстателству́ющу $\Gamma: \omega^{T}$ цу Лео́нтїю Ка́рповичу Архгмандрі́ту $B$ B $B$ B 10.

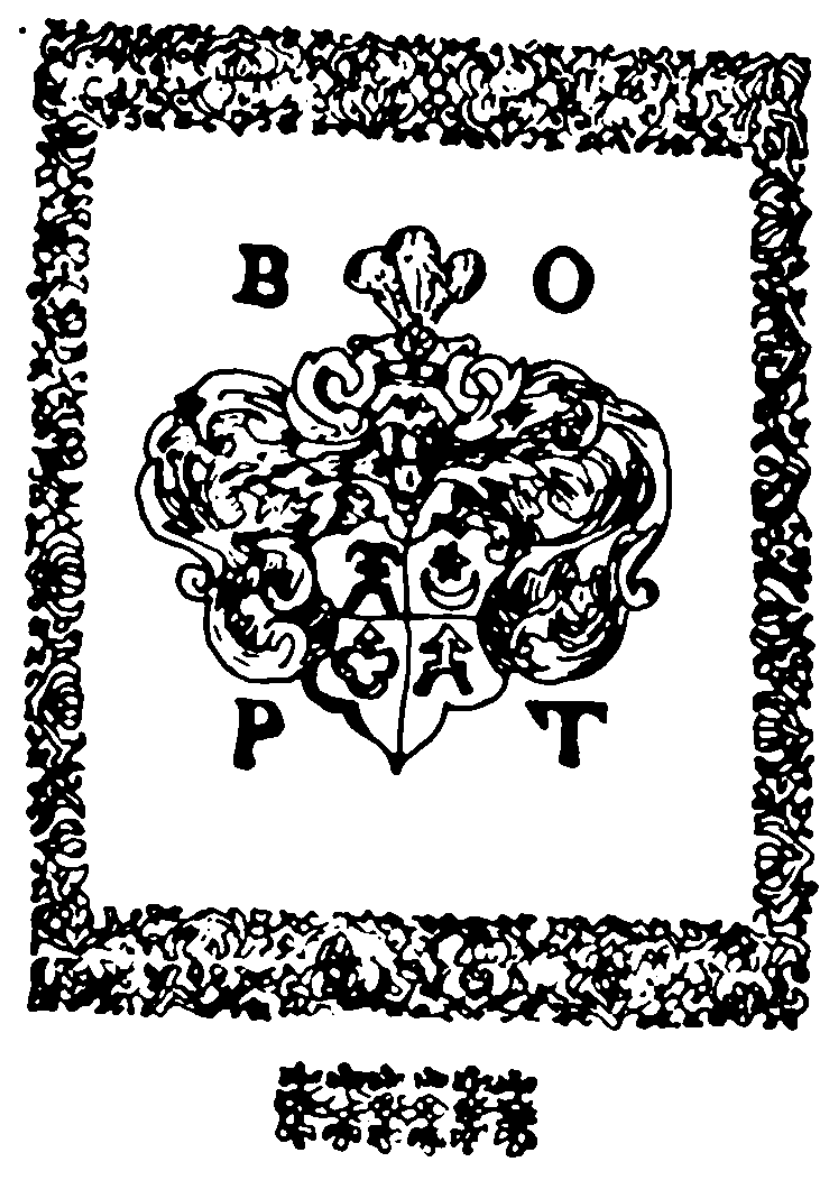

уччителЕіз Шіколным" Ӓвторъ:

I: $\mathrm{C}: \dot{\mathrm{u}}, \mathrm{T}: 3: 3$.

Похи́локъ грамма́тїки в" '́зику гре́цком й Латінском" са́мы до до-

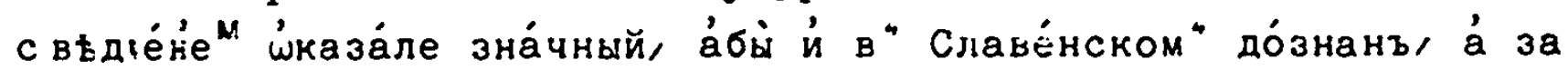
ч.áco" подо́бнымъ досвьдичен"ем" й зна́чне '́ка́занъ бы", на повйн- 
ной ва́шей Люботща́те ${ }^{Л}$ ни Оу́чйтеле пи́лности зале́жати бу́детъ. Вь-

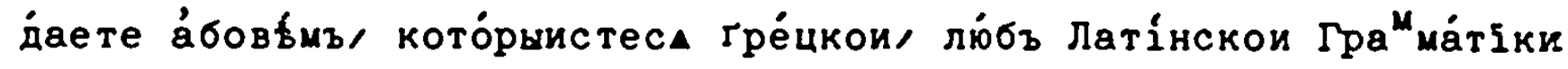
худозству оучйли, што ш́на ёсть ку пондт"ю "̈ак" ذазы́ка чи́стости та́кз й пра́вогш á сочи́нногш/ ве́длугъ вла́сности діа́лектшвз й мо-

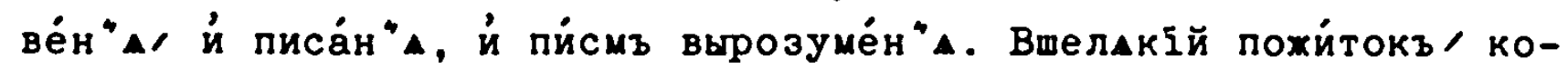
то́рыйкол-

векъ

[IIO]

векъ преречо́ньхъ 'ази́кшвъ Гра ма́тіки чини́ти звы́клы, бе пе́н"А и́ Славе́нскаА в" свое́mъ 'азйць Славе́нскомз оучинни́ти мо́хетъ: Нау́читъ в" рече́нгихз розозна́йм ро ${ }^{3}$ личиности гра "ма́тรчны сло́ва ча́стій: научитз Йме́нз склоне́ніА, à Глаголш́вз спраже́ніА, ве́длугъ вла́сности '́ко ие́нгй (на чо́мз на́mз ба́рзо сходи́ло) 'ази́ка чи́сте Славе́нскогш: Нау́чи пора́дку й спораже́н"А сли́вз кото́рыи за которыми/ длі лацнбйтогш/ найдуіочогоса в" них" ро́зуму пона́т"А/ ведлу́гъ Сочине́ніА покла́даны бы́ти ма́ютъ. Оу́ка́хет зле́ поло́хеное сло́во: оу́ка́хет збы́тнее, оу́ка́хетъ и́ чого́ бы недоста-

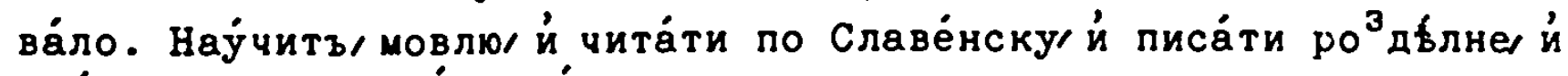
что́мое вырозумьва́ти ла́-

uнw,

[III]

цнш, гды при не́й/ за пови́ннымз потща́ні̄емъ ва́тимъ/ чи́таны будутъ зви́клымз шки́ль спо́собо" Славе́нскіи Ле́кціи, й на Ру́скій 'ази́къ перекла́даны, Һакш то з" Притчгй Солшмоновыхз/ а́лбо з" Прему́дрости е́гі் любо Сира́ховы: ӑлбо йншее што чйстым" 'азыкомъ

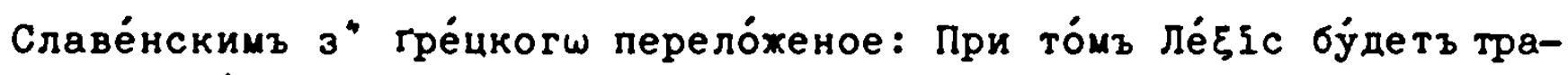
до́ванъ: Aprуме́нта да́ваны: Ді̄́́лектъ в" звы́лой шко́лной розмо́вь Славе́нскій, мехй тща́телми под кара́н"емъ захо́ванъ. За тако́вымъ

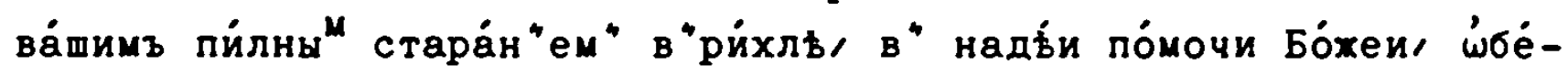
цую Славе́нскому в" на́родь на́mемъ 'азыкови поднесе́н"е/ вьрозу-

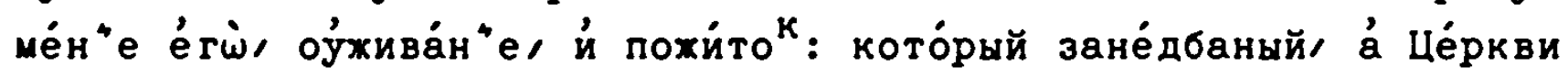
на́mей приро́дный буд́учи, по не-

$$
)(x
$$

ма́лy

[IIIб]

ма́лу на́родз на́mъ в" набохе́нство зазнбйлъ. На шдно́мъ те́ды толко

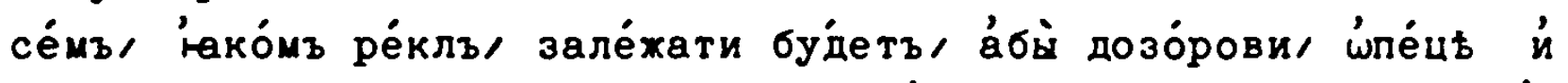
промыслови ва́mему повы́реныи дът́ки й младе́нцы льт́ свойхъ й ча́-

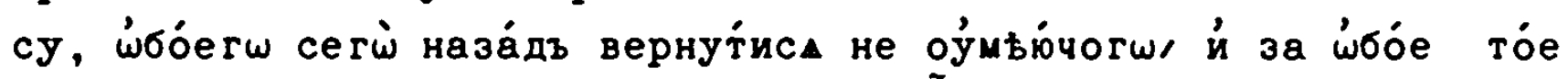

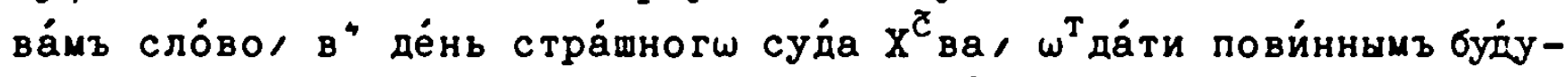
чимъ/ на даре́мне не тра́тили. Дьт́камъ оучийтиса почина́ючимъ Бук- 
ва́рь зви́кле ре́кши/ Алфавита́рь, 3" тои гра"ма́тіки вйчерпненый áбb́ склоне́ніАмъ гра"ма́тичнымъ з" льт́т детйннхъ 3 " мо́вою зара́зъ привыка́ли, до вьуче́н"А пода́ванъ неха́й буд́етъ. По Часосло́ва за й Уалті́ри (которыи: іпу́сканы бйти не ма́ютъ) вы-

уче́н "юса / ӧван грамма́тіка 3 "выкладомъ, то́ ёсть/ 3 " показова́н"емъ й оу́хыва́н"емъ е́й похиткш" настугіитъ. А где́ бы са хто са́кв Грамма́тічногш худо́зства не оучия й той дьт́мъ иं младе́нцемъ, чита́ти б̈жъ по Славе́нску оумвючим", до вьојче́н"А подава́ти е́й ма́-

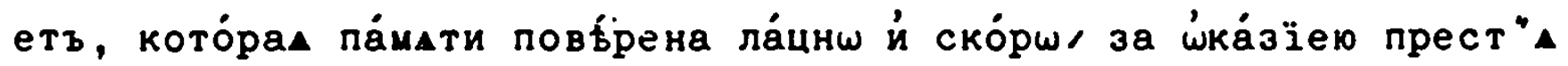
Йхъ до знаменйтшеи шко́лы ви́розумьна йми будетъ, й до похите́чногш в" худо́зствь е́й оухивван"А приве́дена. гра"ма́тіце се́й на чо" бы сходйло, не ёсть дале́це е́й йстотное, Һакъ ва́мъ оучйтелс вла́сное Анномалны, мо́влю йме́нъ й гл̃з зобра́н"е и́ до вьд́омости оучча́mи са пода́н"еl што пе́вене", за повйнны" стара́н"ем" ва́шимъ

$$
\text { )( } \Delta
$$

[Iy 6$]$

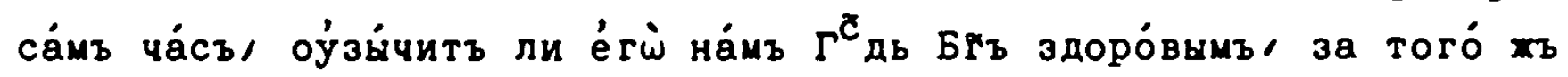
добротливвого Бта помоч"юر бе ${ }^{3}$ до́лгои труд́ности в"ри́хль на́мз нагоро́дитъ. Здравству́йте возлюбле́нніи, й $\dot{\omega}$ люботрух́дшемъ молбтеcs.

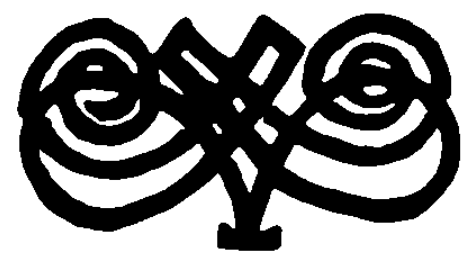

YTO ECTъ ГPAMMATIKA:

Е゙стъ йзв́сстное худо́хество бл̃гш й гла́ти й писа́ти оуччámеe; Коли́кш е́стъ ча́стій грамма́тіки: Четв́ри:
రpӨorpáфia:
Eтімолória:
Cи́нта弓ic:
Проси́ña:

чесо́my оўча ${ }^{T}$ cí чети́pи ча́сти;

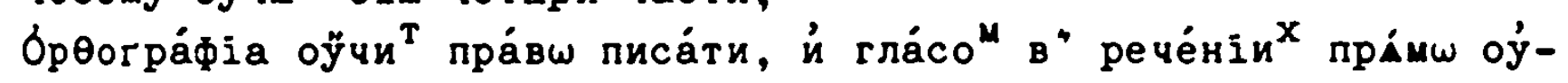
дариіти.

Éтіноло́ria оўчи" рече́ніА в" свод и" ча́сти то́чны возносйти. Синтаціс ойчитв словеса̀ сло́хны сочина́ти.

Проси́діа оўчи ${ }^{\mathrm{T}}$ ме́тром, йлй мб́рою коли́чества стїхй слага́ти. '́ ОРӨОГРАФІИ: 
Что́ е́ctz ópөorpáфia;

ட́стъ ча́сть Грамма́тїки пе́рвал, Есстество писме́нъ, сво́йство их,

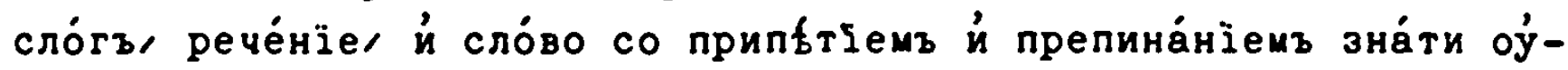
yámas.

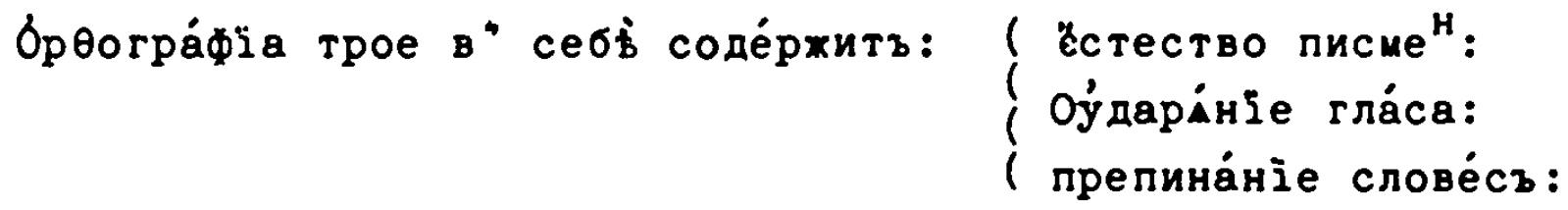

Что́ е́стъ писме́нъ ёстество;

Естъ коего́хдо пйсмене достол́пное начерта́ніе.

Что́ 'єстъ оударініе гла́са;

Сстъ рече́ній проси́діею ве́рхнею знаменова́ніе.

Что́ 'сстъ слове́съ препина́ніе;

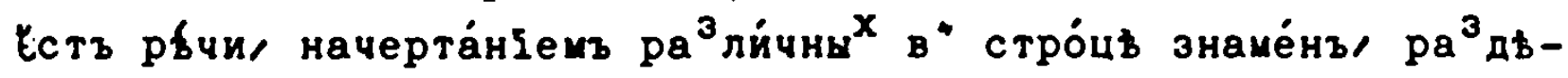
ле́ніе.

$\dot{\omega}$ писмени или '́̀ "ळтествь писме́нъ:

पтó

[2]

что́ е́cts писмиं;

'Łсть рече́ніА ча́сть нера ${ }^{3}$ дылнал.

Коли́кш е́стъ писме ${ }^{H}$ Слава́нш";

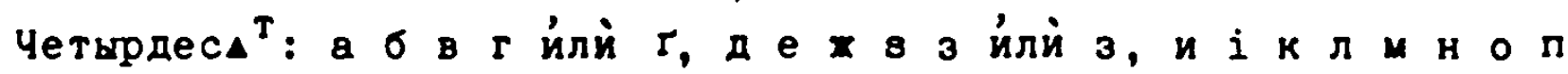

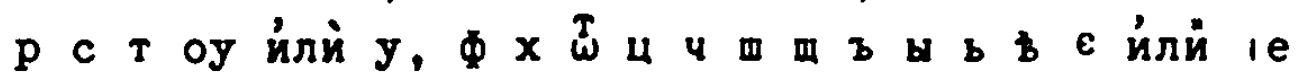

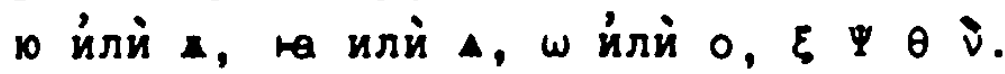

¿́ раздъле́нїи писме́нз:

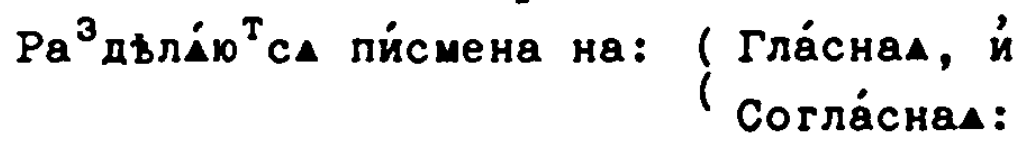

iे ГЛАССыхз :

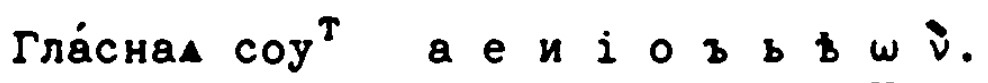
’́ ра ${ }^{3}$ дъле́нїи гла́сны пе́р“вомъ:

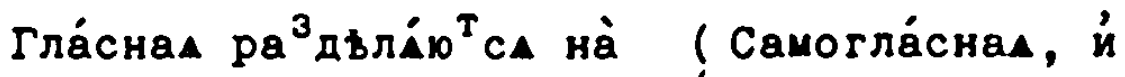
( Припрахногла́снам :

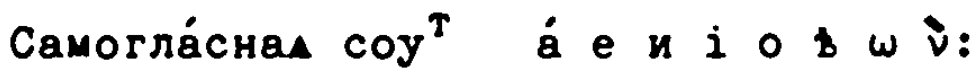

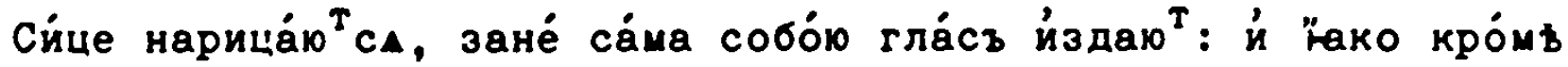
сих ни е́ди́нъ сло́гъ соста́витиса мо́хетъ.

Припра

Припрахногла́сна соfть, з й ь:

Сйuе нари́чут"са, понехе са́мa собо́ю гла́са и́зда́ти не мо́тутъ.

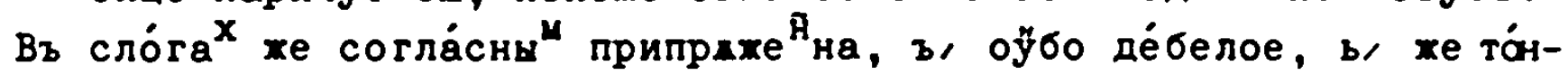




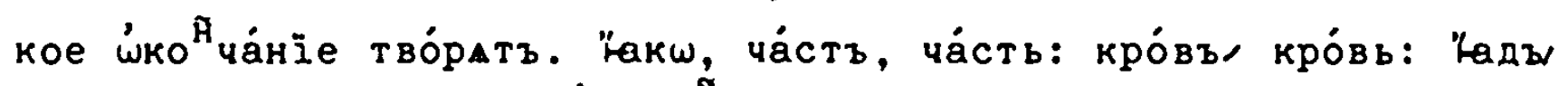
饬ь: пе́рстъ, пе́рсть: й про

‘́ ра ${ }^{3}$ дьле́ніи гла́сны ${ }^{X}$ во́ро ${ }^{M}$ :

Auе оубо и́ не тво́ра ${ }^{T}$ Слава́не пи́сменс ${ }^{M}$ свои $^{M}$ гла́сны ${ }^{M}$ вто́parw

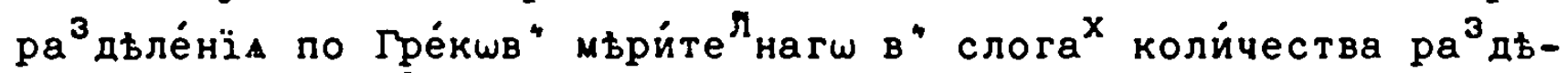

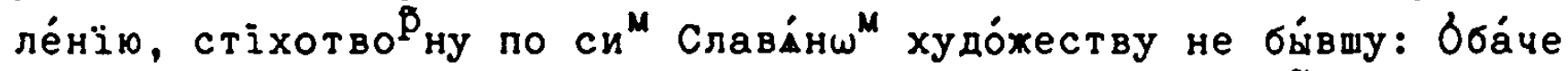

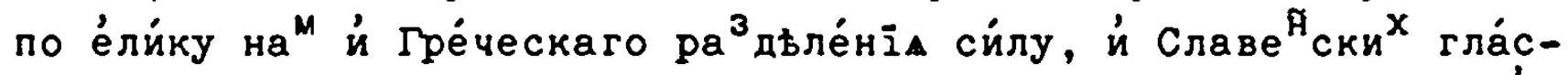
ны $^{X}$ й двогла́сны писме́нъ ко Гре́чески ${ }^{\mathrm{X}}$ прии́скрность вбдьти, ис-

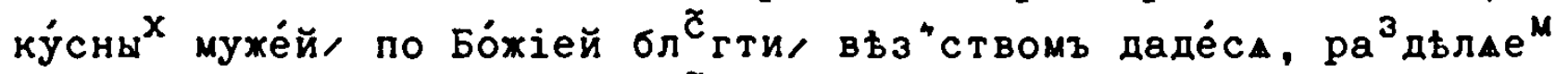
гла́снан на тро́е: на (До ган:

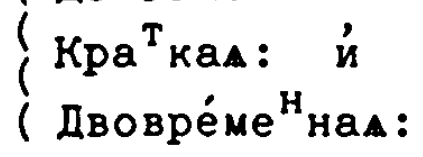

Долган суяь, и

Kpa ${ }^{T}$ каA, e o:

Двовре́ме нал: a i: $\dot{\text { म: Нарица́ю }}{ }^{T}$ же са

сйце,

сйuе, поне́xe в" сло́га ${ }^{x}$ стїхотвор̆нагш ме́тра, коли́чество ймутъ

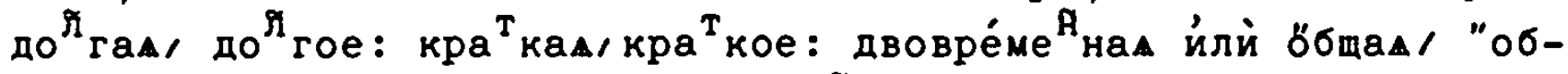

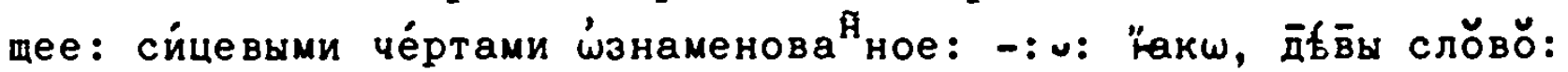

$\dot{\omega}$ ДВОГЛАСН ВГХъ:

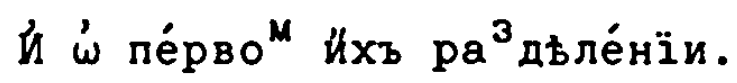

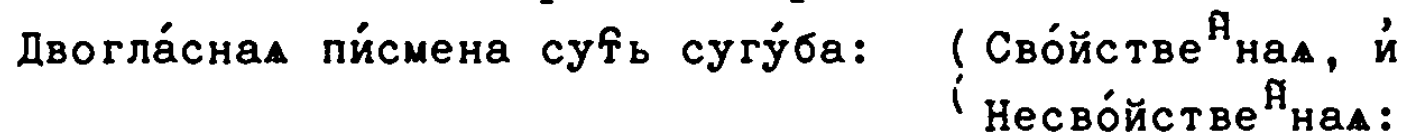

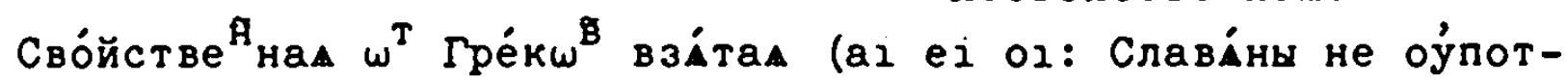

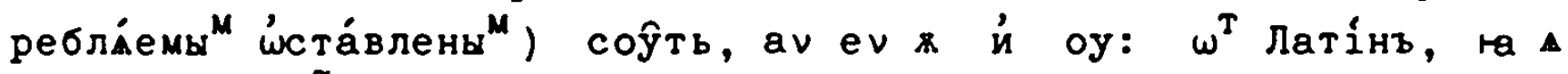
lе 10: Славе ${ }^{\text {म }}$ ское же е́ди́но, ш:

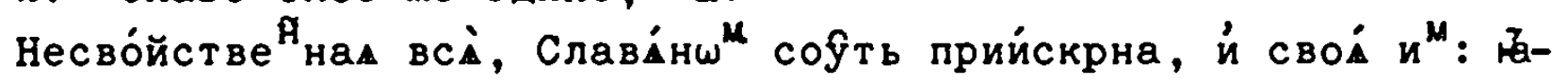

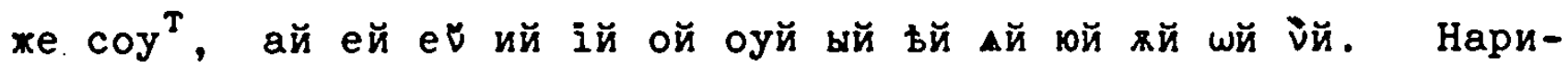

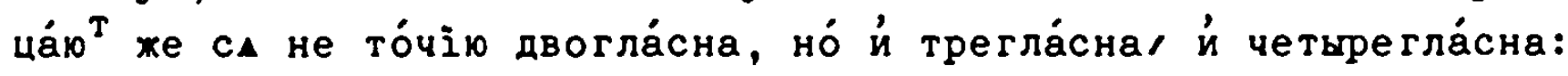
поне́же йнам $\omega^{T}$ ни ${ }^{X}$ двома гла́сныма состо́⿴囗十

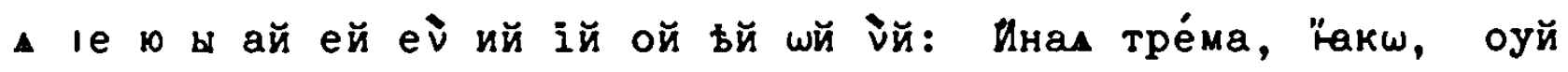
แй юй $\triangle \breve{и ~}$

И Йна

И Йно четь ма: "Екш, хй:

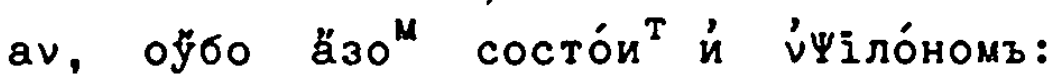

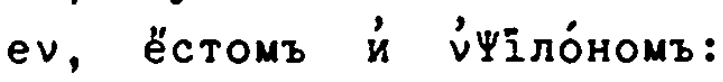

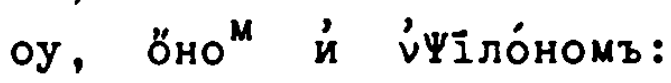

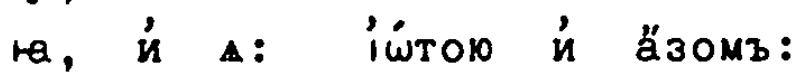


ie, †ítron й ёстомъ:

10, †'́́тою й Öномъ:

ы, ёремъ й f́́тою:

ай, ӓзомз й йтою:

ей, ёстомъ й Ӥтою:

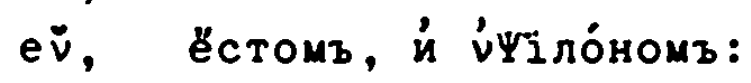

ий, дв‡ма йтама:

їй, †ंш́roю й йтою:

ой, ठ̈номъ иं йтою,

ьй, Бт"емъ й йтою:

шй, فंмér ою मे йтою:

نй, ¿४чรлономъ й йтою:

оуй, б̆ном ічілономъ й йтою:

вй, ёремъ †ं்́тою й йтою:

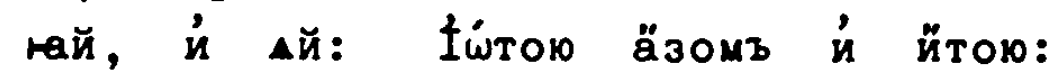

юй, †'́́тою о̆номъ й йтою:

«й, Ғштою ономъ їчглономъ й йтою.

'́ ВТОРОМъ ДВОГЛАсныхъ ра ${ }^{3}$ длёніи:

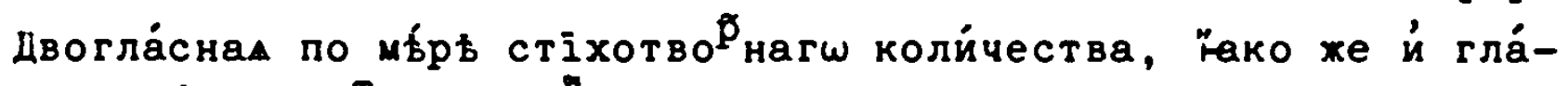
снац трегу́ба $\operatorname{coy}^{\mathrm{T}}:$ ( До ${ }^{\pi}$ гах,

Kpa кан, и
Öбщан:

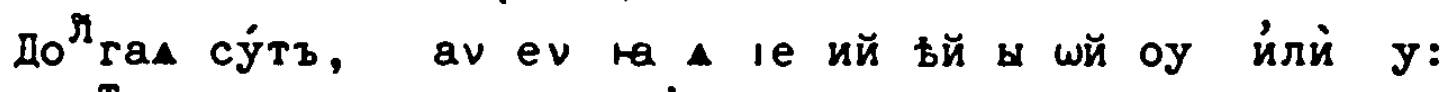

Кра каA сойть, ей: $\dot{и}$ ой:

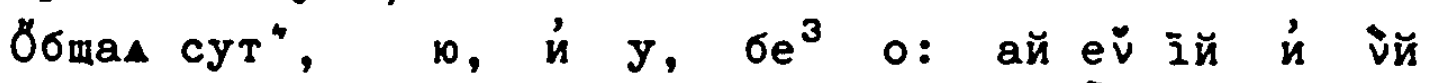

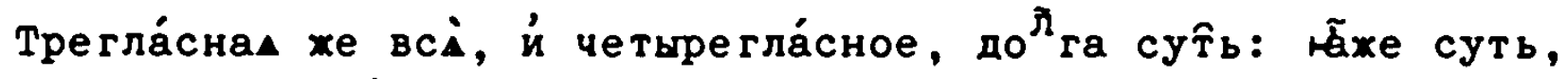
оуй เй $А$ юй \& $\dot{и}$ хй :

í СОГЛАСНВIXъ:

Согла́снал пи́смена сут", б в Г Г д ${ }^{4}$ з

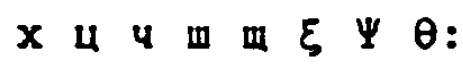

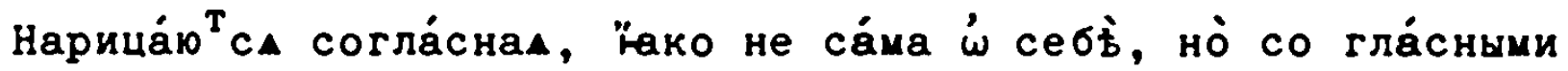
сло́rъ составлі́ть, й гла́съ йздаю ${ }^{\mathrm{T}}$ :

$\dot{\omega}$ ПЄРВОМъ СОГЛАсныхъ ра ${ }^{3}$ длёніи:

Пе́рвымъ согла́сны ра $^{3}$ дьле́ніемъ ӧва суть. $\left\{\begin{array}{l}\text { По гла́сна: б̆ва, } \\ \text { Бе }{ }^{3} \text { гла́сна: }\end{array}\right.$

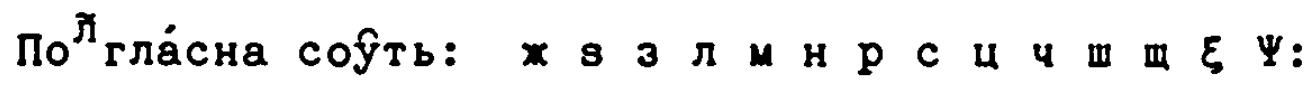

A프

Cи́ue

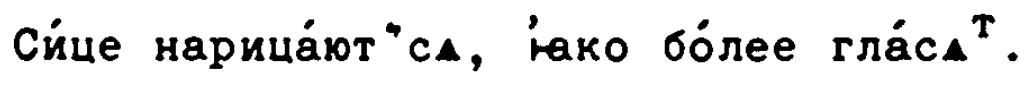


Бе ${ }^{3}$ гла́сна соўть, б в г Г д К п Т Ф

Сйе нарече́нна, зане мнбе гла́cА ${ }^{T}$.

$\dot{\omega}$ ВТОРОМъ СОГЛАснихъ ра ${ }^{3}$ дьленніи:

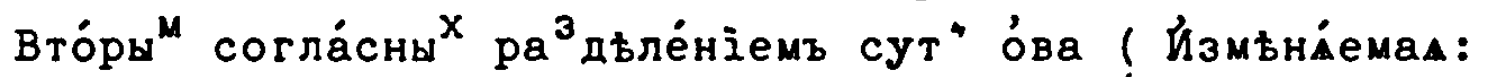

( రбомmánuas:

( Táemaa:

( Cугу́бaA:

( Сугубству́ющаa:

( Стра́ннан:

Йзмниемал сут",

Сйце рече́нна, Ұако Ймена на $r k$ й $x$, конча́mалса в" сказа́-

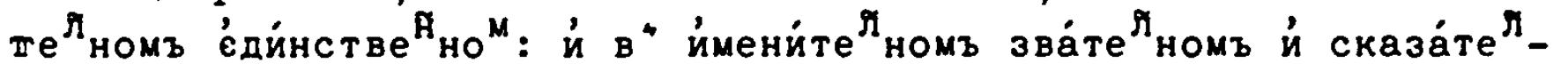

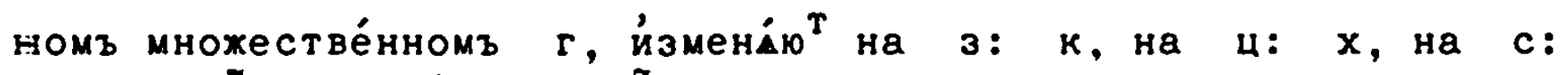
в" зва́те но" же еди́нстве номъ 3 , на $\pi:$ Н, на ч:

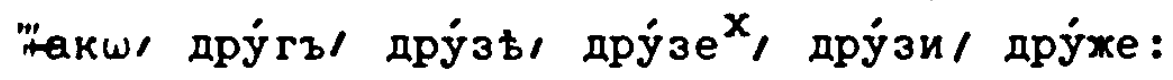

члкъ, ць, це
духъ, съ, си, члвче:

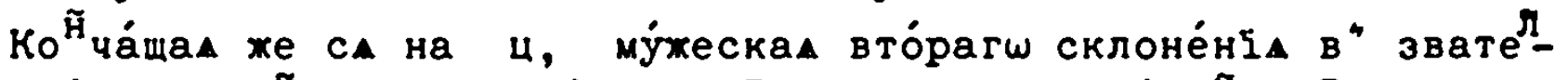

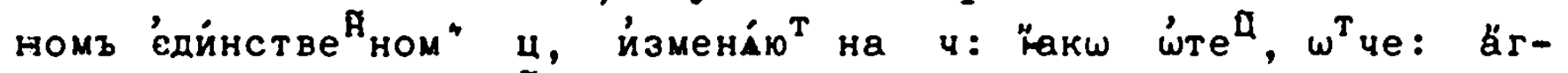
нецъ, Йгнче: й про

гли же мно́гіи на

гу жу ку чу шy,

KO ${ }^{\text {A }}$ บá

[5]

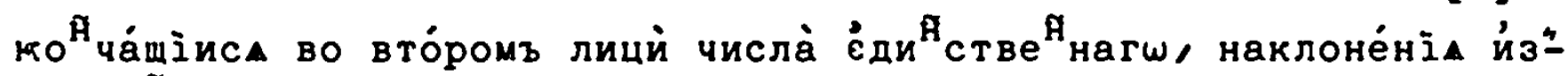

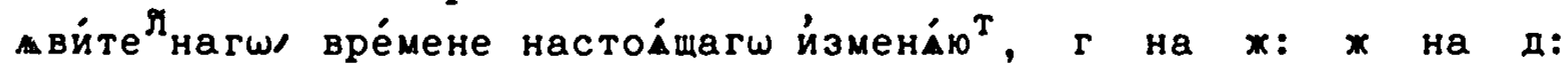
ке на ч: ч на т: ш на с: "акш, могу̀, мо́жеши: ви́жу, диши: теку̀, тече́ши: молочуे, ти́ши: прошу̀, сиши.

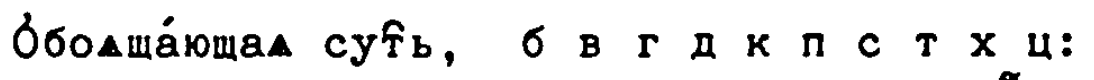

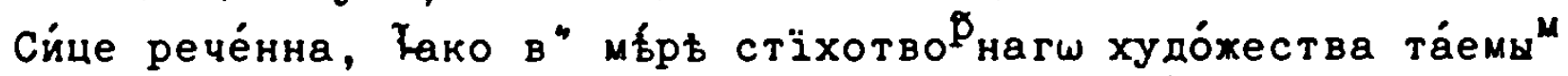
пре праже ${ }^{\tilde{H}_{\text {на, }}}$ предиду́шъ сло́гъ ёстествомъ кра́то о́ обомша́ютъ: Си́рьчъ б̆бسз TBÓpA ${ }^{T}$.

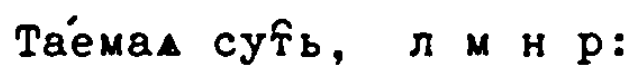

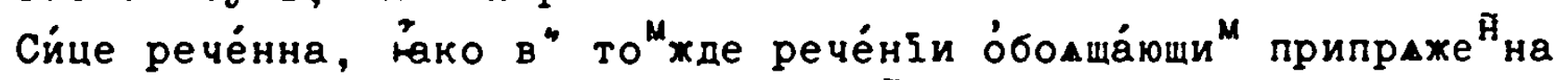
та́ю ${ }^{\mathrm{T}}$ : сіест", сло́гъ ёстествомъ кра́то ${ }^{\mathbb{R}}$ б́бомша́ютв.

Сугу́бам, з $\xi \Psi:$

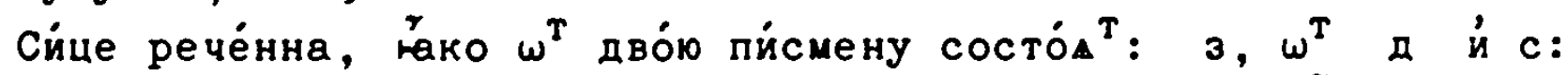

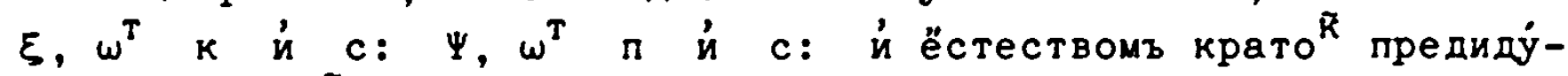
四ъ сло́гъ '́nо ${ }^{\pi}$ жа́ютъ.

Сугубству́ющал, $x$ ч щ щ:

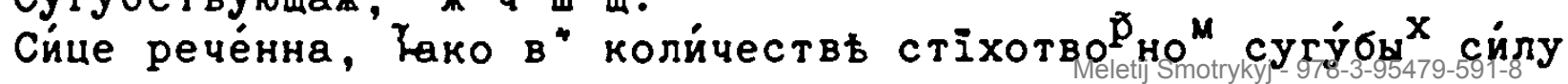


притїхуть.

Стра́ннаa, rs $\Phi \xi \Psi \theta:$

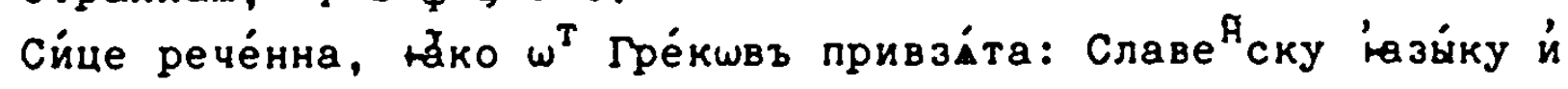
кро́мt си ${ }^{\mathrm{X}}$ состо́ати могу́mу.

оу́⿴囗十

[56]

\section{广ेBWEHIA:}

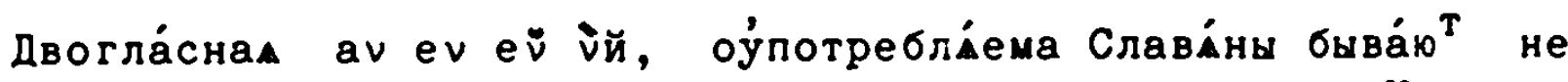
свое́гш и" 'ази́ка дбла, но за прийскрное пйсм" гре́ческих. пйше-

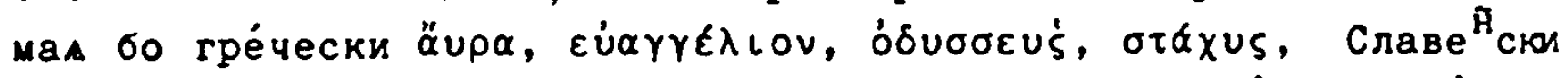

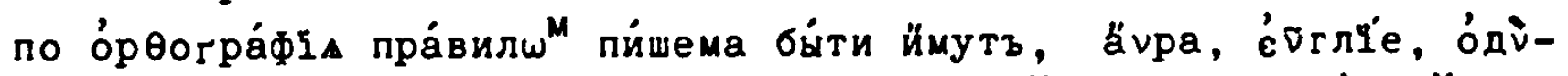

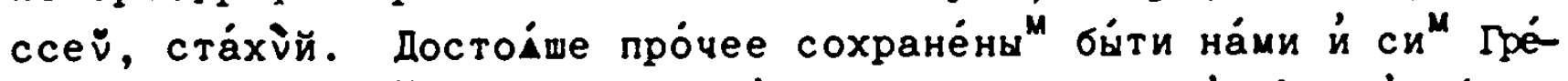

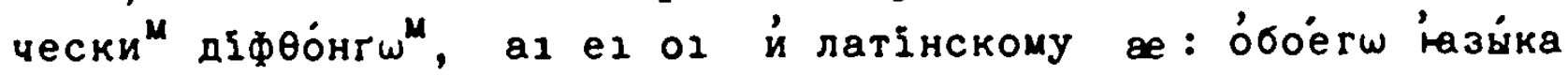
рече́ній дбла Слави́ны оу́потребліемы

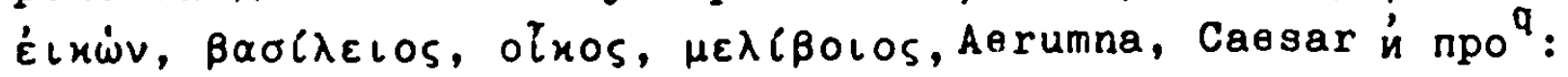

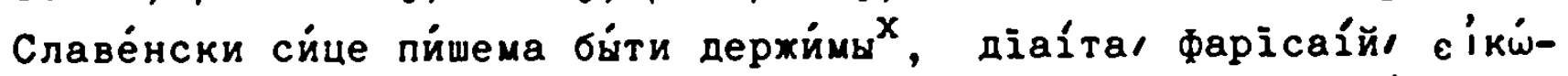
на, Васі́лецй, о̋ıкосъ, мелівоцй/ áеру́мна, ка́есарь. Но́ о́ста́в-

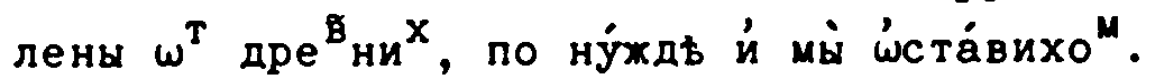

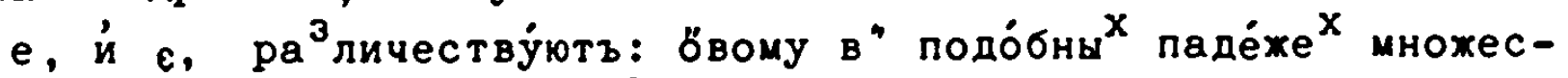

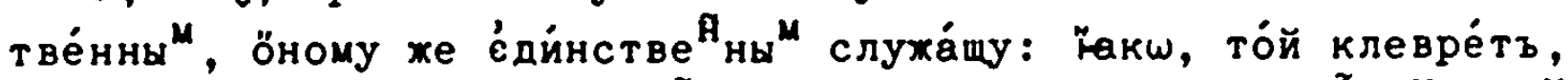

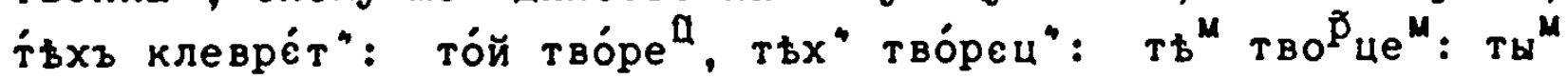

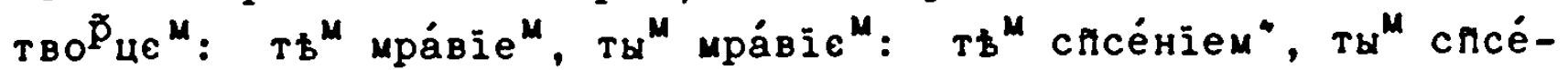
ніє $\varepsilon^{\mu}$, иं про

To ${ }^{*}$ де

То́хде хранимо є́стз ра ${ }^{3}$ личчіе ме́хду $о, \dot{u}$ w: ӧному е́динст-

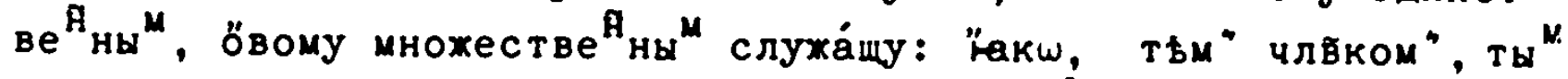
члвкшмъ: тъмъ во́ино ${ }^{M}$, ты ${ }^{M}$ во́инш" ${ }^{M}$ й про

ме́хду и, и́ I: $\mathrm{pa}^{3}$ личчіе е́сть, биному, сіестъ, и: й начина́

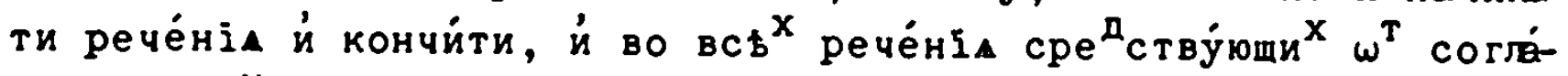

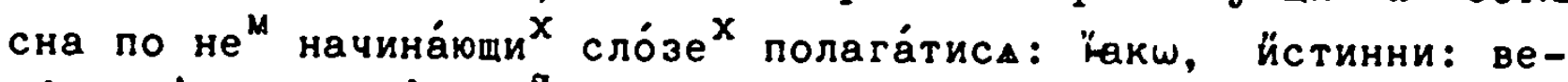
ри́ги: и́м乇́ніе: и́ про ${ }^{q}$ : ठ̋вому, сі́ест", 1: ни начина́ти, рече́ніА

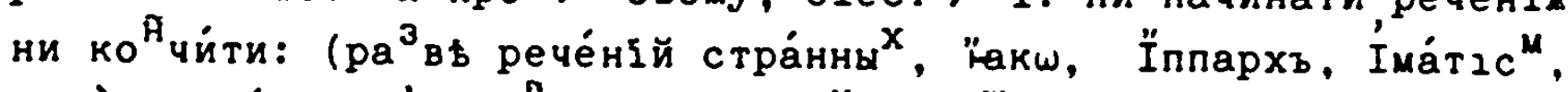

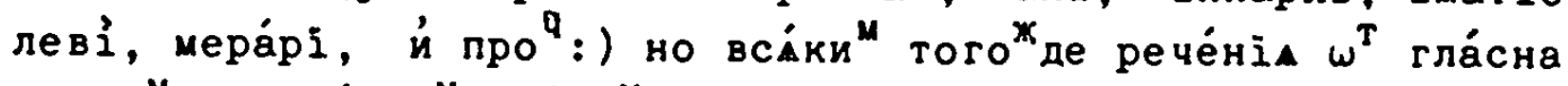

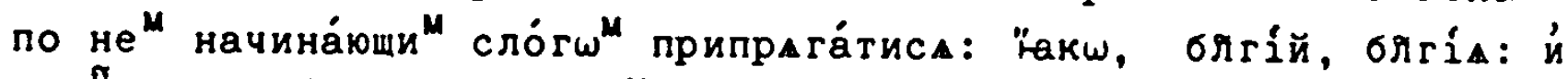
про . Согла́сну же по не сло́гъ начина́юшу в" и, претвора́ти-

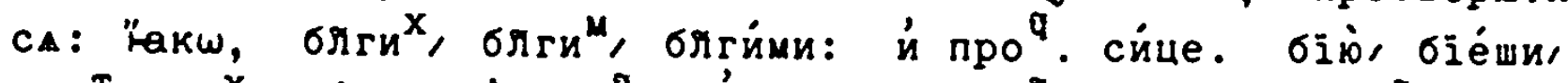
бі $\varepsilon^{T}, \sigma u^{x}$, би́ти:

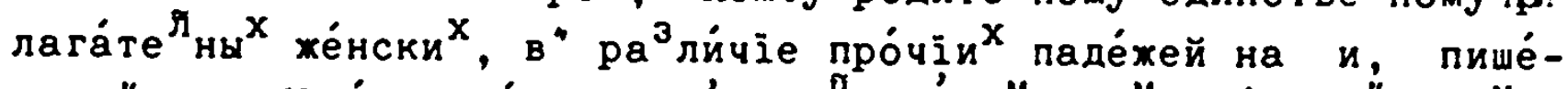

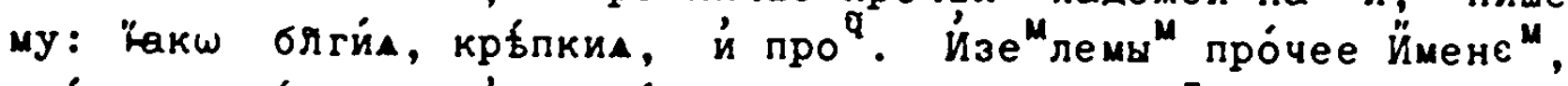
Глймъ, Нарб́чіємъ, и́ прича́стіємъ, $c^{*}$ при пре 


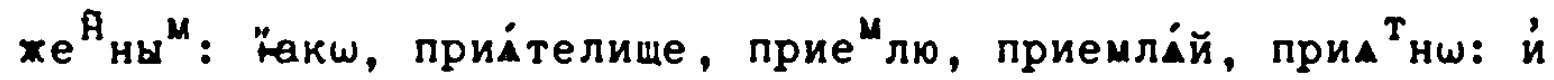
си ${ }^{M}$ подо́бнан.

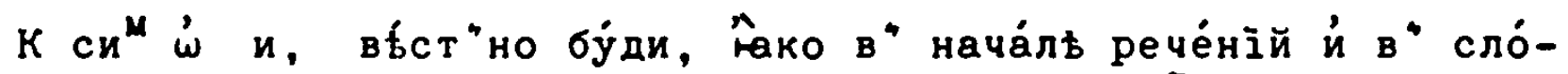
зехъ полага́емо де́белш произно́си ${ }^{\mathrm{T}}$ са: Гакш, йсти ${ }^{\mathrm{A}}$ на, йско́ни: й про . Припрага́emо же гла́сному, и́ $\dot{\omega}$ себі́ сло́гъ твора́mеe, мárки

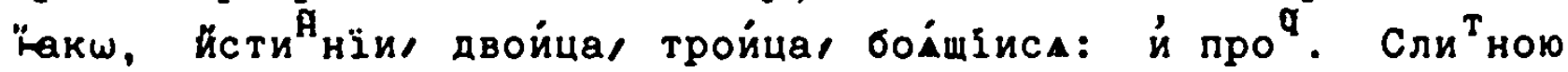
же знаменова́ное, со предиду́щи ${ }^{M}$ сло́го во е́дйнъ сло́гъ сливае ${ }^{\top}$ са:

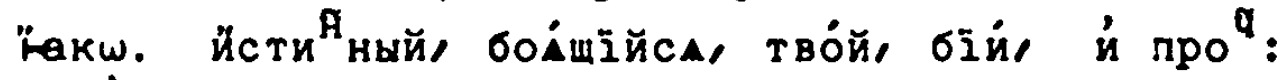

$\dot{и} \mathrm{Cооу⿰}^{3}$, де́белш произно́си ${ }^{\mathrm{T}} \mathrm{cA}$.

й. мбстоиме́нiе, мйгкw.

оу, й : Åmе и́ во всьхъ рече́ніА сло́зехъ нера ${ }^{3}$ личнь помага́емa [-пола-] би́ти 'быкоша. йскуснбйшими оба́че писца́ми, оу $B$ " нача́ль рече́ній. ४, же й у сре́ды й в" концй оупотребліема шбри́-

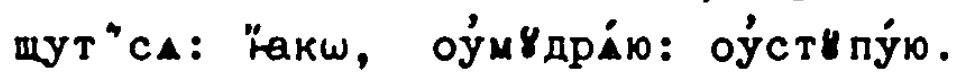

Ф: нбсть писма, нй же двогла́сное, но сло́гъ: тf́ хе боу⿰ва" зае

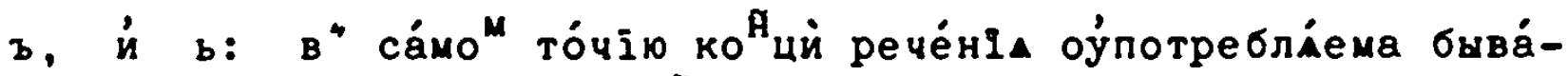

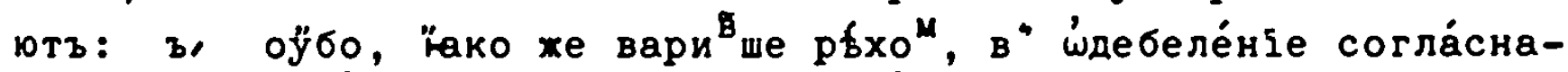

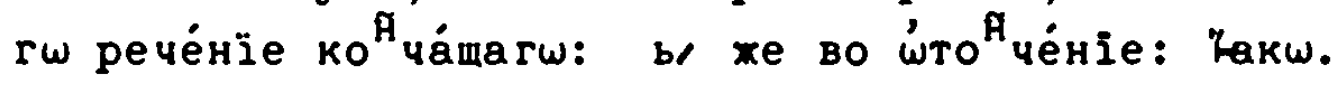

сосудв,

сосу́дъ, че́стенъ: ко́нь, сһо́вень: й про

ы: В нача́ль рече́ніА не полага́e ${ }^{\mathrm{T}} \mathrm{cA}$.

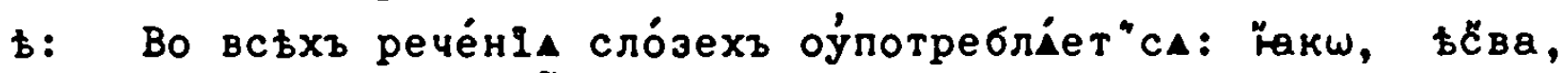
ьс̈та, сньдо́ховь: й про

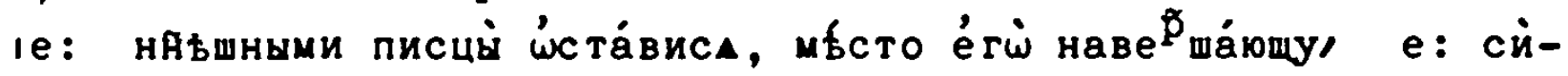
ре cerí le, силу прита́жетъ. Гакш, оуедине́нї, ёстество, й по $q$

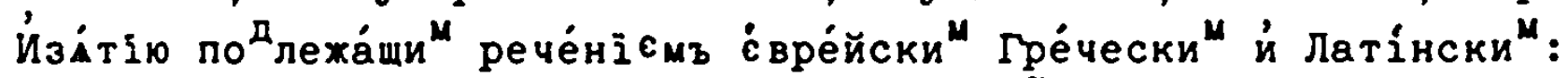

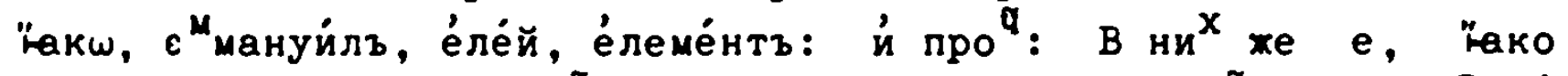
же й в" рече́нйи Славе ${ }^{\text {म }}$ скихъ согла́сному припра́хе ${ }^{\text {म }}$ 廿Іло́ну гре́ческому, йлй е латі́нскому подо́бнь.

10, й $\pi:$, дре́вле йз"глаша́mес, Һко же іо латінское,

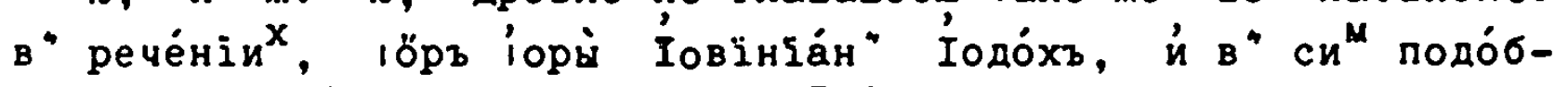

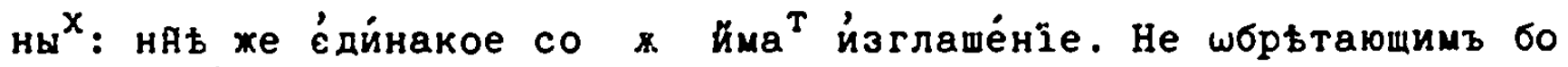
са Славе

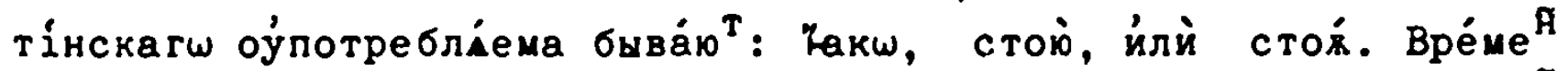
обб́че на́mи писца́ми $\pi$, ஸ́тинюम '́ста́виса, мб́сто е́rw нむ наве ${ }^{\tilde{p}_{\text {ma- }}}$ 


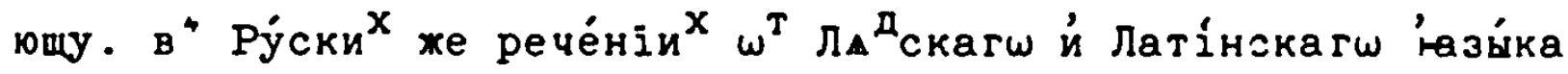

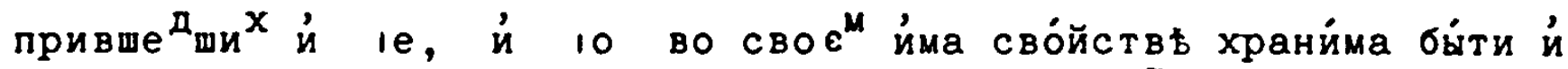

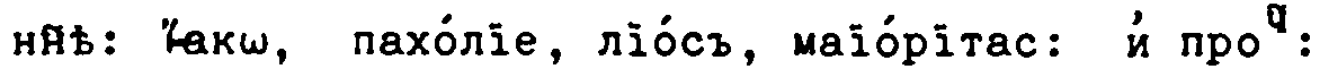

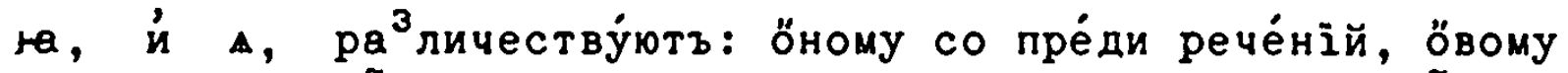
во сре́дь й в" ко ий полага́ему: накш, 'авла́шеса. й про :

¿: Гре́чески ${ }^{M}$ то́чїю рече́нї ${ }^{M}$ ёстъ приклаД̆н, йногда гла́сна-

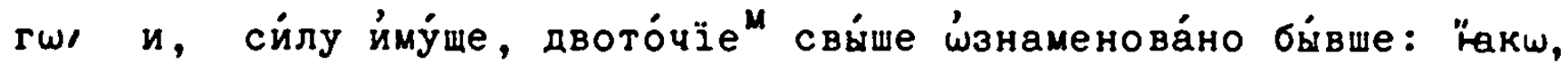

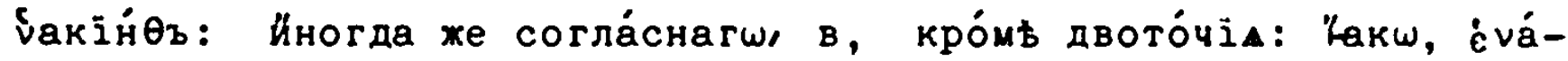
pĩctz.

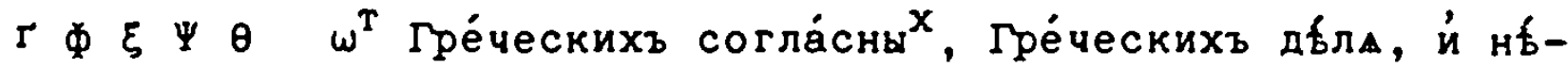

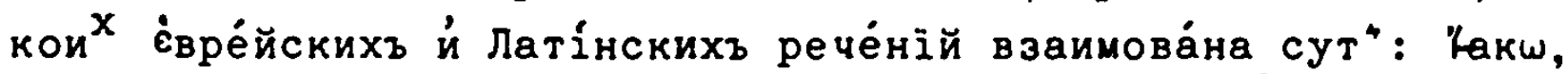

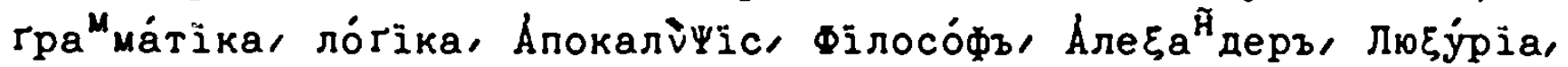

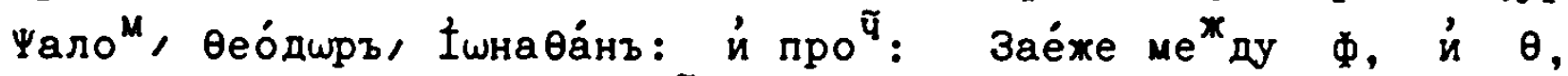
$\mathrm{pa}^{3}$ ли́чїе өі́ль, өїліппъ, фе́кла: но Өеофі́ль, Філіпп", Өе́кла. й про ".

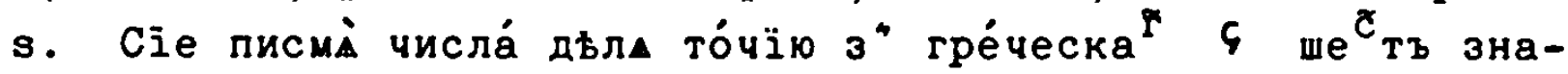
мену́ющагш привзи́са,

Славе

[8]

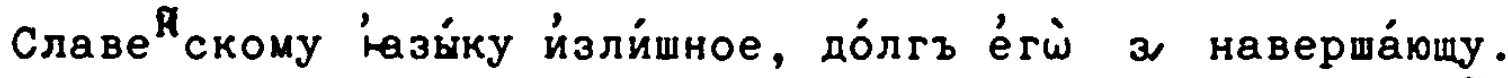

a, $\dot{u} 4:$ el $\dot{u}:$ : потребле́ніА, склоне́ній и́ спраже́ній на́вы, й про́чї несклана́е-

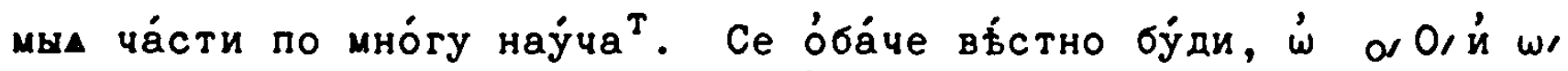

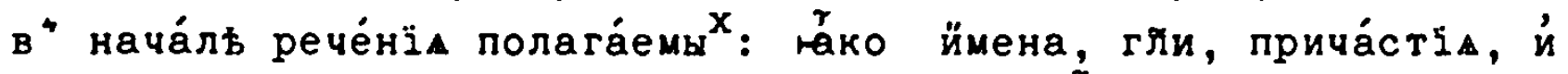

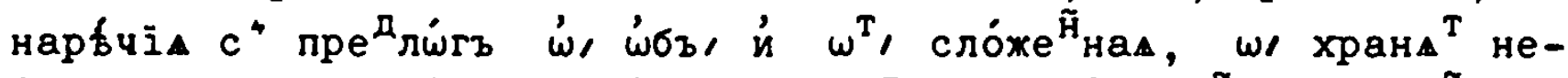

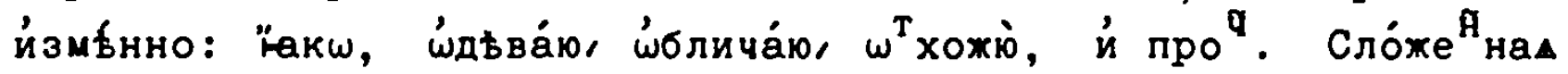

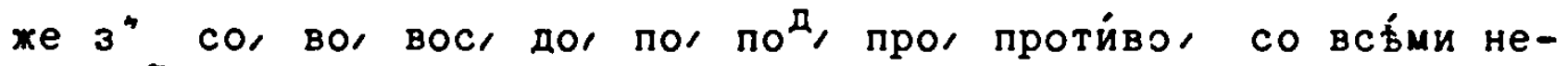

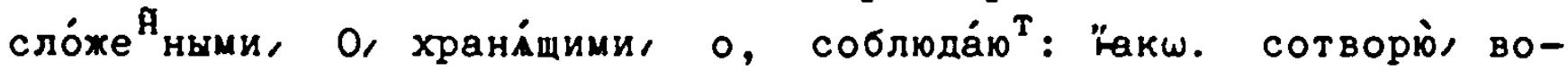
веду, во ведуу, донесуу понесу, поде́млю, прохоху, противоидіу: о̆нъ, ӧсе́л", о̋стровъ, ӧтрокъ, о̋ко, оре́л", о́те́цъ: й про .

ПРАВИЛА ОРООГРАФІИ:

$\Pi^{\hat{p}}$ вое: Ко правописа́нїю нале́жи ${ }^{\mathrm{T}}$, вА́шшими пйсмены пи́шема

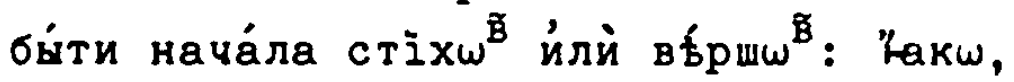

БРу дающу, за́висть ни ма́ла спбетъ:

Не даю́щу же, вса

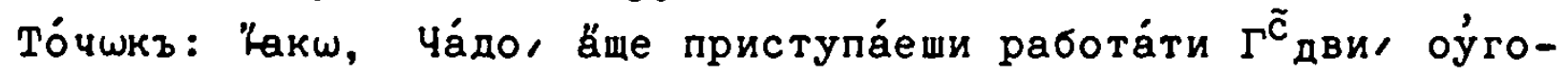
тови 


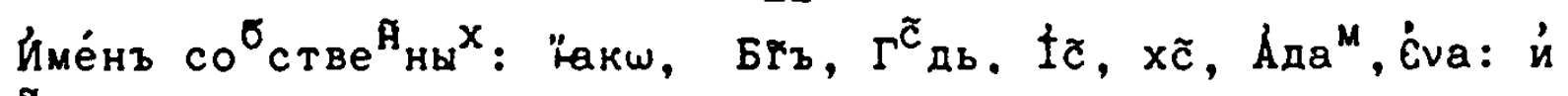
nро 9 .

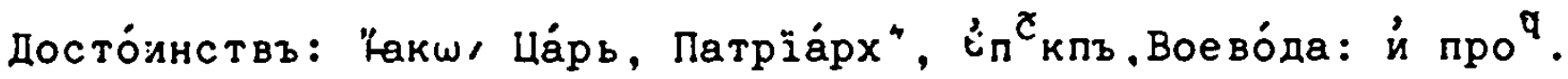
худо́хествъ: "Екш, Грамма́тіка, ло́гіка, Філософі́, өеологі́: й про q.

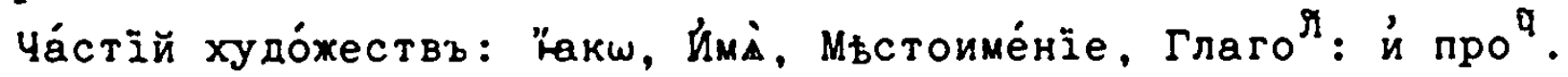
Brópoe:

Пра́вш писа́ти хота́щему, и́ сою $^{3}$ писме́нъ гла́снњ ${ }^{X}$ со согла́сны ${ }^{M}$ в" сло́зђхъ храни́ти о́па́снш досто́ ${ }^{T}$ : да̀ йм же стро́чне полага́емы

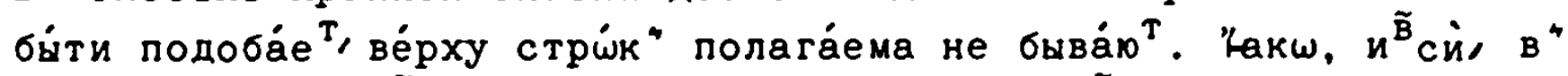

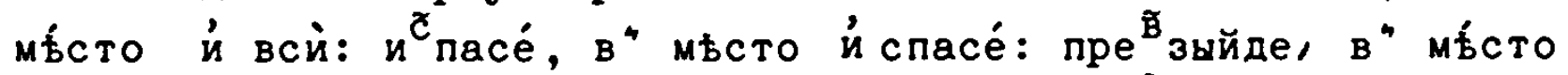

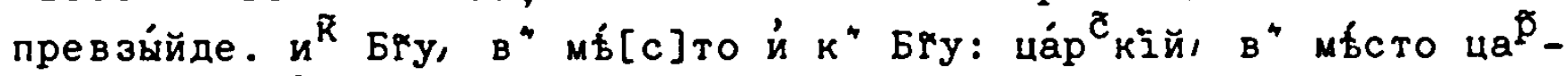
скїй: й про .

\section{Tре́тее:}

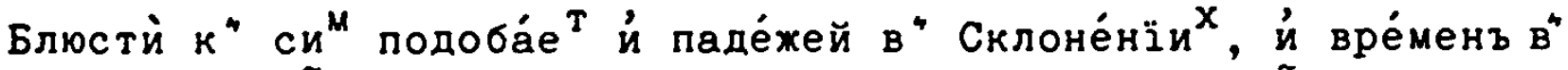

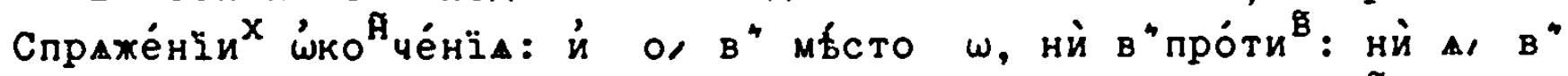

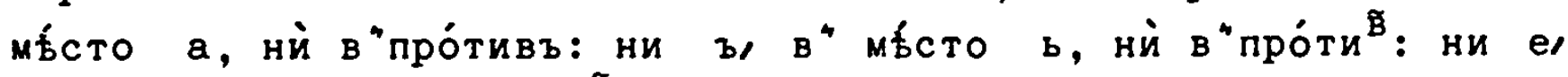

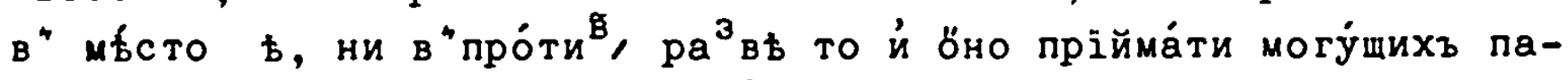

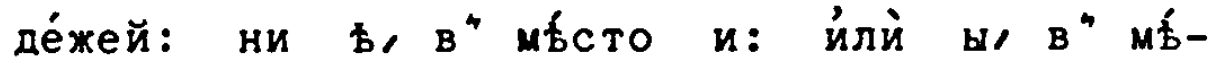

сто и, ни о́бо́ та в"проти полага́ти. Их же оукќ́зы в" паде́же

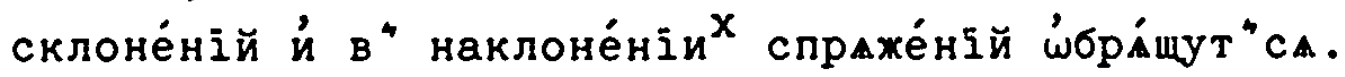

\section{Четве́ртое:}

То́хде храни́мо бу́ди й в" согла́сныхъ нб́́кои": нй же Ф/ в" ми́-

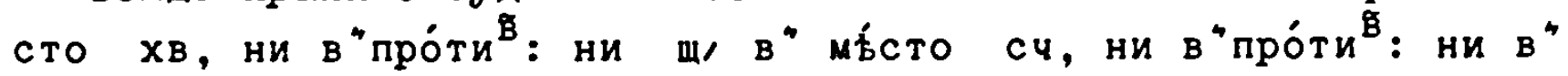

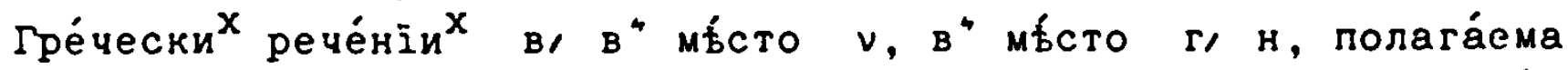
би́ти ймоу' ${ }^{\mathrm{T}}$ : 'Łакш/ хвала̀, á не фала̀: фо́рма, á не хво́рма: и́с-

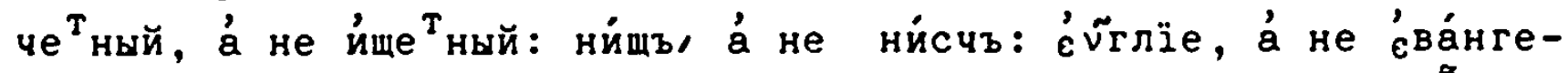

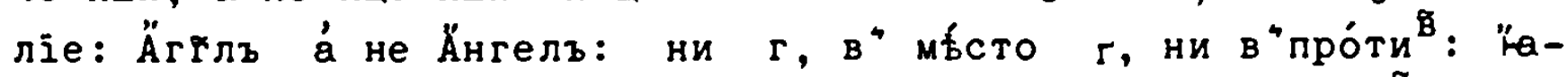

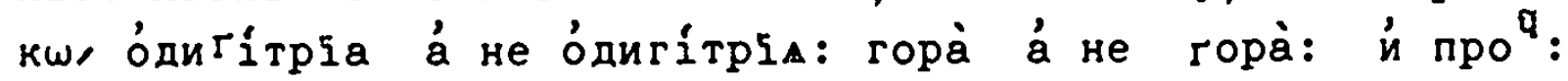

\section{пítoe:}

Onácнш про́чее блюдо́мо бу́ди: во Гре́чески рече́ніи ор ópөогра́фїи Гре́ческой в" Латінски" латінстей храни́мьй би́ти: й во е́вре́йски ${ }^{X} \dot{\varepsilon}$ вре́йстей. "акш, Данійл" Михайлъ/ Мартінъ Фїлове́й: मे про .

\section{Wécтое :}

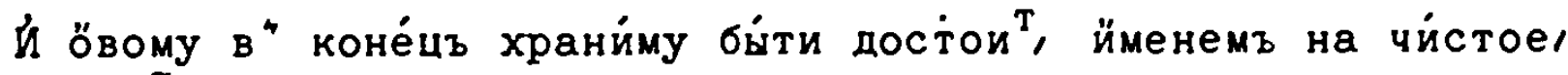
ный, ко Яа ча́щи"са прилйчны бв́ти два̀ нн: "акш, стра́н-

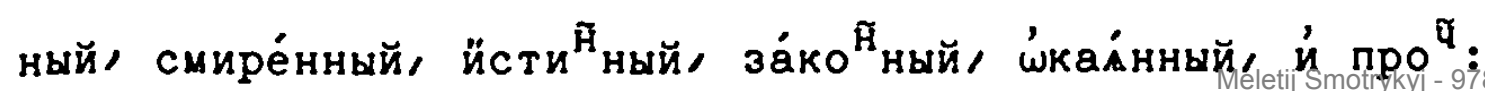


прича́стієм" же е́дйно: "̈акш, чйтаный, смире́ный, чте́ный, Һ́калный, ви́дьный: иं проq.

\section{'ं ПРООСДIИ:}

илй $\dot{\omega}$ оудара́нїи гла́са: Æxe проси́діею ве́р"хнею рече́нїй знаменова́ніе би́ти реко́хом.

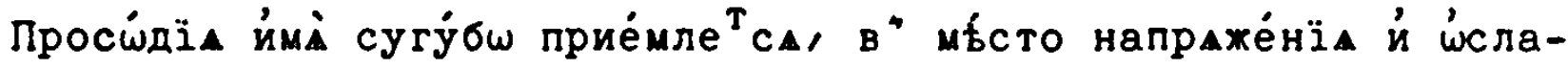

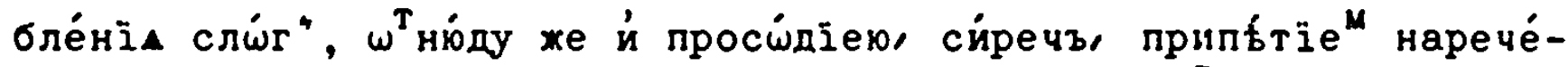
са: и́ в" мб́сто вса́кагш зна́меніа просйдійна. Пер вымъ оўбо ӧбразо приа́то припб́тіе, ко просш́діи стіхотво́рной нале́жи ${ }^{\top}: \dot{\omega}^{\mu}$ не́й

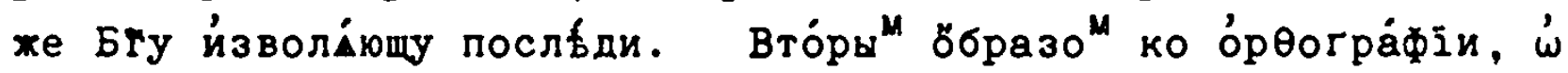
не́й же няь: 'єст" же просбідіА о́рөогра́фіА, во ${ }^{3}$ ноше́ніА йлй оуттис-

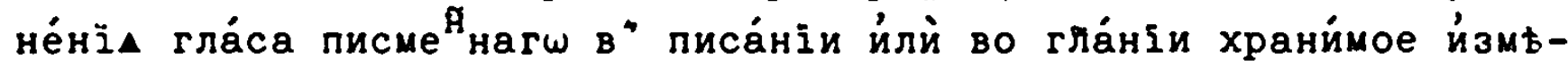
не́нї.

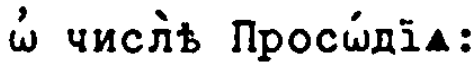

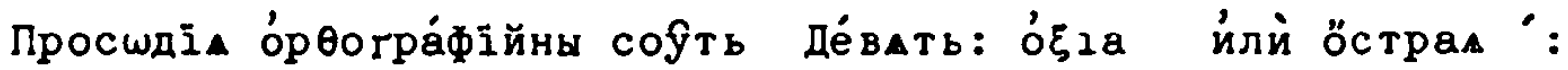

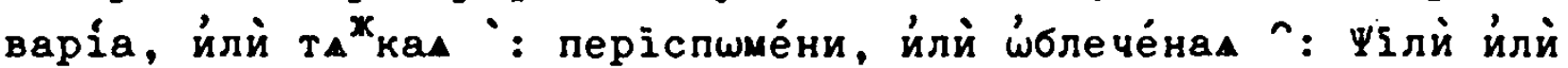

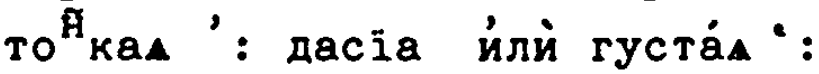

ёрикъ

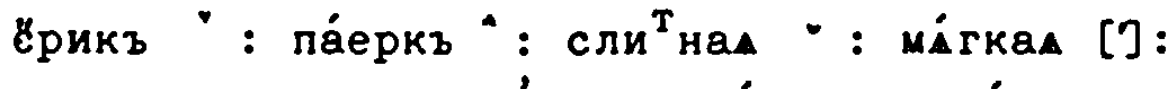

$$
\begin{aligned}
& \dot{\omega} \text { раздьле́нци просш́діА: }
\end{aligned}
$$

Раздьла́ю ${ }^{\mathrm{T}}$ са[!] просш́дїム на четь́ри: на

ஸ́ оударе́ніи:

$$
\begin{aligned}
& \text { Bpéma: } \\
& \text { Дýxъ: и } \\
& \text { Стра́сть: }
\end{aligned}
$$

О’́даре́ніе ёстъ возноше́ніе йлй оутисне́ніе лйбо сре

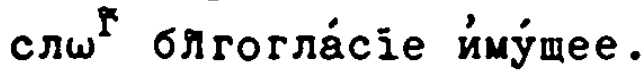

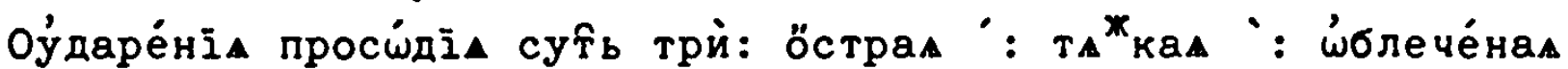

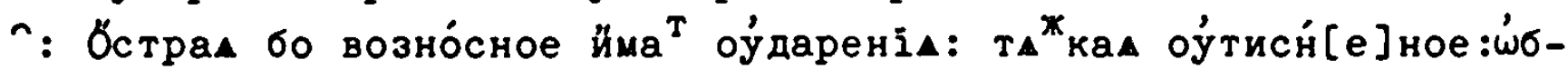
лече́нал, сре́дчее:

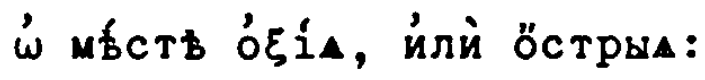

ठ̆стрыа мб́ста $\operatorname{coy}^{\mathrm{T}}$ ше́сть: си́реч" сло́г" (Ко ча́емый:

Преко й́ чемй :

( Пропреко ${ }^{\text {ч }}$ чемый :

(Пре

Пропре Понча́емый:

Непревосхо ${ }^{\text {ный }}$ :

गेBЪЩЕНIE :

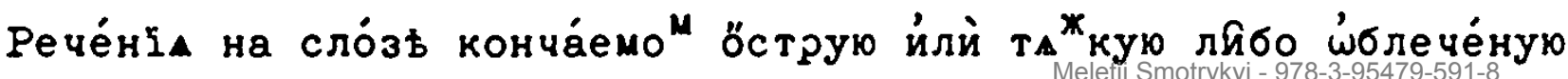


прие мию́ал, изо-

стре́на нарица́ю ${ }^{T}$ са: на преконча́емо нча́емо ${ }^{M}$ пропре[из]остре́на: на пре на пропре Донча́емо ${ }^{M}$, пропре Достре́на: на непревосхо ${ }_{\text {но }}$, непреострима:

\section{Пра́вило сло́ra Конча́емагш:}

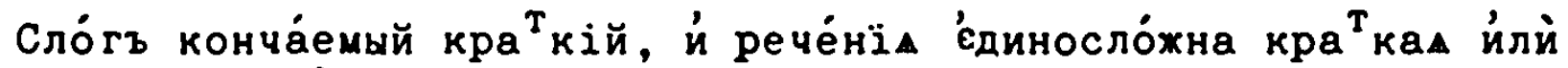

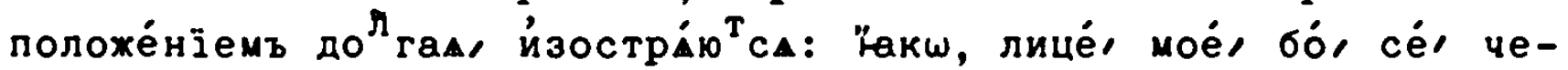

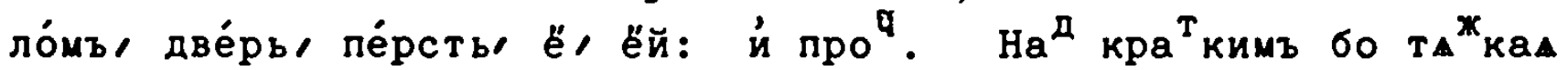
йлй 'ंблече́наА не полага́ $\varepsilon^{T}$ ca.

Прии́скрнье оба́че е́диносло́жны сйцевы ${ }^{M}$ беспросйдїйны полага́емы" быва́ти: "ако же в" ма́ль $\dot{\omega}$ се" рече ${ }^{\mathrm{T}}$ са.

Пра́вило сло́га Преконча́емагш:

Преконча́емый кра́то ${ }^{\mathbb{R}}$ су́щъ, й конча́емый кра́то ${ }^{\mathbb{R}}$ йму́щъ, йзостра́ет"са: "̈акш, сло́во, не́бо, мо́ре, ӧва, й про $\kappa$ " посльдуюшему кра ${ }^{T}$ кому изостріет"са.

Йлй о́бо́й до́лгъ су́щъ: Һакш, дбвы, бъчи: й про .

Йли, конча́емый ойбо до́лгъ, преконча́емый хе кра́тов: Какш, но́вый, ёли: и́ про

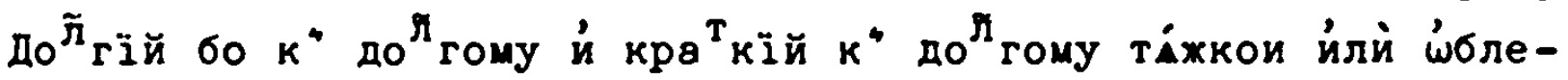
че́нои не прие́млетъ.

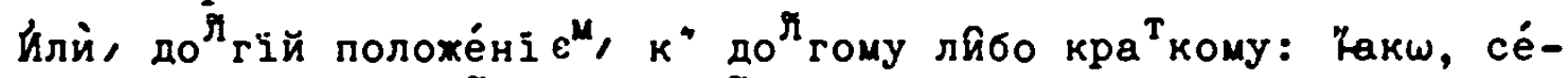

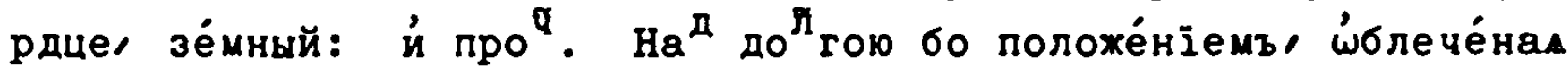
не полага́e ${ }^{\mathrm{T}} \mathrm{cA}$.

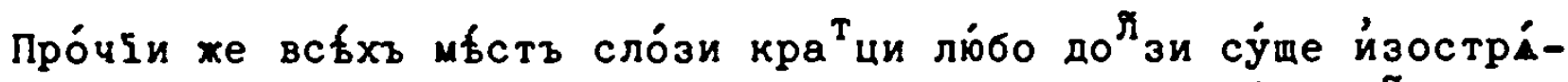
${ }_{10}^{\mathrm{T}}$ са: Пропреконча́емый, Цакш' па́стыра, ёстество: й про Пре нча́емый, Гакш, сваще́нническое, оўзниковыма: й про

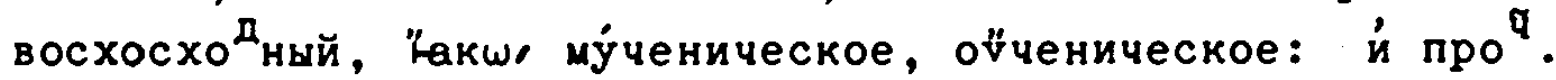

\section{Увъще́ніе:}

Въс ${ }^{\mathrm{T}}$ но К ${ }^{*}$ си $^{M}$ бу́ди, конча́емый иं преконча́емый сло́гъ на сли

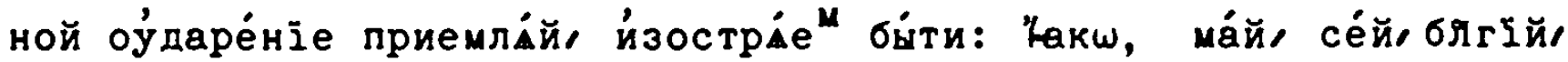
змій, зно́й, любодбйство, сво́йство: й про .

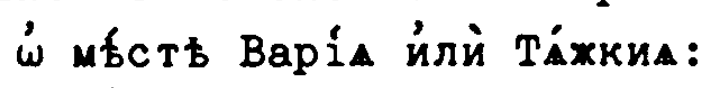

Мы́сто та́жкиА ёстъ е́дйно: Си́речъ, сло́тъ конча́емый ёстествомъ

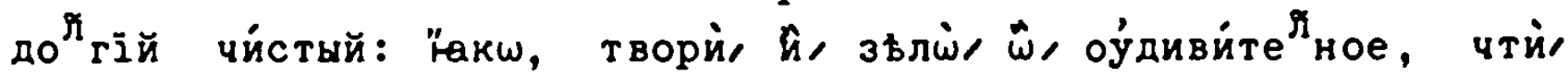


дв̈ь трй: $\dot{и}$ про

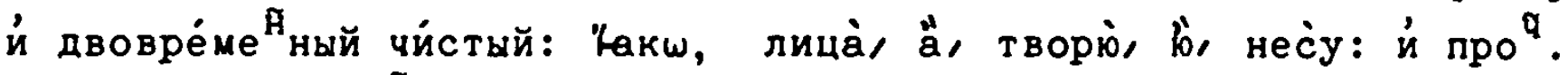
ра́звъ ёже йзостріет" са.

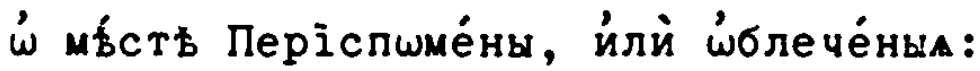

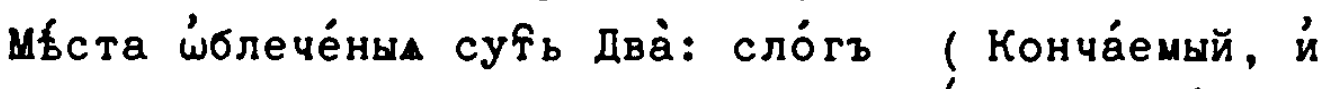

(Прекончв́емый :

Пра́вило сло́га Преко й ча́емагш:

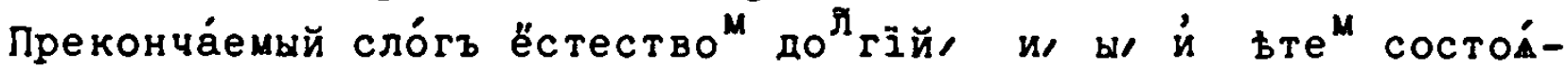
щій, конча́емый ёстествомъ кра́то ${ }^{\mathbb{R}}$, ёстом, йлй ӧ, ном состод́ш" й-

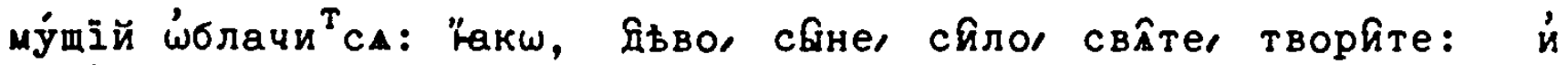
про . Йза́ты ${ }^{M}$ рече́нї $\varepsilon^{M}$, два் йлй мно ша согла́сна ёстество до

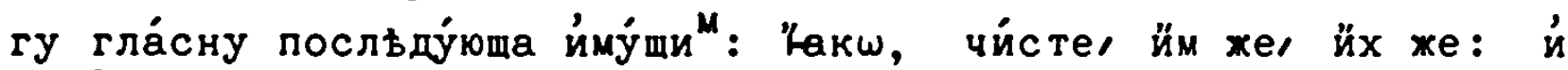

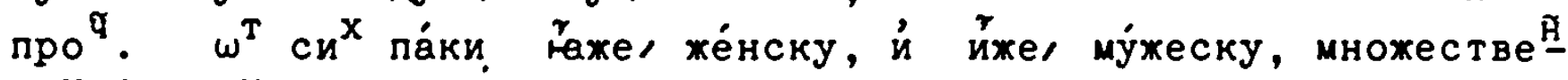

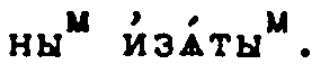

\section{Пра́вило сло́га Конча́emarw:}

Рече́ніА е́диносло́жна й мно́госло́жна на конча́емо ${ }^{M}$ ёстество

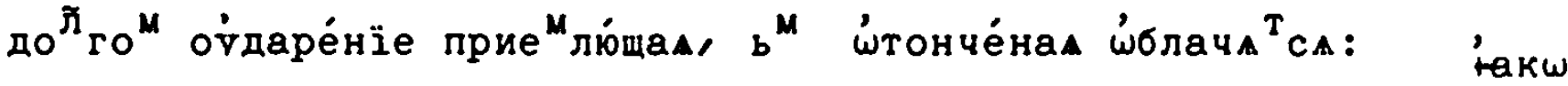

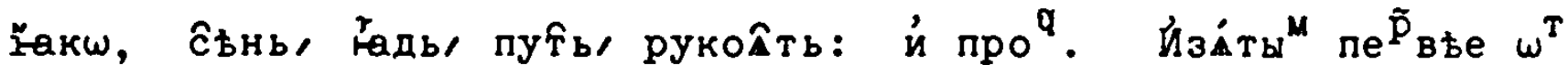

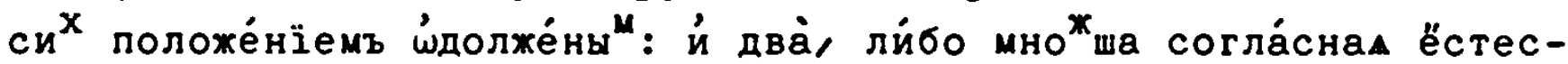
твомъ до́л"гому гла́сну посльду́юща йму́щи": "Һакш, сме́рть, со́хль, тро́сть, вб́твь/ вйждь: й проq.

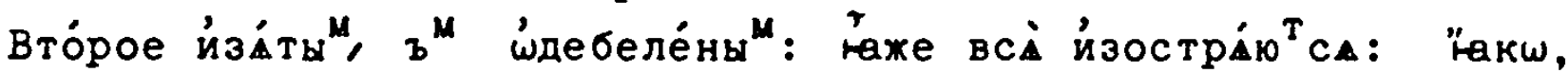
всі́къ, человбкъ, кре́стъ, сьдйтъ, твойхъ, и́ про : ра́звь $\omega^{\mathrm{T}}$ сь-

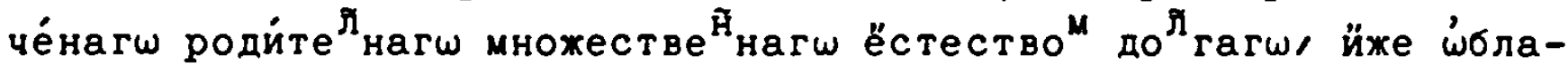

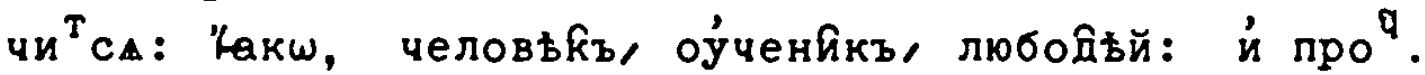

\section{уे вще́ніА:}

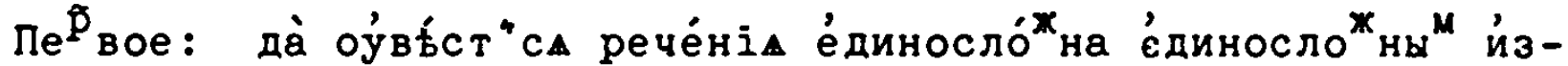

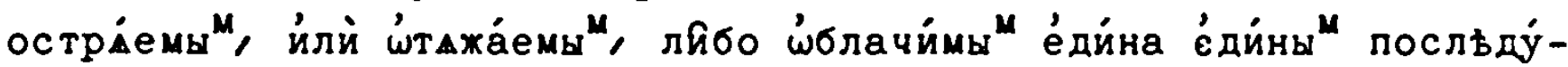
юша бе ${ }^{3}$ просйдійна полага́ема быва́ти: "̈акш, что́ се' что́ е́стъ, мы́ бо, да́д ми, мйр"ти, бы́ст ми, кто́ сей, й пр".

Bто́poe: ра́внь рече́нї ${ }^{M}$ двосло́жны ${ }^{M}$ й мно́госло ${ }_{\text {ны }}{ }^{M}$ на конча́емо ${ }^{M}$ изострдемы ${ }^{M}$ йлй '́тажа́емы лйбо 'бблачи́мы ${ }^{M}$, прилага́емаА е́ди́носло наА рече́нїа бе ${ }^{3}$ просйдїйна полага́ема быва́ти, та́жкой й '́блече́ной в" 


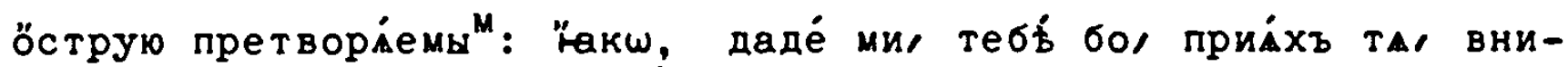
ма́й ми, прочти́ се, й про .

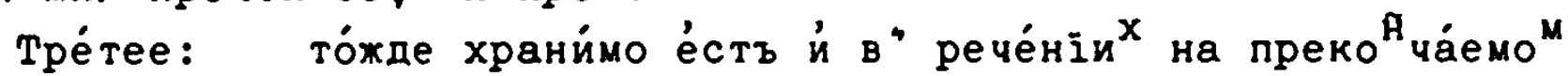

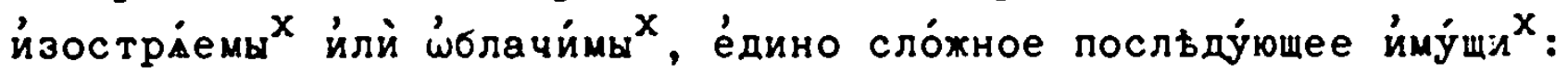

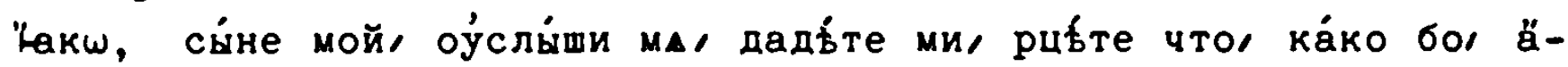
ще ли, ста́ни зде, и́ про : Еৈе все́ во всы́⿱ сло́ва ча́стех" хра-

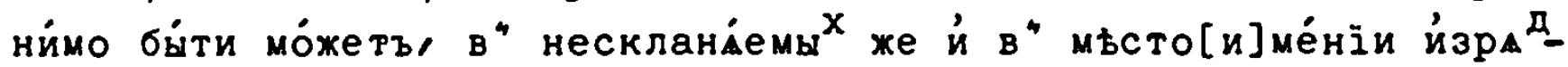
нье.

$\omega$ Временй:

Bре́ma ко просш́дїи стїхотво ной нале́жи ${ }^{T}$, ёст" же протаже́ніе йлй сокраще́ніе гла́снагш лйбо сло́га:

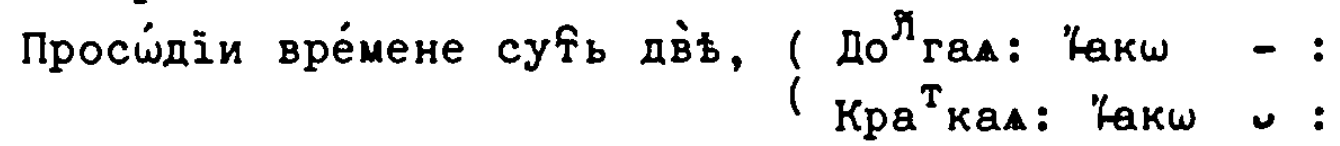

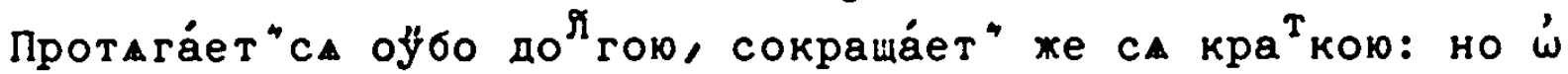
$c e^{M}$ посль́ди.

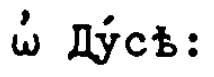

Ду́хъ ёстъ йзноше́нїе рече́ніА '́гуще́ное илй '́тонче́ное.

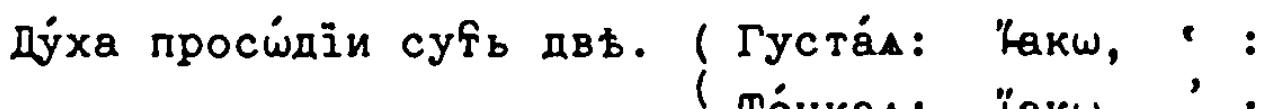

(тонкаa: 'Гакш,':

ஸ́гуща́eт"ca ойбо густо́ю, То́нкою же '́тонча́ет"сА.

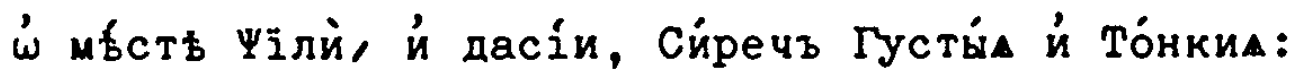

Густа́ полага́ет"са со пре́ди рече́нгй Гре́чески

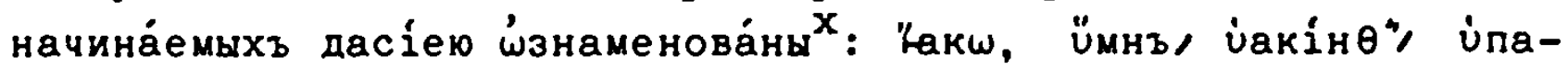
ко́й: й про q.

То́нкал в" нача́ль рече́ній всь ${ }^{X} \omega^{T}$ гла́снагш начина́емы ${ }^{X}$ Саве́нских, й нб́коихъ Гре́ческихъ й Латінскихъ: "Һкш, е́чноуХ, ärнец*, Ӓдвена: 'и про

Оуввьие́ніе:

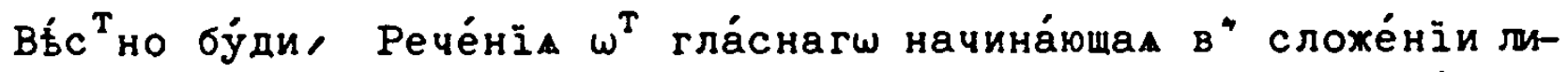

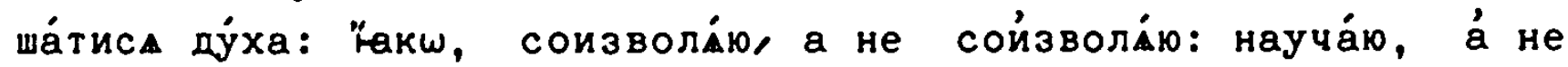

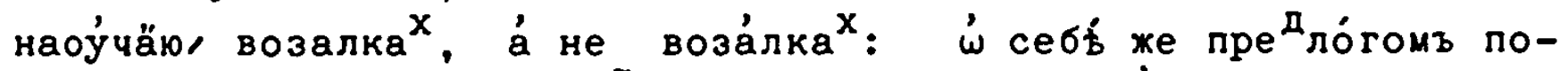

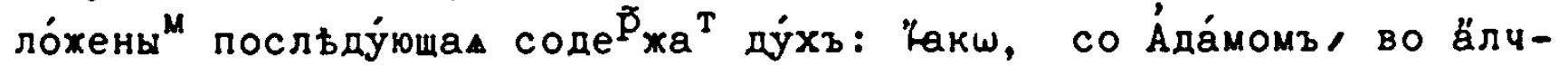
бђ, ко ӓгниу: й про q.

¿́ Стра́сти:

Стра́сть е́сть ка́чество гла́са оумале́ніе постра“дшагш, йлй припрА "ногла́снагш $\omega^{\mathrm{T}}$ ложе́ніем", и́лй дв̀у сло́гу в" е́дйн сло́гъ с"ли́тіем", лйбо согла́снагш оумагче́ніем".

Проси́

[136]

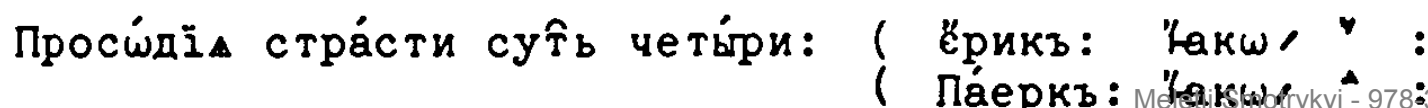




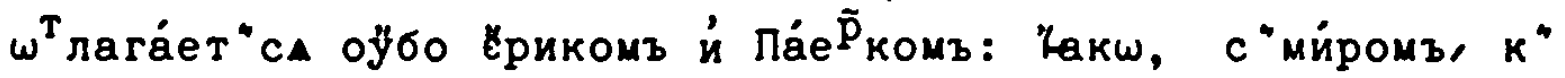
Бг̃у, в" до": в" мбсто со мйро", ко Бгу, во до": в"ну́тр члка, " "

Й па́еркъ оӱбо на рйвше рбхомъ, во и вьща́ніи тво́ритъ.

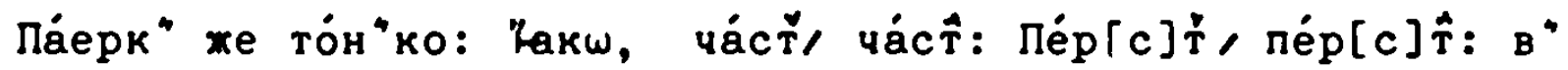
мбсто ча́стъ, ча́сть: пе́рстъ, пе́рсть.

Сли́тною слива́ет"са: 'Какw, мо́й, ма́й, Мойси́й, змій

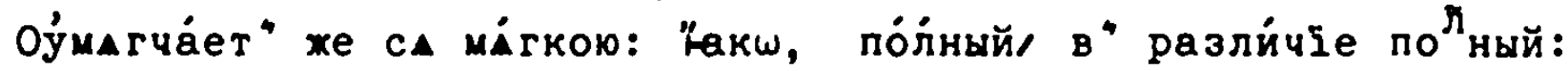
во́ н́xе, в разли́чіе во́нже и́ кройы разли́чества: Какш, Со́ниъ: хва́линый, суд́ба். й проq.

¿́ мfсть Е́рика й Па́ерка:

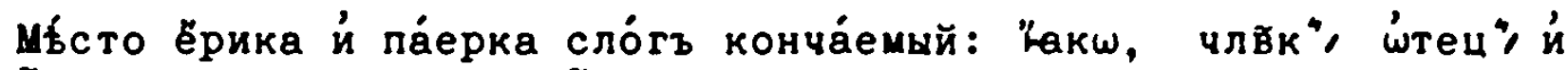

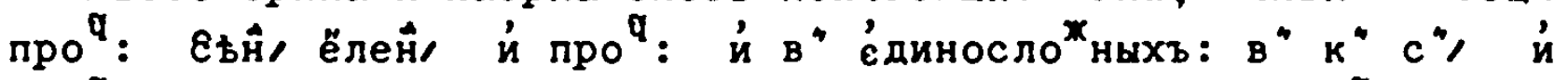
про : в" мбссто въ/ къ, Съ: йлй во, ко, со, й про". $\dot{\omega}$ mf́ctb Слитныa:

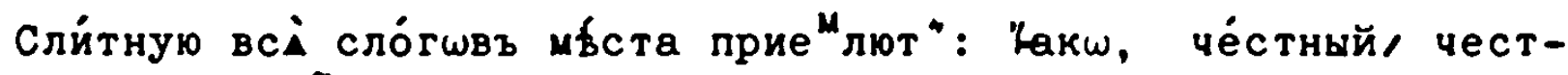

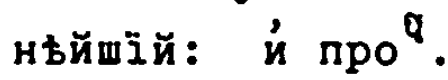

\section{$\dot{\omega}$ мбсть мігкиа:}

мírкan полага́eт"са в" ро́гъ де́сный пи́смене оумагча́emarw: "a-

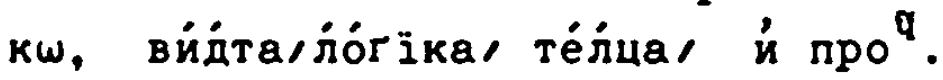

\section{'ं ПТРЕПИНАНІИХъ СТРОЧНЕІХъ:}

Препина́ніа стро́чна суть де́сать: черта̀, : запата́ ,: двото́-

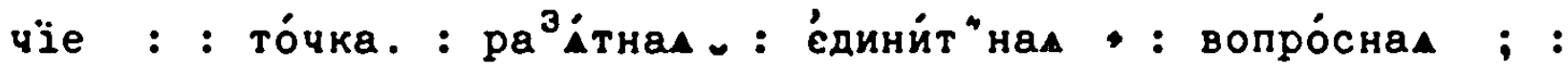

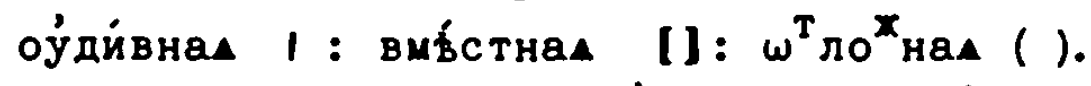
$\dot{\omega}$ мв́сть Черты:

че та̀ полага́ет"са по нача́томъ гла́ніи в" ма́ль востор гненомъ, $\omega^{T}$ до́хомъ о́бáue не препі́томъ.

$\dot{\omega}$ mfств zanatbia:

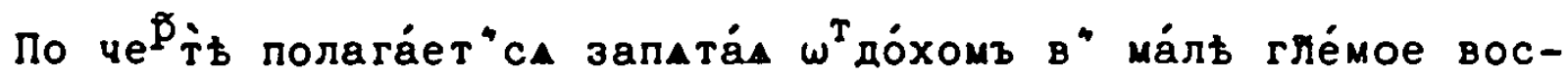
то[p] ráomaa й препина́юmaA.

¿́ mfсть Двото́чїа:

По запато́й полага́етса двото́чіе, ра́зуму гле́магш сло́во пре-

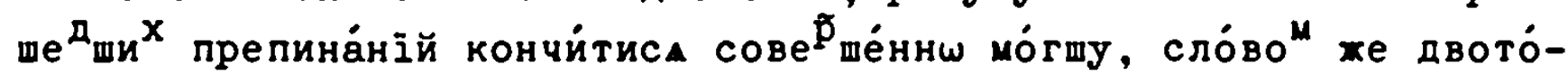
чіс нѐу в" соверше́ніе прише

шу, $\omega^{T}$ до́хомъ оба́че востор гáemy й препина́ему. 
’́ мб́ctb То́чки:

По двото́чіи полага́eт"са то́чка, соверше́н" гле́мarw ра́зумъ заключа́ющал: $u^{x}$ же всб́⿱一ъ во оу́ка́зъ, Блхе́нъ му́жь, йже не́ иде на совб́тъ нечести́вы”, й на путй грбшны не ста̀, й на съда́лищи гу

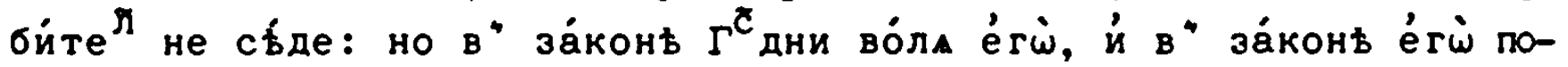
оуччитса де́нь й но́щь.[ОБ, Чл.I, I-2]

$$
\text { '́ mf́ctb } \mathrm{Pa}^{3} \text { ÁтныA: }
$$

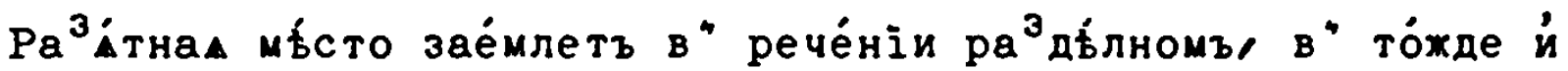

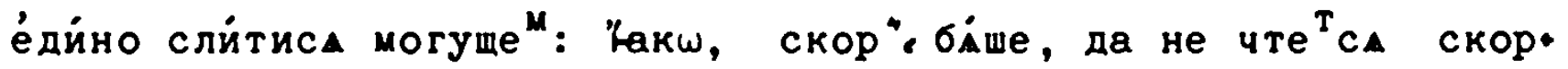
ба́ше: не.су́щимъ, в" ра ${ }^{3} л \dot{u} ч і е$ несу́щим".

$\dot{\omega}$ мбсть દ̇дини́тныа:

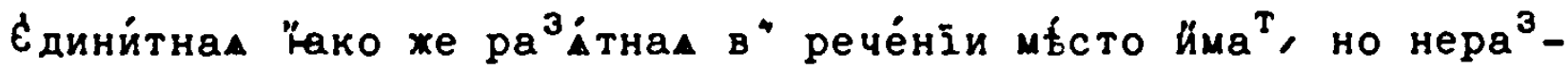

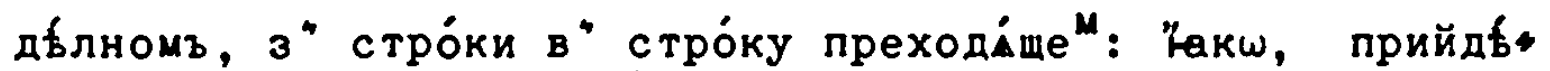
те поклоньм" са: $\dot{и}$ про".

\section{¿́ mb́ct}

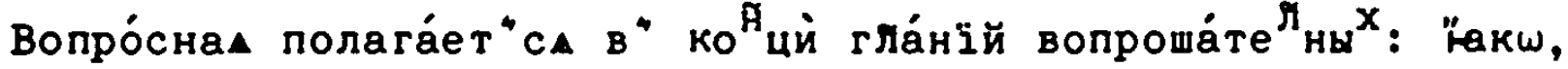

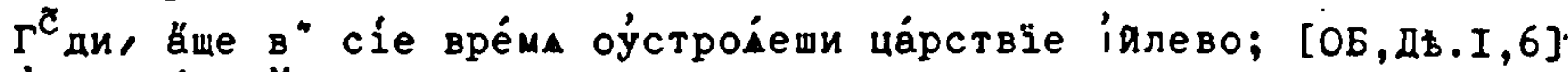
и, рий на $\mathrm{a}^{\mathrm{a}}$ когда́

когда́ сіп бу́дутъ; й что 【е́стъ] зна́менїе твое́гш прише́стві̃ й кончйны вбка; [ОБ, Мө.24,3] й про".

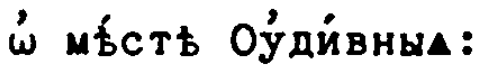

О’́ди́внаА полага́ет"сА в" концй гла́ній оу́диви́те

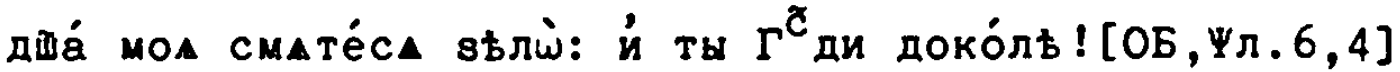

\section{ம் mf́ctb Bмf́ctнHa:}

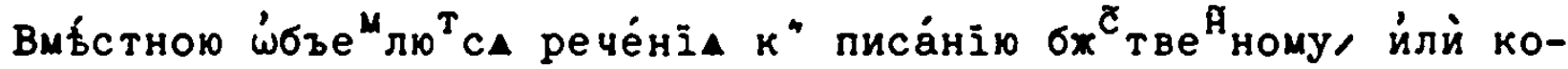
ему́ ли́бо чу́хдему, в" коне лага́емал, йлй $\omega^{T}$ предиду́щихъ лйбо $\omega^{T}$ посльду́ющи зае́млемам: ${ }^{M}$ же не су́щи" ра́зум" сокрове

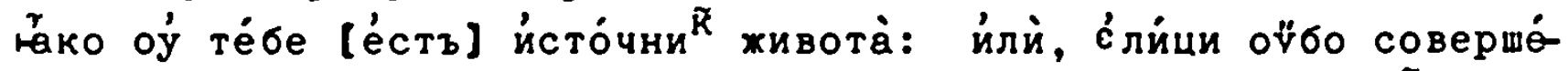

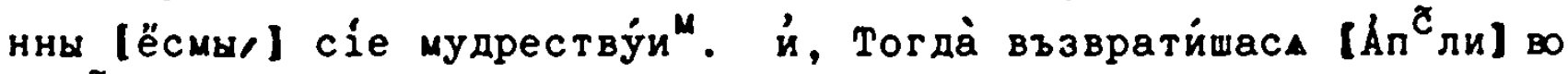

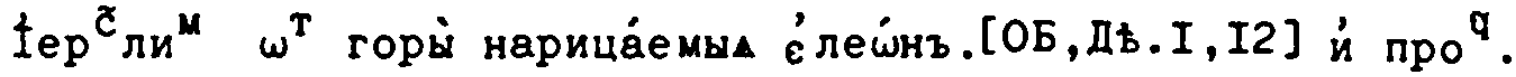

$$
\dot{\omega} \text { мбстt } \omega^{\mathrm{T}} \text { ло́жныа: }
$$

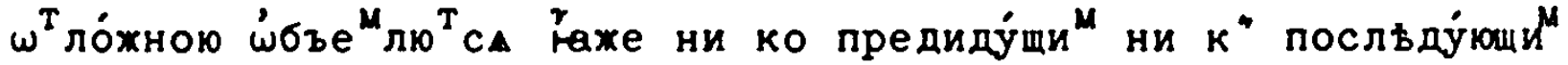

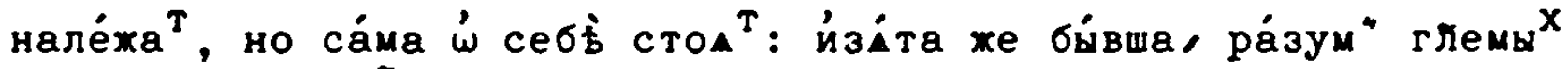
ив́лъ й соверше

$$
\kappa \omega \text {. 'ं }
$$

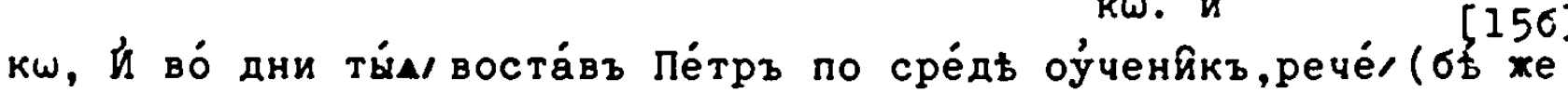

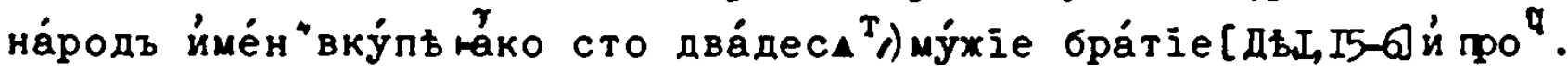


$\dot{\omega}$ тітль й $\dot{\omega}$ Словотітль: $\dot{и} \dot{\omega}$ под ними пйшемыхъ:

ті́тла пише ${ }^{\mathrm{T}}$ са сйuе, $\sim$ :

Словотітла же си́це, $\sim$ :

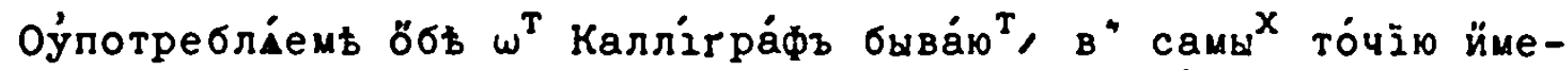

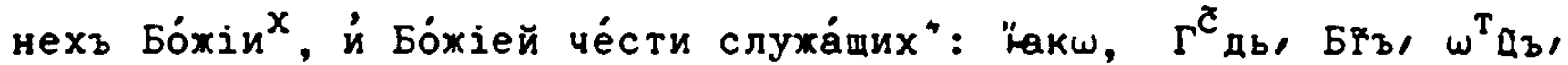

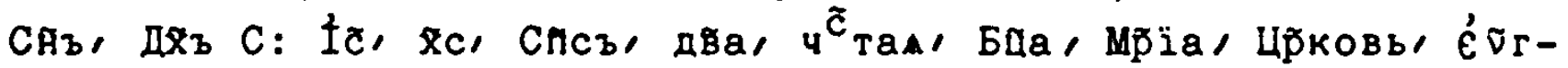
лї, Сйце прв मоре хс: й про

Коне́и" во кра" ць со́браныа ठрөогра́фі৯.

Сла́ва Бйу соверши́вшему.

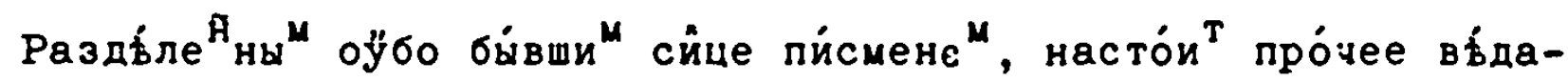
ти что́ е́стъ Сло́гъ, что Рече́ніе, й что Сло́во.

\section{‘े сло́зь.}

Сло́гъ быва́етв c" писме́нъ. Ест" же сло́гъ дву йлй мно́гихъ пи-

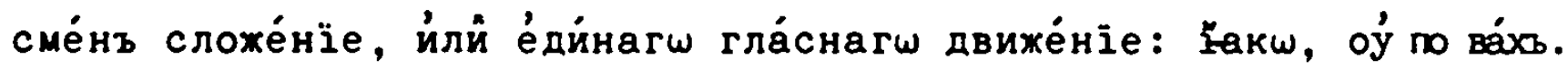

ڤ́ Рече́ніи:

Сло́зи произво́да Тече́нiе. Єст" же рече́ніе, сло́гами соста́вленое ве́щи нарече́ніе: "акш, на̀ ми́лость.

ம́ сло́в :

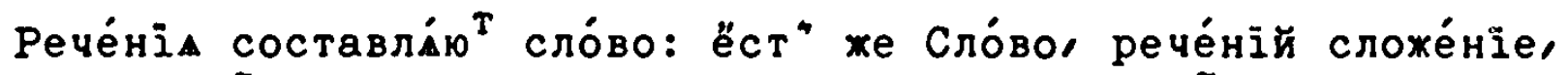

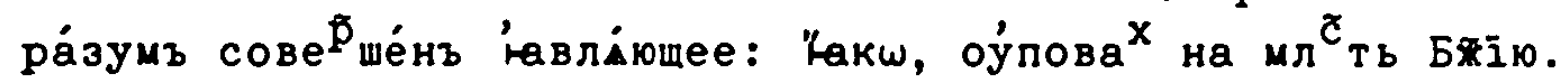

'́ етімологІи:

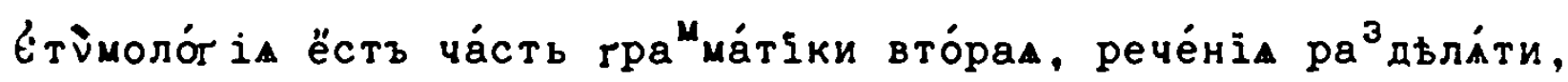
й ко свое́й кое́ждо сло́ва ча́сти со ра ${ }^{3}$ сужде́ніемъ $\omega^{\mathrm{T}}$ носити оучча́maA.

\section{’́ о́смй ча́стехъ сло́ва:}

ча́сти сло́ва сутิь ӧсмь: Йма: Мьстоиме́ніе: Глаго́ль: Прича́стїе: Нарб́чїе: Предло́гъ: Сов́зъ: Мећ доме́тї.

\section{Оуввъие́ніе:}

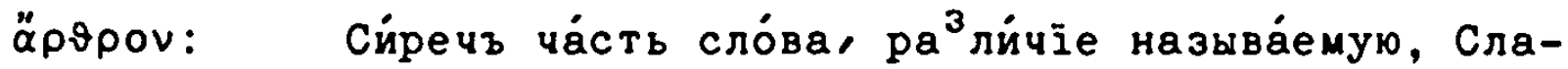
ве́нскому 'ази́кови несвойстве́нну йста́вихо

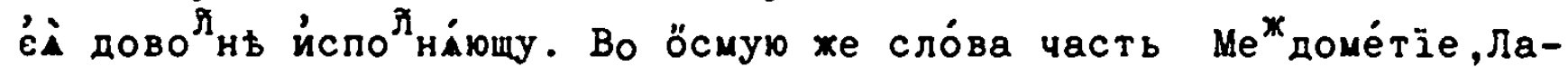
ті́нски interiectio называ́емую свойстве

$$
\text { В Свойстве нь приххо. } \mathrm{Pa}^{3} \text { дь }
$$

Раздьле́ніе ча́стій сло́ва:

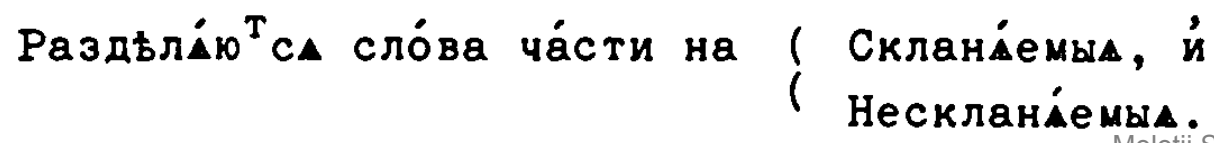


Скландемы сутিь четь́ри, Йма: Мъстоименне: Глаго́лъ: Прича́стіе. Нескланйемыа чети́ри, Нарб́чіe: Пре Tìe.

\section{¿े ИМ ЕНИ:}

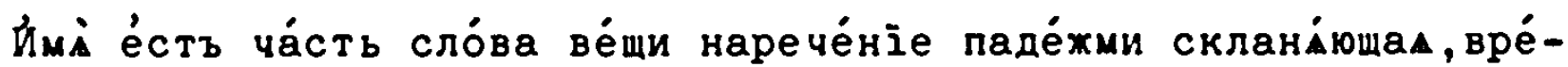
мене же дй́̆ство и́лй страда́ніе знамену́ющагш, не иму́щам.

\section{Раздьле́ніе Имене:}

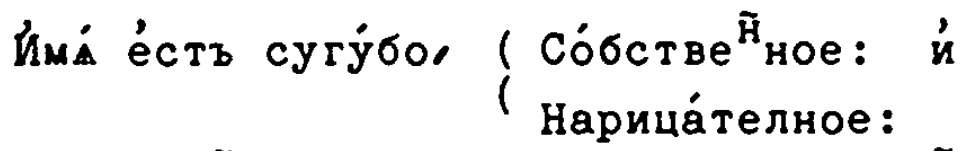

Со́бстве

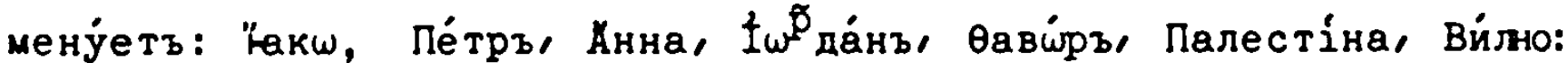
ห่ про .

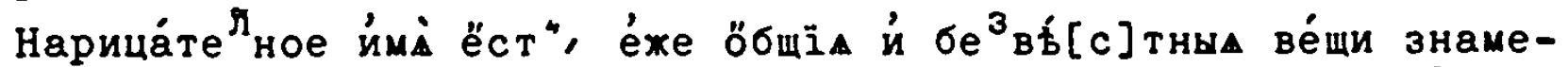
ну́етъ. Юка, о́те́цъ, ца́рь, дб́ва, град, дре́во, ко́нь, й проq . $\mathrm{Pa}^{3}$ дьле́ніе ймене Нарица́телнагш:

Нарица́

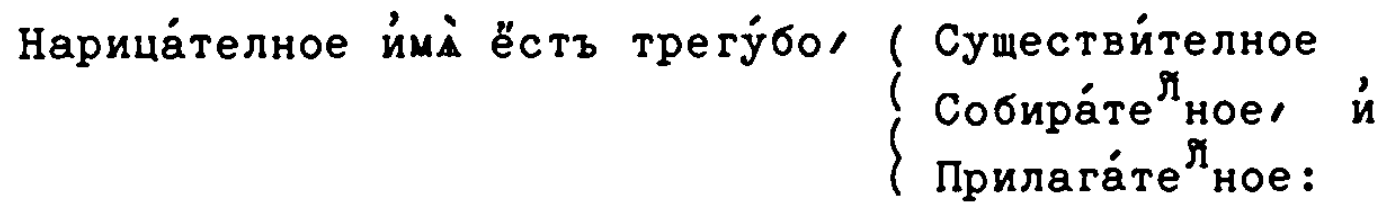

Сушествйте ное ймі ёстъ, е́му́ же прило́хено бы́ти не мо́хетъ,

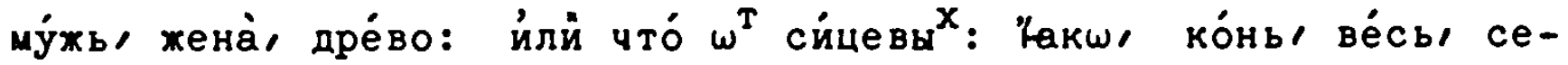
ró: í про

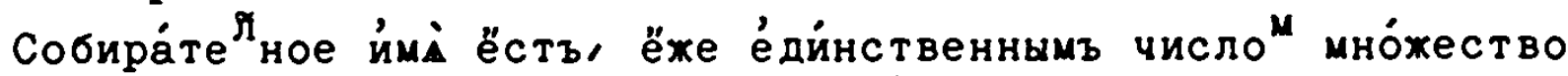

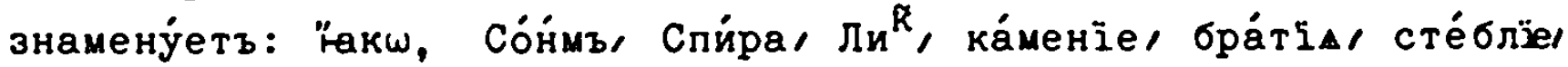
зе́ліе: й про

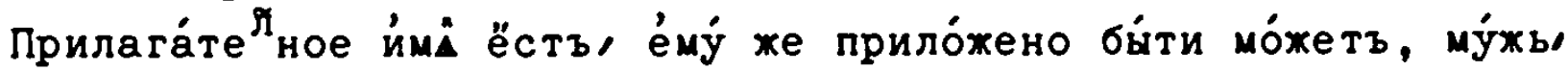

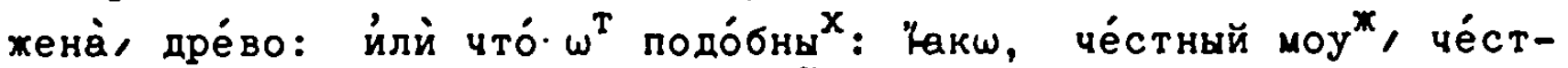
наА жена̀, че́стное дре́во. й про .

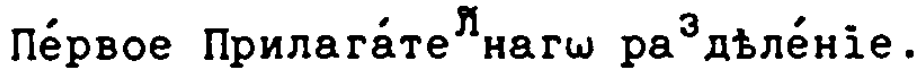

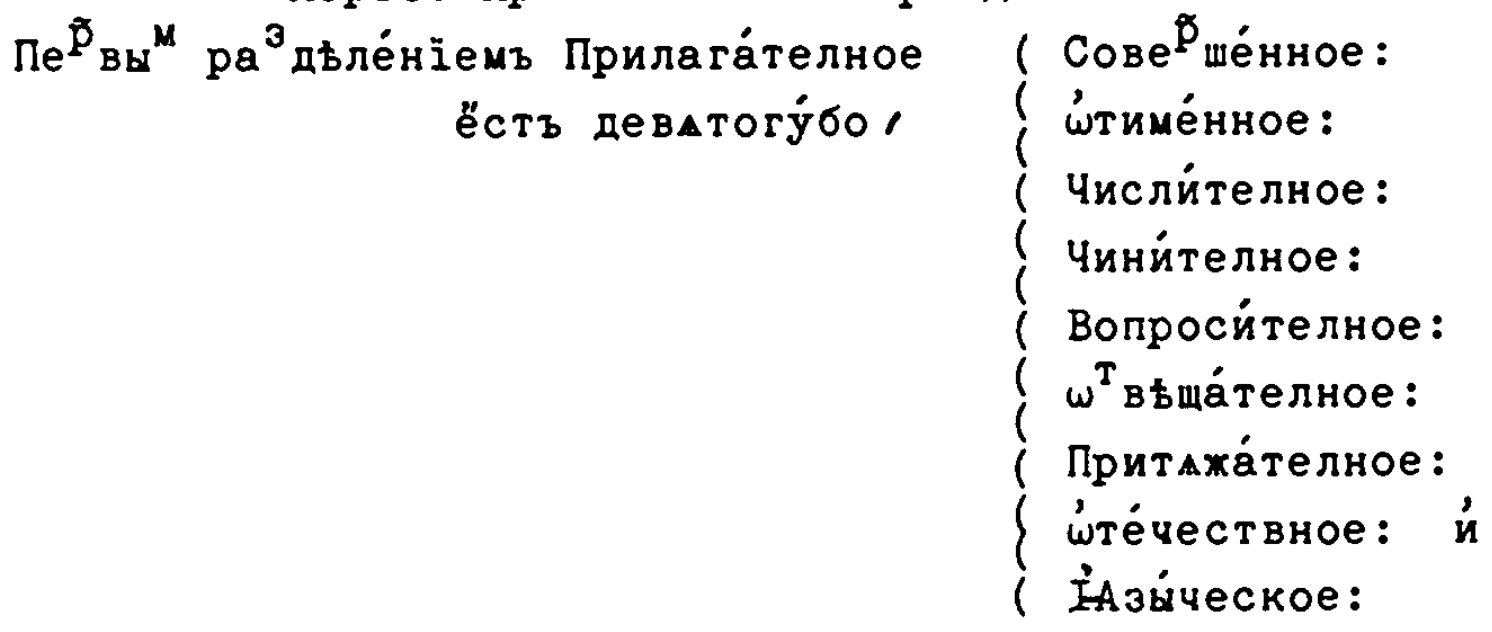


Сове

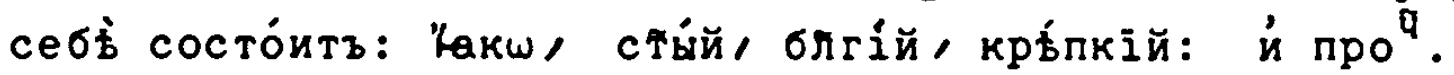

ஸ́тиме́нное ёстъ, ёхе $\omega^{T}$ нарица́телныхъ нб́кои ${ }^{X}$ йме дит": Кекш, желб́зный, древи́ный, ка́ме ный: й про".

числите "ное ёстъ, ёже число́ знамену́ет" про́стш: "Њакш, е́дйнъ, два், трй: й про

Чините йне е́стъ, ёже число́ чино́вне располо́хеное знамену́етъ: Һакш, пе́рвый, вто́рый, тре́тїй: и́ проq.

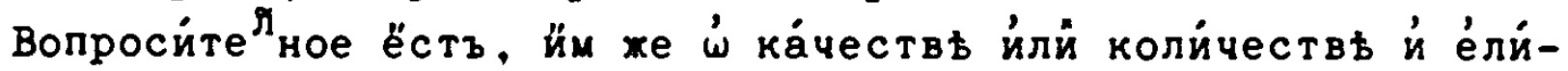
чествь чесо́rw вопроша́е": Какш, како́въ, коли́къ/ е́ли́къ.

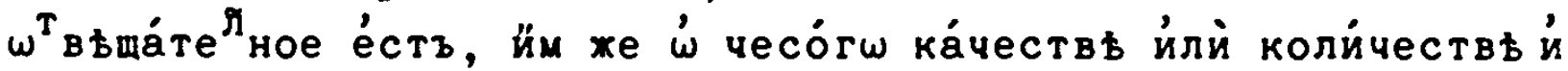
е́лйчествђ $\omega^{\mathrm{T}}$ выщава́емъ: 汭, толи́къ, тако́въ, сйцевъ, сели́къ.

Притаха́те ное ёстъ ёже ве́mи ко́еа притаха́ніе знамену́етъ: La-

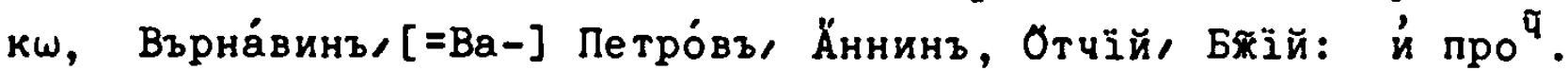
'́те́чествное ёстъ, ёже $\omega^{T}$ '́те́чествна вйда имме́нъ вземлет"са:

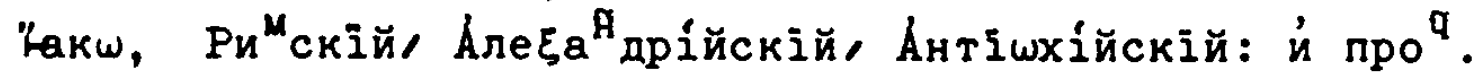

İзйче

[18]

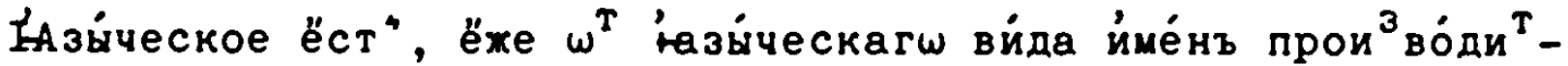

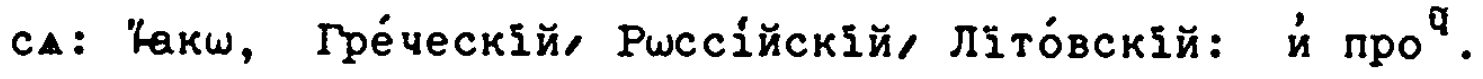

\section{Bтópoe Прилага́те}

Вто́римъ ра ${ }^{3}$ дъе́ніе Прилага́те ${ }^{\text {Hое }}$ ёст" сугу́бо

Сих про́чеe кое́xдо, йлй,

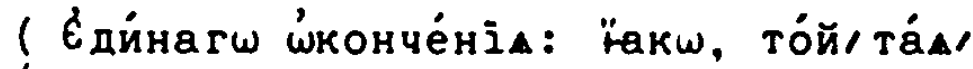
и то́е, йрод".

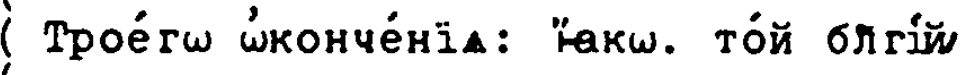
тáa бr̆́áa, тóe бrróe.

( Цвлое ёстъ: йй,

оусъче́ное:

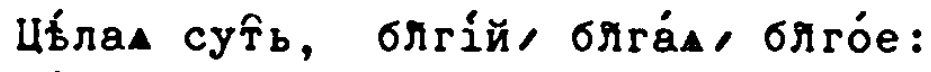

Оусьче́наА, бйъ, бйга, бйго:

Tре́тіе Прилага́те ${ }^{\Re}$ нагш pa ${ }^{3}$ дле́ніе:

Тре́ти ра дъле́ніемъ Прилага́телное ёстъ сугу́бол (Ооравниемое и

Оуравндемое ёст", ёхе оуравна́емо бйти мо́хетъ: "Екш, чйстый, сйлный, мно́гїй: иं про

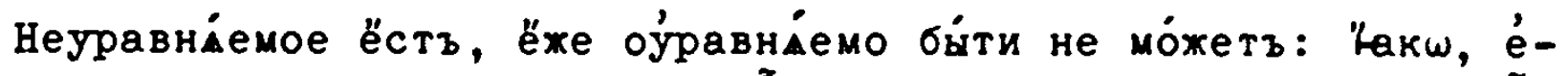

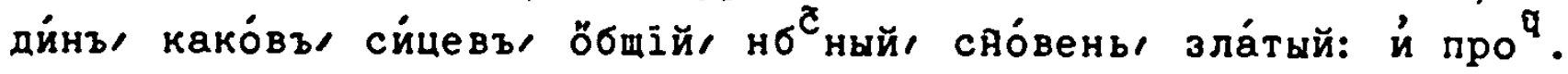


Посльду́ю ${ }^{\top}$ ймени се́дмь, Оу́равне́ніе: Ро́дъ: Вйдъ: Число́: Наче та́ніе: Паде́жь: й Склоне́ніе.

$$
\text { மे Оуравне́нги: }
$$

Оуравне́ніе ёстъ, ймене оуравна́емагш по сте́пенє оуравне́ніА в оде́нїе.

\section{Ка́ム ймена оуравна́ю ${ }^{\mathrm{T}} \mathrm{c \Delta}$;}

Viмена прилага́те нал, йх же знаменова́ніе растй йлй ма́льти

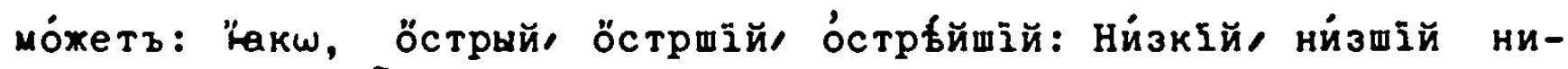
жа́йшій: й про".

\section{‘́ сте́пенехъ Оуравне́ніа:}

Сте́пеніе оурравне́нї соэ̂ть трй.

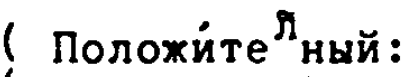

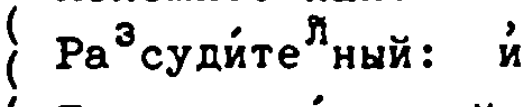

( Превосходйтелный.

Положи́те ный сте́пень, е́стъ пе́рвьй гла́съ ймене прилага́те

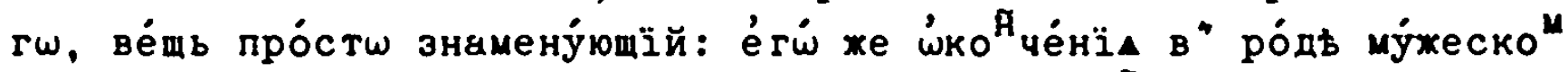

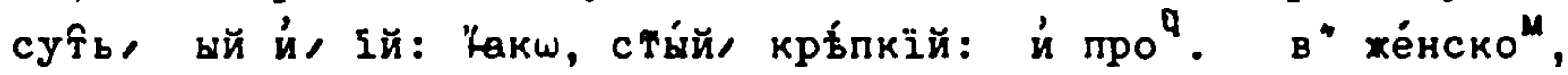

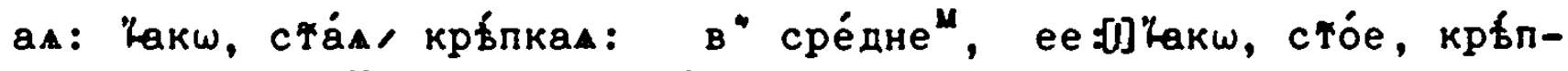
кое: В нбкои йме́нъ їе, йлй ее: Гакш, Бо́хіе, сяо́внее: в"

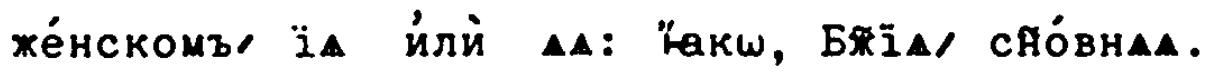

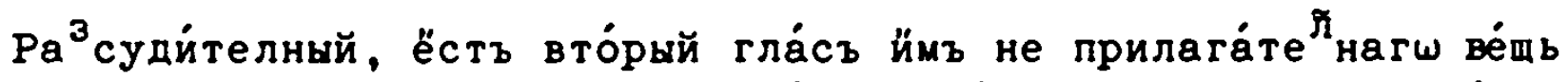
растиму йлй малйму знамену́ющй, е́гі́ же '́конче́ніе му́хеское е́стъ,

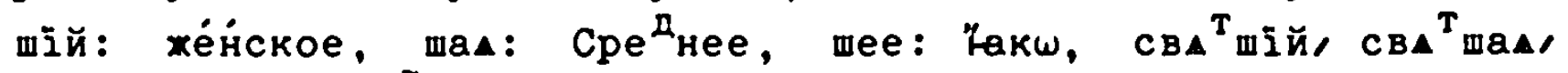
свА ${ }^{\mathrm{T}}$ mee:

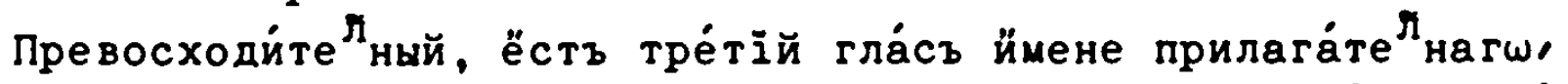
ве́щь в" высоча́йше" йлй ниха́йше" сте́пени полага́ющй: е́гі́ же '́-

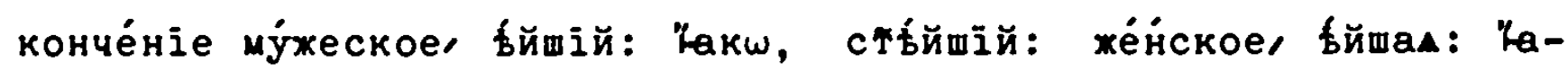

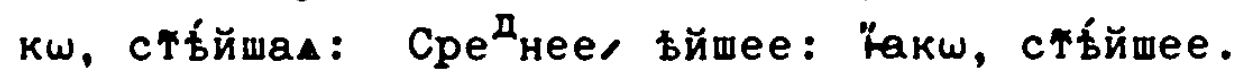

\section{Оу́въще́нїе:}

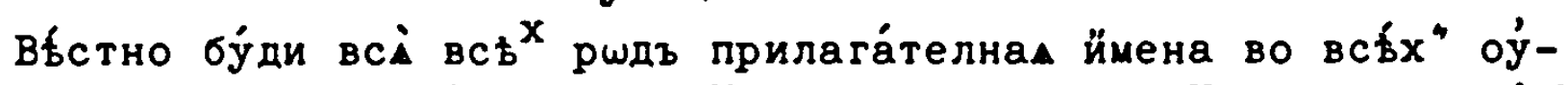

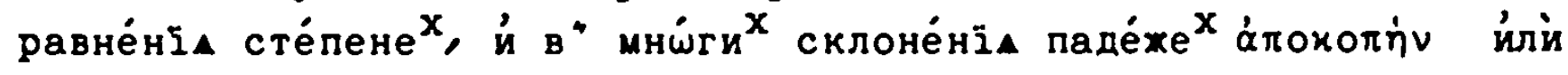

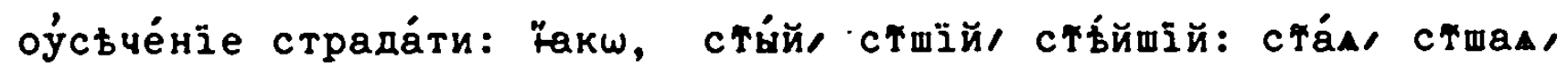

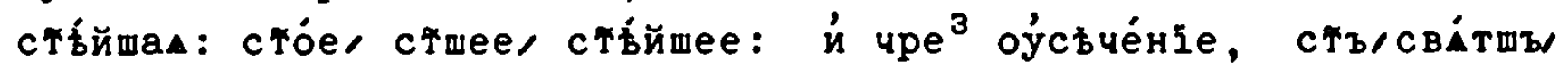

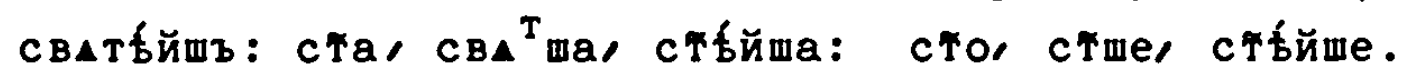

\section{Раздьле́нїе оуравне́нда:}

Оу́равне́нїе прилага́телныхъ и́ме́нъ ёстъ 
Пра́вилное е́стъ, е́гда̇ всй трі́е оу́равне́нї сте́пеніе $\omega^{T}$ тогйжде сло́ra начина́ют": laкw, чи́стый, чи́стшій, чистбйшїй.

Непра́ви ное ёстъ, е́гда̇ ко́йждо оуравне́нїА сте́пень $\omega^{T}$ тоги́хде

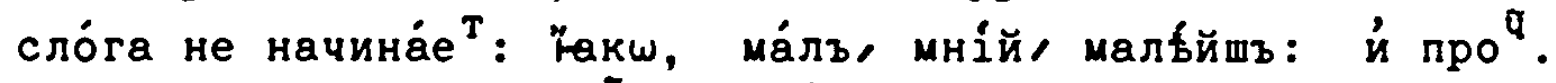

Непра́ви ${ }^{\jmath}$ наг оурравне́нга ймена.

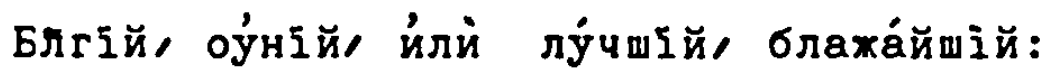

злый, го́ршїй, зльйшій.

Ве́лIй, бо́лїй, и́лй ва́mшій, велича́йшгй.

Ма́лый, мні́й, и́лй ме́ншїй, малъйшій.

’́ СОСТАВЛЕНІИ ПРАви ${ }^{\Re}$

Пра́вило, а̃.

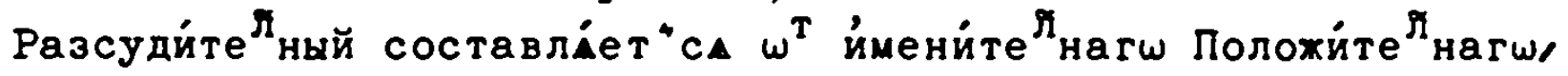

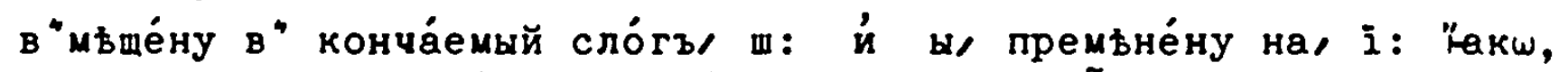
пра́вый, пра́вшїй: оуббо́гій, ој́бо́гшій: и́ про .

Превосходи́телный составла́ет "са $\omega^{\mathrm{T}}$ йменйтелнагш ра ${ }^{3}$ судйте $\mathrm{I}_{\text {- }}$

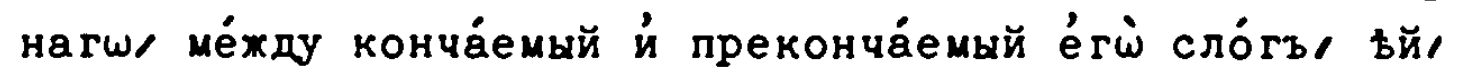

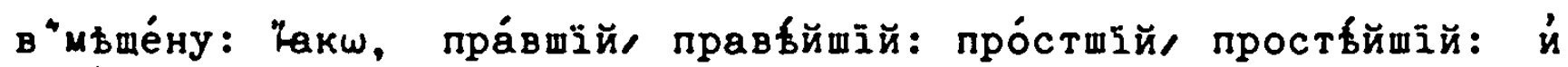
npo $q$

ל̌sítie:

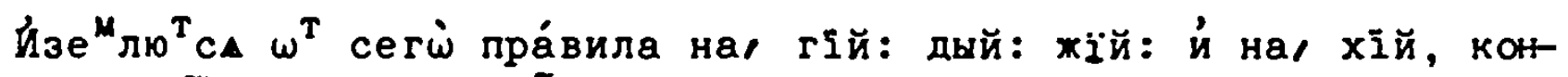

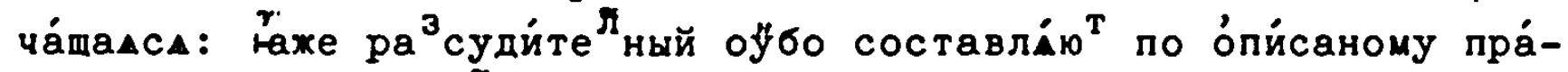

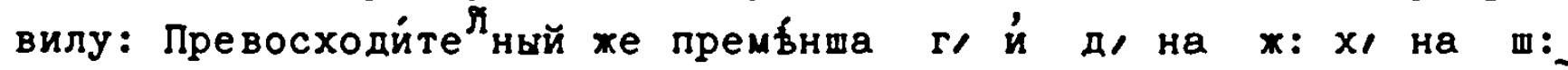
ж, же цбло сохра́нша, ме́жду конча́емый и́ преконча́емый ра ${ }^{3}$ судйтёнагш сло́гъ в"мьща́ютъ, ай: Какш, дра́гій/ дра́гшรй/ драха́йшій:

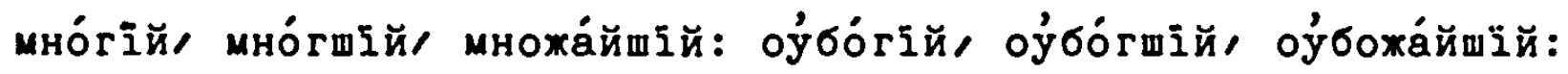

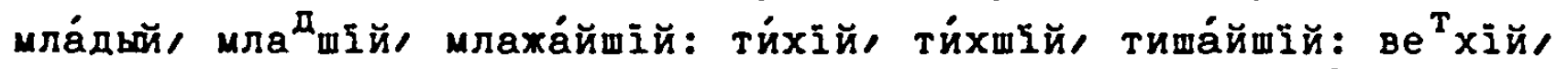

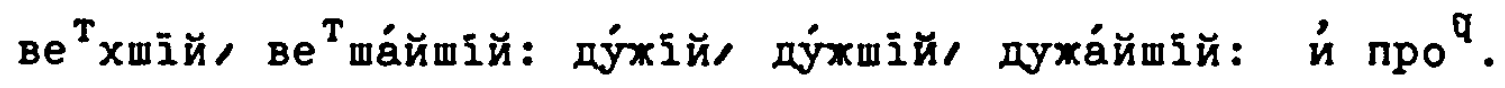

\section{Пра́вило, в.}

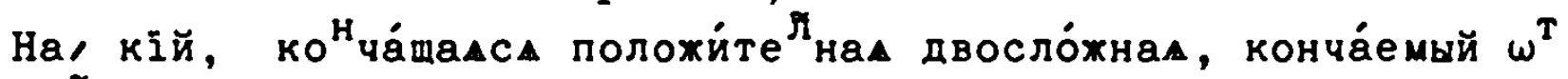

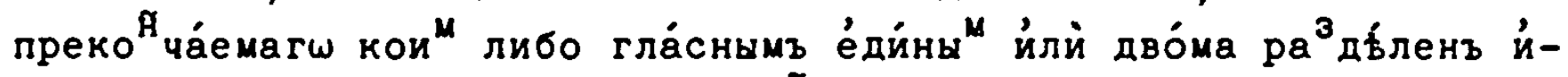
му́maа, в" составле́нїи ра судди́те

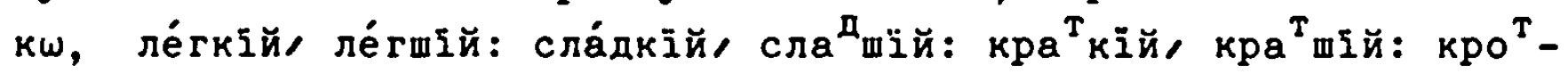
кій, кротшій: крбпкїй

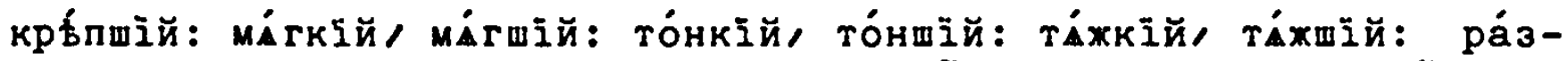

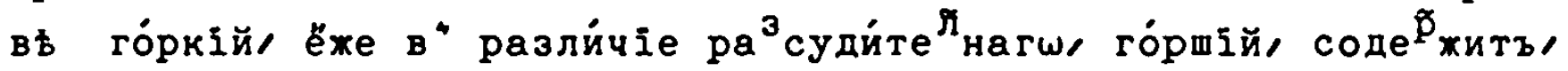
к, го́ркшій.

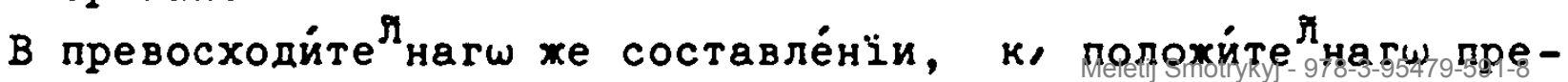


мбнша на, 4, ме́жду конча́емый й преконча́емый ра ${ }^{3}$ судйтелнагш

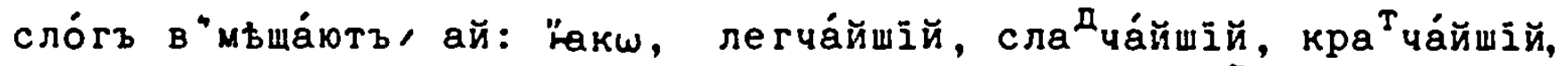

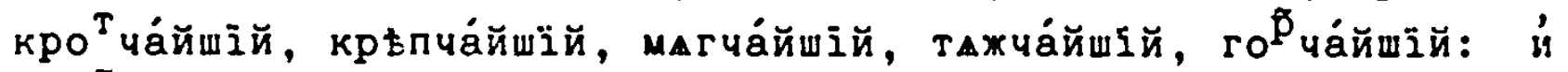
про ${ }^{q}$.

$$
\text { Йза́тїe, a. }
$$

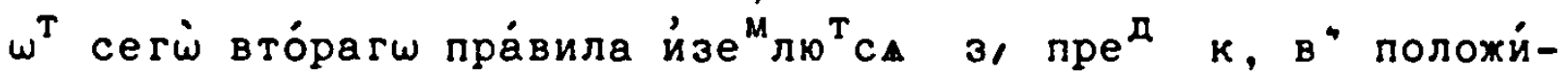

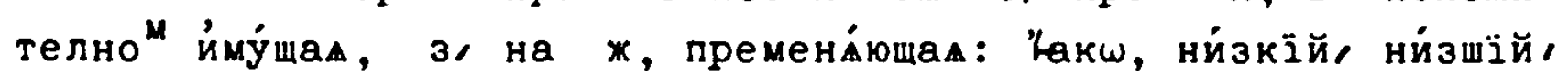

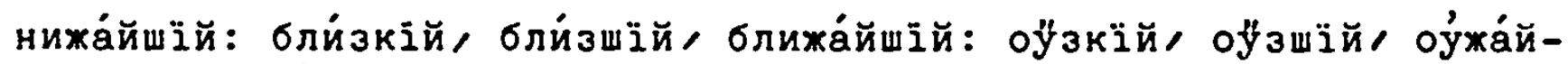
шій. й проq.

$$
\text { Йза́тїe, в. }
$$

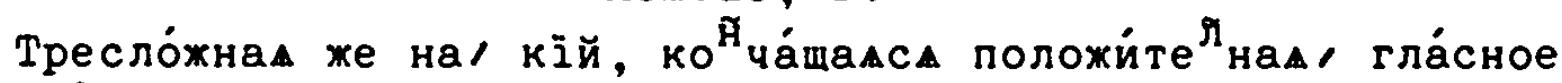
преко "ча́емагш в" ра ${ }^{3}$ суди́те номъ К/ на ш. премена́ютъ: в" превосходи́те йноз па́ки то восприе ше: Һакш, глубо́кїй, глуббшй, глубоча́йшїй: широ́кїи/ ши́ршїй, широча́йшїй: жесто́кїй

же́ct

же́стшій, жесточа́йшїй: дале́кїй да п्र̆й, далеча́йшій: й про

$$
\text { Пра́вило. } \mathbf{x} \text {. }
$$

На ный, конча́щаАсА положи́тенлаА [=-телн-] е́ди́но йлй два̀ согла́сна припраже́на себї $\omega^{T}$ преконча́емагш и́му́щаА, " $^{4} \mathrm{pa}^{3}$ судй-

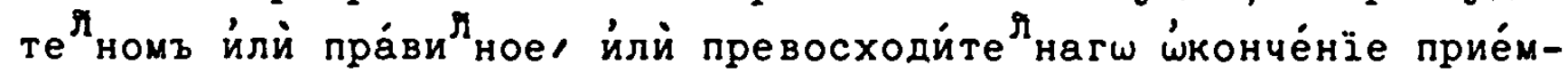

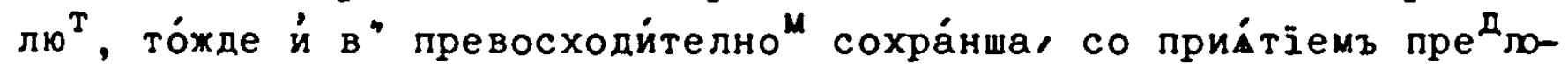
га, пре: "акш, сла́вный, сла́вншїй, и́лй славнбйшїй преславнбй-

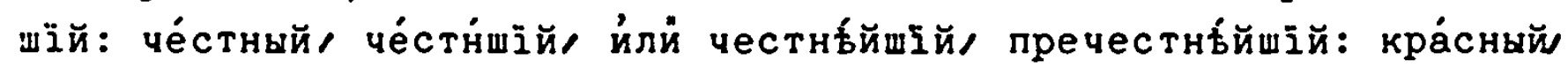
кра́сніші̆й йлй краснбйшій, прекраснб́йшій.

На су́губое о́бáче нн, конча́mаaсA по пра́ви нагш оу́равне́ніА

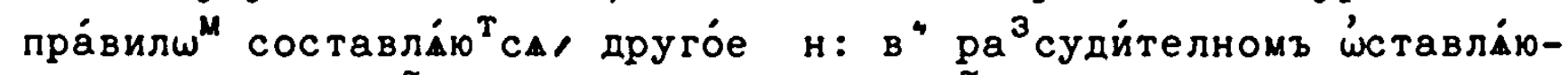

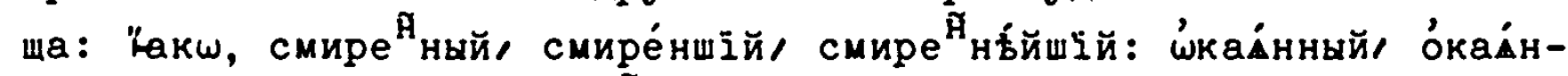

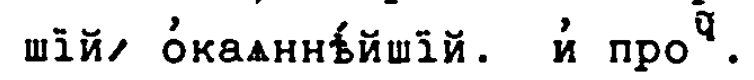

Оўвъще́ніе, а̃.

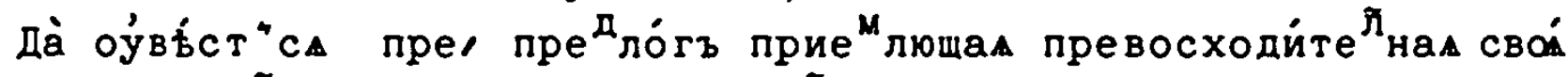

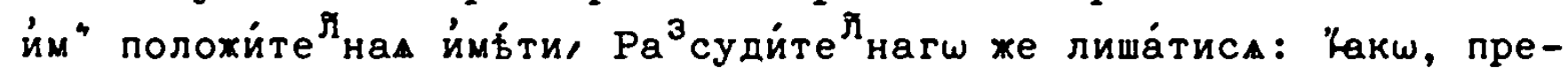
славнб́йшій, пресла́вньй: пречестнб́̆̆-

шіั̆

[216]

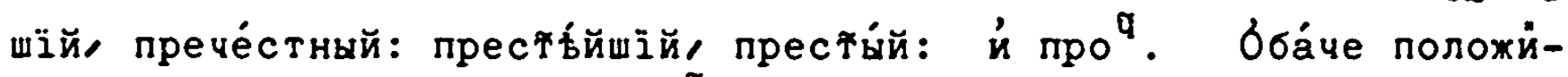
те наА сйцева, превосходи́те нагш ва́шшу си́лу прийма́ти: престй́̆

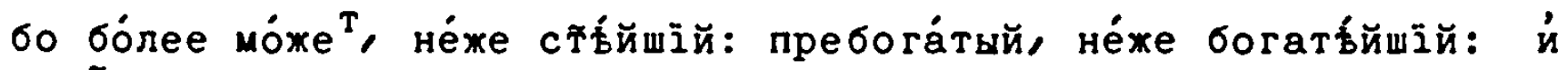
про, 
льй, силнбй, простра́нньй: и́ про . Йм же роди́телна ра́звь пра́вилна не о́брьта́емъ, крfппа, силнбйша: й про . Н̈Ако же й нелравй нь тему: й про". Да не ка́ко в" превосходи́телен" в"зи́йдутъ.

के РОДь:

Род ёстъ Мъстоиме́ніе по́ла ра ${ }^{3}$ дьле́ніе:

Ро́ди сутिь се́дмь: ( Му́хескій

Жён́скйй:

( Сре́дній:

(ठбощй :

( Всікій:

$\{$ Не доумћнний :

( Преобощій:

M'́xe

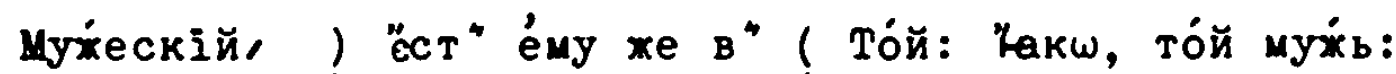

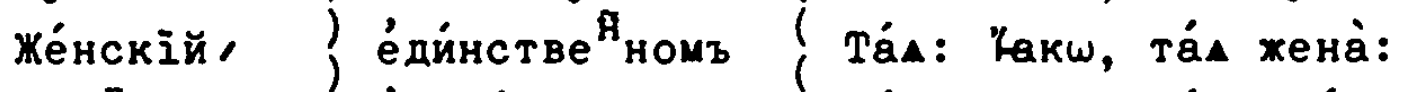

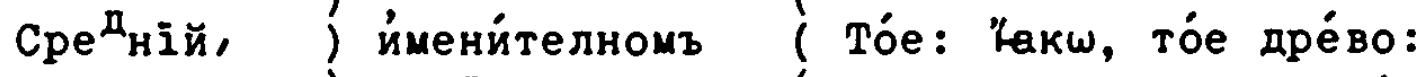

ठомій, \{ пред лага́етъса

Вса́кї̆, \{ мвс́тоиме́ніе,

Недоумънншй)

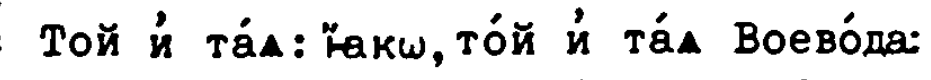

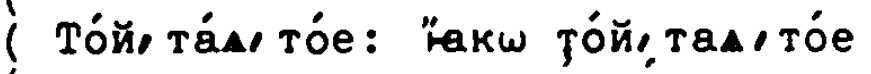
исполнь:

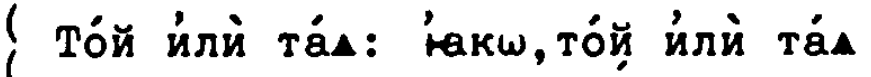
неа́сить.

Преобшій е́стъ, йже е́дйнвмъ муххески" йлй же́нсски" ро́домъ '́бо́й по о́бъемлетъ: Какш, то́й о́ре́лъ: та́ ла́стовица:

‘́ познава́ніи Ро́дшвъ.

Ро́ди и́ме́нъ познава́ют"са ( Пра́вилы О̋бщими, си́речъ знаменова́нідво́ма ӧбразома:

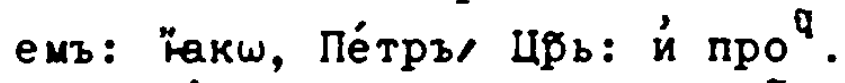

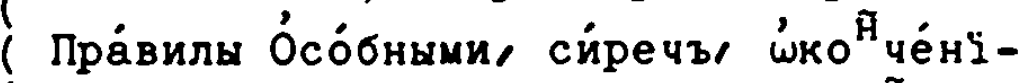

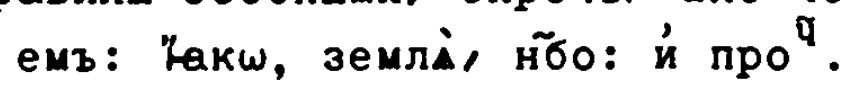

í ПРАВИЛЕхъ Ӧбщй,

йми же ро́ди йме́н" познава́ю" са оу́ка́зо" знаменова́ніА.

ГРАВИЛА ठЪБЩА СУТЬ, ӦСМъ:

Пе́рвое пра́вило $\dot{\omega}$ Муйеских.

Mýxe

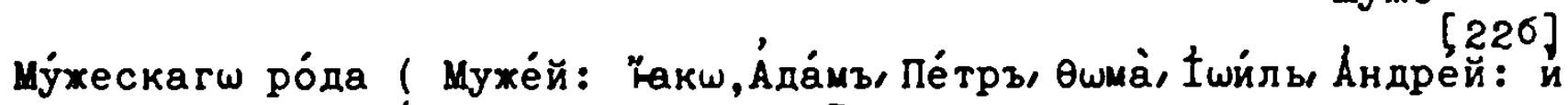
ймена суริธ.

Досто́инствз мухеских": Какш, Патріа́рха Lа́рь ن̈na ${ }^{T}:$ मे $п$ по .

Ӑгглъ: "юкш, Михайлъ, Гаврійл": про".

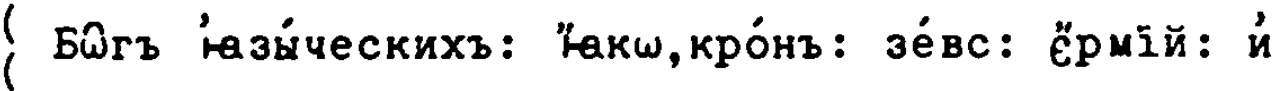


(x) , про ${ }^{q}$.

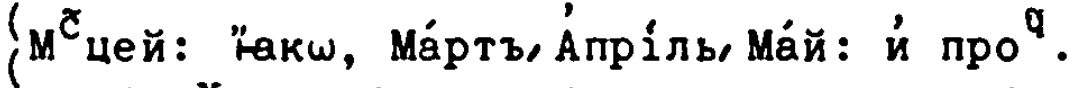

(Чети́pe ${ }^{\mathrm{X}}$ вселе́нныА ча́стій: КакшлВосто́къ, за́-

( падъ, С́́верь, ӥгъ.

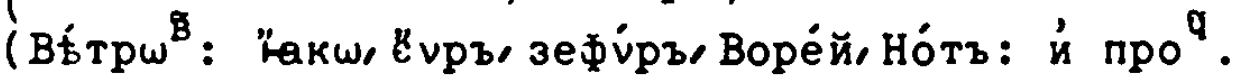

Вто́poe пра́вило ’́ хе́нскихъ:

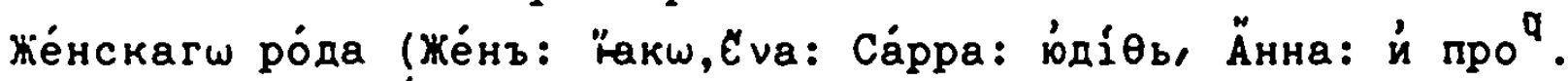

ймена суть. (Досто́инствъ хе́нскихъ: Һакш,ма́ти, дойлица:й, про .

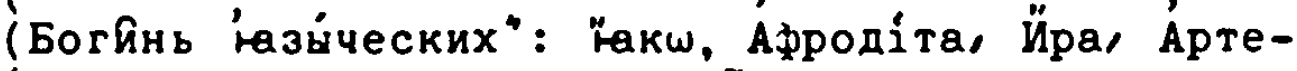

мі́да: йлй дів́на: й про".

Tpétee

Tре́теe пра́вило $\dot{\omega} \mathrm{Cpe}^{д_{н и}}{ }^{\mathrm{X}}$ :

[23]

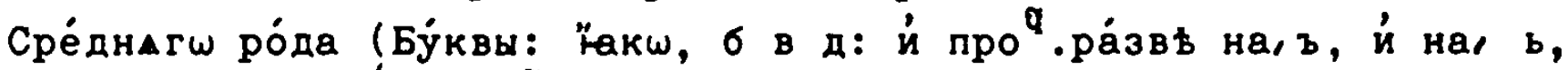

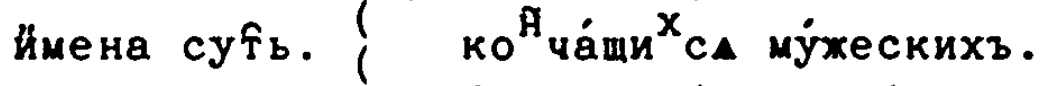

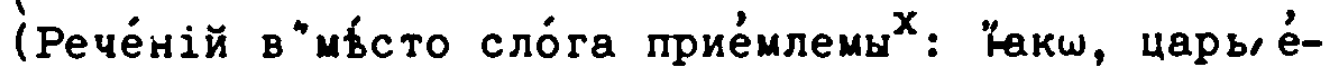
диносло ${ }^{\star}$ но: Ӓнна, четверописме ${ }^{\mathscr{H}}$ но: (Глагڤлъ й нарбчій в"мбсто йме́н" взи́ты : Какш, (мое́ разумбти: си́речъ, ра́зум" мой: йно вчера̀, Йно днесь: сйречъ, йншій ёстъ де́нь вчера́mнійо йншій няьшній:

Оу́вьще́ніе:

Вб́стно бу́ди всї иंме́нъ ро́ды познава́емы Слава́нш" быва́ти з"

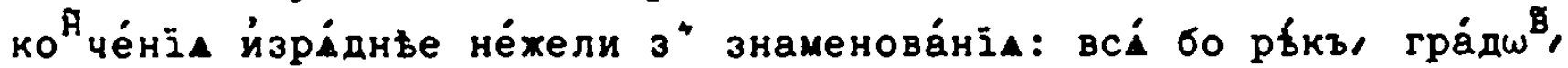
стра́нъ, ца́рствъ, древе́съ, зе́лій, скФтъ, й бу́квъ на, ъ, й на,ь.

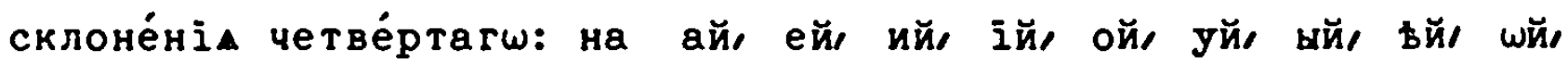
й іे̆̆ cxода́maа мýxеска сутিь.

Ha a

[236]

На, a, и́ на, ь, тре́тіАгш склоне́ніА, же́ніска, ра́звь со́бстве ншхъ му́жески на, $a$.

На, о, на, е, й на, їé, сре́дна.

Четве́ртое пра́вило '́ ठ̋бщихъ:

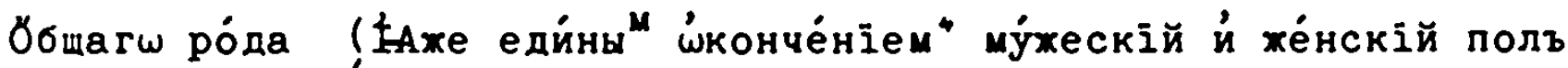
ймена суть: ( знаменуют : Һакш, то́й, й та́а чликъ, судіа, во́инъ, во́й, во́хдъ, ойжика, свъдйтель, Воево́да, та́ть: й про

\section{Па́тое пра́вило '́̀ Всі́ких.}

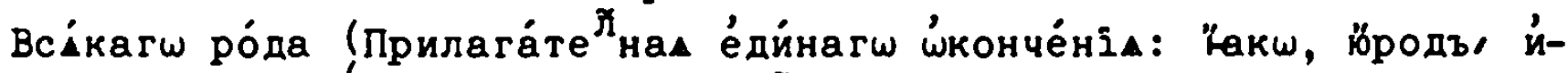
ймена су $\hat{\tau}_{\mathrm{b}}$ : ( сполнь: й про

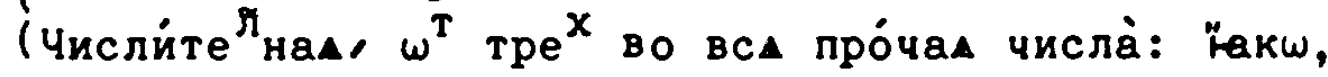




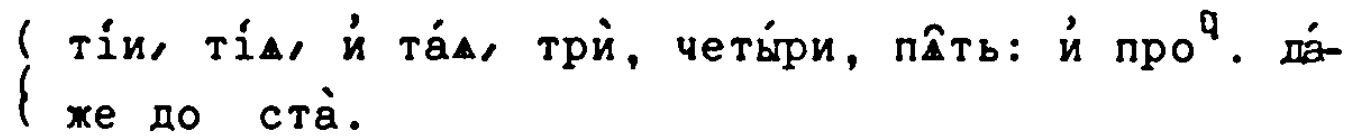

Ше́стое пра́вило $\dot{\omega}$ Недоумђнинах :

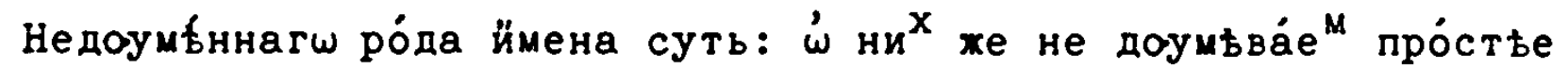
ли мујжеское прилага́телное прием лютъ, лйбо же́нское: Какш, то́й,

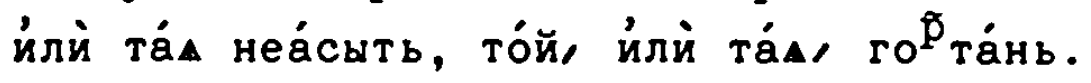

$$
\text { Се доре пра́вило '́̀ Прео́бщих : }
$$$$
\mathrm{Ce}^{\text {मnoe }}
$$

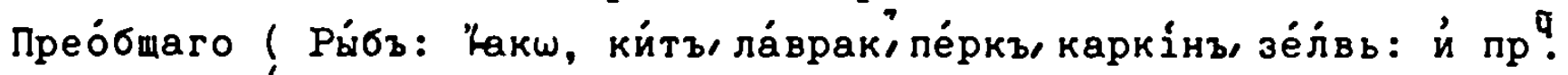

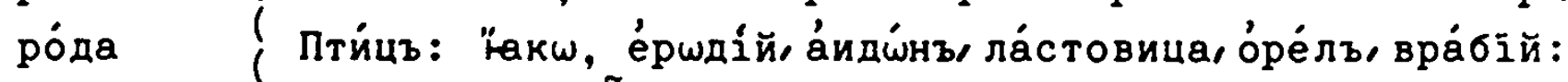
ймена суть вd и про ".

Звбрей: "акw, пі́өикъ, кроторы́а, міेга́ли, мышь: и́ про?.

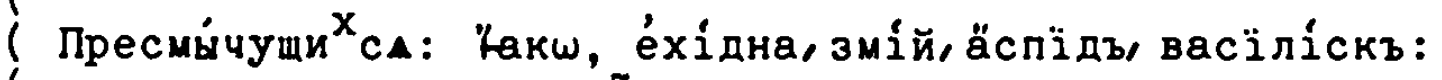
и про '.

(Несько́мы : "акш, пчела̇, вру́хъ, о̋сва, мра́вій, пру́зи, скни́na: й про

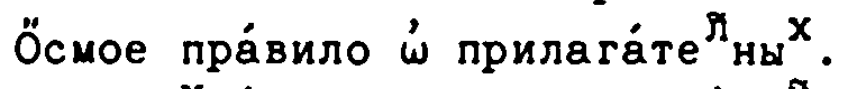

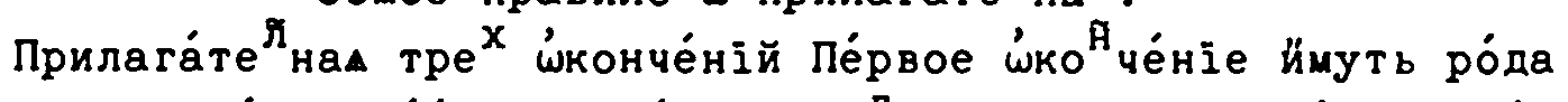

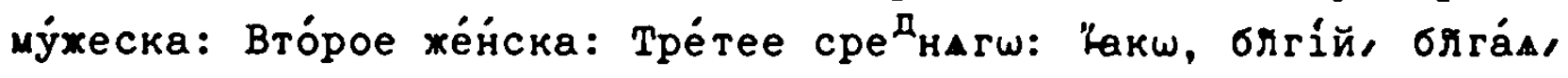
блго́e.

‘் пра́вилехъ О́со́бныхъ:

йми же ро́ди йменъ познава́ют"са правле́нїемъ бконче́ніА.

$$
\text { Конча́mалса на, a: }
$$

Ha, a, [246]

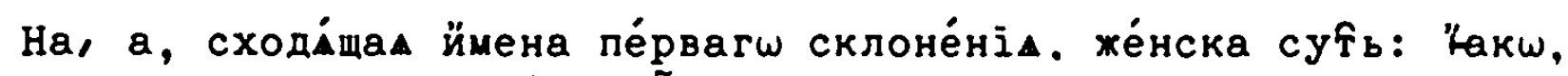
де́лва, ру́чка, сно́ха: и́ про

$$
\text { ל̌sitĩe à. }
$$

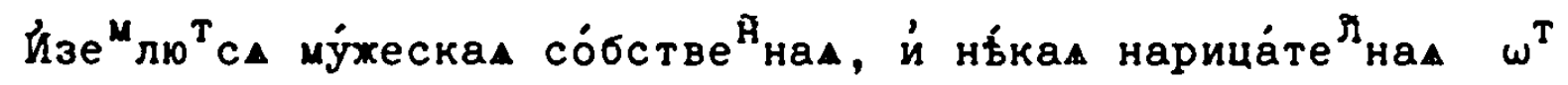
Гре́кз взи́тан на, е́та: in про

$$
\text { Изйтie B. }
$$

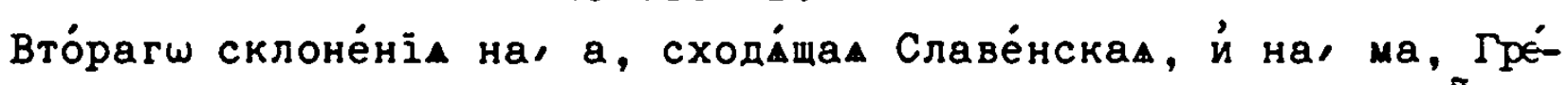

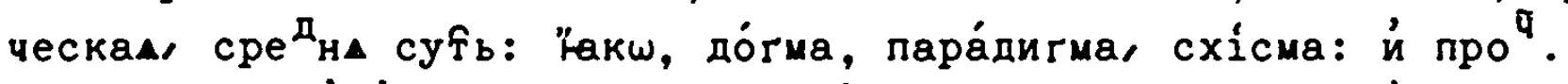

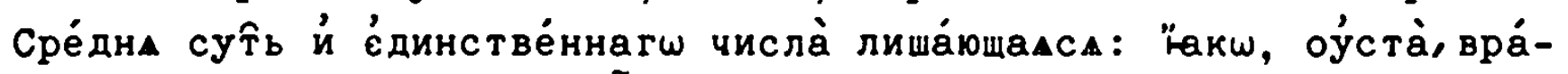
та, вереа̀, лі́двїa: й про q.

\section{Конча́щалса на, А:}

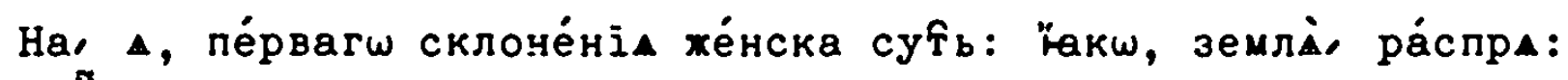
и npo ". nथ०

Bто́parw склоне́ніА сре 


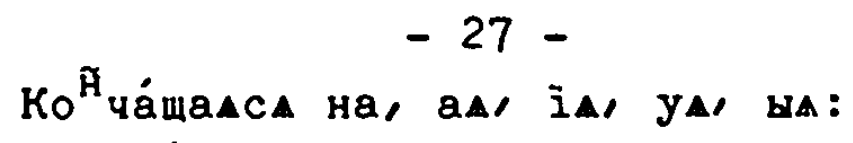

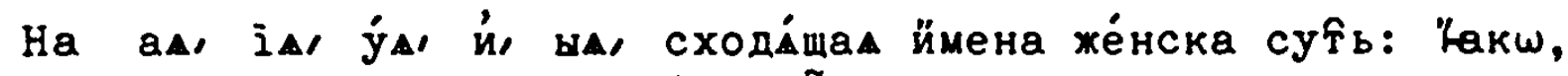
бrraa, Бо́xïa, yешýa, вы́a: $\dot{n}$ про $q$.

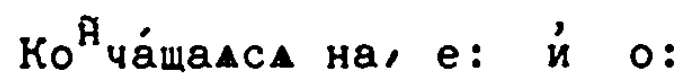

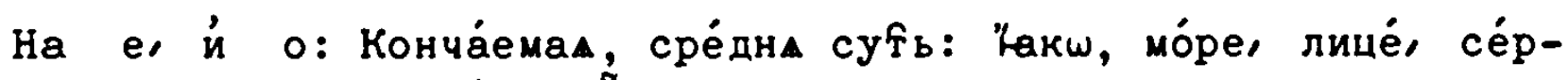
дие, зла́то, дре́во: й про

Ко ча́mасса на, и, '́ ы:

На, $и$, йна, ы, же́нска сутिь: "Екш, Самараныни, любы, непло́ды. й про

\section{Конча́щасса на, їa:}

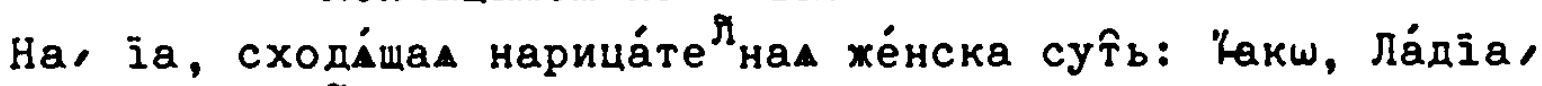
Скйніа: иं про

Со́бственнаА жел ӧва сутิь му́хеска, о̋ва же́нска: познава́ютъ же

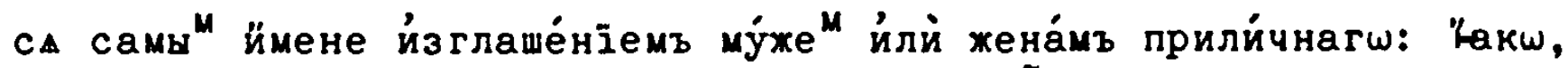
3axápïa, Iwcía, Mápïa, Aнаста́cia: й nро .

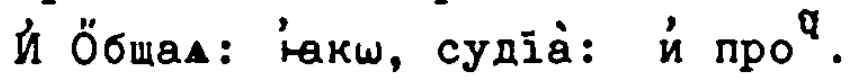

Конча́mалса на, еe: їе,

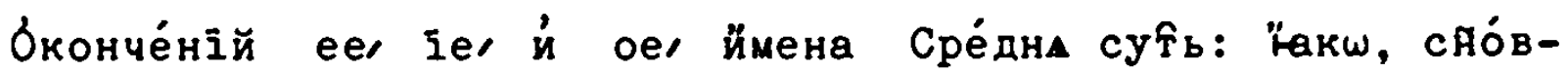
неe, здра́вїe, сто́е: и́ про ".

\section{Конча́mаАсА на, в:}

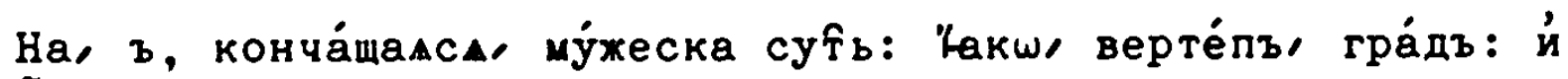
npo ${ }^{\text {q }}$

\section{Конча́щассь на, b:}

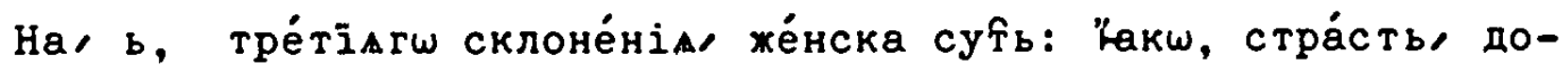
бродбтель, пе́рсть'

Г̆́сль, Со́хль, Ве́рвь: и́ про q.

[25 6]

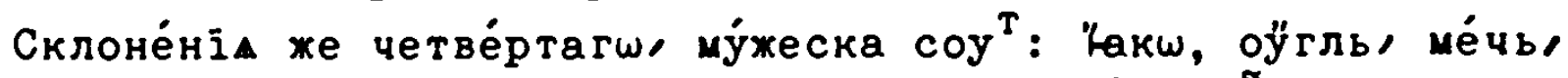
рукойть, ревни́тель, во́пль, пли́щь, стра́жь: й про .

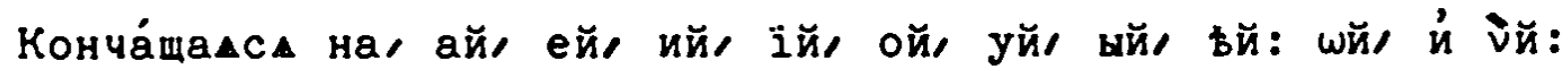

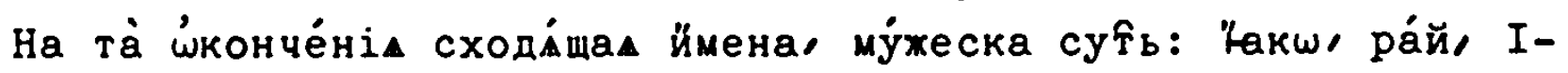
ере́й, Мог̆си́й, блгій, мра́вت̈й, зно́й, кра́гуй, стй́̆, любодбй, "йршй, ста́х

$$
\text { i, y, b, 10, w/ v: }
$$

На та̀ гла́снан, ймена Славе

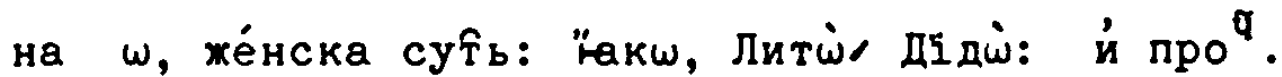

$$
\text { 'ं Вйдь: }
$$

Ви́дъ е́стъ первоо́бразнагш рече́ніА й произво́днагш раздьле́ніе. 
Вйди су欠ิь два̀: ( Первоо́бра ${ }^{3}$ ный: и́

(Произво́дный:

Первоо́бразный вйдъ ёстъ, йже $\omega^{T}$ йнуду не произво́дит"са: "Юкш, зла́то, дре́во: й про

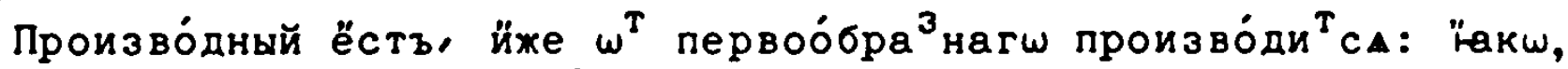
зла́тый, древи́ный: й про ${ }^{q}$.

$\dot{\omega}$ вйдехъ

‘े ВИДЕхъ ПРОИзВОДН ЫІхъ йме́нъ:

[26]

Вйди произво́дных" и́ме́нъ сутьь о̆смь: (О́тчеиме

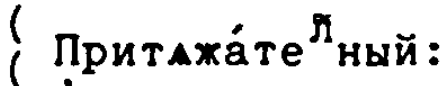

( О́те́чествный :

( Властели ${ }^{\text {Ный : }}$

( ҰАзы́ческій:

(Глаго́лный:

( 'ंтиме́нный :

( Ојмали́телный:

( Оуंничихйтелный:

О́тчеиме́нна йлй притаха́телна ви́да и́ма́ е́стъ, ёже $\omega^{T}$ о́тца̀ на сы́на йзлива́ет"сA: Какw, Па́вловъ, Па́влова, $\omega^{T}$ Па́вла: Петро́въ, Петро́ва, $\omega^{T}$ Петра̀: и́ про ${ }^{q}$. ра́внв, Па́вловна, Петро́вна: и́ про

О́те́чествнагш вйда йма́ е́стъ, ёже $\omega^{T}$ ӧтчества происхо́дит": " $\kappa \omega$, Вилнанйнъ, $\omega^{T}$ Вйлна: Лвовани́нъ, $\omega^{T}$ Лво́ва: сйце, Лвованйни, Вилнаныни: '́ про .

Властелйннаг $\omega$ ви́да и́ма́ е́стъ, ёже $\omega^{T}$ вла́сти происхо́дитъ: †а$\kappa \omega$. царе́вичъ, царе́вна, $\omega^{T}$ цара: : Воево́дичъ, воево́динна, $\omega^{T}$ воево́ды: ста́ростанна, каштеліна. 'и́ про q.

¿ази́

[266]

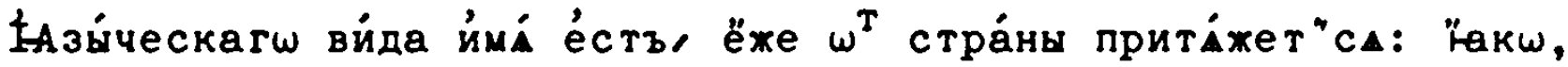
Гре́къ, Грекини, $\omega^{T}$ Гре́ціи: Ри́сс, Ршсси́ни, $\omega^{T}$ Ре́ссіи: Ле́хъ, Лехйни, $\omega^{\mathrm{T}}$ Ле́хіи: $\dot{и}$ про ${ }^{q}$.

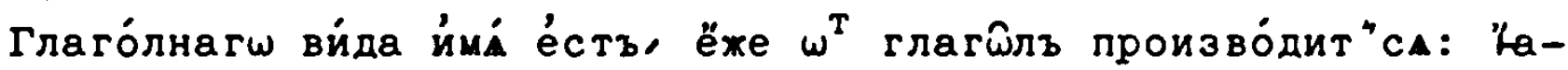
$\kappa \omega$, чте́ніе, чте ${ }^{\mathrm{A}}, \omega^{\mathrm{T}}$ чтуу : сль́шаніе, сли́шатель, $\omega^{\mathrm{T}}$ сль́ш: про : : си́це, слу́ханіе, $\omega^{T}$ слу́хаю: чита́ніе, $\omega^{T}$ чита́ю: й про . О́тиме́ннатш ви́да и́ма е́стъ, ёже $\omega^{T}$ йме́нъ начертава́ет "са: Гакш, со не́чный, $\omega^{\mathrm{T}}$ соллнца: зла́тый, $\omega^{\mathrm{T}}$ зла́та: и́ про ${ }^{\mathrm{q}}$.

оумалителнагш вйда и́ма́ е́стъ, ёже ве́щи оуммале́ніе знамену́етъ: 'акш, словице́, сло́ва: ти́лице, тв́ла: й про .

Оуничихи́телнагш ви́да има́ е́стъ, ёже оуничихе́нд̈е ве́щи прино́- 
ситъ: Гакш, вре́тище, вре́ту: женйще, жен̈ъ: ды́тище, диті́ти: й npo ${ }^{q}$.

$\dot{\omega}$ числьे:

Число́ е́стъ мно́жества и́лй ма́лости йз "Авле́нїе:

Числа̀ сутिь трй, ( Ёдинстве́нное,

(Дво́йственное, й

( Мнохестве́нное:

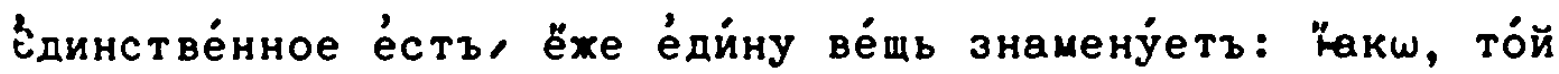
บЛ ВКъ :

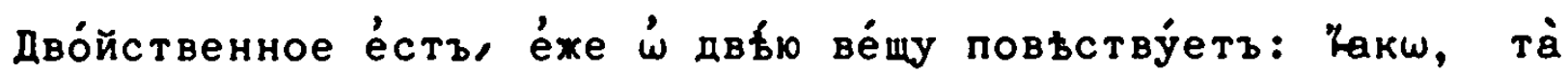
члвка:

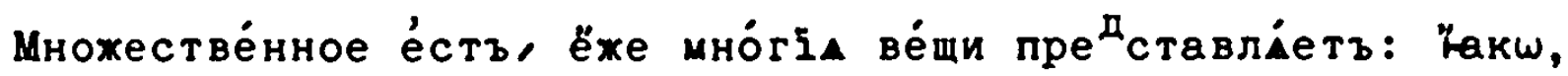
ті́и чภвии.

$\dot{\omega}$ HAYE РТАН IИ:

Начерта́ніе е́стъ, про́стагш й сло́хеннагш рече́ніА разлйчіе: Начерта́ніА суศ́ трй: ( Про́стое:

$\left\{\begin{array}{l}\text { Сло́женное й } \\ \text { Пресло́хенное: }\end{array}\right.$

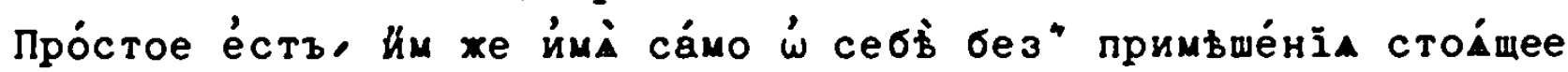
познава́ет" са: "Һакw, сла́вный:

Сло́женное е́стъ, Йм же дво́ма рече́н̆ма состои́mее йма познава́ет"сА: Какш, пресла́вный:

Пресло́хенное е́стъ, Им же тре́ми рече́ним сло́хенное ймі предлага́етса: 'Һкш, препрославе́нный.

'ं ЛАДСЖИ:

Паде́жь, е́стъ '́конче́ніА в" склоне́ніихъ йзића:

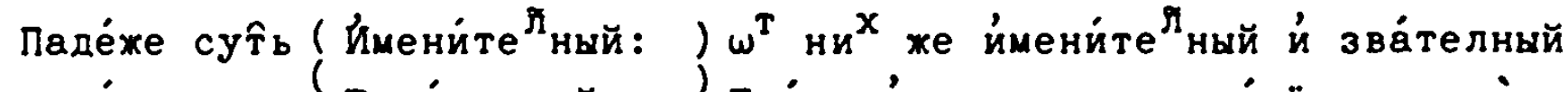
се́дмь:

(Роди́телный:

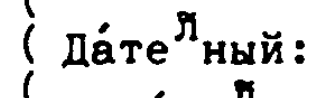

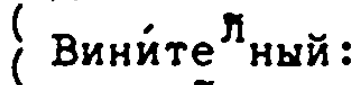

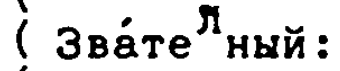

( Творйте ${ }^{\text {лнй : }}$

( Сказа́те $\mathrm{I}_{\text {ный }}$
) Пра́ви и́менуютъса: про́чіи же всй ) Ко́свени.

Йени́телный е́стъ, Йм же йменујемъ: Какш, чликъ.

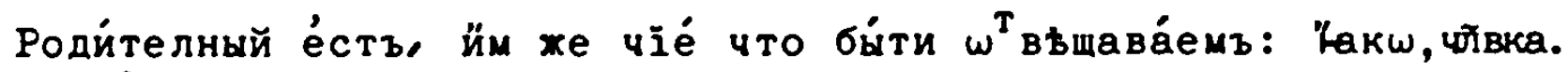

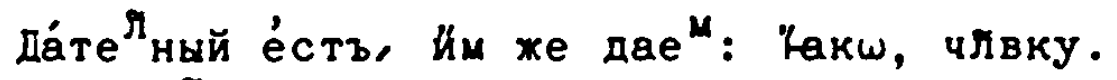

Вини́те Нвй, е́ст", Йм же кого́ пови́нна творимъ: Какш, чливка. Зва́те ный е́стъ, Й же зове : Какш, члче. 
Твори́те Ный е́стъ, йм же тво́римъ: "̈кш. чйвкомъ.

Сказа́те ${ }^{\Re}$ ный ёстъ, йм же ска́зуемъ: 'Һакш, '́ чливць. ¿े СКЛОНСНІи:

Склоне́ніе "ст" рече́ній паде́жми й числы склана́ніе:

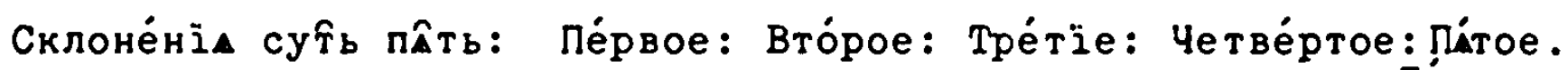
первое

Пе́рвое Склоне́нїе:

[28]

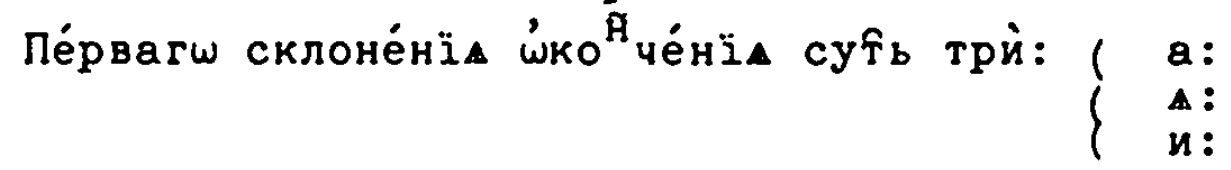

a: Му́хеских, Же́нскихъ, о̋бщихъ, й Всікихъ йме́нъ: А, й, и: же́н̆скихъ: Их же Роди́телный на, ы: Дателный й Сказа́телный на, ち: Винйтелный на, у: Зва́телный на, о: Твори́телный на, ою:

Й му́жескихъ оӱбо Ймени́телный Вини́те нагш числа̀ на, Ђ: да́те ный й твори́те ный на, ама.

ЛАРАДИГМАТА.

му́жеское: числа̀ ध́ динствённагш:

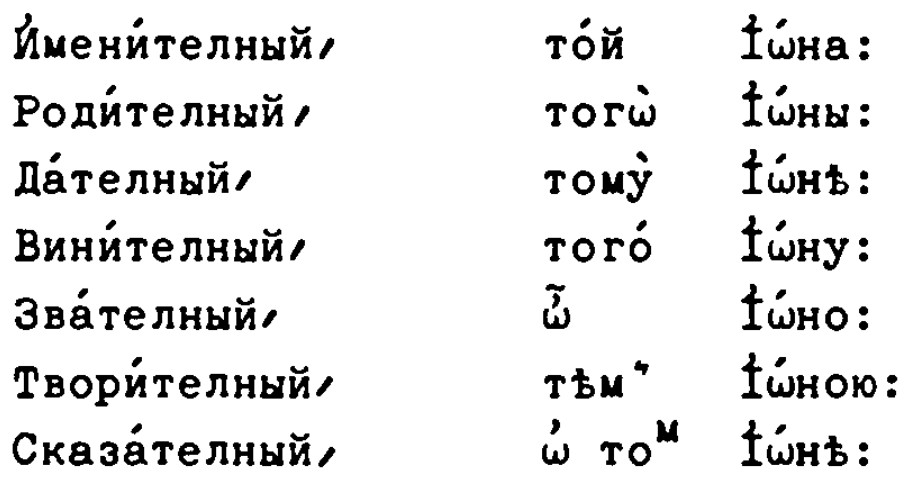

Гe Двой [28 б]

Дво́йственнаѓ числа̀:

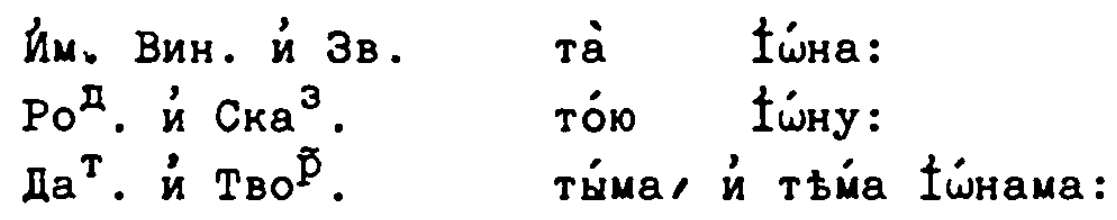

Мнохестве́ннагш числа̀:

Йени́телный,

Роди́телный,

Да́телный,

Вини́телный,

Зва́телный,

Твори́телный,

Сказа́телный,

Же́нское Ймениंтелный,
Tin

†ंшны:

$T b^{X}$

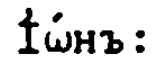

$\mathrm{Tb}^{M}$

Tல́A

I'́на ${ }^{M}$ :

$\tilde{\omega}$

†ंшны:

†ंнн:

тьй Єйнами:

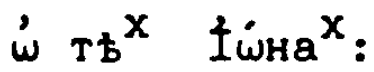

числа̀ е́динстве́ннагw:

та́A Дьв́a: 
Родйтелный,

Да́телный,

Винйтелный,

Зва́телный,

Твориंтелный,

Сказа́телный, тод Дьвы:

то́й ДҺв́:

туі́ Дьв́:

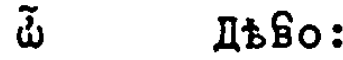

TOڤ ДЬв́ON:

ஸे то́й Дьв́ь:
Двой

Дво́йственнагш числа̀:

Й: Вин: म́ Зва ${ }^{\mathrm{T}}$ : тे Дьвь:

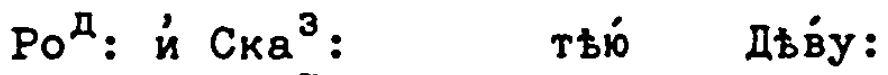

Да ${ }^{\mathrm{T}}:$ й Твор : ти́ма й тьм́ Дьв́ма:

Множестве́ннагш числа̀:

Йменйте ный,

Роди́телный,

Да́телный,

Вини́телный,

Зва́телный,

Твори́телный,

Сказа́телный, ті́ Дъвы:

TБХ Дちвъ:

ть Дь Дьамъ:

ти́ Дちв́ :

ஸे Дьвы:

тьйи Дђв́ами:

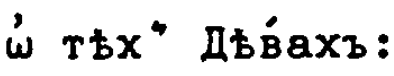

О̋бщее: числа̀ е́динстве́ннагш:

Йме : то́й й та́ム Воево́да:

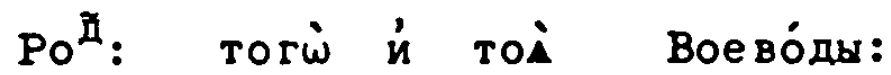

Да ${ }^{\mathrm{T}}$ : тому $\dot{и}$ то́й Воево́дь:

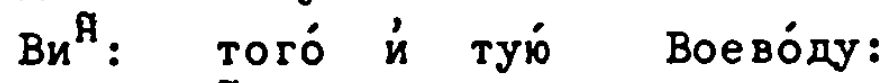

उва ${ }^{\mathrm{T}}: \tilde{\omega}$ Bоево́до:

Твор: тБM" मे тою̆ Воево́дою:

Ска ${ }^{3}$ : $\dot{\omega}$ то ${ }^{M}$ й то́й Воево́дь:

Дво́йстве

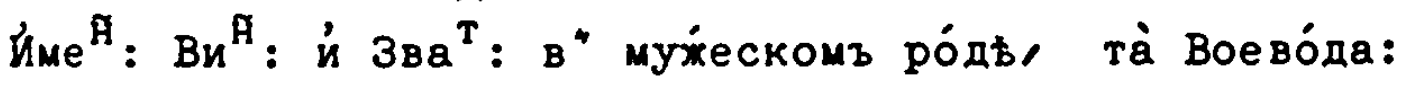

B" же́нскомъ, ì Bоево́ды:

Poम : и $\mathrm{CKa}^{3}$ :

то́⿴囗十 й ть́ Boeвóдy:

ца ${ }^{\mathrm{T}}$ :

ти́ma й Ttúa

Мнохестве́ннагш числа̀:

Йме ${ }^{\mathfrak{A}}$ : ті́ й ті㇒ Воево́ды:

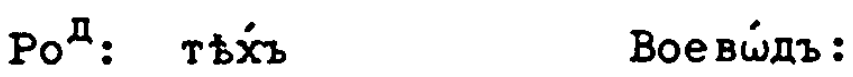

Дa ${ }^{\mathrm{T}}$ : тйв Bоево́дамъ:

Ви ${ }^{\text {म }}$ т т́丶 Воево́ды:

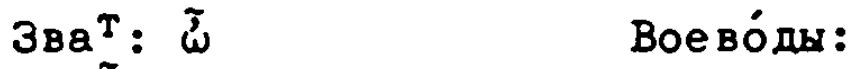

Твор: тьии Воево́дами: 
Ска ${ }^{3}: \dot{\omega}$ тьх́в Воево́дахъ:

Оу́въте́ніе: 2 .

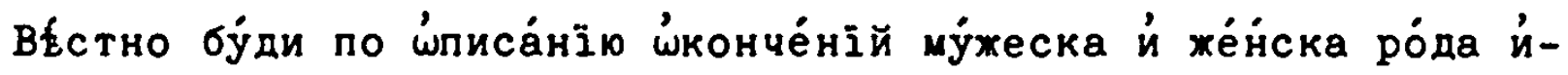
ме́нъ, скландемы бы́ти Гре́ческимъ Латі́нскимъ й ह́вре́йскимъ му́же-

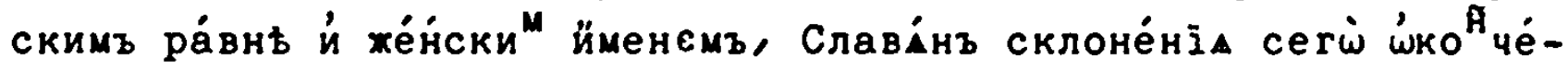
ніе приемшимъ: Какш, Өшма̇, Варна́ва,

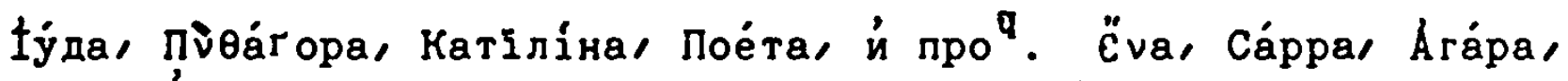

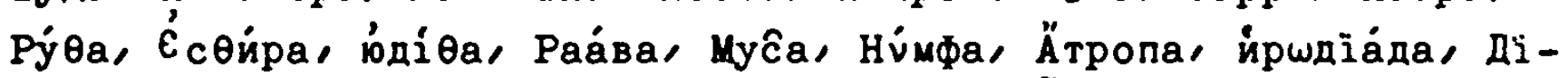
áна, Вене́ра, Дідш́на, ю́нш́на, Сирйна: и́ про . храни́му о́ба́че и́ свое́му ймз ймени́телну й зва́те

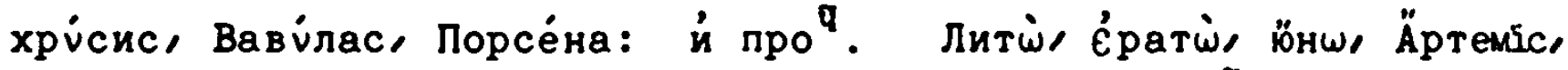

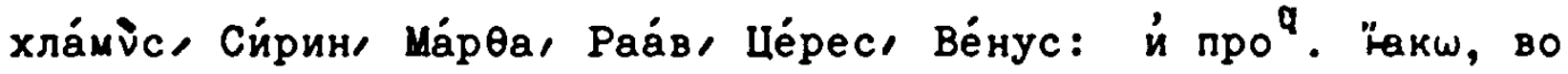
оу́ка́зъ:

Числа̀ е́динстве́ннагш:

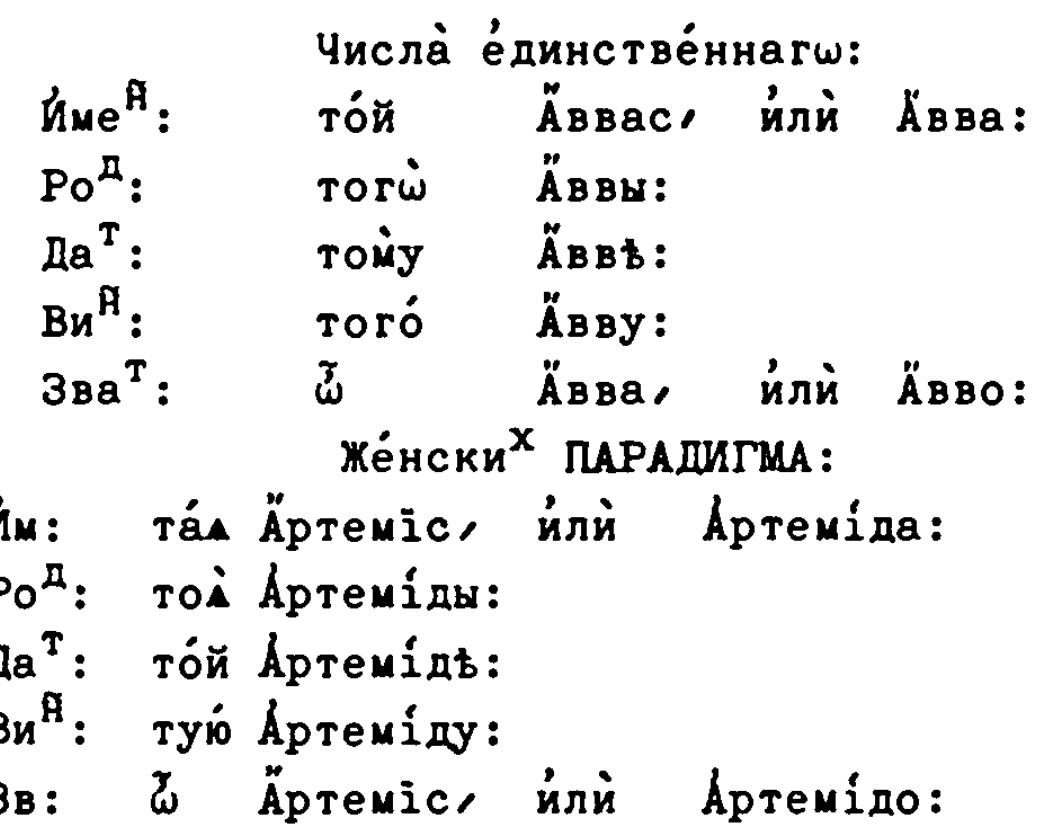

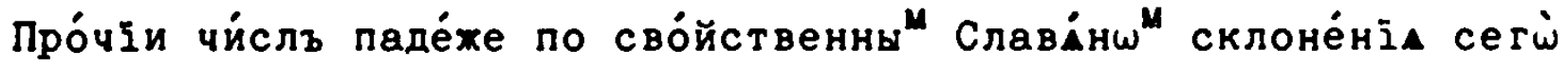
ஸ́конче́ніемъ.

$$
\text { оу́въmе́нīe: в. }
$$

Всї склоне́ніА сеті́ на, га: ка: ха: конча́щалса ймена в" да́-

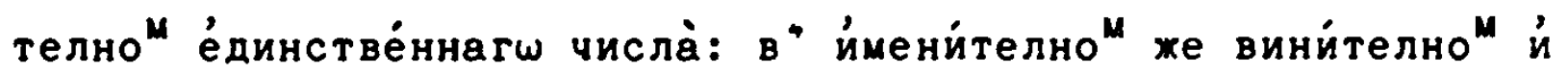
зва́телно дво́йственнагш са́ма же́н́ска премђна́юща г, на з: К,

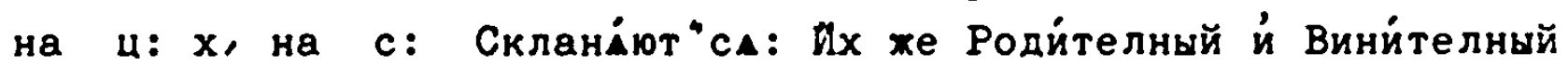
Мнохестве́нный на, и, не на, ы.

$$
\begin{aligned}
& \text { HA, ГA: }
\end{aligned}
$$

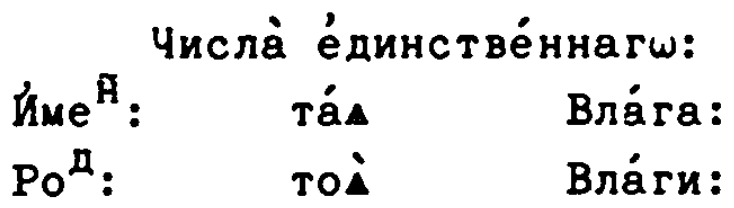




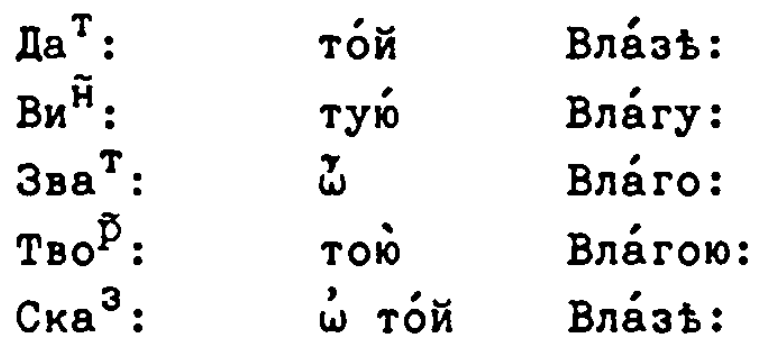

Дво́йственнагш числа̀:

$\hat{и ̆}_{M}: \mathrm{Bи}^{\mathrm{A}}: \dot{\text { и }} 3 \mathrm{Ba}^{\mathrm{T}}:$ ít Pon:

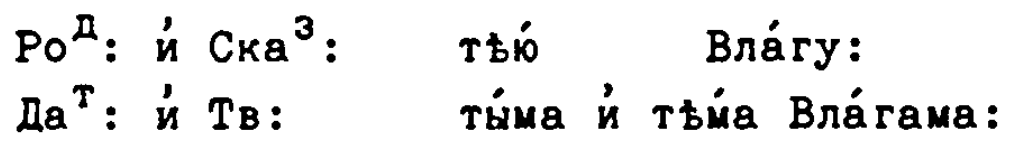

Мнохестве́ннагш числа̀:

\begin{tabular}{|c|c|c|}
\hline $\operatorname{lime}_{\mathrm{A}}^{\mathrm{A}}$ : & Tía & Вла́rи: \\
\hline Pon: & $T 千 \dot{x} z$ & Brárz: \\
\hline$\not a^{T}:$ & TÉMz & вла́ra ${ }^{M}:$ \\
\hline $\mathrm{Bu}^{\mathrm{A}}$ : & 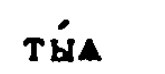 & вла́ги: \\
\hline $38 a^{T}:$ & $\stackrel{\jmath}{\omega}$ & Вла́ги: \\
\hline$T_{B O}{ }^{p}:$ & тьи́n & Вла́гами \\
\hline $\mathrm{C}_{k a^{3}}{ }^{-}$ & $\stackrel{\dot{\omega}}{T t^{x}}$ & Вла́гахъ: \\
\hline
\end{tabular}

\begin{tabular}{|c|c|c|}
\hline \multicolumn{3}{|c|}{ Числа̀ е́динстве́ннагш: } \\
\hline h́me ${ }^{\text {A }}$ & ráa & Рука̀: \\
\hline Poम": & TOA & Рукй: \\
\hline$\not a^{\mathrm{T}}:$ & то́й & Pyùt: \\
\hline $\mathrm{Bu}^{\mathrm{A}}:$ & Tyí & Pyḱy: \\
\hline Зва ${ }^{\mathrm{T}}:$ & $\tilde{\omega}$ & Pyk̂o: \\
\hline TBO ${ }^{p}$ : & TOї & Руко́к: \\
\hline $\mathrm{CKa}^{3}:$ & $\dot{\omega}$ то́й & Pуцेь: \\
\hline
\end{tabular}

\section{Дво́йственнагш числа̀:}

\section{Дво́й}

[3Iб]

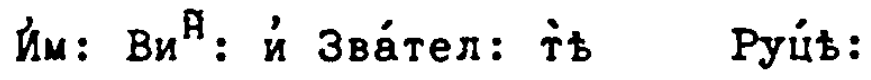

Роди ${ }^{\mathrm{T}}$ : й Сказа́тел: тью́ Руќу:

да ${ }^{\mathrm{T}}:$ й Тво $\mathrm{T}^{\mathrm{p}}$ : т́́ma й тьи́ Рука́ma:

Мнохестве́ннатш числа́:

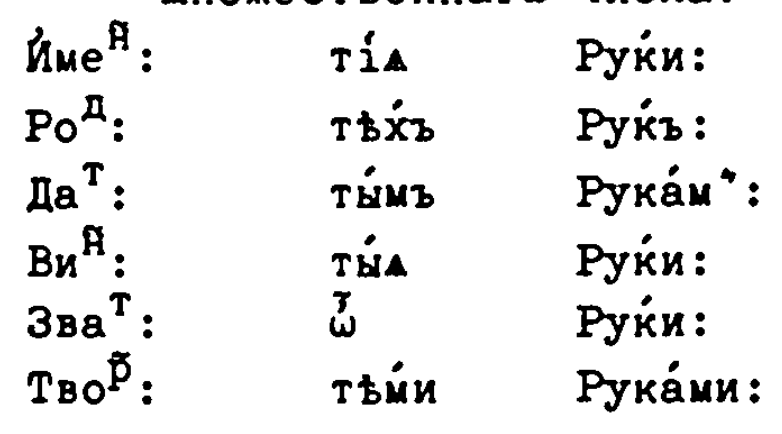




$$
\text { Ска }{ }^{3}: \quad \quad \dot{\omega} \text { ть }^{\mathrm{x}} \text { Рука́хъ: }
$$

$$
\mathrm{HA}, \mathrm{XA} \text { : }
$$

\begin{tabular}{|c|c|c|}
\hline Йme & ráa & Chóxa: \\
\hline Pon: & TOA & Сно́хи: \\
\hline$\not a^{T}:$ & то́й & Сно́сь: \\
\hline $\mathrm{Bu}^{\tilde{A}}:$ & Tyю́ & Сно́ху: \\
\hline Зва ${ }^{\mathrm{T}}:$ & $\omega^{3}$ & Сно́хо: \\
\hline$T_{B O}{ }^{p}:$ & & Снóxою: \\
\hline$C_{\kappa a^{3}}:$ & $\dot{\omega}$ то́й & Сно́сь: \\
\hline
\end{tabular}

Числа̀ е́динстве́ннагш:

Дво́йственнагш числа̀:

Двой

$$
\begin{aligned}
& \text { Йм: Вин: й Зва }{ }^{\mathrm{T}} \text { : ї сно́сь. }
\end{aligned}
$$

\begin{tabular}{|c|c|c|}
\hline & Мнохестве́ннагш & иисла: \\
\hline Йм $e^{\text {A }}$ & Tía & Сно́хи: \\
\hline Pon: & $T b^{X}$ & $C_{H} \dot{\omega} \times \mathbf{x}:$ \\
\hline T: & $T b^{M}$ & Сно́хамъ: \\
\hline $\mathrm{Bu}^{\mathrm{F}}:$ & T'́⿴囗十 & Сно́хи: \\
\hline $\mathrm{Ba}^{\mathrm{T}}$ : & $\stackrel{3}{\omega}$ & Сно́хи: \\
\hline TBO $^{p}:$ & тьй & Сно́хами: \\
\hline$\kappa a^{3}:$ & $\begin{array}{r}\dot{\omega} \mathrm{Tb}^{\mathrm{X}} \\
\text { Иза́тіe: }\end{array}$ & Сно́хахъ: \\
\hline
\end{tabular}

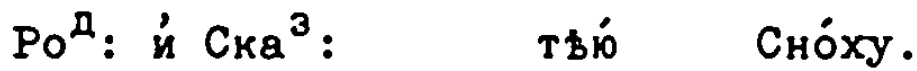

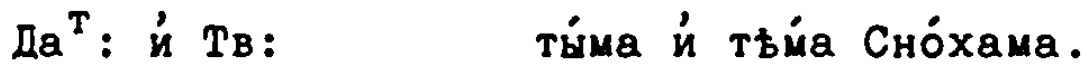

Ймена̀ на, жа: ца: ча: та: ша: на, а, чи́стое: й на, $А$, чи́с-

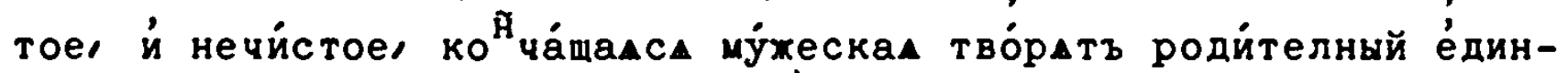
стве́нный, ймени́телный й зва́телньй мнохестве́нный на, и: хе́нскаА на, А: зва́телный на, е: Твори́телный на, ею: Вини́телный мнохестве́нный му́хескал на, в: й, А: хе́ңскал на, А: Қакш,

$$
\text { HA, ЖA . }
$$

\begin{tabular}{|c|c|c|}
\hline 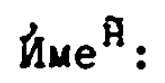 & Táa & Mpéxa: \\
\hline Pon: & TOA & Mpéxa: \\
\hline $\mathrm{Ha}^{\mathrm{T}}:$ & то́й & Мре́жи: \\
\hline $\mathrm{Bu}^{\mathrm{A}}:$ & Ty'́ & Mpéxy: \\
\hline $3 \mathrm{Ba}^{\mathrm{T}}:$ & & Mpéxe : \\
\hline $\begin{array}{l}\mathrm{T}_{\mathrm{BO}} \overline{\mathrm{p}}: \\
\mathrm{C}_{K \mathrm{a}^{3}}:\end{array}$ & $\begin{array}{l}\text { тою́ } \\
\dot{\omega} \text { тón̆ }\end{array}$ & $\begin{array}{l}\text { Mpéхею: } \\
\text { Мре́хи: }\end{array}$ \\
\hline
\end{tabular}

WtH

\section{ЖЕНСКОЕ ПАРАДИГМА:}

\section{Числа̀ е́динстве́ннагш:}




$$
-35-
$$

Дво́йственнагш числа̀:

\begin{tabular}{|c|c|c|}
\hline Йме $^{\text {म }}$ : & Tís & Mpéxa: \\
\hline Po ${ }^{\text {A }}:$ & $T \hbar \dot{x} b$ & MpéXz: \\
\hline$\not a^{T}:$ & T $\dot{B} M^{4}$ & Мре́жам": \\
\hline $\mathrm{Bu}^{\mathrm{A}}:$ & TÉA & Mpéxa: \\
\hline $3 \mathrm{Ba}^{\mathrm{T}}:$ & $\tilde{\omega}$ & Mpéжa : \\
\hline Tво & $T ち \dot{\mu} и$ & Мре́жами: \\
\hline $\mathrm{CKa}^{3}$ : & $\dot{\omega} T^{x}$ & Mpéxa $^{x}:$ \\
\hline
\end{tabular}

$$
\begin{aligned}
& \text { Йме }{ }^{\tilde{H}}: \mathrm{Bu}^{\tilde{H}}: \text { й } 3 в a^{\top}: \text { ì } \\
& \text { Poम : и } \mathrm{CKa}^{3} \text { : ть́丿 мpéxy: } \\
& \text { да }{ }^{\mathrm{T}}: \text { й Тво } \text { Тे }^{\tilde{p}} \text { ти́ма и́ тьм́ мре́жама: } \\
& \text { Множестве́ннагш числа̀: }
\end{aligned}
$$

\begin{tabular}{|c|c|c|}
\hline $\ln _{m}{ }^{\tilde{H}}$ : & то́й & ю̆ноша: \\
\hline Роди ${ }^{T}$ : & Tor $\dot{\omega}$ & ю̆ноши: \\
\hline Ila ${ }^{\mathrm{T}}:$ & romy & Виноши: \\
\hline $\mathrm{Bu}^{\mathrm{A}}$ : & Toró & ß̈ношу: \\
\hline $3 \mathrm{Ba}^{\mathrm{T}}:$ & & йноше : \\
\hline $\mathrm{T}_{\mathrm{BO}} \overline{\mathrm{p}}$ : & $T b^{M}$ & їношею: \\
\hline $\mathrm{C \kappa a}^{3}$ : & $\dot{\omega}$ то & внооши: \\
\hline
\end{tabular}

Сйце де

$$
\text { Ha, WA }
$$

МУЖЕСКОС ПАРАДИГМА:

Числа̀ е́динстве́ннагш:

Дво́йственнагш числа̀:

$$
\begin{aligned}
& \text { Йм: } \text { Ви }^{\text {म }}: \text { й } 3 в a^{\mathrm{T}}: \text { та̀ } \\
& \text { Poम : и́ } \mathrm{CKa}^{3} \text { : то́ } \\
& \text { Да }{ }^{\mathrm{T}} \text { : й Тв: ти́ма и́ тьм́а Йношама: }
\end{aligned}
$$

Множестве́ннагш числа̀:

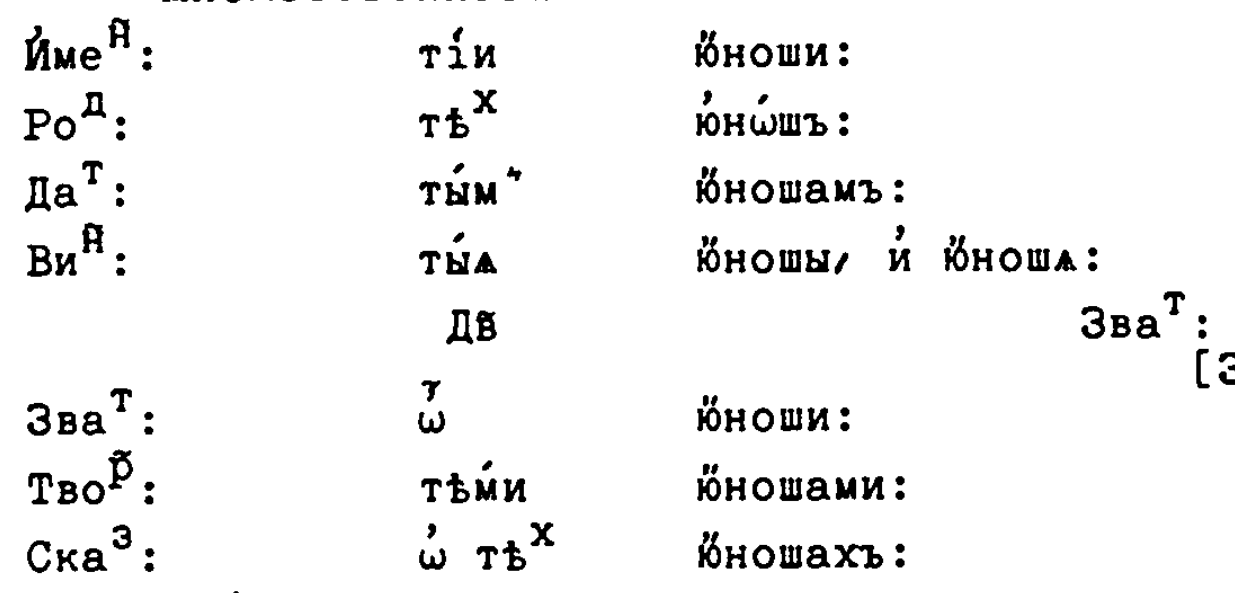


Числа̀ е́динстве́ннагш:

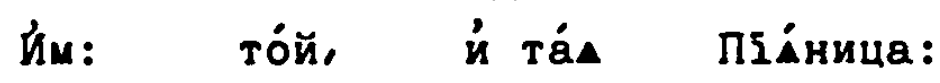

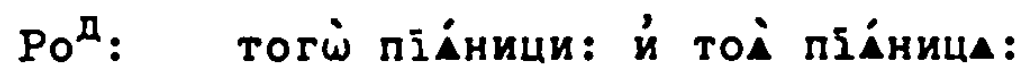

Да ${ }^{\mathrm{T}}$ : томуу иं то́й піАници:

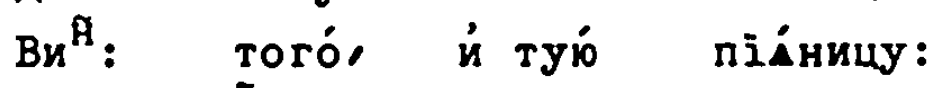

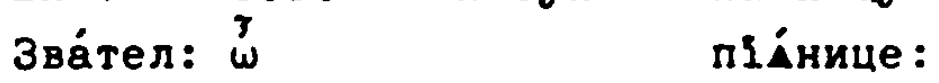

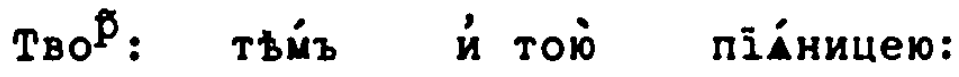

Ска ${ }^{3}$ : '́ं том иं той пїници:

Дво́йственнагш числа̀:

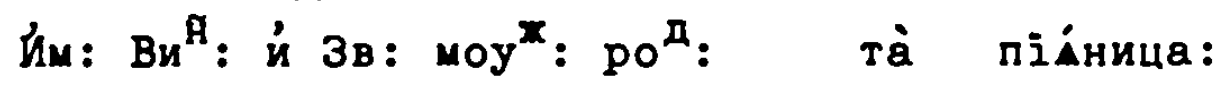

Же́нскатш, is піАннив:

Poम: й Ска ${ }^{3}$ : то́ю й тью́ тїіницу:

Да ${ }^{\mathrm{T}}:$ й Тв: ти́ма й твм́ піА́ницама:

Мнохестве́ннатш числа̀:

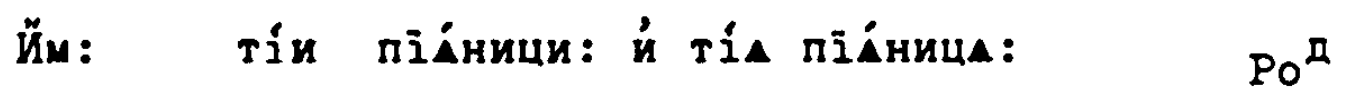

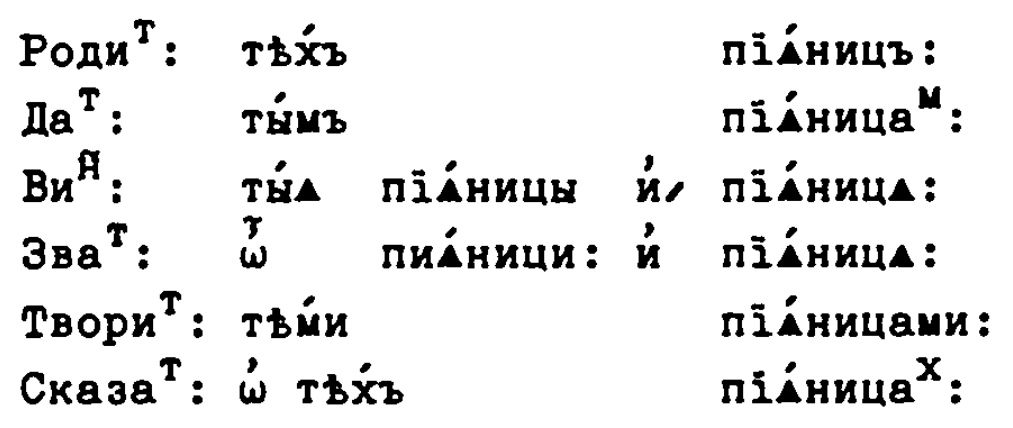

Bсі́каГW ПАРАДИГМА.

Числа̀ е́динстве́ннагш:

Йme : то́й тá й тóe ஸ́брі́ma:

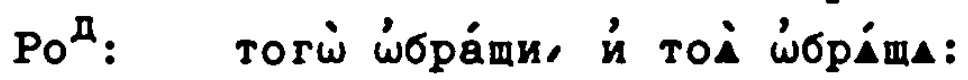

да ${ }^{\mathrm{T}}$ : тому то́й $\dot{и}$ тойy 'ंбріщи:

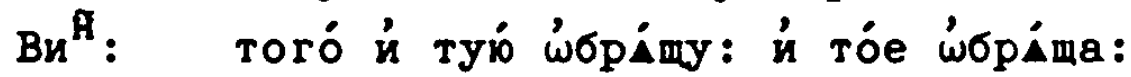

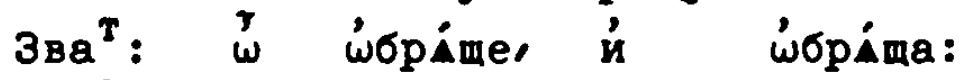

TBOp: Tв тоі й твй

Ска ${ }^{3}$ '

Дво́йственнагш числа̀:

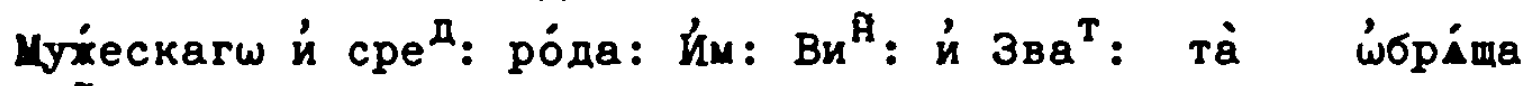
$\mathrm{xe}^{\text {H }}$ :

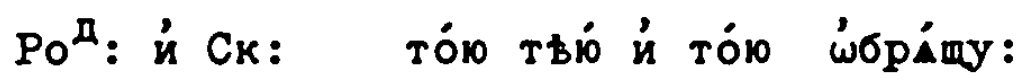

ar

म2. ${ }^{\mathrm{T}}:$

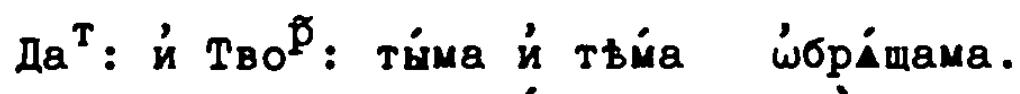

Мнохестве́ннагш числа̀:

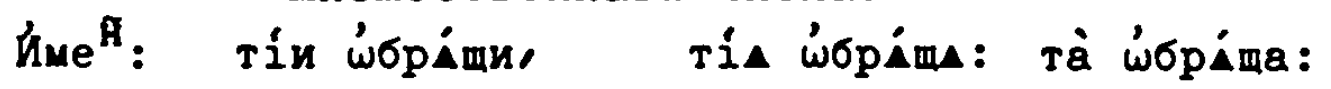




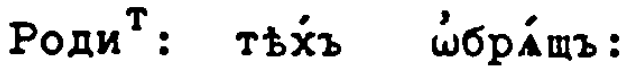

Да ${ }^{\mathrm{T}}:$ ти́ms

Ви $^{\text {म }}$ т т́́

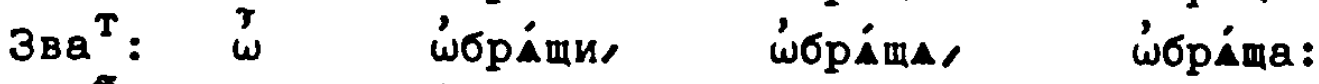

Твор: тьй ம́бра́mами

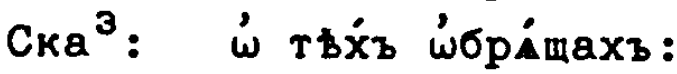

ПАРАДИГМА М'́хески на А' чи́стое:

Числа̇ е́ динстве́ннагш:

Йме : то́й उaxápia:

Роди ${ }^{\mathrm{T}}$ : тогі் Заха́ріи:

मа ${ }^{\mathrm{T}}:$ тому उаха́ріи:

Вини ${ }^{\mathrm{T}}$ : тoró उaxápin:

उва ${ }^{\mathrm{T}}: \quad \stackrel{\jmath}{\omega} \quad$ उaxápie:

Tво ${ }^{\mathfrak{p}}$ : TB ${ }^{M} \quad$ 3axápien:

TBO

Ска ${ }^{3}:$ 'ं ro" उаха́ріи:

Двӧйственнатш числа்.

Й : $\mathrm{Bu}^{\mathrm{A}}:$ й $3 \mathrm{Ba}^{\mathrm{T}}$ : т̇̀ उaxápia:

Po ${ }^{\text {I }}$ :

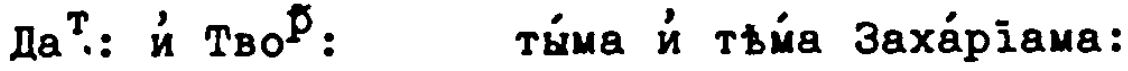

Мнохестве́ннагш числа̀:

\begin{tabular}{|c|c|c|}
\hline Йме ${ }^{\text {A }}$ & тín & Заха́ріи: \\
\hline Pon: & $T ち \dot{\mathbf{X}} \mathfrak{b}$ & Заха́рій: \\
\hline$\not a^{T}:$ & $T \mathbf{u}^{M}$ & Заха́p̈ia $a^{M}:$ \\
\hline $\mathrm{Bu}^{\mathrm{A}}:$ & TóA & 3axápia: \\
\hline $3 \mathrm{Ba}^{\mathrm{T}}$ & & Заха́piи: \\
\hline $80^{f}$ & тъи́n & Заха́plamи \\
\hline$k a^{3}$ & $\dot{\omega} T B^{x}$ & 3axápia $a^{x}$ \\
\hline
\end{tabular}

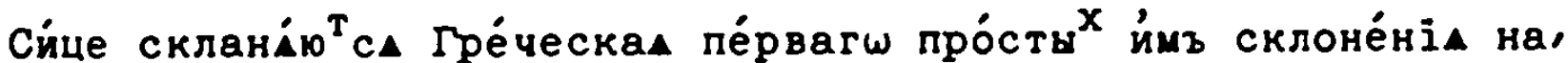

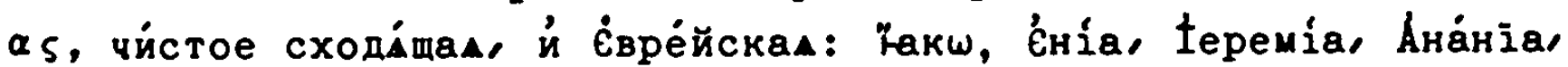
Месcía, йліà, Софо́на, Йса́іа: и́ проq.

Йзіты ко четве́ртому склоне́нію возносй-

In

M\&Mз :

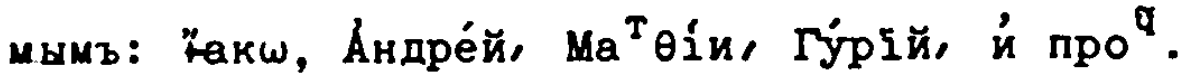

Же́нски ${ }^{X}$, Числа̀ е́динстве́ннатш:

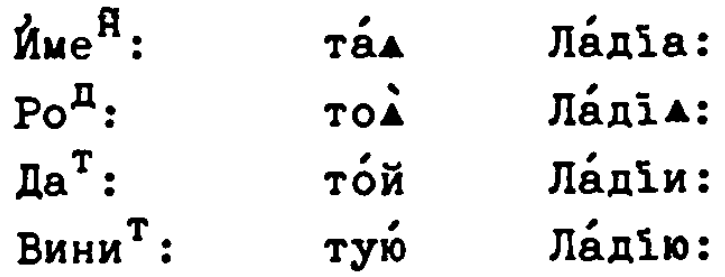




\begin{tabular}{|c|c|}
\hline $\begin{array}{l}3_{\mathrm{Ba}}{ }^{\mathrm{T}}: \\
\mathrm{T}_{\mathrm{BO}}^{\mathrm{p}}: \\
\mathrm{Cка}^{3}:\end{array}$ & $\begin{array}{l}\mathbf{\omega} \\
\text { Tою́ } \\
\dot{\omega} \text { то́й }\end{array}$ \\
\hline
\end{tabular}

Дво́йственнагш числа̀:

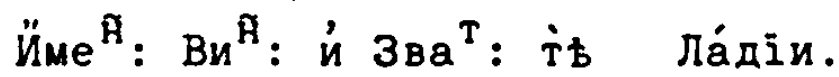

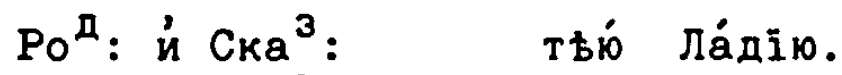

Да ${ }^{\mathrm{T}}$ : й Твор : ти́ма и́ тьм́ Ла́дїама.

Множестве́ннагш числа̀:

\begin{tabular}{|c|c|c|}
\hline 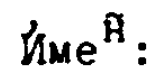 & Tís & ЛáдїА: \\
\hline Po & $T D X b$ & Ла́дїй: \\
\hline Да ${ }^{\mathrm{T}}:$ & TИ́Mz & Лáдїамъ: \\
\hline $\mathrm{Bu}^{\mathrm{A}}:$ & 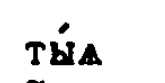 & Лáді̄: \\
\hline $3 \mathrm{Ba}^{\mathrm{T}}:$ & $\stackrel{r}{\omega}$ & Лáдїه: \\
\hline TBO ${ }^{p}:$ & bun & Дїами: \\
\hline $\mathrm{Cка}^{3}$ : & $\dot{\omega} T b^{X}$ & $a \times b:$ \\
\hline
\end{tabular}

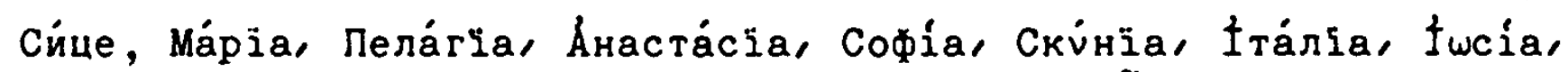
Лéxia, Лiта́віа, Лíвí, 亡думе́a, 士уде́a: и́ про q.

о̋бщеe: Числа̀ е́динстве́ннагш:

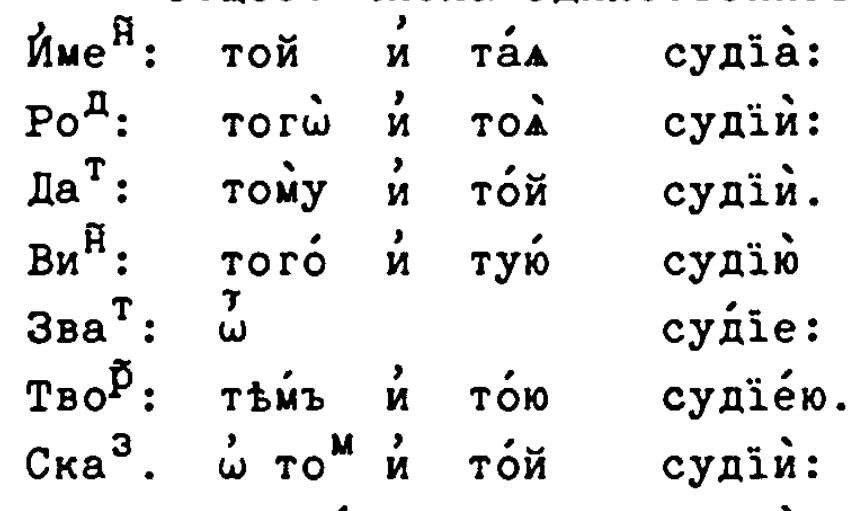

Дво́йственнагш числа̀:

Й. Вин. и́ Зв. мух́еска ро́да, та̀ суд̈їа:

же́нска, ìt суд́ї.

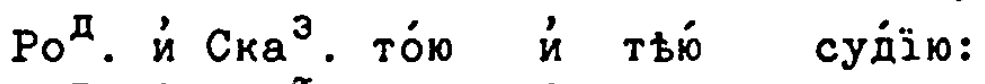

Да ${ }^{T}$. й Твор. ти́ма, и́ ть́丿а судїа́мa.

Множестве́ннатш числа̀:

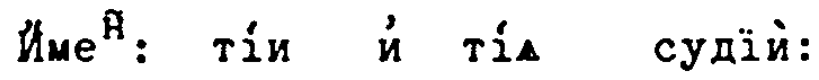

Poम: тьх́в судій:

Дa ${ }^{\mathrm{T}}:$ тймъ судї́mъ:

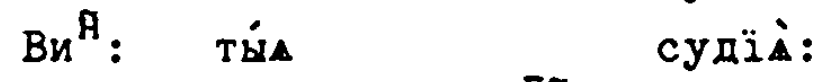

มอ

$3 в a^{\mathrm{T}}:$

судій:

суді̄́ми:
$3 \mathrm{Ba}^{\mathrm{T}}: \quad \stackrel{\top}{\omega}$

Tво : тьми 


$$
-39-
$$
CKa ${ }^{3} . \quad \dot{\omega} \mathrm{T} \hbar \dot{x} b$
судї́хв .

ПАРАДИГМА НА, И.

Ŭme ${ }^{\hat{H}}:$ тáa

Числа̀ е́динстве́ннагш:

POम: TOA

Самаранынии:

$\not a^{\mathrm{T}}:$ то́й

Gамаранына:

$\mathrm{Bu}^{\text {मे }}$ : тую

Самаранынии:

उва ${ }^{\mathrm{T}}: \stackrel{3}{\omega}$

Самаранйню:

TBO $\tilde{p}$ тої

Самараныни:

$\mathrm{Cra}^{3}$ :

$\dot{\omega}$ то́й

Самаранынею:

Цво́йственнагш числа̀:

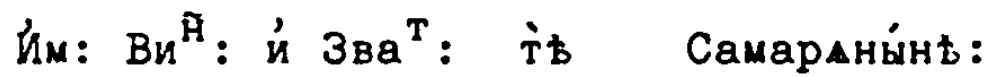

Po

Да ${ }^{\mathrm{T}}$ : й Тво
Множестве́ннагш числа̀:
Йme ${ }^{\text {म }}$ ті́
Самаранына:

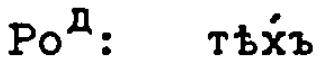
Самараныिн :
да ${ }^{\mathrm{T}}:$ т́́mъ
Самараны́нам"
$B u^{A}:$ T'́
Самаранына :
उва ${ }^{\mathrm{T}}: \stackrel{\stackrel{T}{\omega}}{\mathrm{T}}$
Самаранына :

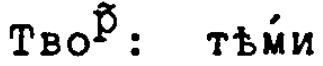
Самаранынами:
Ска ${ }^{3}: \dot{\omega} \mathrm{Tь}^{\mathrm{x}}$
Самараны́на $\mathrm{X}$ :

Сйue, Є̇гіптаныни, Сумантаныни, Грекйни, Ршссйни: и́ про

\section{ПАРАДИГМА}

сугу́бое '́конче́ніе ймуши же́нскии, на, А: й на И.

Числа̀ е́динстве́ннагш:

Йме ${ }^{\tilde{H}}:$ та́a Ст่́на, йлй ств́ни.

Pó: TOA CTína:

Да ${ }^{\mathrm{T}}$ : то́й Ст́́ни:

Ви ${ }^{\tilde{H}}:$ тую Стйн:

Зва ${ }^{\mathrm{T}}: \stackrel{\jmath}{\omega}$ Сти́ни:

Tво : тою Свати́нею:

Ска ${ }^{3}$ : ‘́ то́й сти́ни:

Дво́йственнагш числа̀:

Йн: Вин: й $3 \mathrm{Ba}^{\mathrm{T}}$ : ì ст скин:

Poम : и Ска ${ }^{3}:$ тью́ Стйн:

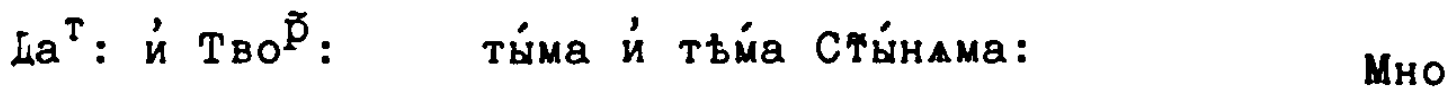




$$
-40-
$$

Мнохесте́ннагш числа̀:

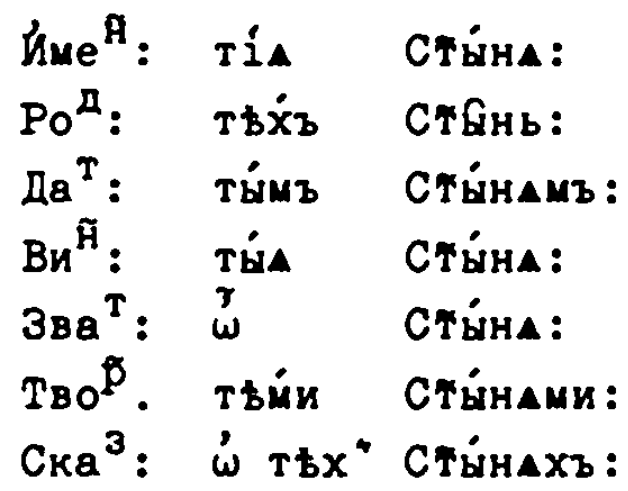

Сйе гордына, йлй гордв́ни: Рабына, йлй Рабыни: мл тына, йлй мл ${ }^{\complement}$ тыни: й про

ПАРАДИГМА Гре́ческих, на, и:

Числа̀ е́динстве́ннагш:

Ğме : та́

Poम: тод Чмарме́ни:

да ${ }^{\mathrm{T}}$ : то́й Џмарме́ни:

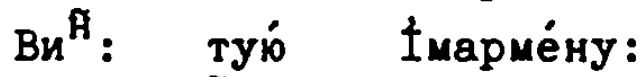

Зва $: \stackrel{\underset{\omega}{\omega}}{\boldsymbol{T}}$ 士марме́ни:

Tвор: тою́ Iмарме́ною:

Ска ${ }^{3}$ : ’े то́й Імарме́ни:

Дво́й

Дво́йственнагш числа̀:

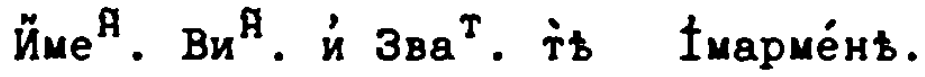

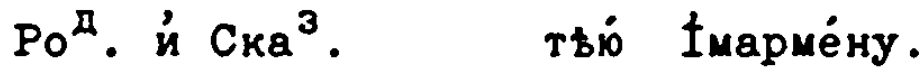

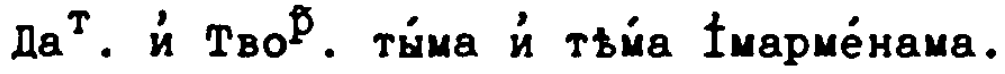

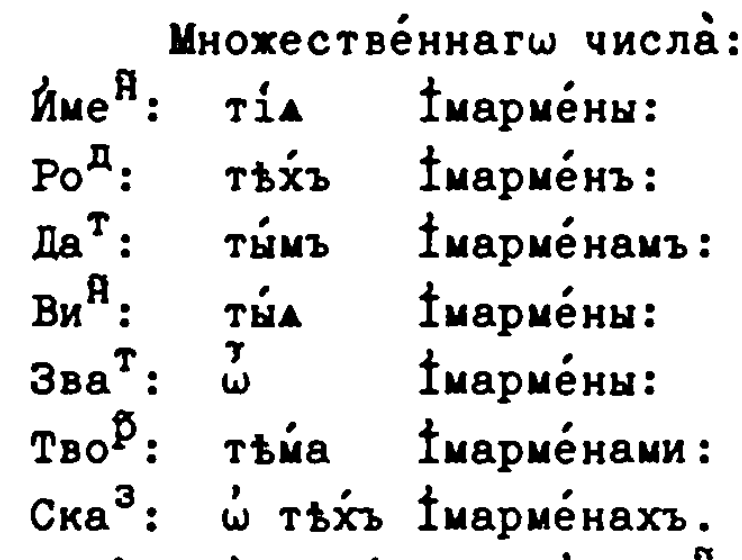

Сйе, ха ва́ни, міेгалй, Ста́кти: й про .

$\dot{\omega}$ Ётероклгтехъ, илй Аномалех".

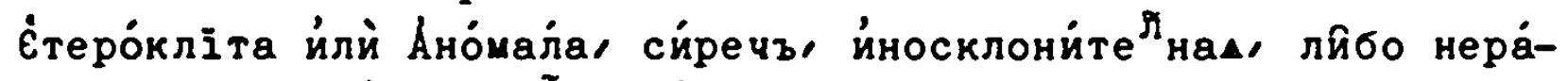
внаА наричутъсА ймена̀, '๋хе йлй паде́хи, лйбо в" склоне́ніи, и́лй в" кое" либо $\omega^{T}$ посльдова́те ныхъ лише́ніе, илй и́зоби́ліе, лй и́змъне́ніе стра́хдутъ. Éтеро́ 
غ́теро́клітта пе́рвагш Склоне́ніА.

Лиша́ющалса числа̀ е́дистве

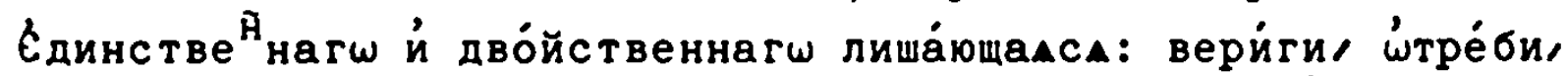
йзге́би, өйвы, Аөйны, Өе́рмы, Лідвіа, Вереї: и́ про

ВTOРОЕ СКЛОНЕНIЕ.

Bто́parw склоне́ніА '́конче́ніА суศь четв́ри

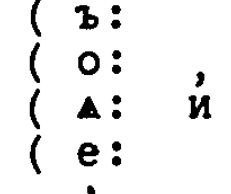

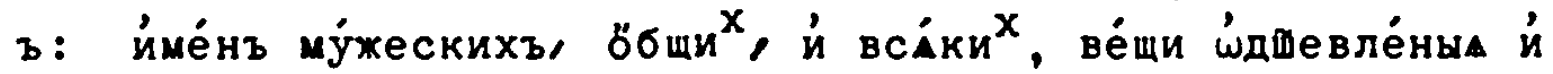
бер ду́шныл знамену́ющихъ: про́чал же сре́дни ${ }^{\mathrm{X}}$ : Йх же роди́телный

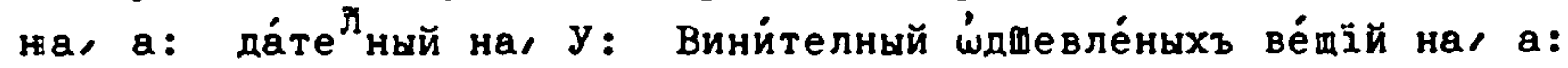
$\mathrm{Бe}^{3}$ ду́шны всі́кш йменителному подо́бенъ: Зва́телный на, е: Творйтелный на, ом: Сказа́телный на, в: Да́телный дво́йстве ный ома. Твори́телный на, ама: Какш во ојка́зв.

\section{ПАРАДИГМАТА НА, ъ:}

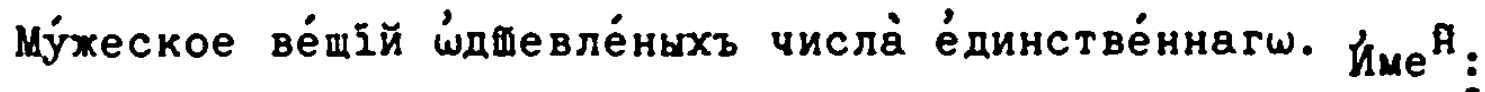

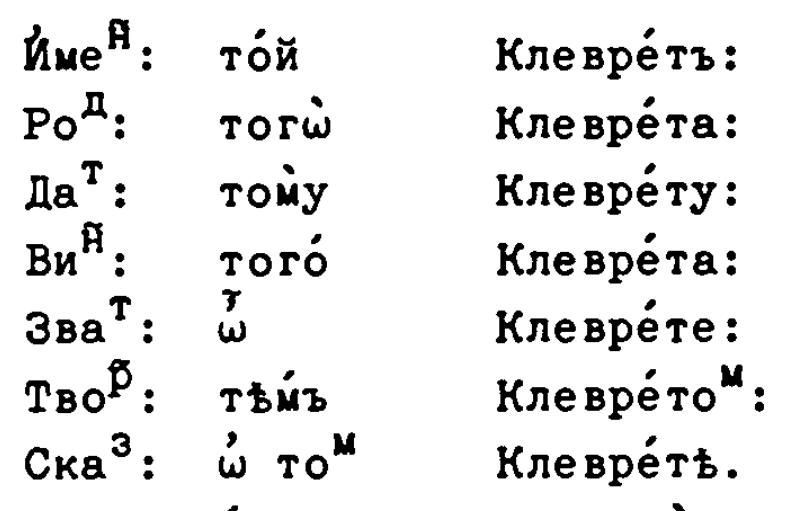

Дво́йственнагш числа̀.

\begin{tabular}{|c|c|c|}
\hline 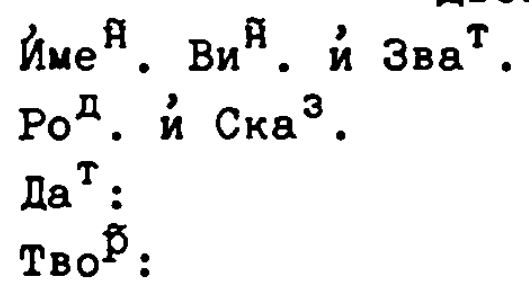 & 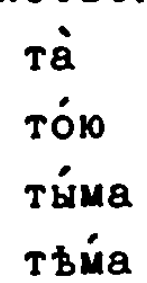 & $\begin{array}{l}\text { Клевре́та. } \\
\text { Клевре́ту. } \\
\text { Клевре́тома. } \\
\text { Клевре́тама. }\end{array}$ \\
\hline
\end{tabular}

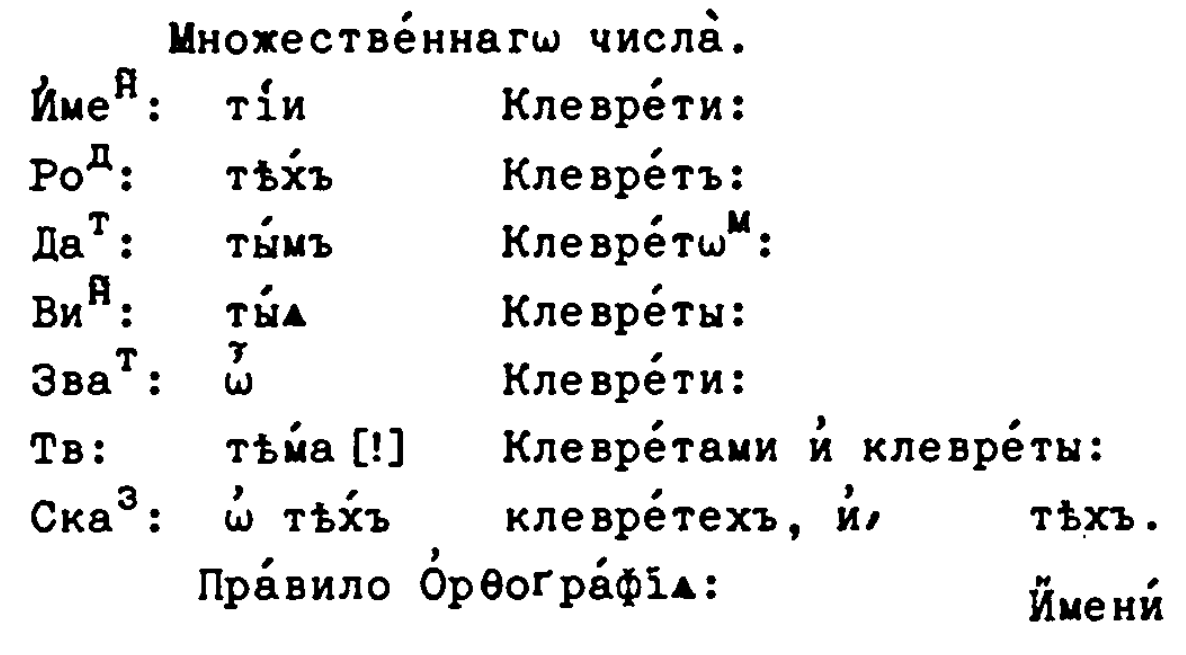


Йменителный '́динстве́нный, на, е: Родйтелный множестве́нный

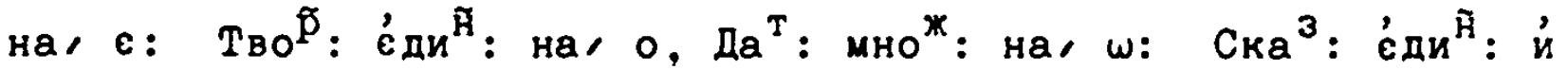

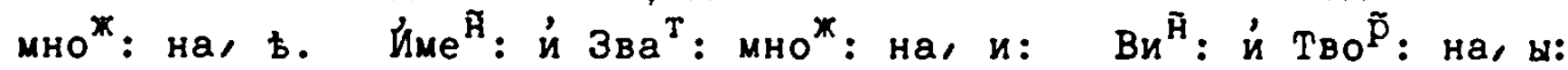

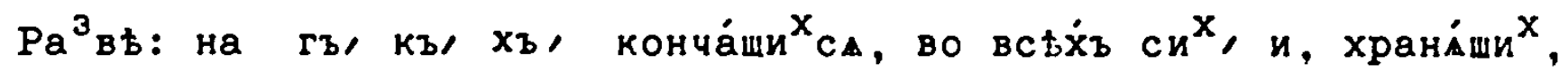
Иix же оу́ка́зы ма́лш посльд́и.

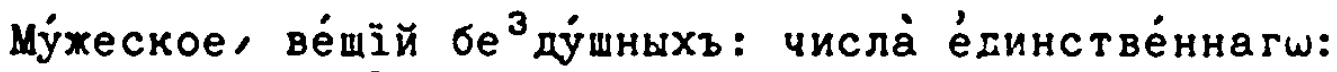

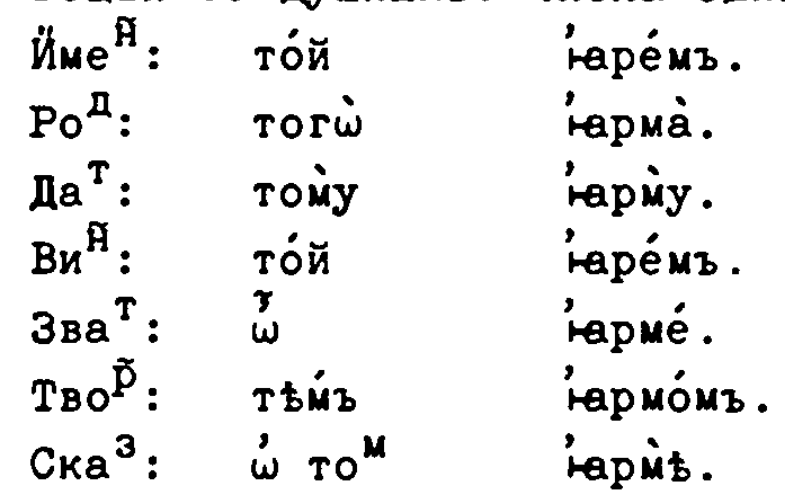

Дво́йственнагш числа̀.

йме ${ }^{\text {म }} \cdot \mathrm{Bи}^{\text {म }} \cdot$ й 3 ва $^{\mathrm{T}}$. та̀

Pоम. 'ं $\mathrm{CKa}^{3}$.

"арма.

$\mathrm{Da}^{\mathrm{T}}$.

Tón

$\mathrm{T}_{\mathrm{BO}}{ }^{\mathrm{p}}$.

ти́ma

Kapmy.

'армо́ма.

тьи́a 'арма́ma.

Множестве́ннагш числа̀.

l̆ме : ті́ 'ормй.

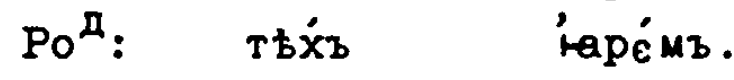

$\mathrm{Za}^{\mathrm{T}}:$

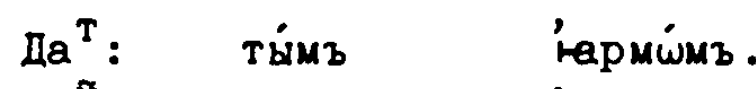

$\mathrm{Bu}^{\mathrm{P}} \cdot{ }_{\boldsymbol{T}}^{\mathrm{T} \dot{\mathrm{B} A}}$

उва ${ }^{\mathrm{T}}: \quad \stackrel{\boldsymbol{T}}{\omega}$

Твор : тьй

Ска ${ }^{3}: \quad \dot{\omega}$ тьх́з

öбщеe ве́щи ம்

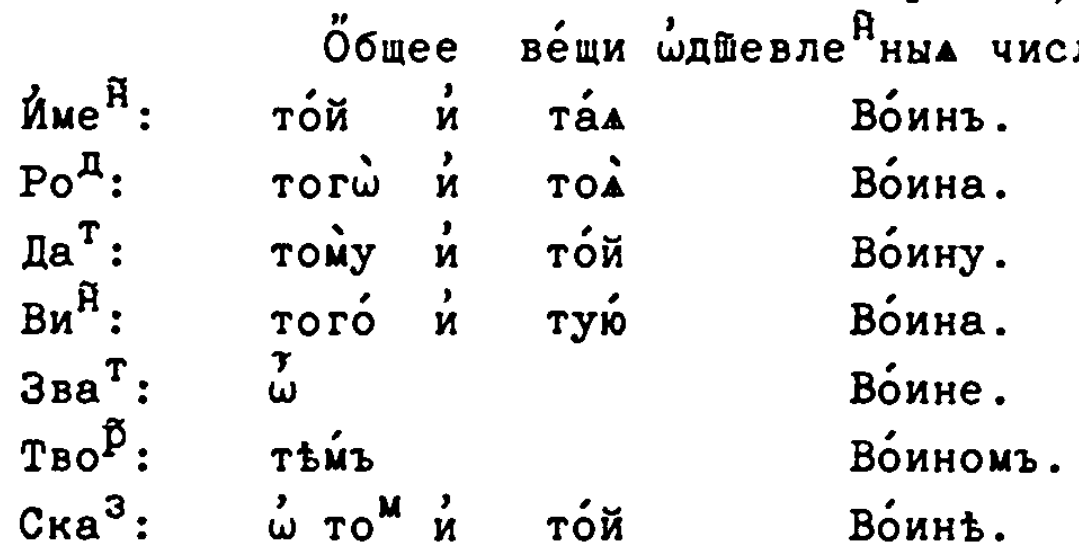

Дво́йственнагш числа̀.

Й. Ви ${ }^{\text {म }}$. й Зв. моу ${ }^{*}$. ро́да та̀ $\mathrm{Za}^{\mathrm{T}}$ : же́нскагш T⿱t) $T_{B O}{ }^{\grave{p}}$ :

во́ина:

во́инь.

во́инома.

во́инама. 
Множестве́ннагш числа̀.

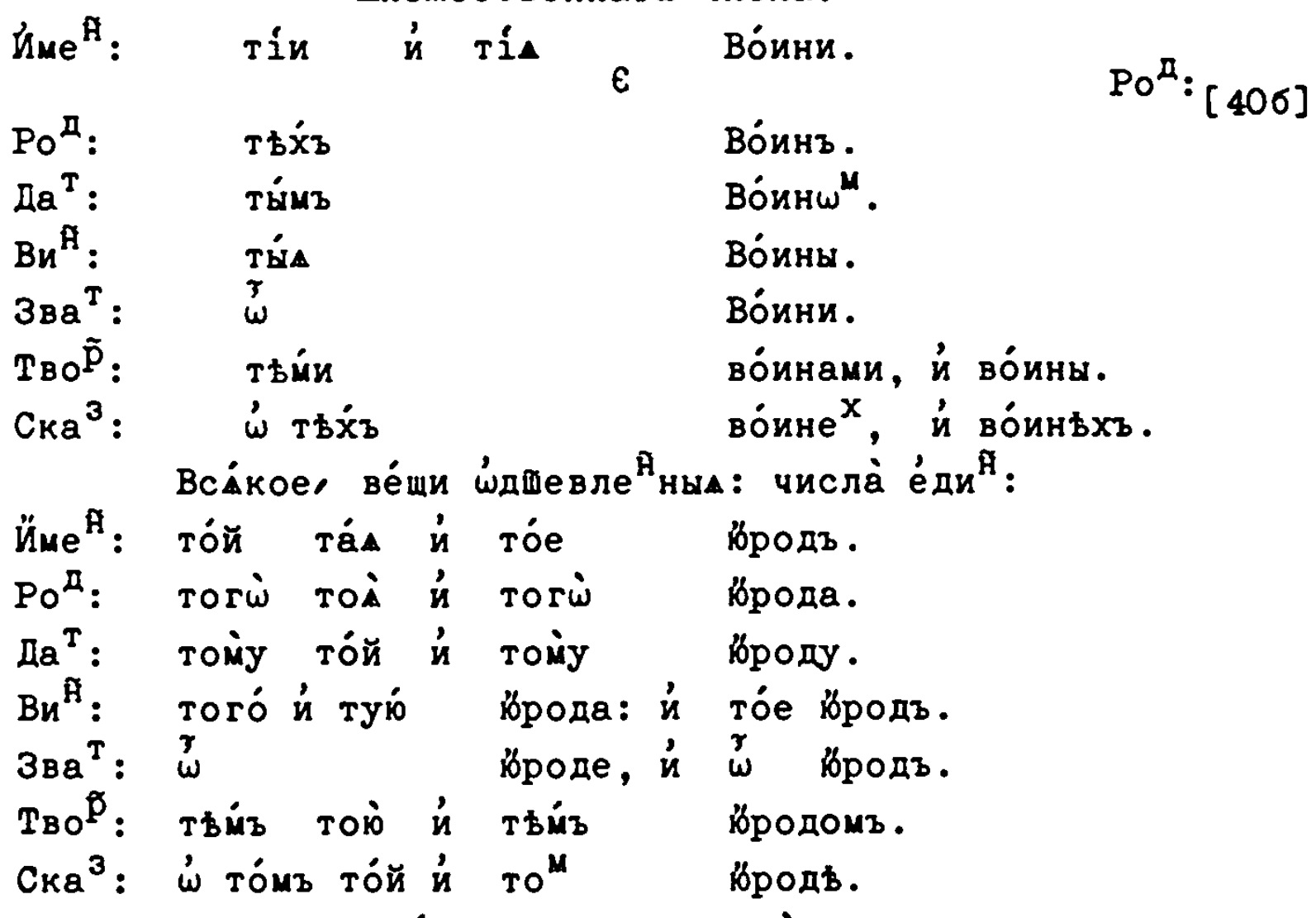

\section{Дво́йственнагш числа̀:}

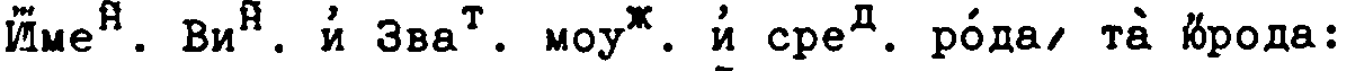
Же́нска ${ }^{7}$. it "̈родь.

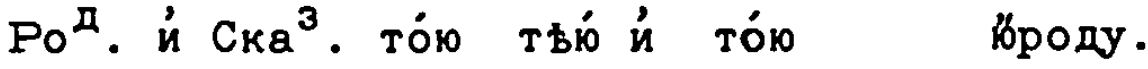

मа ${ }^{\mathrm{T}}$. Tи́ma

TBOP : Tちía "̈родома.

Њродама.

Mнохе

Мнохестве́ннатш числа̀:

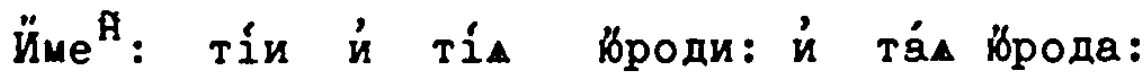

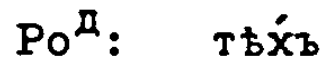

"̈ршдъ:

Да ${ }^{\mathrm{T}}:$ ти́мз

$\mathrm{Bu}^{\text {मी }}$ : Tи́⿴

उва ${ }^{\mathrm{T}}: \stackrel{\boldsymbol{T}}{\omega}$

Tво ${ }^{p}$ : тьй

16родшнъ :

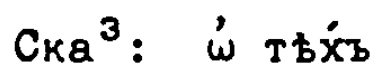

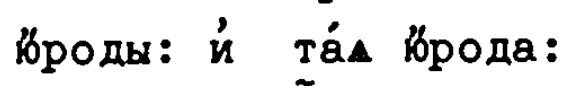

йроди, й $\stackrel{?}{\omega}$ юрода:

\%родами, й йроды:

ipродех", иं ̈родьхъ.

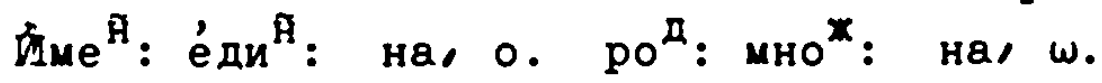

Сре́днее на, 0 :

Числа̀ е́динстве́ннагш:

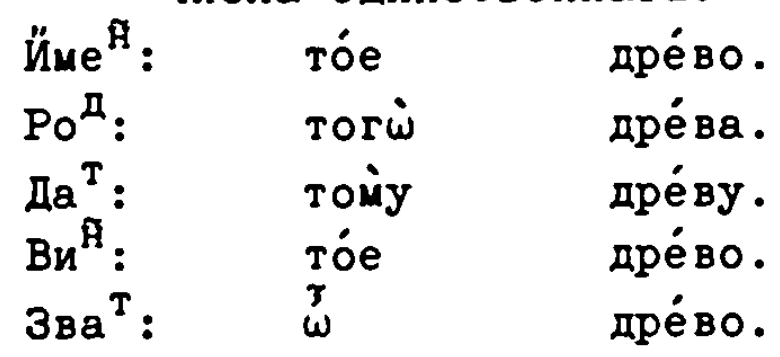




$\begin{array}{lll}\text { Tво } & \text { тьй } & \text { дре́вомъ. } \\ \text { Cка }^{3}: & \stackrel{\omega}{\omega} \text { то } & \text { дре́вь. }\end{array}$

Дво́йственнагш числа̀:

Йм: $В{ }^{\AA}:$ й Звател: та̀

Роди ${ }^{\mathrm{T}}: \dot{и}$ Сказа ${ }^{\mathrm{T}}:$ то́ю

मа ${ }^{\mathrm{T}}$ :

$\mathrm{TBO}^{\mathrm{p}}$ : дре́ва.

дре́ ву .

ти́мa дре́вомa.

тbía дре́ вамa.

Мнохестве́ннагш числа̀:

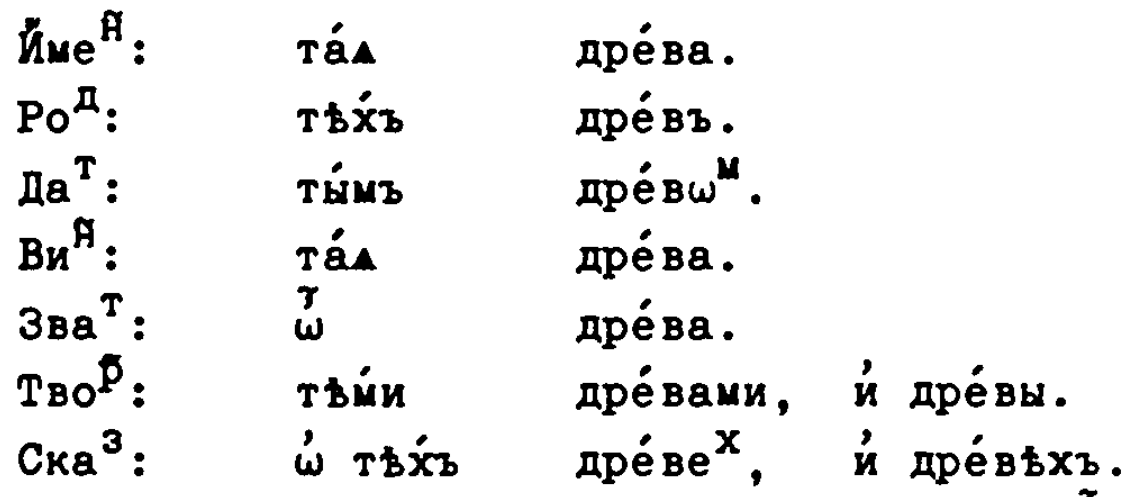

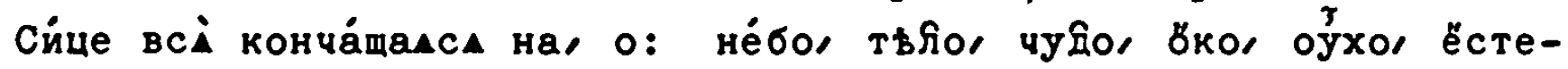
ство, льяо, бра́mно, зла́то, ло́рекло, здо́, блбдо, ми́ро, ве́дро,

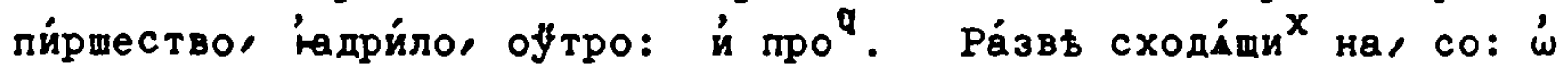
ни ${ }^{x}$ xe по ма́ль.

\section{Oу́въме́ніе a:}

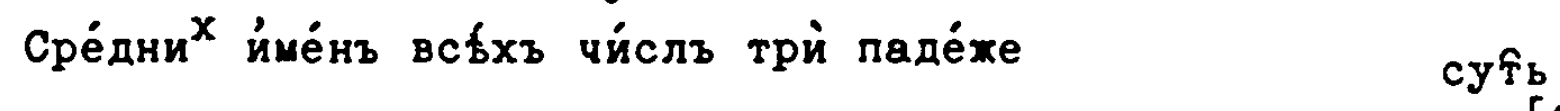

суя⿱宀 подо́бии, Йени́телный, Вини́телный, и́ Зва́телный.

оу́ввше́ніе :

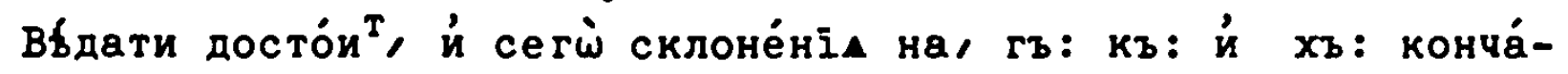
щалса ймена̀ премена́ти в" Зва́телно" е́динстве́нномъ $r$, на/ $x: K$,

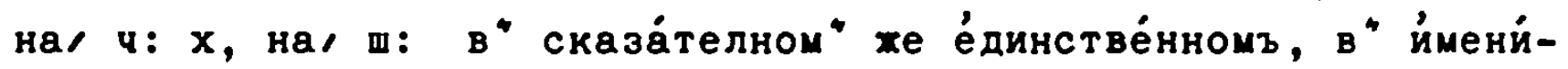
телномъ зва́телномз й сказа́телно мнохестве́нномъ $r$, на, $3: \kappa$,

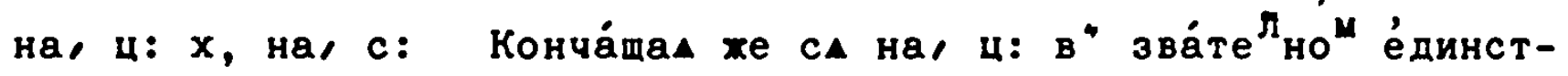
ве́нно ц, на, 4 .

ПLРАЦИГМАТА На, Гъ.

Числа̀ е́динстве́ннагw:

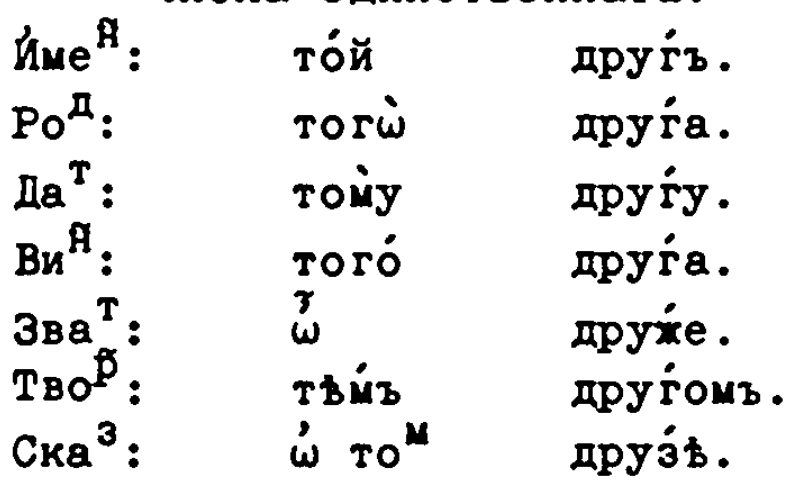


Дво́йстве

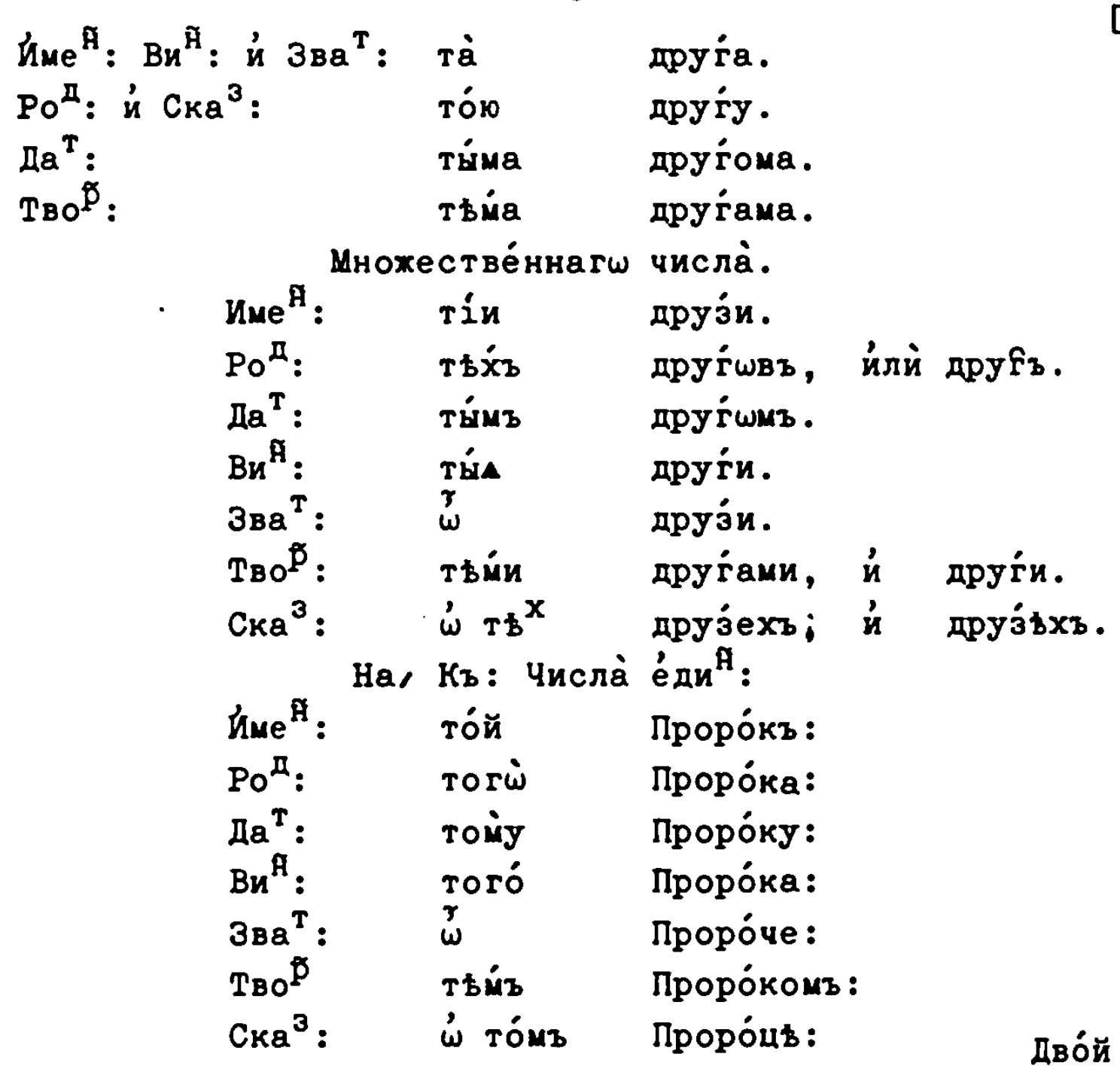

Дво́йственнагш числа̀:

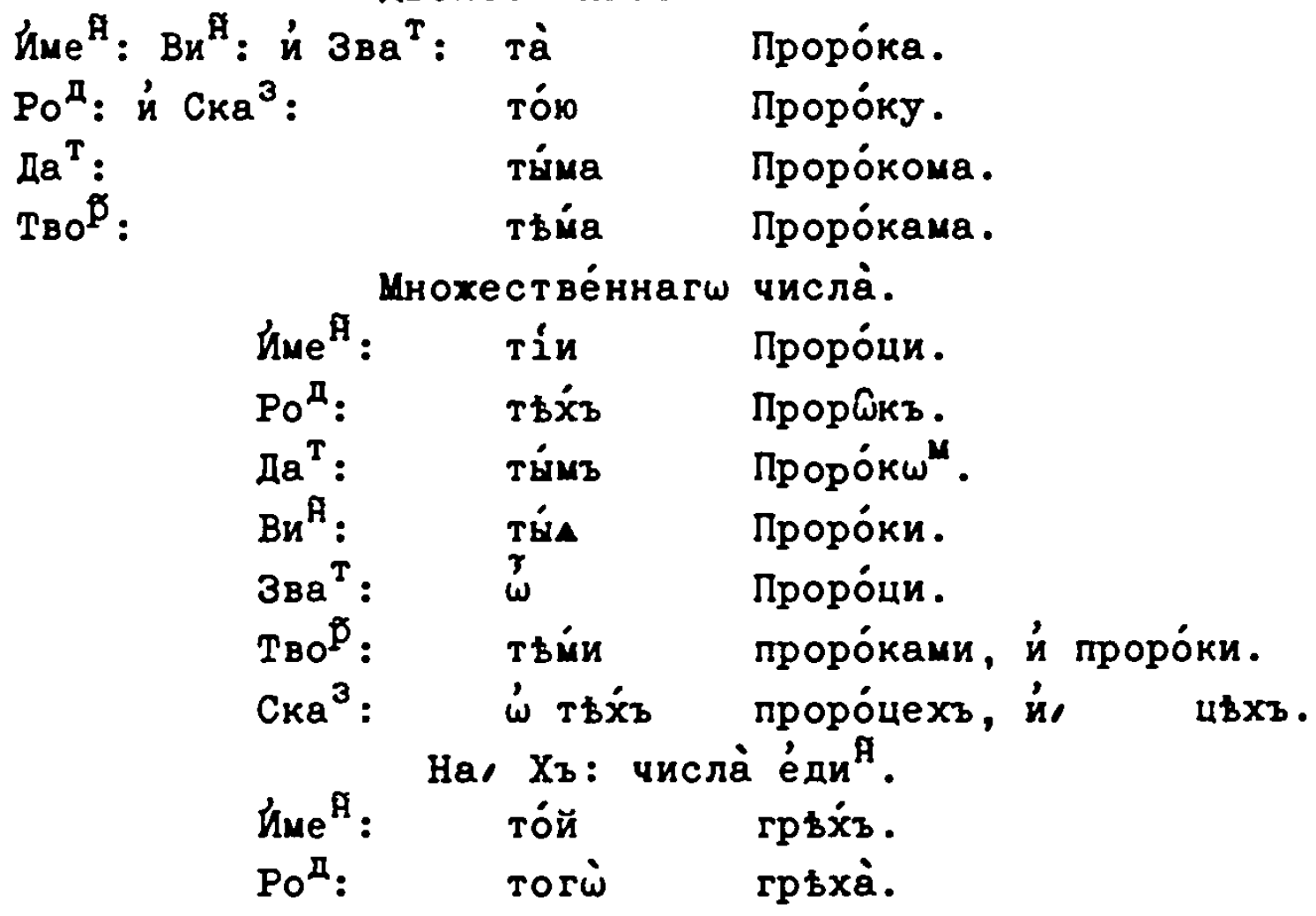




\begin{tabular}{|c|c|}
\hline$\not a^{T}:$ & roiny \\
\hline $\begin{array}{l}\mathrm{B}{ }^{\mathrm{A}}: \\
3 \mathrm{~B} \mathrm{Q}^{\mathrm{T}}:\end{array}$ & \begin{tabular}{l} 
той \\
\multirow{\omega}{\omega}{}
\end{tabular} \\
\hline $\begin{array}{l}T_{B O}{ }^{p}: \\
C_{K Q^{3}}:\end{array}$ & $\begin{array}{l}T \hbar \dot{M}_{b} \\
\dot{\omega} T O^{M}\end{array}$ \\
\hline
\end{tabular}

Дво́йственнагш числа̀.

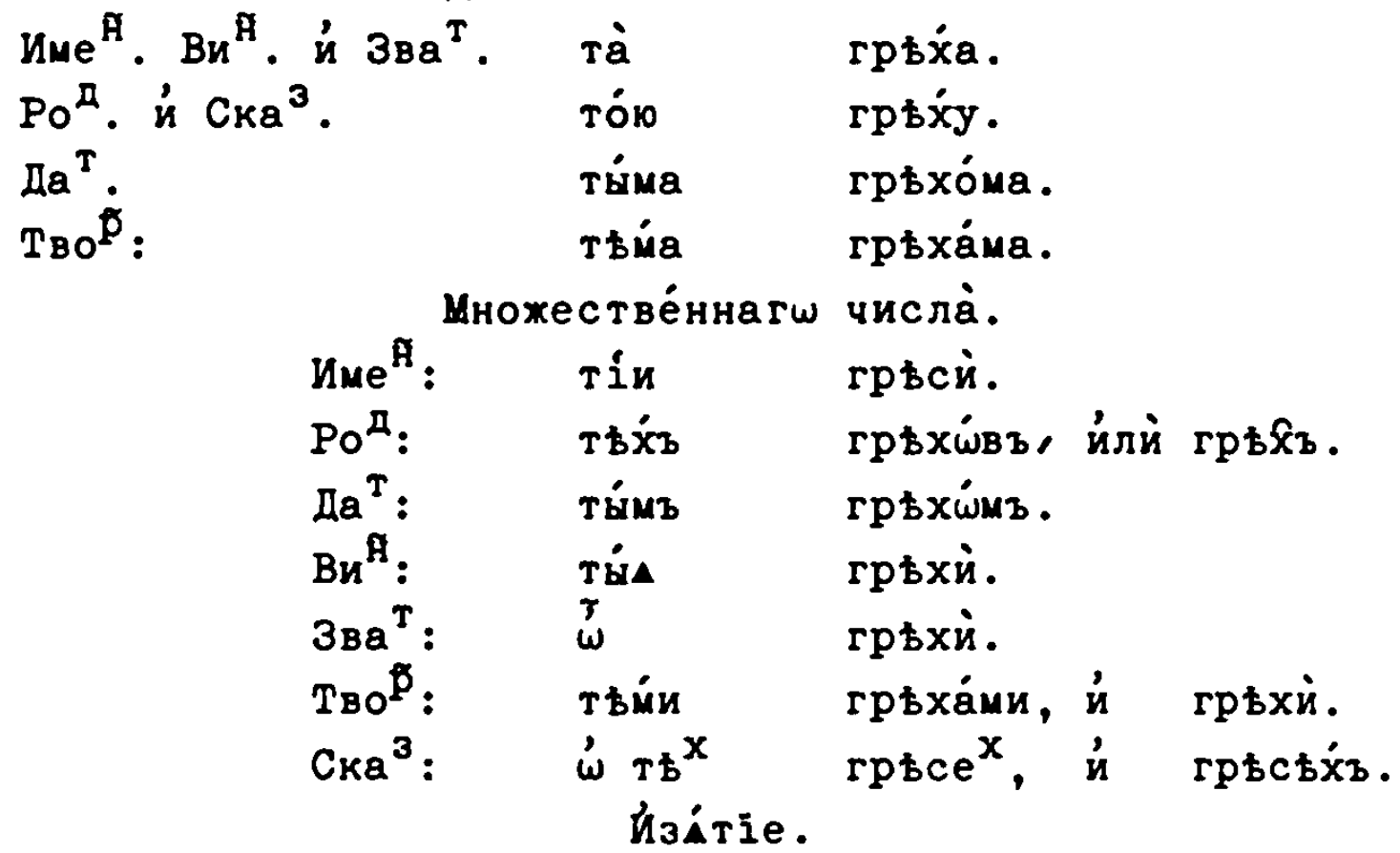

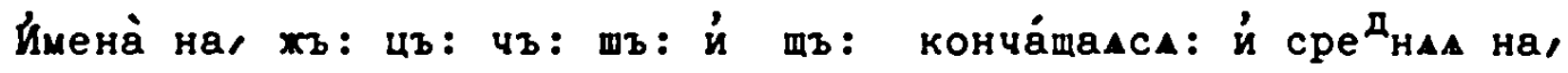
е: Твори́телный е́динстве́нный твори́тъ на, $\mathrm{e}^{\mathrm{M}}$ : Да́телный дво́йственный на, ема: мнохестве́нный на, $\varepsilon^{M}$ : вини́телный на, $\varepsilon$, йлй на, А.

MAPA

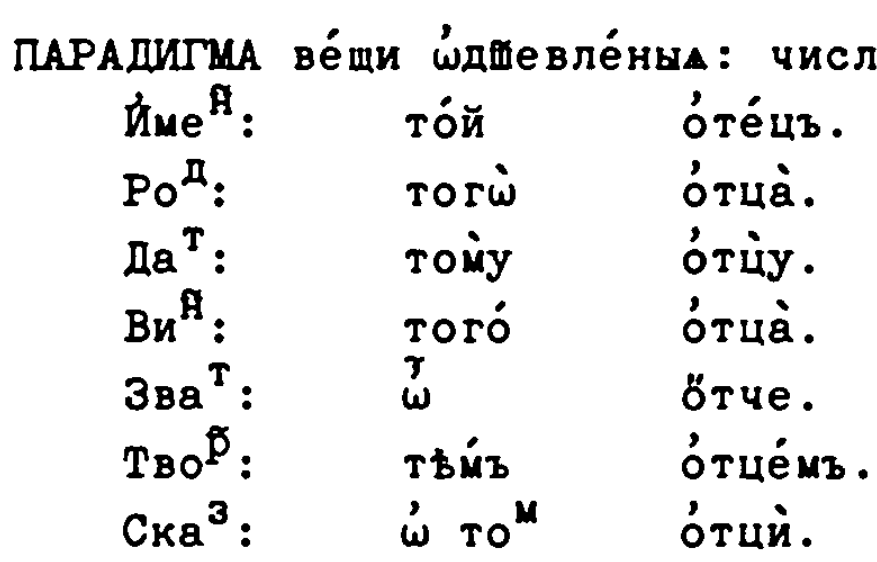

Дво́йственннагш числа̀.

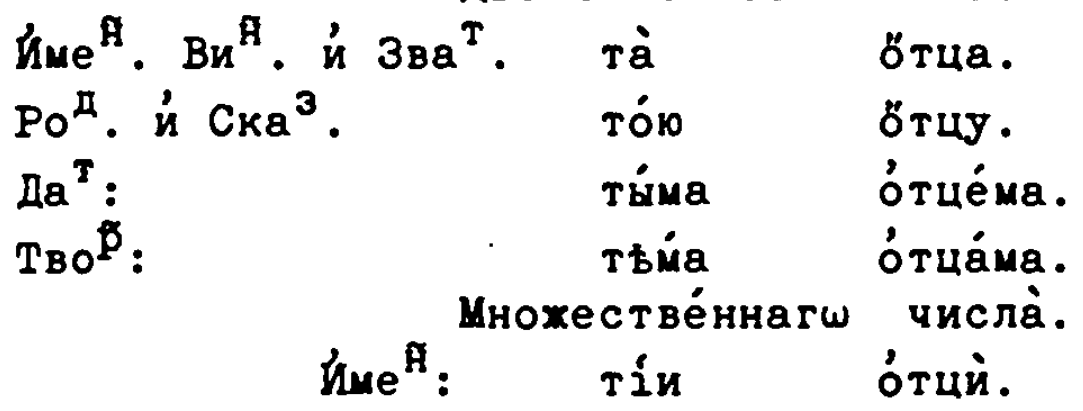




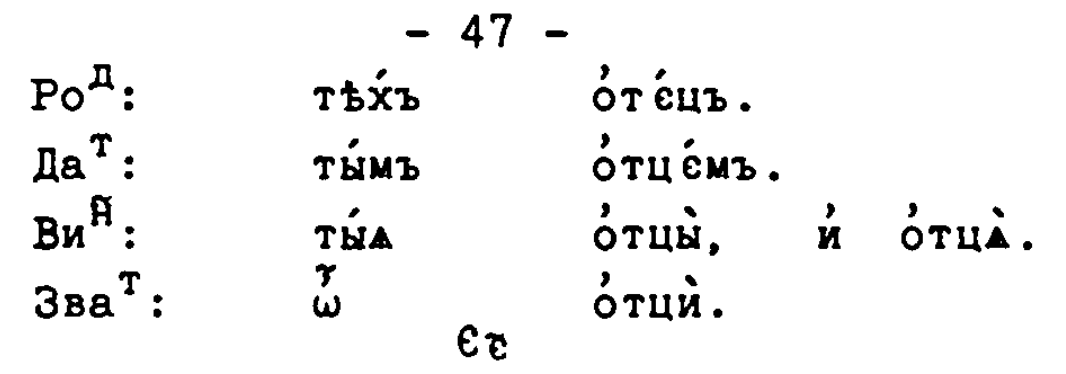

твор : твйи о́тца́ми, йлй о́тці.

TBO $0^{\mathfrak{p}}:[446]$

Ска ${ }^{3}: \quad \dot{\omega}$ тъхъ óтuе́xъ.

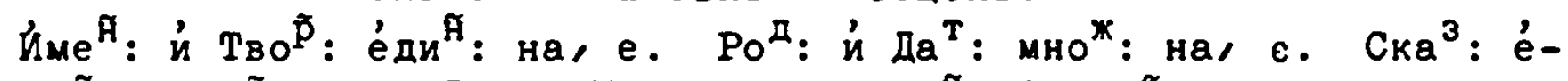

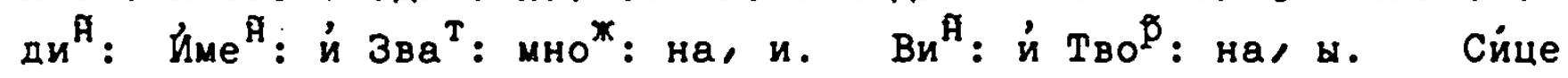
ВСї на, Жъ: Чъ: Чъ: Шъ: Щъ: КОНча́щаАСА.

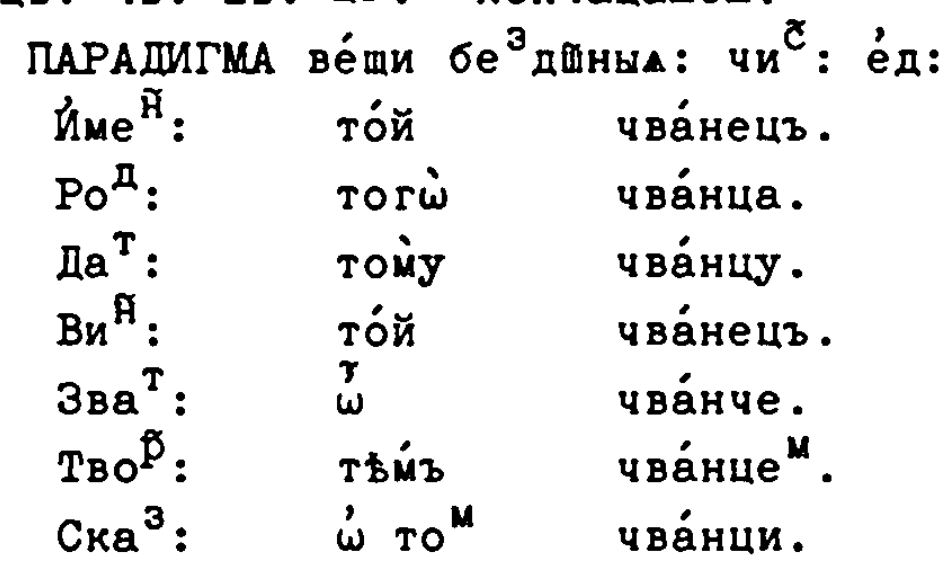

Дво́йственнагш числа̀.

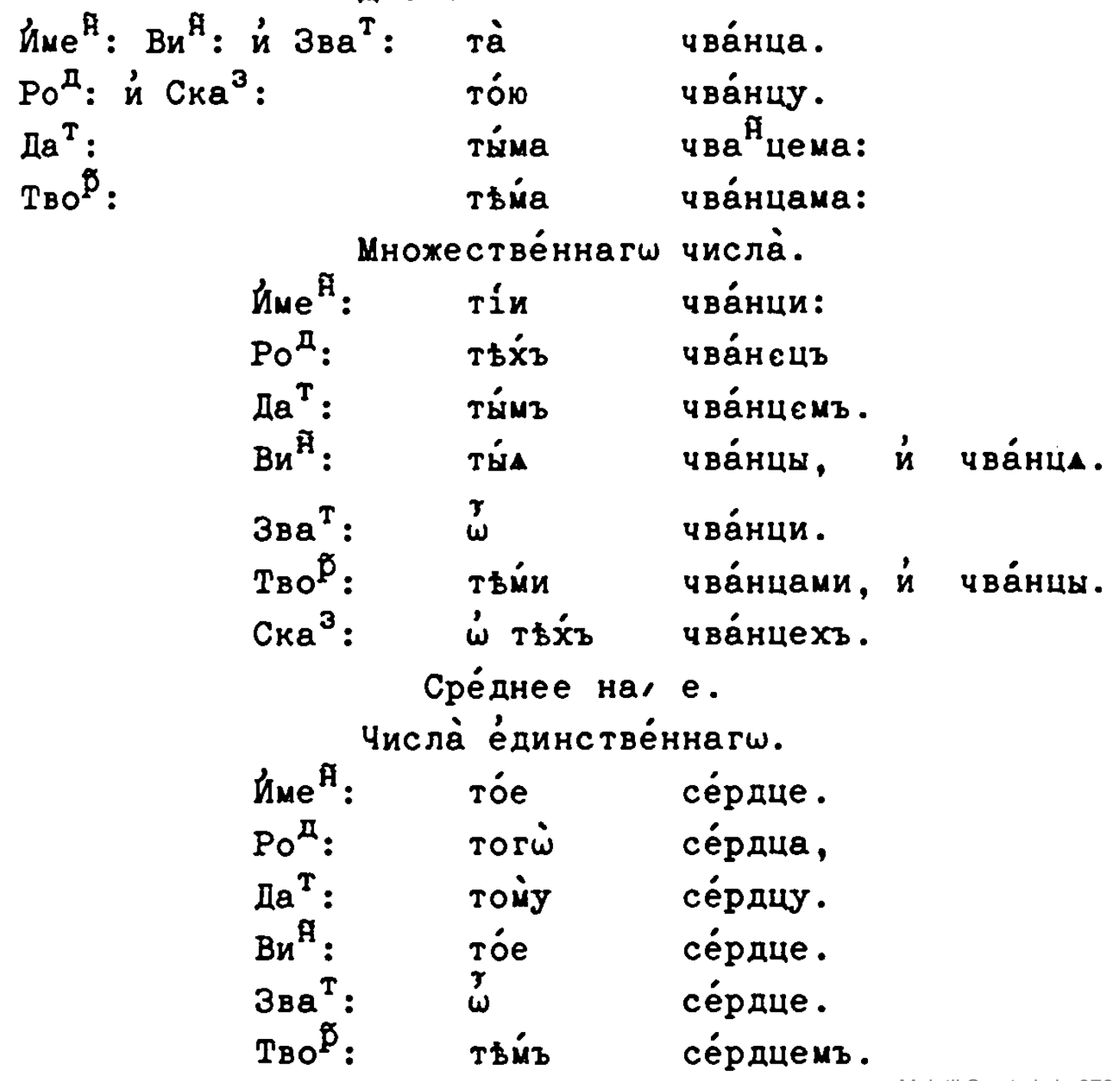




$$
\text { Ска }{ }^{3}: \quad \dot{\omega}_{\text {то }}{ }^{48-} \text { се́рдци. }
$$

Дво́йственнагш числа̀:

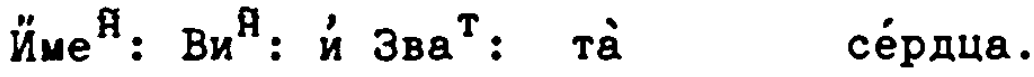

$$
\begin{aligned}
& \text { Poम : й } \mathrm{CKa}^{3} \text { : тón cépдцy. } \\
& \text { да }{ }^{\mathrm{T}} \text { : ти́ma cе́рдиемa. } \\
& \text { Tво : Tьйa cépдuama. } \\
& \text { Йме }{ }^{\text {Mнохестве́ннатш числа̀: }}
\end{aligned}
$$

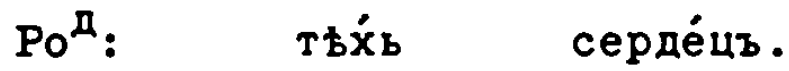

$$
\begin{aligned}
& \text { да }{ }^{\mathrm{T}} \text { : ти́mb се́рдие }{ }^{M} \text {. } \\
& \text { Ви }{ }^{\text {म }} \text { тáa cépдua. } \\
& \text { Зва }{ }^{\mathrm{T}} \stackrel{3}{\omega} \text { cépдua. } \\
& \text { твор : тьй се́рдиами, й се́рдцы. }
\end{aligned}
$$

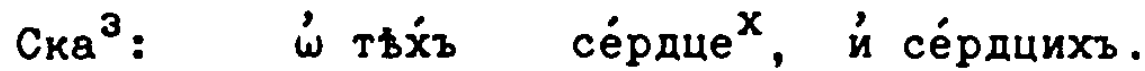

Cи́це, лице́, слине, су́дище, тре́бище, вре́тище, ны́рище, ло́хе, mope: 'ं про .

$$
\text { О’́въще́ніе, }
$$

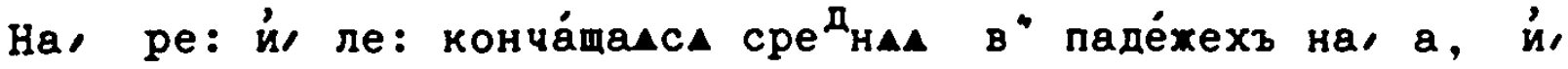

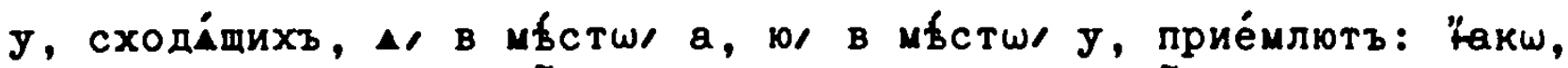
мо́ре, раر рю: и́ про : по́ле/ лА/ лю: й про

$$
\text { оуввще́нїе, в. }
$$

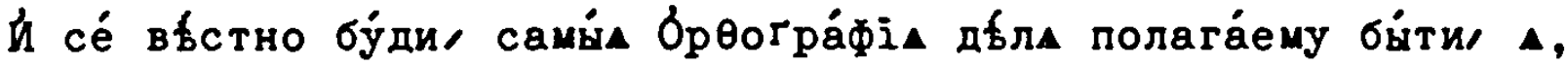
во '́конча́нги зде й в" пе́рво" склоне́ніи вини́телнагш множестве́ннагш, в" пе́рвом хе и́ Роди́телнагш на, жа, ца, ча, ша, и́, ща,

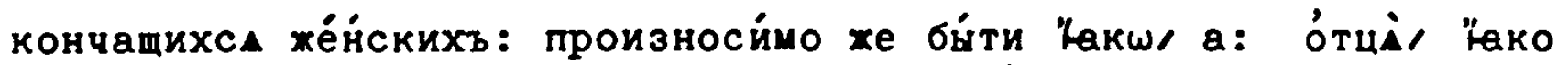
хе о́тиа̀, чва́нца/ Һако хе чва́нца: и́ про". Денни́ци/ мре́ха/ йноши, предоте́ча, '́брі́mа, "әко

xe'

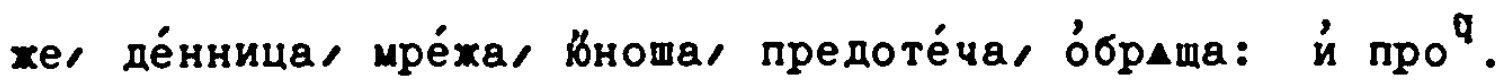

$$
\text { ојввие́ніе, } \mathbf{r} \text {. }
$$

Склоне́ніА сегі் ймена, йзрА мощй в" паде́хехъ ма́ла всбххъ: Һакw,

$$
\text { Числа̀ е́динстве́ннагш: }
$$

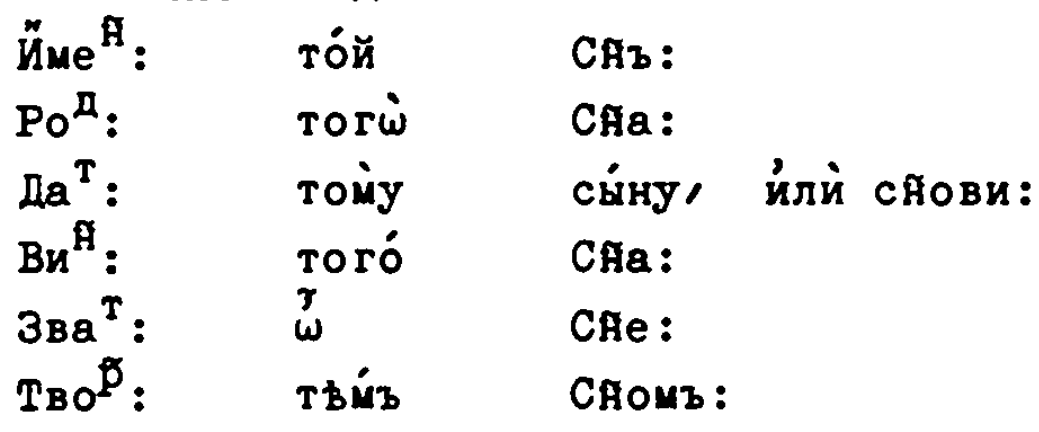




\section{Ска ${ }^{3}$ : $\dot{\omega}$ то ${ }^{M}$ СЯв:}

Дво́йственнагш числа.

\begin{tabular}{|c|c|}
\hline 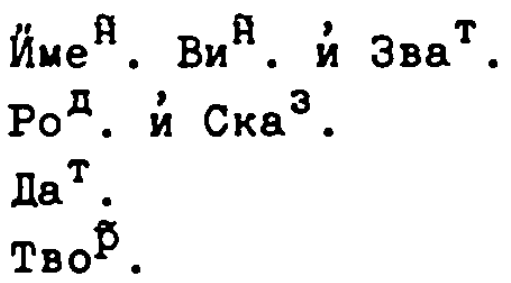 & $\begin{array}{l}\text { Tà } \\
\text { Tóro } \\
\text { Túma } \\
\text { Tちía }\end{array}$ \\
\hline
\end{tabular}

Мнохестве́ннатш числа̀:

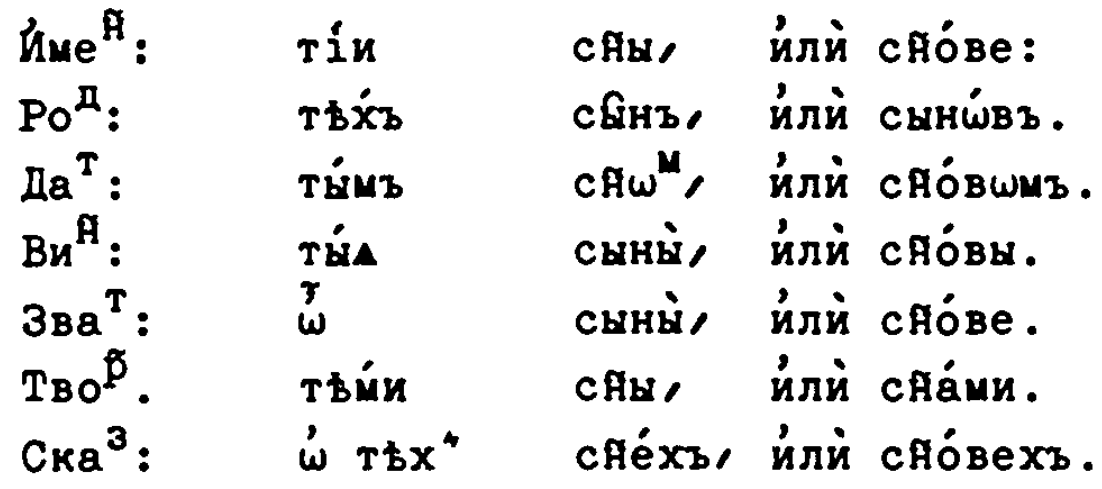

MHoxe

[466]

Сйце, ду́хъ, ра́бъ, вра́нъ, крі́нъ, гро́бъ, до́хдъ, мра́зъ/ бра́къ,

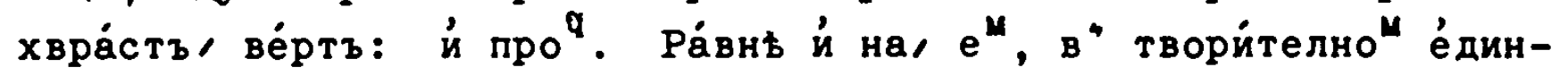
стве́нномъ сході́щал: "Һкш во оукќ́зъ.

$$
\begin{aligned}
& \text { Числа̀ е́динстве́ннагш: } \\
& \text { йме то́й хре́цъ: }
\end{aligned}
$$

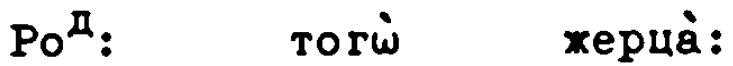

$$
\begin{aligned}
& \text { да }{ }^{\mathrm{T}} \text { : тому жерйу йлй херце́ви: }
\end{aligned}
$$

й про́чал, 'Һако хел о́те́uъ.

\section{Мнохестве́ннагш числа̀:}

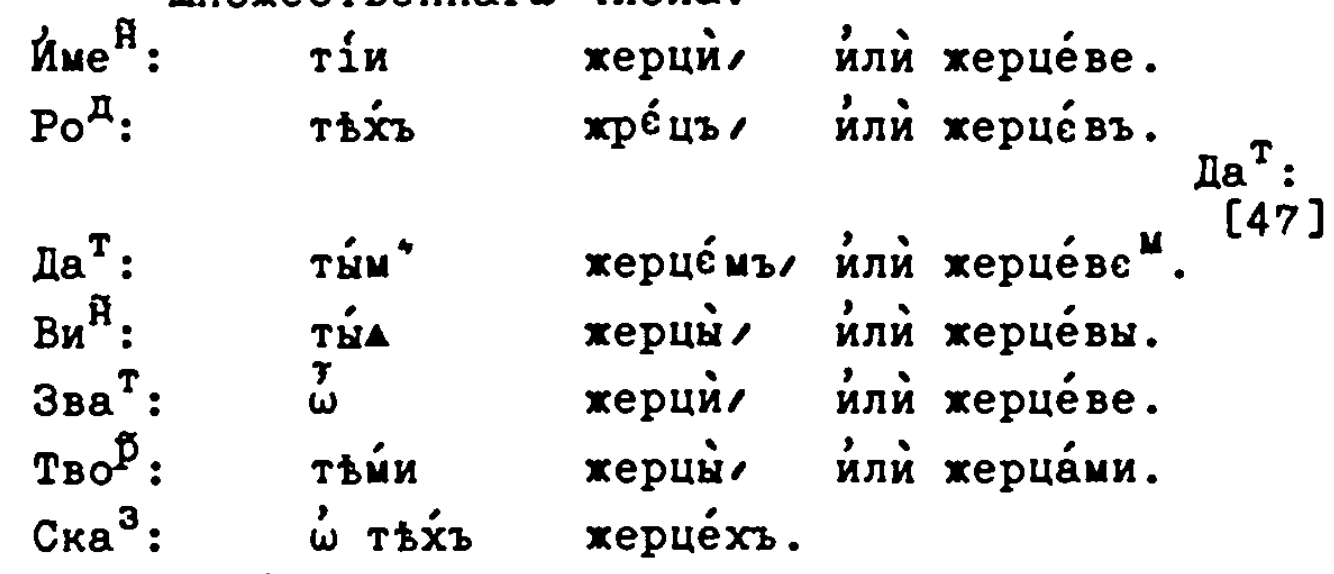

Жерце́въ, притаха́телна Йменителный нал е. Жерив́въ существи́те тво́рецъ: й про ${ }^{q}$.

ПАРАДИГКАТА: сре ${ }_{\text {нихъ на, }}$ : й со:

Vx хе роди́телний на, е: да́телный на, и:

Сйце скландема: на, А:

Числа̀ е́динстве́ннатш:

$$
\text { lime }{ }^{\text {: }} \text { tóe ótpoù: }
$$




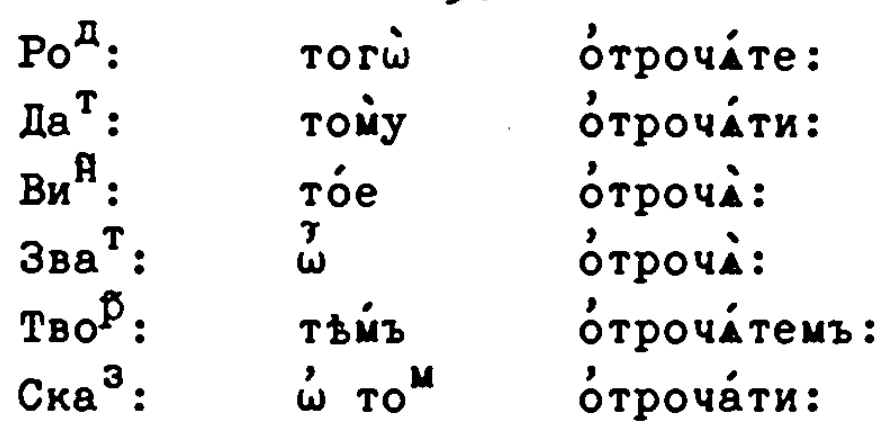

Дво́йственнагш числа:

Дво́й

$[476]$

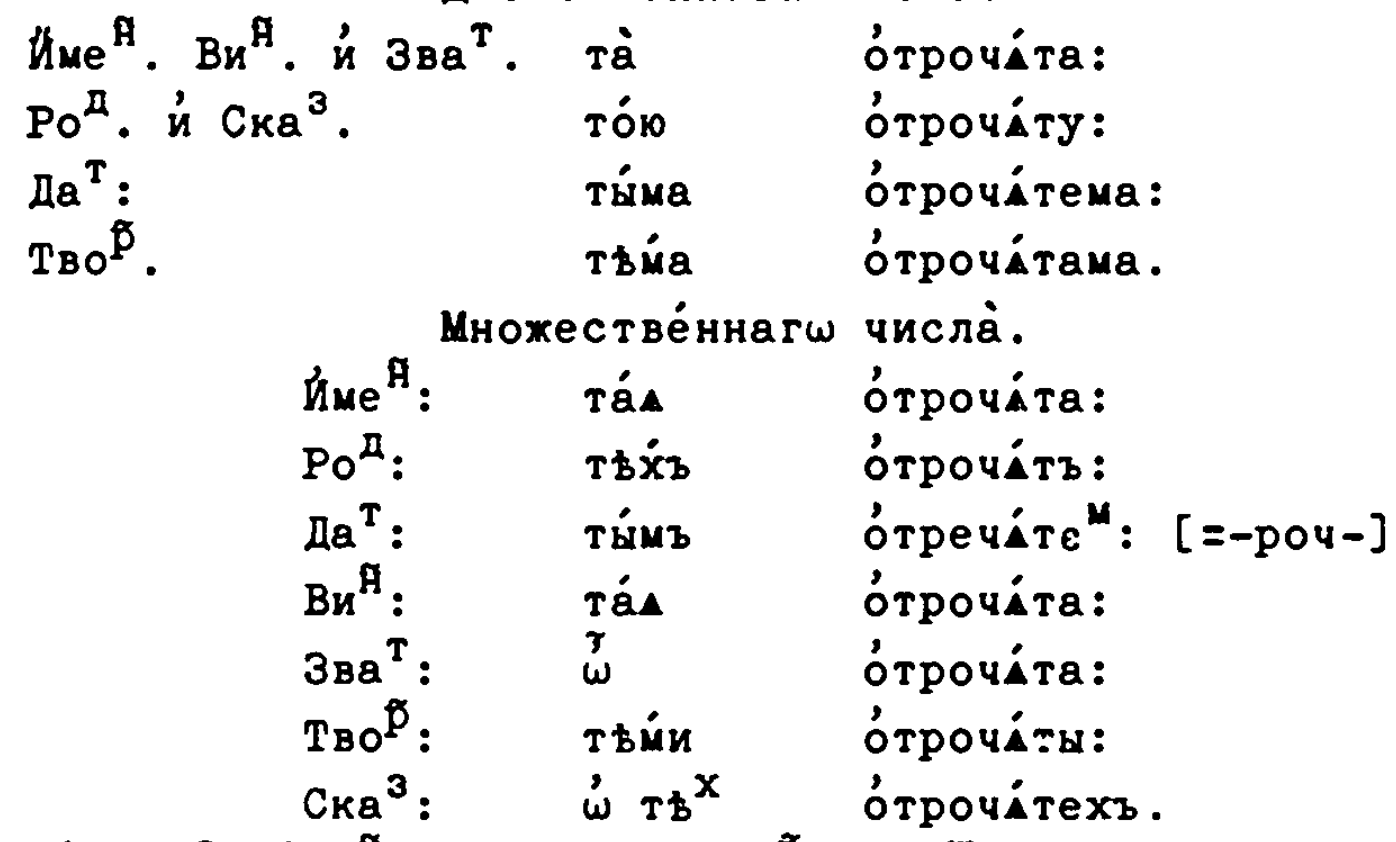

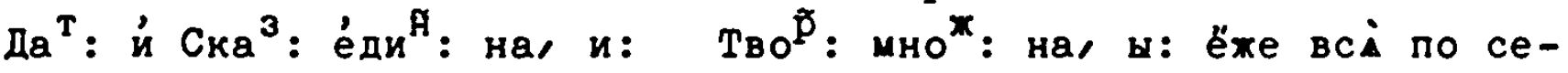
му Паради́гмати склані́ющалса й со конча́щимиса на, мА: Сохрана́тъ.

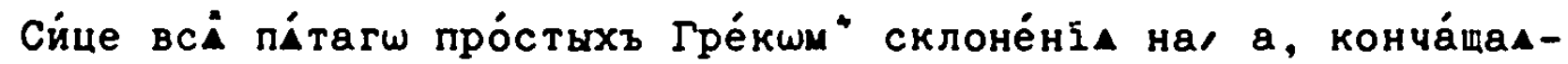
са сре́дима: Какш, Пара́дитма, ёмвлима, Катапета́сма, А́кро́ама,

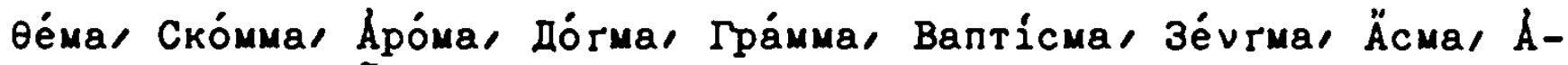
наөе́мa: й про .

Конча́

Конча́mаА хе са славе́нскаА на, мА: А/ во прочїихъ паде́хехъ иззьнйютъ на, е: Сйце скланӒема.

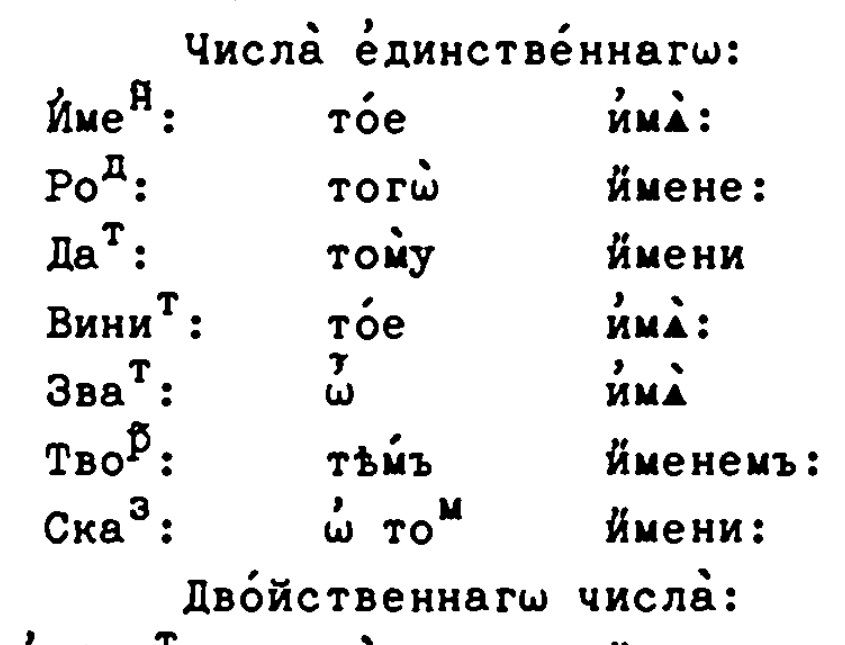

Й. Вин. й $3 в Q^{T}$. та̀ ймена: 


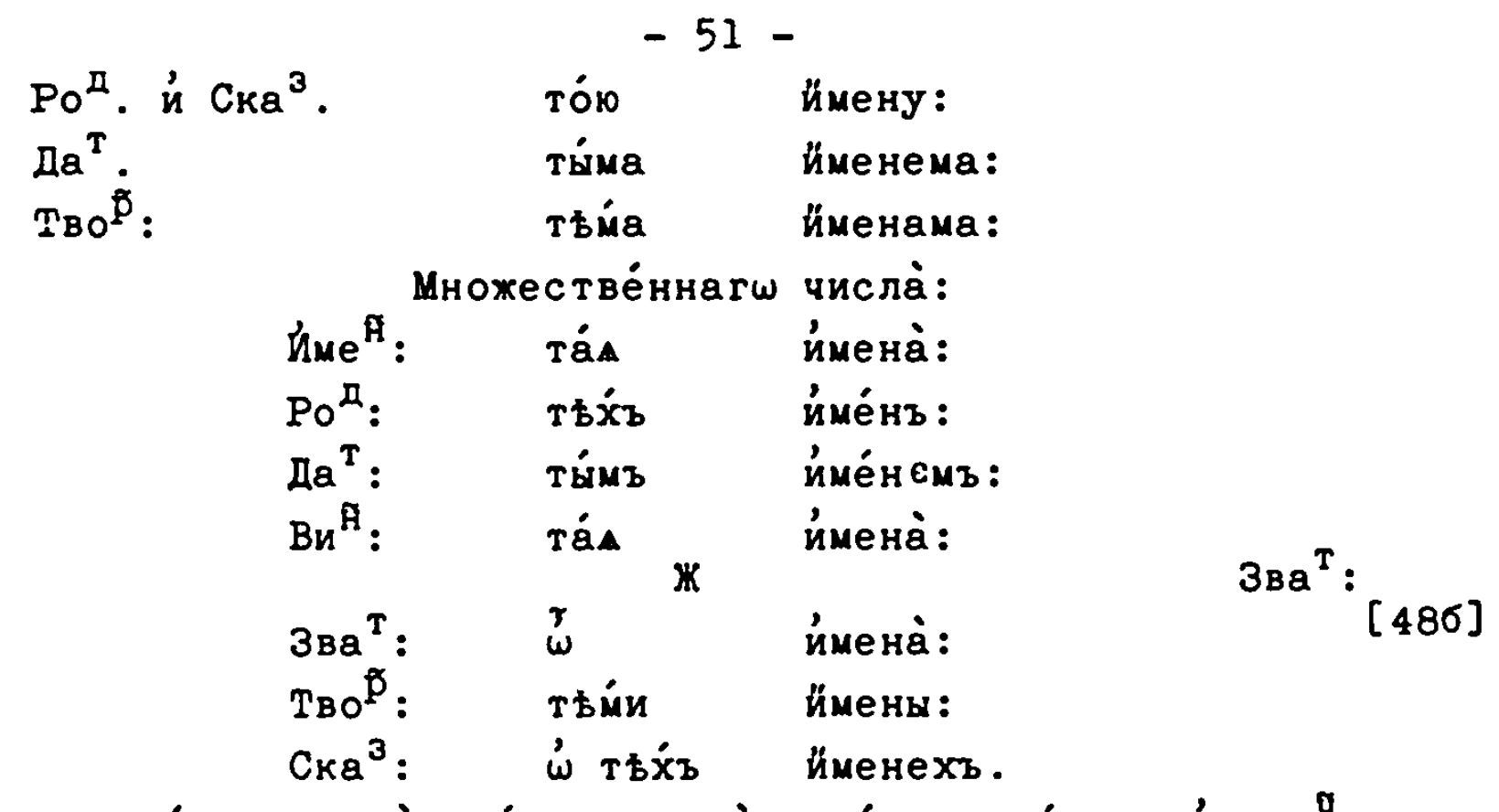

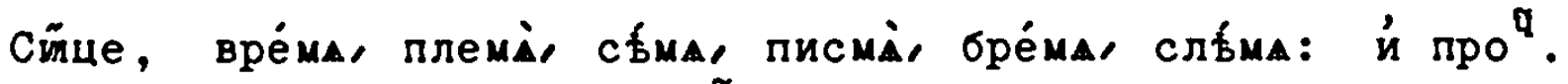

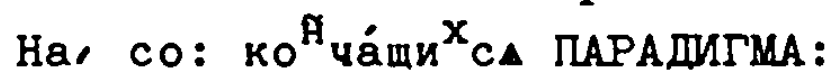

$\dot{\omega}$ ни ${ }^{x}$ же вбстно бу́ ди, йменйтелну, вини́телну, и́ зва́телну е́динстве́ннымъ, во оу́[по]требле́нйи не бы́ти, ибсто йхъ оу́лотреблйемы" наполнїющи": 'Һакш,

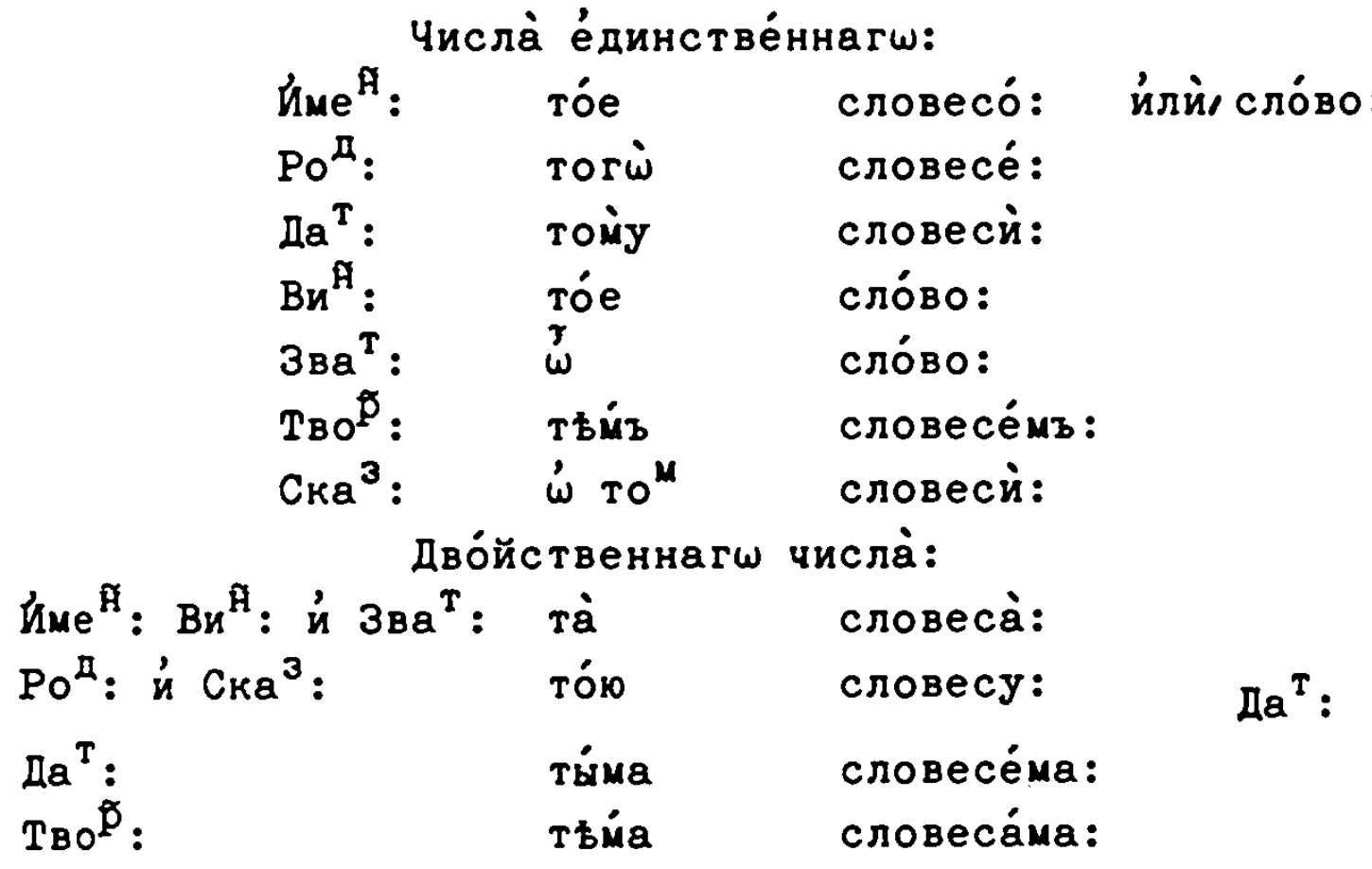

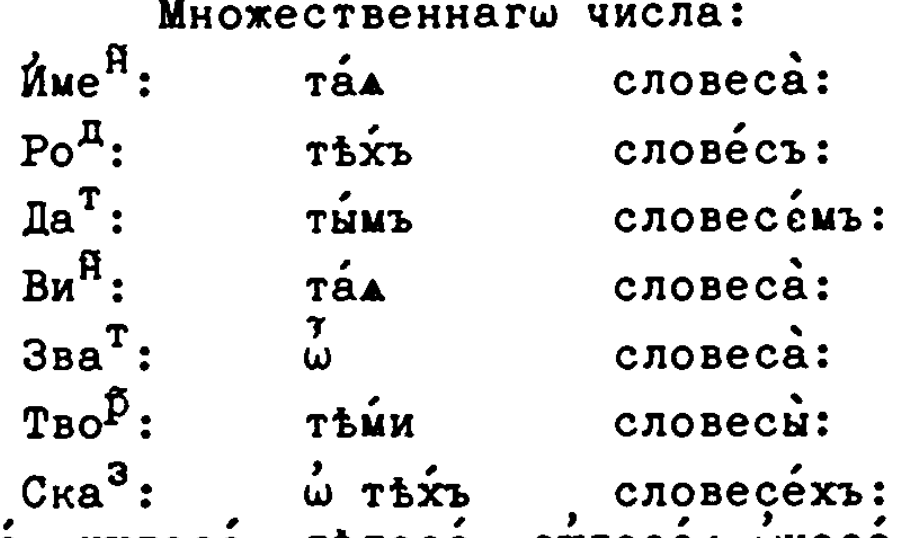

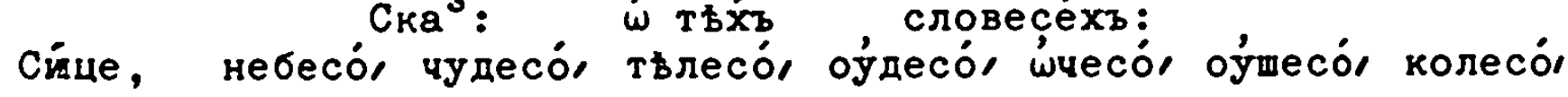


древесо́: иं про ${ }^{q}$. О’употребла́емы йхъ сйречъ, не́бо, чудิо тАлิо, оўхо, б̆ко, ко́ло: й про ${ }^{q}$ : скланиемвмъ "акш, дре́во: оўдъ, й подоббнам е́му, Гакш Клевре́тъ.

$$
\text { Оувъте́нїе, a. }
$$

Сло́во: érдà превб́чне Бүa $\omega^{T}$ ца̀ Сло́во знамену́етъ, вини́телный й зва́телнвй сугу́бъ приемлетъ, сіестъ сре́дна ро́да и́ му́хеска, Сло́вог и́ Сло́ва: Сло́воя й Сло́ве.

$$
\text { О’увьше́ніе, в. }
$$

K сем̀y склоне́нію и́ о́те́чествнал му́хескац возно́са ${ }^{\mathrm{T}}$ сА, хе́нскимъ ко пе́рвому возноси́мымъ. ймени́телньй й зва́телний мнохест-

\begin{tabular}{|c|c|c|}
\hline \multicolumn{3}{|c|}{ Числа̀ е́динстве́ннагш: } \\
\hline Ume & то́й & Римланйнъ: \\
\hline Pon: & Tor $\dot{\omega}$ & РимлАнйна: \\
\hline$\not a^{T}:$ & Tomy & РимлАнйну : \\
\hline $\mathrm{Bu}^{\mathrm{A}}$ : & Toró & Римльни́на: \\
\hline Зва ${ }^{\mathrm{T}}:$ & & Римланйне: \\
\hline TBOop & Tちய́m & Римланином \\
\hline Ска ${ }^{3}$ : & $\dot{\omega}$ & РимлАнйнь: \\
\hline
\end{tabular}

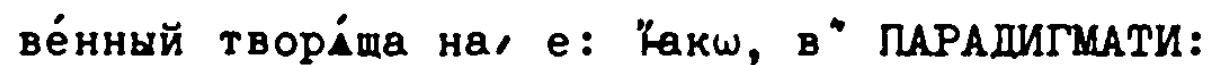

Дво́йственнагш числа̀:

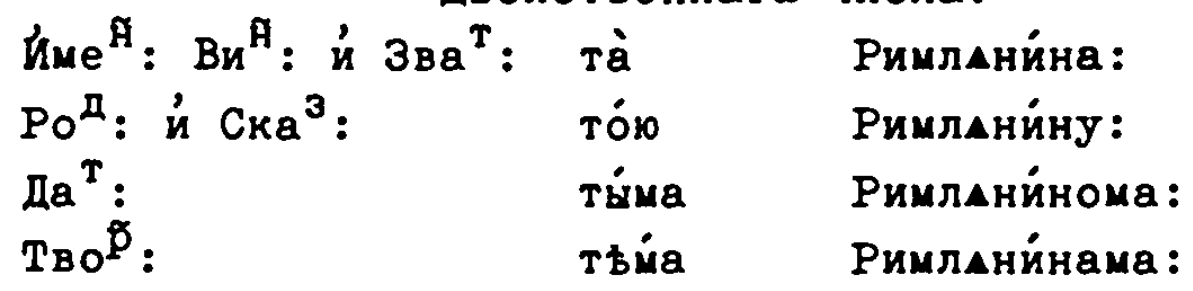

\begin{tabular}{|c|c|c|c|}
\hline Йme ${ }^{\text {म }}$ & тín & Римліне: & Pon: \\
\hline Po ${ }^{\text {I. }}$ & $T ち \dot{x} z$ & Римлх́нз: & [50] \\
\hline$\not a^{T}:$ & TÉMB & Римлі́ншмъ: & \\
\hline $\mathrm{Bu}^{\mathrm{A}}:$ & Túa & Римліны: & \\
\hline $3 в a^{T}:$ & $\stackrel{\beta}{\omega}$ & Римліне: & \\
\hline $\mathrm{T}_{\mathrm{B}}:$ & тьй & Римліну: & \\
\hline Ска ${ }^{3}$ : & $\dot{\omega} T \dot{b} \dot{X} b$ & Римлі́нехъ: & \\
\hline
\end{tabular}

Мнохестве́ннатш числа̀:

Сйце, Галіле́анин", Парөцнйнъ, Персанйнъ, Є́ламітинъ: Гала́тинъ, ВилнАнйнъ, ЛвовАни́нъ, КорїнөАнйнъ, Єૅгі́птАнинъ, хрістї́нинъ: й про

О’́въте́ніе

$\dot{\omega}$ йменехъ Грёческихъ й Латі́нскихъ Славе́нски по сегі் склоне́ніА пра́вил $\omega^{\mu}$, скландемв ${ }^{x}$ : . 


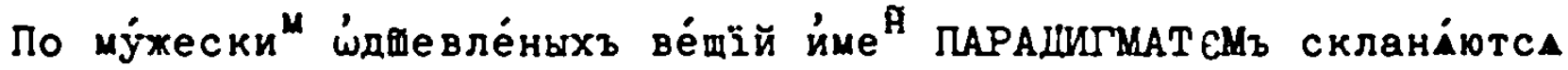

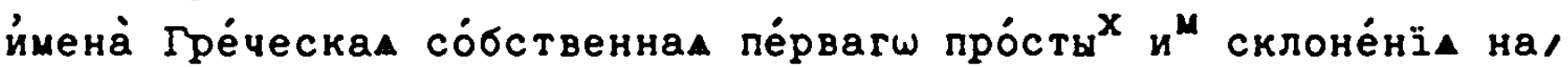
$\eta S$, й четве́[p]тагш на, os, нечи́стаА: й Латі́нскам на, us, й еr,

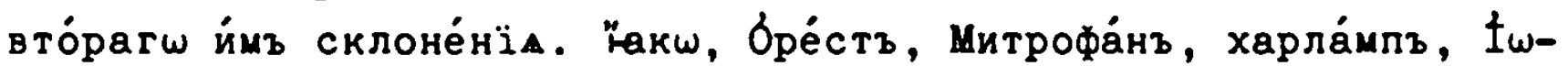

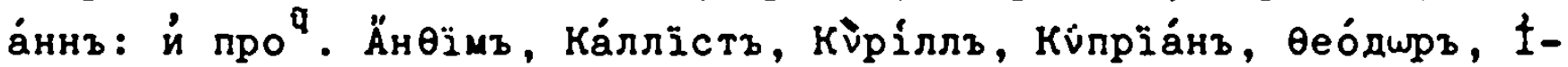
усстъ, Мартінъ, Августінъ, Сілве́стръ: й про $q$.

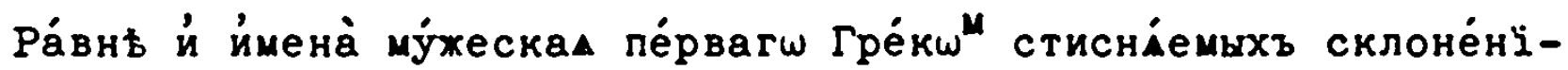

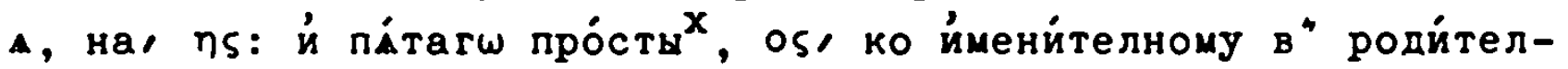
номъ пріе́млющихъ. Латінн" же тре́тїагш, и́ четве́ртагш: "акш/ Ди-

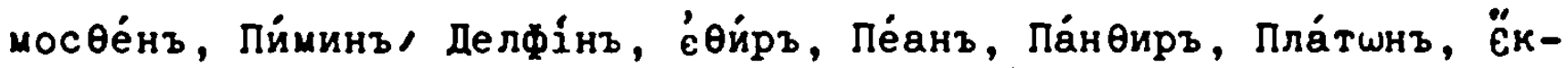
тшръ, Дефе́нсоръ, фе́лї ъъ, Аквіна ${ }^{\mathrm{T}}:$ й про ${ }^{q}$.

\section{Оујвъте́нї: 8 .}

Па́тагш про́сть Гре́кш" склоне́ніА в" роди́телно", $\tau$, прие́млюmал ймена̀: йли́ в" йно кое́ либо согла́сное өе́мате '́конче́нде йз-

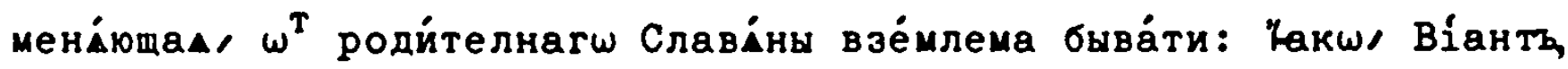
Мама́нтъ, ६енофо́нтъ, орїзо́нтъ: Трапезу́нтъ, Ӓравъ/ Адш́нїдъ Ме-

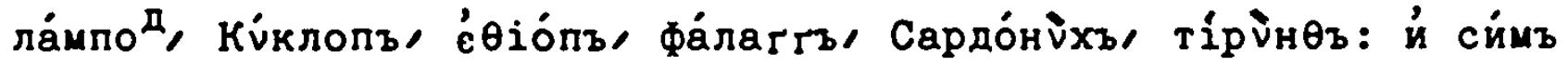

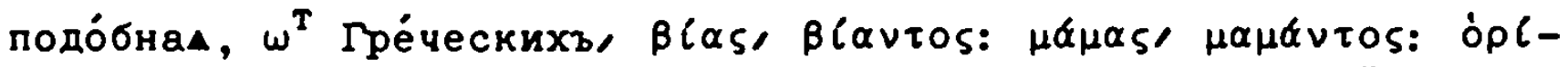

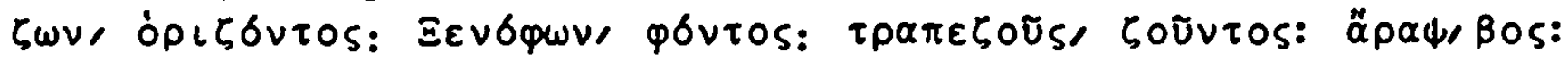

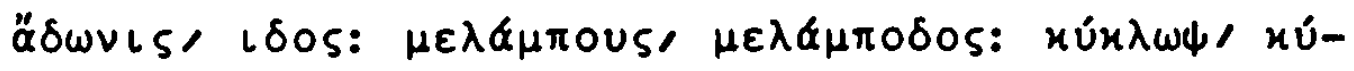

$x \lambda 0$

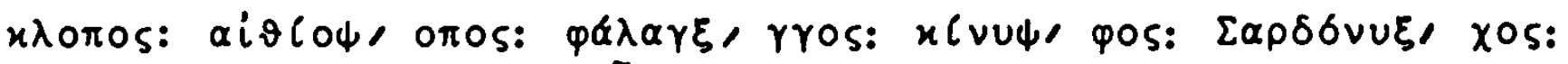

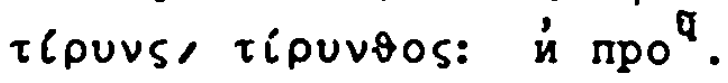

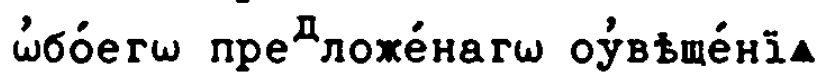

ПАРАПИГМА:

Числа̀ е́динстве́ннагw:

\begin{tabular}{|c|c|c|}
\hline йme ${ }^{\mathbb{R}}$ : & то́й & ópéctъ: \\
\hline Роди ${ }^{\mathrm{T}}$ : & тогं் & ópécта: \\
\hline$\not a^{T}:$ & Tomy & ópécту: \\
\hline Вини $^{T}$ : & & ópécта: \\
\hline $\mathrm{T}_{\mathrm{BO}} \mathrm{p}:$ & & $\begin{array}{l}\text { оресте: } \\
\text { оре́стомъ: }\end{array}$ \\
\hline $\mathrm{CKa}^{3}$ : & $\dot{\omega}$ TOM & ópécть: \\
\hline
\end{tabular}

Дво́йственнагш числа̀.

Йu: $\mathrm{Bu}^{\mathrm{H}}:$ й $3 \mathrm{Ba}^{\mathrm{T}}:$ та̀

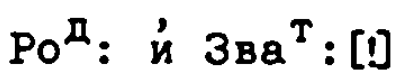

$\not a^{\mathrm{T}}$ :
Tón

Tи́ma ópécta:

ópécty:

ópéctoma: 
$\mathrm{T}_{\mathrm{BO}}^{\mathrm{p}}$ :

$$
\text { тьйa ópéctama: }
$$

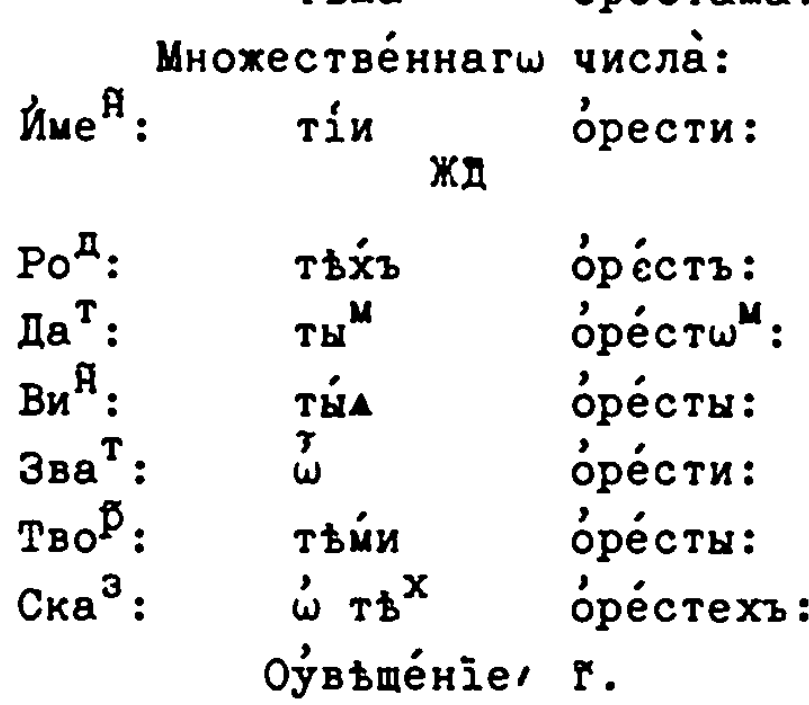

Всї пре похе́ныхъ '́конче́ній, й подо́бнам ймъ ймена̀ Славіны оупотребліема быва́ти й в" свои" и" Гре́ческихъ и́ Латі́нскихъ Өе́матехъ да̇ оу́вб́стсA: во про́чіих паде́жехъ всб́хъ чи́слъ, ра ${ }^{3}$ вь зва́телнагш е́динстве́ннагш то́жде со ймени́телны су́щагш, Славе́н-

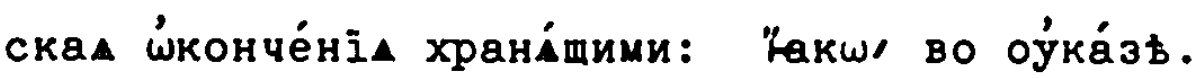

\begin{tabular}{|c|c|c|c|}
\hline \multicolumn{3}{|r|}{ HHATW. } & \\
\hline Йме & тón̆ & Bíac: & \\
\hline Po & Tor $\dot{\omega}$ & Ві́анта: & \\
\hline$\mu a^{T}:$ & Toxy & Bíaнту: & \\
\hline $\mathrm{Bu}^{\mathrm{A}}:$ & Toró & Bíaнта: & \\
\hline Зва ${ }^{\mathrm{T}}:$ & & Bíac: & \\
\hline & Tъи́ъ & Ві́антомъ: & $\mathrm{C}_{\mathrm{K} 2^{3}}:[52]$ \\
\hline$k a^{3}:$ & $\dot{\omega}$ TOM & Bíaнть: & \\
\hline
\end{tabular}

Дво́йственнагш числа̀:

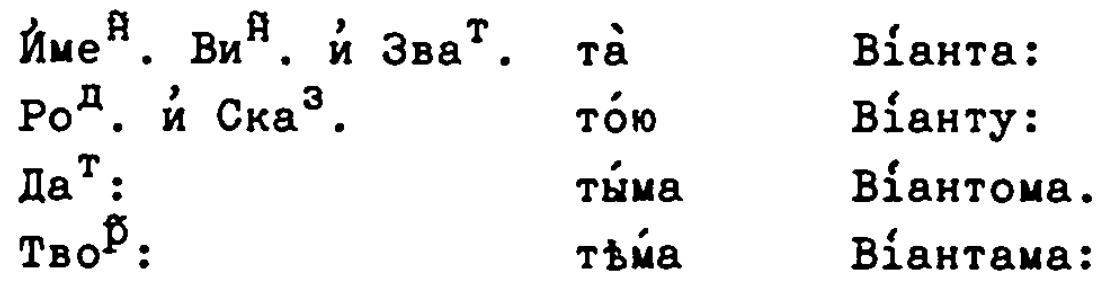

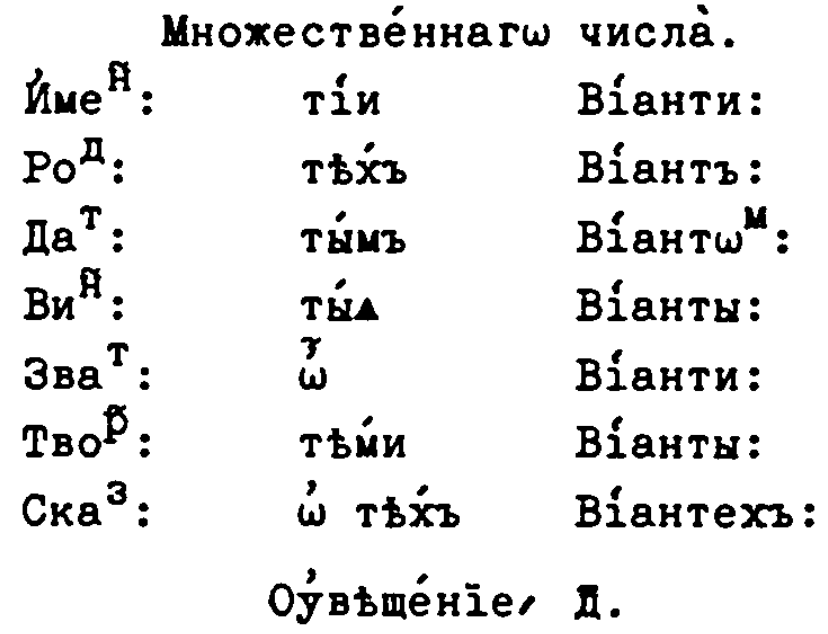


Оўпотребла́ема быва́ютъ Слави́ны й про́чал Гре́ческал четве́рта-

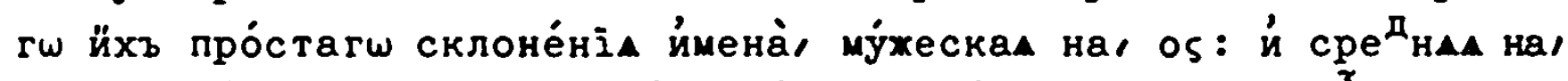

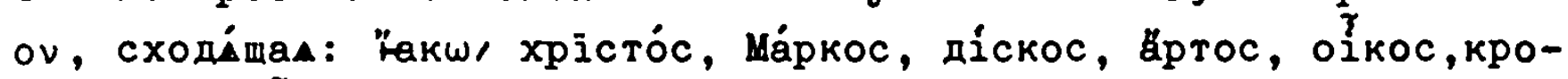

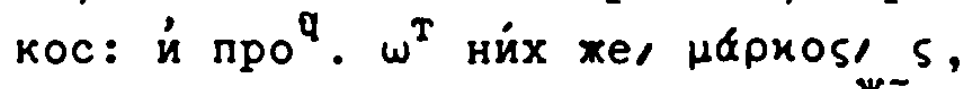 Wẽ
$\omega^{T}$ mé

[526]

$\omega^{T}$ ме́me ${ }^{T}$ й тво́ритъ Славе́нское ймі, ма́рко, во всбхъ паде́хехъ "акш Проро́къ, ра́звь зва́телнагш на, ку, не на, че, сходйщагш, скландемое. Про́чал же/ 5 , во всfхъ паде́жехъ храндітв: laкw/ ді́скос, діскоса: йртос, äртоса: оі́кос, ойкоса: кро́кос, кро́коса: и́

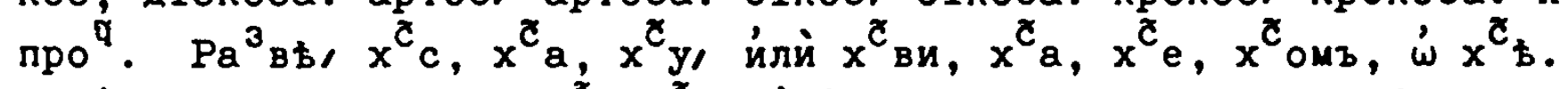
†исуус, прече́стное $x^{c} a \Gamma^{c}$ да ймі, ӧвогда скландетсл пра́вилнь,

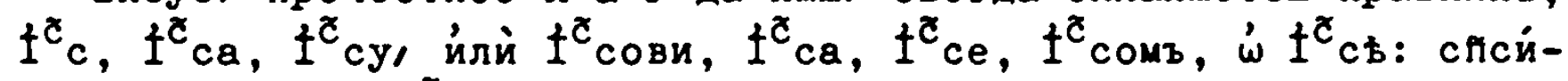
телному ймени, $x^{c} c$, припраххено пребыва́етъ йногда несклани́емо:

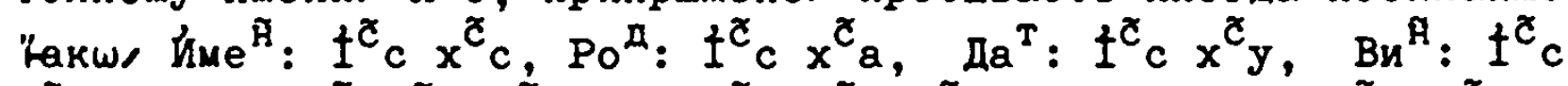

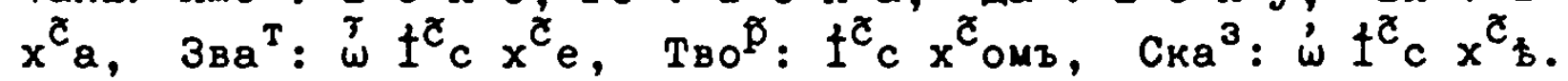
Сре́дна же сутিь, схо́ліон, Ли́тронъ, Когно́віонъ, Вараөронъ, Гйна́сіонъ, Носокомеโонъ, ६енодохе Іонъ, Газофйла́кіонъ, Тропа́ріонъ, Конта́кіонъ: й про ".

Й на чйстое оўбш, ov, cходи́maа, ко четве́ртому склонёнїю воз-

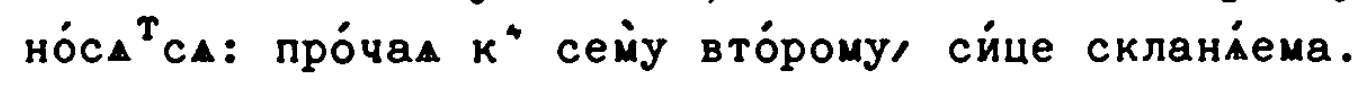

числа̀

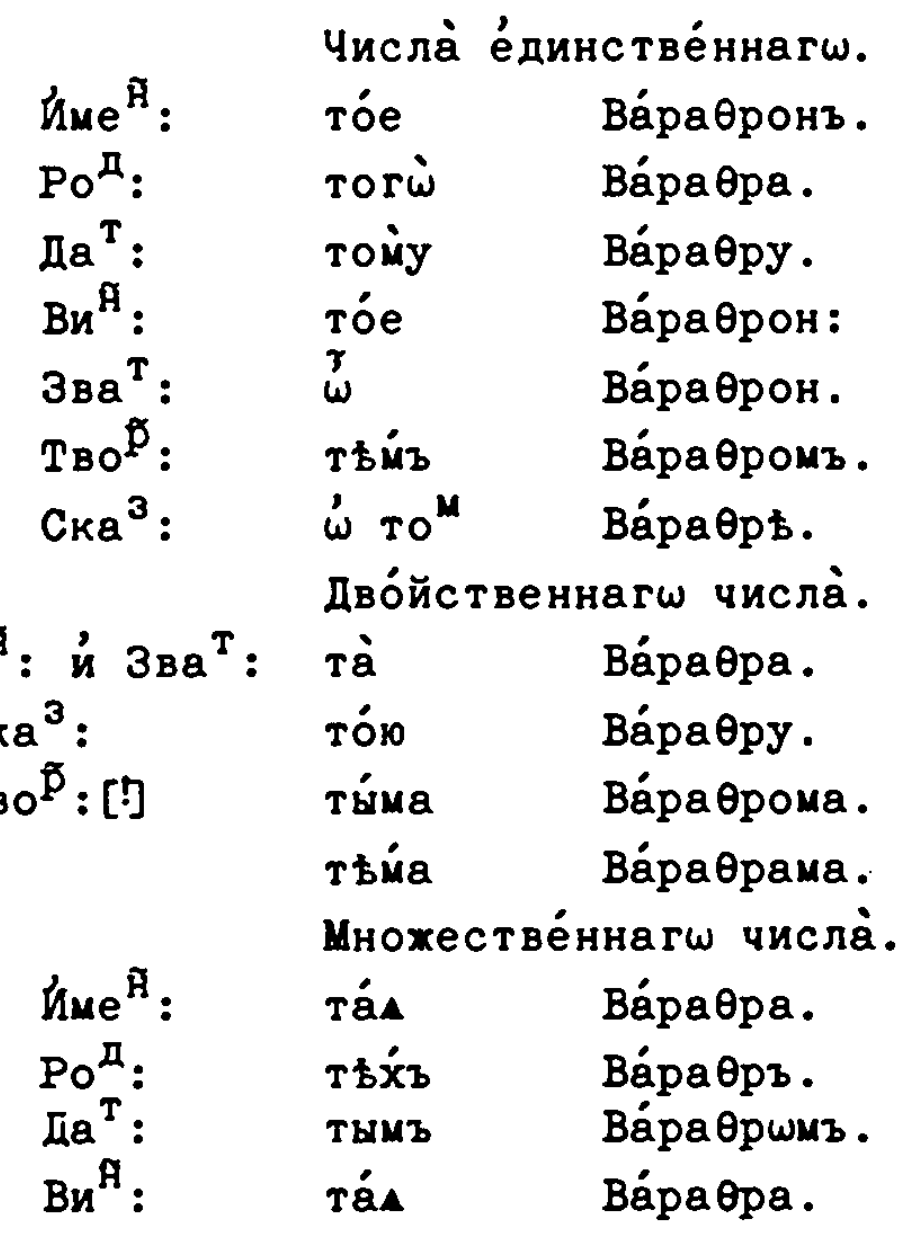




\begin{tabular}{|c|c|c|}
\hline Зва ${ }^{\mathrm{T}}:$ & $\stackrel{r}{\omega}$ & 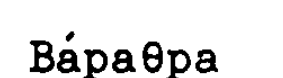 \\
\hline $\begin{array}{l}\mathrm{T}_{\mathrm{BO}}^{\mathrm{p}}: \\
\mathrm{C}_{K \mathrm{a}^{3}}{ }^{\mathrm{a}}:\end{array}$ & 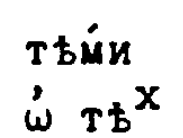 & $\begin{array}{l}\text { Bápa } \theta \text { pы. } \\
\text { Bápa } \theta \text { pexz }\end{array}$ \\
\hline
\end{tabular}

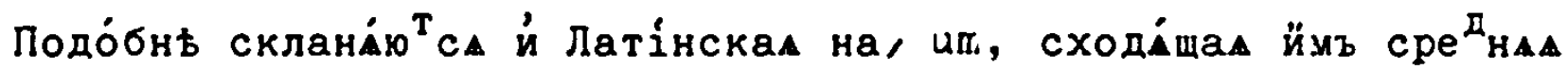
ймена̀: Гакш, Кондіме́нтумъ, Сакраменнтум", Темпераме́нтумъ: й про ${ }^{q}$. ёгда же, um $\omega^{T}$ ме́щутъ, му́жескій оу Слава́нъ род восприе́млют : Какш, Сакраме́нтъ, Темпераме́нтъ, Кондіме́нтъ: й про по пра́вил $\omega^{M}$ склоне́ніА сегі́ му́жески" склана́ютъса. Éтеро́кліта вто́рагш склоне́ніА: До́мъ: Бра́тъ: й про

Числа̀ е́динстве́ннагш.

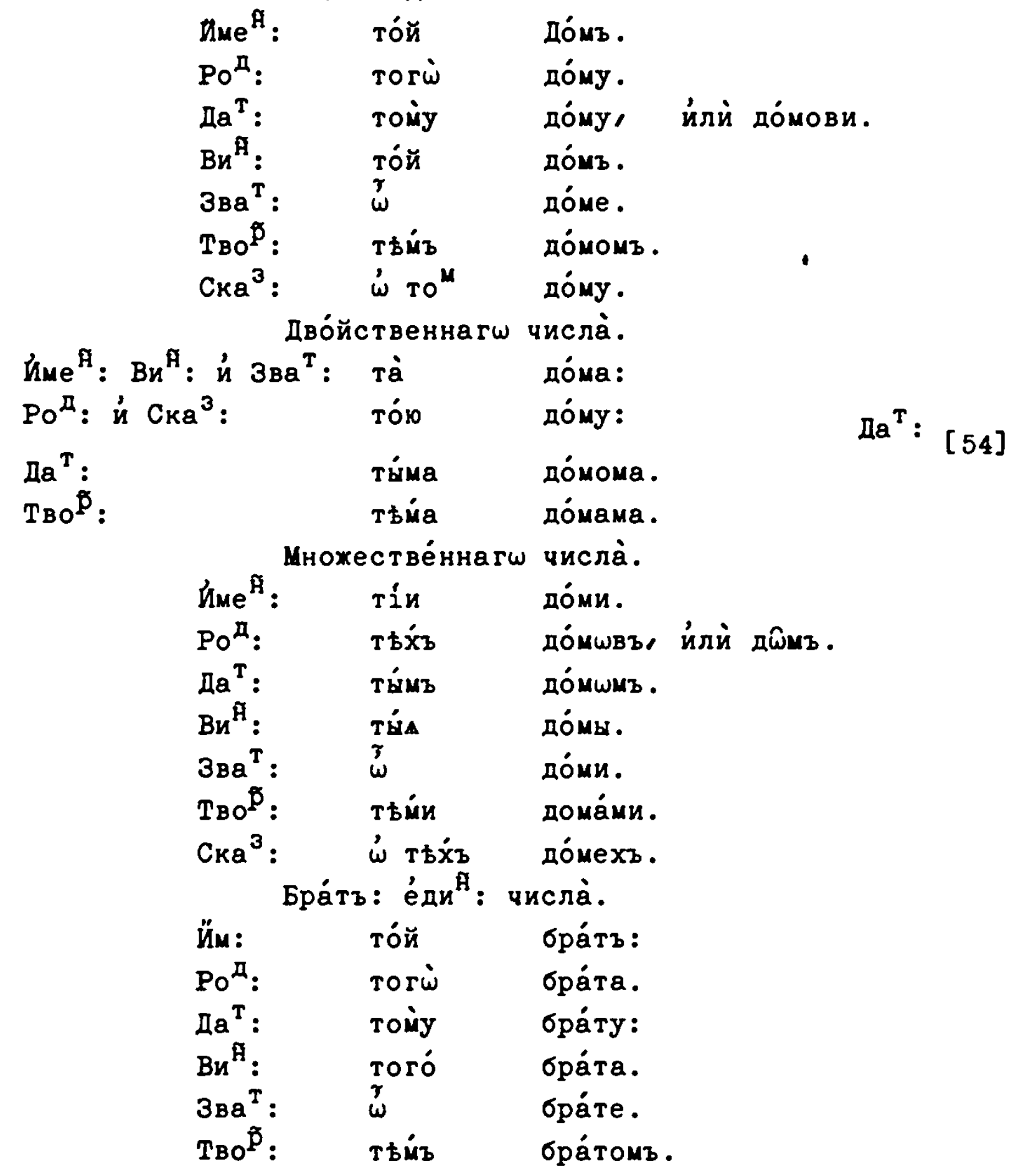




\section{Ска ${ }^{3}:$ '́ं то́mъ бра́ть. \\ Дво́йственнагш числа̀.}

Й: Вин: й Зва ${ }^{\mathrm{T}}:$ та̀ бра́та. Po

Poम: иं $\mathrm{CKa}^{3}$ :

Tór

бра́ту.

[546]

Lia ${ }^{T}$ :

тв́ma

бра́тома.

TBO ${ }^{\mathrm{p}}$ :

Tъúa

бра́тама.

Мнохестве́ннагш числа̀.

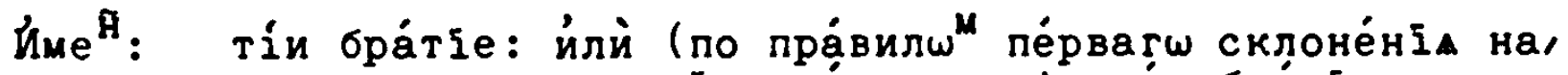
โа, же́нскихъ.) та́ бра́ті木.

Poम : $\quad$ тъ бра́тій: йли

Да ${ }^{T}:$ ты ${ }^{M}$ бра́тї $e^{M}:$ йлй

Ви ${ }^{\tilde{H}}:$ ти́н бра́ть: йлй

Зва ${ }^{\mathrm{T}}: \stackrel{3}{\omega}$ бра́тїе: йли

Тво ${ }^{\mathbb{P}}$ : тьи́и бра́тรами: йли

$\mathrm{Cка}^{3}: \quad \dot{\omega}$ тьх́з бра́тїехъ: йлй

оу́въще́ніе:
тоA бра́тіA.

то́й бра́тїи.

тую́ бра́тію.

ఓ⿱龴⿵ брáтї.

то́ю бра́тіею.

‘े то́й бра́тїи.

Вб́cтно бу́ди всбхъ склоне́ній собира́те наг $\omega$ й мнохестве́ннагш числа̀ лиша́тиса, существйтелному ймени до́лгъ йх" йспо на́юmу.

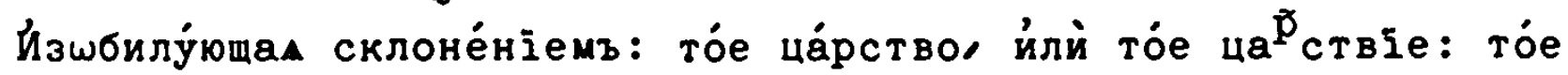
велйчество,

йлй вели́чествіе: зна́ма, йлй зна́менїе: и́ про ".

йлй

Йзмьніемах ро́до", склоне́ніемъ, й падежи. Во дво́йственномъ

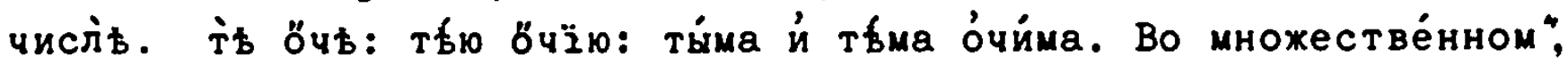

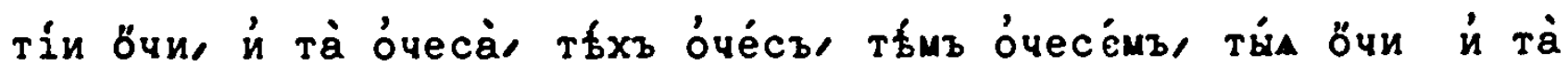

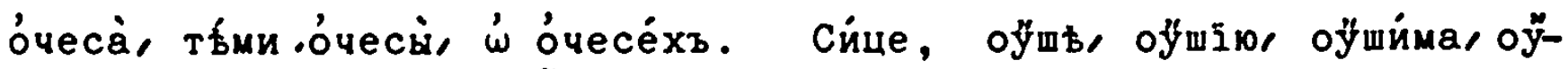
ши йлй оу́шеса̀:

Лита́юmaаса числа̀ е́динстве́ннагш сре́днаА: оу́ста̇, вра́та, ложе- сна̀, клічча: й про

Е́динстве́ннагш й дво́йственнагш: нача ${ }^{T}$ ки, о́ме́ты: й про .

Лиша́юmалса чйслъ, й паде́хей: друг" дру́га: Си́це скланц́емо. Числа̀ е́динстве́ннагш:

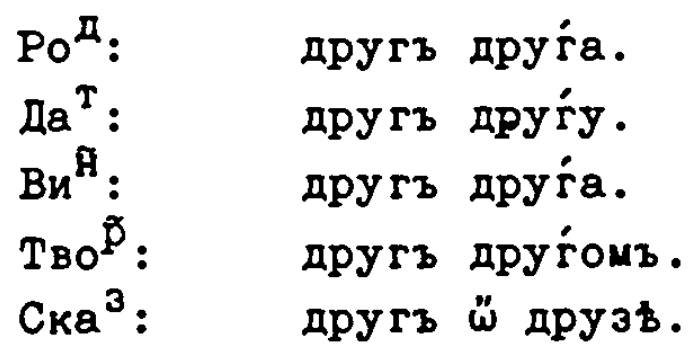


Дво́йственнагш числа.

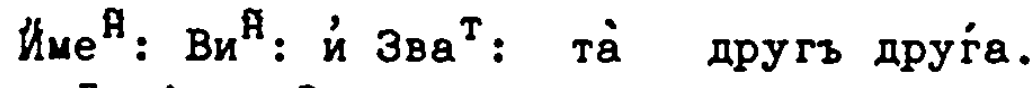

Pо ${ }^{\text {म }}$. $\mathrm{CKa}^{3}$.

$\not a^{\mathrm{T}}$ :

TBO

то́n другъ друѓy.

ти́ма другъ друѓов.

тьма другъ друѓма.

Мнохестве́ннагш лиша́етъсА.

TPÉTIE CKлOHEHIE.

Tре́тіпгш склоне́ніА '́конче́ніе ёстъ е́ди́но, ь: йме́нъ же́нскихъ: Йх же роди́те ный, да́телный, зва́телный, й сказа́телный на, и: Вини́телный ймени́телному подо́бенъ: твори́телный на, ію.

\section{ПАРАПИГМАТА :}

\begin{tabular}{|c|c|c|}
\hline \multicolumn{3}{|c|}{ Числа̇ е́динстве́ннагш: } \\
\hline Úme ${ }^{\text {A }}$ & ráa & За́nовьдь: \\
\hline Pon: & TOA & за́повьди: \\
\hline$a^{T}:$ & то́й & за́повьди: \\
\hline $\mathrm{Bu}^{\mathrm{A}}:$ & Tyío & उв́повьдь: \\
\hline $\mathrm{Ba}^{\mathrm{T}}:$ & $\stackrel{3}{\omega}$ & за́повђди: \\
\hline${ }_{0}^{p}:$ & ro & 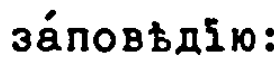 \\
\hline$c a$ & $\dot{\omega}$ Tó & за́повђди: \\
\hline
\end{tabular}

Дво́йственнагш числа̀.

Дво́й

[56]

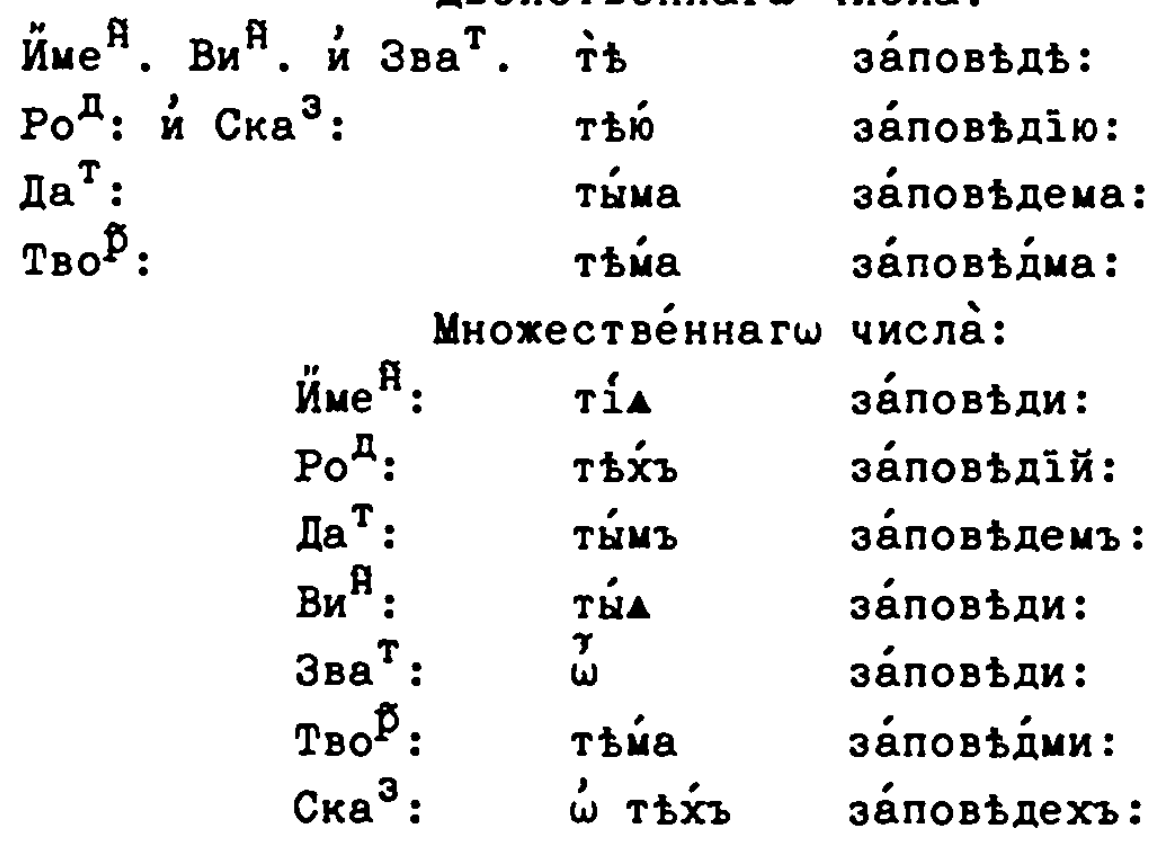

Сйе, блгода́ть, добродб́тель, пло́ть,хйзнь, ра́дость, ча́сть, ле́сть, ку́пель, ве́щь, ве́сь, сла́нь, ве́рвь, вєтвь, ги́бель, мило́ть, две́рь, де́брь, де́рзость, су́сль, жу́пель, миялость, за́висть, Карость, скорбь, пе́рсть, па́жить, піьнь, со́хль, тве́рдь, оўдоль, че́рвень, ча́mb, ча́дь, ста́дь, хлйбb: й про 
 \\ Оујвъщёніе.}

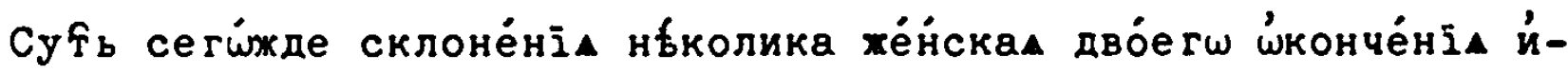
мена̀: йх же роди́телный на, е: зва́телный ймени́телному вто́ратш ஸ́конче́ніА подо́бный. "̈акш, числа̀ е́динстве́ннагш.

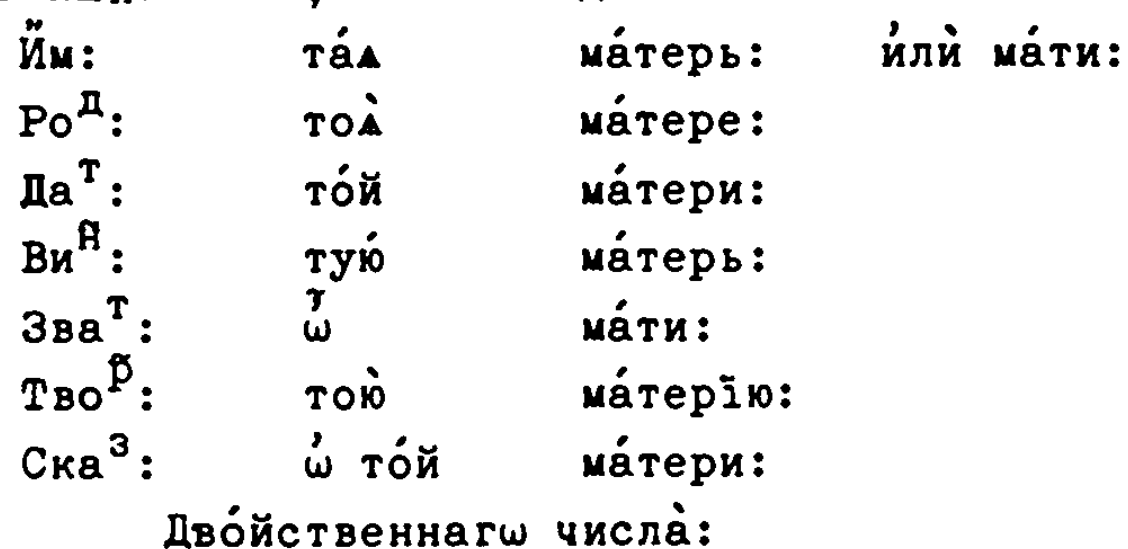

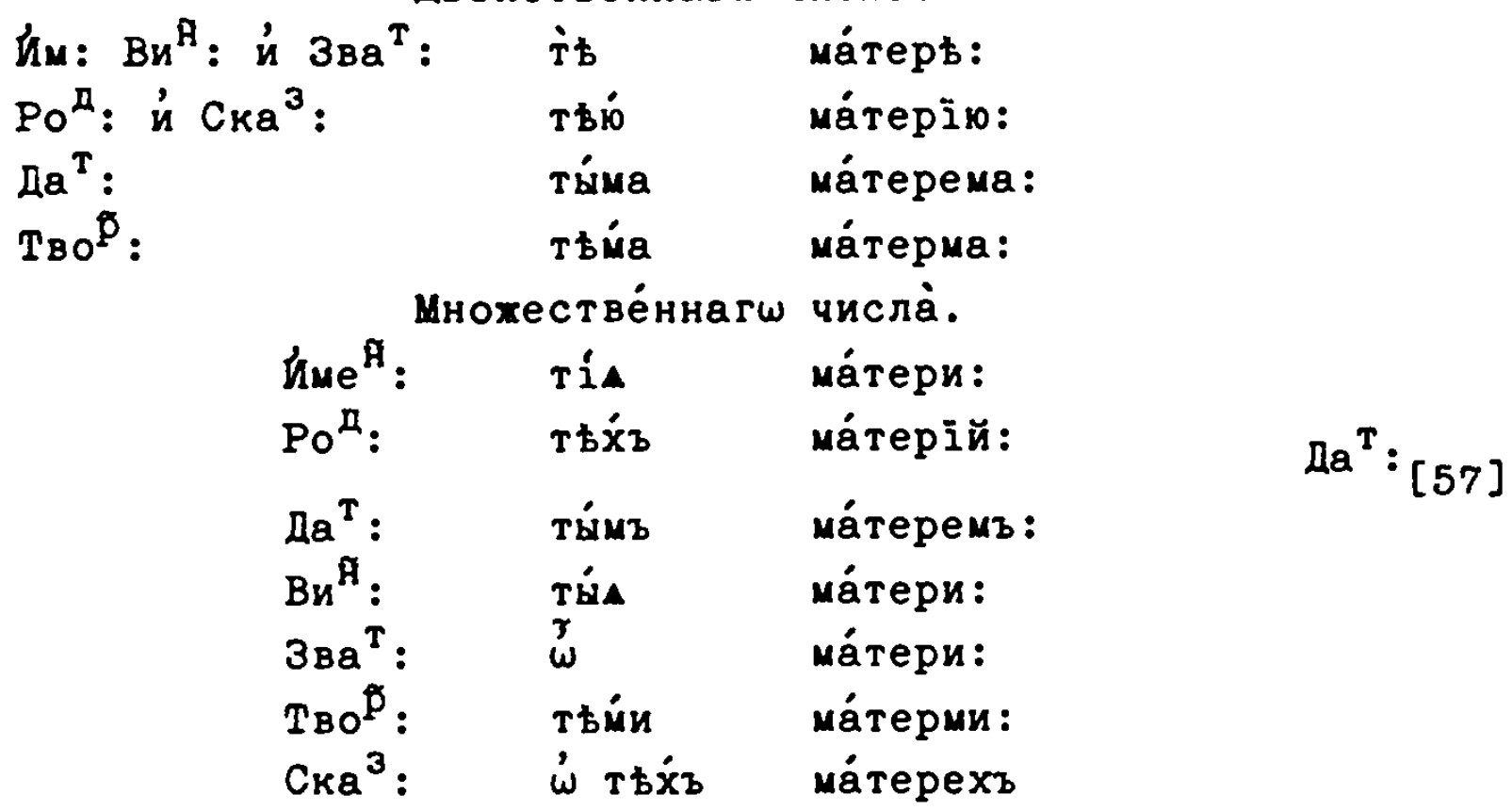

Сйце, любо́вь, йлй любы: непло́двы йлй неплоды: дще́ры и́лй дщй: це́рковь йлй це́ркви: кро́вь йлй крвй: свекро́вы и́лй све́к$\mathrm{pu}:$ й про

'́ йменехъ Гре́ческихъ в" сі́е склоне́ніе во ${ }^{3}$ эноси́мыхъ:

По пе́рвђе ம்йсаному склоне́ніА сегі் пра́вилу и́ Гре́ческаА па́тагш про́сты и" склоне́ніА же́нскал на, ᄂS, й US, конча́mалса ймена̇ склана́ют"сА, в" роди́телно" возраше́ніА йлй не и́му́щаА, йлй

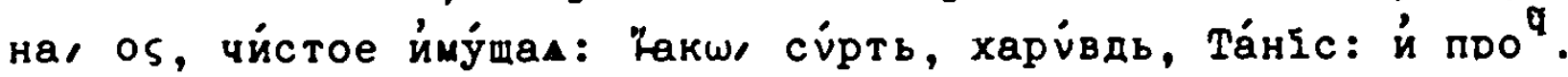

Й та̀ о́бáче, й всї сегі் '́конче́ніА про́чал, свої ймъ Гре́ческаА паде́xей о́конче́ніА храна́mа, блголбпнъе по сему ПАРАДИГКАТИ склаHÁNT ${ }^{*}$ CA.

sE

числа̀

$$
\begin{aligned}
& \text { Числа̀ е́динстве́ннагш: }
\end{aligned}
$$

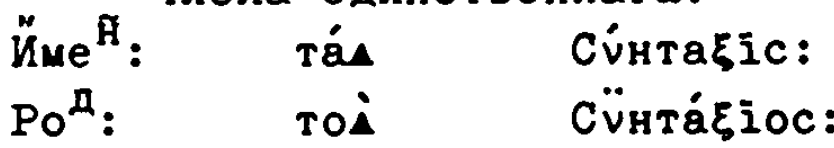




\begin{tabular}{|c|c|c|}
\hline \multicolumn{3}{|c|}{$-60-$} \\
\hline$\not a^{T}:$ & то́й & Cйнта弓і: \\
\hline $\mathrm{Br}^{\mathrm{A}}:$ & Tý́ & Cं́нтац̆ін: \\
\hline Зва ${ }^{\mathrm{T}}$ : & $\stackrel{\jmath}{\omega}$ & 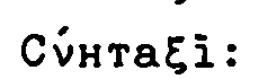 \\
\hline$T_{B O}{ }^{p}:$ & той & 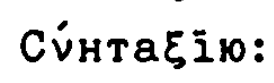 \\
\hline $\mathrm{Cка}^{3}$ : & ஸे то́й & Сйнта६̆и: \\
\hline
\end{tabular}

Дво́йственнагш числа̀:

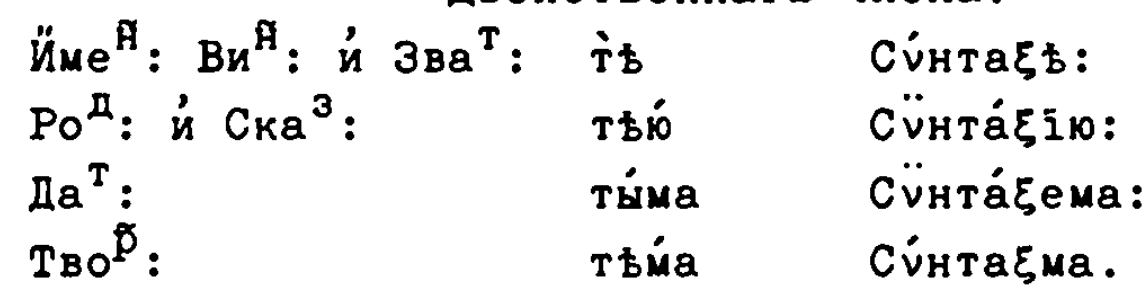

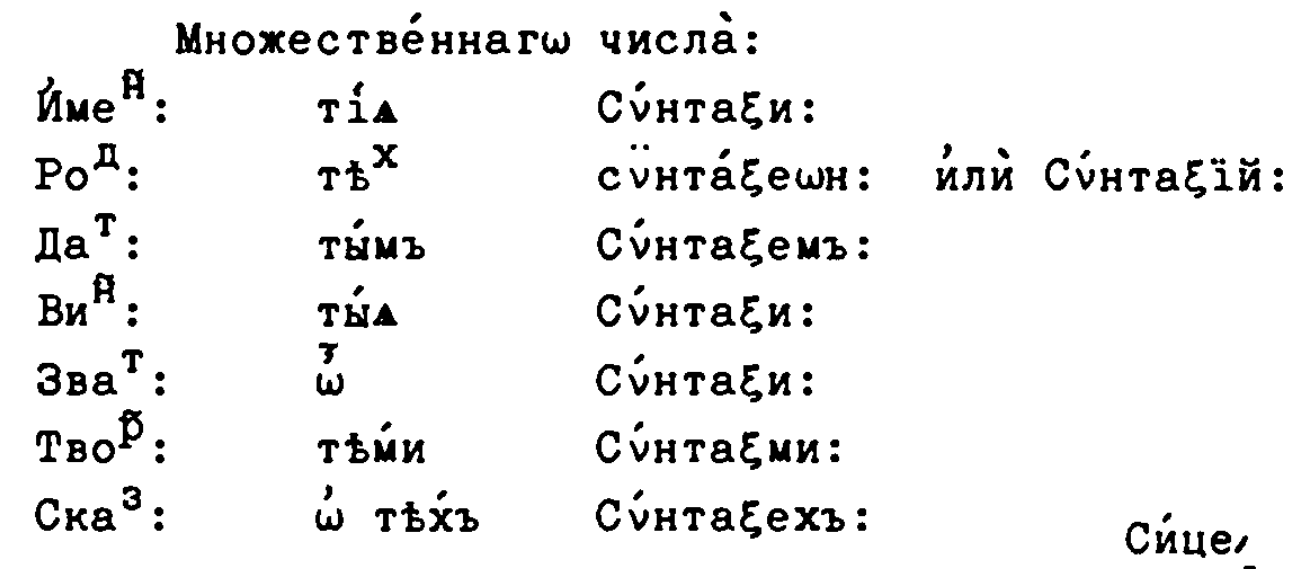

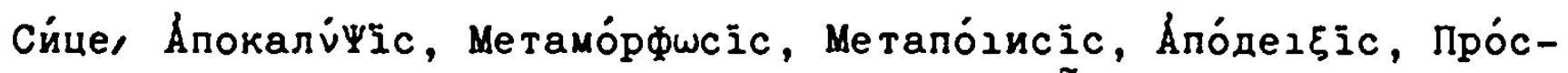
өесіс, С́лличіс, ёкөесіс, ёктасіс: й про

$\dot{\omega}$ йменехъ Латінских в" сі́ склоненіе во носимнхъ:

$\mathrm{K}_{3}$ сем̀у Слава́нъ склоне́нію и́ тре́тіАгш Латінъ склоне́ніА на,

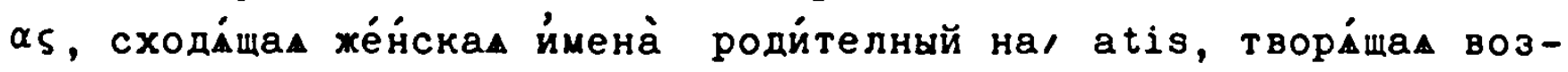

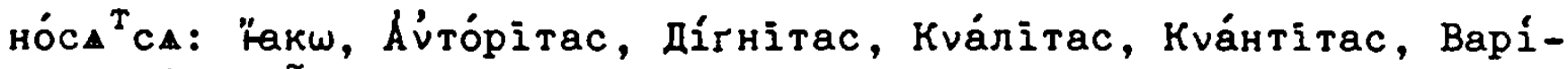
етас: й про ${ }^{q}$ : Си́це склани́ема.

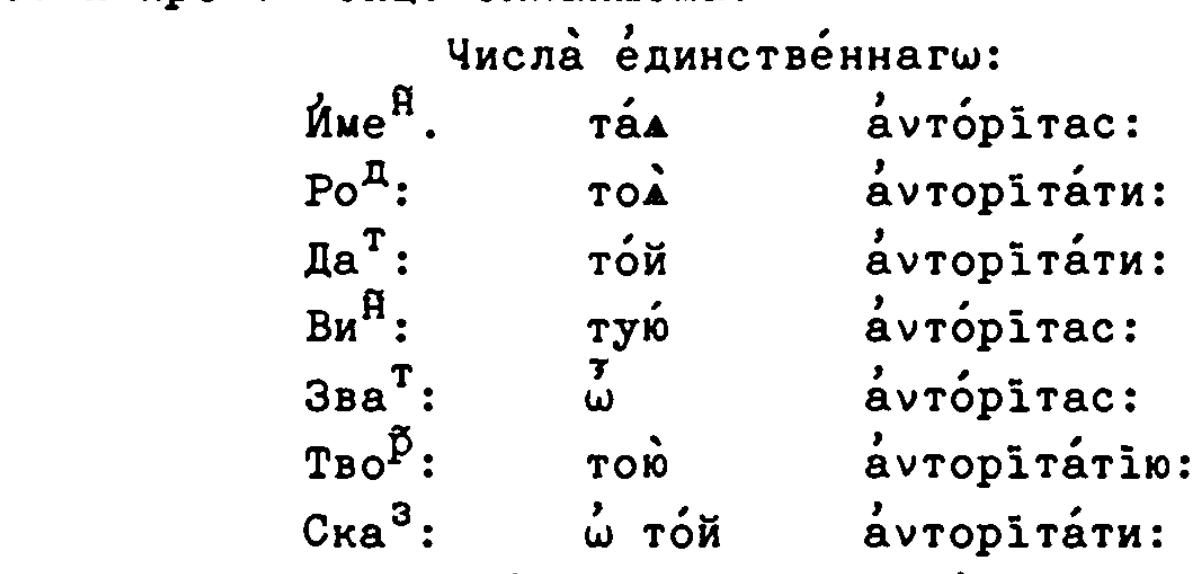

Дво́йственнагш числа̀:

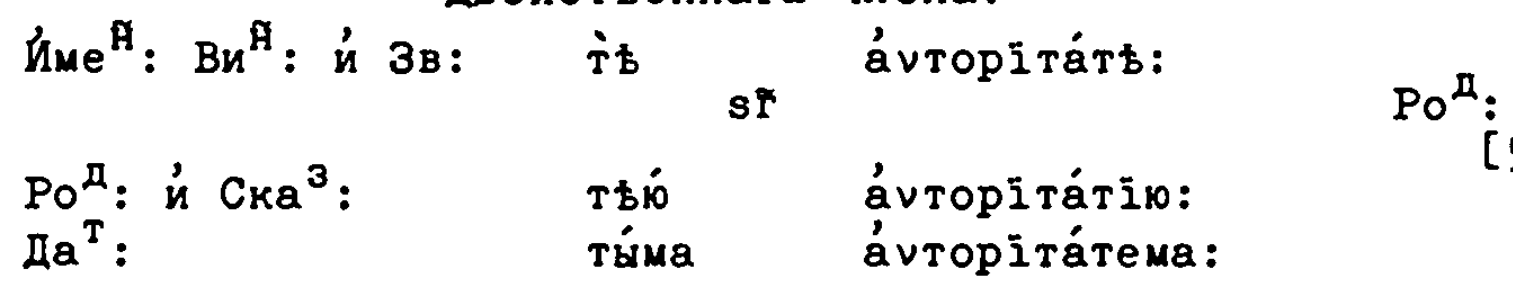


TBO ${ }^{\mathbb{p}}$ :

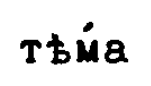

ávторі̃тáT́ma:

\begin{tabular}{|c|c|c|}
\hline \multicolumn{2}{|c|}{ Mнохестве́ннагш } & числа̀ \\
\hline hime ${ }^{\text {f }}$ : & tín & ávторітт́ти: \\
\hline Pon: & $T \hbar \dot{x} z$ & ávторітт́тій: \\
\hline$\not a^{T}:$ & T'́MB & ávторіта́темъ: \\
\hline $\mathrm{Bu}^{\mathrm{A}}:$ & Túa & ávторіта́ти: \\
\hline 3ва ${ }^{\mathrm{T}}:$ & & ávторіта́ти: \\
\hline $\mathrm{T}_{\mathrm{BO}}^{\mathrm{p}}$ : & тьйи & ávторіта́т́ти: \\
\hline $\mathrm{CKa}^{3}:$ & $\dot{\omega} T \hbar \dot{x} z$ & ávторіта́техъ: \\
\hline
\end{tabular}

Числа̀ е́динстве́ннагш й дво́йственнагш лиша́ющалса: мо́щи: пе́рси: пле́щи: и́ про

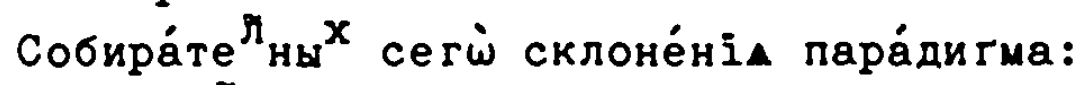

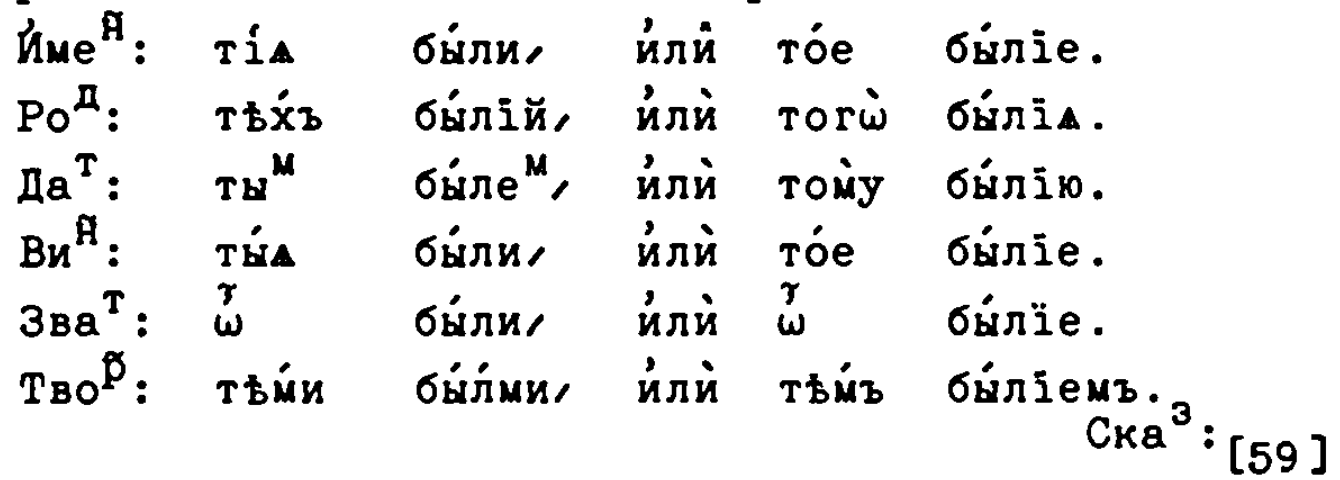

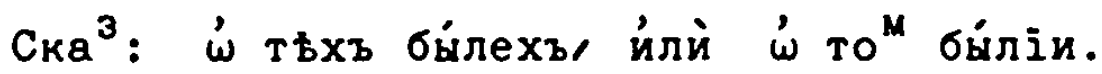

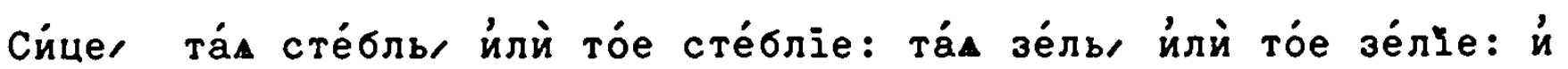
npo

чЕТВЕРТОЕ СКЛОНЕНІЕ:

Четве́ртагш склоне́ніА Славе́нскихъ име́нъ му́хеских,

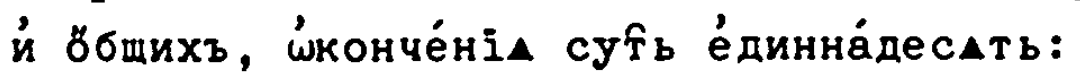

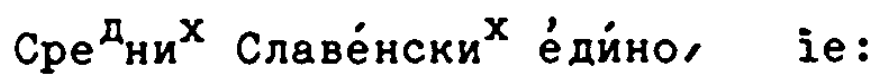

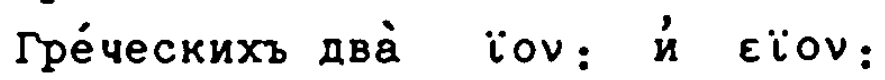

Й же родйтелный на, А: да́телный й зва́телный на, ю: Винй-

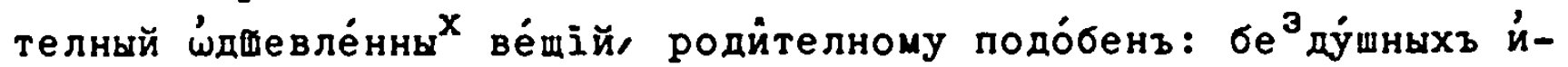
мени́телному: твори́телный на, $\mathrm{e}^{M}$ : сказа́телный на, и:

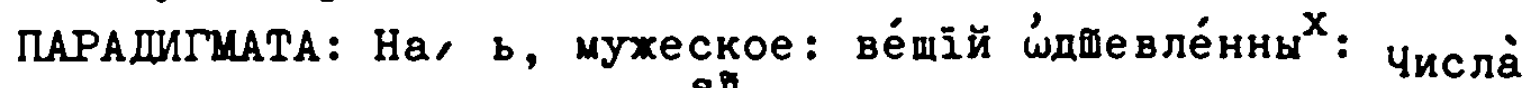
sĭ 


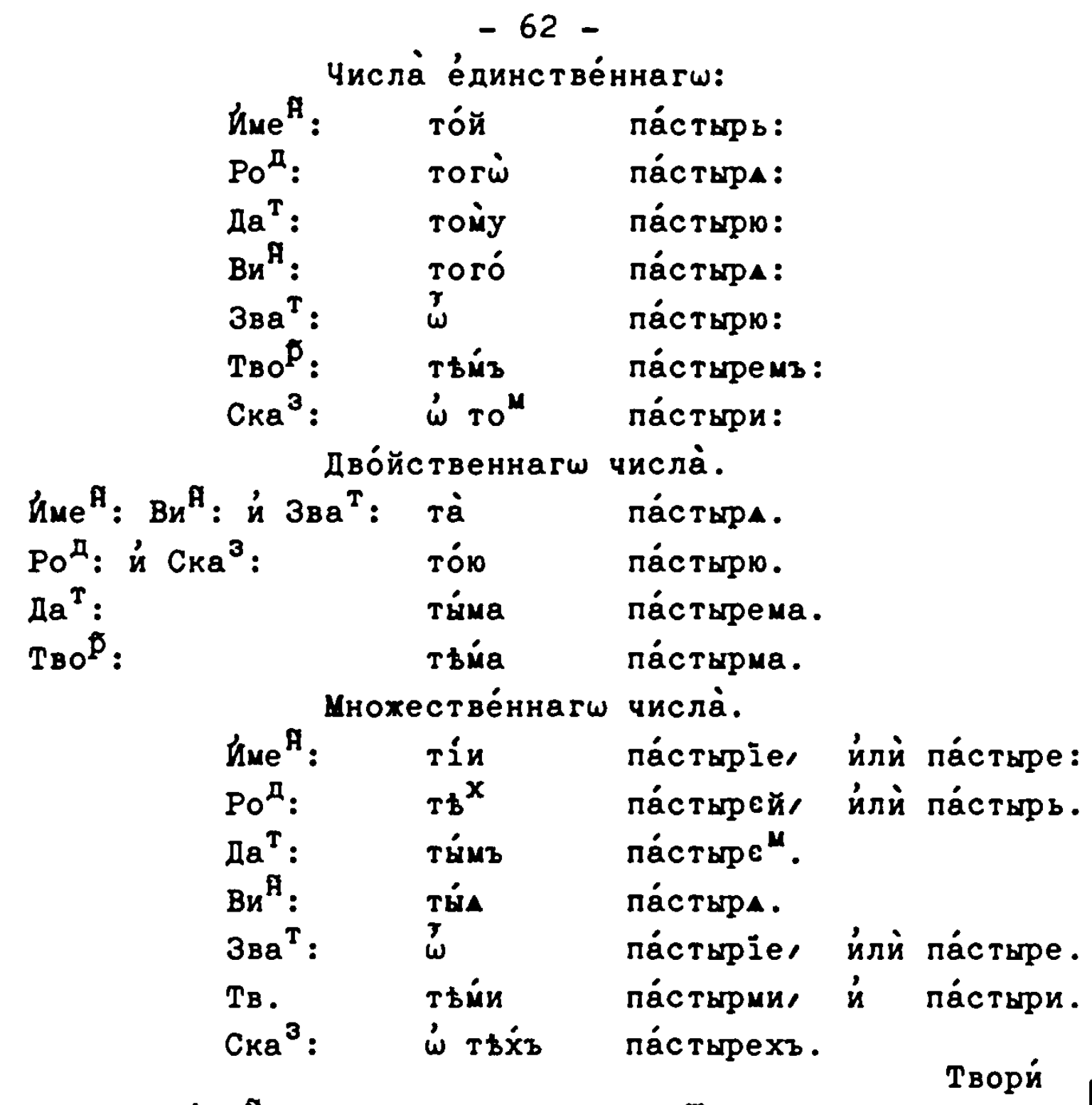

Твори́телный е́ди ${ }^{\text {: }}$ на, е: Да́телный мно*: на, $\varepsilon$ : Сйце, Сотвори́тель, оу́тьшйтель, Ца́рь, Кни́зь, ревни́тель, томи́тель тща́тель жа́тель/ позори́тель, строи́тель дблатель, ласка́-

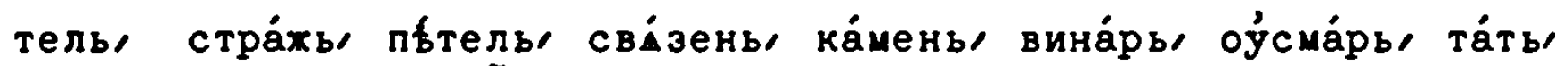
му́хь, Елени: й про .

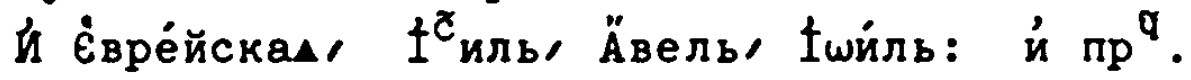
Й Латінскап, Аннібаль, Асдруббаль: й про́чал.

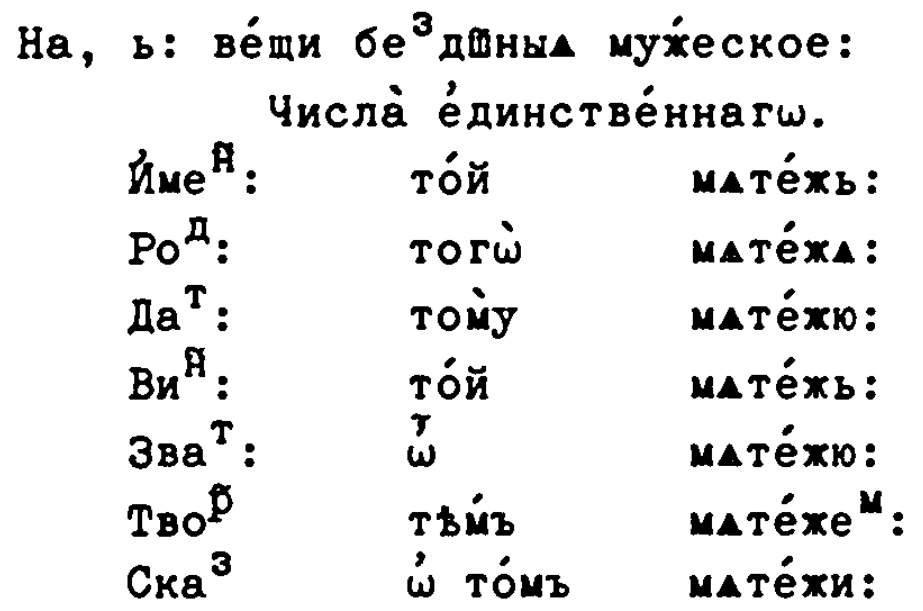

Дво́йственнагш числа̀: 


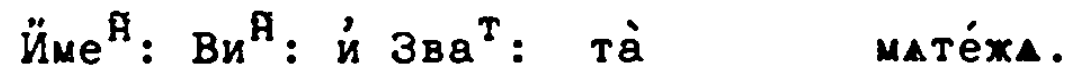

$$
\begin{aligned}
& \text { Poम : и } \mathrm{CKa}^{3}: \text { тólo matéжю. } \\
& \mathbf{s} \tilde{\varepsilon} \\
& \text { Дa }{ }^{\mathrm{T}}: \\
& \text { ти́ma } \\
& \text { Matéxema. } \\
& \text { TBO } \\
& \text { T\&́ma } \\
& \text { matéxua. }
\end{aligned}
$$

Да ${ }^{\mathrm{T}}$ :

[606]

\begin{tabular}{|c|c|c|}
\hline $\begin{array}{l}\text { Йme } \\
\text { Po } \\
\text { Po: } \\
\text { да }{ }^{T}:\end{array}$ & 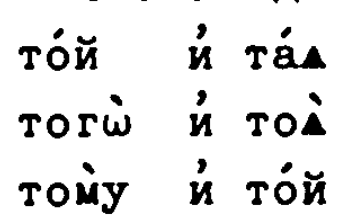 & $\begin{array}{l}\text { свъдйтель: } \\
\text { свъдйтелА: } \\
\text { свьдйтелю: }\end{array}$ \\
\hline $\begin{array}{l}\mathrm{Bu}^{\mathbb{R}}: \\
\text { Зва }\end{array}$ & 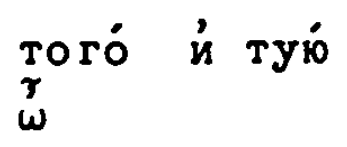 & $\begin{array}{l}\text { свъдйтелА: } \\
\text { свьдйтелю: }\end{array}$ \\
\hline $\begin{array}{l}\mathrm{T}_{\mathrm{BO}}^{\mathrm{p}}: \\
\mathrm{CKQ}^{3}:\end{array}$ & $\begin{array}{l}\text { тちй й тою } \\
\dot{\omega} \text { то }{ }^{M} \text { й той }\end{array}$ & $\begin{array}{l}\text { свьди́телемъ: } \\
\text { свђди́тели: }\end{array}$ \\
\hline
\end{tabular}

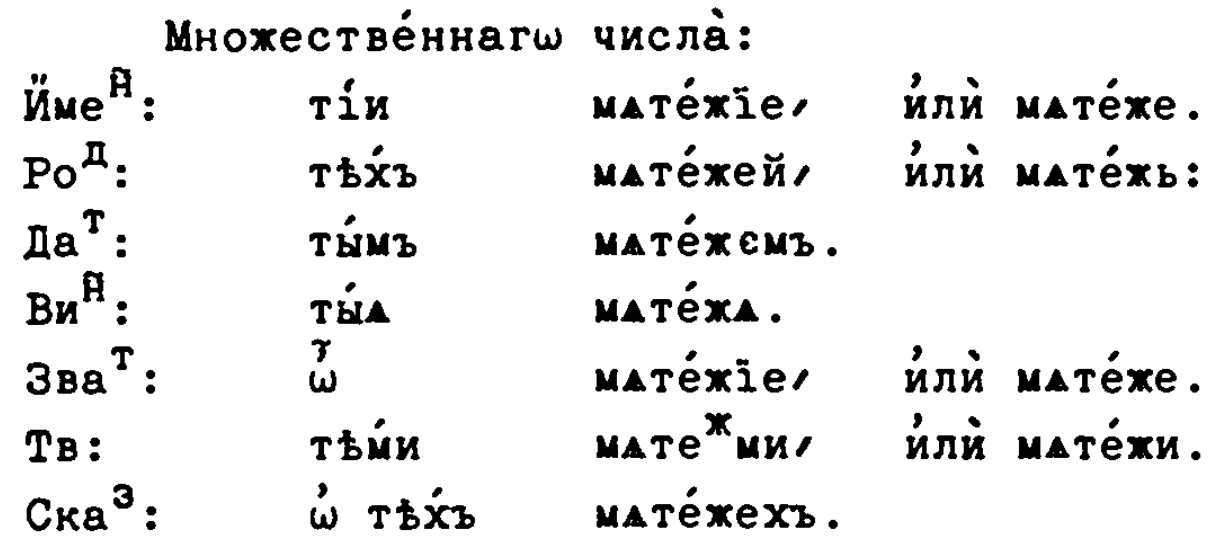

Сйце, паде́жь сбверь кла́дезь, во́пль, б̈гнь, кличчь плйщь дреколь б̆лтарь рукойть ойгль горта́ны путь го́лоть: й про :

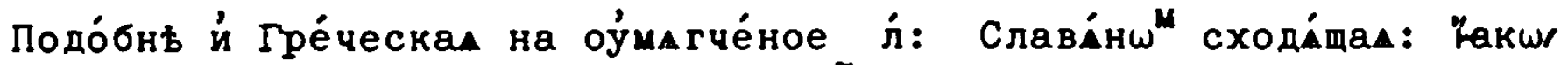
Константіно́пол́, Адрїано́пол́: и́ про .

\section{őбmee:}

Числа̀ е́динстве́ннагш.

$\mathrm{Bu}^{\mathrm{A}}$ :

Дво́йственнагш числа̀:
свьдйтель.
свьдйтелю.
свьдйтелема.
свьдйтелма.
Йме ${ }^{\mathrm{H}}: \mathrm{Bu}^{\mathrm{B}}:$ й Зва $^{\mathrm{T}}:$ та丿 $\dot{\mathrm{a}}$ iे тón й TÐ்́
ти́ma
Tちúa

числа̀.

йм: ті́и йті

свьдйтеліе: йсвђди́теле.

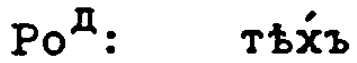

свьди́телей: $\dot{и ̆}$ те́ль.

Дa ${ }^{\mathrm{T}}:$ ти́мз

свђдйтел емъ.

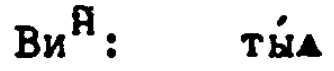

свьдйтела.

उва $\mathrm{Ba}^{\mathrm{T}}: \quad \stackrel{\mathbf{w}}{\omega}$

свьдйтеліе:

свъдйтеями: й

лe.

Tво ${ }^{\tilde{p}}$ : тьй 


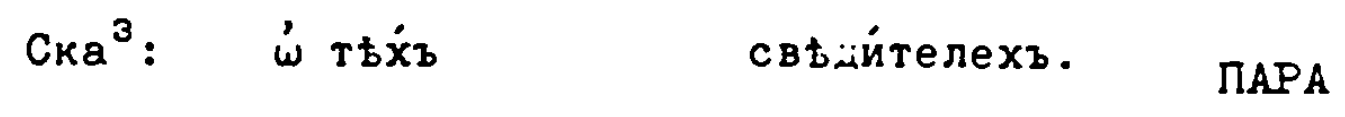

ПАРАДИГИА На, ай.

Числа̀ е́динстве́ннагw:

\begin{tabular}{|c|c|c|}
\hline & 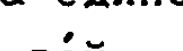 & \\
\hline Име ${ }^{\mathrm{H}}:$ & той & ходотай: \\
\hline Po & Tori் & ходота́А: \\
\hline$\not a^{T}:$ & romy & ходота́ю: \\
\hline $\mathrm{Bu}^{\hat{\mathrm{A}}}:$ & ró & ходота́A: \\
\hline 3ва ${ }^{\mathrm{T}}:$ & & ходот \\
\hline Tво $\bar{p}:$ & $\dot{M} 3$ & xодоT \\
\hline$\kappa a^{3}:$ & $\dot{\omega}$ то & xодотá \\
\hline
\end{tabular}

Дво́йственнагш числа̀:

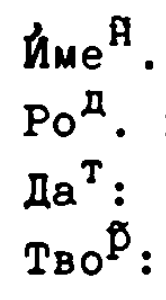

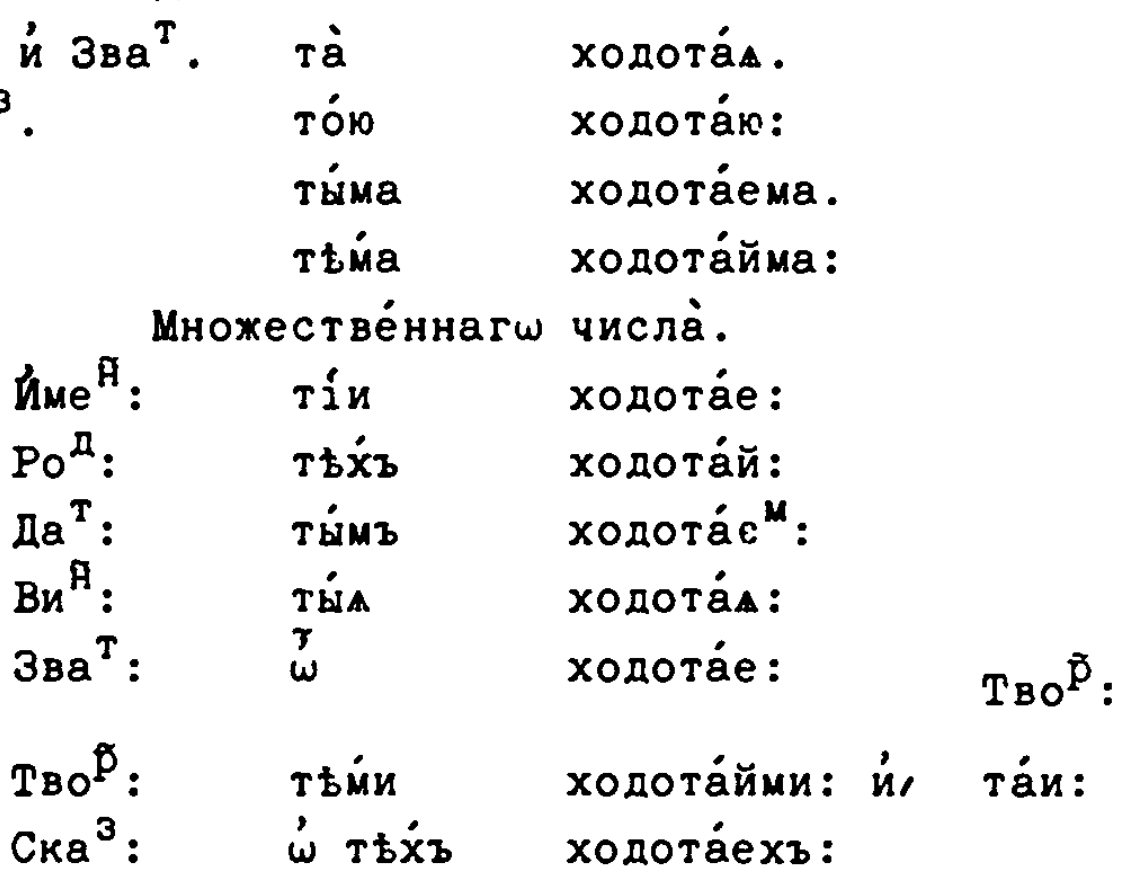

Ска : $\quad$ тьми $\quad$ ходотайми:

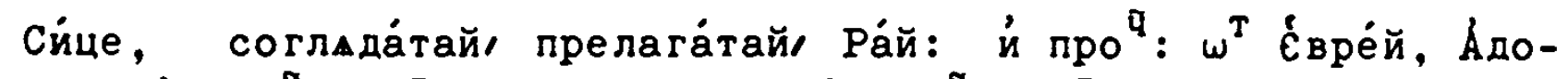
на́й: и́ про ${ }^{q}: \omega^{T}$ Латінъ, май: и́ про ${ }^{q}: \omega^{T}$ Гре́къ, Ніккола́й, Ке -

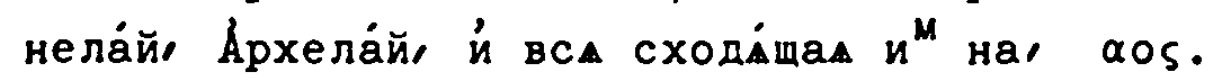

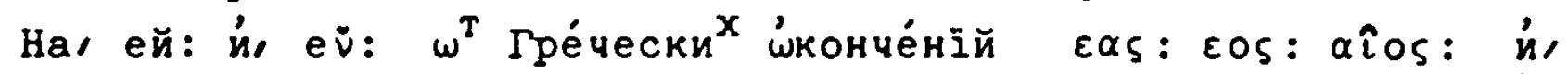

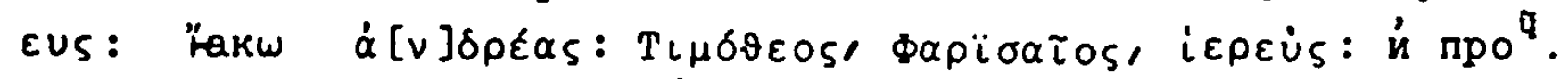

\begin{tabular}{|c|c|c|}
\hline \multicolumn{3}{|c|}{ Числа̀ е́динстве́ннагш. } \\
\hline Йme ${ }^{\text {म }}$ : & то́й & іере́й: \\
\hline Po ${ }^{\text {म }}:$ & Tori் & іере́A: \\
\hline$\not a^{T}:$ & roìy & ¿ере́ю: \\
\hline$B n^{\mathrm{A}}:$ & Toró & iepéa: \\
\hline $3 \mathrm{Ba}^{\mathrm{T}}:$ & & iepér: \\
\hline$T_{B O}{ }^{p}:$ & $T \hbar \dot{M} z$ & ¿̇ере́емъ \\
\hline $\mathrm{Cка}^{3}:$ & $\dot{\omega}$ To & іере́и: \\
\hline
\end{tabular}

Йме $^{\text {म }}: \mathrm{Bn}^{\text {म }}:$ и 3 ва $^{\mathrm{T}}:$ та̀ iepé 


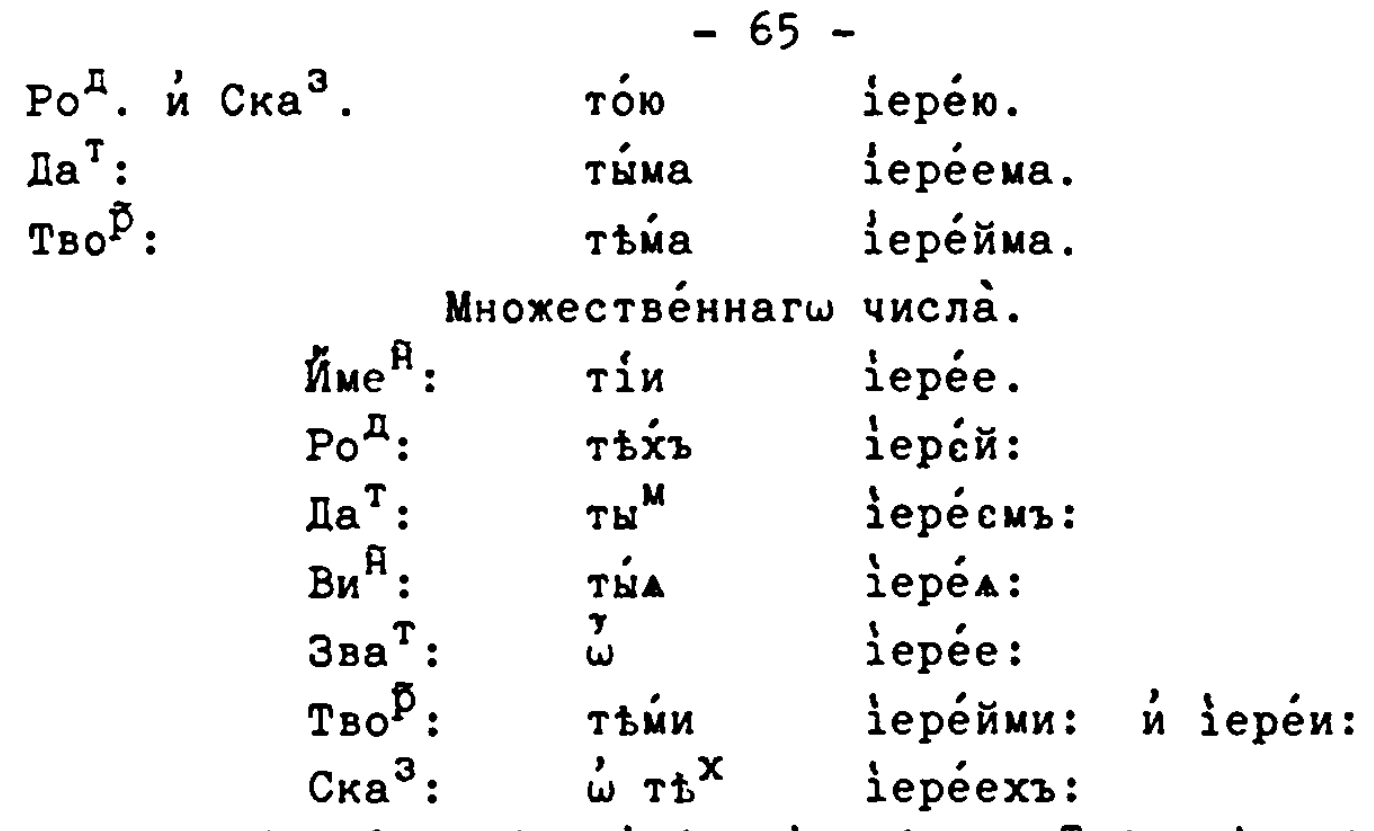

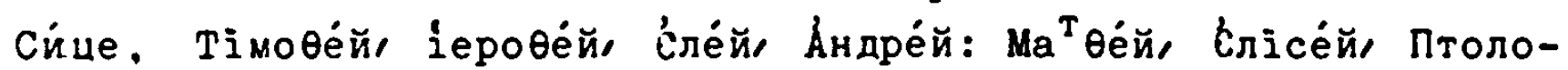

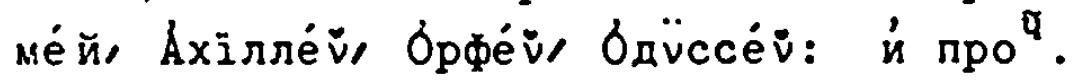

Ha, $і \overline{и ̆: ~ и ̆ \prime ~ и и ̆ . ~}$

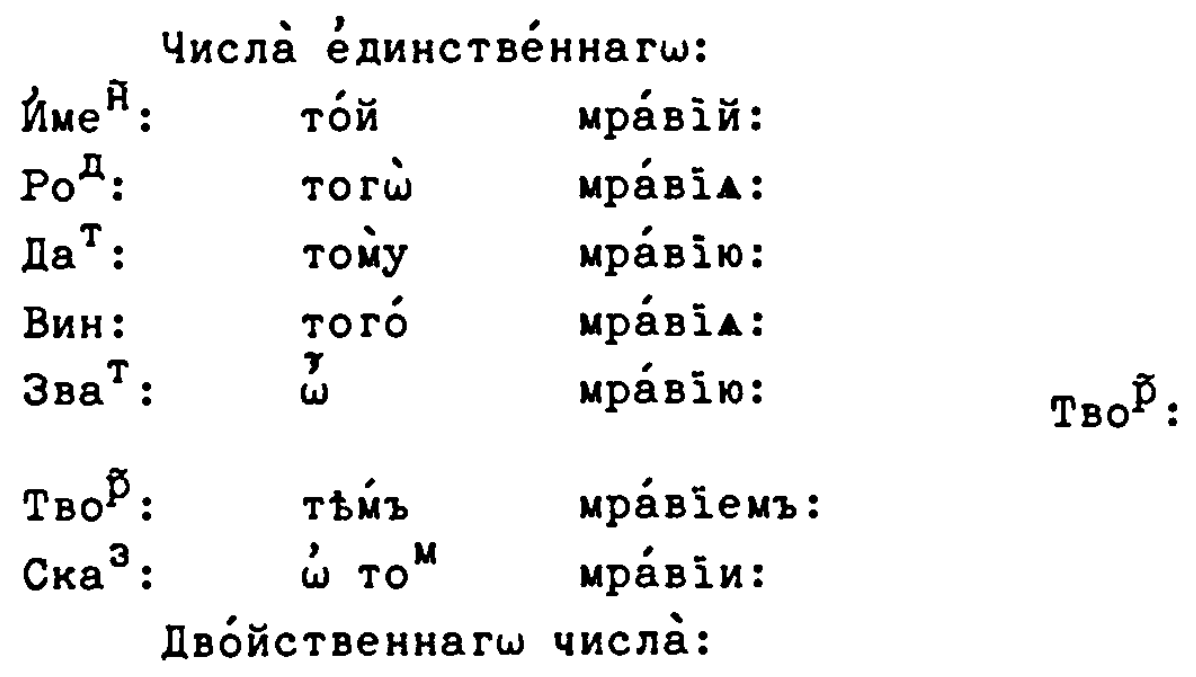

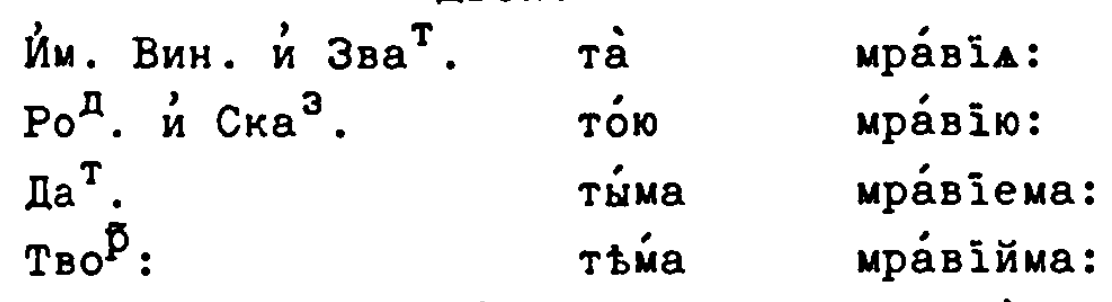

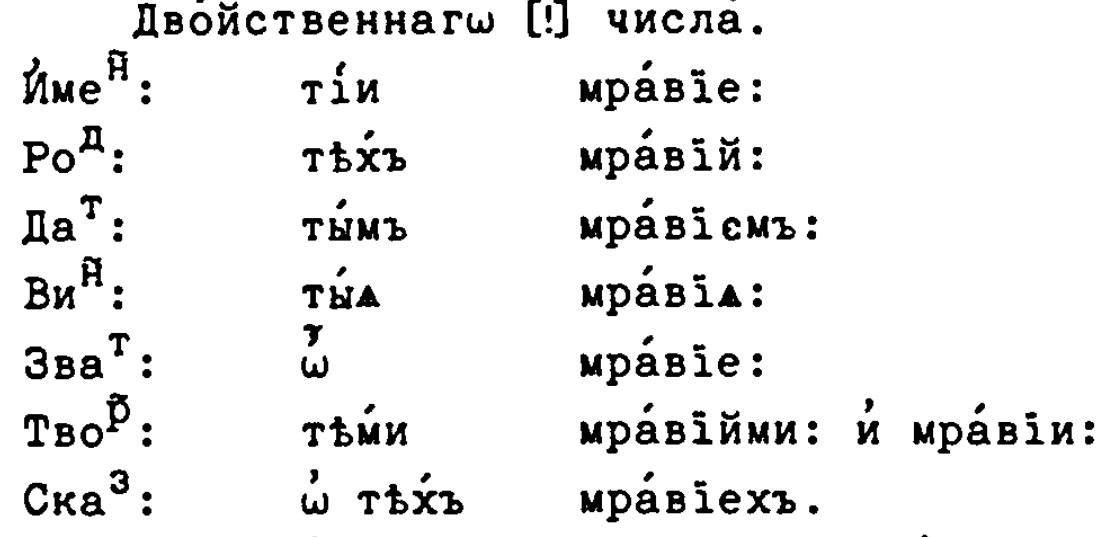

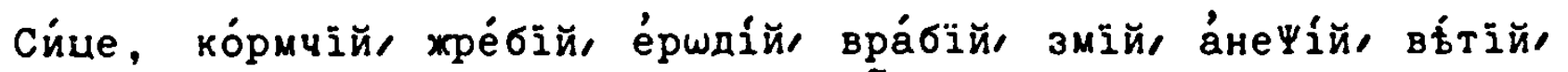

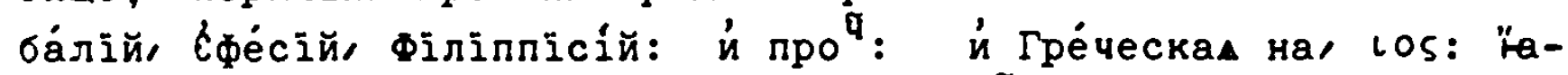

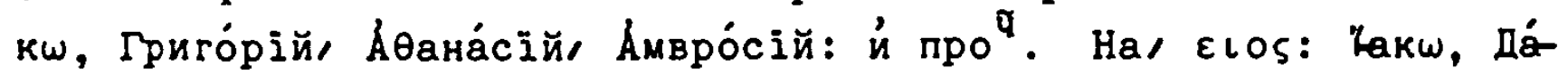




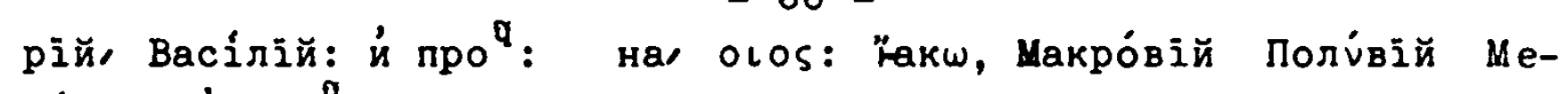
лівій: й про .

Ha

[636]

Ha, $\varepsilon l \alpha \varsigma:$ i $\alpha \varsigma:$ й

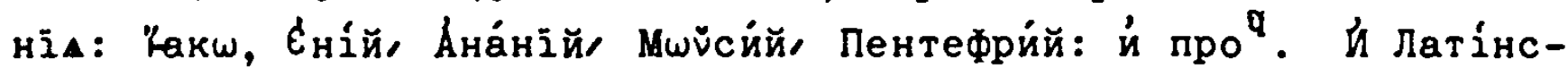
кал на, ius: Юакш, Га́ій, Те́ртій: й про .

оу́въще́ніе:

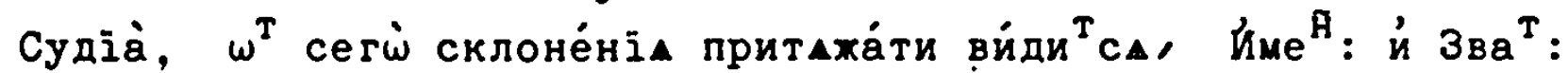

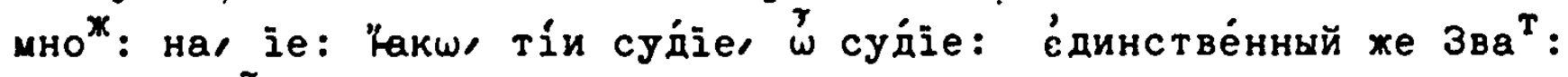
на, ій: $\stackrel{\jmath}{\omega}$ судій: לименителному сему в" разлйчіе.

На, ой: $\dot{n}$ шй $\omega^{T}$ Гре́ческихъ:

Числа̀ е́динстве́ннагш:

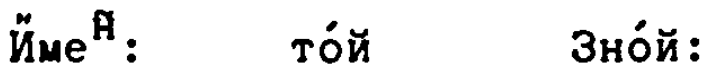

Poम": тогі் зно́А:

मа ${ }^{\mathrm{T}}$ : томेy зно́ю:

Ви ${ }^{\text {: }}$ то́й зно́й:

उва ${ }^{\mathrm{T}} \stackrel{\boldsymbol{T}}{\omega}$ зно́ю:

TBOp: тьй зно́емъ:

Ска ${ }^{3}$ : $\dot{\omega}$ то ${ }^{M}$ зно́и:

Дво́йственнагш числа̀.

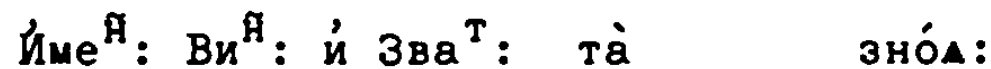

Poम: й $\mathrm{CKa}^{3}$ : то́ю उно́ю:

मа ${ }^{\mathrm{T}}$ :

ти́ma зно́ема:

TBo

тьй зно́йма.

$\not a^{T}:$

[64]

Мноестве́ннагш числа̀:

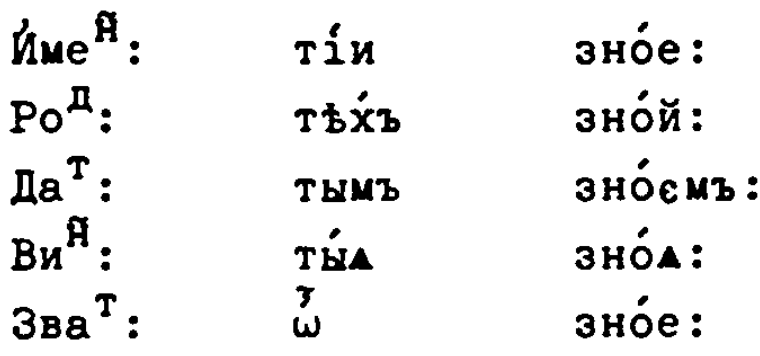

Тв: тьйи зно́йми: й зно́и:

$\mathrm{CKa}^{3}: \quad \dot{\omega} \mathrm{T} \leftarrow \dot{x} \mathrm{~s}$ зно́ехъ.

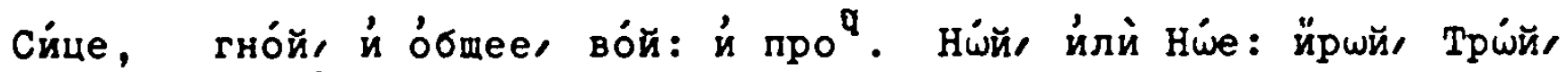
міншй: иं про

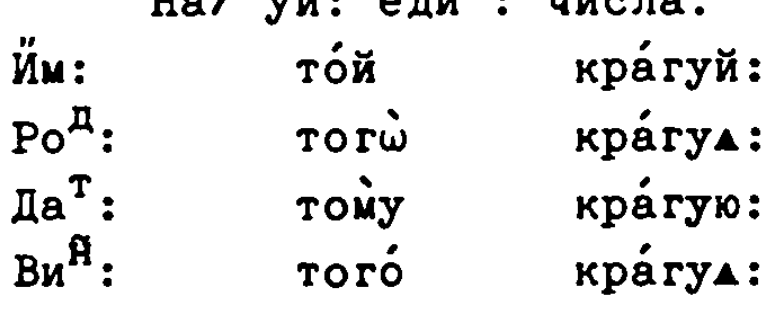




$$
\begin{aligned}
& \text { Зва }{ }^{\top}: \quad \stackrel{3}{\omega} \quad-67-\frac{}{\omega} \quad \text { кра́гую: }
\end{aligned}
$$

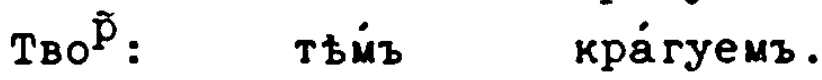

$$
\begin{aligned}
& \text { Ска }{ }^{3}: \text { í то́мъ кра́гуи. }
\end{aligned}
$$

$$
\text { Дво́йственнатш числа். }
$$

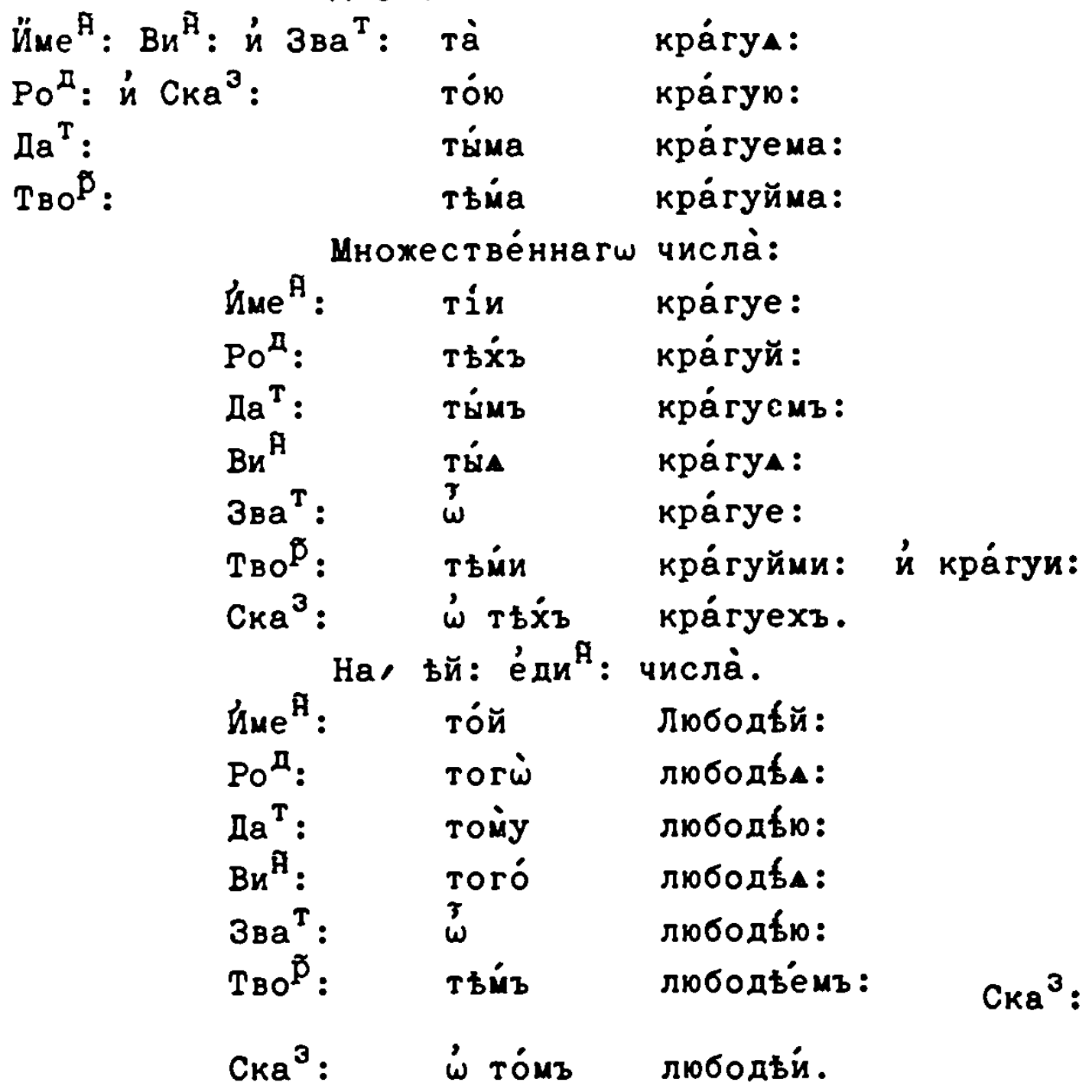

Дво́йственнагш числа்.

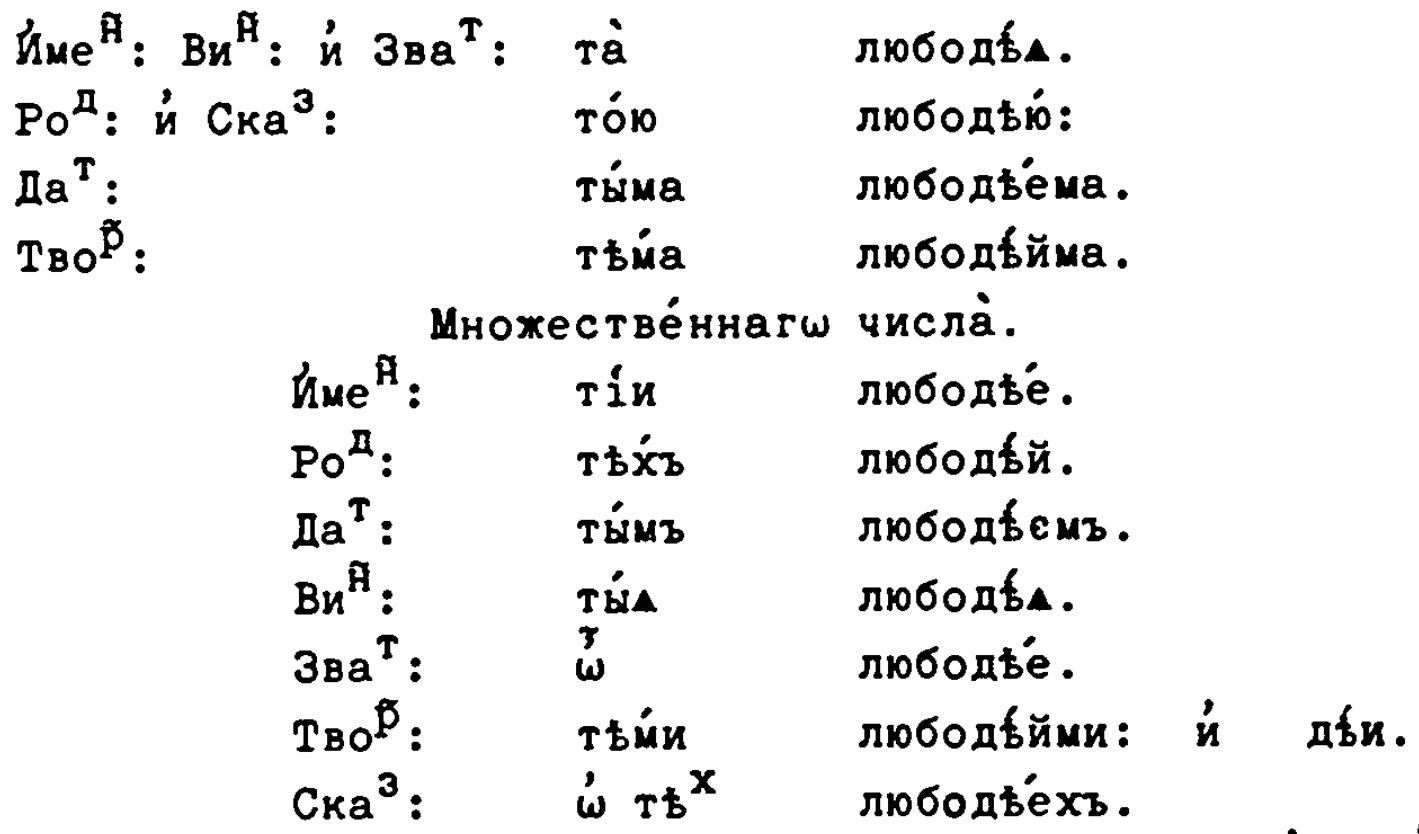

Си́це, чародбй, зло́дьй, прелюбодбй, сквернодбй: й про 
На, лА.

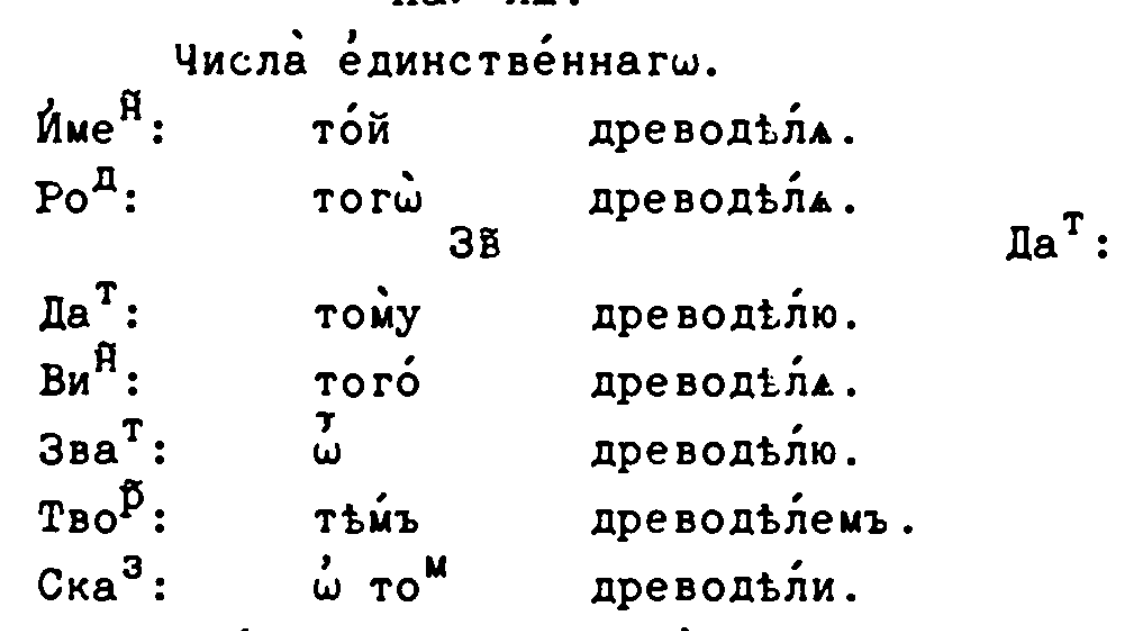

Дво́йственнагш числа̀:

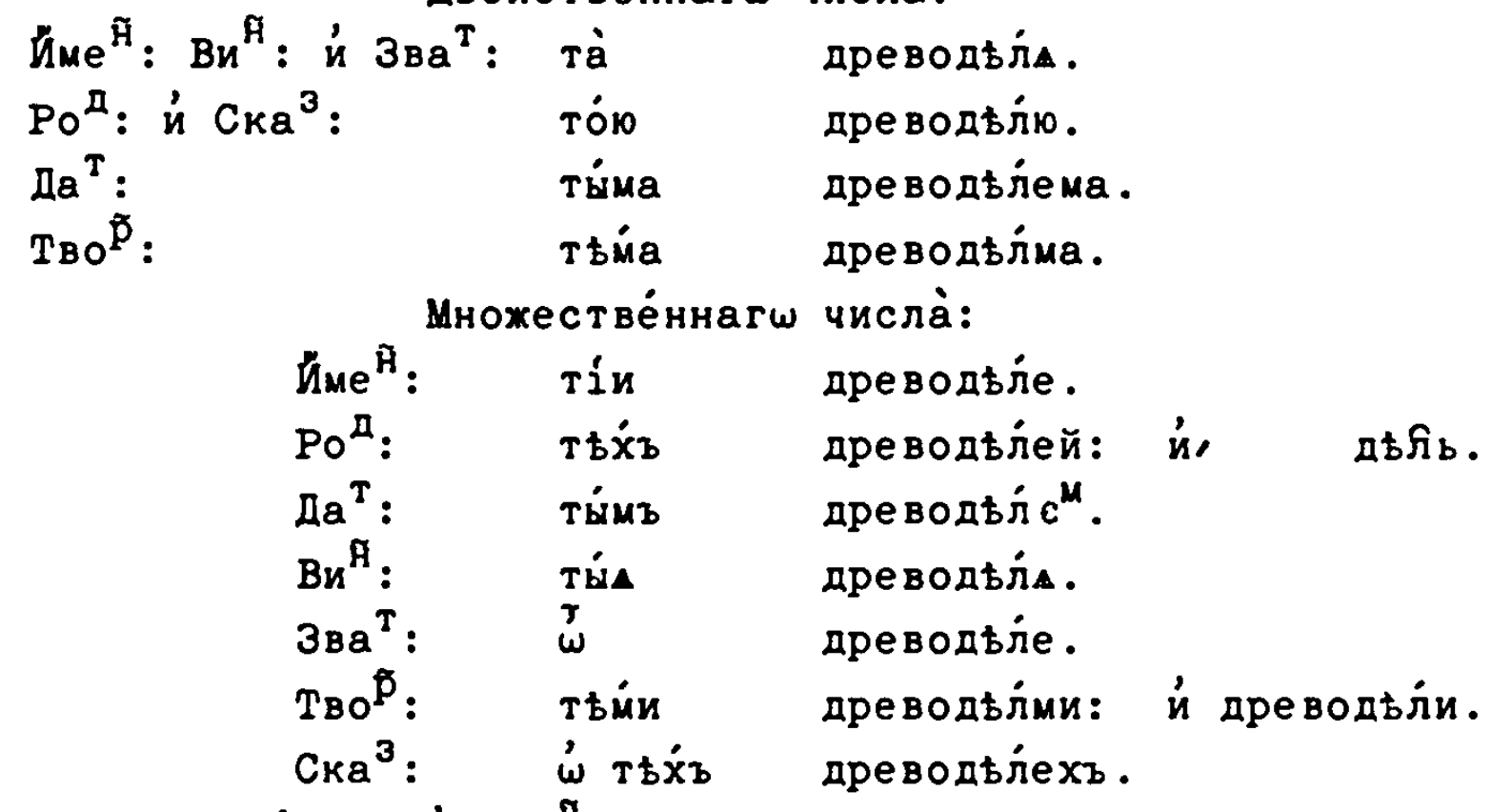

Сйе, сердобо́ла: й про

Cpéd

Cре́днее на, іе:

[66]

\begin{tabular}{|c|c|c|}
\hline \multicolumn{3}{|c|}{ Числа̀ е́динстве́ннагш: } \\
\hline Unue ${ }^{\mathrm{A}}$ : & Tóe & зна́меніе. \\
\hline & Torw & знаменіц. \\
\hline$\not a^{\mathrm{T}}:$ & томуy & зна́менію. \\
\hline $\mathrm{Bu}^{\mathrm{A}}:$ & Ióe $_{y}$ & зна́меніе. \\
\hline $\begin{array}{l}\text { Зва: } \\
\text { Tво } \bar{p}:\end{array}$ & $\begin{array}{l}\omega \\
T ち \dot{M} b\end{array}$ & $\begin{array}{l}\text { знамензе. } \\
\text { зна́меніемъ. }\end{array}$ \\
\hline Ска ${ }^{3}:$ & $\dot{\omega}$ то & зна́меніи. \\
\hline \multicolumn{3}{|c|}{ Дво́йственнагш } \\
\hline Зва ${ }^{\mathrm{T}}:$ & Tà & эна́менїа. \\
\hline${ }^{T}[\eta]$ & Tór & зна́менїю. \\
\hline & Túma & зна́менїема. \\
\hline & Tьмa & $\begin{array}{l}\text { зна́ме А́ма. } \\
\text { числа̀: }\end{array}$ \\
\hline
\end{tabular}




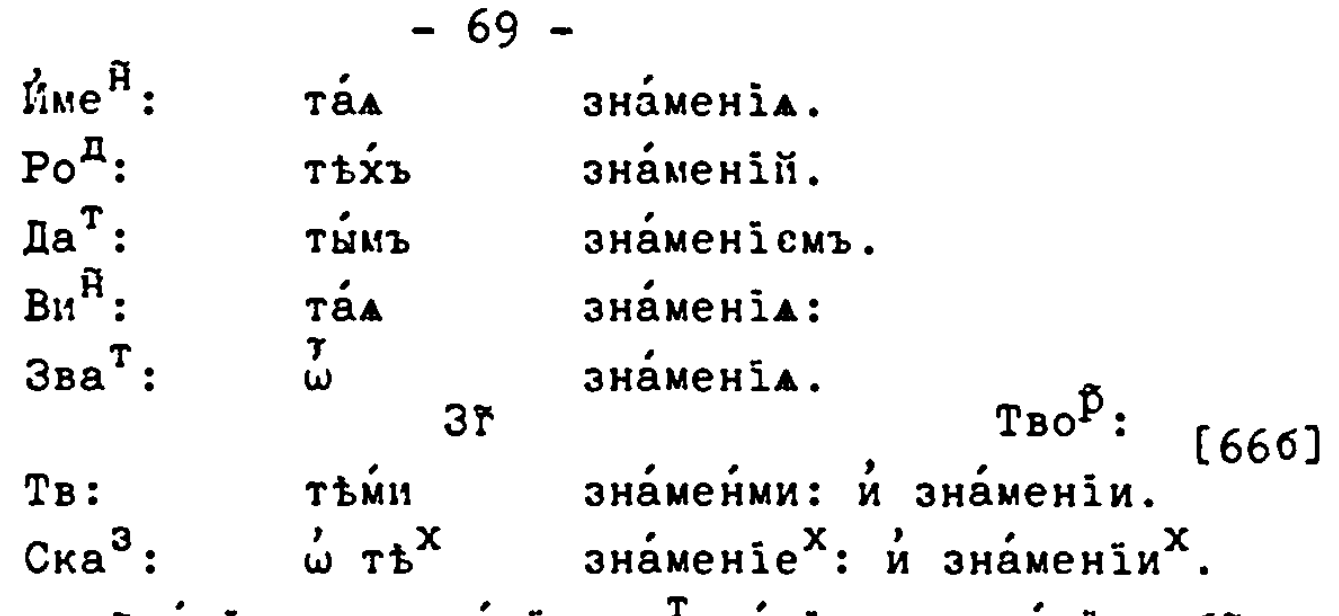

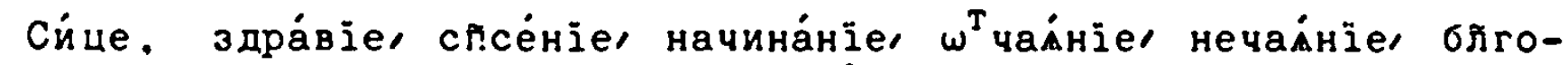

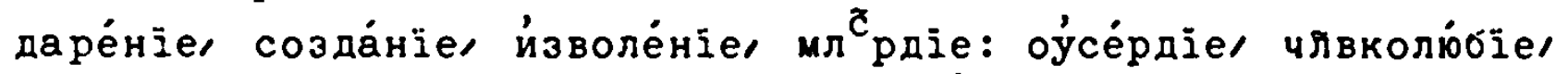
Һ́счи́дie, ца́рствїe, прише́ствїе: й про

Оу́вєще́ніе $\dot{\omega}$ множестве́нномъ сре́днихъ сказа́телномъ.

Сре́днАа склоне́нїА сегі் сказа́телный множестве́нный на, ихъ,

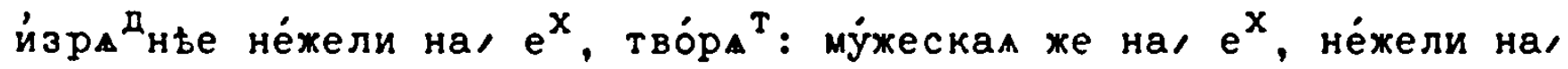
ихт.

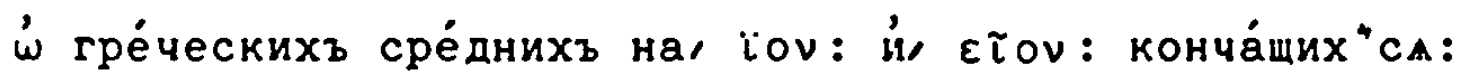

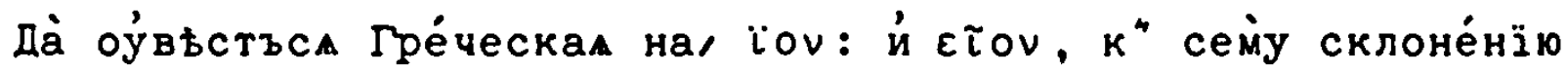
возносйма бы́ти, и́ си́ие скландема,

\begin{tabular}{|c|c|c|}
\hline$\ddot{u_{м e}}{ }^{\tilde{H}}:$ & Tóe & Кодно́вїон: \\
\hline Po" & Tor $\dot{\omega}$ & КО2но́віА: \\
\hline да ${ }^{\mathrm{T}}:$ & roìy & Ко1но́він: \\
\hline $\mathrm{Bu}^{\tilde{\mathrm{H}}}:$ & tóe & Коіно́вIон: \\
\hline $3 \mathrm{Ba}^{\mathrm{T}}:$ & $\stackrel{\boldsymbol{r}}{\omega}$ & КО工но́віон: \\
\hline $\mathrm{TBO}^{\tilde{p}}:$ & $T \dot{\Delta M B}$ & Когно́вїемв: \\
\hline $\mathrm{CKa}^{3}:$ & $\dot{\omega}$ тo ${ }^{M}$ & Кочно́вїи. \\
\hline
\end{tabular}

Дво́йственнагш числа̀.

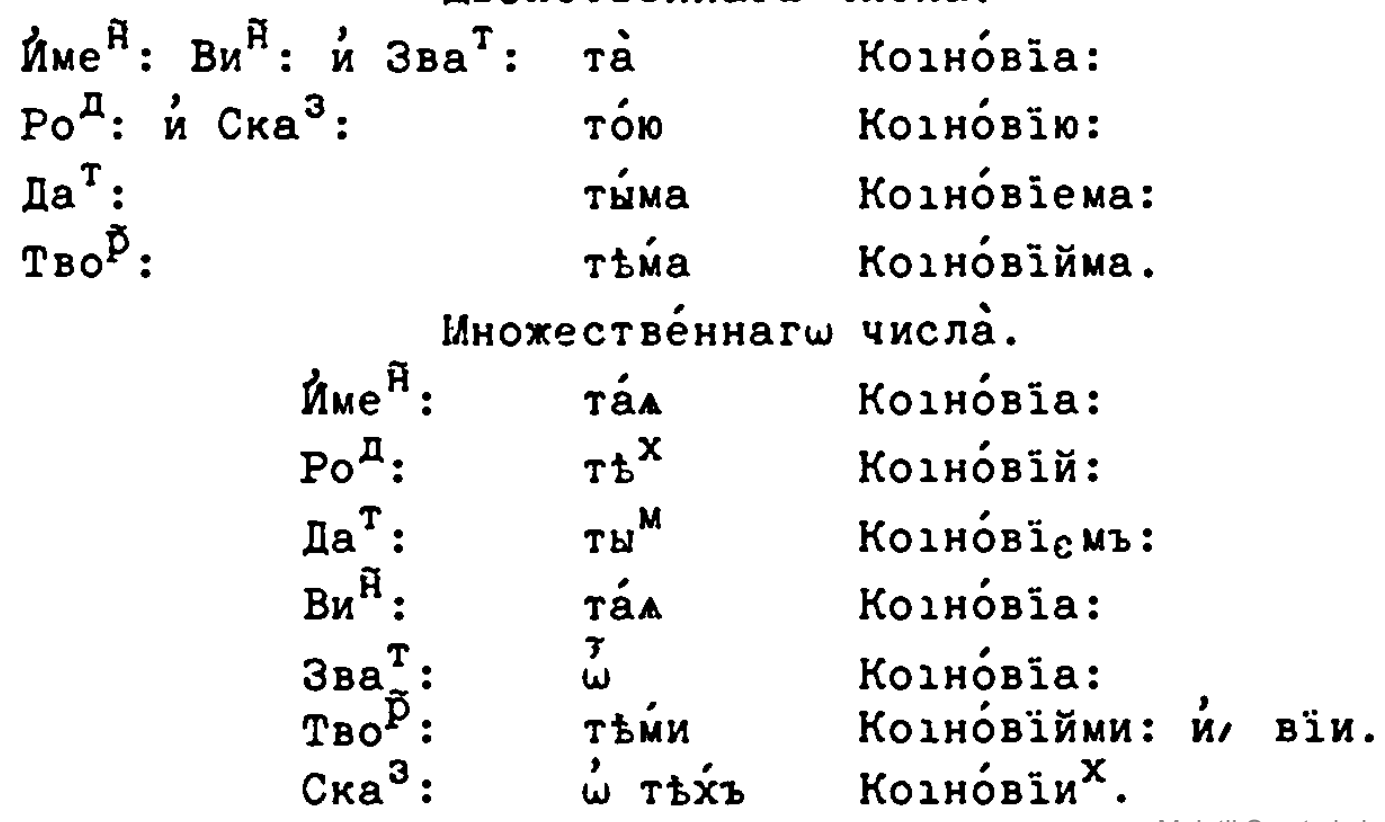


Cйuе, газофйла́кіон, гймна́сіон, трола́ріон, конта́кіон, крати́ріон, потиріон, носокомеโон, ६енодохеโон: й про .

$$
\text { 3д cxó }
$$

\section{Схо́лгон:}

Гре́ческал сіА, и́ си" подо́бнам, во муйеское '́конче́ніе схода́maА, мух́ескъ ро́дъ прие́млютъ: $\omega^{\mathrm{T}}$ ни ${ }^{\mathrm{X}}$ же посльднее согла́сное $\dot{\omega}-$

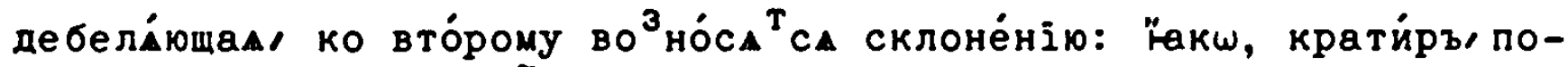

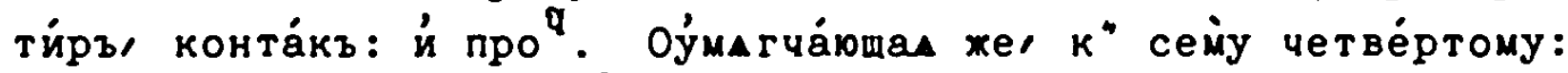

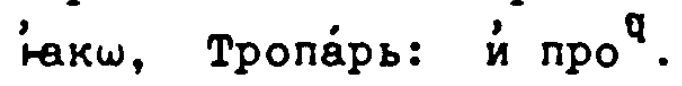

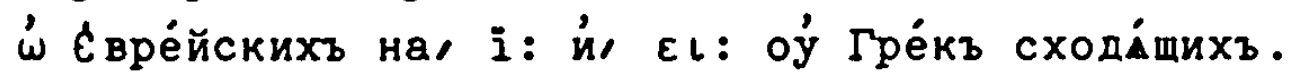

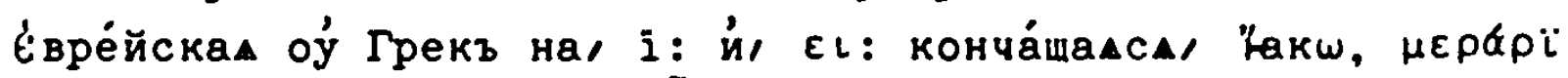

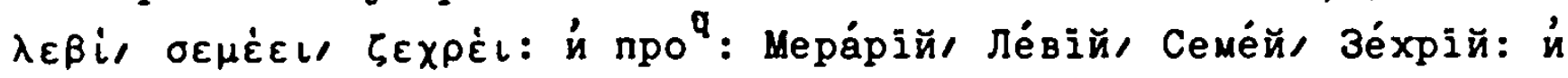

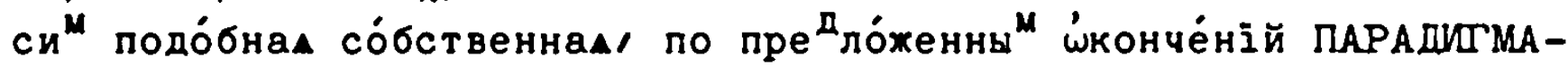
TEMъ су⿰⿱乛夕丶 склани́ема.

\section{Оу́въще́ніе ’́ Зва́телномъ е́динстве́нномъ:}

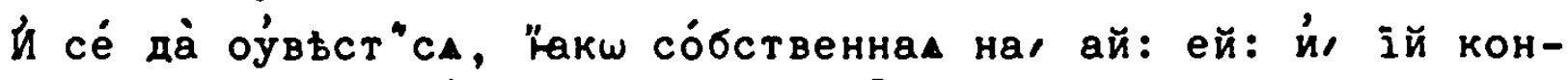
ча́mалса, зва́теленъ е́динстве́нъ тво́рА

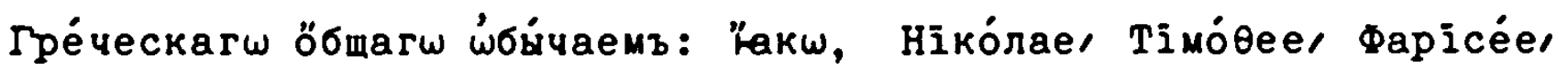

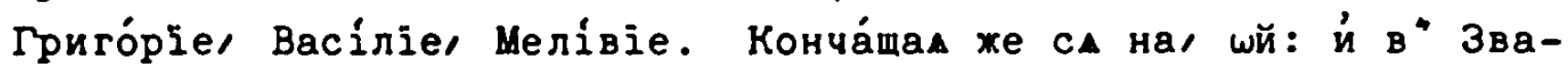
телномз й в"

\section{йме}

Йенителномъ е́динстве́нномъ Гре́ческое өе́ма содержа ${ }^{\mathrm{T}}$ : 迆, й-

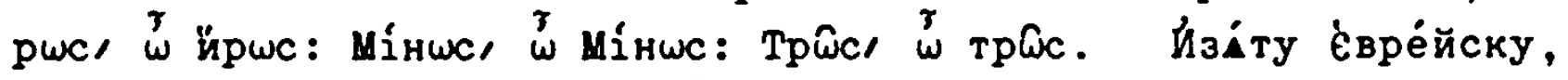
Нйй, йлй Нйе, сйцево Өе́ма йму́щу.

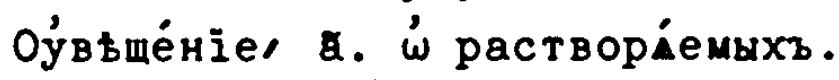

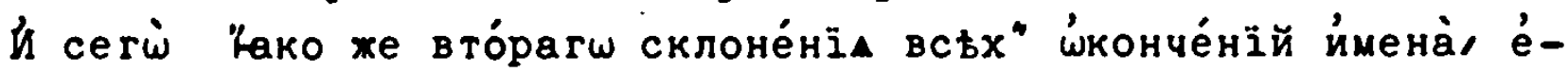

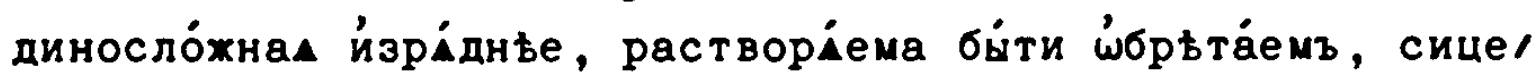

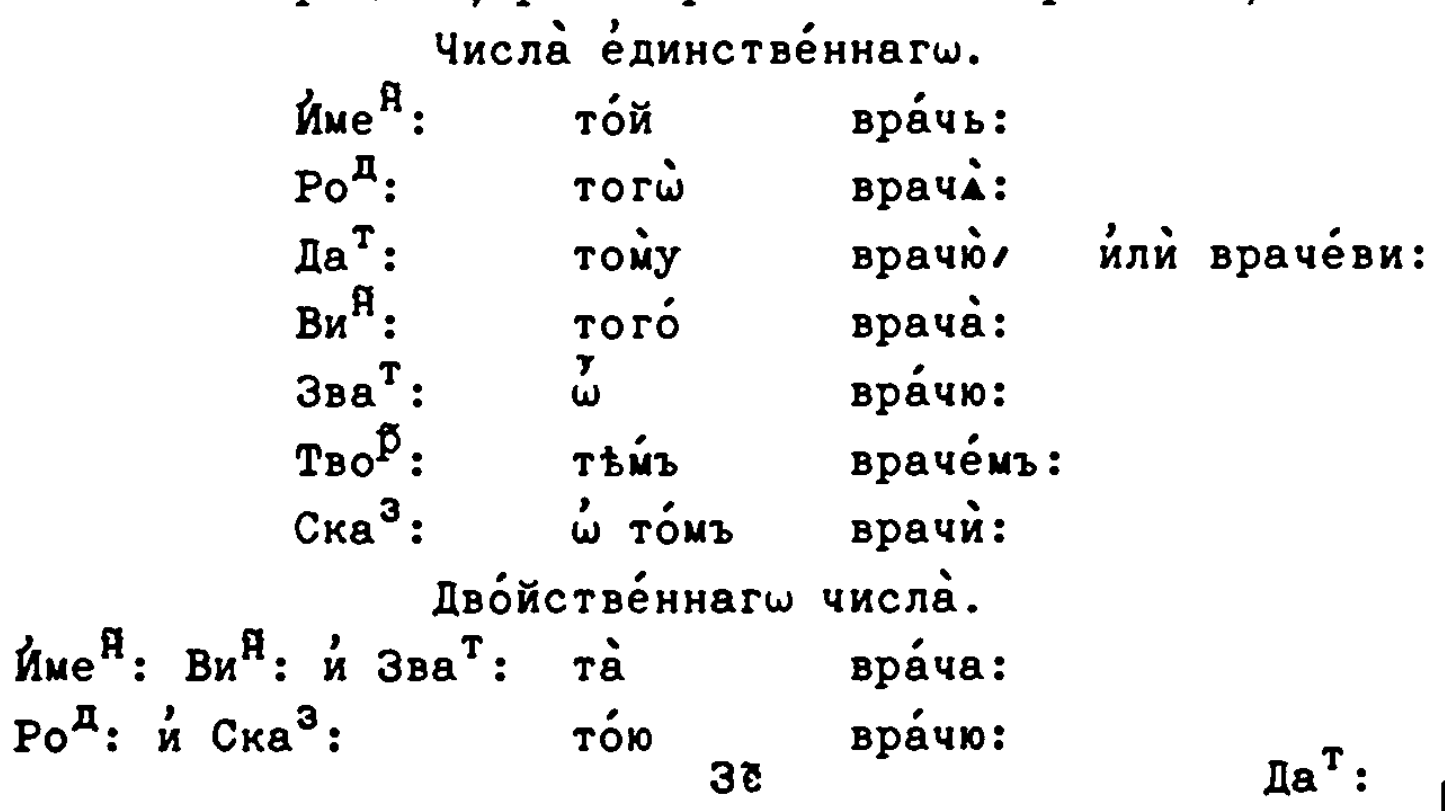


La ${ }^{T}:$ $\mathrm{T} \geq \mathrm{O}^{\widehat{\mathrm{p}}}$ :
Tína

Ttía вра́чемa:

вpáuma:

Һіножестве́ннагш числа̀.

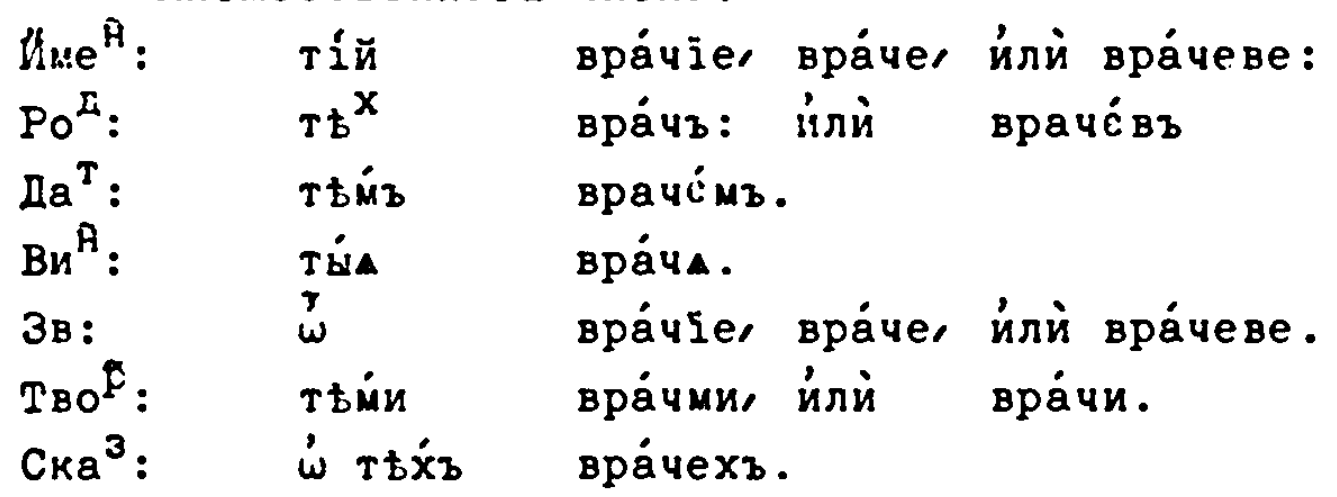

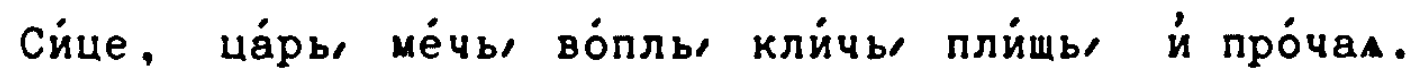

Оу́вђше́нї: В.

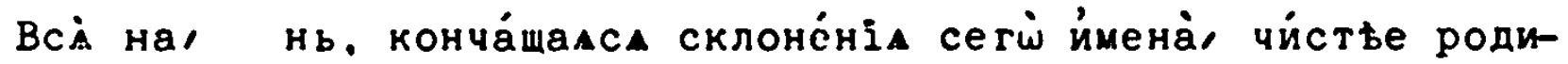
телный е́динстве́нный сходи́ти тво́рА ${ }^{T}$ на, $\mathrm{e}$, не́жели на, А: Гакш, ко́рень ко́рене: сте́пень сте́пене: ка́мень не: де́нь дне: пла́мень, не: й про . Именителный же мнохестве́нный на, іе: нежели на, е: "̈кш, ка́меніе, сте́пеніе, кореніе, дні́е, пла́меніе: is npo ${ }^{q}$.

Путि

ПуТิь, путй, В" роди́телномъ е́ди": й в" Вини́телномъ мно": не́жели путі: й äще ка́ си́мъ подо́бнаА.

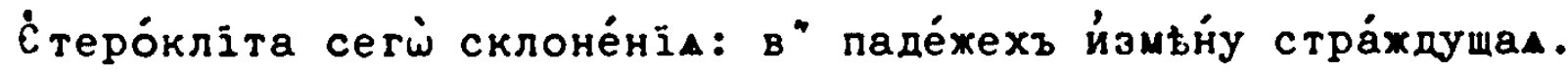
Числа̀ е́динствённагш.

\begin{tabular}{|c|c|c|}
\hline \multirow{2}{*}{\multicolumn{3}{|c|}{$\Gamma^{n h}$}} \\
\hline & & $\Gamma^{c}$ дb. \\
\hline Pon: & Torí & $\Gamma^{\mathcal{E}}$ да. \\
\hline $\mathrm{Ha}^{\mathrm{T}}:$ & Tomy & $\Gamma^{c}$ ду, илй $\Gamma^{c}$ дви. \\
\hline & $\underset{\gamma}{\text { Toró }}$ & \\
\hline $\begin{array}{l}3 \mathrm{BQ}^{\mathrm{T}}: \\
\mathrm{T}_{\mathrm{B}}^{\mathrm{p}} \mathrm{:}:\end{array}$ & $\boldsymbol{\omega}$ & $\Gamma^{c}$ ди. \\
\hline $\mathrm{Cka}^{3}:$ & $0^{M}$ & $\Gamma^{\boldsymbol{c}}$ \\
\hline
\end{tabular}

Дво́йственнагш числа̀.

\begin{tabular}{|c|c|}
\hline 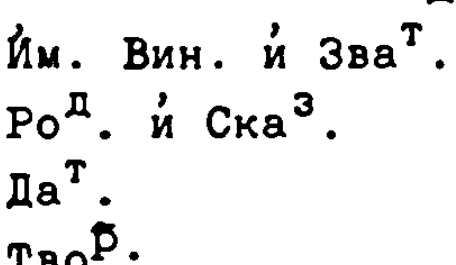 & $\begin{array}{l}\text { Tà } \\
\text { Tón } \\
\text { Tóma }\end{array}$ \\
\hline
\end{tabular}

\begin{tabular}{|c|c|c|}
\hline $\begin{array}{l}\text { Une } \\
\text { Po }\end{array}$ & 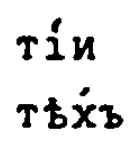 & $\begin{array}{l}\text { Госпо́nіe. } \\
\text { Го́сподей. }\end{array}$ \\
\hline $1 a^{T}:$ & Tட́mb & Гócnодемъ. \\
\hline
\end{tabular}




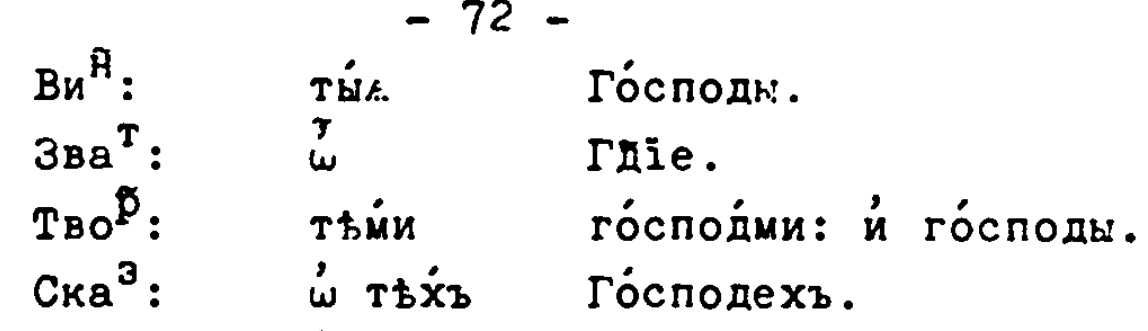

му́жеское е́динстве́ннагш и́ дво́йственнагш числа̀ лиша́ющееса; лю́діе: Сйце скланиемо: лю́діе, люде́й, лю́демъ, люди, $\stackrel{3}{\omega}$ лю́діе, людмй, $\dot{\omega}$ лю́дехъ: $\omega^{T}$ необйчна, лю́дъ.

Собира́телньхъ склоне́ніа сегі் пара́дитма, сйце в" множестве́нномъ числіt склана́емое: Йм: ті́и ка́меніе: йлй то́ ка́менїе.

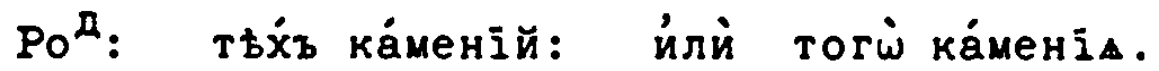
Да ${ }^{\mathrm{T}}$ : ти́мъ ка́меніемъ: и́ли́ тому ка́менію. Вин: ти́ ка́меніА: йлй то́е ка́меніе. Зва ${ }^{\mathrm{T}} \stackrel{\boldsymbol{J}}{\omega}$ ка́меніе: Тво :

Твор: тьйи ка́мен́ми: и́лй тьйъ ка́меніемъ.

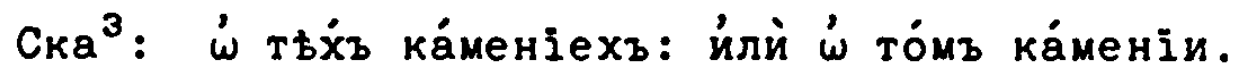

пі́тос склонсніс.

Пи́тое Склоне́ніе ёстъ йме́нъ Прилага́телньхъ тро́егш '́конче́нйА.

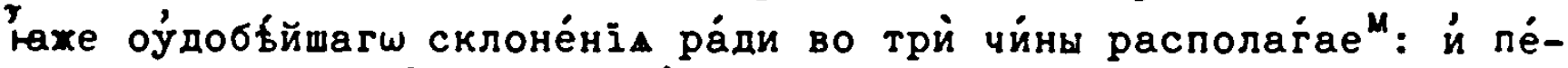

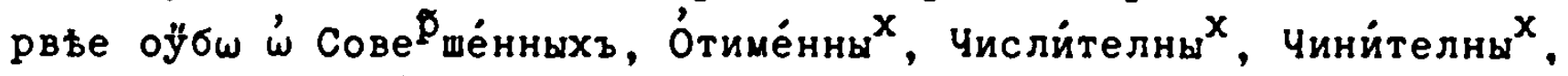

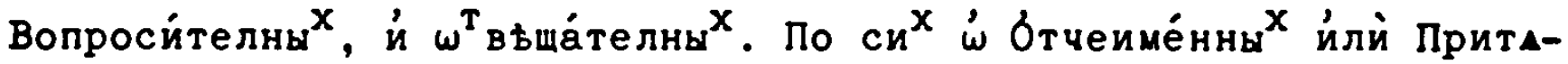

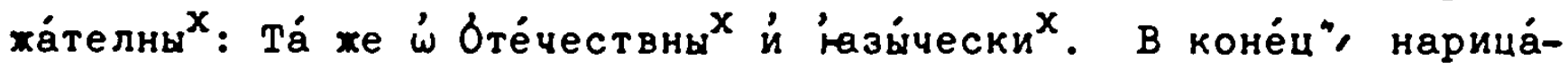
телны прилага́телны ${ }^{M}$ же́нскимъ подо́бны пара́дигма. Й пе́рвагш оўбш чйна йме́нъ му́жеска ро́да ம́конче́ніА ёста два̀: ый: й, ій:

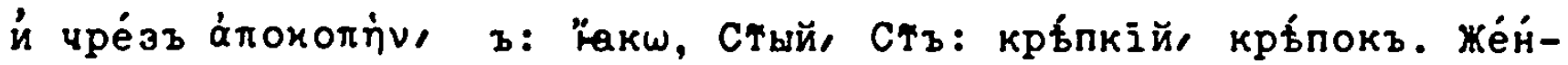

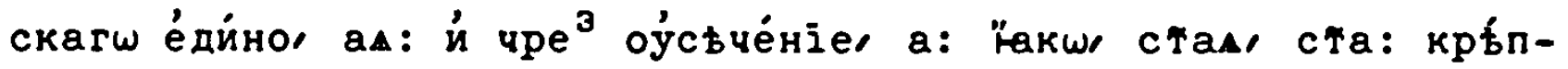

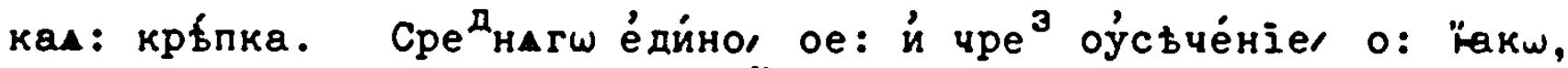

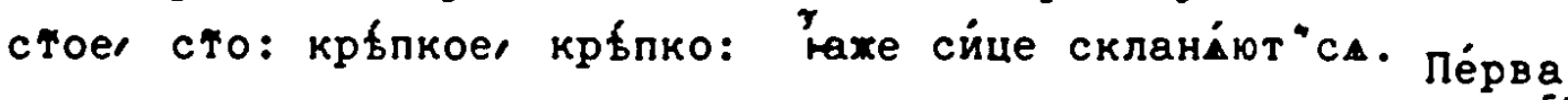

Первагш чйна прилага́телныхъ ПАРАДИГМАТА:

ПАРАДИГМА муंхески ${ }^{X}$, на, Ый: и́ чре ${ }^{3}$ оусьче́ніе на, 3. Числа̇ е́динстве́ннагш:

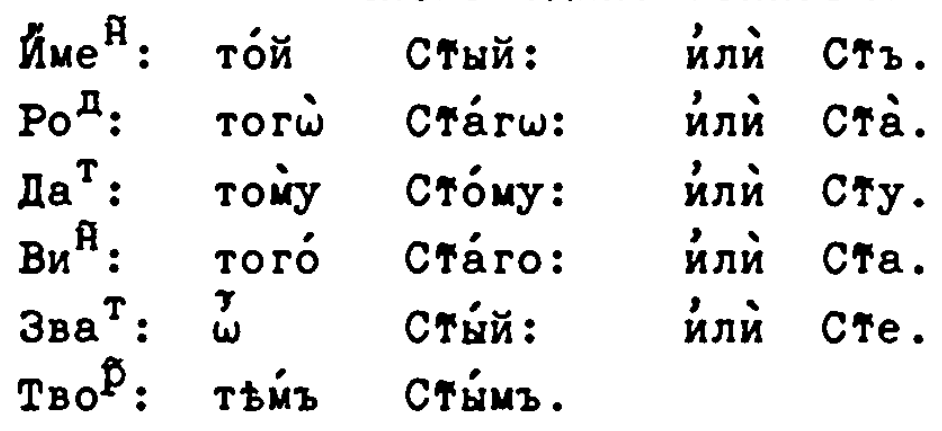


Ска ${ }^{3}:$ के то сто": йлй стьм" й сть.

Двӧйтвеннатш числа̀:

hri: $\mathrm{Bu}^{\text {म }}$ : is $3 \mathrm{Ba}^{\mathrm{T}}$ : та̀ Cra.

Poम: и́ Ска ${ }^{3}:$ тón Cry.

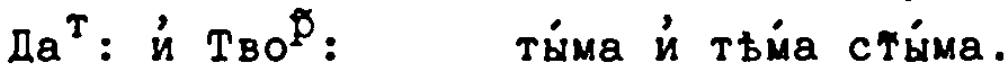

Множестве́ннагш числа̀.

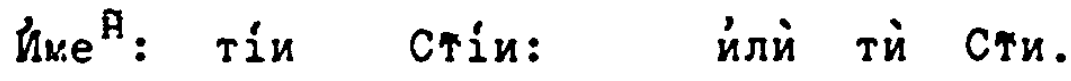

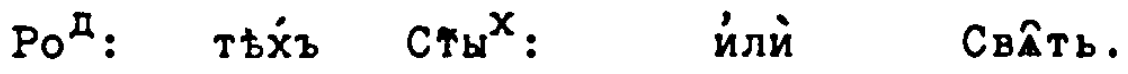

да ${ }^{\mathrm{T}}$ : тйmb Crímb.

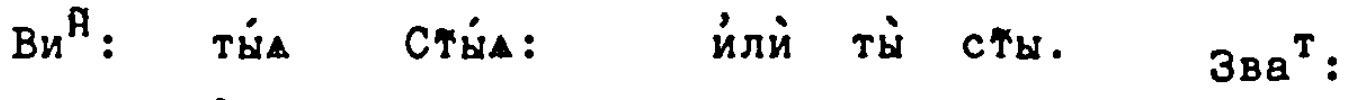

Зва ${ }^{\mathrm{T}}: \stackrel{3}{\omega}$ стіи: иंлй сти.

твор: тьй сти́ми.

Ска ${ }^{3}$ : $\dot{\omega}$ тђхъ сти́хв.

Родйтелный е́динстве́нный на, $\omega, \mathrm{Bu}^{\mathrm{A}}:$ на, о:

Же́нски на, ал: и́ чре ${ }^{3}$ оусбче́ніе на, а:

Числа̀ е́динстве́ннагш:

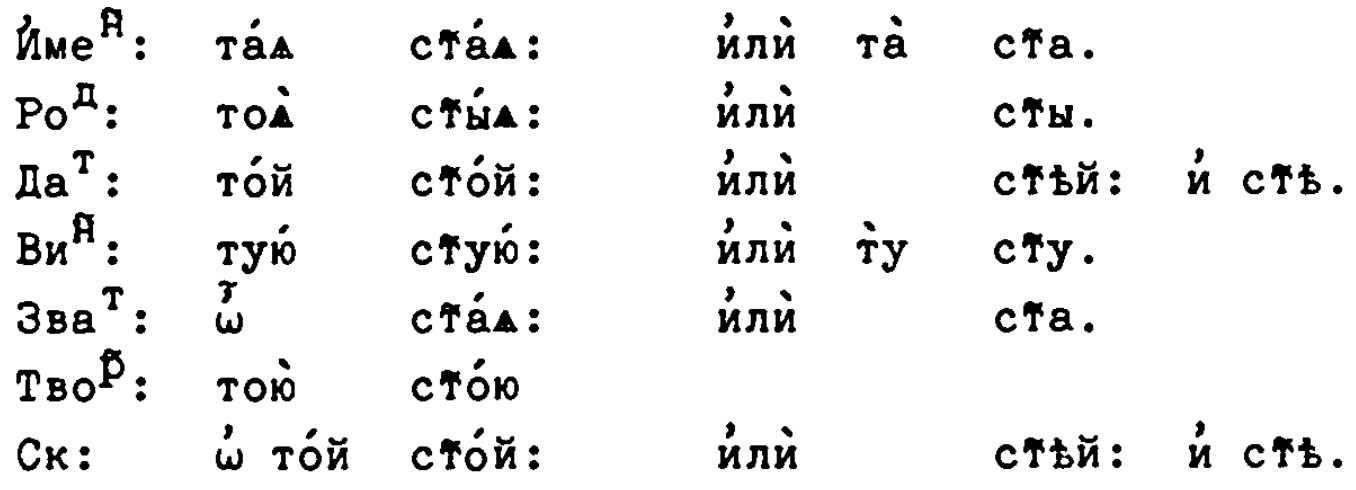

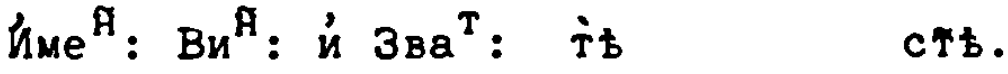

Poम : и $\mathrm{CKa}^{3}$ : Ttí cry.

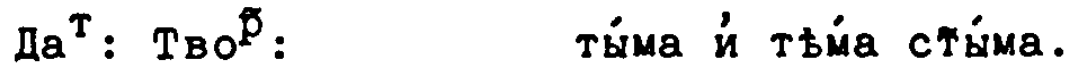

Мнохестве́ннагш числа̀.

Йме : ті́ сті́: йлй тй сты.

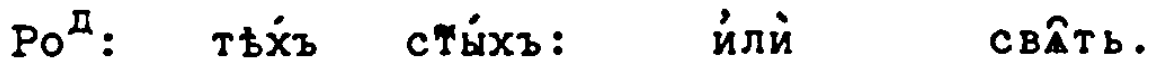

Ia ${ }^{\mathrm{T}}$ : ти́mb cт́́mb.

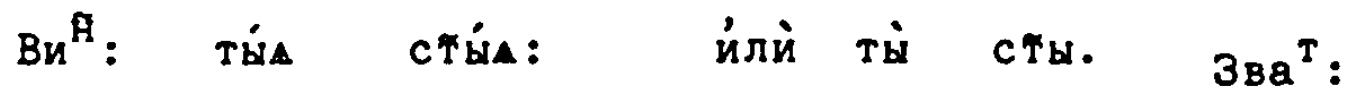

Зва ${ }^{\mathrm{T}}: \dot{\omega}$ ств́: иंлй сты.

Твор: тьми ствми.

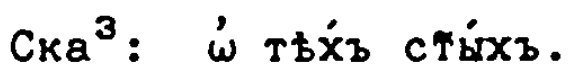

Сре ${ }_{\text {нихъ на, ое: } \dot{и} \text { чре }}^{3}$ оуссьче́ніе на, о:

Числа̀ е́динстве́ннагш:

йme : тóe cróe: йлй то́ сто. 


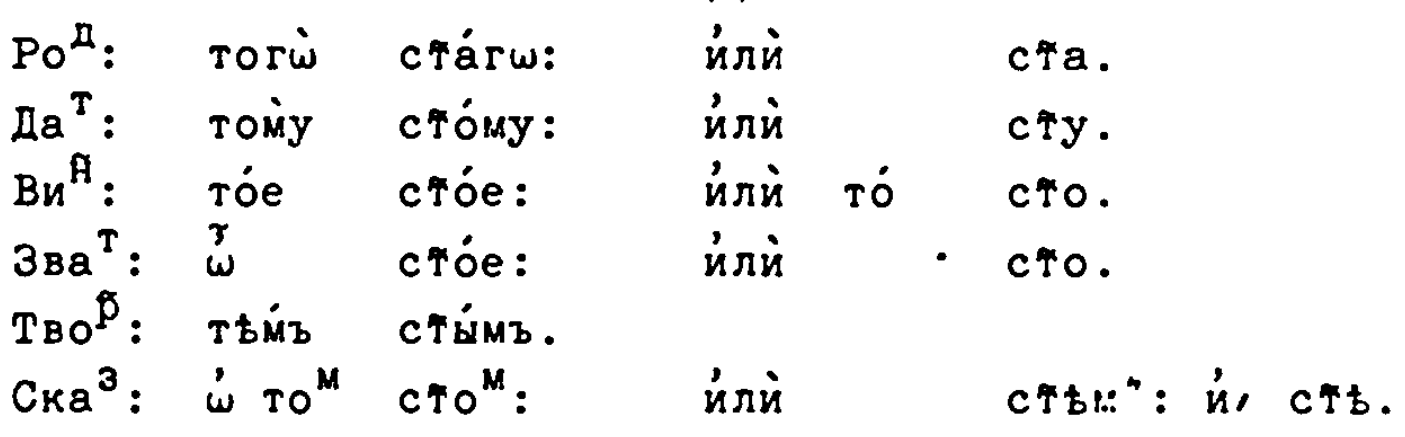

Дво́йственнагш числа்:

Име ${ }^{\text {A }}: \mathrm{Bu}^{\text {月 }}:$ й $3 \mathrm{Ba}^{\mathrm{T}}:$ та丿 cта.

Poम : и $\mathrm{CKa}^{3}:$ тón cry.

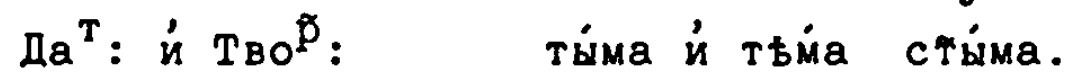

Множестве́ннагш числа்.

йме : та́a ста́a: йлй та̀ cтa.

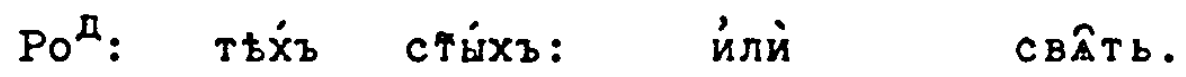

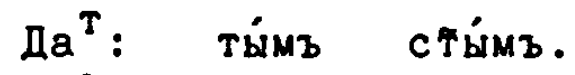

Виम̆: та́A ста́a: йлй та̀ ста. उва

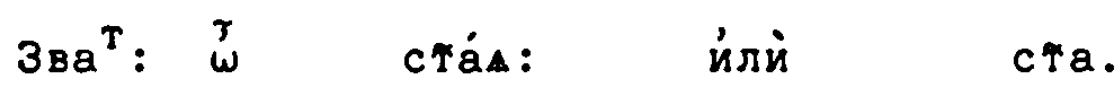

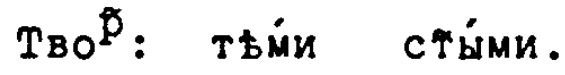

Ска ${ }^{3}: \quad \dot{\omega} \mathrm{rt \dot {x } z}$ сти́хв.

Паради́гмата прилага́телны ${ }^{x}$ на, їй: му́хески ${ }^{x}, \dot{и}$ чре ${ }^{3}$ оуссьче́ніе на, з:

Ha, гій.

Числа̀ е́динстве́ннагw:

йм: то́й блгі́й, йли блгъ.

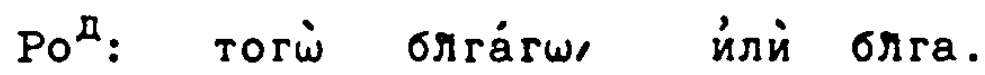

да ${ }^{\mathrm{T}}$ : тому блгому, илй блгу.

Ви : того блга́ro, йлй блга.

Зва ${ }^{\top}: \stackrel{3}{\omega}$ блгій йли блже.

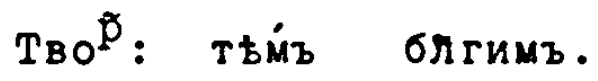

Ска ${ }^{3}: \dot{\omega}$ то $^{M}$ блгомъ, йлй блзђмъ: и́, блзь.

Дво́йственнагш числа்.

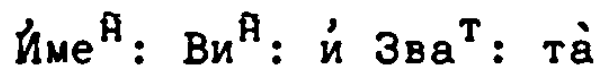

6rira.

Poम: 'ं $\mathrm{CKa}^{3}$ :

тón бrгy.

да ${ }^{\mathrm{T}}:$ и Tво

ти́мa й тьйa блги́ma.

U

Mноже

Множестве́ннатш числа̀.

Име ${ }^{\text {म }}:$ тій

блrí,

йлй тй блзи.

Poम : ть⿱㇒㠯

блги́xъ,

и่лй

блаิrb.

Да ${ }^{\mathrm{T}}$ : тймъ бягймъ.

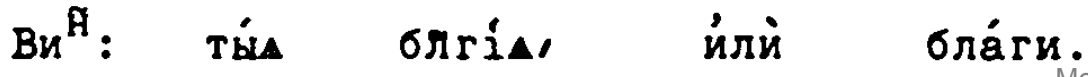


उва ${ }^{\mathrm{T}}: \stackrel{r}{\omega}$ блгіи, иля блзи.

Tвор: твй блгини.

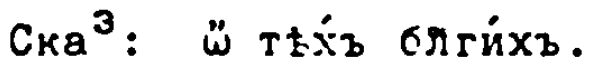

Жёнскихъ на, ал: й чре ${ }^{3}$ оусьче́ніе на, $a$.

Числа் е́динстве́ннагш:

Úme ${ }^{\text {H }}$ тáa блга́a, йлй тà блга.

Po : тод блгін, илй блги.

Да ${ }^{\mathrm{T}}:$ то́й блго́й, илй бла́зћй: й блзђ.

Bu ${ }^{\mathrm{A}}$ : туі́ блгуіо или ту блry.

उва ${ }^{\mathrm{T}}: \stackrel{\jmath}{\omega}$ блга́a, йй блra.

TBOP: тон бrrón.

Ска ${ }^{3}$ : $\dot{\omega}$ то́й блго́й, иंлй блзђй: й бла́зђ.

Дво́йственнагш числа̀. Ймө

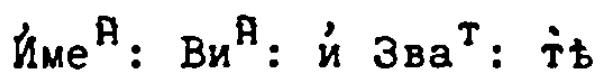

orat.

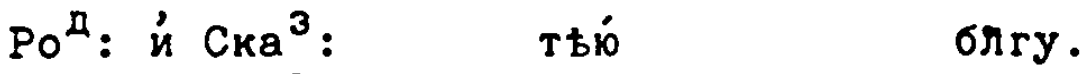

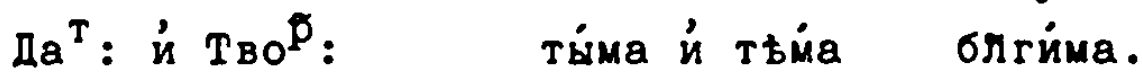

Мнохестве́ннагш числа̀:

Une ${ }^{\text {B }}$ Tía

олría, йлй

блru.

Pon: $T \hbar^{x}$

блги́хъ, йли

блârb.

Да ${ }^{\mathrm{T}}$ : ти́mz блги́mz.

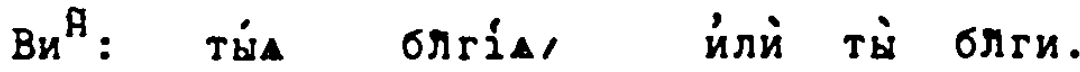

Зва ${ }^{\mathrm{T}}: \stackrel{T}{\omega}$ блгін йли блги.

Tв. тьм́и блгі́ми.

Ска ${ }^{3}$ : '́ тьх́з блги́хз.

Сре ${ }^{Д_{н и}}$ на, ое: й чре ${ }^{3}$ оусьче́ніе на, 0 .

Числа̀ е́динстве́ннагш:

И́me : тóe блróe, йлй то блго.

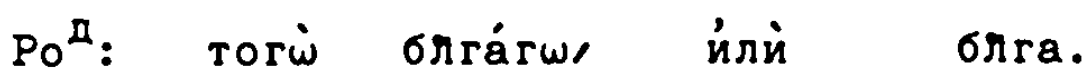

Да ${ }^{\mathrm{T}}$ : тому блгому йлй блгу.

Ви ${ }^{\text {A }}$ тóe блróel йли то блго.

Зва ${ }^{\mathrm{T}}: \stackrel{\boldsymbol{w}}{\omega}$ блróe, илй блго.

Тво ${ }^{\text {p }}$ : тьйв блги́мв.

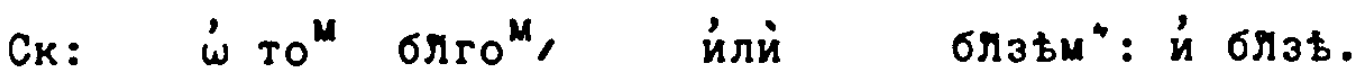
Ив Дво́й

Дво́йственна Ѓ числа̀.

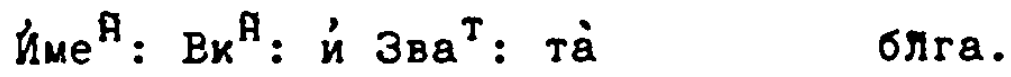

Po :

да ${ }^{\mathrm{T}}$ : й твор: тима й тьм́ блгйа.

Мнохестве́ннагш числа̀. 


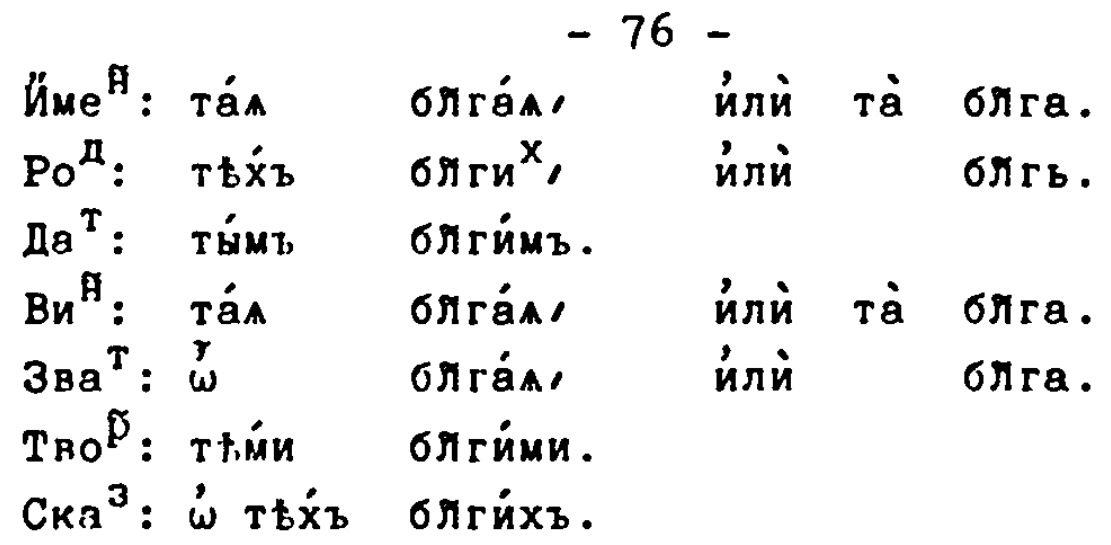

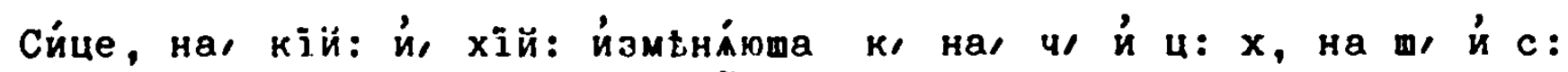
Выстно о́ба́че бу́ди, йменителе щіи, самfмъ ஸ́л®евле́нныхъ му́жеска ро́да ве́щі̆ прилага́телным сво́йственъ быти.

Конча́щалса на, жій: цій: чій: шій:

щій: и́ ій: чйстое, сйее суть скланд́ема. числа̇ Числі் е́динстве́ннагш.

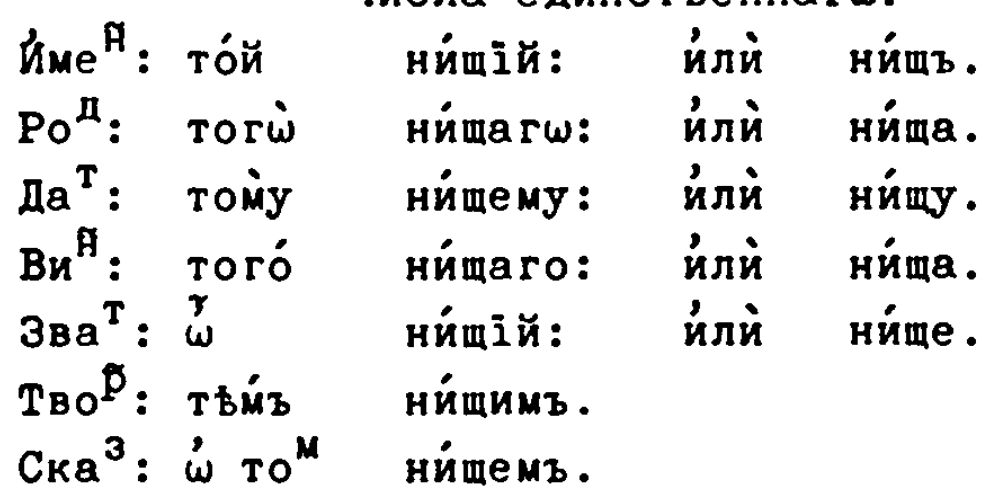

Дво́йственнагш числа்:

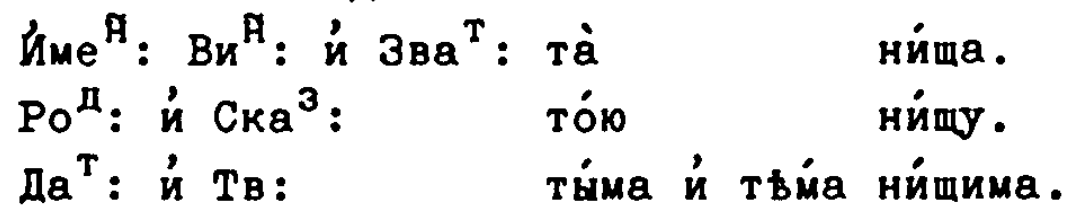

Множестве́ннагш числа்:

име ${ }^{\tilde{1}}$. ті́и нйщіи: йлй нйщи.

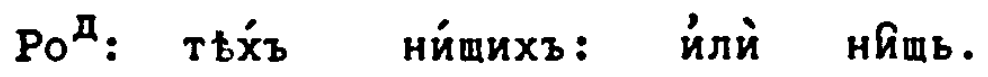

Да ${ }^{\mathrm{T}}$ : ти́мъ ни́щимъ.

Виค : тйа ни́щыл: йлй ты் ни́ща.

Зва $: \stackrel{T}{\omega}$ нйщіи: йлй нйщи.

твор: твйи нйщими.

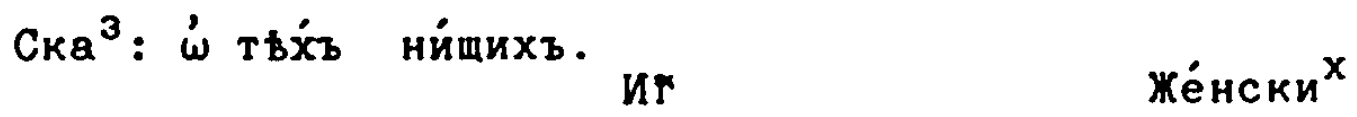

Же́нскихз на, ал: и́ чре ${ }^{3}$ ојсвче́ніе на, a.

Числа̀ е́динстве́ннагw:

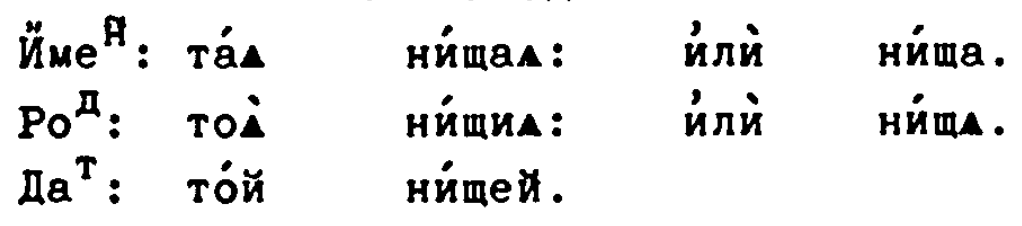


$\mathrm{Bu}^{\text {ค }}:$ тую́

$3 \mathrm{Ra}^{\mathrm{T}}: \stackrel{\mathbf{w}}{\omega}$

Tro ${ }^{\mathrm{p}}$ : Toí

$\mathrm{Cka}^{3}$ : 'w то нйшую: йли

нйmам: иंли

нйuею.

ни́щей.

Лво́йственнагw числа̇:

$\ddot{и ̆ m e}^{\text {म }}:$ Ви $^{\text {म }}:$ й $3 \mathrm{na}^{\mathrm{T}}:$ та̀

нйща.

Pon: и $\mathrm{CKa}^{3}$ :

$T+\hat{B}$

нйmy.

да' ${ }^{\top}$ i $\mathrm{Tr}:$

ты́ma й тьй ни́щима.

Множестве́ннагш числа்.

h́me ${ }^{\text {म }}$ Tín

нйщі̄ : иंлй тй нйща.

Pon: $T^{x}$

нйщихз: и́ли่ нящь.

да ${ }^{\top}:$ тйm

нйщимъ.

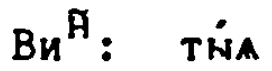

нйmbа :

йлй тй ни́mа.

$3 \mathrm{Ba}^{\top}: \stackrel{\mathrm{T}}{\omega}$

нйщіี : йлй

ни́ща.

TBOp:

Тво : тћйи нйщими.

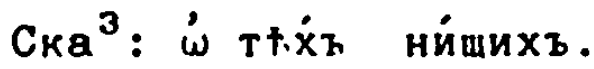

Сре́лнее на, ее: й чре ${ }^{3}$ оу́свче́нїе на, e.

Числа̀ е́динстве́ннагw:

Йme ${ }^{\text {ศ }}$ тóe

нйmee :

йлй то́ ни́ще.

Poम: Torí

нйmarw:

йлй

ни́ma.

मа ${ }^{\top}:$ томуy

ни́mему :

йли

нйषу .

$\mathrm{Bu}^{\text {ศ }}$ : Tóe

нйщее:

йли

нйme.

Зва $\mathbf{a}^{\mathbf{T}}: \stackrel{\mathbf{w}}{\omega}$

нйщее :

йли

нйme.

TBO ${ }^{p}: \tau+\dot{M b}$

нйщимъ.

$\mathrm{CKa}^{3}: \dot{\omega}^{\mathrm{m}} \mathrm{To}^{\mathrm{M}}$

нйщемъ.

Дво́йственнагш числа:

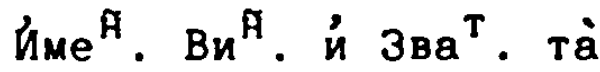

нйma.

$\mathrm{Po}^{\text {म. }}$. $\mathrm{CKa}^{3}$.

Tón

нйmу .

да ${ }^{\top}:$ и Тв:

ти́ma й тъи́a ни́чима.

Множестве́ннагш числа̀.

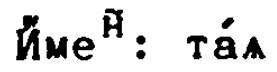

нйщаa :

йлй та் ни́ща.

Poम: TÉxz

нйщи ${ }^{\mathrm{X}}$ :

йлй

нคीณ $\mathrm{b}$.

Да $\mathbf{a}^{\mathrm{T}}:$ тймъ

нй๊щим .

$\mathrm{Bu}{ }^{\text {ค }}: \quad \mathbf{a}$ A

нйщах:

หมี'

Зва $\mathbf{B}^{\mathrm{T}}: \stackrel{\mathbf{w}}{\omega}$

нйщaа :

йлй

$\mathrm{Bu}{ }^{\mathrm{A}}$ :

тво : тьм́

нйщими .

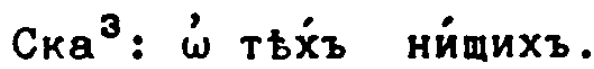

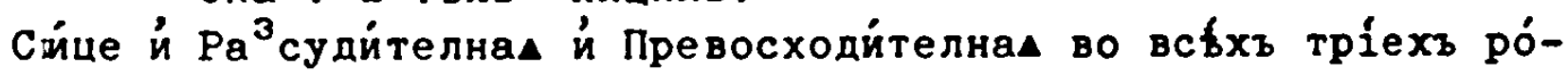


дехъ: й прича́стіА на, шій: й щій.

Оу́вєще́ніе: $\mathbf{a}$.

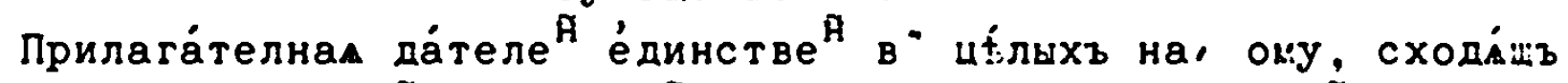

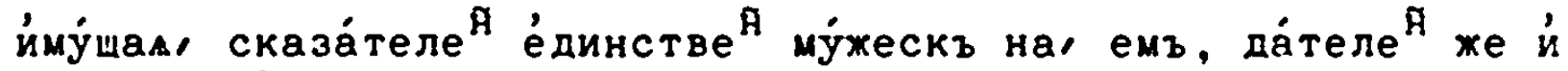
сказа́теле

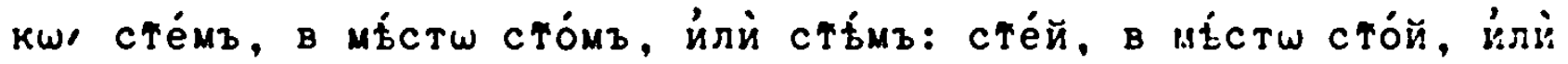

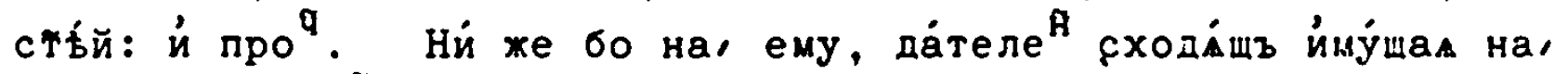

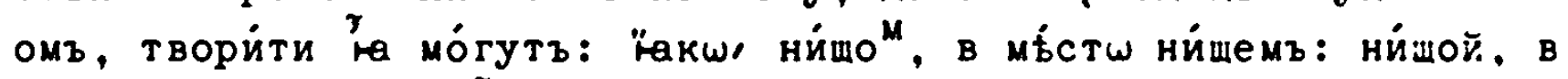
мб́стш нйщей: иं про .

Ра́внь, роди́теленъ й да́теленъ множестве́нъ: твори́теле

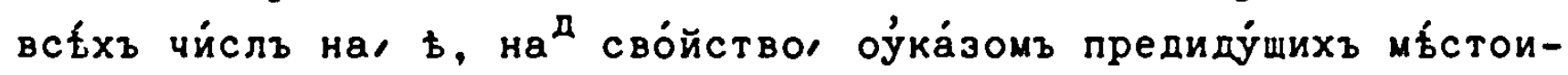
ме́нїй, оу́потребли́еми '́брьта́ют

CA:

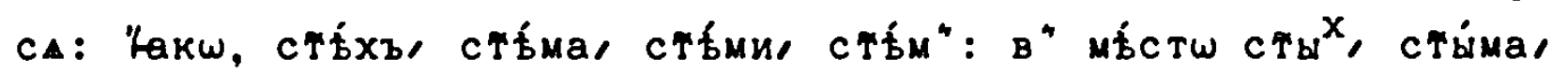
стимми, стймз: Йнђхъ, йнђма, йньми, йнђмъ: оујка́зомъ мђстоименіа, б̆нъ, сво́йственнь глемъ.

$\dot{\omega}$ прилага́телны блгогла́сіа дб́ла гла́сное

$B^{*}$ оу́сьче́мыхъ прие́млюшихъ.

оуввше́ніе: в.

Прилага́телнал на, Кій, й на, ный, е́дйным" йлй дво́ма согла́сныма оупрежденна, конча́mалса, блгогла́сіА ды́ла ӧва оўбш, е:

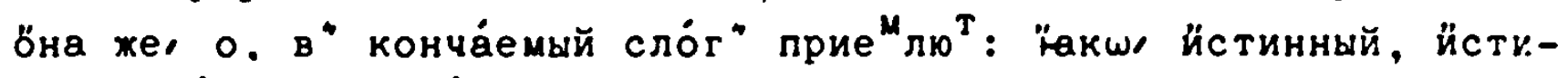
ненъ: оу́добннй, оуддобенъ: кра́сный, кра́сенъ: че́стный, че́стенъ: й про . Де́рзкій. де́рзокъ: сла́дкій, сла́докъ: краткій, кра́токъ: й про ${ }^{q}$. Нб́каА же и́ $\omega^{T}$ конча́щихъса на, кій: е. прие́млютъ, йз-

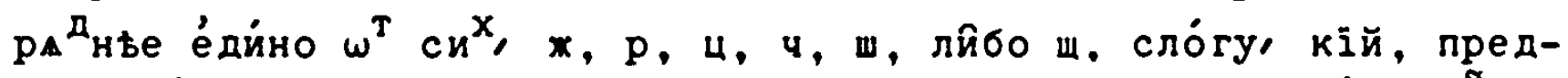

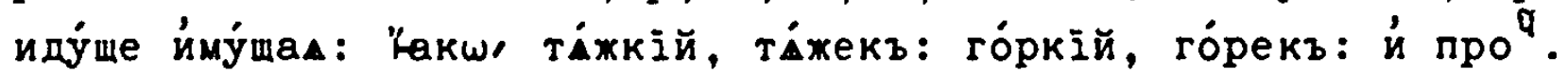

Вто́рагш Прилага́телныхъ чйна паради́тмата. ПА

ПАРАДИГМА ठ̆тчеиме́нных йлй ПритАжа́телныхъ на, ій:

$[766]$

й чре ${ }^{3}$ оу́съче́ніе на, ъ, мујжескихъ.

Числа̀ е́динстве́ннагш:

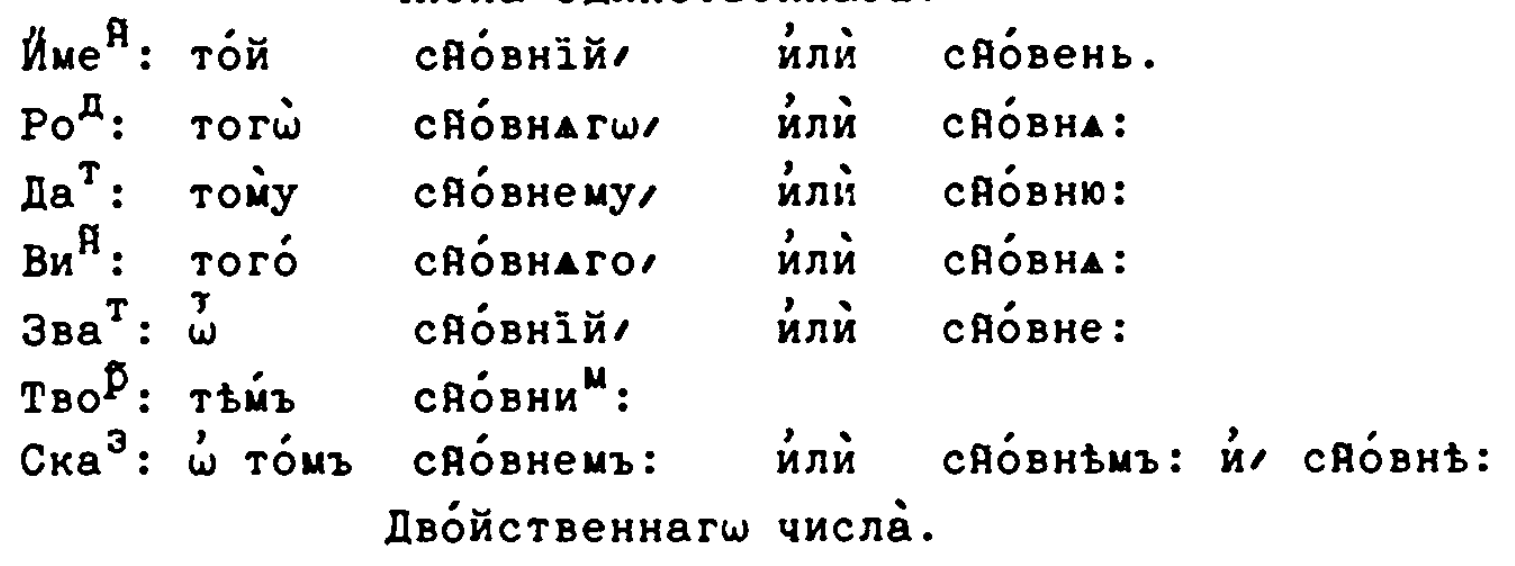




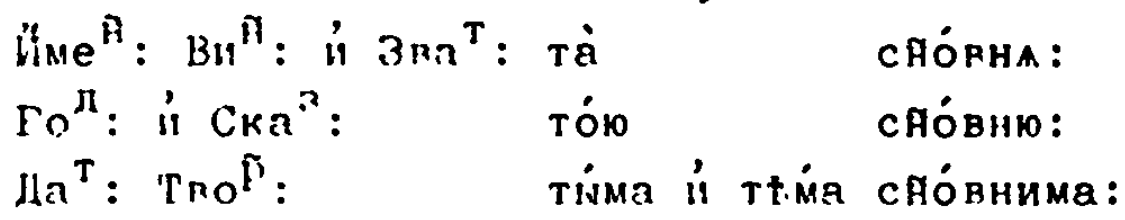

MHохестре́ннагш числа̀:

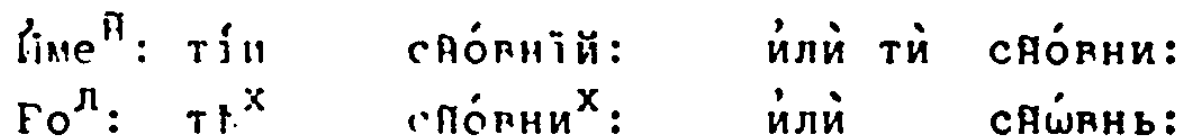

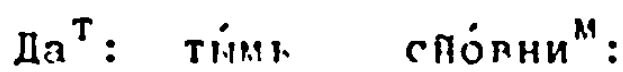

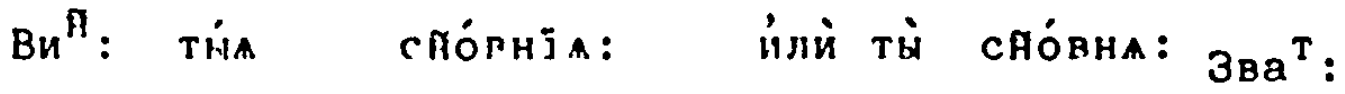

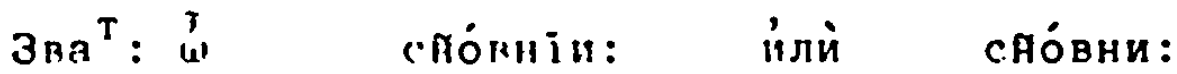

Tróf: түйи сповними:

Ска ${ }^{3}: \dot{\omega} T+\dot{x}$ т сповни ${ }^{x}$ :

Жйнскихт иа, ам: il чре ${ }^{3}$ оусстиеніе на, $а$.

Џисла̀ е́ иинстве́ннаги:

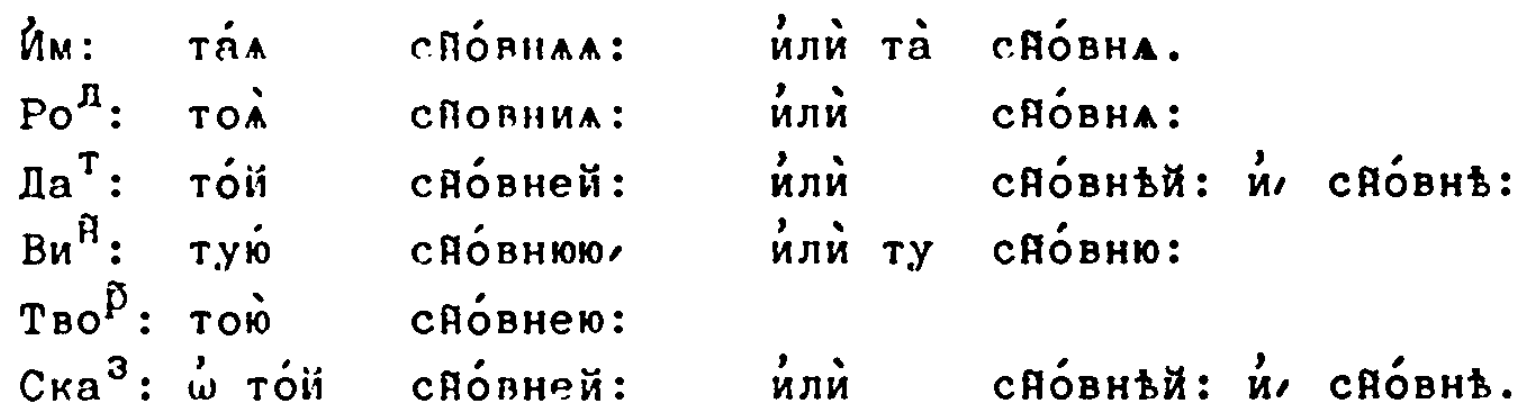

Дво́йственнагш числа̀:

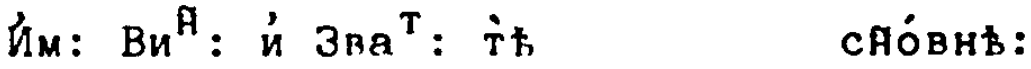

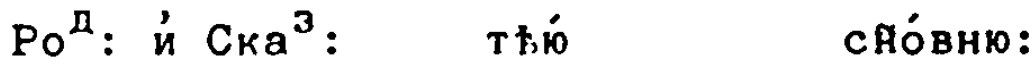

да ${ }^{\top}$ : й Тв: ти́ма и́ тьм́а сяовнима.

Множестве́ннатш числа̀.

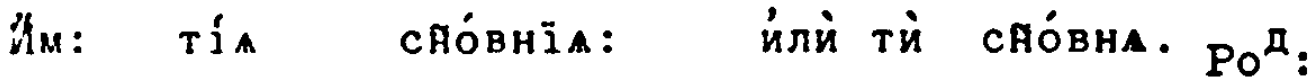

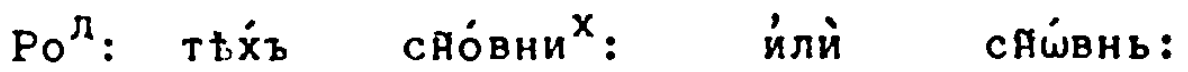

Да ${ }^{\mathrm{T}}$ : тйMb СคО́внимъ:

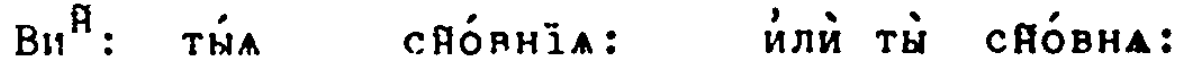

Зва $: \stackrel{3}{\omega}$ сЯоввніА: йлй сЯо́вна:

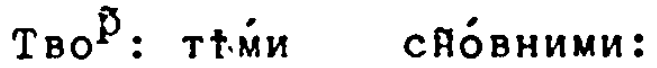

$\mathrm{CKa}^{3}$ : is ть́丿

Сре́лнихъ на, ее: й чре ${ }^{3}$ оусьче́ніе на, $е$. числа̀ е́динстве́ннагш.

Йме ${ }^{\text {f }}$ то́ соровнее йлй то сно́вне:

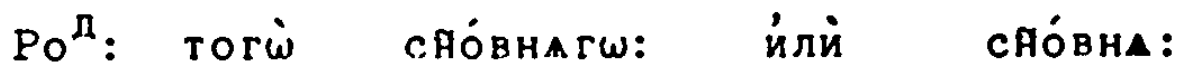

да ${ }^{\mathrm{T}}$ : тому сио́внему: йлй сяо́вню:

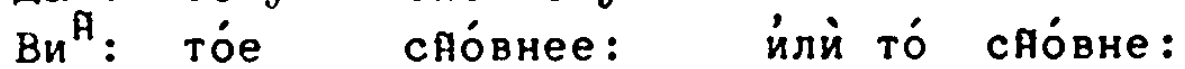

Зва ${ }^{\top}: \stackrel{\tau}{\omega}$ сศо́внее: йли сяо́вн:

Тво ${ }^{\tilde{p}}$ : тћй сศо́внимъ: 


$$
-80-
$$

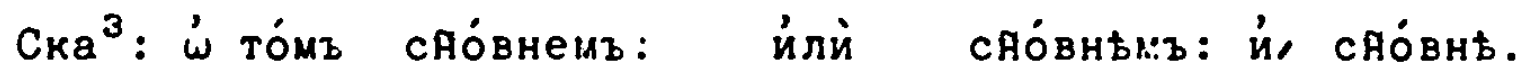
Дво́йственияагш числа̇.

Йме ${ }^{\text {A }}: \mathrm{Bu}^{\mathrm{A}}:$ й $3 \mathrm{Ba}^{\mathrm{T}}:$ та

$\mathrm{Po}^{\text {म }}:$ i $\mathrm{CKa}^{3}$ :

Tón

тймa й тьм́a

$\not a^{\mathrm{T}}:$ is $\mathrm{TB}_{\mathrm{B}}$ :

Множестве́ннагш числа̀.

CคÓBHA:

СЯо́вню:

сЯо́внима.

Mroжe

ÜM: Táa сคÓBHAA:

йлѝ та̀ сЯо́вна:

Pon: $T \ddagger \dot{x} z$

Сคо́вни ${ }^{X}$ :

и่лй

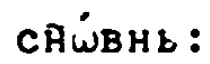

मаa ${ }^{T}:$ тв́mz

СคО́внИМz.

$B u^{\text {म }}$ : Tás

CคÓBHAA:

उва ${ }^{\mathrm{T}}: \stackrel{T}{\omega}$

CFÓBHAA:

йлй та̀ сศо́внA:

Tво $:$ Tьм́и

САО́вними:

Ска ${ }^{3}$ : '́㇒ тђх́з сศо́внихз.

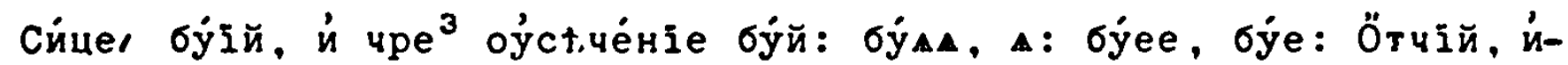
лй о́течь: б̆тчаА, йлй ӧтчА: б̆тчеe. йлй ӧтче: сре

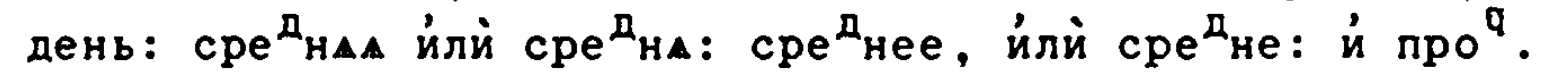

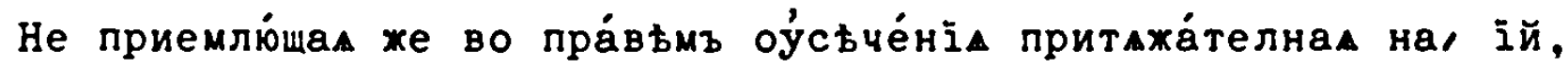
конча́mалса, сице скланіют"са: Му́жеское:

Числа̀ е́динстве́ннагш:

Йме : то́й Бо́хій:

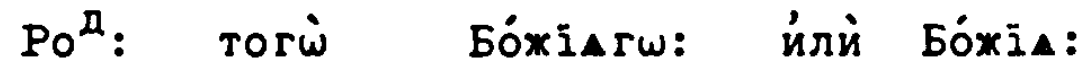

Дат : той Бо́xiемy: йлй Бӧхію:

Вия : того́ Бо́xíro: йлй Бо́xí:

Зва $\mathrm{T}^{\mathrm{T}}: \stackrel{\mathbf{T}}{\boldsymbol{\omega}}$ Бо்жій:

$T_{B O} \tilde{p}: T \leftarrow \dot{M}$

Бовхіимъ:

TBO

[786]

Ска ${ }^{3}$ : $\dot{\omega}$ то ${ }^{M}$ Бо́жіемъ: и́ли Бо́хіи.

Двӧйственнагш числа̀:

Йме ${ }^{\mathrm{A}}: \mathrm{Bu}^{\mathrm{A}}:$ й $3 \mathrm{вa}{ }^{\mathrm{T}}$ : та̀

Бóxïa:

Pоम : и $\mathrm{CKa}^{3}$ :

Tór

bóxin:

$\not a^{\mathrm{T}}: \mathrm{TBO}$ : ть́ма й тьм́a Бо́хіима.

Множествённагш числа̀.

Йер : тіи Бо́хіи:

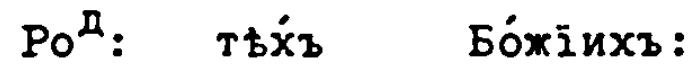

Да ${ }^{\mathrm{T}}$ : ты ${ }^{\mathrm{M}}$ Бо́жіимъ:

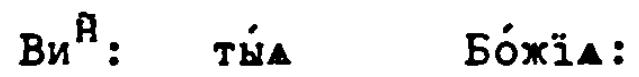

Зва ${ }^{\mathrm{T}}: \stackrel{\jmath}{\omega}$ Бо́жїи:

Твор : тьй Бохжйими:

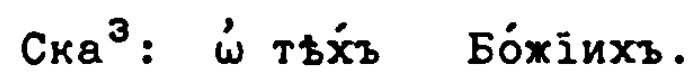


Жён́ское на, іА:

Числа̀ е́динстве́ннатш.

Йme : тáa Бóxĩa:

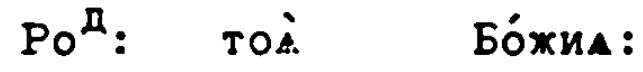

Да ${ }^{\mathrm{T}}:$ то́й Бо́xіей:

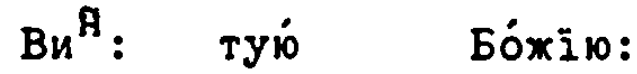

Зва ${ }^{\top}: \stackrel{\top}{\omega}$ bóxia:

Зва ${ }^{\mathrm{T}}$ :

Tво : тою́ Бо́xïen:

Ска ${ }^{3}$ : ‘े то́й Бо́хіей: иंлй Бо́хіи. Дво́йственнагш числа̀.

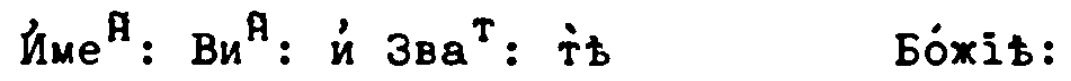

Po ${ }^{\text {I }}$ и $\mathrm{CKa}^{3}$ : Ttí bóxilo:

Да ${ }^{\mathrm{T}}$ : й Тв: тйма и́ тьма Бо́хіима.

Мнохестве́ннагш числа̀.

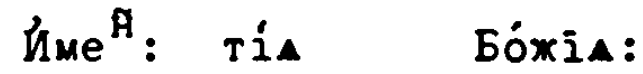

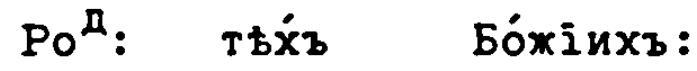

Да ${ }^{\mathrm{T}}$ : тймz Бо́xіимz.

$\mathrm{Bu}^{\text {म }}$ : Túa bóxî:

Зва ${ }^{\mathrm{T}}: \stackrel{T}{\omega}$ Бӧxī:

Твор : тьми Бо́хіими:

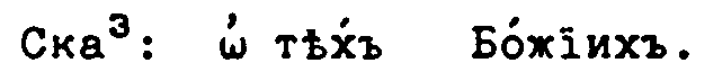

$$
\text { Cре́днее на, ìe. }
$$

числа̀ е́динстве́ннагw:

Ймe ${ }^{\text {म }}$ тóe bóxie:

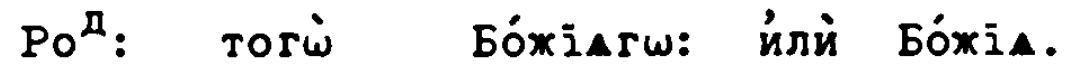

Да ${ }^{\mathrm{T}}$ : тому Бо́xiемy: илй Бо́xīю. $\mathrm{Bu}^{\mathrm{A}}$ :

Ви : тóe Бóxie:

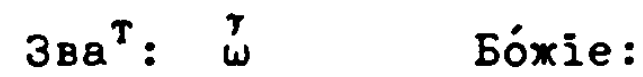

Тво : тьм́в Бо́xіимъ.

Ска ${ }^{3}:$ '́ том Бо́хіем": йли Бо́хіи. Дво́йственнагш числа்.

Йм. Вин. й Зва ${ }^{\mathrm{T}}$. та̀ Бо́xia.

$\mathrm{Po}^{\text {I }}$. и $\mathrm{CKa}^{3}$. Tór Бóxír.

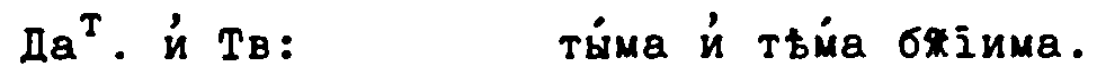

Мнохестве́ннагш числа̇:

Йme ${ }^{\text {: }}$ тá Бо́xí.

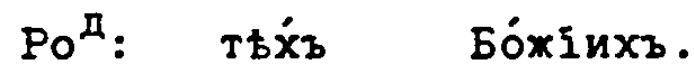

Да ${ }^{\mathrm{T}}$ : ти́мъ Бо́хіимъ. 


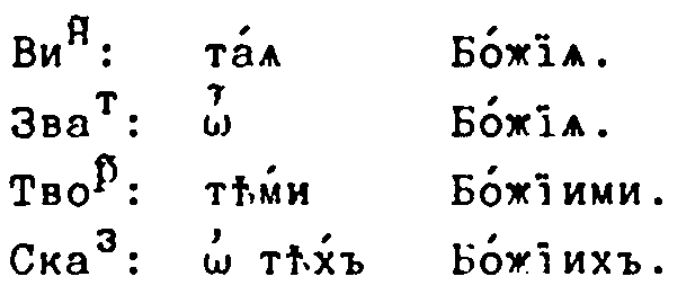

Си́uе, ве́лій, тре́тій, ци́вій, про́чій: и́ про́чаa.

ПАРАДИГМАТА ПритАжа́тплннхт на, инъ: ина: ино. мүंе [80] Му́жеское нал инъ: й чре ${ }^{3}$ оусстие́ніе нал вль.

иисла̀ е́линстве́ннатш.

Йме ${ }^{\text {: }}$ то́й Варна́ви

Po: тогі் Варна́вина: йлй Варна́вла:

Да $^{\mathrm{T}}$ : тому Варна́вину: йлй Ва ${ }^{\tilde{p}_{\text {на́влю: }}}$

Вия : того́ Варна́вина: и́лй Варна́влА.

Зв: $\stackrel{\jmath}{\omega}$ Варна́вине: йлй Варна́вле:

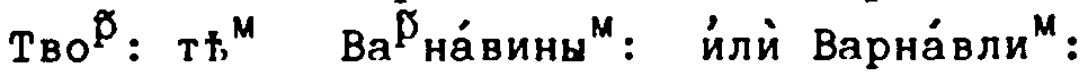

Ска ${ }^{3}: \dot{\omega}$ то Марна́виномъ: нєм": й нћ:

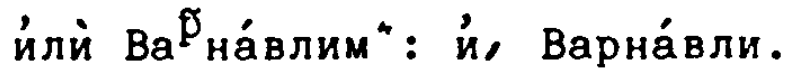

Дво́йственнагш числа̀:

Йме ${ }^{\mathrm{A}}: \mathrm{Bи}^{\mathrm{A}}:$ й Зва $^{\mathrm{T}}$ : та̀ Варна́вина: и́лй Варна́влА.

Poम : й Ска ${ }^{3}$ : то́ Варна́вину: и́лй Варна́влю.

Да ${ }^{\mathrm{T}}$ : й Твор : тыма й тьм́а Варна́виныма: и́лй Варна́влима.

Множестве́ннагш числа̀.

Йме : ті́ Варна́вини: йлй тй Варна́вли.

Роम: ть́丿் Варна́вины : йлй Варна́

I илй вли ${ }^{\mathrm{x}}$ :

Да ${ }^{\mathrm{T}}: \mathrm{Tu}^{\mathrm{M}}$ Варна́вины ${ }^{\mathrm{M}}:$ йлй Варна́вли ${ }^{\mathrm{M}}$.

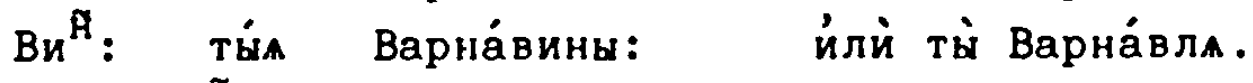

Зв: $\stackrel{\gamma}{\omega}$ Варна́вини, йли Варна́вли.

Тво : тьм́и Варна́виными, йлй Варна́влими.

Ска ${ }^{3}:$ '́ ть́х́ Варна́виныхъ: йлй Варна́влихъ.

Же́нское на, ина: и́ чре ${ }^{3}$ ојсћие́ніе на, влА:

Числа̀ е́динстве́ннагш:

Йе ${ }^{\AA}$ : та́a Варна́вина: и́лй та̀ Варна́вла.

Род: - той Варна́вины: йлй Варна́вла:

Да ${ }^{\mathrm{T}}$ : то́й Варна́виной: нбй: й, нъ: и́лй Варна́вльй: и́,

Ви ${ }^{\AA}$ : тую́ Варна́вину: йлй ту Варна́влю:

Зва ${ }^{\mathrm{T}}: \underset{\omega}{\omega}$ Варна́вина: йли Ва ${ }^{\mathbb{P}}$ на́вла:

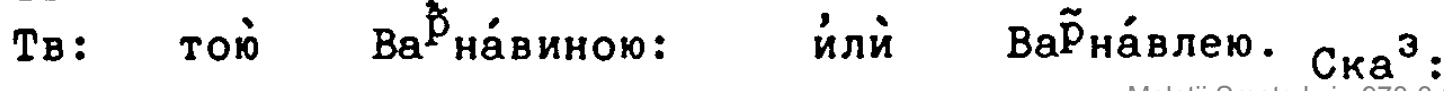


Ска ${ }^{3}: \dot{\omega}$ то́̆ Варна́виной: нむй: й нむ: и́лй Варна́вльй: й,

Дво́йственнагш числа̀.

Варна́вли.

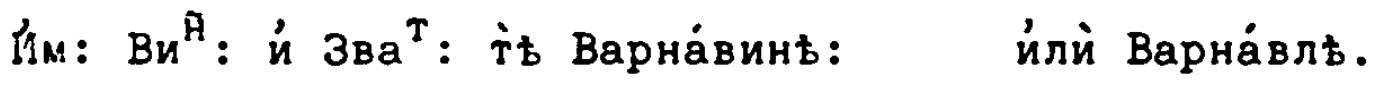

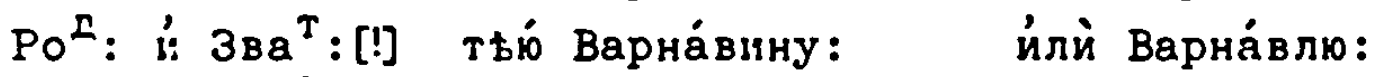

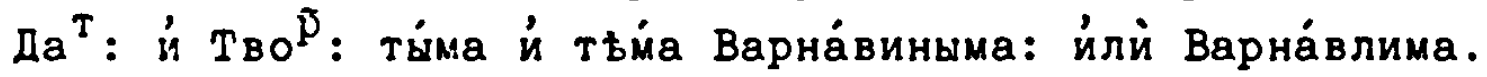

Мнохестве́ннагш числа̀:

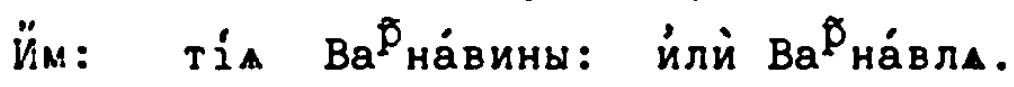

Pод: тџх́ъ Варна́виныхъ: йлй Варна́влихъ: й Варнаิвль.

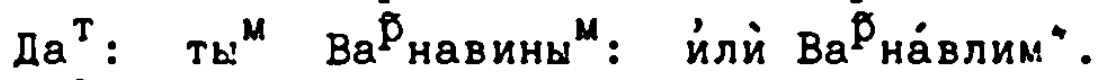

Вин ${ }^{\mathrm{A}}$ : тйл Варна́вины: и́лй ты Варна́вла.

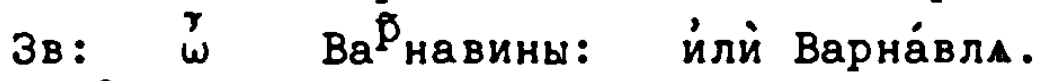

Твор : тьми Варна́виными: и́лй Варна́влими.

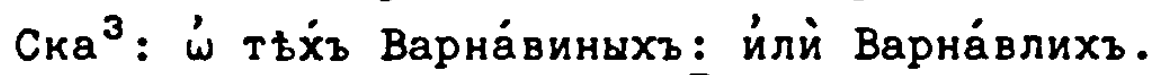

Is $\quad$ Cpe $^{д_{\text {Hee }}}$

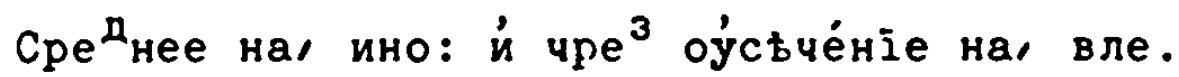

Числа̀ е́динстве́ннагш:

Йме : то́е Варна́вино, йлй то Варна́вле.

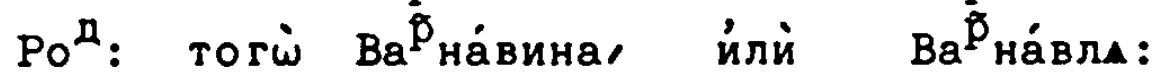

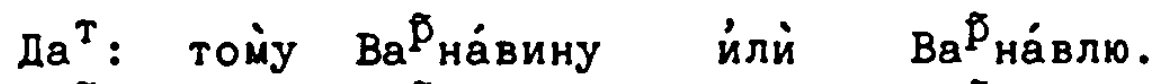

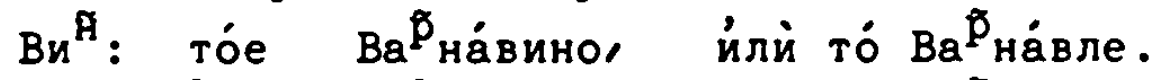

Зва ${ }^{\mathrm{T}}: \stackrel{r}{\omega} \mathrm{Ba}^{\mathrm{p}}$ на́вино, йлй $\mathrm{Ba}^{\mathrm{p}}$ на́вле.

Твор̃ тђм́з Варна́винымъ, и́лй Варна́влимъ.

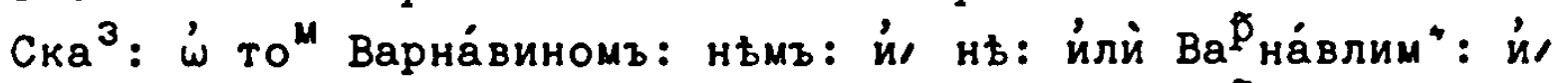

Дво́йственнагш числа̀:

Ва ${ }^{\tilde{p}}$ нвли.

Йме ${ }^{\text {मे }}$ Ви ${ }^{\tilde{H}}:$ й $3 в a^{\mathrm{T}}$ : та̀ Варна́вина, и́лй Варна́влА.

$\mathrm{Po}^{\text {म }}$ : й $\mathrm{CKa}^{3}$ : то́ю Варна́вину, и́лй Варна́влю.

$\not a^{\mathrm{T}}$ : й Тво : ты́ма и́ тђм́a Варна́виныма, йлй Варна́влима.

Мнохестве́ннагш числа̀:

Mноке 
Са́ррино, йли Cáppe: й про.

ПАРАДИГКАТА ПритАха́телнЫХъ

на, Овъ: Ова: ОВС: й на, евъ: ева: евО. цујжеское на, овъ: и́ чре ${ }^{3}$ оу́сьче́ніе на, вль:

If Числа̀

Числа̇ е́динстве́ннагш.

[826]

йме ${ }^{\AA}$ : то́й Па́вловъ: йлй Па́вль.

Pод: тогі் Па́влова: йлй Па́вла.

Да ${ }^{\mathrm{T}}$ : тойу Па́влову: йлй Па́влю.

Ви ${ }^{\mathrm{A}}$ : того Па́влова: йлй Па́вла.

Зва ${ }^{\mathrm{T}}: \stackrel{+}{\omega}$ Па́вловъ: йлй Па́вле.

Твор : тちи́ъ Па́вловы": и́лй Па́вли".

Ска ${ }^{3}$ : '́ं то́мъ Па́вловомъ: и́лй Па́вльмъ: и́ Па́вли.

Дво́йственнагш числа்,

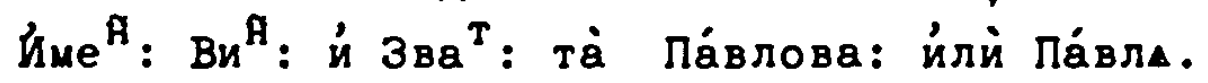

Poम: й $\mathrm{CKa}^{3}$ : то́ю Па́влову: йлй Па́влю.

Да ${ }^{\mathrm{T}}$ : й Твор: ти́ма й тђйа Па́вловыма: и́лй Па́влима.

Множестве́ннатш числа̀.

Йме ${ }^{\text {: }}$ ті́ Па́вловы: йлй тй Па́вли.

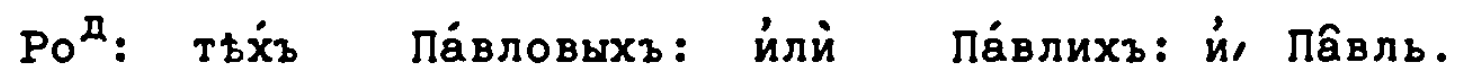

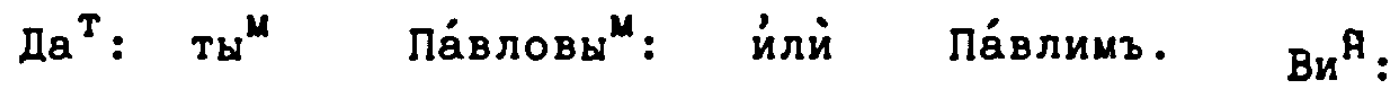

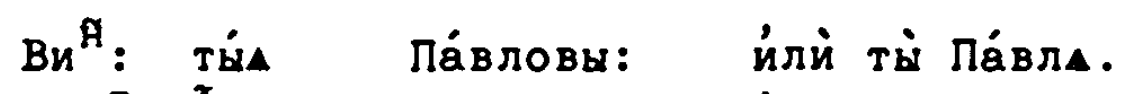

Зва ${ }^{\mathrm{T}}: \stackrel{\mathfrak{\omega}}{\mathrm{T}}$ Па́вловы: йлй Па́вли.

$T$ : тьйи Па́вловыми: и́лй Па́влими.

Ска ${ }^{3}: \dot{\omega} т \ddagger \dot{x ъ}$ Па́вловыхъ: и́лй Па́влихъ.

Жёнское на, ова: й чре ${ }^{3}$ оусьчче́ніе на, влА.

Числа́ е́динстве́ннагш.

Йме ${ }^{\text {: }}$ та́ Па́влова: йлй та̀ Па́вла.

Род: тод Па́вловы: йлй Па́влА.

Да ${ }^{T}$ : то́й Па́вловой: вьй: й, вь: и́лй Па́вльй: и́, Па́вли.

Ви ${ }^{\text {म }}$ тую́ Па́влову: йлй ту Па́влю.

Зва ${ }^{\mathrm{T}}: \stackrel{\xi}{\omega}$ Па́влова: йлй Па́влА.

Твор : тоюे Па́вловою: йлй Па́влею:

$\mathrm{Cка}^{3}$ : '́̀ то́й Па́вловой: вьй: и́, вђ: йлй Па́вльй: й Па́вли.

Дво́йственнагш числа̀.

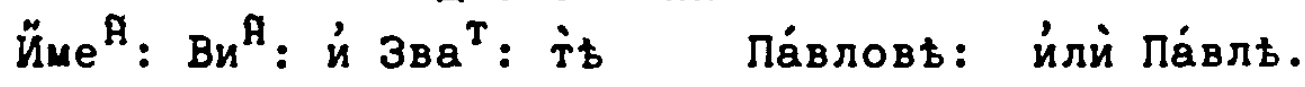

Poम : й $\mathrm{CKa}^{3}$ : тђі́ Па́влову: йлй Па́влю.

Iд Па́влову: илй Па́влю. Да $^{\mathrm{T}}$ :

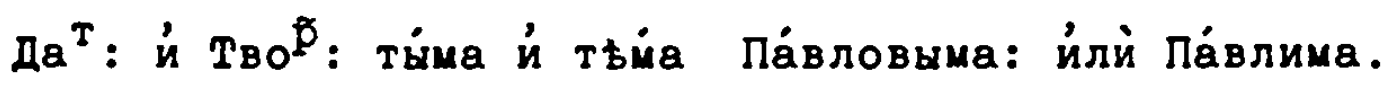


Mножестве́ннагш числа̀:

lik: ті́ Па́вловы: йлй тй Па́вла.

Род: тъ ${ }^{x}$ Па́вловьі ${ }^{x}$ йлй Па́влихъ. и́ Па́вль.

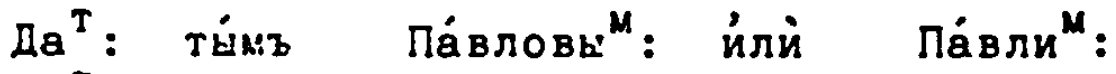

$\mathrm{Bu}^{\AA}:$ ты́ Па́вловы, йлй ты் Па́влА.

Зва ${ }^{\top}: \stackrel{3}{\omega}$ Па́вловы, йлй Па́вла.

Твор̃ тђи́и Па́вловыми: и́лй Па́влими.

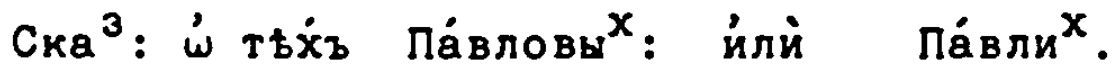

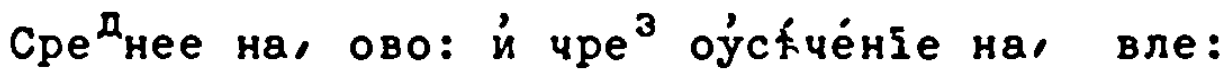

числа̀ е́динстве́ннатш:

Йме ${ }^{\text {: }}$ то́е Па́влово: йлй то́ Па́вл́е.

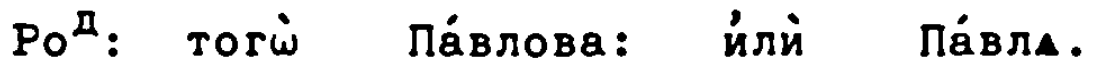

да ${ }^{\mathrm{T}}:$ той Па́влову: йлй Па́влю.

Ви${ }^{\text {म }}$ то́e Па́влово: и́лй то́ Пáвл́е.

Зва ${ }^{\mathrm{T}}: \dot{\omega}$ Па́влово: йлй Па́вл́.

Твор : тъ ${ }^{M}$ Па́вловы ${ }^{M}$ йлй Па́влимз. Ска ${ }^{3}$ :

[84]

Ска ${ }^{3}:$ '́ том Па́вловомз: вђм": и́, вь. и́лй Па́вльмъ: й Па́вли. Дво́йственнагш числа̀.

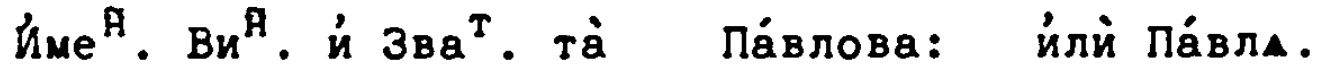

Род. и $\mathrm{CKa}^{3}$. то́ю Па́влову: и́лй Па́влю.

Дат . й Твор. ти́ма й тъм́а Па́вловыма: йлй Па́влима.

Множестве́ннагш числа̀.

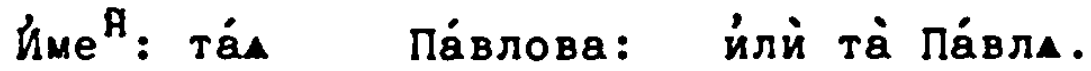

Poम: ть ${ }^{x}$ Па́вловы ${ }^{x}$ йлй Па́влихъ.

$\not a^{T}: \mathbf{w}^{M}$ Па́вловы ${ }^{M}$ йлй Па́влимъ.

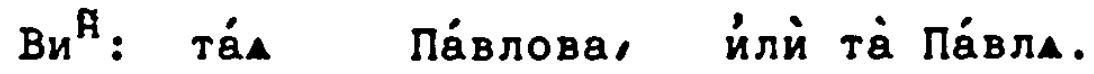

Зва ${ }^{\top} . \stackrel{5}{\omega}$ Па́влова, йлй Па́вла.

твор: тьми Па́вловыми, йлй Па́влими.

$\mathrm{Cка}^{3}$. '́ ть Па́вловы ${ }^{\mathrm{x}}$ йлй Па́вли ${ }^{\mathrm{x}}$.

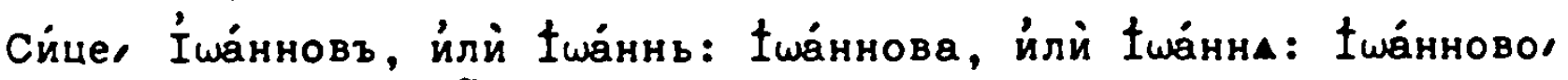
йлй Ғша́нне: и́ про ${ }^{q}$. Андре́евъ, Андре́ева, Андре́ево: Єере́евъ, ва, во: й про́чая оу́съче́ніА не прие́млющан.

Tpétí [846]

Tре́тіАгш чйна Прилага́телныхъ ПАРАДИГМАТА.

ठте́чествныхъ й 'азйческихъ Прилага́телныхъ Мујхеское Ф́конче́ніе, скій: Же́нское, ска́а: Сре йе, ское: Й чре ${ }^{3}$ ојсъче́ніе, скъ: ска: ско:

ПаРАДЙГМА муंхеское на, скรй: числа் е́динстве́ннагш. 


$$
-86-
$$

Йме ${ }^{\mathscr{A}}$ : то́й Ршссійскій, иंлй Ршссійскъ.

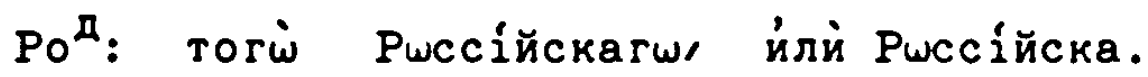

$\mathrm{Ia}^{\mathrm{T}}$ : тому Ршссійскому, йлй Ршссі́йску.

Вй: того́ Ршссі́йскагол йлй Ршссійска.

Зва ${ }^{\mathrm{T}}: \stackrel{\gamma}{\omega}$ Ршссійскій, йлй Ршссійсте.

Твор: тьй Ршссійскимъ.

Ска ${ }^{3}$ : '́ то́мъ Ршссійскомъ, йлй Ршссі́йстьмъ: й Ршссійсть.

Дво́йственнагш числа̀.
Йме ${ }^{\text {A }}:$ Ви $^{\text {A }}:$ й $3 в a^{\mathrm{T}}:$ та
Ршссійска.
Poम :
да ${ }^{\mathrm{T}}: \mathrm{T}_{\mathrm{B}}^{\mathrm{p}}$ :
$\begin{array}{ll}\text { тón } & \text { Ршссі́йску. } \\ \text { тйma й тђйa Ршссійскима. }\end{array}$

Мнохестве́ннагш числа̀:

Йе ${ }^{\text {: }}$ тіи Ршссійскіи: йлй Ршссійстіи: й тй Ршссійсти.

Род: тьх́ъ Ршссійскихъ: йлй Ршссійскъ.

Дат : ти́мъ Ршссійскимъ.

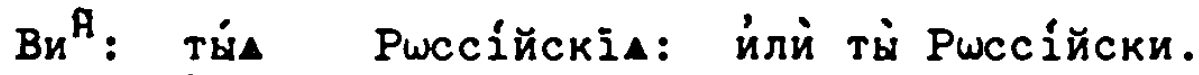

Зва ${ }^{T}: \stackrel{T}{\omega}$ Ршссійскіи: йлй Ршссійстіи: й Ршссійсти.

Твор: тьйи Ршссійскими.

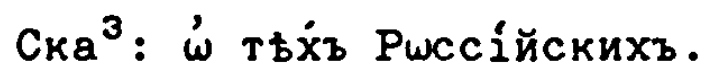

Же́нское на, скап: и́ чре ${ }^{3}$ оу́сђче́ніе на, ска.

Числа̇ е́динстве́ннагш:

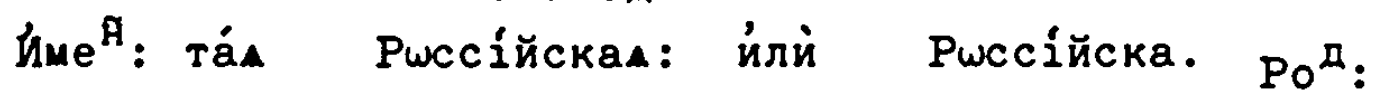

Род: тоі РшссійскіА: йлй Ршссі́йски.

Да ${ }^{\mathrm{T}}$ : то́й Россі́йской: йлй Ршссійстьй: й Ршссійстђ.

$\mathrm{Bu}^{\text {म }}$ : тую Ршссійскую: йлй ту Ршссійску.

Зв: $\stackrel{r}{\omega}$ Ршссійскал: йли Ршссійска.

Tво : тою Ршссі́йскою.

Ска ${ }^{3}$ : '́㇒ то́й Ршссі́йской: йлй Ршссі́йстьй: и́, Ршссі́йсть.

Дво́йственнатш числа̀:

Йм: $\mathrm{Bu}^{\text {म }}:$ и $3 \mathrm{Ba}^{\mathrm{T}}:$ ì

Pоम: ${ }^{\text {म }} \mathrm{CKa}^{3}$ :

TÐ10

Рwсcíйсть.

मа ${ }^{\mathrm{T}}:$ i $\mathrm{T}$ :

ти́ма й тьйa Ршссійскима.

Множестве́ннатш числа̀.

Úm: Tí РucсійскіА.

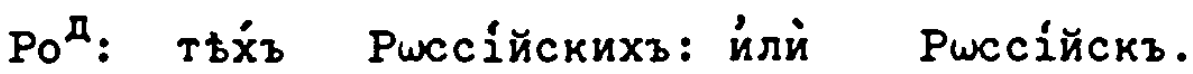

Да ${ }^{\mathrm{T}}:$ ти́мз Ршссі́йскимъ.

Вия : ти́ РшссійскіА: йлй ты் Ршссійски. Зва ${ }^{\mathrm{T}}$ :

Зва ${ }^{\mathrm{T}}: \stackrel{\boldsymbol{T}}{\omega}$ РшссійскіА. 
Твор: тьй Ршссійскции.

Ска ${ }^{3}: \dot{\omega}$ тьх́з Ршссійскихъ.

Сре́днее на, ское: и́ чре 3 оусьче́ніе нал ско.

числа̀ е́динстве́ннагш:

Úme : то́ Ршссі́йское: йлй то Ршссі́і̆ско.

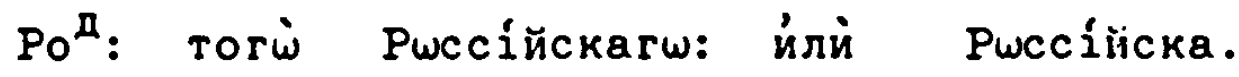

да ${ }^{T}$ : тому Ршссі́йскому: йлй Ршссійску.

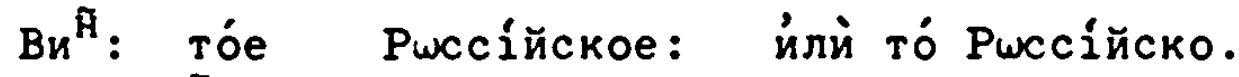

Зва ${ }^{\top}:{ }_{\omega}^{3}$ Ршссі́йское: йлй Ршссі́йско.

Твор: тьй Ршссійскимъ.

Ска ${ }^{3}: \dot{\omega}$ томз Ршсійскомъ: и́ли Ршссійстьмъ: й ршссійсть.

Дво́йственнагш числа̀:

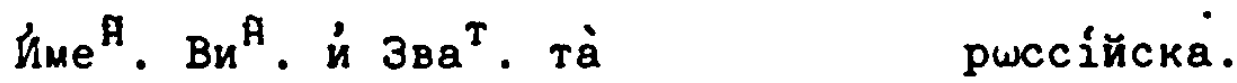

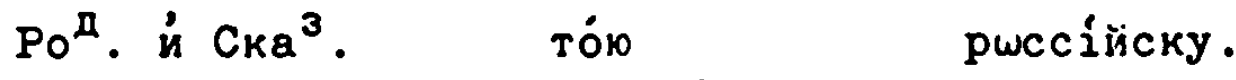

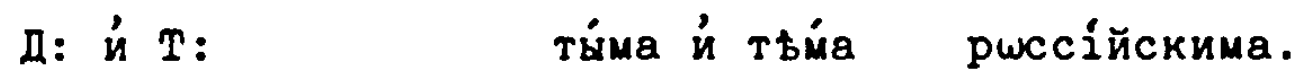

Мнохестве́ннатш числа̀.

йме : та́⿴ Ршссійскам: йлй та̀ ршссійска.

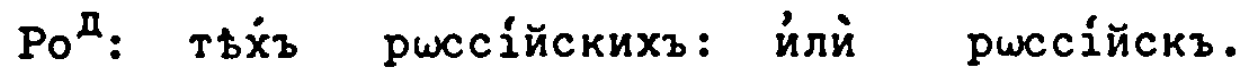

Дат ${ }^{\top}$ тв́мз ршссі́йскимъ.

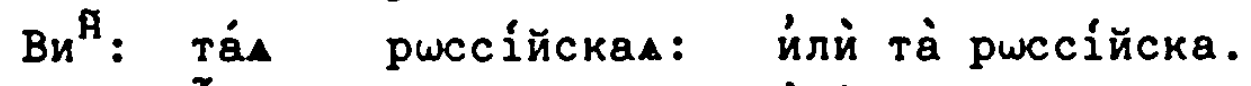

Зв: $\stackrel{r}{\omega}$ ршссійскал: йлй ршссійска.

Твор: тьйи ршссійскими.

Ска ${ }^{3}: \dot{\omega}$ ть⿱㇒㠯\zh20ъ ршссійскихъ.

O’́въще́нíe.

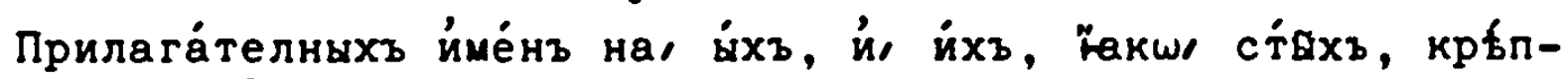
кихъ: й про : конча́ш"сА вини́теленъ мнохестве́нъ $\omega^{T}$ про́стагш в"

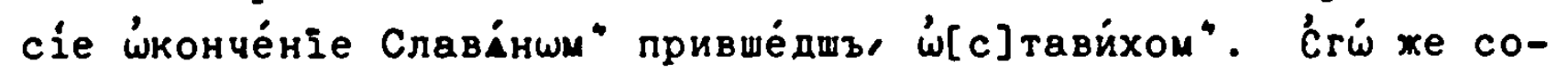

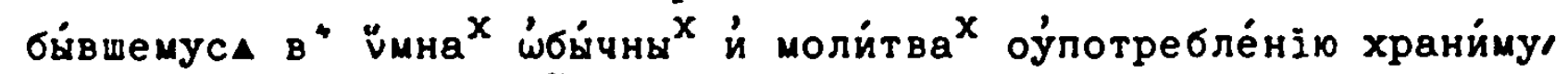

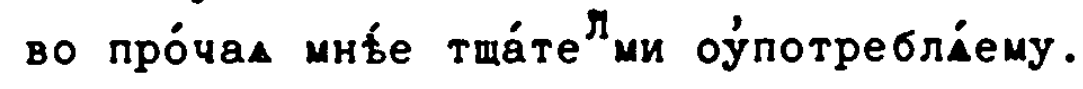

MAPA

Паради́гмата Прилага́телны е́динагш 'конче́ніА '́бра́mеши нал a, в Пе́рвомъ склонёніи: на, в, Во второмъ: Сегі́ склонёніА е́сть йспо́лнь, несклана́телное; во всбхз ро́дехъ, й всб́хъ чйслъ паде́жехъ си́це прие́млемое.

ПАРАДИГИА Нарица́телныхъ хёнंскихъ

прилага́телнымъ же́нंскимъ подо́бныхъ:

Числа̀ е́динстве́ннагш:

h́me : rás

Вселе́ннал.

Pon: Toi

вселе́нньа. 
Да ${ }^{\top}:$ то́й вселе́нной: и́лй вселе́ннъй.

$\mathrm{Bu}^{\mathrm{A}}:$ туі́ вселе́нную.

Зва ${ }^{\mathrm{T}}: \stackrel{\text { T }}{\omega}$ вселе́ннал.

Tво : тою вселе́нною.

Ск: $\dot{\omega}$ то́й вселеннной: йлй вселе Дво́йстве ${ }^{\text {Н }}$ нагш й Мнохестве́ннагш числа̀ лиша́ет"сА: Про́чан в" си́цевыхъ, "юкш хе ста́a склана́ема.

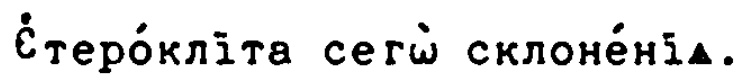

Ве́съ: оббо́й: дво́й: тро́й: че́тверо: па́теро: ше́стеро: и́ про́чам. числа̀ е́ди": Моу". Двоे: числа̀: лиша́ет"сА. Множе: числа̇

Bécz:

Bcerì:

Bce iy :

Bceró:

‘े Béç:

Bсtи́z:

๘́ все́mb:

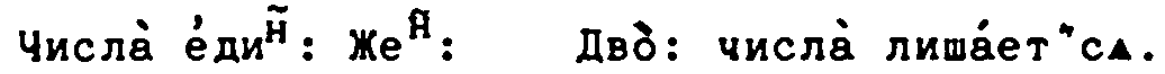

Bcì :

Bcei :

Bcén̆:

Bcio:

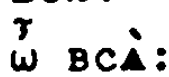

Bcér:

ஸे все́й

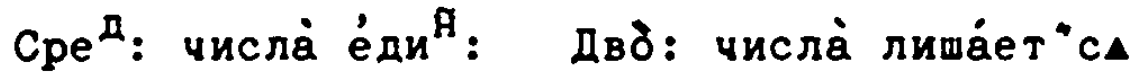

Bcé :

Bcerì:

Bceìy :

Bcé :

$\stackrel{\boldsymbol{\gamma}}{\omega}$ Bcé :

Bсђи́z:

¿́ BCémъ:

моу : числа̀ е́ди ${ }^{\text {月 }}$ Двоे: числа̀

обо́й.

óбóerw.

óбóemy. öбa.

óón.

óбóma.
Всй.

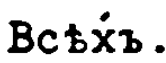

Bctúz.

Bci.

‘े Bcì.

Всьм́и.

$\dot{\omega} \mathrm{Bc} \pm \dot{x} z$.

Мно“: числа̀.

BCi.

Bctíx .

Bctír.

BCÀ.

w BCi.

всьи́n.

$\dot{\omega}$ BCt文z.

$\mathrm{Cpe}{ }^{\text {Hee }}$

ино : числа்.

[88]

BCi.

Bctx́z.

Bctíz,

BCi.

W BCi.

всьй .

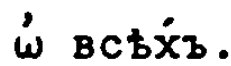

мно : числа̀ :

обо́и.

обо́ихв.

óбо́nuz. 
óóero.

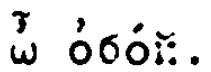

обо́n".

'ं óroe $\mathrm{M}^{\mathrm{M}}$. óóa.

๘े обов.

обо́ими.

‘े обовихъ.

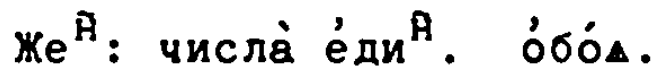

обо́ea.

óбóeñ.

óón.

'

$\stackrel{r}{\omega}$ ó60

$[886]$

óróer.

'ं о́бое́й.

Двоे: числа̀ ӧбち.

óరtio.

óбt́ma.

Мн: чис. оббо́.

óбо́ихz.

обо́имz.

óóa.

‘े óóa.

обо́ими.

í о́бо́ихъ.

Cpe

óóé.

öбa.

óбór.

oróerw.

óбóma.

множ: числа்.

óбós.

обо́ихъ.

óбо́emy.

óбóe.

обо́имъ.

‘े óróe.

óóóa.

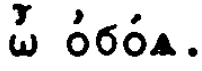

оббо́имz.

обо́ими.

¿́sóóm".

í о́бо́иxъ.

Сйuе, Дво́й, дво́а, дво́е: Тро́й, тро́а, тро́е.

Че́тверо, сйе скланиет"са.

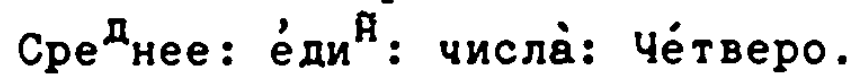

че́твера.

че́ тверу.

че́тверо.

ॐे yétверо.

$\stackrel{3}{\omega}$ че́тве

че́твером".

$\dot{\omega}$ че́тверу.

Дво̀: числа̀ че́твера.

мно: числ: че́твери.

че́тверу.

че́т верій.

че́тве $\hat{p}_{\text {Ma. }}$.

че́твере ${ }^{M}$. 
че́твери.

$\stackrel{\jmath}{\omega}$ че́твери.

че́тверми.

¿́ че́тверехъ.

Сйце, па́теро ше́стеро, се́меро: й про ${ }^{q}$. да́же до дева ${ }^{T}$ деси́теро, йлй до дева ${ }^{T}$ деса ${ }^{\top}$ де́ ватеро.

$$
\text { ¿́ склана́ніи йме́н" Числителны. }
$$

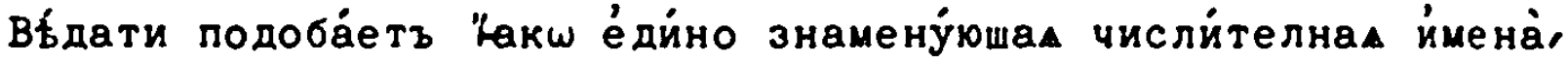
е́динстве́ннь то́чїю склані́кт"са: дво́е, дво́йственнь: тро́е, й мно ха́йша, мнохестве́ннь: Сйце,

Моу⿰: Числа̀ е́динстве́ннагш:

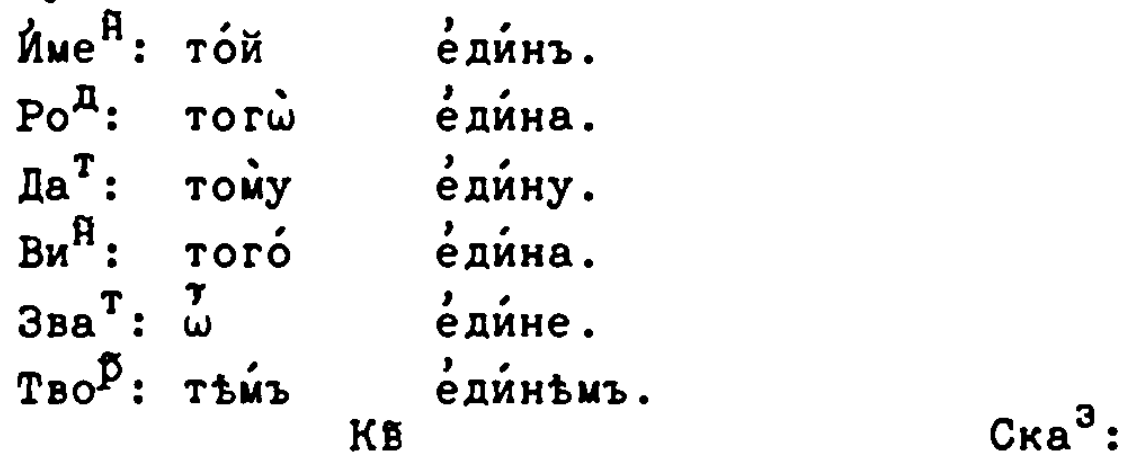

CК: ’́ то́мъ е́дйномъ: ньмъ, нђ. Дво́йственнагш числа̀.

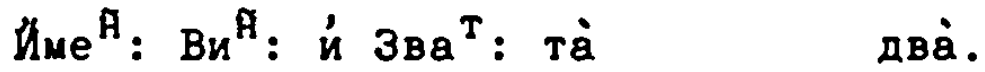

$$
\begin{aligned}
& \text { Poम : } \mathrm{CKa}^{3} \text { : тьї дво́ю. } \\
& \text { Да }{ }^{\mathrm{T}}: \text { й Тв: тв́ma и́ тьи́а дво́ма. }
\end{aligned}
$$

Mнотестве́ннатш числа்.

Йe ${ }^{\text {: }}$ ті́ трі́.

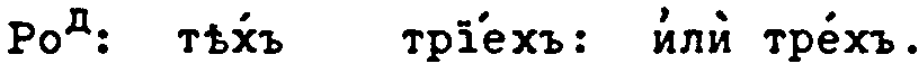

$\not a^{\top}: \tau w^{M}$ трїе́щъ: йлй тре́щъ.

Ви ${ }^{\mathrm{A}}$ : ти́A три́.

Зва $: \stackrel{T}{\omega}$ тpíe.

Твор: тьй тре́ии.

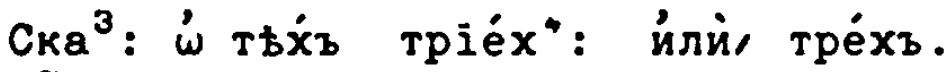

Же ${ }^{\AA}$ : Числа̀ е́динстве́ннагш:

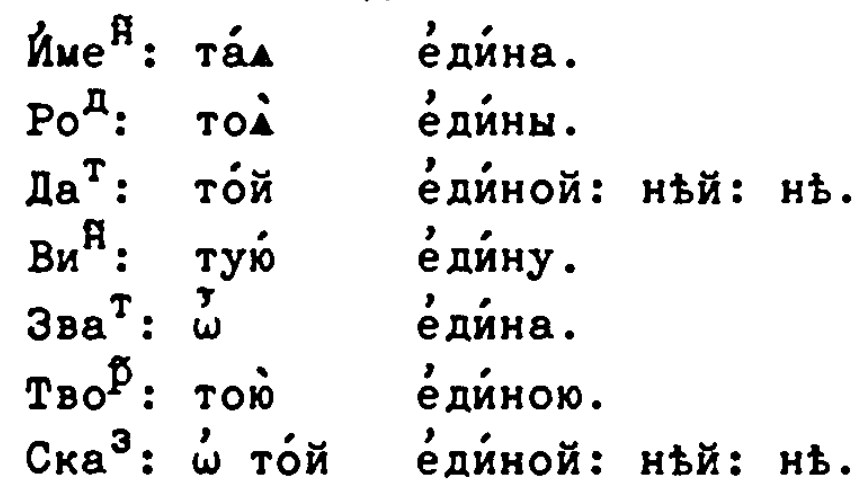




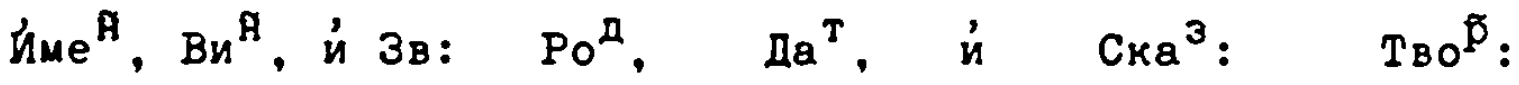

Се́дмь, Седмй,

Сe д ${ }^{n !}$ мà.

Oca:bs

[Q1]

ӧсмь. о́смй, öc"Nà.

Де́вать, деватй, йлй, $т \mathrm{e}^{\mathrm{M}}$ :

дев ${ }^{T}$ ма̀.

Де́сать, десатйо йлй, те ${ }^{m}$ :

десي ${ }^{\top}$ мà.

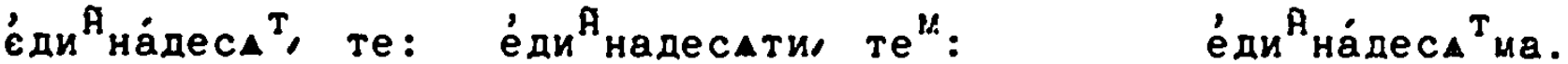

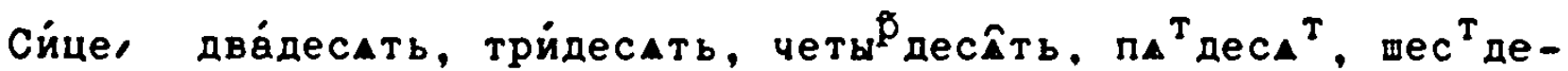

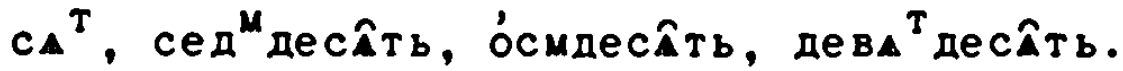

Сто́: ёже сйце склани́ет"са.

числа̀ е́динстве́ннагш.

ĺme ${ }^{\text {म }}$ Tóe Cтó:

Pon: Torì ctà:

मa ${ }^{\mathrm{T}}:$ Tomy city:

Bu ${ }^{\mathrm{R}}$ : тóe ctó:

उва ${ }^{\mathrm{T}}: \stackrel{3}{\omega} \quad \mathrm{cTó}:$

Tвор: т́́mb сто́mb:

Ска ${ }^{3}$ : '́㇒ то́mb сть́.

Дво́йственнагш числа̀:

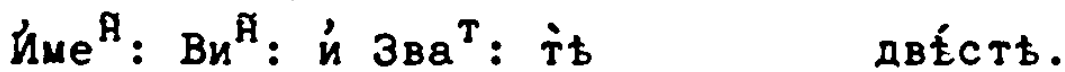

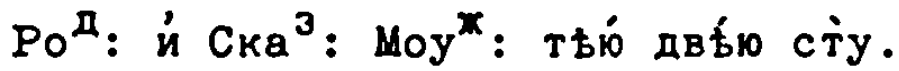

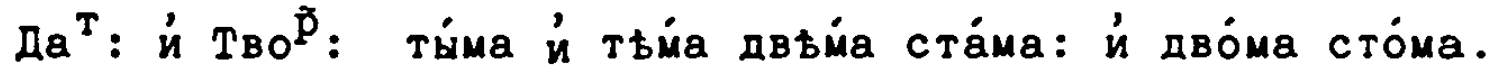
Kम Мно

$[916]$

Мнохестве́ннагш числа̀:

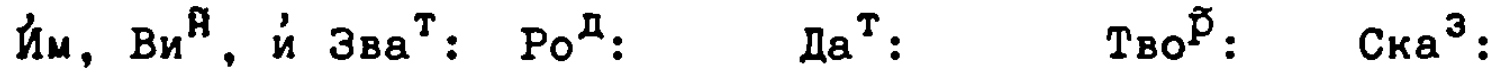

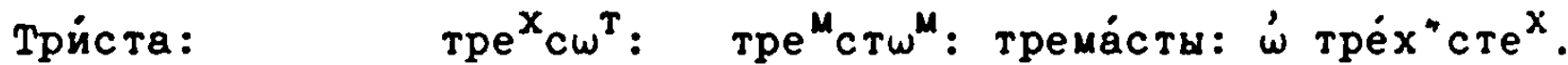

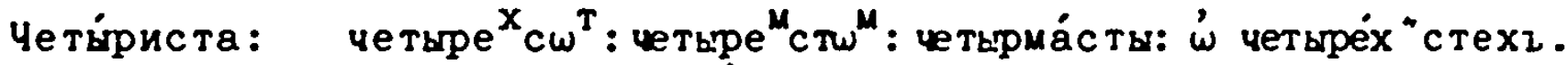

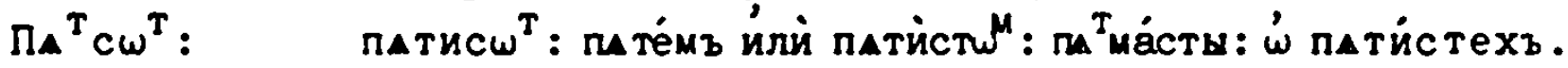

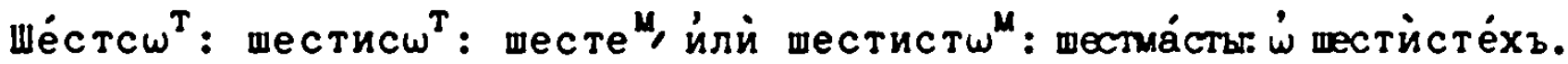
Седмсйтв:седмиси́тв: седмисти́мъ, седма́сты: '́ седмйсте́хъ.

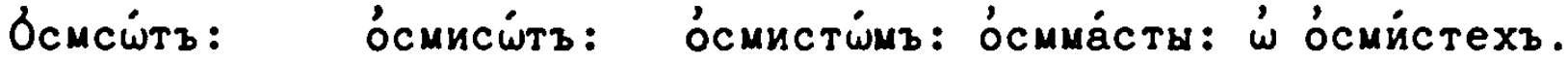

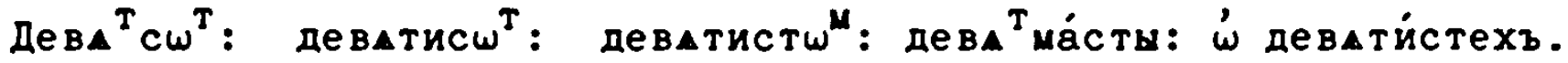

Тйсаща: Сйе скланает"са.

Числа̀ е́динстве́ннагш.

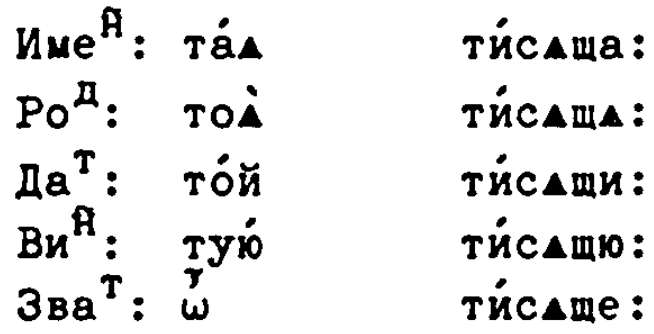




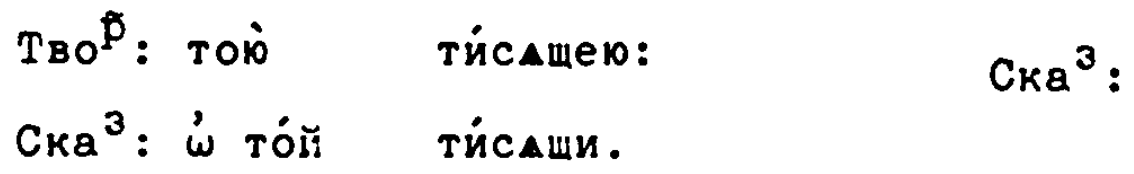

дво́̆́ственнатш числа̀.

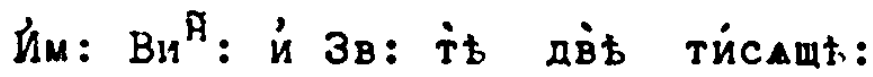

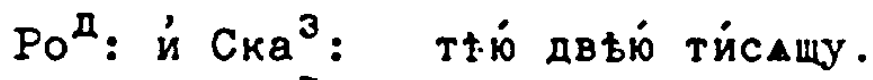

да ${ }^{\mathrm{T}}$ : й Тво

Мнохестве́ннагш числа̀:

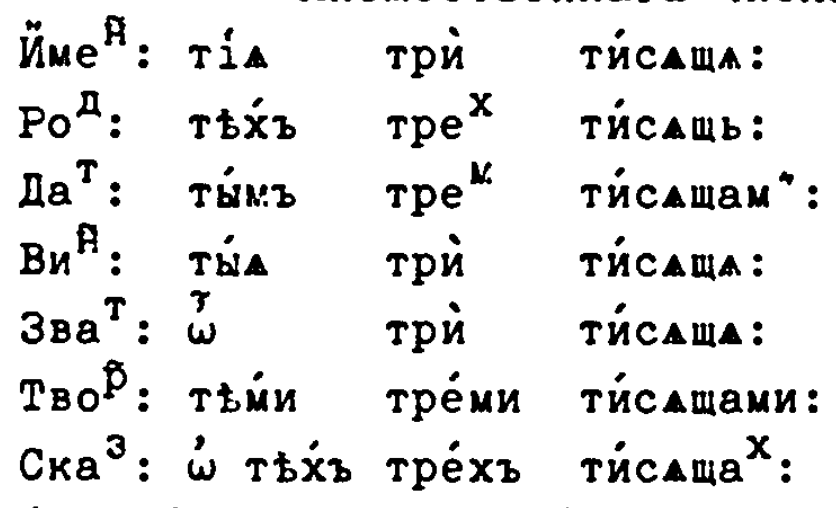

Сйе четв́ри ти́саща множествённы то́чію: про́чаa же.

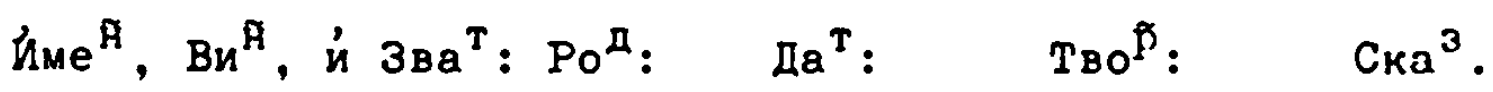

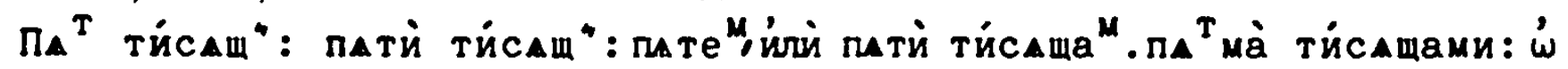
กАтй ти́саща ${ }^{X}$.

Шес" ти́саш": шести ти́саш": шесте", йлй шести ти́саща". шестма̀ ти́Ке сащами: $\dot{\omega}$ шестй ти́саща

[926]

Седмь ти́сашъ: седмй ти́сащъ: седмй ти́сашамъ. седмма̀ ти́сашами: $\dot{\omega}$ седмй ти́саща $\mathrm{x}$.

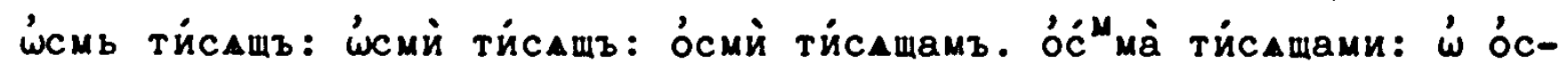
мй ти́саща ${ }^{x}$.

Дева́ть ти́сащъ: Деватй ти́сащ": деватй ти́саща". дева"ма̇ тйсащами: '́ं деватй тйсаща ${ }^{x}$.

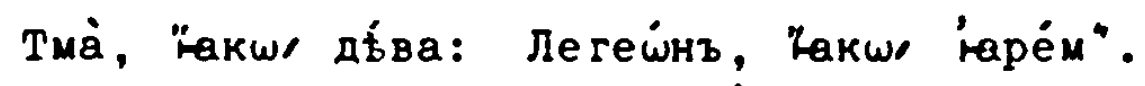

$$
\text { оу́вьше́нї. }
$$

По соверше́ніи склоне́ній, й $\dot{\omega}$ сло́хенны йме́нъ склана́ніи ні́что решй достои́ше: йх же ӧва простты подоббіемъ склани́ют"са: юакш, ठте́цъ, ठтиа̇: Пра́отецъ пра́отца: му́дрый, мујдрагш: прему́дрый, премуддрагш: достойнъ досто́йна: недостойнъ, недостойна: й прочча. Ова в" са́момъ то́чію Пра́вомъ: Пакш, дому влади́ка,

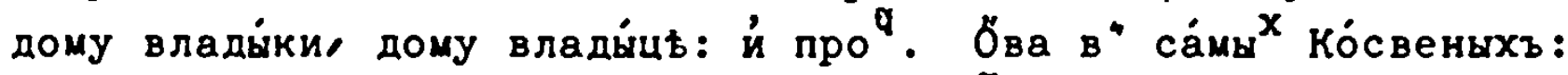
гакш, другъ друга, дру́гъ другу: й про . Ӧва же во 'ббо́ихъ: "а-

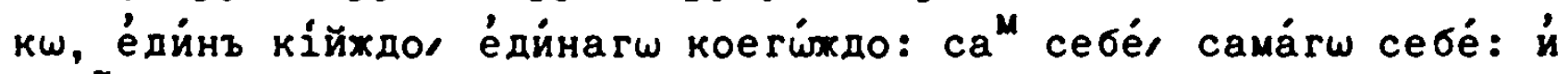
про . Но́ оу́чителей любому́дрьхъ потща́нію, оудоббъ наверши́ти та் 
могу́щу, о́ста́вихом.

¿́ МБСТОИменIи.

$\dot{\omega} M t$

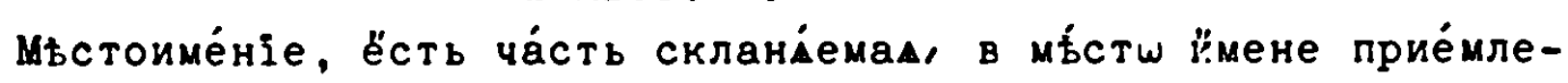
Mak.

\section{Mt.стоиме́нía cоy ${ }^{T}$ о́смна́десать.}

Ӓзъ: тй: себе́: са́мъ: о̆въ: о̆нъ: кто́: то́й: се́й и́лй сі́й: мо́й: тво́й: сво́й: кі́й: чі́й: на́шъ: ва́шъ: érì: Йже:
$\dot{\omega}$ посльдую́щихъ Мьстоиме́нію.

Посльду́ютъ мьстоиме́нї б̆смь:

'ं Вйдь.

( Вйдъ:

Ка́чество:

Ро́дъ:

Число́:

Начерта́ніe:

Лице́ :

Паде́жь: й

Склоненніе.

Вйдъ е́ст" сугубб: ( Первообразный: й

Лервообра ${ }^{3}$ нагш вйда Мьстоиме́ній е́сть трина́десать:

Перво [930]

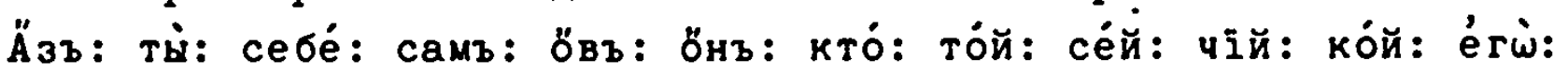
Hxe.

\section{Произво́днагш пиิть:}

мо́й: тво́й: сво́й: на́шъ: ва́шъ: Произво́дат"са оӱбш $\omega^{T}$ первоо́бразныхъ сйце, мо́й тво́й сво́й, $\omega^{T}$ роди́телны, мене́, тебе́, себе́: на́шъ, ва́шъ, $\omega^{T}$ родйтелну мнохестве́нну, на́съ, ва́съ.

‘́ Ка́чествђ, йлй Знаменова́ніи:

Ка́чествъ мьстоиме́ніА е́ст" пйтb:

Оукказа́телное:

Возносителное.

Возвратителное.

Въпроси́телное:

Прит ха́телное.

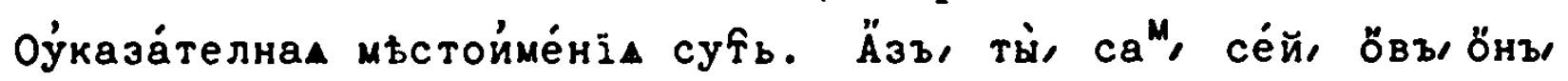

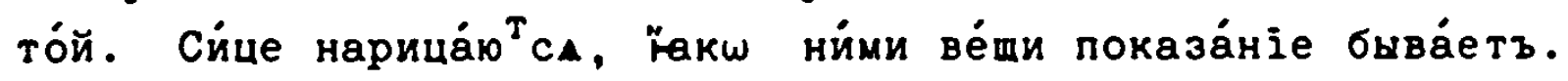

Возноси́телнан су⿰彳 та́хде: ca", се́й

öвъ।

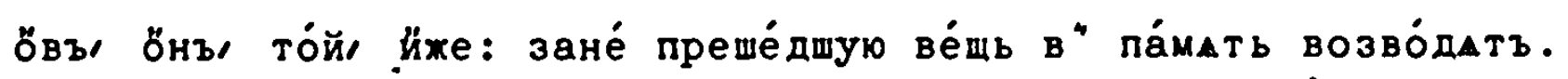

Возвратителное е́сть, себе́: зане́ знаменова́ніе е́rí на то́хде лице́ во врама́ет"сА, ёже предйде. 


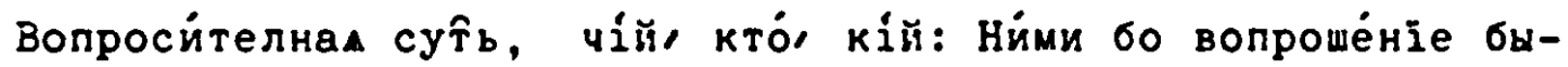
ва́eтz.

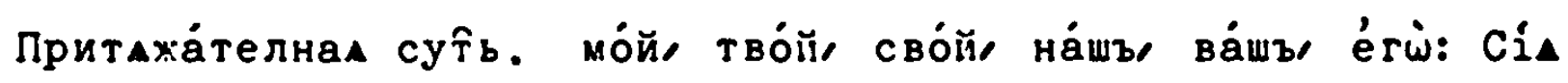
притаханніе вёши знамену́ютъ.

$$
\text { í Pónt. }
$$

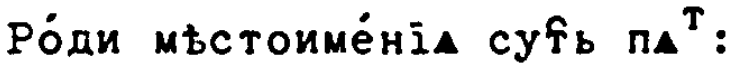

\section{Мујжескій \\ Же́нскій, \\ Сре́днїй \\ О๊бщій, \\ ( Всйкій:}

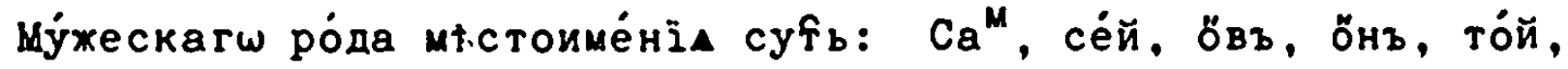
чі́й, кі́й, йже, мо́й, тво́й, сво́й, на́шъ, ва́шъ, е́rí:

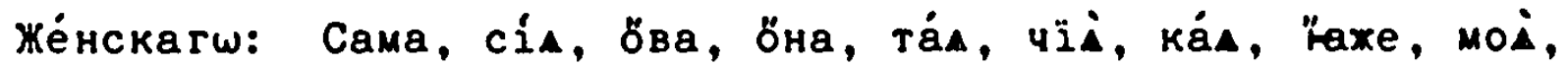
твоі, свої, на́ша, вáwa, éì.

Cре́днатш: Са́mо, сі́е, б̆во, б̆но, то́е, чїé, ко́е, что́ и́лй иеcó, ěxe, mое́, твое́, свое́, на́we, вámb, [!] érú.

Őouarw: Kтó

ӧбща

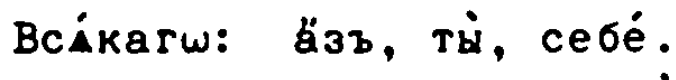

'́ числ̈ь.

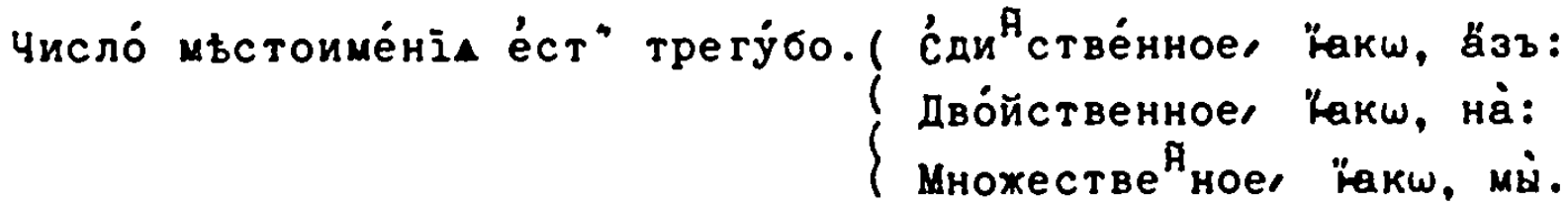

¿́ Начерта́ніи.

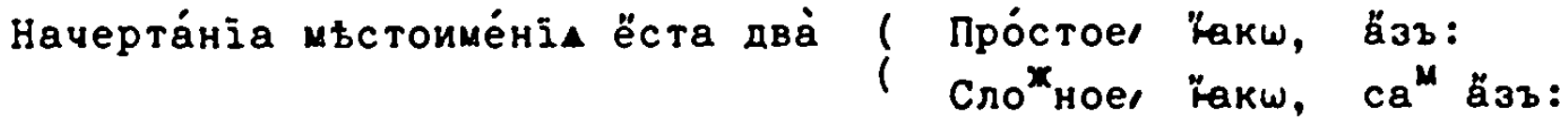

\section{$\dot{\omega}$ Лициं.}

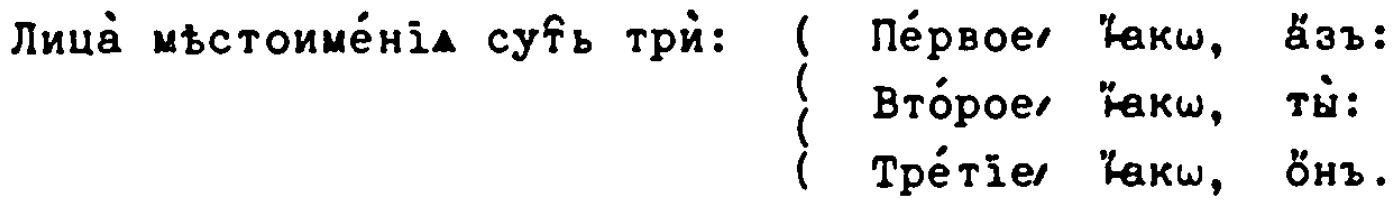

\section{Оу́въще́ніе :}

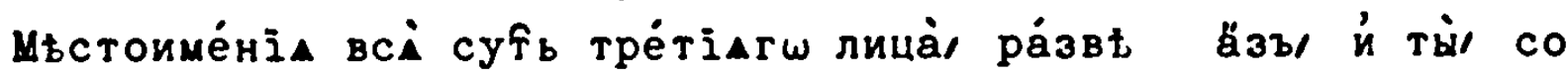
свойми йма паде́хми: $\omega^{T}$ не́ю же о̆но пе́рвагшl о̆во вто́рагш ёстъ лица̀.

'́̀ naде́xu:

Ладе́хей мьстоиме́ніА е́сть се́д".

( Йменйтелный :

Пaдé 


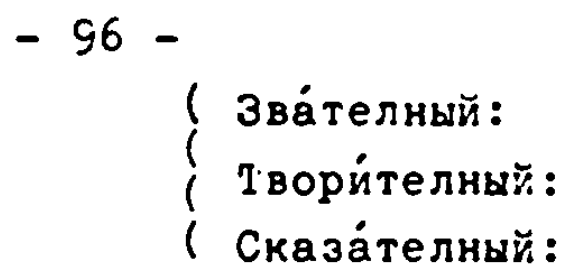

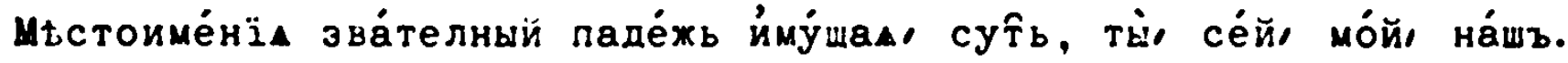
ஸ́ Склоне́нїи.

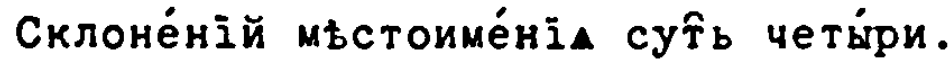

$\left\{\begin{array}{l}\text { Пе́pвoе: } \\ \text { Вто́рое } \\ \text { Tре́тї: } \\ \text { Четве́pтoe: }\end{array}\right.$

’́ пе́рвомъ Склоне́нї.

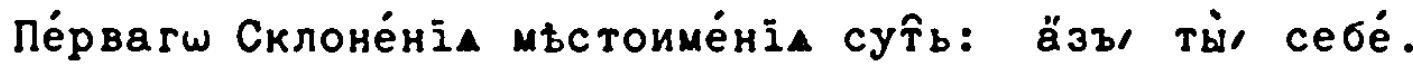

Ӓзъ: Числа̀ е́динстве́ннагш.

ל̆ме ${ }^{\text {: }}$ äзъ:

Ви ${ }^{\text {: }}$ мене́, йлй нї.

Poमn: мене́:

Зва ${ }^{\top}:$ лиша́ет ${ }^{\top} с \Delta$.

Да ${ }^{\mathrm{T}}:$ мнेђ, йлй мй:

Tво Р : мно́ю.

Ска ${ }^{3}$ : ’́ мй́.

Дво́й :

Дво́йственнагш числа̀.

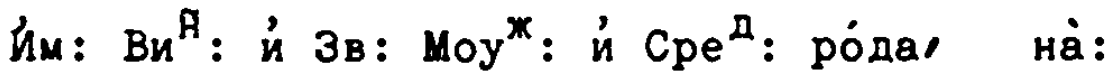

же́ нскагш:

Ḣ:

$\mathrm{Po}^{\text {म. }}$ и $\mathrm{CKa}^{3}$ :

หán:

Да ${ }^{\mathrm{T}}:$ и Тво $^{\tilde{p}}$ :

нáma:

Мнохестве́ннагш числа்.

йме ${ }^{\text {म }}$ : мы:

Poम: на́съ:

Зва' : лиша́ет "са:

да ${ }^{T}$ : на́мъ:

тво : на́ми:

Виम : ныл йлй на́съ:

Ска ${ }^{3}:$ '́ на́съ :

Tй: Числа̀ е́динстве́ннагш.

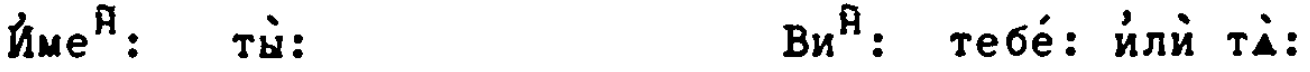

Poम: тебé: $3 \mathrm{Ba}^{\mathrm{T}}: \dot{\omega}$ ты:

Да ${ }^{\mathrm{T}}:$ тебі́ йлит ти: твор : тобою:

Cка ${ }^{3}:$ '

Дво́йстве́ннагш числа்.

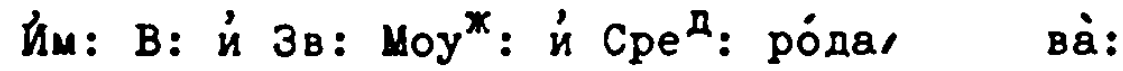

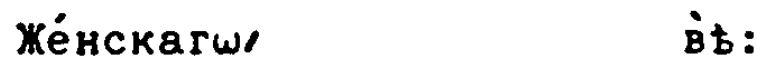

Poम:

Báb:

П $\mathrm{a}^{\mathrm{T}}:$ и $\mathrm{T}_{\mathrm{BO}}^{\mathrm{p}}$ :

вáma:

Множестве́ннагш числа̀:

Множе [96]

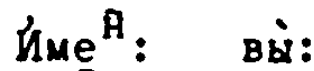

Poम: вácz:

Зва ${ }^{\mathrm{T}}: \stackrel{\mathbf{\omega}}{\omega} \mathrm{в \dot { \textrm {C } } :}$

твор: ва́ми: 


\section{- 97 -}

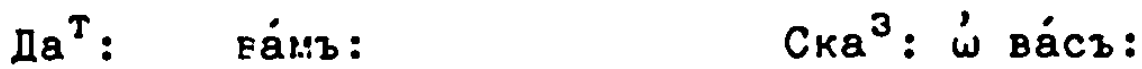

Bü ${ }^{\mathrm{A}}$ : выे йлі: ва́съ:

Cебе́: पисла̀ е́динстве́ннагш.

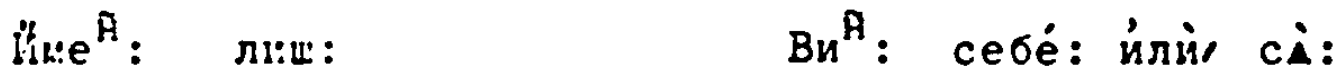

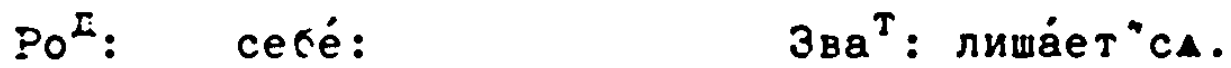

La ${ }^{\mathrm{T}}$ : себі́, йли, сй. Tво

Ска ${ }^{3}:$ '́ ceбi.

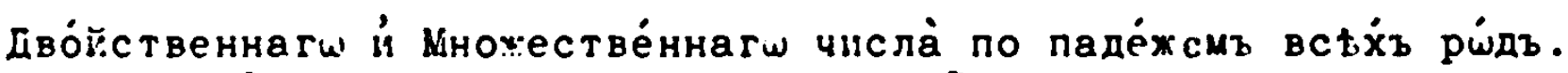

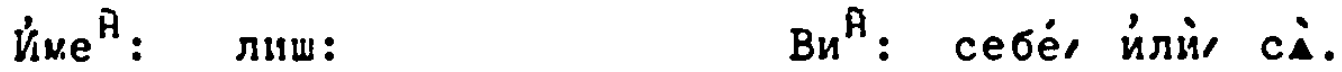

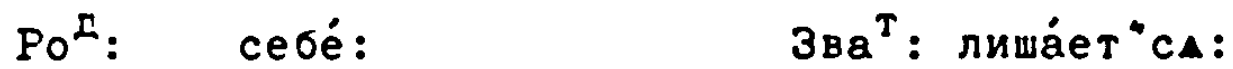

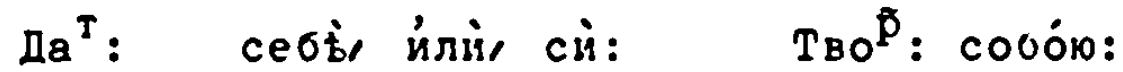

Cка ${ }^{3}:$ í ceбi.

Оу́въще́нуе.

Ви́стно бу́ди винйтелныхъ на́съ. и́

ת вáç

[966]

ва́съ вожде́ніемъ всб́хъ склоне́ній му́жескал й же́нскаА и́мена̀ й

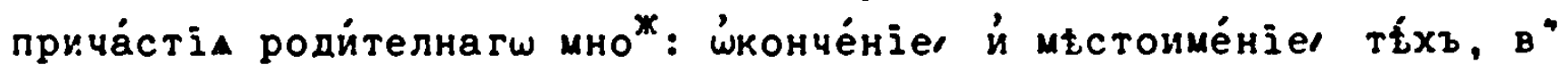
мьсто виниттелнагш прийма́ти дерха́тиса: во свое пра́вилно паде́-

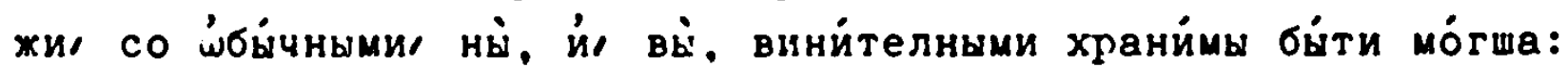
"акш, Помиялуй на́съ $\Gamma^{\complement}$ ди грєٔшныхъ й недосто́йныхъ ра́бъ свойхъ

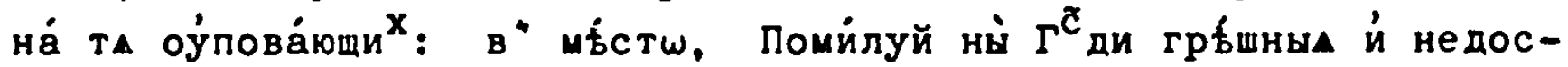
то́йныа рабы́ своА на́ та оуंпова́ющыА.

BTOPOC СКЛОНСНIC.

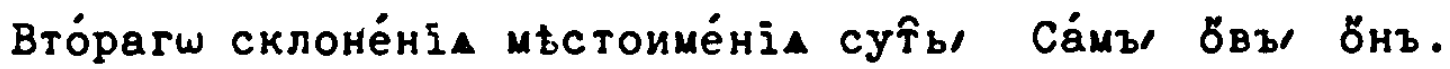

Са́mъ: числа் е́динстве́ннагш. Моу":

Йме ${ }^{\tilde{R}}$ : са́mъ: Зва"

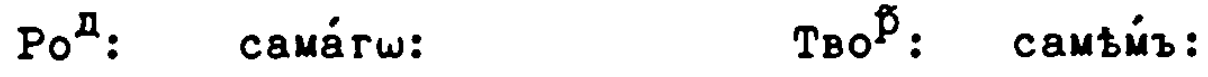

да ${ }^{\mathrm{T}}:$ camóny: Сказа ${ }^{\mathrm{T}}: \dot{\omega}$ само́мъ

Ви ${ }^{\text {म }}$ camáro:

Дво́йственнаго числа.

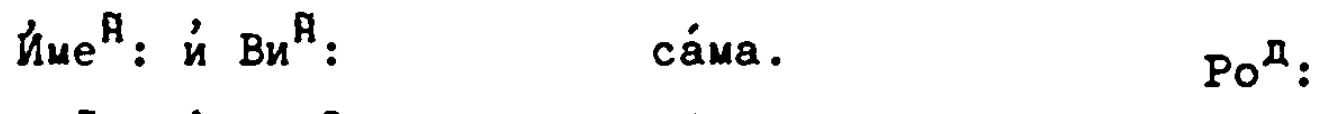

Poम. मे $\mathrm{CKa}^{3}:$ сámy:

$\mathrm{Ha}^{\mathrm{T}}:$ иं Tво ${ }^{\tilde{p}}:$ cambía:

Множестве́ннагш числа̀.

Йне : са́ми: Зва ${ }^{\mathrm{T}}:$ лиша́ет"са:

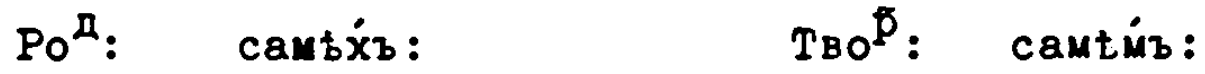

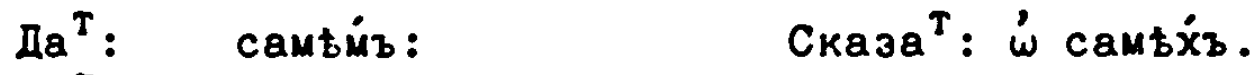

$\mathrm{Bu}^{\text {म }}$ : cámb:

Cама̀: е́динстве́ння $\mathrm{Ke}^{\text {म }}$ : 
Ŭme : сама̀ :

Зва" ${ }^{\mathrm{T}}:$ лиша́ет "сА:

Poम: самы́:

TBо : camón:

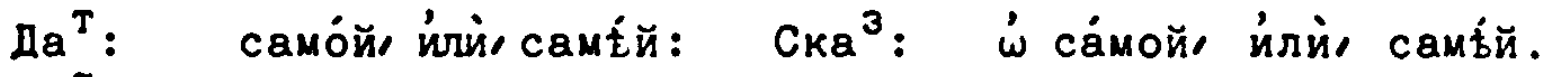

Bй : са́му :

Дво́йственнагш числа̀.

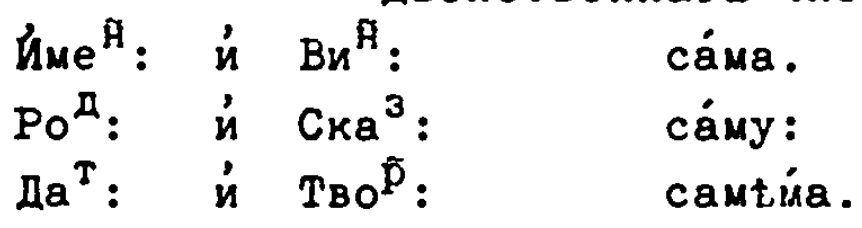

Множестве́ннатш числа̀.

Йme ${ }^{\tilde{A}}$ : са́mы:

Poम: $\quad$ मaúfxb.

मa $\mathrm{a}^{\mathrm{T}}$ - camtimb:

Лв ${ }^{\mathrm{T}}{ }^{\mathrm{T}}$ :

$\mathrm{Bи}^{\mathrm{A}}$ : са́mы: Сказа ${ }^{\mathrm{T}}: \dot{\omega}$ саме́хъ.

Зва ${ }^{\mathrm{T}}$ : лиш:

Са́mо: е́динстве́ннагш числа̀.

Йме : са́мо: उва́те ${ }^{\Re}:$ лиша́ет"са:

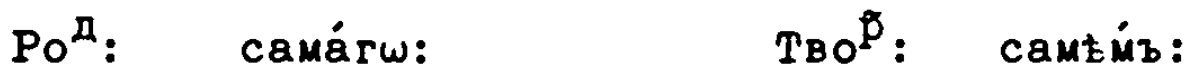

$\mathrm{La}^{\mathrm{T}}:$ самому: $\mathrm{CKa}^{3}:$ '́ самомъ:

$\mathrm{Bu}^{\mathrm{P}}$ : cámo:

Дво́йственнатш числа̀.

Йме ${ }^{\tilde{H}}:$ й $\mathrm{Bu}^{\tilde{H}}:$ cáma:

Poम: मे $\mathrm{CKa}^{3}:$ cámy:

да ${ }^{T}:$ иं Tво : самб́мa.

Мнохественнатш числа்.

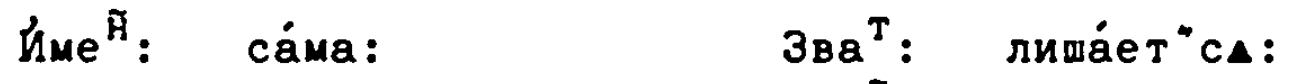

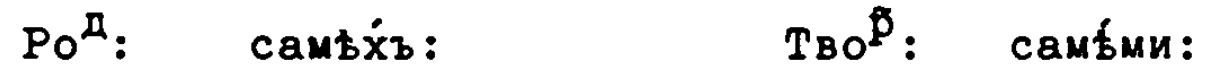

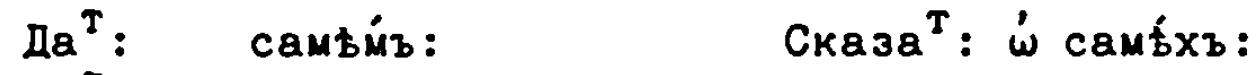

$\mathrm{Bu}^{\mathrm{A}}$ : cáma:

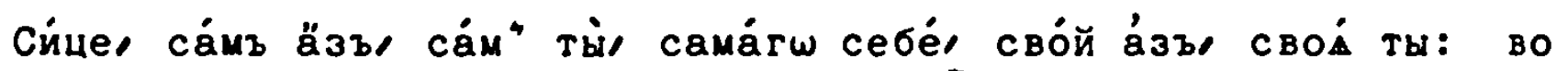

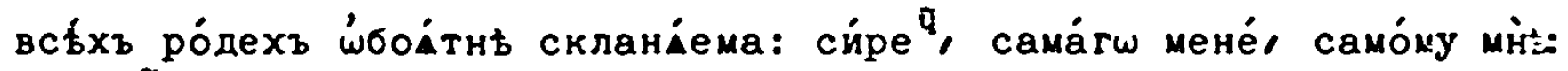
i npo ${ }^{q}$.

ÖBr:

Őвъ: е́ди ${ }^{\text {F }}$ числа:

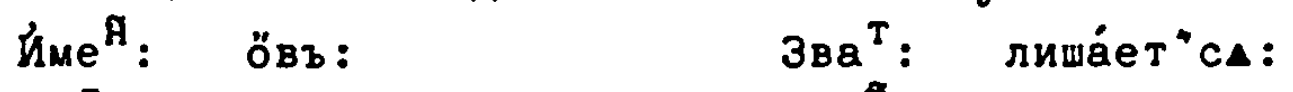

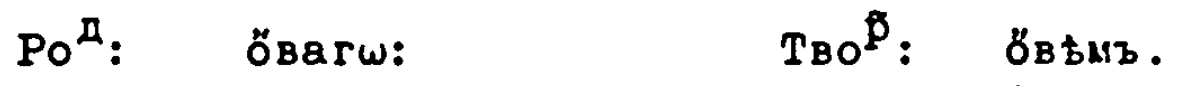

मа ${ }^{\mathrm{T}}$ : бовому: Ска ${ }^{3}: \quad \dot{\omega}$ ӧвомъ.

$\mathrm{Bu}{ }^{\mathrm{A}}$ : ठ̈ваго:

Дво́йственнагш числа்:

йме ${ }^{\text {मे }}$ й Ви $^{\text {मे }}$ о̆ва:

Pоम 


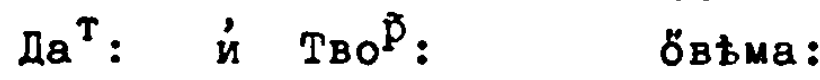

Множестве́ннатш числа்.

lime ${ }^{\text {A }}$ ӧви: Зва ${ }^{\mathrm{T}}:$ лиша́ет" сА:

Pоम: о̋вђхъ: Твор: о̆вђми.

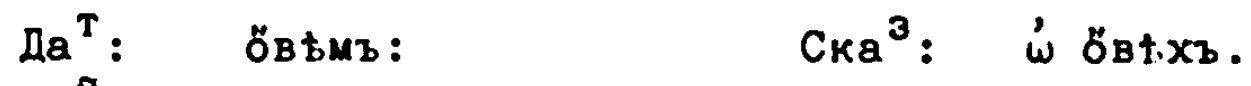

$\mathrm{Bu}{ }^{\mathrm{A}}:$ О̋вы :

Öва: 'еди ${ }^{\AA}:$ числа̀: же $^{\text {म }}$

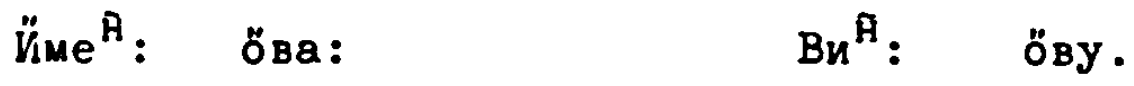

Pоम : о̆вын: उва" : лиша́eт"сA.

Да ${ }^{\mathrm{T}}$ : б̆вой йлй б̆вђй: Твор : б̆вою.

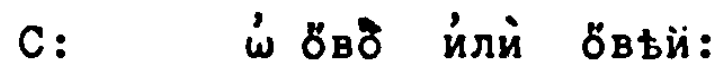

\section{лr Двӧй}

Дво́йственнагш числа̀.

[986]

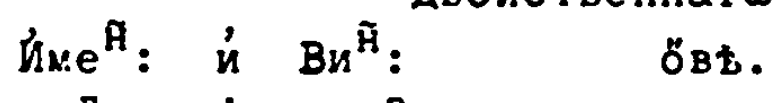

Poम:

Да ${ }^{\mathrm{T}}:$ й Твор: о̋вђма.

Множестве́ннагш числа்.

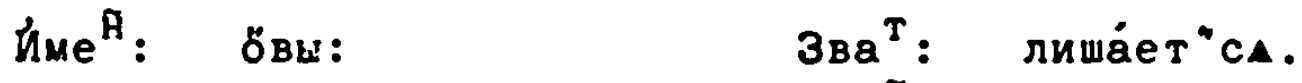

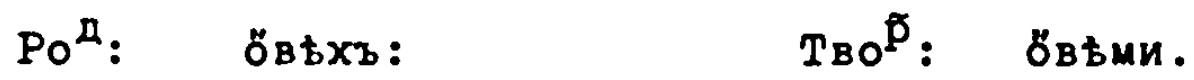

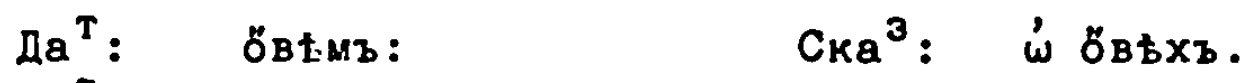

$\mathrm{Bu}^{\mathrm{A}}:$ б̆вы:

Ӧво:

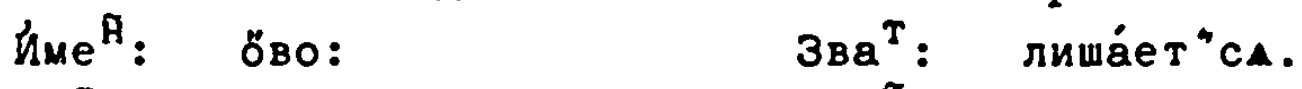

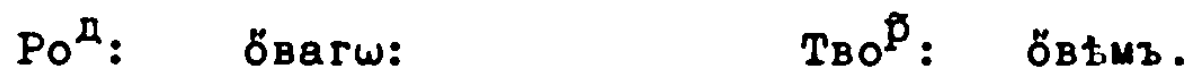

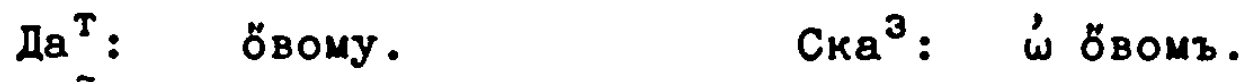

$\mathrm{Bu}{ }^{\text {म }}$ : о̆во.

Дво́йственнагш числа.

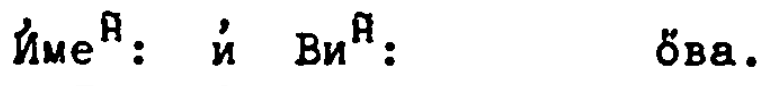

Poम: मे $\mathrm{CKa}^{3}:$ б̆ву.

Lа ${ }^{\top}:$ и твор: о̆вьма.

Мнохестве́ннагш числа்.

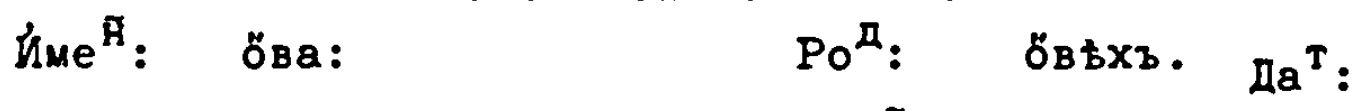

да ${ }^{\mathrm{T}}:$ бов屯ив: Тво : бовむми.

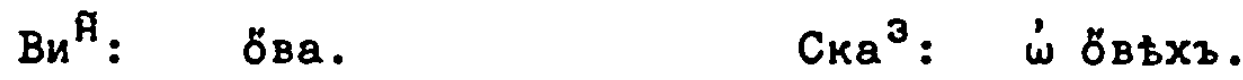

Зва ${ }^{\mathrm{T}}:$ лиш:

Ӧнъ: $\quad$ е́динстве́ннатш числа́. $\operatorname{Moy}^{\mathrm{x}}$.

Kмен : ठ̆нъ:

Звате

Poम: Őнarw:

Tвор : б̆нав.

Да ${ }^{\mathrm{T}}$ : б̆ному.

Ска ${ }^{3}:$ 'ं о̆номъ. 
$B n^{\text {A }}$ : őharo.
Цво́йственнагш числа̀.
Aме: и $\mathrm{Bu}$ :
Poम:
да ${ }^{\top}:$ иं тво

\section{Множестве́ннагш числа்.}

Йме म $^{\tilde{A}} \quad$ онни:

Зва́те": лиша́ет "ск.

Poम: о̋нむхz.

TBOp: öhtus.

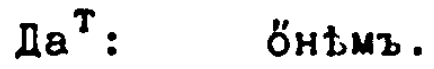

CKa ${ }^{3}: \quad \dot{\omega}$ Öнtхъ.

$\mathrm{Bu}^{\text {म }}$ : о̋нь.
Ӧнвे :
е́динстве́ннагш числа̀:
Me ${ }^{n}$ :

לиме ${ }^{\text {: }}$ онна̀:

$\mu \mathbf{a}^{\mathbf{T}}$ :

ӧной йли: ӧн士ั̆.

Poम: ŐHsA:

Ви ${ }^{\text {: }}$ б̋ну.

תน

$$
B u^{A}:
$$

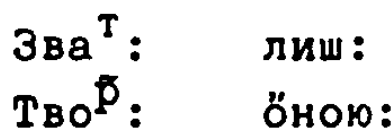

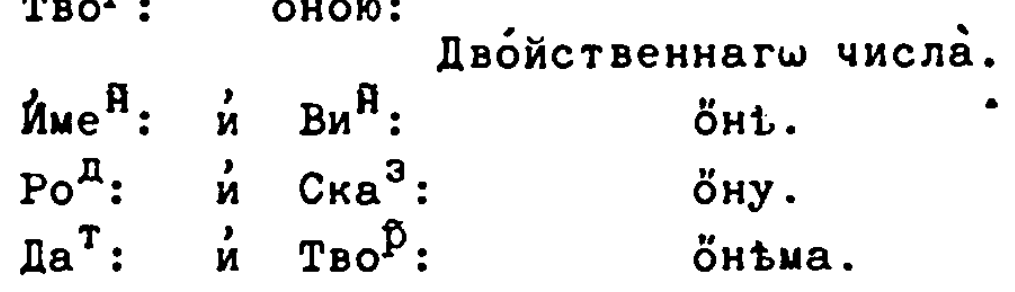

Множестве́ннагш числа̀.

Йме ${ }^{\text {ค }}$ оны :

Зва́те

Poम: $\quad$ őнt๖z:

$\not a^{T}:$ б̆нむмъ:

Tвор : ӧньми.

Вин : ठ̆ны:

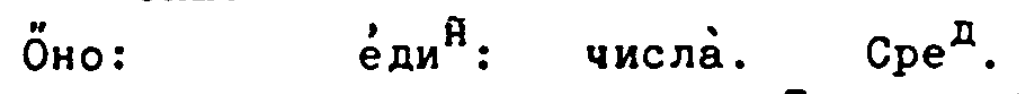

Йе : ӧно.

Poम: о̆нагw.

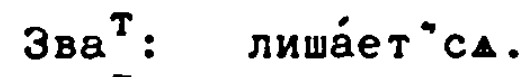

मа ${ }^{\mathrm{T}}$ : б̆ному.

Tвор: о̆н土גiz.

$\mathrm{Bu}^{\mathrm{A}}$ : ӧно.

Cка ${ }^{3}$ : '́ о̆нокъ.

Дво́йственнагш числа்.

lume ${ }^{\text {म }}$ : $\mathrm{Bu}^{\text {म }}$ :

őнa.

Poम: й Ска ${ }^{3}$ :

$\mathrm{na}^{\mathrm{T}}: \quad \dot{\mathrm{T}} \mathrm{TBO}^{\mathrm{p}}$ :

ӧну.

öнtмa.

Luroxe

Множестве́ннагш числа்.

Йме ${ }^{\text {: }}$ о̆на:

Poम.

मа ${ }^{\mathrm{T}}:$ о̆нむмз :

$\mathrm{Bu}^{\mathrm{A}}$ : о̆на:
Зва́те $e^{\wedge}$ лиша́етъса.

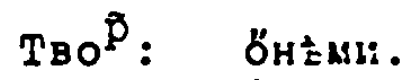

$\mathrm{CKa}^{3}: \quad$ 'ं ӧнむхъ. 


\begin{tabular}{|c|c|}
\hline Cáaıы̆̆ & Canáa' \\
\hline Ӧвый, & öваa, \\
\hline ӧныц̆ & ӧнам \\
\hline
\end{tabular}

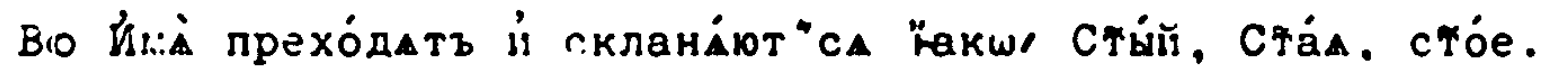

\section{TPCTIE СКЛОНенIC.}

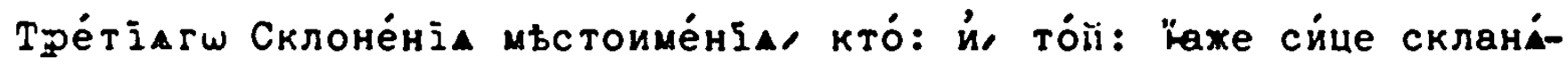
$1 \mathrm{~T}^{\mathrm{N}} \mathrm{CA}$.

о̋бшее: кто́: е́дй : числа்:

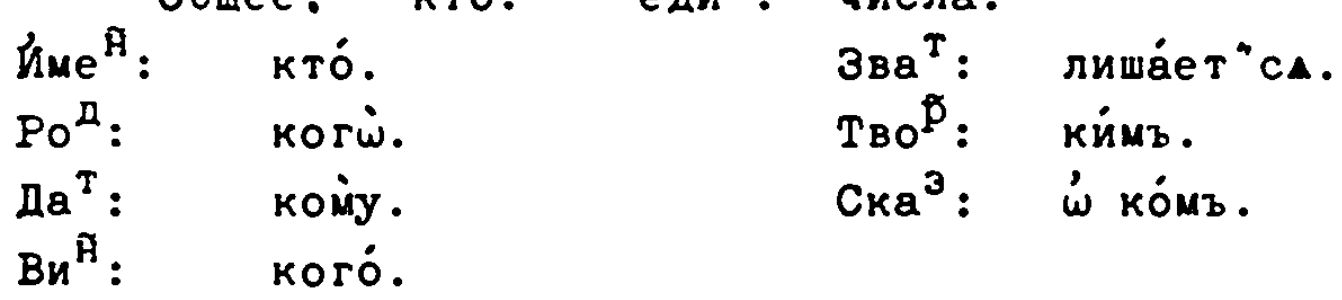

Цво́й: й Мно*: числа̇ лиша́ет"cА.

лг

Crime, [1006]

Сйuе, ни́кто: кто́либо: никто́ же: кто́ оубб: кто́ сей: и́ проф.

$$
\text { Cpę: что́ йлй чесо́: числа̀ е́ди }
$$

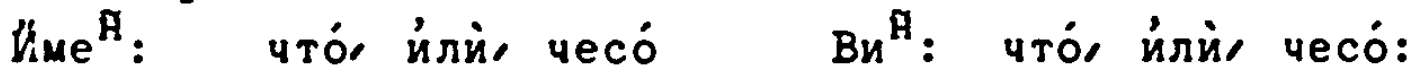

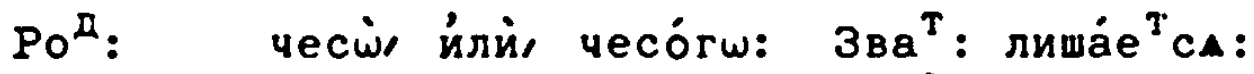

да ${ }^{\mathrm{T}}$ : чем̀у, йлй чесо́му. Тво $:$ чймъ:

Ска ${ }^{3}$ : $\dot{\omega}$ че $\mathrm{e}^{\mathrm{M}}$ йлй, $\dot{\omega}$ чесо́mъ.

Дво́й: и́ мно“: числа̇ лиша́е

Сйце, нб́что: что́либо: ничто́ же: что́ оуббш: что́ се: и́ про́чаa.

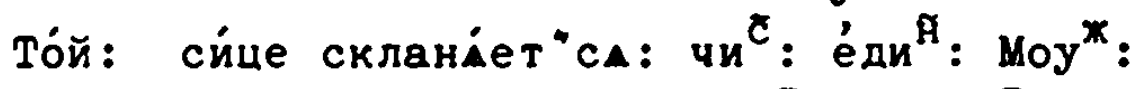

Йме ${ }^{\text {: }}$ то́й:

Зва ${ }^{\mathrm{T}}:$ лишв́ $\mathrm{e}^{\mathrm{T}} \mathrm{cA}$.

Pon: тoŕं:

TBOp : Tち்́.

дa ${ }^{x}:[1]$ romy :

Cка ${ }^{3}$ : '́̀ то́m.

Ви${ }^{\text {म }}$ : того́, и́лй то́й ве́щій: бе ${ }^{3}$ душншхъ.

Дво́йственнагш числа̀.

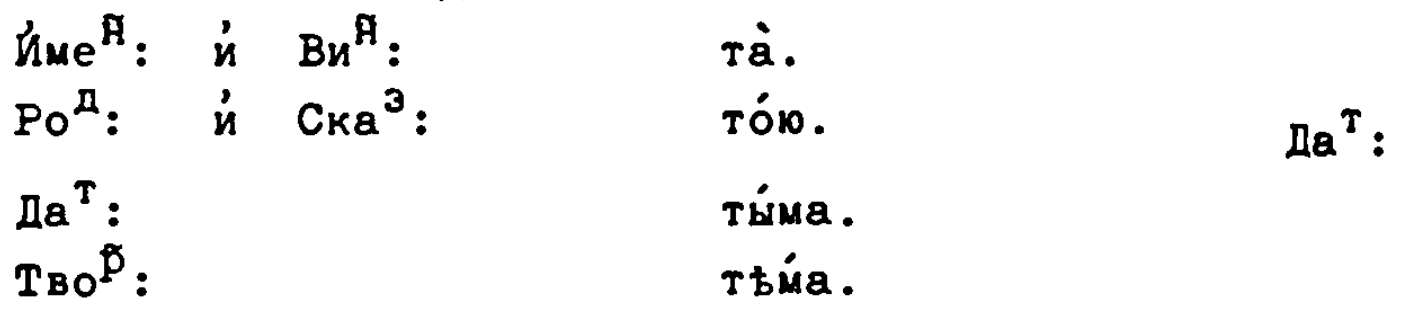

[101]

แнокестве́ннатш числа்:

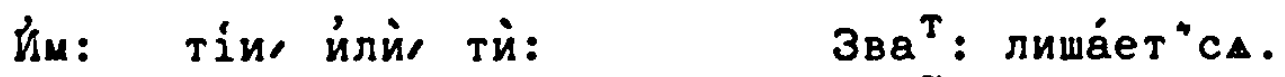

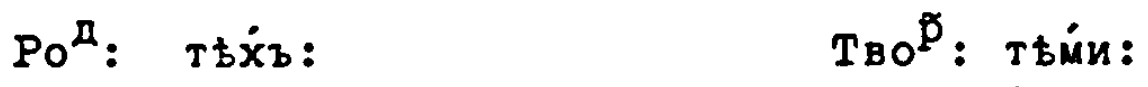

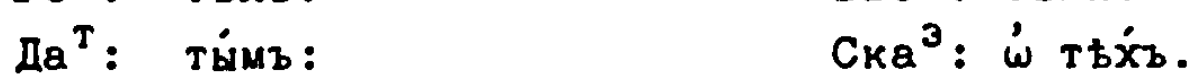

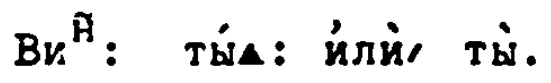

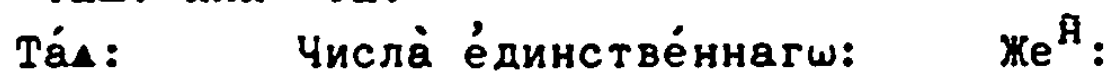




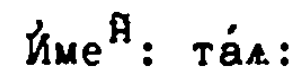

Pon: TOA:

Да ${ }^{\mathrm{T}}:$ то́й.

$B n^{\text {ค : }}$ тую́.
Зва́те : лиша́ет"сА.

Tвор : тою.

Ска ${ }^{3}:$ 'ं то́й.

Uัме

Poम : मे $\mathrm{CKa}^{3}:$ Tf́r.

मа ${ }^{\mathrm{T}}$ : ти́ma.

TBop: Ttúa.

Мнохестве́ннатш числа̀.

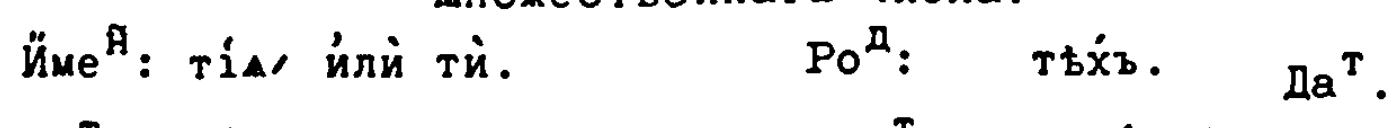

да та́мъ. Зва". лиша́ет"са.

$\mathrm{Bu}^{\mathrm{A}}$. ті́ йлй тй Тво

Ска ${ }^{3}$. $\dot{\omega} \mathrm{T} \pm \dot{x} ъ$.

Tóe: Cpen. е́динстве ${ }^{\text {म }}$ числа̀.

Йme . тóe.

Зва́те

Pon: Torí.

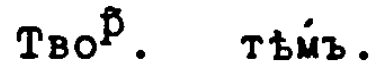

да ${ }^{\mathrm{T}}$. Tomy.

$\mathrm{CKa}^{3}$. '́㇒ то́mъ.

Bu ${ }^{\text {f. Tóe. }}$

Дво́йственнагш числа.

Йme ${ }^{\text {म }}$ मे Ви $^{\text {म }}$ та丿.

Poम. й $\mathrm{CKa}^{3}$. тón.

$2 a^{\mathrm{T}}$.

ти́ma.

TBop.

тьúa.

Мнохестве́ннагш числа̇.

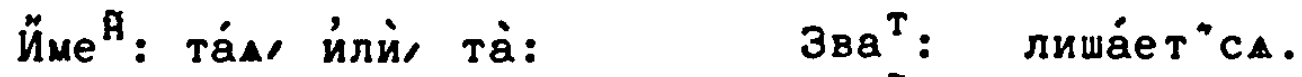

Poम: $T \downarrow \dot{X} b$ :

Тво : тьии.

मа ${ }^{\mathrm{T}}:$ T́ंмъ:

Ви ${ }^{\text {ค }}$ та́. йлй, та̀:

Ска ${ }^{3}: \quad \dot{\omega} \mathrm{T} \dot{\mathrm{x} z}$.

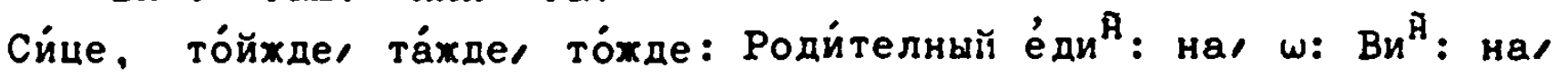
0 :

पe

ЧЕTBEPTOE CКЛOHCHIC.

[102]

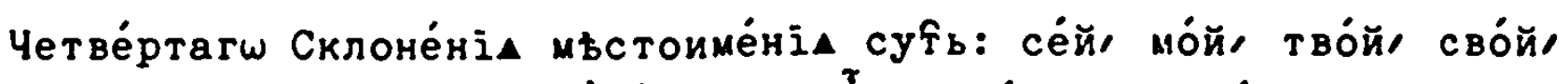

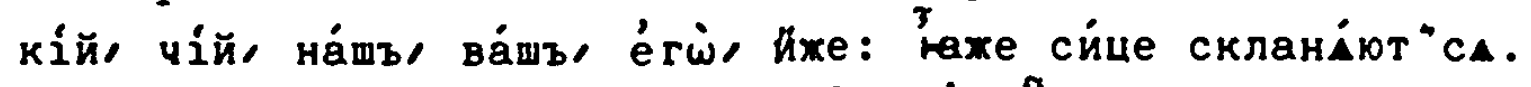
Се́й: Моу" : числа̀ е́ди ${ }^{\mathrm{A}}$ :

йме : се́й йлй сі́й.

$\mathrm{Bu}{ }^{\text {मे }}$ ceró.

Pon: cerí:

Зва ${ }^{\mathrm{T}}: \quad \stackrel{\boldsymbol{\jmath}}{\boldsymbol{\omega}} \mathrm{cí}$.

मa ${ }^{\mathrm{T}}$ : ceing.

Tво : симз.

$\mathrm{CKa}^{3}:$ iे cémъ. 
Двӧйственнагш числа̀.

Йm: $\mathrm{Bu}^{\tilde{\mathrm{H}}}:$ иं $3 \mathrm{Ba}^{\mathrm{T}}$ :

cia.

Poम. иं $\mathrm{CKa}^{3}$ :

céю.

Дат ${ }^{\mathrm{T}}$ :

си́мa.

Множестве́ннагш числа̀.

Йме $e^{\text {: }}$ сі́и.

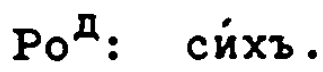

да ${ }^{\mathrm{T}}: \quad \mathrm{u}^{\mathrm{M}}$.

$B{ }^{\text {P }}$ : CíA.

cía:

Йме : сіА, йлй, сй.

Pon: ceí.

Да ${ }^{\mathrm{T}}$ : се́й.

$\mathrm{Bu}^{\mathrm{A}}$ : cír.
Зва ${ }^{\top}: \omega^{3}$ сіи.

Твор: сими :

$\mathrm{CKa}^{3}: \quad \dot{\omega}$ сихх .

Же"

Дво́йственнагш числа̀.

Hu: ì $\mathrm{Bu}^{\mathrm{A}}$ :

Poम : ${ }^{\text {म }} \mathrm{CKa}^{3}$ :

cíb,

मа ${ }^{\mathrm{T}}:$ иं $\mathrm{T}_{\mathrm{BO}}^{\mathrm{p}}$ :

cén.

cúma.

Мнохестве́ннагш числа̀.

Ŭme ${ }^{\text {I }}$ cía.

Зва ${ }^{\mathrm{T}}: \quad \stackrel{\mathrm{T}}{\omega} \mathrm{ci \Lambda}$.

Pon: $c u^{x}$.

Tвор: сими.

मа $^{\mathrm{T}}$ : сйmъ.

$\mathrm{Bu}^{\mathrm{A}}$ : cín.

Ска ${ }^{3}$ : '́ сиххъ.

Pon:

[1026]

Cie: Cpeñ е́динстве́ннагш числа̀.

Une ${ }^{\text {: }}$ cíe.

उва ${ }^{\mathrm{T}}: \quad \stackrel{\mathrm{w}}{\omega} \mathrm{cie}$.

Pon: cerí.

TBop: cúmz.

मа ${ }^{\mathrm{T}}$ : ceiry.

$\mathrm{Bu}^{\mathrm{A}}$ : cíe. йлй, cé.

$\mathrm{CKa}^{3}$ : '́̀ се́mъ.

Вия: сіе. илй се́.

Йme ${ }^{\text {A }}$ и $\mathrm{Bu}^{\text {म }}$ : cía.

Poम: и Ска ${ }^{3}:$ cér.

$\mathrm{La}^{\mathrm{T}}:$ й Тв: си́ма.

Мнохестве́ннагш числа̀:

Йme : cía:

Poम : сиххз:

$\not a^{T}:$ сймз:

$\mathrm{Bu}^{\mathrm{R}}$ : cía.

мо́й:
Зва ${ }^{\mathrm{T}}: \quad \stackrel{\gamma}{\omega}$ cía.

Твор: сйми.

$\mathrm{C \kappa a}^{3}:$ 'ं си́хъ: 
Йме ${ }^{\text {F }}$ : мо́й :

Зва ${ }^{T}: \quad \stackrel{T}{\omega}$ ной.

Poम: мое́rw:

Tвор : моймз.

Да ${ }^{T}:$ moémy:

Ска ${ }^{3}$ : í мое́mz.

Bu ${ }^{\text {R }}$ moéro.

Дво́йственнагш числа̀.

Йм: $\mathrm{Bu}^{\mathrm{A}}:$ й $3 \mathrm{~B}:$ модं.

Poम : и $\mathrm{CKa}^{3}$ :

Да ${ }^{\mathrm{T}}$ :

мое́ю.

мои́ма.

Мнжестве́ннагш числа̀.

йме : мой:

Зва ${ }^{\mathrm{T}}: \quad \stackrel{T}{\omega}$ мой.

Pоम: мойхз.

Тво

मа ${ }^{\mathrm{T}}$ : моймъ.

Ска ${ }^{3}$ : $\dot{\omega}$ мойхъ.

$\mathrm{Bu}^{\text {म }}$ : мод.

Mод: Же ${ }^{\text {म }}$ числа̀ е́динстве́ннагш:

йе ${ }^{\text {म }}:$ MOA:

Да ${ }^{\mathrm{T}}:$ мое́й.

Pö: мое́A.

$L a^{T}:$

Bu ${ }^{\text {मे }}$ моюे:

TBO ${ }^{\mathrm{p}}$ : мое́ю.

उва ${ }^{\top}: \stackrel{T}{\omega}$ mод.

$\mathrm{CKa}^{3}:$ í mó丶万̆.

Дво́йственнагш числа̀.

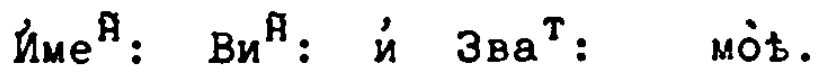

Poम: $\dot{n} \mathrm{CKa}^{3}:$ moéю.

$\mathrm{na}^{\mathrm{T}}:$ й Тво ${ }^{\mathrm{p}}$ : мойма.

Мнохестве́ннагш числа̀.

Йme : мод.

उва ${ }^{\mathrm{T}}: \quad \stackrel{\jmath}{\omega}$ мод.

Pоम: мои́хв.

Твор : мойми.

Да ${ }^{\mathrm{T}}$ : мои́мъ.

Ска ${ }^{3}$ : '́ мойхъ.

$B{ }^{\text {A }}$ : мод.

Móe: Cpe

йме ${ }^{\text {म }}$ moé.

उва ${ }^{\mathrm{T}}$ : $\quad \stackrel{\mathrm{\omega}}{\omega} \mathrm{mo \dot {e }}$.

Poम: moérw.

Тво

$\not a^{T}:$ moémy.

Ска ${ }^{3}$ : $\dot{\omega}$ mое́mъ.

$\mathrm{Bu}^{\text {म }}$ : moé.

Дво́йственнагш числа̀.

йме ${ }^{\text {म }}$ Вин. й Зва

Pод: иं $\mathrm{CKa}^{3}:$ mое́ю.

मа ${ }^{\mathrm{T}}$. й Тво мойма.

Мнохестве́ннагш числа̀:

Ймен: мох.

Pоम : мои́хъ.

उва ${ }^{\mathrm{T}}: \quad \stackrel{\mathrm{\omega}}{\omega}$ мох.

Тво : мойми. 

La ${ }^{\mathrm{T}}:$ моimz.
Ска ${ }^{3}$ :
'ं мойхз.

Вин : мод.

тво́й: Mоу ${ }^{\mathrm{K}}$ : Числа̇ е́динстве́ннатш.

Ймен: твӧй.

Poम: TBoérw.

Да ${ }^{T}:$ твое́му.

Bнн: Tвое́ro.

Йе ${ }^{\text {A }}$ : म Ви $^{\text {A }}$ :

Pon: मे $\mathrm{CKa}^{3}$ :

да ${ }^{T}:$ i Tвo $^{p}$ :

Множестве́ннатш числа̀.

hiме ${ }^{\text {A }}$ твой.

Pon: твои́хз.

Да ${ }^{\mathrm{T}}:$ твоймz.

$\mathrm{Bu}^{\mathrm{A}}$ : TBOA.

TBOA: $\mathrm{Ke}^{\hat{\mathrm{H}}}$

Дво́йственнагш числа̀.

Зва́те : лиша́ет"cА.

TBO : TвойMz.

Ска ${ }^{3}$ : $\dot{\omega}$ твое́mъ.
TBOA.

Tвое́ю.

твойма.
Зва́те

Тво : твойми.

Ска ${ }^{3}$ : 'ं твойхъ.

$\mathbf{M}$

числа̀

е́динстве́ннаг

TBOA:

[1046]

Йe ${ }^{\text {A }}$ : TBOA.

Pon: TBOéA.

Да ${ }^{T}:$ твое́й.

Зва́те : лиша́et"ca.

Tво Pि: твое́ю.

Ска ${ }^{3}$ : '́ं твое́й:

$\mathrm{Bu}^{\mathfrak{A}}$ : TBOї.

Йме ${ }^{\text {A }}$ : Ви $^{\text {A }}$ :

Дво́йственнагш числа̇.

Poम: मे $\mathrm{CKa}^{3}$ :

TBòt:

मа ${ }^{\mathrm{T}}:$ и тво $^{\tilde{p}}$ :

TBoéю.

твойма.

Мнохестве́ннагш числа̀.

Ймен: твод.

Poम: твойхз.

Зва́те

Да ${ }^{\mathrm{T}}$ : твойщв.

Твор: твойми.

$\mathrm{Bu}^{\mathrm{A}}$ : Tвод.

Ска ${ }^{3}:$ के твойхъ.

Tвое́: Cpe

Йме ${ }^{\text {P }}$ : твое́ :

Poम: TBOérw.

Да ${ }^{\mathrm{T}}$ : твое́му:

Зва" : лиша́eт"ca.

TBOp: Tвойmb.

$\mathrm{Bu}^{\mathrm{A}}$ : Tвое́.

Ска ${ }^{3}$ : '́㇒ твое́mъ.

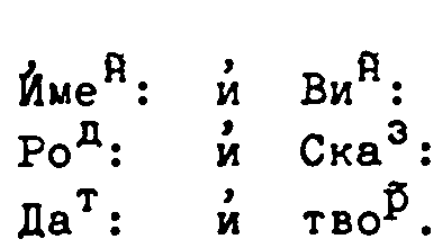

Дво́йственнагш числа̀.

Дво́й

TBOA.

TBoér.

твои́ма. 


\section{$-106-$}

Mножестве́ннагш числа̀.

Ймен. Tвоќ. Зва́те

Род. твойхъ.

Твор. твойми.

Да ${ }^{\mathrm{T}}$. твоймъ.

Сказа ${ }^{\mathrm{T}}$. '́ं твои́хв.

$\mathrm{Bu}^{\text {म. }}$. Tвод.

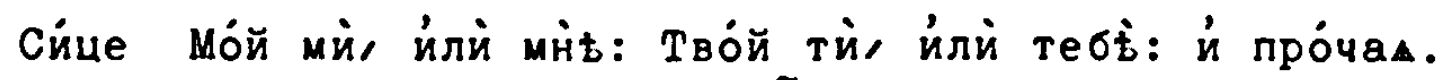
Сво́й: Моу: е́ди ${ }^{\text {ค }}$ числа̀:

йе ${ }^{\text {ศ }}$ : сво́й.

Poम: cвое́rw.

मа ${ }^{\mathrm{T}}$ : свое́my.

$\mathrm{Bu}^{\text {A }}$ : cBoéro.

Йм:

Poम: $\dot{ }{ }^{\text {म }} \mathrm{CKa}^{3}$ :

$\mathrm{Ha}^{\mathrm{T}}:$ i $\mathrm{T}_{\mathrm{BO}}^{\mathrm{p}}$ :
Зва́те

Tво ${ }^{p}$. свойmb.

Сказа ${ }^{\mathrm{T}}$. '́㇒ свое́mъ.

Дво́йственнагш числа̀:

cвоі.

cBoér.

свойма.

MB

Множестве́ннагш числа̀.

Mноже [1056]

Йме ${ }^{\text {म }}$ : свой.

Зва́те : лиша́eт"cА.

Pоम: свойхъ.

Твор: свойми.

Да ${ }^{\mathrm{T}}:$ своймъ.

Ска́за ${ }^{\mathrm{T}}$ : '́㇒ свои́хъ.

Вин: Свод.

Свод̈: Же

Uмен: свод.

Poम: CBOе́A.

Зва́те

да ${ }^{T}:$ свое́й.

твор: cвое́ю.

$\mathrm{Bu}^{\text {म }}$ : cвою.

Сказа ${ }^{\mathrm{T}}$ : '́ं свое́й.

Дво́йственнагш числа̀.

Ймен: и́ Вин. свӧь.

Poम: मे Сказа ${ }^{\mathrm{T}}:$ свое́ю.

मа ${ }^{\mathrm{T}}:$ и тво

Мнохестве́ннагш числа̀.

Ймен: свод.

Зва́те

Pоम: свойхъ.

твор: свойми.

मа ${ }^{\mathrm{T}}$. своймъ.

Сказа ${ }^{\mathrm{T}}$ : '́ं свои́хъ.

Вин. своі.

Свое́: Cpeñ числа̀ е́ди

Ймe ${ }^{\mathscr{A}}$ : cвое́.

Зва ${ }^{\mathrm{T}}:$ лиша́е $\mathrm{T}^{\mathrm{T}}$ сA:

Йंмe $^{\mathrm{A}}$ :

Poम: cBoérw.

मа ${ }^{\mathrm{T}}:$ :

Tвор: своймъ.

Bu ${ }^{\text {म }}$ : свое́. 
Двӧйственнагш числа̀.

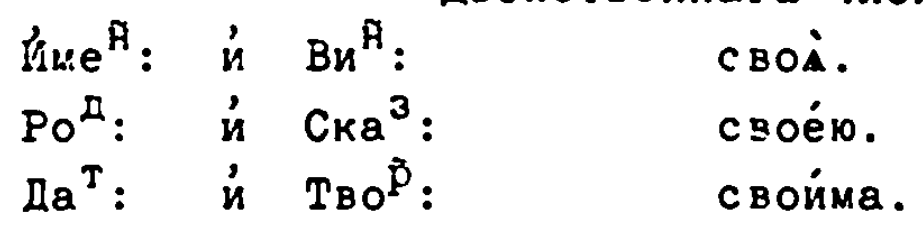

Ціножестве́ннагш числа̀.

Sime ${ }^{\text {मे }}$ cBOA. Зва́те

Po : свойхз. Тво : свойми.

Па ${ }^{\mathrm{T}}$ : своймъ. Ска ${ }^{3}$ : '́ं свойхъ.

Bur : CBOA.

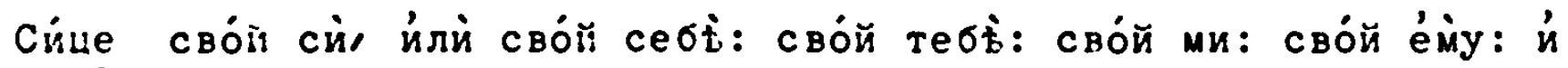
npo ${ }^{q}$.

Кі́й: Џоу*: числа̀ е́динстве́ннагш.

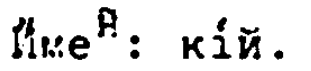

Зва ${ }^{\mathrm{T}}:$ лиша́eт" ${ }^{\text {cA. }}$.

Pon: kóerw.

Да ${ }^{\mathrm{T}}$ : ко́ему.

Тво ко́имъ.

$B u^{\text {म }}$ : kóerw.

Ска ${ }^{3}$ : '́ ко́емз.

Дво́їственнагw числа̀

Дво́й: [1066]

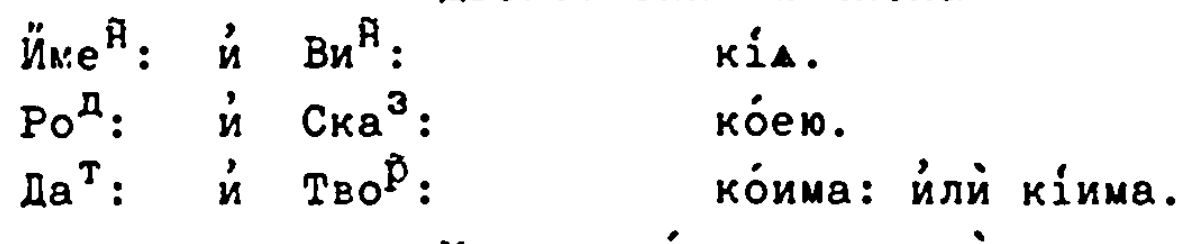

Џнокестве́ннагш числа̀:

йме ${ }^{\text {म }}$ кіи.

Зва ${ }^{\top}$ : лиш.

Pon: кónxb.

Твор : ко́ими йлй, ки́ми.

да ${ }^{T}$ : ко́имъ.

Ска ${ }^{3}$ : 'ं койхъ йлй ки́хъ.

$\mathrm{Bu}^{\mathrm{A}}$ : Kí.

Ка́a: Же ${ }^{\mathbb{R}}$ : е́динстве́ннатш числа̀

Йme ${ }^{\text {f }}$ кán.

Зва ${ }^{\mathrm{T}}$ : лиша́ет "сА.

Poम: KoéA.

Tво : кое́ю.

да ${ }^{\mathrm{T}}$ : кое́й.

Ска ${ }^{3}$ : ‘́ кое́й.

$\mathrm{Bu}^{\mathrm{R}}$ : кую́:

Дво́йственнагш числа̀.

Йu: मे $\mathrm{Bu}^{\text {मี }}$ :

Po :

кí.

मа ${ }^{\mathrm{T}}:$ í TBO

кое́ю.

ко́има, йлй кі́има.

Мнохестве́ннатш числа.

Mное

Зва ${ }^{\mathrm{T}}:$ лиша́ет

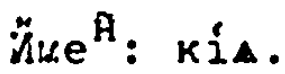

Твор : ко́ими йлй кйми.

Pon: койXз.

C:

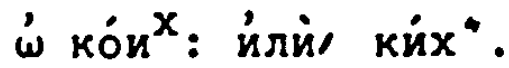

Да ${ }^{\mathrm{T}}$ : ко́имъ.

Bu ${ }^{\text {A }}$ Kí. 
Кое́: Cpe

Йme ${ }^{\text {म }}$ ко́e: Зва ${ }^{\mathrm{T}}$ : лиша́етъсА.

Poम: kóerw. Tво ₹ : ко́имz.

$\not a^{T}:$ ко́емy. Ска ${ }^{3}$ : í ко́енъ.

$\mathrm{Bu}^{\text {ค }}$ : кóe.

Двӧйственнагш числа்.

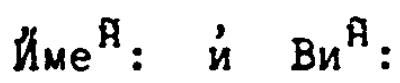

Kí.

Poम: is $\mathrm{CKa}^{3}$ :

кóeю.

$\mathrm{La}^{\mathrm{T}}:$ is $\mathrm{T}_{\mathrm{BO}}^{\mathrm{F}}$ :

ко́има, и́лй кі́иа.

Мнохестве́ннагш числа̀.

Йme : Ко́. Зва ${ }^{\top}:$ лиша́ет"сА.

Poम: ко́ихъ. Твор̃ ко́ими, йлй кійми.

Да ${ }^{\mathrm{T}}$ : ко́имъ. '́ ко́й йлй кихх".

$B n^{\text {म }}$ : KíA.

Си́uе нб́кій, нб́каa, нб́кое: Никій же, ника́ же, нико́е же: Кійждо, ка́аждо, ко́еждо: Ко́йлибо, кайлибо, кое́либо. $M L$ чі́й: Моуж: Числа̀ е́динстве́ннатш: чำ:

Йе ${ }^{R}:$ чій: Зва ${ }^{\top}:$ лиш:

Poम: पiérw. Tво ${ }^{\text {p }}:$ чїйив:

$\not a^{T}: 4$ iéuy. Ска ${ }^{3}$ : $\dot{\omega}$ чїém子.

$\mathrm{Bu}^{\text {म }}$ : viéro.

Дво́йственнагш числа̀.

Йе ${ }^{\text {म }}:$ иे $\mathrm{Bu}^{\text {म }}$ :

yía.

Poम: मे $\mathrm{CKa}^{3}$ :

पiér:

да ${ }^{\mathrm{T}}:$ मे $\mathrm{T}_{\mathrm{BO}}^{\mathrm{p}}$ :

чіัйма.

Мнохестве́ннагш числа̀.

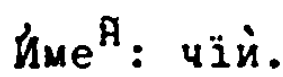
Зва" : лиша́ет"

Poम: $4 \bar{z} \dot{u} \times z$. Tвор : чійми.

Да ${ }^{\mathrm{T}}$ : чіимъ. Ска ${ }^{3}: \quad \dot{\omega} ч \bar{\imath} \dot{x}$.

$B u^{\text {मी }}$ पì.

Чіа: Же $\mathrm{e}^{\text {म }}$ е́динстве́ннагш числа̀.

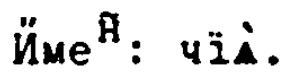
Зва́те

Pon: पiéa. TBO ${ }^{p}:$ पìé.

Да ${ }^{\top}:$ чіе́й. Ска ${ }^{3}:$ 'ं ч чіе́й.

$\mathrm{Bu}^{\mathrm{P}}: 4 \bar{i}$.

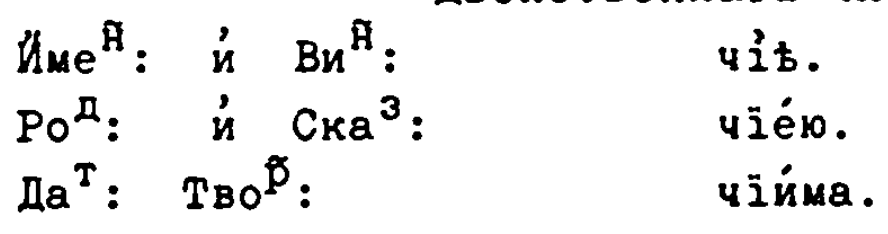


Мнохестве́ннатш числа̀.

Sime ${ }^{\text {A }}$ पi $\dot{i}$.

Зва ${ }^{\mathrm{T}}:$ лиша́ет "са:

Pol: 4 ilixb:

Tво : पійми.

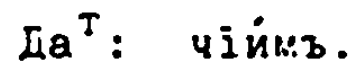

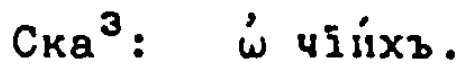

$\mathrm{Bu}^{\mathrm{A}}: 4 \mathrm{i} \dot{\mathrm{A}}$ :

Чіé: Cpe

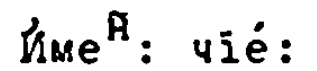

Зва" : лиша́eт"

Poll: पiérw.

Tво

да ${ }^{T}$ : $u \bar{i} u y$.

Ска ${ }^{3}:$ '́ ч

$\mathrm{Bu}^{\mathrm{A}}: 4 \xi \dot{e}$.

$$
\begin{aligned}
& \text { Дво́йственнагш числа். } \\
& \text { Ŭme }{ }^{\text {A }} \text { : } \\
& \text { บiá. } \\
& \text { Poम : } \quad \text { प } \mathrm{CKa}^{3} \text { : } \\
& \text { La }{ }^{\mathrm{T}}: \text { } \dot{\mathrm{u}} \mathrm{T}_{\mathrm{BO}} \mathrm{P}^{\hat{0}} \text { : } \\
& \text { पi อ̇o. } \\
& \text { чіймa: }
\end{aligned}
$$

Сйе, ньчій ньчї ньчіе́.

на́wъ: Ноу: числа̀ е́ди ${ }^{\mathrm{A}}$ :

Ŭме ${ }^{\text {: }}$ на́шъ.

Зва ${ }^{T}: \quad \stackrel{3}{\omega}$ на́шъ:

Pon: нámerw.

Tво ${ }^{\mathrm{p}}$ : на́шимъ.

да ${ }^{\mathrm{T}}$ : на́шемy.

Ска ${ }^{3}$ : $\dot{\omega}$ на́шемъ:

$\mathrm{Bu}^{\mathrm{A}}$ : нáwero.

Дво́йственнагш числа.

经: $\mathrm{Bu}^{\mathrm{A}}:$ и $3 \mathrm{Ba}^{\mathrm{T}}$ :

нáma.

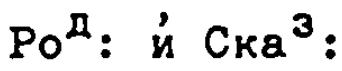

Háwer.

$\not a^{T}:$ и $\mathrm{T}_{\mathrm{BO}}{ }^{\tilde{p}}$ :

на́шимa.

Мнохестве́ннатш числа̀.

Úме : на́ши.

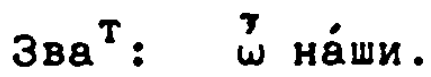

Poम: на́шихъ.

Твор : на́шими.

да ${ }^{\top}:$ на́шимъ.

Ска ${ }^{3}$ : $\dot{\omega}$ на́шихъ.

Вй ${ }^{\text {A }}$ нáwa.

Háwa: Же$e^{\text {म }}$ е́ди ${ }^{\text {म }}$ числа̀:

Йме ${ }^{\text {A }}$ на́ma:

$\not a^{\mathrm{T}}:$ на́шей:

Poम: нámea. дa $^{\mathrm{T}}$ :

$\mathrm{Bu}^{\mathrm{A}}$ : нáwy:

Tвор : нámeю:

Сказа ${ }^{\mathrm{T}}$ : $\dot{\omega}$ на́шей. 
Зва ${ }^{\top}: \stackrel{\text { w }}{\omega}$ на́wa.

Дво́йственнагш числа்.

Йме ${ }^{\text {A }}: B и^{\tilde{A}}: \dot{и}$ Зва $^{\mathrm{T}}$ :

หघ்யむ.

Pод: и Ска $^{3}$ :

нáwe

$\mu_{a}{ }^{T}: \dot{и} \mathrm{~T}_{\mathrm{B}}$ :

на́шина.

Множестве́ннагш числа̀.

Йме ${ }^{\AA}:$ на́ша: Зва $: \quad \stackrel{w}{\omega}$ на́шА:

Род: на́шихъ:

Твор: не́шими:

Да ${ }^{\top}:$ на́шимъ :

Сказа' : '́ на́山ихъ.

$\mathrm{B}{ }^{\text {म }}$ : нáwa:

На́ше: Cpe

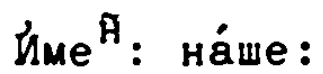

Зва ${ }^{\top}: \quad \stackrel{+}{\omega}$ нáwe.

Poम: нáwe rw:

тво $\bar{p}:$ на́шимз :

Дa ${ }^{\mathrm{T}}$ : на́шемy:

$\mathrm{CKa}^{3}:$ '́ на́шемъ:

$\mathrm{Bu}^{\mathrm{A}}$ : нáwe.

Дво́йственнагш числа்.

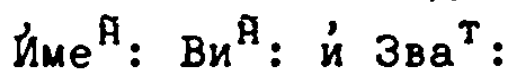

нáma:

Pоम: и $\mathrm{CKa}^{3}$ :

нámero.

Да ${ }^{\mathrm{T}}:$ иं тво $^{\hat{\mathrm{p}}}$ :

на́шима:

Множестве́ннагш числа̇:

亿̆мен: на́ша.

Зва ${ }^{\mathrm{T}}: \quad \dot{\omega}$ на́ша:

Род: на́шихв.

твор : на́шими :

Да ${ }^{\mathrm{T}}$ : на́шимъ :

Ска ${ }^{3}: \quad \dot{\omega}$ на́шихъ :

$\mathrm{Bu}{ }^{\text {म }}$ : нáwa.

Ва́шъ: моу $^{\text {}}:$ е́ди ${ }^{\AA}:$ числа̀:

Ймен: ва́шъ:

Зва́те

Poम: вámerw:

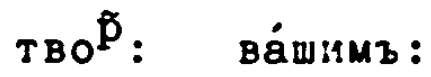

Да ${ }^{\mathrm{T}}:$ вáwemy:

Pon:

вин: ва́wero.

Сказа ${ }^{\mathrm{T}}: \dot{\omega}$ ва́шемъ.

Дво́йственнагw числа்.

Ймен: 'и Вин:

Род: й Сказа ${ }^{\mathrm{T}}$ :

$\operatorname{дa}^{\mathrm{T}}:$ и $\mathrm{\tau}$ во ${ }^{\mathrm{p}}$ :

вáma.

вáuero.

ва́шима.

Множестве́ннагш числа̀.

Ймен. ва́ши.

Зва́те

Poम: ва́шихъ:

тво р. ва́шими.

Да $\mathrm{a}^{\mathrm{T}}$ : ва́шимъ.

Сказа' ${ }^{\top}$ '́ ва́шихъ.

Bи ${ }^{\text {ค }}$ : вáwA.

Báma

Báma: Же : Числа̀ е́динстве́ннагw. 
亿́me ${ }^{\text {. }}$ вáma.

Poㅁ: вámea.

да ${ }^{T}$. ва́шей.

$\mathrm{Bu}^{\text {मे. }}$ вámy.

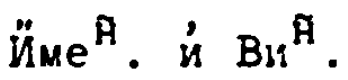

$\mathrm{Po}^{\text {म. }}$. $\mathrm{CKa}^{3}$.

$\mathrm{Ia}^{\mathrm{T}}$. í $\mathrm{TBO}^{\mathrm{p}}$.
Зва́те

Tво p. вámeю.

Ска ${ }^{3}$. $\dot{\omega}$ ва́шей.

Дво́йственнагш числа̀.

вáuも.

вámeю.

ва́шима.

Мнохестве́ннагш числа̀.

Йме $e^{\text {म }}$ : вáwA.

Poम: вámихъ:

Зва ${ }^{\mathrm{T}}:$ лиша́ет"сА.

Да ${ }^{\mathrm{T}}$ : ва́шимъ:

Tro : ва́шими.

Bй ${ }^{\text {A }}$ Báwa.

Ска ${ }^{3}$ : $\dot{\omega}$ ва́шихъ.

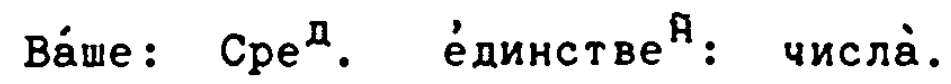

Йme ${ }^{\text {A }}$ : вáwe:

Poम: Bámerw:

Зва" : лиша́ет"сA:

да ${ }^{\mathrm{T}}:$ ва́шему:

Tво : ва́шимъ.

$\mathrm{Bu}^{\text {म }}$ : Báme:

Ска ${ }^{3}:$ '́ ва́шемъ.

Дво́йственнагш числа̀:

Дво́й

Йме ${ }^{\text {म }}$ :

вáma:

Po $:$ i $\mathrm{CKa}^{3}$ :

вámeю:

$\mathrm{Ia}^{\mathrm{T}}:$ и $\mathrm{T}_{\mathrm{BO}}^{\mathrm{p}}$ :

ва́шима:

Множестве́ннагш числа̀.

Úme ${ }^{\text {ศิ }}$ вáma:

Зва" : лиша́ет"са.

Pоम: ва́шихъ:

Твор: ва́шими.

Да ${ }^{\mathrm{T}}:$ ва́шимъ:

Сказа ${ }^{\mathrm{T}}$ : '́̀ ва́шихъ:

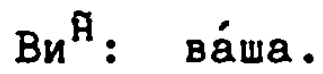

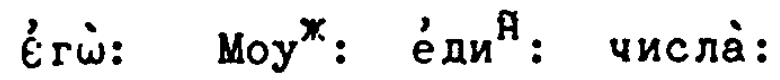

Йме : лиш:

Зва" : лиша́ет" са:

Pon: érì:

TBO : ЙMB:

да ${ }^{\mathrm{T}}$ : émy :

Сказа ${ }^{\mathrm{T}}$ : $\dot{\omega}$ ёмъ: й блгогла́сіа дь

Ви ${ }^{\text {A }}$ éró йли й:

תА $\dot{\omega} \mathrm{He}^{\mathrm{M}}$ :

Дво́йственнагш числа̀.

亿име ${ }^{\text {म }}$ :

à:

Poम: и $\mathrm{CKa}^{3}$ :

ëro.

मа ${ }^{\mathrm{T}}:$ и $\mathrm{T}_{\mathrm{BO}}{ }^{\mathrm{p}}$ :

Hัma.

Hноте

Множестве́ннагш числа̀.

Viме ${ }^{\text {: }}$ лиш:

Зва́те ${ }^{\pi}$ : лиш.

P०म : й×ъ:

тво : йми. 
Да ${ }^{\mathrm{T}}: \quad \ddot{и ̆}_{\mathrm{B}}:$

$\mathrm{Bu}{ }^{\text {म }}$ : 它.

Йме ${ }^{\text {: }}$ лиш.

Ска ${ }^{3}$ :

$\dot{\omega}$ йхъ: $\dot{и}$ блгогла́сіћ ра́ди 'े ниххв:

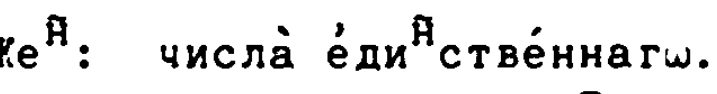

Pon: éd.

да ${ }^{\top}:$ éй.

$\mathrm{Bu}^{\mathrm{A}}$ : $\mathrm{n}$ :

$388^{\mathrm{T}}$ : лиш.

TBop̃ : ёю.

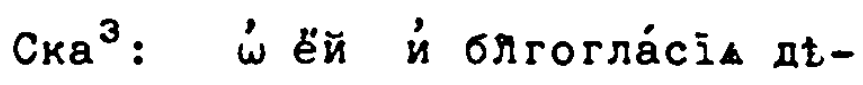
лА 'ं не́и.

Дво́йственнагш числа̀.

לиме ${ }^{\text {म }}$ :

Po ${ }^{\text {I }}$ : मे $\mathrm{CKa}^{3}$ :

да ${ }^{\mathrm{T}}:$ i $\mathrm{T}_{80}^{\mathrm{p}}$ :

$\hat{\xi}$.

ëю.

йма.

Множестве́ннагш числа̀.

йме ${ }^{\text {म }}$ лиш:

Зва́те

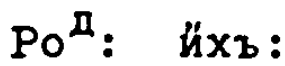

Твор : йми.

$\not a^{T}:$ ймъ.

Ска ${ }^{3}:$ 'ं нйхз.

$\mathrm{Bu}^{\mathrm{A}}: \mathrm{i}$ :

Érì: Cpen. ézи ${ }^{\text {A }}$. числа̀.

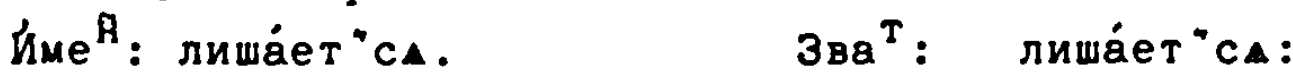

Pon: érì:

Tво ${ }^{\mathrm{p}}$ : ймз :

дa ${ }^{\mathrm{T}}$ : émy :

Ска ${ }^{3}: \quad \dot{\omega} \mathrm{e}^{M}: \dot{и}$ блгогла́сїа дь-

$B u^{\mathrm{A}}$ : ë:

ла $\dot{\omega} \mathrm{He}^{\mu}$.

érì:

[III6]

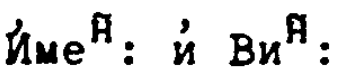

Poम: иं Ска ${ }^{3}$ :

$\mathrm{Ha}^{\mathrm{T}}:$ i $\mathrm{TBO}^{\mathrm{p}}$ :

Дво́йственнагш числа̀.

á:

ěю:

Йma:

Множестве́ннагш числа:

亿ме ${ }^{\text {म }}$ лиш.

Зва" : лиша́eт"

Poम: Йхъ.

Твор: йми.

मа ${ }^{\mathrm{T}}$ : ймъ.

Ска ${ }^{3}:$ '่ нйхз.

$\mathrm{Bu}$ : $\hat{a}$.

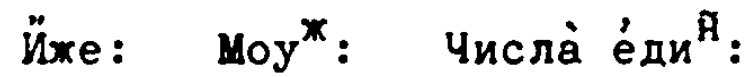

Ймe ${ }^{\text {म }}$ : йжe :

Poln: érí xe:

Зва́те ${ }^{\Re}:$ лиша́етсA:

$\not a^{T}$ : émy x́e:

TBO ${ }^{\tilde{p}}$ : йм же:

$B n^{\text {म }}$ : éró xe

$\mathrm{Cка}^{3}:$ के не

Дво́йственнагш числа̀.

Дво́й

Йm: ห่ $\mathrm{Bu}^{\mathrm{A}}$ :

Роम

ăxe.

ëю xe: 
La ${ }^{\mathrm{T}}:$ й Tвор :

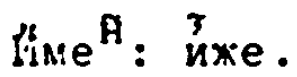

йма же.

Mножестве́ннагш числа̀.

Pon: йx жe. Зва" : лиша́ет" ${ }^{\top}$ :

Да ${ }^{\mathrm{T}}$ : Йм же.

Tво : Йи же:

$\mathrm{Bu}^{\mathrm{P}}$ : Taxe.

Сказа ${ }^{\mathrm{T}}$. 'ं нйх же.

ḦAxe: Же$e^{\text {A }}$ е́ди ${ }^{\text {म }}$ числа̀:

Úue ${ }^{\text {R }}$ : "axe.

Pon: èd xe.

Зва". лиша́ет"сA.

да ${ }^{\mathrm{T}}$ : е́й же:

TBO p. éí жe.

$\mathrm{Bu}^{\mathrm{A}}$. म̈ $\mathrm{xe}$.

Ска ${ }^{3}$. 'ं не́й же.

lime ${ }^{\text {म }}$ :

Дво́йственнагш числа̀.

Poम: и $\mathrm{CKa}^{3}$ :

๖ய̈e :

да ${ }^{\mathrm{T}}$ : и $\mathrm{T}_{\mathrm{BO}}{ }^{\mathrm{p}}$ :

ёю we:

йма же.

Uhue : Yaxe:

Множестве́ннатш числа̀.

Pon: Йx жe.

Да ${ }^{\mathrm{T}}:$ Йм же:

Зва : лиша́етъса

Вин: raxe:

$\mathrm{H}$ 3ва ${ }^{\mathrm{T}}$ :

Твор: йми же.

[1126]

$\mathrm{Cка}^{3}$ : $\dot{\omega}$ нйх же.

l:же: Cре

Йue ${ }^{\text {R }}$ : ëжe :

Зва": лиша́ет"cА.

Pon: érí xe.

Tвор: йм же:

да ${ }^{\mathrm{T}}$ : émy $\dot{x e}$.

Ска ${ }^{3}$ : $\dot{\omega} \mathrm{He}^{M}$ же.

$\mathrm{Bu}^{\mathrm{A}}$ : ĕme:

Й : मे $\mathrm{Bu}^{\mathrm{A}}$ :

Poम : и $\mathrm{CKa}^{3}$ :

Да ${ }^{\mathrm{T}}:$ и $\mathrm{T}_{\mathrm{O}}^{\mathrm{p}}$ :

Дво́йственнагш числа்.

äxe.

ëю xe.

йма же.

Множестве́ннагш числа̀.

Йme : Yoxe:

Poम : йx xe:

Ia ${ }^{\mathrm{T}}:$ йm жe:

$\mathrm{Bu}^{\mathrm{P}}$ : Yoxe:
Зва" : лиша́eт "сA:

Твор : йми же:

$\mathrm{Cка}^{3}$ : 'ं нйхъ же:

Оу́вьще́ніе

Вы́стно бўди $c$ " предло́гомъ полага́емое е́rí: прийма́ти со тре́-

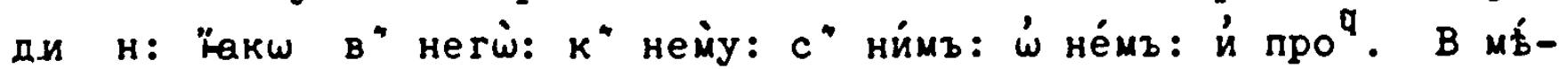

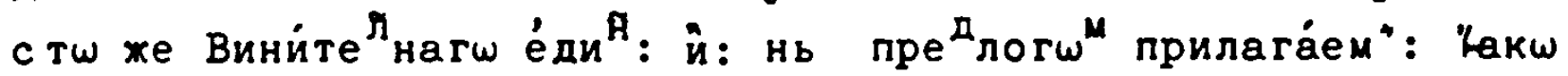
на́ нь: То́жде твори́телно ёстъ й со йже: во всы́xъ ро́дехъ. 


\section{- 114 - \\ ¿ ГЛАГОЛЕ:}

Глаго́лъ, ёстъ ча́сть сло́ва силанд́енањ со ра ${ }^{3}$ личннии наклоне́ніи й времены ды́́̆ство йлй стра́сть йлй сре́днее что́ знамену́ющах .

Глаго́лъ ёстъ четверогу́бъ.

$\left\{\begin{array}{l}\text { Лйчный: } \\ \text { Безли́чный: } \\ \text { Стро́потный: и́ } \\ \text { Лиша́емый: }\end{array}\right.$

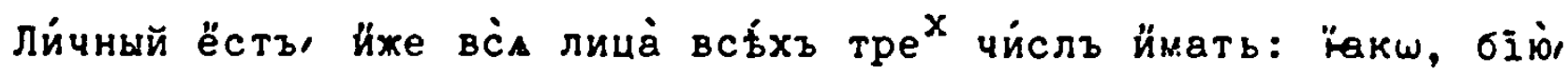
біёши, біе́тъ: біе́ва, біе́та: біе́мъ, біете́, бію́тъ.

Безличчный ёстъ, йже пе́рвагш й вто́рагш лица̇, всбхъ тріе́хъ чйслъ, в" мнш́гих же и́ тре́тіАгш множествённагш лишаетъсА. Се́й сугу́бъ ёстъ: ( ठ̆въ Дьйствйтелнагш й знаменова́ніА й спраже́ніА: "акw, подоба́етъ, досто́итъ, льяь ёстъ: иं про

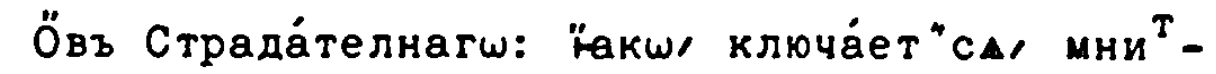
са, глет"са: й проंчаa.

Cтро́

[1136]

Стро́потный ёстъ, йже по пра́вилу ли́чны не спрага́ет"са. Ï̈кш/

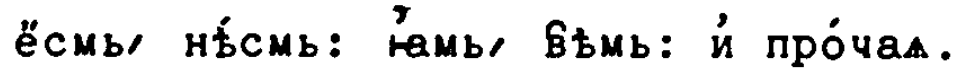

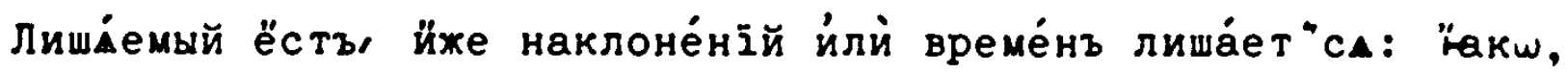
ṕ́xъ: оу́снуy: и́ про́чам.

Пе́рвое Гла личчнагш раздђле́ніе.

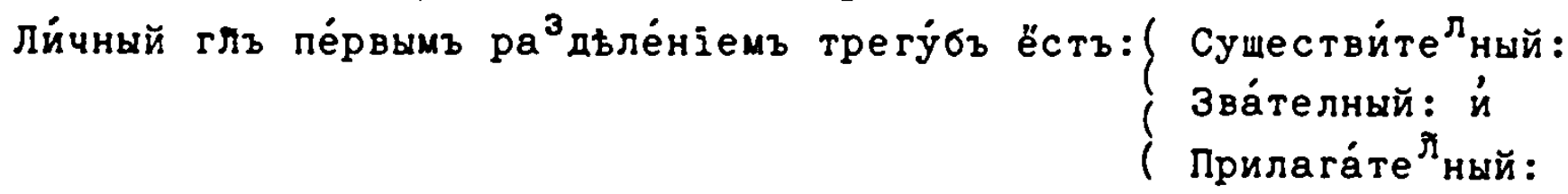

Существйтелный е́стъ, йже ве́шъ $\dot{\omega}$ себђ́ стод́щую, нй же дьйству́ющую ни́ же стра́хдущую знамену́етъ: Сицевъ гль е́стъ, ёсмь: й быва́ю:

Зва́телный ёстъ, йже со́бстве ${ }^{\text {म }}$ ну́етъ: "акш, нарица́юса Пе́тръ: Сйцеви гли сутิь и́мену́юса, нарица́юса, зову́са, прозыва́юса, глюса.

Прилага́телный ёстъ, йже йлй ды́ланіе, йлй страда́ніе, йлй сре म̆не что் знаменуетъ: Тако́ви субъ всй про́чій гли, существйтелным" й зва́телны" йзі́ты".

Вто́poе гла личчнагш раздђле́ніе.

зто́poe

Вторы ${ }^{M} \mathrm{pa}^{3}$ дьле́ніе глъ сугу́бъ ёстъ. ( Преходйтелный, й

Преходи́телный ёстъ, йже бе ${ }^{3}$ приложёніА падежА, соверше́ннато 
ра́зума не тво́ритъ: "̈акш, любліо творю́: й про".

Самостод́телный ёстъ, ӥже '́ себі соверше́н" ра́зумъ, бе ${ }^{3}$ при-

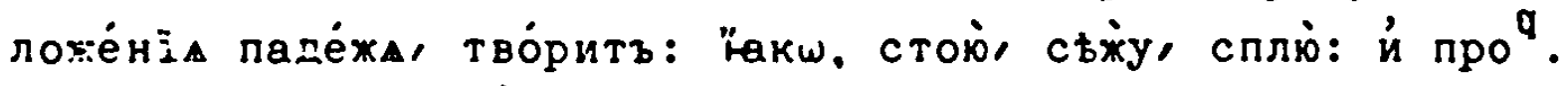

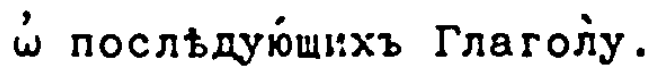

Посл夫дјютъ глу де́вать.

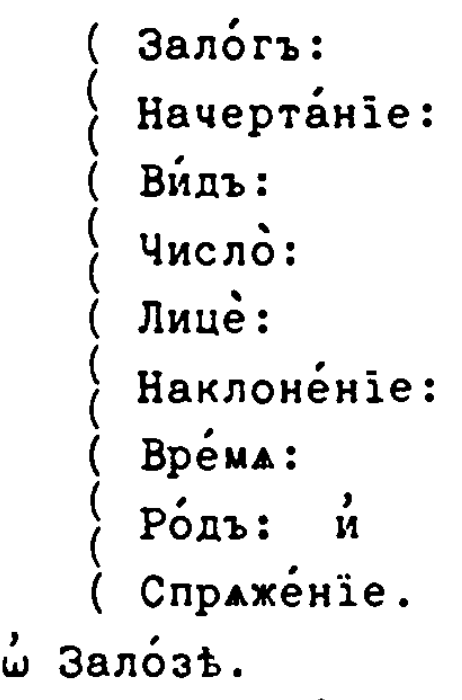

Зало́гъ, ёстъ случчай, йже глагі́лъ ф́конченіе со знаменова́нїемz 'авл́етz. $\mathrm{Hr}$ Зало́

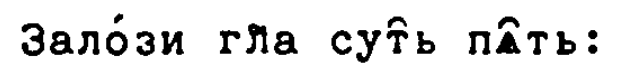

$$
\left\{\begin{array}{l}
\text { Дьйствителный: } \\
\text { Страда́телный: } \\
\text { Сре́дній: } \\
\omega^{\top} \text { ложителный: й } \\
\text { о̋бщі̆ : }
\end{array}\right.
$$

Дьйстви́телный залогъ ёстъ, йже ды́̆ство знамену́етъ, й сло́га,

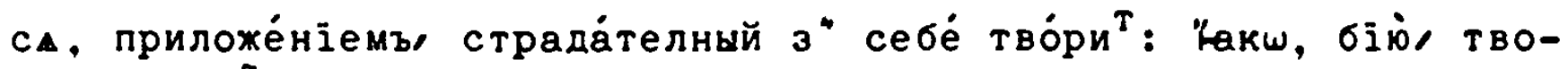
pio: '́ про

Страда́телный ёстъ, йже страда́ніе знамену́етъ, й $3 а \omega^{T}$ ложе́ніемъ, са, сло́га, дьйстви́телный быва́етъ: Гакш, бї́сса, творі́са: и́ про ${ }^{q}$.

Сре́дній ёстъ, йже нй дййство знаменуетъ нй страда́ніе, й во

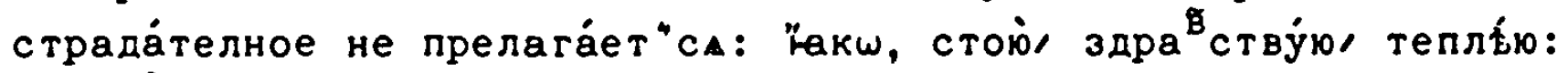
й про ${ }^{q}$.

$\omega^{T}$ ложителный ёстъ, йже '́конче́нїе ойбш страда́телнагш йма ${ }^{T}$,

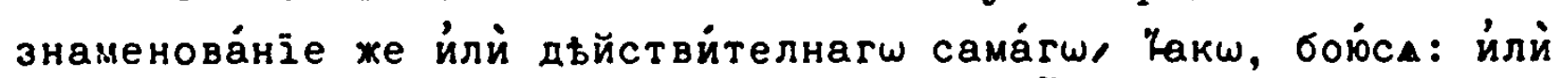
can:árw cре

о̋бщій ёстъ, йже '́конче́ніе страда́телнагш йма ${ }^{T}$, знаменова́нїе же дђйстви́телнагш в" ку́пь и́ страда́телнагш: "акш, каса́юса: и́ npo ${ }^{q}$.

$$
\text { Разли́чіе зали́гъ. }
$$$$
\mathrm{Pa}^{3} \boldsymbol{л и}
$$

Разли́чіе ме́жду страда́телны ${ }^{M}, \omega^{T}$ ложителны ${ }^{M}$ й ӧбщимъ: $\omega^{T} \dot{A} т у$ 


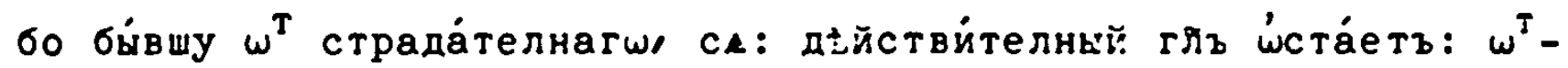

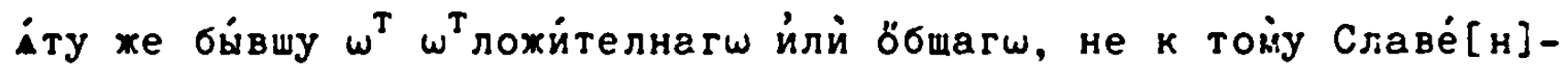

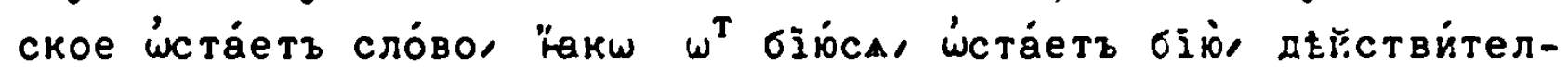

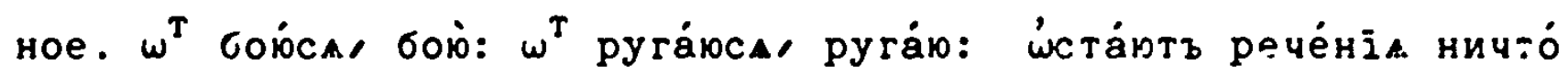
же Славе́нски знамену́юшақ.

Ме́жду дъйствителн:" же и́ Сре́дним" различчіе ёстъ: "̈акш ӧнъ оӱбш восприх́тіе ${ }^{M}$, сA, тво́ритъ страда́телннт̆, ӧвъ же знаненова்-

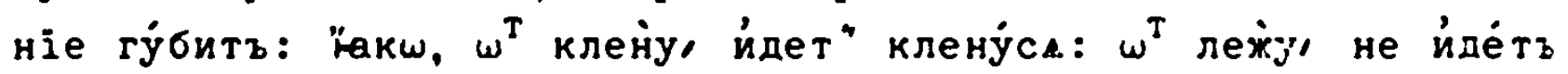
леху́сA.

ஸे Начерта́нїи.

Начерта́ніе глгола̀ ёстъ трегубо. ( Просстое: Накшر є̈:лю.

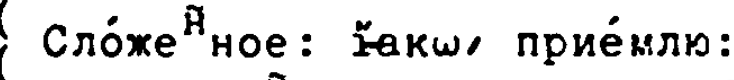

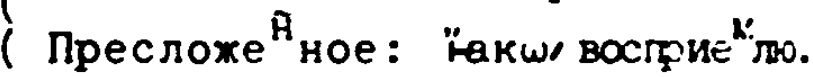

'ं Bínt:

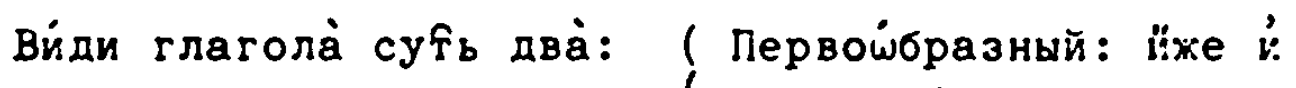

Соверше́нный: ت̈акш, чтуу стою: й

про́чам. $\dot{и}$

Произво́дныц: :

Hд Про

[1156]

Производный сугу́бъ ёстъл( Øвъ ођббш Начина́телный: Пакш. каме-

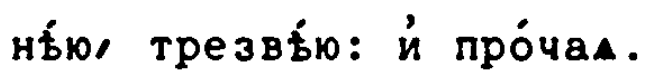

Őв же О’учаща́телный: "̈акш. чита́юл ставár: й про́чаa.

Начина́телный ёстъ, йже ве́ть начина́ему знамену́етъ, $\dot{~}$

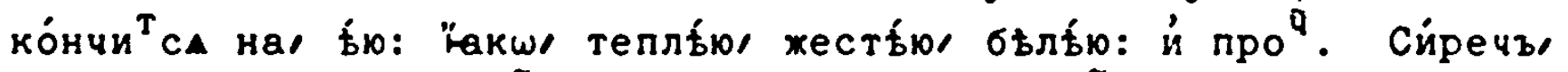

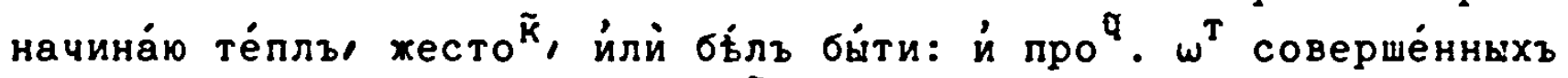
гль, тепліо, жецेу б土лї: й про

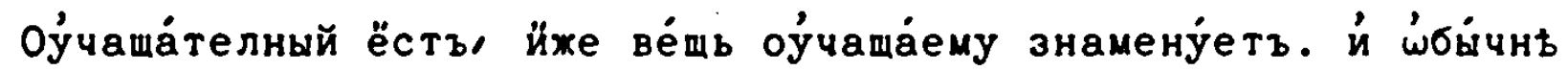

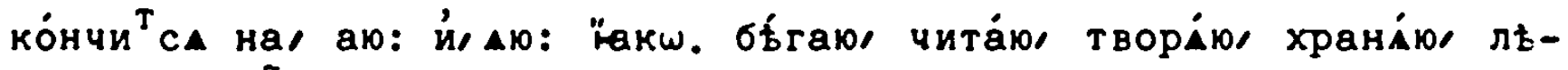
та́ю: й про . Си́речъ, ча́стш бб́гъ, йлй чте́нїе, лйбо творе́ніе, й

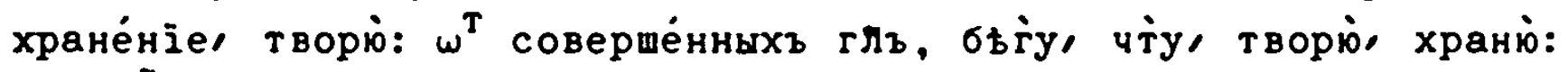
и nрo ${ }^{q}$.

числа̀ гла трй суТь.

'́ чистіь.

ध̈динстве́нное: "акш, глю.

Дво́йственное: "акш: гле́ва.

множестве́нное: "акш, глем" О’́вь

Оўв вще́нїе.

Славіне Пако те во Йменехъ, сйце й во Глехъ дво́йственное ймуть число́, по всђ трі́мъ ро́дшмъ/ во всб́хъ тре́хъ лицехъ скла- 
háenoe.

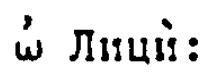

Лица̇ гла суริь три: $\begin{aligned} \text { ( Пе́рвое: } \\ \text { ( Вто́рое: } \\ \text { (Тре́тіе: }\end{aligned}$

Пе́рвое лице́ ёстъ, е́ку́ же кое́либо сих приложитиса мо́хетъ.

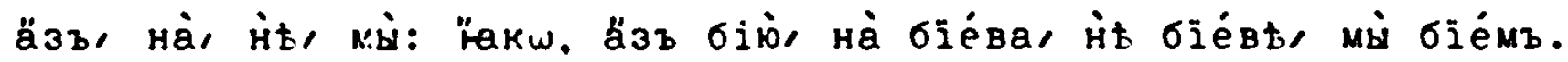

Вто́рое лице́ ёстъ, е́му же кое́либо сих" прилохитиса мохетъ,

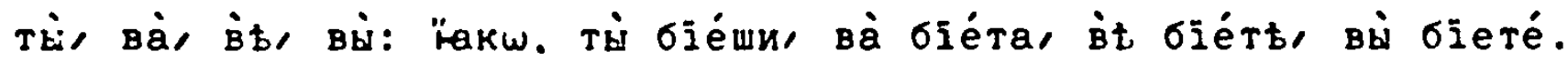

Тре́тіе лице́ ёстъ, е́му же кое́либо сих" прилохитиса мо́хетъ.

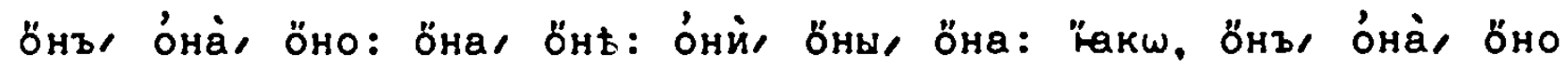

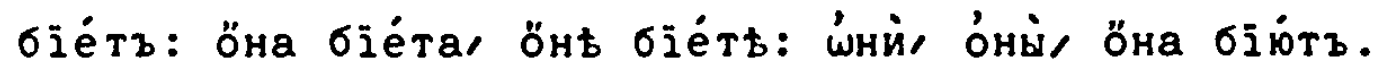

\section{Оу́вње́ніе :}

$\mathrm{H \tau}$

Повелй

Повели́телный й மіолителный пе́рвагш лица̇ во е́динстве́ннш" чисj̇t лиша́ют" $\mathrm{CA}$.

$$
\text { '́ Наклоне́ніи. }
$$

Наклоне́ніе ёстъ слу́чай, йже различчный д́йства йлй страда́ніА ӧбразъ пока́зуетъ.

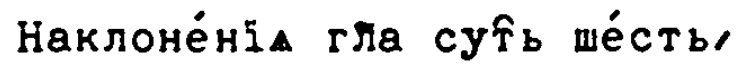

$$
\left\{\begin{array}{l}
\text { Изъави́телное: } \\
\text { Повелиттлное: } \\
\text { Моли́телное. } \\
\text { Сослага́телное: } \\
\text { Подчинителное: й } \\
\text { Неопредєле́нное. }
\end{array}\right.
$$

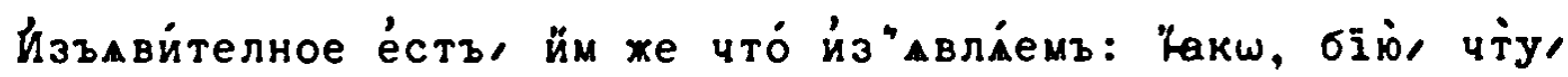
стою: 'и про ${ }^{q}$.

Повели́телное ёстъ, йм же что́ повельва́емъ: Какш, бій, чтй, сто́й.

Моли́телное, йм же '́ чесо́мъ мо́лим": "̈акш, оу́сль́ши, во́ними, прйзри.

Сослага́телное, йм же сослага́телнь бы́ти что́ оуввшава́ем": تа$\kappa \omega$, ёше бы хотьлъ, да́лъ бы.

По чини́телное, ёже в" ра́зума соверше́ніе друго́й сло́ва ча́сти

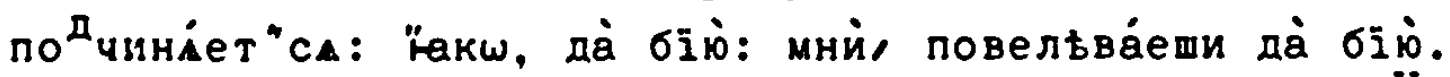

Heonpe [I17]

Неопредұле́нное, ёже вре́ма йзъавлін., числа̇ лица̇ и́ ро́да не опредьлиетъ: 'акш, би́ти, стод́ти: й прочал.

$\dot{\omega}$ Вре́мени.

Вре́мА ёсть слу́чай, йже йлй настои́mеe, йлй Преше́дшее, и́лй 
грАдучщее дђйство лйбс страда́нїе 'авліетъ.

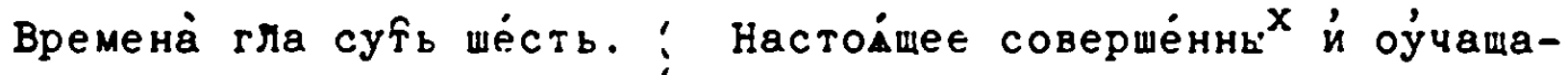

телнихъ.

Преходи́mеe :

Преше́ дшеe:

Мимоше́ дшеe :

Непредє́лное: $\dot{n}$

Буं дущеe :

Настои́щеe ёсти, йм же настов́щее д\{́̆ство йлй страда́нїе знаме-

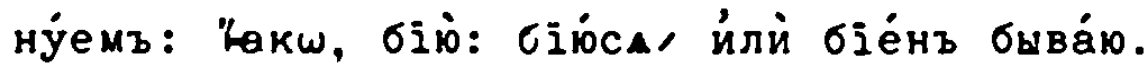

Прехода́щее ёстъ йм же несоверше́ннш про́шлое д\{йство йлй страда́нїе знаменуемъ: Какш, би́хъ: бйх"сА, илй біе́нъ е́смь, й б̆́xъ.

Преше́дшеe ёстъ йм же Соверше́ннш пре́шлое дййство илй стра-

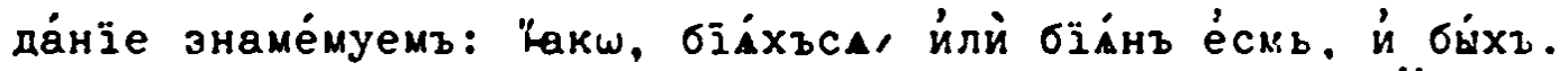

Mик:о [1176]

Мимоше́дшее ёстъ, йм же дре́вле совершенннш преше́дшее дєйство

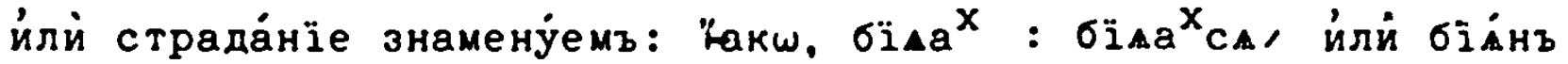
быва́хъ .

Непред\{́лное ёстъ йм же в ма́ль соверше́ннш пре́шлое дбйство йлй страда́нїе зна́менуемъ: 'акш. побйхъса, йлй побїенъ бйхъ.

Буддущее ёстъ, йм хе градујщее ды̆йство йлй страда́нїе знамену́емъ: 'акш, побію́: побініса, йлй побїе́нъ бу́ду.

\section{¿́ Составле́ніи Време́нъ.}

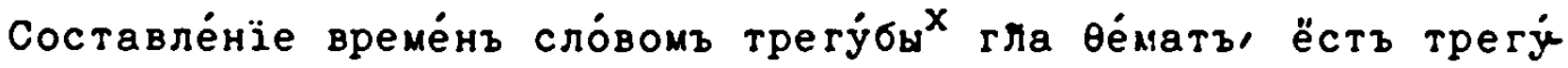

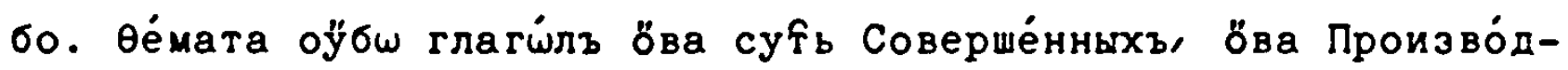

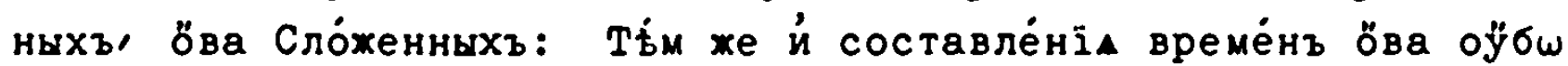
быва́ю ${ }^{T} \omega^{T}$ соверше́нны ${ }^{X}$, ӧва $\omega^{T}$ начина́те ${ }^{\eta_{H b}}{ }^{X}$ й оуччаша́телны ${ }^{X}$, о̆ва же $\omega^{T}$ сло́хенньхъ: Всб́мъ о́бáче про́чіи ${ }^{M}$ и́сто́чни ${ }^{R}$ ёстъ Өе́мa глъ соверше́нныхъ: "акш, $\mathrm{B}$ " схиматі́сма сиххъ вйдьти ёстъ.

Схима

Схиматі́мъ составле́ніА глъ Совершённыхъ й Ојча́mателнь ${ }^{x}$.

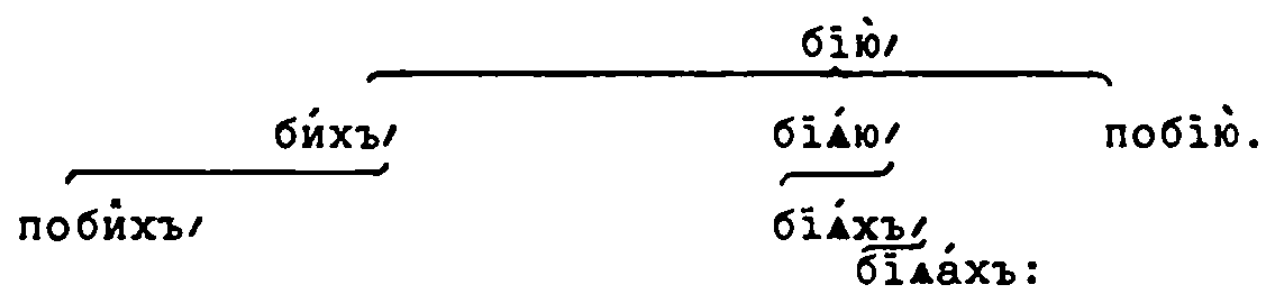

Схиматісмъ Составле́ніА глъ Сло́хенньхъ:

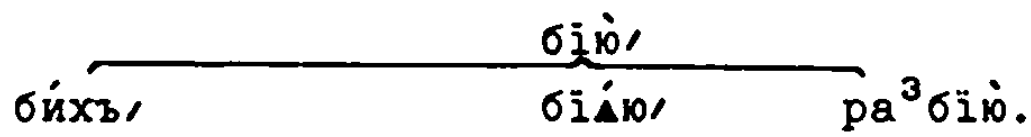




$$
\begin{aligned}
& \frac{-119-}{\mathrm{pa}^{3} \sigma i \mathrm{i} 101} \\
& \overbrace{\mathrm{pa}}{ }^{3} \sigma \mathrm{i} \wedge \dot{\mathrm{a} x \mathrm{z}} \text {. }
\end{aligned}
$$

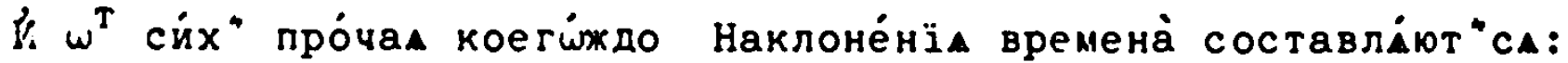
$\dot{\omega}$ йх же составлёніи на свойхъ йаъ мб́стехъ.

$\dot{\omega}$ Pónt.

Póдъ

[1186]

Pónъ гяа, ёстъ спра га́емыхъ глъ по ро́дшмъ склоне́ніе.

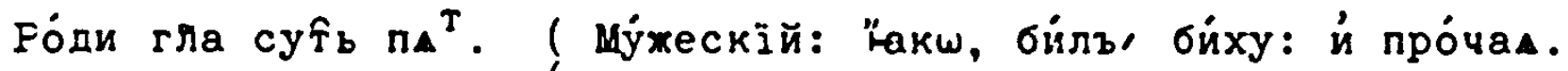

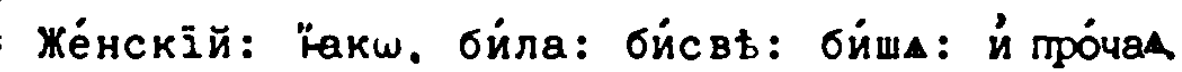
Сре́дній: "̈акш, бйло: й про

ठбщее: Какш, бйсва: бйша.

( Вси́кій: Какw, бїю, біе́ши, бїе́тъ, біе́мъ,

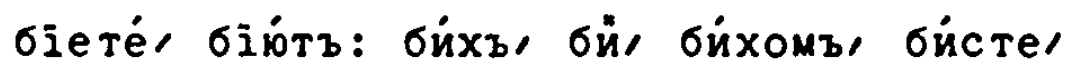
бiáme: ì nро́чas.

ம் познава́ніи рйдъ гла.

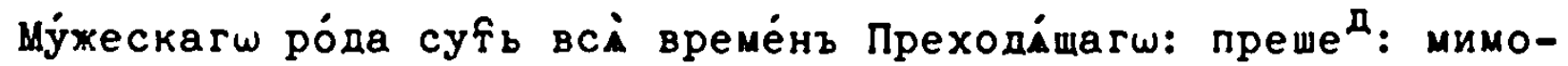

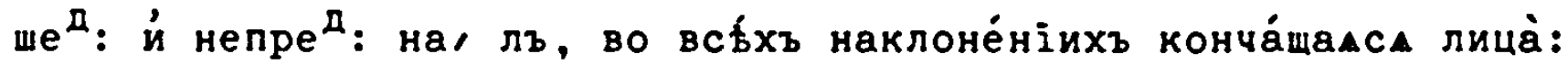
й лице́ тре́тї мно* : cхода́mеe на, $\mathrm{xъ}^{*}$

Же́нскагш ро́да вса́ ть" же време́н" на, ла, конча́щалса лица̇:

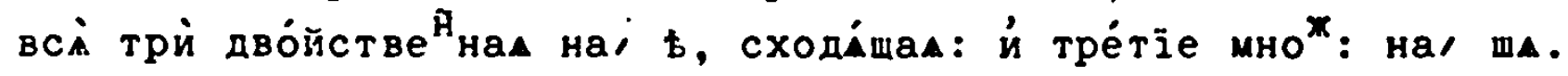

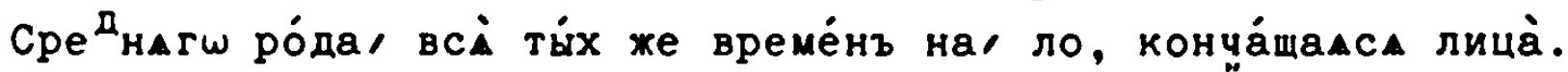
öбmarw

ӧбщагш ро́да, вс⿱亠䒑 всб́хъ време́нъ дво́йственнаћ на, a, кончащаАсА лица̇: й тре́тіе мно*: на, ша: сході́mеe.

Оу́въще́нїе:

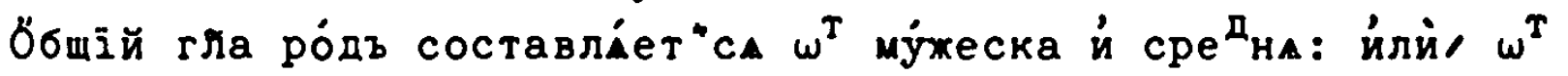
же́нска й сре

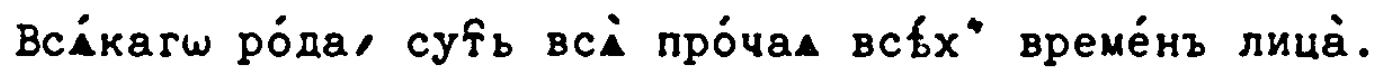

‘́ Cпраже́ніи:

Спраже́ніе ёстъ склоне́ніа глагі́лъ наклоне́нми, вре́мены, чйслы ли́цы и́ рйды правле́ніе.

$\mathrm{Pa}^{3}$ дьленніе Cпраже́нї.

Cпраже́ніе ёстъ сугу́бо. ( Пра́вилное: й Cтропо́тное:

Пра́вилное ёстъ, ёгда пе́рвое лицѐ наклоне́ніА йзъавителнагшы вре́мене настод́щатш ко́нчитъса на, у: йлй на, 10: Какш, текуу гоHì̆ cธ́م). 
Стропо́тное ёстъ ёгда пе́рвое лицё наклоне́нін. й "Авйтелнагш

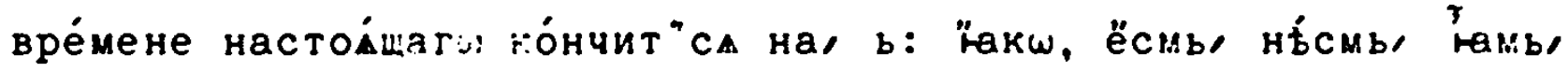

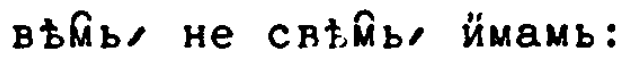

Cпраже́ніа гйъ ёста два̀: ( Пе́рвое:

Crраже́

Пе́рвое спраже́ніе, ёстъ глати́лъ вто́рое лице́ наклоне́нїа из"А-

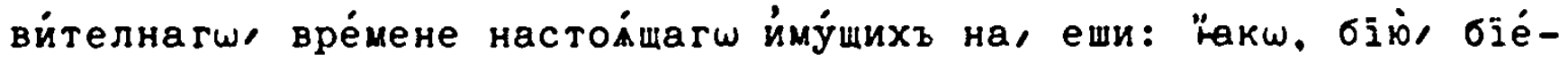

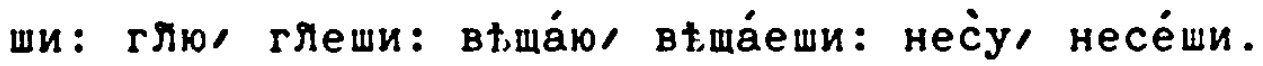

Bто́рое спраже́нїе, ёстъ глаги́лъ вто́рое лице́ наклоне́ніл и́зави́телнагш, вре́мене настод́mагш и́му́щихъ на, иши: "̈акш, сль́шу, сли́шиши: творіо, твориии: таю̆ тайши: ношюо носсиши.

$\dot{\omega}$ ஸ́конче́ніихъ пе́рвагш Склоне́ніА.

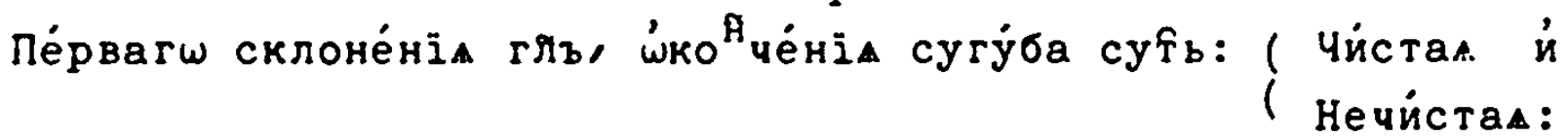

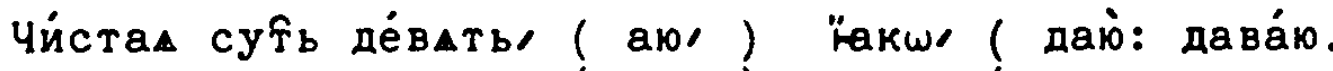

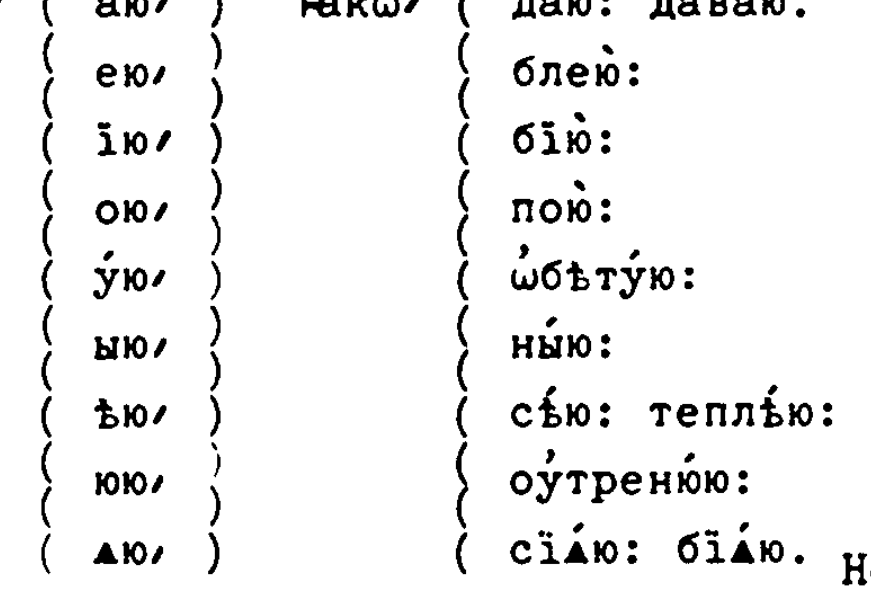

Нечистое [120]

Нечи́стое ёстъ е́дйно, у, согла́снымъ ма́ла ко́и ждо бнечиша́емое,

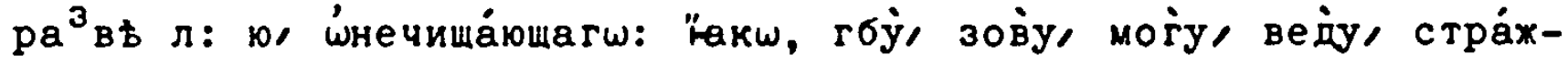

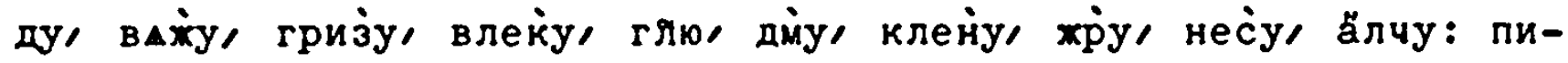
ìy, xómy.

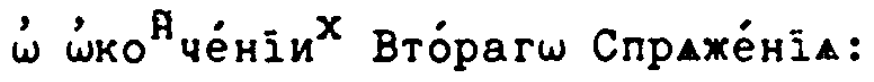

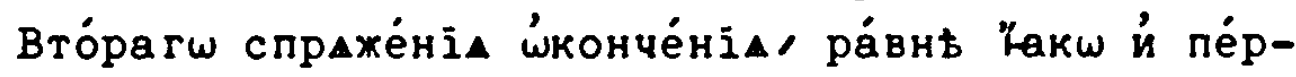
Barw/ cyrýбa cyर̂́:

$\left\{\begin{array}{l}\text { Чйстал: : } \\ \text { Нечи́стал: }\end{array}\right.$

Чйста ёста два̀.

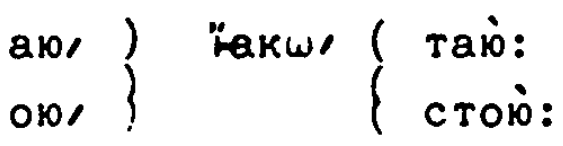

Нечи́стое е́ди́но, кои"ждо ма́ла согла́снымъ '́нечиша́емое: "акш, скорбї, мертвіо, бегіо, бдіо, гньздіо, дождіо, лежіо, слезіо, дьліо,

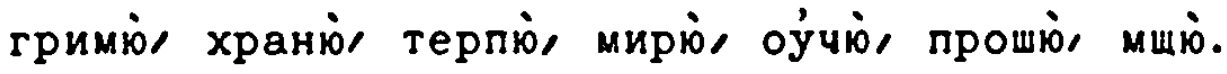

Оувьше́ніе: ã.

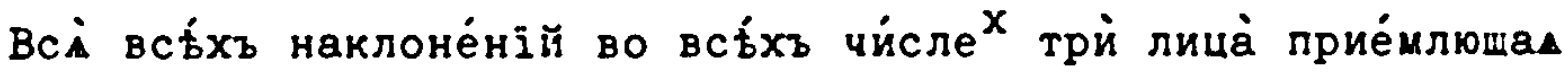
времена̀, Мьстоиме́ніц ӧва предиду́ща себі́ приемлютъ. Въ е́динст- 


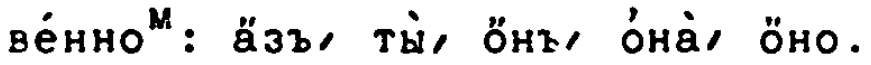

$0 \quad$ Въ дво́й

[1206]

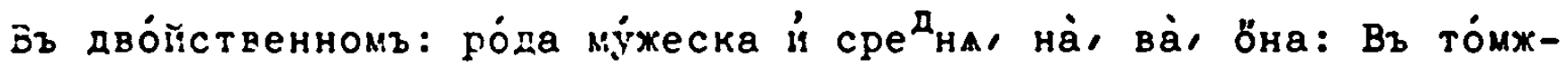

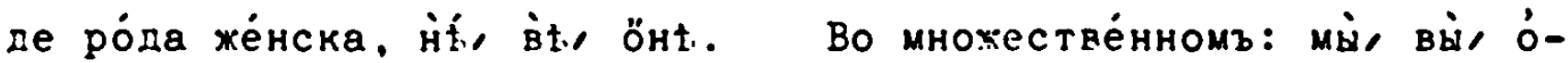
нй, ӧны, б̆на: Г̈кш, во оукка́зђ.

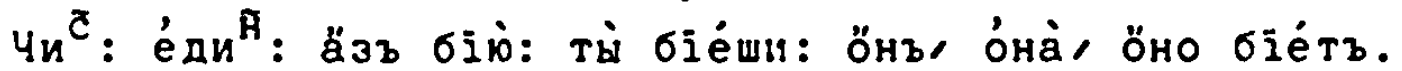

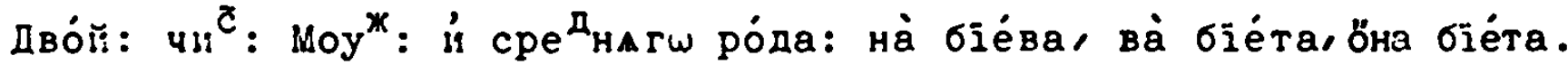

Жёнскатш Póna.

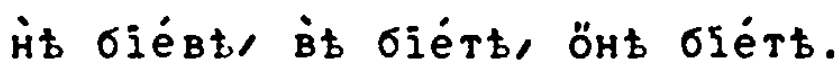

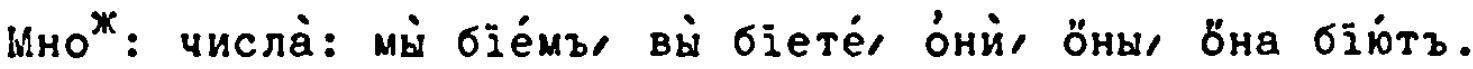

оу́вње́ніе: : :

Поне́же оґ́бш ма́ла ни е́дйнъ соверше́нный глъ е́стъ Славйншмъ, свое́г $\omega$ оучаща́телна оу́потреби́телнь йлй на оупотребле́нце не й-

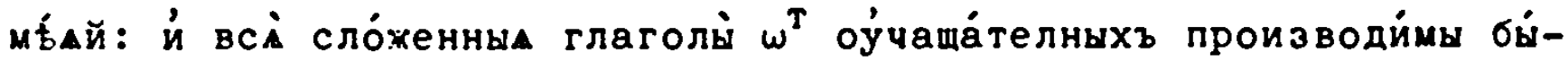
ти '́брьта́емъ: сегш ра́ди таковыхъ склоне́ніа в" Паради́гмата о́бо'ему спраже́нї, ґакш по всб́м" всєхъ наклоне́ній вре́менсмъ скланіемыхъ пре дага́емъ.

Пара́дигмa Пе́рватш Cпраже́ніа.

napá

[121]

Глгола் ли́чнагш, зало́га дђйствйте нагш, Ви́да соверше́нна, Наклоне́ніА йзъАйтелнагш.

Bре́ma hactó́mee:

С́ди ${ }^{\text {म }}$ стве́ннь:

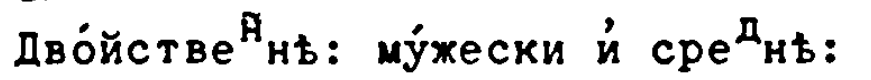
Же́нски:

Mножестве́ннь:

чтуу чте́ши, чте́тъ. чте́ва, чте́та, чте́та. чте́вь, чте́ть, чте́ть. чте $\mathrm{M}^{\mathrm{M}}$, чтете́, чту́тв.

Преходи́mеe.

Éди ${ }^{\text {H }}$

что́хъ, че́лъ, чла̇ чло́, чте́.

Дво́й: моуж : й сре $\Psi e^{\tilde{H}}$ :

Мно :

что́хова, что́ста,

cta.

что́ховь, что́сть,

что́хомъ, что́сте, cTb.

чтóma.

$\omega^{T}$ чтуу: изиьн́ше $у$, на, охъ.

Оу́вњше́нїе:

Нбкіи гли ко тре́тіему преходйmaгш лицуу пріемлютъ, ть, из-

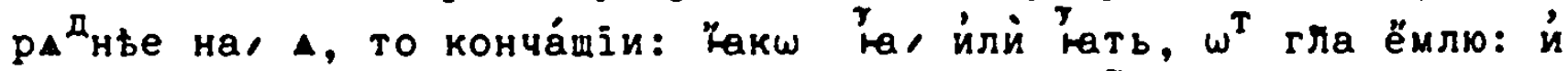

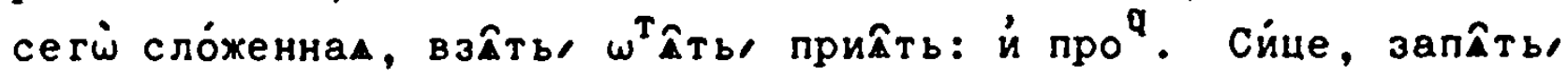

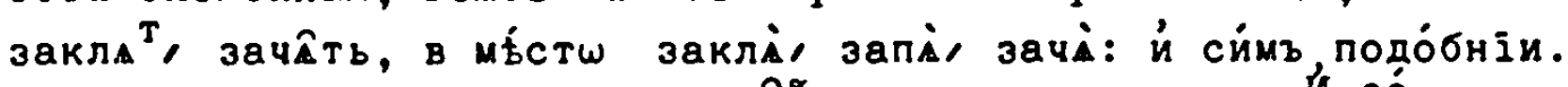
OB

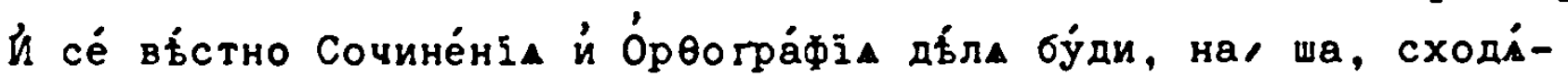




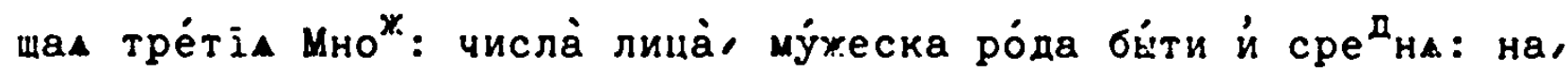

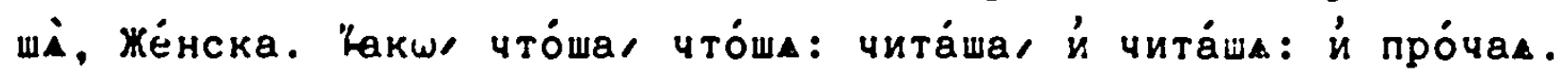
Ви́да оуччаша́телна, вре́мА настои́шее.
$\ln { }^{\mathrm{R}}$ :
чита́ю, чита́еши, чита́етъ.
Дво́й :
чита́e日a, чита́eта, ета.
MHO :
чита́eвь, чита́et⿱, ет‡.
чита́емъ, чита́ете, чита́ютъ.
Оу́вџше́ніе:

Сложе́ніе гль поне́хе $\omega^{T}$ вйда производнна оучаша́телна бйти о́-

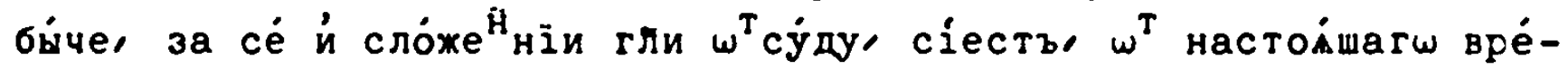
мене Ви́да оу́чаща́телна скландеми бйти начина́ютъ непреді́лное й буддущее $\omega^{T}$ соверше́нныхъ зае́млюще.

Преше́ дшеe:

દ̆й : чита ${ }^{\mathrm{X}}$, чита́лъ, чита́ла, ло. чита́ше.

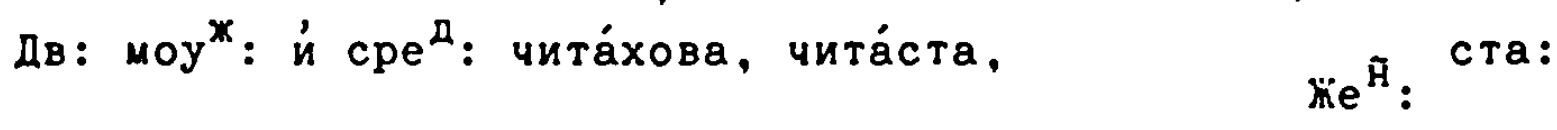

Жe $:$ чита́ховt, чита́ctt, сть: мно*: чита́хомъ, чита́сте, чита́хуо йлй чита́ша.

$\omega^{T}$ чита́ю: йзмђ்́ше, 1 , на, хъ.

Мимоше́ дшее:

Єпи

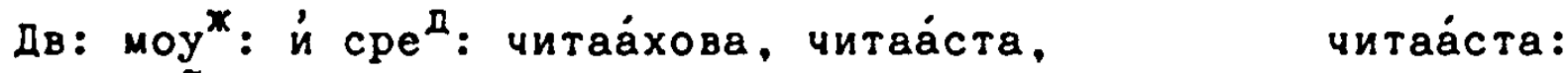

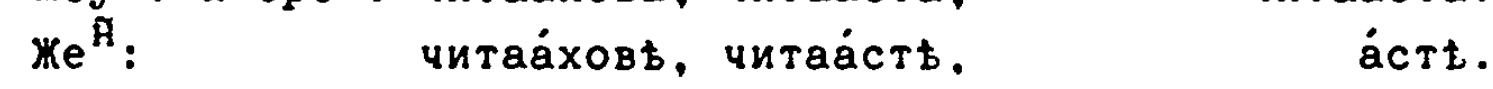

Мно*: читаáхоъ, читав́сте, читаáху, илй читаáша.

$\omega^{T}$ чита́хъ: ко Нัча́емьй дру́гимъ ӓзомъ раство́рше.

Не предьл́ное :

є́ди : прочто́хъ, проче́лъ, ла̀, ло́, прочте́.

дво́й: Моуж: и́ Сред: прочто́хова. прочто́ста, ста. Жe $\mathrm{A}^{\mathscr{A}}$ прочтоховь, прочто́сть, ct5.

мно*: прочтохом, прочтосте, прочтоша.

$\omega^{T}$ что́хъ: предло́гомъ, про, нара́щше.

Будиушее :

Єпи ${ }^{\text {म }}$ прочту. прочте́ши, прочте́тв.

Дв: Моу*: й Сред ${ }^{\text {д }}$ прочте́ва, прочте́та, та.

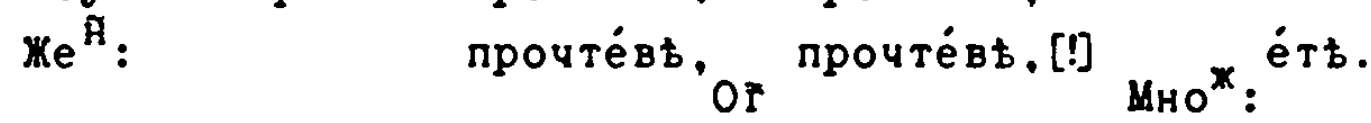

Мно : прочте́м", прочтете́, прочтуंтъ.

$\omega^{T}$ чту: предло́гоъ, про, нара́mше.

оу́въие́ніе: 
Bремена̀: преходйшее, преше́дшее, мимоше́дшее й непредб́лное на-

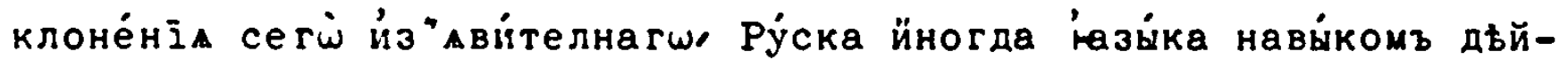

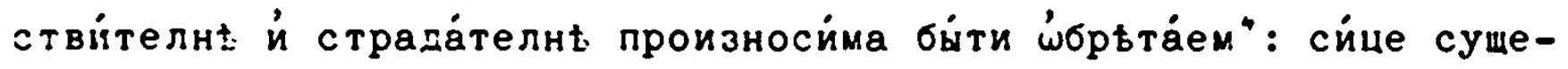
ствителным глголомз растворіема: "акш,

Преходи́щеe.

धли ${ }^{\text {म }}$ : че́лъ е́смь, че́лъ е́cй, чла̀, чло́, че́лъ ёстъ. Дво́й: Ноу": и́ Cpe Же чла̀ ёста. Мно ${ }^{*}$ : члй ёсмы, члй е́сте́, чл̀̈ ёсть. Cйце прешеддее: чита́ль е́смь: й про : Muмоше́дшеe: читаárъ е́смь: й про": Непредблное: проче́лз ёсмь: $\dot{n}$ про ${ }^{q}$.

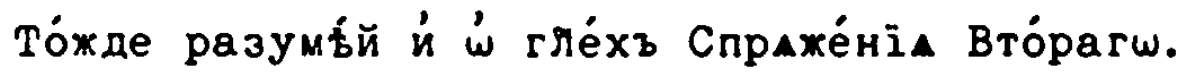

Накло

Наклоне́ніа Повели́телнагш. Вйда соверше́нна.

Bре́ma настои́щее:

'́n ${ }^{\mathrm{A}}$ :

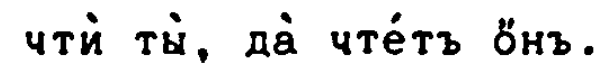

Дво́й: Моу*: и́ Cpe

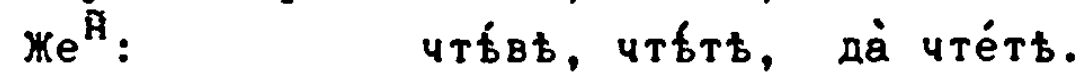

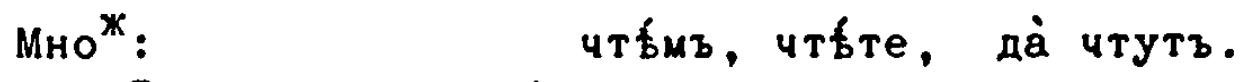

$\omega^{T}$ чте́ши, еш, йзе́mше.

Вйда оуччаща́телна, настои́mее.

$\operatorname{\epsilon an}{ }^{\mathrm{A}}$ : чита́й, да̇ чита́eтz. Дво́й: Моу*: и́ Cpe范 чита́йва, чита́йта, да̇ чита́ета. Же ${ }^{\widetilde{H}}:$ чита́йвь, чита́йть, да் чита́еть. Мно*: $\quad$ чита́им", чита́йте, да̇ чита́ютъ. $\omega^{T}$ чита́еши: еш, йземе: $\dot{и}$ й слйтною знаменова ше.

धди ${ }^{\text {म }}$ : Будимеe.

Дво́й: Моуж: й Сред: прочтбва, прочтб́та, да̇ прочте́та: $\mathrm{He}^{\overline{\mathrm{H}}}$ :

MHO* :

$\omega^{T}$ прочте́ши: еш, изе́мше. прочтfвв, прочтtтt, да̀ прочте́ть. прочтf́, прочтє́, да் прочту́тъ.

ㅁำ Накло

Наклоне́ніА Молителнагш, Ви́да соверше́нна

Вре́ma настод́mеe.

$\epsilon_{\text {ди }}{ }^{\mathrm{H}}$ :

чтй ть่, чтй о̆нъ.

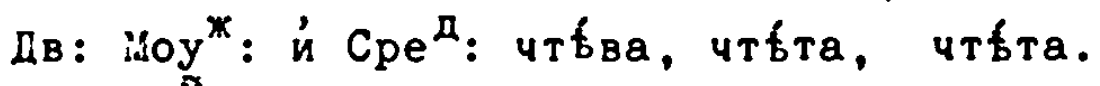

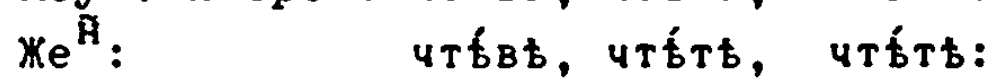


MHO* :

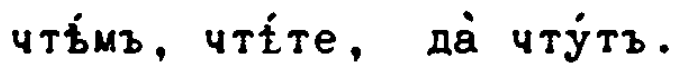
Ви́да оучащ: Вре́ка настоќш.

$\operatorname{En}^{\text {म }}:$ чита́й тட், чита́й ӧнъ.

Дв: М: й Cре $\nVdash e^{\text {म }}$ : чита́йвะ, чита́йтЕ, чита́йтЕ. Mно* : чита́имъ, чита́йте. да̇ чита́ют". Будище :

$\ln ^{A}:$ прочтй тыे, прочтй ӧнъ: Дво́й: Моуж : й Сре $\mathcal{H} e^{\text {F }}$ прочте́в., прочті́тt, прочті́т土. Mно*: прочтб́мъ, прочтб́те, па̀ прочту்т".

Составлі́тьса наклоне́ніа сего̀ Време́на по правилшмъ Повелйтелныхъ.

Наклоне́ні Сослага́телнатш: Вйда соверше́нна, Bремa настод́mеe:

äще бы: гды бы́мъ чита́лъ:

$$
\text { Én }{ }^{\overline{\mathrm{H}}} \text { : }
$$

є̇ди ${ }^{\text {म }}$ :

äme бымъ.

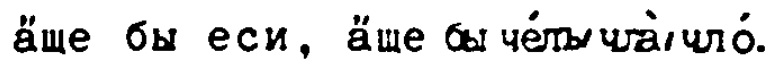

Дво́й: Моу*: и́ Cpe $\mathcal{K e}^{\tilde{\mathrm{H}}}$ :

äme $\sigma_{\Delta}$ члб́свв, чла́ста. cтa. $M_{\text {HO }}{ }^{*}$ : ämе бы члйсмы, чльст土. cть.

$\omega^{T}$ вто́рагw лица̇ преходйщагш йз"

Преході́mee :

äще $\sigma_{b}{ }^{x}:$ гд⿱ $\sigma_{ы}^{M}$ былъ чита́лъ. є́ди : Дво́й: Моу": и́ Среда : ӓще б́́ссва чла̀, б́́ста, ста.

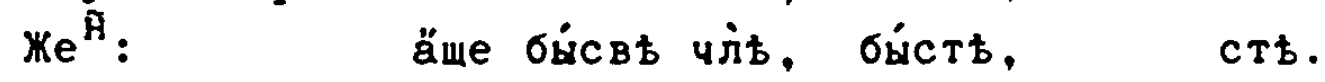

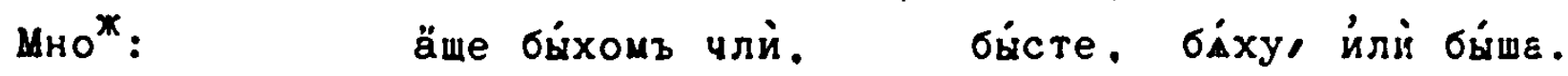

$\omega^{T}$ вто́рагш лица̇ пре́xод: из" Вйда Оуччаща́телна, Bре́mı настод́щее:

äще бы: гды бі́мъ чйтовалъ.

$\iota_{д и}{ }^{\text {: }}$ äme бымъ, äme бы е́сй. ämе бы чита́лъ, лая ло. or Дво́й

Дво́й: Моу*: й Среда : ӓще бы чита́ласва, чита́ласта. ста. Жe $\mathrm{e}^{\text {म }}$

ämе бы чита́льсвь, чита́льсть, ctb. Мно äще бы чита́лисмы, чита́листе. чита́ли. $\omega^{T}$ вто́рагш лица̇, Преше́дшагш, чита́лъ. กрeшé amee.

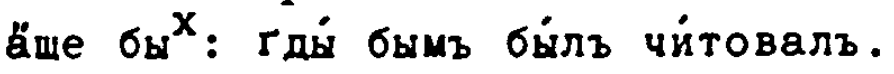




$$
\text { - } 125 \text { - }
$$

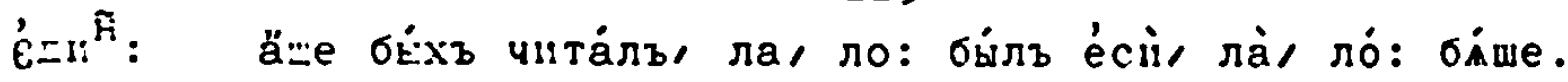

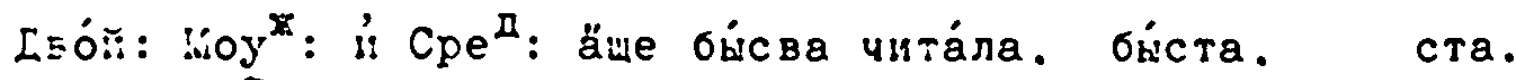 $\aleph^{\hat{\text { मे }}}$ :

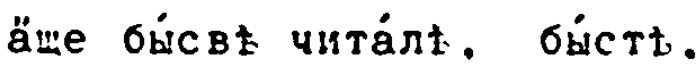
crt.

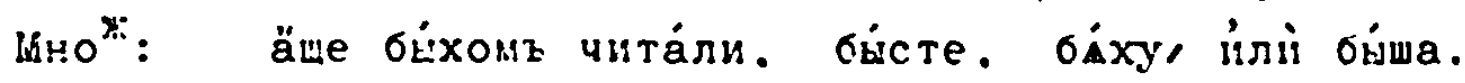

$\omega^{T}$ тогйmne лица̀. чита́лъ.

\section{Mимо ше́ дшеe :}

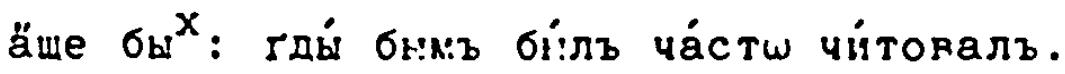

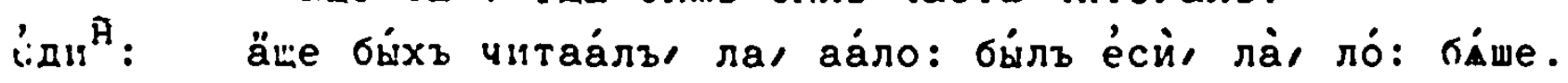

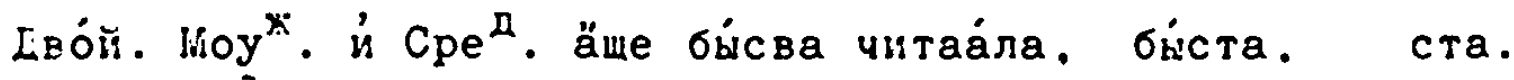
Же ${ }^{\hat{H}}$. äще бйсвt читаárt, би́стt, стt.

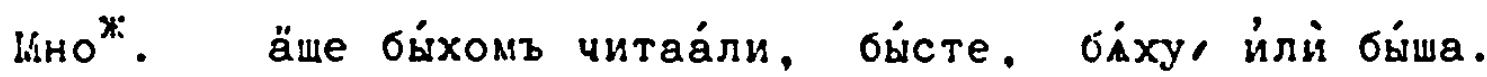

$\omega^{T}$ вто́parw лица̀, мимоше́ дшагw: читаárъ.

Heпредћл́ное:

ä山е $\sigma_{b}$ : гды́ бымъ былъ прочита́лъ.

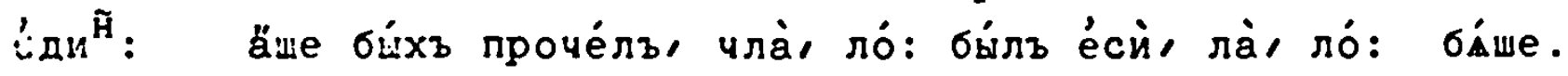

дво́й. Моу ${ }^{*}$ й Сpe

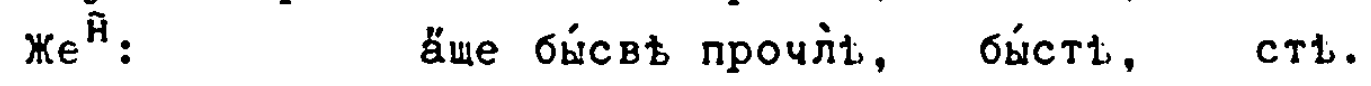

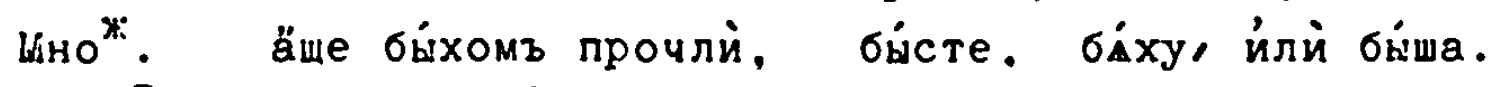

$\omega^{T}$ вто́рагш лица̇ непредŁл́нагш, проче́лъ.

Будіуше :

äще би : тды́ бымъ прочита́лъ напото́мъ.

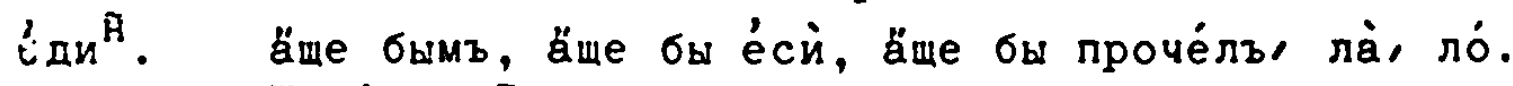
Двой. Коу". и́ Сред. ӓще бы прочла́сва, прочла́ста, ста. Же . äme бы прочлt́cвt, прочлі́сть, сть.

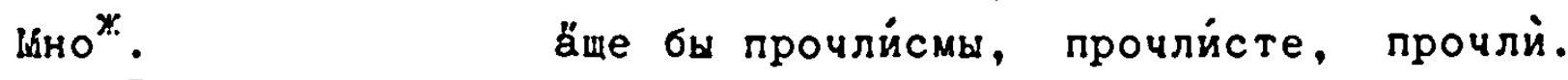
$\omega^{T}$ тогйде лица, непредьлнагш: проче́лъ. Накло

Наклоне́ніА Подчини́телнатш' Вйда Соверше́нна, Bре́ma настои́mee.

Да̇: áби́mz чита́лъ.

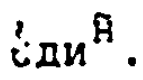
дà чт̀т, чте́ши, чте́тъ.

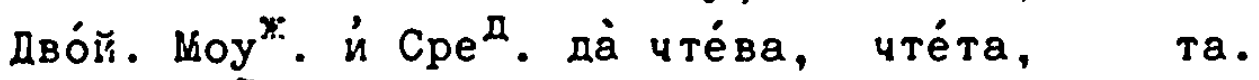
\% $\mathrm{e}^{\tilde{R}}$. पте́вt, чте́ть, тt. Мно*. да̇ чте́мъ, чтете́, чту́тъ. то́xде со йз"Авите́лнагш настои́цимъ.

Преході́mee: да̇ би́xъ: áбйkz бйлъ чита́лъ. ¿́ди म 


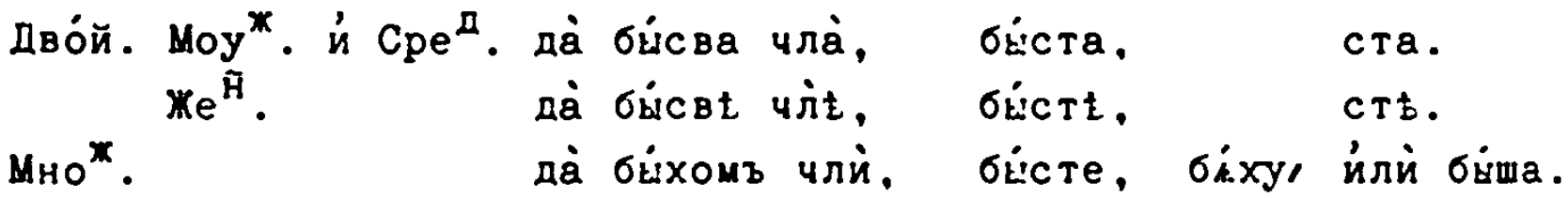

$\omega^{T}$ вто́рагw лица́, преходи́marw: че́лъ.

Вйда Оучаща́телна, настов́mеe:

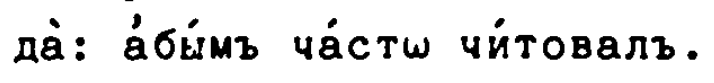

Єли ${ }^{\text {ค }}$ да̇ чита́ю, чита́еши, чита́етъ.

Дво́й. Моу”. и́ Сред. да̇ чита́ева, чита́ета. ета.

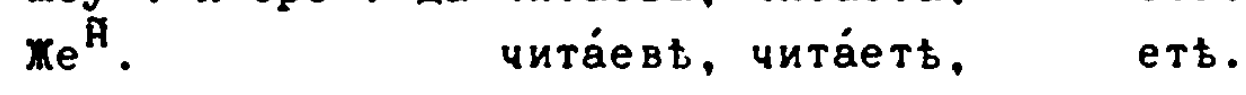
Мно . да̇ чита́емъ, чита́eте, чита́ютъ. то́xде со из "Авителнатш наст: оуччащ:

Пре ше́ дmee :

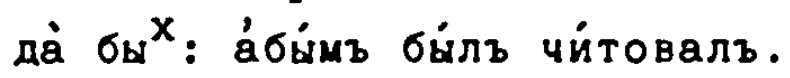

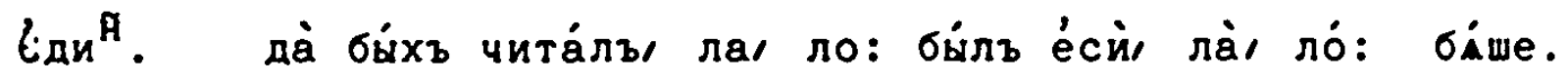

Дво́й. Моу⿰ ${ }^{\star}$ й Сред. да̇ би́сва чита́ла, бйста, ста.

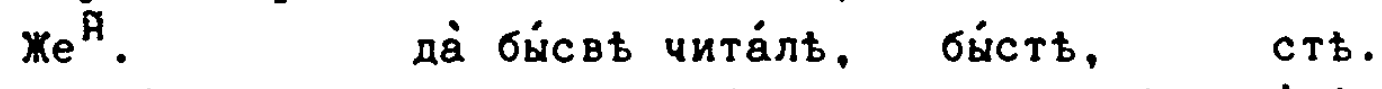

Мно ${ }^{x}$ да̇ бйхомъ чита́ли, би́сте, біху, йлй быша.

$\omega^{T}$ вто́ратш лица̇, преше́ дшагш: чита́лъ.

Мимоше́ дшеe :

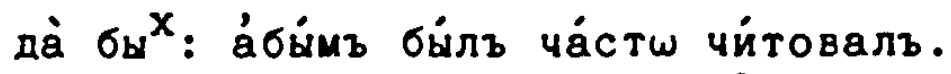

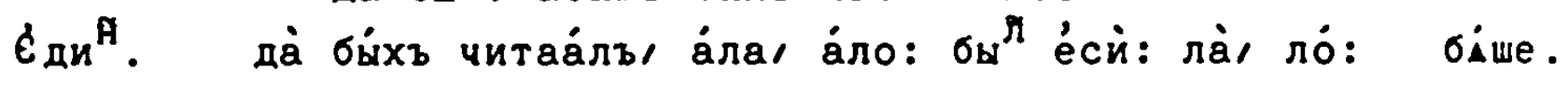

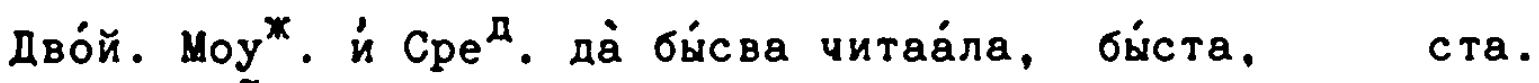

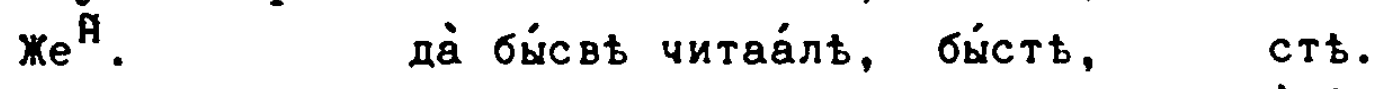

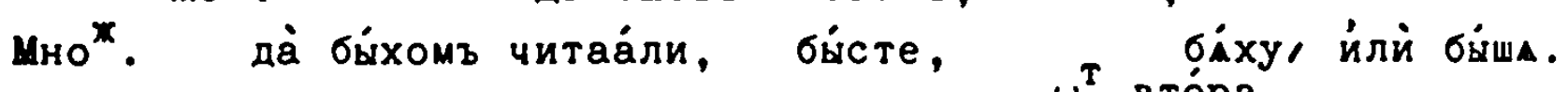
$\omega^{T}$ в тópa

$\omega^{T}$ вто́parw лица̀, мимоше́дш: йз “А́⿴囗

Непредъл́но :

да бы ${ }^{x}:$ а́бымъ былъ прочита́лъ.

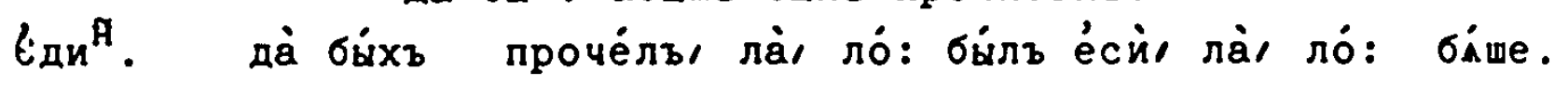

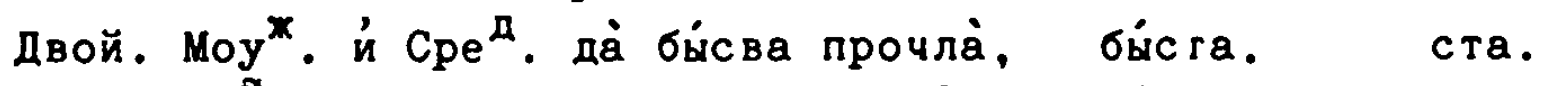

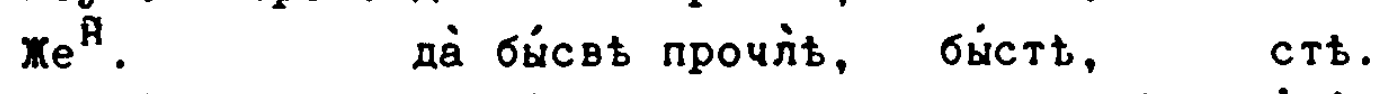

Мно ${ }^{x}$ да̀ бйхомъ прочлй, бйсте, бїху йлй быша.

$\omega^{T}$ вто́рагш лица̇, непредьл́нагш, проче́лъ.

Будіymee :

да̀: áбы́mb прочита́лъ напото́mъ.

$\hat{\varepsilon}_{\text {ди }}{ }^{\text {म }}$.

да̇ прочту, прочте́ши,

Двой. Моуж. й Сред . да̇ прочте́ва, прочте́та, $\mathrm{Xe}^{\mathrm{H}}$. прочте́в, прочте́ть, прочте́тz. Мно : да̀ прочте́м", прочтете́, прочту́ть.

éra. ért. 
то́:де со йз"Авителнагш будјщuмъ:

Наклоне́ніА Неопредьле́ннагш, Bíда соверше́нна,

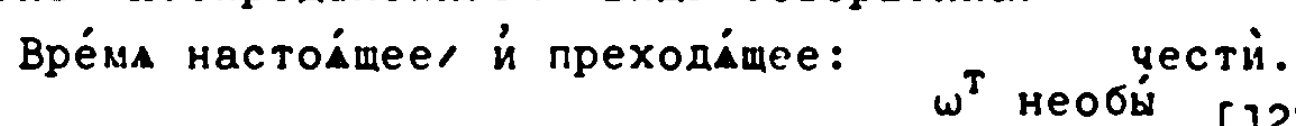

$\omega^{T}$ неоов́чна чето́хъ: то́хъ, изин.нше на, сти. Ви́да оуччаша́телна, Настод́щеe й Преше́дшее: чита́ти.

$\omega^{T}$ чита́хъ: изз"мtн́ше, хъ. на, ти.

Мимоше́ дшее : читах́ти.

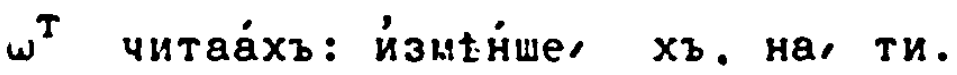

Непреділное, $\dot{n}$ Бу́дущее: прочестй.

$\omega^{T}$ прочето́хъ необйнагw: то́хъ, йзит́нше на, сти. Оуввще́нї:

Неопредћле́нніии чйслъ, лйщъ, й рйдъ лиша́ют"са. ‘் Припрага́емыхъ Сопраже́ніе $\mathrm{e}^{M}$ :

Припрага́ет" са сопраже́ніе тро́е. ( Времена̀ прича́стіл. ( Дьеприча́cтіА: ( Причастодfтї.

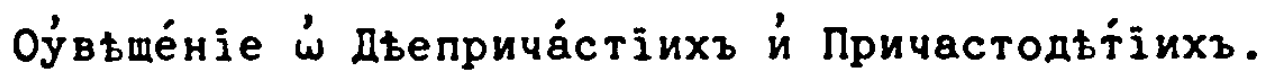

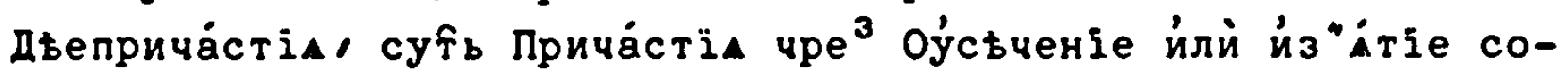
краше́нал й зна менова́ [1276] менова́ніемъ $\omega^{T}$ прича́стій ( $\omega^{T}$ нйх" же и́ составла́ют"са) по толи́ку ра ${ }^{3}$ личеству́юшан: По е́ли́ку прилага́телное оусъче́ное $\omega^{\mathrm{T}}$ цћлагш различествова́ти б́би́че. Про́чіихъ паде́хей во всы́хъ ро́дехъ й чйслехъ, рáзвt ймени́телна, лиша́ют"са.

Причастодf́їе, ГЛъ Прича́стный нарица́ет"сА, ну́хду дєйства знаменуюшій: Мно́гахды й прилага́телныхъ име́нъ сйлу притіхущій: е́стественнь же во сре конча́шем" са оу́потребла́емый

Прича́стіА зало́га дŁйствителнагш, Ви́да соверше́нна, Вре́мене настод́щагw.

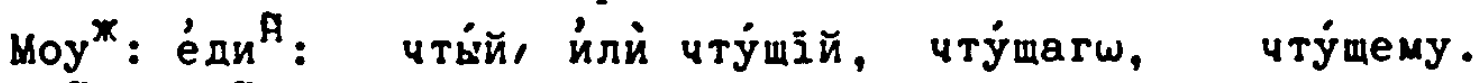

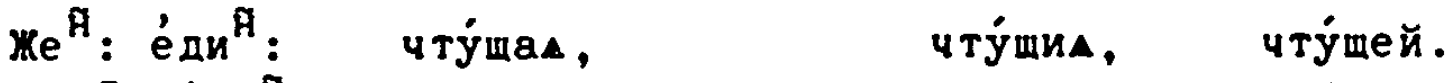

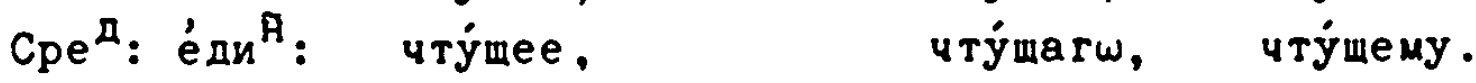

чти́й, $\omega^{T}$ чтуу йзмъне́ну, у: на, ый: чтущ̈й, $\omega^{T}$ чтуу: приложе́ну, щ亡̆.

Преходйmarw.

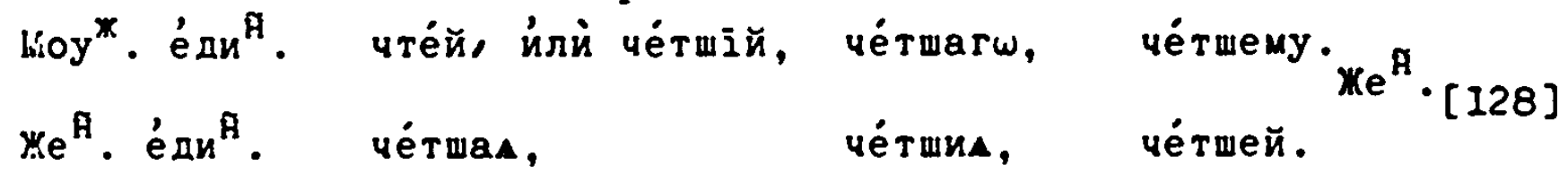




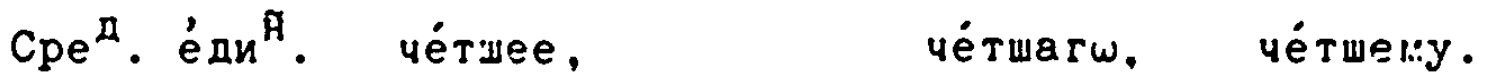

чте́й, $\omega^{T}$ чте́: прило́хену, й: че́тшїй, $\omega^{T}$ необв́чна чето́хъ: охъ, йзмине́ну на, шій:

Вйда оуччаша́телна,

Вре́мене настод́щатш.

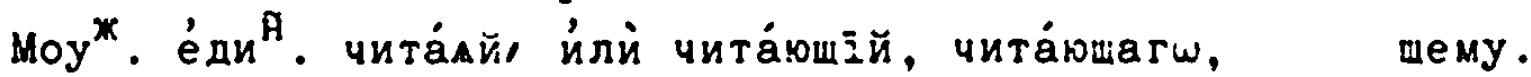
Же $:$ е́ди ${ }^{\text {म̆ }}$ чита́юшал, чита́ющиа, чита́ющей. Cpe ${ }^{\text {म }}$. éди ${ }^{\text {H }}$ : чита́юшеe, щarw, щенy.

чита́лй, $\omega^{T}$ чита́ю: 10, йзмџне́ну на, Ай. чита́юшій, $\omega^{T}$ чита́ю: прило́хену, щій.

Моу $^{*}: \dot{e}_{д и^{\text {ค }}}$. чита́вый, กреше́дша гш: Же Сpe ${ }^{\text {म }}$. е́ди ${ }^{\text {月 }}$. чита́вшеe, чита́вшагш, чита́вшеку. чита́вшиА, та́вшей. вwarw, вшемy .

$\omega^{T}$ чита́хъ: прело́жену, хъ, на, вый.

Mимоше́ дшагw.

Моу ${ }^{*}$ е́ди ${ }^{\text {A }}$. читаа́вый,

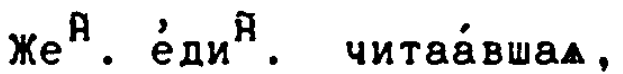

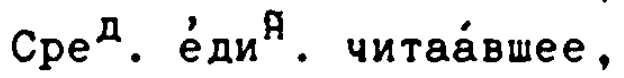
$\omega^{T}$ читах́хъ: прело́хену, хъ, на, вый.

читаáвшагw, читаáвшему.

$\Pi$ Жe $e^{\text {A }}$ читав́вшиА. читав́вше:̆. [1286] вшему .

\section{Henре дьлнагш:}

Моу* ${ }^{*}$ е́ди ${ }^{\text {म }}$ прочте́й, йлй проче́тшій, проче́тшагш, проче́тшему. Же ${ }^{\mathfrak{A}}$. е́ди ${ }^{\text {凡 }}$. проче́тшан,

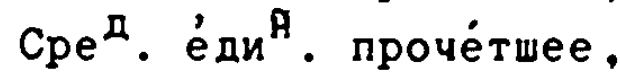
проче́тшиА, проче́тшей. прочте́й, $\omega^{T}$ прехо Буду шаг $\omega$ :

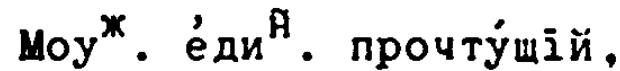

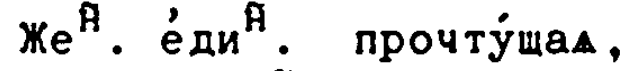
Cpe проче́тшаг $\omega$.

$\omega^{T}$ прочту: прилоххену щій.

оу́въше́нie

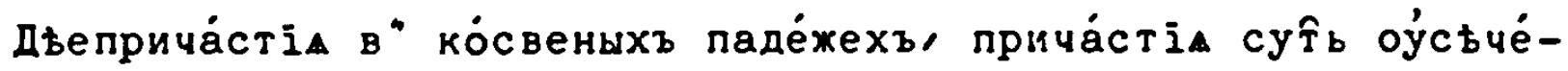
ніе постра"дшаА, тоги́хде в" нйх со иі́лыми знаменова́нї. дњепри

Дьеприча́стіА Зало́га дьйствйте нагш' Ви́да соверше́нна, прочту́maгw, прочту́mему. щих, щей. marw. шему. Вре́мене настовнагw.

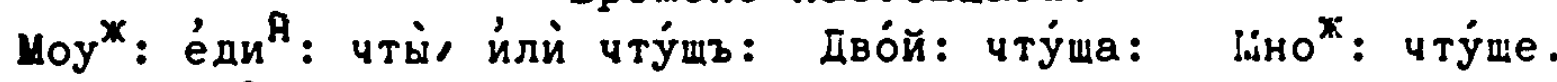

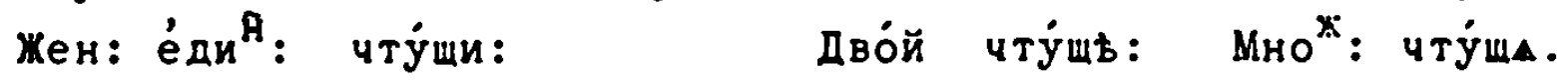




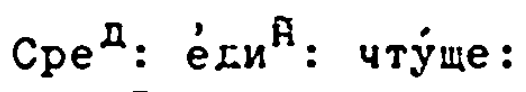

Дво́й: чту́ща: Мно*: чту́ща.

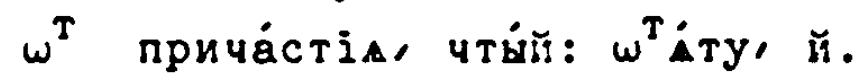

กрexoдímarw:

lооу": е́дин: че́тъ, илй че́тшъ: Дв: че́тша: Множ: че́тше.

Же́н: е́гин: че́тши:

Дво́й: че́тшь: Мно*: че́тшА.

Cper : е́дин: че́тше:

дво́й: че́тша: Мно : че́тша.

$\omega^{T}$ чте́й: $\omega^{T} \dot{\text { Ату }}$ й:

Bйna оуччаща́телна,

Вре́мене настои́щагш.

Коу : е́дин: чита́А и́лй чита́ющъ: Дв: чита́юща: Мно*: чита́юще. Же Cpe ${ }^{\text {I }}$ :́дин: чита́юше:

Дв: чита́ющђ: Мно : чита́ющa.

Дв: чита́ющa: Мно : чита́ющa.

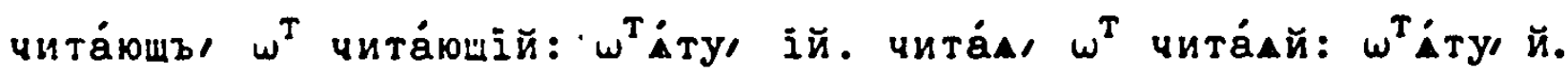
Преше́ дшагw.

แоу" ${ }^{*}$ е́ди" Жен: е́дин: чита́вши. Cpe ${ }^{\text {म. }}$. ди ${ }^{\text {月 }}$ : чита́вше. Дво́й: чита́вшђ. Мно*: чита́вшА. чита́вз, $\omega^{T}$ чита́вый: $\omega^{T}$ ло́хену, ый. чита́вшъ, $\omega^{T}$ чита́вшій: $\omega^{T}$ ловженуы $і \tilde{y}$.

\section{Linnоше́ дшаг}

Моуж.е́дин. читаáвъ йлй читав́вшъ: Дв: читав́вша: Мно : читаáвше. же́н. е́дин: читав́ви. Сре

Дв: читаáвшь: Мно : читаáвша. читав́въ $\omega^{T}$ читав́вьй: $\omega^{T}$ ло́хену ьй. читав́вшъ, $\omega^{T}$ читав́вшій: $\omega^{T}$ rохе́ну' $\bar{\imath} \breve{и}$.

Henpe дъ́ннагш:

Wоу": е́дин. проче́ты йлй проче́тшъ: Дв: проче́тша: Мнох: проче́тше. Жё. е́дин: проче́тши.

Дв: проче́тшь: Мнох: проче́тшА. Cpe ${ }^{\text {I. }}$.

[130]

Cpe ${ }^{\text {I }}$ éди ${ }^{\tilde{H}}$. проче́тше:

Дво́й: проче́тша: Множ: проче та. проче́тъ, $\omega^{T}$ прочте́: $e$, прело́хену. проче́тшъ, $\omega^{T}$ проче́тшїй: ій $\omega^{\top}$ róжену.

Lioy ${ }^{*} \cdot$ éди ${ }^{\tilde{H}}$. прочтуंшъ:

үён: е́дин: прочту́ши. Cpe ${ }^{\not}:$ éди $^{\tilde{H}}:$ прочтуंше :
Буд́ущагw:

Двӧй: прочту́ща: Множ. прочту́ще.

Дв: прочту́щћ: Мно : прочту́ща.

Дв: прочту́ща: Мно : прочту́ща.

$\omega^{T}$ прочтущ்

Гла Лйчнагш/ Зало́га Страда́телнагш/ Вйда соверше́нна, Наклоне́ніА йз"АвителнагшI 


\section{$-130-$}

Bре́мa настод́.

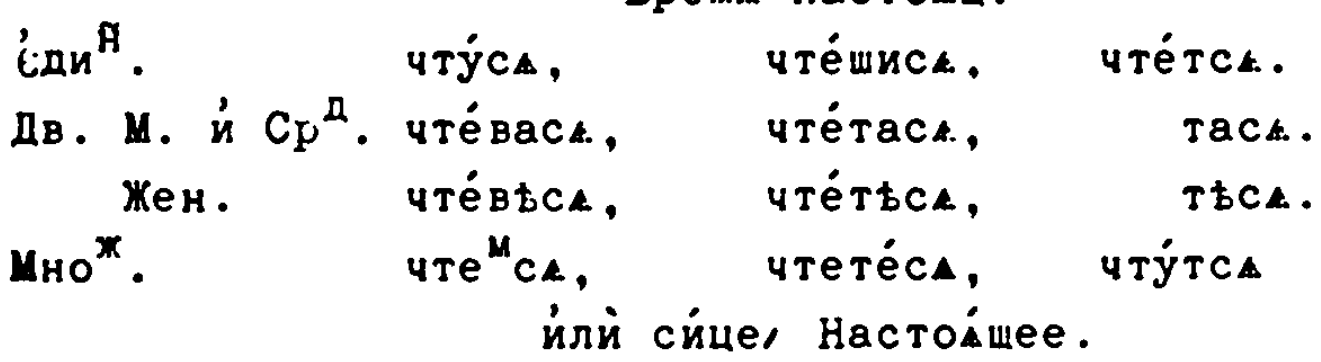

$\varepsilon^{\text {म. }}$ что́м" мал мо бивáю, еши. етъ.

дв. М. и́, C. что́ма бива́ева. ета, та.

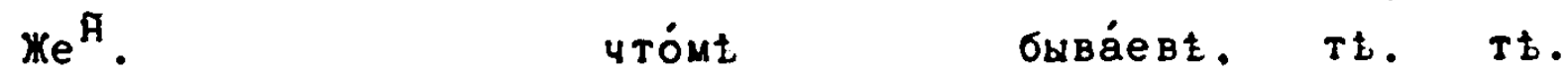
мно $^{\star}$. Моу ${ }^{\star}$. Жен $\pi$ กрехо

Преходйmee :

[1306]

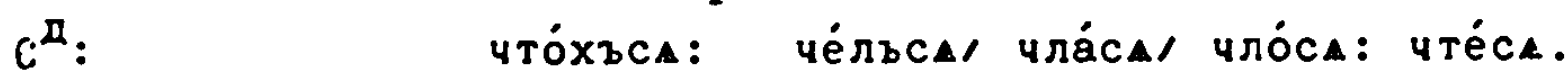

Дв: Моу"

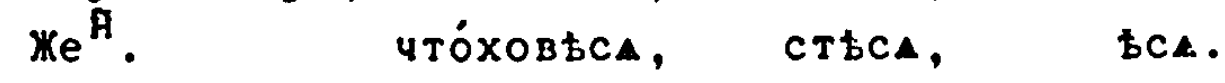

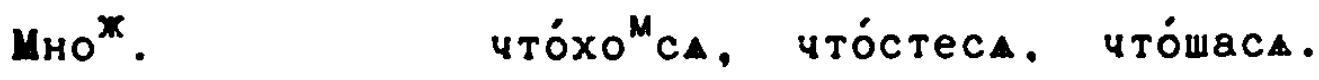
йлй

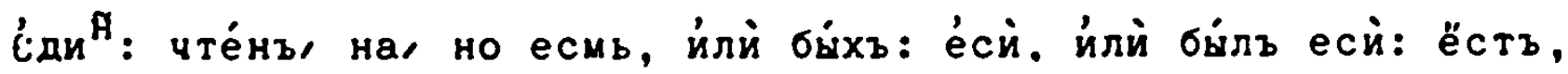
йлй бйсть.

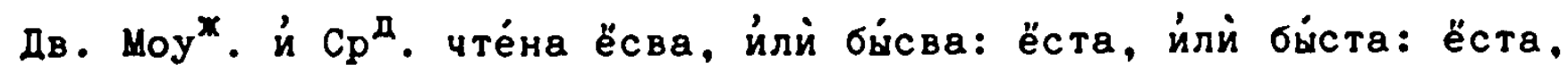
йлй ста.

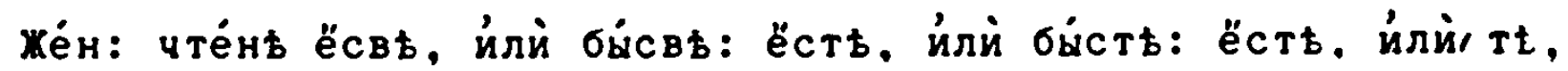

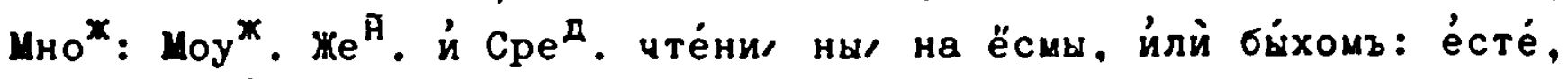

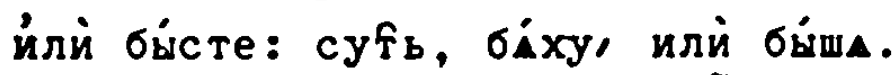

Вйда оуччащáte ${ }^{n_{H a}}$

Bp: Hactóim:

धдй

Дв: М. й C. чита́eвaca. Жe $e^{\text {: }}$ чита́eвьcム,

MHO : чита́em"cム, чита́ешиса, eтacs, etbca, eтecs, йлй

द.

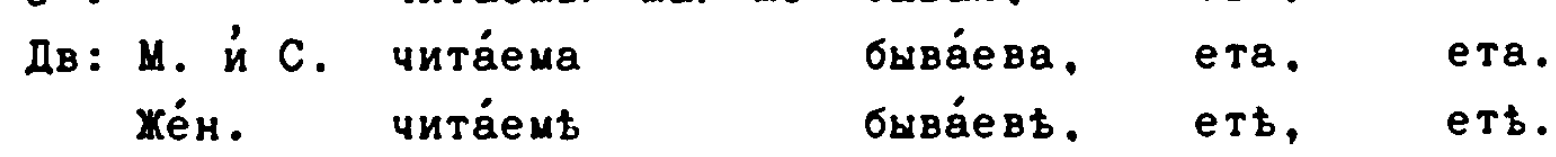

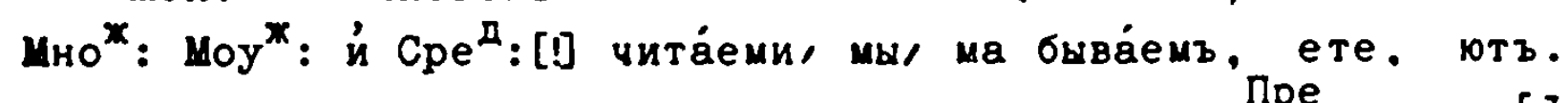

Преше́ дшеe :

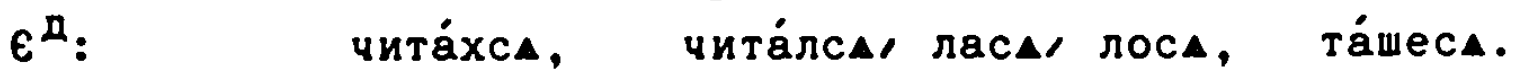

Дв: М. й С. чита́ховасА, та́стасА,

craca. 
Же́н. чита́хов

†CA.

$\because$ Hо :

стесA. хуса. йлй,

maca.

йлі,

$\epsilon^{2}$ : पйтанъ, на, но ёсмь. йлй бйх": е́сй. йлй овил е́сй: ёстъ. бíctb.

Дв: ц́. й С. чита́на ёсва, и́лй бйсва, ёста. йлй би́ста: ёста, iлsi, cта.

Жён. पитанђ ёсвђ, йлй бйсвђ: ёстђ, иллі быстt: ёсть, หris, $c т \pm$.

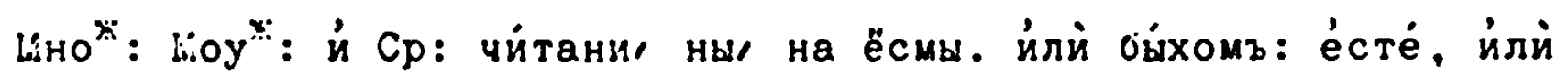

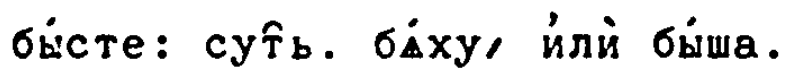

แимоше́ дшее :

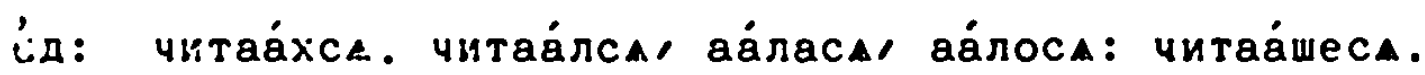

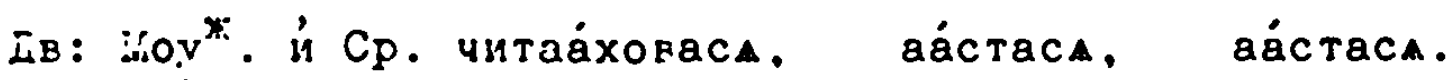

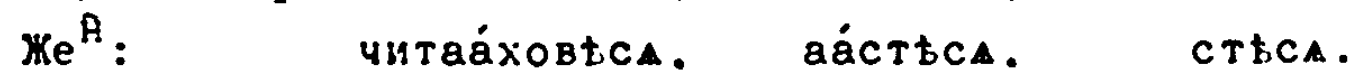

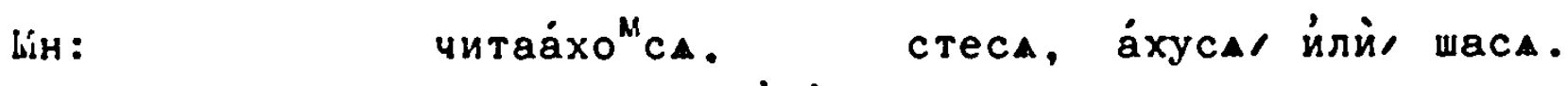
и่ли่,

¿̊. чйтанъ, на, но быва́хъ, быва

Д: М: и́ С: чйтана быва́сва, ва́ста, ста.

Же

กम MHO $^{*}$.

Мно : Mоу $^{*}$. Же ва́ху' йлй быва́ша.

He предьл́ное.

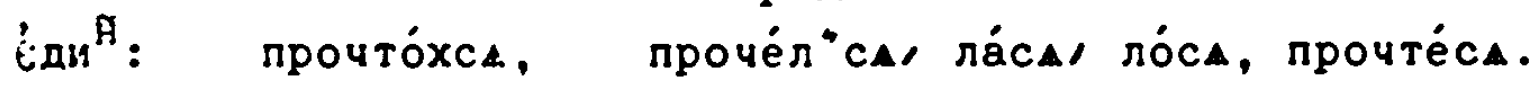

Дв: Моуж: й $C_{p e}$ म. прочто́ховаса, $\mathrm{Ke}^{\text {म }}$ :

$M_{H}{ }^{*}$ :

прочто́[xo] BちсA,

craca,

CTaCA.

crbca,

cтъcА.

прочто́xомса,

creca,

maca.

\section{и่ли่,}

'́дй б̆́ctb.

Дв: 的. й С. прочте́на ёсва, йлй би́сва: ёста, илй быста: ёста, йлй, ста.

Же йлй, сть.

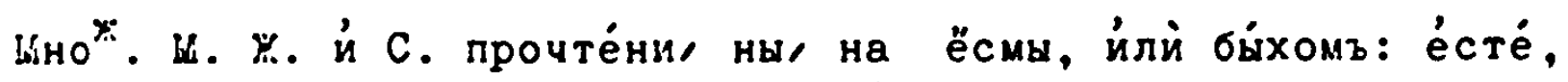

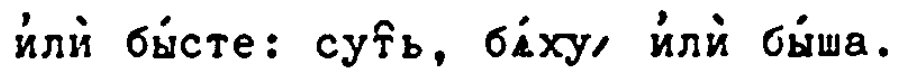

Будіуmee:

'̈ди ${ }^{\text {H }}$ прочту́са, прочте́шиса, прочте ${ }^{T}$ са. 
Дв: Н. й $\mathrm{Cp}$. прочте́васк,

$\begin{array}{rr}\text { étack, } & \text { étack. } \\ \text { е́тtck, } & \text { értck. } \\ \text { ете́ca, прочту́т"ck. }\end{array}$

Мно ${ }^{*}$ :

กрочте́вtсA, йлй

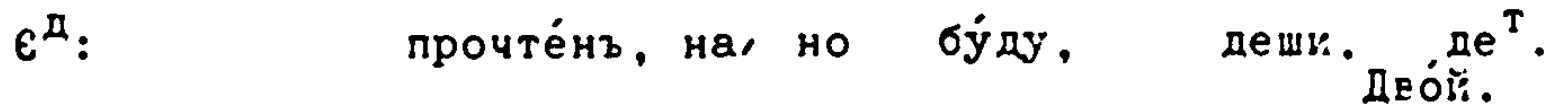

[132]

Дв. М. и́ С. прочте́на буддва, дета, та. Же ${ }^{\text {H }}$ прочте́н1. буंдевє, детt, тв.

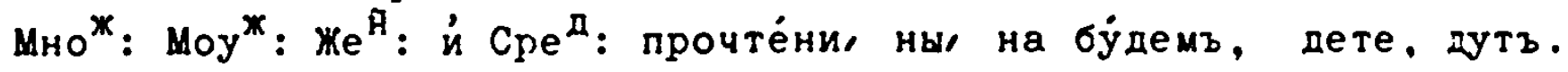
Наклоне́ніА Повелителнагше Ви́да соверше́нна, Вре́ma hactó́mee.

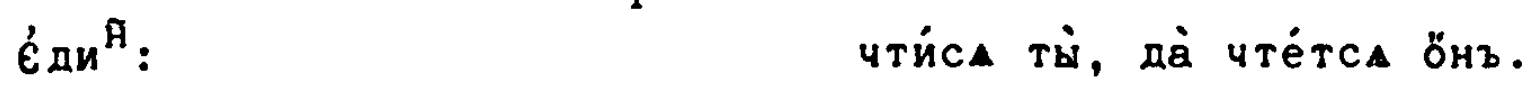

Дво́й: Моу*. и́ Cpe

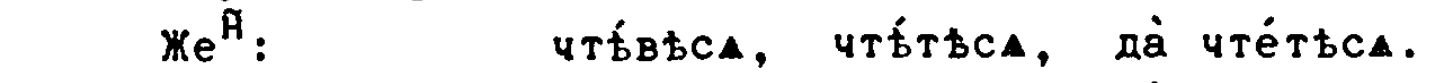
Mно

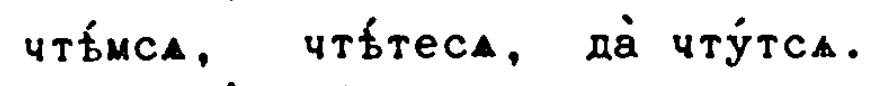
Вйда оучаща́телна, Вре́mム настод́щеe.

$\epsilon_{\text {ди }}{ }^{\text {म }}$ : чита́йса тй, да̇ чита́етса ठ̈нъ.

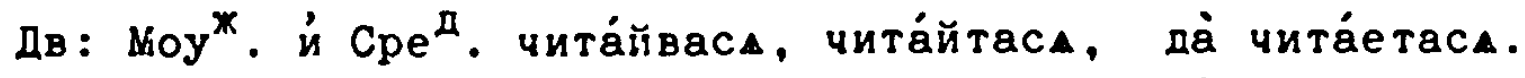
Ж: पита́йвђсA, чита́йтђсA, да̇ чита́етђсA.

$M_{\text {H }}$. чита́и"cА, чита́йтесА, да̇ чита́ю ${ }^{\mathrm{T}} \mathrm{cA}$.

Будіушеe:

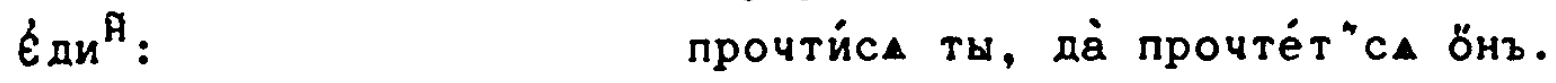

Дво́й: прочтб́васA, прочтбтасА, да̇ прочте́тасА.

Же́н. прочтб́вђсA, прочтf́tちca, да̇ прочте́тtсA. กт

Mно*. прочтб́мса, прочті́теса, да̇ прочту́тса. $\mathrm{MHO}^{\mathrm{x}} \cdot[1326]$ Наклоне́ніА Моли ${ }^{T}$ : Вйда соверше́н:

Bре́ma настод́mee.

धди ${ }^{\text {A }}$.

чтйса тй, Чти́сА Ӧнъ.

ДB: M. í C. YTf́baca,

บтtтaca, YTÉtaca. $\mathrm{Ke}^{\tilde{\text { म }}}$ : पT⿱́口вbCA. MHO ${ }^{*}$ : YTf́MCA,

บTÉTbCA, पTÉTÐCA. पт́́treca,

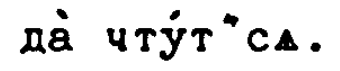

Ви́да оуччащ.

$\epsilon_{\text {ди }}{ }^{\text {म }}$. Bре́ma hactó́l.

Дв. Моуж. и́ С. чита́йвасА, чита́йтаса: чита́йтасА.

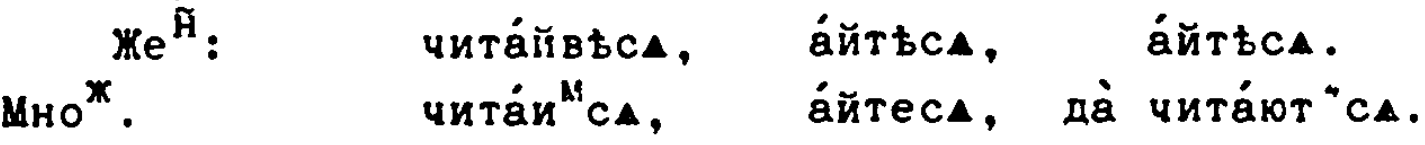




\section{Будіушеe .}

$\dot{C}\left[u^{\mathrm{H}}{ }^{\mathrm{H}}\right.$.

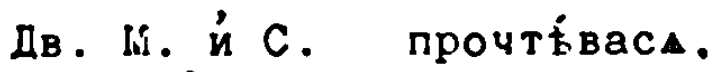
$\mathrm{He}^{\mathrm{H}}$. Liно*. прочтїса тӥ. ПГОчтйсА Ӧнъ.

fTaca. ÉTaca.

Наклоне́ніа Сослага́телнагш, Bíда совершённа,

Bге́ma hactómee.

ämе бы: гды́ бым са чита́лъ.

$$
\text { : }: 2 x^{\mathrm{A}} \text {. }
$$

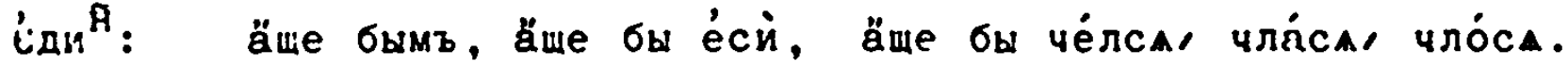

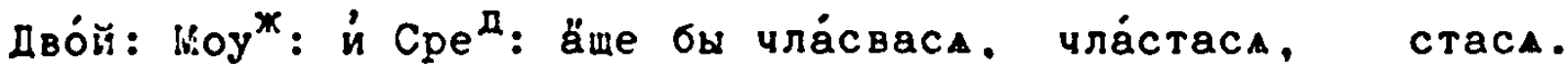

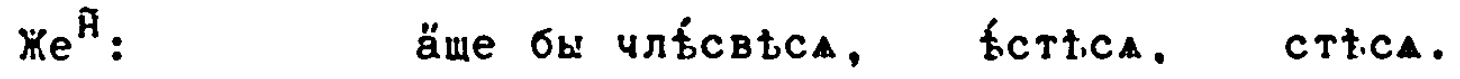

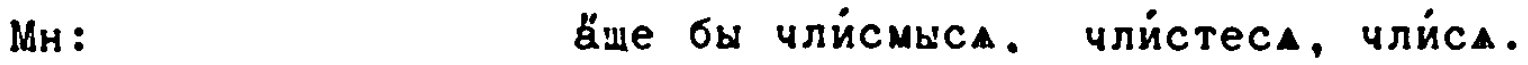

Преходи́mee:

гди́ бчмъ бйлъ чйтанъ.

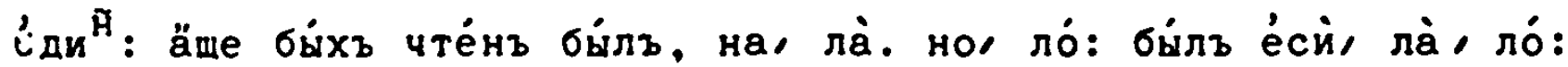

бiue.

Дво́й. Моуж. й Сред. ӓще би́сва чте́на была̀, би́ста, ста.

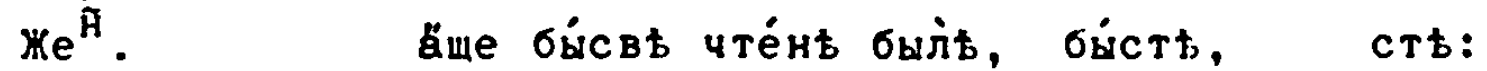
мно*. ämе бы́хомъ чте́ни, ны, на былй, бы́сте, біху, и́лй б́́ша. Вйда оуччаща́телна,

Bp. настойщ.

Гди́ бЫмъ СА чйтовалъ.

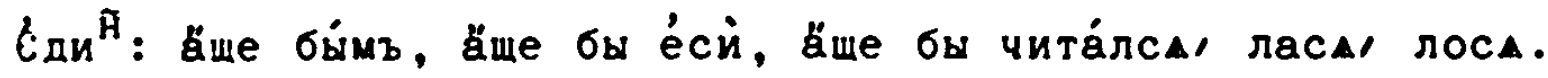

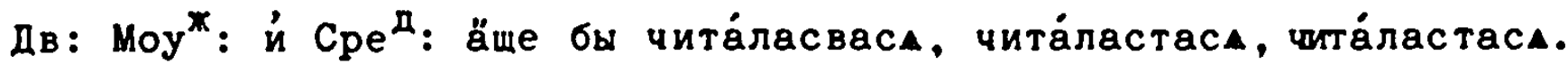
We $e^{\text {म }}$

ăme бы чита́льсвђсA, чита́лђстьсA, чита́льстђсA. МHO ${ }^{\text {X }}$

[1336]

Mно :

ämе бы чита́лисмьса, чита́листесА, чита́лисА.

Преше́ дшеe :

гді́ бнмъ бйл чйтованъ:

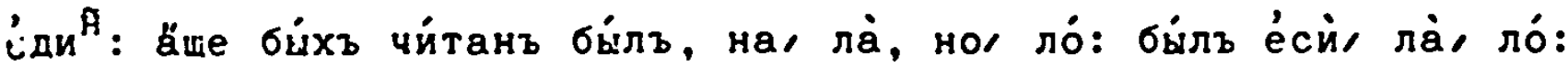
бíme.

Цвв: Ноуж: й Cре

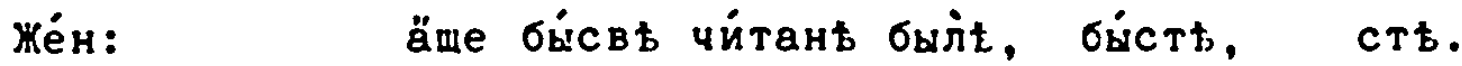

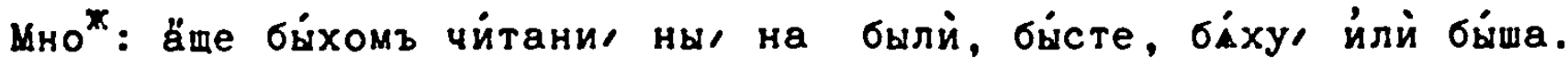
Мимоше́ дшеe :

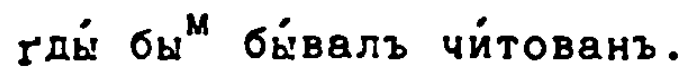

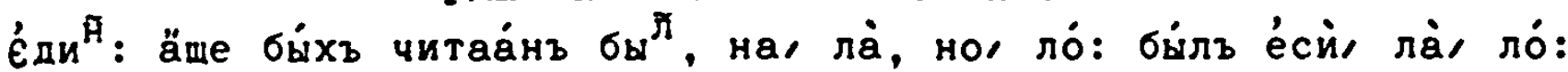
бÁme. 


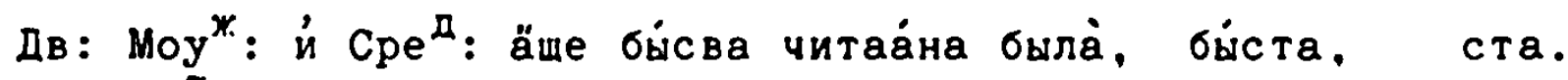

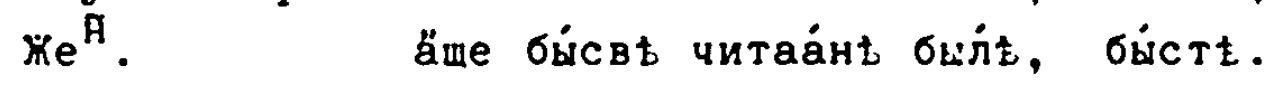

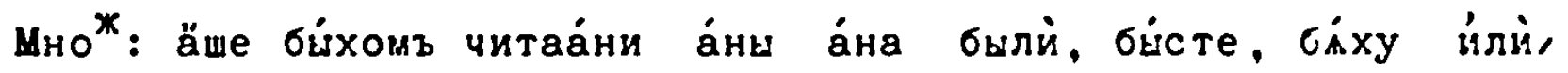
бb́wa.

Непредџлное:

Henpe

гди́ бымъ бйлъ прочйтанъ.

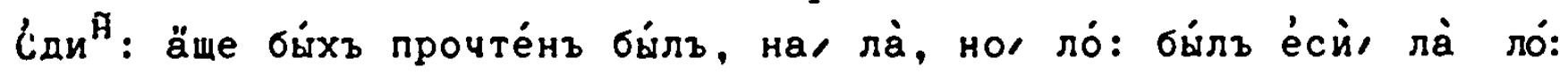
oime.

Дво́й: Моуж: й Cpę: ăще би́сва прочте́на была̀, бйста. ста.

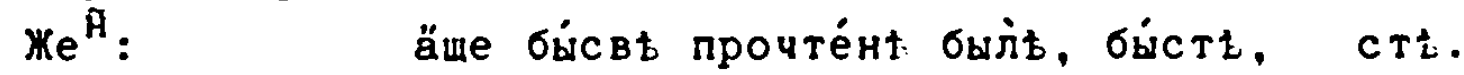

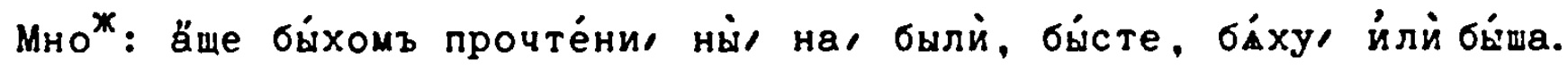

Будйше :

гді бы былъ прочйтанъ налото́мъ:

є̇ди : ämе бымъ, ämе $\sigma_{ы}$ е́сй, äme бы проче́лса, чла́са, ло́са.

Дв: Моуж: й Сред : ӓше бы прочла́сваса, прочла́стаса,

ctaca. $\mathbb{K} e^{\tilde{H}}$ :

äще бы прочлб́свђса, прочлб́стьса.

ctbck.

$\mathrm{MHO}^{\text {* }}$ :

äще бы прочли́смыса, прочли́стеса, прочліска.

Наклоне́ніА По Чинйтелнатш, Вйда Соверше́нна,

Bре́ma настод́шеe.

Дà: áó́mb cA чита́лъ.

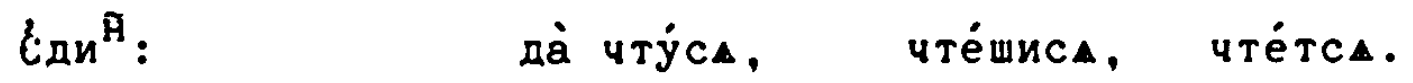

Дв: Моу*: й Cpe Ж $e^{\mathscr{H}}:$

да̇ чте́Btca. पте́tbca.

Мно ${ }^{*}$ :

да̇ чте́mca, чтете́ca,

TbCa.

Преходйmee :

Да் бы́xъ: áбы́mъ бы́лъ чи́танъ.

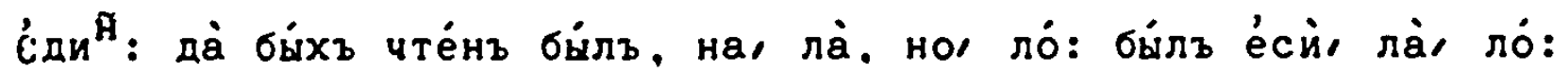
óme.

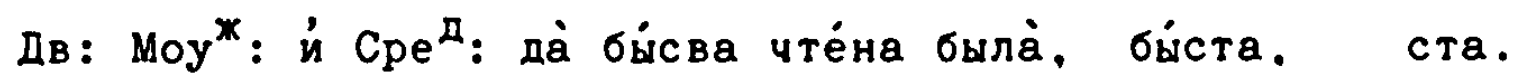
We $e^{\tilde{A}}$ :

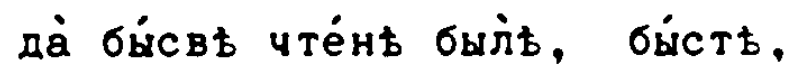
crt.

мно*: да̇ би́хомъ чте́ни, ны на былй, бйсте. біхуу йлй бі́ша. Вйда Оу́чаща́телна,

\section{Bp: настовщ:}

Да̀: áбйmb са чи́товалъ.

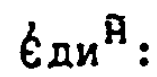

да̀ чита́⿴囗十,

чита́ешиса, чита́ ${ }^{T}$ CA.

Дво́й: Моуж Мно ${ }^{\text {* }}$ $\nVdash e^{\widetilde{H}}$ :

да̀ чита́eвaca,

etaca,

etbca,

да் чита́eвьca,

да̇ чита́e"ca, чита́eteca. Преше́ дmee: 


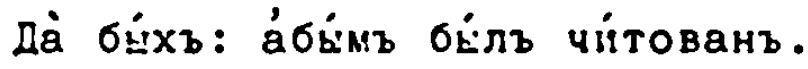

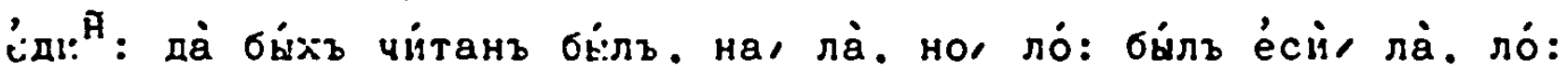
бíve.

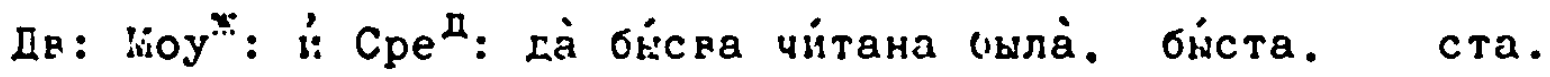

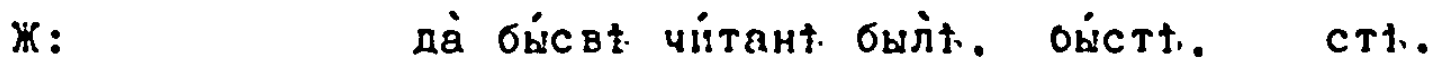

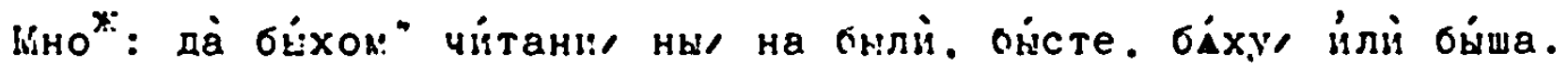
Mun:owér.wee :

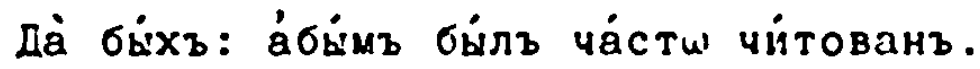

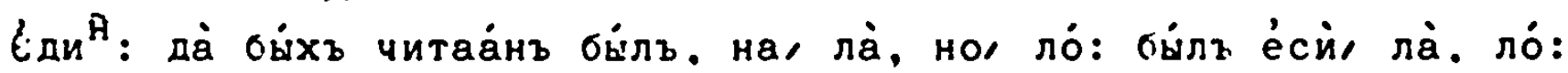
oime.

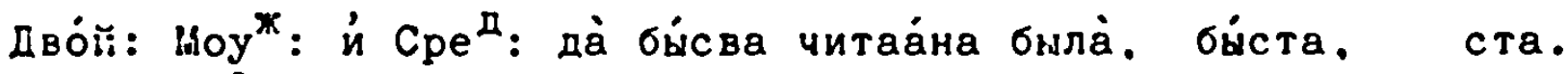

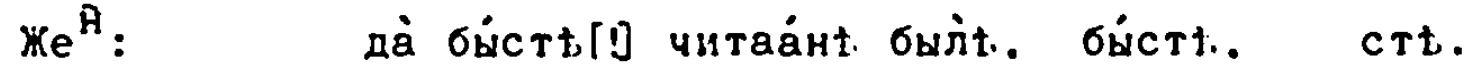

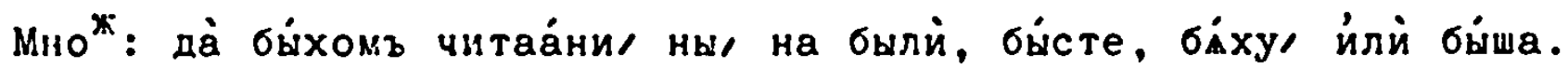
Heпредtriное:

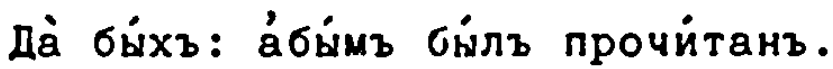

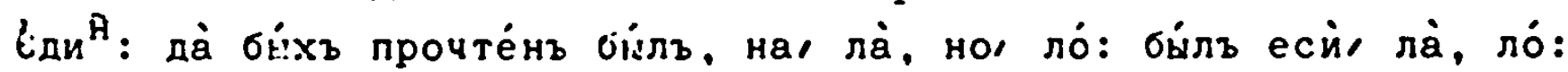
ónue.

Дв: $M:$ и́ С: да̀ би́сва прочте́на была̀. бйста. ста. Же

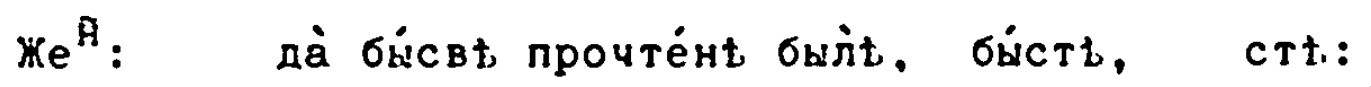

Мно : да̇ бйхомъ прочте́ни, ны на, былй, бйсте, бїхулйлй би́ша.

Будищеe :

Да̇: áбb́mb ca прочита́лъ напо́томъ.

ध̈: дà прочту́са, прочте́шиса, прочте́тса.

Дво́й: Моуж: и́ Сред: да̇ прочте́васА, прочте́тасА, прочте́таса.

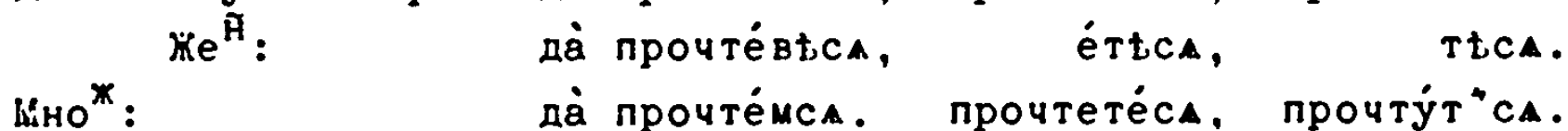

Наклоне́ніА неопредtле́ннагш, Вйда сове ше́нна,

Вре́ma настойmee.

Преходи́mee :

настойய.

Преше́ дшеe:

Uимоше́ дwee :

Henpe atriнoе:

Буд́уше :
Чести́са: йлѝ, что́му би́ти. Чести́са: йлй, чте́ну б̈́ти. Bйда оуччащ:

Чита́тиса: йлй чита́ему быва́ти. Чита́тиса: и́лй, чйтану быва́ти.

мимо

Читав́тиса: йли́, читаа́ну быва́ти. Прочестйса: йлй, прочтёну би́ти. Прочести́са: йлй, прочтому бйти. Прича́сті^ зало́га Страда́те $\mathrm{H}_{\text {нагw }}$ Вйда сове ше́нна, 
Bре́нenе настойmarw:

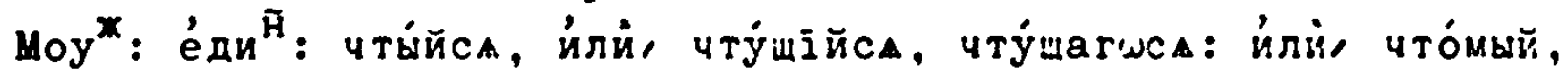
что́мarw,

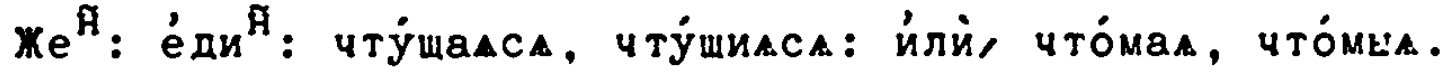
$\mathrm{Cpe}^{\text {д̆}: ~ е ́ д и ~}$

Преході́marw.

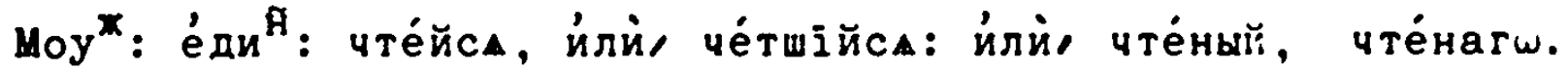

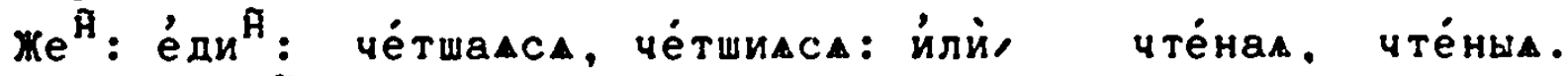

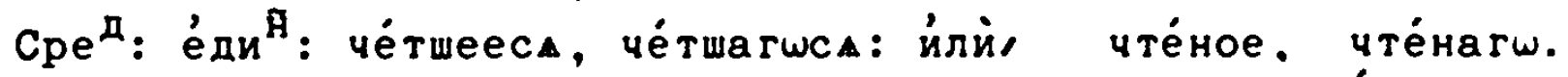
$P$ вйда

\section{Ви́да ојчаща́телна,}

\section{Вре́мене настод́щатш:}

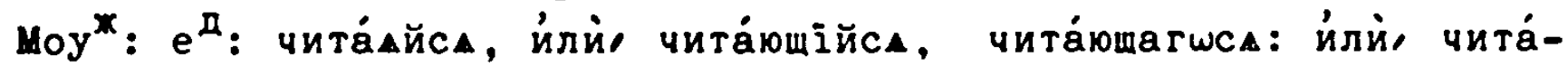
емый, читаемагш.

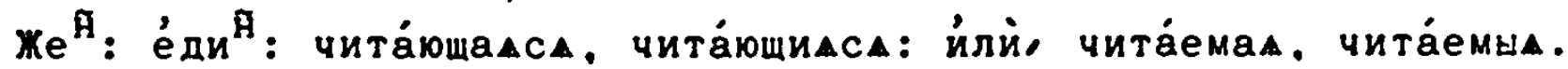

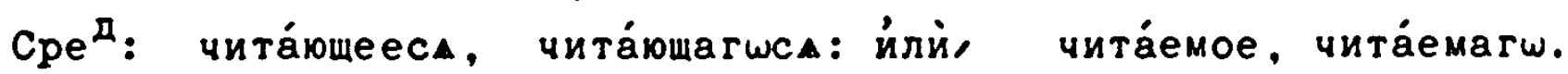
Лpewé дwarw:

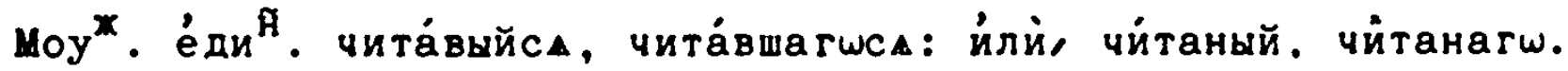

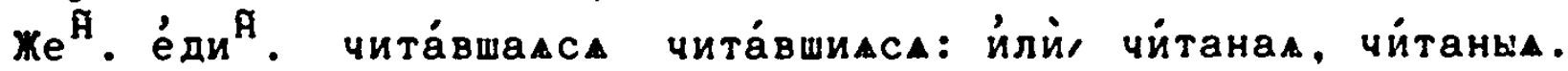
$\mathrm{Cpe}^{\text {Д }}$. е́ди мимоше́ дwarw:

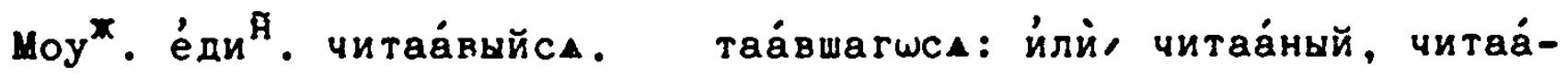
нагw.

Же Сре Непредьлинаг: Henpe ${ }^{\text {म. }}$

йлй, проче́тшійса, проче́тшагшса: и́лй

моу $^{*}$. е́ди ${ }^{\text {A }}$ прочте́йса, йлй проче́тшійс
прочте́ный, прочте́нагш.

Же $\mathrm{f}^{\mathfrak{A}}$ е́ ди ным.

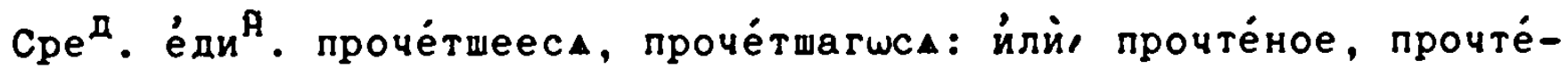
нагw.

Буд́уща

Моу“. е́д. прочту́щійса, прочту́щагшса: и́лй, прочто́мый, прочто́marw.

Жен MbL.

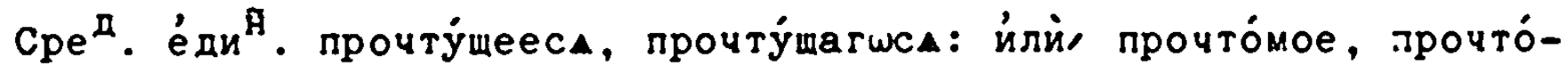
marw. 
L亡епричáctí Зало́га Страда́телнатw, Bíда соверше́нна, Bре́мене настод́marw.

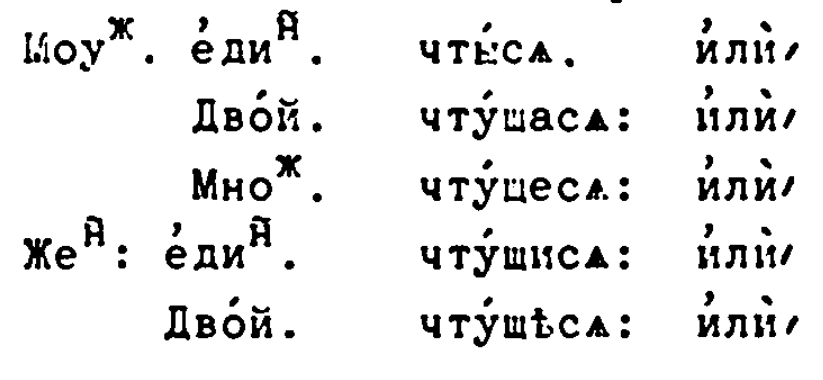

Мно*. чту́щаса: йлй,

Cpe". е́дй. чту́шеса: йлін

Дво́̈. чту́шаса: йлія

Мно . чту́шаса: йлй,

\section{PE}

Преході்щагш:

Моу". е́ди ${ }^{\tilde{H}}$. че́тса: йлй, чте́нъ.

Дво́й. че́тшаса: йлй, чте́на.

Мно . че́тшеса: йлй, чте́ни.

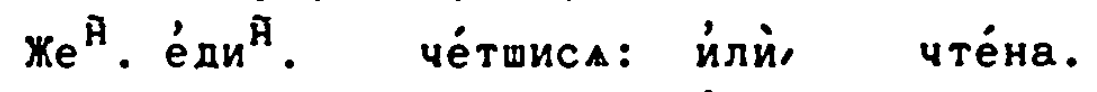

Дв. पе́тшђса: йлй, чте́н.

Мно*: че́тшаса: йлй, чте́ны.

Cpe е́дй ${ }^{\text {I }}$ че́тшеса: йлй, чте́но.

Дв: че́тшаса: йлй, чте́на.

Мно: че́тшаса: йлй, чте́на.

Ви́да оуччаша́телна,

Вре́мене настойщатш.

Моу ${ }^{*}$. е́ди ${ }^{\text {. }}$ чита́аса, йлй, чита́ющъсА: йлй, чита́емъ.

Дв: чита́ющаса: йлй,

Мно : чита́юmeca: йлй,

Же ${ }^{\text {म }}$ : е́ди ${ }^{\AA}$ : чита́юшиса: йлй

Дв: чита́юmђса: йлй,

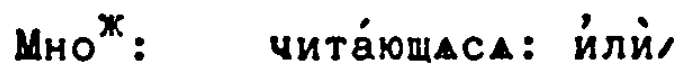

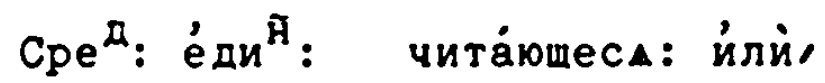

Дв: чита́юmaca: йлй,

Мно : чита́юraca: йлй

Преше́ дшагш:

моу": е́ди". чита́в"са: йлй, чйтанъ.

Дв. чита́вшаса: и́лй, чйтана.

Мно*. чита́вшеса: йлй, чи́тани.

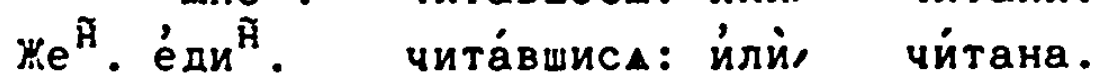

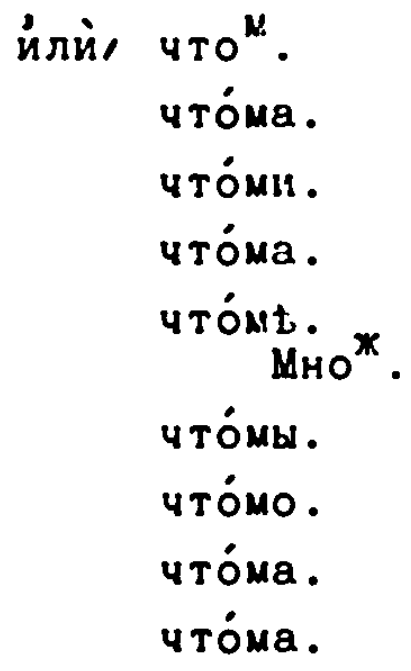

чита́eмa.

чита́еми.

чита́ema.

чита́emt.

чита́eмы.

чита́емо.

$$
\text { Cpe }{ }^{n}
$$

чита́ema.

чита́ema. 


\begin{tabular}{|c|c|}
\hline $\begin{array}{l}\text { ДE. } \\
\text { МHO } .\end{array}$ & 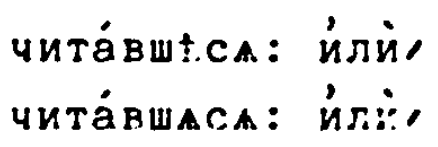 \\
\hline & чита́вшеск: йr:⿱亠䒑, \\
\hline $\begin{array}{l}\text { Дв: } \\
M_{\text {HO }} *:\end{array}$ & 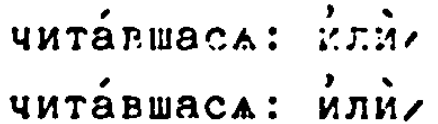 \\
\hline
\end{tabular}

Mииоше́ лwarw:

Моу”. е́ди". читаáв"сA: йл̀, читаäнz.

Дв читаáвшаса: йлі., читаáна.

Мно*. читаввшеса: йлй, читав̈ни.

Же

Дв. читаáвшt.cA: и́лй, читаáнt.

Мно*. читаáвшаса: йлй читаáне.

Cpe . е́ди

Дв. читав́вшаса: и́лй, читаáна.

Мно*. читаáвшаса: йлй, читаáна

Непредьл́нагш:

Моу*. ёди ${ }^{\AA}$. проче́тса: йлй прочте́н.

Дв. проче́тшаса: йлй прочте́на.

мно*. проче́тшеса: и́лй, прочте́ни.

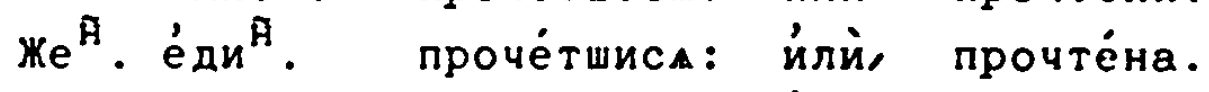

Дв. проче́тшъса: йлй, прочте́нь.

Мно*. проче́тшаса: йлй, прочте́нн.

$\mathrm{Cpe}^{\text {д }}$. е́ди ${ }^{\mathscr{H}}$. проче́тшеса: йлй, прочте́но.

Дв. проче́тшаса: йій прочте́на.

мно*. проче́тшаск: йлй, прочте́на.

Будущатw:

Моу". е́ди". прочту́ш"са: йлй, прочто́м".

Дв. прочту́щаса: йлй, прочто́ма.

мно . прочту́шеса: йли, прочто́и.

Же $\mathrm{H}^{\tilde{H}}$. ёди ${ }^{\tilde{H}}$. прочту́шиса: йлй, прочто́ма.

Дв. прочту́щьса: илй, прочто́мь.

мно ${ }^{*}$ прочту́щаса: йлй, прочтомы.

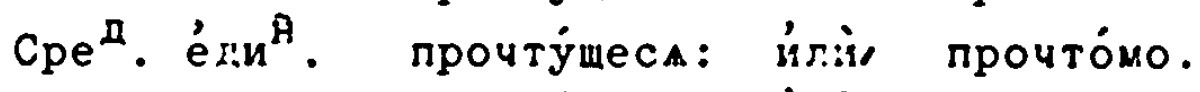

Ців. прочту́щаса: йлй, прочто́ма.

Мно*. прочту́шаса: йлй прочтома.

\section{Увъте́ніе.}

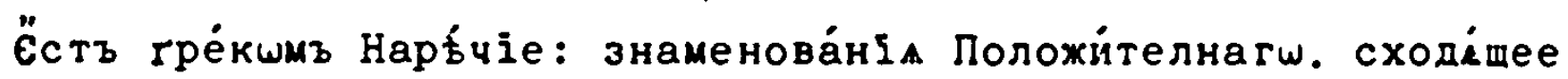
Ha, عov: "̈ekw, 


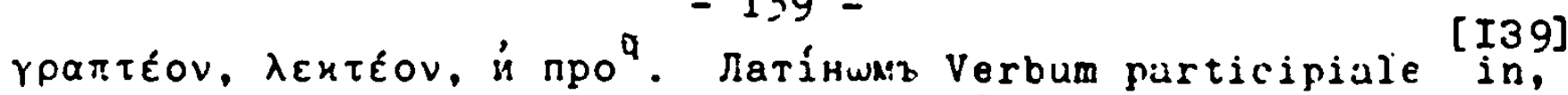

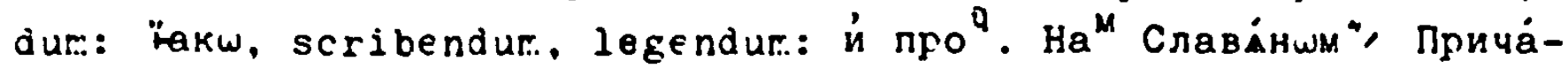

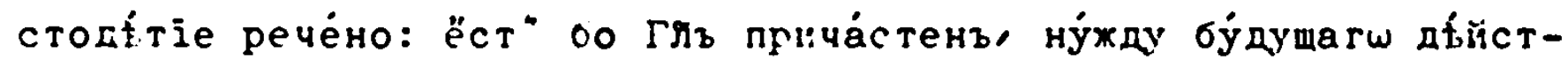
ва знакену́ющій: "ேкш. писа́телно, чита́телно: и́ про".

причастодtтle Bp: Hactónuarw:

Чнта́телно.

Ëxе и́ по пра́вилшм" Прича́стї̆ всбми тре́ми поды склана́ет"са, criue,

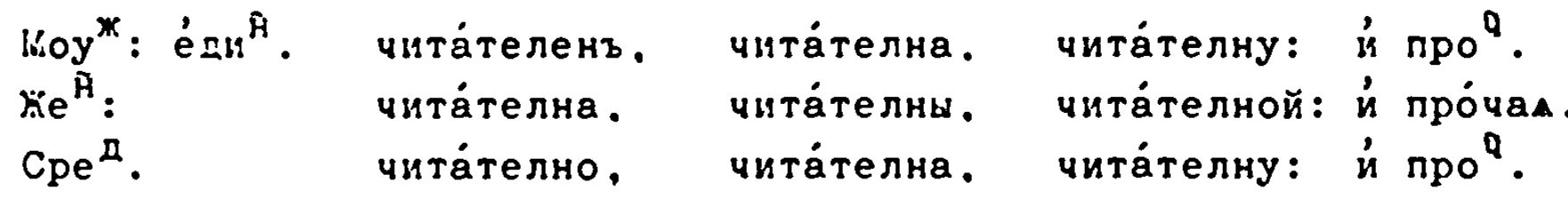
Коне́uз пе́рвому Спраже́нію.

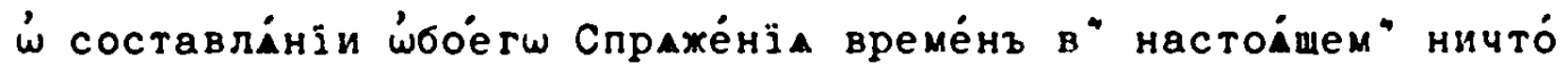
же: мно́гу на се́ поиска́нію, за Славе́нска Лец̆іко́на лише́ніел йзыскуему. Бо́хінм о́баче поспьйіемъ трудолюбйвыхъ потща́ніе о́бое́ на", ско́рte наде́жды препо $P$ да́сть.

[I396]

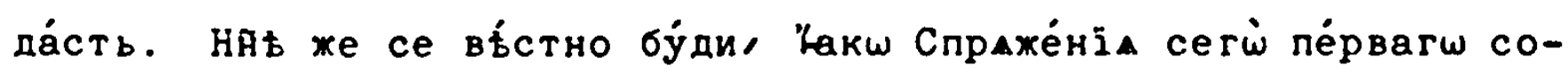

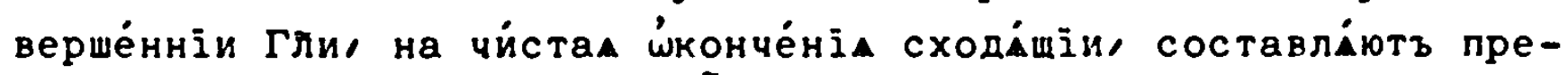

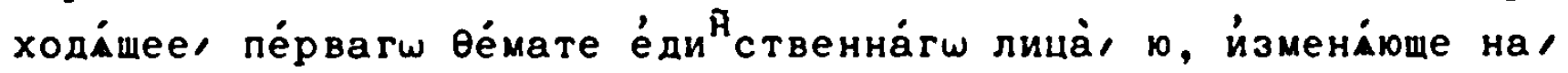

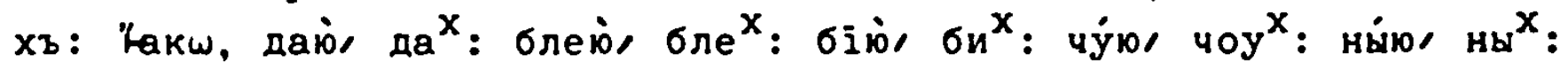

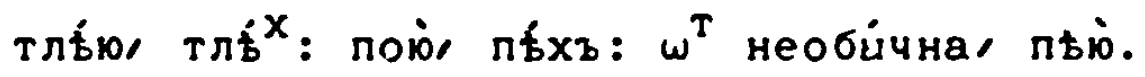

Нечистьх же 'конче́ній гли, ӧви нал $0^{x}$, о̆ви же на, $a^{x}$, преходи́mee тво́ратв.

\section{Ha, oxb:}

Глии конча́щіиса на, бу, гу, ду, зу, ку, пу, су, ту: Гакш,

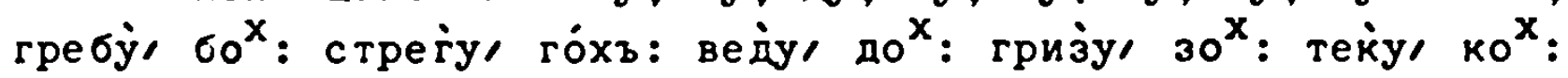
cony' conox: несуy, cox: nлету, то

Ha, axb:

ГЛи конча́щіиса на, ву, жу, жду, лю, му, ну, ру, чу, шу, щу:

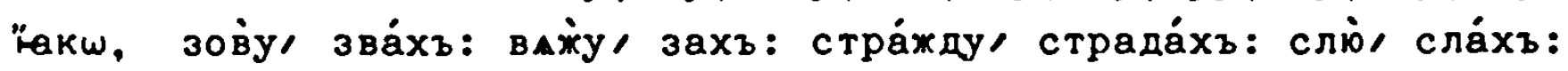

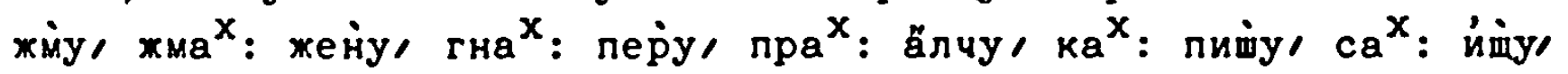
иска ${ }^{x}$.

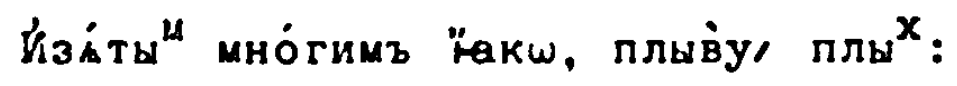

кленуу

[140]

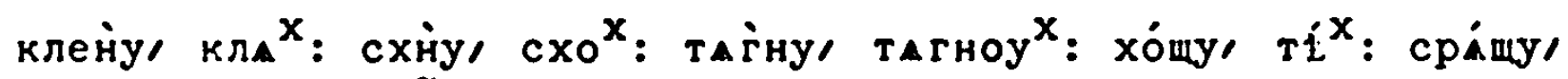
трьто́хъ: й про

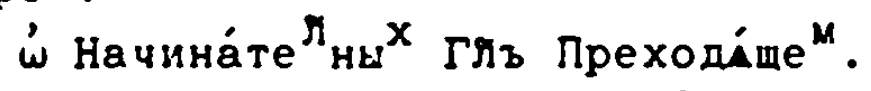

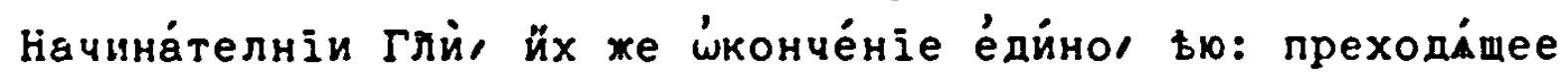

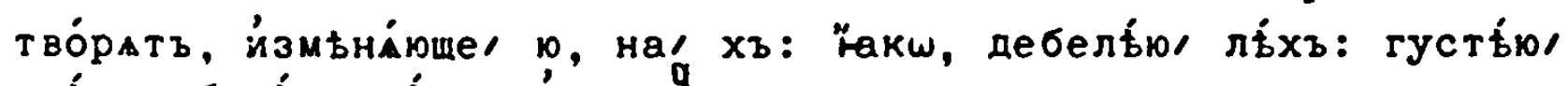

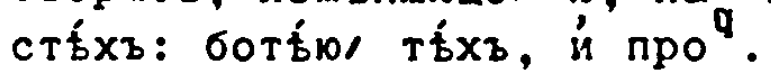


‘் Преше́ дшек:з.

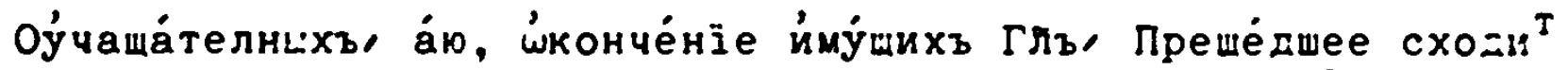
на, ахъ: "акw, 'ада́ю, 'ада́хъ: глаша́ю, глаша́хъ: й про

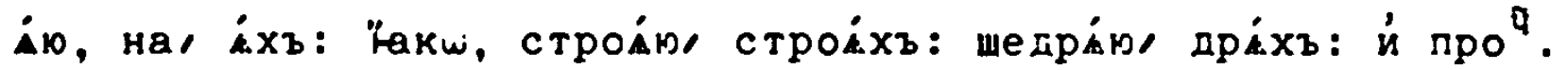

ую, на, овахъ: Ґакш, совџту́⿴囗 това́хъ, ходотайствую, ствовáxъ: 'ं про".

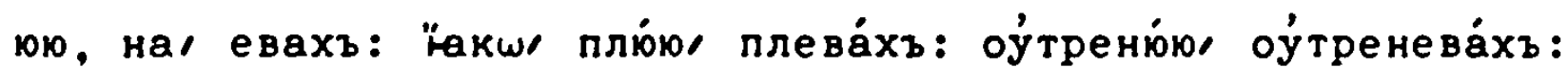
ห่ npo

$\dot{\omega}$ Боу́душемъ.

Буддушее Глъ вси́ческихъ, оуччаша́телни пе́рвагш лица̇ Вре́mене Настойmагш наклоне́ніА йз "Авй

P

телнагш Ви́да совер "ше́нна, составли́етъса, то́хде c" ни", ра́зв нараще́ніл суще.

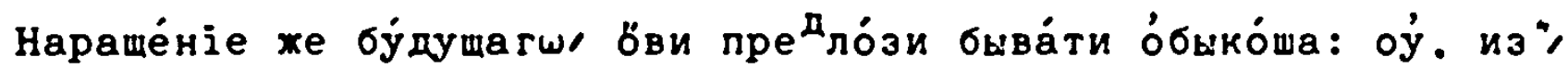
йлй $\mathrm{c}^{\star}$, во, со, на, '́, по, при, за, вос, рас.

ל̆зи́тіе:

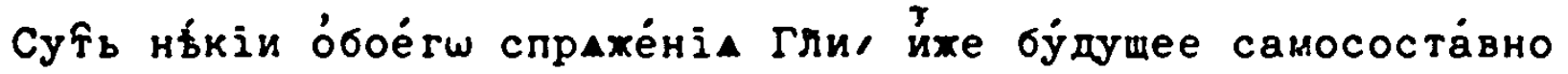

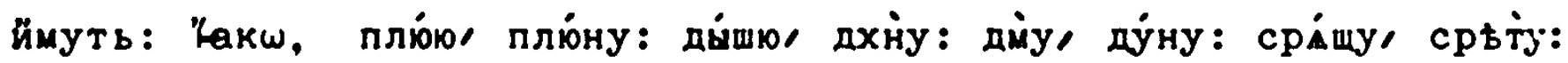

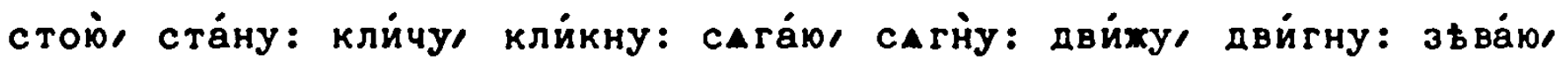
збну: дерза́ю, дерзйу: стага́ю, стагіу̇: ка́плю, ка́ну: вне́млю/ внимуy: даю̆, да": со всбми свойми сло́хеными. и́ сим подо́бніи.

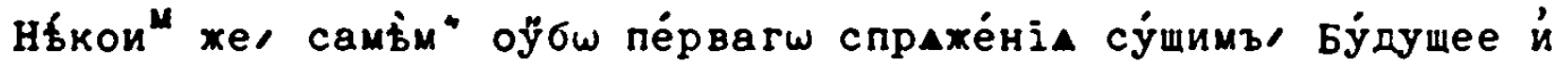

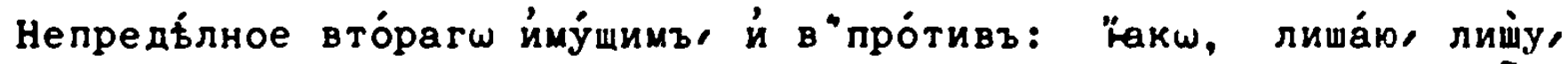
лиши : купу́ю, купліо, купихх : проша́о, прошіо, простихъ: й про".

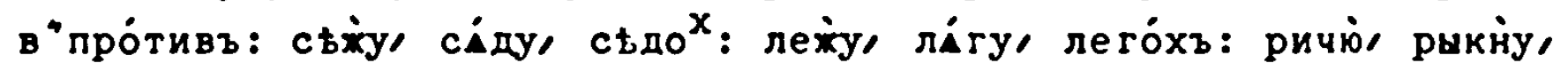
рыкну́хъ: '́̀ про́чал.

i no

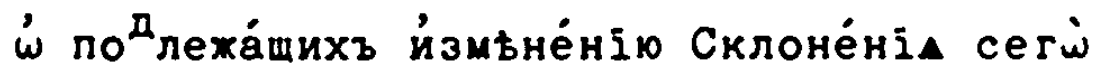

начерта́телныхъ согла́сныхъ.

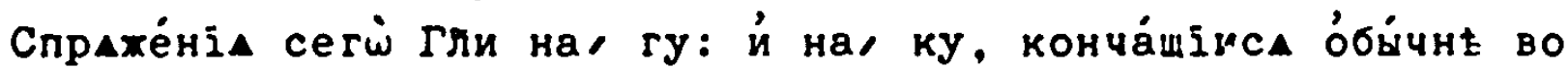
вто́ромъ й во про́чіих всы́хъ чйслъ лйцихъ Вре́мене настойшабшы во тре́тіе же е́ди" стве́нном" Преходйmагш Наклоне́ніа йзъавителна, оубб на, $x$ : $K$, на, ч: претворіютъ. Во Повелителнагш же й цолйтелнагш наклоне́ніА вто́ромъ е́дй стве́нномъ лицй настод́щагш: $r$, на, з: К, на, ц: в" Неопредьле́нномъ обо́е на. щ: "акш. могуу, мо́хеши. й про : мо́хе, мозй, мощй: теку, тече́ши, й про тече́, тецй, тещй. Й ӓще кій ГЛъ начерта́телное ймать, $x$ : йзи́нитъ се́ во пред лохенныхъ време́нъ лйцихъ на, ш. Һ $\mathrm{c}$. $\dot{\omega}$ Повелйтелномъ й Молйтелном" непра́вилнь кончймомъ. 


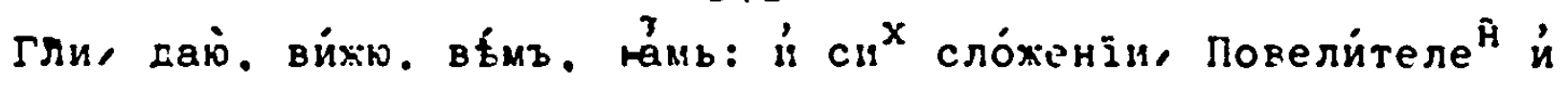

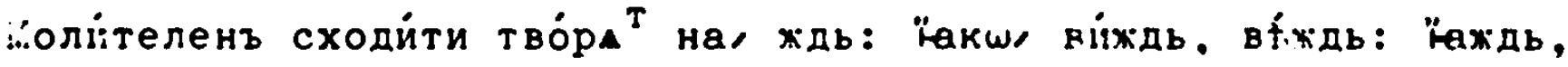

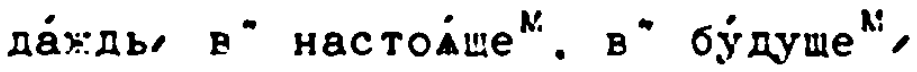

дайi:

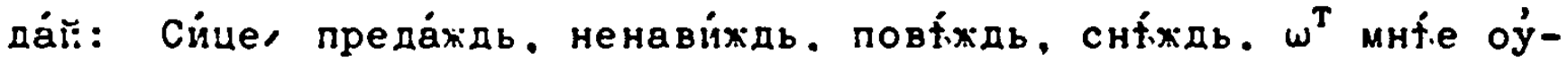
потребліемьхъ, дадй. вйди. вы́ди, 'адй. й äще кіи про́чіи.

Пара́дигмa Вто́рагw Cпрахе́нī.

Глгола̇ Личнагш. Зало́ra дыїствителнагш, Ви́да соверше́н"на, Наклоне́ніА Йзъавйтелнагш.

Bpéma Hactoámee:

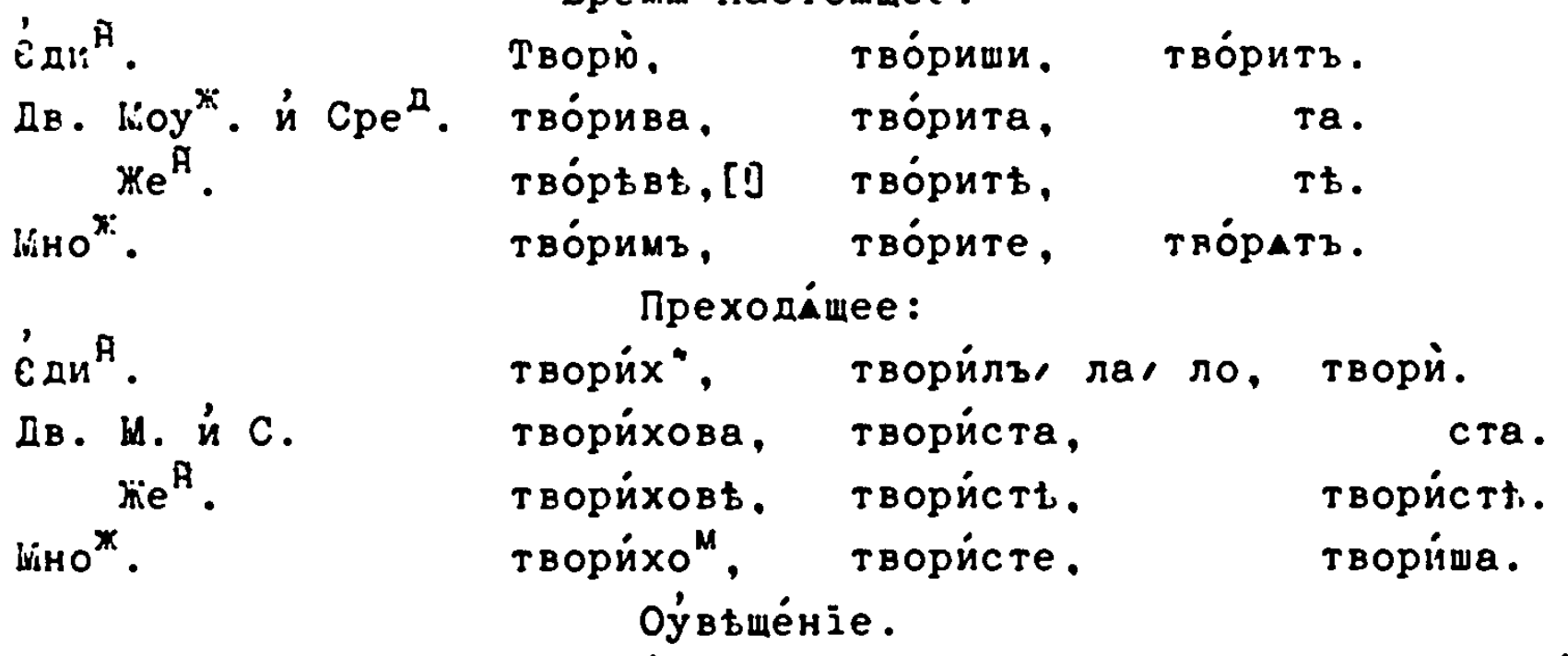

Поне́же всй Гйи вйда оу่чаща́телна пе́рвагш сутьь спрахе́ніА, й всй е́динакш по пред лохе́нному в" пе́рвомъ спраже́ніи Пара

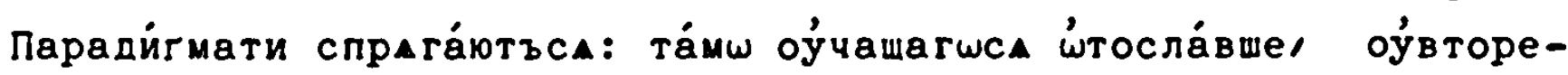
нie érì, '́ставліемъ.

Ви́да оу́чащáтелна,

Bpéma hactó́mee.

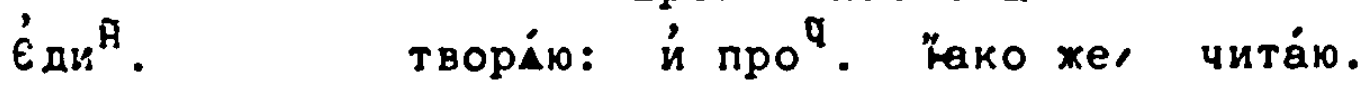

חpe wé дwee :

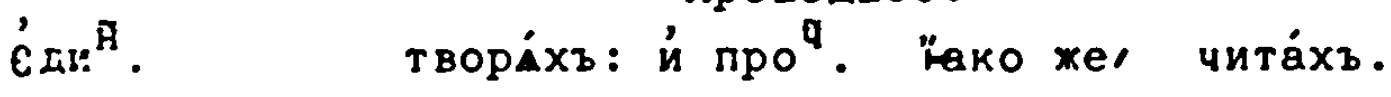

є̇й

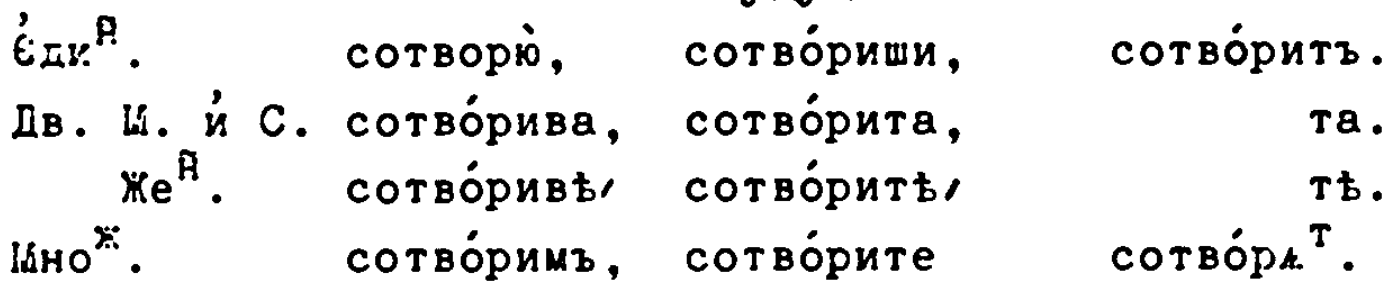

Непредьлиое:

Є́гин. сотворих 
Lв. М. и С. сотворихова, сотвори́ста Же ${ }^{\tilde{H}}$. сотвори́ховt, cтt, стћ.

Мно*. сотворйхомъ, сотвори́сте, ри́ша. Наклоне́ніА Повели́телнатш, Вйда соверше́нна,

Bре́me настойuee.

$\hat{\epsilon}_{\text {дй }}$.

Дв. М. и́ С. твори́ва, Же ${ }^{\text {月. }}$ твори́в Мно . $\epsilon^{n}$ धди ${ }^{\tilde{H}}$.

Дв: М. и́ С. сотвори́ва. Же ${ }^{\hat{A}}$. сотвори́вt, $M_{H O}$. $\dot{\epsilon}_{\text {ди }}{ }^{\mathrm{A}}$. Дв. Моу*. и́ Сре $\mathrm{Ke}^{\mathfrak{A}}$. $\mathrm{MHO}^{\mathrm{x}}$.

Én. творйвь, твориंмъ, Ви́да оуччащ: Вp: настоди:

Наклоне́ніА Молит : Ви́да совер:

Bре́mム настойmeе.

Вйда оуччш: Вp: настойш. твори́та, да̇ тво́рита. твори́т, да̇ тво́рить. твори́те, да̀ тво́рАтъ. Будиуше : сотворйи", сотвори́те, да̇ сотво́рА ${ }^{T}$.

творй ты, да் тво́ритъ ӧнъ. й про ${ }^{q}$ : "ако же чита́й тй.

сотворй тй. да̀ сотво́ритъ ӧнъ. ри́та, да̇ сотво́рита. ри́тt, да் сотво́рить.

творй ть். творй ӧнъ.

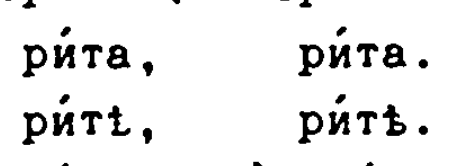

ри́те, да̇ тво́patz. твори́й тй: и́ про ${ }^{q}$. Н̈ко же, чита́й тй.

\section{Будуymee :}

Бу́дy

$\operatorname{Cinh}^{\text {मे. }}$

Дв. Моу⿰ ${ }^{x}:$ и $\mathrm{Cpe}^{\text {д }}$. сотворивва, сотворй тй, сотворй ӧнъ. $\mathrm{e}^{\mathbb{R}}$. сотвори́в, Мно сотвори́мъ, $\begin{array}{ll}\text { ри́та, } & \text { ри́та: } \\ \text { ритть, } & \text { ри́ть. }\end{array}$ ри́те, да̀ сотво́рцтъ.

Наклоне́ніћ сослага́телнатш⿱ Ви́да соверше́нна, Bре́ma настов́mеe.

ämе бы: гды бымъ чинйль:

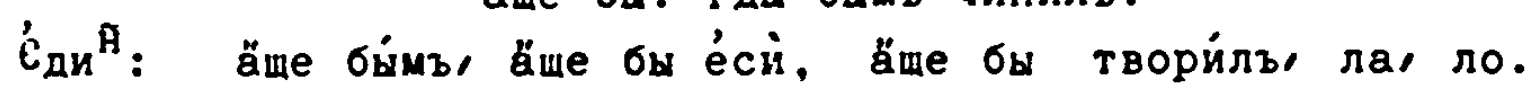
д. М. и́ C. ämе бы творйласва. Жe ${ }^{\text {म }}$. äme $\sigma_{ы}$ творйльсвt, cта, ста. Мно ämе бы твориялисмы. твори́листе, творияли. Преході́mee: äme $\sigma_{\mathrm{x}}^{\mathrm{x}}$ : гды́ бымъ былъ чинйлъ. 


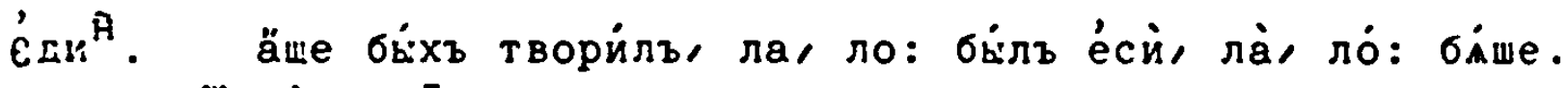
цв: Моу $^{*}:$ й Cpe

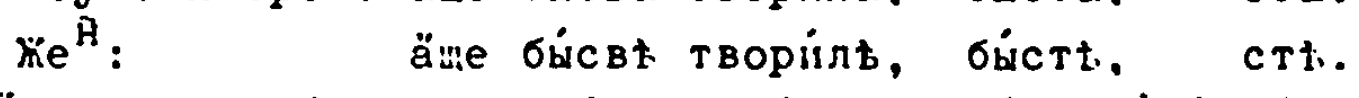

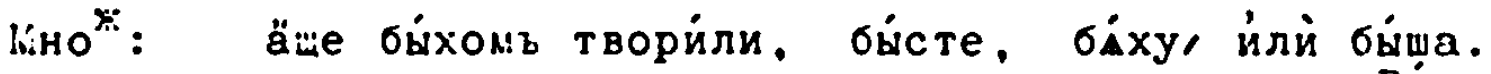

\section{Ви́да О’́чаща́телна, Bp: настодњ:}

Búna

гдиं бымъ бйлъ чйнивалъ.

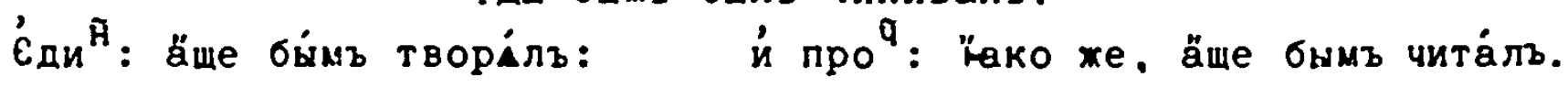

Преше́ дшее :

гды́ бымъ бйлъ чйнивалъ.

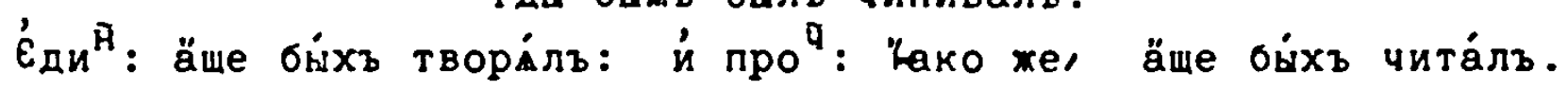

Мимоше́ дшее :

гды́ бымъ бйлъ ча́сть чйнивалъ.

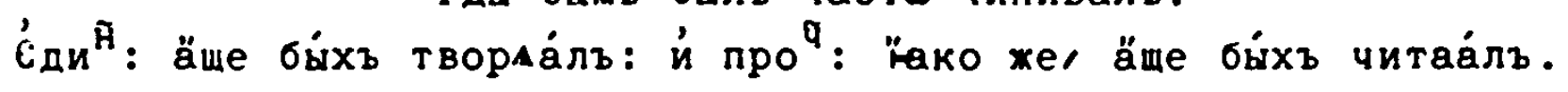

Hепредьлное :

гды бы бйлъ оуччинйл:

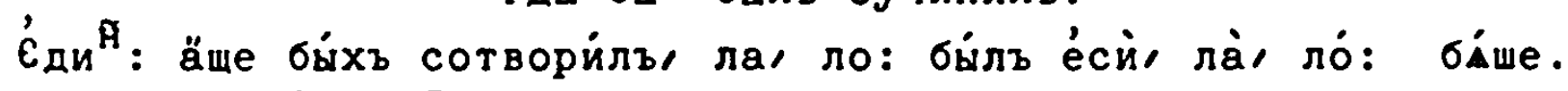
Дв: Моу": и́ Сред : ämе би́сва сотворйла, бйста, ста:

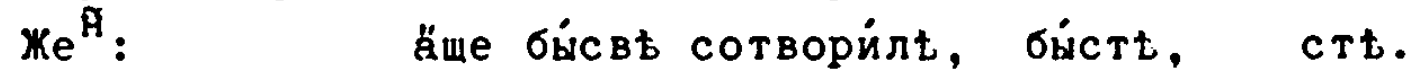
Мно*: äще би́хомъ сотворйли, би́сте, бйху, йлй б́́ша.

\section{Буд்уше .}

Бу́дущеe :

ămе бы: гды́ бымъ ојчинйлъ напото́мъ.

$\dot{\epsilon}_{д и^{\text {A }}}$ : ăще бымъ, ӑще бы е́сй, ӑще бы сотворйлъ, лал ло.

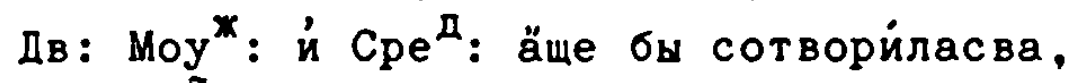
cra, ста. $\mathrm{Ke}^{\overline{\mathrm{A}}}$ :

ăme $\sigma_{ы}$ сотворйлtсвђ,

crt, ctђ. $\mathrm{MHO}_{\mathrm{H}}{ }^{*}$ :

द̆ще бы сотворйлисмы, Наклоненіа по чинителнагш, Вйда сове шённа, сте, сотворйли.

Bре́ma настои́mеe.

да̇, а́бы́мъ чинйль.

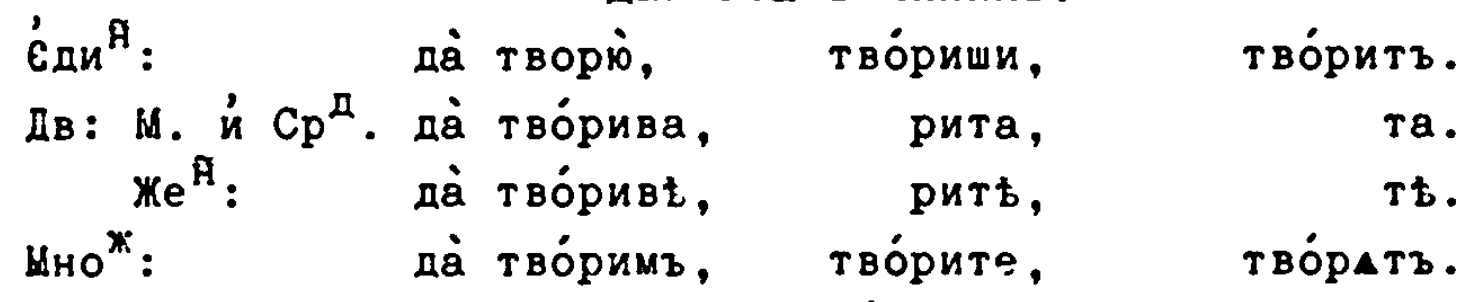

Преходи́mee :

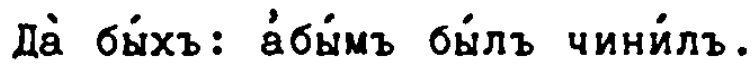

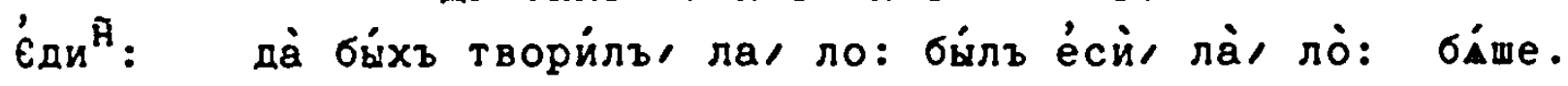

Дв: Моуж: и́ Сред

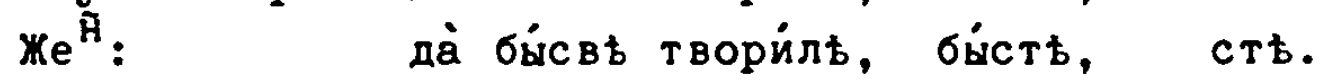




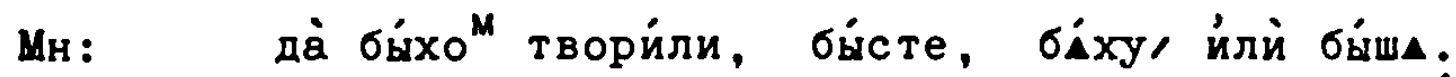

\section{Ви́да оуччаща́те ${ }^{\Re}$ на,}

$\mathrm{Bp}:$ настои́mеe :

Да்: áбы́mъ ча́cтw чинйлъ.

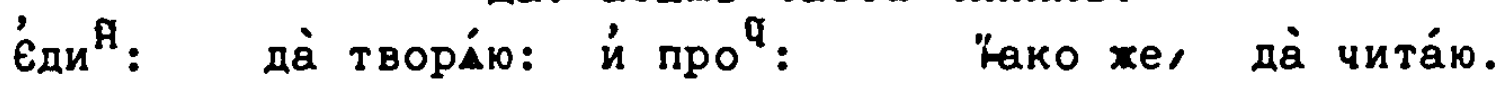

Преше́дшеe:

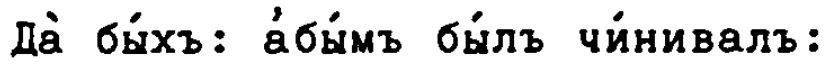

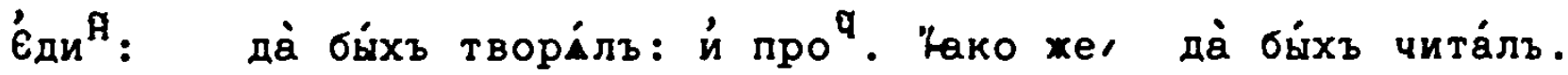
Мимоше́ дшее:

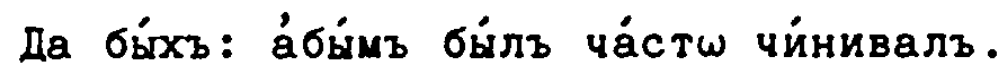

Єдия ${ }^{\text {: }}$ да̇ би́хъ творца́лъ: й про

Боу́дущеe:

Да்: áбы́щъ оујчинйлъ.

єдй ${ }^{\text {: }}$ да̀ сотворю̀, сотво́риши, сотво́ритв.

Дв: М. и́ С. да̀ сотво́рива, о́рита, та.

Же ${ }^{\text {म }}$ да̇ сотво́ривь, оорить, ть.

Мн: да̀ сотво́ри ${ }^{M}$, сотво́рите, сотво́ратъ.

Непредьлиое :

Да் бйхъ: áби́мъ бы́лъ оуччини́лъ.

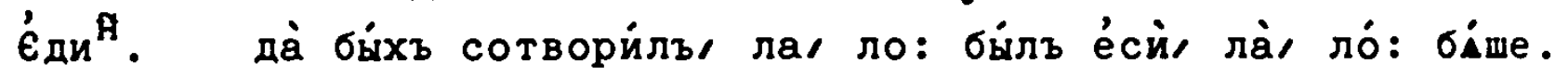

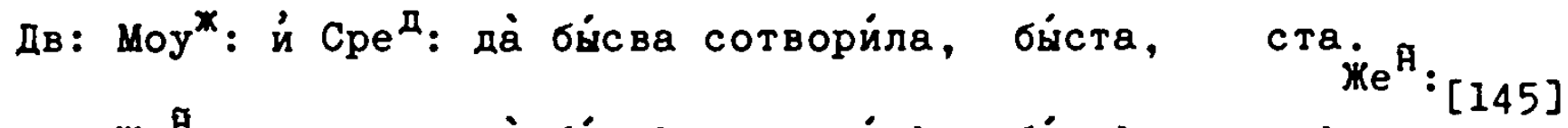

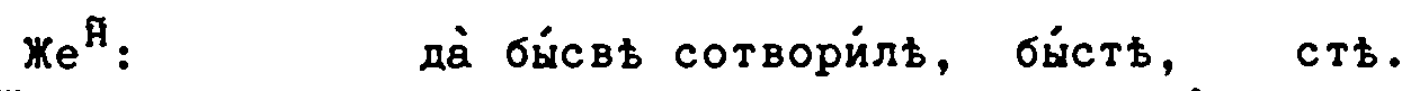

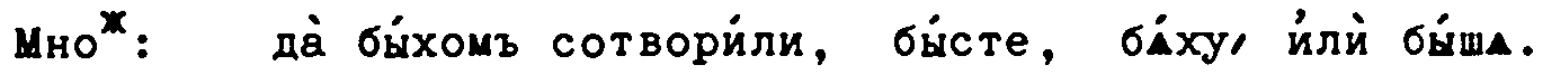

Наклоне́ніА Неопредьле́ннагш, Вйда соверше́нна,

Bре́mА Настод́mee, й Преходи́mee:

$$
\text { Вйда оуччащ. }
$$

Bре́mA Hасто̊́mee, й Преше́дшеe:

Мимоше́ дшеe:

Бу́дущее, й Непредблное:

\section{Прича́cтіム \\ Зало́га Страда́те ${ }^{f}$ наги[!] Вйда соверше́нна,}

твори́ти.

Вре́мене настои́щагw.

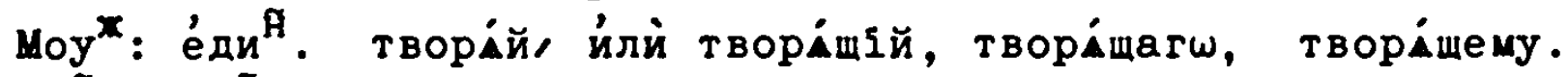
Же $\mathrm{e}^{\tilde{H}}$ : Cре

Преходи́marw:

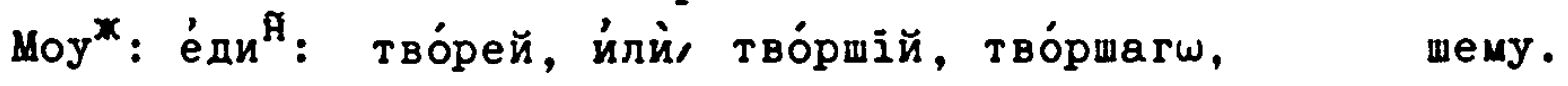


Же $e^{\Re}: \dot{e}^{\text {д }}{ }^{\text {H }}:$ тво́pшам, Cper : е́д: тво́ршеe,

моуж: е́д: твори́вый,

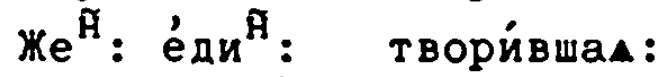
Cpe
C\&

тво́рших, тво́ршей. тво́pwarw, тво́ршему: йлй, $\operatorname{Moy}^{*}:$

[1456]

\section{Ви́na оу́чаm:}

вшагш, твориввшему.

твори́вшиА :

Bwarw: шей.

вшему .

Bp. настод́marw.

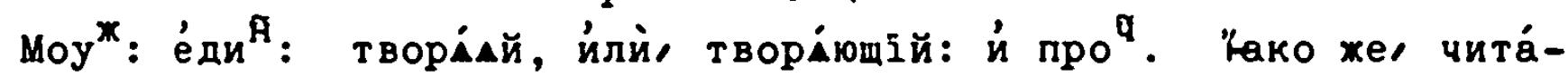
Ай, чита́ющ亡̆̆.

Преше́ дma r $\omega:$

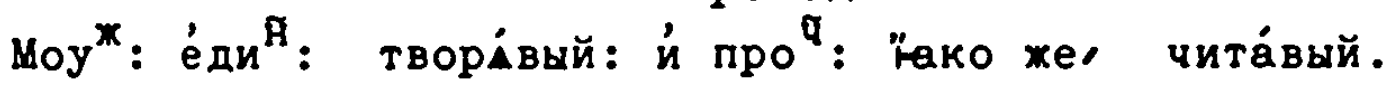

Mимоше́ дmarw:

моу $^{*}$ е́ди ${ }^{\AA}:$ творАа́вый: й про . Гако жел читав́вый.

Буд́уща гш:

моу" : е́д: сотворищцй,

Жен : е́ди ${ }^{\text {म }}$ сотворйmан,

pimarw,

щих,

mar $\omega$, mему.

щей.

щему.

\section{Непредьл́наг $\omega:$}

моу $^{*}:$ е́ди $^{\text {ศ }}$ : сотворе́й, йлй, сотво́ршій, сотво́ршагш,

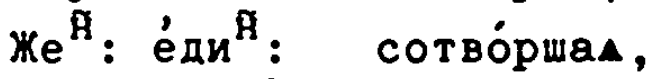
$\mathrm{Cpe}^{\text {म }}:$ éди $^{\text {A }}$ : сотво́pwee,

$\begin{array}{cc}\text { шим, } & \text { шей . } \\ \text { шаг } \omega, & \text { шему }\end{array}$

we my. [I46]

Дъеприча́сті^ Зало́га Дъйствйте нагш, Вйда совершенна,

\section{Вре́мене настод́щагw.}

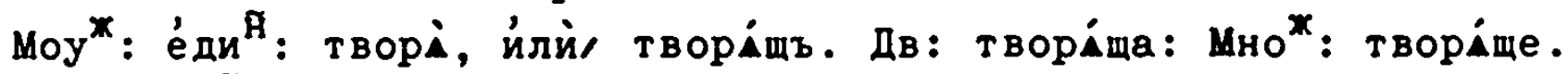
Же $e^{\tilde{A}}$ : е́ди ${ }^{\mathscr{H}}:$ твори́mи. Cpe म $^{\text {ёди }}{ }^{\mathfrak{H}}:$ твори́me:

ДВ. творйщち: Мно : творйща. Дв. творйma: Мно : творйma.

กреходи́marw:

Mоу $^{*}: \dot{e ́ z h}^{\text {f }}$. тво́рь.

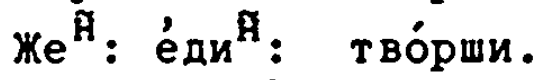

Cpe

моу: е́ди ${ }^{\text {म }}$ : твори́въ.

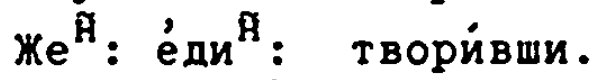
Сре
Дв: тво́pwa.

Дв: тво́pwb.

Дв: тво́pwa: йли่,

Дв . твори́вша .

Дв: твори́вшь.

Дв: твори́вша.

Ви́да оуччах́телна,

Вре́mене настои́marw.
Mно : тво́pwe.

Мно : тво́рша.

Мно : тво́рwа:

Мн. твори́вше.

Мно : твори́вщА.

Мно : твори́вша. 


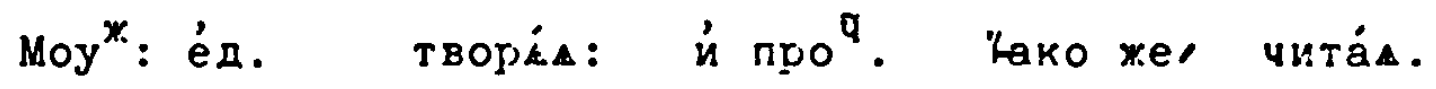

Пре wé дwarw:

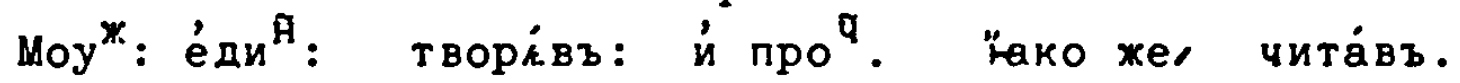

\section{мимоше́ дwarw:}

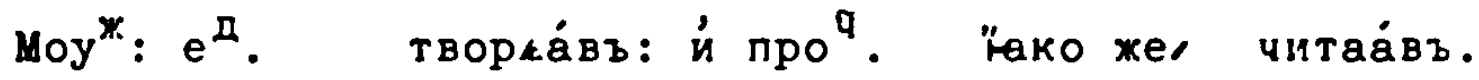

\section{Буд்уша rw:}

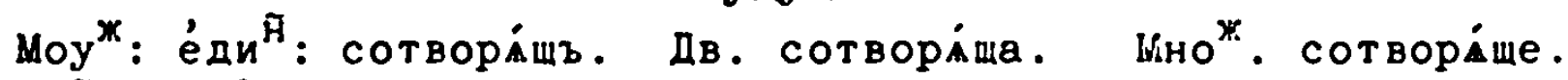

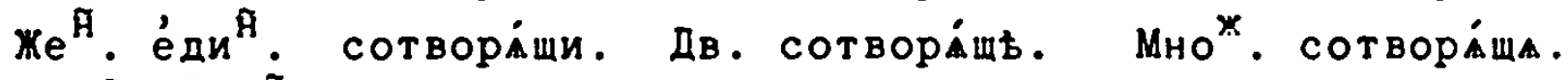

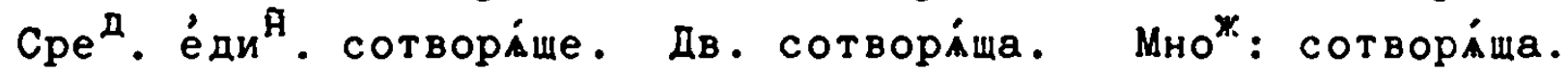
Henpeдћjirarw:

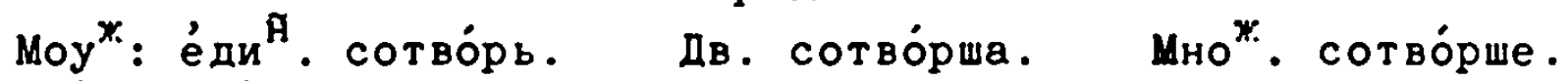

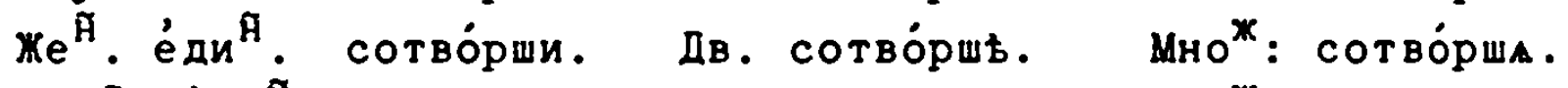

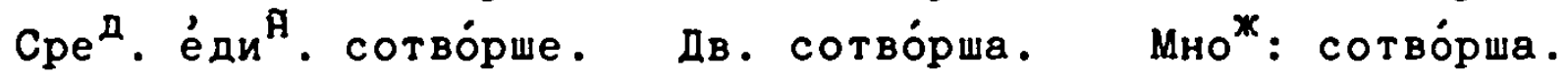

Гяа Лйчнагш: Зало́га Страда́телнагш/ Ви́да соверше́нна, Наклоне́ніл йз"Ави́телнагш.

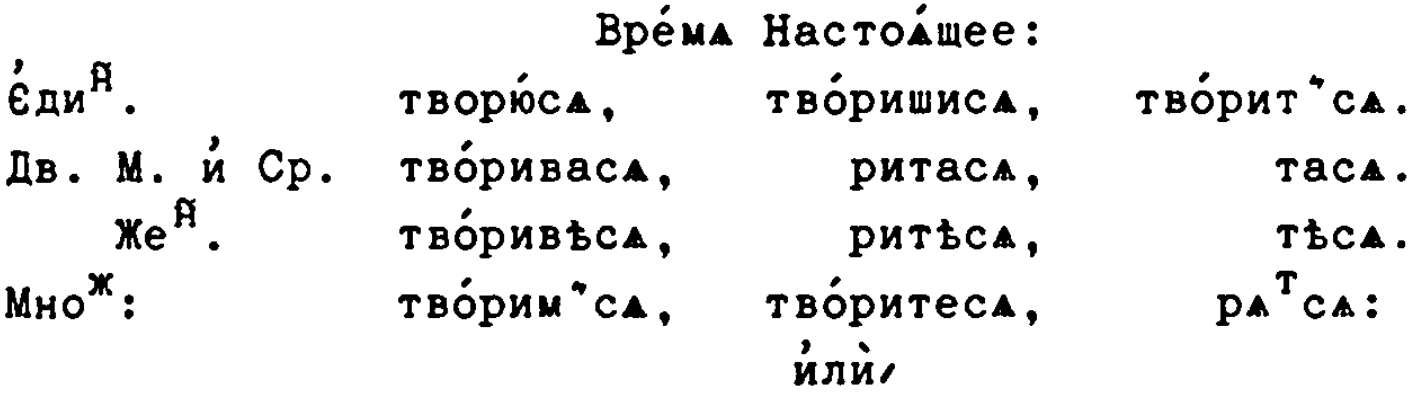

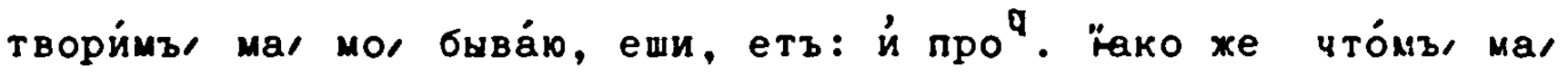
мог быва்ю.

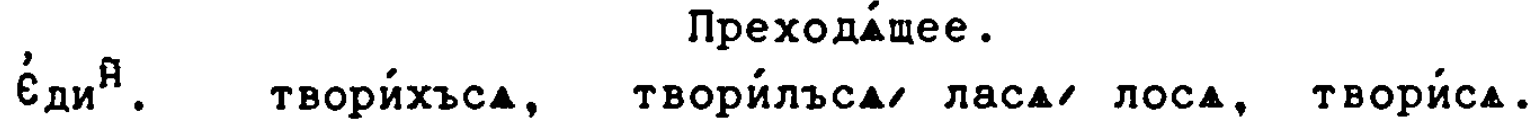

Дв: $\operatorname{моу}^{*} \cdot \dot{и} \mathrm{Cpe}^{\prime}$. твори́ховаса, ри́стаса, ри́стаса.

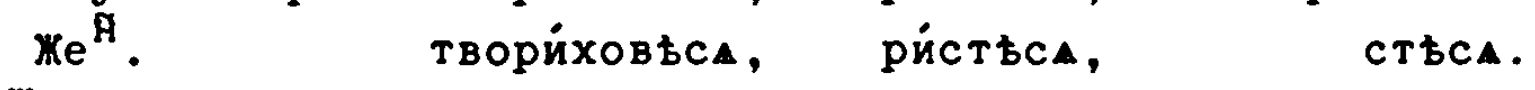

Мно ${ }^{*}$ твори́хом"са, ри́стеса, ри́шаса. йлй

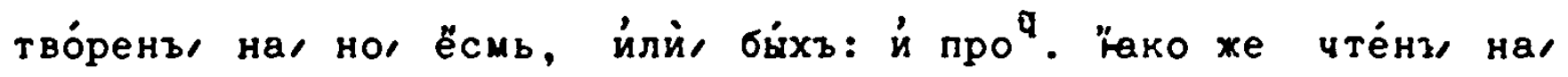
но, ёсм* йлй $\sigma_{\mathrm{b}} \mathrm{x}$.

Вйда оу́чаща́те $e^{\text {n }}$

Hactó́mee :

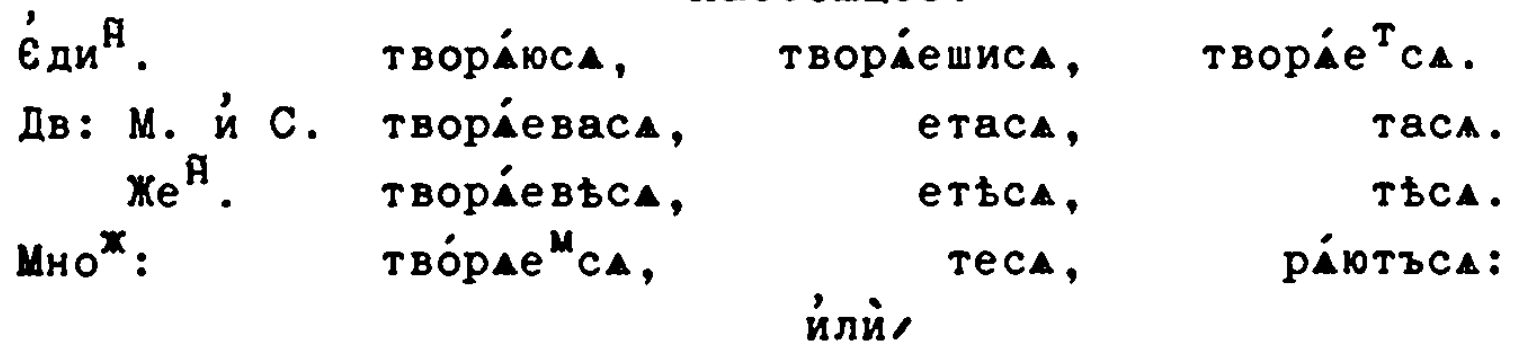


твори́емъ, ма, мо, быва́ю: и́ про ' 'ако же, чи́таемъ, ма, мо, быва́ю.

Cมี

Преше́ дшее :

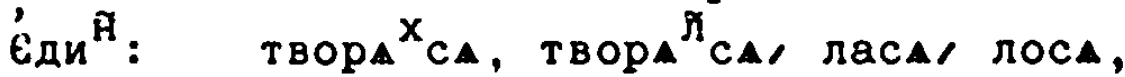

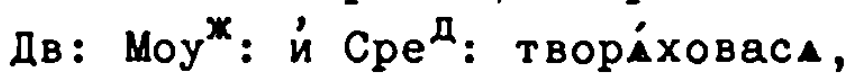
xe ${ }^{\tilde{H}}$ :

Mно $^{*}$ : páctaca,

CTbCA,

CтеcA,

\section{йлй}

Пре́x []

[1476]
T Bopámeca.

páctaca.

crbca.

хуса, йлй,

т вори́шасA.

тво́ранъ, на, нол ёсмь, йлй бйхъ: й пр" : Юако же чйтан", на, нол ёсмь, йлй, бых".

Мимоше́ дшеe.

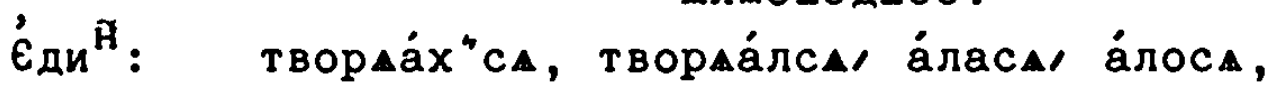

Дв; Mоу $^{*}:$ й Cpeम $\mathrm{Ke}^{\tilde{\mathrm{H}}}$ :

творАáховъсA,

\section{AactacA,} áctbca,

pǻmeca.

\section{craca.}

CTbca.

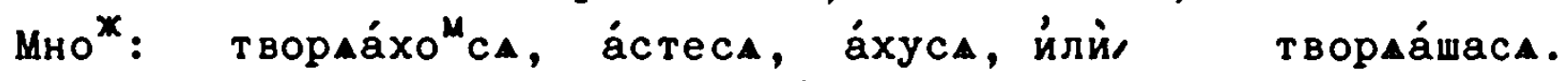

\section{йлй,}

тво́ранъ, на, но, быва́хъ: и́ про : Како же чи́танъ, на, нол бьва́хъ. Буд்щеe :

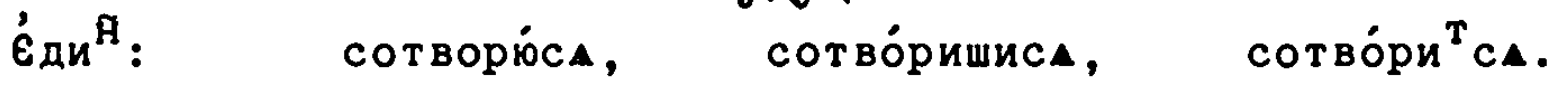

Дв: М: й

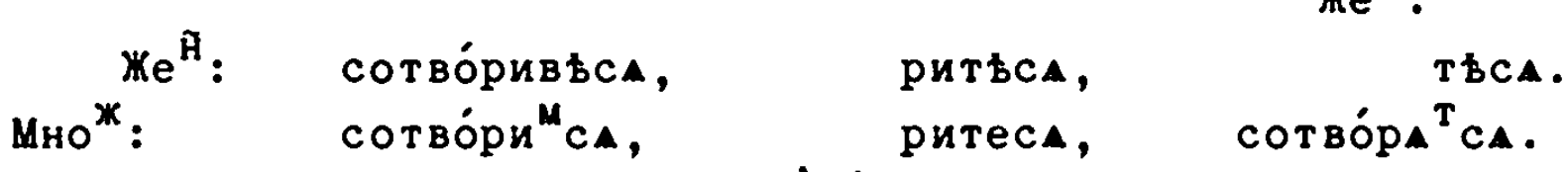
йлй

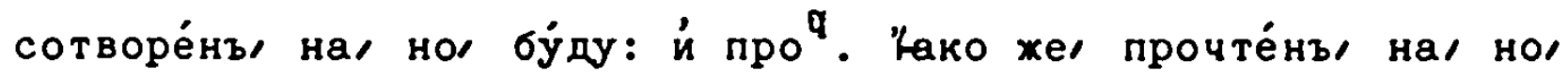
бйдy.

Hепредьл́ное :

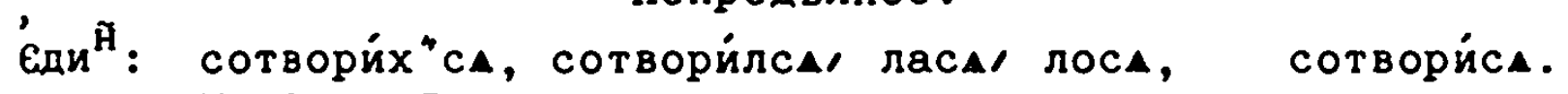

Дв: Моу $^{\text {स }}$ : и

ри́стаса,

CTaca. Жe $e^{\tilde{\mathrm{H}}}$ :

Сотвори́ховвСА,

CTbCA, CTbCA.

$\mathrm{MHO}^{\mathrm{X}}$ :

Сотворйхо са,

CтесA,

púmaca:

\section{йлй,}

Сотворе́нъ, на, нол ёсмь, йлй би́хъ: й про . "ако жел прочте́нъ, на, нол ёсиь, йлй, бы́xъ.

Наклоне́ніА Повели́телнагш, Ви́да соверше́нна.

є́ди $^{\text {ศ }}$ : Bpéma Hactó́mee:

Дв: $\operatorname{Mоу}^{\boldsymbol{x}}:$ и твори́са ты, pи́тасA, да̇ тво́ритъса о̆нъ. да் тво́ритасA. 
Мно ${ }^{*}$ :
$\mathrm{We}^{\text {मี }}$

Éй ${ }^{\text {म }}$
твори́вьсА, ри́тьсА, да̀ тво́ритъсА.

твори́м"сА, ри́теса, да̇ тво́ра ${ }^{T}$ сА.

вйда оу́чащ:

Bре́m: Настойщеe.

C飞

творййсА ты, да̇ твори́е ${ }^{T}$ сА ӧнъ. Дво́й:

[1486]

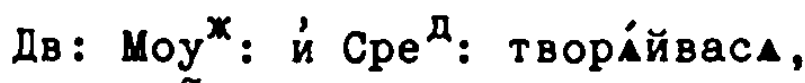
$\nVdash e^{\mathfrak{A}}:$

$\mathrm{MHO}^{\mathrm{X}}$ :

твОРА́ЙвБСА,

рійтасА, да̀ твори́етасА.

рй́̆тьсA, да̀ твори́етьса.

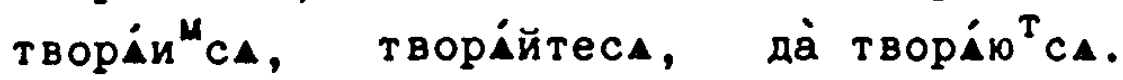

Буд́ущеe :

$\dot{\epsilon}$ ди ${ }^{\tilde{H}}:$

сотвори́са тй, да̇ сотво́рит"са ӧнъ.

Дв: Моу* : й Сре ри́тасA, да̀ сотво́ритасA. $\mathrm{Ke}^{\text {म }}$

Mно :

СотвориंвьСА, ри́тьсA, да̇ сотво́ритьса. Сотвори́м" CA,

Наклоне́ніА Моли ${ }^{T}$ : Ви́да совер:

Bре́mа настод́щеe.

$\dot{\epsilon}_{\text {ди }}{ }^{\text {म }}:$

Дв: М. й С. твори́васА, Же $\mathrm{F}^{\mathfrak{1}}$ : твори́вьса,

Мно ${ }^{*}$ : творйм" CA,

Ви́да оуччащ:

твори́са тв̈,

ри́таса,

рйтьсA,

ри́теск,
TворйсА ӧнъ.

ри́таса.

p'́ţсA.

дà TBÓpa ${ }^{T}$ cA.

\section{$\mathrm{Bp}$ : настойщ:}

$\dot{\epsilon}_{д и}{ }^{\mathfrak{H}}$ : творійсл ты: й про ${ }^{q}$. Како жел чита́йса тн.

Будищеe:

$\dot{\epsilon}_{\text {ди }}^{\text {凡 }}$

сотвори́са тй, Сотвори́са ӧнъ.

Двой :

Дв: М: й C. СотворйвасА,

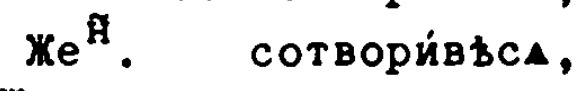
Мнӧ:

рита́са: ри́таса. ри́тьса, ри́твсA. рйтеcА, да̇ сотво́pa ${ }^{T}$ ca.

Наклоне́ніА Сослага́телнагш/ Вйда сове $\mathrm{p}^{\mathrm{p}_{\text {шеннна, }}}$

Bре́ma настод́щеe.

ฉ̆ще бы: гды́ бымъ са чинйлъ.

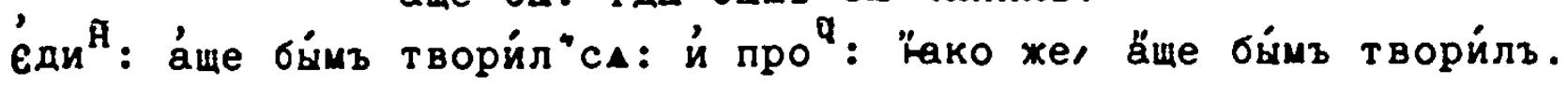
Преходи́mеe :

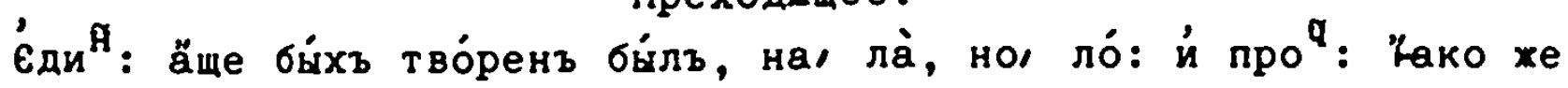
ăще бйхъ чте́нъ бйлъ, нал ла̀, нол ло́.

вйда оу́чащ:

Bре́m: Настои́mee. 


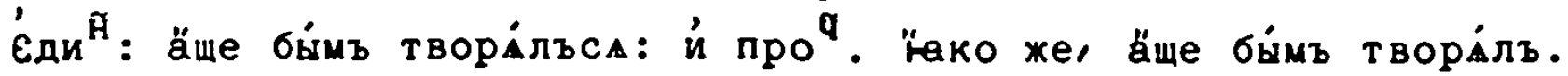
Преше́ дwеe :

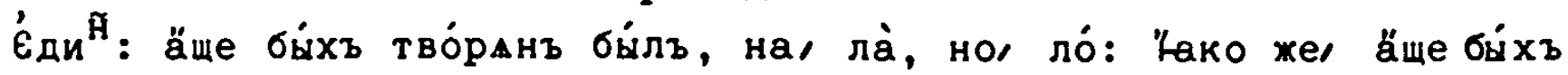
чи́танъ былъ, на, ла̀, нол ло́.

\section{Мимоше́ дшее :}

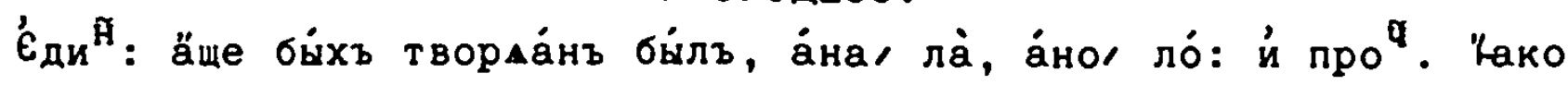

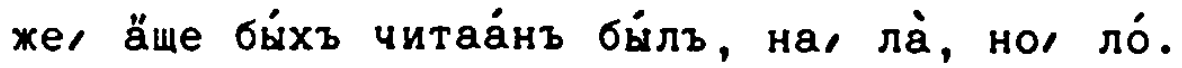

Будйщеe :

Є́дй Hепредъл́ное:

Єдй же, ăще би́х" прочте́нъ бы́лъ, на, ла̀, нол ло́.

Наклоне́ніА по Дини́телнагш, Вйда соверше́нна, Bре́мa настои́щеe.

да̀:

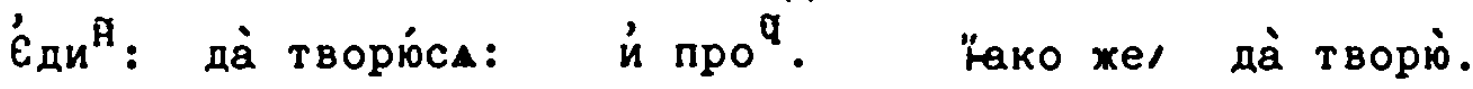

Преходи́щеe:

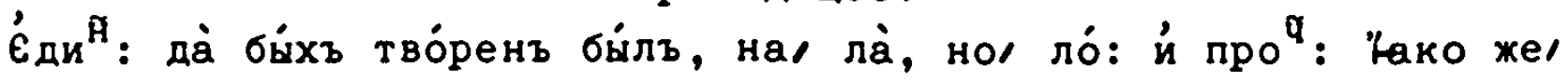
да் бйхъ чте́нъ би́лъ, на, ла̀, нол ло́.

Вйда оуччащ:

$\mathrm{Bp:} \mathrm{Hactoи́mеe:}$

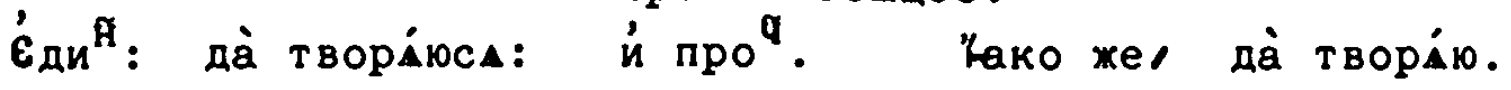

Преше́ дшеe :

Є́дй

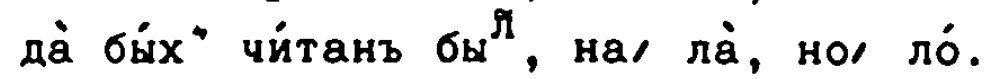

мимоше́ дшее :

Є́дй да̇ би́хъ читаáнъ би́лъ, нал ла̀, но/ ло́.

Буду щеe :

Бу́ду

[150]

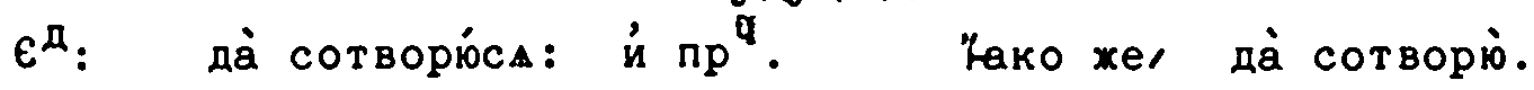

Непредьліно:

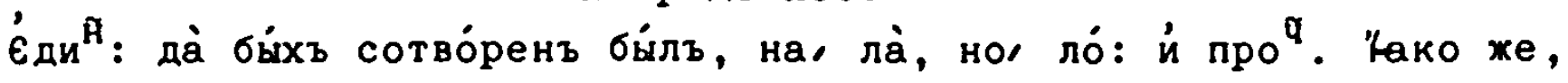
да̀ бйxъ прочте́нъ би́лъ, на, ла̀, но, ло́.

Наклоне́ніА Неопредле́ннагш, Ви́да соверше́нна,

Bре́ma настов́щеe:

Преходи́mеe. твори́тиса: йлй твори́му быти.

твори́тиса: йлй тво́рену бы́ти.

Ви́да Оуччащ: 
Bp: Hactóimee:

Преше́ дшеe :

мимоше́дшее:

Буд́ущеe :

Непредьл́ное: твори́тиса: йлй, твори́ему быва́ти. твора́тиса: йлй, тво́рану быва́ти. творАа́тиса: йлй творАа́ну быва́ти. Сотвори́тиса: йли́ сотвори́му битти. Сотвори́тиса: и́лй, сотво́рену би́ти.

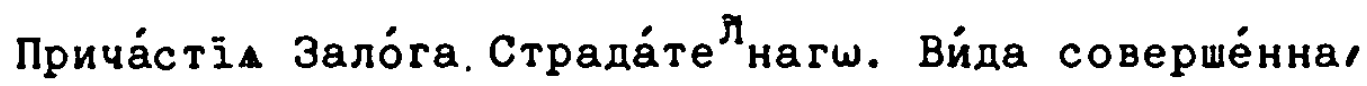

[1506]

Вре́мене настои́щагш.

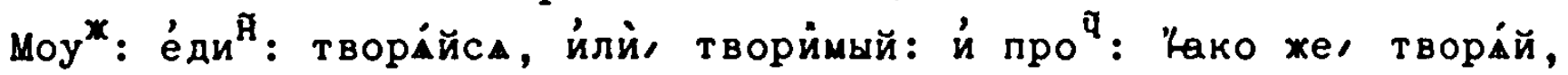
й, что́мषй.

Преходи́щагш:

моу $^{*}$ : е́ди ${ }^{\text {म }}$ творе́йса, й творйвыйса: йлй, тво́реный: й про

Һако же, творе́й, й, твори́вый: й, чте́ный.

Вйда оуччащ:

Bp: настои́щатw.

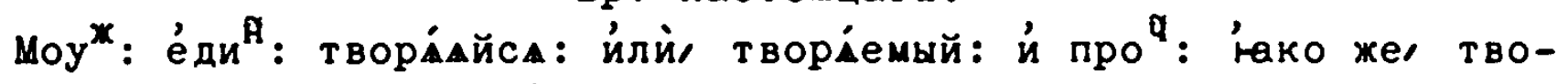
ра́Ай, й́ чита́емый.

Преше дша г $\omega:$

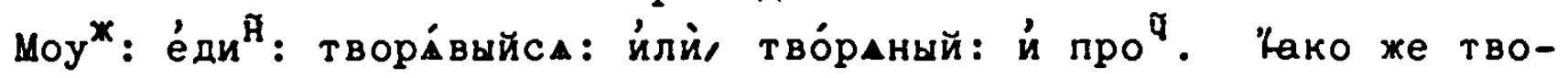
ра́вый, й, чи́таный.

\section{Мимоше́ дшагш:}

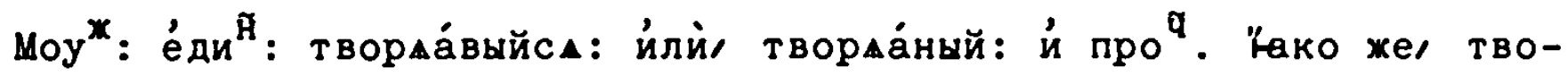
рАа́вый, й́ читаáный.

\section{Буд்щаг}

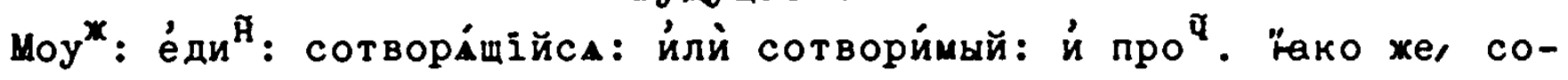
твори́щзй, й, прочто́мый.

\section{Непредьл́нагш:}

Henpe

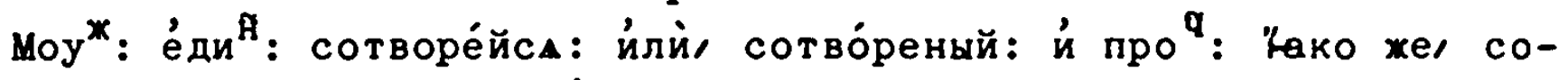
творе́й, йл прочте́ный.

Дъеприча́стіء Зало́га Страда́телнагw/ Вйда соверше́нна, Вре́мене настои́щагш.

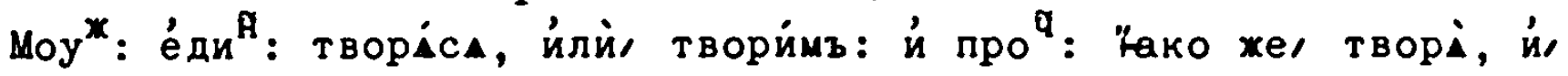
что.

Преходи́ща

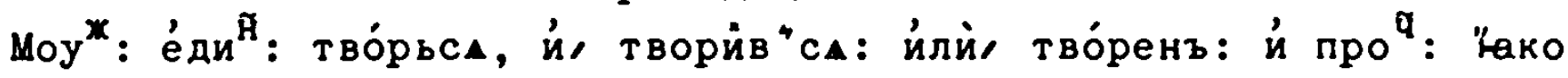
же твӧрь, й твори́въ: й, чте́нъ.

вйда оу́чащ:

Bp. Hactó̊marw. 


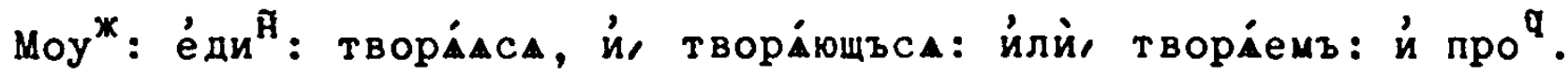
"ако жея творіА, й, чита́емъ.

Преше́ дшагш:

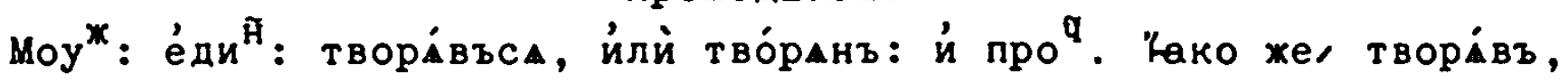
й чйтанъ.

Мимоше́ дшаг $\omega:$

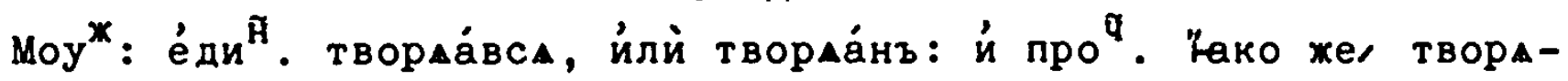
áвъ, й, читаáнъ.

Бу́ дy

Буд́ущаг

Моу" ${ }^{*}$ е́ди" твори́щъ, й, прочто́мъ.

Непредьл́нагш:

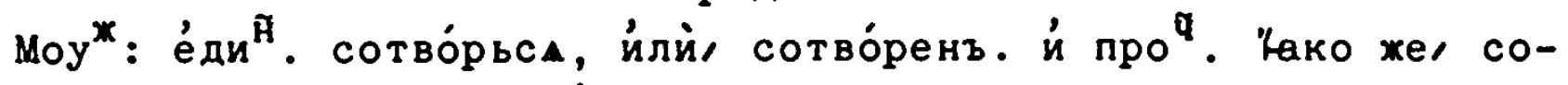
тво́рь, й́ прочте́нъ.

Причастодьт́ї Bp: Настои́marw,

твори́телно.

увъще́ніе.

Сре́днихъ, $\omega^{T}$ лохиттелныхъ, й Ӧбщи Гй спрахе́ніА Парадйгматъ

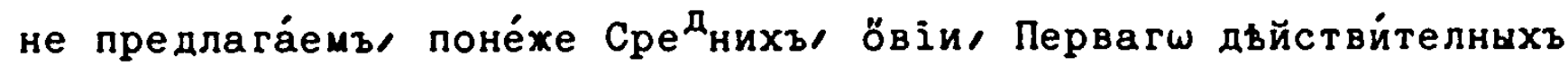
Спраже́ніа ӧбразомъ спрага́ют"са: Қакш, живу, ни́ю, съту́ю, оўпо-

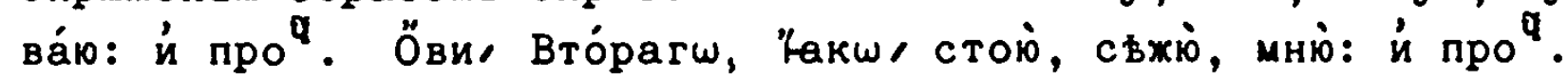
$\omega^{T}$ лохи́телныхъ ӧвіи ӧбразомъ Страда́телныхъ Пе́рвагш Спрахе́ніА, lакш, пеку́са, смъю́ca, гнв́ваюса, ра́дуюса: й про ${ }^{q}$. Ӧвіи вто́ра-

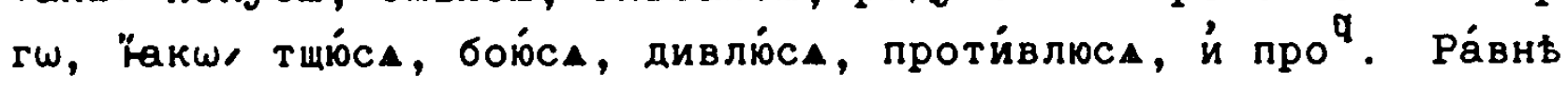
ठбщих", ӧвіи Пе́рвагш, 'акш/ каса́юса: о̋віи Вто́

\section{parw}

рагш Страда́телных" Cпрахе́ніа ӧбразо" спрага́ют"са: Қакш, сты-

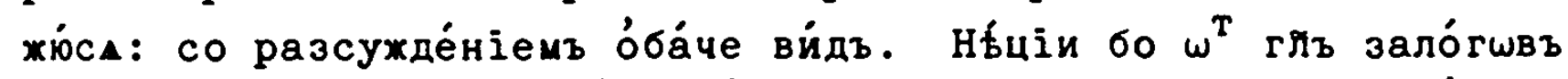
си́хъ, ӧба ви́да ймуть, й по о́бо́ю спрага́ют"са: Нйціи же е́дйнъ $\omega^{T}$ дво́ю: Соверше́нъ, глемъ, йлй Оуччаща́теленъ.

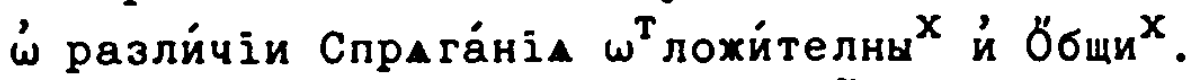

Поне́хе ठбщіи глии прича́стіА Страда́те наА на, мый, й ный,

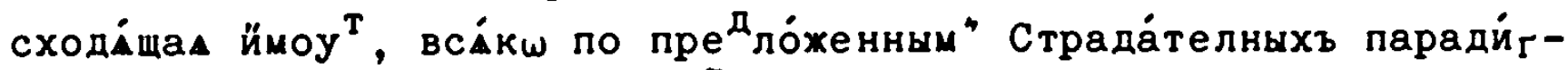

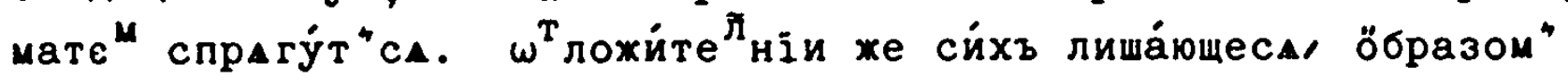
то́чію на, са, конча́щи ${ }^{X}$ са Страда́телны спрага́тиса бу́дутъ: раз-

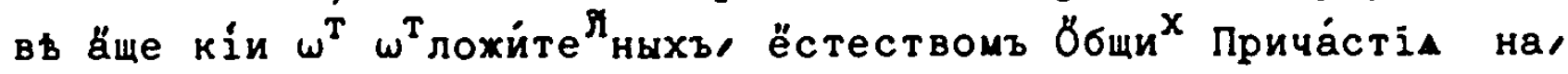

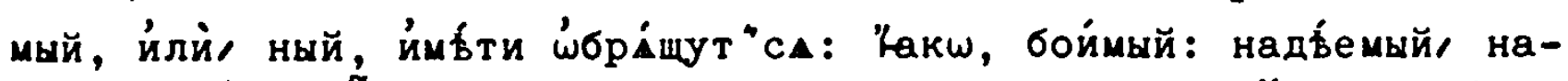

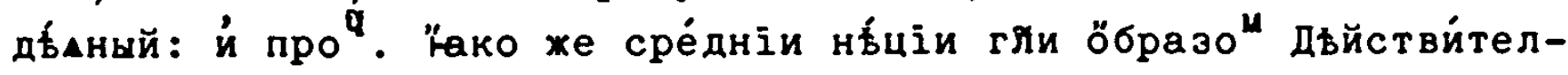

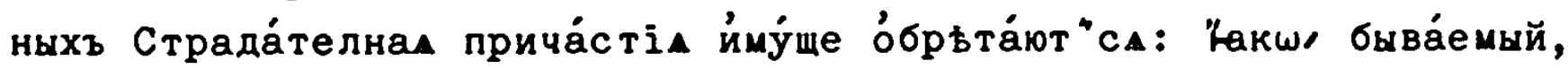


оу́пова́емьй, оу́коснб́ный: й про

$\dot{\omega}$ составлініи Преходи́mar $\omega$ :

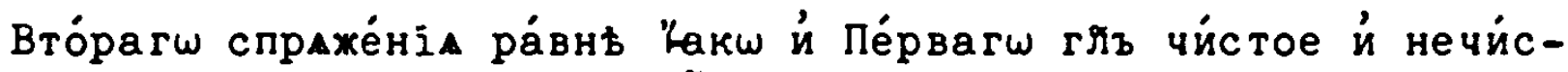
тое о́конче́ніе и́му́щихъ, пра́ви ное Преходи́щагш составле́ніе $\omega^{T}$

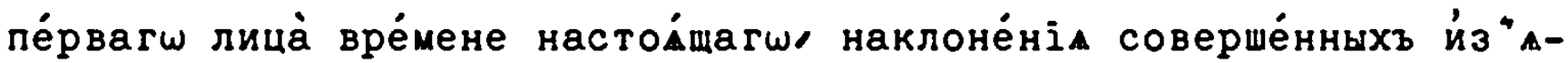
ви́те на быва́ти о́бйче, прелага́ему, 1, на, ихъ: "Накш, скорбюे, скорби́хъ: пла́вю, вихъ: ну́жю, ди́хъ: слезі, зи́хъ: теплю, плйхъ: ломюे, миххъ: хранюे, ни́хъ: о́стріо, ри́хъ: оуччю, чи́хъ: прошюे, сихъ: гощюे, сти́хъ: й про .

Непра́ви нъ, ӧви на, ахъ, ӧви на, ђхъ, ӧви же на, охъ, Преходйщеe составліют":

Ha, axb:

Лежі், жа́хъ: держі், жа́хъ: сплї, и́лй, спї, спа́хъ: стою̆,

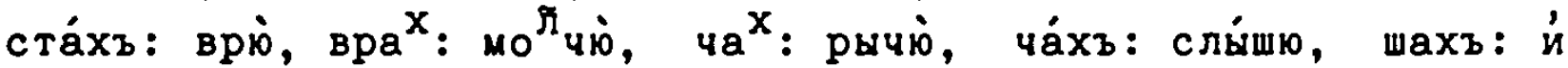
npo ${ }^{q}$.

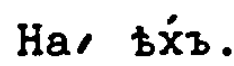

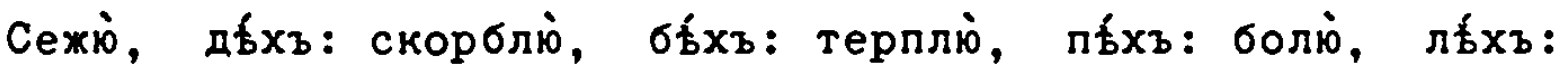

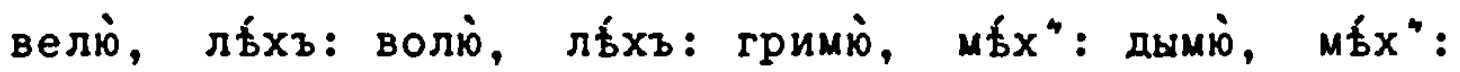

шуміे,

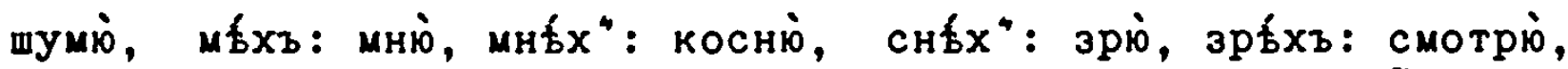

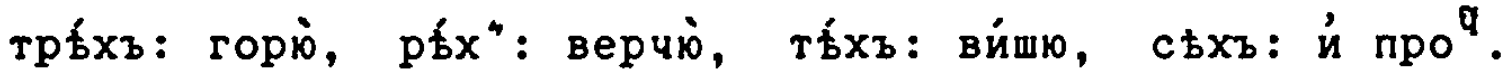

Ha, oxъ:

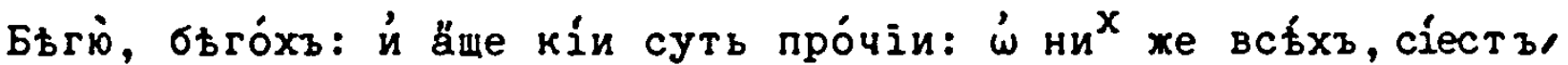

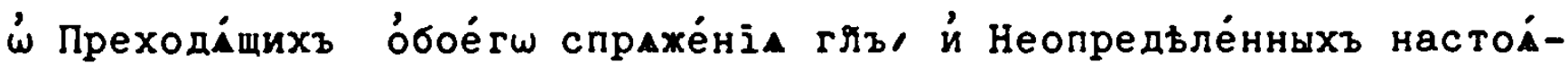

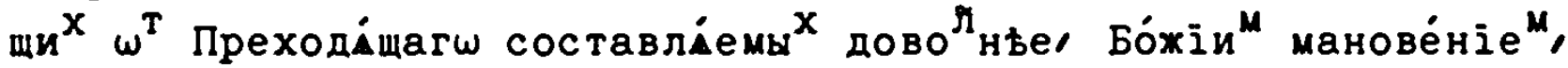
за да́лшим" сво́йствъ глъ обби́лна Славе́нска діа́лекта, й все́й ча́сти неудо́бна, и́ску́сомъ.

$\dot{\omega}$ измьна́емыхъ Спрахе́ніА сегш Начерта́телныхъ:

$$
r, \pi, 4, \text {. }
$$

Bто́parw Cпраже́ніа гли на, гю, жю, 4ю, шю, лю, й жду, ко ча́щіиса, во второмъ Өе́мате лицй прелага́ют", г, оуббш на, $x$, "̆а-

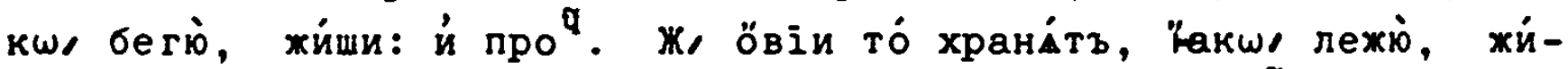
ши: ӧвіи из"мена́ютъ на, д: Гакш, вйжю, диши: й пр". ӧвіи же

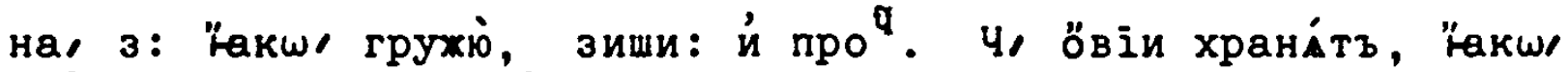
мо чй, чи́ши: й про : о̋віи прелага́ютъ на, т: leкw/ мо $T$ กо лог

лочю̀, ти́ши: й про". Ш, нбкіи хранат", "акш, сль́шю, шиши: й

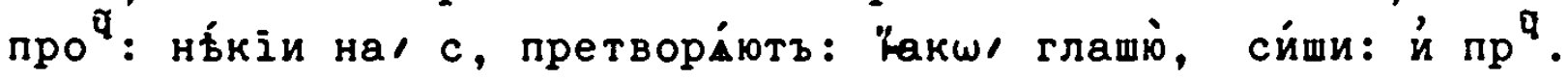




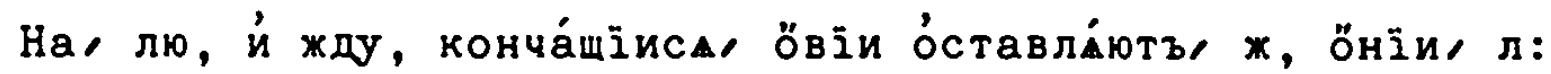

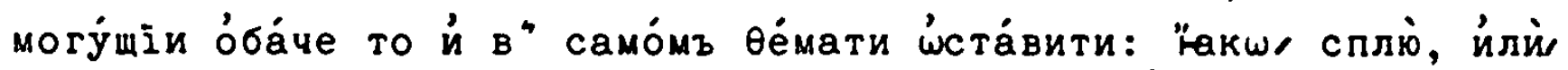
спю̀, спиши: сла́влю, йлй, сла́вю, виши: и́ про $q$. Ро́жду, йлй, рожюे, диши: хохжду, илли, хожю̀, диши: й пр

$$
\dot{\omega} \text { БєзличньІхз. }
$$

Бе ${ }^{3}$ личніии гли, ӧбра ${ }^{3}$ оўбш ймуть тре́тїАгш лица̀: ни е́дйнагш

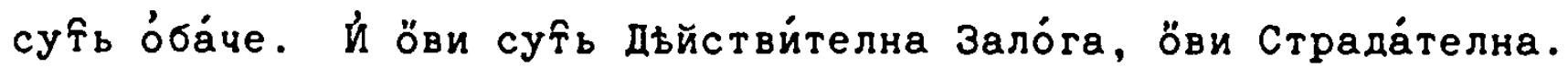

Дьйстви́телнагш: "̈акш, подоба́етъ, досто́итъ, довлбетъ, при-

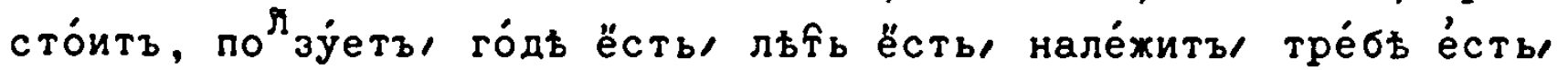
róxe ёсть: й про".

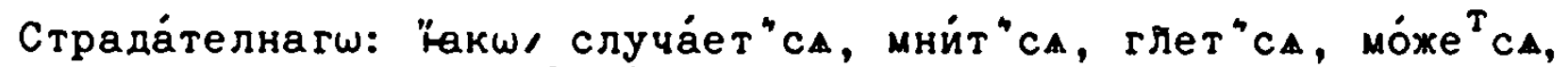
спит "сА, стои ${ }^{T}{ }^{*}$ : глъ быва́ти о́быко́ша, $\omega^{T}$ страда́те нагш оба́че и́зра́днье: érí же ко́еждо тре́тїе е́динстве́нное лице́ бе ${ }^{3}$ лйчнь приемле́

$$
\text { мо би́ }
$$

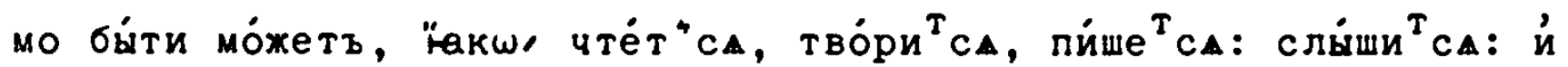
npo ${ }^{q}$.

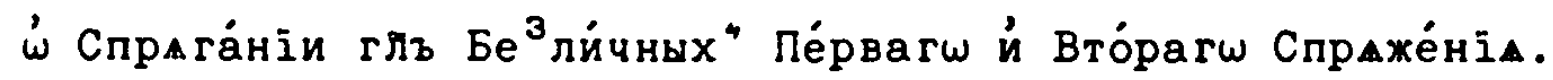

$$
\text { Пара́ди гма Бе }{ }^{3} \text { лйчныхъ Пе́рвагш Спраже́ніА. }
$$

Гла Бе ${ }^{3}$ личнагш, Зало́га Дьйстви́телнагш, Наклоне́ніА Йз"Авйтелна, Bре́ma Настод́щеe.

Подоба́етъ.

חpewé дwee :

мимоше́ дшее :

Подоба́me.

Бу́ дущеe :

Подобаáme.

Восподоба́етъ.

Повели́телнагш й Моли ${ }^{\mathrm{T}}$ :

Hac тои́mee:

Бу́ дущеe : дà nодобáetъ.

дà восподоба́етъ.

Cослага́телнагш:

Пре ше́ дшеe :

мимоше́ дшеe:

Бу́ дущеe :

Преше́ дшеe :

мимоше́дшее :

Бу́ дущеe : äще бы подоба́ше.

ämе ба́ше подоба́ло.

ämе бы восподоба́ло.

Подчинителнагш:

да̇ бы подоба́ше.

Дà бíwe подоба́ло.

$\mathrm{Tr}$

да̀ бы் восподоба́ло.

Неопредъле́ннагш:

Heonpe

[1546]

Hactó́mee :

Бу́ду душе :
Подоба́ти.

Восподоба́тйm Smotrykyj- 978-3-95479-591-8 
Си́це, довльетв: '́скудьва́етъ: й про".

Пара́дигма Бе ${ }^{3}$ личчныхъ Пе́рвагш Спрахе́ніА,

Зало́га страда́телнагw/ Наклоне́ніА Й "Авйтелна,

Bре́mム Hactó́mee :

Случа́ет"са.

Преше́ дшеe :

Случа́шеса.

Мимоше́ дшее :

Случаámecs.

Бу́ дущее :

Слу́чи ${ }^{\mathrm{T}}$ сА.

Непредблное :

Случйса.

Повелите ${ }^{\Re}:$ й Моли ${ }^{\mathrm{T}}$ :

Hactó́mee :

Да̇ случа́eт"са.

Бу́дущеe :

Да் слу́чит"сА.

Сослага́телнагw:

Преше́ дшеe :

мимоше́дшее :

Бу́дущее :

Hепредблное : äще бы случа́шесл.

äще бáme случа́лосA.

ămе бы са случйло.

ămе ба́ше са случйло.

Подчинйтелнагш:

Преше́ дшеe :

Да் бы் случа́шеса. Мимо

Мимоше́ дшее :

Дà бáme случа́лоса.

Бу́ дущеe :

Дà би́ сА случи́ло.

Непредб́лное :

Дà ба́me са случи́ло.

Неопредъле́ннагш:

Hactó́mee :

Случа́тиса.

Бу́ дущеe :

Случи́тиса.

Сйце, ключа́ет"сА, глет" са: й про".

Пара́дигма Без"лйчныхъ Вто́рагш Спрахе́ніА.

Гла бе ${ }^{3}$ ли́чнагш⿱ Зало́га дъйстви́телнагшА Наклоне́ніА Й

Bре́mム Настои́mеe.

Преше́ дшеe.

мимоше́ дшеe.

Бу́ дущеe.

Hactó́mee: Повели ${ }^{\mathbf{T}}:$ и Моли $^{\mathrm{T}}$ :

Бу́ дущеe :

Дà досто́ить.

да̀ воздосто́итъ.

Сослага́телнагш:

Преше́ дшее :

мимоше́дшее :
Досто́ит:

достои́me.

Достоха́me.

Воздосто́итв. 
Бу́дущеe :

äще бы воздостои́ло.

Подчини́телнагш:

Преше́дшее :

Да̇ бы достои́ше.

TI

мимо

Mимоше́дшее:

Дà бáme достои́ло.

Бу́ дущеe. Да் бы் воздостои́ло.

Неопредьле́ннагш:

Hactó́mee :

Достоі́ти.

Бу́дущеe . Воздостодтт.

Зало́га страда́телна, Наклоне́ніА йз"Айтелна,

Bре́ma Настои́щеe: Мни́т"са.

Преше́ дшее :

мна́шеса.

мимоше́ дшее :

Mнаámeca.

Бу́дущее :

Bо ${ }^{3}$ мнйт" CA.

Непредблное :

Возмни́са.

Повели ${ }^{\mathrm{T}}:$ и́ Моли ${ }^{\mathrm{T}}$ :

Hactó́mee :

Да் мни́т"

Бу́ дущеe :

Да̀ во ${ }^{3}$ мни́т" CA.

Сослага́телнагш:

Преше́ дшее :

ăще бы мнд́шеса.

Мимоше́дшее:

ăme бíme mнблоса.

Бу́ дущее :

äще бы са во ${ }^{3}$ мнбло.

Непредблное :

äще бáme cА во ${ }^{3}$ мнб́ло.

Подчини́телнагш:

Преше́ дшеe :

Дà бы் мна́шесA.

Мимоше́дшее:

Дà бáme мнблоса.

Бу́ дущеe :

Да̇ бb́ са во ${ }^{3}$ мнбло.

Непредблное :

дà бíwe сA во ${ }^{3}$ мнбол. [!]

Неопредъле́ннагш:

Hacró́mee.

Mнбтиса.

Бу́дущеe :

Bо ${ }^{3}$ мнбтиса.

Сйuе, зри́т" сА, щади́т" сА: и́ проq.

Пара́дигма Бе ${ }^{3}$ лйчныхъ, Существи́телнымъ гйомъ о́конча́емыхъ: Гла бе ${ }^{3}$ лйчнагш⿱ Зало́га Сре́днагш/ Наклоне́ніА йз"Авителнагш/

Bре́mı настоі́mеe:

Преходи́mee.

Пре ше́ дшеe.

мимоше́дшее.
Л屯个ि ёсть.

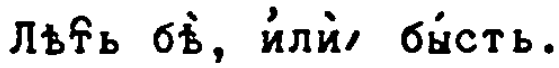

ЛъТิь ба́ше, илй быва́ше.

ЛЬ安 бываáme. 
Бу́ дущеe. ЛЬิิธ бўдетъ.

Повели́телнагш:

Hactó́щеe: Лちтิь да̇ бу́детъ. Моли́телнагш:

Настод́щеe : Лちริ $\sigma \dot{y} д и$.

Сослага́телнагw:

Преходи́mеe :

Прешедшеe.
Äще бы льтิь было́.

Äще бі́me льิिь было́.

T⿻

Подчи

Подчини́телнагш:

[I566]

Преходи́mеe :

Пре wé дuee.
Да் бы льтिь было́.

Да̇ бі́ue льтิь былó.

Неопредъле́ннагш:

\section{Hactoímee:}

Лちริ б์́์

Сйце, мо́щно е́сть, го́ды е́сть, во моохно е́сть, Кавь е́сть, тре́бь е́сть, róme е́сть: й пр ${ }^{q}$ :

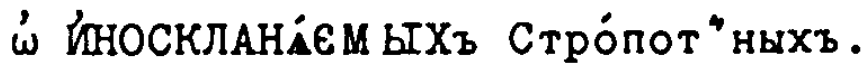

Н̈ако же иंмена̀, ӧва сутิь Скланд́емам, ӧва ЙноскландемаА, сйце й Гй. й 'ं Скланіемы оуббш дово́лнъ.

Йосклана́еміи же.

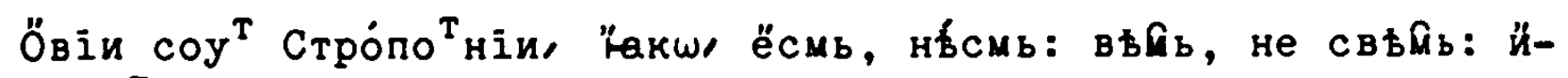
мамь: ґ́мь: '́ ämе кіи про́чіи.

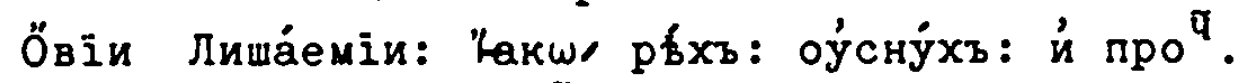

О̋віи Йзобилу́ющіи, йе тожде знаменова́ніе й Спраже́ніе хра-

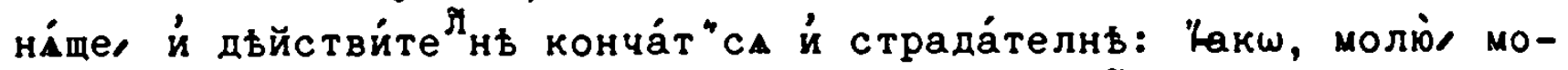
лю́са: пла́чу’ пла́чуса: па́даю па́даюса: й про .

Нарица́ют"са Йносклани́еміи: поне́хе no npá

по пра́вилшмъ пра́ви"ныхъ спраже́ній не спрага́ют"са. Ноं йлй числа̇ ко́егш, йлй Наклоне́ніА, лй Вре́мене, лй '́ко йче́ніА, йлй Спрахе́-

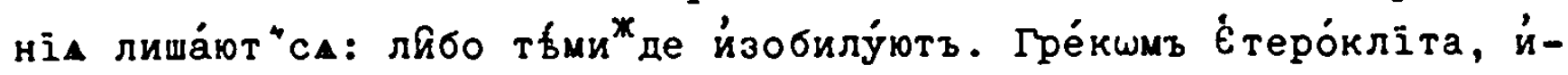
лй́ А́но́мала.

Паради́гмата Спрага́ніА Глагйл" Йносклони́телныхъ Стро́лотныхъ ம́бóerw Cпраже́нї.

Ëсмь, сйue cпрага́et"ca.

Гйа Лйчнагш/ Зало́га Сре́днагш/

Вйда соверше́н"на, Наклоне́ніА йз Авйтелнагш/

Bре́ma настоі́mee.

є̇ди ${ }^{\text {मी }}$ ёсмь, е́сй, ёсть. 


\begin{tabular}{|c|c|c|}
\hline 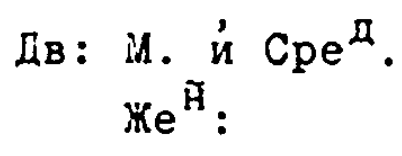 & $\begin{array}{l}\text { ёсва, } \\
\text { ёсвь, }\end{array}$ & $\begin{array}{l}\text { ёста, } \\
\text { ёсть, }\end{array}$ \\
\hline WHO ${ }^{*}:$ & ёсмы, & е́сте́, \\
\hline
\end{tabular}

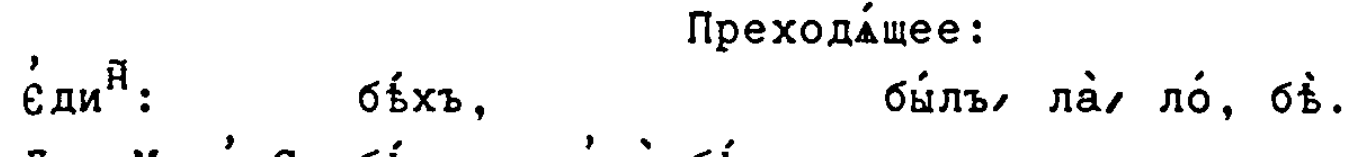

Дв. М. иं С. бі́хова, илй бы́сва, ста, ста.

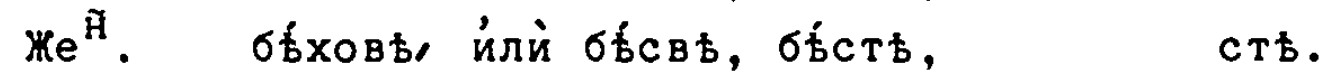

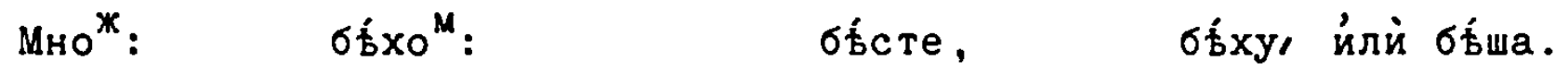

Преше́дшеe.

Преше́д [1576]

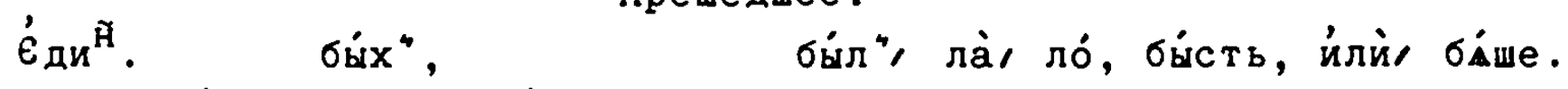

Дв. М. и́ С. бйховал илй би́сва, ста, ста.

Же ${ }^{\text {मे }}$ би́ховь, йлй бйсвь, бйсть, сть.

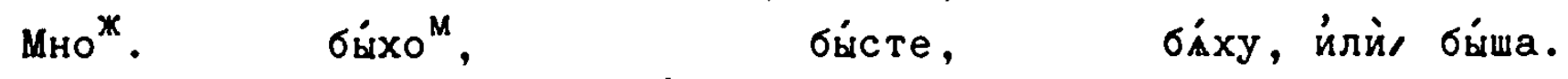

Оу́вьще́ніе.

Оуччаща́те мена̇ '́ставла́емъ: та́ бо по пе́рвому оуччаща́телны спраже́нію пра́ви "Н

Настов́щ. быва́ю: "̈ако жел чита́ю.

Преше́д. бы́ва ${ }^{x}$ " "ако жел чита́хъ.

Мимошед. бываáx": "юко жел читаáx": й про". Боу́ дущеe.

$\hat{\epsilon}_{\text {ди }}^{\text {म }}$.

$\sigma \dot{y} z \mathbf{y}$,

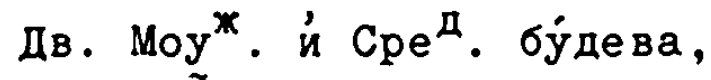

бу́деши,

бу́детъ.

$\mathrm{MHO}^{*}{ }^{*}$.

будевъ,

бу́дета,

eта.

мно . будемъ, бу́дете, дутъ.

бу́деть,

T⿱⺊口 .

Наклоне́ніА Повели́телнагш, Вйда соверше́нна,

Вре́ма Настои́щеe, й Боу́дущеe:

$\dot{\epsilon}_{\text {ди }}{ }^{\text {I }}$.

бу́ди ты்,

да̀ бу́детъ ӧнъ.

д. М. й С. бу́дыва, бу́дьта,

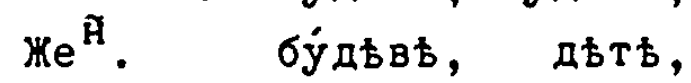

да̀ бу́дета.

Дв

[I58]

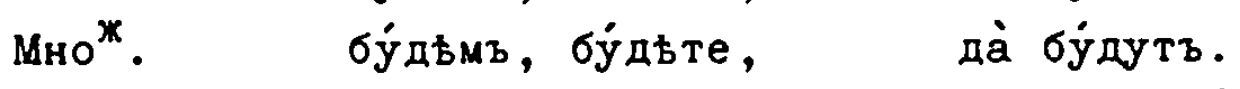

Наклоне́ніА Моли́телнагш Ви́да соверше́нна,

Вре́ма Настов́щеe, й Буд́ущеe:

$\dot{\epsilon}_{\text {ди }}{ }^{\text {म }}$.

Дв. М. и́ C. бу́дьва,

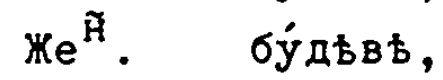
Мно ${ }^{\text {* }}$. бу́ди ты்,

бу́дьта,

бу́дъть,

бу́дฺte, бу́ди ӧнъ.

бу́дтта.

бу́дьть.

да் бу́дутъ. 
Наклоне́ніА Сослага́телнагш, Вйда соверше́нна,

Вре́mム Настои́щеe, й Преході́mеe.

Äще бы: гды́ бымъ бӹль:

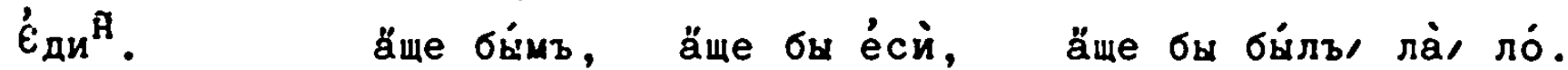

Дво́й. Моу ${ }^{\star}$. й Сре Же . äще бы быльсвв, былf́сть, сть.

Множ. ӓще бы былиссмы, были́сте, былй.

Преше́ дшее :

гды́ бымъ бйлъ.

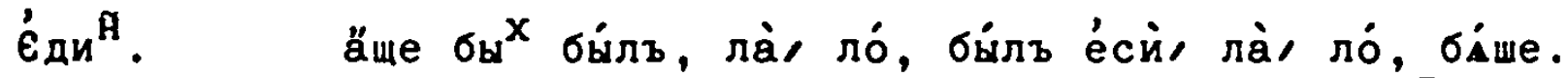
Дв.

[1586]

Дв: М. й С. äще би́cва была̀, Же $e^{\text {: }}$ äще би́cвь быль,

Мно : ăще бйхомъ былй, бйсте, біху, йлй, бйша. Наклоне́ніА по Дини́телнагш/ Ви́да сове $\tilde{p}_{\text {ше́нна, }}$

Bре́mム настои́mee:

да̀ :

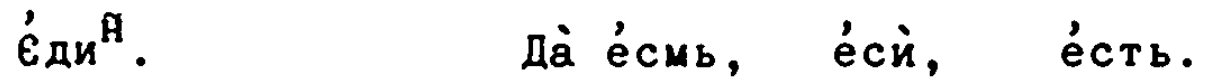

Дв: Моу*: й Сре

Преше́ дшеe :

\section{да̀ бйxъ:}

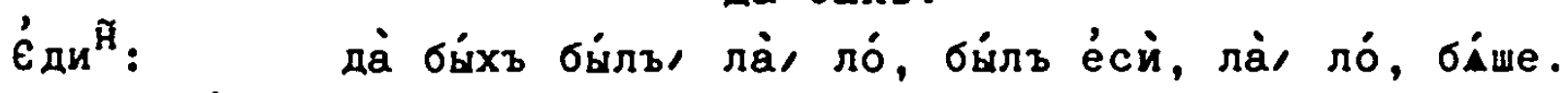

Дв: М: й С: да̀ би́ссва была̀, би́ста, ста. Жен $:$ да бйсвь быль, сть, сть.

Мно : да бйхомъ былй, бйсте, бі́хуر йлй би́ша.

Будіy mee :

да̀ :

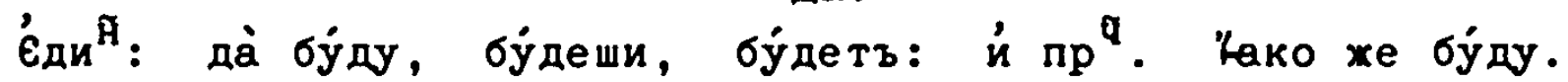

Наклоне́ніА Неопредьле́ннагш/ Ви́да соверше́нна,

Bре́мa Настод́mee: би́ти.

Прича́сті^, Ви́да Соверше́нна,

Вре́мене Настои́щат́.

$\operatorname{Moy}^{*}$.

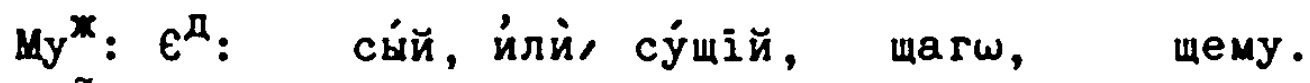

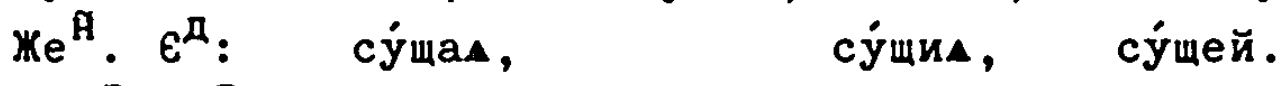

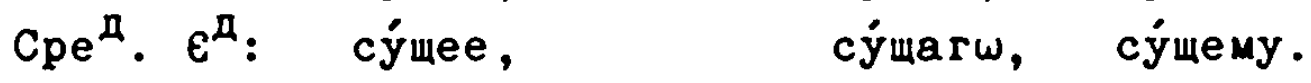

Преше́ дшагш:

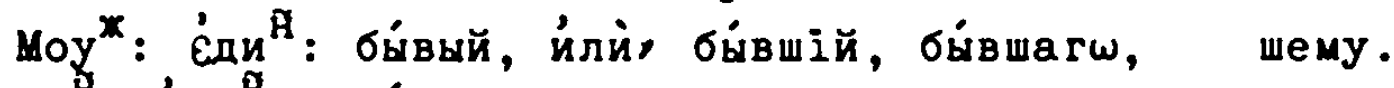

Жен : е́дй 


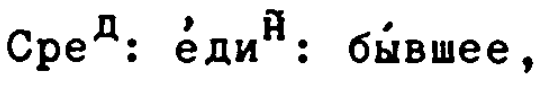

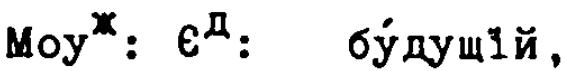

Буд́ущаг

Же $e^{\mathcal{A}}: \epsilon^{\text {म }}:$ бу́ дущал,

warw,

шему .

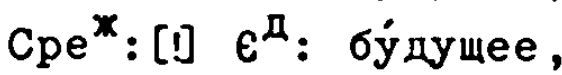

$\begin{array}{ll}\text { щагш, } & \text { щему. } \\ \text { щим, } & \text { щей. } \\ \text { щагш, } & \text { щему. }\end{array}$

Дъеприча́стіл Ви́да соверше́нна,

Вре́мене настои́щагш.

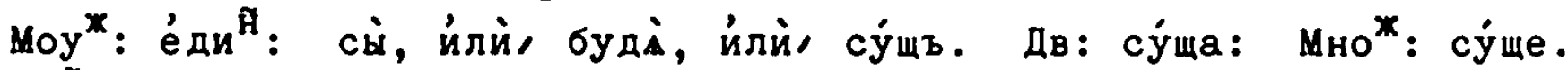
$\varkappa^{\text {म }}: \epsilon^{\text {मू }}: \quad$ су́щи :

Cpe $e^{\text {मू }} \epsilon^{\text {मू}}: \quad$ су́me.

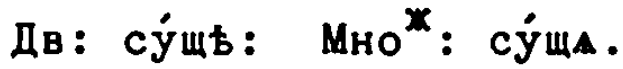

Дв: су́ща. Мно : су́ща.

Moy ${ }^{*}: \epsilon^{\text {मू}}:$ биंвъ

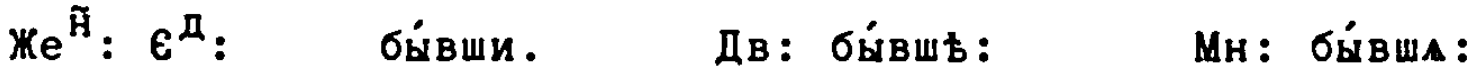

Cp. $\epsilon^{\not}:$ би́вше : Дв: бы́вша:

Буд́ущагш:

Бу́ дy [1596]

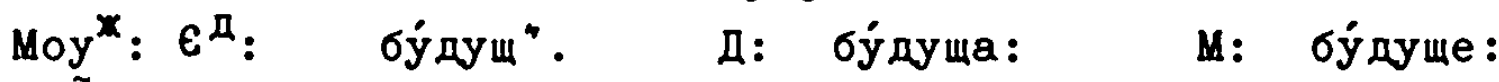

Жен $: \epsilon^{\text {म }}:$ бу́ дущи: Д: бу́дущь:

$\mathrm{Cp}: \epsilon^{\text {म }}:$ бу́дуще म: бу́дуща: $М:$ буддуща.

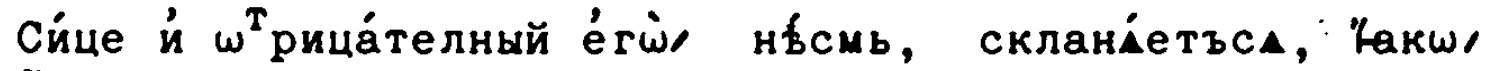
$\dot{\epsilon}_{\text {ди }}{ }^{\text {म }}$ :

нбсмь,

Дв: Моу" $\nVdash e^{\text {मี }}$ :

$\mathbf{M H}_{\mathrm{H}}$ :

Hf́cBb,

нбсмы, нб́си, нбста, Hfстt, нfсте,
Hfсть.

нбста.

Hfctb.

Про́чах всї всf́хъ Наклоне́ній времена̀, не, приемлюща Какш,

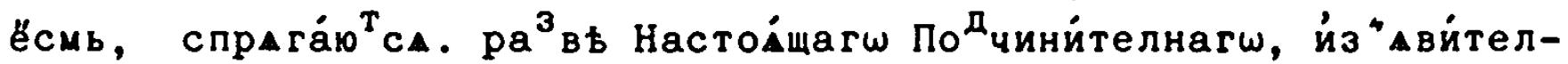
ному $\omega^{T}$ рица́те на подо́бнагш.

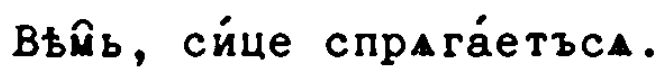

Гйа Лйчнагш, Зало́га Сре

Bpéma Hactó́m:
$\dot{\epsilon}_{\text {ди }}{ }^{\mathrm{R}}$ :
Bち⿳ि口冋,
вf́cu,
Bf́ctb:
Дв: $\operatorname{Moy}^{x}:$ й $\mathrm{Cpe}^{\text {म̆}}$ : в́ва,
в ́ста,
Bfcta. $\nVdash e^{\text {म }}:$
B́́bB,
Bfctb,
Bf́ctb.
Мно ${ }^{*}$ :
вбмы,
Bb́cte,
B⿱́口̆дATb.

$\dot{\epsilon}_{д и}{ }^{\text {मे }}$.

Преходи́mеe.

вбдђхъ, вбдълъ, ла, ло, вєдъ.

Дво́й .

[160]

Дв: Моу: й Сpe 
Же Мно :

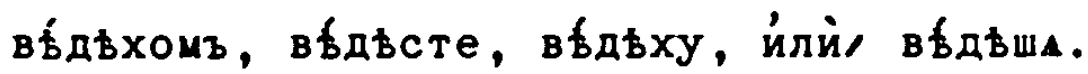
Пре ше́ дшеe :

$\epsilon^{\text {म. }}$ вбдахъ, вбдълъ/ ла/ ло, вธ์дมแe.

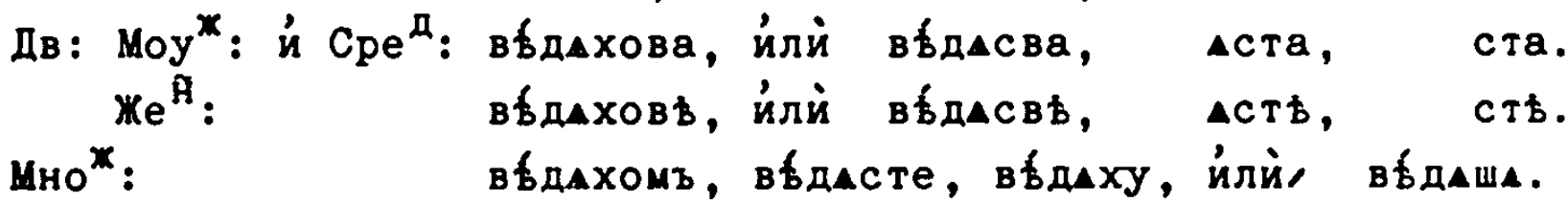
Вйда Оу́чащ:

Bре́mム Настойщ:

Преше मू: мимоше ${ }^{\text {मू: }}$

$\dot{\epsilon}$ ди ${ }^{\tilde{\text { }}}:$

є̇ди : оувьй: й про

Bfдаw:

Bł́даxъ:

Bьдаáxъ: 'ако хе чита́ю.

'ако хел чита́хъ.

Һако хе, читаáxъ.

Буд́ущеe :

Heпредът́ное:

оуввдьхз: 'ं про q.

$\mathrm{y}$

"ако хел вбдъх".

Накло

Наклоне́ніА Повелйтелнагш Вйда соверше́нна:

Вре́ma настои́щеe.

$\dot{\epsilon}_{\text {ди }}{ }^{\mathrm{A}}$ : в бхдь тыे,

Дв: $\operatorname{Moy}^{\star}:$ й Cpe ${ }^{\not}:$ вбха́ва, вбхйта, $\mathrm{Ke}^{\mathrm{A}}$ :

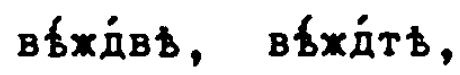
Мно*: вбхдмы, йлй вбдьм", вбдьте, Да் вfсть ӧнъ. Будіущеe:

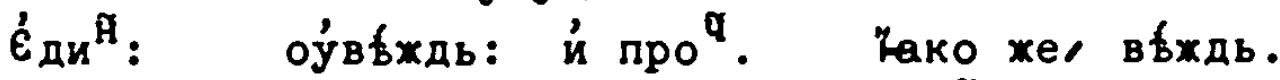
Наклоне́ніА Моли ${ }^{\mathrm{T}}$ : Вйда соверше

Bре́мム настои́щеe.

$\dot{\varepsilon}$ ди ${ }^{\text {म }}:$

Дв: $M:$ й $C:$ в $\mathrm{Ke}^{\mathrm{R}}:$ в в бхдь ти, вбхдь ӧнъ. B६xíta, Bfxд́ta.

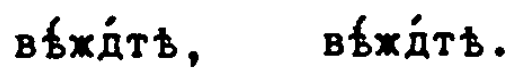

MH:

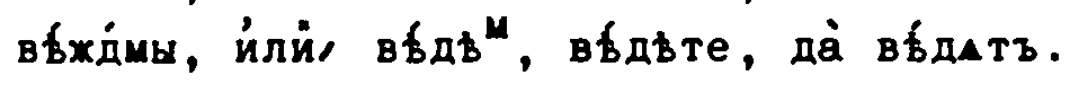

Будіущеe :

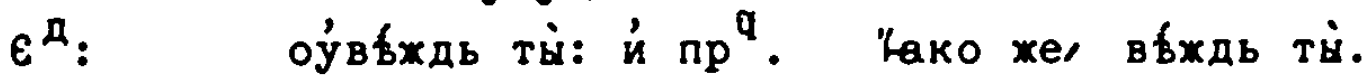
Наклоне́ніА Сослага́телна, Ви́да Совер:

Bp: Настои́щеe, й Преходіщ:

$\epsilon^{\text {म. }}$ ämе бы

Дв: М. й C. ӑmе бы вы́двласва, ласта, cта. Же $e^{\tilde{n}}$ äme бы видьльсвь, льств, сть. 
Преше́ дше :

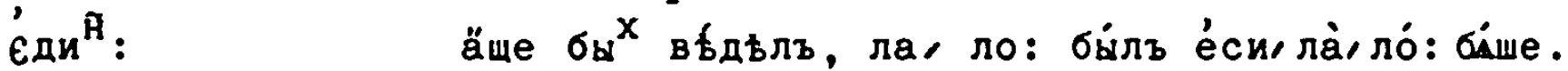
Дв: Моу*: й Сpe

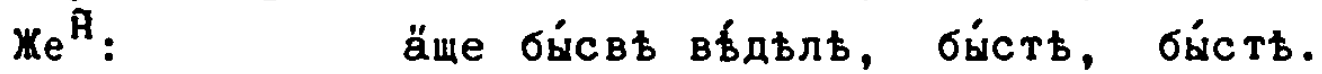

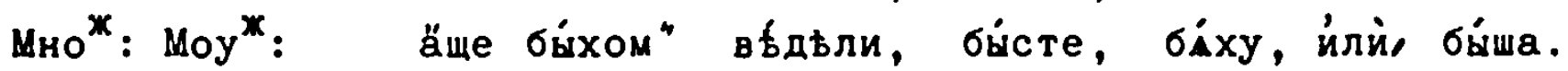
Будимеe.

гды́ бымъ оу́въд́алъ напото́мъ.

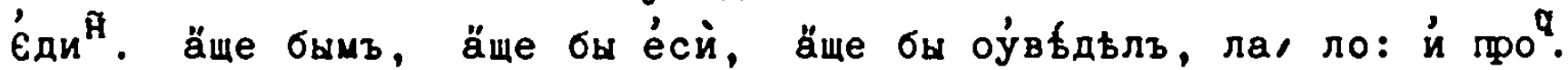
"ако же, ӓще бым", ӓще бы е́сй, ӓще бы вбдьлъ, ла, ло. Непредъл́ное :

гди́ бымъ би́лъ оу́вьд́алъ.

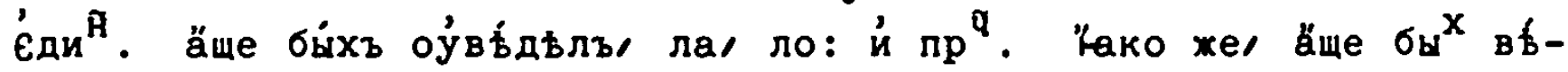
дьлъ, ла, ло.

Наклоне́ніА поДиниителнагш, Вйда Совер:

Bре́m: Настои́щеe.

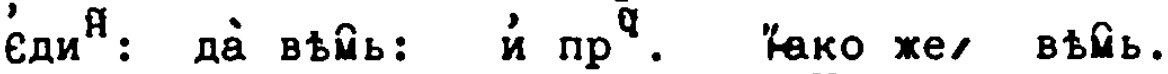

$$
\text { У药 Прехо }
$$

Преходи́mеe: '̆ Преше́дшее :

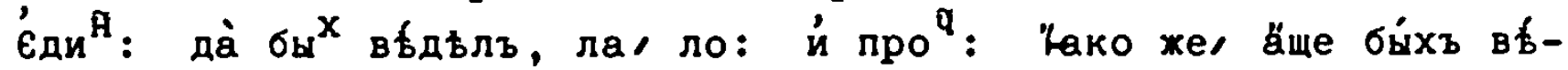
дьлъ, ла, ло.

Буд́ущеe:

є̇ди

Непредъл́но :

єди оуंвйьлъ, ла/ ло.

Наклоне́ніА Неопредьле́ннагш⿱ Ви́да Соверше́н.

Bре́mム Hactó́mеe: Вбдъти.

Бу́ дущеe :

Оуंвйдьти.

Причáctí Зало́ra Сре

Вре́mене Настои́marw.

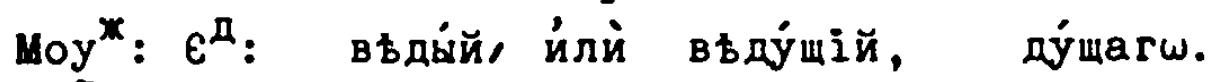

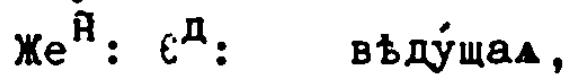

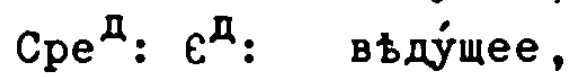

въду́щи .

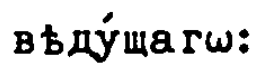

иंли่,

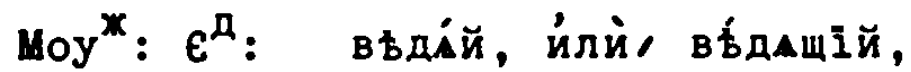
Жe $e^{\widetilde{R}}: \epsilon^{\text {म }}$. вбдащан:

дащагw.

Cpe $: \epsilon^{\text {मू. }}$. вбдащеe:

в бдащиа.

в fдаща $w$.

Преходи́ща гш:

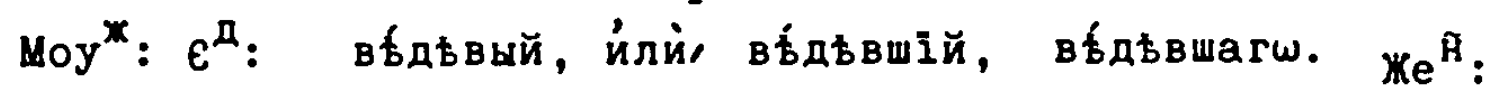



$\nVdash e^{\mathfrak{A}}: \epsilon^{\text {म }}:$
в бдввшаa,
вђдъвшиА.
Cpe $e^{\text {म }} \epsilon:$ вбдввшеe,
в бдьвшагw.

Пре ше́ дшагw:

моу $^{x}: \epsilon^{\text {म }}$ : вьде́й, йлй, в вдшій,

Жe $e^{\tilde{\text { I }}}: \epsilon^{\text {म }}:$ вбдшаa,

шагw.

Cpe $e^{\text {д }} \epsilon^{\text {म }}:$ в вдшеe,

в бдшим.

$\operatorname{Moy}^{x}: \epsilon^{\text {म }}$.

оуंвьду́щ

$\nVdash e^{\widetilde{H}}: \epsilon^{\text {म }}$.

оу въду́щан,

Cpe $e^{\text {म }} \epsilon^{\text {म }}$.

оуввьду́щеe,

в fдuarw.

Буд́ущагw:

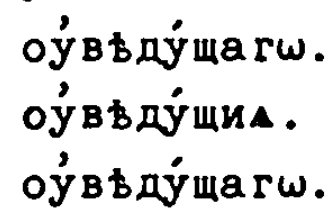

Henpe дьл́нагш:

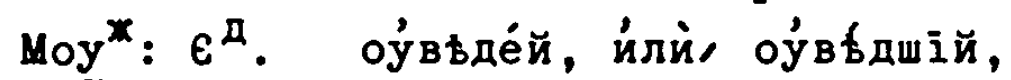

Же $e^{\text {म }}: \epsilon^{\text {मू. }}$ оу вбдшал,

шагw.

Cpe $e^{\text {मू }} \epsilon^{\text {म }}$. оуंвбдшеe,

оу́в диии.

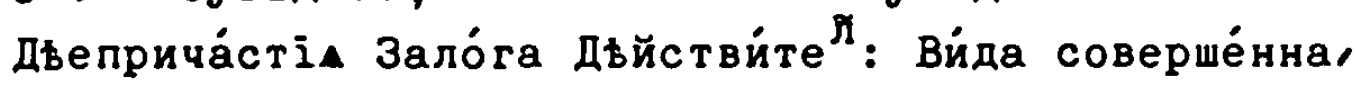

Вре́мене настод́щагш.

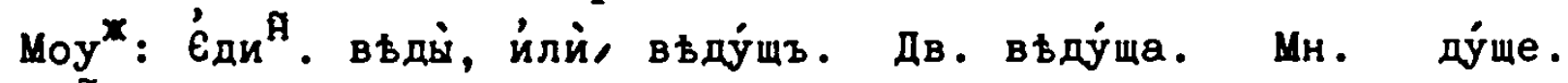
Же $: \epsilon^{\text {म }}$. вьдуंщи:

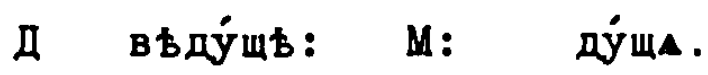

Cpe ${ }^{\text {म }}: \epsilon^{\text {म }}$. въдуंще :

д: вђду́ща: M: ду́щa:

йлі,

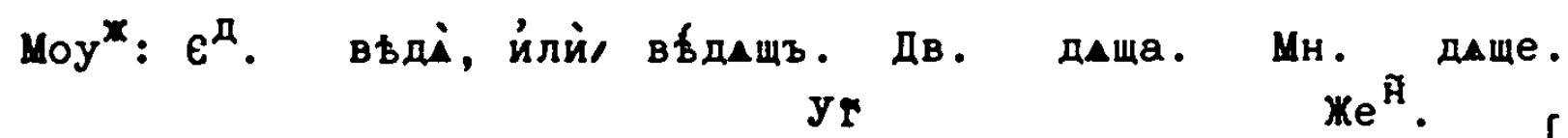

[1626]

же $: \epsilon^{\text {म }}$. вбдами:

Д: Вбалщь; $M:$ дАщи,

Cpe $e^{\text {म }} \epsilon^{\text {म }}$. в бдаше:

Д: Вб́дища: М: даща.

Преходи́щагш:

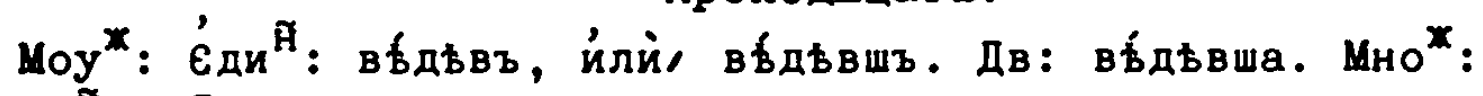

Же $: \epsilon^{\text {म }}$. вбдьвши:

Д: Вбдьвшь: $M:$

вше.

Cpe $e^{\text {म }} \epsilon^{\text {मू. }}$. вв́дввше:

д) вfдьвша: $M$ :

BயA.

вша.

Преше́ дша rw:

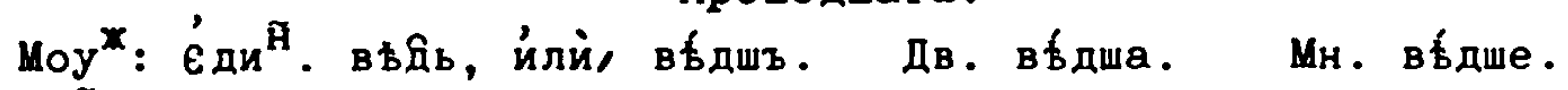

Же $: \epsilon^{\text {म }}$. вбдши: Д. вбдшь: M. вбдшА:

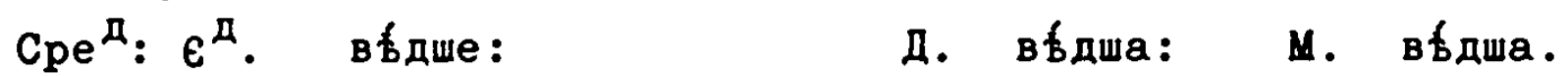

Будущагш:

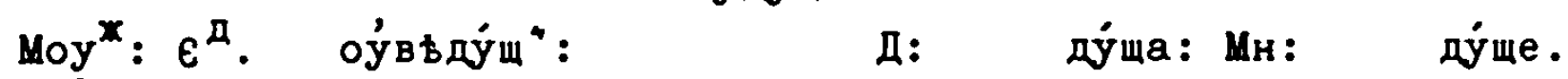

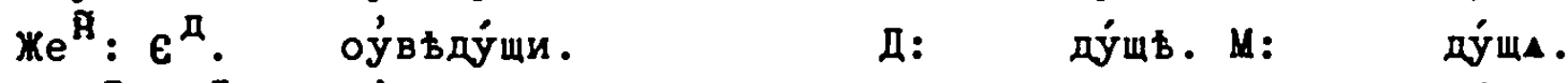

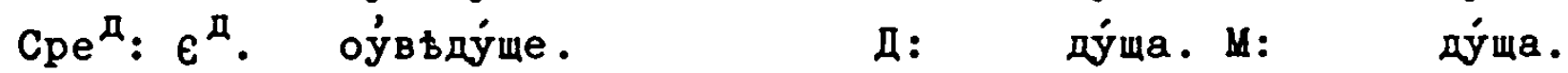

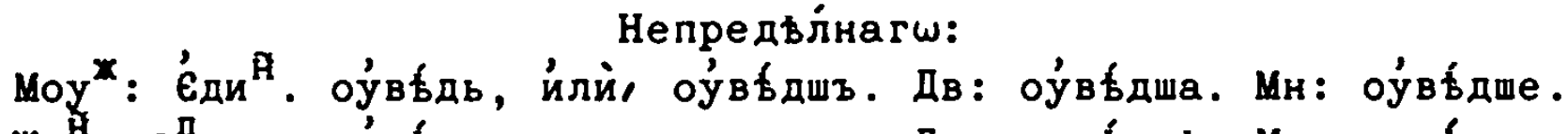

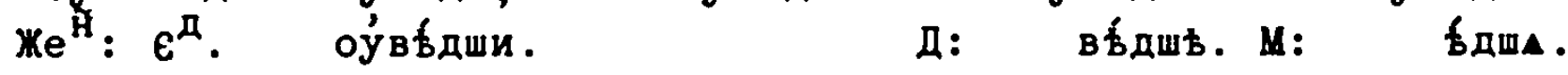


Cpe

Д: вб́дша. M: fnma.

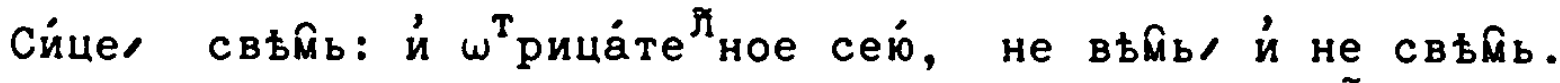
ramb.

п̆mb: Cи́ue Cinparáet"ca.

Гйа Лйчнагш/ Зало́га Сре́днагш/ Вйда Соверше́нна, Наклоне́ніА Й“Ави́телна,

É ди ${ }^{\tilde{H}}$ : Bре́ma Hactó́mee.

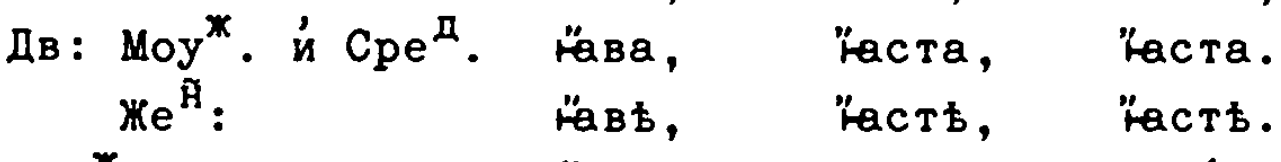
Мно : "̈амы, lacte, "̈ади́тв. Преходи́mee :

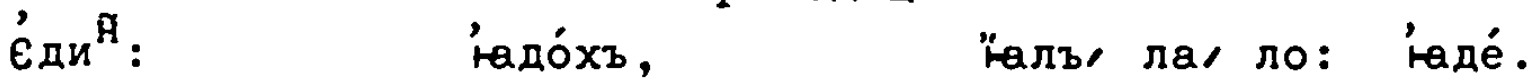

Дв: Моу*. и́ Сp. 'адо́хова, и́лй́ 'адо́сва, 'адо́ста, до́ста. Же ${ }^{\text {: }}$ 'адо́ховь, йлй 'адо́свь, сть, сть. мно*: 'адо́хомъ, 'адо́сте, 'юдо́ma.

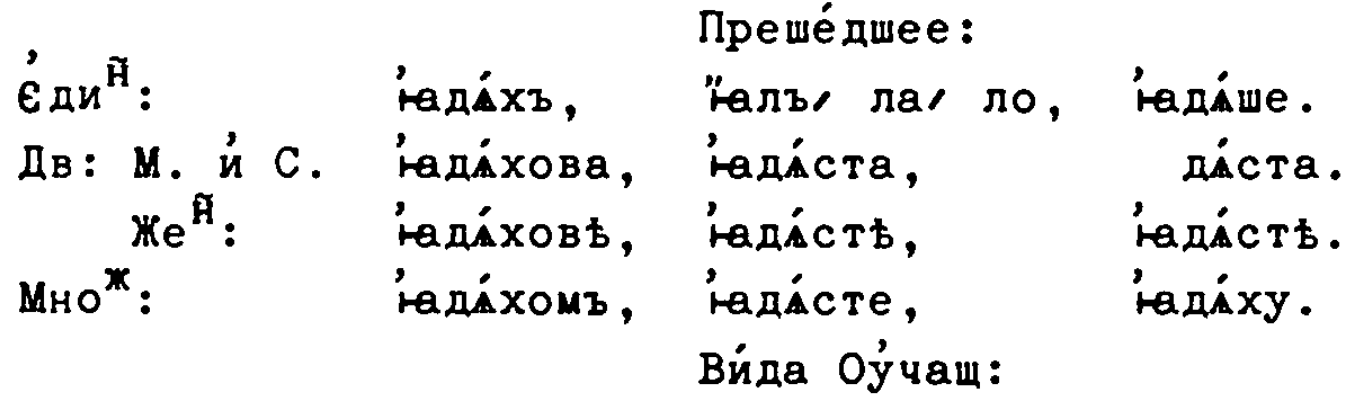

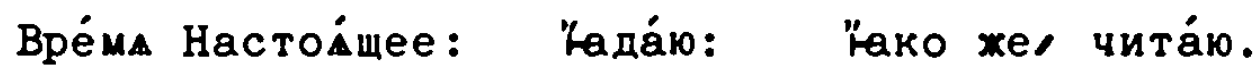
Преше́ дшеe : мимоше ${ }^{\text {I }}$ : 'ада́xъ, Һако жел чита́хъ. 'адаáx": Гако жел читаáxъ. уд Бу́

Боуं дущеe :
$\dot{\epsilon}_{\text {ди }}{ }^{\mathrm{A}}$.
сньदि ,
снбси,
сHб́ctb:
Дв. Моу⿰ $^{*}$. и $\mathrm{Cpe}^{\text {म }}$. снб́́ва, сньста̀, снђста̀. $\mathrm{Ke}^{\text {म }}$. CHÉb, снђсть, сньсть. Мно ${ }^{*}$. снбмы, сньсте́, снђдіт́.

Непредьл́ное:

$\dot{\epsilon}_{д и}{ }^{\text {म }}$ : сньдо́хъ, снбль, ла, ло: сньде́.

Дв: $\mathrm{Moy}^{\star}$.

сньдо́хова, сньдо́ховь, йлй MH . сньдо́хомъ, и่лиे।

$\dot{\epsilon}_{\text {ди }}{ }^{\text {I }}$. cH占Xz, Дв. Моу $^{*}$. и Сpe снбль, ла, ло, сньь. сни́ста, снб́ста. 

$\mathbb{H} e^{\mathfrak{H}}$.
CHfCBE,
chf́cts,
chf́ctb.
$\mathbf{M H O}^{*}$.
снбхомъ,
chfore,
сны́ша.

Наклоне́ніА Повели ${ }^{\mathrm{T}}$ : Вйда Соверш:

Bре́un Настод́mee:

єди ${ }^{\mathrm{R}}$.

"ахдь ты், да̀ Касть ӧнъ.

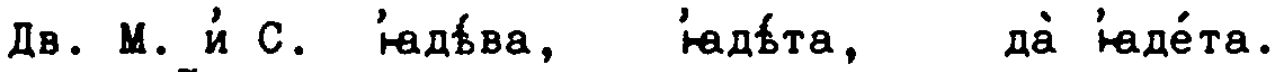

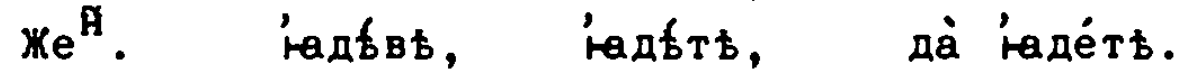

$\mathbf{M}_{\mathrm{H}}$.

$\dot{\epsilon} д{ }^{\text {म }}$. "ахдмы, илй, 'адбм", 'адбте, да̀ 'ади́тъ.

Боу́ пу щеe:

Дво́й.

Дв: М. и́ C. снбхи́ва, хи́ra, да̀ де́та.

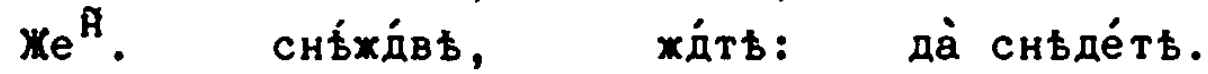

M. снбхдимы, лй, снбдђ", дьте, да̇, дйт".

Наклоне́ніА Моли ${ }^{T}$ : Ви́да совер:

Bре́mа настои́mеe.

$\dot{\epsilon} д{ }^{\text {म }}$.

laxдb ты,

Дв. М. и С. 'адбва, жe ${ }^{\text {. }}$ 'aдfтa, 'antst,

$M_{H}$ : 'Һахдмы, и́лй 'адбм", дбте,

Буд́yщee :

$\dot{\epsilon}$ ди ${ }^{\text {म }}$. снбххд ты,

Дв. Моу $\mathrm{Xe}^{\mathrm{A}}$.

снб́хдав , снбхх́ть,
Һахдь ӧнъ.

iaftra.

ranftb.

да̇, дйт".

CHБৈДЬ ÖHз.

хд́та.

chtoxátb.

Мн. снђхд́мы, йлй, снбдђмъ, снбдђте, да̀ снђдйтъ.

Наклоне́ніА Сослага́те ${ }^{\Re}$ : Ви́да Совер:

Bре́ma Настойmеe: й Преходи́mеe.

$\epsilon^{\mu}$. äще бы , ӓще бы е́сй, ӓще бы Һалъ, ла, ло:

Дв: М. й С. ӓще бы "аласва, Һаласта, ста. Же

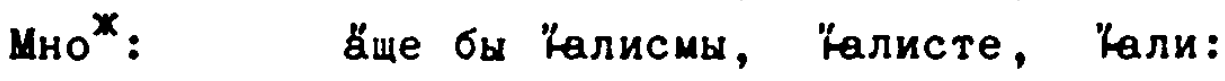

$$
\text { уг преше }{ }^{\text {मू: }}
$$

Пр̃
Преше́дшее:

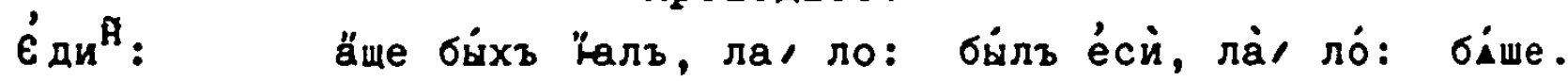

Дв: М. й С. ӓще бйсва 'ала, би́ста, ста. Же ${ }^{\tilde{H}}$ : ăще би́свь "аль, бйсть, сть.

Мно :

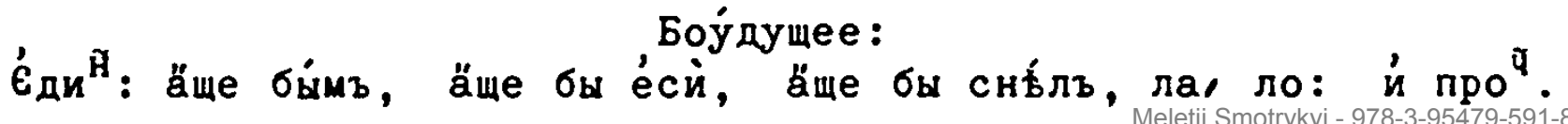


Һако же äще бы́мъ, ӓще бы е́сй, äще бы Һалъ, ла, ло. Непредьлине :

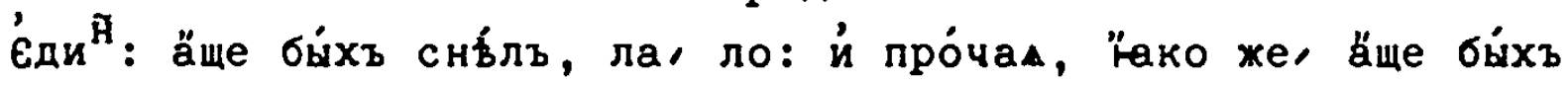
"аль, ла, ло:

Наклоне́ніА ПоДчини ${ }^{\text {T }}$ : Вйда Совер:

Bре́ma Настод́щеe:

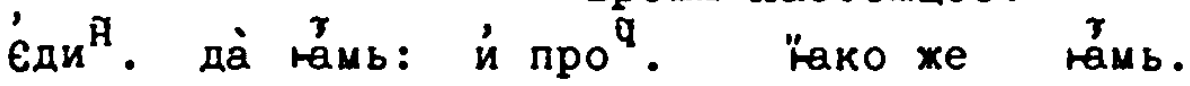

Преходи́щеe: '́ Преше́дшее :

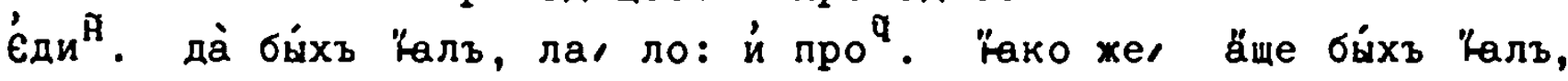
ла, ло.

Боу́дущее :

Бу́дy

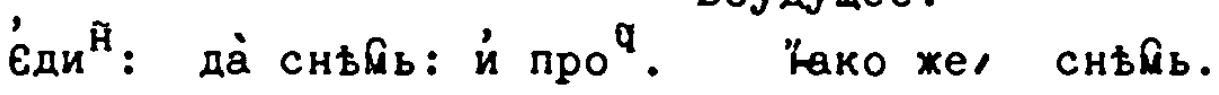

Непредьл́ное:

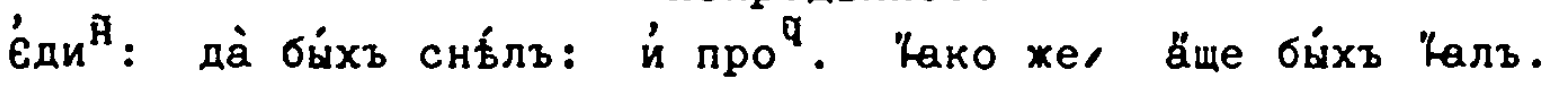

Наклоне́ніа Неопред: Ви́да Совер:

Bре́mA Настои́mеe: 'Һасти.

Бу́дущее: сни́сти.

Прича́cті́ Зало́ra Сpe

Вре́мене Настои́щагш:

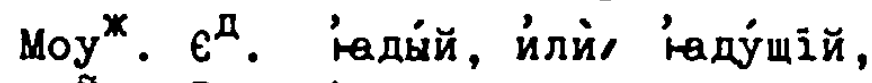

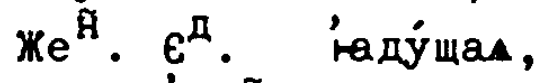

ду́ща $\omega$.

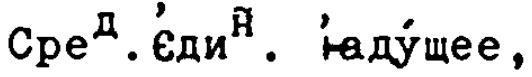

'аду́щим.

'axýщarw:

йли่ง

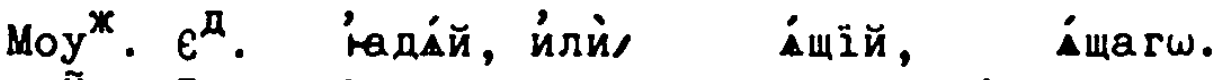

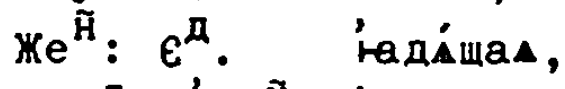

'адйщиа.

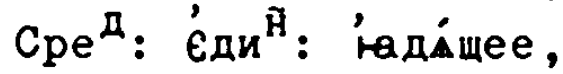

'ади́щarw.

Преходи́щагw: й Преше́[д]ш:

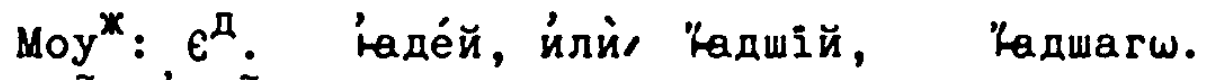

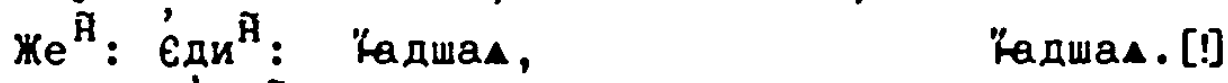

Cpe

Razwarw.

Буд́ущеe :

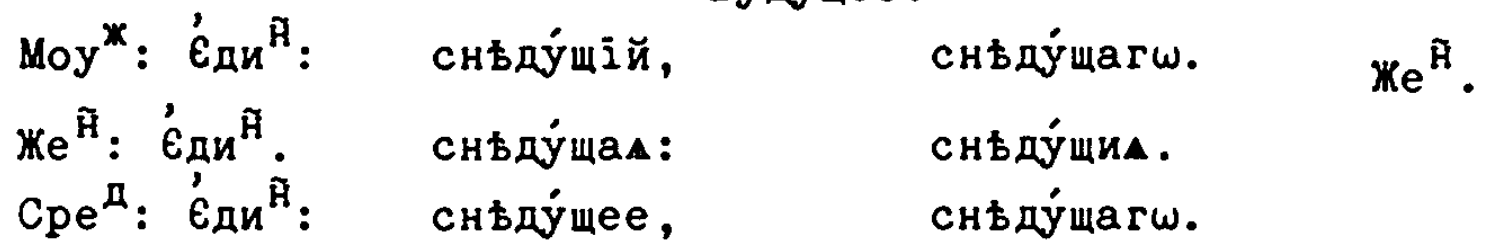

Непредьлнагш:

Mоу" $^{*}: \epsilon^{\text {म }}:$ снбде́й, йлй снбдшій,

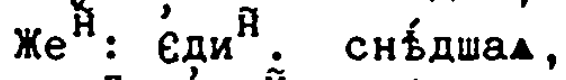
warw. Cpe ${ }^{\dot{\mu}}: \hat{\epsilon}_{\text {ди }}$. снбдшее, 
Дьеприча́стіА Зало́га Дьйстви́те ${ }^{\Re}$ : Вйда Соверше́нна,

Bре́мене Настод́щ.

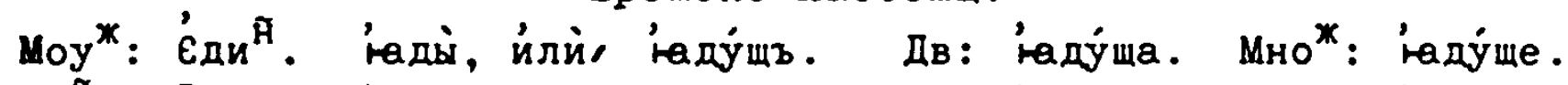
Же ${ }^{\text {म }} \epsilon^{\text {म }}$. 'ंаду́щи:

Cpe $e^{\text {म. }} \epsilon^{\text {म. }}$ íду́mеe:

д:

म: . 'апу́щa: $M$ : ýma:

\section{йлй}

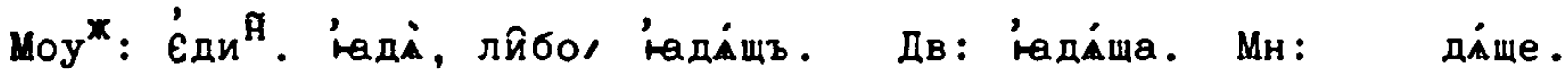

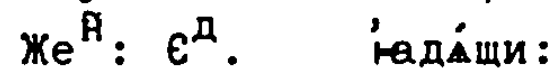

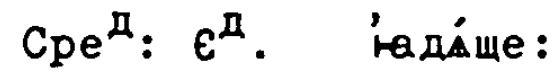

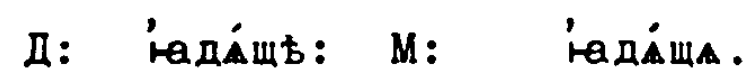

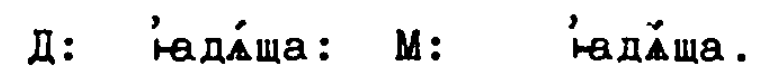

\section{Преходи́щагш й Преше́ дшагш:}

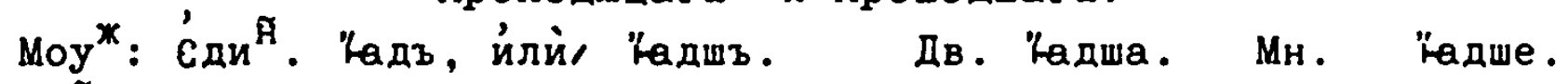

же $e^{\text {म }} \epsilon^{\text {. }}$. Кдши:

$\mathrm{Cpe}^{\text {म }} \cdot \epsilon^{\mathrm{A}}$. "̈аде :

Mоу*: $\epsilon^{\text {म }}$. сньду́ш",

Же $e^{\text {A }} \epsilon^{\text {म }}$. сньдуंщи,

Cpe $e^{\text {д }} \epsilon^{\text {म }}$. сньду́ще.

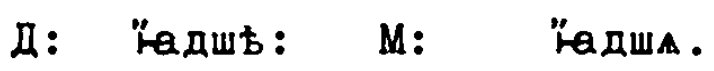

д: lадша: $M$ : "адша.

Буд்ща $\Gamma \omega$.

म: сньду́ща, M:
Д: сньду́щь, M:

Д: сньду́ща, м: ща.

Непредьл́нагш:

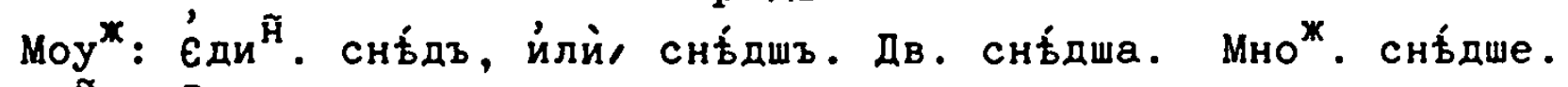
Же $e^{\mathfrak{R}}: \epsilon^{\text {म }}$. снбдши, Cpe $e^{\text {म. }} \epsilon^{\text {म }}$. снб́дше, д: снбдшь, M:

म: снбдша, $M$ : дша.

йmamb: Cи́ue Cnparáet"ca.

Гла Лйчнагш⿱ Зало́га Сре́днагшы Ви́да Соверше́н. Наклоне́ніА Й "АBИ" :

Bpéma Hactó́mee.

єдй ${ }^{\tilde{H}}:$ ймамь, ймаши, ймать.

Дв: $M:$ й Сред : ймава, ймата, ймата.

Же $\mathrm{f}^{\tilde{n}}$ ймавь, ймать, ймать.

мно : ймамы, ймате, ймуть.

Преходи́mеe: й Преше́дшеe.

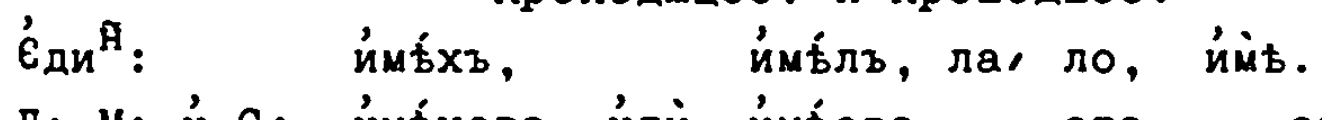

Д: М: й С: и́мtхова, йлй и́мб́сва, ста, ста. Же $e^{\hat{H}}$ ймб́ховь, йлй и́мб́свь, сть, сть.

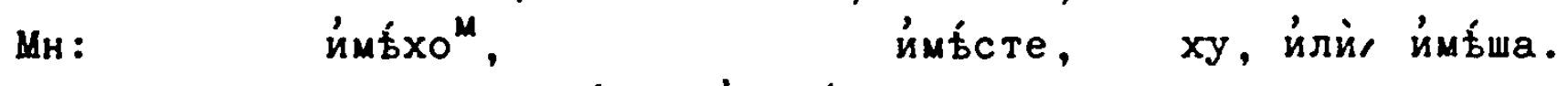

Вйда оу́чаща́телна:

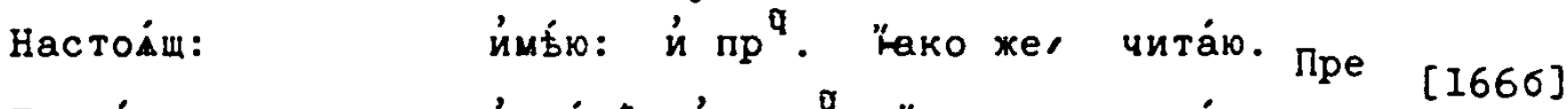

Преше́д: ймьáx": и́ про : "юко жел чита́хъ. 
Muмo: йmъaáx": й np". łakо хе, читаáxъ.

Буд́у щеe:

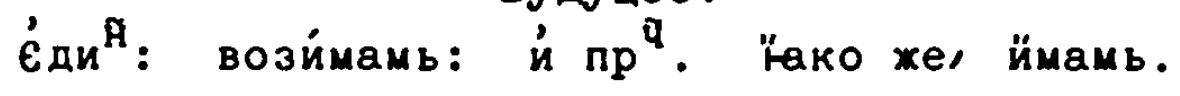

Непредьл́но :

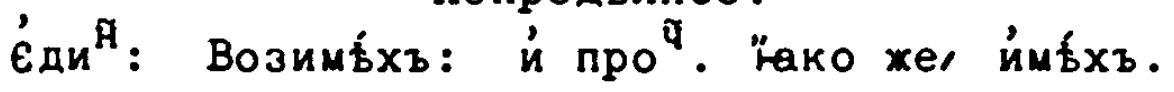

Накл: Повел: Виम : Сов:

$\dot{\epsilon}$ ди $^{\text {म }}$

$\mathrm{Bp}:$ Настовщ:

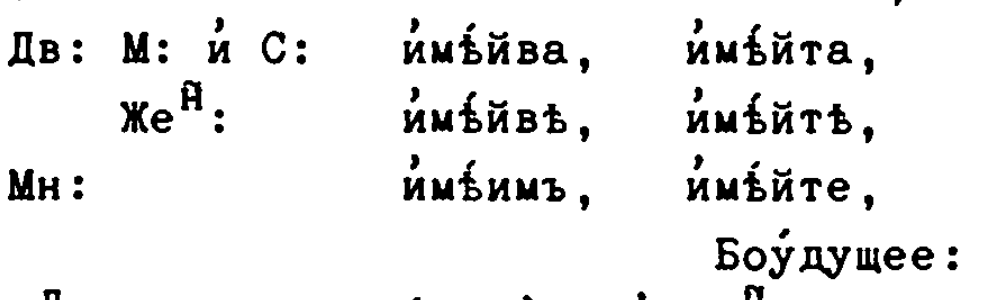

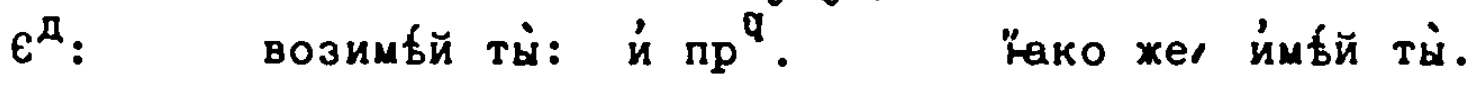

Наклоне́ніА Моли ${ }^{\mathrm{T}}$ : Вйда Соверше́н:

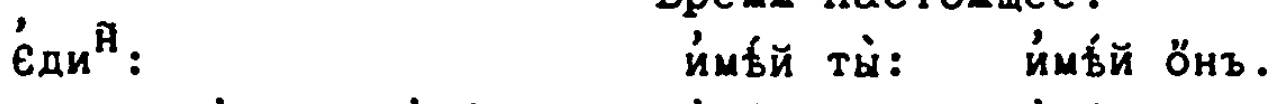

Вре́mа Настойщеe.

Дв: М. й С: и́мб́йва, ймбйта, ймбйта.

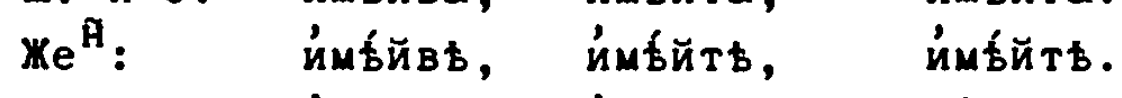

Мн: йм́́имъ, иंмбйте, да் ймуть.

Боу́ дущее :

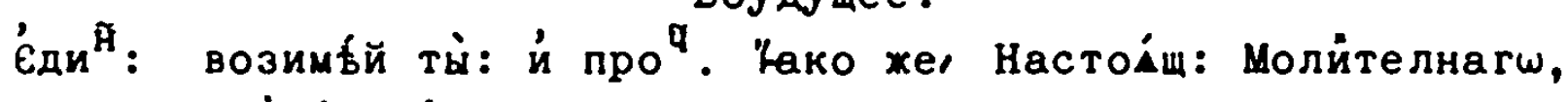
йм६й ти.

Накло

Наклоне́ніА Сослага́телнагш, Вйда Соверше́н:

Bpéma Hactó́mee.

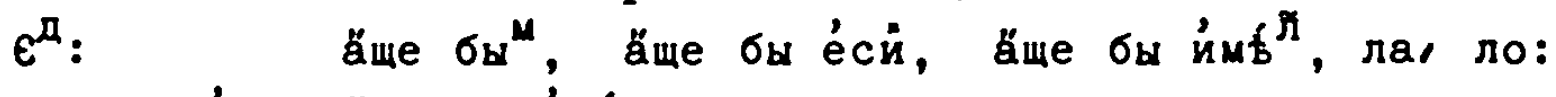

Дв: М: й С: ӑще бы ймбласва, ста, ста.

Же $e^{\text {: }}$ ăme бы ймбльсвђ, льсть, сть.

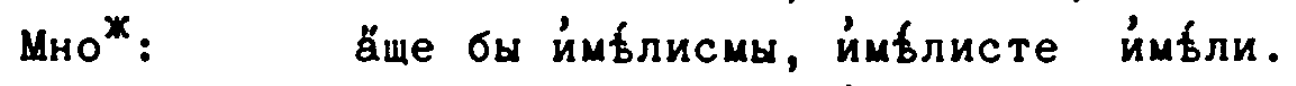

Преходи́mеe: й Преше́дшеe:

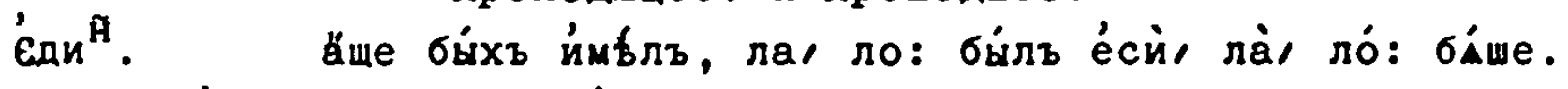

Дв: М. й С. ӓще би́ссва йм́́ла, ста, ста.

Же ${ }^{\tilde{H}}$. ăще бйсвь ймбль, бйсть, сть.

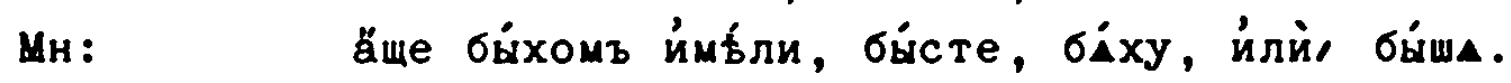

Боуддущеe :

'єий Һако же, ӑще бы ймблъ, ла, ло: й про

Непредьліное:

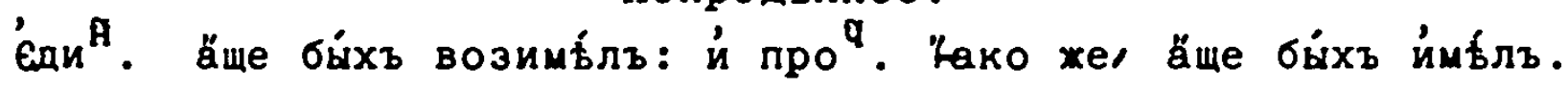


Наклоне́нӓА по पини $^{\mathrm{T}}$ : Вйда Совер:

$$
\text { Bре́ma Hactó́mee. } \dot{\epsilon}_{д и} \text {. }
$$

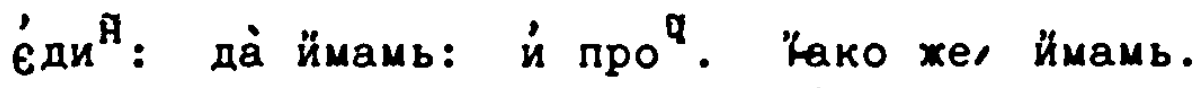

Преходіщ: й Преше́дшее :

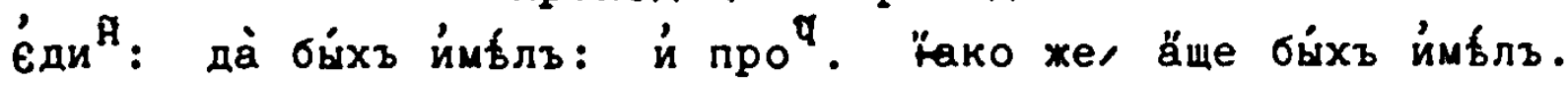

Боу́дущеe :

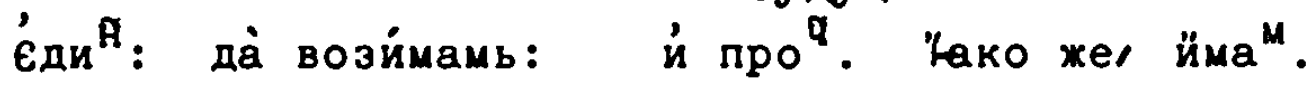

Непредъл́ное:

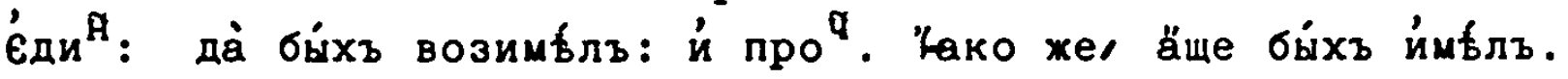

Наклоне́ніа Неопред: Вйда Совер:

Bре́ma Hactó́mеe: ймбти.

Бу́дущеe:

Прича́cті^ Зало́ra Сре́д: Ви́да Сове

Вре́мене настои́щатш.

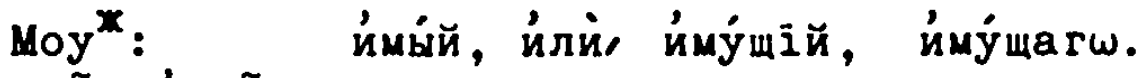

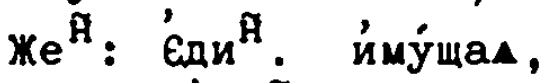

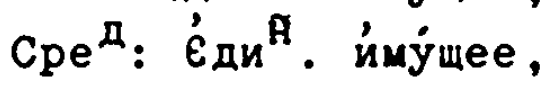

йму́щиА.

йму́ща

Прехо

моу $^{*}: \epsilon^{\text {д }}:$ ймбвый, йлй, имбвшій, вшагш:

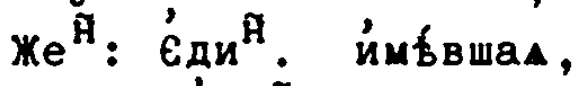

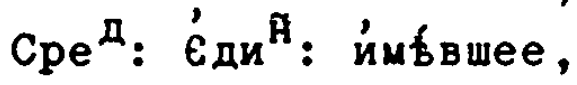
ймб́виа.

úńвшаrw.

Бу́ дy

Боу́дущагw:

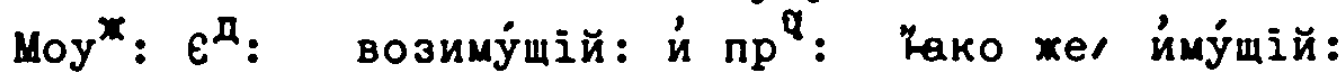

Непредьлінатш:

моу $^{*}: \epsilon^{\text {म }}$ : во ${ }^{3}$ имбвый: й пр : Һако жел ймбвый.

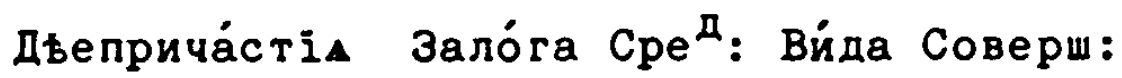

Вре́мене Настойщагш.

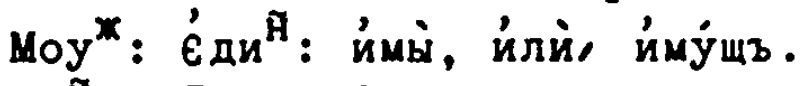

Же $e^{\mathscr{H}}: \varepsilon^{\text {म }}:$ иंму́щи:

Cpe $e^{\text {म }} \epsilon^{\text {म }}:$ имму́ще :
Дв: йму́ща: Мно

д: йму́щь: $M$ :

д: имму́ща: $M$ :
느.

йму́ща.

и́му́⿴囗.

Преход : й Преше́ дшагш:

моу : Є́ди: ймб́въ, йлй ймб́вшъ. Дв: ймбвша. Мн: вше.

Же $e^{\widetilde{R}} \epsilon^{\text {म: }}$ имввша:

Cpe $e^{\text {म }} \epsilon^{\text {म }}$. йmв́ :

Д: ймбвшь, $M:$ BшА.

Д: ймfвшз: M: вша.

Непредьл́нагш:

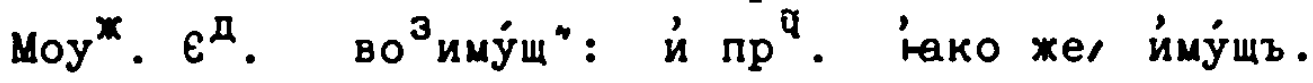

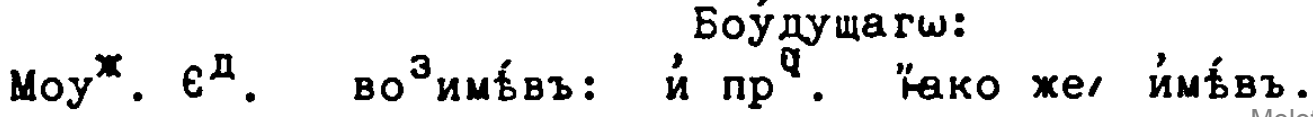




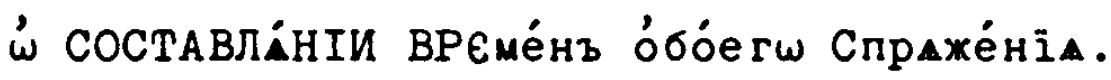

Äще й мно́гагш йску́са в" Славе́нском"

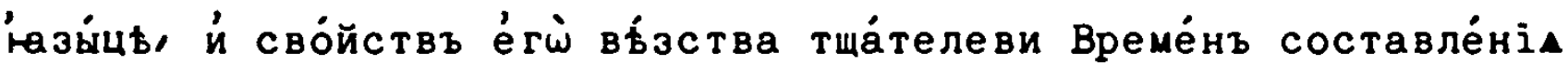
дб́ло быти вбддхомъ: по сйль обаче на́шегш поиска́ніА сухо́ю стопо́ю й на́мъ толи́кш ну́хдну ве́щь прейтй не достод́ше, оу́въще́ннымъ

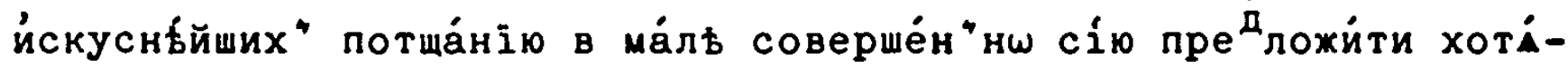
щy.

Составле́ніе Време́нъ о́бое́гш Cпраже́ніл

Зало́га Дъйстви́телнагш Наклоне́ніА йз"Авйтелна.

'́ Преходйщемъ пра́вилнь составліемомъ.

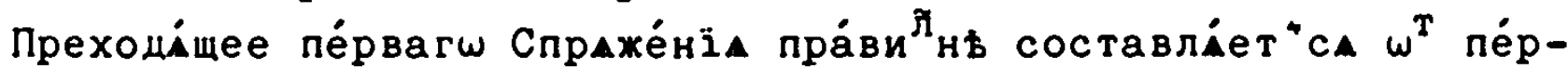
вагш лица̀ настод́щагш, Вйда соверше́нна, йзменйюще, 1, на, хъ: ул же на, оx: Kakw

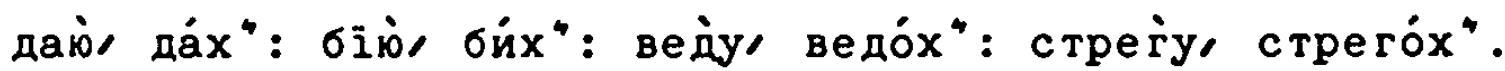

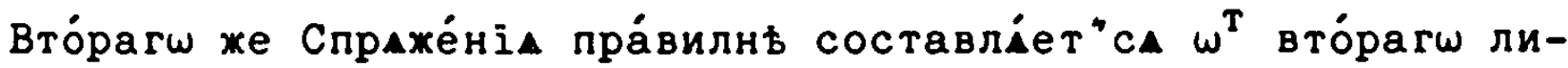

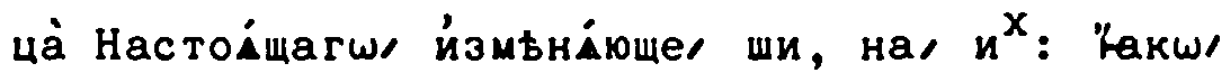

тайши, тайхъ: двойи, двойхъ: гласйши, гласих": гостини,

гости́х": вреди́ши, вредйхъ.

Coctal!]

[I69]

Непра́вилнь соста мно́га суть й ра ${ }^{3}$ личчна, о́соббнагш потща́ннагш йзыска́ніА требу́ютъ: $\dot{\omega}$ нйх" же Бгу поспьшеству́ющу во ма́ль йнде.

$\dot{\omega}$ Преше́дшемъ:

Преше́дшее составлі́ет"са $\omega^{T}$ пе́рвагш лица̇ йз"Авйтелнагш' вре́-

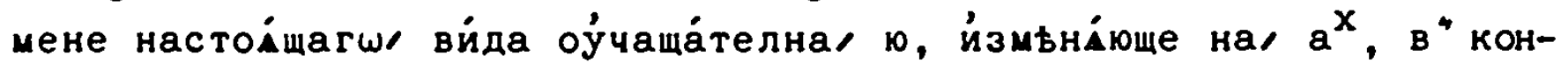

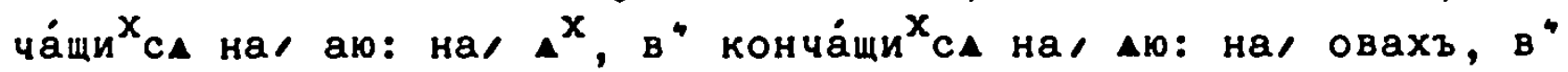
конча́щих"са на, ую: "†кш'

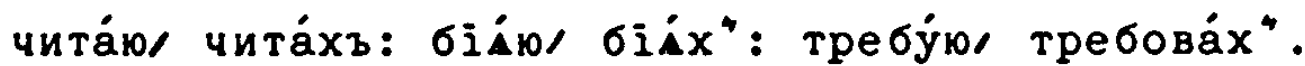

'́ мимоше́ дшемъ :

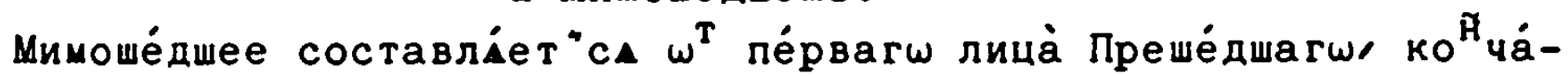
емому растворіему ӓзомъ: "⿴кш'

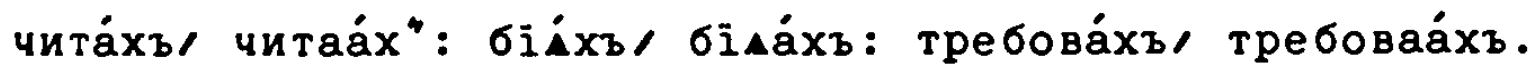
$\dot{\omega}$ Непредьл́номъ.

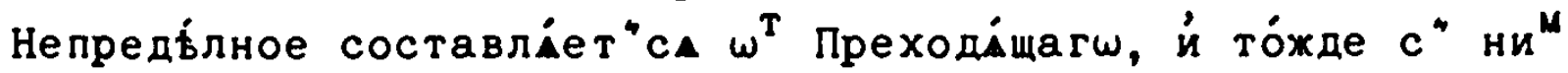
ёсть ра́звь нараще́

HiA.

нї. Иза́тымъ ма́льм" без нараще́ніА свое́ йм" Непредб́лное йму́-

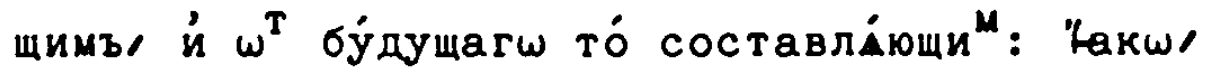

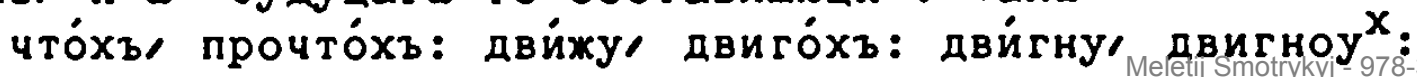


$\dot{\omega}$ Будиущемъ.

Бу́дущее составліет"са $\omega^{T}$ Өе́мате, йли́ $\omega^{T}$ пе́рвагш лица̀ гл̆́a

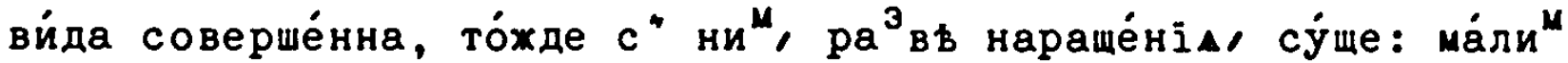

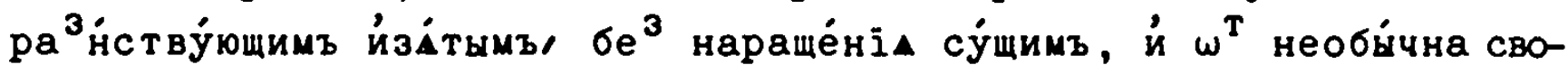

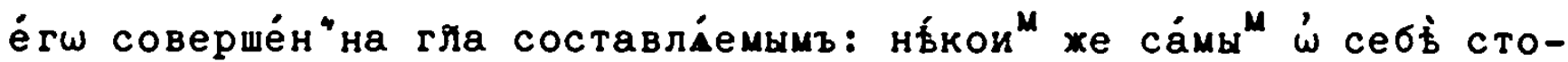
іщимъ: 'Какш'

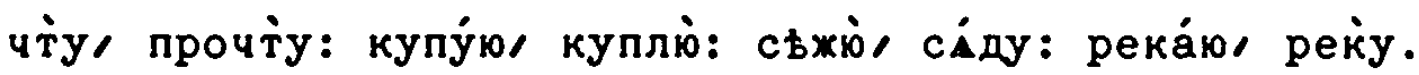

Составле́ніе Време́н" Зал: Дъйств:

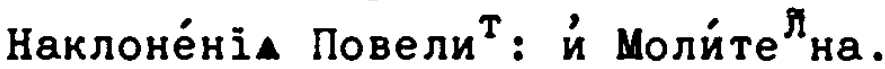

¿́ Настои́ще

Настод́щее Повели́телнаг $\omega$ й Моли́те ${ }^{\mu}$ наг $\omega$ во оббоемъ вйдђ $\omega^{T}$

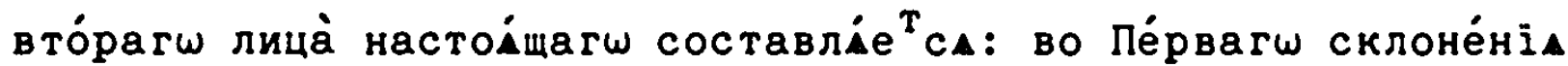
глехъ, еши, á во Вто́parw, ши,

$\omega^{T}$ émлі́

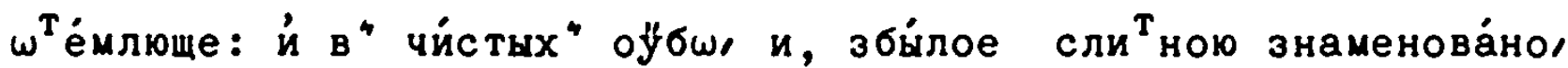
B" нечйсть же оббичнш произносймо прие́млюще: 'Һакш'

біе́ши, бій: біА́еши, біґ́й: стойши, сто́й: става́еши, става́й:

стрехе́ши, стрехй: про́сиши, просй.

'ं Буд́ущемъ:

Подо́бным" ӧбразомъ составлі́ет"сА й бу́дущее, $\omega^{T}$ вто́рагш лица̇ бу́дущагш Из"Авйтелнагш: "акшл

побіе́ши, побій: постои́ши, посто́й: ста́неши, ста́ни: сотво́риши/ сотворй.

$$
\text { Оу́вњще́ніе: }
$$

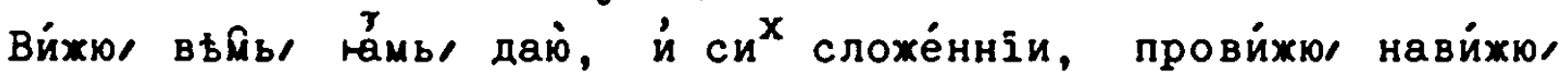
повьда́ю, и́сповьда́ю, й про : Повели́телный й моли́те ний '́бое́-

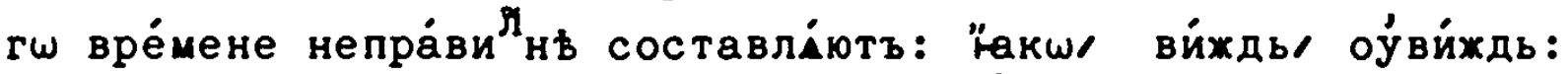

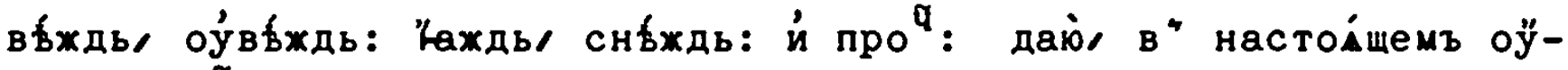
бш пра́ви нь, да́й, в" бу́дуще же стропо́тнђ да́хдь. Й ӓще кіА ЙныА нави́къ препода́сть.

Cocta

[1706]

Составле́ніе Bp: Зало́: Дъйств: Наклоне́ніћ Сослага́телнагш $\dot{\omega}$ всьх" наклоне́ніА сегі் Вре́мене ${ }^{X}$ :

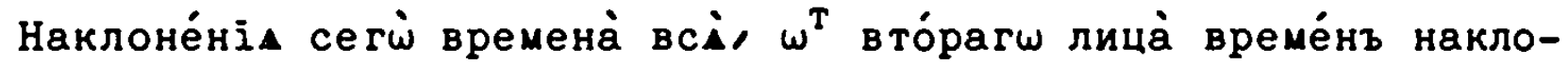

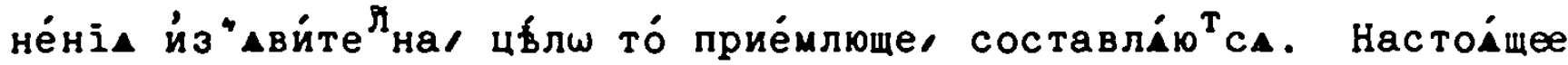

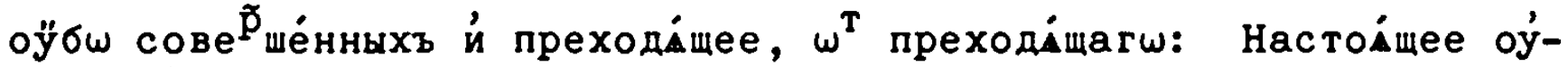

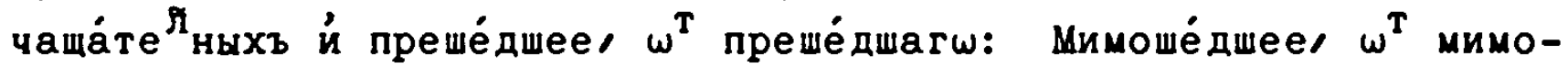

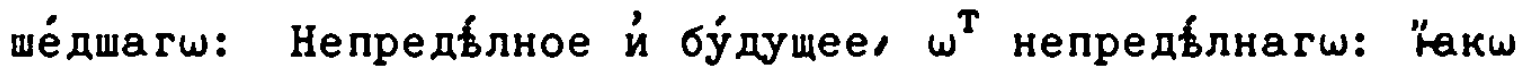
Че́лъ е́сй, че́лъ ёсмь: чита́лъ е́сй, чита́л" ёсмь: читаáлъ е́сѝ, читаа́л" ёсмь: проче́лъ е́сй, проче́лъ ёсмь. 
Составле́ніе Време́н" Зал: Ньйств: Наклон, Подинни́телнагш:

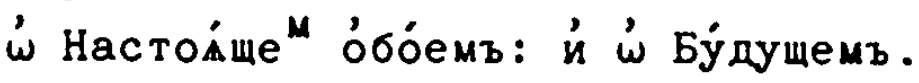

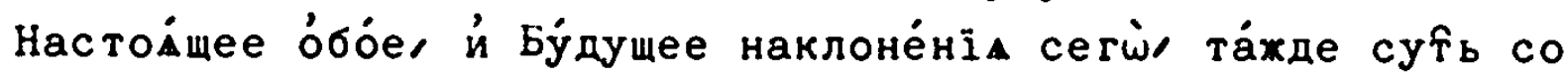
из" "Авителнагш.

'ं Преход: Преше́дше й Мимоше́д.

Преходи́щее, Преше́дшее, $\dot{n}$ Мимоше́дшее наклоне́ніА сегі́, $\omega^{T}$ сво-

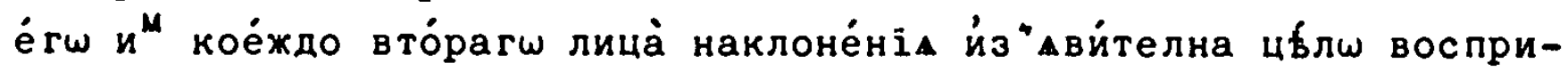
е́млет" сA.

He пра́[!]

[I7I]

Составле́ніе Време́н" Зало́га Дьйст: Наклон: Неопредьле́ннагш. ¿́ Настои́щемъ й Прехода́щемъ.

Настов́щее соверше́нны

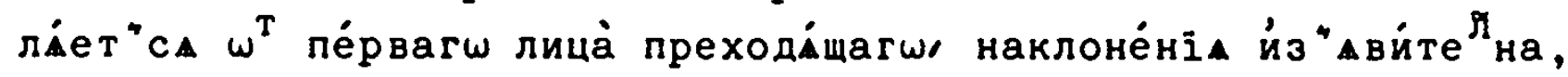
иззмна́юще, $\mathrm{xъ}$, на, ти: йлй $\omega^{T}$ тре́тїагш лица̇, восприе́млюще $\kappa^{*}$ не́му, ти: "akw'

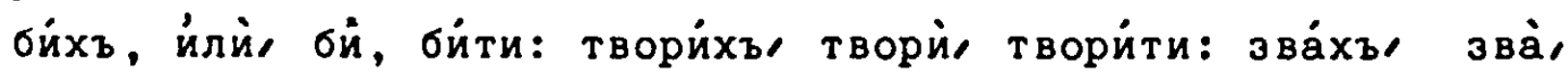
эва́ти: просиххъ просѝ, просйти: вйдђхъ/ вйды вйдьти.

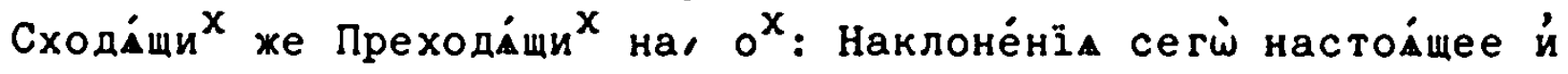
преше́дшее не по пра́вилу' но́ по '́бйку составла́е гребо $\mathrm{X}$ грестй: стрего $\mathrm{x}$ стрещй: ведо́хъ вестй: гризо́хъ, грйсти: теко́хъ, тещй: сопо́хъ, соптй: несо́хъ, нестй: плето́хъ, плестй:

сйце что́хъ, честй, а́ки́ бы $\omega^{T}$ неш́бйчна чето́хъ: бъго́хъ, бб́чи:

й про́чам மконче́ній $с и^{X}$ подо́бнь.

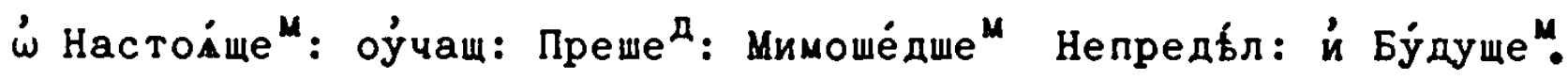
yд Hac то [1716]

Настод́щеe оучаща́телное й nреше́дшеe, $\omega^{T}$ népвагш лица̇ преше́дшагш й "Авйтелнагш, мимоше́дшагш же мимоше́дшее, непредблное й бу́дущее непредб́лнагш составла́ют"сал хъ, премьна́юще на, ти: "rakw/

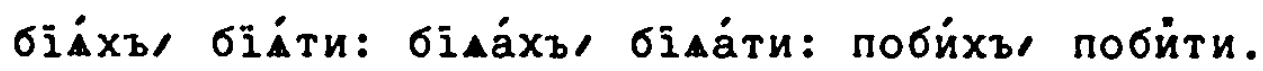
Оу́вьще́нї:

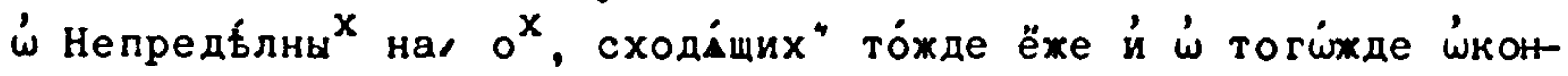
че́ніА прехода́щих бу́ди ра́зумно: $\dot{\omega} н и^{\mathrm{X}}$ же ма́лш вйш"ше.

Составле́ніе Време́нъ Дъеприча́стїй Зало́га Дьйстви́телнагш:

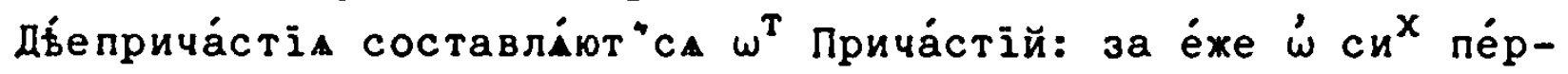
Bbe. 
Составле́нї Време́нъ Прича́стій Зало́га Дьйствйте Настойщагш Соверше́нныхъ: й оучама́телныхъ Пе́рвагш Спрахе́нї

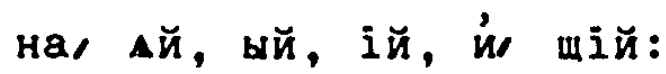

Пе́рвагш спрАхе́нї вре́мене настойща

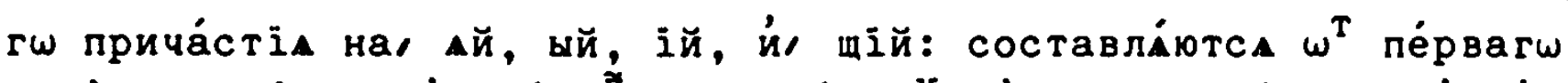

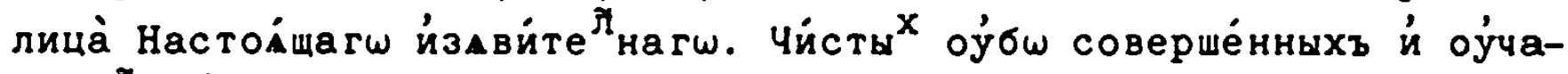
máте $\mathrm{n}_{\text {ны }} \mathrm{X}$,

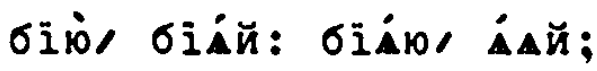

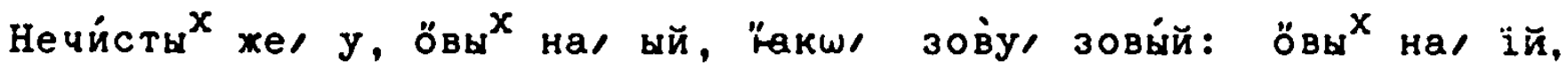
Һакш' текуу кій: чйсты же й нечисты пе́рвому лицेу прилага́rome, щій: "Екш'

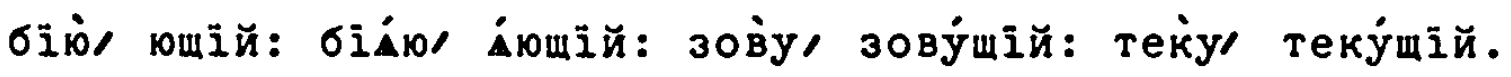

Оу́въще́нїе

$\dot{\omega}$ Гrе́xъ пе́рвагш спрахе́ніА на, Ай, ый, й ій, Прича́стїe настойщеe творйщй

Гли пе́рвагш спраже́ніА на чйстое, 10 , сходи́шіи соверше́нныи $\dot{b}$

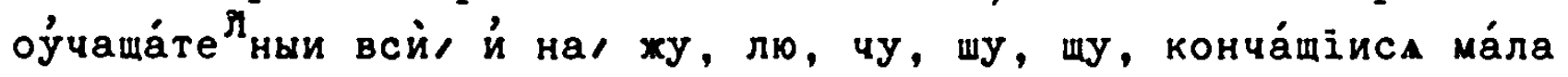

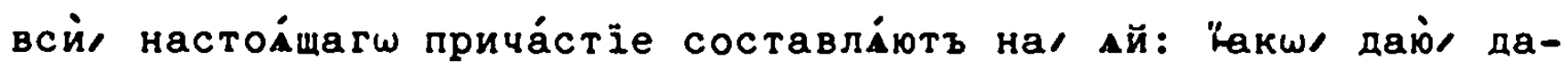

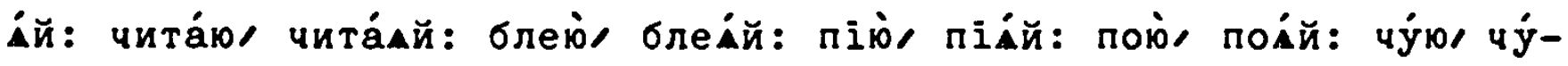

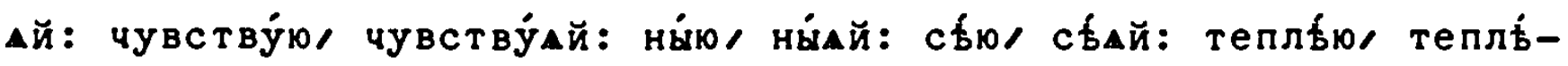

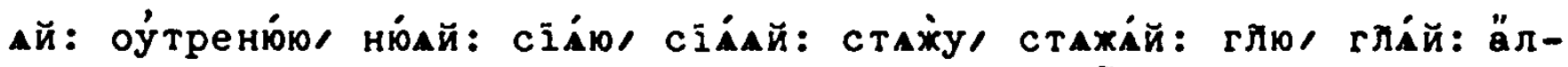

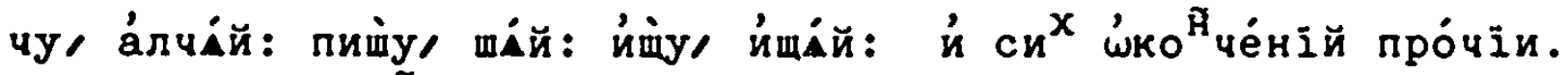

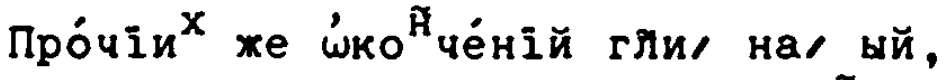
yฮ

To co

$[1726]$

то́ составлінтв: "̈акш'

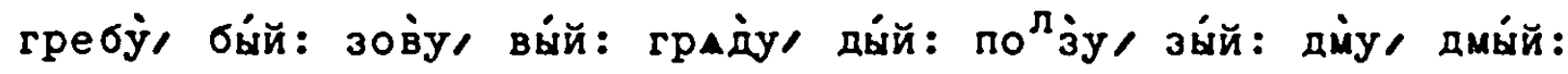

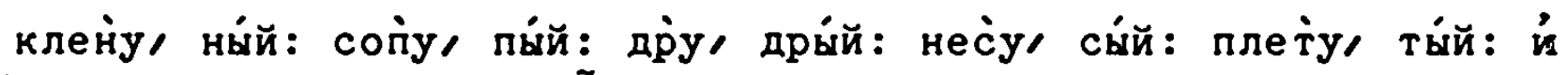
сим подо́бніи. Ра́звь '́ко йе́ній гу, ку, ху, на, ій, составлі1ощихз: "Екw'

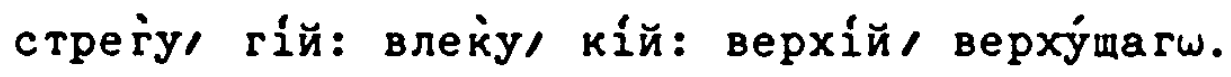

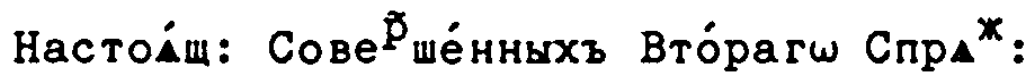

на, Ай, й щій, Конча́mих"сА.

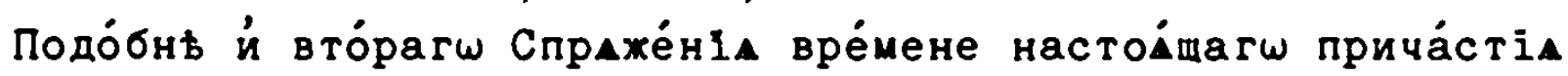

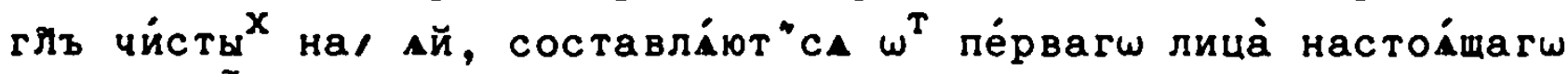

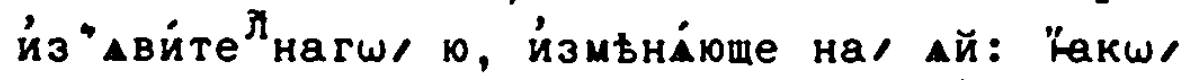

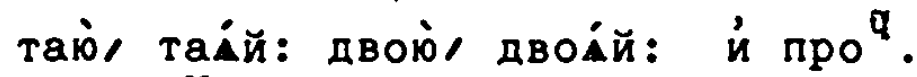

Й нечисть', "акш'

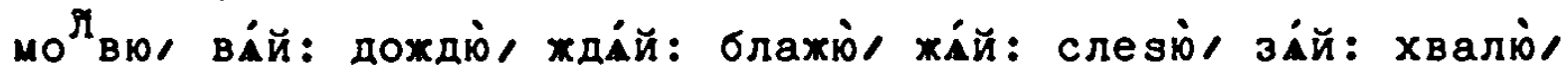




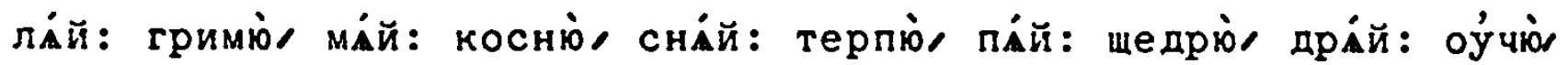

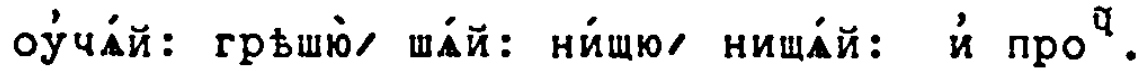

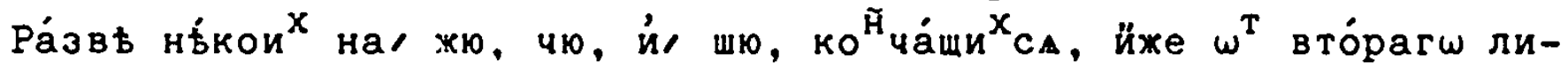

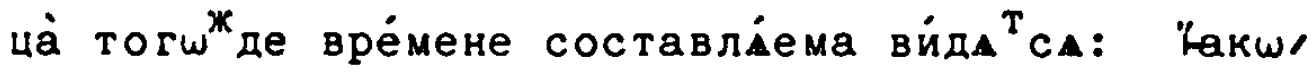

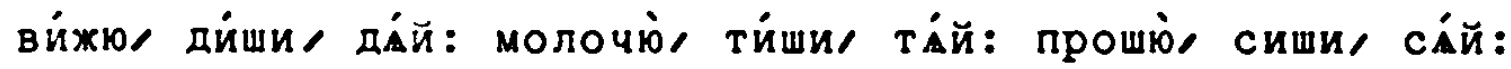
Һлй сих оука́зомъ, й про́чїихъ

'́кон

'ڤконче́ній гйъ прича́стієм" $\omega^{T}$ вто́рягш лица̇ составла́емымъ быва́ти.

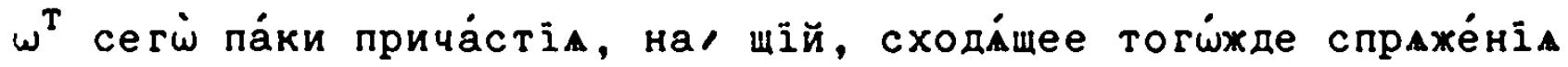
настои́mеe прича́стіе составла́ет "са ме́жду, А, й, й, щї, прие́млюue. "̈akw

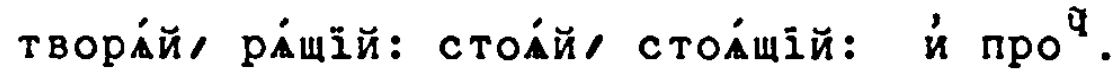

\section{Преход̈:на, шій: ей: й вый:}

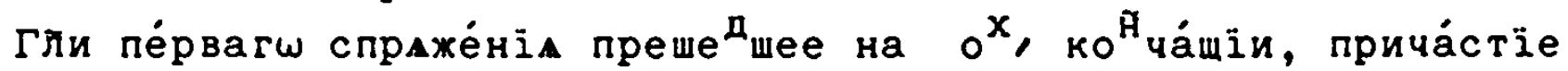
тоги́жде тво́рат" на, шій, йлй на/ ей, составла́юще ӧно $\omega^{\mathrm{T}}$ пе́рва-

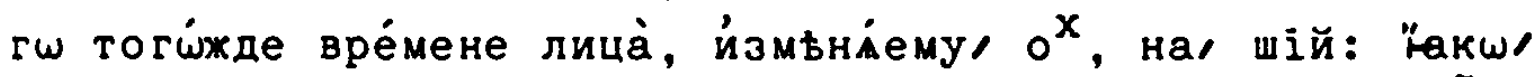

текох, кшій: несох, сшій: стрего́хъ, гшїй й про

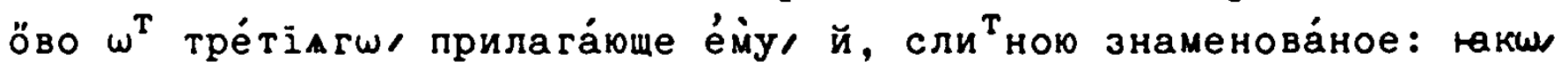
тече́, че́й: несе́, се́й: стреже́, же́й:

Конча́щіи же преше́дшее на, $\mathrm{a}^{\mathrm{x}}$, на, $u^{\mathrm{x}}$, йлй/ на йно ко́е ஸ́конче́нїе, прича́стїе ${ }^{X}$ тво́ратъ на, вый, тре́тїему то́ тоги́жде лицेу прилага́юще: "̈акш/

зва̀, зва́вый: жй, вый: писа̀, вый: ’́ про .

Bто́parw же спраже́нї гйи, на, $u^{x}$, преше́дшее конча́щїи, причáctīe тоги́жде тво́рА ${ }^{\top}$ на/ шїй, на/ ей, $\dot{n}$ на, вый: пе́рвое ӧно

$$
\omega^{\mathrm{T}} \text { nép }
$$

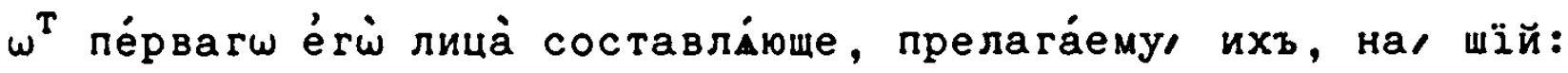

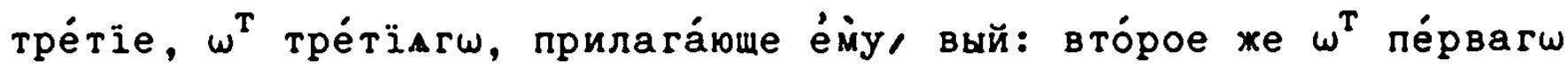

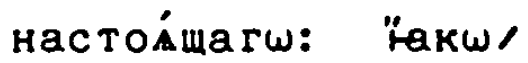

ну́жю, нуже́й: ну́дих, ну́дшій: нудй, вый: прошю, ше́й: просих, сшій: просй, вый: гощю, ще́й: гостйхъ, стшій: гостй, вый: $\operatorname{np}{ }^{q}$.

Конча́щіи же на, $\mathrm{a}^{\mathrm{x}}$, ко́ша, тре́тїему то́.лицेу преше́дшагw прилага́юше: ґакш/

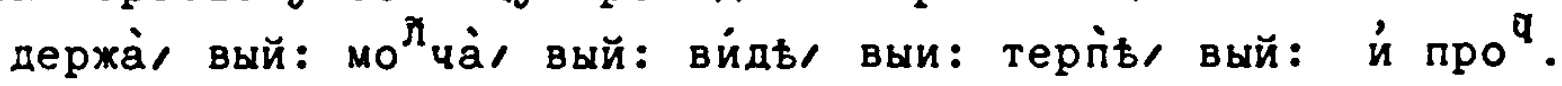

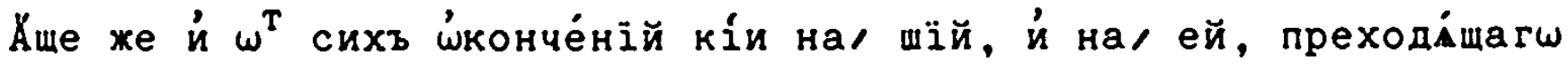
прича́стїа йму́ще '́бра́щоу ${ }^{T}$ са, по предло́женым" о́бо́ег

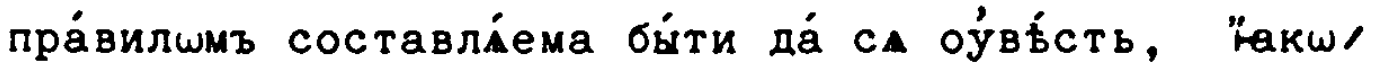




\section{$-174-$}

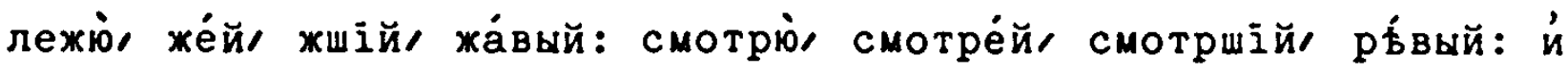
про́чаs.

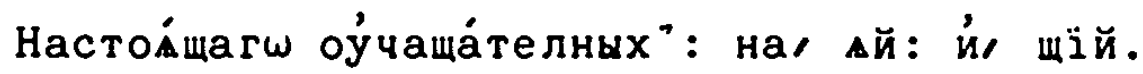

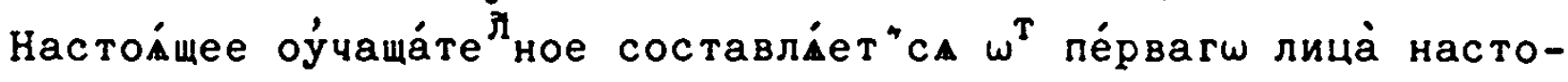
мщагш оуччаща́телна, накл: из"Ави́телна, измьна́юще

10, на

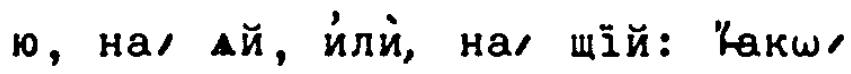

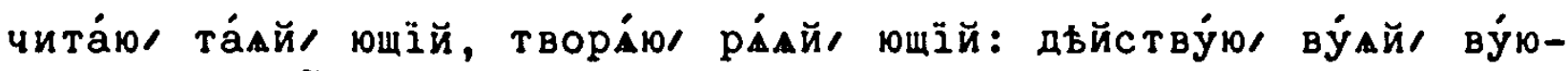
щїи:

Преше́ дша гw:

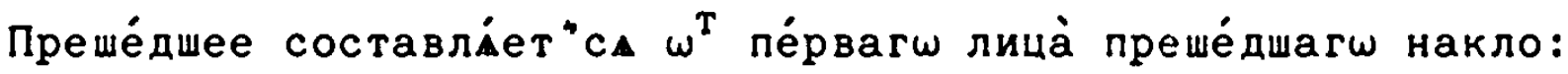

из"Авйтелна, прелага́юще, хъ, на, вый: "акш/

чита́хъ, чита́вый: творА ${ }^{X}$ раввый: дђйствова

Мимоше́ дшагw:

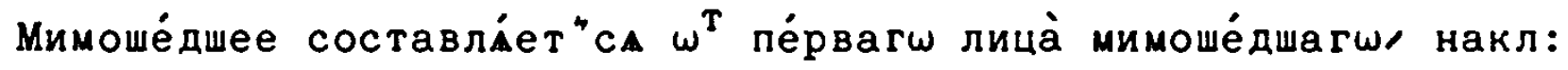
из "Авйтелна/ премъна́юще, хъ, на, вый: "акш'

иитаáхъ, а́вый: творАа́хъ, вый: дъйствоваáхъ, дђйствоваа́вый.

Непредьл́нагш:

Непредблнагш прича́стїа на, шїй, ей, и́, вый, по '́писа́нїю пра́-

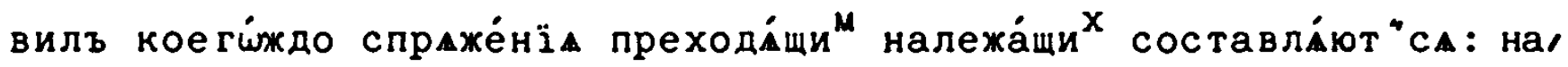
шїй, $\omega^{T}$ пе́рвагш лица̇ непредблнагш составлдемы ${ }^{M}:$ на, вый, $\omega^{T}$

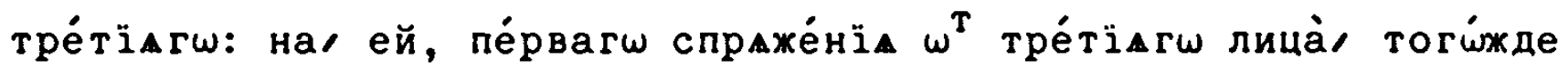

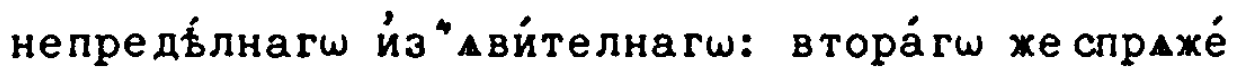

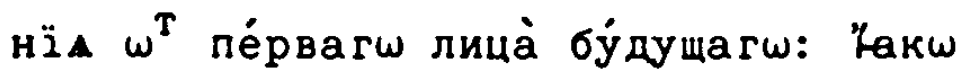

HIA

$[1746]$

понесох, поне́сшїй: понесе́ се́й: пострада̀, вый: и́ про

сотворих, ршій: сотворю, ре́й: сотворй, риввий: й про

оувьще́нїе :

Вбстно бу́ди е́диносло́жны пе́рвагш спраже́нїа на, ох", прехода́щее твора́щы го̆ы, прича́стіе тоги́жде вре́мене на, шїй, составлі́-

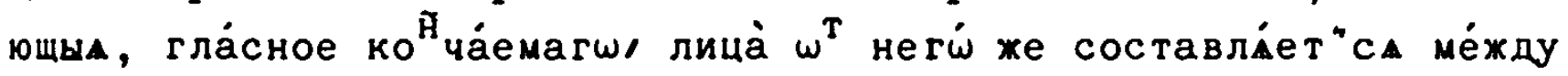
согла́сна прелага́ти, си́це,

чте́, че́тшій: дре́, де́ршій: тре́, те́ршїй: й про

Буд̆ущаг $\omega$.

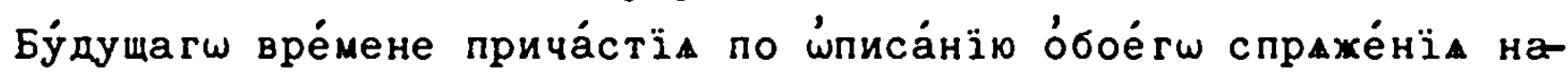

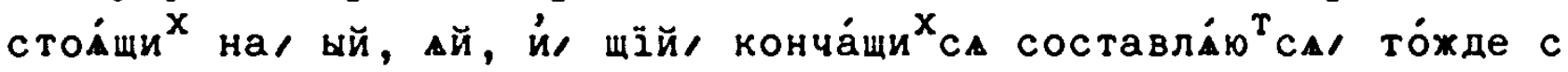
нимми, ра́звь нараще́нїа, су́ща: "̈акш/

прочти́й, прочту́щї̆ $/ \omega^{T}$ прочту: сотворй̆̆ $\omega^{T}$ сотворю: сотво

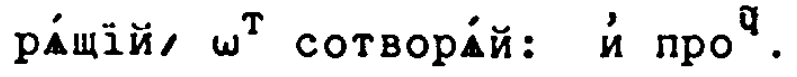


Составле́ніе Прича́стій гйа Страда́телнагш: Настои́щагш на, мый. о́бое́г̄ спрахе́нї настод́щее совер ше́нны шённы ${ }^{X}$ й о’чаща́телныхъ на, мый, составлі́е ${ }^{T}$ сА кое́ждо $\omega^{T}$ вто́рагш лица̇ сво́егш ви́да, вре́мене настои́щагш, наклоне́ніА йз"Ави́телна, залогга дъйствйтелнагш йзмьни́юще, ши, на, мый, Һакшы

чте́ши, чте́мый: чита́еши, чита́емый: тво́риши, твори́мый: твора́еши, твори́емый.

Конча́mал же са вре́мене сегі́ прича́стї на, омый, $\omega^{T}$ пе́рвагш ли-

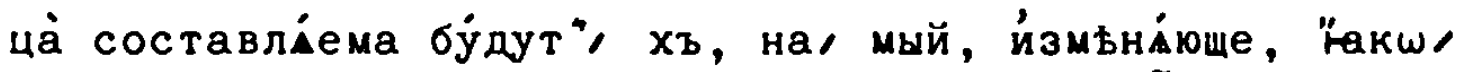

что́хъ, что́мий: ведо́хъ, ведо́мый: иं про

Преходи́щагш на, ный: и́, тый.

Пе́рвагш спрахе́ніл преходи́щее на, ный й тый составла́ет"са $\omega^{T}$ тре́тінгш лица̀ преходищщагш, накл: Й "Авйтелна, восприе́млюще " не́му, ный, иллй тый: "акш'

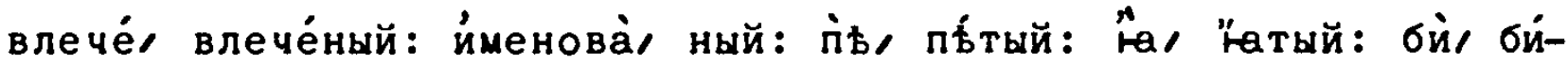
тьй: й про .

біёный й семуу подоббнаА, по ни́жей б́й́саному вто́рагш спрахе́нїА пра́вилу составли́ют" сА.

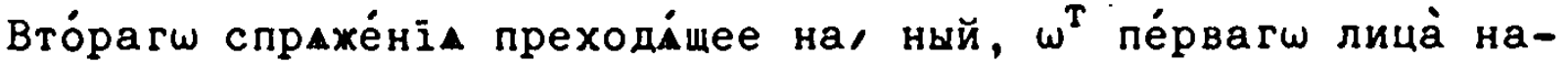
столщаг

$$
\text { Из }{ }^{4} \text { А Ви́ }
$$

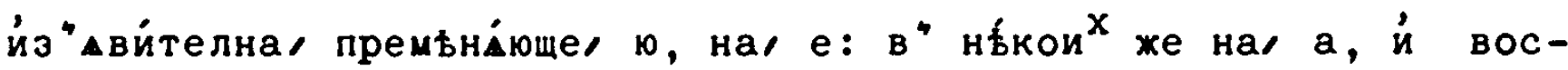
прие́млюще, ный: "̈акш'

творю́, тво́реный: расчю́, расче́ный: прошю́ про́шеный. Вйдьный, и́ семуу подо́бнаа: по вышей '́пи́саному вто́рагш спрахе́ніА пра́вилу составлі́⿱一土т" са.

\section{Преше́ дшагш, ’ُ Мимоше́дшагш:}

Преше́дшее й Мимоше́дшее $\omega^{\mathrm{T}}$ пе́рвы лйцъ кое́хдо свое́ гш вре́мене наклоне́н̈а из"Ави́телна составли́ют"сА, хъ, измђни́юще на, ный: "艹akw/

чита́хъ, чи́таный: читаáхъ, читаáный: творА́хъ, тво́рАный: творАа́хъ, творАа́ный.

$$
\text { Непредълинагш, иं Будущагш. }
$$

Непредблнагш составле́ніе быва́етъ по и́писа́нїю составле́нї прича́стїй преходи́щагш: "акш/

прочте/. прочте́ный: сотворіо, створе́ный.

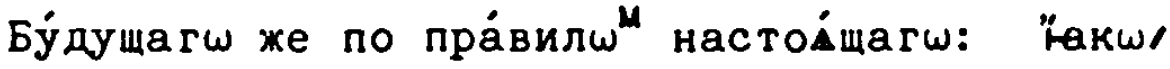

прочто́хъ/ прочто́мый: тво́риши, сотвори́мый. 
Составле́ніе Дђеприна́cтій о́бóerw Зало́ra.

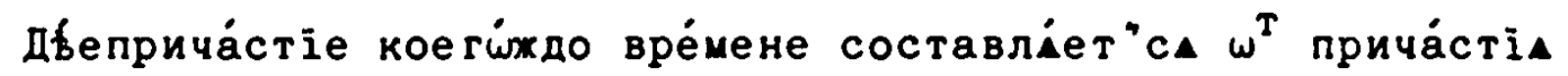

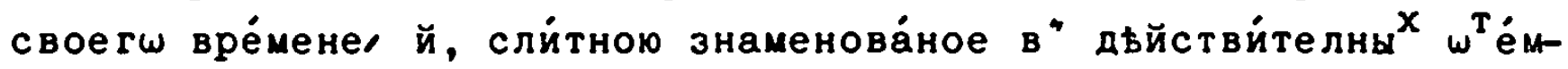

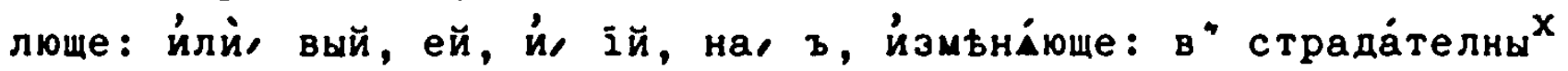
же, ый, йлй, ій, на, з, йзмьні́юще: Қакшл

Двйствйтелнныхъ.

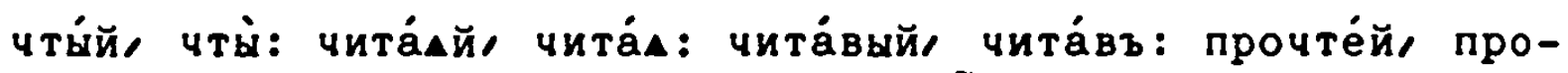

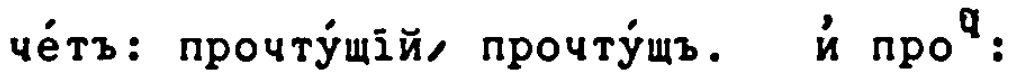

Страда́телныхъ:

что́мый, что́мъ: чте́ный чйтан": читаáный, читаáнъ: прочте́ный, прочте́нъ: прочто́мый, прочто́мъ.

Составле́нї Причастодыті亡:

Причастодfтїе составліет"сA $\omega^{T}$ Heопредьле́ннагш настойщаг

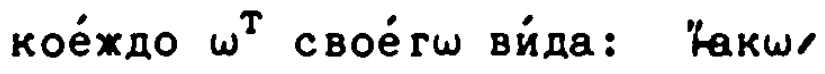

чита́ти, чита́телно: твори́ти, твори́телно.

'ं ПРИЧА்СТIИ:

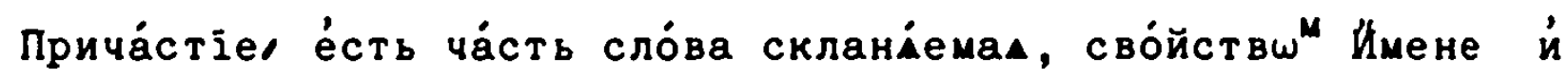
Глагола̀ причаща́ющалса. Нарица́ет"сА прича́стїe $\omega^{T}$ причаще́нї:

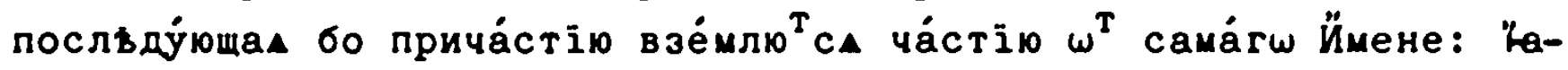

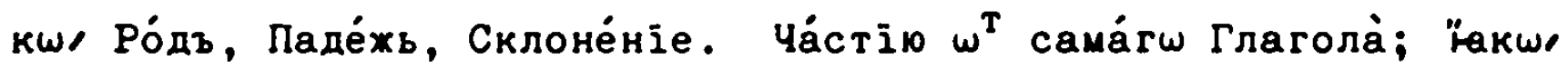

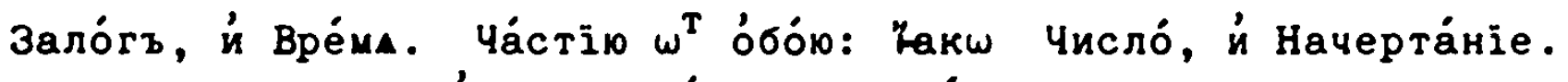
'́ посльдующихз Прича́сті̄ю.

Посльду́ютъ Прича́сті̄ се́дмь:

$\left\{\begin{array}{l}\text { Ро́дъ, } \\ \text { Начерта́нїе, } \\ \text { Число, } \\ \text { Паде́хь, } \\ \text { Вре́ма, } \\ \text { Зало́гъ, й } \\ \text { Склоне́ніе. }\end{array}\right.$

ஸ́ Pónt Прича́сті́.

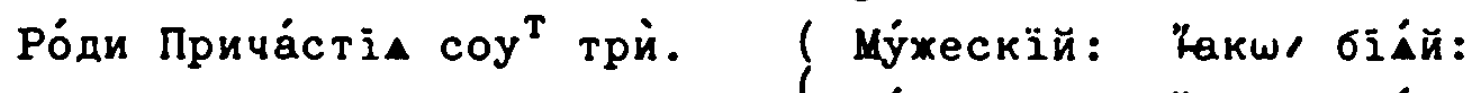

Женнкій: "̈акш/ бїндал:

( Средній: "вкшл бїюеее.

’́ Начерта́нїи Прича́сті̄:

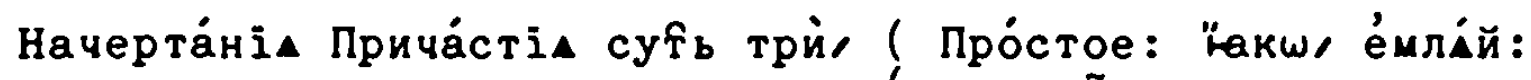

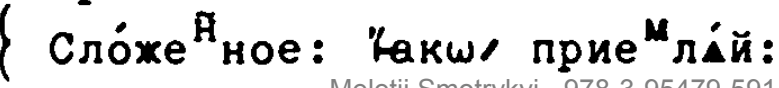


¿े чисть:

( Пресло́хеное: "акшљ восприемлій.

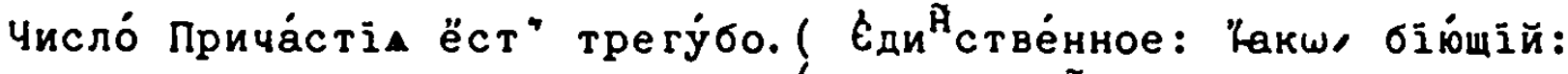

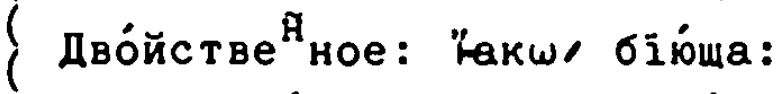

( Мнохестве́нное: Какш/ біющіи:

$\dot{\omega}$ Паде́хи:

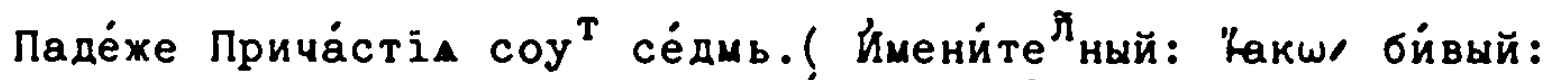

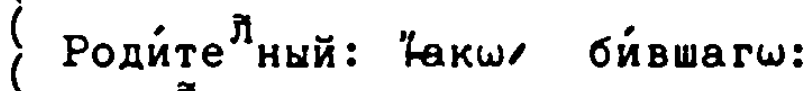

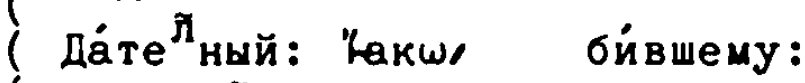

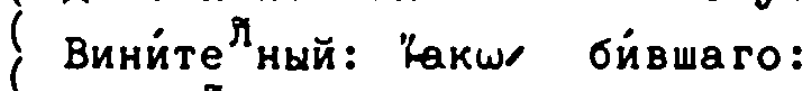

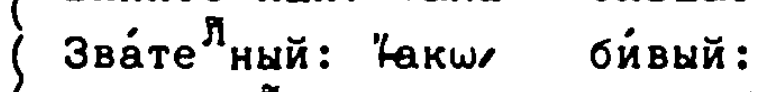

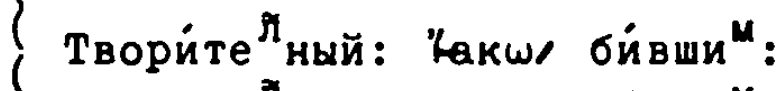

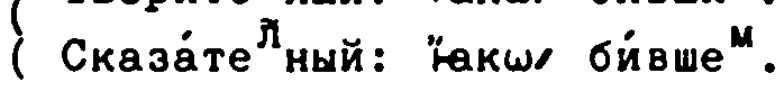

ஸे Bременй:

Времена̀ Прича́стіА ( Настойщее ГЛъ Сове $\mathrm{p}_{\text {ше́нны }}$ й Оу́чаща́телныхъ:

сутิ ше́сть. ( Преходи́шее:

Мимоше́ дшеe:

(Бу́дущеe:

( Непредблное:

'́ '́конче́ніих" Време

$\dot{\omega} \dot{\omega}_{K} \mathrm{R}^{\tilde{H}}$

[1776]

Настои́щее соверше́нныхъ кончйт"сА на, АЙ, Ій, Ый, й, мий:

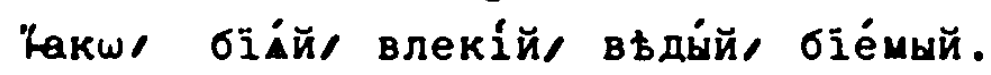

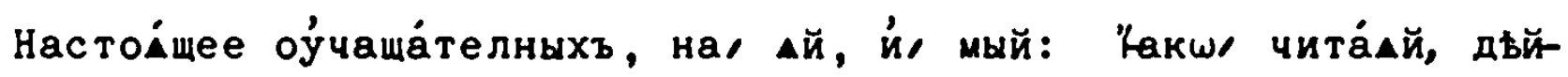
ству́й, бїАй, бїіемый.

Преходіщее, на, ей, ій, вый, й ный: Какш, влече́й, вле́кшій, бйвый, біёный:

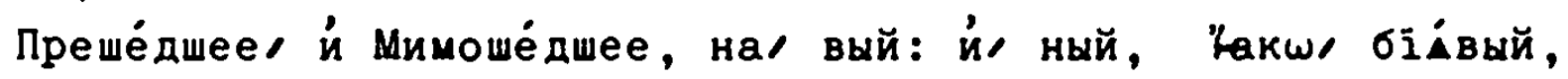

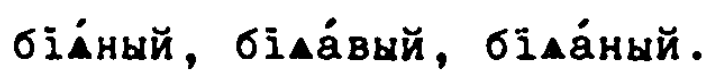

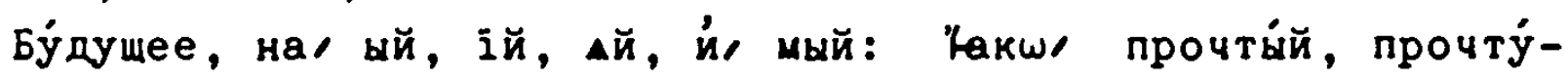
щій, побіАй, побію́щій, побіе́мый.

Непредблное, на, ей, ій, вый, й, ньй: "акш/ сотворе́й, повлекій, побйвый, побіеный.

‘் Зало́зъ:

Залози Прича́стіА суริь паิть.

Дъйствйтелный:

Страда́телный:

Сре́дній:

$\omega$ ложителный:

ठ๊бщій: 


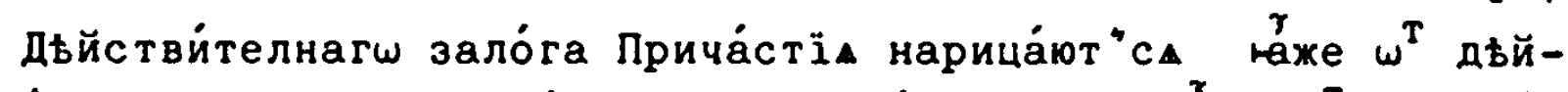

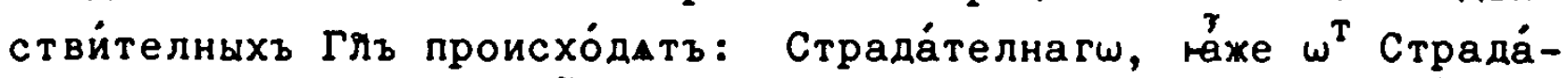

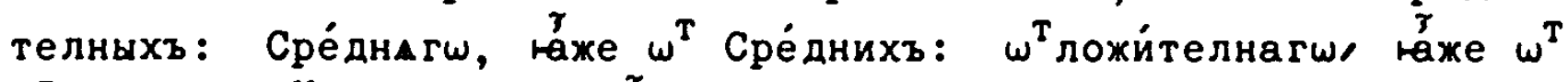
$\omega^{T}$ ложителны

'́ Прича́стї ${ }^{X}$ происходи́щихъ $\omega^{T}$ свойхъ Глагйлъ,

Оуंвъще́ніе.

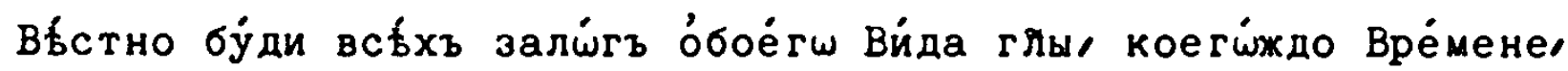

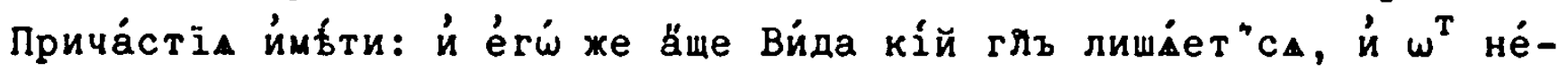
r $\omega$ происходи́щихъ Време́нъ лиша́тисА до́лженъ ёсть.

$\omega^{T}$ Глагола் Дьйстви́телнагш происхо́датъ Прича́стїа всб́хъ Bpe-

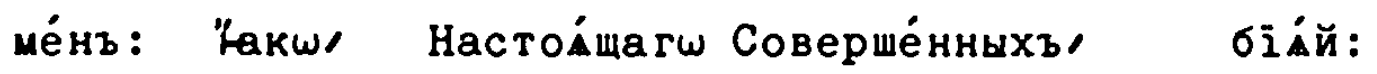

Преходи́ща гw'

бйвый:

Настод́щагш оуччаща́телныхъ, бїінй:

กреше́ дшагw,

бївнй:

миноше́ дшагw,

бїа́вый :

Буддущагш'

Hепредблнагш'

побіА́й, йлі், побію́щій. поби́вый.

$\omega^{T}$ Гйа Страда́телнагш: "акш'

Настои́щ: Сове $\mathrm{p}^{p_{w}}$

Преходи́marw:

$\Phi \mathbf{x}$

бїйсса, йлй, бїемшй:

бйвыйсА, и́лй, бїёний.

Hac то

Hact : оjчащ:

біӒайсА, илй́ бінемый.

Преше́ дша гш,

мимоше́ дш:

бї́выйсА, йлй, бїіный:

Бу́дущагш/

Непредбл:

біАа́выйсА, йли́ бїа́ный:

побію́щійса, йлй побіе́мнй: побйвыйсА, йлй, побіёный.

$\omega^{T}$ Гr̆а Cре́днагш: 'Накш'

Настои́щаг Соверше́нны

Преходищагш'

Настои́щ: Оу́чащ:

седій :

седб́вый :

Преше́ дшаг $\omega$,

сђда́ай.

Mимоше́ дwarw/

сђда́вый.

Бу́дущаг

съдаа́вий:

Непредблнагш'

сїдущій:

съде́й, йлй, съди́й.

$\omega^{T}$ Гла $\omega^{T}$ лохителнагш: "̈акш,

Настод́щагш Соверше́нны ${ }^{X}$ протива́йсА, йлй протива́щійса. Прехоㅁ:

Настов́щ: О’́чащ: проти́вивыйсА, йлй, противле́йсА. противла́АйсА: 
Пре ше́ дша $\Gamma \omega$

Миноше́ дшаг

Бу́дущагш'

Непредб́лнагw, противлі́выйса.

противлАа́выйсА :

воспротивӒщійСА:

воспротивле́йса. $\omega^{T}$ Гra

[ I79]

$\omega^{T}$ Гла ӧбщагш:

Зало́га Дьйствйте

Наст: Сове $\tilde{p}_{\text {ш: }}$ гнушійса, и́лй, гнуша́щійсА :

Преходи́щагш: гнушйвыйсА, йлй, гнуше́йсА:

Наст: Оуччащ: гнуша́АйсА.

Преше́ дшагш: гнуша́выйса :

мимоше́дш: гнушаа́выйса :

Будууща гш: Во ${ }^{3}$ гнуша́щійса:

Непред: возгнуши́выйсА, йлйо возгнуше́йсА :
Зало́га Стра́дате : $^{\mathfrak{I}}$ "акw, гнушиммый . гнушеंный. гнуша́емый. гнуша́ный. гнушав́ный. возгнуши́мый. возгнуше́ный.

‘́ Склоне́нїи Прича́стіл:

Склоне́ніе Прича́сті̄ ёсть е́дино: е́rí xe

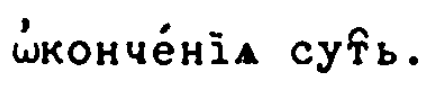

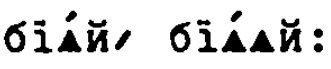

чте́й, прочте́й. то Ккій, то́лкшій. чти́й, въди́й.

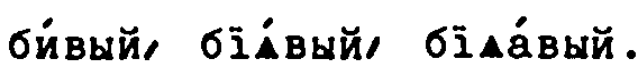
бїémый, бї́емый, побіе́мый бїéный, бї́ный, біАа́ный, побїе́ный.

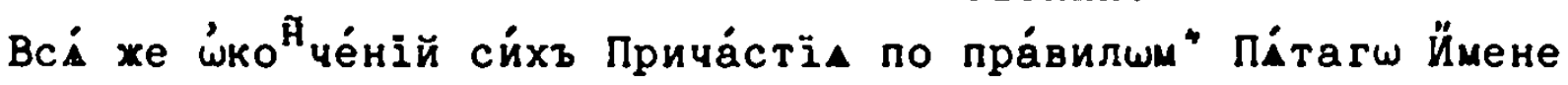
Склоне́ніА склана́⿴囗大

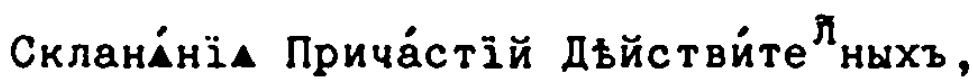
на, Ай, Ій̆, й ый, схода́щихъ: $\Phi$ म Mapá

Пара́дигма налАй, й́ ій.

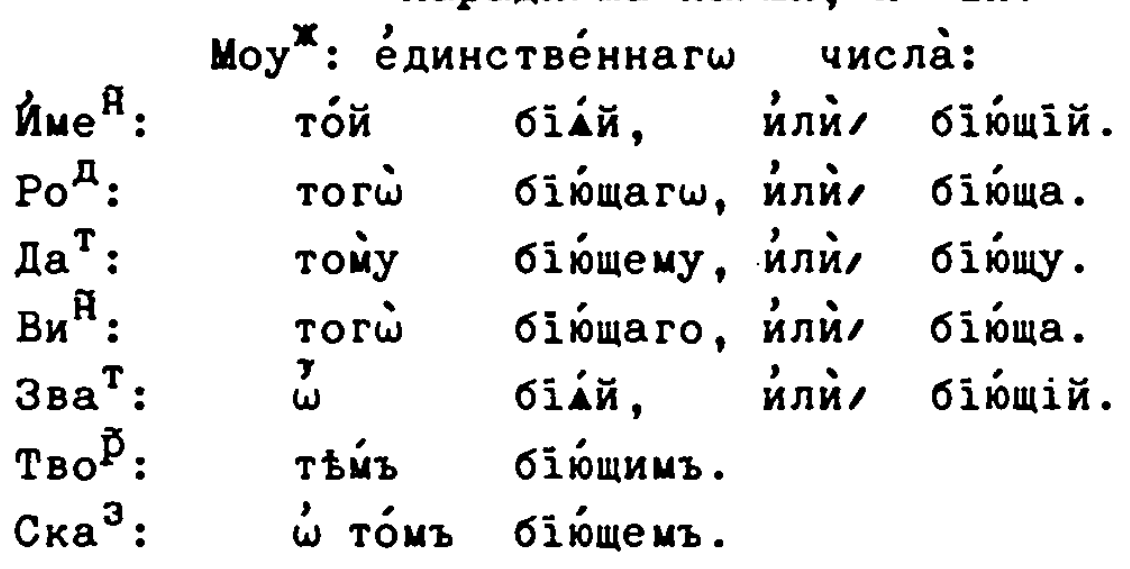

Дво́йственнагш числа̀.

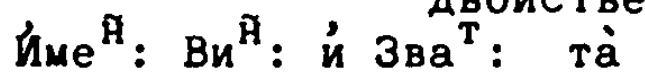




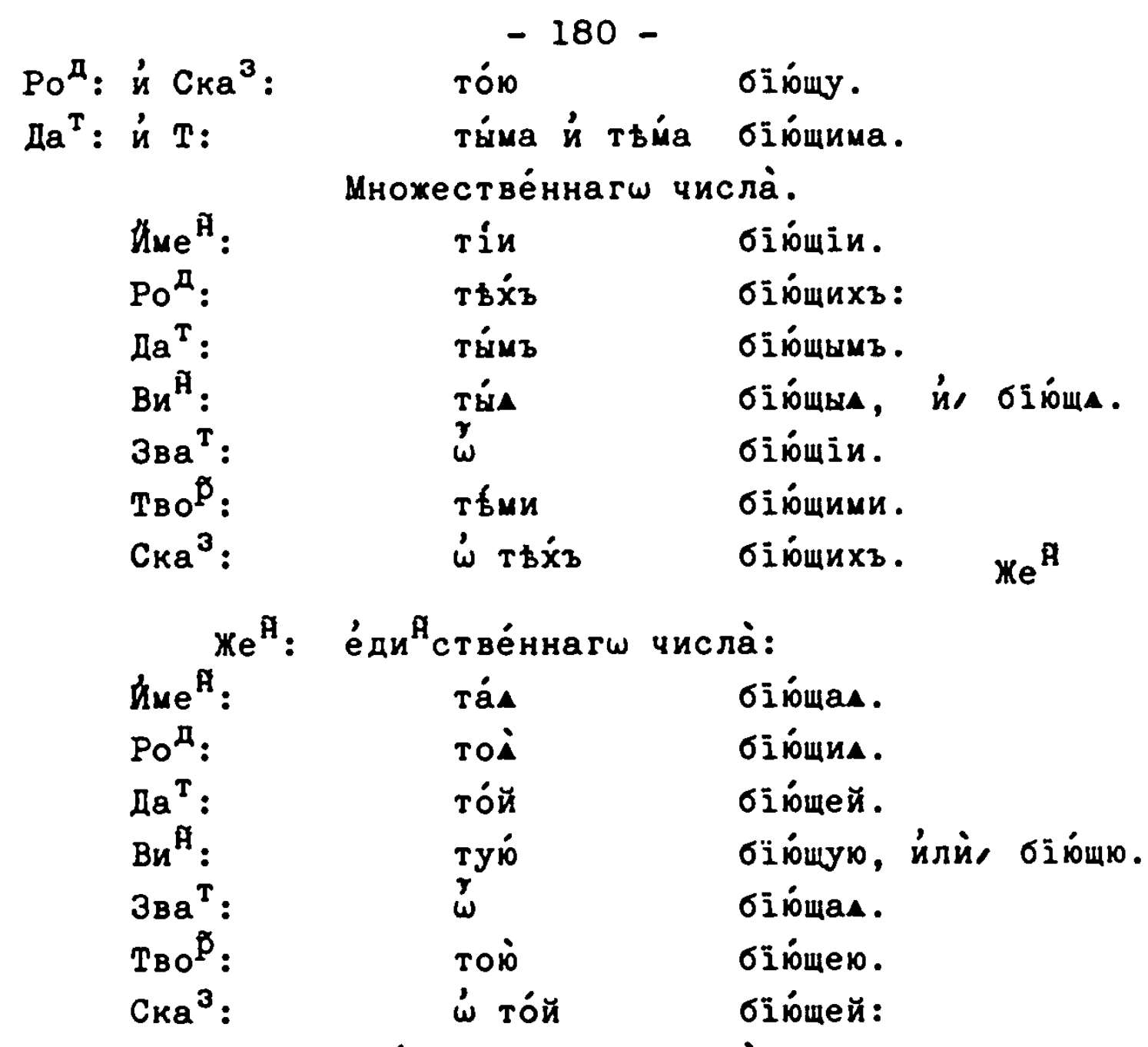

Двӧйственнагш числа̀.

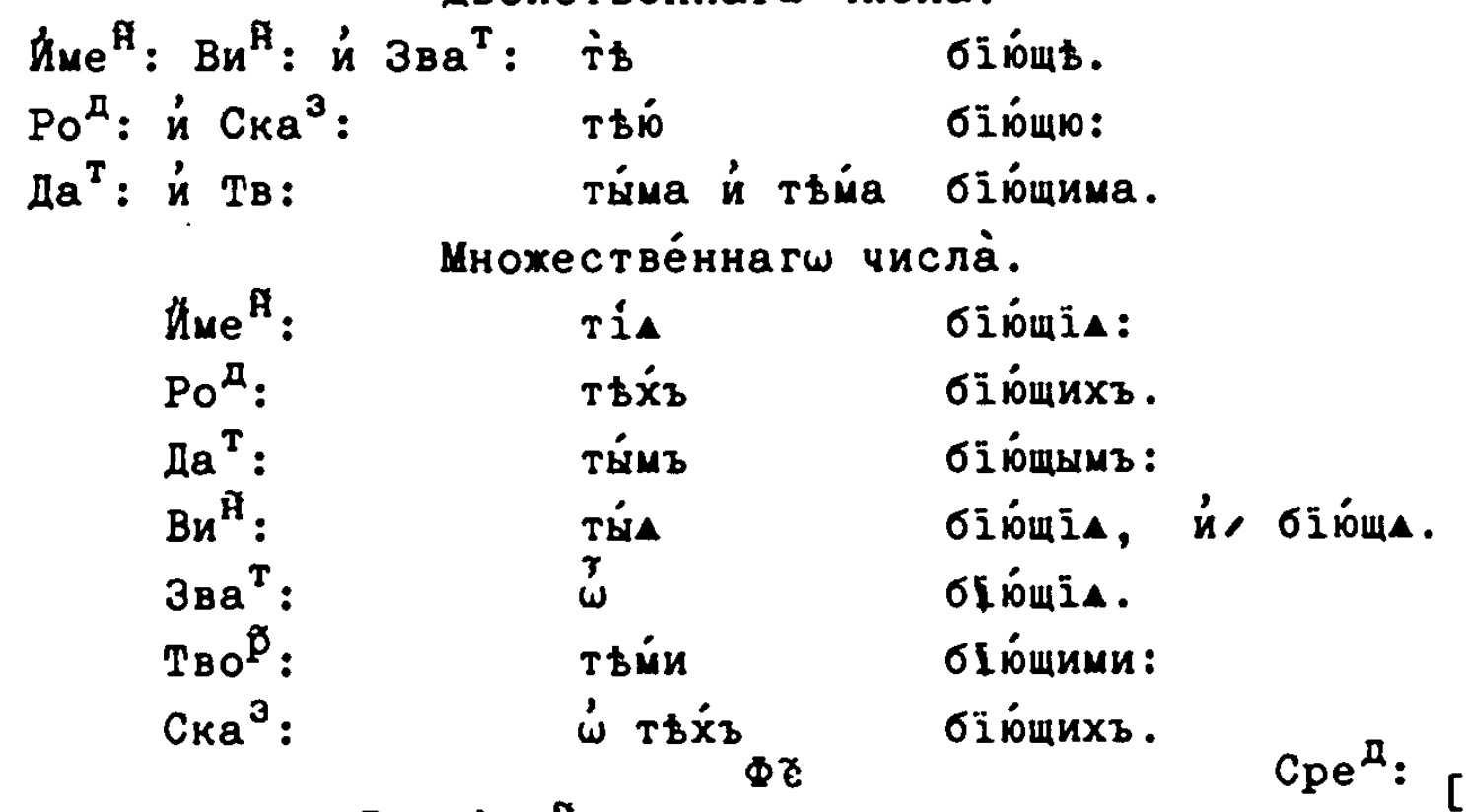

Cpe ${ }^{\text {म. }}$ е́ди ${ }^{\text {A }}$ стве́ннагш числа̀.

Úme ${ }^{\text {मี }}$

Po

$\not a^{T}$ :

$\mathrm{Bu}^{\mathrm{A}}$ :

उв的 :

TBO ${ }^{\mathrm{p}}$ :

$\mathrm{CKa}^{3}$ : тóe

Tori்

roiny

tóe

w

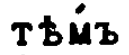

ஸ́ TÓmb бію́щеe :

бїющагш, йлй бїюша.

бїющему, йли, бїющу .

бiюmee.

бірінеe.

біюощимъ.

бі юене 
Дво́йственнагw иисла:

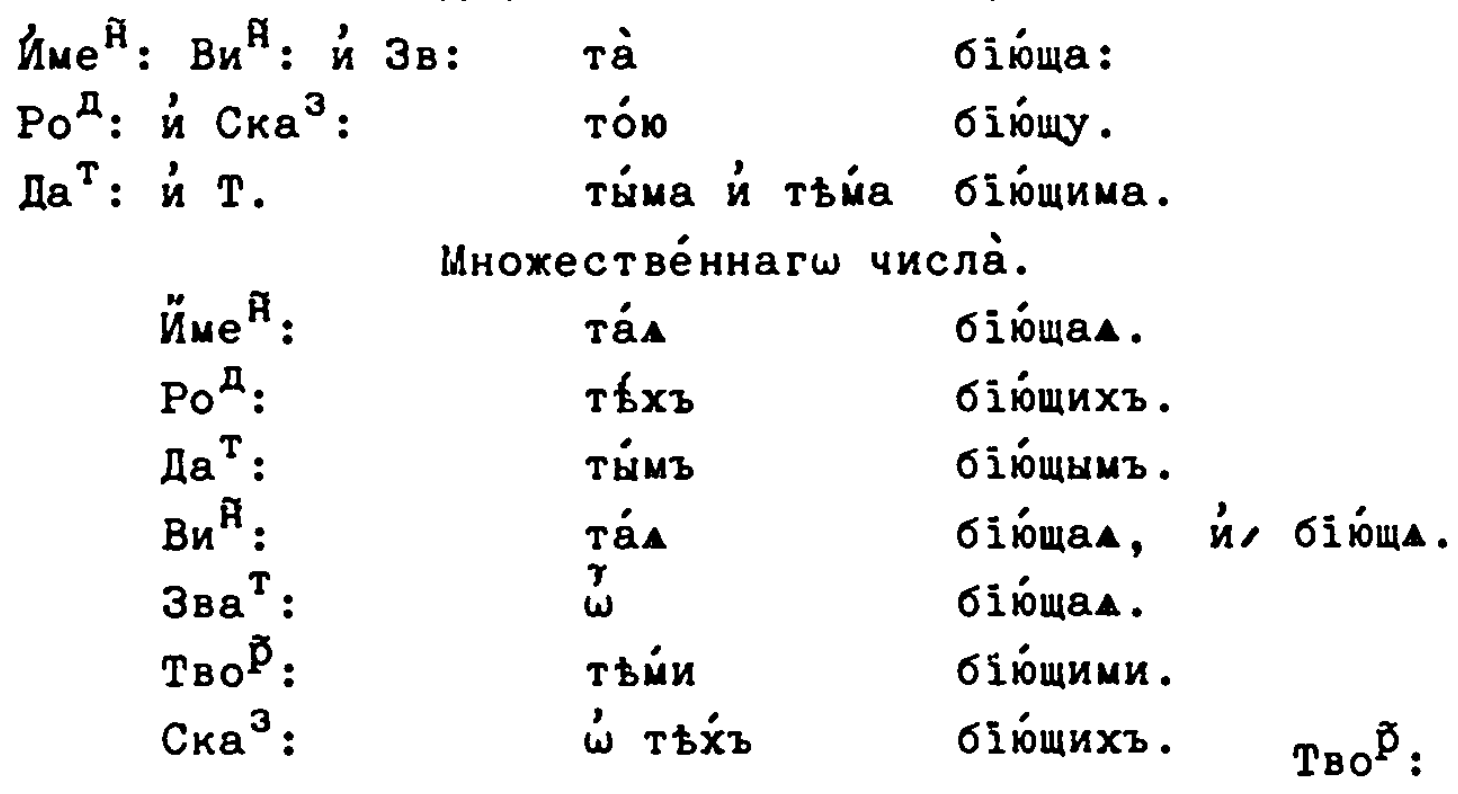

Твори́телный: 'єдй : на, й: да́телный Мно“: на, ы.

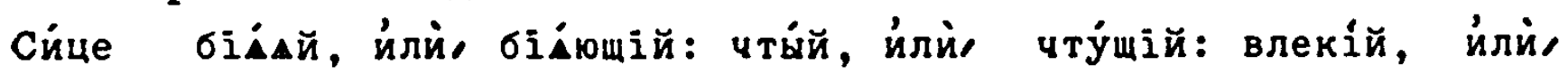
влеку́щіи: й, побію́щй.

оу́в вще́нie :

В ленъ Мно“: роди́телному Мно“: твори́ти подобенъ.

\section{Склані́ніА}

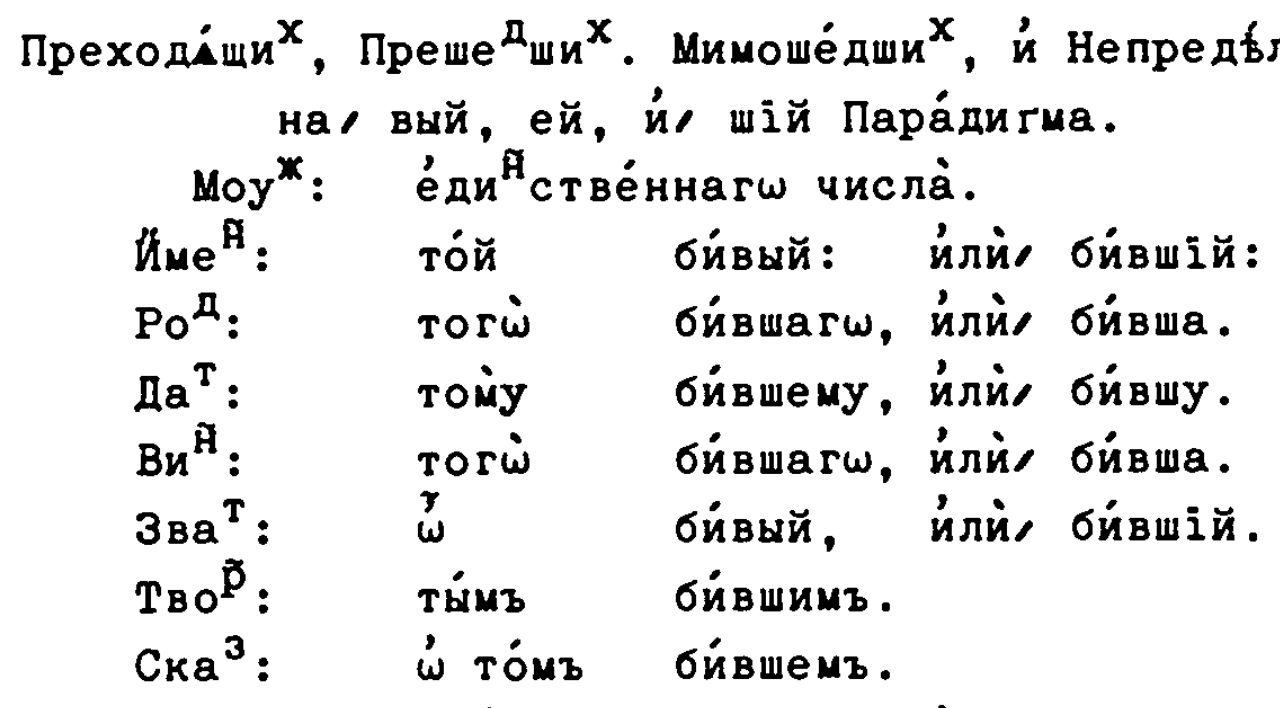

Дво́йственнагш числа்:

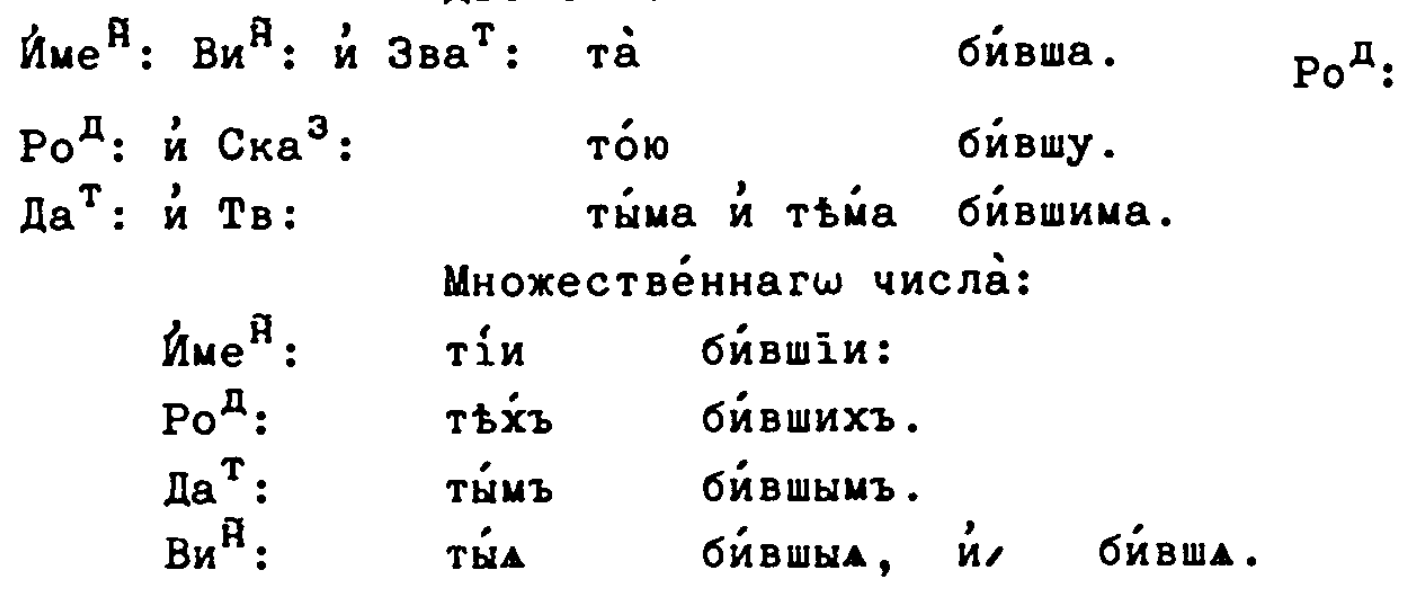




$$
-182-
$$

Зва ${ }^{T}: \quad \stackrel{5}{\omega}$ бившїи.

Tво : тьии бйвшими.

Ска ${ }^{3}:$ í тьर́ бйвшихъ.

Же ${ }^{\text {म }}$ е́ди ${ }^{\text {म }}$ стве́ннагш числа̀:

Ŭme : та́a би́вшан.

Poम: тоі бйвшиА.

Да ${ }^{\mathrm{T}}:$ то́й бйвшей.

Ви ${ }^{\text {म }}$ тую бйвшую, йлй, бйвшю.

उва ${ }^{\mathrm{T}}: \stackrel{r}{\omega}$ бйвшал.

Tво : тою биंвшею.

Ска ${ }^{3}: \quad \dot{\omega}$ то́й бйвшей.

Дво́йственнагш числа̀:

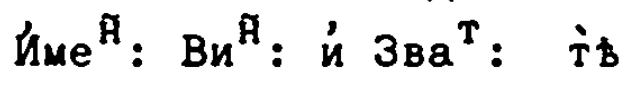

Poम: и $\mathrm{CKa}^{3}$ :

TъB́

бйвшь.

Pon:

бйвшю.

$\mathrm{La}^{\mathrm{T}}:$ иं $\mathrm{T}_{\mathrm{B}}$ :

ти́ma, й твйa бйвшима.

Мнохестве́ннагш числа̀:

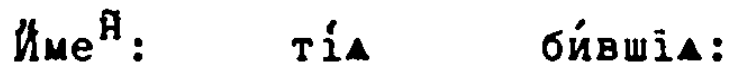

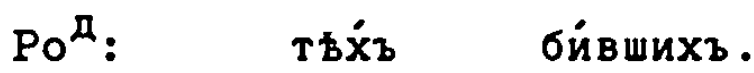

Да ${ }^{\mathrm{T}}:$ ти́мъ бйвшымъ.

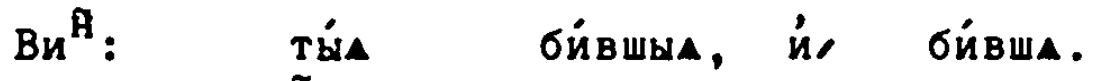

Зва ${ }^{T}: \quad \stackrel{\jmath}{\omega} \quad$ бйвшїА.

Tвор: твйи бйвшими:

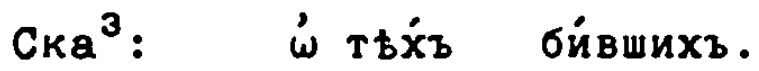

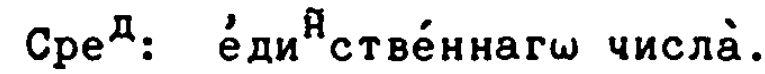

Ulme ${ }^{\text {म }}$ tóe бйвwee.

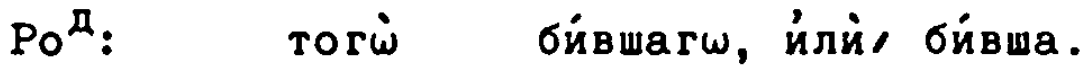

Да ${ }^{\mathrm{T}}$ : томуу би́вшему, и́лй, би́вшу.

Ви ${ }^{\text {म }}$ : тóe би́вшеe.

उва ${ }^{\mathrm{T}}: \stackrel{\boldsymbol{r}}{\omega}$ бйвше.

Твор : тймъ бйвшимъ.

Ска ${ }^{3}:$ 'ं то ${ }^{M}$ бйвшемъ.

Дво́йственнаг

йме ${ }^{\text {म }}:$ Ви $^{\text {म }}:$ и $3 в a^{T}:$ та̀ би́вша. Ро

Poम : и $\mathrm{CKa}^{3}:$ тóю би́вшу.

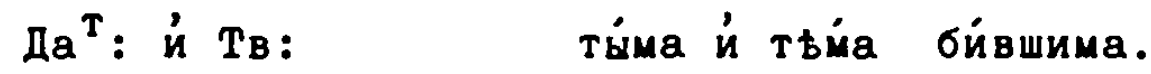

Мнохестве́ннагш числа̀.

Йue : тáa би́вшал.

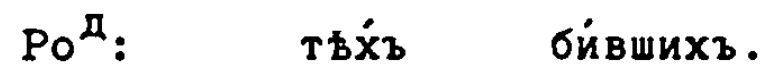




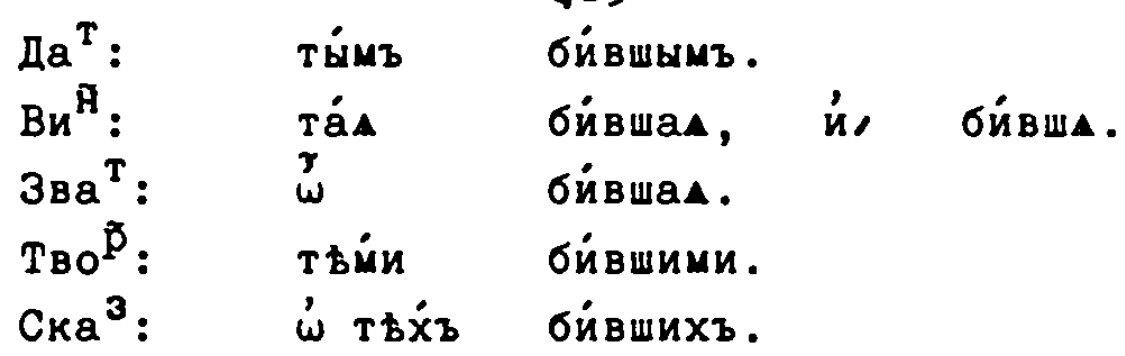

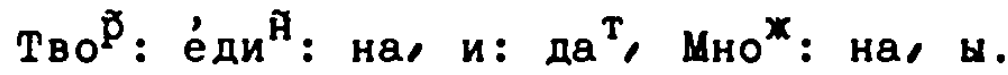

Сице, чте́й, иंлй, че́тші̆й: чита́вый, читав́вый: прочте́й, йлй проче́ тшїй.

Склана́нїа

прича́стї̆ на, мый, й, ный, Конча́щи ${ }^{\mathrm{X}}$ сА, Пара́дигма.

моу* : е́ди $^{\tilde{A}}$ стве́ннагш числа̀.

Ŭе ${ }^{\text {म }}$ : то́й біе́ный.

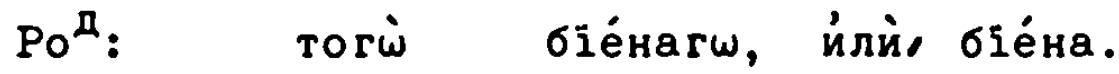

Да ${ }^{\mathrm{T}}$ : тому біе́ному, илй біе́ну.

Ви ${ }^{\text {म }}$ того біе́наго, илй біе́на.

उва ${ }^{\mathrm{T}}: \stackrel{r}{\omega} \quad$ біёний. Тво

Tво : твй біе́нвмъ.

Ска ${ }^{3}$ : ’’ то́мъ біе́номъ.

Дво́йственнагш числа̀:

Йме ${ }^{\tilde{H}}: \mathrm{Bu}^{\tilde{\mathbf{H}}}: \dot{и} 3{ }_{\mathrm{Bq}}^{\mathrm{T}}:$ та̀

Poम: 'ं $\mathrm{CKa}^{3}$ :

Tón

біёна.

Да ${ }^{\mathrm{T}}:$ и $\mathrm{T}_{\mathrm{B}}$ :

ти́ma, и́ тьи́a бїе́ныма.

Mнохестве́ннагш числа̀:

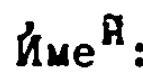

Tin

біёніи.

Pon:

$T \dot{x} \dot{x}$

бїе́нแхъ.

Дa ${ }^{\mathrm{T}}$ :

Tйmb

біе́нымъ.

$\mathrm{Bu}{ }^{\text {म }}$ :

उва ${ }^{\mathrm{T}}$ :

TйA

бїенын,

is

$\stackrel{3}{\omega}$

біёніи.

TBO ${ }^{\mathrm{p}}$ :

\section{w}

твй

біёными.

$\mathrm{CKa}^{3}$ :

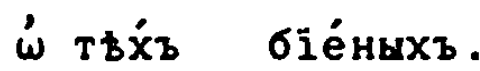

$\nVdash e^{\tilde{H}}$ :

е́ди стве́ннаг чи чила:

Йme ${ }^{\text {मे }}$

Táa

бїенах.

Pon:

тoi

бїе́ныА.

Да ${ }^{\mathrm{T}}$ :

то́й

біёной.

$\mathrm{Bu}{ }^{\text {म }}$ :

Зва ${ }^{\mathrm{T}}$ :

Tyí

$\mathbf{w}$

бїе́ную,

бїеннам.

$\mathrm{T}_{\mathrm{BO}} \mathrm{p}^{\tilde{a}}$ :

тої

біёною.

$\mathrm{CKa}^{3}$ :

'́ то́й

біёной.

Дво́йственнагш числа̀:

йлѝ, біёну. 


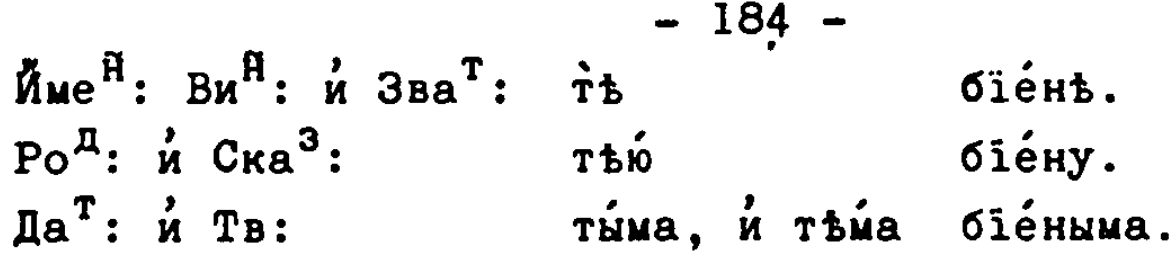

Мнохестве́ннагш числа̀:

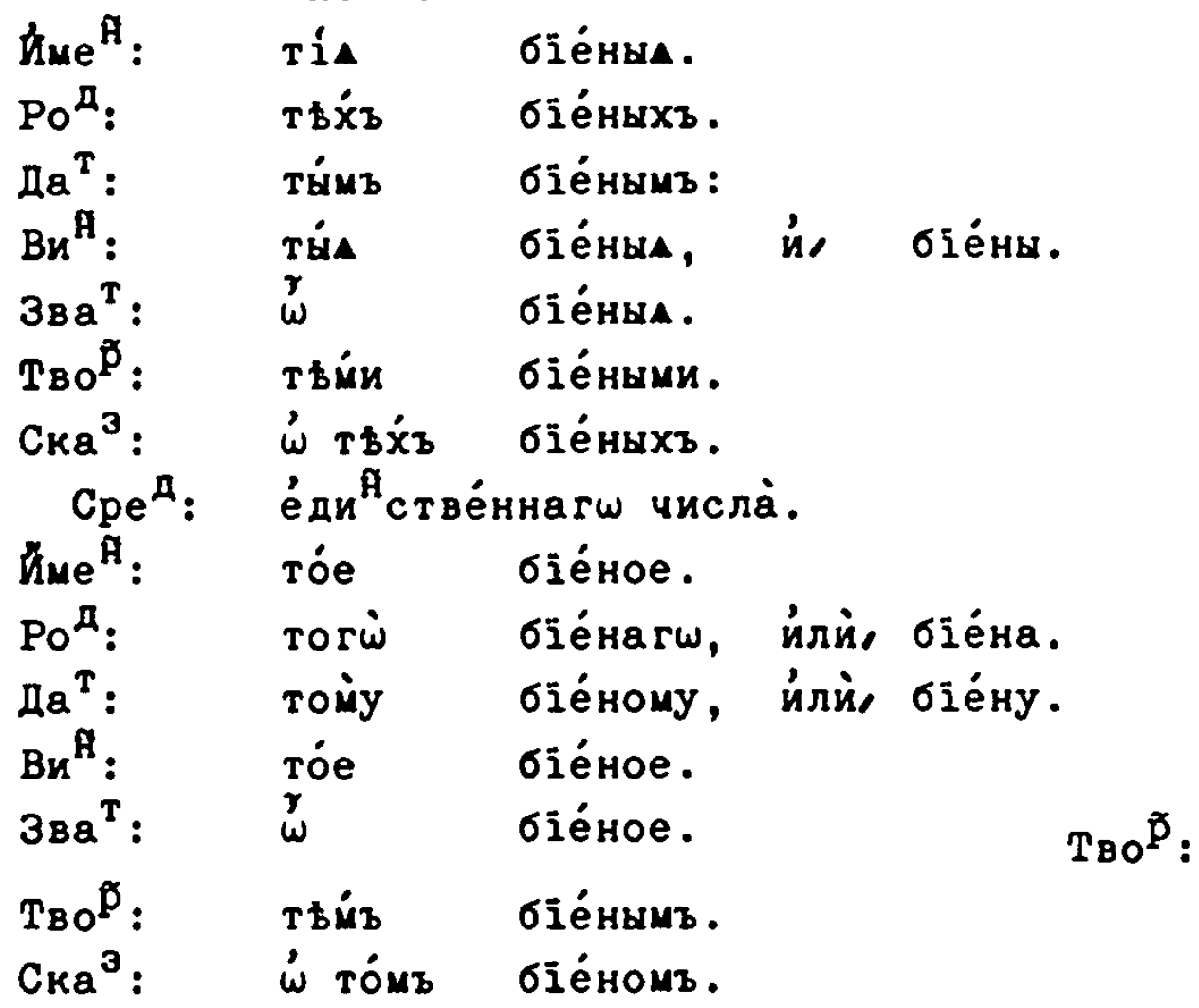

Дво́йственнагш числа்.

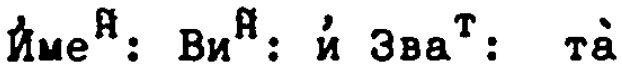
біе́на.
Poम:
Tón
біёну.
Да ${ }^{\mathrm{T}}:$ й $\mathrm{T}_{\mathrm{B}}$ :
ти́ма и́ тьі́а біе́ныма.

Мнохестве́ннагш числа̀.

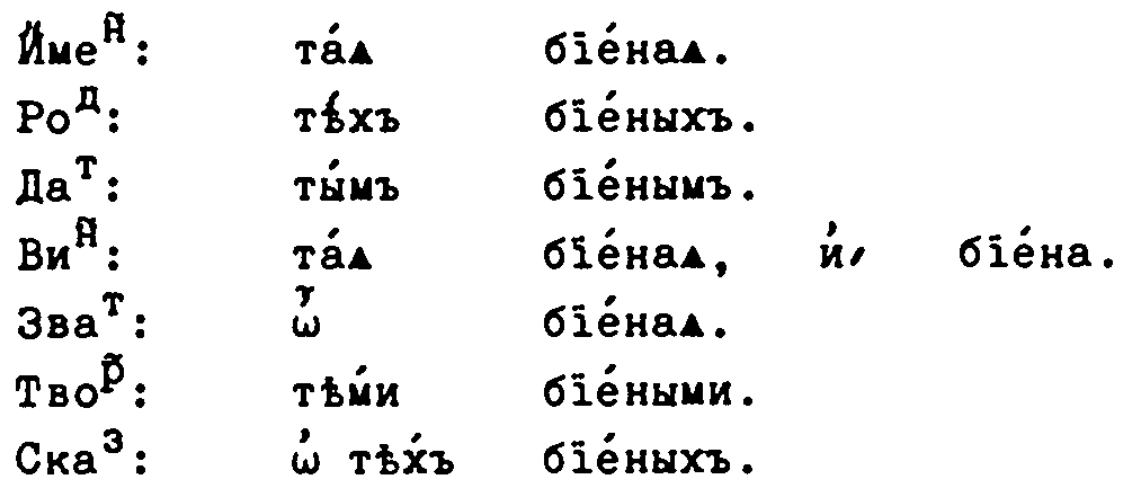

Сйее, біА́ный, побіе́ный, біе́мый, побіе́мый.

Оу́въще́ніе а:

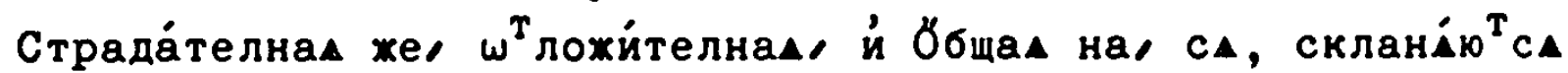

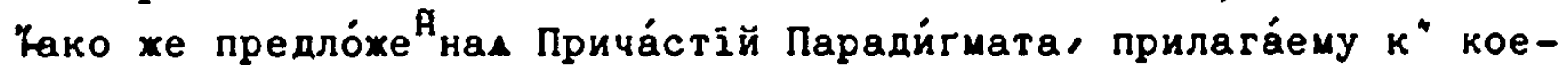
му́хдо Паде́хю Мьстоиме́нію, сА. Х

оу́въще́ніе в:

оу́вв

[1846]

Вйстно бу́ди, рече́ніА Прича́стієщъ подо́бнаА, Какш, пб́тый, 
препь́тый: хва́лный, прехва́лный: Һатый, проклі́тый, пресла́вный, сла́вный, че́стный, вб́стный, чюдотво́рный: й сим подо́бнах, Ймена би́ти Прилага́телнам, не Прича́стї.

\section{í НАРЬЧIИ:}

Нарбчіe, ёсть ча́сть сло́ва нескланх́еман, Ймени йлй Глу ва́щ-

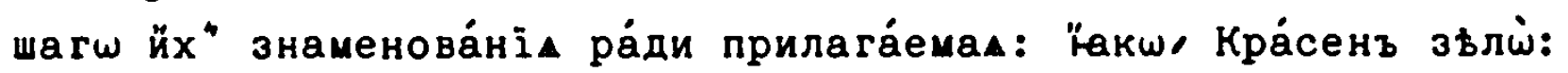
Прійде ско́pw.

$\dot{\omega}$ Посльдую́щи ${ }^{x}$ Hapfuію.

Посльду́ю ${ }^{T}$ Нарбчїю четь́ри.

$$
\left\{\begin{array}{l}
\text { Ви́дъ, } \\
\text { Начерта́ніе, } \\
\text { Ојравне́ніе, й, } \\
\text { Знаменова́нїе. } \\
\dot{\omega} \text { Ви́дъ: }
\end{array}\right.
$$

Вйды Нарбчї $\operatorname{coy}^{\mathrm{T}}$ два̀: ( Первоо́бразный: Какш' дне́сь, вчера̀:

$$
\text { й про?. }
$$

(Произво́дный: Какш' мујдре, до́брь: и́

$$
\text { про }
$$

¿े Начерта́ніи:

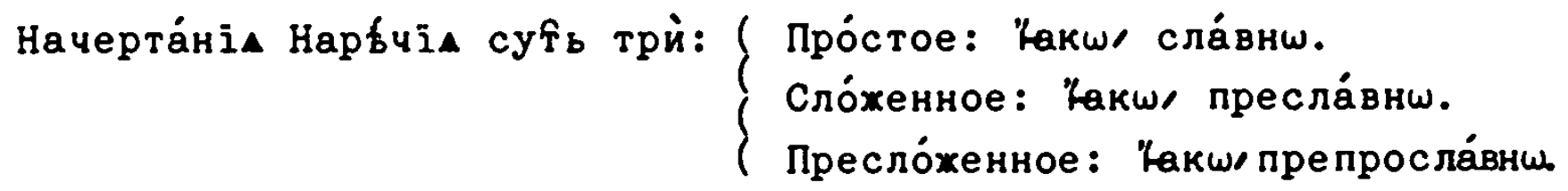
¿́ оуравне́нгіи:

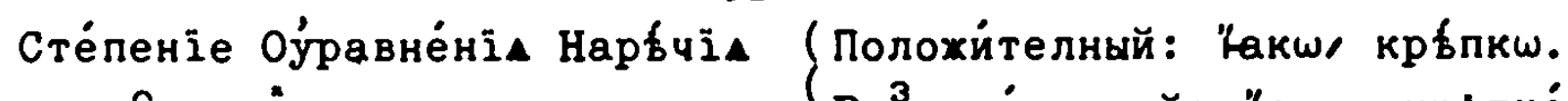
су⿰ิ乛े трй.

( $\mathrm{Pa}^{3}$ судйтелньй: Һакшر крђпча́е: (Превосходи́телный: Какш' крьпча́й-

\section{’́ Знаменова́ніи:}

Знаменова́ніА Нарб́чіム сут̂́ разли́чна.

$X B$ Hacto

III. [1856]

Вре́mене ( Настойщагш: Какш, дне́сь, нй, оуххе, заутра, по́здь, доне́ль хе, досе́ль, до́ндехе, вьну, присснш: и́ про '. Преше́дшагш: ґакш/ дре́вле, вчера̇, пре́хде, ло́нь, пе́р-

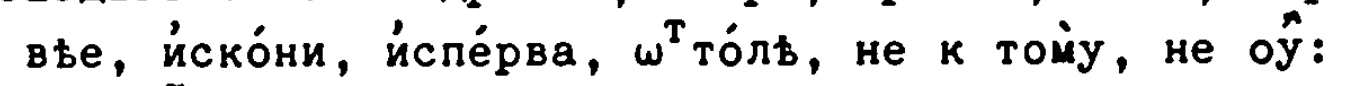
й npo .

Граду́щагш: Һакшл ойтрш, во оўтріе, йногда.

мб́cта (На мб́сть: ко вопроше́нію, Где; зде́, ту, се зде́, та́мw, ӧнде, йнде, вну́трь, вйь, го́рђ, до́ль, ни́зу, близ, дале́че, пре́дь, сре́дь, протӥву, ойду, иде́ же, '́бо- 
$\{$ боду, внъу́ду: $\dot{x}$ про

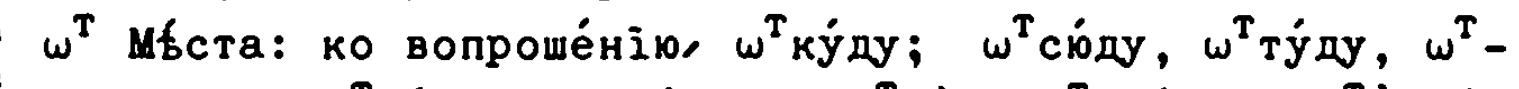

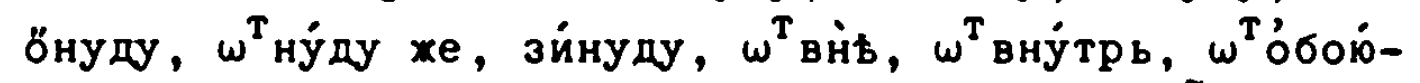
ду, здале́ча, соза́ди, с"вв́ше, с"нйхе: й про

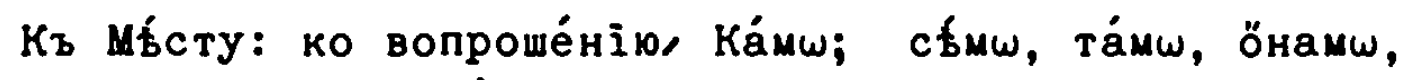

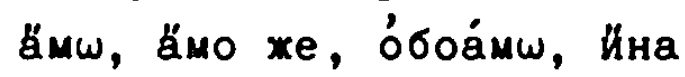

$$
\kappa \omega,[!] \text { во́нъ }
$$

мш, во́нъ, вну́тръ, го́ру, до́лу, ни́зу, вспи́ть: й про.

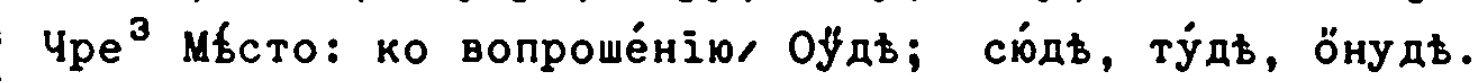

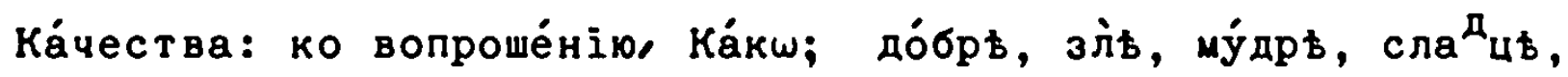

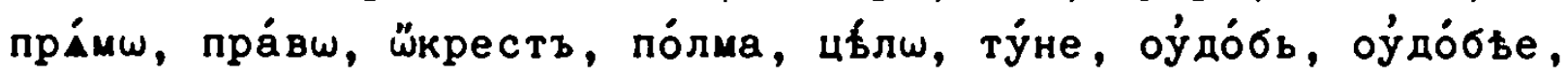

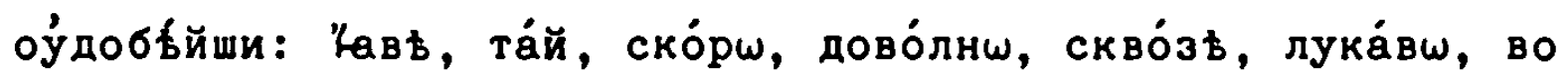

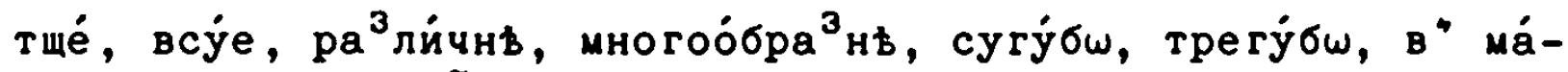
ль, ма́ла: й про ${ }^{q}$.

Коли́чества: ко вопроше́ні̄ю, Кола́кш; мно́гш, ма́лш, во изоби́ль, дово́лнь, дово́лнье, доволнбйши: по вели́ку, по мно́гуу, по ча́сти: й про

Числа̀: ко вопроше́нїю, Коли́кощи; мно́гащи, мно́гахды, е́вйною, йлйл е́дйнощи, два́щи, йлй, два́хды, трйщи, трйхды, чети́рихды, пи́тощи, шести́хды, седийхды: й про ": йлйо е́дини́цею, двои́цею, трети́цею, стори́цею: й про 9 .

Чйна: Қакшы по ри́ду, пе́рвье, пре́хде, по се́мъ, та́че, про́чее,

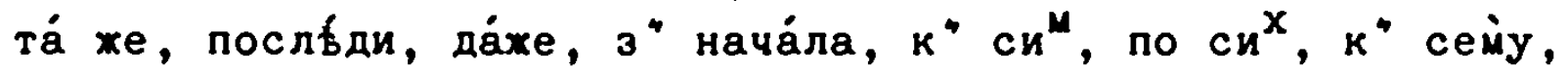
no $\mathrm{ce}^{\mu}$, $X Y$

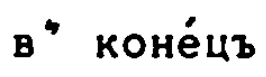
[1860]

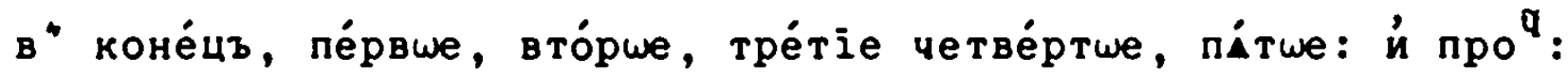
па́ки, е́щѐ, пе́рвье не́хе, пре́хде не́хе, пре́хде да́хе, пре́хде да́ же не: й про

Слу́чаa: "акшљ по слу́чаю, й про

Повеле́нім: Пакшљ прійдй, прійдъте, принесй, приведй, грАдй, воста́ни: й пр "

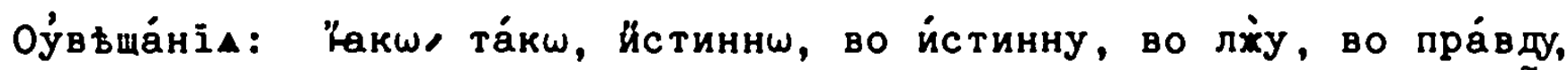
ёй, ве́сма, бо́хма, чейу нй; по что́ нйं й зђлй, всі́кш: й про

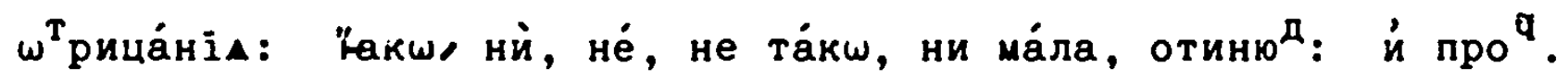
Преще́нї: "акшо не́, ника́ко же: й про ".

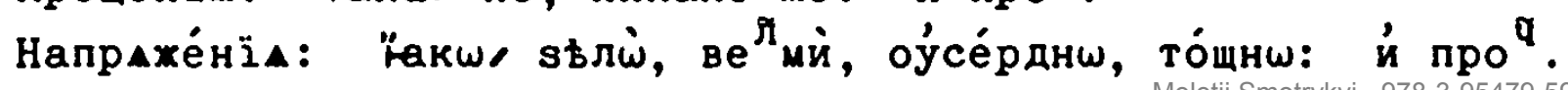




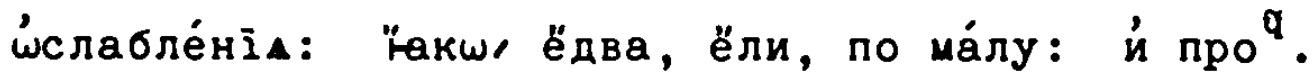

$\mathrm{Pa}^{3}$ эужде́ніА: lакш' па́че, па́че же, на́йпаче, бо́лее, лйш"ше, ва́щше, мно́хае, мнб́е, не́xе, не́хели: й про

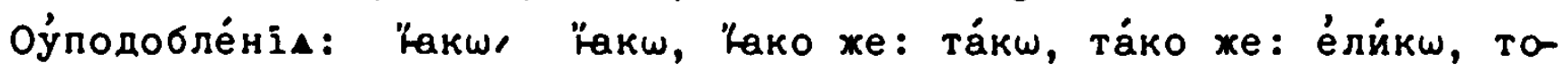
ликкш: е́лихды, толихды: ёлма, то́лма: ко́ль, толл: си́це, ӧвакw/ ӧнакw: а́ки бы, а́ки́: म̀ пр q.

Ра́зн

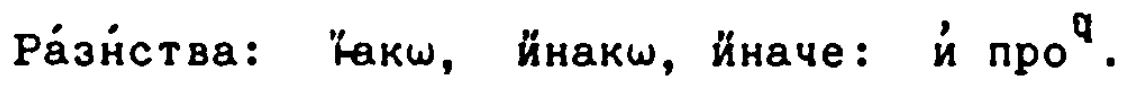

Недоумв́ніА: Накше не́гли. й про

Bопроше́ніА: 'Какш' чесо̀; воскујю; по что́; во что́; чеси́ ради;

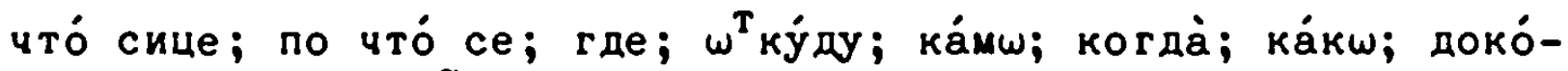
ль; ойду; й про

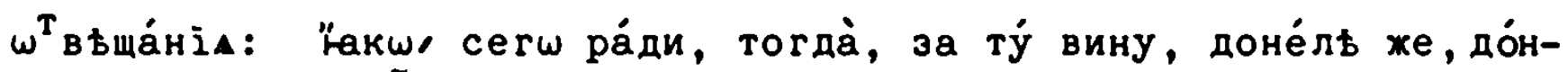
деже: 'и про

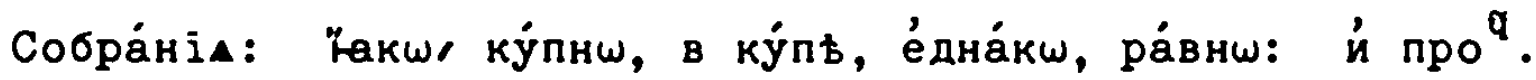

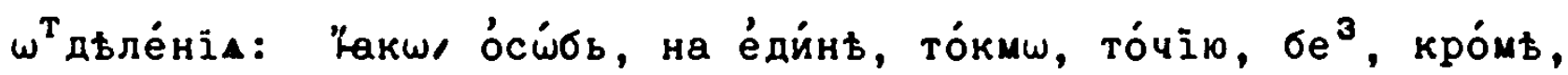
разав, св́́не: и́ про́чаa.

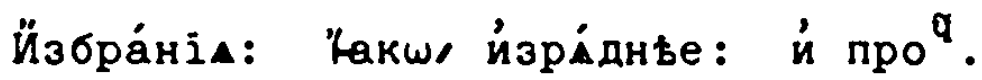

Оу́скоре́ніА: Ґакшر äбіе, внеза́пу, напра́снш: и́ про́чам. Оукказа́ніА: "акш, се́, ӧнш: и́ про ".

О’́въще́ніе Őpөогра́фійно:

НАкw: Нарб́чіе Оўподобле́ніА: знамену́ющее, Һакъ, йжъ, а́бо́-

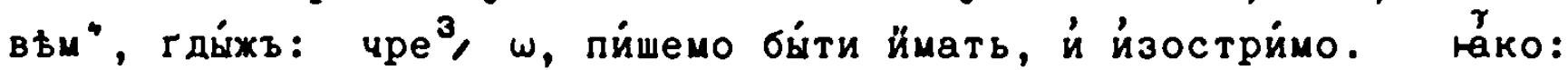
Мехдоме́тіе оу́дивле́ніА: знамену́ющее, "акъ ба́рзо: чрез, о, пйшемо бйти ймать и́ ம்лачи́мо.

$$
x \not{\omega} \quad \dot{\omega} \operatorname{npe}^{\text {म }}
$$

[ 1876$]$

'́ пРєдЛОЗЬ.

Предло́гъ ёсть ча́сть сло́ва нескландемаa, йнымъ сло́ва ча́стемъ слохнь й сочини́телнь предлага́емам.

Всб́" пре "лйгъ ёсть двадеси́ть.

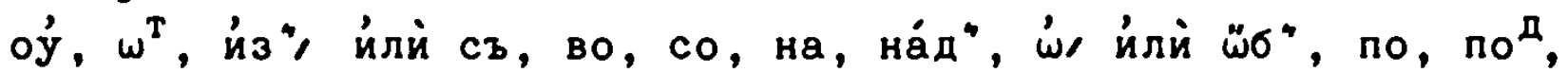
пред , при, до, ко, за, вос, нис, рас, пре, про.

$\dot{\omega}$ посльдуіощихз Пре доѓгови.

Посльду́етъ Предло́гови е́дино: си́речъ, Паде́жь. ¿́ Паде́жи Предло́га. 
Паде́xe Пред̆лóra суть пйтb.

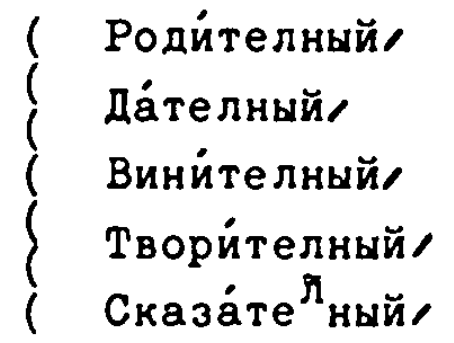

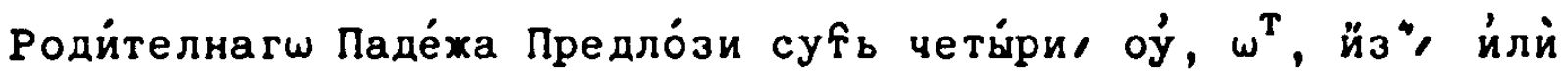
съ, до.

да́телнагш Паде́ха, два̇: ко, и́, по́, сказујемое Рйсскй ве́длугъ:

Виниттелнагш; е́дйнъ: за̀.

Вини

[188]

Твориттелнагш, е́дйнъ: со.

Сказа́телнагш/ два̀: прй, й, по́: сказујемое Рйсски, по́сль.

Вини́телнагш, й Твори́телнагш, четыри: пре

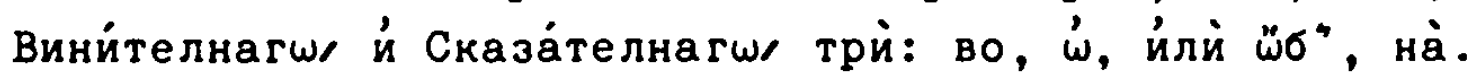

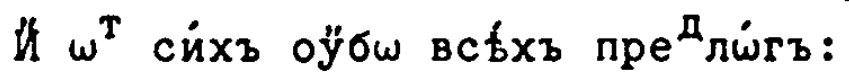

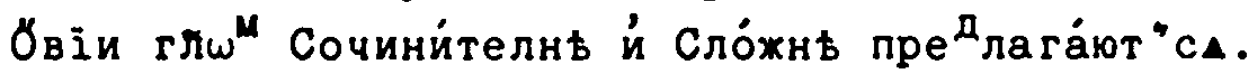

ठвіи же слохнн точію:

Сочинйтелнь й Слохнь пре Дага́еміи сутิь

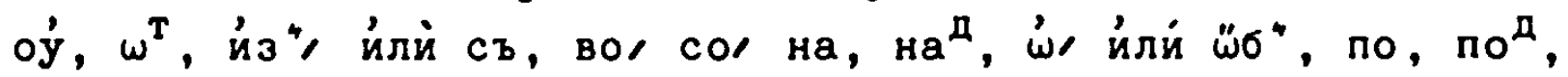
пре

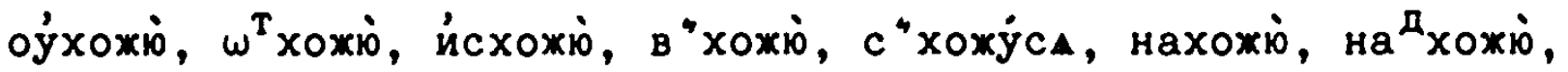

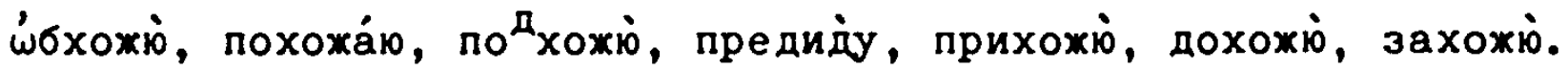
Сло́хнь то́чію пре восхохюे, нисхохї, расхоху́сн, прехохї, прохохї.

$$
\mathrm{Xz} \quad \dot{\omega} \mathrm{CO}
$$

[1886]

$\dot{\omega} \cos 35$.

Сојјзъ/ ёсть ча́сть сло́ва несклани́емах, йныц сло́ва ча́сти чино́вне в" ра́зумъ сва́зующам.

ஸे Посльдую́щихъ Соузоови:

Посльду́ютъ Сој́зови трйл

Начерта́нle:

Знаменова́ніе: и́

( Чинз.

ஸे Начерта́ніи:

Начерта́ніа Соуза сутิь трй: ( Про́стое: "акш/ пре́xде:

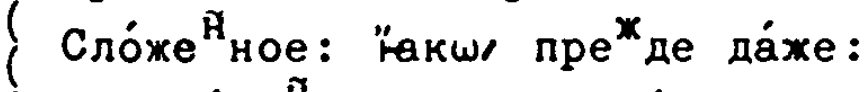

( Преслохе

’े Знаменова́ніи:

Знаменова́нї Соуза сут̂́ де́вать, ( Сопрага́телное:

Раздьлителное: 


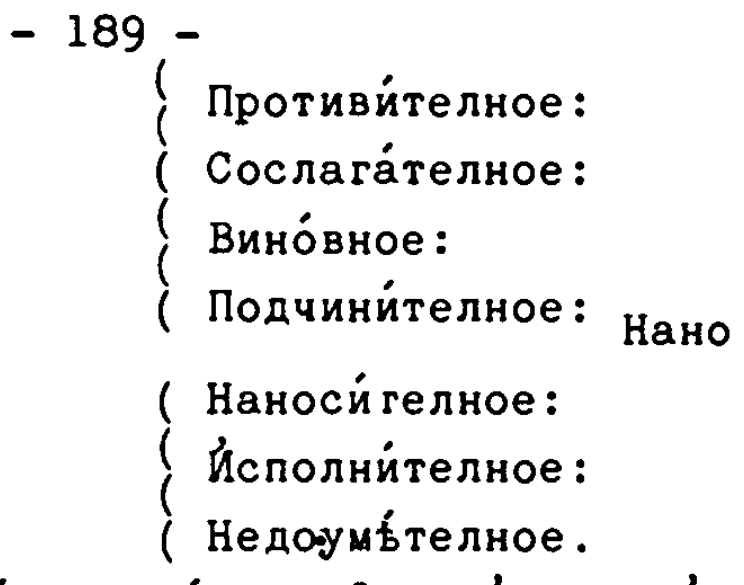

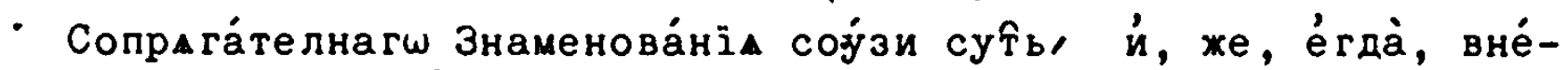
гда, тогда̇: и́ пр

Ра ${ }^{3}$ дьлителнагш: йлй, лй, лйбо, нй, нй же: $\dot{и}$ про

Противи́телнагш: но́ понѐ, äще и́, оба́че: $\dot{и}$ про́чам.

Сослага́телнагш: äще, äще $\sigma \omega$, ăще оўбw, ăще не, äще ли, äще же, ӓще бы, небь: й про

Виносло́внагш: бо́, йбо, дб́ла, ра́ди, д́́лма, поне́же, ойбш, зане́, "юкшл йна́че, ёже, во е́же: й про ".

Подиинйтелнагш: да̀, дабы், небы்: и́ про́чаА.

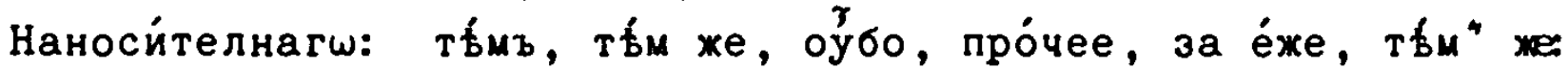
й про $q$.

Йсполнителнагш: ждо: жде.

Недоумб́телнагш: е́да̀; чй; чйли; лй;

ஸे Чйнь:

чйнъ Сој́за ёсть трегу́бый,

$$
\left\{\begin{array}{l}
\text { Предлага́телный. } \\
\text { Подлага́телный: } \\
\text { й ठбщій. }
\end{array}\right.
$$

Пре Дага́телнагш Чйна Сој́зи сутิь: но́, не бо, й оубо, да̇, за е́же, тб́м же, поне́же оӱбш, а̋ще бо, йлй нй, нй же, йбо: й про . Подлага́телнагш' же, ойбш, лй, бо̀: й пр".

ठ̋бщагш: о́ба́че, ăще, поне́, зане́, про́чее: म́ про .

$$
\text { Оу́вьще́ніе ठ́pөогра́фійно. }
$$

оӱбш: Соујза Йсполни́те нагш, знаменующее, боввьъ: ть: 4ре ${ }^{3}$, $\omega$, пйшемо бы́ти ймать й йзостри́мо.

оубо: Соу́за Наноси́телнагш, знамену́ющее, пре́то: те́ды: чрез, о, пйшемо бы́ти ймать й '́блачймо.

$$
\text { ¿े междометіи. }
$$

Междоме́тіе, ёсть ча́сть сло́ва нескландеман, содержа́щаa в" се-

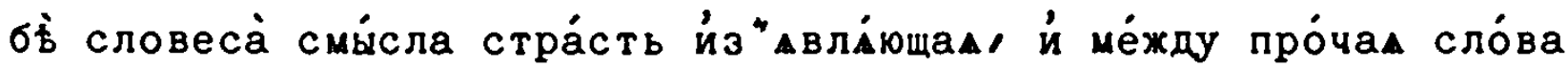
ча́сти в"мьта́emaA. 


\section{$\dot{\omega}$ Посльдую́щихъ Ме}

Посльду́ет" Мехдоме́тію дво́е. ( Начерта́нї: и́

’́ Начерта́ніи:

í Ha

[190]

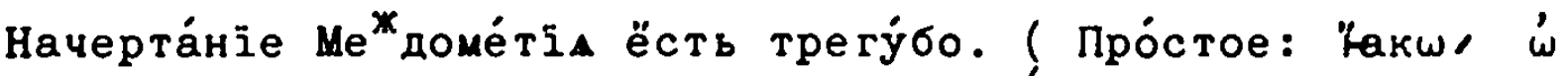
Сло́женное: "̈акш' се́ $\omega^{\mathbb{A}}$. Преслохенное, Һакш' да́xдь то́ Бж̃e.

Знаменова́нї Междоме́ті сутिь разли́чна.

Чуди́marwca: 'Һакw' cé.

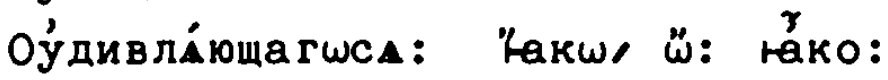

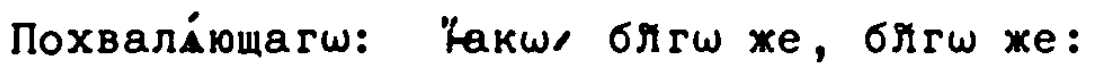

Оука́зующагш: 'lakw/ céf cé

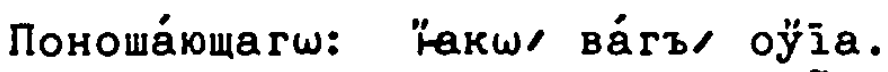

Жальющагw: lakw/ ärъ, äxъ, à.

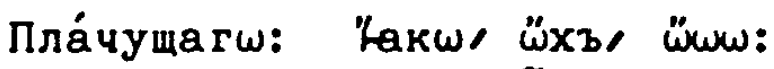

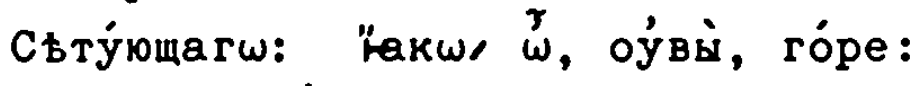

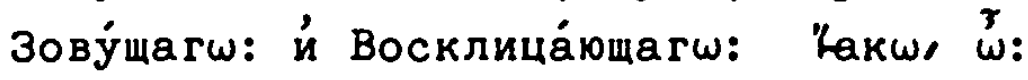

Презира́ющагw: łaкw, rí:

Mepза́marwca: Lakw' фé:

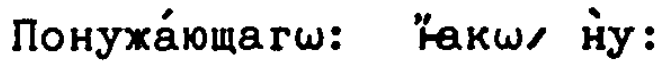

Pányюuarwca: Kakw' rón̆.

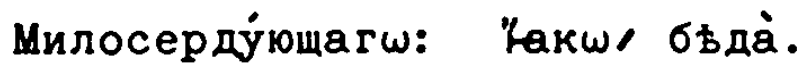

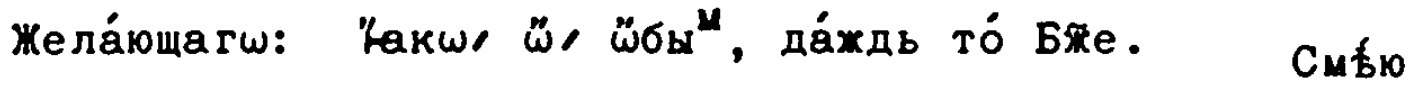

Cmbiomarwca: Kakw' xà, xàl xà.

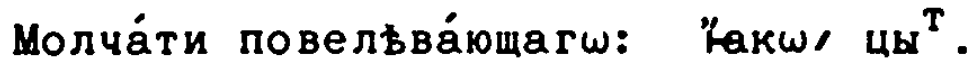

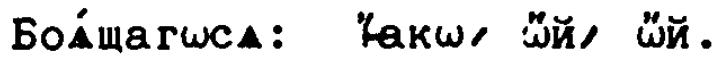

Зову́щагш: Какw, ге́й.

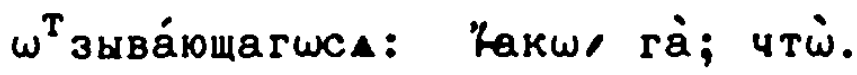

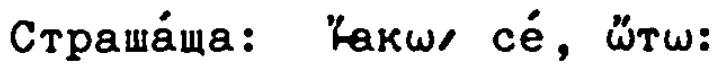

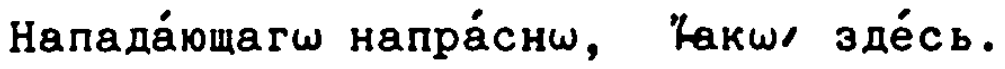

Оу́вьще́ніе రрөогра́фійно.

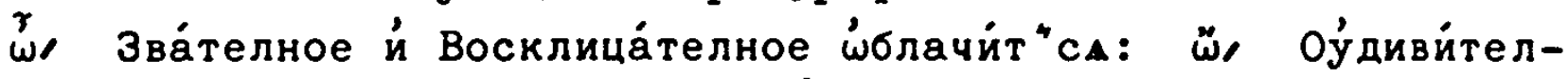
ное й Жела́телное йзостри́ет"са: $\hat{\omega}$, Сьтова́телное '́таха́е

ठ́смй ча́стемъ сло́ва Коне́цъ.

Сла́ва Бгу нача́ти й соверши́ти да́вшему. 


\section{- $191-$ \\ ¿े CӤHTAEИ:}

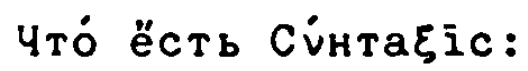

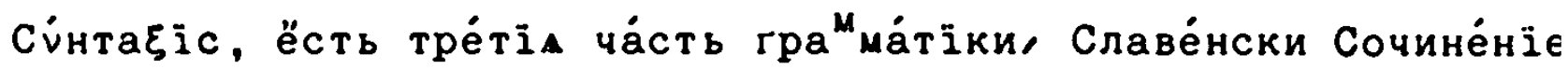
нарица́емаa: "̈аже рече́нí ко о́смй сло́ва ча́стемъ возноси́мал, йзвб́стнымъ нб́коимъ чйномъ ойчитъ сочиніти, й тбмъ сокрове́нъ и́хъ ра́зумъ $\omega^{\mathbf{T}}$ крива́ти.

Синтац̆іс ёсть сугі́бa

( Про́стан: $\dot{и}$

ठбразнаа.

Про́стал ёсть, "̈ахе оўчитъ пра́вила о́смй ча́стїй сло́ва, в" ро́дехъ, чйслехъ, паде́жехъ, вре́менехъ, лйиихъ, й наклоне́ніихъ согласующихъ. "ேкш, Дру́гъ вы́ренъ, оуты́ха ёсть жйтію. (Сира́х" $\left.r^{\tilde{n}}: \varsigma_{0}\right)[05, \mathrm{Cp} .6, \mathrm{I6}]$

ӧбра ${ }^{3}$ наА ёсть, "ахе оўчитъ ӧбразъ пра́вилнагш сочине́ніА од́сту́плшихъ: Пакш, Пе́тръ й Па́велъ Ап ли, ӧвъ 'азикшвъ, ӧнъ о́брђза́нї.

¿́ СОчиненІИ ठомй ча́стї̆ сло́ва:

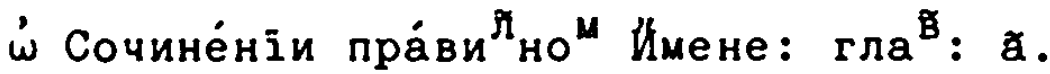

$\dot{\omega}$ Прилага́телномъ й Существи́телномъ: Пра́вило а:

Йма Прилага́телное, Йме́нное, Мьстоиме́нное, Прича́стное, Дьеприча́стное, й Причастодбтелное Существи́телному, е́му́ же са при-

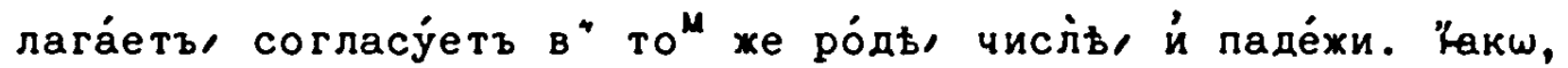

Дру́гъ йзв́́стенъ в" неизвы́стнђ ве́щи познава́ет"са. ( Ённій Пое́:) й Лучче ёсть оуббо́ "ходй̆ во простоть свое́й, не́хели бога́тв оу́муча́ай оу́стйђ сво̀ь. (При ч: $\left.r^{\tilde{H}}, \theta i:\right)[O Б, П р . I 9, I]$

Пристеже́нї:

Пе́рвое:

Существи́телнам Соз́за ча́стицами сопрахе нал мно́гажды множестве́нное притаххутъ Прилага́телное: 'Һакы Пе́тръ й Андре́й рохде́ни в" Галіле́и, воспита́ни во Џуде́и.

Bтópoe:

$\mathfrak{E}_{\text {ди }}{ }^{\text {с }}$ стве́нное Прилага́телное, мно́ги ${ }^{M}$ ра $^{3}$ лйчныхъ рйдъ Сущест-

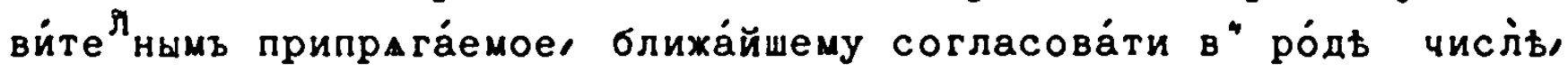
й паде́хи, дерхит"са. "̈акш,

Безу́міе твоё, презо́ръ, й го́рдость ти́готна мй ёсть.

Во Һ́пшевле́ныхъ ве́щехъ прилага́телное дво́йствен ное, й мнохе-

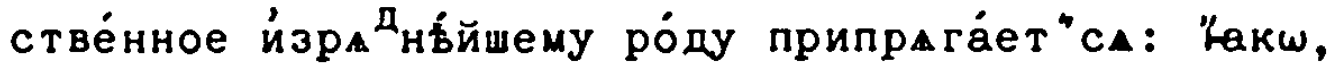

ठте́цъ и́ ма́ти че́стна ми ёста: й, 
Бра́тъ, сестра̀, й ча́до любе́зни мй су欠ิь.

म.

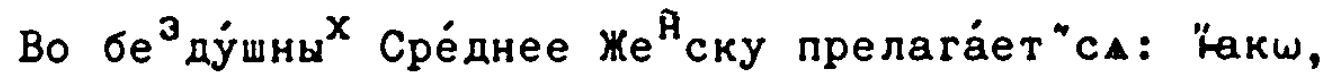

Паматозлоббіе й Һарость, вре́дна ёста члв̈ку, ме́рзка же Бгу.

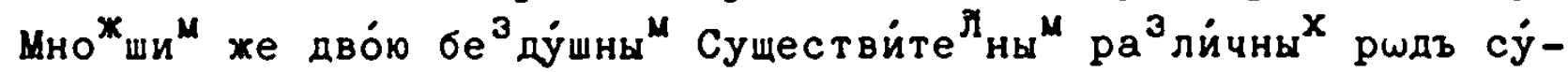
щымъ, прилага́ет "сА прилага́теле ${ }^{\widetilde{H}}$ множестве ${ }^{\tilde{H}}$ сре́днА ро́да: "⿴кш,

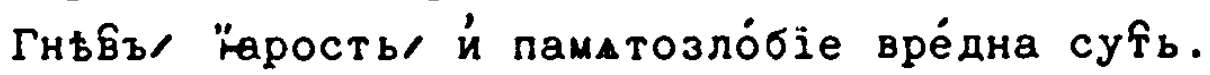

\section{$\tilde{\varepsilon}$}

Существйтелному в" коемлибо числ́⿱ су́щему припрага́емо прилага́телное/ приискрнђе ближа́йшему припра́хет"са. "Накш, Лице́, оу́ста̀, о́чеса̀, й ве́сь зра ${ }^{\mathbb{R}}$ твӧй йзмъне́нъ вйжю. Йзітie:

Мно́гажды Существйтелное Прилага́телному в" томжде ро́ды числ̀ь й паде́жи сочинд́емое, в" роди́теленъ коему́ждо Прилага́те паде́xю/ в" е́дйном" иं то"жде

$$
\text { ఓ pázy }
$$

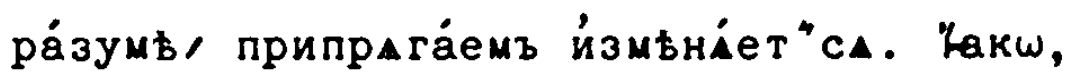

Высо́каa древе́ç падо́ша:

в" мfсcтw, всі высо́кан дре́ва.

Ссуंщыл младе́нєцъ иंзбй Иродъ:

в мбстш: всї ссу́щы младе́нцы:

Терпеливвю мучченицъ Варва́ру, сво́й е́й о́те́цъ мече́мъ ஸ́бе ${ }^{3}$ главй:

в мб́стш, му́ченицу.

$\dot{\omega}$ Прилага́телномъ, и́ Собира́телномъ:

\section{Пра́вило в.}

Собира́телнаА Прилага́телным" сочина́ют"са, ӧва по пре Дохе́нному Существйтелныхъ пра́вилу: "Ғакше

Спйра царскан: Лйкъ Агтглскій: й проq.

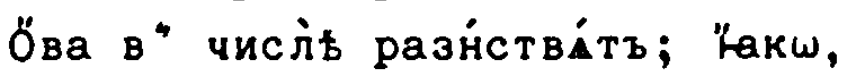

Бра́тї мод до́бри й велйци, й не бйговолй в" ни Гадь. $\dot{\omega}$ дво́ю Прилага́те ${ }^{\tilde{n}_{H y}}$

$$
\Pi p a^{\tilde{B}}: \mathbf{P} \text {. }
$$

Дво́ю йлѝ мноха́йши" полага́емымъ Прилага́телнымъ е́ди́но их

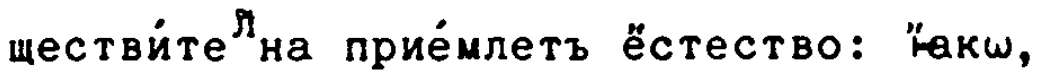

Лу́чше нйщъ пра́веденъ, не́же бога́тъ ло́жъ. (Прит ${ }^{\mathrm{T}}: r^{\mathfrak{n}}: \theta_{\mathbf{I}}$ ) Пристеже́нї : [OS , חp. 28,6]

пе́рвое:

Гре́ческагш сочине́ніА ӧбразом", й Славе ${ }^{\text {म }}$ ски Сре 
га́телны Существи́телны ёстество себі́ придб́вш" в" е́дйно й то" жде со Существителными чистіь й па де́xи де́жи, ӓще й в" различчныхъ ро́дех" полага́емы быва́ти случае ${ }^{\mathrm{T}}$ са . lакw Зла́ку тра́вному й ве́ртны" наса"де́нієм", до́ждъ Ма́а поле но ёсть.

й Спсе́нно, пре дасто́й па́сты о́вча́рни: сіесть поле ${ }^{3}$ на ве́щь: сйсе́нна ве́щь: и́ про́чаА.

Bтópoe:

Мно́гажды тако́ва Прилага́телнаА е́ди стве́ннь и́ множестве́ннь во Сре́днем" ро́дь бе ${ }^{3}$ Существйтелны оу́потребла́ема '́бра́щут"са: "⿴кw, Архістратізи Бжіи, поле́зное на́шъ и́спроси́те.

й, В" домуу Дв" Вь стра́шнаА соверша́ют" сА. 'и про".

$\dot{\omega}$ Прилага́телныхъ Существйтелнь полага́емыхъ:

Пра́вило ди.

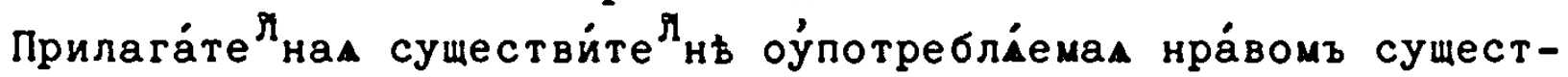
виттелны родйтеленъ притіхутъ: Какш,

Въ сі́е ну́хды прийдо́хомъ.

й, Что́ ймб́нї ёст" ми, твое́ ёсть.

й, Мно́го стажа́нї ку́плею прииждиве́. и́ про .

¿́ Прилага́телныхъ ојсъче́ных":

Пра́вило: $\tilde{\varepsilon}$.

Прилага́телное Ој́съче́ное ӧвогда Су $\stackrel{\mathbf{T}}{\mathbf{B}}$ ществй

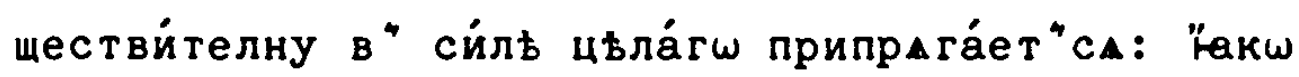

Дру́гу вб́рну нб́сть изиб́н:(Сира ${ }^{x}: r^{\pi}:$ s. [ОБ, Ср.6, I5]) й про : ठ̆огда же ёстество йзмfнше, существйтелна в" ко́е ждо ро́ды сйлу прие́млетъ: "акш,

Мно́зи бу́дутъ пе́рвіи, посль́дни, й послв́дніи, пе́рви.

$\left(\mathrm{Ma}^{\mathrm{T}} \theta: \mathrm{r}^{\mathfrak{I}}, \theta \Psi_{.}\right)[0 \overline{\mathrm{M}}, \mathrm{M} \theta .19,30]$

Оувьще́ніе:

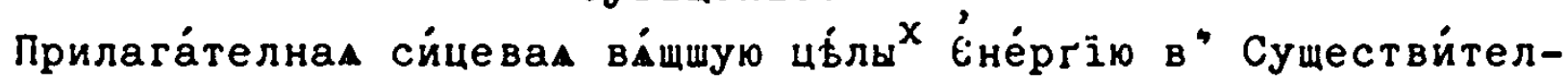
ныхъ, йм же сА припрдіжутъ, содьлова́ютъ: Какш,

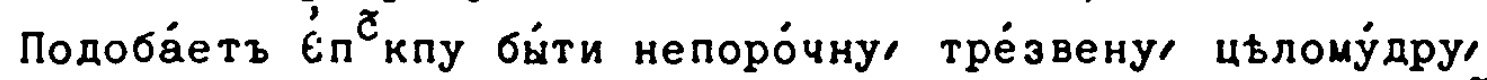
блгоговййну че́стну, страннолюбйву, ојчйтелну. й про ( $\left.: T_{i}^{M}: r^{\tilde{N}}: \Upsilon^{\mp}\right)[O 5, I . T M, 3,2]$

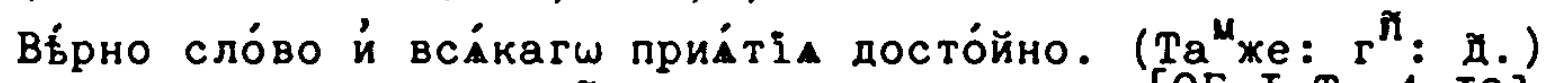
$\dot{\omega}$ Родйте ${ }^{\tilde{n}}$ но Гла ${ }^{\widetilde{8}}$ : в. 
’́ дво́ю Существи́телну.

$\Pi \mathbf{a}^{\mathbf{B}}: \mathbf{3}$.

Дво́ю Существи́те ${ }^{\Re}$ ну $\mathrm{pa}^{3}$ ли́чны ве́щій стека́ющуса, друго́е ихх в" роди́те ном" полага́емо бйвати ӧбйче: "Һакw,

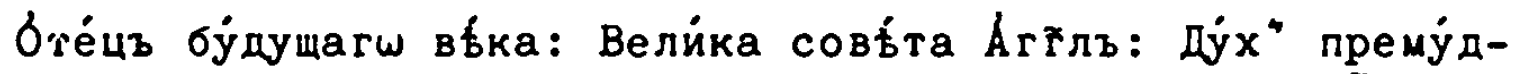
рости и́ ра́зума: Жа́ло сме́рти: ма́ти щедри́тъ: и́ тро .

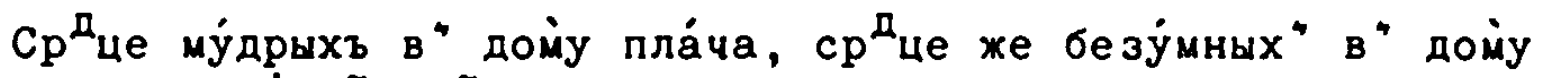

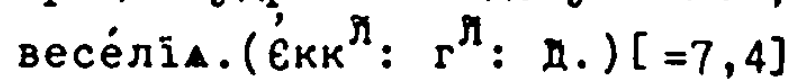

\section{Пристеже́нїа:}

При

Пе́pвое :

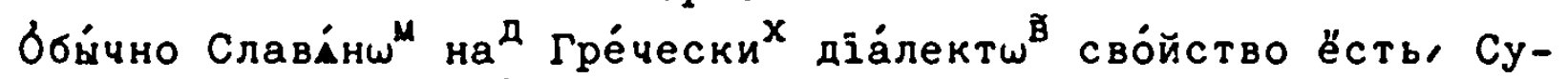

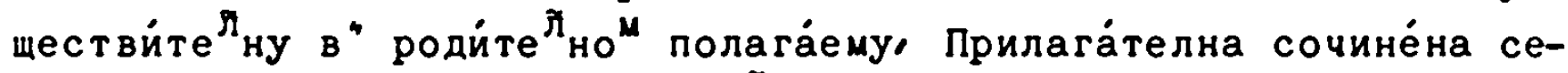
бі не йму́щему, в" Прилага́теле ${ }^{\text {म }}$ притажа́теленъ своему Существй-

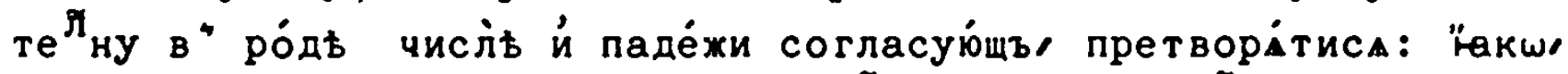

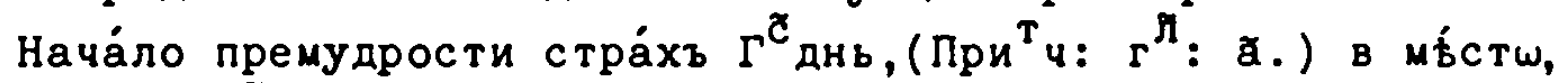

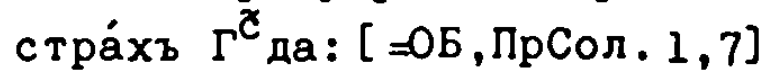

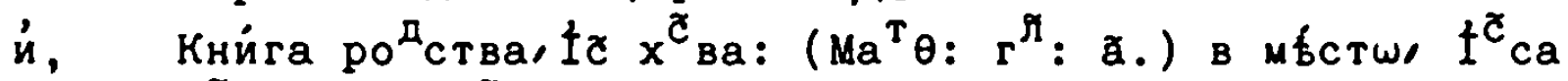
$x^{\complement} a:$ i npo ${ }^{q} .[=0, M \theta . I, I]$

Bтópoe:

Йму́щему же йнъ себв́ Прилага́теле ${ }^{\AA}$ сочине́нъ, ну́жда ёсть в" роди́телно п преби́ти неподвйжну. "акш,

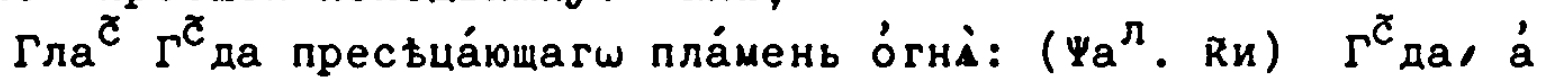
нё $\Gamma^{\complement}$ днь. $\left[=05, \Psi_{\pi} \cdot 28,7\right]$

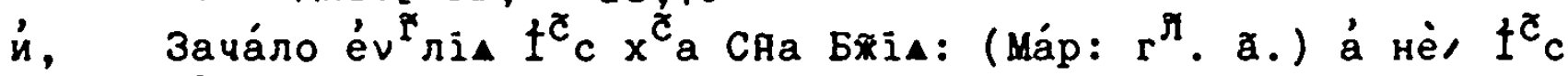
$\mathrm{x}_{\mathrm{Ba}}:[=\mathrm{Ob}, \mathrm{Mp} . \mathrm{I}, \mathrm{I}]$

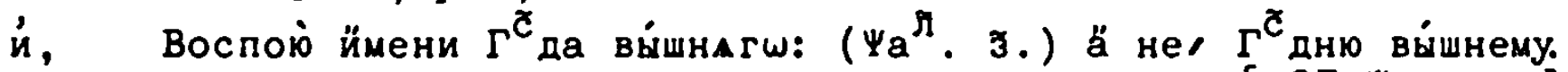
до́брt гймз/ $\left[=05, \Psi_{\pi} .7,18\right]$

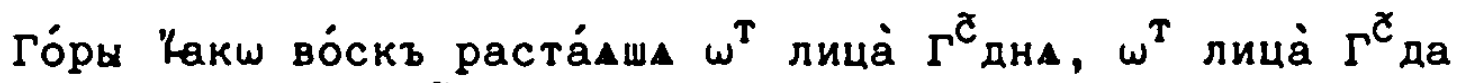
все́л землї: ( $\left.\Psi_{a}{ }^{r}: q_{s}\right)\left[=05, \Psi_{л}, y 6,5\right]$

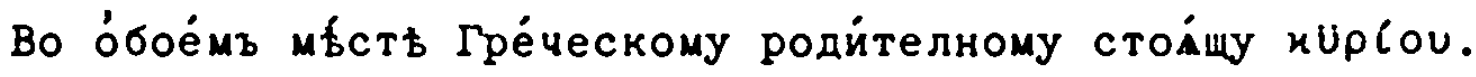
Недо́брt па́ки,

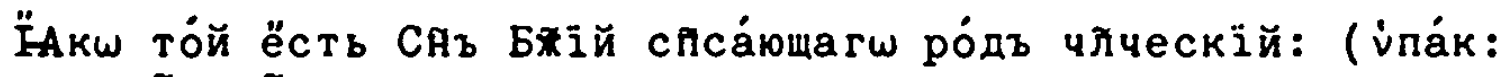

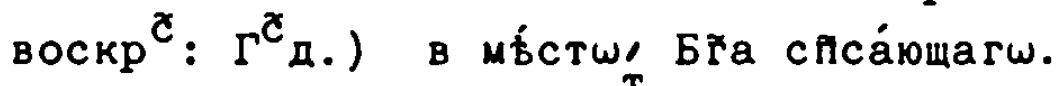

$$
\stackrel{\mathbf{\omega}}{\mathbf{r}} \text { Tpé }
$$

Tpétíe:

[I946]

Ра́внь й ко послб́дуюшему Возноси́телному, Предиду́щагш ёстес-

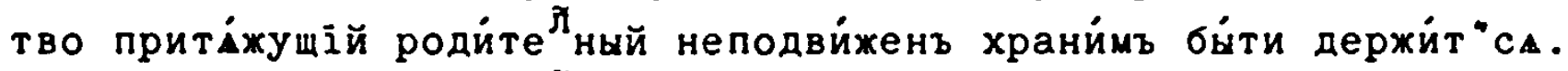

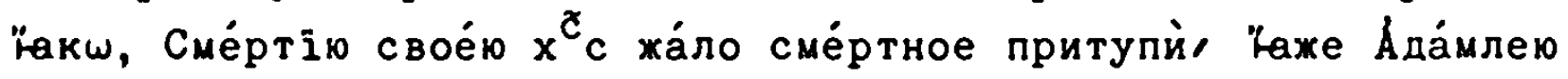
сме́ртї воцари́са: жа́ло сме́рти, "̆аже: á нел сме́ртное: 


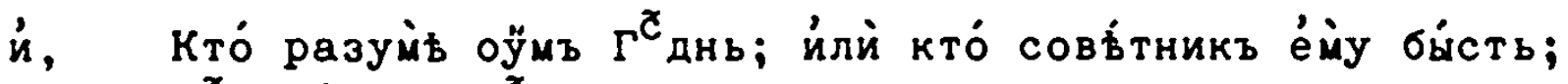

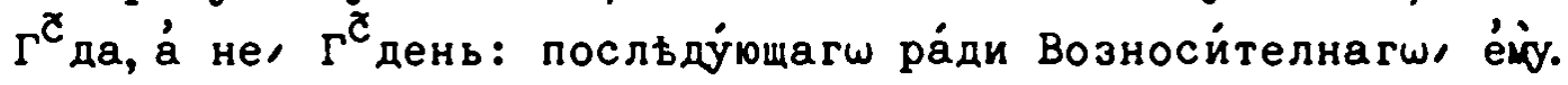
йначе бо, е́mу, вознесе́т"сA ко, оймъ.

\section{Й}

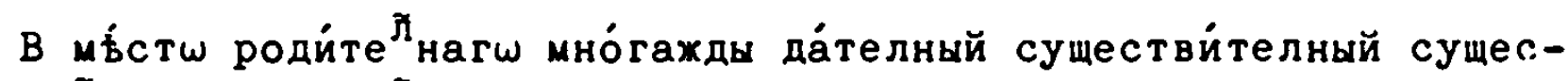
твйте ${ }^{\not}$ ну сво́йстве

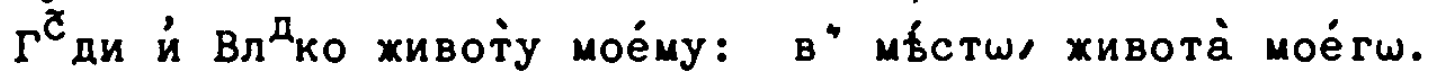

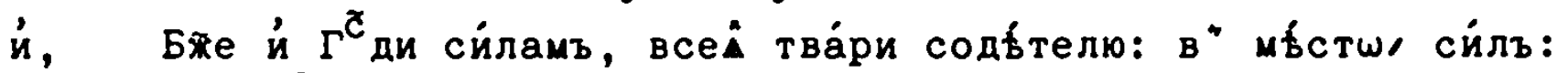

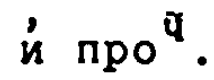

$$
\begin{gathered}
\dot{\omega} \text { Ймене }{ }^{\mathrm{X}} \text { Глаго }{ }^{\AA_{\text {ныхъ : }}} \\
\text { пра́вилог з. }
\end{gathered}
$$

Глаго́лнымъ Йменемъ роди́телный слухитъ: 'акш,

Сотвори́тель всед̈ вселе́нныа: Йзбавйтель всегі́ мйра: Ој́тьши่

тель

тель дшึъ члвчески : Пре Дата́телница вырныхъ й помо́щница: Вра́тарь ца́рства нб $\sigma^{\complement}$ нагш: й про

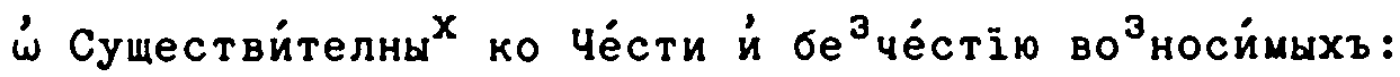
Пра́вило:

СуществйтелнаА ко Че́сти йлй Безче́стї во ${ }^{3}$ носймал родйтеленъ прие "лютъ: "накш,

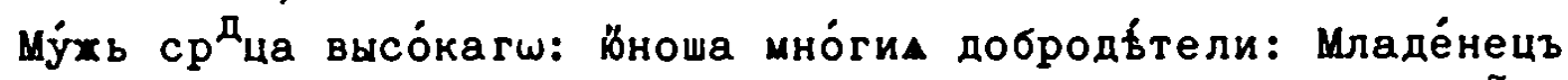
чйстын совбсти: Се́рдце проклітагш паматозло́біА: и́ про

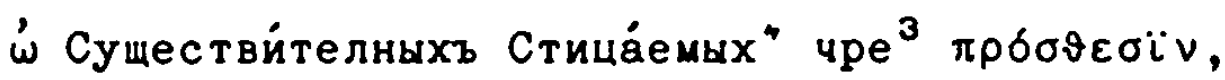
сйречъ, чре ${ }^{3}$ прилохе́нїе спрага́емыхъ:

$$
\Pi p a^{\text {B }}: \tilde{\theta} \text {. }
$$

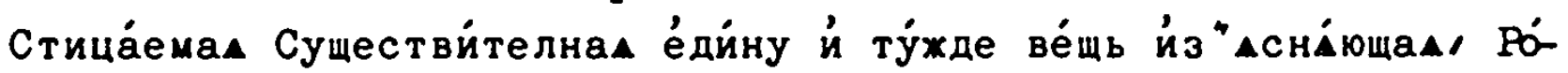
домъ оўбш й Числомъ по слу́чаю Паде́хе же по ну́хды согласова́ти, держа ${ }^{T}$. 'акан,

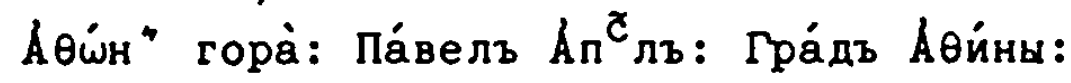

$\dot{\omega}$ Родйтелномъ со Ймены,

собра́нїе, ча́сть число́ й чйнъ знаменующими:

$$
\text { Пра́вило: } \tilde{1} \text {. }
$$

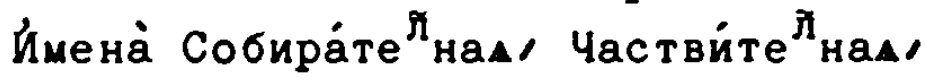

$$
\text { Wี Числи }
$$

Числителнам, й Чини́телнаА, роди́телны мнохестве́нны приті́хутъ:

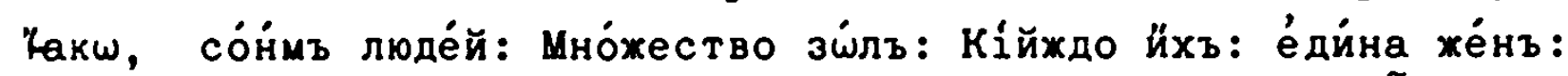
Пе́рвый сйса́емыхъ: Супру́гъ воли́вь пйть. й про $q$ 
ЧаствйтелнаА оба́че и́ Числи́телнаА ча́стье то́йжде паде́жь со

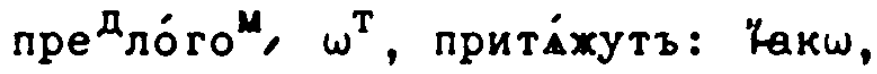

Никто́ же $\omega^{T}$ ни поги́бе:[ОБ, I $\left.\omega, I 7, I 2\right]$

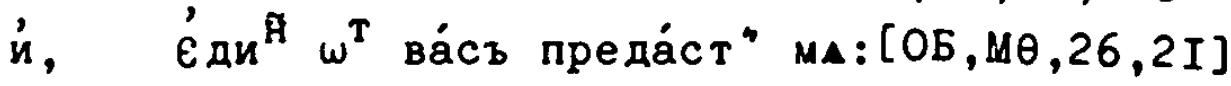

й, h̆до́ша $\omega^{T}$ оуччени́ъ е́rì два்.

Пристехе́ніА:

Пе́рвое :

Числи́телнам, е́дйнъ, два̀, трй, чети́ри, Существи́телнымъ сочине́на, Прилага́телныхъ пра́вило", согласу́ютъ ймъ в" ро́дь иисл̀ь й паде́жи: 'акw'

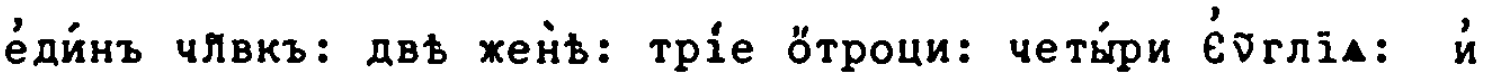
про

Brópoe:

Про́чаА Числи́телнаА тре́тимъ гла Существи́телна е́динстве ${ }^{\text {H̆}^{M}}$

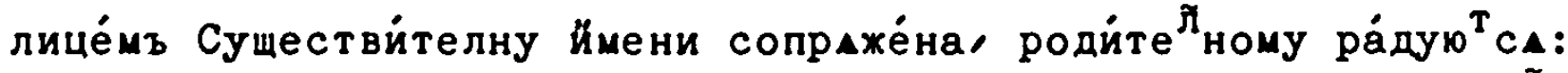

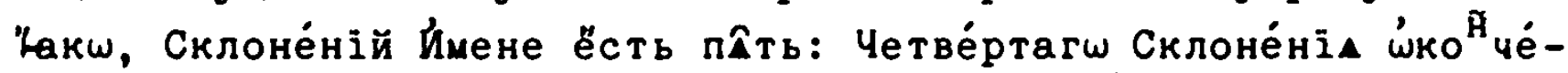

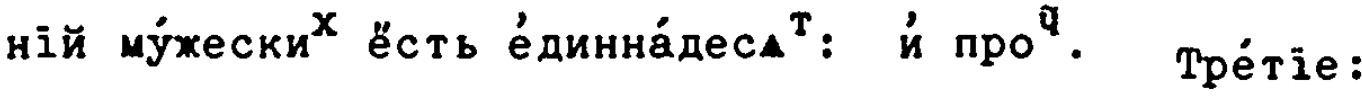

\section{Tpérie:}

Сопраже́на же тоги́жде гла, йлй йнагш ко́егш тре́тимъ множест-

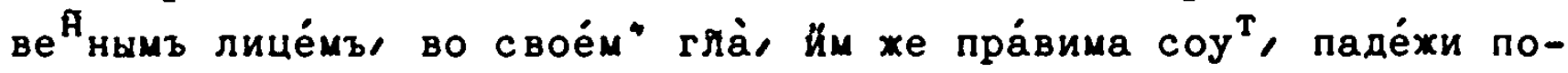

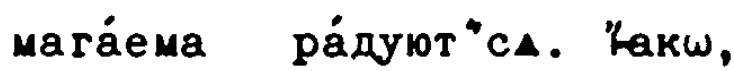

Вйди Прои во́дны ${ }^{3}$ име́нъ сутิь се́дм": Пе́рвоо́бра ${ }^{3}$ нагш Вйда

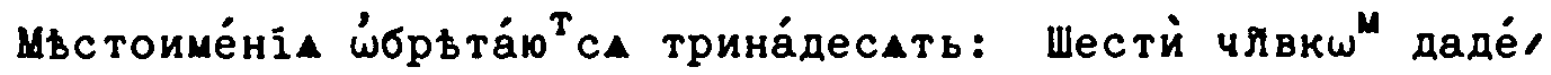
се́дмаго пре́зрь.

$\dot{\omega}$ Прилага́телны Родйте ${ }^{\text {म̆ому сочиніемы }}{ }^{x}$

Пра́вилог а̃.

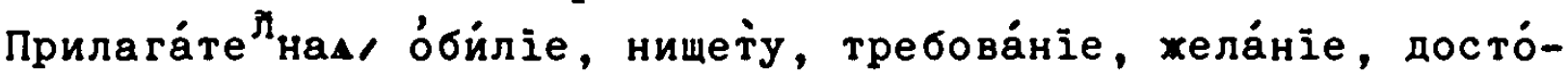

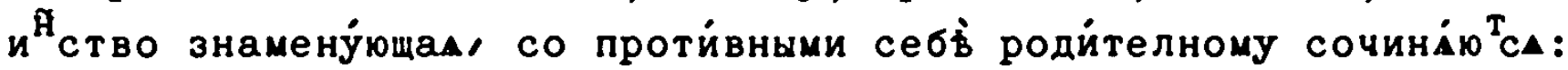
ஜакш, Йспо́лнь сла́вы й че́сти: То́щъ всі́киА добродбтели: Пре-

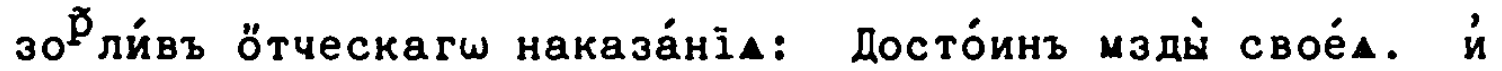
про

’’ Прилага́телныхъ Размђре́ніА

Пра́вило: ві.

Йзвбстно ра ${ }^{3}$ мре́ніе знамену́ющам Прилага́телнас Роди́телному сочинант" СА. "Какш,

Высо́къ три́десати ла́ктій: Широ́къ четыре́хъ пі́дій: й про Tैं $\quad \dot{\omega} \mathrm{Pa}^{3}$

$\dot{\omega}$ Разсудйтелныхъ й Превосходи́телны ${ }^{\mathbf{x}}$ :

пра́вило: ri: 
$\mathrm{Pa}^{3}$ суди́телнаА й Превосходи́телнаА, ӧва со мно́гими тоги́хде ро́да оуравніема: ӧна со е́ди́ны тогш́хде, йлй со мно́гими ра ${ }^{3} л \dot{4}$

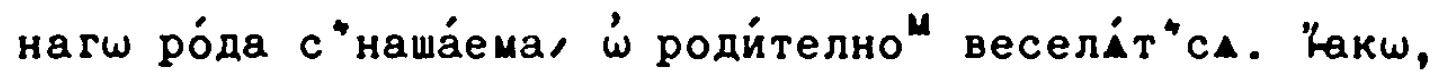

члегкъ члика лу́чшій: Є̈лень ско́ршїй всб́хъ зв́рей: Всб́хъ царе́й Блгочестивъйшій Ко стантінъ Ве́л: Веніамінъ сяш́въ †а́ковли ${ }^{x}$ млажа́йшій: $\dot{n}$ про .

\section{Пристехе́ніА :}

\section{Пе́рвое :}

$\mathrm{Pa}^{3}$ суди́телнагш роди́телный Сој́за, не́хе, йлй, не́хели, примъше́ніемъ, B" Имени́теленъ паде́хь прехо́ди" : Гакш,

Оучче́ншій ёсть Іша́ннъ, не́хе Пе́тръ: че́стнше ёсть зла́то не́хели сре́бро: $\dot{и}$ пр

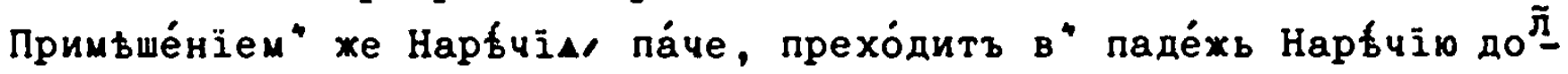
жный: "акші,

Тщали́вша па́че Ға́кова спуде́a ஸ́брьта́ю Џша́нна: и́ про . Ра́внь й Превосходйтелнагш: Какш,

Тщаливбйшу па́че всбхъ спуде́й да́хдь Џша́нну:

\section{Bтópoe :}

$\mathrm{Pa}^{3}$ судйтелный й Превосходи́телный свое́ гш ймъ Полохи́телнагш паде́хь сво́йственнь прие́млютъ: 'Һки,

Горрекъ горта́ни, горкшїй горта́ни, горча́йшій горта́ни: и́ про . Ма́лъ во́зрастомъ, мній во́зрастом", мальйшій во́зра-

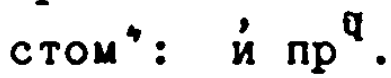

\section{Tpérie:}

$\mathrm{Pa}^{3}$ суди́телнымъ мно́гахды припрага́ет"са твори́телный Преимбні$\Delta: \operatorname{ran} \omega$,

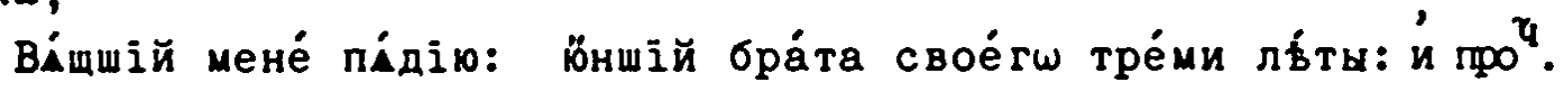
Четве́ртое:

Нра́вомъ Ӓттікъ и́ Слава́не Полохи́телнатш оу́потребла́ютъ в мfс-

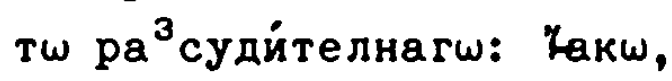

Блиго ёсть оу́пова́ти на $\Gamma^{\complement}$ да, не́хели оу́пова́ти на чйвка:

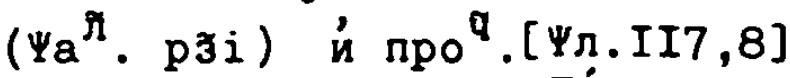

\section{пи́тое:}

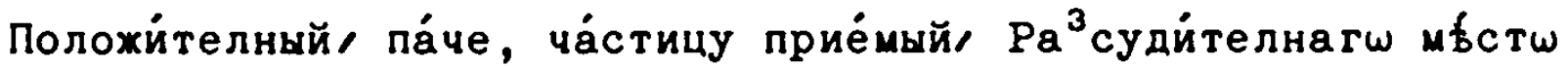

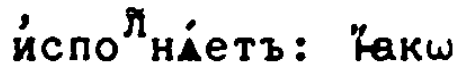

Блххенно ёсть па́че дах́ти, не́хели прийма́ти: й про .

Wéctoe:

Wéctoe:

[1976]

Прилага́телнаА си́лу Превосходи́телны йму́щаА, тв́хъ ӧбразомъ родйтеленъ мнохестве́нъ прита́хутъ: 'Юакш, 
Верхо́вный $A^{\complement}{ }^{\complement}$ лшвъ Пе́тръ: Изрі́дньй Бтослш́въ Григо́рій: й npo $q$.

’́ Да́телномъ со Йменемъ:

Гла́ва: $\mathbf{~ . ~}$

Пра́вило: ді:

Прилага́телнаһ, подо́біе, по́лзу, винуу, оудообіе, оу́тьше́ніе, блгать, прийскр"ность, ра́венство, ви́рность, ра́зушъ, й сиххъ про ти́вное знамену́ющал, да́телна взы́щутъ: Какш,

Подо́бенъ $\omega^{T}$ йу: поле́зенъ мно́гимъ: повйненъ су́ду: оудо́бенъ прочте́нію: сла́докъ оу́стшиъ: горекъ горта́ни: лю-

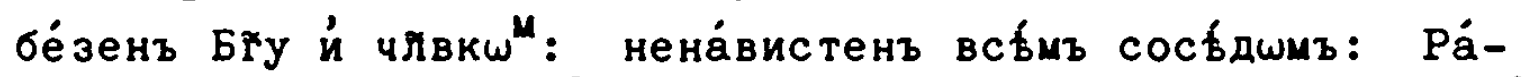
венъ $\omega^{\mathrm{T}} \dot{\mathrm{u}}:$ Вб́ренъ $\Gamma^{\mathrm{C}}$ деви: наказа́нъ за́кону бжію: и́ по". Пристехе́нїе:

Сла́докъ, го́рекъ, кра́сенъ, до́бръ, тщали́въ, бога́тъ, оубо́гъ, поле́зенъ,

оу́до́

[198]

оу́доббенъ, и́ си" подо́бнаА, на да́телный прие́млютъ Вини́теленъ со Предло́гомъ, во: "Һкш,

сла́докъ во снвд́ь: кра́сенъ во видб́ніе: тщаливъ во добродбтель: поле́зенъ во целбу̀: оубо́гъ во грбхъ: богат во милость: оу́до́бенъ во б́брвте́ніе: го́рекъ во вкуше́ніе: й про

$\dot{\omega}$ твори́телномъ со Йенемъ

глава̀: да:

Пра́вило: ̃̃i:

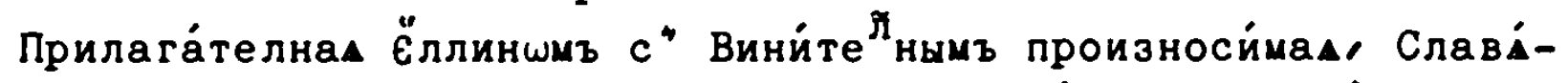
нш" ${ }^{M}$ " Твори́телны Существи́телныхъ, ро́дъ, о́те́чество, йлй ча́сть

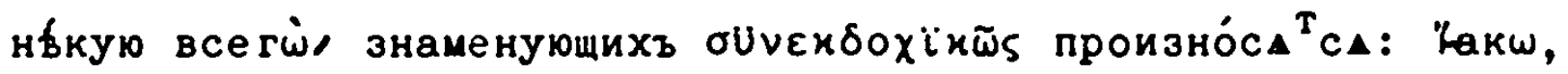
о́те́чество Галіле́анинъ: йменемъ Пе́тръ: лице́мъ че́рменъ: зуба́ми ббл": власа́тъ главо́ю: Ва́рваръ гла́сомъ: Ви ${ }^{\mathfrak{H}}$ нйнъ ро́домъ: й про .

Пристехенніе:

Мно́ги" Прилага́те ${ }^{M}{ }^{M}$, оби́ліе, нищету, сла́ву, бе ${ }^{3}$ сла́віе, ка́чество, и́ коли́чес́тво знамену́ющи ${ }^{\prime}$, Творителньй припрд́ хет"

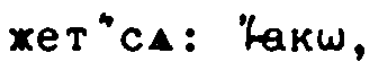

достойніемъ бога́тъ: высо́къ че́стію: нарочйтв вла́стію: чйстъ се́рдцемъ: нечйстъ дшею: ве́лій тв́лом: ма́лъ оу́мо́мъ: ни́щъ ду́хомъ: про́стъ нра́вы: кра́сенъ лице́мъ: й проч̃. 


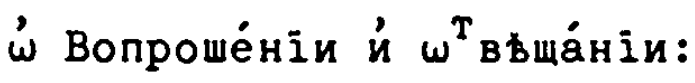

глава̀: $̃$.

Пра́вило: §i.

ҒАко́во Вопроше́ніе сло́вомъ паде́ха во Йменехъ, й вре́мене, во

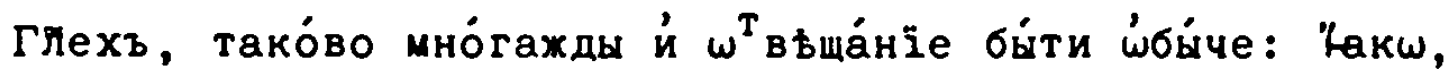
Кто́ согрњшй се́й и́лй роди́теле е́гі்; нй се́й, нй роди́теле

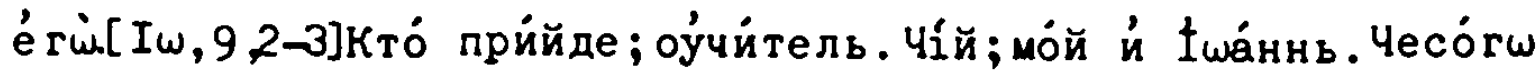
ва́ю оўчитъ; грамма́тїки. Мене́ кого́ б́́ти мнйши; Петра̀ †а́ковла сна. Кому собесъдујеши; Йскуссну му́жу Кӥріллу. '́ чесо́мъ; '́ грамматйчнъ худо́хествь. Кі́иъ діа́лектом; Славе́нским. Оу́чи́шиса Славе́нска 'азы́ка; оу́чю́са.

Пристехе́нї:

Bonроси́телнаА й $\omega^{\mathrm{T}}$ въща́телнаА, ко ли́че

ли́чество, ка́чество, й число́ знамену́⿴щал, Возноси́телны Мъсто-

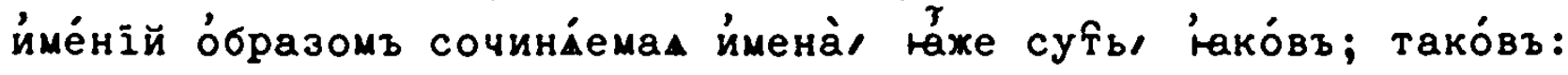
коли́къ; толикк: е́ликъ; сели́къ: посльдуююему не предиду́щему Существи́телну в" то́мжде ро́ды, числіь, й паде́жи сочина́ют"са, "La-

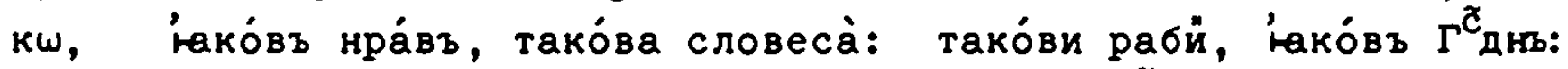
толикимъ оу́се́рдіемъ, е́лйка сйла: й про .

$\dot{\omega}$ СОЧИНєНТИ МъстоимёніА:

’े Оу́ка́зателныхъ, мй: тй: сй:

гла́ва: ã.

\section{Пра́вило Пе́рвое:}

Первооббра ${ }^{3}$ ныхъ Мъстоиме́ній да́телнїи, мй, тй, сй: в мf́стш Произво́дны мо́й, тво́й, сво́й, во всі́комъ ро́дь числьв и́ паде́жи СУществйтелнымъ сочина́ют" сА. "Екш'

о́те́uъ ми ёсть: в мб́стw/ о́те́цъ мо́й: о́тuà ти: в" "в́стw/ ótuà твое́rw: ótuý си: в мб́ctw/ ótน̀y свое́my. Сочи

Сочинано са ти́хде мй, тй, сй, да́телніи во вси́ком" ро́дђ чисїђ й паде́жи, й Прилага́телнымъ: Какш,

Пречйстый тй ӧбразъ: пречйстагш тй ӧбраза: пречйстому тй о̋бразу: пречйстымъ тй ӧбразомъ: $\dot{\omega}$ пречйстомъ тй ӧбразъ: пречйстіи тй ӧбрази: й про ${ }^{q}$. в мб́стш/ пречи́стый тво̆й ӧбразъ: й про '.

Пристехе́нї:

Пе́рвое :

Тйхде, мй, тй, сй, да́телнїи мно́гажды и́ свои́мъ Произво́днымъ 


\section{$-200-$}

во вси́ко ро́дь числь й паде́жи во Существи́телны сво́йствь сочиHÁЮT"CA 'LEWW'

мо́й ми, тво́й ти, сво́й си: Łaкw,

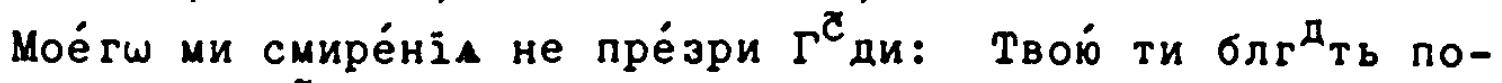
да́хдь ми $x^{\complement} e$ мо́й: во свое́мъ си кро́вь сохранй мА ма́ти Бóxia: í npoq.

\section{Bтópoe :}

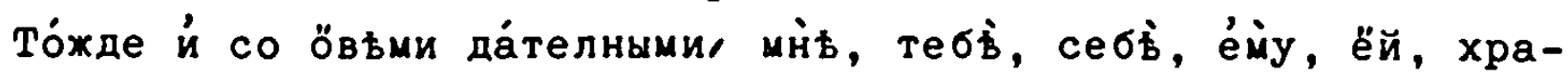
нймо быти о́бйче: "̈акш,

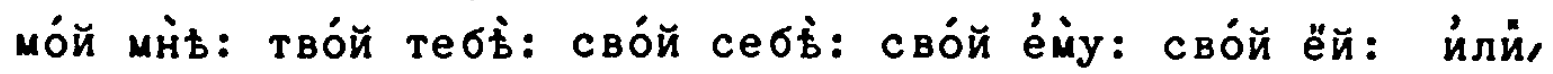
свод́ émy: свод́ е́й: свое́ е́й: свое́ е́му: й про . Сво́й е́му 'азйкъ, ёже хо́щетъ гйтъ:

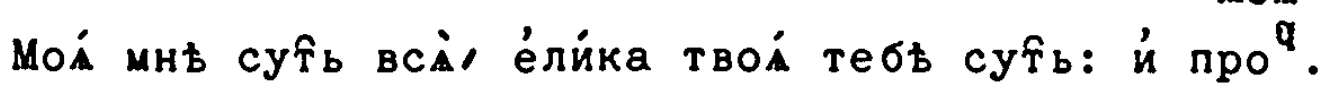

Tpétĩe:

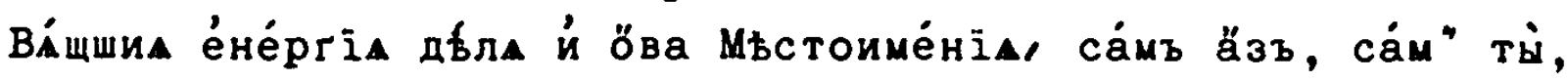
самárw ceбé, самárw érí: во всбхъ ро́дехъ, числе́хъ, и́ паде́хехъ

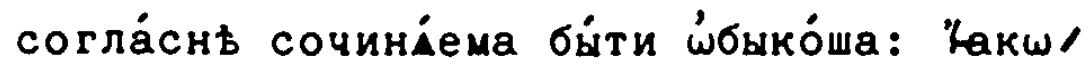

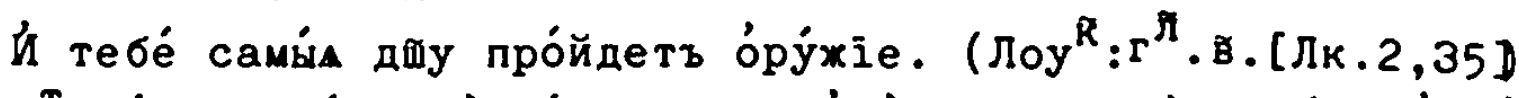

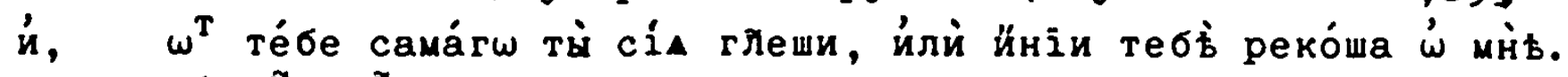
$\left(I \omega a^{\AA}: r^{\tilde{H}} \cdot \operatorname{Ri}_{.}\right)[I \omega .18,34]$

Четве́proe:

Бйгл́пное Ӑттіческагш дї́лекта сво́йство, дво́ю Оу́каза́те ныхъ Мьстоиме́ній, й, Соу́зомъ сви́зану да́телну, й Славдннш" ёсть $\because$ оупотребле́ніи: Һакш,

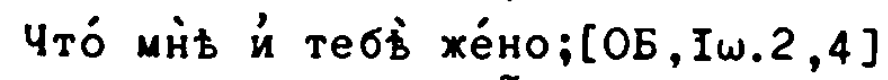

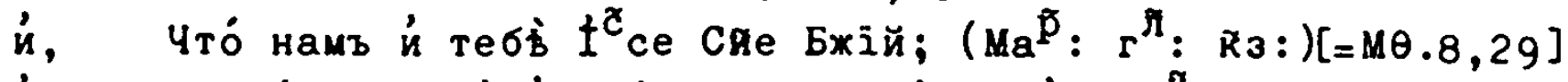

й, Ничто́ же тебі́ и́ пра́ведному сейу $\dot{и}$ про

$\dot{\omega}$ Возноси́телны ${ }^{x}$

Глава̀ в.

‘े Возноси́телномъ й Предидуи́е ${ }^{M}$ :

Пра́вило, Вrópoe:

Во ${ }^{3}$ носиттелнаА, са́мъ, се́й, ӧвъ, ӧнъ,

ц

тóй

[2006]

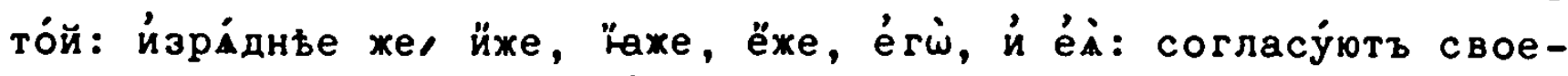

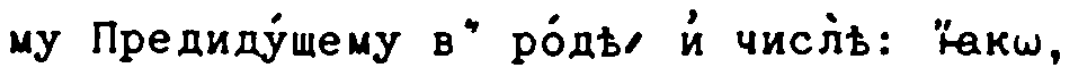

Ка́мень е́го же небрегоша зи́хдущіи, се́й би́сть во главу ойглу: (ча́лм: рзі.)[ОБ.чл.ІІ7, 22]

и, Mápi

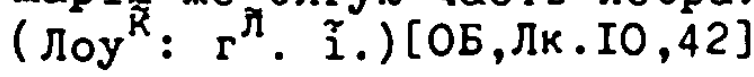


$\dot{u}$, Йзййе $\mathfrak{I}^{\complement}$ с со оучченикѝ свойми на ӧнъ по́лъ пото́ка ке́дрска, йде́же бі́ вы́ртогра́дъ, вонㅕ же внйде са́м" й оу́ченицй

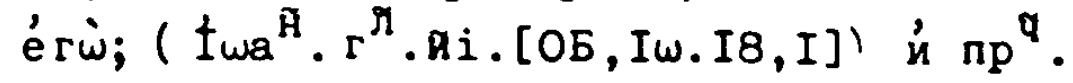

Пристеже́нде:

йже, Каже, ёже, Возноси́телнаа ме́жду дво́ма ро́домъ ра ${ }^{3}$ нству́ющима Существи́телныма поло́женнаА, Существи́телным", йлй зва́тел-

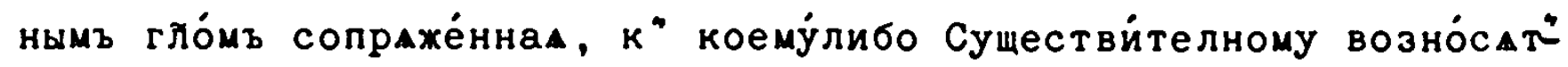
ca; "̈акw'

ёсть мб́сто на восто́цъ во Є́де́мь, йхе, йлй, ёхе ра́й нарицáet"ca.

й, Вйдђхъ высокопа́рну птйцу, "аже, йлй, йже орре́лъ и́мену́ет"cA. í $n \mathrm{p}^{\tilde{q}}$.

Оу́въще́ніе Пе́рвое:

Ёсть Аттікш" сво́йствод Славе́нску азыку вси́кш стра́нно, Возноси́телному со Предидујщимъ в" то Жде паде́жи сочина́тиса, на посльду́ющі̆ гйъ, йм же пра́

виму

[20I]

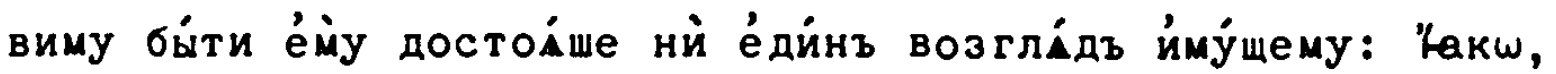

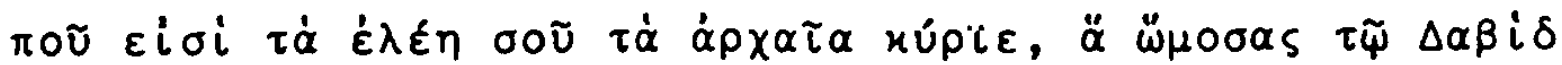

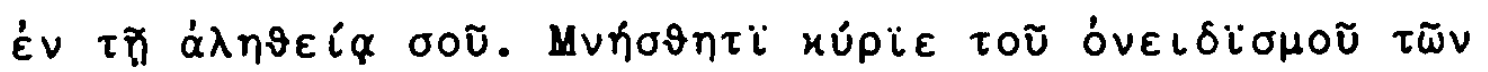

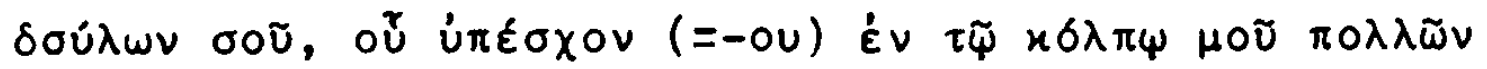

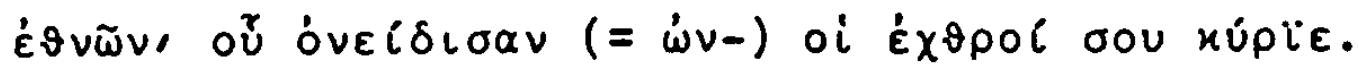
Славе́нски преве́дено сице:

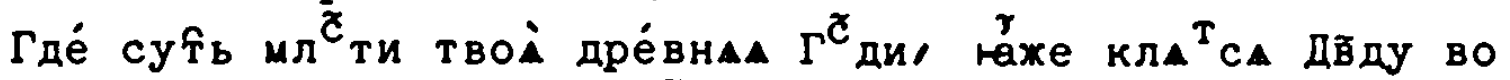
йстиннь твое́й; поманй $\Gamma^{\widetilde{C}}$ ди поноше́ніе ра́бъ твойх", ёже оуде́ржа в" на́дрь мое́мъ мно́ги 'ази́ки, ёже поноси́ша вра́зи

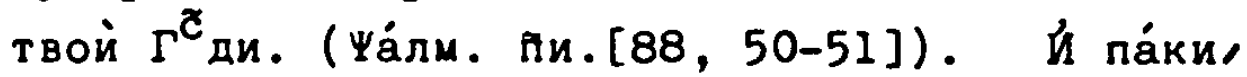

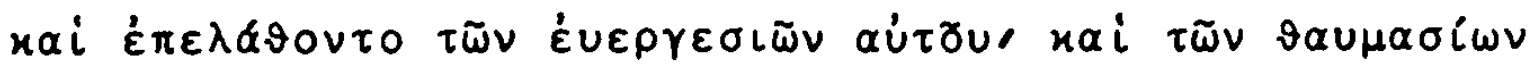

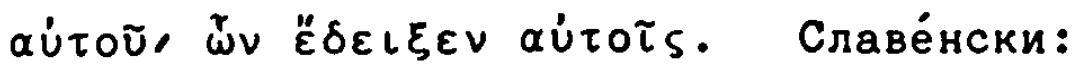

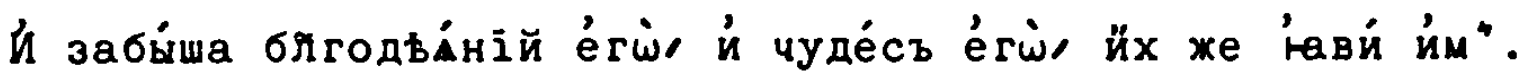
(ча́лм. бз.[77, II]) Й е́ще́,

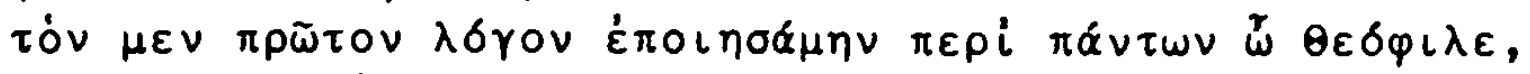

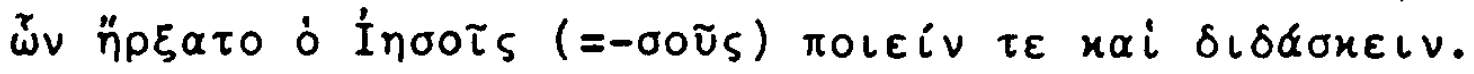

Славеннски :

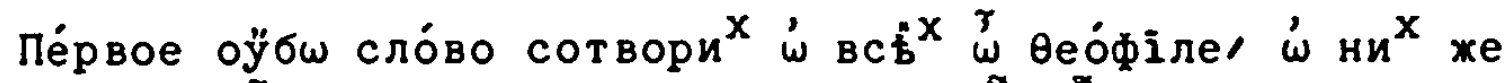

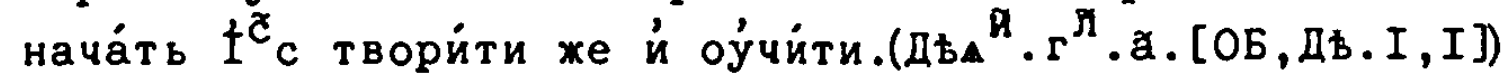

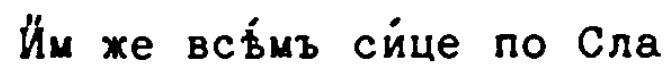

Цв ве́нска

[2016]

ве́нскаш 'азы́ка сво́йству преве́деныи" би́ти достод́ше,

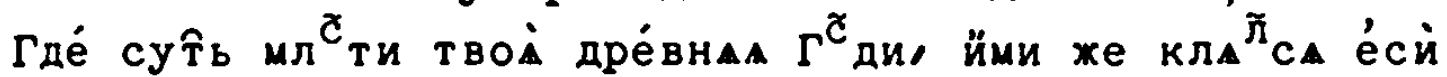




$$
\text { - } 202 \text { - }
$$

Двду во йстиннь твое́й: ПомАнй $\Gamma^{\mathcal{C}}$ ди поноше́ніе ра́бъ твойхъ, ёже оу́де́ржахъ в" на́дръ мое́м" мно́гих 'өзыкъ, йм же поноси́ша вра́зи твой $\Gamma^{\mathfrak{C}}$ ди: й па́ки,

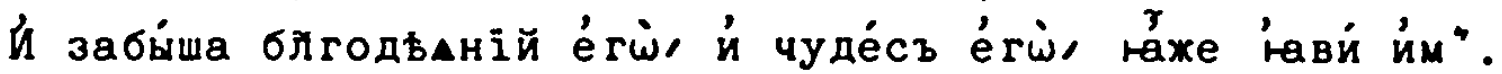
Й émé,

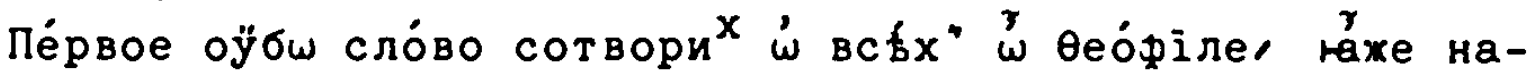
ча́ть $\mathrm{I}^{\complement}$ с творитт же й оуччи́ти.

Cи́uе бо мно́ган си" подо́бнал в" Бо“: писа́ніи Ӓттіческагш дїа́лекта сво́йства йску́сніи прево́дници преводи́ша: "акш во оукка́зы

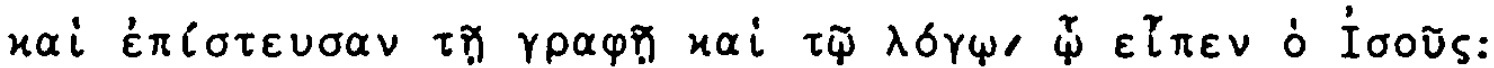

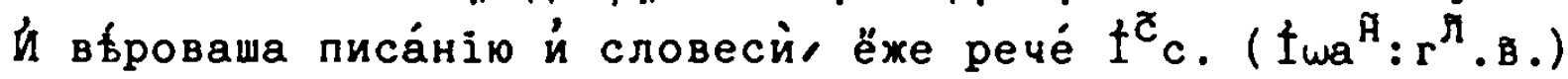

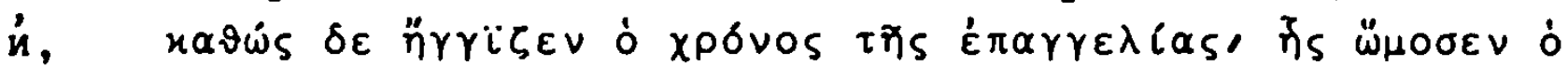

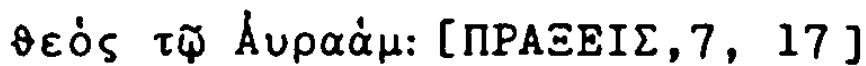

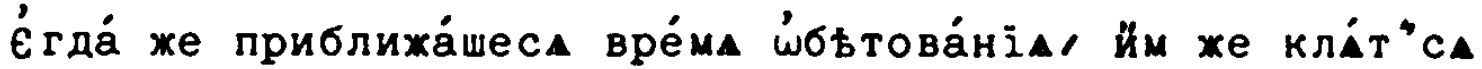

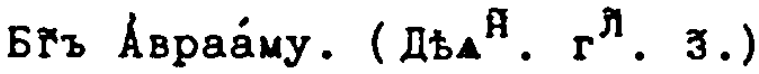

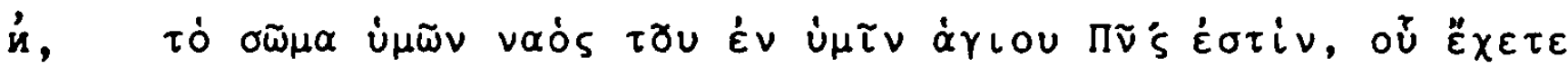

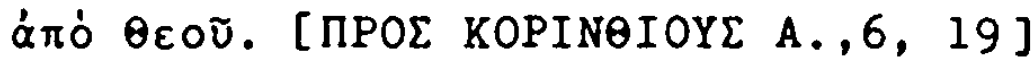

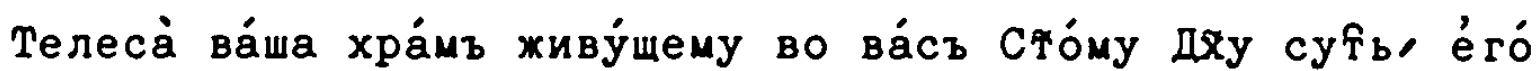
xe thate

$\omega^{T}$ Bra.

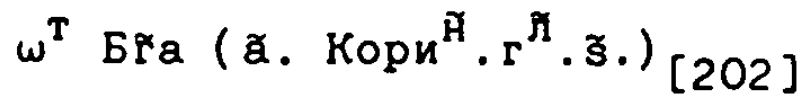

По Ӓттіческа діа́лекта, сво́йству превестй и́мб́вше,

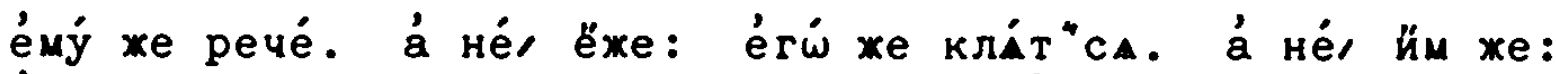
Érí же ймате, á не, éró же: и́ про q.

Оу́въще́ніе Вто́poe:

Пра ${ }^{\tilde{\text { B }}}$ : Tре́ті́:

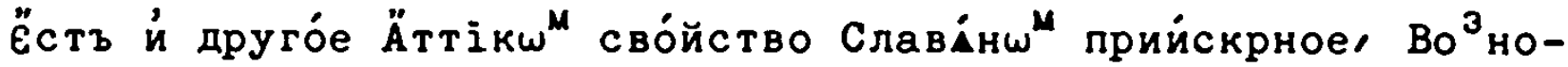
си́телному свое́ Пре иду́щее пре вари́ти: Ґакш,

Érдá же оусль́ша [ $\mathfrak{I}^{\mathfrak{c}} \mathrm{c}$ ] Какш боли́тъ Ла́зарь, тогда̇ пре-

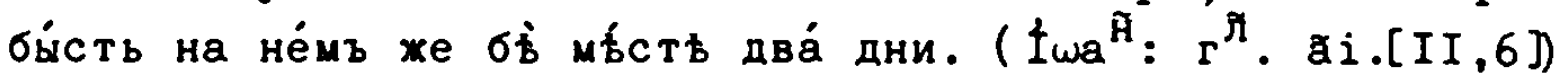
й, Во́ $\dot{H}$ же äще де́нь ско́рблю, приклонй ко мніь ойхо твое́:

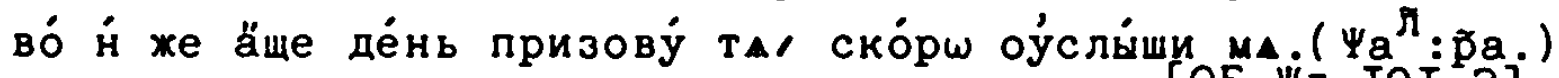
Пра́вило, Четве́ртое:

Сво́йстве но Славе́нскому 'азйу, Пако же Гре́ческому й cé

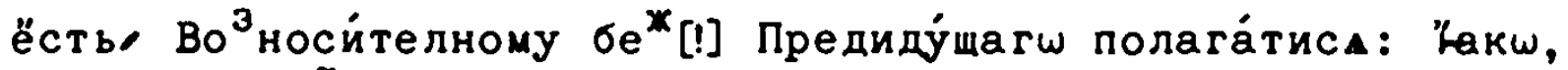
Глю ґ́xe подоба́етъ: й не оусслишиши йх же не подоба́етъ: и про

\section{Пристеже́ніе:}

Полага́тиса Ӓттікшвъ нра́вомъ B" то" паде́жи, в" не" же Преди- 
ду́щему полохиттса достод́ше, зае́два ёсть свойственно: Какш,

Бйгоу́менъ ёсть йже не $\underset{\mathfrak{\omega} \tilde{f}}{c \kappa о p}$

би́тв

[2026]

бйтъ 'ं них" же не ймать, но ра́дует"са $\dot{\omega}$ нйх" же ймать:

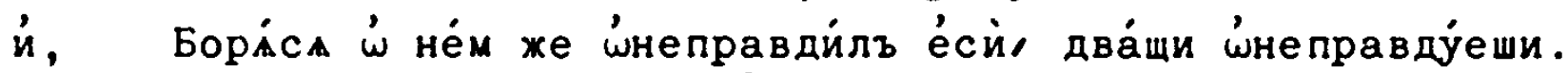
Славе́нски сво́йственнье оумо ̆̈чуему Предиду́щему, Во ${ }^{3}$ носйтелному же во Гй паде́хи полага́ему, сйще.

Бл̃гојјннй ёсть, йже не ско́рбитъ $\dot{\omega}$ йх же не ймать, но ра́дует"са '́̀ f́xe йма́ть:

и, Бори́са $\dot{\omega}$ в" не ${ }^{M}$ же '́неправдйлъ е́сй, два́щи '́неправду́еши:

й пр". НАко же сво́йственнье глем",

пода́ти ми '́ставле́ніе, raxe содьА эльь: не́жели,

йх же содьи́хъ зльь: й про

оуввще́нie тре́тіе:

Поне́xе зде́ '́ Гре́ческих" Арөръ на́шимъ азкомъ Разлйчій йлй чле́н $\omega^{8}$ сочине́ніи словво:

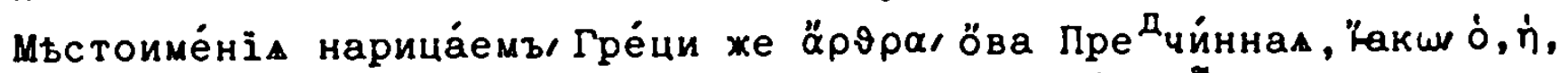

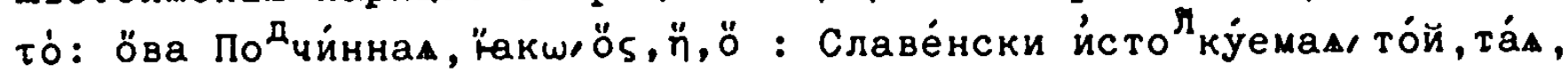
то́е: й йже, йаже, ёже, со свойми всбхъ чйслъ паде́жми. Досто́итъ на́мъ вы́стны Славе́нскагш дї́лекта тща́тела сотвори́тилне йм же ӧбразомъ сво́й

[203]

сво́йстве бо діа́лекту тf́хъ оу́потребле́ніе, Пре чйнныхъ йзри́днье, льпота்

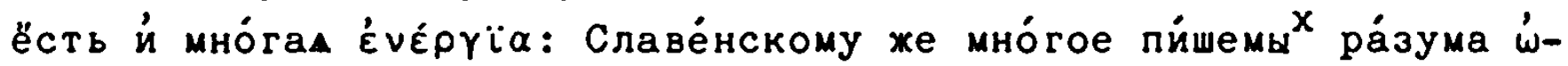
мраче́ніе, й Сочине́ніа грамматічна смате́ніе, ра́звь чйстш Во ${ }^{3}$ но-

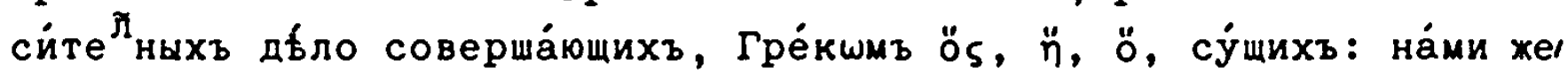
йже, Каже, ёже, преводи́мыхъ, вы́ну й Гре́кшмъ й славйншмъ Преди-

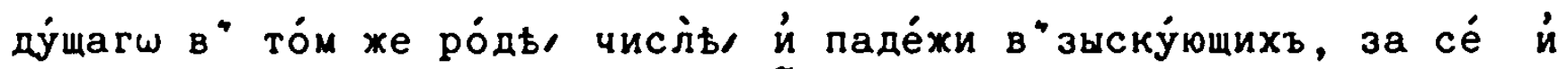
По Диинна ймъ, на́м же Возноситте ${ }^{\sharp_{н а}}$ рече́ныхъ. Гйющимъ бо Гре́кшщъ,

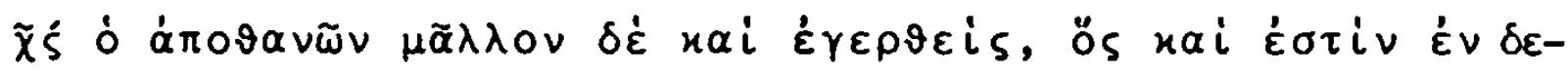

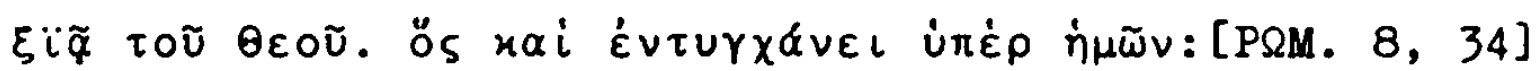
до́брь Славе́нски глемъ,

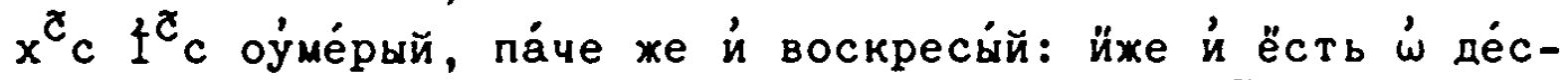
ную Бrа, йже й приповьдујетъ $\dot{\omega}$ на́съ. (Римл. $\mathrm{r}^{\Re}$. й)

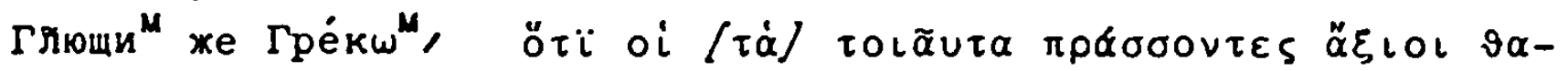
v\&rou cioiv: [PQM. I, 32]

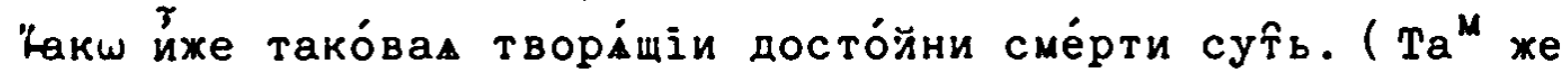
r. 天.) nai $\Pi \alpha$ 


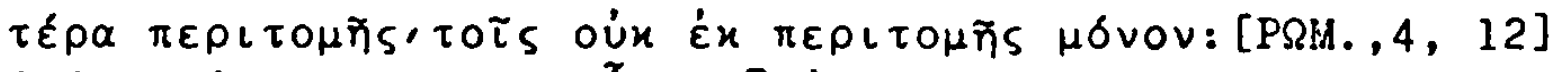

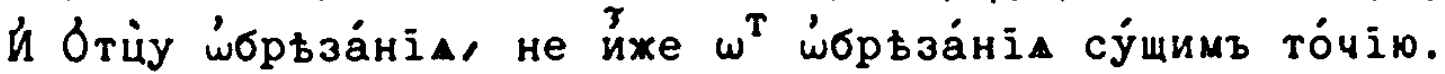
(Ри ${ }^{M}: r^{\mathfrak{H}}:$ д. $)$

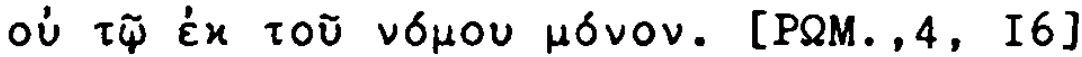

He ёже то́чію су́щему $\omega^{T}$ за́кона: ( $\mathrm{Ta}^{M}$ же)

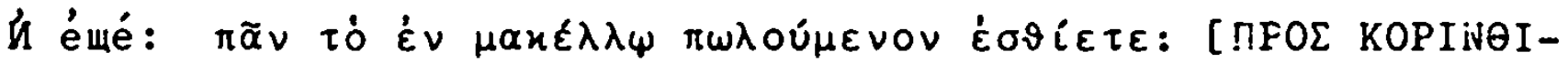
OY $[$ A., 10, 25]

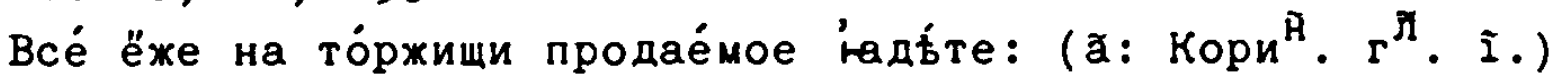
Славе́нски преводи́ще, всје Мъстоиме́ніп о̋ва, йе, й, ёже, прича́стіє ${ }^{M}$ прилага́emb:

иже твори́щїи: йе су́щимъ: ёже су́щему: ёже продае́мое:

йе ходйщимъ:

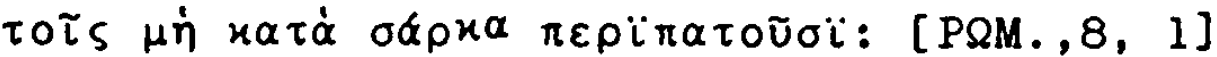

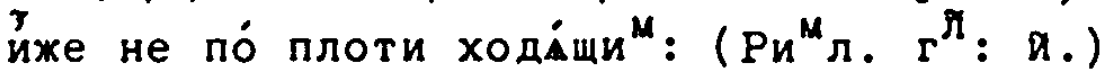

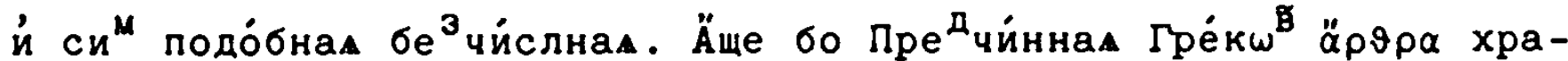
на́ще, преводи́ти Слава́нш достов́ше, что́ бы сегі் нейску́снђе было́ свое́ на ${ }^{M}$ Славе ${ }^{\text {म̆}}$ ска діа́лекта чйстое сво́йство чу́ждагш нима́ ла сему прили́чными сво́йствы Һннечища́ти. Тб́м же вб́стно бу́ди,

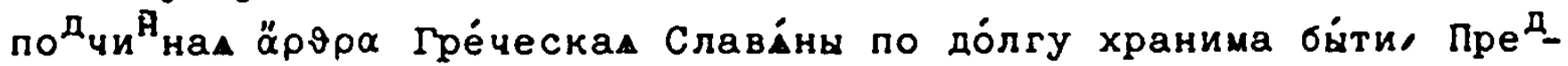
чйннаА же то́кмш в" претвора́ніи прича́стій во гйы Қакш е́гда̀

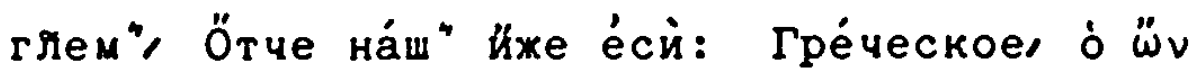

Прира

приразумбемое прича́стіе, на вто́рое гйа лице́ претво́рше: Йм же

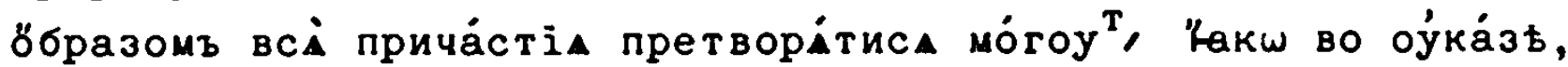

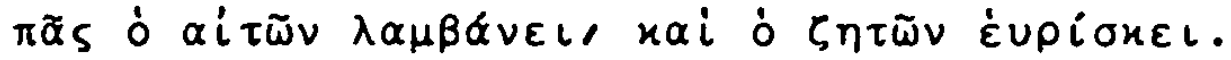

Славе́нски

Вса́къ просай приемлетъ, й йщхй Прича́стіА та̀ во гйы гретво́рше, рече́мъ,

Вса́къ йже про́ситъ, прие́млетъ, й йже йщетъ, ஸ́брьта́етъ.

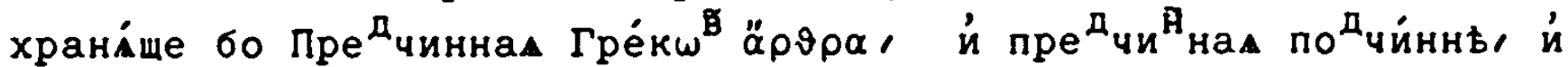
всґ всбхъ чйслъ паде́жА ймени́телны е́динстве́нны несво́йственнђ

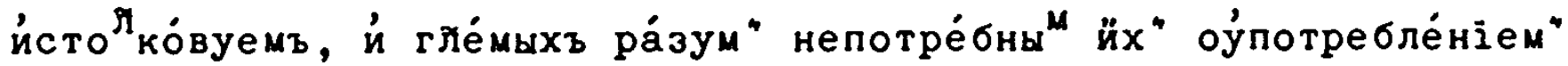
$\mathrm{pa}^{3}{ }_{\text {вра }}{ }^{\mathrm{T}}$ н '́гуща́емъ, й '́нечища́ем": ёже о́бо́е ви́дыти, грамматі́ч-

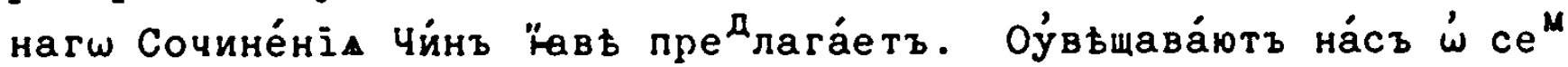
й йку́сны прево́дник" мно́гіи, Славе́нскагш 'азы́ка сво́йство в" преведе́ніи сохра́ншихъ, оу́ка́зы; Гакш,

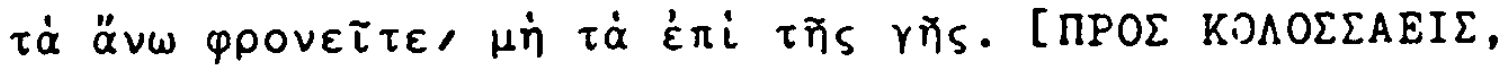
$3,2]$

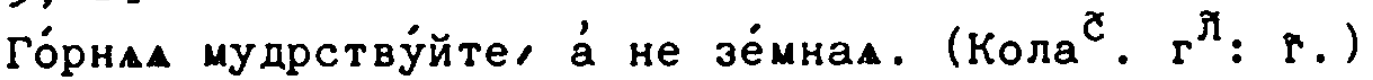




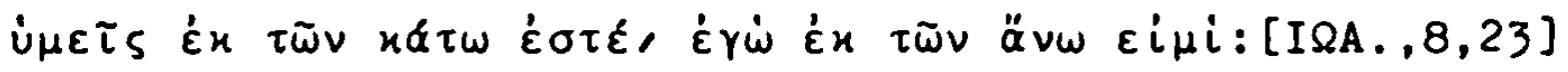
Bì $\omega^{T}$ нй

цะ $\left(I \omega a^{\mathfrak{H}} \cdot r^{\mathfrak{H}} \cdot \cap_{.}\right)$

нихъ е́сте́, äзъ $\omega^{T}$ вйшнихъ ёсмь.

нихз

[2046]

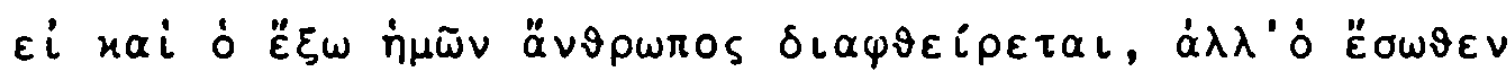

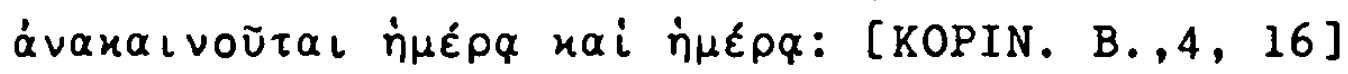
Äще й внбшній на́шъ чливкъ тлбетъ, но́ вну́трній ஸ́бновлі́-

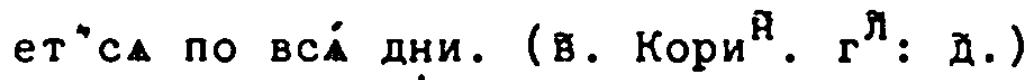

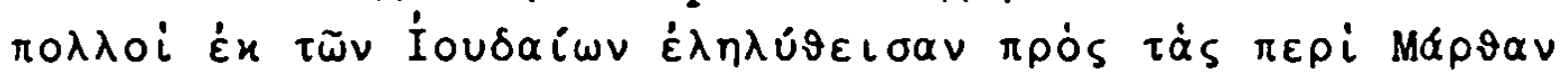

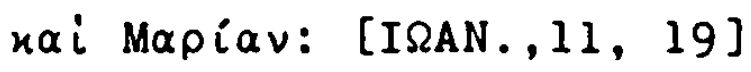

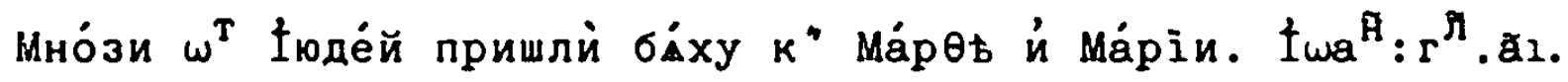
Й сим подо́бнал бе ${ }^{3}$ чйслнаА Божестве́нныхъ писа́ній мб́cта.

$$
\begin{gathered}
\dot{\omega} \text { Во }{ }^{3} \text { вратите }{ }^{\mathfrak{A}_{\mathrm{Hb}}{ }^{\mathrm{x}}}: \\
\text { Глава், } \mathbf{\Upsilon} . \\
\text { Пра́вило, } \tilde{\varepsilon}:
\end{gathered}
$$

Во ${ }^{3}$ врати́телныхъ себе́, себі́, сі், собо́ю, érí, éà, со всы́ми ймъ всб́⿱хъ чйсль паде́жми оу́потребліемъ, возвраща́ему коему́ждо лицेу, в" ко́свено" ко́емъ паде́жи, са́му на́ са: 'Какш,

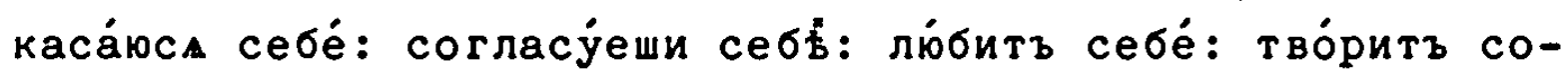
бón: мо́ли ${ }^{\mathrm{T}} \mathrm{cA} \dot{\omega}$ себі:

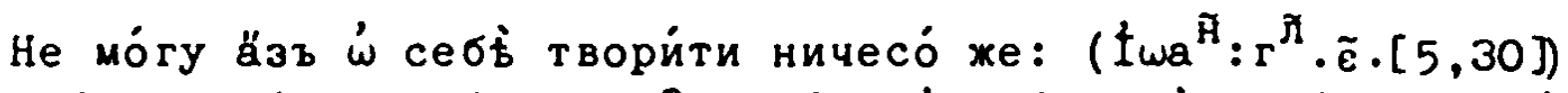
й, Бре́мене па́че себе́ не во двиза́й, й крб́пшу и́ бога́тшу себе́

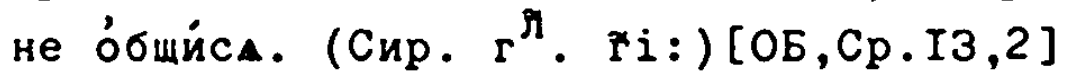

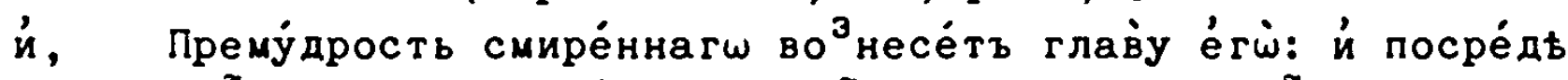

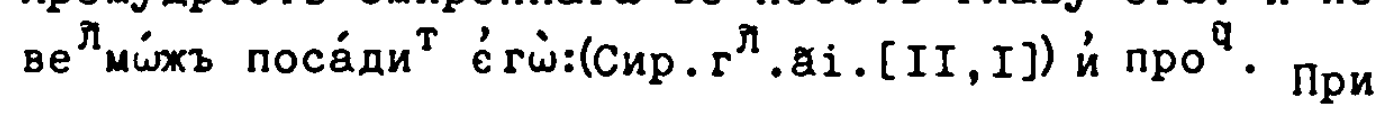

\section{Пристеже́ніе:}

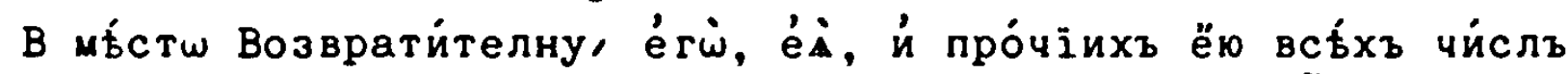

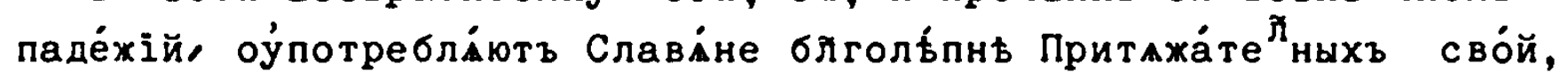
свод, свое́: "̈акш,

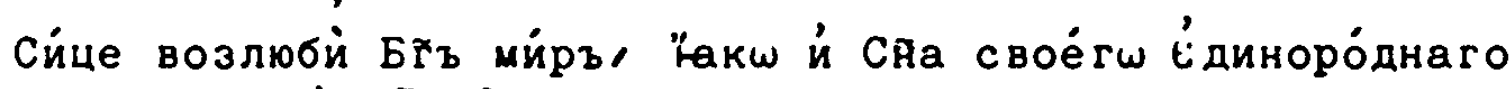

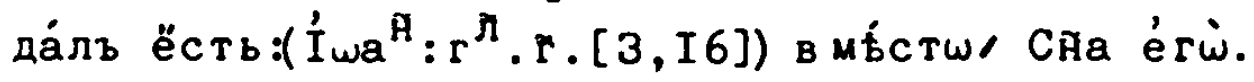

$\dot{u}$ Äще жена̀ пу́ститъ му́жа свое́гш, и́ поса́rне

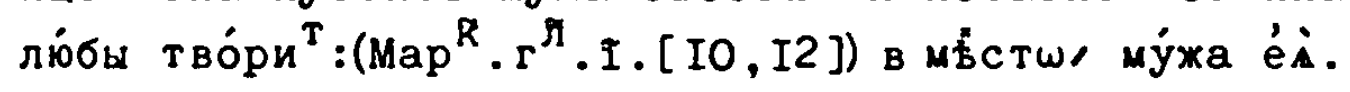

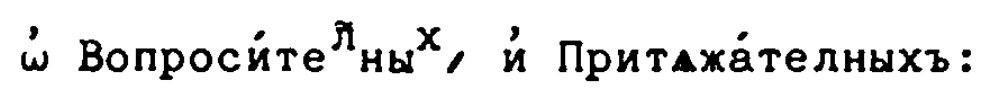

\section{Глава், д̆:}

Пра́вило, § :

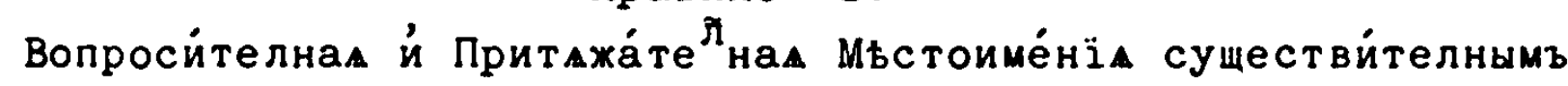

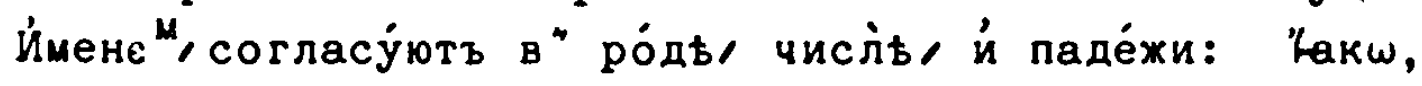


кто́ человв́къ; чій сйъ; ка́А тва́рь; мо́й о́те́щъ: твод дще́рь:

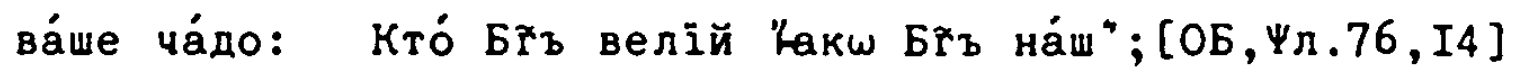
Ка́ о́бщина̀ во́лку со ӓгнцемъ, тако́ же й грб́шниму[!] со бл-

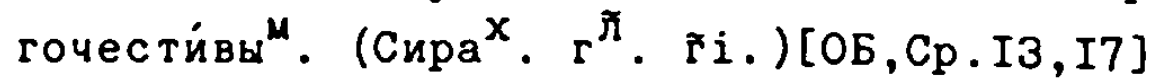

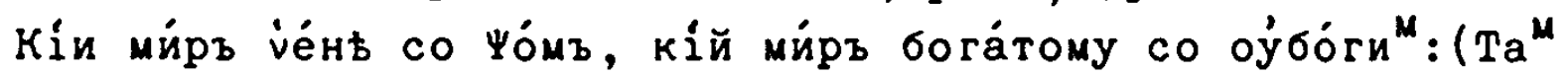
же) иं npo ${ }^{q} \cdot[O 5, \mathrm{Cp} . \mathrm{I3}, \mathrm{I8}]$ $\dot{\omega} M b$

$\dot{\omega}$ Мьстойме́ніихъ существйтелнь оу́потреблі́емв :

[2056]

Глава̀, х.

Пра́вило: за:

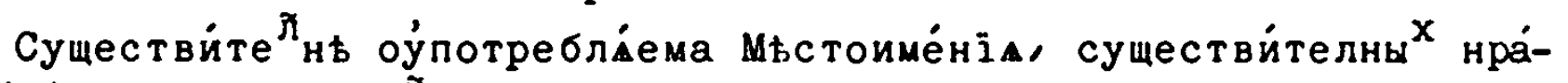
во "Йен " родйтеле

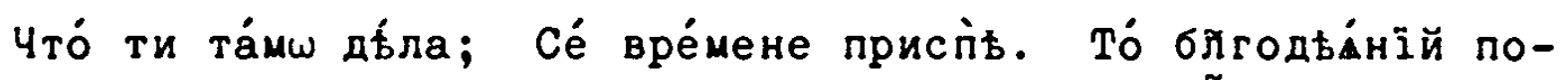
каза̀. Öно собесьдова́нї востомануу: и́ про

Пра́вило: $а$ :

Существи́телнам недоумбннатш знаменова́ніА: "акш, любы, ми́лость, попече́ніе, жела́ніе, ре́вность, й сим подо́бнал, е́гда̀ ды́̆̆ство йлй притажа́ніе знамену́ют", притажа́телным" сочина́ют" "са: "акш, Любо́вь мой: жела́ніе твое́: ре́вность ва́ша: й про .

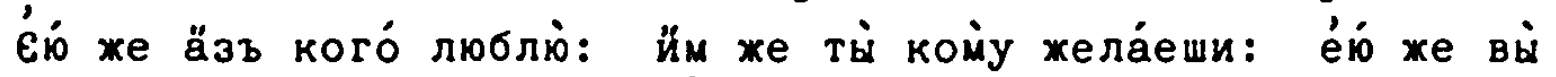
по кому ревну́ете: $\dot{и}$ про

Érдá же страда́ніе знамену́ютъ, Родйтелны мене́, тебе́ себе́, на́сы ва́съ, прита́хуть: laкw,

Любо́въ мене́, жела́ніе тебе́, ре́вность ва́съ, попече́ніе на́съ: 'ं про '.

ध́ं же ӓзъ любллен бы

вáю

[206]

ва́ю: йм" же тѝ жела́нъ быва́еши: в" не́й же вй ревну́етесл: йм же '́㇒ на́съ печалу́ете:

Пра́вило, $\tilde{\theta}$.

Существйтелны ${ }^{M}$ Частвйтелны ${ }^{M}$ роди́теленъ первообра ${ }^{3}$ ныхъ припрӥет "са : "̈акw"

Ча́сти мене́ '́тщети са:

сі́есть, руку, но́гу, ӧко, сми́сль: йлй что́ тако́во дш்̃ лйбо ти́ла погуби́хъ.

Да́ждь ми тебе́ нбчто: полль себе́ даде́ ми: й про ". Пра́вило $\tilde{i}$.

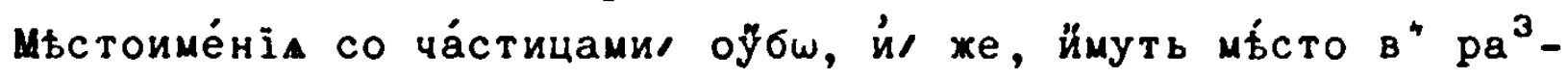
дьленніих "нки 


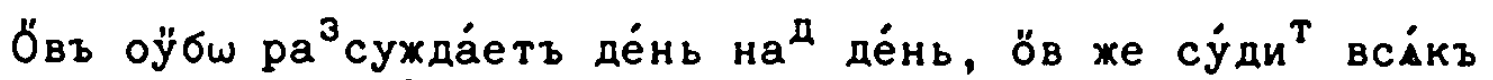

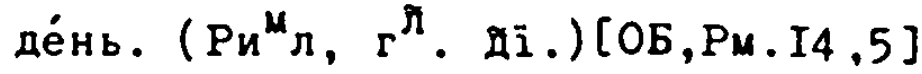

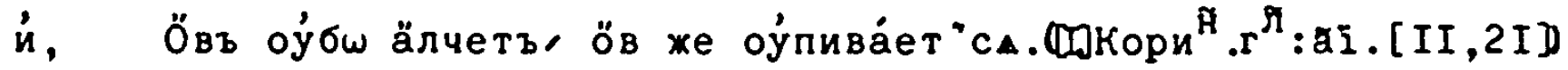

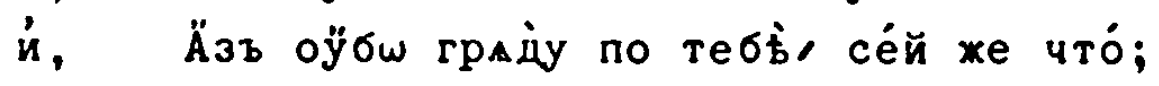

$$
\begin{aligned}
& \text { 'ं СОЧИНЕНГИ ГЛАГОЛА: } \\
& \dot{\omega} \text { Ймените }{ }^{\hat{H}_{\text {но }}} \text { со ГЛ̆омъ: } \\
& \text { Гла }{ }^{\tilde{B}} \text {. } \mathbf{a} \text {. } \\
& \text { Пра́вило: а. }
\end{aligned}
$$

йменйтелный Гйу ли́чному Накло

не́нĩ

[2066]

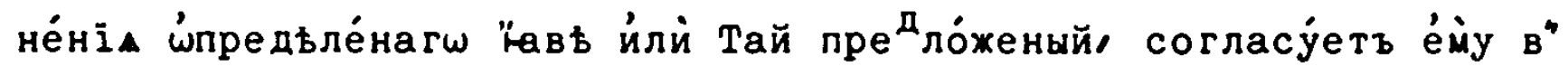

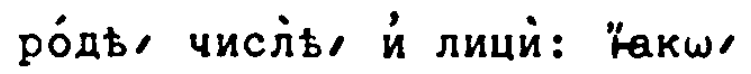

Йско́ни сотворй Бг̃ й, Äще хо́щеши соверше́нъ бйти, йдй прода́ждь ймб́ніа твод́, даждь нйщим, й ймб́ти бу́деши сокро́вище на ибсй: й прийдй,

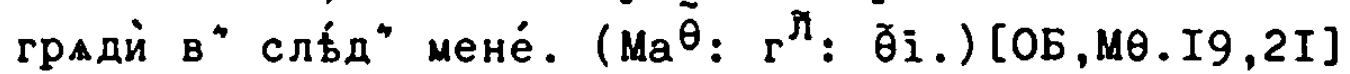

$\dot{\omega}$ Йенйтелномъ Дво́йственно ${ }^{M}$ :

Пра́вилол в.

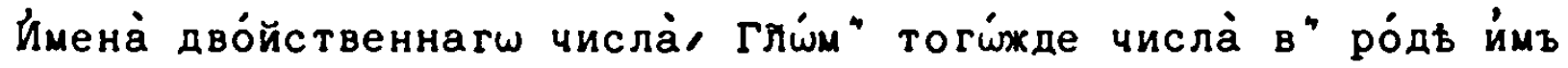
й лицй согла́сна сочина́ют"сА. "Накш'

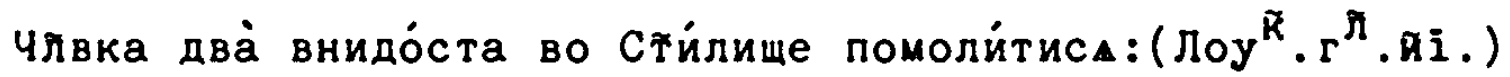

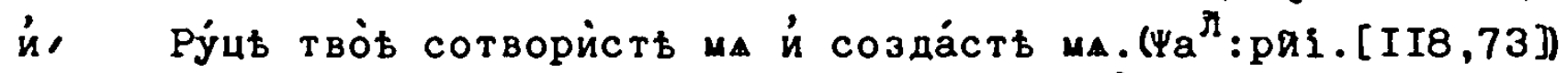
й, Рамена́ mол побо́рета по тебі: й про

Пристехе́нін:

Пе́рвое :

Два̀ и́мена̀ Соу́зомъ сопраже́ннаА, дво́йственнагш числа̀ Гйш́мъ/ в"

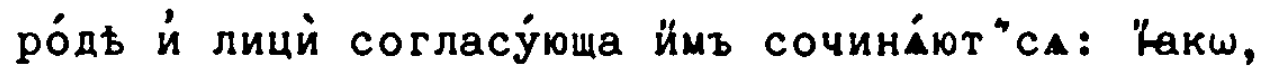

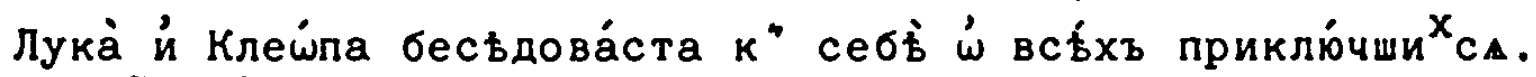

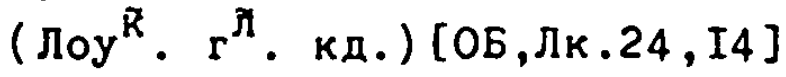

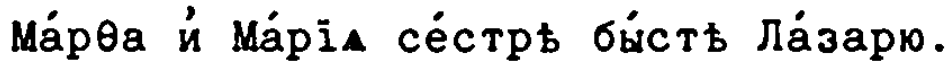

\section{Brópoe:}

Bтó

[207]

Множша же дво́ю ймену сопраже́на Сојзом иं несопрахёна, ӧвогда мнохестве́нъ гйъ приемлютъ: 'Һкш,

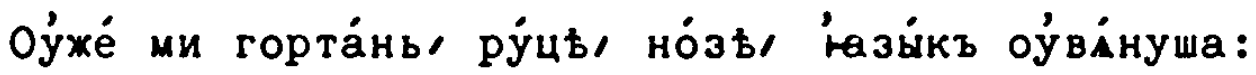

ӧвогда же е́динствённы" оудоволіют"са: "Һакш,

Нищета̀, чистота̀, й послуша́ніе спаса́етъ Нноки.

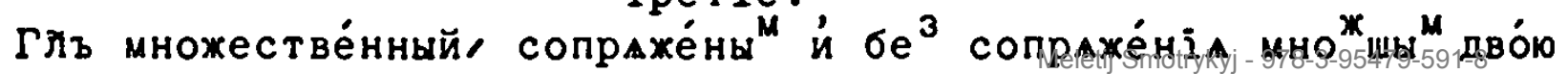




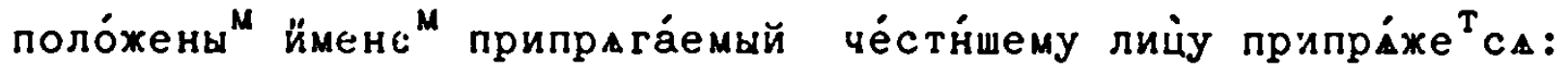

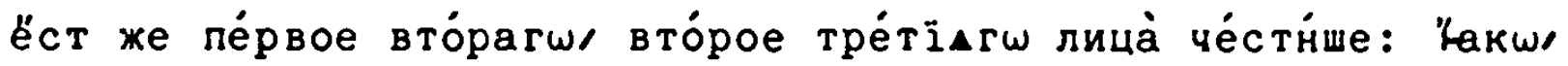

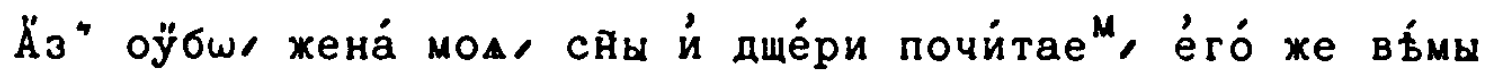
Бra: ти́ же й дома́шніи твой почита́ете, éró же не ви́сте: й про ${ }^{q}$.

\section{Четве́pтое:}

Дво́йственъ Глъ, дво́ма йменема припрага́емый в" лицй йма со-

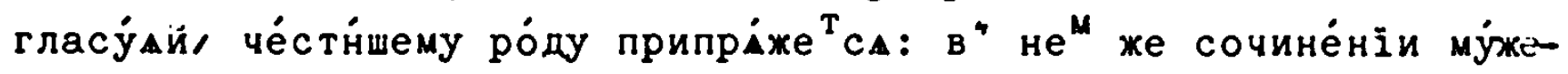
скій ро́д" же́нскатш и́ сре́днагш⿱ сре́дній же́н́скагш че́стншій ёсть: "lakw,

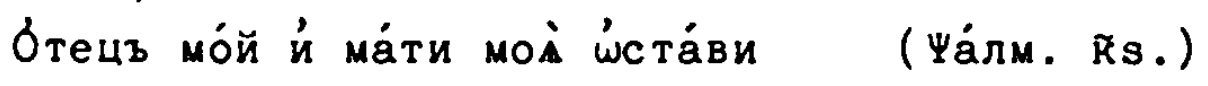

ста ma: [OБ, $\Psi л .26$, IO]

cta

[2076]

й Мл ть й йстинна срьто́стьса, пра́вда й ми́ръ '́блобыза́стаCA: ( Ұа́лм. пд:) [ОБ, ४л.84,II]

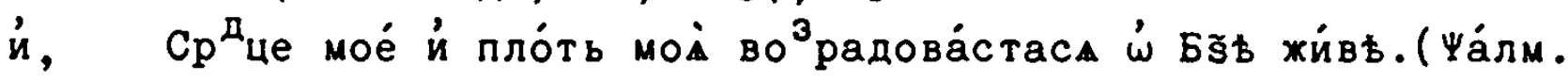

ñ.) $[O 5, \Psi \pi .83,3]$

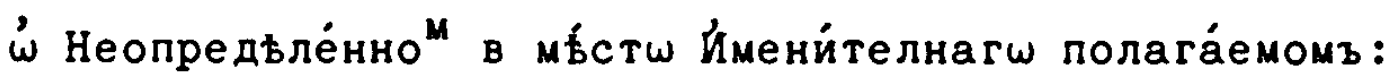

Пра́вило: $\mathbf{x}$.

Мно́гажды до́лгъ Ймените й нагш Неопредъле́ный глу наверша́етъ: Какw, Нв́сть мое́ да́ти: й про

$$
\begin{gathered}
\dot{\omega} \text { Йени́телномъ по Гл̆в: } \\
\text { Пра́вило д. }
\end{gathered}
$$

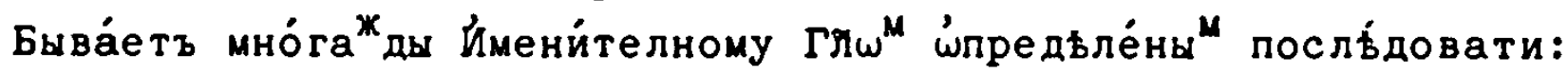
"акш, живе́тъ бе ${ }^{3}$ печа́ленъ: оуммира́еть йнъ: вмьниет"сА сть: й npo ${ }^{q}$.

’’ Предидущ́емъ й Посльдую́ще

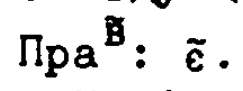

Существи́телны ${ }^{M}$, Зва́телны предиду́тъ й посльду́ютъ Ймени́те

Со́тове медо́вніи словеса̀ до́бра, сла́дкость же йхъ и́сцьле́ніе дйА. ( При $\left.{ }^{\mathrm{T}} 4, r^{\Omega}, \widetilde{3} \ddot{i}:\right)[O Б, \Pi p \cdot 16,24]$

Сластолю́біе ёсть

ёсть ойдица дї́вола влеку́щал во поги́бель.

й, Бога́т“ство мно́гимъ злш" ёсть покро́въ.

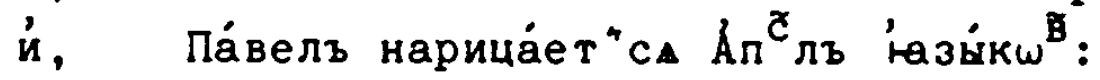

Мнйшиса бйти му́дръ: Ӓзъ сли́шахъ та̀ ӧтро

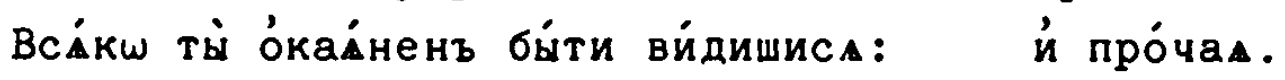

Йногда друга́гш йменителна до́лгъ, Неопредъле́нный наверша́етъ: 


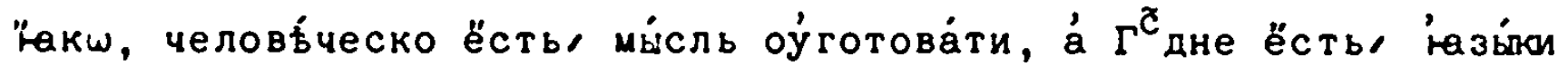
стро́ити.

¿́ Uменйтелныхъ Собира́телны

Пра́вило, ฐ̃.

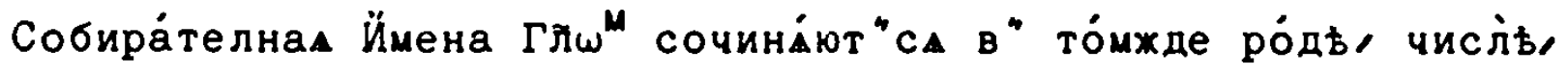
й лицй: Lакш,

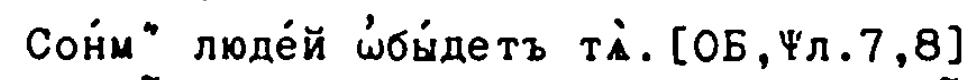

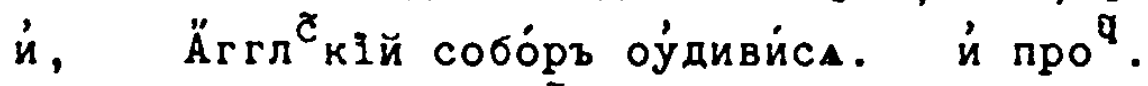

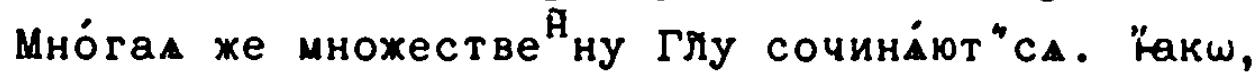
Вса́ку ра́дость ймt́йте бра́тіА мод̈:

$\dot{u}$ дро́ждіе не и́скида́шаса $\omega^{T}$ не́г $\omega:$ й про ${ }^{q}$.

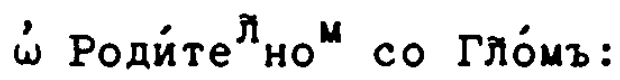

Глав $\dot{a}$, в.

Пра́вило: ॐ3.

Глй послуша́ніА, преслуша́ніц, жела́

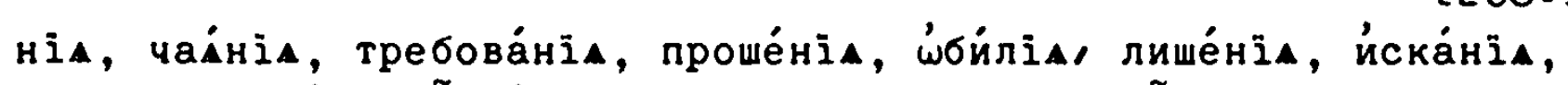
стыдбніА, й про :

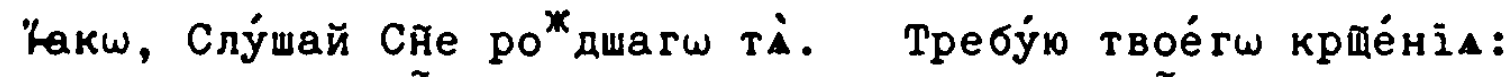

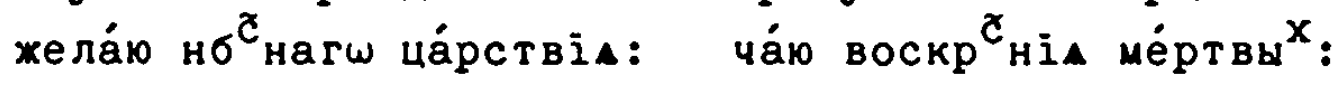

лиша́юса прему́дрости: йіу цьломуддріА:

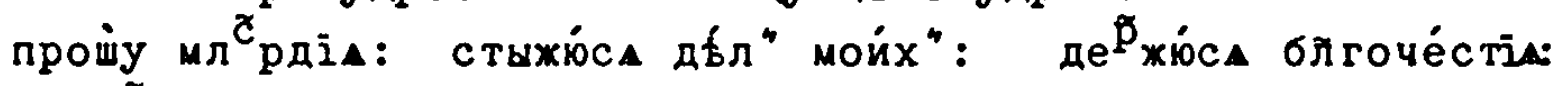

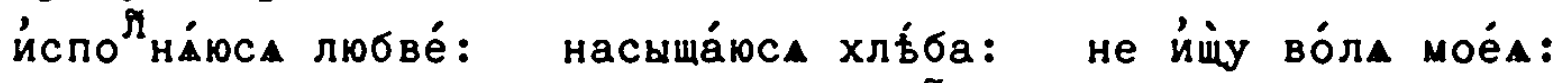
не требу́ю привреме́нныхъ: $\dot{и}$ про

$\dot{\omega}$ Гле́хъ ча́стицу, не, приемлющих

Пра́вило, й.

Гйй Вини́телному сочина́еміи ш'рица́ніА ча́стицу, не, приемлюще, вини́телный претвори́ют" в" роди́теленъ: "акш,

Чáдо, живота̀ нищагш не оулишй й не оуминй ӧчію просли́ву' дш̃А ӓлиущиА не '́скорбй, й не ра ${ }^{3}$ драха́й му́жА в"нище-

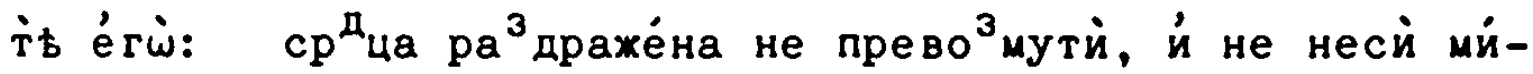
мw требу́ющагш дах́ніА.

$\dot{\omega}$ Гйв, ёсмь, Роди́телному сочиндемомъ: Пра́вило, $\tilde{\theta}$ :

$\Gamma \tilde{H}_{3}$

Гль ёсмь, притаха́ніА сйлу ймущщ", роди́те ному сочина́ет"сА:

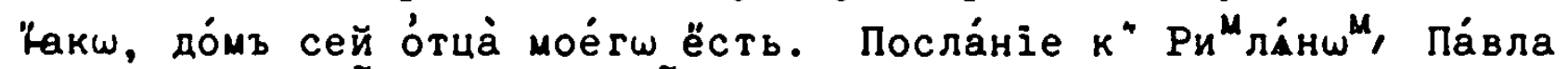
ёсть Ап ${ }^{\complement}$ ла. й про 
¿́ Да́телномъ со Гймъ:

$\Gamma \mathbf{a}^{\mathrm{B}}: \mathbf{x}$.

Пра́вило, í.

Да́телному Сочина́ют" СА Гйи служе́ніА, Помага́нї, повинове́ніА, посльдова́нїА, завидб́ніА, поноше́нїА, прербка́нїА, ревнова́нїА, со вђтова́ніА, навђтова́ніА, внима́нї: и́ про

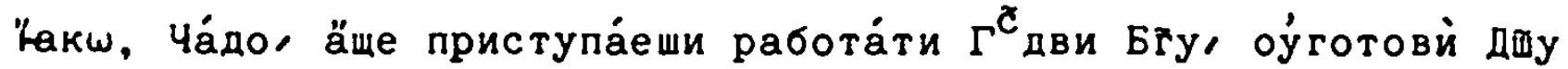
твою во и́скуше́ніе. Помозй ми Бж̃е саиси́телю мо́й:

Повину́йтесА наста́вник $\omega^{M}$ ва́шим" й покара́йтесА:

посльду́йте е́муу: не завйди творйщимъ безако́нї:

поноша́ет" ми вра́гъ: прекосло́виши йстиннь:

не ревну́й лукавну́ющи : во́нми ми: совьту́ю тебі:

навьту́й злобї: म́ про

‘́ ӧбщемъ Да́телномъ со Гйовъ:

Пра́вило, व̃i.

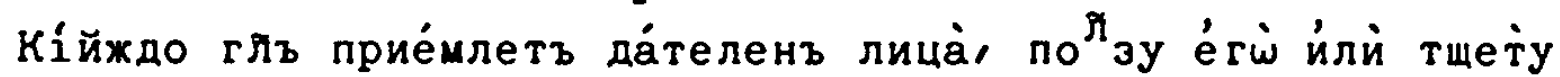
знамену́ю",

Чв

lakw:

"акш Мн̀ь насади виногра́дъ се́й.

С̆е äще прему́дръ бу́деши, тебі் прему́дръ бу́деши й йскрны ${ }^{M}$ твоймз.

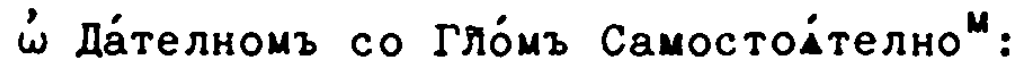

Пра́вило, вї.

Всб́хъ зали́гъ Глй́ъъ сочиндемъ быва́етъ да́теленъ Самостод́теленъ : 'Һакш,

Бร̃.у даю́щу за́висть ничто́ же оу́спьва́етъ.

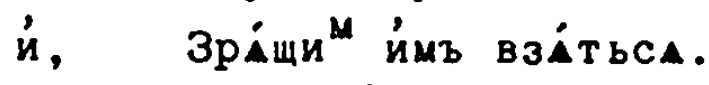

$\dot{\omega}$ Гл̆ь, ёсмь, Да́телному сочинцемомъ:

Пра́вило, rí.

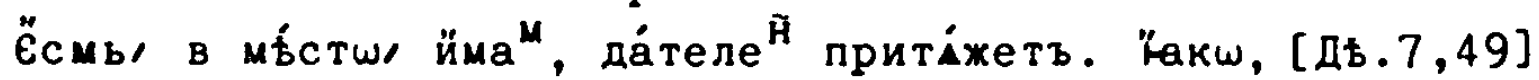

нбоо ми ёсть престо́лъ, земла́ же под̆но́хіе нога́mъ моймъ:

й Сутьь ли тй ча́да, накажй Á: Сутิь ли тй дщери, внима́й тб́лу йxъ.

$$
\begin{gathered}
\dot{\omega} \text { Вини́телном со Гломов: } \\
\text { Гла }{ }^{\tilde{B}}: \text { д. } \\
\text { Пра́вило, ди. }
\end{gathered}
$$

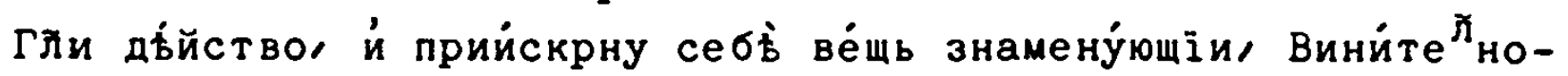
My СочинА́⿴囗"

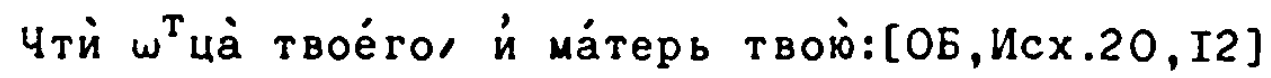


й ббличй прему́дра й во лююби

Tì:

$T \dot{A}:[\Pi p \cdot 9,8]$

й Пи́хъ вино̀, и́ спа́хъ со́нъ сла́до ${ }^{\kappa}$.

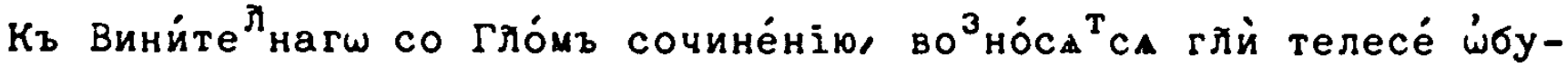

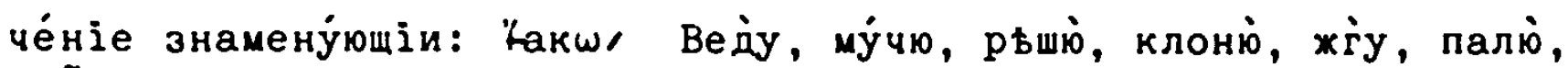

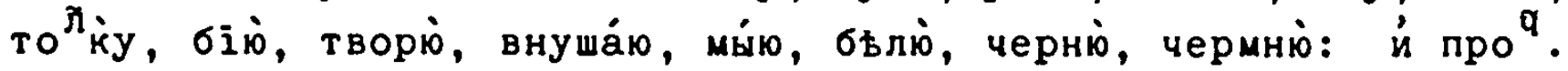

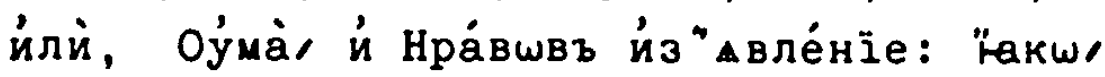

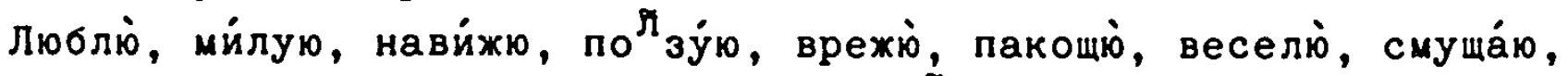
оу́тьша́ю, клеве́щу, оу́ничиха́ю: й про Ф.

йлй, Наказа́ніе, й страстова́ніе: "اкшл

Оуччю, наоу́ча́ю, нака́зую, грf́ю, теплю̀, мочю̀, сушю̀, оу́вьщава́ю, слю, полага́ю: й проq.

Йлй, Сла́ву' й Че́сть: 'Һакш,

хвалю̀, сла́влю, пою̆, велича́ю, оу́блаха́ю, почита́ю, воспьва́ю, честву́ю, велича́ю: [?] й про q.

Йлй, Ра́зумъ: "акш'

บิ์

[2106]

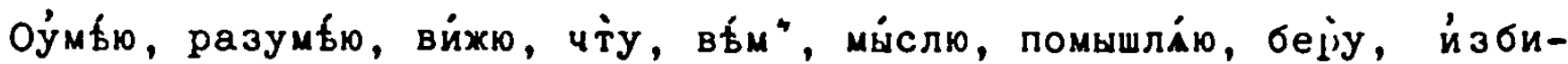
рáю: й про

Йли, Притажа́ніе: 'акш'

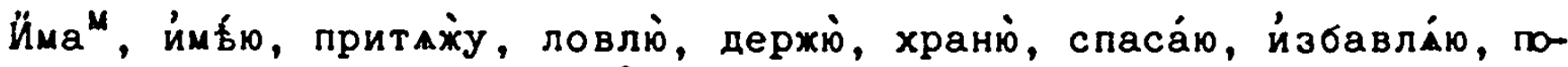
бъжда́ю, ஸ́брьта́ю: иं про".

Илй, Ле́сть: "Екш'

Лщю, прел́ща́ю, кра́ду, вмъна́ю, науща́ю: и́ проq.

Йли, Рукодьл́іе, й Худо́хество: Қакш,

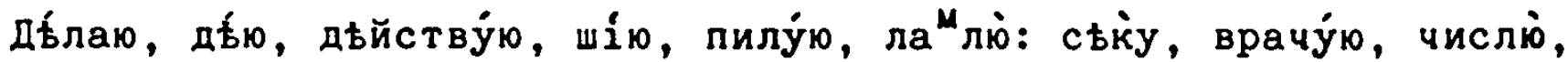
мб́рю, зйжду, ша́рю, пишу, теш்: й про ".

йли, купова́ніе, й продава́ніе: "ғкшљ

Купу́ю, продаю̆, йзмъна́ю, ценю̀, приобрђта́ю, прижію, прииждива́ю: й про q.

йли, е́ст ${ }^{\complement}$ ве́нное произведе́ніе: 'акшл

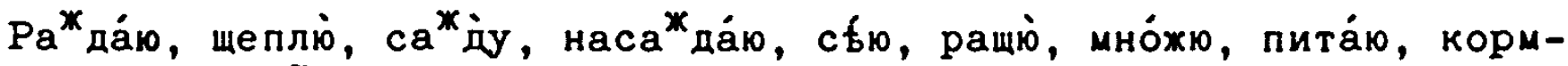
лі:

के дво́ю

[211]

‘́ дво́ю Вини́телну со Гйовъ:

Пра́вило $\tilde{1}$.

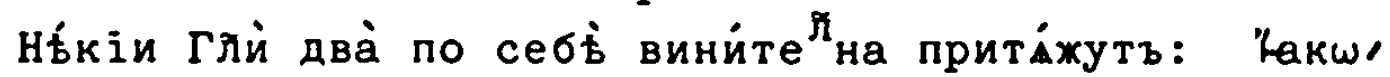
Йже напо́итъ вы́ ча́шу студе́ны воды во ймі мое: и́ про .

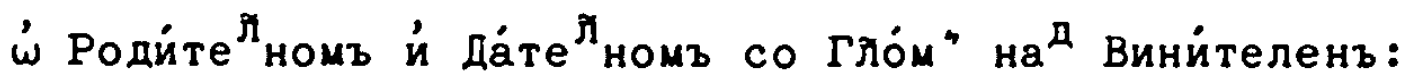




$$
\begin{gathered}
-212- \\
\Pi p a^{8}: \mathbf{s}_{i} .
\end{gathered}
$$

Глй оучченіц, лише́ніА, й äще кіи йніи, на вини́теленъ родйтелному ра́дуют"са: 'аки,

оу́чю́ тА тра"ма́тїки: Лиша́ю ті $3 e^{M}$ ныхъ бла̂гъ.

Äще кто лише́нъ ёсть прему́дрости: й про ${ }^{q}$.

Йзітї:

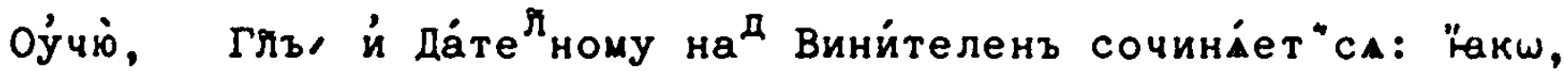

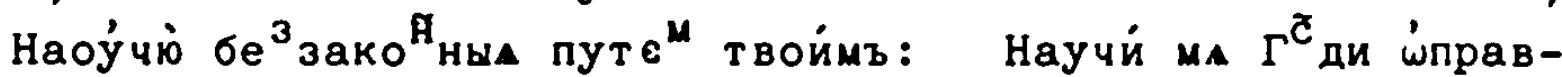

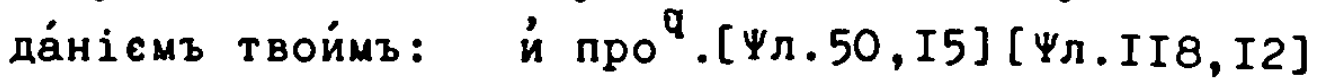

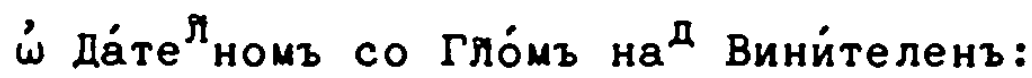

$\Pi p a^{8}:$ з̃ .

Гяии дайнїа, во дахініА, вруче́ніА; веле́ніА, йзъавле́ніА, $\omega^{T}$ пуще́ніА, сказова́ніА, оу́по

4.

добле́

добле́нін, й си" подо́бніи Да́те Какш, Да́ждь ми ру́ку по́мощи: тй на" Бже согрђше́ніА на́ша: Оу́подобй $\Gamma^{\mathfrak{C}}$ дь ца́рство нб $\sigma_{-}$

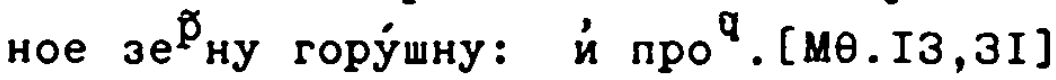

‘́ Зва́телно со Глом́ъ:

Гла ${ }^{\mathrm{B}}: \tilde{\mathrm{e}}$.

Пра́вило йі.

Зва́те ${ }^{\Re}$ ный вто́рому лицेу Повели́телнагш й Моли́телнагш Наклоне́-

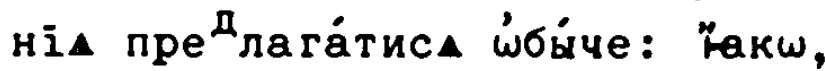

Слу́шай сне рох" шагш тА, й не нерадй е́гда̇ coctapteт"cА

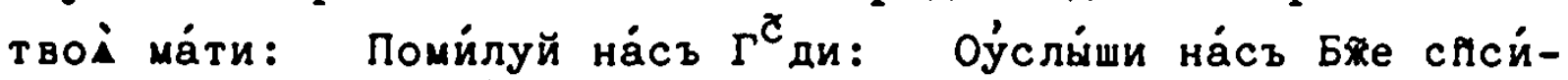
телю на́ш": й пр".

Присте же́ніе:

రвогда, Зва́теленъ ш́ставліет"са: "̈акш,

Преста́ни $\omega^{T}$ зла̀ и́ сотворѝ бйго́е, взыщй мйръ, й похени́ éro: й про

రвогда, Повелителенъ: "ркш'

†̇́до, тебе́ восхва́латъ бра́тіе твой:[Быт.49,8]

и, Бйе мо́й на́ тА оупова́хъ: и́ про ${ }^{q}$ '

$\dot{\omega}$ Твори́телномъ: äбіе и́ $\dot{\omega}$ Гла Страда́телнагш сочине́ніи:

Гла ${ }^{\text {ह }}: \tilde{\mathbf{s}}$.

Пра́вило $\boldsymbol{\theta}_{\mathbf{i}}$.

Твори́телный Страда́телнымъ Гл̆ ${ }^{M}$ сво́йственный паде́жь ёсть: 


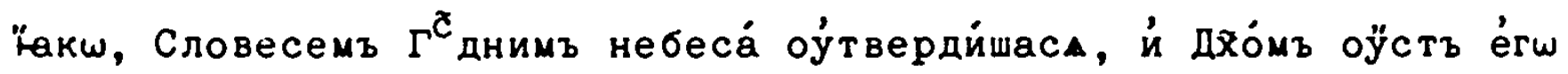
всі сила йхъ. $[\Psi л .32,6]$

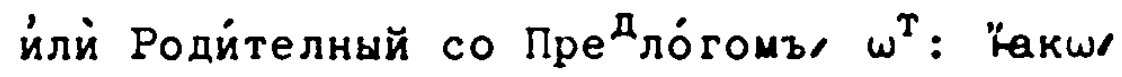

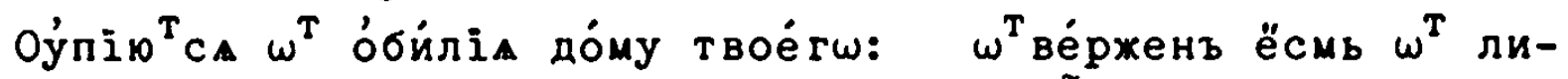
ца̇ ӧчію твое́ю: $\omega^{T}$ ту́ка й ма́сти йспо ниса дйá моА:

й $\mathrm{np}^{\text {q }} .[\Psi \pi .62,6]$

Пристеже́нїе:

Глй гнуша́ніА, вла́сти, й кла́твы твори́теленъ прита́жутъ: Ґакш, возгнуша́са дш̃а мод непра́вдами люде́й сйх"; Клену́са йменемъ Бйіимъ: Владб́ю І̇уде́йскою страно́: и́ про

$\grave{\omega}$ Твориттелномъ

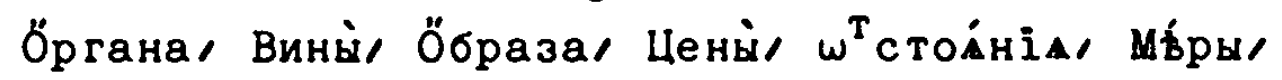

Преимбніа, й, ம்биліа:

$$
\Pi p a^{\tilde{E}}: R \text {. }
$$

Твори́телный ды́йство свое́ ӧргану, виньљ, ӧбразу дбйства, це-

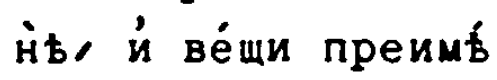

$$
\text { पе̃ Hïa }
$$

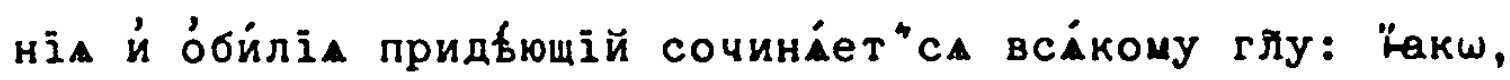

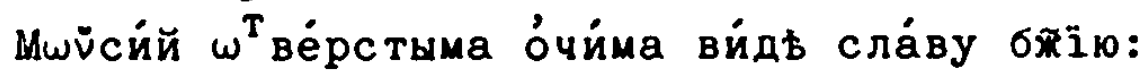

й, Ада́млим" преступле́ніем" сме́рть воцари́са:[Рим.5, I4]

и, Возлю́биши $\Gamma^{\mathcal{C}}$ да Бта твое́го всбмъ ср диемъ твоймъ, й всею дйéю твое́ю: й про ${ }^{q}$ [M $\left.\theta .22,37\right]$

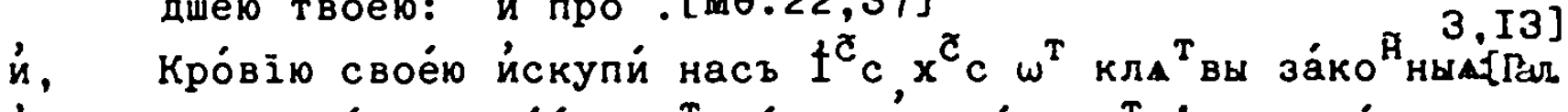

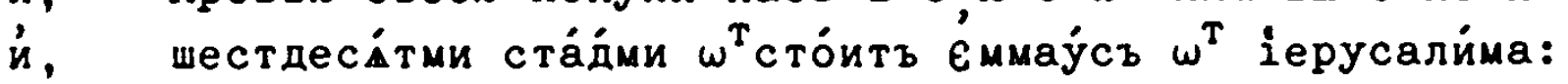

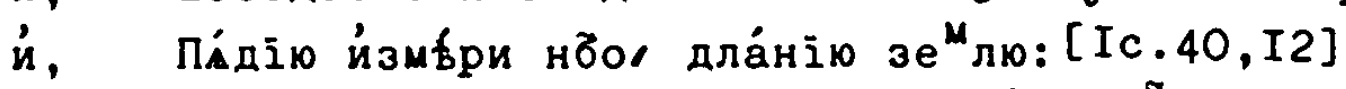

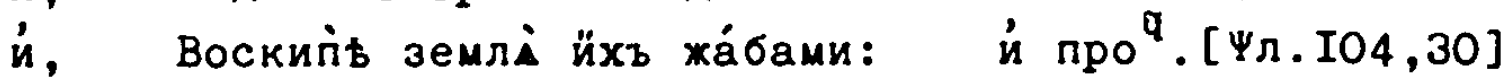

ம் Сказа́телномъ со Гйо́mъ:

$$
\begin{aligned}
& \text { Гла }{ }^{\tilde{B}}: \text { ว. } \\
& \text { Пра }{ }^{\text {B }: ~ R a . ~}
\end{aligned}
$$

Сказа́те ный со предло́гомъ, '́, всі́кими гйы прие́млет"са: Ка-

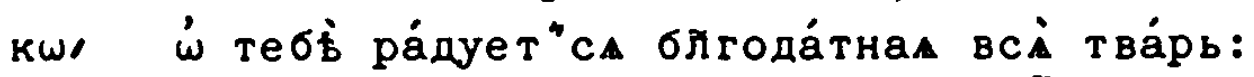

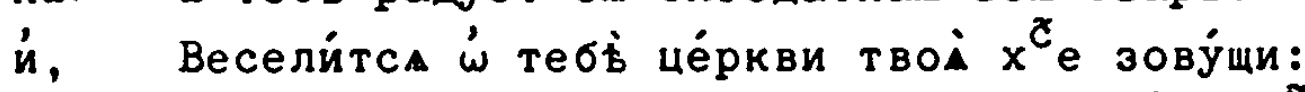

й, Се́й ёсть, $\dot{\omega}$ не́м же ёсть пи́сано: й про .

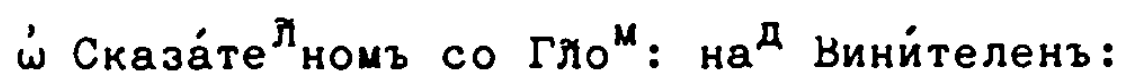

$$
\text { Гла }{ }^{\tilde{B}}: \text { З. [!] }
$$

\section{Пра́вило Квв.}

Приемлет"са Сказа́телный со Предло́го, '́, й на" Вини́теленъ:

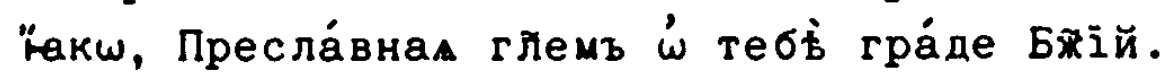




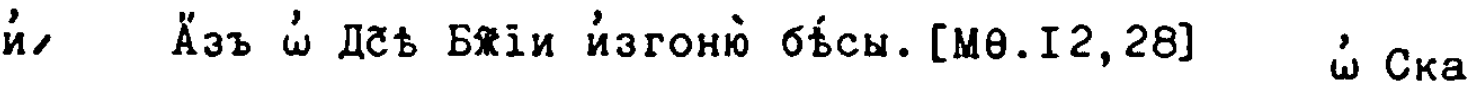

¿́ Сказа́телномъ со Предло́гомъ: на, на

$$
\Pi p a^{\tilde{B}}: \quad \widehat{R} \text {. }
$$

Глй Купова́ніА й Продава́ніА над Вини́теленъ, ӧвы й про́чыА цены сказа́телныа со предло́гомъ на, приемлютъ: на коли́цы, на толи́цђ, на ма́ль, на вели́цђ на мно́зђ; на ва́щшб, на мноха́йшђ:

'акш' На три́десати сре́бренице ${ }^{X}$ й на лобза́ніи л́стивномъ предаде́ †'́да $\Gamma^{\complement}$ да.

ஸ́ Паде́жехъ Вре́мене:

$$
\text { Гла }{ }^{\tilde{B}}: \text { й. }
$$

\section{Пра́вило, К̆д.}

Ко вопроше́нію врс́менному когда̇; $\omega^{\mathrm{T}}$ въщава́етъ Роди́телный: Накш, настов́щагш дяе́ роди́са:

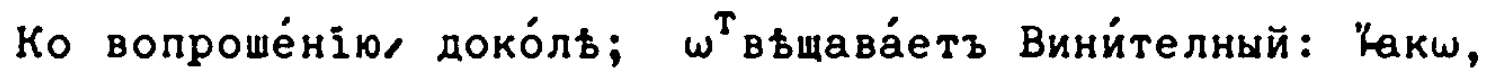
преби́сть оу ме́не трй дни.

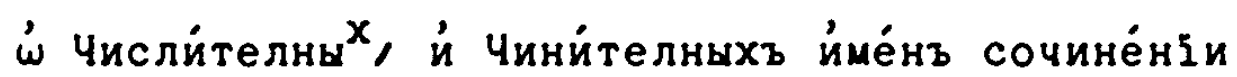

\section{Глава̀: $\tilde{\theta}$.}

Пра́вило, ฉ̊є.

Числите в томхде ро́ды, числьв, й паде́жи: 'акш'

ёдйнъ

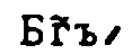

Бг̃ъ, й е́дина вбра е́дино креще́ніе.[ЕФ.4,5]

$\dot{u}$, пе вый де́нь, вто́рал годи́на, тре́тї льто:

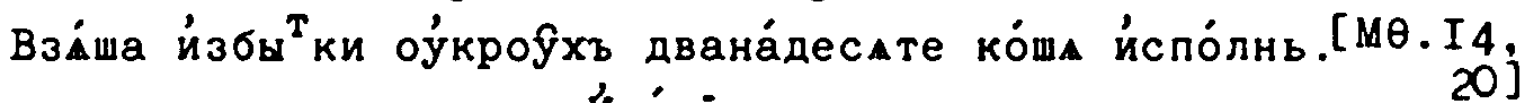
Йзит́т丨:

числи́телнаА пйть, ше́сть, се́дмь, и́ про́чаА на, b, конча́щаАсА, äще мно́гаждь й Прилага́телны пра́вилом, существи́телны чинанот" са: "̈акш,

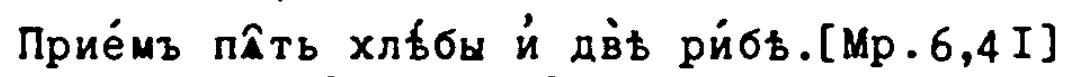

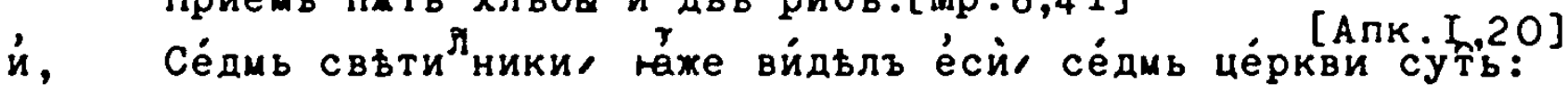

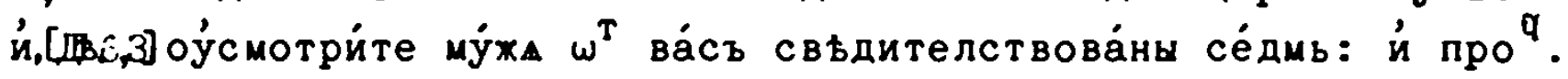
Мно́хае о́ба́че в" Йени́телном й Винйтелномъ существи́телному Ймени сопрага́ема, родите

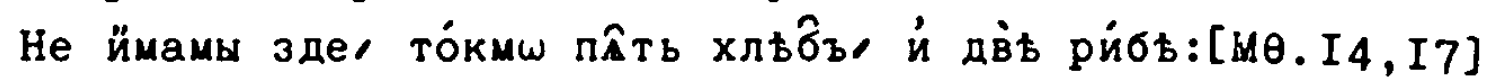

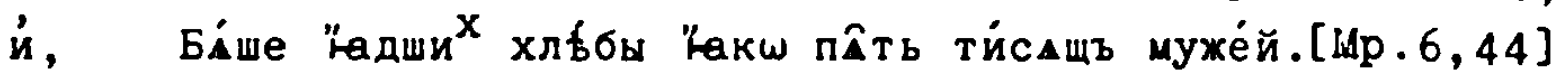

$\dot{n}$, дадб́те имујщему де́сать мна́съ: $[$ мө.25,28]

и́ ம்бра́щ"са ви́дьхъ се́дмь свьтйлникъ зла́тыхъ, й по́средь сед- 


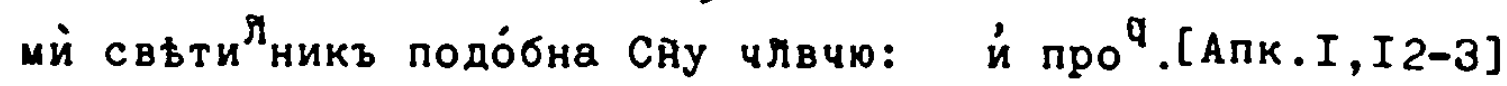

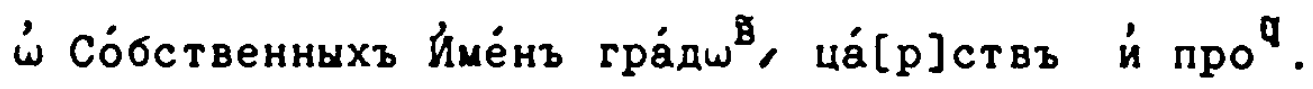

Сочине́ніи:

Гла ${ }^{\text {B }:} \tilde{i}$.

Пра́вило, Rss.

Пра

[214]

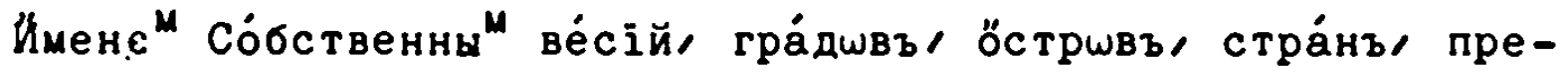
дъภิъ, й царствъ во всбхъ мбста ра ${ }^{3}$ лйчіихъ, во свойхъ и́мъ стоАніА йлй двихёніА паде́жехъ пре Дага́ют"сА Предлози. Стойнію на мfсть знаменуему, на вопроше́ніе, Где́; оу́потребліемъ Сказа́телна со Пре поогомъ, во: Накш,

Родйса во Виөлее́mь: похй в" Капернау́щъ: пострада̇ в"

іерусалйъ:

Знамену́ему движе́нію до ми́ста, на вопроше́ніе/ Ка́мш; оу́потреб-

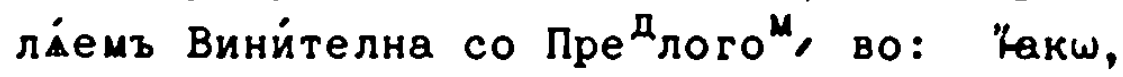

йду во Іерусалимз: прййде во Џуде́ю.

Знаменујему движе́нію $\omega^{\mathrm{T}}$ мбста, на вопроше́ніе, $\omega^{\mathrm{T}}$ ку́ду ; оу́по-

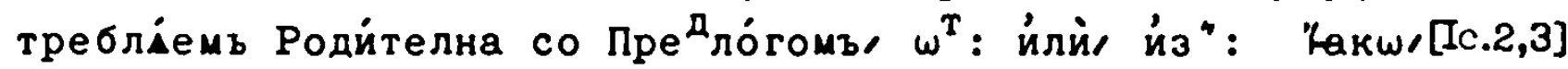

$\omega^{T}$ Сійна йзы́де За́конъ й сло́во $\Gamma^{\mathbb{C}}$ дне йз" 1ерусали́ма:

$\dot{u}, \quad \omega^{T}$ Назаре́та мохет" ли что́ добро́ бв́ти: й про $\{$ [ Знамену́ему двихе́нію чре мъ́сто, Ку́дь; оу́потребли́емъ Винйтелна со Пред ло́гомъ, скво́зъ: "акш'

йдйше скво́зь Галіле́ю: и́ про $q$. [Mp.9,30] í Co

$\dot{\omega}$ Сочине́ніи Гйъ Самостоітелны :

$$
\text { Гла }{ }^{8}: \text { â. }
$$

Мно́гіи Гйй Самостод́телнь, сіесть, бе ${ }^{3}$ посльду́ющагш паде́ха полага́ют" ca: 'Łakw,

Ӓзъ оу́сну́хъ, й спа́хъ, воста́хъ, Какш $\Gamma^{\complement}$ дь засту́питъ мA: й про

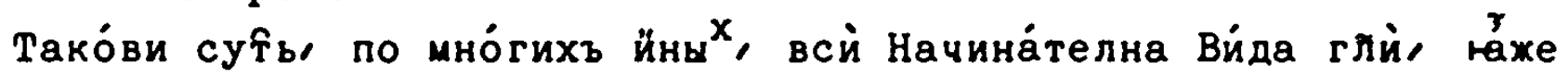

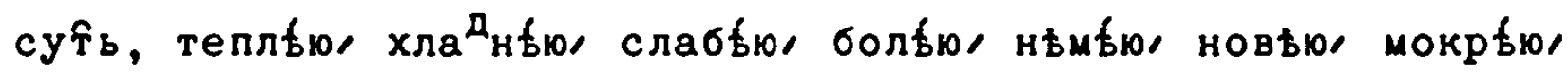

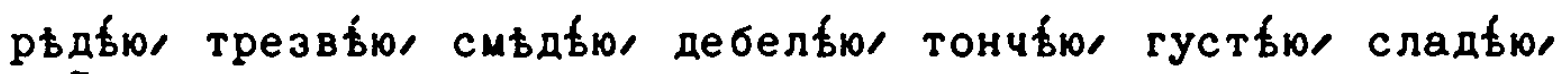

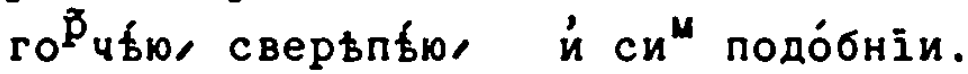

$\dot{\omega}$ Сочиненіи гль Самостовте ны $^{x}$,

бйодђініемъ Пре дй́гъ паде́жА притіхущихъ:

Глава̀, вї.

Пра́вило, Rй.

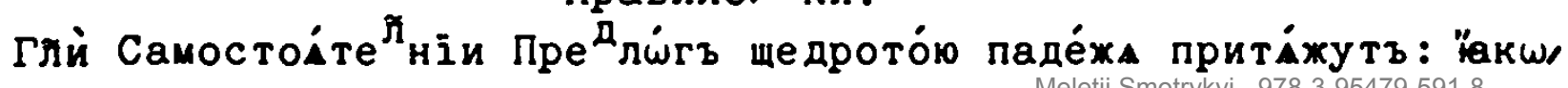




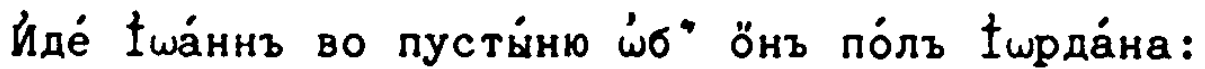

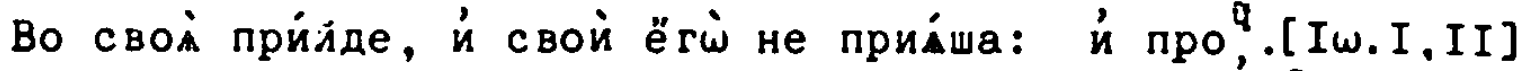

$\dot{\omega}$ Сочине́ніи глъ Преходйтелны ${ }^{x}$ на ${ }^{\not}$ сво́й йм" паде́хь, йнъ Пре

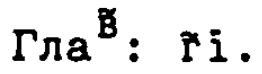

\section{Пра́вило: $R \theta$ :}

Преходйтелніи Глй на паде́ха прие́млю ${ }^{\mathrm{T}}$ : 'акш'

Чáдо заступй во ста́рости о́тиа̀ твое́го, й не '́скорбй е́rí в" животь érì: и́ про".

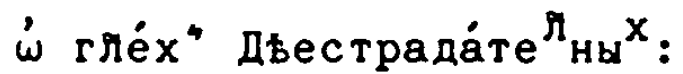

$$
\text { Глав : }
$$

\section{Пра́вило,}

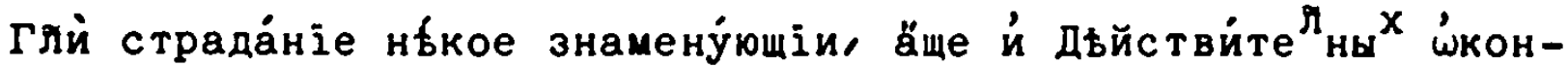
че́ніе ймут", Страда́телны ӫбразомъ родйтелному с" пре $\omega^{T}$, сочина́ют" са: 'lakw,

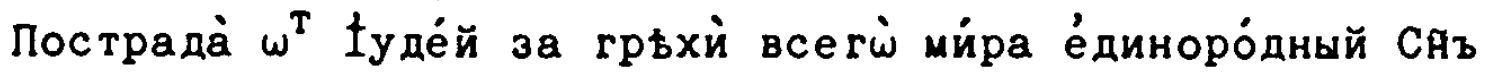
Бӝй.

\section{$\dot{\omega}$ СОчИНєНІИ НЕОПРєдђле́ныхъ :}

Глава̀: ã.

\section{Пра́вило: а.}

Глй Неопредђле́ніи пред собо́ю вини́

теленъ, по себі́ свойхъ гль паде́жь прие́млютъ. "Ека, хо́щу ті் хити хиво́тъ че́стенъ и́ блгочести́въ: и́ проq.

Пристеже́ніА:

Пе́pвое :

Мно́гажды и́ пре тщю́са бйти ма цьломуддра: मे про

Bтópoe:

Йногда Неопредьле́ну Неопредьле́н" преди́детъ: "̈акш, Повелй да́ти ми пйти:

и, Бл̆га́а твори́ти хотб́ти, на́ше ёсть, Бо́хіе же ёсть, да́ти исспо нити: й про

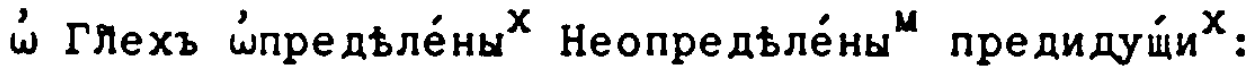

$$
\Pi_{p a}{ }^{8}: \text { : }
$$

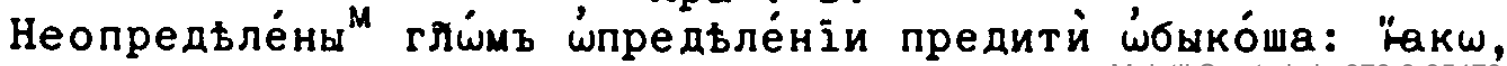


Дады́те имъ вы "̈асти: [ОБ, м0.I4,I7;Mp. 6,37]

и, Съдо́ша лі́діe "̈асти й пйти, й воста́ша и́гра́ти.

Пристехёнї:

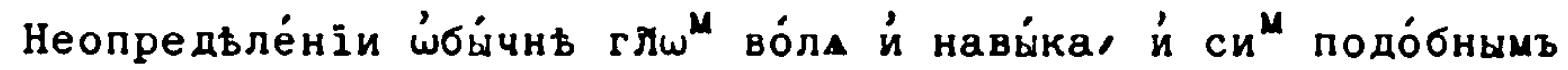
припріхут"са: "Накш,

хо́щу ви́дъти та́: '́бы́ue rर̃á

ти йстин

ти йстинну: не смŁю рещи: понужда́юса йзыйтй $\omega^{\mathrm{T}}$ сі́ду: й npo 9 .

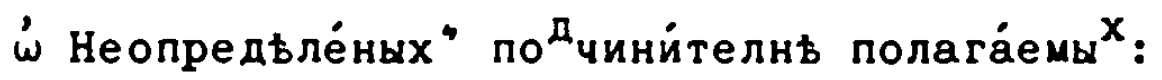

Пра́вило: $\mathbf{r}$.

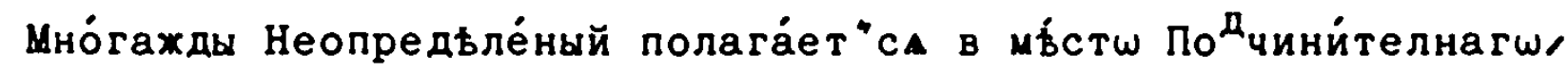
прие́мъ Сојзъ, ёже, йли, во е́xе: "акш,

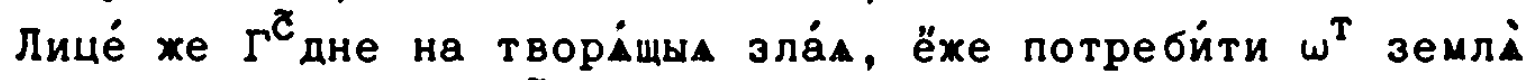

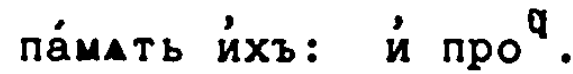

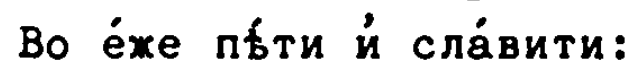

Иногда же й ра ${ }^{3}$ реша́ет"са в" По диини́теле" : "акш,

дерxáxy érì ëxe не '́титй $\omega^{T}$ нйхъ:

Гре́ческому бо сйце су́щу

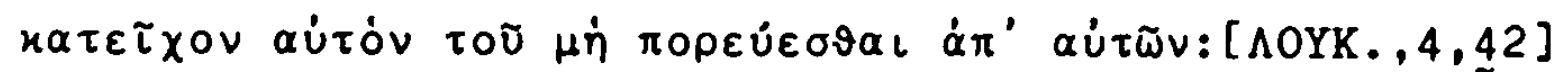

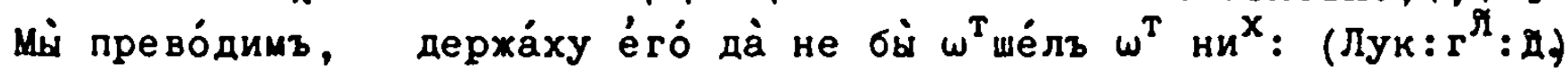

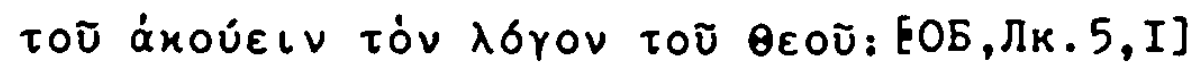

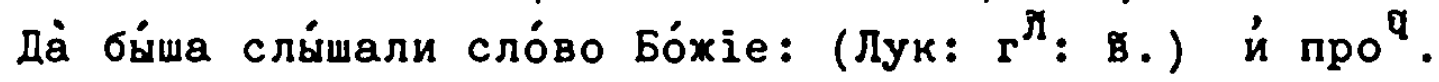

\section{Пра́вило д.}

ёже, Соу́зъ, Неопредъле́ному предло́женое мно́гажды Пре Дао́ги ко, $\omega^{T}$, по, 3а, во, $\dot{\omega}$, восприе́млетв: 'акш,

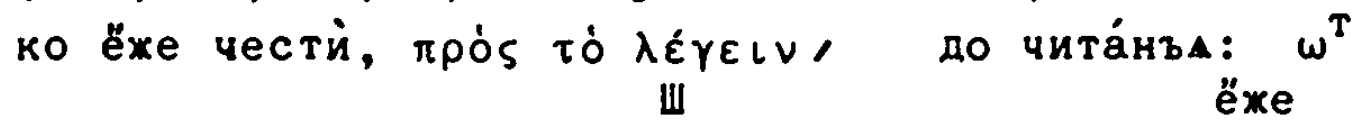

[2166]

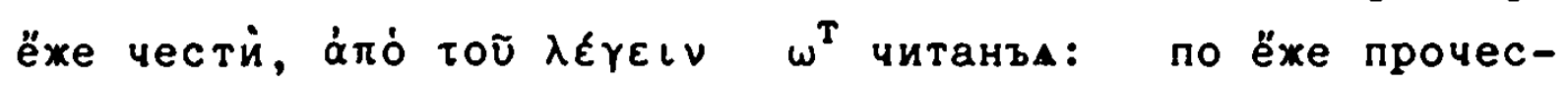

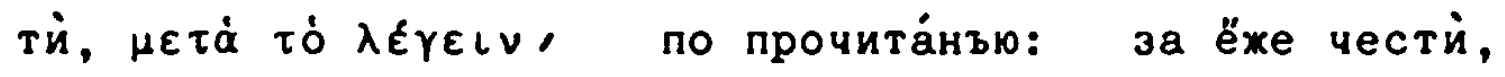

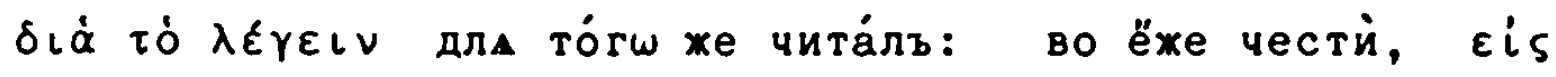

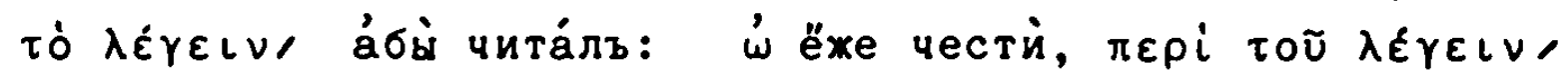

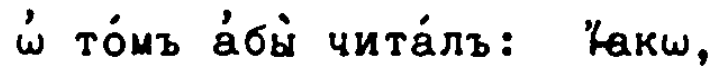

ஸे ёже сподобйтиса на́мъ досто́йны бы́ти:

и, $\dot{\omega}$ ëxe оу́сль́шати $\Gamma^{c}$ ду Бғу на́шему гла́съ моли́твы на́шеА. про ${ }^{\mathbb{1}}$. Сйце й страда́телнь,

ко ёже чести́са: $\omega^{T}$ ёже чести́са: по ёже чести́са: за ёже чести́са; во ёже чести́са: $\dot{\omega}$ ëже чести́са: оувъще́ніе: 


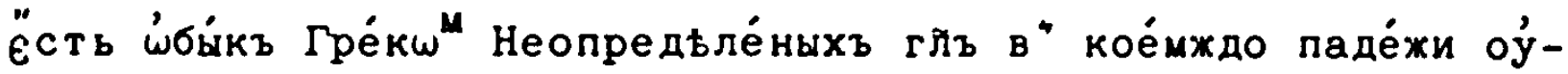
потреблі́ти: знаменова́нї й $^{\mathrm{X}}$ по прилага́емымъ ймъ сре́днагш ро́да

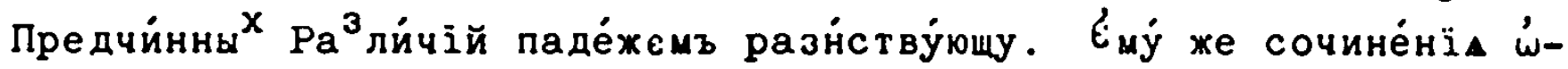
би́ку в" нбкои й Славе́нстіи прево́дници посльдова́вше, во всбхъ паде́жех" е́дйно, ёже, сохранйша: '́ं не" же вы́стно бу́ди, не Мьстоиме́ніе Слави́ншмъ бы́

$$
\text { ти то́ }
$$

ти то́ но́ Сој́зъ, знаменова́ніа Виносло́вна, Ру́ски ска́зуемый, не-

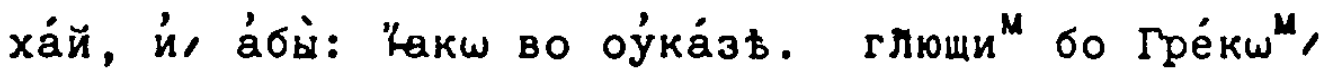

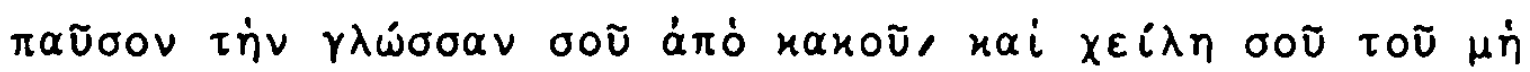
$\lambda \alpha \lambda \tilde{\eta} \sigma \alpha \iota \delta \delta \lambda \circ \mathrm{V} .[\Psi \mathrm{A \Lambda} .33, \mathrm{I} 4]$

Славе́нски прево́димъ,

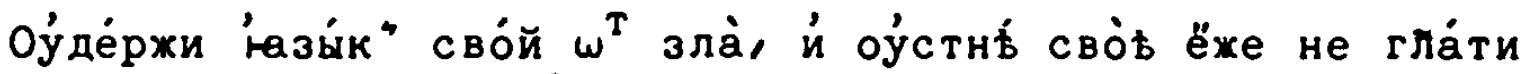
л́сти: Руंски йсто йовуемъ,

Гаму́й Һзы́к сво́й $\omega^{T}$ зло́гш⿱ й оуста́ твой нехай не мо́BATъ зра́ды.

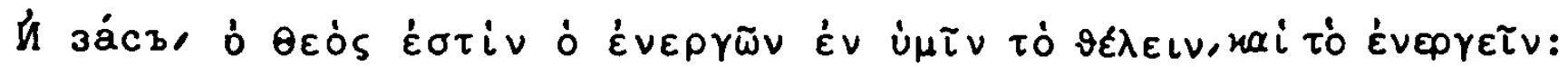
Сі́есть, БРъ ёсть дђйству́й во ва́съ й ёже хотб́ти, й ёже дбати: Ру́ски, Бо́гъ ёсть кото́рый справу́етъ в" ва́съ й то́ áби́сте хотб́ли, й то́ а́би́сте чинйли.[Філіп.2,13]

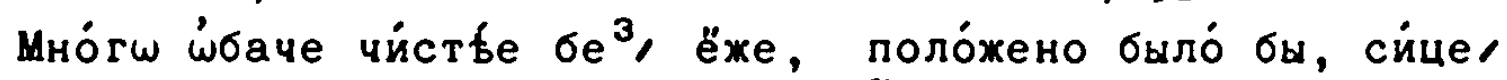

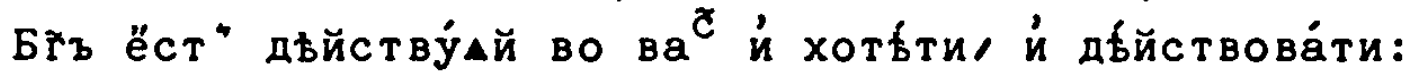

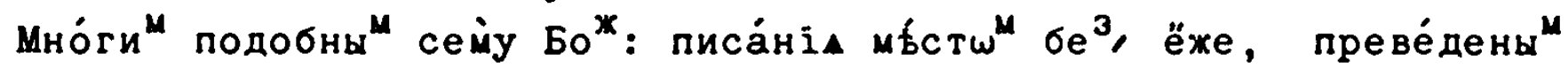
бивши": во оукка́з"

Йхе во ӧбразь Бо́хіи си́й невосхище́ніе[м] непщева̇ бы́ти ра́-

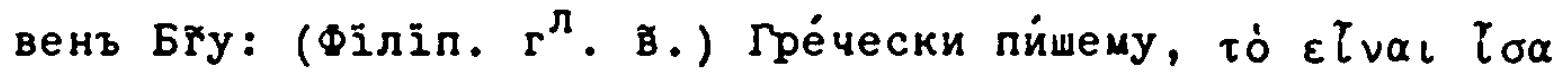

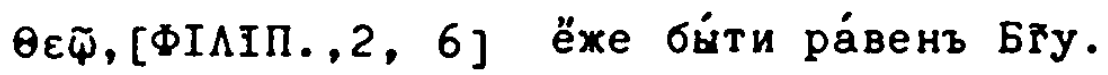

й, внй

Шв

де с $н$ M $^{M}[2176]$

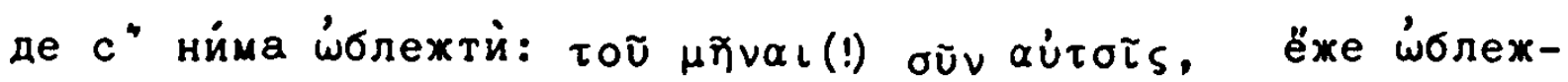

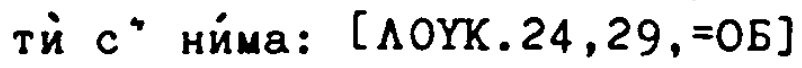

й, Вне́гда приближа́тиса на́ мА злобу́ющи", снб́сти пло́ти мод:

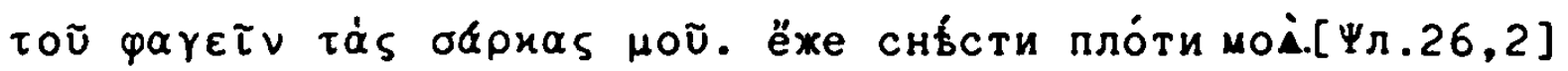

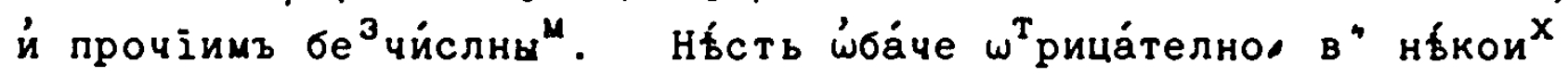
м́́стехъ сохране́но, ёже, мно́гое пйшемы разумб́ніћ оудо́біе подава́ти; "вкш во оука́зь:

ஸ́б"ид̀у ӧлтарь тво́й $\Gamma^{\complement}$ ди, ёже оу́сль́шати мй гла́съ хвалы

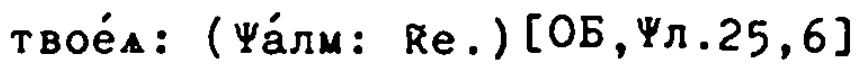

й, Бу்ди ми в" БРа защитителА, и́ в" до" прибб́жища ёже спасти́ 
MA: $\left(\Psi_{a}{ }^{\AA}: \pi_{.}\right)\left[O 5, \Psi_{3} .30,3\right]$

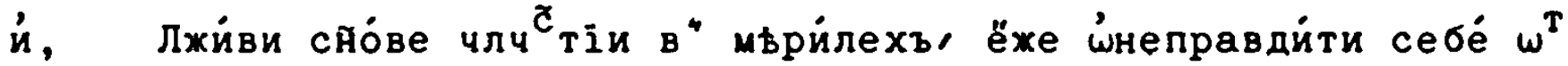

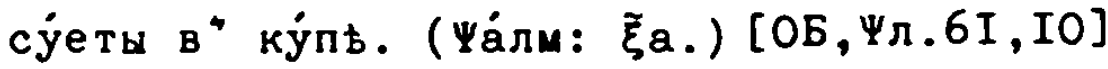

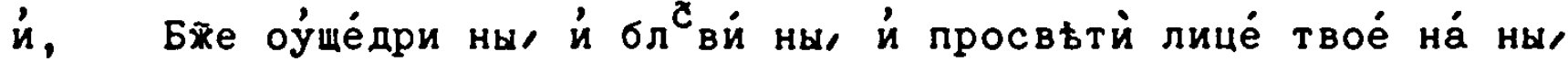

й помйлуй ны, ёхе позна́ти на землй путิь тво́й, во всб́хъ

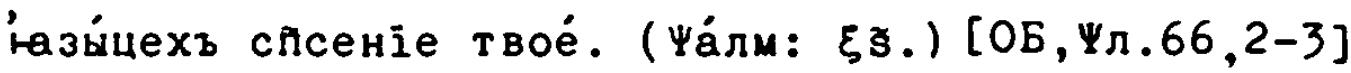

В сихх и́ проччіи бе бе числны

$\dot{\omega}$ глу ймамь, и́ хо́mу, Неопредьле́ны прилага́ему:

$$
\Pi p a^{8}: \text { म. }
$$

Сво́йственно ёсть оу Слава́нъ, Неопредбле́ны всбхъ време́нъ прилага́emy

би́ти

бы́ти глуу хо́щу, йлй ймамь, во Бу́дущагш вре́мене показа́ніе: 'Ња$\kappa \omega$, хо́щу, йлй ймамь честй: в" мб́стш, прочтуy:

Не ймать $\omega^{T}$ ступйти, до́ндеже посв́ти Ви́шній.

’’ Прилага́телно" со Неопредъле́ны ${ }^{M}$ :

$$
\text { Гла }{ }^{\text {В }} \text { : }
$$

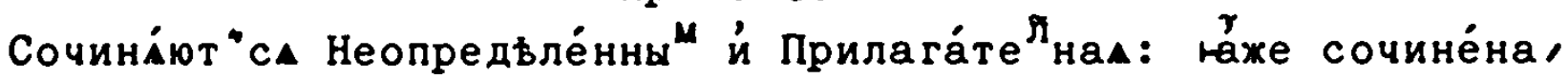
геру́ндій Латі́нски на, di, й, dum, сйлу притажа́ти ви́да ${ }^{\mathbf{T}}$ са: Ha$\kappa \omega$, сйленъ гла́ти дово́ленъ научйти: йску́сенъ помощй: й про . ’́ Неопредьле́номъ со глы Двихе́ніА на мб́сто:

$$
\text { Гла }{ }^{\mathrm{B}}: \mathbf{\Upsilon} .
$$

Неопредьле́ншй со Глы йлй Прича́стіи движе́ніе на мбсто знамену́ющими сочине́нъ, Геру́ндій Латінскихъ на, dum, сйлу прита́хетъ:

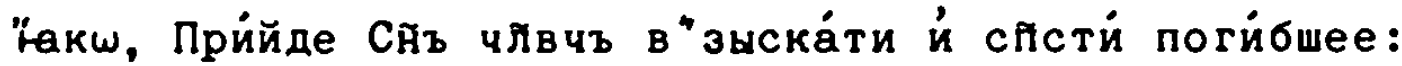

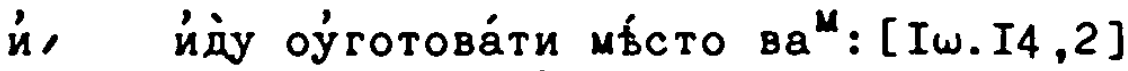

$\dot{u}$, не посла́ мА $x^{飞}$ с крести́ти, но́ бяговъсти́ти. [IКор.II7]

\section{Пристеже́ніе:}

Не то́чію Геру́ндій, но́ й Супінъ на,

tum,

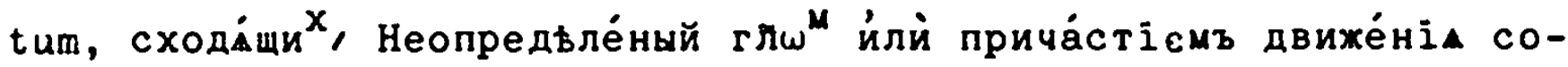
чине́нъ, сйлу приті́хетъ: Какш,

Что́ и́сходйсте в" пустйн вйдъти; [MO.II,7]

и, Не прийдо ${ }^{X}$ воврещй ми́ръ, но́ ме́чь.[Мө.IO, 34]

й, Снъ чйвчь не прййде да̀ послу́хатъ е́муу но́ послужйти: и́ про . [Mp. IO ,45] 
‘́ Прилага́телномъ ро́да Сре́дна со Неопредъле́ны ${ }^{M}$ :

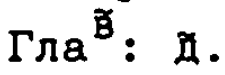

$$
\begin{aligned}
& \text { Пра }{ }^{8}: \text { ว. }
\end{aligned}
$$

Неопредьле́ному Прилага́телное Сре

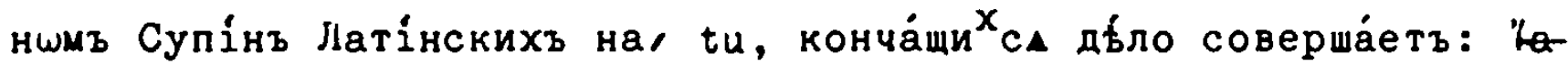
$\kappa \omega$, сту́дно твори́ти: злобо́хно гла́ти: бе за́стно разумбти: и́ npo 9

’’ СОчИНєНІИ Д૬єПРИча́стій:

$$
\begin{aligned}
& \text { Гла }{ }^{\tilde{B}}: \text { a. } \\
& \text { Пра }{ }^{8}: \text { a. }
\end{aligned}
$$

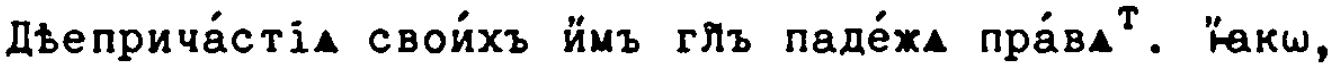
Виді ра ${ }^{3}$ бойникъ нача́лника хиззни на́ кр ${ }^{\complement}$ ть висі́ща:

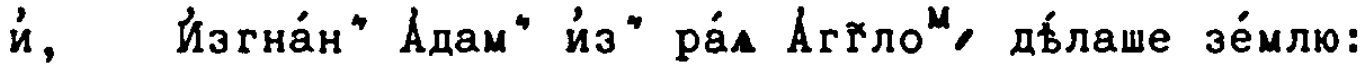

й, Рцй ми, ка́кш во́зриши на

$$
\text { с лйนе }
$$

слице, не поклони́в"са посыла́ющему о́чес $\varepsilon^{M}$ твойм" сладчи́йшій свбтъ; ка́кш причасти́шиса трапе́зђ не поклонйв"сА толи́кихъ глй [= благъ] пода́телеви;

\section{Пра́вило в.}

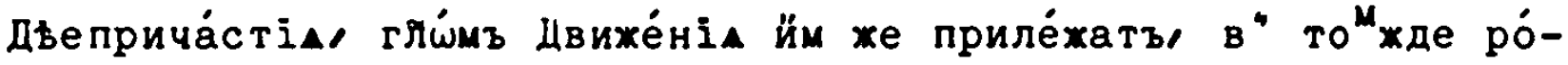

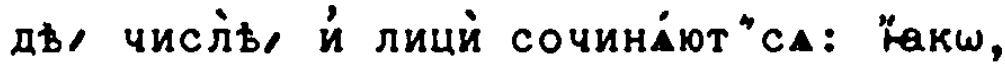

оу́трудйх"са зовы: вопіи́ctь глющв: кла́нахусА зову́ще: теко́ша рида́юща: иं про .

\section{Пристехе́ніе:}

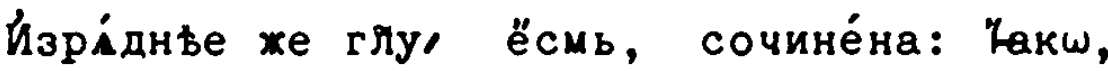
Бисть шу́мъ, и́ и́споллни до́мъ, йде́хе бі́ху оученицй [Дь.2,2]

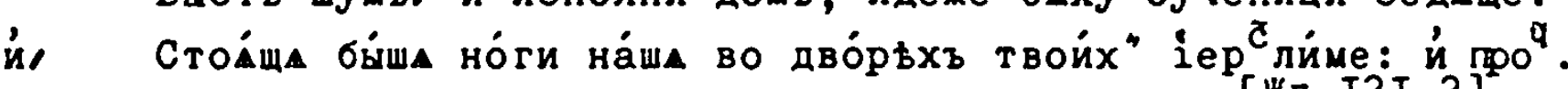
Пра́вило, r: $[\Psi \pi .12 I, 2]$

Оу́потребліема быва́ютъ Слава́ны, по гре́ческому прича́стій со-

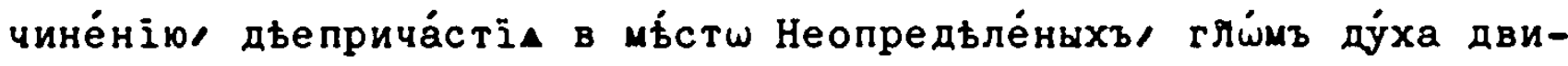
хе́нїе знамену́ющимъ припрахе́на. "Һкш,

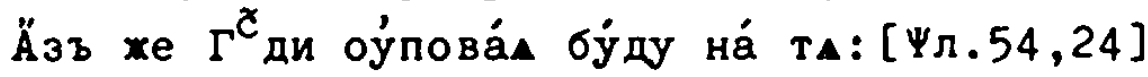

й Нá нь оу́пова́юще бу́дем": в мб́стшر оу́пова́ти:

Оўмъ не преста́етъ

Шд лука́

[2196]

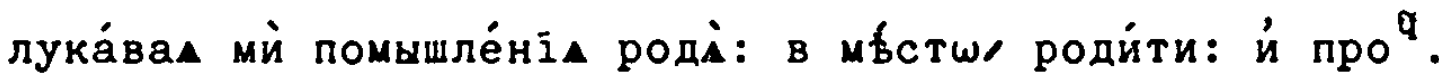
Пра́вило, д̆.

Дъеприча́стї Ймене ${ }^{M}$ Существи́телнымъ по Прилага́телныхъ пра́-

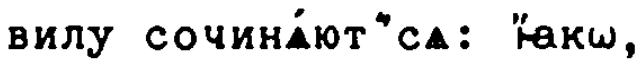




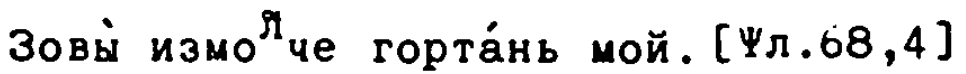

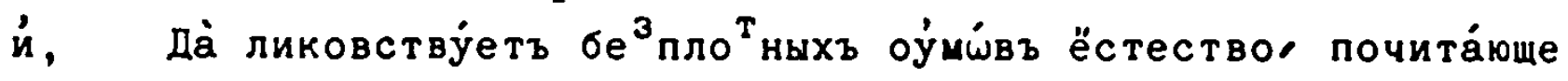
сто́ то́рхество Бйим Мáтере.

¿́ СОЧИНЕНIИ ПГРИЧАСТОДЬт̈IА:

Пра́вило, व.

ПричастодбтіА Гре́кшмъ Нарбчі৯ ПолохителнаА на, દov, Латі́нш

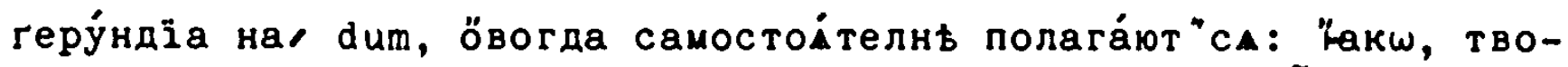
ри́телно: гла́телно: носи́телно: оу́пова́телно: й про ${ }^{q}$ ӧвогда гл̆ъ/ ёсть, приемлютъ: Һакш, чита́телно ёсть: писа́телно ёсть:

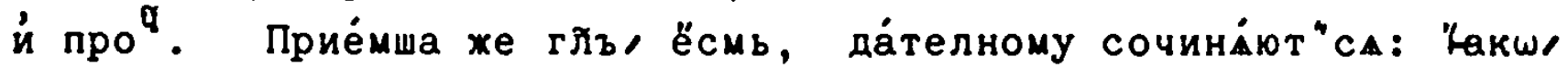

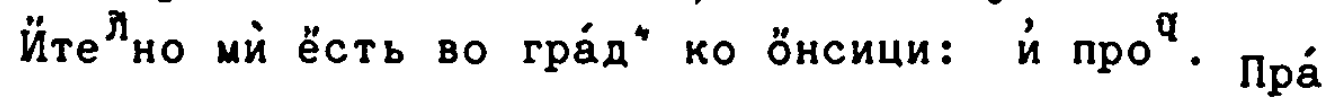

Пра́вило в.

[220]

Причастодб́тіА мнохицею свойхъ гль паде́хА прита́хутъ: Lакш:

Ну́хдъ нбсть противостои́телно: побори́телно мй ёсть по йстиннь: иं про .

Пра́вило $\mathbf{x}$.

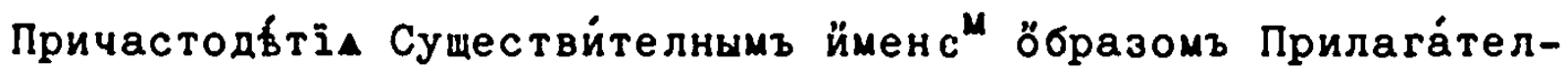

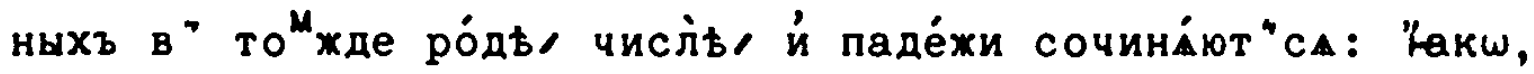
Люби́теленъ мй ёсть САъ тво́й:

й, Йстинное мудрова́ніе, про разумб́ніе ёсть твори́телныхъ и́ не твори́телныхъ ве́щій:

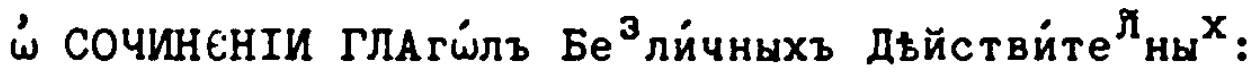

Глава̀, a :

$\Pi p a^{B}: \mathbf{a}$.

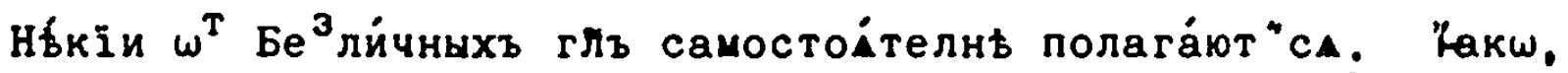

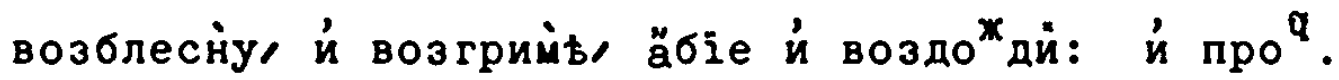

'ं Йенйтелно" со Бе ${ }^{3}$ лйчнымъ:

Глава̀, в.

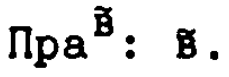

Гй́мъ, грими́тъ, дохдйтъ, снв

แil $\tilde{\varepsilon}$

жи́т

[2206]

хи́тъ, мно́га*ды Ймени́телный пре

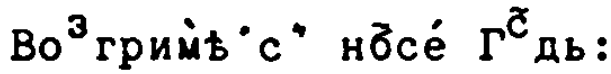

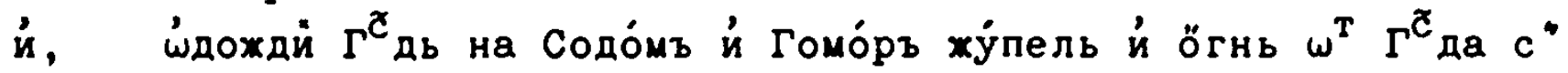
нб̈се́.[Быт. I9,24]

Пра́вило, $\mathbf{r}$.

Гиу, дождйтъ, сопосльдујетъ винйте ный, за е́хе лйченъ бы́ти тогда̇ су́ди ${ }^{\mathrm{T}}$ ca: : Накw, 
ம்ож дйтъ на грбшники сбти, ӧгнь, и жу́пель, и́ ду́хъ бу́ре $\dot{\text { и про }}{ }^{\tilde{q}} .[\Psi \pi \cdot 10,6]$

ம் Роди́телномъ со Бе ${ }^{3}$ лйчнымъ:

$$
\text { Гла }{ }^{\tilde{B}}: \text { Ћ. }
$$

Ëсть, бе личчнь прихтое, пре Неопредьле́ный либо йную ку́ю сло́ва ча́сть в мб́стш Йменителнагш по себб́ же Роди́те ный прита́жетъ. Какш,

Разумйва му́хи ёсть/ снисходйти временй:

й, Йску́сна ёсть оучи́телА, в" поуче́ніи кра́тку бы́ти:

тоги́xде ро́да ёсть нб́ть.

ПристехёніА :

Пе́рвое.

мно́га夫ды, ёсть, и́ста́влено приразумъва́ет"са: 'Һакш, Нищету носи́ти терпели́внш, не коеги́ждо но́ му́жх му́дра.

Brópoe :

Bтo

Безлйчну, ёсть, й нб́сть; о̋вогда при Неопредьле́нномъ Мьстоиме́ніе в" Ймени́телномъ са́мо, о̆вогда со йменемъ сим, дв́́ло,

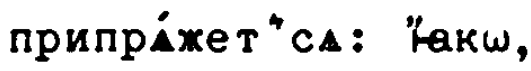

Hв́ctb moé дátu:

й, нáше ёсть Настод́mах творйти:

й, Мое́ дбло ёсть, себі் внима́ти: $\dot{u}$ про

Tpérie:

Та́жде, ёсть, й, нб́сть, бе ${ }^{3}$ личнь оу́потребліема, Прилага́телна, мо́щно, й, возмо́хно, прие́млютъ: Какш,

За́повђди десАтосло́віА и́спо́лнити чйвку ёсть мо́щно:

й, Сло́во иззе́дшее из " оўстъ, во врати́ти нбсть мо́щно:

й, Зла́А твори́щему нб́cть возмо́жно спасти́са: и́ пр

$\dot{\omega}$ Да́телномъ со Бе ${ }^{3}$ лйчнымъ:

Гла ${ }^{\mathrm{B}}:$ д.

$\Pi p a^{8}: \tilde{e}$.

Досто́ить, подоба́етъ, льтิь ёсть, оўне ёсть, "̈авь ёсть, го́дь ёсть, ли́ше ёсть, вредйть довлбетъ, льfіо ёсть, сту́дъ ёсть, мо́щно ёсть, во ${ }^{3}$ можно ёсть, й про́чіи, пре Неопредьле́ный, йлй йну ку́ю ча́сть в мб́cтw Ймени́ Ймените Довльеть ти блг ть мох: 
и, Достои́ше ва́мъ сі́ твори́ти, ш̈ны же не шставли́ти.

$\dot{u}$, Дне́сь подоба́етъ ми в" домуу твое́мз бйти:

й, вси́ ми льтิь сутิь, но́ не всй на по́лзу.

Пра́вило, $\mathbf{3}$.

Досто́итъ, й подоба́етъ Неопредђле́ну сочиндеми, Прича́стодбтій силу притаххуть: "юкш,

Подоба́етъ на́мъ и́споллнити вса́ку пра́вду: а́ки́ бы рещй,

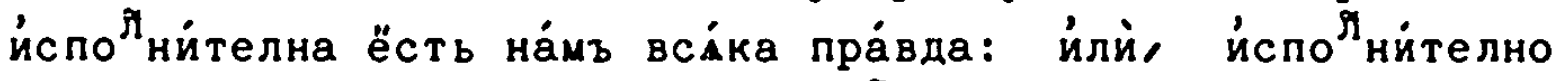
ёсть на́мз всі́ку пра́вду: и́ про

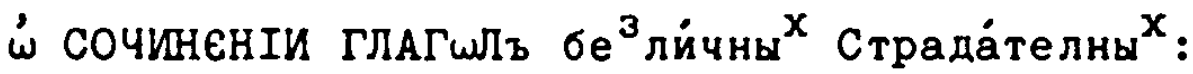

Глава̀, ̃.

Пра́вило, з.

Глймъ Безли́чнымъ Зало́га Страда́телнагш, предйдетъ И́мени́телный мно́гахды '́ставліемый: посльду่ет" же Твори́те нйй йлй Родйтелный со Пред̆логомъ, $\omega^{T}$, лйбо в мб́стш си да́тел ный:

[222]

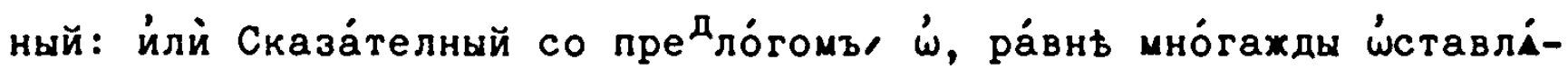
емый: 'Łaкw,

Посла́ніе твое́ прочте́ca мно́ю: йлй, $\omega^{T}$ мене́: и́лй, прочте́ ми са. Живе́т"са Йми бйоче́стнш: Спит" ми са сла́дuь: щади́т" ми са вьне́цъ пра́вды: стро́итъса '́ мн̀в ве́щь: й про .

$\dot{\omega}$ СОЧИНЕНІИ ЛРИЧАСТIA:

$$
\text { Гла }{ }^{\circledR}: \text { а: }
$$

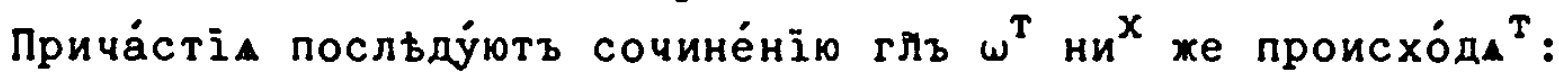

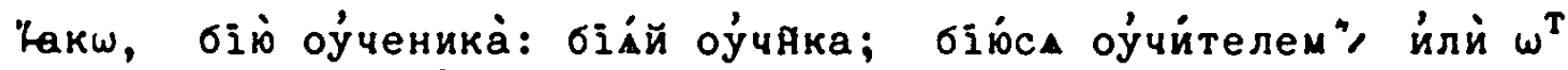
оуччйтелА: й про

Нด́cть ни́щъ ничто́ же и́мtán̆, но́ мно́гихъ жела́Ай:

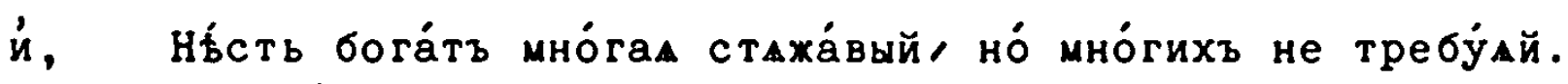

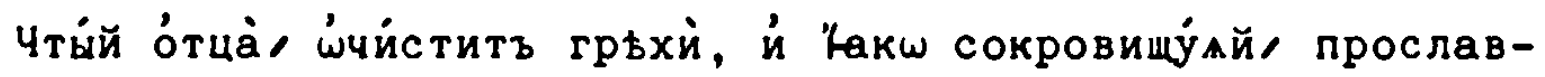
лінй ма́терь свою. Не ца́вый требу́ющему, ни же са́мъ тре-

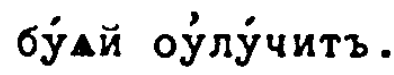

оу́въще́ніе:

‘́ согла́сіи сочине́ніА Прича́стій со Существйтелными ймены, в" сочиненіи Ймене прелохи́хомъ.

Прá

Пра́вило, в.

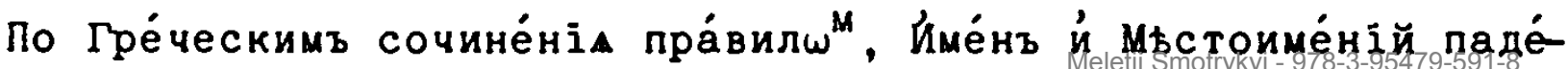


же прича́стій паде́жа сочина́емы бы́ти себї в" то́мжде ро́дђ чис-

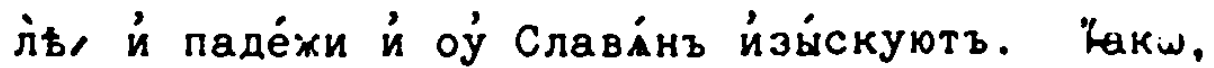

С́стестве́нъ нецу́гъ се́й йны ${ }^{M}$ ёсть/ за ле́гкое ра́зума, наде́жцнал оу́же ймб́ти мнд́щимъ: в мб́стшл мнб́ти.

и, Нико́му же когда̇ не би́сть похва́лно, бы́дна поми́ловавшему. в мб́стш, помиловати: й про".

\section{Пра́вило, $\tilde{\text {. }}$.}

غ́ллинісмъ ёсть, Прича́стій гла существйте на со ймены оу́потребле́ніе: Kaкw,

Coгpt.шáти члвки сујщыа, ничто́ же дйвно:

й, Члвку су́щу всі́ческихъ ча́ати подоба́етъ: и́ про

\section{Пра́вило, д.}

Си́й, су́щал, су́щеe, прича́стій, и́ про́чіихъ всб́хъ оу́потребле́-

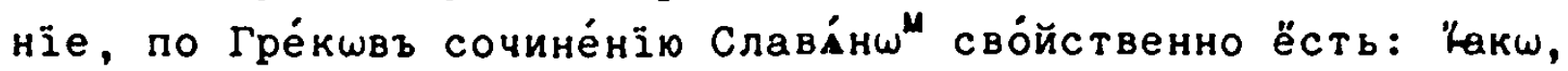

Бтъ сйй ми́ра, баъ щедри́т". Чливъ во че́сти сйй не разу-

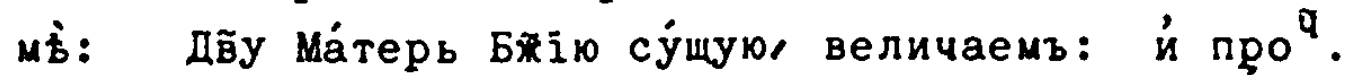

\section{Пра́вило: ₹.}

Прави

Прича́сті^, нарица́емый, ймену́емый, гле́мый, мнймый, й сим подо́бнал, при дво́ существи́телну ра ${ }^{3}$ лйчных" ри́дъ полага́емаА, силу ве́щи носа́щему существи́телному в" ро́дь, числьь, й паде́жи сочина́ют"са: "̈акш, Град, Аөйны нарица́емый. Два, престо́лъ Búmharw rf́émaa: и́ про q.

'́ СОЧИНЕНIИ НAPВчIA:

Гла ${ }^{\text {B }}: \mathbf{a}$.

Пра́вило, व̃.

НарбчіА приме́щут“сА Йменем, Глаголи́мъ/ Прича́стїмъ, Дьепри-

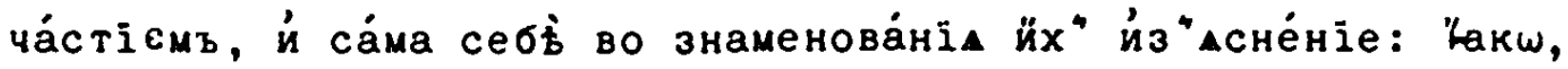
тщали́въ дово́лнь: чтй приле́жнш: молйй оусе́рднш: йспы-

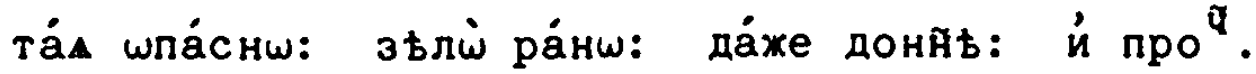

Пра́вило, в.

Нарбчіа Йме́нъ, $\omega^{T}$ нйх же производдт"са, паде́жа соде́ржатъ: ஜакш, досто́йнt мзді вб́чныхъ бйгъ тво́риши дьภ̂० твоѐ, дちர்o

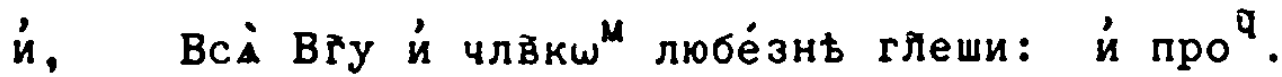

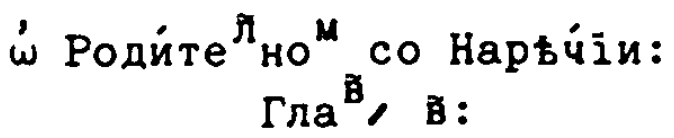

Пра́вило, $\mathbf{r}$. 


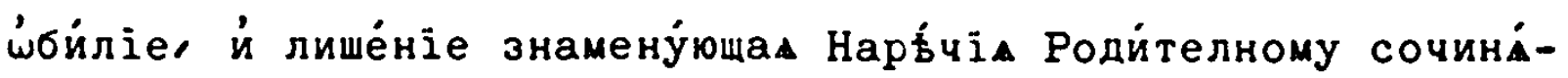
ют"сА. "Юкш, дово́лнь ймать смире́ніА, ма́лш цђкому́дрїА: [=-ло-] й про प्व.

\section{Пра́вило, п.}

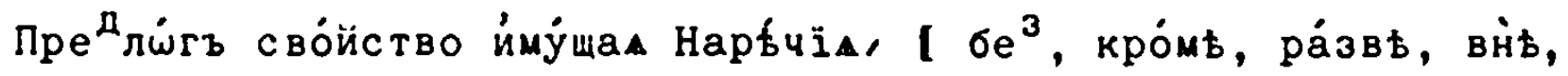
вну́трь, свб́не, близз, дале́че, ӧкрестъ, в мб́стш, пре́хде, посль́ди, да́же до, '́та́й, па́че, протйву, й про ". [ Роди́теленъ при-

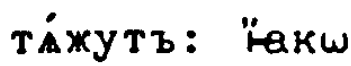

Вну́трь до́му: вй́ двора̀: дале́че гра́да: $\sigma \mathrm{e}^{3}$ ма́тере: ра́звь грђха̇: бли ${ }^{3}$ сме́рти: ӧкрестъ гра́да: пре́жде прише́ствї: да́же до сы́тости: па́че вс́⿱㇒⿻ све́рстникъ: вмfстш за́кона: '́та́й оуччителА: й про".

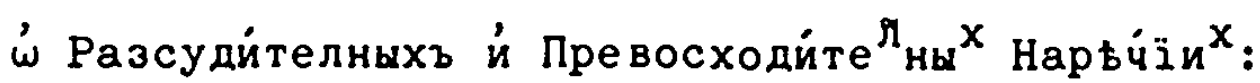

Пра́вило ₹.

РазсудйтелнаА й Превосходи́телнаА

Haṕ

Нарб́чia по ёстеству йме́нъ, $\omega^{T}$ нйх же происхо́датъ $\dot{\omega}$ Родйтелномъ ра́дуют"сA. "Һакw,

ско́рte, йлй ско́рши слезы схне́т" ничто́ же:

й, мншха́йши про́чіихъ А́по́стшлъ, Па́велъ во Блговьствова́ніи потрудйса: й про .

‘் Дáтелном" со Нарьйіемъ:

Гла ${ }^{\text {B }}$ : $\mathbf{}$.

Пра́вило, $\mathbf{3}$.

Пра́мw, й проти́в, е́гда̀ согла́сіе знамену́ютъ, Роди́телну со-

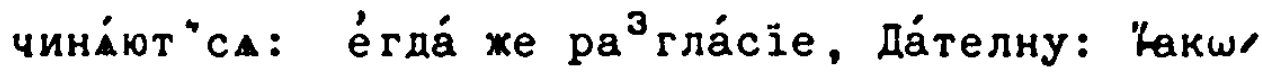

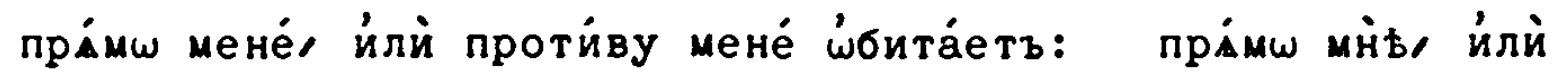
проти́ву мніь бори́тъ.

’́ Вини́телном со Нарьйіемъ:

Гла ${ }^{\text {है }}$ म.

Пра́вилол з.

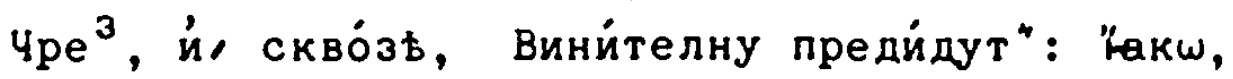
чре ${ }^{3}$ мене́, сі́ссть пре ${ }^{3}$ мене́:

й сквоз йглено оу’хо.

‘́ Зва́телном" со Нарьи́іемъ:

Гла ${ }^{\tilde{B}}:$ ¿.

Пра́вило, й.

Нарб́чіА Повеле́ніА Зва́телному паде́жю, й повели́телному Накло- 
HéHín npe [a]

лагна́т"сA: [ =-лагают-] 'Қакw,

градй Ғша́нне ви́хдь: принесй рцб́щъ, и́ '́ воскресе́ніА наде́х возопій: й про

$\dot{\omega}$ Твори́телномъ со Нарьйіемъ:

Глава̀, s.

Пра́вило,

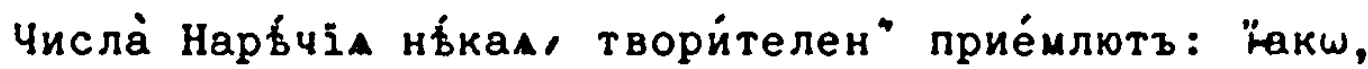
е́дйною дне́мъ: два́щи се дийцею: трйщи ль́томъ: й про седмйцею дне ${ }^{M}$ хвали́хъ та: й пр ${ }^{q}$.

Tókmw' тóчiю:

Пра́вило, $\tilde{i}$.

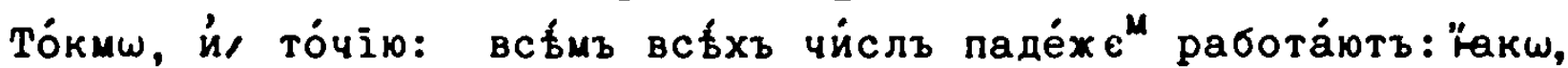

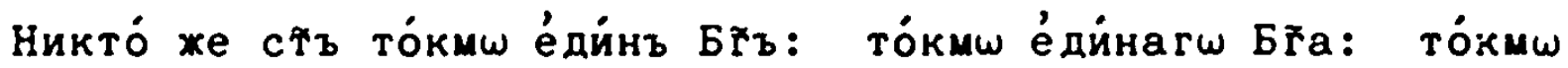

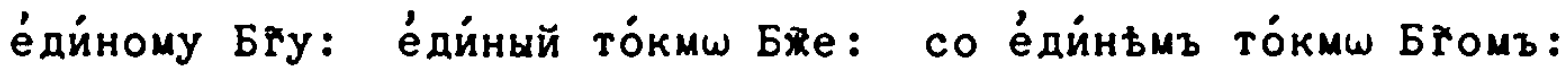

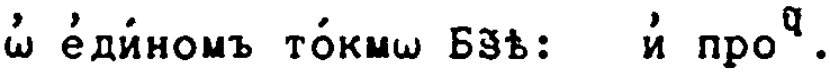

\section{Пра́вило, а̃.}

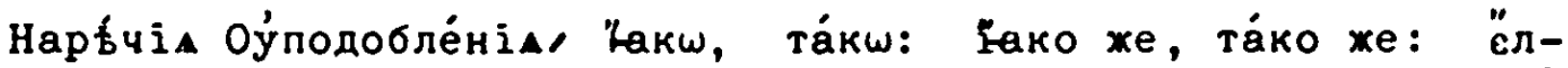

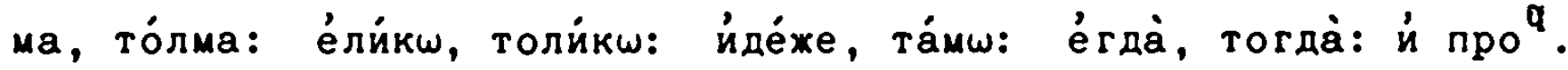
Другъ дру́гу сово ${ }^{3}$ носи́тисА

гакш йспе́рва, та́кш

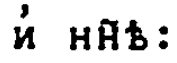

иं нйв: Һако же $\omega^{\mathrm{T}}$ ии ва́ши, та́кожде й вы: е́ликкш е́сй великъ, толиккш себе́ смирйй: ёлма смири несе́шиса: и́де́xе ёсть сокро́вище ва́ше, та́мш бу́детъ й ср मа це вáше: érдà хо́щеши и́спыта́ти, тогда̇ пощадй мл тиве:

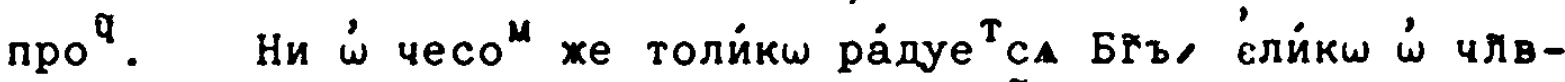
ческо ${ }^{M}$ йсправленіи й списеніи: $\dot{и}$ пр ${ }^{q}$.

Пристехе́ніе:

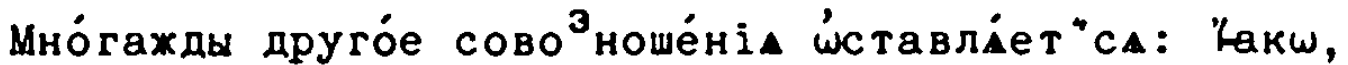

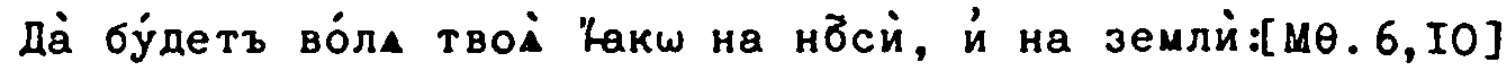

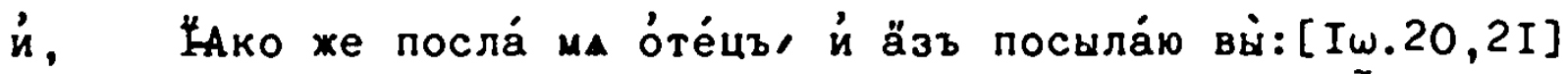

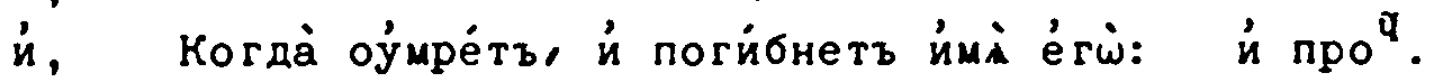

Пра́вилог ві.

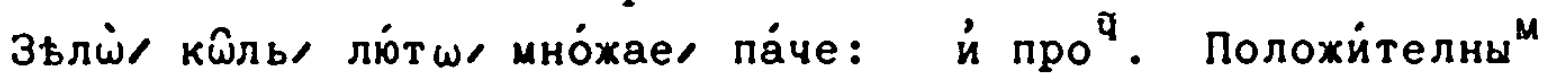

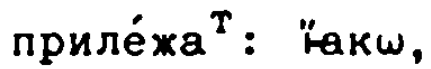

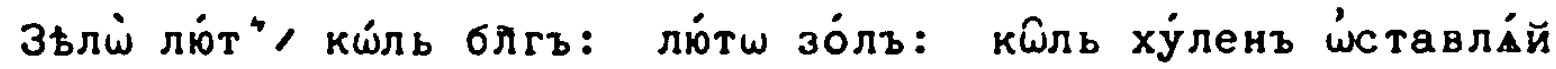


о́тиа̀, й прокла ${ }^{T} \Gamma^{\complement}$ дем" ра ${ }^{3}$ драха́ай ма́терь свою̆:

Мно́гш, колли, дале́че, ма́лш: й про ${ }^{\mathbb{Q}}: \mathrm{Pa}^{3}$ судйгелнымъ, й Превосходителны": "̈акш,

мно́гш оуче́ншій ёсть оучченикъ, не́жели оучйтель: дале́че луччше ёсть житт в" дом̆у
щี
cMb́

[2256]

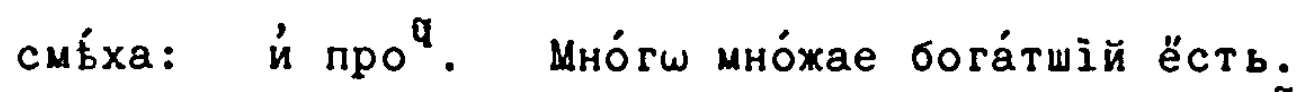
Ко́лми всы́хъ ве́щій, вре́ма драха́йша ве́щь ёсть: й про

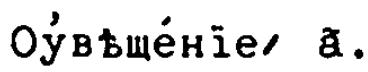
‘́ Нарьйїихъ $\omega^{\mathrm{T}}$ рица́нї.

Никто́ же не: нй не: ньс́ть нй: не́ не.

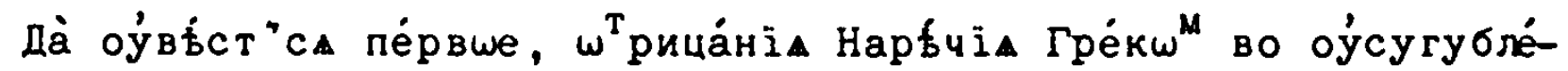

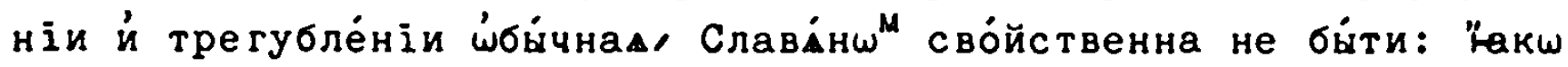
во оукка́зь: Гйю Гре́ци,

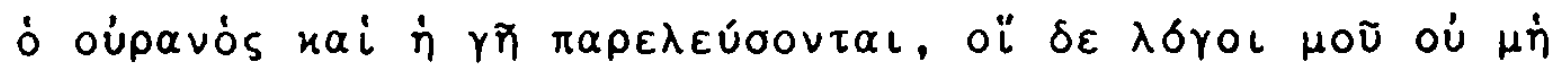
$\pi \alpha \rho \varepsilon \lambda \vartheta \tilde{\omega} \sigma\llcorner:[\Lambda$ не́бо й земла̀ пре́йдет, словеса́ же мод̈ не мимоиду́тъ. Й па́ки Гре́ци,

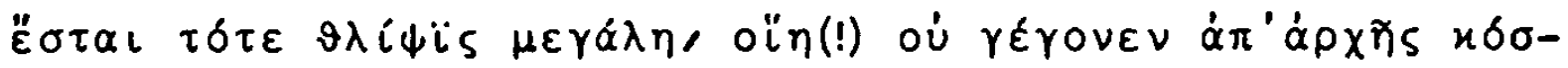

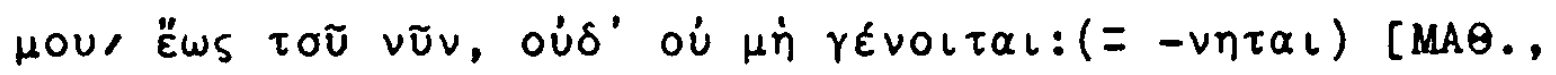
24, 21] мы:

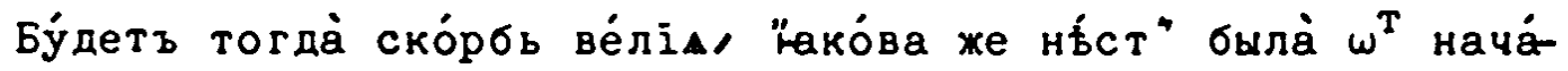
ла мйра досе́ль, ни́ же ймать быти.

За е́xе несво́йственнь Славе́нски гйемъ, [OF, Mp.II, I4]

Да̀ не к тому $\omega^{T}$ те́бе во ви́ки никто́ же пло́да сні́сть:

Рече́м же сво́йственнь, си́це преведе,

Да̇ никто́ же к то

iy

мy $\omega^{T}$ те́бе во вfки пло́дъ снб́сть: и́ па́ки,

Нй е́дину заповьдь твою не сотворйхъ:

но́, Нй е́дйну за́повьдь твой сотворйхъ: й е́ще́,

Не согрьшй никто́ же Һако же а̋зъ:

но́, Никто же согрьшй "пко же ӓзъ: й йнде

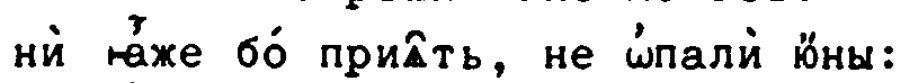

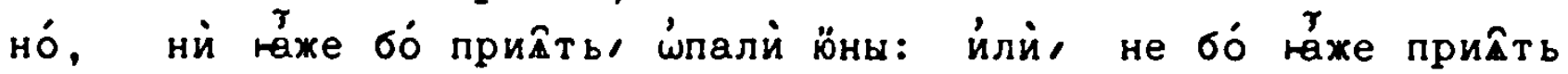
ம்плй ஜ̈ны:

Й Слава́н $\omega^{M}$ бо сугу́бое $\omega^{T}$ рина́ніе, твори ${ }^{T}$ оу́въща́нїе: е́ди́но же, й

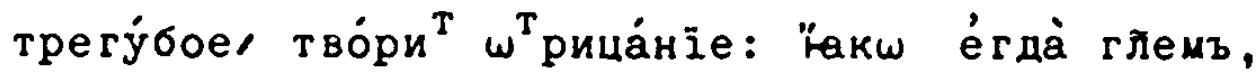

Не сотворй та́кш всйкому 'ази́ку 
й, Никто́ же '́ ம̈ности твое́й да̇ не неради́тъ.

Оўвьще́ніе, в.

¿े $\mathrm{Pa}^{3}$ лйчіи Нарб́чію Пре́жде да́же: й Пре́жде не́же:

Рйсски ска́зуему, пе́рвей по́ки: и́ пе́рвей нб́жъ.

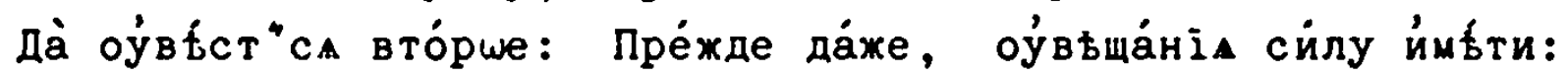

Пре́хде не́же, $\omega^{\mathrm{T}}$ рица́нін: за е́хе до́брь глемъ:

пре́жде да́же гора ${ }^{M}$ не бы́ти: пре́жде да́же не снитисл йма:

пре́жде да́же не поги́ну: пре́жде ца́же не '́тйду: пре́жде да́же не прийтй дню $\Gamma^{\mathfrak{C}}$ дню вели́кому: й про

Сйце бо гйемъ,

Ско́рш пре дарй да́xе не по

щพ

paбo

работим" са:

Рйхлш оу́передй по́ки не буддеъ зневолени: й про За е́же, пре́жде да́же не, и́, пре́жде не́же, то́жде знамена́телна ёста, й ӧба $\omega^{T}$ рица́телна.

'́ СОЧИНЕНІИ ПРЕДЛОга:

Глава̀: а̃.

Пра́вило: $\approx$.

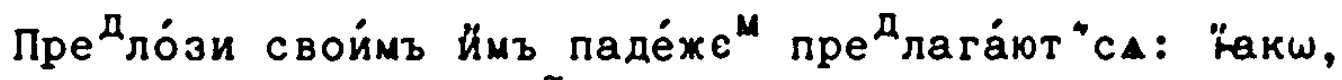

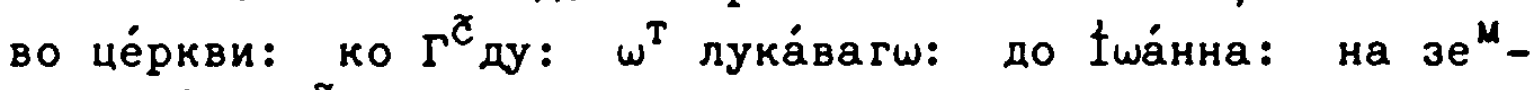
ли: $\dot{n}$ про

'ं Родите

оу่, $\omega^{\mathrm{T}}, \dot{\text { изз }}$, йлй йс, лй, $\mathrm{c}^{4}:$ до:

$$
\Pi p a^{8}: \text { в. }
$$

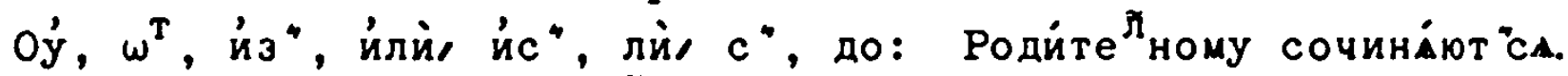

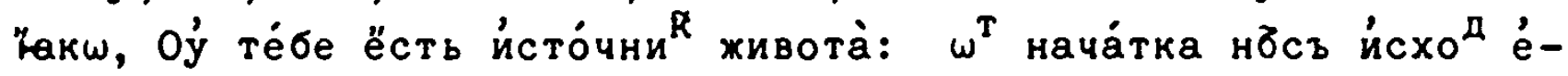

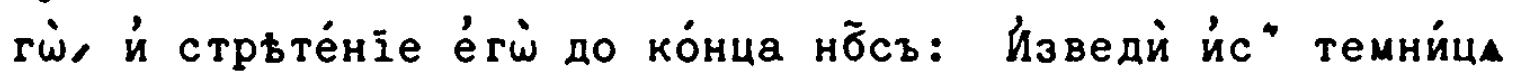
дш̃у мою: со гото́вагш жи́лища свое́гш: c" нб̄се́ при́зрь

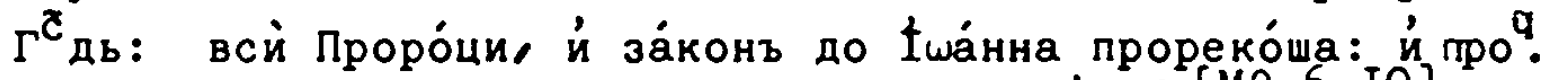
í मа́ $[M \theta .6, I 0]$

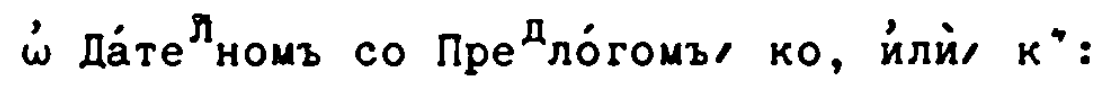

Пра́вило $\mathbf{7}$.

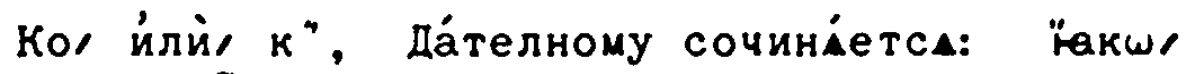

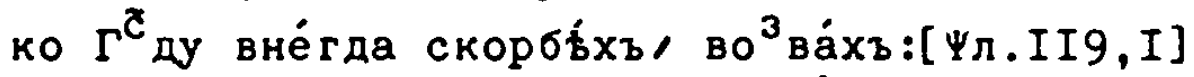

й, K" Бгуу мое́му во ва́хъ: й про

$\dot{\omega}$ Вини́телномъ: со Пре да́ггомъ, во ${ }^{3}$, йлй, вос:

Пра́вило дี. 


$$
-229-
$$

$\mathrm{Bo}^{3}$, йлй, вос, в мб́стшر за, Вините

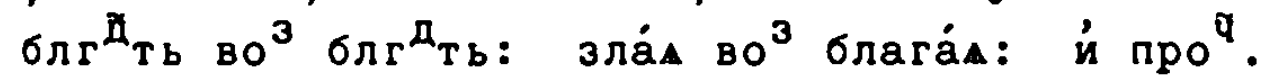
Нб́сть оба́че нера ${ }^{3}$ су́днь оу́потрео̆л́емъ пред̆логъ се́й сочинйтелнь, слохнь бо сочина́емый ёсть.

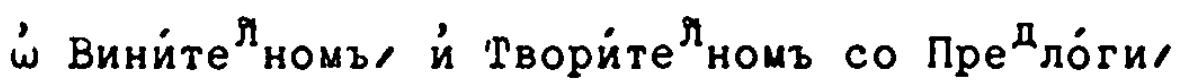

$$
\text { во, йлйв", на, пре }
$$

Пра́вило, 天.

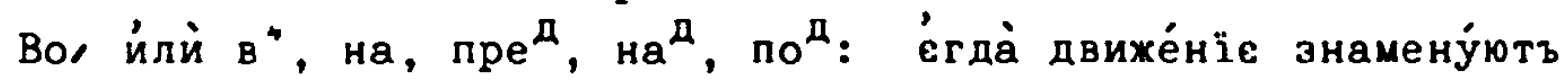
Вини́телному Сочина́⿴囗十" СА. "ЕКш,

Во всію зе́млю йзййде въща́нїе йхъ: $[\Psi \pi .18,5]$

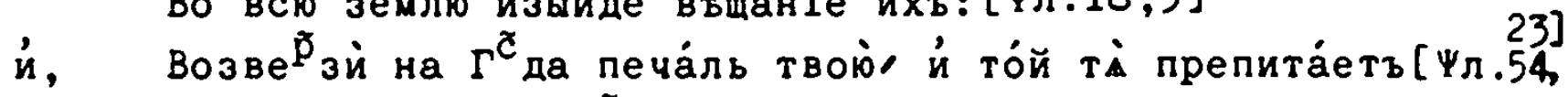

$\dot{u}$, моли́твы твод й мл тынн твод взыйдо́ша пред Бга:[дь. I0,4]

$\dot{u}$, На मа не́ же оўзриши Дх̃ схо

да́ща й пребыва́юща на не

ди́ща

[2276]

$\dot{u}$, по твою мл ть прибьга́емъ Бце Дво/ молиттвъ на́шихъ не пре́зри.

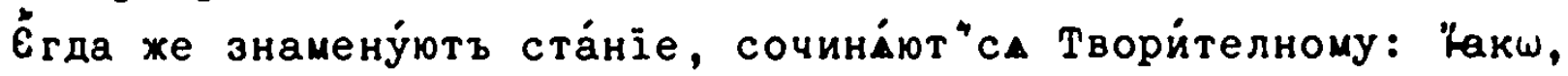
Во црокви стод́ще сла́вы твое́ :

й, На ка́мени ма вбры оу́твердй:

$\dot{u}$, Грб́хъ мо́й предо мно́ю ёсть выну: $[\Psi \pi .50,5]$

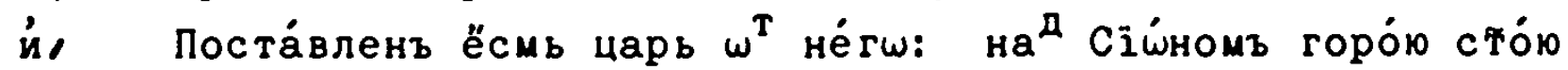

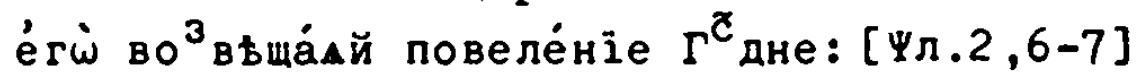

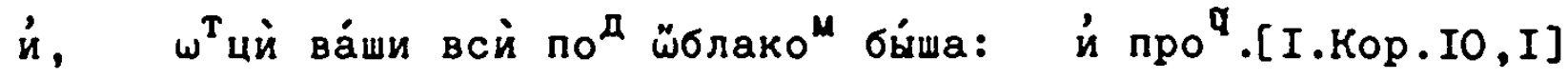

$\dot{\omega}$ Твори́телном" со Пред ло́гом", со:

Пра́вило, §.

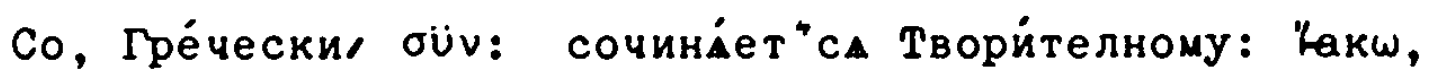
со Бтотоъ Авраа"лим": дне́сь бу́деши со мно́ю в" рай: й про ${ }^{q} .\left[\pi_{\kappa} .23,43\right]$

¿́ Сказа́телномъ со Предло́гомъ, прй:

Пра́вило, з.

Прй, сочина́ет"сА Сказа́телному: Какш,

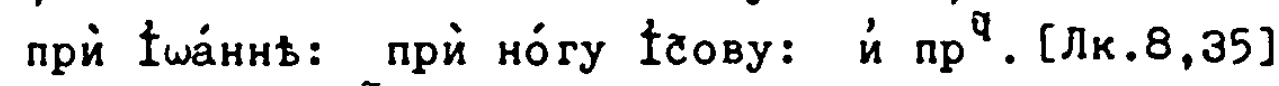

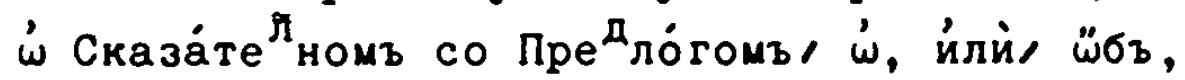
Пра́вило, й.

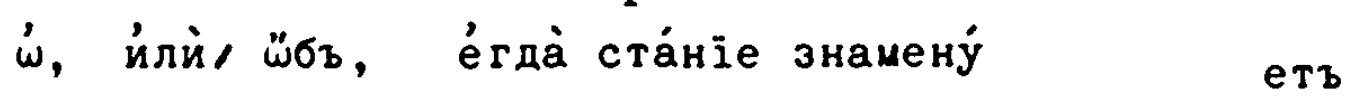

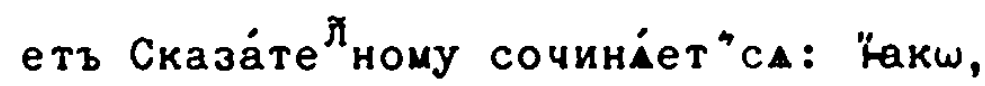

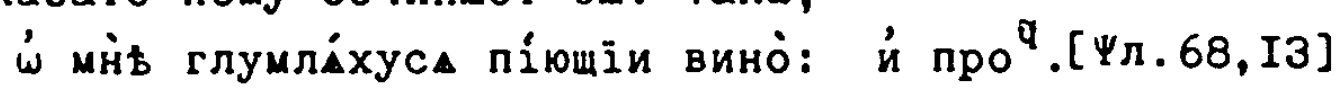


Érда * знаменуетъ движе́ніе Вините

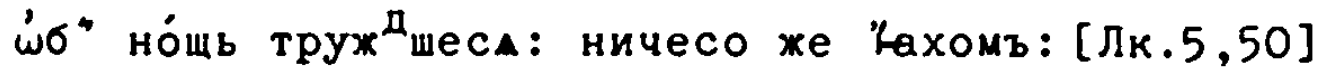

и,

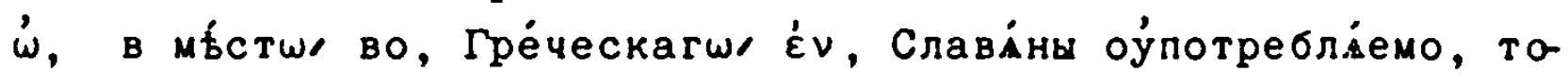
му́хде паде́жю сочина́ет"са: Какш,

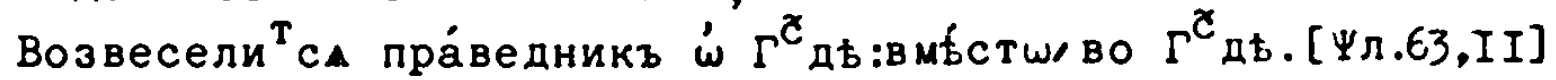

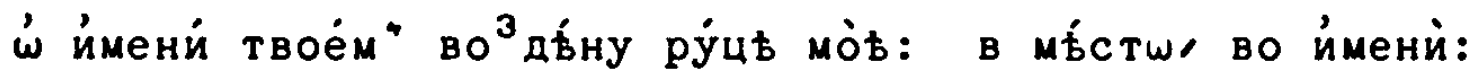

й про ${ }^{\text {q }} .\left[\Psi_{л} .63,5\right]$

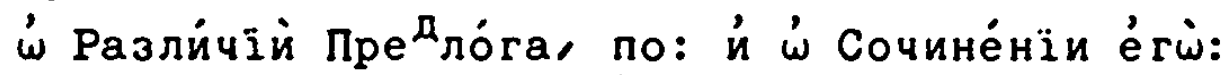

$$
\Pi p a^{\tilde{\theta}}: \tilde{\theta} \text {. }
$$

По, ска́зуемое, ве Дујгъ, Да́те По жесто́кому твое́му й непокайнному $\mathrm{cp}^{\text {मу }}$ : По ймени твое́му й хиттіе твое́:

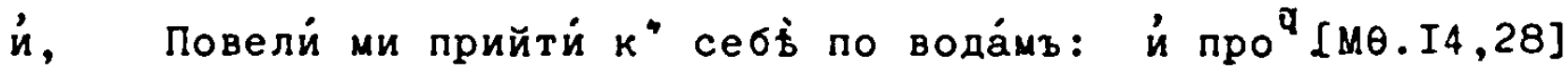

По, ска́зуемое, по́сль: сочині́ет"са Сказа́телному: Какш,

По сиххъ дру́гаa повб́ствова́ти ймамъ:

й, По стра́сти ше

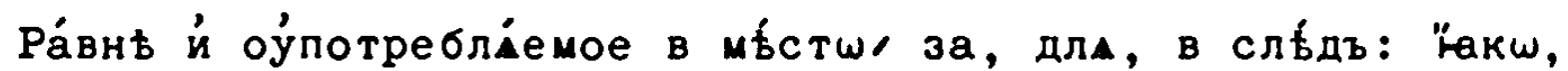

Положі் дйy мою்

щ

กо тебі:

по тебі:

[2286]

й, Ревну́ поревнова́хъ по Бъь Вседержители:

й, Градй по мніь. [Mө.I9,2I]

Сочиндет"са, по, й Вините ${ }^{\mathfrak{H}_{\text {ному }}}$ е́тда̇ знаменуетъ, до, й по, с" Вини́телным Ри́сское: "̈акш,

По тебе́ сло́во недале́чае: по ди̃у твою̆ прийдо́ша Ӓгі̃ли Бжіи.

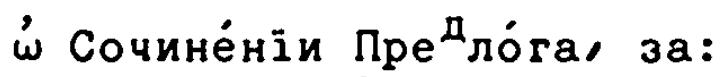

$\Pi p a^{\tilde{B}}: \tilde{\mathrm{i}}$.

3а, вре́мА знамену́, сочини́ет"сА Родйте ному: "Екш,

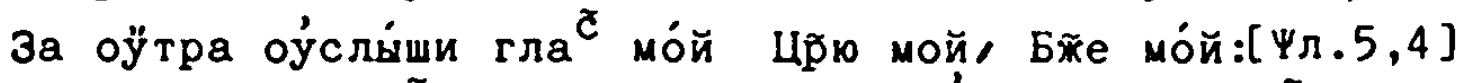

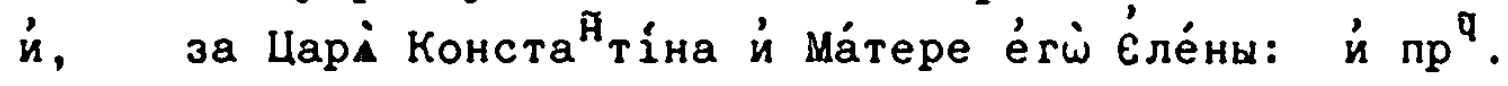

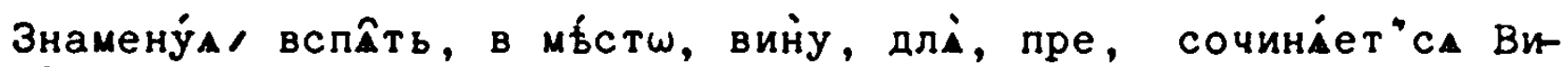

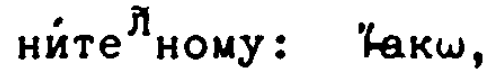

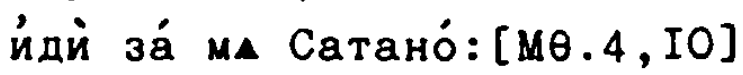

й, во даша ми зла́а за бл̆га́a:

й, за бе ${ }^{3}$ зако́ніп на́ша наве́лъ е́сй сі́ на на́съ:

и, за грб́шники оу́мре́ бе ${ }^{3}$ грб́шный:

й, за скудость нака́занны муже́й. 


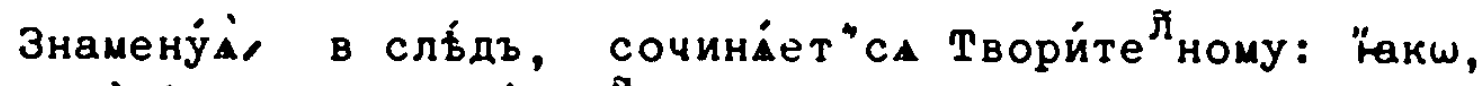
йдй за мно́ю: й пр".

$$
\text { Глава̀, в. }
$$

Пра́вило, а̇.

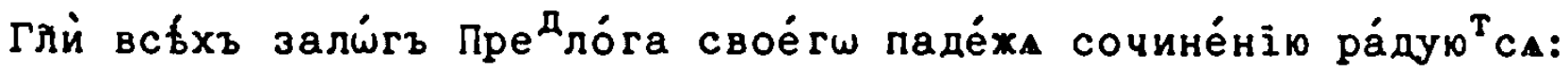
Накш, Слове

$$
\text { щ区 cá тво }
$$

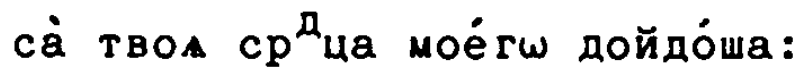

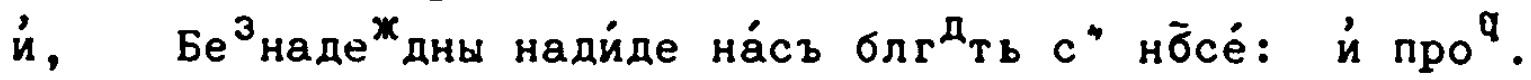

Пра́вило, ві.

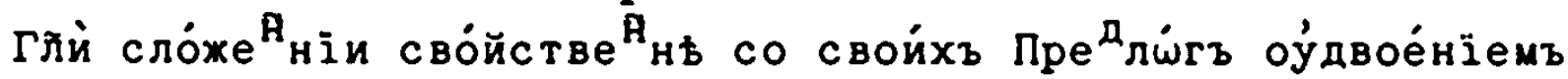

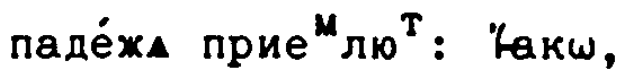

$\omega^{T}$ хох́y $\omega^{T}$ те́бе: снйде c" нб̄cé: Внйду в" до́мъ: За́йде за

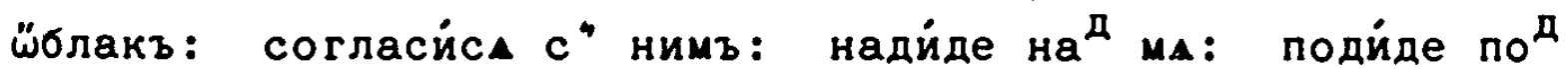
ма: предйде пред лице́нъ моймь: П̈ри мніь прййде: й про".

\section{$\dot{\omega}$ СОЧИНЕНІИ СОУЗА:}

Пра́вило, а:

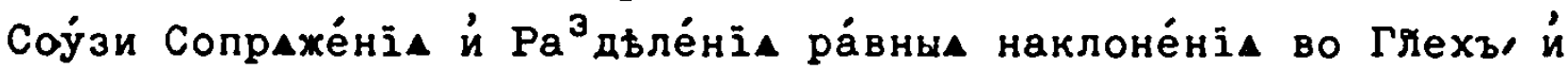

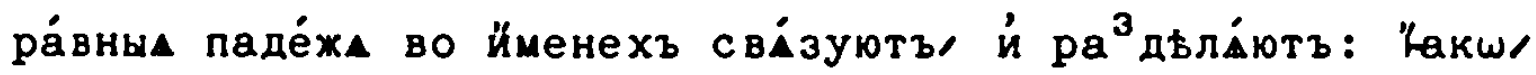
$3 e^{M}$ лі е́сй ѝ néneлъ: [Быт.3, I9] и, что $\dot{\omega} \mathrm{ce}^{M}$ рекуу ли что во ${ }^{3}$ глю; й про Пра́вило, в.

Дб́лА, ра́ди, дб́лма, ӧбразом" Пре Да́гъ Родйте слуххатъ: Һакш,

Тебе́ ради оу́мерщвлі́ми ёсмы Bécb

ве́cb де́ нb: [2296]

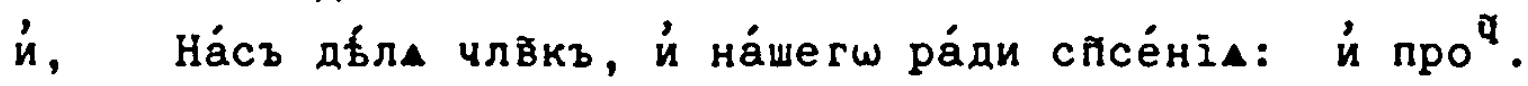
Пра́вило, זे.

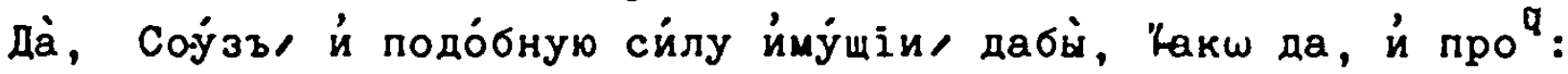

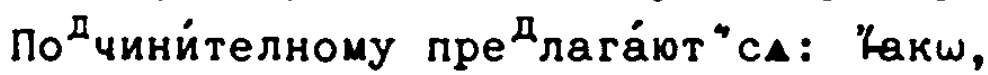
да̇ творі் во́лю $\omega^{T}$ ца̇ мое́rw:

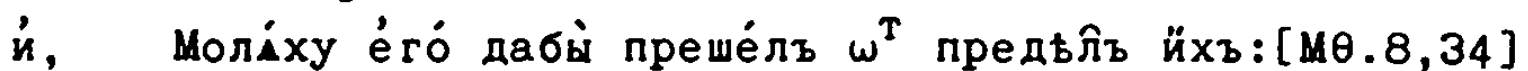

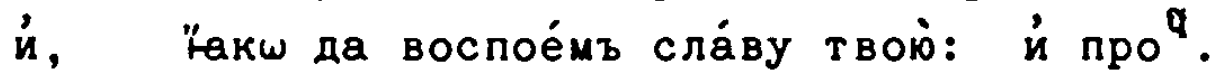

\section{Пристехе́ніе:}

Йзрд́днъе тре́тіему Повели́телнагш всб́хъ чйслъ лицेу да̇, Соуंзъ приле́хи ${ }^{\mathrm{T}}$ :

да̀ прййдетъ ца́рствїе твое́: да̇ бу́детъ во́ла твод்: $\dot{n}$ проq Пра́вило, д̃: 


$$
-232-
$$

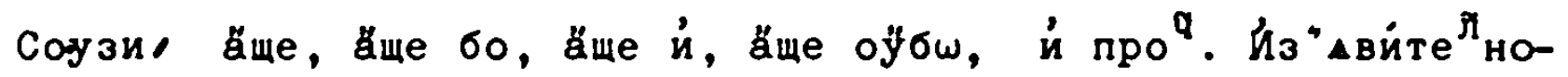
му предйдуть: Какш,

Аще хо́щеши соверше́нъ бы́ти, йдй, и́ прода́ждь всі ймбнїА Tво : : $[M \theta . I 9,2 \mathrm{I}]$

Äще бы, ӓще не, ăще бы оўбw, й про . Сослага́телному: "акш, Аще бы вра́гъ поносия" ми, претерпб́лъ быхх оўбш: й äще бы ненавидій мА, на́

MA

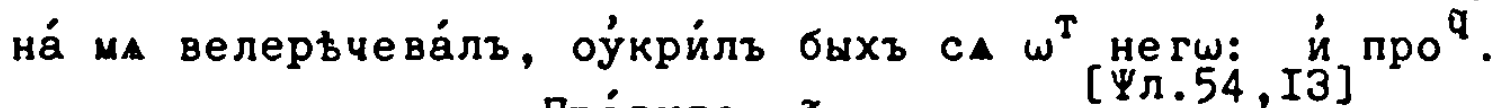
Пра́вило, є.

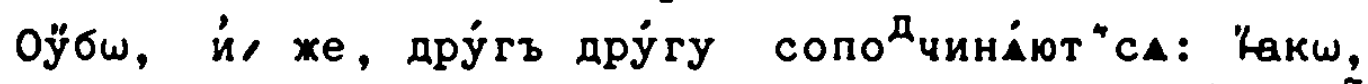
Се́й оўбш оу́тьша́ет"са, ты́ же стра́хдеши: и́ про".

\section{Пра́вило, $\mathbf{3}$.}

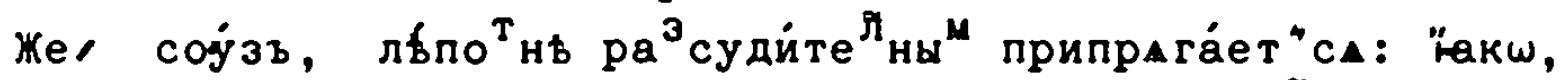
изрйднье же: бо́лее же: мно́хае же: й про".

Пра́вило, з.

Ëхе, соу⿰зъ, й во е́хе, Рйсски, а́бы, йлй, неха́й, Неопредъле́ну предйдутъ: Какш,

оу́де́ржи ази́къ сво́й $\omega^{T}$ зла̀, й оу́стны́ сво̀ ёхе не гла́ти

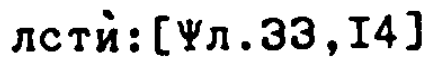

й, Воздви́гль мі е́сй во е́хе оу́тренева́ти й славослови́ти дерха́ву твою непобъдймую: й про

Мно́гажды '́ста́влени приразумъва́ют "са: Һакш,

Очи мой на вбрныА землї поса да́ти ґ́ со собо́ю: приразумъва́ему ёхе поса“дати:[廿л.I00,6]

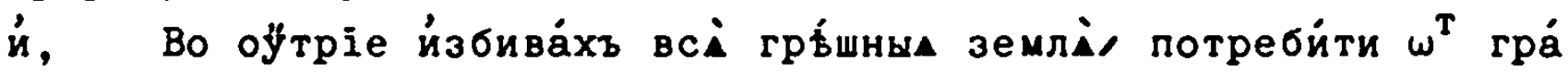
да

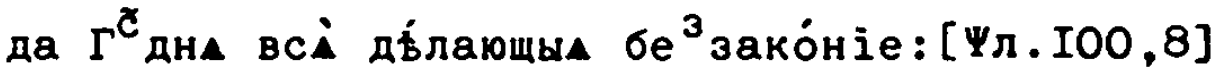
во е́xе потреби́ти, приразумъва́ему: и́ проq.

$\dot{\omega}$ СОчИНЕНІИ МЕЖдОМЕтіА :

Пра́вилол

ш̈ле, $\dot{и}, \hat{\omega}$, Сьтова́ніА: $\dot{u} \ddot{\omega}$, Оўдивле́ніА: Родйтелному со-

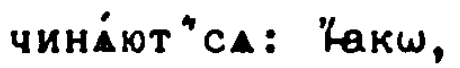

$\ddot{\omega}$ мене́ '́кайннагш члвка: $\ddot{\omega}$ прему́дры суде́бъ твойхъ $\mathrm{x}^{\mathrm{C}} \mathrm{e}$ : ì про .

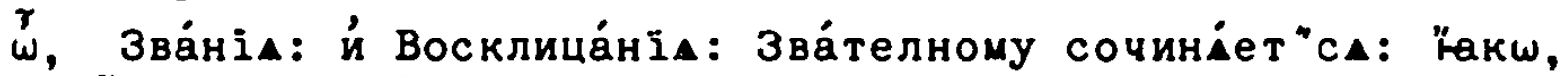
$\stackrel{\gamma}{\omega}$ Ғшанне: $\stackrel{\gamma}{\omega}$ глубино́ бога́тства, й прему́дрости й ра́зума Бóxis: ì npo . 
Пра́вило, В.

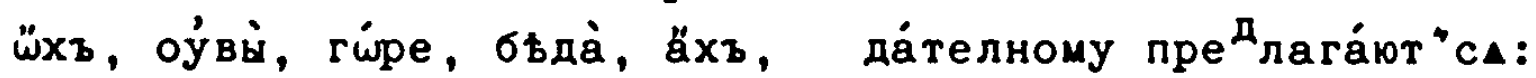
Һакш, оувв́ мнь: гйре вамъ: й про

Пра́вило, $\mathbf{r}$.

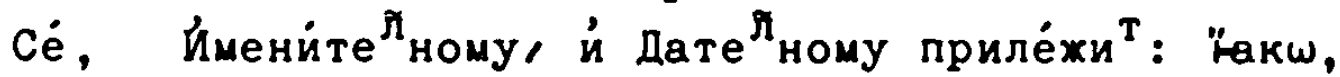

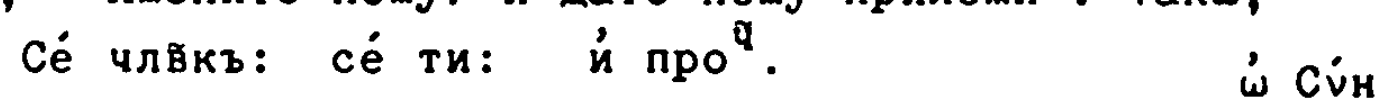

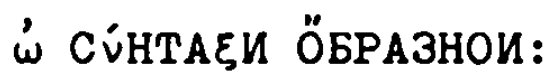

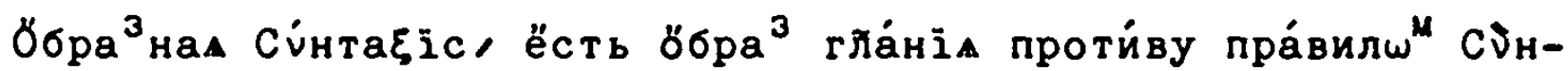
та́દешс, йску́сны писа́телей оу́отребле́ніемъ оу́тве́рженый.

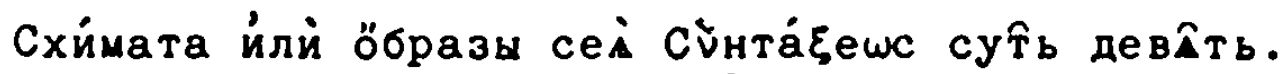

\begin{tabular}{|c|c|c|}
\hline 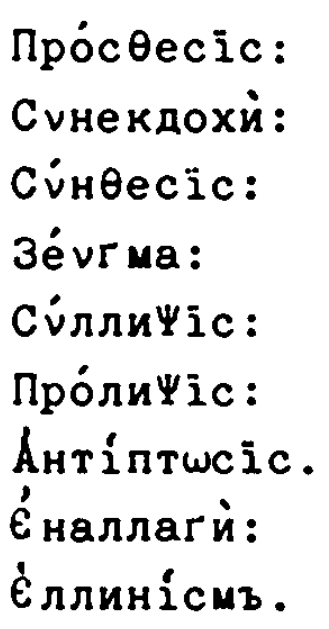 & Славе ${ }^{\mathbf{A}}$ ски. & 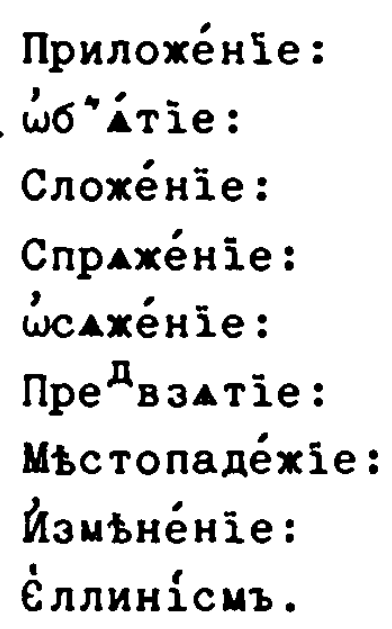 \\
\hline
\end{tabular}

ஸे Про́сөеси, и́лй Прилохе́ніи.

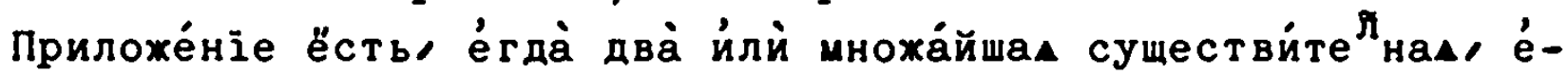
дйну й ту́жде ве́щь знамену́ющал стица́емал на́ми нарица́емал/ кро́ut Сау́за в" тóm xe па

дéxю

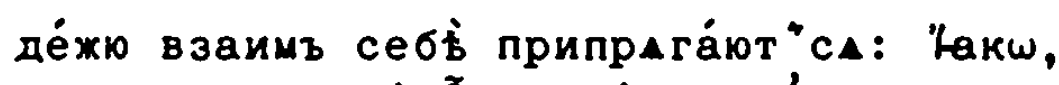

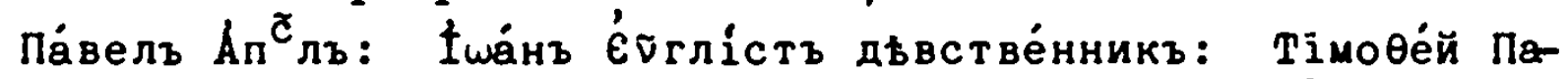
трїа́рхъ: град вйлно: Просөесіс схи́ма: й про .

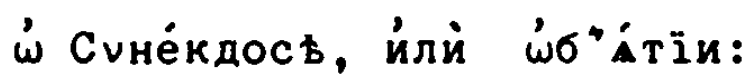

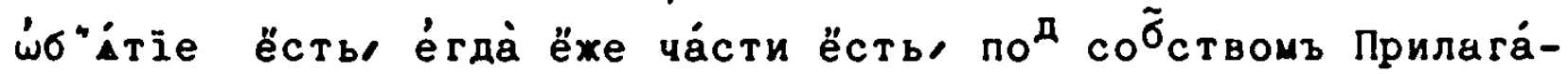

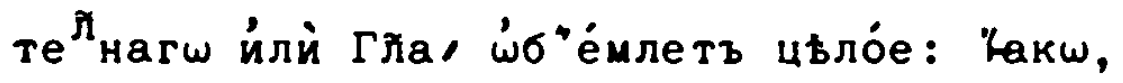

†̈́сифъ кра́сенъ лице́мъ: боліо главо́ю: Ахілле́й ско́ръ нога́ma: $\dot{n}$ про .

’́ Сйнөеси, илй Сложе́нїи.

Слохе́ніе ёсть е́гда̀ йма Собира́телное е́динстве́нное, сопрага́ет"сА прилага́те Ному и́лй глу мнохестве́нному: "Екш,

Бра́тіА мно́зи: ча́сть йзб́́тыл ча́сть оу́гонзну́ша: и́ пр ஸ́ Зе́vгмати, йлй Спрахе́ніи: 
Спрахе́ніе ёсть, е́гда̀ ну́хдное во сло́вь зае́мле ${ }^{T}$ са $\omega^{\mathrm{T}}$ приблйонагш предиду́щагш, и́лй кра́йнагш, лйбо средатвіющагш, пребыва́ющим" посльдова́телнь", си́речь, ро́ду числуу паде́ху й про́чіим"непору́шнымъ: 'ака,

Стыдынію прешдо

п̀ь нечистота̀, бо́хзни де́рзость, ра́зуму безу́мїе:

й, Пе́тръ оўчитъ Грамма́тіки, Џша́ннъ Діале́ктіки:

$\dot{u}$, Повинове́ніе дру́ги, йстинна же не́нависть ро́дитъ: й про

$$
\text { '́ сйлличи, йлй, '́слже́ніи. }
$$

ஸ́саже́ніе ёсть, е́гда̇ нуж жнагш предиду่щагш, лйбо сре ва́телнымъ непору́шнымъ не преб́́вшимъ: Какш,

Во́ини й Воево́да побъди́ша. Мј́жь и́ жена̀ блгочестиви

сутิь: äзъ оўбш ӑлчбою, б̆н же ха́хдою та́етъ: о̆нъ

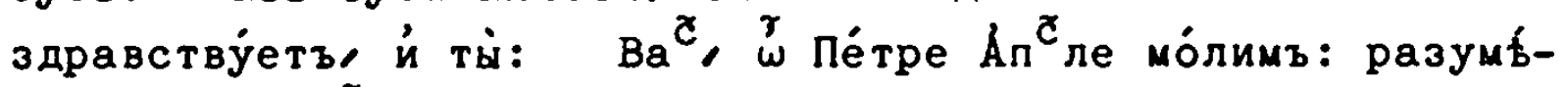
юще всбхъ $A_{n}{ }^{\mathbb{C}}$ лъ.

$$
\text { ஸे Про́личи, и́лй, пре взиітіи. }
$$

Предвзітіе ёсть е́гда̀ рече́ніе нбкое цблое предше́дшее/ в" ча́стехъ быва́етъ оўбш разумб́мо, не восприемле́мо же. Какш, Сศо́ве твои оўча ${ }^{T}$ сл, Геш́ргій Гра"ма́тіки, Григо́рій Ло́гіки, Анто́ній Пое́тіки.

й Бра́тіе мои и́змро́ша, Та́ко В" Ви ни, Сте́фан" в" Кра́ковь, нікола́й в" Кі́евь.

$$
3 \quad \stackrel{\omega}{\omega} A_{H T i}
$$

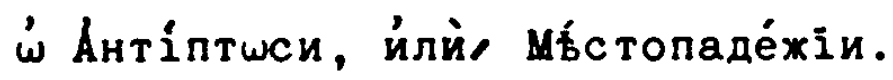

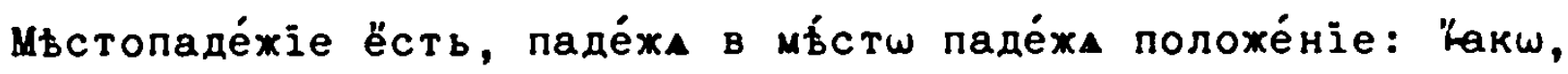
Члвка е́го же вйдиши/ ठ́те́цъ мо́й ёсть: в мб́стш/ члвкв:

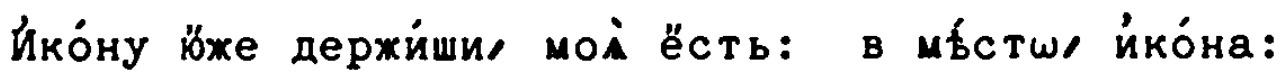
го́дь бв́сть ми, йхе и́зре́клъ е́сй йстинну: в мб́стшлйстинна.

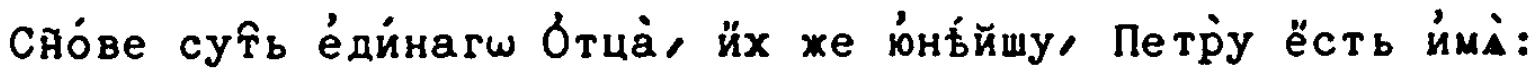
в мб́ctw/ Петр".

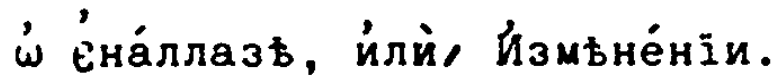

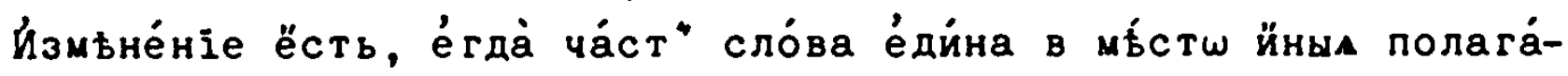

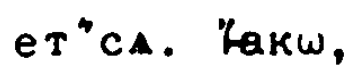

Сйце жи́тіе би́сть е́my: в мб́стш, сицево.

Ве́щь вреда ёсть клевета́ти: в мв́стш/ клевета̀. 
а. Ёллині́смъ, ёсть сочине́ніе о̆бразом" свӧйства ёллинскагш діа́лекта бываемое, му́жескому илй же́нскому существителному,

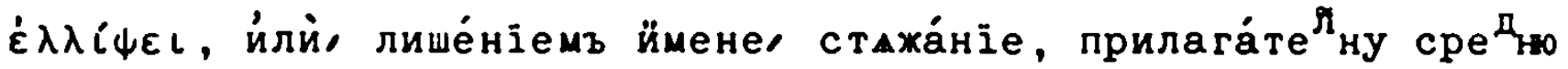
припраже́му . "акш,

Дру́гъ вы́ренъ о’́

тธ́யно

тб́шно ёсть й по́лезно сйречь, стАха́нї:

Любве́ добродб́тель й в" невб́рнь й про

в. Ӓттіческа дїа́лекта сво́йствомъ и́ Слава́не прилага́те й Ну Роди́-

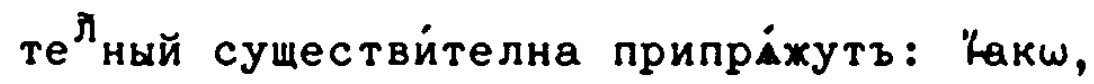

бйголь́пное лица̇: акй бы рещй, бйоль́пное лице́, и́лй блголь́піе лица்:

че́стное нра́ва: цђлому́дрное смире́ніА: й про .

r. Émфа́сешс ди́ла й Слава́не оупотреблиють мъстоиме́ніА, Са́мъ: 'акш' й тебе́ самы́ дйу про́йдетъ ору̇хіе: [Лк.2,35]

$\dot{\omega}$ ни $^{\mathrm{X}}$ же дово́лнье рб́хомъ пре́ди.

$\dot{\omega}$ ЧИНВ ГРАMМАТИЧЕСТЬ.

Пра́вило, $а$.

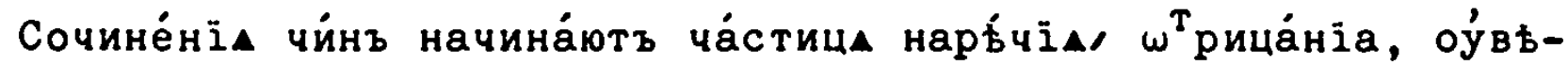
ща́ніа, желаніа, зва́нїа, оу́каза́ніа. й ча́стица сйлы во ${ }^{3}$ но́сныА: 'ако́вы сутিь, е́гда̇, внегда, когда̇, до́ндехе, си́це, Какш, и́

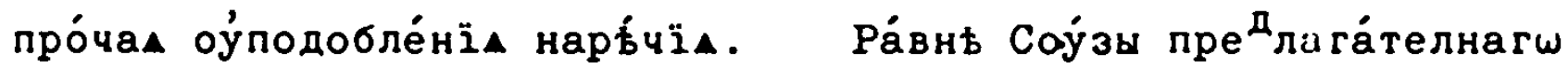
й б̆бщагш чйна. Та́кожде й всі Мехдоме́тїА.

ธв กра́

Пра́вилог в.

[2336]

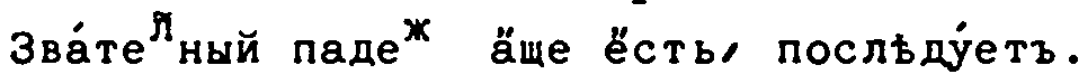

Пра́вило, $\tilde{r}$.

Ймени́телный в" нача́ло глуу: и́лй оу́десо сло́ва, лйбо Неопредъле́ний в мб́стш Йменйтелна.

Пра́вило, д.

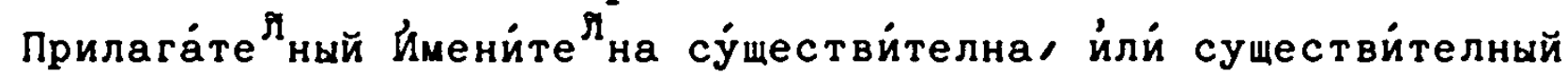

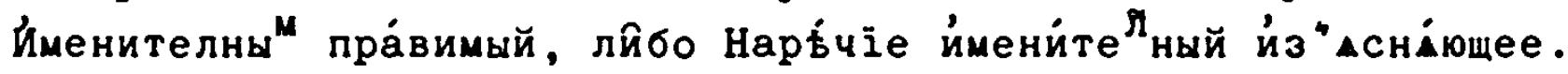

Пра́вило, æ.

Гйъ Лйчный '́предьле́на наклоне́нї: Ӓще ли же бу́детъ гй $\sigma e^{3}$ личенъ, $\omega^{T}$ тогй начне́тса чйнъ. Äще Неопредђле́на наклоне́нй бу́детъ $\omega^{T}$ винйтелна, е́го́ же пре иду́ща себї прита́хетъ, начне́т" cA.

Пра́вило, $\mathbf{3}$. 


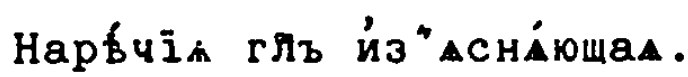

Пра́ви

Пра́вило, з.

Паде́же гло́мъ пра́вимии по чин̀у.

Пра́вилог

Припраже́наА паде́жє воспосльду́ютъ, ймена̇, лйбо йна ка́А. Пра́вило, $\tilde{\theta}$.

Паде́xe предли́гъ.

$$
\text { Пра́вилол ĩ. }
$$

Преди́детъ прилага́телному существи́телный: и́му́щъ же сво́й е́м̀у пра́вимый паде́жь, воспосльду́етъ прилага́те ${ }^{\Re}$ ну.

$$
\text { br } \dot{\omega} \Pi \mathrm{MPO}
$$

'́ ПРосшдІи СТІХотво́рной:

Мa ${ }^{\mathrm{T}} \theta \dot{\text { й }}$ Стрійковскій Кано́нікъ Самои ${ }^{\mathrm{T}}$ скій, дбй Славе́нскихъ хроногра́фъ достовбрный в" четве́ртой свое́ хроноло́гіи кнйзь пи́ шетъ, ठвідіа Сла́внаго ӧнаго Латі́нскаго Пое́ту в" Са́рма скихъ

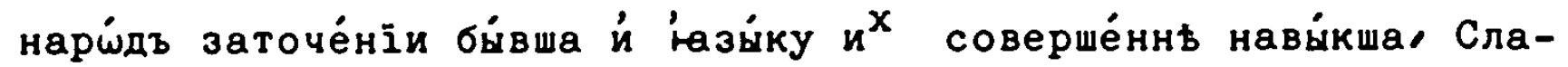
ве́нскимъ дї́лекто за чи́стое е́rí кра́сное й любопріе́мное Стіхй йлй вирши писа́вша.

За е́же во мо́хну Стіхотво́рну ху́дохеству в" Славе́нскомъ 'ази́-

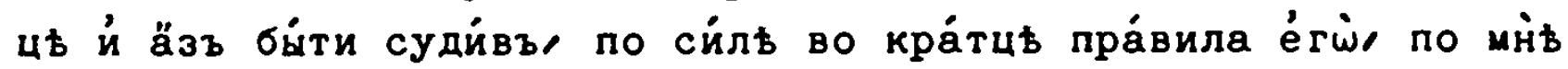

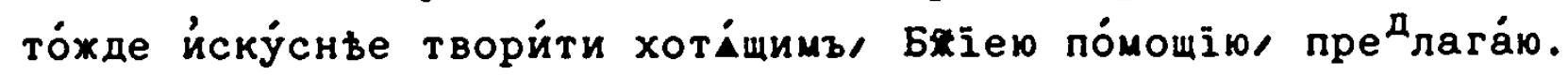

что́ ёсть Проси́шдіa;

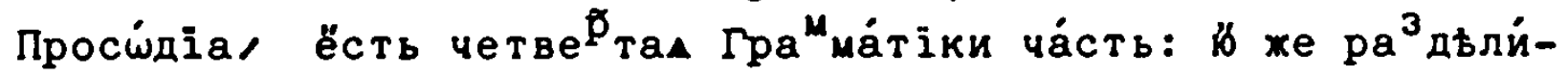
хомъ на ठрөогра́фійну, й гла́са писме́ннагш во гланіи, йлй во гиса́нӥи припбтіе йзмб́нное бы́

ти i⿱

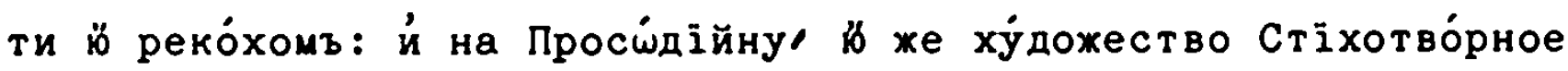
по" ме́тром" йлй мб́рою слш́гъ колйчества, бы́ти гйемъ.

Ка́кш во позна́ніе стіхотворе́нї прийтй мо́жемъ;

Сті́хъ состо́итъ нога́ми: нога̀ сло́гами: сло́зи стихі́ми, и́лй писмень: за е́же позна́ніемъ писме́нъ, сли́гъ, й ни́гъ, во Стіхотворе́ніА позна́ніе при́йдем. Й '́ं Писме́нехъ оӱбш й сло́гахъ во брөогра́фіи доволнье: зде́ же '́ Количчествь слйгъ: $\dot{\omega}$ Нйг" собст-

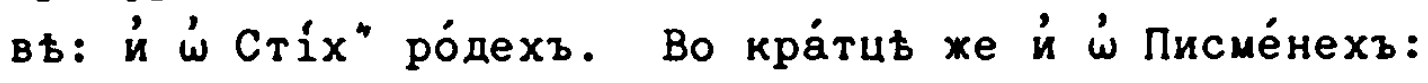

'ं Писме́нехъ.

Писмена̀ пре́ди ра ${ }^{3}$ дьлихомъ на) ( Гла́снам: й 
Гла́снан раздьли́хоз на,

( Самогла́снаа: '́,

Припражногла́снал, рече́нйй 'кконче́ніе на согла́сное сходіщее ш́дебелїющал, йлй '́тонча́ющаА.

Cano

[2356]

Самогла́сннми, двогла́снаА, трегла́снаА, й четверогла́снаА со-

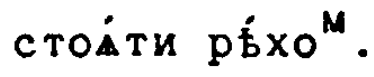

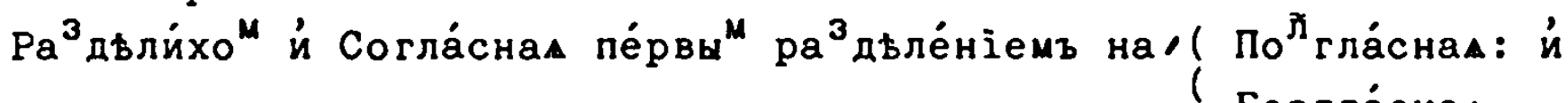
Безгла́снам.

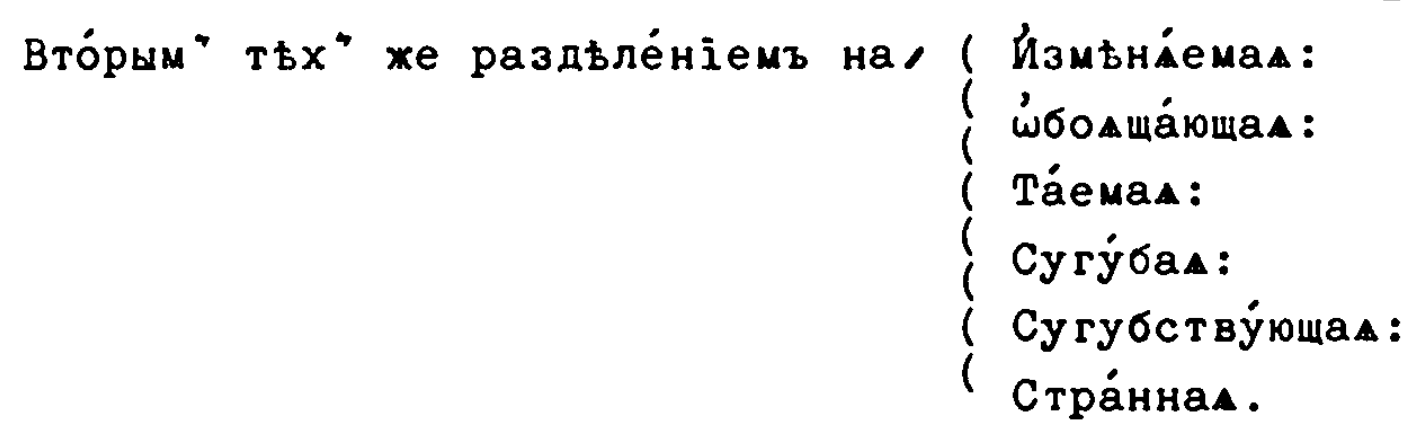

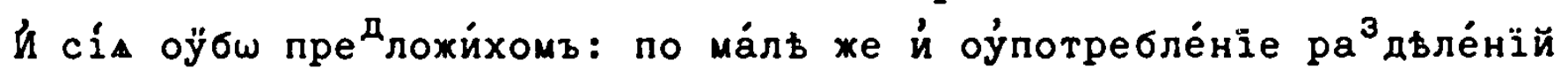
нб́коихъ, ко Стїхотво́рной Просйдїи налеха́щихъ предло́химъ.

'́ Сли́rв Коли́чествь.

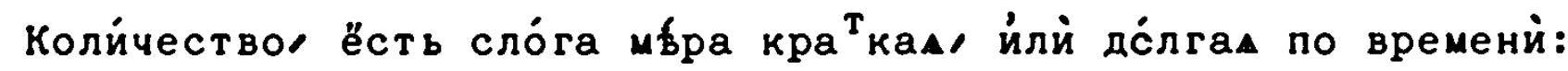
ёхе сокраще́нїе и́ли протаже́нїе гла́снагш, лйбо сло́га бы́ти,рі́хомъ:

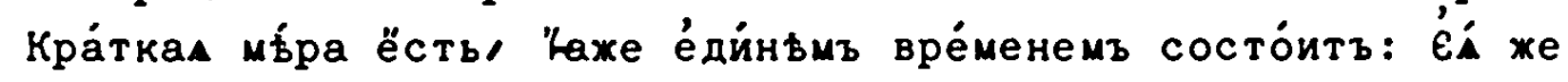
начерта́ніе ёсть сйцево: - :

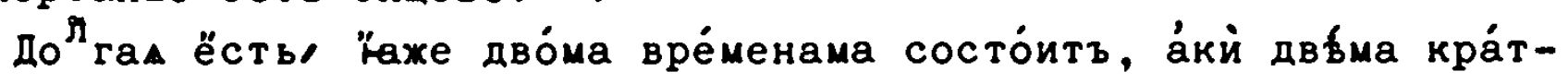
кима состод́щал: éá же начерта́ніе - :

$\dot{\omega}$ Раздьле́ніи Сли́гъ сло́вомъ Коли́чества:

Коли́чества сло́во с сло́гъ ёсть трегу́бъ. ( Кра́ткій:

( Доллгій: й

Кра ${ }^{T}$ кій ёсть, йже кра́ткимъ вре́менемъ начертава́ет"са: Какш, сло́во:

До́лгій ёсть, йже до́лгимъ вре́менемъ начертава́ет"са: "Екш, ймĀ :

Двовре́менный, йлй ஸ́бод́тный ёсть йже й до́лги" й кра́ткимъ вре́менемъ начертава́тиса мо́хе ${ }^{T}$ : Һакш, в

$\dot{\omega} \mathrm{Pa}^{3}$ дьле́ніи Слйгъ словво Чйна.

Чйна сло́во сло́гъ ёсть трегу́бъ.

( Пре́дній:

( Сре́днїй: й

( Послвднїй. 
Пре मаій ёсть Йже в" нача́ль рече́ніА полага́ет"сА.

Сре́дній, йже ме́жду пе́рвымъ й послбднимъ полага́ет"сА.

Посль́дній, йже в" концй рече́ніа полага́ет"са: "акш, ठтроковйца: о́, пе́рвый

$$
\text { ъ } \tilde{\varepsilon}
$$

ёсть сло́тъ: ца, послб́дній: про́чіи же сре́дни сутิь.

$\dot{\omega}$ познава́ніи Колйчества сли́г".

Сли́гъ коли́чество Слава́ншм" познава́емо будетъ, Ёстествомъ писме́нъ: Полохе́нїемъ: Прираце́нгемъ: и́ '́конче́нїемъ.

‘் Познава́емыхъ Ёстеством":

Писмена̀ преди реко́хомъ сугу́ба би́ти/ Самогла́сна й Двогла́сна: и $\omega^{\mathrm{T}}$ ஸ́бо́, бва ёстествомъ кра́тка/ ӧва до́лга/ б̆ва же о̋бща бы́ти пре дохихомъ: за е́хе й зде́ глемъ, Писмена̀ Самогла́снам ёстеством" кра́ткаА, би́ти, е: й о: Двогла́снал ёстест[в]ом кра́ткац, ей: йر ой.

Писмена̀ Самогла́снаА ёстествомъ до́лгаА, и: ь: й $\omega:$ Двогла́снац ёстествомъ до́лгац сво́йственнац: оу́: ы: $\varepsilon$ : ra: А: Несво́йстве наА ёстествомъ до ̆⿱гаА: ий: ђй: шй: оуй: ४й: ый: єй: юй : юй: Ай.

Писмена̀ Самогла́снац ёстествомъ б̈бщаА: $a, i, v$.

Писмена̀ Двогла́снаА сво́йственнаА

ёсте

ёстествомъ б̋бщал, $y$, й $ю:$ Двогла́снаА несво́йстве ${ }^{\tilde{H}}$ наА ёстествомъ ӧбщах: ай: ій: й їй: Сй предло́женымъ, полагаемъ правила $\dot{\omega}$ ёстествомъ познава́емыхъ.

Пра́вило '́ Самогла́сныхъ ёстество ${ }^{M} \mathrm{ka}^{\mathrm{T}}$ кихъ

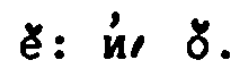

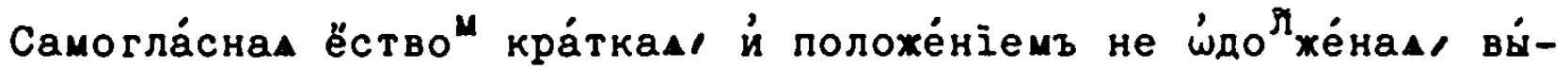

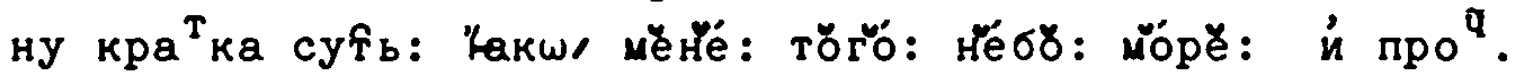

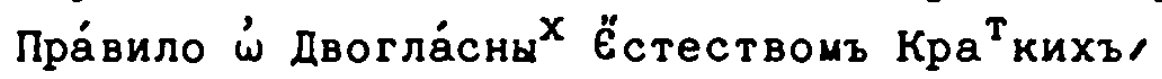

ей: й ой.

Двогла́снаА ёстествомъ кра ${ }^{T}$ каА сйлою гла́снагш посльду́ющагш рече́ніА ёстество кра́ткихъ прита́хутъ: "Екш, моӗй ӓгници: чи́с-

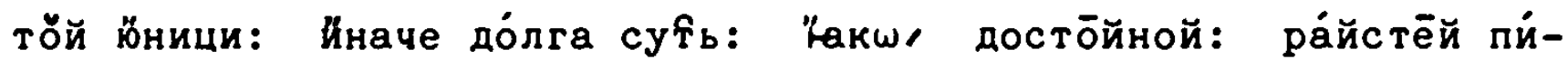
ци: сватӧй це́ркви: и́ про ".

Пра́вило '́ Самогла́сныхъ й Двогла́сныхъ

сво́йственныхъ й несво́йстве и, ち, й w: До сво́йственнам: Бй, уй, 


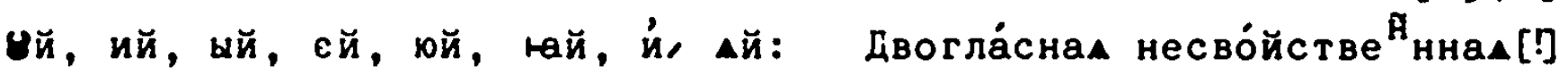

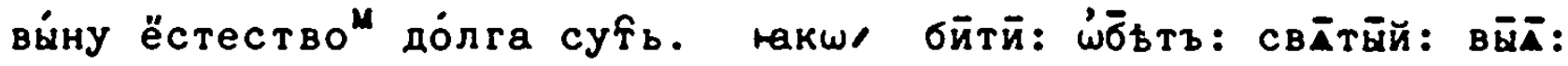

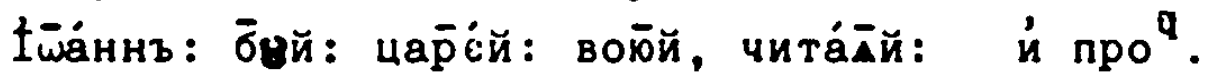

Пра́вило ’́ Двовре́менныхъ Самогла́сныхъ,

$$
\text { a: } i: \dot{u}, v \text {. }
$$

a: Во є̇вре́йскихъ, Гре́ческихъ, й Славе́нскихъ рече́ніихъ вйну двовре́менно ёсть: Полохёніемъ, и́лй Приращеніемъ, лй '́ко

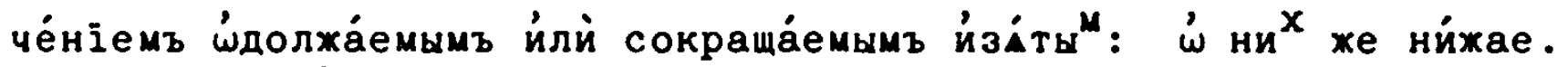

i: во '́ере́йски то́чію й Гре́ческихъ рече́ніи

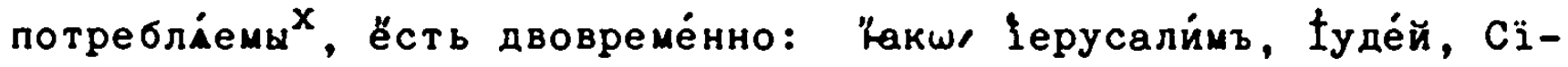

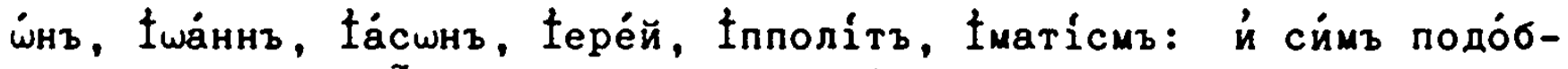
нал: Во славе ${ }^{\mathfrak{A}}$ ски $^{X}$ же, гла́сному и́лй двогла́сному ёстествомъ дслгу предиду́ще двовре́менно бу́детъ: Какш/ бїю: біА́хъ: здра́віА: здра́вїм: благій: сій: и́ проq. Предидуще же гла́сному йлй двогла́сному сво́йстве кра кому, и́ то́ кра́тко бу́детъ:

kakws

[238]

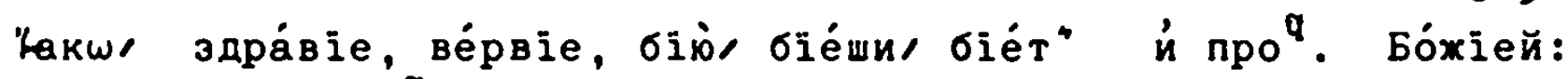
ве́ліей: и́ про ${ }^{q}$.

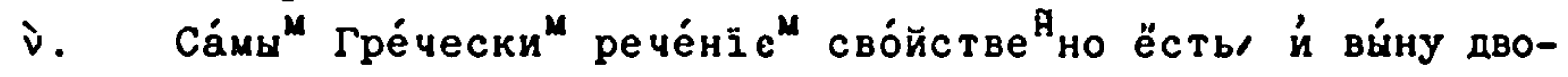

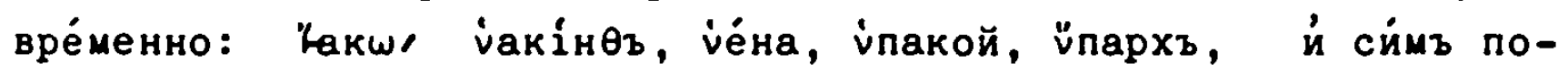
до́бнам.

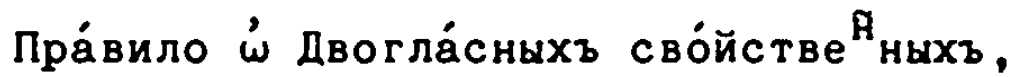

$$
\begin{aligned}
& \text { y: й } 10 .
\end{aligned}
$$

Ho/ Полохе́ніемъ нево ${ }^{3}$ бане́но, ви́ну '́бойтно ёсть: уر же сво́йствомъ кра́ткагш гла́снагшl ёстествомъ кра ${ }^{T}$ ко да́ са вмбнитъ: до́лго би́ти хоти́ще, сйце во сре́ды й в" ко́нцихъ рече́ній пи́шемо бу́детъ, 8: в" нача́ль же/ оу́: ஸбо́е ёстествомъ до́лго.

Пра́вило ’́ Двогла́сныхъ несво́йстве aй, ій: й, ій.

ай, ій, й, ій, в" е́дйно й томжде рече́ніи йлй в"концй

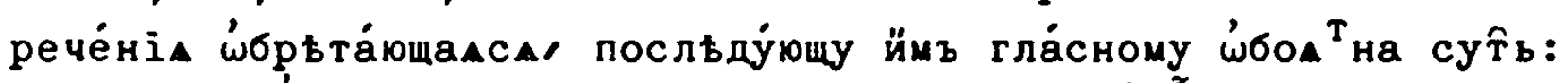

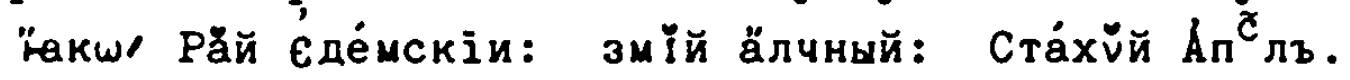

Посльду́ющу же согла́сному' естество

до́лra

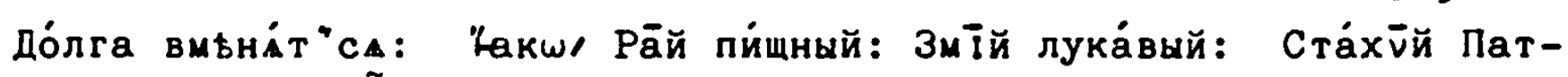
piápxъ: $\dot{\text { n }}$ nрo 
Положе́ніемъ сло́гъ ёстествомъ кра́ткій '̈до жа́ет"са. ёст" же Положе́ніе дво́ю согла́сну йлй мно́гшихъ, лйбо Сугу́багш, йлй Сугубству́ющагш е́дйному ёстество кра́ткому йлй ӧбщему гла́сному при-

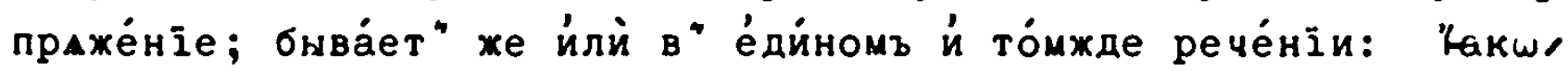

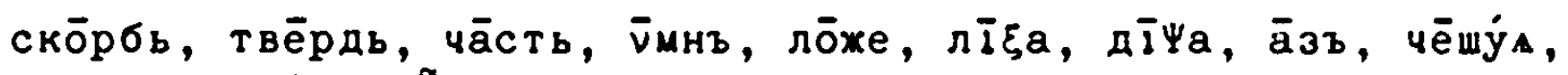
влёче́тъ: й про". йлй в" разли́чншхъ: си́речъ, е́гда̇ пе́рвое ре-

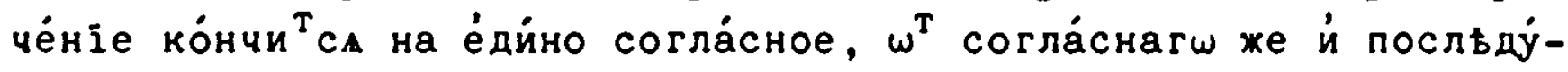
юще начина́етъ. "акш, Бо̄г" мой: Спаситёл" мо́й: Пйшёт"Пе́тръ: й про .

ЙзÁtia:

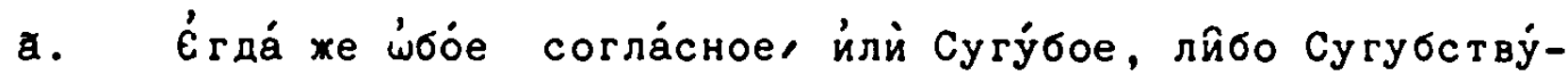
ющее $k$ " посльдующему рече́нію нале́жати бу́детъ, предицујщій ёстествомъ кра́ткій сло́гъ в" сво

$\dot{e} m b$

[239] е́мъ ёстествъ пребу́детъ: Қакш/ Бо̄же̌ всеси́лне: при́йдӗ женйхъ. в. Же, Cопрага́те нагш знаменова́ніа Соу́зъ, предиду́щее ё-

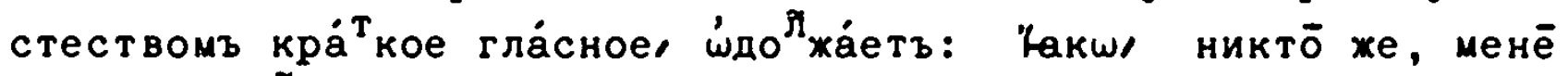
же: и про

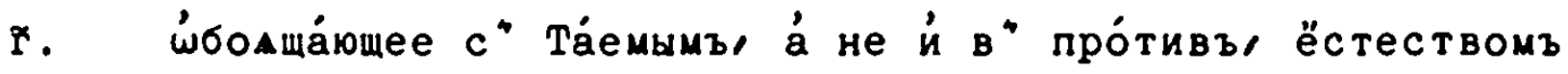
кра кау '́ не й ӧбщу гла́сному в" то́мжде рече́ніи посльдующа, $\dot{\omega}-$

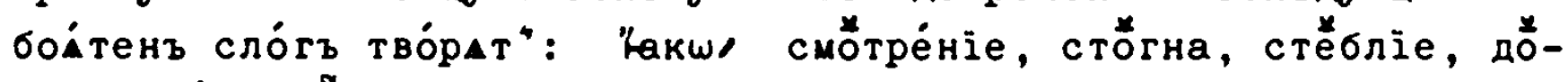
гма: й про q.

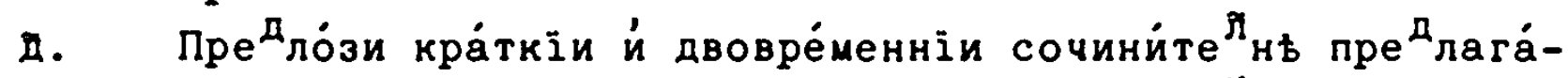
еміи во свое́мъ ёстествђ ви́ну пребу́дутъ: Һакшл нӑ зе́млю: со̆ жено́ю: во̆ черто́гъ: ко̆ сме́рти: й про

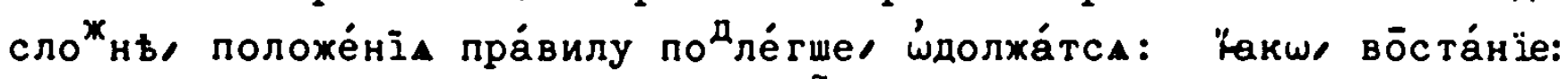
прётворе́ніе: за̄сту́пница: й про

$\dot{\omega}$ ПОЗНАВАЕМЬIXъ Наращёніемъ.

Нараще́ніе Слава́нш" ёсть сугу́бо: Возраща́ющее, ёже й Возраще́ніе: '́ Прираща́ющее, ёхе и́ Прираще́нїе.

Во ${ }^{3}$ ращáющее ёсть Нараще́ніе рече́ніе со преди йлй Пре

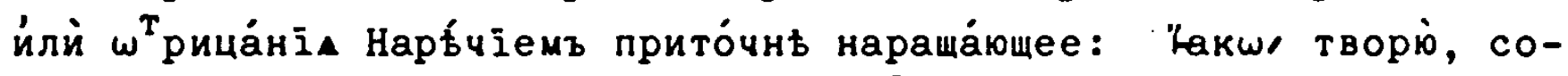

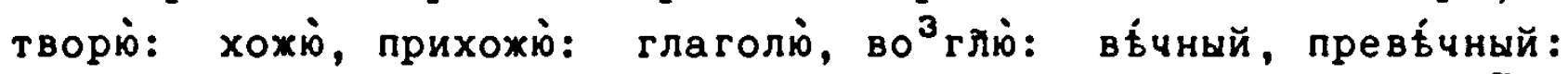
постихимнй, непостихимый: сме́ртный, бе ${ }^{3}$ сме́ртный: й про

Прираща́ющее, ёсть прираще́ніе рече́ніе со за́ди сло́гов йлй

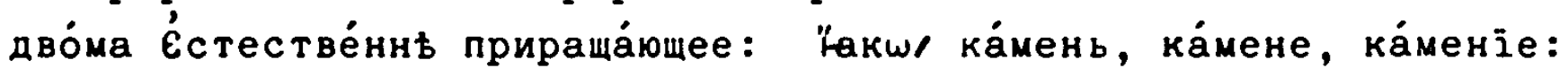
челови́къ, человб́ка, человб́кома: творю̀, тво́риши: творйхъ, творйхомъ, твори́хова: й про ${ }^{q}$. 


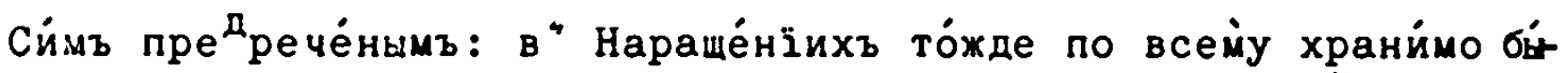
ти гйемъ, ёже во про́чіихъ ёстествомъ кра́ткихъ йлй до п̆гихъ й-

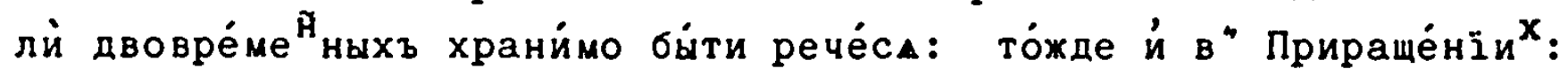
развь на, а: прираща́емьхъ.

\section{‘́ Прирашеніни нал a: \\ Пра́вило:}

Приращёніе на, а: Йме́нъ, и́ Гйъ й Прича́стїй коегі́либо склоне́ніА, числа̀, й паде́жа: во Гдее́хъ вре́мене, й наклоне́нї б́бо́егш спраженін, ёстествомъ

$$
\text { до́лго }
$$
до́лго ёсть. Пакш' вра́гъ, вра̄га̀: печа́ль, печа̄ли: ӧлтарь, о̆л-

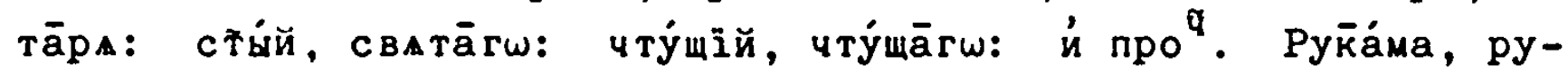
ка́ми: ю̈ноша̄ма, ю̆ноша̄ми: клевре́та̄ма, клевре́та̄ми: дре́ва̄ма, дре́ва̄ми: й про й. Писа̄хомъ, писа̄хова, писа̄ти: Молча̄хова, молча̄ти: иं про й.

\section{Йза́тїe:}

Вини́телнагш е́динстве́ннагш Прираще́ніе на, а: ӧбще ёсть: ła-

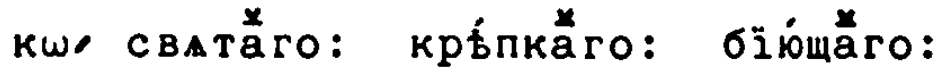

$$
\text { Оу́вње́нїе : }
$$

Цво́ю во е́дйномъ рече́ніи нал а, прираще́нїю су́щу: пе́рвое ёю о̋бще будетъ: вто́рое ёстествомъ до́лго: 'акш' А́ромӑта̄ма: Схїсма̊та̄ма: й проq.

'ं ПОЗНАВАНІИ '́КОНче́ніемъ:

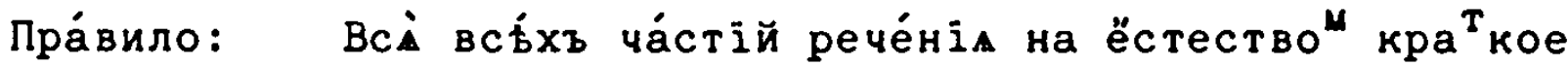

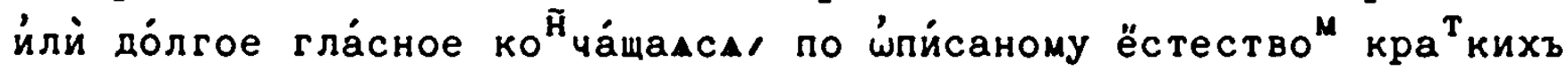
й до́лгихъ самогла́сныхъ пра́вилу, йна кра ${ }^{\mathrm{T}}$ ка бу́дутъ, йна до́лга.

$$
\text { O'́в }
$$

Оу́въще́ніе $\dot{\omega}$ двовре́менну, і. й $\dot{v}$.

Ha/ $i, \dot{n}$ на, $\dot{v}$ : Рече́ніа Славе́нскал не ко́нча ${ }^{\mathrm{T}} \mathrm{cA}$. Пра́вила $\dot{\omega}$ ёстествомъ кра́ткомъ в" ко й ци, $а$ :

\section{Пе́pвoе :}

'́ко Н̈че́ніе, a: Йменъ, Прича́стій, й Гйъ ёстествомъ кра́тко

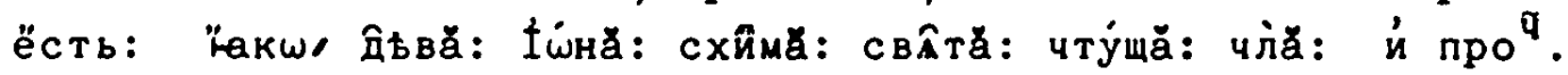

\section{Bтópoe:}

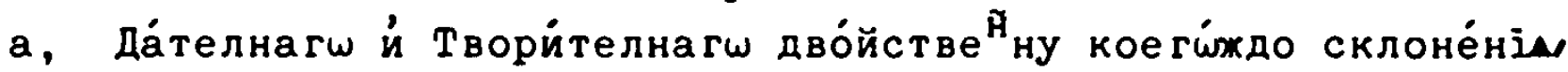
ёстествомъ кра ${ }^{\mathrm{T}}$ ко ёсть: "̈кш/ рука́мӑ: йношамӑ: человє́комӑ, че-

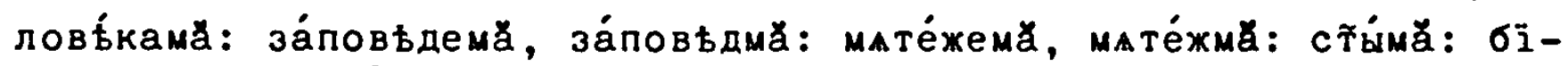
ю́щима̊: иं про .

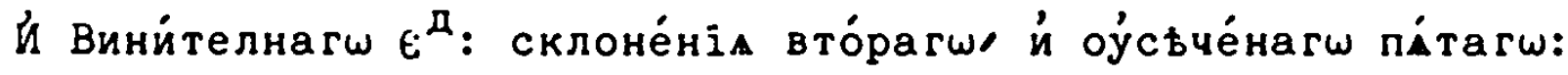




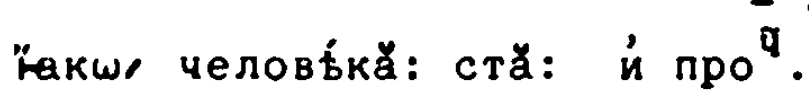

Tpétĩe:

a, Йени́телнагш, Вини ${ }^{\mathrm{T}}$ : й Зва́тел: множестве ${ }^{\mathrm{H}}$ ное Сре́дни ко егі́либо склоне́нї, ёстествомъ кра́тко ёсть: ̈̈акш/ дре́ Bă :

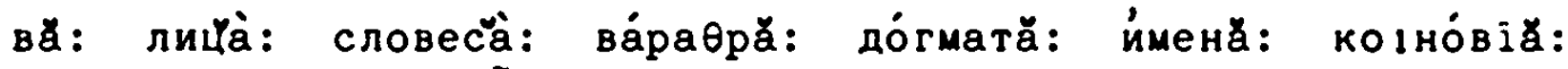

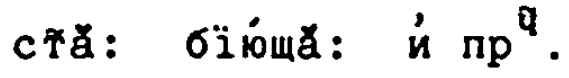

$\dot{\omega}$ Ë́стеством до́лго", в" коний a.

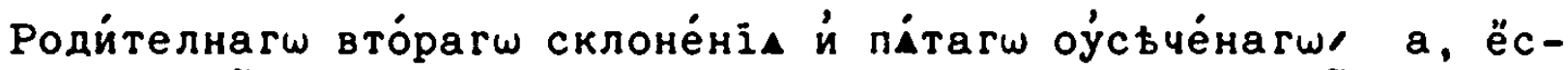
тествомъ до ${ }^{\Re}$ го ёсть: "акш/ человбка̄: сва́та̄: й прой.

Про́чеe, a: ви́ну ӧбще:

$$
\text { ஸ́, y: оу́въще́нї: }
$$

Вбстно бу́ди, $y$, в $^{*}$ нача́ль рече́ніА ника́ко же й в" стїхотво ре́ніи полага́емо би́ти.

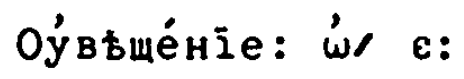

E, прие́mлемо в" мнохестве́нном" числь' в мfстш дре́внагш/ 1 , ёстествомъ до́лго бы́ти прие́млемъ: "̈акш/ о́тие̄м": зміє̄мъ: о́тёцъ:

\section{O’́в бще́нї,}

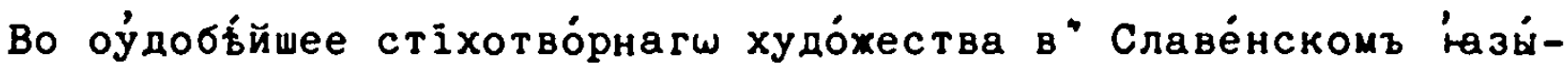
ць йзшбрьте́ніе и́ оу́законе́ніе, ъ, конча́ему слогу [ё]стеством кра́тку припра́хенъ, й гла́сну предиду́щъ, Һ́долха́ющъ бы́ти прие ле $\mathrm{e}^{\mathrm{M}}$

Ëpi

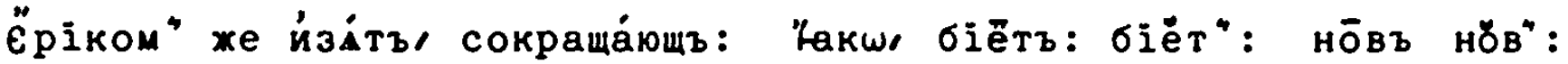
й про đ. припрахе́нъ, b, вы́ну сокраща́ющъ: иза ${ }^{\top}$ же па́еркомъ

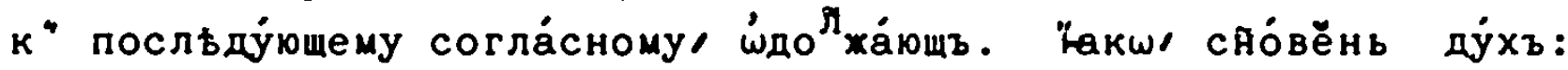

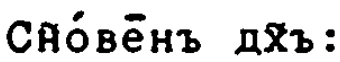

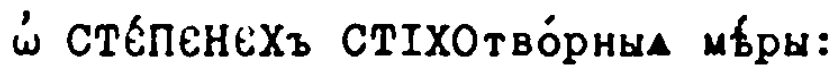

Кра́тких, до́лгихъ, й ӧбщихъ сло́гъ сказа́нію предложе́ну бы́вшу

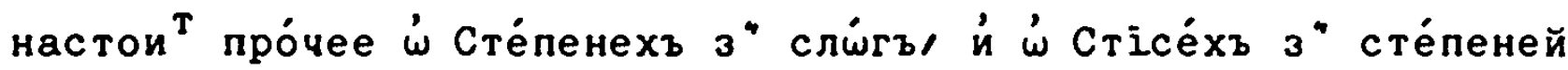
состои́щихъ сказа́нї:

'́ Créneни:

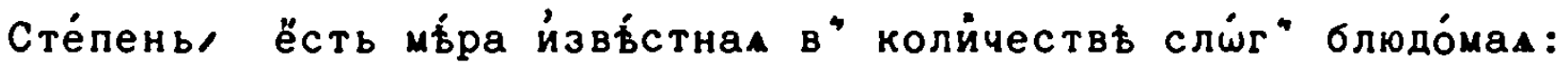
йлй, Сте́пень ёсть мьри́телное сли́гъ состоднїе.

’́ числ̀ь Сте́пеней:

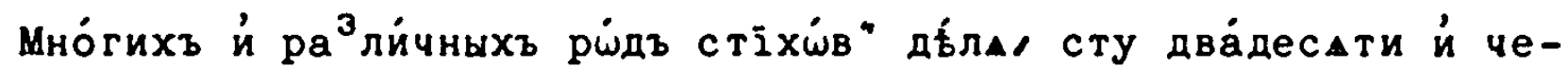
тыре́мъ сте́пенє ${ }^{M}$ числймымъ двосло́хнїи четь́ри: тресло́хныхъ ӧсмь: четьресло́жны $х$ ше́сть 


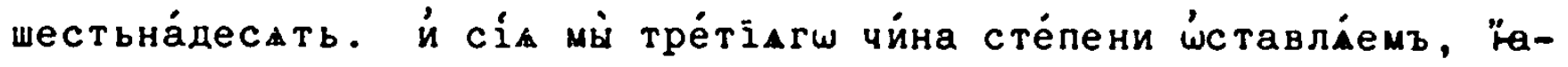
кw мнб́e Слава́нъ оу́потребле́нію служа́щын.

\section{Двослӧніи:}

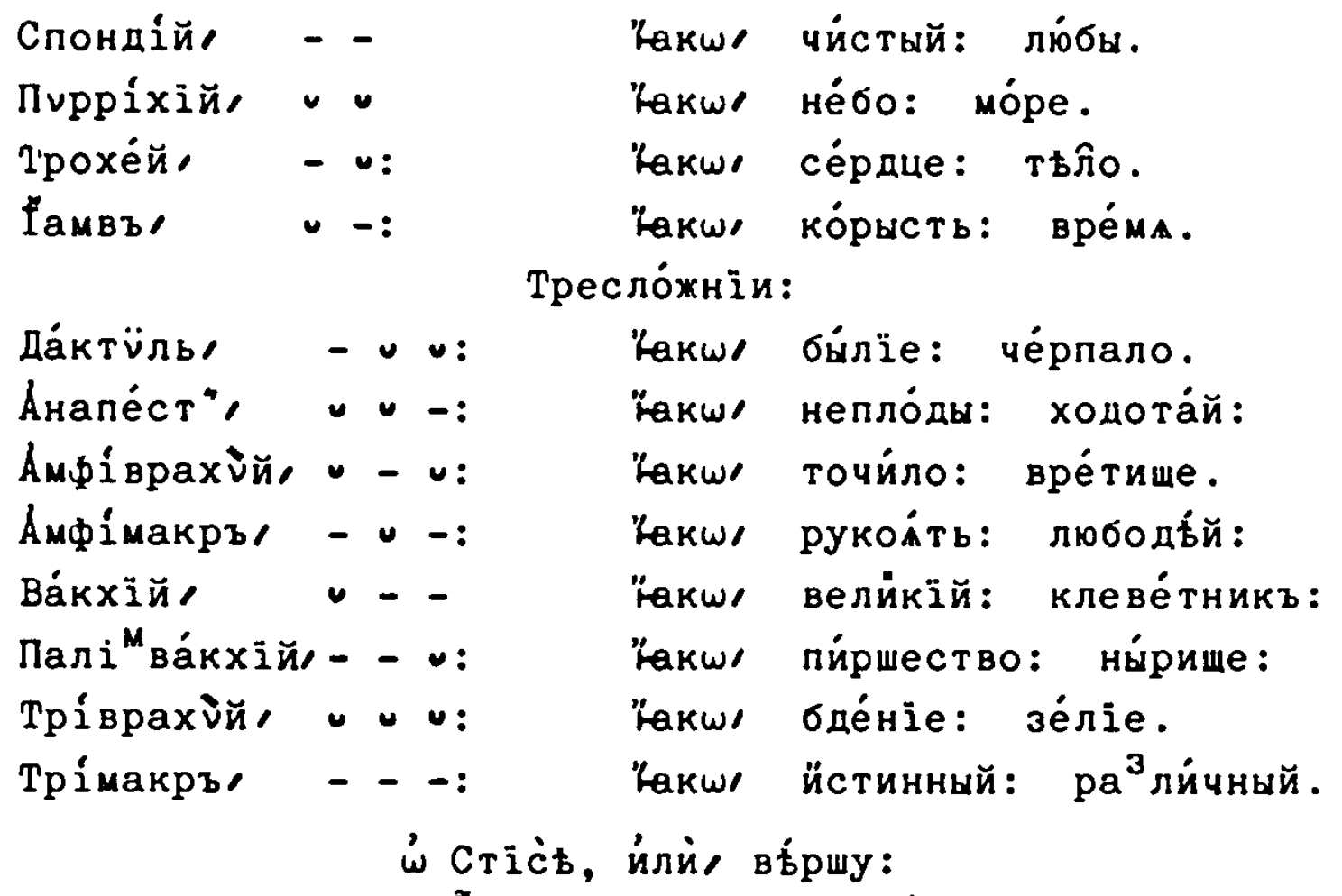

Сті́x" ёсть, прави ное сте́пеней во йзвб́стномъ ро́ды сочине́нïe.

$$
\text { แर्? Колй }
$$

Коли́ки сутิь сті̄хи́въ ро́ди;

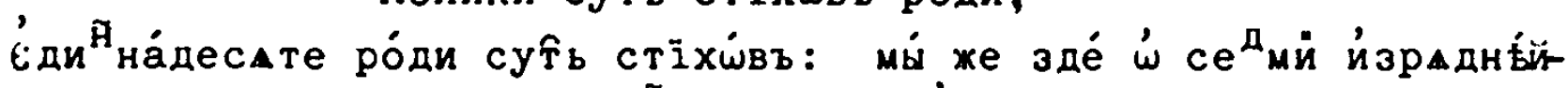

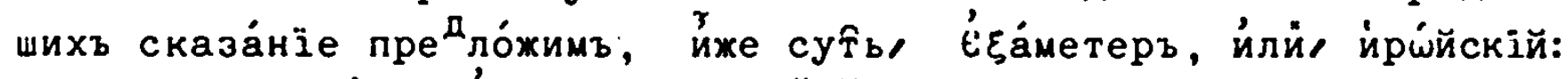
Пента́метеръ, йлй, є̇легійскій: Іамаійскій: Са́фійскій: фале́́-

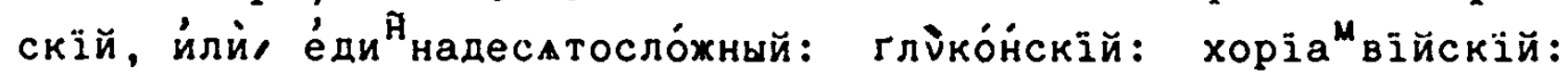
Асклипіа

’́ Pónt Cтїxà ирййскагw: йлй Шестомб́рнагw:

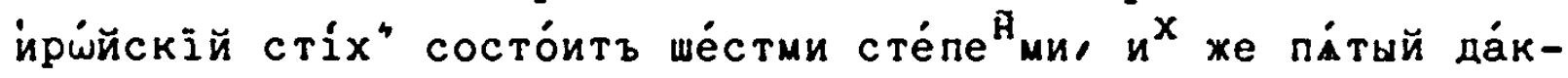

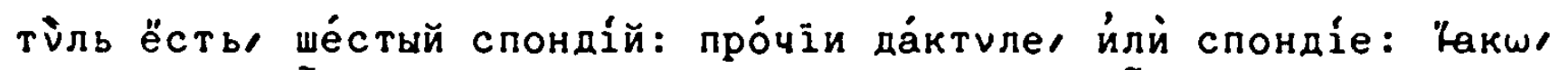
Са ма́тски новора́стныа му́сы стопу пе $\tilde{p}_{\text {не }}$

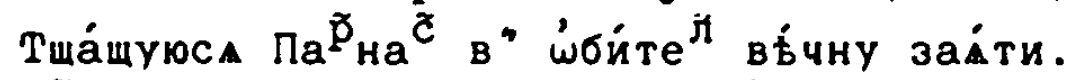

$\mathrm{x}^{\mathrm{Z}}$ е цро приймй:

Й ди́ $\times 0^{M}$ Сва́ты $^{M}$ пб́ти оуччй Ршссійскій

ДоР $\left[=\mathrm{Po}^{\not}\right]$ на", чйстыми мб́ры Славе ${ }^{\tilde{H}}$ ски ӥмны.

Пристеже́ніе:

Нв́когда па́тый сте́пень спондій 'бб"е́млетъ: за е́же Сті́хъ тако́въ Спонді́йскій нарица́ет"сА: йм жел йлй ве́ліА ве́щи кое́ [243]

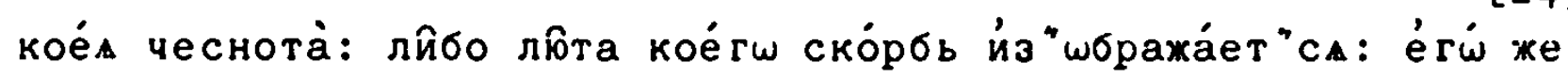


ро́да пара́дигма четве́ртый й па́тый $\omega^{T}$ пре скихъ.

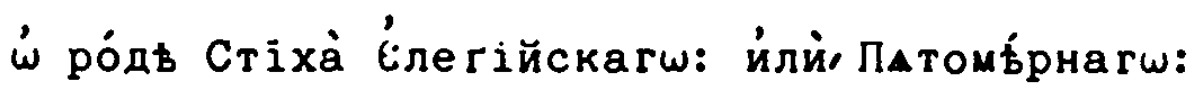

Є́легıйскій сті́хъ ви́ну ма́ла йрййскому припраже́мьй па ма̇ сте́пеними состо́итъ: йх же пе́рва два̀, Да́ктиле заемлютъ и́лй спонді́, припраже́ну йма сло́гу до́лгу полу́степень нарица́ему. Про́чіа два̀

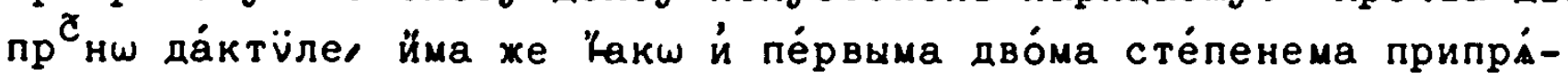
жет"са сло́гъ, полу́степень реко́мый со пре́диду́щи" па́тый составли́ющъ сте́ne ${ }^{\tilde{H}}$, 'акш'

Йсти ${ }^{\text {म }}$

\section{иршелегі́йскій :}

$\mathrm{Xp}^{\widetilde{C}}$ те е́лика про́са ${ }^{\mathrm{T}}$ йны да ${ }^{*}$ дь $\mathrm{u}^{M}$ пребога́те:

Мн๋̀ тебе́ слап̆ча́йшій да́ждь, мене́ вза́йма тебі́.

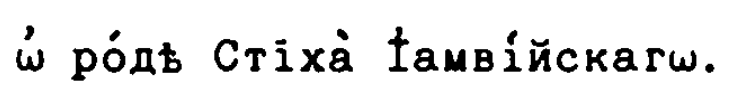

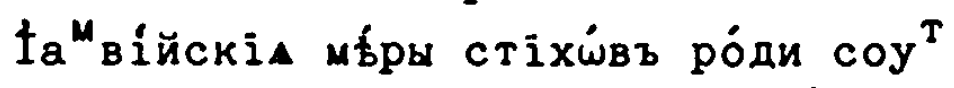

$$
\text { แ मे }
$$

трина

[2436]

тринадесатоличчны $\omega^{T}$ ни $^{X}$ же двана́деса ${ }^{T}$ мнбе оу́потребліемы $\dot{\omega}-$

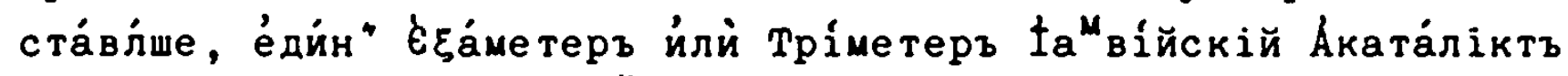
рече́ный, предлага́емъ: Йм же Бл: โша́ннъ Дамаскі́нъ мно́гїа сос-

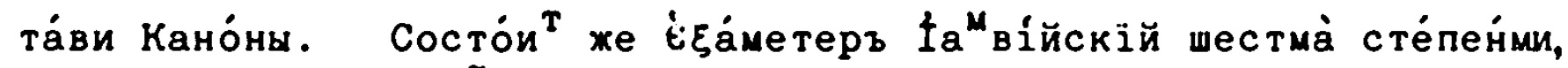
$\omega^{T}$ ту хъ сте́пенехъ са́мый прие́млетъ Та́мвъ: Какш'

молю́ Ісґ́се '́ста́ви мод грехй:

Несоверше́нъ же си́й и́ нечйстъ в" ко́ем"ждо сте́пени На"ва при-

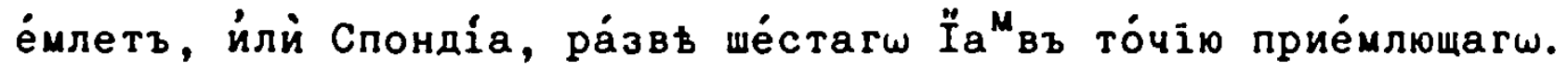
Lakw

Поми́луй мА ка́ющасょ Бо́хій Сло́ве:

Си́й же хром, ска́зшнъ [!] йлй холі́амвъ Гре́чески ре́ченъ, во всб́хъ про́чіих" На"ва йлй спонді́a сохра́нь, в" ше́стомъ сте́пени прие́млетв спонді́: Һакш,

Пою́ ти Благода́тнаА пб́снь ра́дধйса.

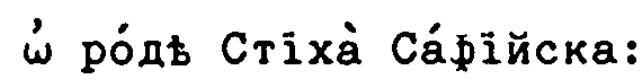

Сті́xъ Сáфĭ́скій пA тà сте́пенми со

сто́итв

сто́итъ, пе́рвымъ трохе́емъ, вто́ри" спондіемъ, тре́тимъ да́ктӥлемъ, четве́рты ${ }^{M}$ й патым.трохе́емъ. Éмуं же стїхйвъ ро́дови по ко-

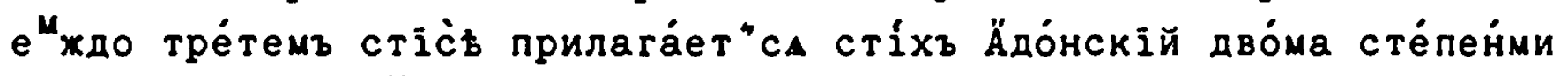

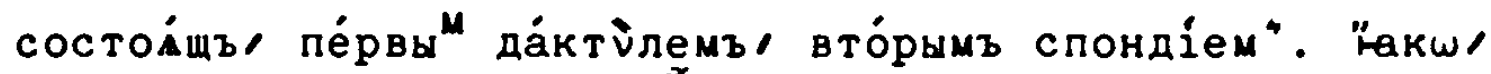

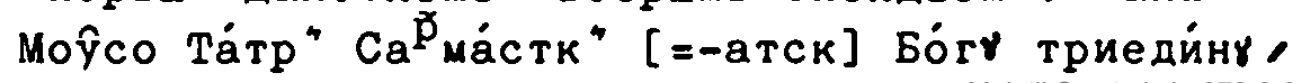


До́лжную да́й че́сть покло́на со ӥмны,

Чйстою Слава́нъ, е́го́, да́вшемy ти Мы́рою пб́ти.

’́ ро́дь Стїха̀ Фале́vска, йлй е́ди надесатосло́жнагш.

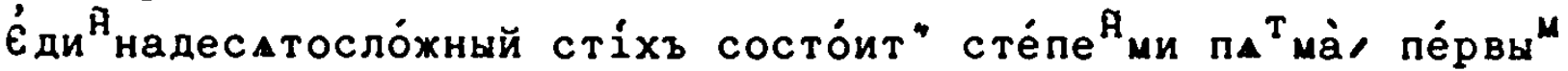

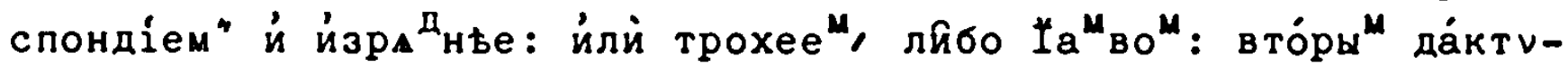

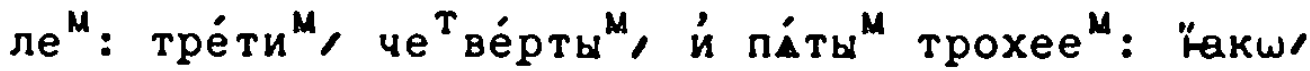

Оутьшителю дйше, '́кайнна

Не пре́зри мене́, хвалу́ ти даю́ща.

$\dot{\omega}$ ро́дь Стіха̀ глїко́нска:

глікконскій сті́хъ состо́итъ сте́пе ${ }^{A_{\text {ми }}}$ трема̀: во пе́рвомъ прие ${ }^{M}-$ лї спонді́а, во вто́ром" й тре́тіемъ да́кті̀ла: 'Һакw

be

Oўmъ

[2446]

Оўмъ чйстъ, и́ непоро́чное

да́ждь ми се́рдие Icł́ce мо́й.

’́ ро́дь стїха̇ хорїамві́йска Асклипіа́дска:

Асклипіа́дскій сті́хъ четйpи соде́ржи т сте́пени, во пе́рвом при-

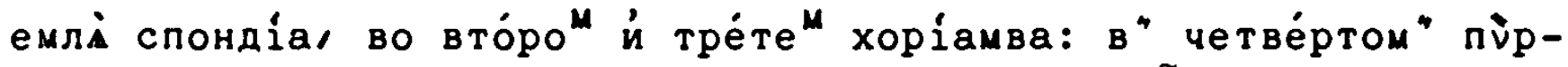

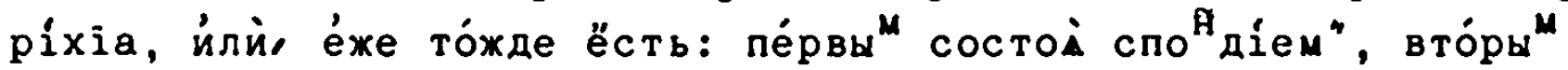
да́кті̀ле" й сло́го" до́лги", пресьче́ніе Латі́нски Саesura pe-

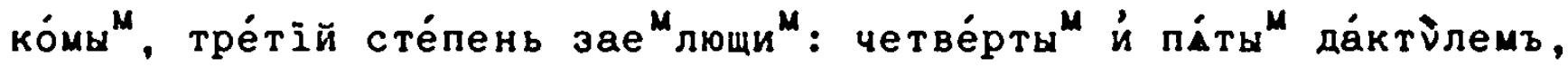

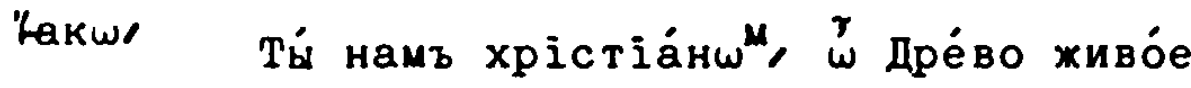

щитт бо̆ди на дре́вь врага் побъж шее.

Про́чна Стіхйвъ ро́ды произво́лнь '́㇒тавла́емъ: сіА и́ во всб́хъ про́чіи оу́добное позна́ніе довль́ти суди́вше.

ஸे Пресьче́нїи,

Гре́чески, тонпे, Латінски, Саєsuга, рече́номъ.

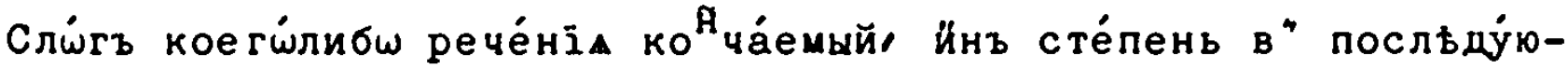
щее рече́ніе начина́ющй̆ Пресьче́ніе нарйче ${ }^{\mathrm{T}}$ са: érí же кро́мь

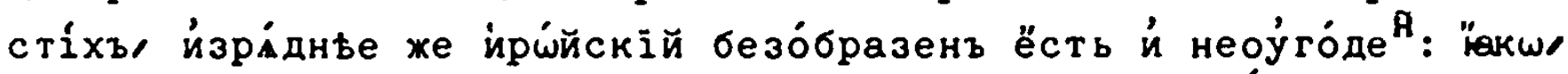
Лжи́

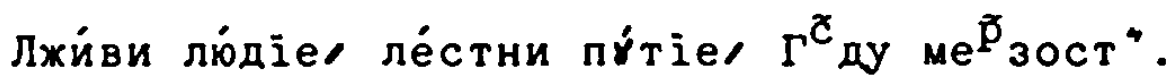

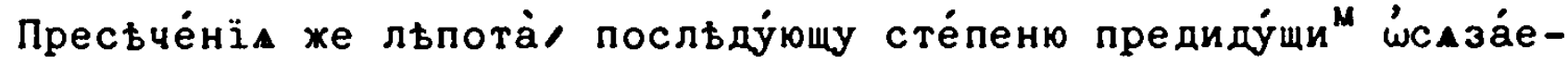
му, чйсты й бйгоуго́дны стіхй представла́етъ: 'Юко же во Парадйгмати стіхъ ро́да иро́йска пре похи́са.

$\dot{\omega}$ Сло́зь коег $\omega^{*}$ до ро́да посльд́не ${ }^{M}$.

Сло́гъ стіха̀ коеги́ждо послв́дній ӧбщъ ёсть: сйречъ, кра кій 
в ме́ctw до вмьни́тиса бу́детъ.

¿́ CTPACTEX

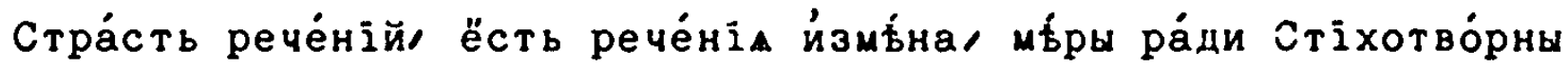
быва́еман.

Стра́сти сут́ сугубб. $\quad\left(\begin{array}{l}\text { ЙзобйліА, й } \\ \text { Скудости: }\end{array}\right.$

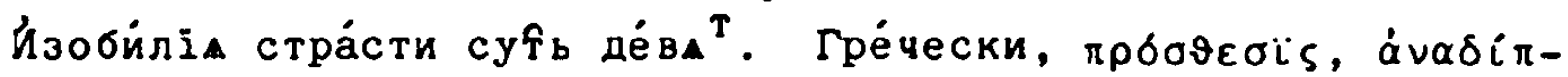

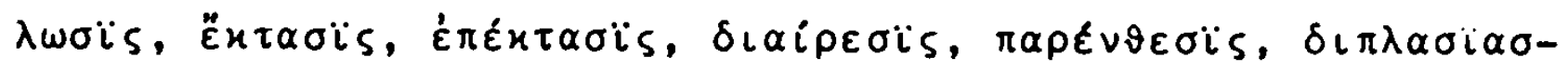

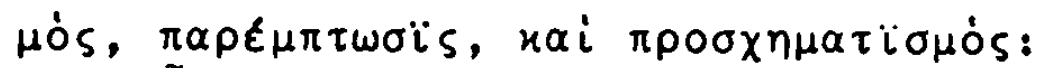

Славе ${ }^{\mathfrak{A}}$ ски Прилохе́

Hie.

ніе, Оу́сугубле́ніе, Напрахе́ніе, Распростране́ніе, Раздьле́ніе, Вмъще́ніе, Оу́двое́ніе, Прида́ніе, Припа́тіе:

Ску́дости стра́сти, изоби́ліа стра́сте" в"про́тивъ полага́емиа,

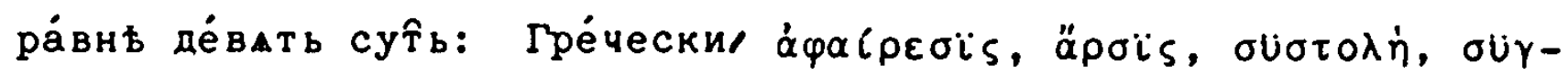

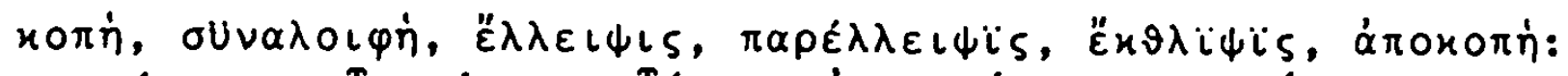
Славёнски, $\omega^{\mathrm{T}}$ ложе́ніе, $\omega^{\mathrm{T}}$ àтіе,

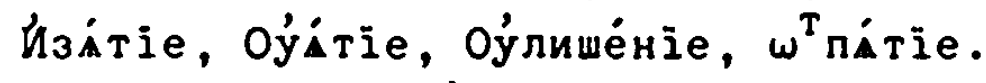

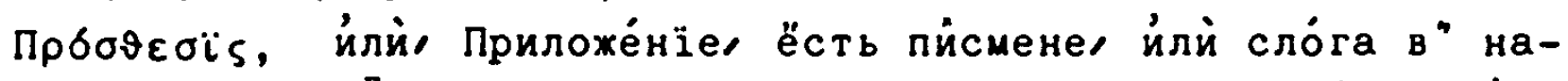

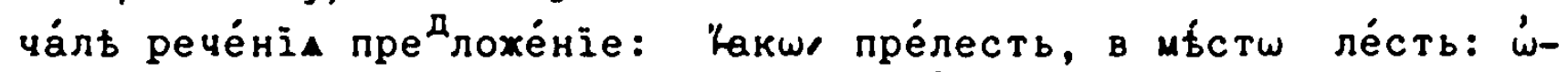
две́рникъ, в" мб́стш две́рникъ: примра ${ }^{\mathbb{R}}$, в мб́стш мра́къ: прему́дрость, в мf́стш му́дрость: $\dot{n}$ про $q$

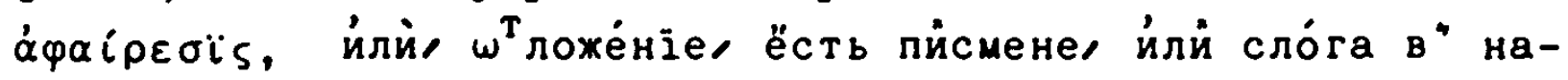

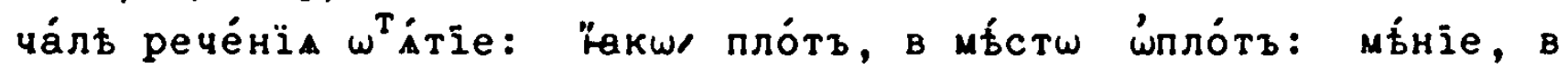

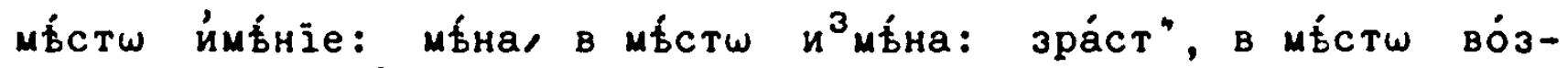
раст": $\dot{\text { n }}$ про".

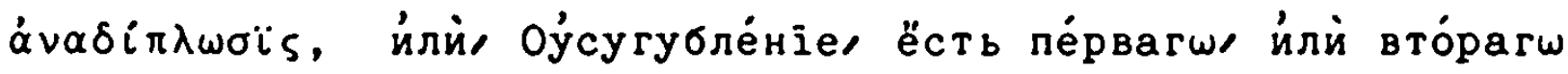
писмене, лй

бо сл

бо сло́га повторе́ніе: "̈акш, ёстесмы, в мйстш ёсмн: ёстесте, в мб́ctw е́cté: й про

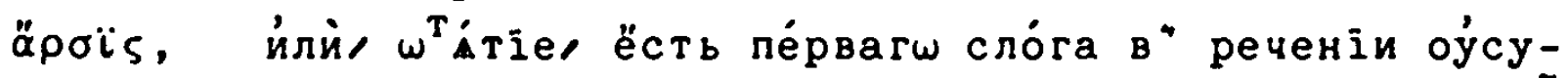

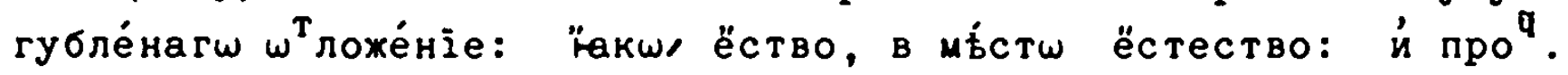

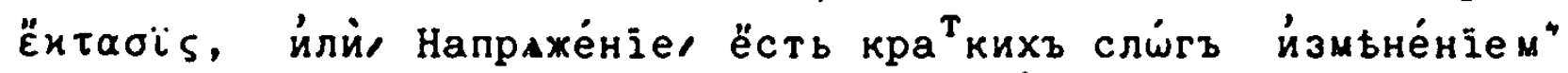

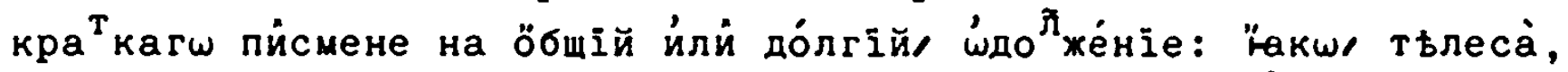

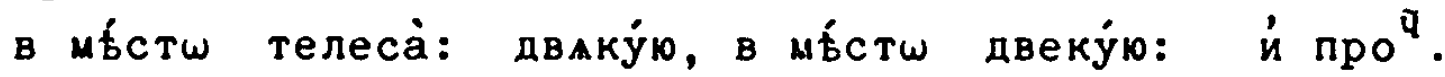

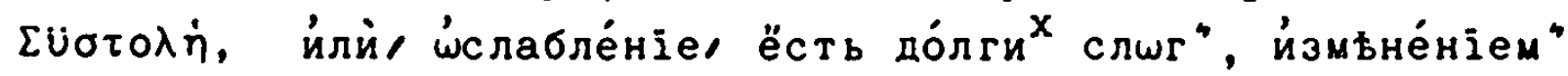




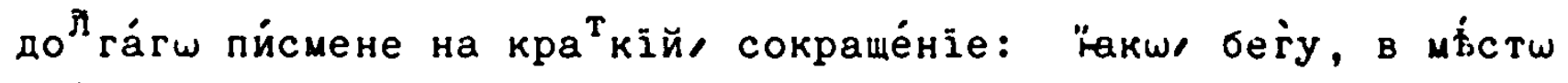

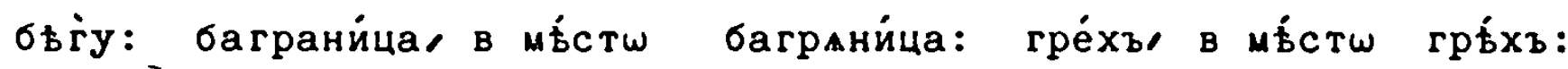
ù про ${ }^{q}$.

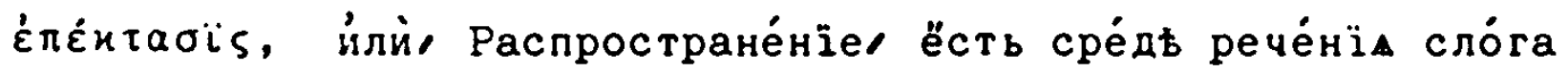

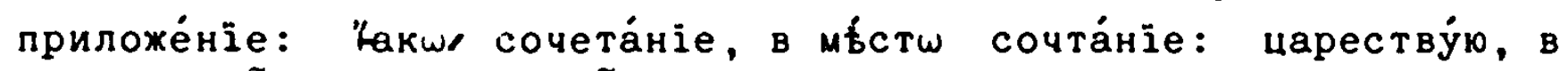

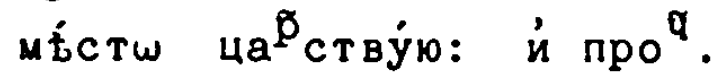

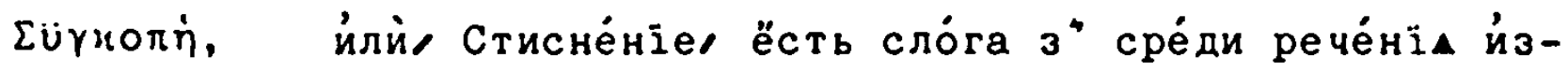

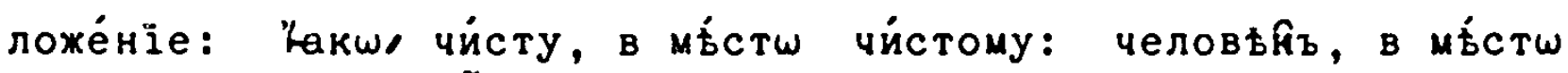
члввккшвз: иं про .

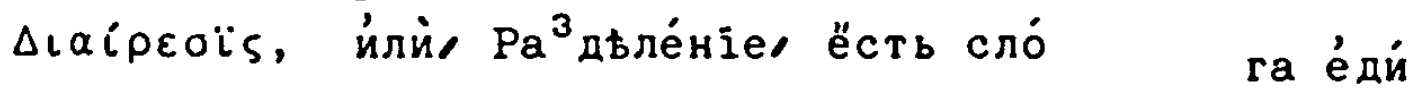
га е́ди́ [2460]

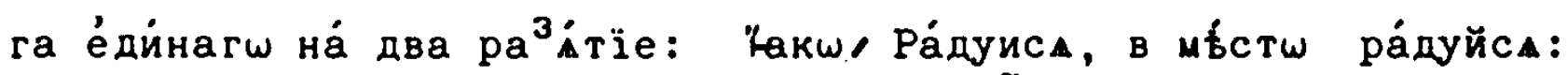
досто́иный, в ми́стш достойный: й про .

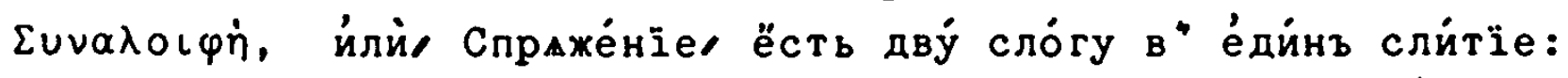

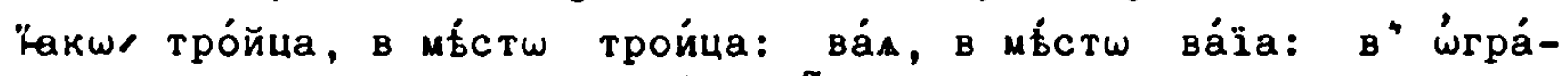

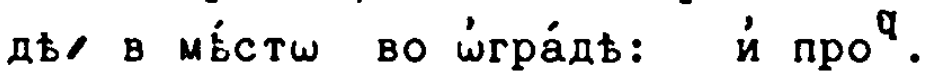
оу́вње́ніе:

По рујчны стра́сти се́й вб́ждь быти предлогге съ, во, со, ко: иже гла́снаА свод '́ставлаю́ще, ёрико" согла́снам к" предиду́щему

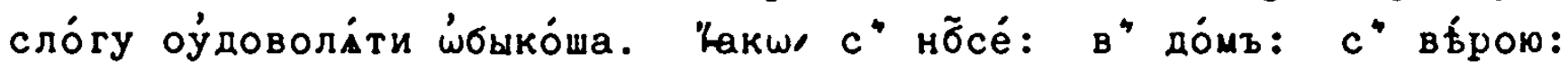

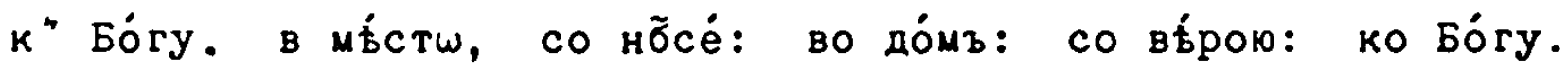

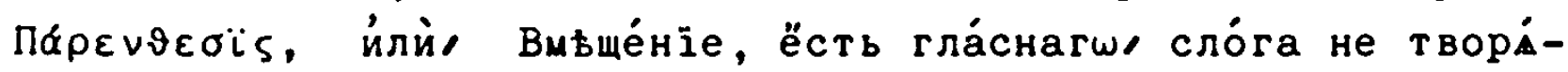

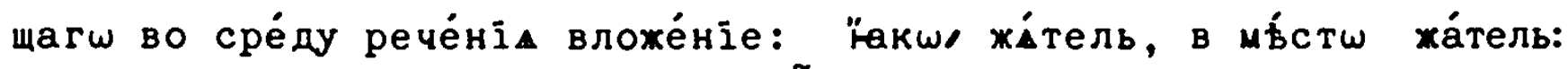
ку́белъ, в мб́стш ко́белъ: $\dot{и}$ пр

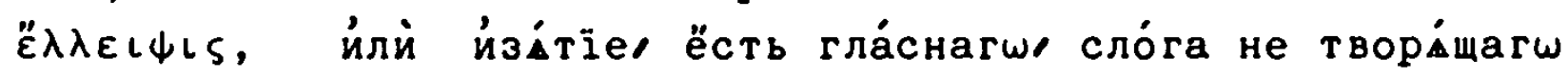

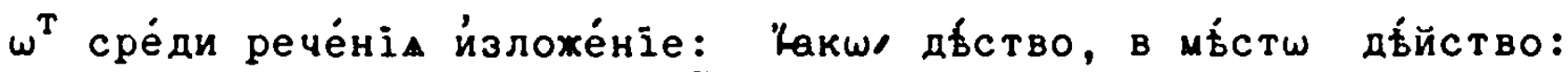

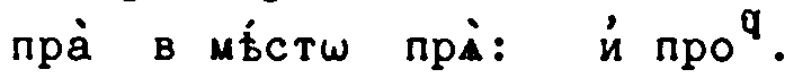

$\Delta \ddot{i} \pi \lambda \alpha$

[247]

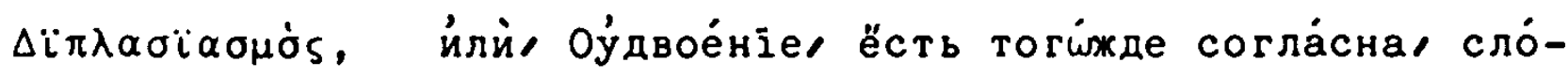

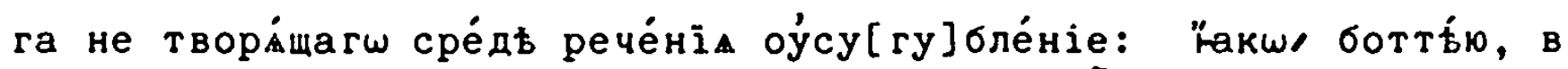

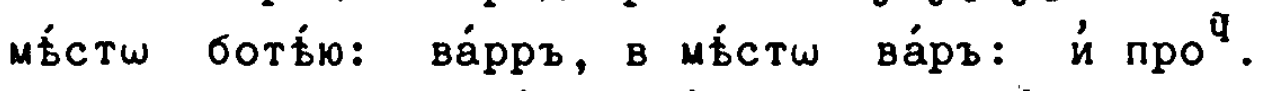

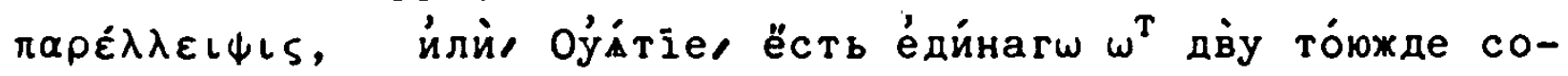

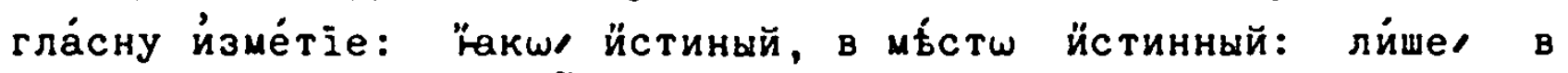

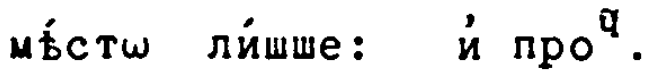

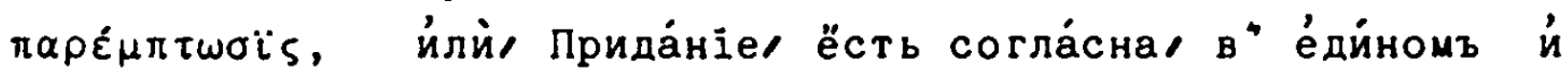

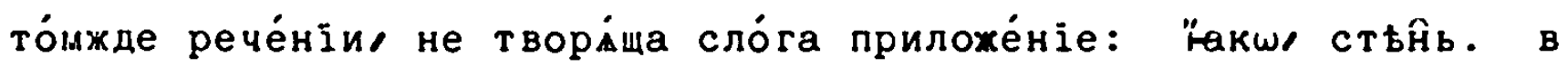

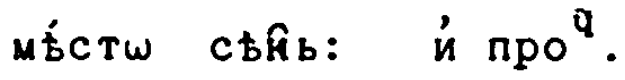

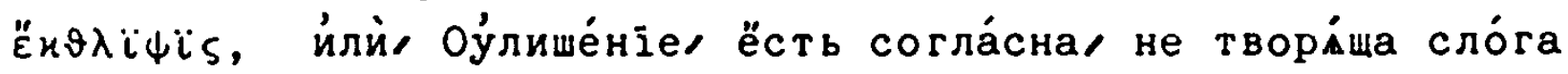

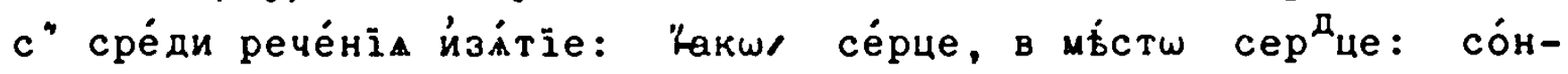


це, в мfсть со́лнце: й про ${ }^{q}$.

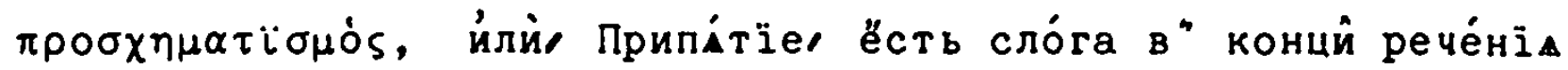

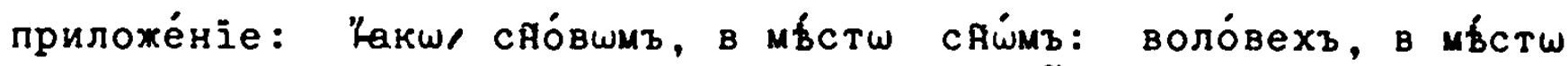
во́лехъ: вра́чеве, в мб́ctw вра́че: и́ про qٔ.

$$
\dot{\alpha} \pi \sigma
$$

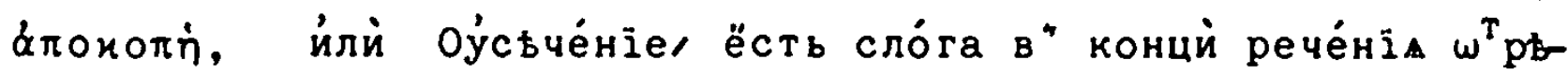

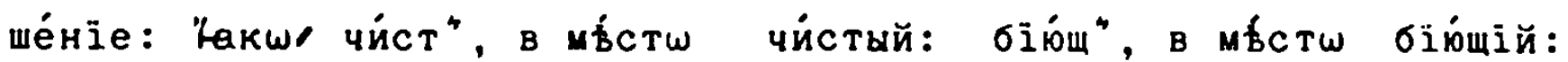

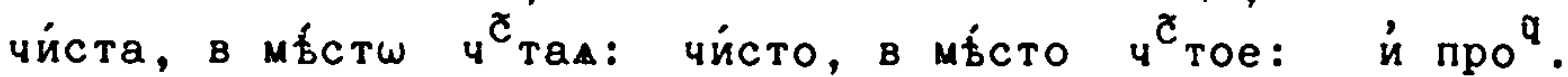

\section{Сла́ва Бүу нача́вшему й соверши́вшему.}

Преблгослове́нной Двь БДи поспъшествова́вшей, че́сть. Аийнь .

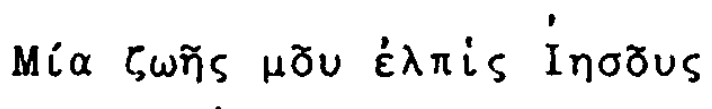

ó $\chi \rho \ddot{i} \sigma \tau \delta \varepsilon$.

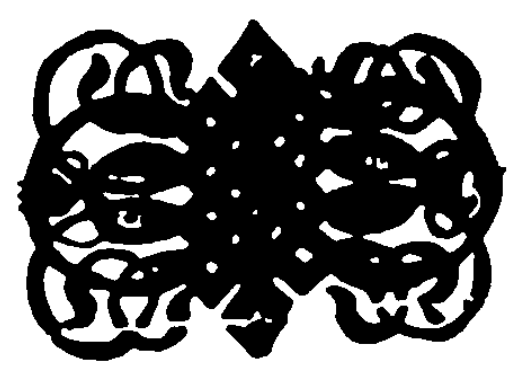


V E R Z E I C H N I S

der im Grammatiktext angefürten Beispiele

a 14,190

aoije I87

аввас, авва 32

АвГУстінъ 53

Авель 62

ars 190

Arapa 32

агнеи, -нче 7 , I5

Адам II, 24

адвена I5

Адонай 64

Адшнїдз 53

Адрїанопл' 63

аерумна 8

азз $94,95,96$ (на, мы), мы 240 , мы бо I4, ны

97 , мене 238 , - же 240

аидшнъ 26

Аквінат 53

аки I87,- бы 187

акроама 50

Алеदандеръ IO

алеदандрїскі 20

алчу I 20, I 39, I72

Амв росі 65

aмw I86,-0 we I86

Ананіа 37, -іи 66

Анастасіа 27,38

анаэема 50

ангель, агтль II

Андрей $24,37,65$

Андреев 85

ане $\psi$ म 65

Анна I9,25; Аннинъ

$20,-$, Аннь 83

Аннібаль 62

Антїшхіскї 20

Ан $\because$ IM 3

anoдеi穴 60

апокал U४іс I0,60

апріль 25

аравз 53

арома $50,24 \mathrm{I}$

Артеміда 25,32; Артеміс 32

apтос 55

Архела 64

Асдрубаль 62

асма 50

аспідз 26

атропа 32

aupa 8 auтopiтrac 60-I

А૭анасін 65

Аэины 4I; градъ I95

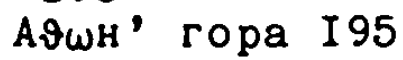

Афродіта 25

ax了 190,233

Ахіллеч 65

ame, - бы I89,232;

- бы оуба 232; -

бw 109,$232 ;-$ -

I89; - и I89,232;

- ли I5, I89; - не

I89, 232 ; - oyow

$\mathrm{I} 89,232$

баграница, -ра- 247

балї 65

бдю I20; бденіе 243

без I87,235

безмвстно 220

безсмертныи 240

бepy 2 II

бï 8 , I I4-2I , I 39 , I 69-72, I76-84, 2 I I, 223,24 I-42,248;

бити II7,239; бї10С A I I5-6, II8;

Oi ANO II8, I20, I69-

70, I 72, I77-9, 239

б 7 พี $8,13,20,22$,

$26-7,74-6,239$;

блтв II,I8,20;

блаханті 22;

блг̃ $\omega$, $\sigma л \tilde{\Gamma} \omega$ жe

I 90

блтодареніе 69

олтдать 58

б лг̃нено I97

блахю I72

блеко I 20, I 39, I72

близ I85; - зь 225

близкіи, -зшїи,

-xaйі 23

блюдо 44

60 I3, I89

бог' MOम 240; Боже

всесилне 240

богат I98;-т вйї 23

бน̃a 18

Божі $I 8,20-I, 27$,

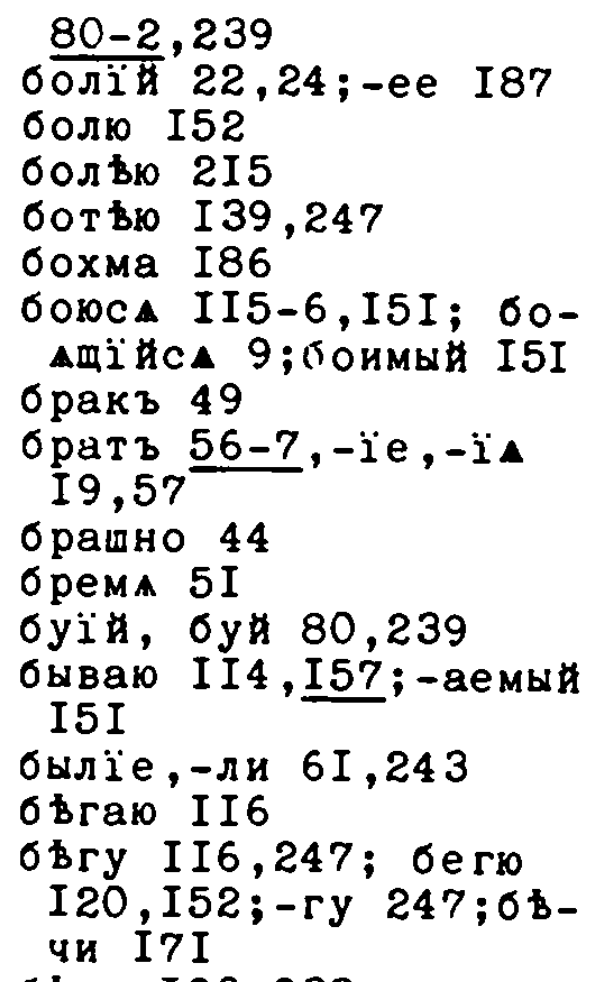

бвда I90,233

бвль (зубами) I98

б Блю II6,2II

б Влью II 6

в',Въ,во I6; во алчбв I5; $8 \%$ Во дОМ I6; во еже I89,232; во изобиль I86; во истинну I86; в'конец I86; в купв I87; во лжу I86; в'мал в I86;

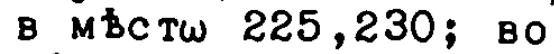
H' же, в он же I6; внут рь I85-6,225; 8 ' нутр члัка I6; Во/в' шградв 247; во правду I86; воскую I87; в слвдъ 230-I; во тще I86; во чертогъ 240; во что I87; во I87-8 $\mathrm{BO} / \mathrm{B}, 229-30$

Вавилас 32

вагъ I90

ваїа, ваА 247

ваптісма 50

варъ 247

вараэронъ $55-6,242$

варваръ гласом I 98

Bapietac 60

Варнава 32 ; -винъ 20 , -/-вль 82-3 


\section{- $250-$}

Васілеі 8

Васілї 66 , - ie 70 васіліскъ 26

вашъ 94-5, I02, I IO-I, 206

ведро 44 веду I20, I 39, I7I,

І75, 2II; вести I69 великі 243;-ка COвьта аггль I94 величаю 2 II величество, - іе 57 велї 22, I 98,239; величайі 22 велми I 86 велю I52

Венера, Венус 32

Веніамінъ I97 ве рвь 27,58; $ө$ p вервїе 239 вереа 4I, -еa 26 вериги 8,4 I ве рть 49 вертепь 27 верховны 198 Bepxin 172 верч10 I52 весь, сщ. I9, 58 весъ, ВСA, Все, ми . 88; вси II веселю 2 II; -лит'сА 2 I 3

весма I 86

ве тхїम, -хшї min 22

вещь 58

BЗATB I2I

виж10 I 4 I , I 52, I 70, I73,2II; - - 7 7 ; I73, I6; -дъный I2, I4 ВИЛнО І 9 ; -ЛнАНИНЪ 28,$52 ;-Л$ нАныни 28 винарь 62

вищю I52

Віантъ,-асъ 53,54

влага $32-3,237$

владыка 93

владвю 2 I3

власатв главою 198 влеку I 20, I72, I75, I77, I8I; влечеть $2+0$

BMBHAL 2 II ; -AET'CA CBATb 208

внегда I89,235

внезапу I87

внемлю I40; вниму I 40
вонМи II7;-ми 210 вниду 231 внима Ми I5

, внушаю 2 II

вн В I85,225; вньуду I 86

воведу IO

воевода II , 24-5, 3I-2

воеводинна, -дичз 28

вождъ 25

во3/-c 228-3, вос

I 87

возалках I5

возолесну, возгримь

aоi. и воздожди 22 I

возведу IO

возглю 240

возгнушащї НА I79

воздостоитъ I54

возимамь I67-8

ВОЗМн ВТИСА,-НИТ' $C_{A}$

I5 4

возможно есть I56, 222

воз расть 246

воинь $8,25, \underline{42-3}$

во 25

вол:-ехз, -овехъ 248

волю I52

вонъ 186

вопль $27,63,7$ I

воре 25

восподобати, -аеть

I53

восприемлю II6

ВОС П РОТИВАщ̈ НСА,

- вле Йс I78

воспвваю 2 II

востани I86

востокъ 25

восхожю I88

воюम 239

врабін 26,65

вparz $24 \mathrm{I}$

в үань 49

врата 26,57

вратарь I95

в рачь $70-1,243$

врачу10 211

в режю $2 \mathrm{II}$; -диши

I 69, -дитв 222

в рема $5 \mathrm{I}, 243$

вретиіле $29,48,243$;

-т० 29

в рух 26

в p 152

вселеннаА 87-8
ECIATS I 86,230

Bcye I 86

ВСАKъ I4;-KW I86

४торн 20;-pwe I86

B' $x 0 \% 10188$

вчера 25, I 85;-ашнін 25

выну I 85

BL:СОК I I96, I 98

вы $27,35,239$

в Бдаю I50

B BM I I 4, I $20,(-M B)$

I 4 I , I56, I59-63, I 70,

I 77, I79, 2II

ввренъ I 98

в СстныЙ 185

в тв I 4,58

в Бтї 65

вьчны 240

в Б落 I 20

BAKY I 20, I 39

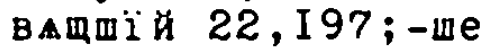
I87

ra 190

Гавріиль 24

газофилакіонь 55 , га70

Гаї 66

галатинъ 52

галілеанин 52, I98

гоу I20

где I87

re 190

гибель 58

гимнасіонъ $55, \mathrm{r}-70$

глагол II

г $\tilde{\pi}$ I I 6, I 20, I 72,240 ; глемый 224; гл̃ателHO 22I; Г ̃̈юCA II 4;

гл̃ет'CA II4; I53-4

глатаю I 40

глашю I52;-сиши I69

глуоокіи, -бшіи, -6очайші 23

ГнушаА ПСА I78

ГHלBaюCA I5 I

ГH Б3д10 I20

$\Gamma \omega$ I 90

ГОЙ I 90

годь есть I53,I56, 222

гоже есть I53, I56

голоT' 63

гоні II

ropa, r- II

ГордынА, -ни 40

rope I90; $r \omega-233$ 
ropy I86; ropb I85

горекъ 78, I 97, I98;

горкї и, -ркшї и, -рча-

ห⿰ті $22-3$

гортань 20,63

горчвю 2 I5

ropmin 22

гоp 152

Гс̈дь II, I8,7I-2

гощю I52, І7 $\overline{3 ;-c}$ тиши

169

град I9,27

грамма 50

грамматїк IO; r- II

гребу I39,I72; rpeсти I7I

грекъ 28;-кини 28 ,

39; Греціа 28;

греческї 20

Григорї 65;-іе 70

гризу I 20 , I39; гристи I7I

гримю I20, I52,I73;

гримитъ $22 I$

гробъ 49

гружю I52

гpbxb 45-6,247(//

(pexs)

гpвmio I73

гpt10 $2 I I$

грАду I72;-ди 186

Гурї 37

гусль 27

густ вю I 39,2 I5

да I89,23I; дабы $I 89,23 I$

даваю I 20

дам I40-I; даждь, дади I4I, I70; дажд ми I4;даждь то Бже I90; дадите ми, даде ми I5; даль оы II7;

дак I 20, I $39-40$, I 69 $-70,172$

даже I86; - до 225

далекїи, -лші и, -леча-

йї 23;-лече I85, 225,227

Данінл' II

Дарі 65

два $20,90-I$; дваде сатв 9 2; дважды, -апи, двоице 10 I86, 226

двекую/двн- 246

две рь I 3,58

дверникъ 246 двигну I40, I 69

движу I 40, I 69

двоица 9

дво 88,89 ; двое 90

Двою I72;-ойи I69

дв в I4; - женв I96;

дв Вст в 92

дебелью $\overline{\mathrm{I}} 9,2 \mathrm{I5}$

дебрь 58

девАт ь 92 ; деватде сатдев $\overline{\text { AT }}$ ро 90;

деватдесатеро 90;

- сать 92; деватсWт 92

делва 26

делфін 53

денница 35,48

день 25,7I

де ржю I52,I73,2II; $-10 \mathrm{CA} 209$

дерзаю I40;-зну I40

дерзок , $-3 \mathrm{Ki}$ म 78

дерзост в 58

десАт ь 92

дефенсо $\overline{\mathrm{pz}} 53$

дивїи 82

дивлюСА I5I

ДимосЭенъ 53

дит А 29

діаіта 8

діана 25,32

дігнітас 60

Дї 27 ; Дідшна 32

діскос 55

ді 4 a 240

дл 4230

дму I20,I40,I72

днес ь 25,185

до I $87-8,288$

добродьтель 27,58

доб р в I85-6

довл вет т I53-4,222

доволенъ 219 ; -лнш,

-лнъ, -лнъе, -лнњй-

ми 186,225

догма $26,50,240$,

242

дождз 49; дождю

I20, I72;-дитв 22 I

доилица 25

доколь I87

долу I86;доль I85

дом з 56

дондеже I 45,187 , 235

донель же I85, I87

донесу IO

досель I85 достоннъ 93, I96;-онный/-ОЙ- 247,238 ;

- ИН В 224

достоитъ II4, I53-5,

222-3

дохожю $I 88$

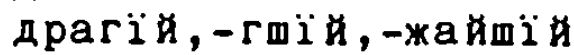
22

древле 185

древо I $9,24,27-8,52$, 43-4, 24I-2; древесо 52

дре вод ВлА 68

дре вАный $2 \overline{0,28}$

дрекол в 63

дру I72, I74

другъ $7,44-5$; - друга $57-8,9 \frac{3}{3}$

дужї,$-ж ш і$ म , -жайші 22

дуну 140

духз 7,49;- с. I8; премудрости и разума I 94

душа 35

дхну 140

дще $\mathrm{pb}_{\text {, дщи }} 59$

дымю I52

дыпю I 40

д вва 5, I 3-4, I8-9,

$30-I, 24 I$

двиство/двс- 247

двиствую I74, I77, 2II

двлак 2II;-аніе I3;

-атель 62

д влма I89,23I

д Влю I20

двлА I89,23I

дътище 29

म $6102 \mathrm{II}$

e I 3

егда $189,226,235$

ЕГИПтАнинъ 52 ; -ныни 39

еда 189

едва 187

единъ $20,90-I$; - чл̃̈К ъ

I 96; - кійждо 93; eдина женъ I95; единнадесат 92; единицею, единощи I86, единою 226

еднаки I87

eжe I89,2I7,? 32

еम I 13,186

е ікшна 8

Eктасіс 60 
Eктшръ 53

єкงecic 60

сламітинъ 52

сле $65,(\mathrm{e}-) 9$

елементв 9

елен' I6,I97;

слени 62

ели I87; єли I

елма I87; - толма 226

еликь 20;-ижды I87;

-икш I87; - толикш 226

धлісе 65

ємвлима 50

емлю II6, I76; زа, јать

I2I; јетыи I75,I85

Еммануилъ 9

Єніа 37; Єні 66

enटknz II

$€$ parw 32

Єрмі 24

е ршді 26,65

есмь I I4, I20, I56-9;

ссть 222;есмы,есте,

естесмы,-сте 246;

буду I57;быст' ми

I4; сы I58-9,224

ество 246 ; єстество

I $3,(\mathrm{e}-) 9,44,246$

धс७ира 32

€va II , 25, 32

єит̃ліе 8, II, I8

Evapictв IO

єUнуX I5

єUpz 25

EФeci 65

є७иръ 53

evionz 53

ехідна 26

e me 86

жало смерти I94

жатель $62,(/ /$ жа- $) 247$

* ry $2 I I$

*де, ждо I89

жe I89,232

желаю 209;-аніе 206

жельзныи 20

жена I9,24,29;-нище 29

жестокї, -стші

-сточа

жест tю I I 6

жедy II6, I 39

живу I5I;-ветъ 208;

- ветсA 222

жизнь 58

жмY I 39 жребі 65

жрецъ 49

xpy I20

жупель 58

3' начала I86

3а I $87-8,229-30$;

sa eжe I89,228;

зане I89;за ту

вину I87

не завиди 210

зависть 58

зайде $23 I$

заклА(ть) I2I

Законны II

западъ 25

заповьдь $58,24 I$

3ana (Tb) I2I

заступница 240

заут ра 185

3axapia 27,37

зах0ж10 I88

зачА ( $\mathrm{Tb}$ ) I2I

здалеча 186

зде 185

3 дес ь I90

उдо 44

здравї $27,69,239$

здравствую II5

Зе вс 24

зел'въ 26

зеліе, -ль I9,6I, 243

землА $24,26,35$

земны I3

зеигма 50

зефиръ 25

उexpi 70

зижду 2 I I

злато $27-8,44$

златы 20,28

злобожно 220

злодь 67

зльй, -ьйї 22;

उл क 186

змія I3, I6,26,65,

242; - алчны 239;

- лукавы 239

знаменіе 68-9

знамА , -менї 57

знои I $3,27,66$

зову I $20,139, I 7 I-2$,

I73;-ycA II 4

зраст' 246

зрю I52; зри I90;

з рит'сA I55

з ваюю I40; з вну I 40

з и I89; и к' Бг̃y II;

и убо I89; ио० I89

ขакінэъ I0,239

ІасWн в 239

иде же I85,226

I думеа 38

иена 239

ie pe $27,64-5,239$;

-еевъ 86

Ie pemia 37

Ie pove 65

Іе русалинъ 239

иже 94-5, IO2, I I 2-3, 206 ; $c r \omega 94-5, I C 2$, III-2; CA II2; 10 I4; им же, их же I4

изъ, сь I87-8, (ись) 288

избавитель всегш міpa I 95

и ЗбавлАО 2 II

и збираю 2 II

изволеніе 69

изгреби 4 I

измьна 246

ИЗМ БнАК 2 I I

из рАдны I98; -н Ве I87

I исус 55, i II, I 8,55

или I89

Иліа 37

имамь I20, I56, I66-8, 2II, 2I9; им вю $\frac{\text { Iо́6, }}{\text {, }}$ 2 II

імармени 40

i матїм 8,23I

именуюсА I I 4 ; -новани

I75;-нуемь 224

ИМнъ I5,240

имА II , 26, 50-I , 237 , 242

им вніе 8,246

инъ 78; ино, иниі 25

инакш I87; инамш I86

иначе I87, I89

инде 185

иногда 185

Ішаннъ 53,239;-нновъ,

Ннь 85

Іовініан' 9

IодОХ в 9

Ішил ь 24,62

Iшна 30,24 I

I $\omega_{\text {на }} \overline{\mathrm{aHz}}$ IO

іоръ,-ры 9

Iwcia 27,38

Ішрданъ I9

ипако I5,239

uпархв 239 
una T 24

Inпархъ 8

Inполіт 239

Иpa 25

Иродіада 32

иршम̆ 27; иршс 70

Иcaia 37

искони 9,185

искусенъ 2 I9

испе pва I85

испов дан I70

исполнь 24-5, I 96

исполнителна, -но

223

ИСПОЛНА:СА 209

І сииль 62

истиненъ 243 ; -нны

8-9, I I , I 3, 78, 247;

- ннш I86

исх $0 \% 1288$

исчадіе 69

исчетны , ище - II

Італіа 38

ително $22 \mathrm{I}$

Іуда 32 ; І ддеа 38

іуде 239

Iуств 53

ищу I39,I72,209

$\mathrm{K}^{\prime} / \mathrm{Kb} / \mathrm{KO} I 6 ; \mathrm{K} / \mathrm{KO}$

Бry I6; K' семy, $k$ '

сим I86; Ко I87-8,

$288\left(/ k^{\prime}\right)$; ко агниу

I5; ко смерти 240

каесарь 8

какш I87; како бо

I5; каковъ 20

Каллістъ 53

камень 62,7 I-2, 240 ;

-енї I9

каменны 20

каменью I I6

камш I87

кану I40

каплю I 40

каркінъ 26

касаюс I I5, I5I, 205

катапетасма 50

Катіліна 32

каштелАна 28

Киклопз 53

Kипріанъ 53

Кирілль 53

кит в 26

кi $94-5,102,107-8$;

- ждо I08; -ждо иХ

I95; каА 206 кладезь 63

клеветникъ 243

клевещу $2 \mathrm{II}$

клевретв $8, \underline{4 I}, 52$, $24 I$

клену II6, I20, I39,

I72;-yc4 II 6,2 I 3

кликнУ I 40

кличь $63,7 \mathrm{I}$

кличу I 40

клОню 2 II

ключа 57

ключает'CA II4, I54

KHA3b 62

кобель 247

когда I87,235

коилиоо 108

коіновіон 55,69 ,

242

коль толь I87,226

коликъ 20

колми 227

коло 52; колесо 5 I

комета 26

конь 9 , I 9

КОндіментъ, -тумъ 56

Константінъ I97

Константїнопол' 63

контакіон 55,70;

-акз 70

корень 7 I

КОрїнЭАнинъ 52

кормль 2 II

кормчї 65

корысть 243

косню I52, I73

крагуи $27,66-7$

краду 2 II

красенъ 78, I98;

-сный, -сн'ші й

-снвйін 23,78

кратирїо, - ръ 70

кратокъ 78;-ткї,

-тші月, - тча йін

$22-3,78$

крест т I4

крінъ 49

кровь, крви 59

крокос 55

кром в I87,225

Кронъ 24

кроткї̆,-тшї̆,-тчай- лстецъ 49

正藏 22-3

кроторын 26

крьпокъ 72 ; - пкї

$20-I, 8,72,87,24 I$;
- Пщ

$22-24 ;-\pi k \omega,-114 a e$,

ғча मити I85

६енодохеіонъ 55,70

दеноФОнт в 53

Кто 94-5, IOI, 206 ; - лиоо

IOI; - ce I I 4, IOI, -yoo IOI

киалітас 60

киантітас 60

кубель 247

купель 58

куплю I40,I70; купую

I 40, I70, 2I I

купнш I87

лаврак' 26

ладіа $27,37-8$

ламлю 2 I I

ласкатель 62

ластовица 24,26

ЛВОВ 28; ЛВОВАнИнъ 28 ,

52 ; -ныни 28

Леві 8; Левї 70

легешнз 93

легкї , $-г$ шї , -гчайі 22-3

лежy II6,I40;-ж10 I20, $\mathrm{I} 52, \mathrm{I} 74$

лест в 58,246

лехъ 28; лехини 28

Лexia 28,38

ли I89; либо I89

лик I9; - агг̃лскіи I92

Литш 27,32

литронъ 55

лице I3,27;-ца I4,242

литаю I $40 ;-10$ с 209,212

литу I 40

лиш'те I87,247(/лише);

лите есть 222

Лiвía 38

$\pi i \xi a \quad 240$

лї $\mathrm{OCb} I O$

Літавіа 38

Лїтовскї 20

лОВлю 2 II

логіка IO-I,лb-I6

ложе 48,240

ложесна 57

ломю I52

лонв I85

лукав 186

луча $\Xi 5$

луч⿴囗十 22

лщ.6 2 I I 


$$
-254-
$$

льпо есть 222

льть еств II $4,\left(-\mathrm{T}_{b}\right)$

I53, I55-6, 222

льтаю II6

льто 44

любезенъ I98; -знь 224

люблю I I5,205,2I I

любителенъ $22 I$

любовь, $-б ы 27,59$,

206,243

любодВ $27,67,243$

любодвй тво І 3

людіе 72; людз 72

лю у рі $\mathrm{I}$

лют 226

лАгу I 40

лАДВї $4 I,(-a) 26$

маи $I 3, I 6,25,64$

мä̈орітас IO

макрові 66

мал в 22, І97-8;-лый, -льйшъ, -льйші 22,

I97;-ла I86,-лш

I86,227

Мамантъ 53

Mapia I8,27,38

Mapкoc 55

мартв 25

мартінв II,53

Mapงa 32

мати,-терь 25,59;

мати щедршт в I94

Мат ७e 65 ;-i 37

Мелампод 53

Менелаи 64

менші 22

Me papi 8;-pï 70

мертв10 I20

Meccia 37

метаморфшсї 60

метапоіисіс 60

мечь 27,7 I

мигалй 40 ;-ли 26

млс̃рдї 69

милост ь 58

Мл̈стьнА, -НИ 40

милоть 58

милу 2 II

мир' ти I4

MUPO 44

мирю I20

Митрофанъ 53

Михаил в II,24

Міншс 70

младенецъ чисты соввсти I 95

M०ч10 2 II младыи, -дшіи,

-жаяті 22

мніи 22,I97; мен-

mar(,-тему 24

многін $20 ;-r$ 目

жайтї $22 ;-r \omega$

I86,227; -xae I87,

226 ; -гажды, -гащи

I86

многоОор:13н В I86

иножество зшл в I95

множю 2 I I

Мню I5I-2; мнИТСА

I I 4 , I53, I55 (

тисА); мнимы 224

Mory I2O,I40; MOжетсA I53

мой I 3, I 6, 94-6,I02, I04-5,200,206; мн I06; моей агници 238

Мшисий 27,66 ; МоU-

ciम I6

мокр вю $2 I 5$

молвю I72

Молівї 8,$66 ;-\ddot{i e}$ 70

молочю I52,I73;

- $у$ у, -отипи 7

молчю I52,I73,24I

молю,-юсА I56,205

море I $3,27,48,238$, 243

мощи $6 \mathrm{I}$

мощно есть I56, 222

мравї $8,26-7,65$

мразъ 49

мракъ 246

мрежа $34-5,48$

мудрость 246

мудрый 93;-ре I85, -p B I86

мужь I9,24,62; -

срдиа высокагш

I95

Myca 32

мученическое I3

мучю 2 II

мщ10 I 20

мыслю 2 II

мыш b 26

MแL 2 II

мьна 246

мвнї 246

мьpю $2 I I$

мъстоименїе II
мАгкї̆,-г⿴囗十 22;

- гчаम̆і 23

матежь $62-3,24 I$

на I87-8,229; - велиць, - вАM片 $2 I 4 ;-e-$ динь I87; - землю 240; - колиць 2I4; - маль 2I4; - милость I8; мнозъ, - множайш 214 ; - толиць $2 I 4$

навижю I70,2 I I

навьту злсов 210

над' I87-8,229

надиде 231

нЕцХожю I89

над ъемый, надьлный I5I

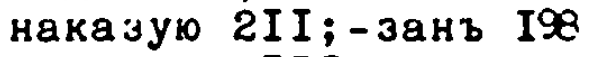

належитъ I53

напраснш I87

нгрицаюса (Петръ) I I4;

-вемы 224

нарочитъ нластїю I98

насаждан 2II; насадих $2 I 0$

насынalocs 209

научаю I5, 2 II

наущаю 2 II

нах $0 \times 10$ I 88

начатки 57

начинаніе 69

наш $94-6$, IO2, I09-IO

не I86,I89; не 60 I89;

не бы I89; не к тому

I85; не не 227; не та

kw I86; не у I85

неасить $24,(-с ы-) 26$

ног̈ны 20

небо I $3,22,44,52,238$,

243; небесо 5I

негли I87

недостоинъ 93

неже, нежели I87

ненавиждь I4I

ненавистенъ I98

неплоды $27,59,243$; не плодвь 59

непостинимы 240

несу I4, I 20, I7I-3; не-

сти I7I;несудим'- не

сущимъ I7

нечалніе 69

нечистъ д̃me 10 I98

ни I86, I89; ни же I89; никако же I86;ни мала I86; ни не 227

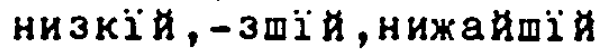
$2 I, 23$ 
низу I85-6

никі же 108

никто же IOI; ( не)

227,240

н UMфa 32

нис I87

нисхожю I88

ничто же IOI

нищъ II $(/-$ счъ $), I 98$;

нимі и, 一мз 76-8

нищю I73

Ніколаи 64;-ае 70

но I89

нОВЫЙ I 3,242

НОВ В० 215

Нผй, Нผе 70

носокоме іонъ 55,70

HOT 25

ношю I20; носително

$22 I$

ну 190

нужю I52, I73

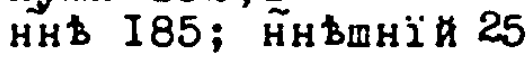
нырище 48,243

ныю I 20, I 39, I5 I , I72

HБKї I08

HБКТ IO IOI

HBM B० $2 I 5$

н Всм В II4, I 20, I56,

I59;нвсть 222 ; - ни 227

НВчіम I09

нвчто IOI, 206

$\omega$ I 3,I I 90,232; $\omega \omega \omega \omega$

I 90

$\omega / \omega \sigma^{\prime}$ I87-8,229-30

oбaчe 189

шбличаю I0

обоамw I86

.0०म, 06а, 00 в 88-9

wб оюду I85-6

wорвтаю 2 II

об pama $36-7,48$

w6xожю I88

00年 20

wо ЫM I 90

wo bye 2 I7

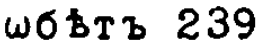

шб вту I 20

ов $94-5,98-9$; ова

I 3; OBWम̆ IOI

овакس I87

огнь 63

шдве рникъ 246

одигітріа,-ri- II

Одисceu 8,65

шдвваю I0 wh $\omega$ I 190

Oikoc 8,55

шкаАнный, -ншї ,

-нНВйї II, 23;

-Аны I2

Око IO,44,52; очи

I3; очв 57 ; wчесо

$5 \mathrm{I}$; о чеса I3

wкреств I86,225

wre 232

олтарь $63,24 I$

ометы 57

Онъ IO ,94-5,99-IOC,

206 ; оны IOІ;онш

I87; онде I85; ону-

म $\mathrm{B}$ I86

онакш I87; онамш

I 86

wnachw 224

шилотв 246

орел в $10,26-7$

Opecт в 53-4

орізонтъ 53

Opфeu 65

осва 26

осел' IO

шскудввает т I54

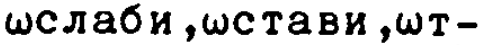

пусти и прости 2 2

осмь 92; осмдесать

92; осмсшт в 92

ocw b 187

Oстровъ IO

острый, - p⿴囗十

mi $2 I$

ост р10 I52

$\omega T$ I $87-8,228 ; \omega T$ -

внутрь I $86 ; \omega$ твн в

I 86 ;

$\omega$ ткуду I86-7;wт-

нуду же I86;wто-

боюду I86;wтону-

ду I86;wтсюду I86;

шттол в I85;

ду 186

wTa 225

отець $7,10,16,18-9$,

$43,46-7,48-9$, I 99 ,

$242 ;-6$ д дума 5

в вка I94

$\omega T \omega$ I 90

wт реби 4 I

Отрокъ IO

отроковица 238

От роча $26,49-50$

шт X0жю I0, I88;-жy

$23 I$

штчаниіе 69 отечь 80 ;отчї 20

WTAT b I2I

$\omega \times$ b I 90,233

Павель апс̃ль І95; Павловъ,-ва $28 ;-/-в л ь$

84-5; -вна 28

падаю, -10са I56

падежь 63

пажить 58

пакощю 2 I I

паки I86

Палестіна I9

паль 2 I I

пан $и$ ръ 53

парадитма 26,50

парЭАнинъ 52

пастырь I3,62

naтpiapx' II;-xa 24

пахолї IO

паче I87,225-6; - же, найпаче I87

пеанъ 53

пекус4 I5I

Пелагіа 38

Пентефрии 66

пе рвый 20 ; - спісаемых ъ I $95 ;-$ Bwe I86;-B be

I85-6;-B be неже I86

пе ркз 26

перси $6 I$

пе $\mathrm{pc \tau}$ т/ $\mathrm{T}, \mathrm{I} 6$

пе рсть I $3,\left(/-T^{\prime}\right)$ I 6,27 , I 58

персАнинъ 52

пе py I 39

Петръ I9,24, I98; Петров в 20,28;-ва 28;

-вна 28

печаль $24 \mathrm{I}$

пилую 2 II

Пиминъ 53

пиршество 44,243

ПИСмА 5 I

питаю 2 II

Пu૭aropa 32

пишу I20, I 39, I72-3,

2II ,24 I; пишет' Петръ 240; пишетсА I53; писателно $22 \mathrm{I}$

пища 35

піэ икъ 26

пію I72

пінница 36

плавю I52

пламень 7 I

планета 26

Платшнъ 53 


$$
-256-
$$

плачу, -уса I56

племА $26,5 \mathrm{I}$

плету I39,I7I-2;

плести I7I

илещи $6 \mathrm{I}$

плищь $27,63,7 \mathrm{I}$

плотв 246

плоть 58

плыву I 39

пльнь 58

плюю, плюну I 40

nо I87-8,230; по

велику I86; по малу

I87; по многу I86;

по рАду I86; по сем /-Mb I86; no chx

I86; по случаю I86;

по части I86; по

что I87; по что ни

I86; nо что ce I87

nooi10 I I8, I70-I,

I78-84; побих всА,

побіенв бых/буду

I I8

поборително $22 \mathrm{I}$

поб вждаю 2 I I

повели дати $2 I 6$

повиненъ I 98

повинуйеса 210

повлекі I77

повьдам I70

пов Вждь I 4 I

под I87-8, 229

подемлю IO

подиде 231

подобаетв II4, I53, 222-3

подобенв I98

подх 0 10 I88

поета 26,32

поздв I 85

позоритель 62

поль 206

полагаю 2 II

поле 48

полезенъ 198

ползу I72

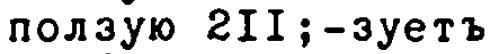
I53

Поливї 66

полма I86

полны I6

пол'ны I 6

помози ми 210

помышлАю 2 II

поне I89; понеже

I89; - yбо I89

понесу IO,I74 поношаетъ ми 2 IO

понуждаюсА 2 I7

псрекло 44

Порсена 32

посльди I86,225

посльдуйт 2 IO

постижимнй 240

постонши I70

пострадах I74;-a

$2 I 6$

потиріон, -ръ 70

похожаю I88

почитаю 2 II

now I 20, I 39 (/ n b10),

I 75, I84, 2 I I , I72

правы и, -вмї

खi $22 ;-8 \omega$ I 86

праотецз 93

npe 187,230

пребогаты 23

превзыйде II

прев вчны 240

пред I87-8,229

предаждь I4 I

предиду I88;-иде $23 I$

предотечА 48

предстателница

в врных' и помопница I 95

предь I85

прежде I85-6,225;

- даже I86, I88, 288; - даже не I86, I88; - неже I86, 228

презорливъ I96

прекословиши 210

прекрасньипі 23

прелагатай 64

прелесть 246

прел'щаю 2 I I

прелюбодњ 67

премудрость 246

премудры 93

препрославенны 29

препрославнш I85

препьтый I85

престы

преславны $29 ;-н \omega$ I 85

претвореніе 240

прехвалны 185

прехожю I88

пречисти I99

при I87-8,229

приведи I86

приемлю IIó,I7ó; примть І2I; приемлая 9

прижік 2 II

призри II7

принждиваю 2 II

прилежнш 224

примрак 246

принеси 186

приобрвтаю $2 I$ I

приснш Iо5

пристоитъ $і 53$

прит Ажу $2 I$ I

прих ожю $I 88,240$

пришествіе 69

приателице 9

приатнW 9

ПОИАХ

"ị̆де скорш I85;при-

иде 231 , - женихъ

240; прїди, -дьте I86

про I87

провижю I70

продаю 2 II

прозываюса II4

проклАты I 85

пророкз 45

Прост раннви 24

прость I98;-стшї,

-ствйі 22

прос⿰есіс 60

прстивонду IO

ПрОтивостоАтелно $22 \mathrm{I}$

противу I 85,225

противюсА I5I;-вА исА

I78

прох

прочї 82;-чеe I86,

I 89

прочту I 22-39, I 69-70,

I74-7, I79, I83, 219;

прочти се I5

протю I20, I52, I70-I,

I73, I75;-шу 7,209

прощак, прощь I 40

прузи 26

прА/npa 247

прамш I86,225

Чалом IO

Птоломе 65

пут в I4,63,7 I

пчела 26

пьтель 62

пАт ь 26,9 I; патдесат

92; nate po 88,90 ; na-

Twe I86; патощи I86;

กАTс $\omega$ T 92

Раав 32; Раава 32 
par z 49

рабынА, -ни 40

равенъ I98;-внш I87

ради I89,23I

радость 58

paдуюсA I5I;-yет'ca

2I 3; раду диса 247

раждаю $2 I I$

pa36i10 II8-9; paz-

біАa×b II 9

развв I87, 225

различный 243 ; -нь

I 86

разум' 25

разумив 222

разумвю $2 I I$; -вти 25

рад 27,64;- сдемс-

кї 239;- пищны

239

ранстей пити 238

ранш 224

pac I87

pacnpa 26

pacxoжyc4 I88

ращ10 2II; pac ч10 I75

pe 0 po 237

ревнитель 27,62

ревность 206

не ревну 210

реку I70; ptx з II4,

I56; puвте что I5;

рекаю I70

римлАнинъ 52

римскї 20

рожду, рожю I53

ршсс 28; ршссини 28,

39 ; Pwccia 28; pwcci искї $20 ;-/ \in k b$

86-7

pyraica II 6

рука 33-4,24I

рукоАть I4,27,63,243

Pyจa 32

ручка 26

рыч10 I52; рич10 I40

рыкну I 40

рвдвю 2 I5

pboro $2 I I$

$\mathrm{c} / \mathrm{cb} / \mathrm{co} I 6 ; \mathrm{co} / \mathrm{cb} /$ из І I6, I88, I87, 229;

со Адамомъ I5; C'Bнmе I86; cо женою 240; созади I $86 ; \mathrm{c} \% \mathrm{co}$ миром 16 ; сниже I 86

сажду 2 II

сакраментумъ,-тъ 56 c2ми 94-5,97-8; -

аз 95,$98 ;-$ ты

98; - ceбe 93;caмы IOI

самарнныни 27,39

сардоних в 53

Cappa 25,32 ; Cap-

ринъ, Саррь 83-4

свекровь,-кры 59

свервпвю $2 I 5$

Свой $9 \downarrow-5$, IO2,

I06-7, 200; - a3b

98;- ему I07;-

ми I07; - си I07;

СВОА тЫ 98

СВОЙСтво I3

свьдитель $25,63-4$

Св Бм I $20,156,163$

свьне I87,225

Свазень 62

ст̃ I4,2I; ст̃ 20-I, $23,27,72-4,78,87$, 238-9, 24I-2; свАт-

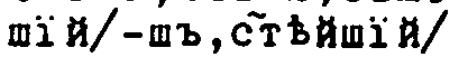
$-1032 I$

СТТНА,-НИ 39-40

Сваще нническое IЗ

ceбe 94-6,97

седмь 92 ; седмдесать

$92 ;-м$ ижды I86; ce-

дмсшт в 92

сеम I $3, \sqrt{\text { Ci }} 94-6$, I02-3,206,239; ce

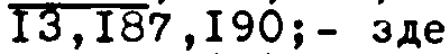

I85; - H( $\mathrm{b})$ I90;-

си I90; - то I90;

сегш ради I87

селикъ 20

село I9

Семе 70

семе ро 90

сердобола 68

сердие I $3,27,47-8$,

243, ( / ce pue) 247 ;

- проклатапU паматозлобіА I95

Силвестръ 53

силлишіс 60

силенв 2I9;-лны

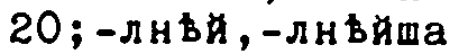
24

сило I4

с интаkіс 59-60

Сирин 32 ; Сирина 32

сирть 59

сице I87,235

синев в 20

Ci $\omega_{H}$ b 239 сї I0 I20, I72

сквернодьи 67

сквоз в I86,225

скиніа 27,38

скнипа 26

скомма 50

скорб ь 58,240

скорбю I 20, I52; -блю

I52; скоронше - скор'

6 awe I7

cкоpu 186

слаб вю 2 II

славный, -внші и, $-в н в$ ші

23,29 , I 85 ; славнш I85

славлю $2 I I ;-/-$ в10 I53

сладокъ 78, I 98;-дкін,

- дшї, -дчанші $22-3$;

-ди в I86

сладвю 215

слань 58

сле 310 I $20,152,(-\mathbf{2 1 0})$

I72

словице 28

слово, словесо 5, I3, $5 \mathrm{I}-2,237,242$

слухаю 28;-ханіе 28

случает' $C A$ I53-4; ; случитисА I54

слута 209

слышю 28, I 52, (-шу ) I20; сльшитсА I53; слитаніе 28;слышатель 28

сл ВмА 5I

слю I39,2II

смерт ь I4

смертны 240

смиренный, -енші нвйї II, 23; -еный I2

смотрю I52,I74; смотреніе 240

смущан 2 II

см Вдвю $2 I 5$

не смью 217

CM bюCA I5I

сниде $23 I$

снизходити 222

сноха 26,34

сн Вжитв $22 \mathrm{ZI}$

снвмь I63-6; снвдохо-

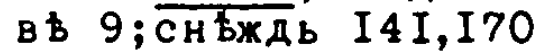

сов вту10 I40,2IO

согласуеши себь 205

соглАдата 64

созданіе 69

СОИзволАИ I5

солнечны 28 
слиние 48,247 ,(сонце)

248; - прв̈дное I8

сон'мз I6,I9; - люде

I 95

сопу І 39, ( сопти) I7I 2 сотворю IO, I4I-5I,

I 70, I 74-5, I77,240

сосудв 9

сотворитель 62;-

всеА вселенныа I95

Coфia 38

Софоніа 37

сохль I $4,27,58$

сочтаніе,-чет- 247

c ̃̌ç I8

cnacalo $2 I I$; crace

II; c⿱艹ссенїе 8,69;

спасител' мо 240

спира I9;- царскан

I92

спль II5, I52-3(/cmo)

спит'CA I53,222

средень,-днї 80

сред в I85

cрбту I 40 ; c pamy

(стрвтохз) I 39-40

ставаю II 6, I70

стадь 58 ;-дми 2 I3

стакти 40

стану I40,I70;ста-

ни зде I5

старостанна 28

Cтаxu 8,27;- апс̃л 239; - патрїархъ 239

стебль,-ліе 6I;-лї I9, 240

степень 7 I

сто 92; ста 26,242;

сторицею I86

стогна 240

стою $9(/-x)$, II5-7,

I 20, I 40 , I5 I-2, I70,

I73;стоАти II7;

СтоитсА I53

страх в 27,62

страхду I20, I39

странны II

страсть 27

cтpery I39,I69-73;

стрещи I7I

строитель 62

ст роАю I40; Строит ъcА 222

студъ есть 222;студно 220

стыжюс А I5I,209

ствнь 247

СтАГаю, СтАГнУ I40
cтAKY I72

сугубш 186

судъа I6

судище 48

судіа $25,27,38-9$, 66

сумантАныни 39

супругъ волШвъ

ПАт $\mathbf{b}$ I95

сусль 58

сушю $2 I I$

схима $24 \mathrm{I}$

схісма 26,24 I

cхну I 39

c'xожусA I88

схоліОн 55

сй I8, 48-9, сыне

I4; - мОЙ I5, 248;

сйовень $9,20-\mathrm{I}$,

$27,78-80,242$

с вве рз 25, 63

c bxy I I 5, I $40,(-\infty 0)$

I5I , I70, сежเ I52;

с вдит І I 4 ; седАй,

свде , свдавы

I78

c bKy $2 I I$

c BMw I 86

c bMA $26,5 \mathrm{I}$

сьнь I4,I6,247

с Вту10 I5I

c b10 II -20, I72,2II

сюд \& 186

CАГаю, САГну I40

саду I40,I70; cА дущі 176

та жe I86

Ta 186

таков 20, I99

т акL I86-7,226;

тако же I87,226

там. I85-6,226

Таніс 59

тать 25,62

таче 186

таю I20, I69, I72

твердь 58,240

т во I I , 94-5,IO2, I05-6,200,206;

- Ти I06

творецъ 8,49

т ворю I 4, I I5-6,

I4 I-5I, I 70, I73,

I75,2II , 240;

- DCA II5;-ИтСА

I53,205; твори

І 3 ; творително
I5I , I76, 22I ; т ВО pАК

I I 6, I 4 I -5I , I 74-5

теку 7, I I9, I 40, I 7 I -3;

тещи I7I

теліua I6

темпе раментумъ, -нтъ 56

тепль II6,I52,2I I

теплью I I5-6, I20, I72, $2 I 5$

терпю I20,I73;-пль

I52

Tepтї 66

Tewy 2 II

т исАща 92-3

тихї 22

Тімоэе 65 ; -ee 70

TіринЭ马 53

т л В10 I 39

тма 93

тогда I87, I89,226

то 94-5, IOI-2, 206,

238; тойдд I02;

тВMъ, тВм'же, твм же I89

токмW I87,226

толь I 87

толижды 187

толикъ 20,I99;-к() I87

толма I87

толку 2II;-KÏम I79

томитель 62

тонкї,-нші 22

ТОНчВ10 2 I5

точило 243

точїю I87,226

Tощ子 I96

тощн 186

Tpane зунть 53

требиме 48

т peб y 10 I 69,209

треов есть I53,I56

T peryow I86

т ре зв вю II 6,2 I5

третицею I86

треті 20,82 ; $і$ ie I86

три $I 4,20,26,9$ I ; три -

деслт ь 92 ; трижды,-щи

186,225 ; триста 92;

тріе отроии I96

трои 88-9;трое 90

т роица $9,247(/-0$ - -$)$

тропаріон 55,70 ; -арь

70

Tpwe 70

T poct i I 4

T pe 174 
T py:M ن.WCA II 5

Ty IE 5

Tудь I66

туне ISó

тцаливь I98, 224;

тцэливші, -в ьйу I 97

тщлітль 62

Tщ10. I5I,2I6

ты $94-y 6$ (ва, вы),

вы 97 т теб́ 00 I5

т Бло 44,243;тало 52;

тьлесо 5I; т бле心а,

телеса 246 ;т блие 28

TAгну I 59

тАКекъ 7E; тАЖкї,

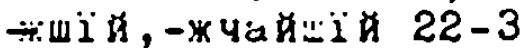

y $187-8,228$

уолажа: 2 II

yow I89,232; yoo I89

yórb I98; yoorï,

-гшїи, -жаишї 22

увиждь $I 70$

увы I90,233

ув им I60-3; увьждь I70

ув ьиаваю 2 I I

угль 27,63

удъ 52; удесо $5 \mathrm{I}$

у поб b , - 00 be, - Бйши

I86

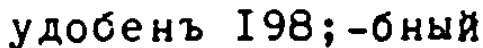

78, I 98

удоль 58

уду I85, I87

уединеніе 9

уже I 85

у:кика 25

у зкї 23

узниковыма I3

уї I 90

укосньный I52

умираетъ шіъ 208

уну дрА⿱О 9

yis 5102 II

уничижаю $2 I I$

унї 22; унша丿 Г山 24;

уне ECTक 222

упова: I5I; - ax I8;

-аелкй I52;-ателно $22 I$

усердіе 69

усерднш I86, 224

услыши II7; - :1 I5

усіар р 52

усну $\times$ В I56;-нy II4 уста 26,57

устн ह 4 I

уступую 9

ут ренWW I20, I 40, I72

утрш, во утрї I 65 ; ут po 44

ут bmaw 2 II

ут Бшитель 62 ; - дйъ

члвческих ъ I 95

ухОж10 I88

ученикъ I 4

ученическое I 3

учк I 20, I52, I73,

2II-2; учениі I97

yxo 52,44; yweco 5I;

ушеса, уши, ушь 57

Qавwpz I 9

фалаггъ 53

4 apicaib 8 ;-cee 70

Фe I90

Өекла, $\Phi$ - I0

Фелїз 53

จема 50

Өeодшpъ I0,53

งеологіa II

Өe офіль,

Эермы 4 I

$\theta$ ивы 4 I

Філіпnв,8 - IO

фirinnici 65

філософь IO;-фї II

$\Phi$ i rove

Owмa 24,32

форма, хво- I I

xa xa xa I90

халвани 40

Харивдь 59

Харлампъ 53

хвала,

хвалный I6, I 85

хвалю I72-3,2II

хвраств 49

хладнью $2 \mathrm{I} 5$

хламис 32

хл $А \sigma_{b} \quad 58$

ходотаи 64,243

ходотайствую I40

хожю I5 3,$240 ;-ж д y$

I53

xощу I 20, I $39,2 I 6-7$,

2I9; sme бы хотыл

I I7

хрэню $1 \mathrm{I} 6, \mathrm{I} 20$, I52,

$2 I I ; x$ ранаю II 6

хрістїнинъ 52

Xрістос $55 ; \widetilde{x C ~ I I, I E, 55 ~}$ царь I I , I $9,24,62,7$ I, 239 ; царе вичь, цире в-

на 28; царскї II

цирлтво,-вї 56,69

царству10,-pec- 247

це ню 2 II

Le pec 32

це рковь, -кви I8,59

цыт I 90

ц ๖лw I86

чндв 58

чародь 67

частв, $-T^{\prime}$ I 6

часть, $-T^{\prime} I 6,58,206$,

240

чанд 58

ча10 209

чванецъ 47,48

ч л̈вкъ, чел В В Вкъ 7-8, I4,

I $6,25,29-30,240-2,247$

ч йволюбї 69

челомъ I3

че рвень 58

че рменъ лицемъ I98

че рмню 2 I I

че рню 2 II

черлало 243

чествую 2 II

честенъ 78-9;-стный,

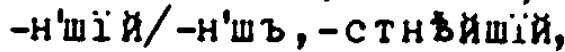
пречестн вишї 9,16 ,

I $9,23,78, I 85, I 97$

четверо $88,89-90$

четвертwe I86

четыри $26,9 \mathrm{I}$;-pe euг̃лін I96;-рдесать 92;

-рижды I86;-риста 92 че шу А 27,240

чи, чили 189

числю 2 II

чисть I98;-тый,-тшї,

一т Биші I4, I $8,20,22$,

$243,247-8$; чисто 10ници 238

чита10 28, I I 6, I 22-39,

I 57, I 66, I $69-70$, I72,

I 74-7, I83,239; -аны म̆

І 2 ; -ателенъ, -ателно

I39, I76, 22I; -анї 28

4 i $94-5$, I $02, I 08-9,206$

4 pe 3225

чтець 49

что, чесо IOI; чT $\omega$ I90;

что естъ I4, 206; чт०

лиос IOI; что ce I4,

IOI; 4TO сине I87; что 
чесо, чесо ради I87; чему ни 186

чту 28 , II $6-7$, I 2 I-39, I70-I, I74-6, I79,I8I, I83, 2II , 2I 9, 24 I ; чти I 3 ; чести I7I;чтет'CA I53; чтен, -нын I2, 28; чтеніе 28

чувству 10 I72

чудо 44,52 ; чудесо 5 I ч10дотворны I85 чу10 I39, I72

mapro 2 II

шесть 9 I; шестдесат 92 ; шестеро 88,90; шест ихды I86; шестcWT 92

широкв I 96; -окї, -pmï , - рочайї 23 miso 2 II

пумю I52
щадит'сA I55,222

щедрю I73

ще дрАб I40

щепль 2 II

: 5325

Dдi $\theta_{a} 32,-i \vartheta_{b} 25$

1Онш, Оншна 32

юнота $35,48,24$ I;

- многиА добродв-

тели I95

юнแับ I 97 юрод' $20,25, \underline{43}$

iнвлашеса IO

je日 I 186 ; - есть I56, 222

iagb I4

јадаю I40, I63-6

іадрило 44

і-акW I87, I89, 226,235;

- да 23I; јако I87,

I90; - me I87,226

јаков I 99

јам в II4, I 20, I 4 I, I I56, I63-6, I70; вс ва 9

i peмz 42

japoct 58

\section{P}

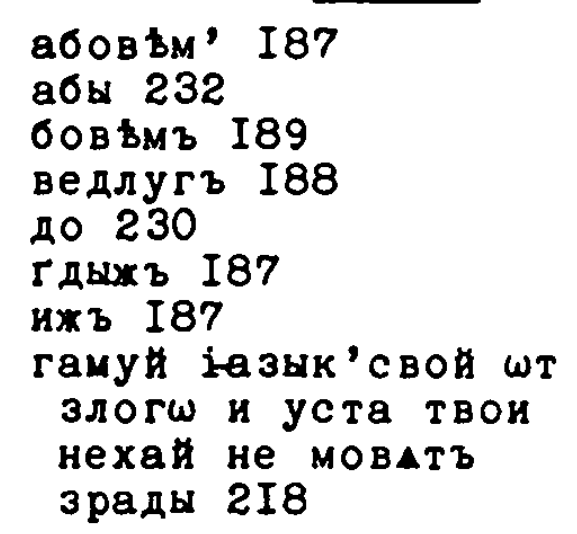

"Aswuls 53

AL AiO4 53

$\dot{\alpha} v \alpha \delta i \pi \lambda \omega \sigma \iota s 246$

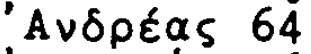

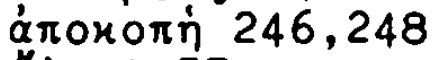

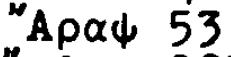

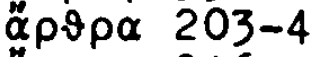

apols 246

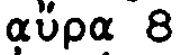

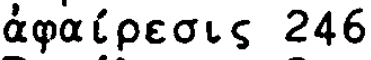

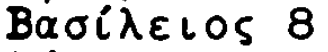

Bías 53

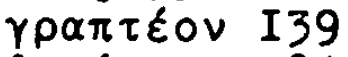

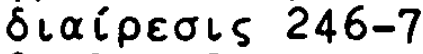

$\delta\llcorner\alpha \tau \tau \alpha 8$

$\delta \iota \pi \lambda \alpha \sigma\llcorner\alpha \sigma \mu o ́ s$ 246-7 Eixw்r 8

Caesar 8 aerumna 8 нехан 232

перве нвх з 228

перве поки 228

no 230

посль $I 88,230$

прето I88

по прочитанъо $2 I 7$

Griechisch

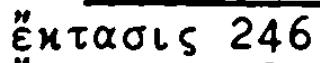

है $x \forall \lambda \iota \psi \iota s$ 246-7

है $\lambda \lambda \in \iota \psi \iota \varsigma$ 246-7

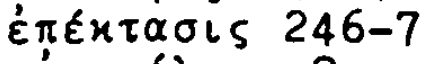

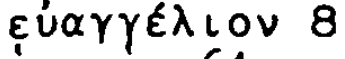

iepeUs 64

Kí $\cup \square 3$

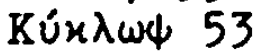

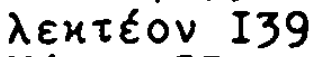

M\&uas 53

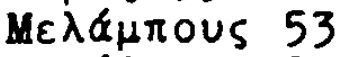

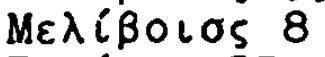

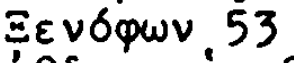

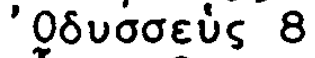

olnos 8

ón

Lateinisch рыхлш упереди поки не будем зневолени 228 теды 189

T b $I 89$

(гды бымъ) учинилъ 143

(гды бымъ) чиниль I42, чинивалъ I 43-4

( абы/дль тогш ке/ $\omega$

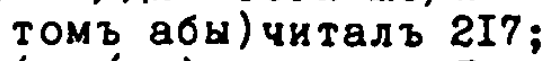

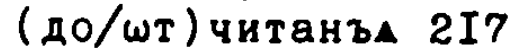

iakъ,- барзо I87

$\pi \alpha \rho \varepsilon \lambda \lambda \varepsilon \iota \psi \iota \varsigma$ 246-7

$\pi \alpha \rho \varepsilon \mu \pi \tau \omega \sigma \iota \varsigma$ 246-7

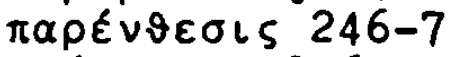

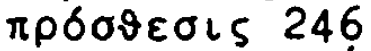

$\pi \rho \circ \sigma \chi \eta \mu \alpha \tau \iota \sigma \mu o ́ s ~ 246,248$

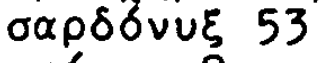

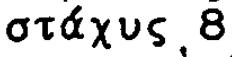

ouүหотท่ 247,246

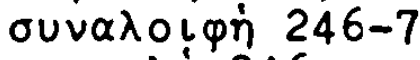

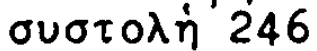

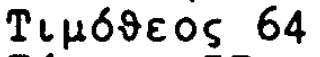

Tipuvs 53

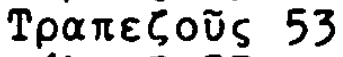

$\varphi \alpha \lambda \alpha \gamma \xi 53$

$\varphi \alpha \rho\llcorner\sigma \alpha \tau$ ○S 8,64

griech.Zitate auf $S_{\text {.: }}$

20I-4,208, 2I7-8, 227 


\section{VERZKICHNIS}

der grammatischen und verstechnischen Terminologie

bei Smotryckky

адонскї стіхз саніискін 244 акаталіктъ/тріметеръ іамвї̈CKI 244

а:::Фів рахй 243

амі імакръ 243

анапеств 243

аномала 40,I56/єтерокліта/ иносклонителнан имена/неравнаА 40

антіптшсіс/мвстопадежіе 233-4

арэронъ/различіе/членъ 203 асклипіадскін стіхз 243,245

безгласное (согласное) 6-7, 237

бездушнаА вещь $4 \mathrm{I}$;-mное I92 безличенъ глаголь $235 ; \sigma$-чны r. II 4, I5 3 , (дъйствителный) 22I, (страдателнын) 223

беспросшдінное (реченіе) I 3-4

б ̃̈голасї I2,78

будущее врема II8, I70

буква 25

вакхї 243

Bapia/tAжka (просшдia оp७ографіннан) I2

веселитисА (о падежи) I97

вещь бездушнаА, - шдш̃евленал 4 I

взыскати (прилагателное дателна) I98

видъ: первообразныи, производны 28; имене 2I,27-28, мьстоименіА 94,глагола II6, нарвчї I85; совертенныи, учащателны (глагола)I25, I 45 ; I 22 , I 45

винителныи падехь 29,2 I -2, $225,228-30,235,24$ I -2

винословное (знаменованїе) 218

властелинный видъ имене 28

вложеніе (гласнаты во среду ре $ч \in H і ̈$ ) 247

вмьстнаА (препинаніе строчное) I6-7

вмьденіе (страсть реченін) 247

возвратителное (качество мьстоименіА; мвстоименї) 94, 205
возглАдъ имВти 200

возносителное (качество мъстоименіА;мВстоименіе) 94,200,203 возноситиса (К склоненію) 52 вознотеніе гласа I2

возращеніе (наращеніе со преди приточны нарамакмее) 240

вопросителное прилагателное I9-20, 72; въпросителное/во- (качество мъстоименї;мвстоименіе) 94-5, 205-6

вопроснам (препинанїе строчное) I6-7

вопротеніе I99

восклицателное (๘) I4

воспосльдовати 236

в ремА (просшдїА,п-А стіхотворныА) I2,I5,237; времА (глагола): настолmее совершенных и учамателныхъ, преходацее, прешедтее, мимошедшее, непредвлное, будуmee II4, II8, I69; (причастї) I77 всАкї ро дз (имене) 24 , (мвстонмене) 95,(глагола) II9

B Bpm/ctix IO

герундї 219

глаголь (часть слова) I8, II4; личныи, безличнын, стропотныи, лишаемы II 4,207 ; существителный, звателный, прилагателны II4; преходителный, самостолтелный I I 4, 2I5-6; совершеннын, производныи, слохеннын (Свойственнъ) I I8,23I; начинателнын, учамателный II8; скланаемый, иноскланаемыи, ст ропотнын, липаемый, изобилующї I56; д Вест радателны 216 ; $\omega п$ редвленъ, нешпредвленъ 2I 6-7

глиніе удивителное I7

глаголны видъ имене 28; глаголHое имА I 95

глас писменны 236

гласнац 4, гласное 236: долгое, краткое, двовременное/обтее 5; самогласнаА, припражногласное $4,23 ?$

ГЛUкОнскі стіхз 243,245

грамматіка 3

густам просшдїа/дасіа I2,I5

дактилз 243

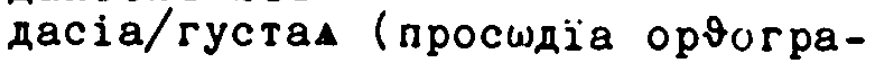


(і инаА) I2, I5

дателнни падежь $29,210,222$, $225,228,230,233,24 \mathrm{I}$; дате ленъ самостолтеленъ 210

движеніе единапш гласнаты I8

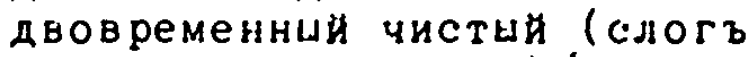
словом количества)/WنоАтный I 4, 237; двовременнос/общее (гласное) 5,239;

двогласное: долгое, крагкое, обтее 6 ; д. двовременное 239 (естествомв краткое: 38 , е. долгое 238 , е.ойее 238; положеніемъ/приращеніемъ/ шкинченіемъ шдолженное/сокращенное 239; ШоОлтное 239) свойственное 5 ; (естествомъ долгое/обцее $238, \omega-$ оолтно 239) несвоиственное 239

двойственное число 29 , I 6 двоточіе (ирепинаніе строчHoе) IO, I5-6

дебелое (шкончаніе) 4, (извьцанї) I 6

діалект (греческіи) I94

долгв наве ршати 208

долгї (слогъ, словомъ количества 237) естествомъ/положенїем I3,- чистї I3; долгал мьра (по времени) 237 ; долгал просшдїа времене I5,- положеніем I3; долгое (гласное/двогласное) 5 другі й именителенъ 208

духъ ( просшдї) : ГустеА, тонKaA I2, I5

дьепричастї I27, I7I, I76,220; дьепричастное имА I9I

дьест радателный гл̈ 216

дъйство (знаменующі Глй)

II 4 ; - : настомпее, несовершеннш проплое, совершеннш прешл ое, $c-\omega$ преше дшее, в'маль совершеннш преіндшее, гр.ядущее II8; дьиствителный залогъ глагола II4; д-ное знаменованіе/спраженіе (глагола) I I 4

дьланіе II4

дьло совершати 203,220

єдинитнал (препинанїе строчное) I6-7

единнадесатосложныи стіхз 243

единосложное (реченіе) I4

сдинственное число 29 , I 16

є乡аметеръ/шестом Брншй/иршй- скї стїв 243

елегійкї/пато: Брний стіхъ/пентаме терв 243-4

еличество 20

сллинісмз 224,233-5

criqucic 235

сналлаги/изивненіе 233-4

срикъ I2,I5-6, (-ікъ) 242

естество I92

$\because$ Теронліта/вномала/нериннам/иносклонителнал име нü 40,38, I56 : тимслотїа 3,18

женскї родз (инен:е) 24-5, (мьстоименіа) 95 , (глаголе) IIS

заемлюще I 22

залогъ глагола II5-6,- причастіА

I77: ДЬйстителиы, стридтелный, среднїи, штловителін:я, оо世茫

jallataa (nрепинаніje cтрочное) Ió звателный падежь 29,2I2,225-6, $232,235,242 ;$ звателний глаголь I I 4

зеитма/спраженіе 233

знаменованїе $24,-$ мьстоиненїа/ качество 94, - нарьчіА I85-7, соуза I88-9,- междом:етін I90; - недоумьнне 2 б 6 ; зніменовати 90

іамвъ 243; іамвіпскіи стіхз 243-4 - с६аметеръ/шестомьрен 244 (чиет совершен; нечисть несовершенъ) извьданіе I 6

изглашеніе 27

излохеніе (гласнагш ченін;слога з'среди реченї 24 ? измвненіе/снэллаги 233-4

измвнаемое (согласное) 7,237; измВнати (А на е) 50; Измвну стра дати 7 I

изношеніе реченї I5

изобилї (въ рсдь, числь, падежи)

40; изшбилукщї гль I56; изшоилуютаА (склоненіемъ) 57

изостратиса I3; изостримо I89;

изострена (о弓іа на кончаемом слозь) I2

изшсковати (числителннА родителна) 224

Изъавителное наклоненіе II7, 232 ИзаснАющї̆ (именителньй нарбчіе) $235-6$

Изати 70; изат̈̈е I27, (страсть реченіл)247, ( соглзснаты с среди речєнї) 247

Именное имА I9I 
има (часть слова) I8-9;- собственгое, - нарицателное I9; - именное, прилагателное, мЂстоименное, причлетное, двепричас:ное, причастодьтелнсе I9I;- иносклонителное 40

именителный падежь 29,233 , 235,242

иносклонителнаА/нерлвнаА имена/аномалу/:те соклітӓ 40 ИнОСКЛОНАемЫЙ ГЛ̈ъ I56

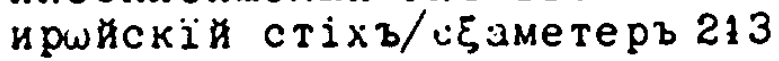
качество (гласа) I5;-/знаменованіе (мбстоименї):возвратителное, возносителнсе, въпросителное, притажателно, указателное 94

количество $5,20,236-7$; - слшгъ (єстествомъ писменъ, положеніемъ, прирапеніемъ, шконче ніемъ) 238

кончаемы (слогъ) I2-4; кончимый I40

косвеный падежь 29

краткї (слогъ), естествомъ, положеніемъ I4;- - словомъ количества 237; краткан (просшдіа времене) I5,- мъра 237; краткое (гласное) 5, (двогласное) 6

лице (мъстоименін): первое, второе, третіе $94-5$, (глагола) II7

личныи глаголь II $4 ; 235$

лишаемы глаголь I I4, I56

лишеніе (в родь, числь, падежи) 40;- (имене) 235

малость 29

междометіе (часть слова) 58; знаменованін: бонщаг

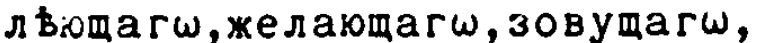
зовуща ти и восклицецдаг $\omega /$ званіА и восклицаніА/Звателное

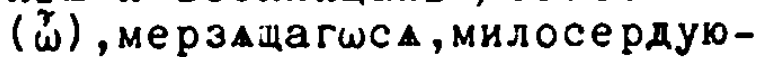
даг $\omega$, молчати повельваюдаг $\omega$, напацакща $\Gamma \omega$ нап расн $\omega, \omega \tau$ зываюда $\Gamma \omega c \Delta$, плач уда $\Gamma \omega$, поношающа $\Gamma \omega$, понужајоща $\Gamma \omega$, похвал $410-$ mаг $\omega$, пре зира:ода

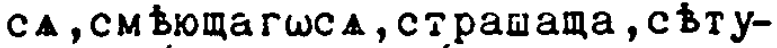
ющаг $\omega /$ втованін/こвтователное $(\hat{\omega})$, удивлАю口агшсА/удивленіА/удивителное и желателное $\left(\begin{array}{c}\omega \\ \omega\end{array}\right)$, указующа $г \omega$, чудндаrwCA $\$ 89-90,232-3,235$
Mетръ/мвра 236

мимотедпе врема I I 8

многосложное (реченіе) I4

множественное число 29 , I 6

мнохество 29

молителный II7;-лное наклоненїе

I I7 , I70

мужескіи родъ (имене) 24 , (мвстоимен

мвра/мєтръ 236:долган по времени, краткан 237

мвстоименіе (часть слива) I8, 94, І99;- пола 24; мВстоименное ИMA I9I

мъстопадежіе/антіптшсіс 233-4

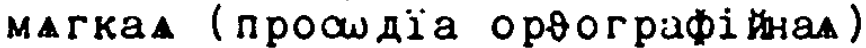
I2, (страсти) I6

наклоненіе (глагола)II4,II7:изАвителное, повелителное, молителное, сослагателное, подчинителное, неопредъленное; шпредвле Hoe 207

напракеніе слога I2; - (страсть реченін) 246

наращеніе I69, (: возращеніе,прираденіе) 240

нареченіе вещи I8

нарицателное (има) : судествителное I9, I9I, ссбирателное, прилагателное I9

нарвчіе (часть словы) I8,224-7, I85-7: вопрошенін, виемене грАду па и збраніА, качества, количества, мъста, напраженіА, недоумвніА, шслабленім, $\Delta, \omega т$ рицані $і$, повелені $\mathbf{i}$, прещеніА, разн'ства, разсуждені А, случаА, ув вщаніА, указаніА, уподобленін, ускоренін, числа, чина

настолmее врема (совершенных и учащателных) II 8

начертаніе: глагола (простое, сложенное, пресложенное) I I6, имене $2 I$, реченін $29,(-,-,-$, сложное 95), мвстоименіА 94-5, мехдометін I90, нарвчіА I85, причастін I76-7, соуза I88; Mbры (в прослдін) 237

начертателншй согласныи I40,I52 начинателный: видъ $2 I 5$, гл̃ъ II\&, І 39, I77; - произвсдный видъ глагола II6

недоумвнный родъ (имене) 24,26 неопредьленъ глаголь 2I6-9; -енны 235 ; -енноє наклоненіе II7, I7 I , 208, 232 
неподвижен (прилагателен)I94 непорушны (посльдователны ) 234

неправилное уравненіе прилагателных 22

непревосходный (слогъ) 2-3 непредьлное врема II8, I69 непреострима (оรіа на непреВосходном слозв) I3 неравнаА/иносклонителнаА имена/аномал'а/єтерокліта 40 не разсуднв (употреблати) 229 нескланнеман (часть слова)

$$
\text { I8-9 }
$$

неуравнаемое прилагателное 20

несвойтвенное (двогласное)

5 ; -ннв (творити) 78

нечистое 34 ; - оконченї гл̈в I 20 , I 39

нога (ctixa) 236

шблачитисА (слогъ) I4;-чимо

I89; 66

ШбоАтныН/двовременныИ слогъ 237; оболщаюmе (согласное) 7,237

образ (гл̃нніа) 233; -/схима 233; образнал синтаद̆іс I9I, 233

шбщї гл̈ъ I5I,I79; - залогъ глагола I5I; - слогъ (посльднін) 245-6; - чинъ предлога 189; - родъ (имене)24,25, (мь-

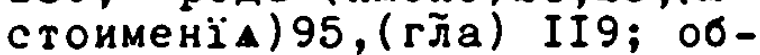
mее (гласное) 5, (двогласно) 6

шбнкнути 226; шбыча 70 об'Атї/синекдохи 233

шгущатисА I5

шдебелАти, - Ающее 70,237 ; шде беленый,-ное согласное I4; шдебеленіе (согласнагш) 9 долхеніе (краткагш) 246

шдшевленан вещь 4 I

шконченіе 5,20 (дебелое 4; тонкое 4-5); (прилагателных) 20 ; - Гл̃з (чистое, нечистое) I 20,24 I

okia/octpaA I2

шнечищати (согласнымъ гласное оконченї) I20

шпредвленъ гл̈ 2I6-7

opo or paфia 3-4

шслабленіе (страсть реченін) 246-7; - слога I2

остраa/okia I2 шс Аженїе/силличіс 233-4

штвынаніе I99; штввщзтелное прилагателное I 9-20,72

штдохъ восторгненый I6

отечествный видъ имене 28 ;-вное

85 ; -вноє прилагателное I؟-20,72 штименный видъ имене 28 ;-нное

прилагателное I9-20,72

штлагатиса (сриком'/п'ерком') Is

штложеніе (псипражногласнагш) I5,

(страсть реченіи) 246

штложителны гл̃

глагола I I4-5

штложнам (препинаніе строчное)

I $6-7$

штмещи (с) 55

штончати(сA) 237,15 ; штонченое

(согласное) I4; штонченіе (

гласнагш) 9

шт рицаніе 227

штрвшніе (слога в' конци реченї) 248

отчеименный/притажателный видъ

имене $28,72-3$

штАжатисА (слогъ) I4

wтатіе (писмене/слога в' началь реченін - страсть реченін) 246

падежь: правый,косвеный 29; именителный, рсдителный, дателний, винителны , звателный, творителный, сказателный 29; - имене 2I; - мъстонменіА 94-6; - причастіА I77; - предлога I87

паеркъ I2-6,242

палімвакхї 243

парадигма 30,70

пентаметеръ/патомърнын/єлегіи-

скї стіхв 243-4

первообразное реченіе 27;-зный видъ (имене) 28, (мъгтоименіА)

94, (глагола) II6

пе ріс пшмени/шблеченнаА I2, I4

nuppixi 243

писмА 4,236: гласное 236 , самогласное 238, двогласное 239, согласное, припракногласное, вапшее IO

повелителны II7;-лное наклоненіе I70,23I

повтореніе (писнене) 246

подлагателный чинъ предлога I89

псдобіе 93

подручный (предлог страсти спраженї) 247

подчинителное наклоненіе II7,I7I, $2 I 7,23 I$

подчинное (мъстоименіе) 203 
полагати (прилагателнан) I92 полгласное (согласное) 6,237 положеніе (слога) 239-40 положителный степень уравненін 2I;-лное 226;-лное наpвчіе 22I;-лное знаменованіе нарвчін I 38 полустепень 244 посльднї слогъ (чина словомъ) 237; - - стіха 245-6 послвдовати 208,223 ; - уующ ін I 99

правило общее/лнаменованіе 24; - особное/шконченіе 24 правилное уравненіе прилагателныхь 22; п-ое спрахеніе гл̃ II9

правописаніе/орจографіа IO правити (падежем гла) I96,

(числителное) 220; правленіе склоненіА гйъ наклснен'ми, в ремены, числы, лицы, роды ПП правы падежь 29

преведеніе 204; преводникъ (искусныи) 202,204

превосходителный $227,-$ степень урєвненї 2I-2;-лное I97;-лное нарьчіе 225 предварати (возносителному свое предидупее) 202

предвзатіе/проличіс 233-4 предизострена (о छіа на предкончаемом слозв) I 3

предити 208.2I6,232; предидущі I $99-200$

предкончаемый (слогъ) I2 предлагателный чинъ предлога I 89

предлагати (с4) $212,228,233$ предлогъ I5,23, I I 3, I 40, I87, 228-3I, 236, - сложнв/сочинителнь/сложнв и сочинителн в предлагаемы 188

предложити $2 I 7,-ж е н ы ~(г \tilde{л у ~}$ именителны ) 207 ; предложеніе (писмене/слога в' началь реченін) 246

предні слогъ (чина словомъ) 237

предчинное (различіе) 203 преизострена ( о $і$ іа на прекончаемом слозв) I 3

прекончаемы (слогъ) I2-3 прелагати 22/пременати 23; прелагати (среднее женску) I 92

пременати 23/прелагати 22 преобщі родъ имене 24,26
препинанїА строчнаА: вмВстнаА, вопроснаА, двоточіе, сдинит'наА, запАтаА, бтложнаА, точка, удивнаА, черта I6

пресьченіе/саеsura 245

"1ретворати (согласное) I40; претвораніе (причастї во гли) 204 пресложеное начертаніе глагола

II6; - - pеченін 29

преходителный гль II 4,2 I 6

преходаиее времА II8, I52, I69

претедшее врема II7, I69

приближнее предидущее 234

привтедшее 87

приданіе (страсть реченін) 247

придвти себв естество (существителных) I93

придвати свое двйтво (творителны органу,..) 213

прилагателны 235-6; - глъ II4; -лное има I9,I9I,2I9, - - размъренї I96;-лное: вопросителное, шт в вщателное, штечествное, штименное, прит ажателное, Сове ршенна е , чинителное, числителное, ; зыческое I9

прилагати (оконченіе) I73, (има имени) I9I

прилежати ( соузъ г̃.му лицу повелителнаг 2 ) $23 I$

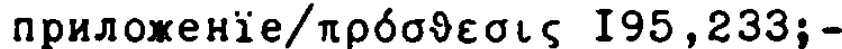
(страсть реченї)246, (слога в конци/средв реченіА)247-8, ( согласна в реченіи) 247

примещиса (нарвчіе имени) 224 примытеніе (в реченіи) 29,(соу3а) I97

припрагати (реченіе) I4, (прилагателное существителному) I9I; -са (дателному) 2I2,232; припр

припрахногласное 4, I5,237

припвтіе (измьнное гласа писмен-

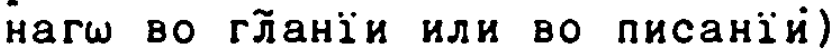
236

ирипатїе (страсть реченіа) 248 приразумвватиса 222,232

приращеніе (созади слогомъ)240-I пристеженіе I9I,222

притажати (существителнам прилагателное) I9I

прит Ажателныи/отчеименный видъ имене $28,72,78,82-4 ;$-лное (качество мВстоименї)/- мВстоименіе 94-5;-лное прилагателное I9-20,72, 205-6

причастенъ Гг̃ъ I39;-стное имА I9I 
причастіе I8,I7I-6,223 причастодьтіе I27, I39,I76, 22I,223,-телное имА I9I производити I2I;-сА 28 производни! видъ (именъ)28, (мъстоименіл) 94,(глагола) начинателный, учащателный II6; - ное реченіе 27

проличіс/предвзатіе 233-4 пропредкончаемы (слогъ) I2 пропредизострена (оңіа на пропредкончвемом слозв) I 3 про/пре/изострена (оңіа на пропрекончаемом слозв) I 3 пропрекончаемый (слогъ) I2 просшдіа/удараніе гласа/ припьтіе $3-4$, I2, 236 ; n-a времене (долгаА,краткаА)I5; n-a орэографійан (варіа) тАжкаА, дасіа/густаА, єрикъ,

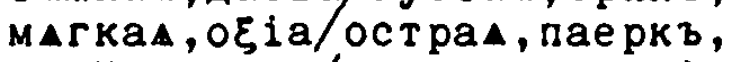

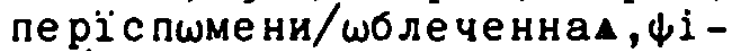
ли (тонкаА, слитнаА) ( 2, I5-6, 236; п-а стіхотворнаА 236 простыи (і-зыкъ) 87 ; -тан сUнта乡̈іс I9I;-тое има 93,- начертанїе реченіА $29,-$ - гл̃ I I 4

просэесіс/приложеніе 233

прот гатиса I5

протаженіе (гласнагш/слога) I5, 237

філи/тонкаА I2,I5

работати (нарьчїе падежу)226 радоватиса (числителное родителному ) I96,2I2,225,23I разгласіе 225

раздълати (соузъ имена) 23I; раздвленіе 206, (страсть реченің) 247

различествовати 8 различїе (часть слова) I8, - /арөронъ/членъ 203

разн'ствити (в' числв) I92 раз решатиса (неопредвлены В' подчинителен) 217

разсудителный 227 ,- степень уравненіА 2I,22;-лное I97,

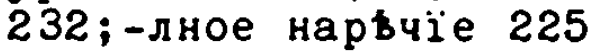

разсужденіе видъ I5I разум (глемагш словом) I6-7 разатіе (единагш слога на два) 247

разатнан (препинаніе строчное) I6-7

распространеніе (страсть реченї) 247 растворати 70;-са (единосложнаА имена) 48 ; -раема имена 70, I 23 речэніе 9, II, I8

родъ: имене (всакї,женскї,мужескї, не доум внный, общї , пре общі ніА 94-5,- гл̃а ( ВсАкї,женскї, мужескін, общї, среднін) II9, причастї I76

родителны падежь $29,222,224-6$, $228,230-2,235,242$

самогласное 4 (краткое,долгое, общее) 238

самосоставное будушее I 40

самостомтелны глаголь I I4-5, 2 I5 сафїскї стіхъ 243-4

Свойство І99; свойственное (дво-

гласное) 5 ; с-ннь (творити) 78 свАзовати (соузи имена) 231

сила I93, (вампа) 23, - /єнергіа I93

силличіс/

синекдохи/шб'Атїе 233

синтагма I

сUнта乡іс 3,I9I; - простаA, - образнам 233

синэесіс/сложеніе 233

сказателныи падежь 29-30,2: 3,2293.

скланАтиса I 39; скландемаА (част ь слова) I8-I9

склоненіе (имене) I.-5:30,2, (мъс.. тоименї) I. $-4 .: 94-6$

слитіе (дву слогу в' единъ) 247

слитнаА 9, I $2-3$, I 6 , (просодіа страсти) I5

слово I8; - количества 237

словотітла I8

слогъ 1,I8: начинающї 8, кончаемы и, прекончаемы и, пропрекончае мый, пре дкончаемый, пропредкончаемыи, непревосходны І2; (словомъ чина) преднін, среднї, посльднї 237; (словом количества) краткї, долгї, двов ременны 237 ; (положеніемъ) краткї,шдолженъ, шбоАтенъ 240

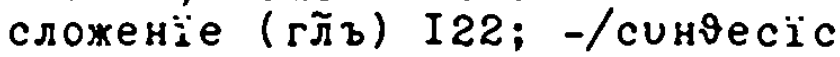
233

сложенны (гл̃ъ) I I8;-ые имена 93; -нное начертаніе (реченін) 29 , (глагола) II6

сложное начертанїе мвстоименін 95; сложн в 229

служити (родителны глаголнымъ именемъ) I95,23I

снашати (разсудителнаА с различными тогшжде рода) I97 
собирателное (нарицателное им4 ) I 9,57, I 92, I $95,209,233$ собственное (има) I9 собство 233,236

сове рпенный: гл̃ з I8, I25;

видъ гл̃а I2I;-нное прилагателное I9-20,70

СОВозноситисА 226 ; СОВознопеніе 226

согласное 4, (полгласное, безгласное) 6, (измьнаемое, о0оamaюmее, странное, сугубое, сугубствующее, таемое) 7,236 согласіе 223,225

согласовати I9I, I96;-сующі I9I

содьловати (вадпую снергію) I 93

сокращатиса I5; сокра́mенїе

(гласнагш/слога) I5,237, (дал-

гагш писмене на краткї) 247 COПОДчинатисА 232

сопосльдовати (гл̃у винителный $22 I$

сопраженїе 207,233; cопраженьи 207; -женны (существителнаА частицами соуза) I9I сослагателное наклоненіе II7, 232

составланіе временъ I69

сочиненіе I92,I99,220-I, 223-4, 228-32,235; сочинатиса ( существителному) I99,207,232; сочинителнь 229,232

союзъ (часть слова) I8, (писмен гласных со согласными) II; са узъ: виновныи, исполнителныи, наносителный, недоумътелный, подчинителныи, противителный, раздьлителныи/раздьлені 4, со прАгателныи/сопраженін, сослагателны I88-9I,23I-2; - общаг $\omega$, прилагателнаг спонді спрагатиса I4I,233

спракеніе (страсть реченін) 247; - глагола(I .-2., правилное, ст ропотное) I I4, II9-20 средніи: родъ (имене) 24-5,

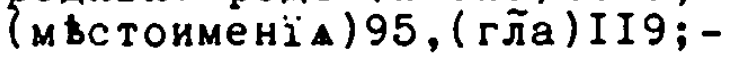
залогъ гл̃a II4, I59, I63, I66; - гл̃в I5I,I78; - слогъ (чина словомъ)237; среднее (удареніА) I2

стекатиса (два существителна) I94

степень уравненін: положителныя, превосходителный, разсу- дителны 2I;- - нарьчї II5; стіхотворныА мьры (двосложнї, треслохніи, четыресложнї ) 242-3 стисненіе (страсть реченї) 247 стиснаемын (имена) 53

стіх/вьр⿴ I0,236,243: асклипіадскіи, гликонскї,є乡аметеръ/ирш скін, іамвїскї, пентаметеръ/єлегі искї, сафінскї, фалеискї/ единнадесАтосложный, хорїамвійскї 243

стїхотвореніе 236; стіхотворнаА просшдіз 236

стихіа/писмА 236

стицати (существителнан чрезъ приложенї спрагаемыхъ) I95

страданіе II4

страдателнй: гл̃ъ 2I2,- залогъ

глагола II4-5

странное (согласное) 7,237

страсть (смысла) I89, (- знаменуเощї гли) II4, (просшдї) I2, I5;

страсти реченї: изобилї (приложеніе, усугубленіе, напракеніе, распространеніе, раздвленіе, вмьщеніе , удвоеніе , припатїе) , скудости ( ніе , стисненіе, спраженіе, изатїе, уатїе, улишенїе , строка II

стропотны гл̃ спракенї гл̃ I I4-20

сугубое (шконченіе) 39 , ( согласне) 7,237

сугубствуюшее (согласное) 7,237

супінв 2I9-20

существителный 235-6;- гл̃ ъ II4,

I55;-лное (нарицателное има)I9 схима/образъ 233

схиматісмз II8

сходити 7I; сходащї 26/кончащї сА/кончаемы на... 27

СХОЛ IOH 70

таемое (согласние) 7,237

творителны (падежь) 29-30,2I2-3, 226,23I,24I, - преимьніА I97, вины, мъры, образа, боилін , органа, WтстоАнїА, преимьніА, цена 2 I 3

творити стїи/в Врши 236

тітла I8

тонкаء (просшдіа)I5;-кое (шкон-

чаніе; изввщаніе) 4-5, I6

точка IO,I5-7

трегласное 6

тресложное (реченіе) 23

тріврахи 243

трімакрз 243 
т poxe 243

тщатель (славенскап дїалекта) $87,169,203$

таккац/варіа (имат утисненое удареніА) I2

увтореніе I4I

увытаніе 227; ув бшеніе 48

ударенї просшдї:остраА,тАжкан, шблеченнаА І2

ударанїе гласа (просшдіа) 4, I2

удвоеніе (страсть реченї ) 247

удесо слова 235

удивнал (препинанїе строчное) I6-7

указ з $4 I, 204$

указателное (качество мВсто-

именіА, мъстоименї) 94

улишеніе (страсть реченіА)

247

умалителный видъ имене 28

умАГчати,-ающеe 70 ;-сь I6;

умагченое $\left(n^{\prime}\right) 63$; умагченї

(согласнаг $\omega$ ) I5

уничижителны видъ имене 28

упредити, упрежденныи 78

уравненіе $2 \mathrm{I}$, (нарвчін) I85

уравнати I97; уравнаемое

прилагателное 20

уступити образъ правилнаг $\omega$

сочиненіА I9I

усугубленіе (согласіА)247,

(страсть реченіи) 246

усьченіе 2I,72,85; (страсть

реченін) 248

усьченое прилагателное 20

утисненіе гласа I2

учащателный гл̃з II8, I2I, I40,

I77; $y-$ видъ I22,I45; $y-$ и

производный видъ гла II6

уатї (страсть реченї) 247

Фалеискї/единнадесатослож-

ны ст ств 243,245

Эема 53, I I8

хоріамвінскін стіхъ 243,245

хром/холіамв в 244 цьлое прилагателное 20,78.193

часть слова (има, Мвстоименіе, глаголъ, причастіе ,нарьчіе, поедлогъ, союзъ, междометіе) I8.I9I; скландемаА, нескландемаА I8 частвителнаА имена $195-6,206$ частина 206, - соуза I9I; - нарвчї (желаніА, званіА, (') рицанїа, уввпаніа, указаніа) 235:- силы ВозносныА 235

черта (препинаніе строчное) I6 четырегласное 6

чинъ 72;- грамматическї 235; -

(слога) преднї, средніи, посльднї 237; - соуза: подлагателный, предлагательы , о0щі 189

чинителное има I95,2I4; ч-ое прилагателное I9,20,72

числителное I96; - имА I95,2I4;

- прилагателное I9,20,72,90

число (имене): сдинственное, двоЙтвенное, мнохественное $2 I$, (мъстоименіА) 94-5, (глегола) II 6

чистыи (слогъ двовременный I4, слогъ естествомъ долгї (3); чистое оконченіе гл̃ I20, I39, I72; чистое (a) 34,37

членъ/арэ ронъ/различіе 203

mестомврный стіхъ/сқаметеръ 243

јазыкъ/діалектъ 236

јазыческї видъ имене 28; јазы ческое прилагателное I9-20

\section{VBRZBICHNIS}

der identifizierten Zitate aus der Bibel von Ostrin (OS)

Genesis - Быт.: I, I (искони 207); 3,I9 (землА 23I); I9,24 (0дожди 22I); 49,8 (Іудо 2I2)

Bxodus - Ис.: 20, I2 ( чти 2I0)

Psalter - $\Psi_{л} .: I, I-2$ (б

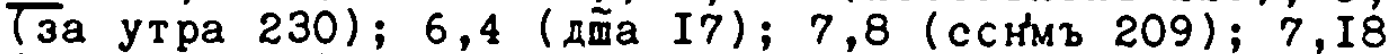

(воспою I94); I0,6 (одождить 222); IR 5 (в) - 
I8,7 (от начатка 228); 25,6 (оо'иду 2I8); 26,2 (внегда 2I8); 26, I0 (отень 208); 28,7 (глас' I94); 30,3 (буди ми 2I8); 32,6 (словесемъ 2I3); 33, I4 (уде ржи 2I8, 232); 50,5 (грьхъ мои 229); 50,I5 (научю 2I2); 54,I3 (аме бы 232); 54,23 (возверзи 229); 54,24 (азъ же 220); 6I,IO (лживи 2I9); 62,I6 (От тука 2I3); 63,5 (о имени 230 ); 63, I I (возвеселитса 230); 66,2-3 (бйе ущедри $2 I 9) ; 68,4$ (зовы 22I); 68, I3 (о мнв 229); 76, I4 (кто

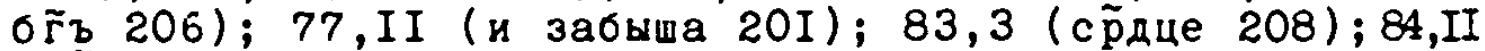
(мілеть 208); 88,50-I (где суть 20I); 96,5 (горы I94); IOC, 6 (очи 232); IO0,8 (во утріе 232); IOI,3 (во н' же 202); I04,30 (воскипь 2I3); II7,8 (бл̃го I97); II7,22 (камень 200); II8,I2 (научи 2I2); II8,73 (руць 207); II9, I (ко ге̃ду 228); I2I,2 (столын 220); I4I, I8 (изведи 228)

suruche jalomos - Пp.: I,7 (начало I94); 9,8 (обличи 2II); I6,24 (сотове 208); I9, I (луче I9I); 28,6 (лучше I92)

Bkkiesiastej - Ekkл.: 7,4 (ceprue I94)

desus Sirach - Cp.: o,I5 (другy I93); 6,I6 (другъ I9I); II, I (премудрость 205); I3,2 (бремене 205); I3,I7 (кам община 206); I3, I8 (кін миръ 206)

Jesaia - Ic.: 2,3 (от Сіона 2I5); 40,I2 (плдїю 2I3)

Matträus - MO.: I,I (книга I94); 4,IO (иди 230); 6, IO (да пріमдств 23I; да будетъ 226); 6,2I (иде же 226); 8,34 (мо лаху 23I); 8,29 (что намъ 200); 10,34 (не приндоох 2I9); II,7 (что исходисте 2I9); II,I3 (вси пророци 228); I2,28 ( 233 о д̈сь 2I4); I3, 3І (уподоби 2I2); I4, I7 (дадВте 2I7; не имамы 2I4); I4,20 (взаша 2I4); I4,28 (по вели ми 230); I9,2I (аще хощеши 207,232; гради 230); I9,30 (мнози I93); 20,28 (сйъ чл̃вчь 2I9); 22,37 (возлюбиши 2I3); 24,3 (рии I7); 24,2І (будетв 227); 25,28 (дадыте 2I4); 26,2I (єдинъ I96)

Markus - Mp.: I,I (зачало I94); 6,4I (приемъ 2I4); 6,44 (баше 2I4); 9,30 (идаше 2I5); IO,I2 (аще жена 205); II, I4 (да не к'тому 227); I9,30 (мнози I93)

Lukas - $\Omega_{K} .: 2,35$ (и тебе 200,235); 5, I (да быша 217); 4,42 (держаху ) 2I7); 5,50 (об' нощь 230); 8,35 (при ногу 229); I0,42 (Марі^ 200); I8, IO (чл̃ка два 207); I9, IO (прияде 2I9); 2I,33 (нбо и землА 227); 23,43 (днесь 229); 24,I3 (идота I 96 ); 24, I 4 (Лука...и та 207); 24,29 (вниде 2І8)

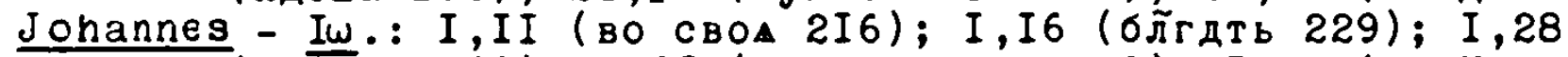
(об'о нъ 230); I,33 (над него же 229); I,47 (от Haзapeта 229); 2,4 (что мнв 200); 2,22 (и ввроваша 202);3,16 (сице 205); 5,30 (не могу 205); 8,23 (вы от 205); 9,2-3 (кто согрьши I99); II,6 (єгда же 202); II,I9 (мнози 205); II,22 (всакъ 204); I4,2 (иду 2I9); I7,2 (никто жe I96); I8, I (изыйде 20I); I8,34 (от тебе 200); 20 2I (іако же пссла мА 226)

Apostelgeschichte - Iв.: I, I (nepвoe 20I); I,6 (го̃ди I7); I, I2 (тогда I7); I,I5-6 (и во дни I7); 2,2 (бысть 220$) ; 6,3$ (усмотрыте 2I4); 7,I7 (єгда же 202); 7,49 (побо 2I0); I0,4 (молитвы 229)

Paulus: Römer-B. - Pим.: I,32 (-ако иже 203); 4 , I2 (и отцу 204); 4,I6 (не еже 204); 5,I4 (Адамлим' 2I3); 8, I (иже не по

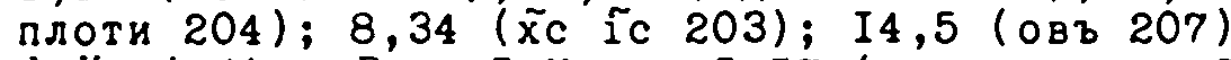
1.Korinther-B. - I.Kop.: I,I7 (не посла м4 2I9); 6, I9 (телеса 202); I0, І (отци ваши 229); I0,25 (все еже 204); 
II, 2I (OBb 207)

$-270-$

2.Korinthar-B. - 2.Kop.: 4,I6 (ame и 205)

Gal:ster-B. - Гал.: 3,13 (кровію 2I3)

Bpheser-B. - Eф.: 4,5 (единз бгв 2I4)

Philivier-B. $=\Phi_{1 \pi}: 2,6$ (иже во образв 2I8); 2,13

(6orb ectb 2I8)

Kolosser-B. - Кол.: 3,2 (горнаA 204)

I.Timothous-B. - I.TiM.: 3,2 (nодобаетв I93); 4,10

Johannes-Offenbarung - Ank.: I, I2-3 (0бpam'cs 2I4); I,20

(седмь сввтилники $2 I 4$ ) 
Vorwort

Грамматіки славенскин правилное синтагма

Учителемъ школным авторъ: Д:С: И Т:З:З. [I-3]

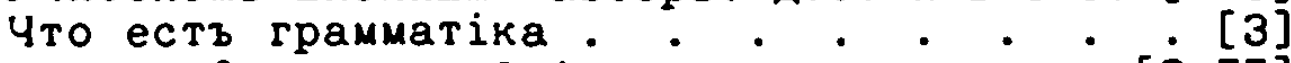

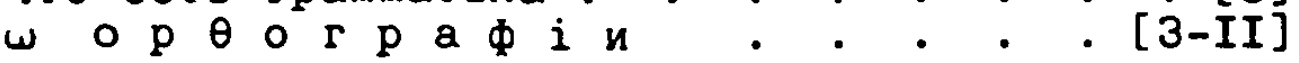

$\omega$ писмени или $\omega$ естествь писменъ; $\omega$ гласныхз [4]; $\omega$ двогласныхъ [5]; $\omega$ согласныхъ; $\omega$ первомъ согласныхъ раздыленіи [6]; $\omega$ второмъ согласныхз раздыленіи [7] увьщеніс [8]; Правила орөографіи а.e [I0], в.е, э.е, I.e, e.e, §.e [II]

$\omega \pi \mathrm{p} \circ \mathrm{c} \omega \mathrm{\omega}$ i $и$. . . . . . [I2-I6]

$\omega$ числь просшдіА; $\omega$ раздьленіи просшдіА; $\omega$ оудареніи; $\omega$ мъсть о६іА или острыа; увьщеніе [I2]; правило слога кончаемагш; правило слога прекончаемагш; увьщеніе; $\omega$ мьсть варіА или тажкиА [IЗ]; $\omega$ мбсть періспшмены или шблеченыа; правило слога прекончаемагш; правило слога кончаемагш; увьщеніА [I4]; $\omega$ времени; $\omega$ дусь; $\omega$ мьсть ४іли и дасіи, сиречь густьл и тонкиа; увъщеніе [I5] $\omega$ страсти [I5]; $\omega$ мьсть ерика и паерка; $\omega$ мьсть слит-

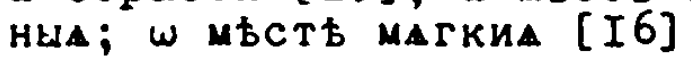

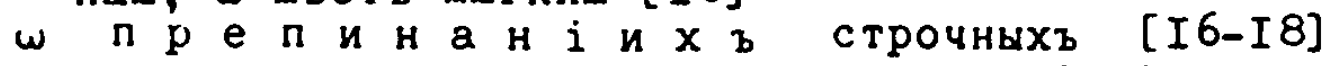

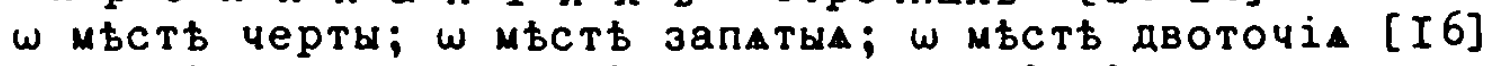

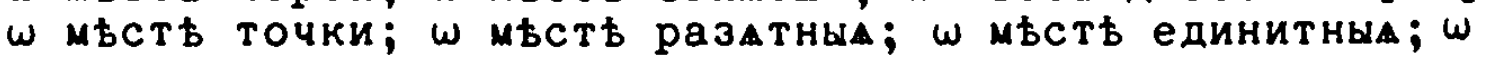

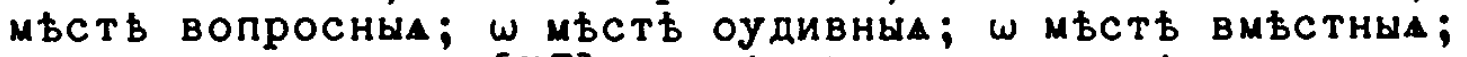
$\omega$ мьсть штложныА [I7]; $\omega$ тітль и $\omega$ словотітль и $\omega$ под ними пишемыхз [I 8]

$\omega$ слозь; $\omega$ реченіи; $\omega$ словь . . . . . [I8]

$\omega$ e т $\nu \mu \circ \pi \circ \Gamma i$ и . . . . [I8-I90]

ш осми частехъ слова; оувьщеніе; раздьленіе частій слова [I8]

$\omega$ и $е$ е н и [19-93]

раздьленіе имене; раздьленіе имене нарицателнагш; а.e прилагателнагш раздьленіе [I9]; В.е прилагателнагш раздьленіе; Ү.e прилагателнагш раздьленіе; $\omega$ посльдующихъ имени [20]; ш оуравненіи; кал имена оуравнаютса; $\omega$ степенехъ оуравненім; оувьщеніе; раздьленіе оуравненіА [2I]; неправилнагш оуравненім имена; $\omega$ состаленіи правилных оуравненій: правило аз изтіе. правило в. [22]; изатіе ‡., В.; правило Р.; оувьщеніе [23];

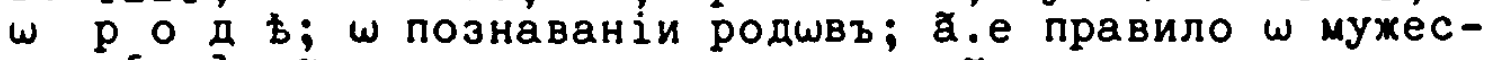
ких [24]; в.е правило $\omega$ женскихз; Ү.е правило $\omega$ средних; оувьщеніе; д.е правило $ш$ общихз; ё.е правило $\omega$ всаких [25]; э.е правило ш недоумьнних; з.е правило $\omega$ преобщих; $и . е$ правило $\omega$ прилагателных; $\omega$ правилехъ

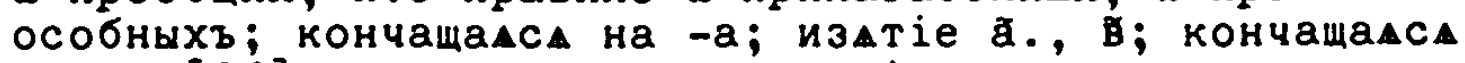
на -А $[26]$; кончамалса на -аА, -іА, -уА, -ым, на -е и -о, на -и и -ы, на -іа, на -ее, -іе и -ое, на -ъ, на -ь,

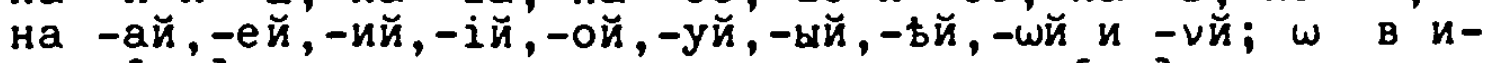
д $b[27] ; \omega$ видехъ производныхъ именъ [28]; $\omega$ ч и с$\pi$ ь; $\omega$ начертаніи; $\omega$ п а де $夫$ и [29]; $\omega$ ск $л$ о$\mathrm{H}$ e $\mathrm{H}$ i $\mathrm{H}$ [30]

a.e склоненіе; парадигмата - мужеское: Iшна, женское: дъва [30], общее: воевода [3I]; увьщеніе ӑ.: аввас или авва, Артеміс или Артеміда; увьщеніе б.: на-га: 
влага [32], на -ка: рука [33], на -ха: сноха; изатіе; на-жа: мрежа [34]; на -ша: юноша [35]; на -ца: піанина, на -ща: шбраща [36]; на-а чистое мужеских: xаріа, женских: ладіа [37], общее: судіа [38]; парадигма на -и: самараныни; сугубое шконченіе имуших женских на -А и на -и: стына или стыни [39]; греческих на -и: імармени; $ш$ етероклітехъ или аномалех" [40]: етерокліта द. Гш склоненіА [4I]

в.е склоненіе: парадигмата на -ъ: мужеское вешій шдшевленыхъ: клевреть [4I], вещій бездушныхъ: юеремъ; общее вещи бдшевленным: воинъ [42], вслкое вещи шд̈шевленныа: юродъ; среднее на -о: древо [43]; увьшеніе $а$. увђщеніе;на -гъ: другъ [44], на-къ: пророкъ, на -хъ: грбхз [45]; изатіе; парадигма вещи шдшевленым: отецъ [46], вещи бездшныл: чванецъ; среднее на -е: сердие [47]; увъщеніе а., в., Ү.: сяз $[48]$, жрецъ; парадигмата среднихъ на-А: отроча [49], на -ма: има [50], на -со: словесо или слово [5I]; увьщеніе а., в.: римланинъ; увьщеніе $\omega$ именехъ греческихъ и латінскихъ по сегш склоненім правилшм скландемых, а. [52], в.: Орестъ [53], . : Biac [54], А.: вараөронъ [55]; етерокліта в.гш склоненіА: домъ, братв [56]; увьщеніе: другъ друra $[57]$

Ү.е склоненіе; парадигмата: заповьдь [58]; увьщеніе: матерь или мати; $\omega$ именехъ греческихъ в сіе склоне-

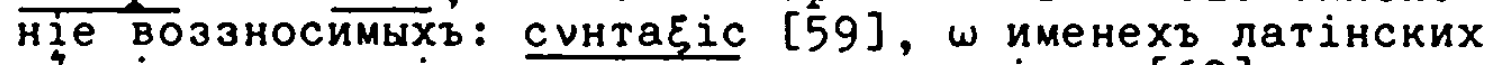
в ${ }^{4}$ cie склоненіе возносимыхъ: avторітас [60]; етерокліта; собирателных парадигма: были или быліе [6I]

д. е склоненіе: парадигмата на -ь: мужеское вещій wдшевленных [6I]: пастырь; веши бездшныа мужеское: матежь [62], обиее: свьдитель [63]; на -ай: ходотай; на -ей и -еv шт греческих: іерей [64]; на-ій и -ий: мравій [65]; увьщеніе; на -ой и -шй шт греческихъ: зной; на -уй: крагуй [66], на -ьй: любодьй [67], на -ла: древодьла; среднее на -іе: знаменіе [68]; увьщеніе $\omega$ множественномъ среднихъ сказателномъ; $\omega$ греческихъ среднихъ на lоv и єгоу : коіновіон [69];

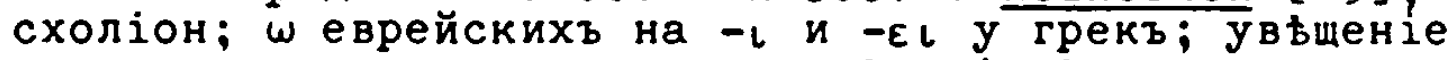
$\omega$ звателномъ единственномъ; увьшеніе $а . \omega$ раствораемыхъ: врачь [70]; увьшеніе в.; етерокліта: гटдв [7I]; собирателныхъ в" множественномъ числь: камеHie $[72]$

е.е склоненіе - прилагателныхъ; $а . \Gamma \omega$ чина мужескихъ на -ый и чрез усьченіе на -ъ: стьй или стъ [72], женских на -ам и -а: стам или ста, среднихъ на -ое и -о: стое или сто [73]; на -гій: блгій или бйъ $[74]$, блган или блга, бйгое или блго [75], на-щій и -ій чистое: нищій или нищъ, нищал или нища [76], нищее или нище [77]; увьщеніе व.; блгогласіА дьла гласное в" усьчемыхъ приемлющихъ: увьщеніе в.; В.гш чина - отчеименных или притажателныхъ на -ій и -ъ: сЯовній или сЯовень [78], на -АА и -А: СЯовнАА или Сновна, на -ее и -е: Сค̆овнее или сяовне [79], божій [80], божіA, божіe [8I], притажателныхъ на -инь и чрез усьченіе на -вль: Варнавин или Варнавль, на -ина и -влА: Варнавина или Варнавла [82], на -ино и -вле: Варнавино или Варнавле [83], притАжателныхъ на -овъ и -вль 
или Павль. на -ова и -вла: Павлова или Павла [84], на -ово и -вле: Павлово или Павле; ґ.го чина - отечествныхз и азыческихъ на-скій и -скъ: [85] ршссійскій или ршссійскъ, на -скал и -ска: ршссійскал или ршссійска [86], на -ское и -ско: ршссійское или ршссіиско; увъменіе; парадигма нарицателныхъ женскихъ прилагателнымъ женскимъ подобныхъ: вселеннаА [87]; етерокліта: весз, вс4, все, обой [88], обоA, oбoе, четверо [89];

бскландніи имен " числителных: единъ, два, тріе; едина [90], двь, три; едино, два, три; четври, пать, шесть [9I], седмь, осмь, девАть, десАть, единнадесАт, сто , двьсть, триста-деватсшт; тисаша [92]; увьшеніе [93]

$\omega$ м

$\omega$ видь; $\omega$ качествь или знаменованіи; указателнаА мьстоименіА, возносителнаА, возвратителное [94], вопросителнаА, притажателнаА; $\omega$ родь, $\omega$ числь, $\omega$ начертаніи,

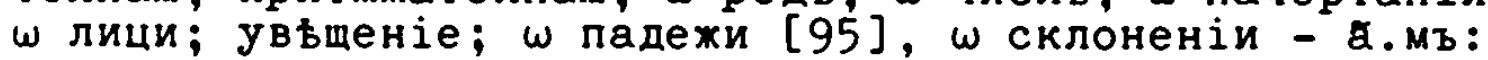

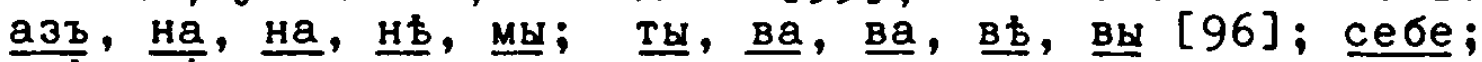
увъщеніе;

в.е склоненіе: самъ, сама [97], само; овъ [98], ова, Ово; онъ [99], она, оно [IOO],

Ү्e cклоненіе: Кто, पто или чесо, той, тал [IOI], тое [ IO2],

д.e склоненіе: сей или сій [IO2], ciA, cie; мой [IO3] MOA, MOe [IO4], TBOЙ, TBOA, TBOе [IO5], СBOЙ, СBOA, CBO-

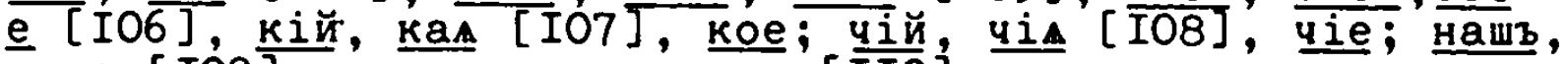
наша [IO9], наше; вашъ, ваша [IIO], ваше; erw, ихз

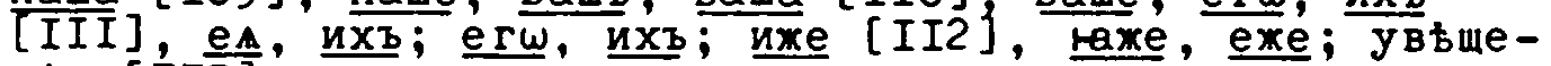
Hie [IIJ]

w $\Gamma \pi$ a $r \circ \pi$ b [II4-76]

a.e гла личнагш раздьленіе; в.е гла личнагш раздьленіе [II4], $\omega$ посльдующихъ глаголу, $\omega$ залозь, различіе залшгъ [II5], $\omega$ начертаніи, $\omega$ видь, $\omega$ числь; увьменіе [II6], $\omega$ лици; увьщеніе; $\omega$ наклоненіи, $\omega$ времени [II7] $\omega$ составленіи временъ, схиматісмз гй совершенныхъ и учащателных, - ГЛз сложенныхъ [II8], $\omega$ родь, $\omega$ познаваніи ршдъ гла; увъщеніе; $\omega$ спраженіи, раздьленіе спраженіА [II9], $\omega$ шконченіихъ а.го склоненіА, - в.гш склоненіА; увъщеніе а. [I20], - в.; парадигма а. гш склоненіА: чту, чтохъ; увьщеніе [I2I], читаю, читах, читаaх, прочтохъ, прочту; увьменіе [I22]; чель есмь, читаль есмь, читааль есмь, прочель есмь; наклоненіА повелителнагw: чти ты, читай, прочти; наклоненіА молителнагш: чти ты $[I 23]$, читай ты, прочти ты; наклоненіА сослагателнагw: aще бымь чель, aщe быхъ чель, aще бымъ читаль [I24]. ame бьхв читаль, ame быхъ читааль, ame быхз прочель, аще бымз прочель; наклоненім подчинителнагw: да 4ту, да быхъ чель [I25], да читаю, да быхз читаль, да быхъ читааль, да быхъ прочель, да прочту [I26]; наклоненіА неопредбленнагш: чести, читати, читаати, прочести; увьшеніе; $\omega$ припрагаемыхъ сопраженіем; увъщеніе $\omega$ дъепричастіихъ и причастодьтіихъ; причастіА залога дъйствителнагш: чтый или чтущій, чтей или четшій [I27], читалй или читающі й, читавй̆, читаавый, прочтей или прочетшій, прочтущій; увъщеніе; дъе-

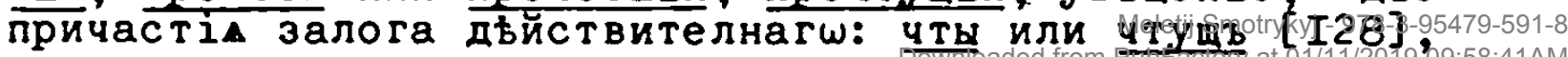


четъ или четшъ, читаА или читающъ, читавъ или читавшъ, читаавъ или читаавшъ, прочетъ или прочетшъ, прочтущъ; залога страдателнагш наклоненј а из Авителнагш: [I29] чтусА или чтом" бываю, чтохъса или чтенъ есмь или быхъ, читаюса или читаемъ бываю, читахса [IЗО] или читанв есмь или бшх, читаахса или читанъ бывахв, прочтохса или прочтенъ есмь или быхз, прочтусА [IЗI] или прочтенъ буду; наклоненін повелителнагш: чтисА ты, читайса ты, прочтисл ты; наклоненіА молителнагш: итисА ты, читайсА ты [IЗ2], прочтиса ты; наклоненіА сослагателнагш: aще бимъ челса, аще быхъ чтенъ былъ, аще бымъ читалса; аще

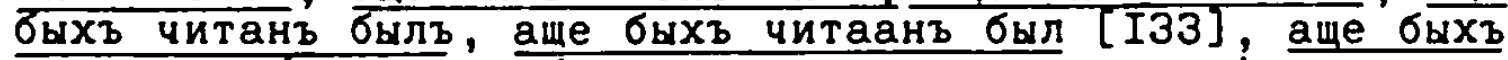
прочтенв быль, аще бымъ прочелса; наклоненім подчинителнагш: да чтусА, да быхв чтенъ быль, да читаюса [I34], да бихв читанъ былъ, да быхв 4итаанъ былъ, да быхъ прочтенв быль, да прочтуса; наклоненім неопредьленнагш: честиса или чтому быти, честиса или чтену быти, читатиса или читаему бьвати, читатиса или читану бывати, читатиса или читаану бывати, прочестиса или прочтену быти, прочестиса или прочтому быти; причастіА залога страдателнагш: [IЗ5] чтийса или чтущійсА, чтейсА или четшійсА, читаАйсА или читающійсА, читавыйсА или читаный, читаавыйса или читааный, прочтейса или прочетшійса, прочтущійса или прочтомый [डЗб]; дБепричастіА залога страдателнагш: чтыса или чтущ"сА или чтом, четса или чтенъ, читаАсА или читающзсА или читаемъ, читав СА или читанъ [I37], читавв"сА или читаанъ, прочетсА или прочтенъ, прочтущ" са или прочтом"; увьщеніе; [I38] причастодьтіе: читателенъ; $\omega$ составланіи шбоегш спраженіа временъ; преходащее - на -охъ, на -ахъ; $\omega$ начинателных гль преходащем [I39]; $\omega$ прешедшемъ, $\omega$ будущемъ; изатіе; $\omega$ подлехащихъ измьненію склоненім сег $\omega$ начертателныхъ согласныхъ; $\omega$ повелителномъ и молителном" неправилнь кончимомз [I40]

парадигма в. г $\omega$ спраженіА залога дъйствителнаг $\omega$, наклоненіА изъавителнагш: творю, творих"; увьщеніе; твораю, творАХъ, творАахъ, Сотворю, $\overline{\text { сотворих }}$ [I4I], наклоненіА повелителнагш: твори ты, творАй ты, сотвори ты; наклоненіА молителнагш: твори ти, творАй ТИ, Сотвори ты; наклоненіа сослагателнагш: аще бымъ твориль [I42], аще быхъ твориль, аще бымъ твораль, аще быхъ твораль, аще быхъ творАаль, аще быхъ сотвориль, аще бымз сотвориль: наклоненіА подчинителнаг творилз [I43], да творАю, да быхз творАль, да быхз творааль, да сотворю, да быхъ сотвориль; наклоненіА неопредБленнагш: творити, творАти, творАати, сотворити; причастіА залога дБйствителнагш: творАй или творАщій, творей или творшій [I44], творивый, ТворААй или творАющій творАвый, творАавый, СотворАщій, Сотворей или Сотворшій; дъепричастіА залога дьйствителнагш: творА или творАщъ, творь, творивъ [I45], творАA, творАВ

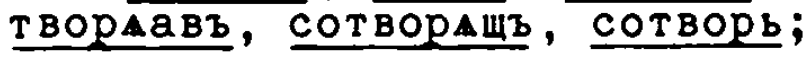

залога страдателнаг сА или творимъ бываю, творихъсА или творенъ есмь или

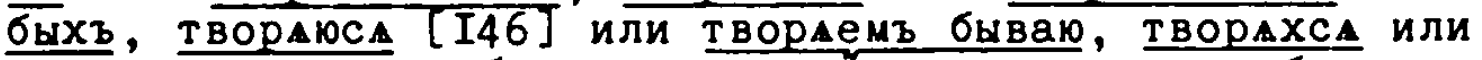
ТворАнъ есмь или быхъ, творАах СА или творАнъ бьвахъ, Сотворюса или сотворенъ буду, Сотворих СА или Сотво- 


$$
-275-
$$

СА тЫ [I47], творАйсА ты, Сотвориса тЫ; наклоненіА молителнагш: творисА ты, творАйсА ты, СотворисА тн; наклоненіА сослагателнагш: аще бымъ творил"сА, аще быхз творенъ быль [I48], аще бымъ творАлзсA, аще быхъ творАнъ былъ, аще быхъ творАанъ былъ, аще бым Сотво-

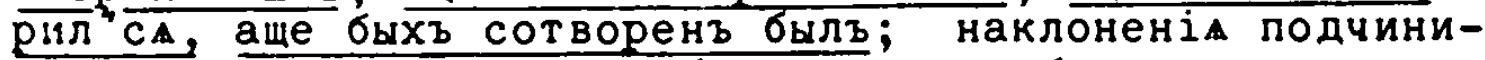
телнаг : да творюсA, да быXз творенъ былъ, да творАю-

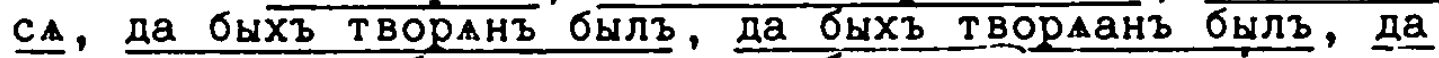
Сот ворюсA, да быхъ Сотворенъ былв; наклоненіА неопредьленнагш: творитиса или твориму быти, творитиса или творену быти [I49], творАтисА или творАему бывати, творАТиСА или ТворАну бЫвати, творАатиСА Или творАану бывати, СотворитисА или сотвориму быти, сотворитисА или сотворену быти; причастіА залога страдателнагш: творАйсА или творимый, творейсА и творивыйсА или твореньй, творААЙсА или творАемый, творАвыйсА или творАный, творАавыйсА или творАаный, СотворАщійсА или сотворимый, сотворейса или сотвореный; дьепричастіА залога страдателнагш: творАсА или творимъ, творьсА и творив"СА или творенъ [I50], творААСА и творАющъСА или

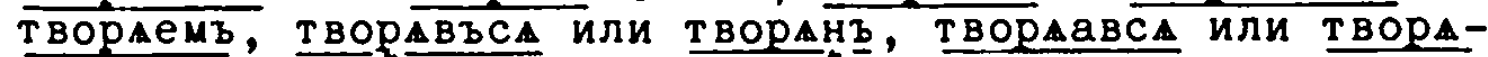
анз, СотворАщ СА или сотворим", сотворвСА или сотворенв; причастодьтіе: творително: увьщеніе; $\omega$ различіи спраганіа штложителных и общих [I5I]; w составлАніи преходАщаг $\omega$, на -ахъ, на -ьхъ, на -охъ; $\omega$ измьнаемыхъ спраженіА сегш начертателныхъ $\Gamma, *, 4, w$ [I52], $\omega$ безличныхъ; парадигма безличных а̃.гш спраженіА: подобаетв [I53], залога страдателнагш: случает "сA; парадигмa без"личныхъ в. гш спраженіА: достоитъ [I54], залога страдателна: мнит са; парадигма безличныхъ существителнымъ гломъ окончаемыхъ залога среднАГ есть [I55]; $ш$ иноскланаемыхз стропот"ныхъ: есмь [I56],

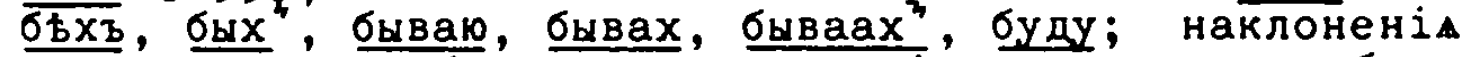
повелителнагш: буди ты; наклонені молителнагш: буди ты [I57]; наклоненіА сослагателнагw: аще бымз былз, аще бых былъ; наклоненіА подчинителнагш: да есмь, да быхз быль, да буду; наклоненіА неопредьленнагш: быти; причастіА: сый или сущій, бывый или бывшій [I58], будущій; дьепричастіА: сы или будА или сущъ дущ; कтрицателный: нбсмь;

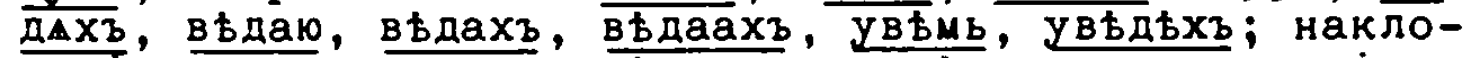
неніА повелителнагш: вБждьты, УвБждь; наклоненіА молителнагш: Вьждь ты, УВБждb ты; наклоненіА сослагателна: аще бым вьдьл [I60], аще бых вьдьль, аще бымз увьдьлъ, аще быхъ увьдьлъ; наклоненіА подчинителнагш: да вьмb, да бых вьдьлъ, да увьмь, да быхъ увђдьлъ; наклоненіА неопредбленнагш: вђдђти, увђдъти; причастіА залога среднагш: вђдый или вђдущій или вьдай или

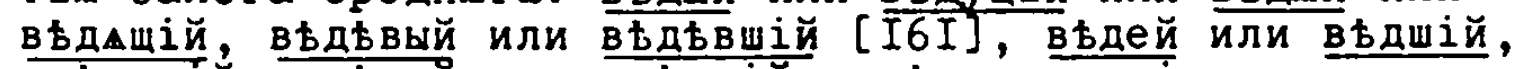
увБдущі й, увьдей или увьдшій; дьепричастіл залога дъйствителнагш: вђды или вђдущъ или вђдА или вђдащъ, вБдБвъ или вђдђвшъ, вђдь или вђдшъ, увБдущ", увБдь или

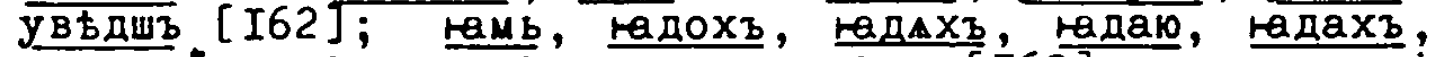
-адах", сньмь, сньдохз или сньхъ [I63]; наклоненіА повелителнагш: юаждь ты, сньждьты; наклоненіА молителнагш: паждь ты, снбждь ты; наклоненіА сослагател-

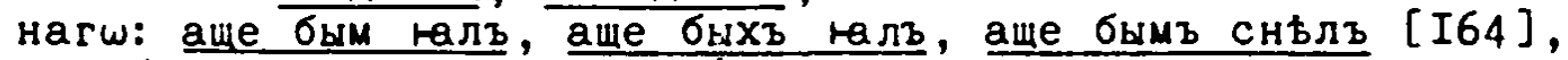
аще быхз сньль; наклоненім подчинителнагш: да тамь 
да быхъ налъ, да сньмь, да бнхъ сньлъ; наклоненіа неопредьленнаг $\omega:$ юсти, снбсти; причастіА залога среднагш: юдий или юдущій или юдай или юдащій, юдей или юдшій, снбдущій, сньдей или снђдшій [I65]; дђепричастіА залога дьйствителнагш: юды или юаущъ или

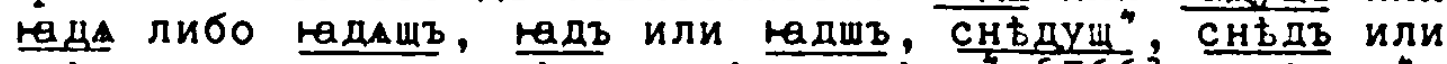

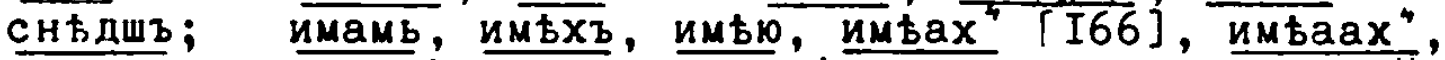
возимамь, возимьхъ; наклоненіА повелителнагб: имьй ты, возимьй ты; наклоненім молителнагш: имьй ти, Возимьй ти; наклоненіа сослагателнагш: аще бым имьл, аще быхъ имьль, аще бым возимьл", аще быхъ возимьлъ $[167]$, наклоненіА подчинителнагш: да имамь, да быхъ имьлъ, да возимамь, да быхъ возимьль; наклоненіА неопредьленнагш: имБти, возимБти; причастіА залога среднагш: имый или имущій, имввый или имьвшій, возимущій, возимђвый; дьепричастіА залога среднАгш: имы или имущъ, имьвъ или имьвшъ, возимущ", возимьвъ [I68],

$\omega$ составланіи временъ обоег $\omega$ спрахеніА; составленіе временъ обоег $\omega$ спраженіА залога дьйствителнагш наклоненіА из"Авителна: $\omega$ преходащемъ правилнь составлаемомъ, $\omega$ прешедшемъ, $\omega$ мимошедшемъ, $\omega$ непредьлномъ [I69], $\omega$ будущемъ; составленіе времен" залога дьйствителнагш наклоненіА повелителна и молителна: $\omega$ настолщем совершенна вида и учащателна, $\omega$ будущемъ, увьщеніе; составленіе времен залога дьйствителнагш наклоненіА сослагателнагш: $\omega$ всьх" наклоненіА сегш временех [I70]; составленіе времен" залога дыйствителна$\Gamma \omega$ наклоненіА подчинителнагш: $\omega$ настолщем обоемъ и $\omega$ будущемъ, $\omega$ преходищем, прешедшем и мимошедшем, $\omega$ настолщемъ и преходищемъ, увьщеніе; составленіе временъ дъепричастій залога дьйствителнагш [I7I]; составленіе временъ причастій залога дьйствителнагш: настолщагш

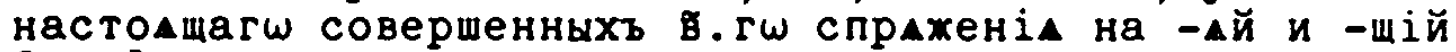
[I72], преходащагш на -шій, -ей и -вый [I73], настолщагш учащателных" на -Ай и -щі̆, прешедшагш, мимошедшаг $\omega$, непредьлиаг ставленіе причастій гла страдателнагш: настомщагш на -мый, преходащагш на -ный и -тый, прешедшагш и мимошедшаг $\omega$, непредьлнагш и будущагш [I75]; составленіе дьепричастій обоегш залога, составленіе причастодьTis [I76]

w $n \mathrm{p}$ и 4 a c $\mathrm{T}$ i $и$ [I76-85]

$\omega$ посльдующихъ причастію, $\omega$ родь причастіА, $\omega$ начертаніи причастіА [I76], $\omega$ числь, $\omega$ падежи, $\omega$ времени, $\omega$ шконченіих" времен причастіА, $\omega$ залозь [I77], увьщеніе [I78], ш склоненіи причастіА, склананім причастій дьйствителныхъ: на -Ай и -ій: біӐ̆. біющій

[I79], біющал, біющее [I80], увьщеніе, склананіА преходищих преше дших мимоше дших и непредьлных на -вый, -ей и -шій: бивый или бившій [I8I], бившаА, бившее [I82], склананіА причастій на -мый и -ный: біеный, біенаА [I83] біеное; увъщеніе а, в. [I84]

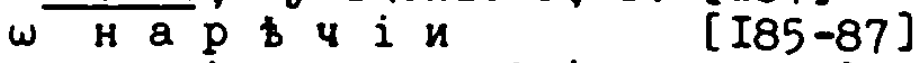

$\omega$ посльдующих нарьчію, $\omega$ виды, $\omega$ начертаніи, $\omega$ уравненіи, ш знаменованіи: времене, мвста [I85], качества, количества, числа, чина, случац, повеленіА, увъщаніА,

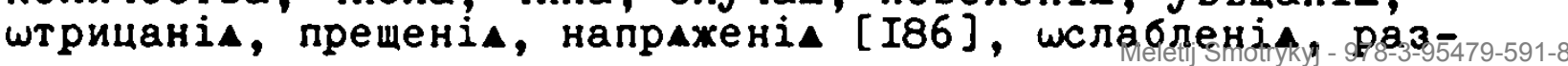


сужденіА, уподобленіА, разиства, недоумьніА, вопрошеніА, штвђщаніА, собраніА, штдьленіА, избраніА, ускореніА, указаніА; увъщеніе орөографійно [I87]

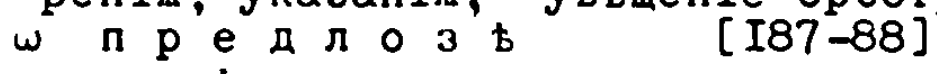

$\omega$ посльдующихъ предлогови, $\omega$ падежи предлога [I87], $\omega \mathrm{c} 0 \mathrm{y}$ b $\mathrm{b}$ [

$\omega$ посльдующихъ соузови, $\omega$ начертаніи, $\omega$ знаменованіи [I88], увьщеніе орөографійно [I89]

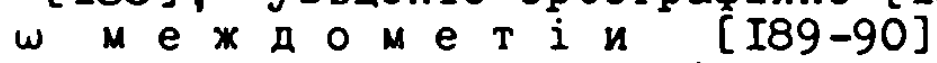

$\omega$ посльдующихъ междометію, $\omega$ начертаніи, знаменованіА междометіА, увьщеніе орөографійно [I90]

что есть синта乡іс [I9I]

w сочиненіи осми частій слова:

$\omega$ сочиненіи правилном и ме н е: глава $а$ :

w $\Pi$ р и л a $г$ a т е $л$ н м в: правило а, пристеженіА: a.e, в.е, г. [I9I], д., е., изатіе; номъ: пр-о в.; $\omega$ двою прилагателну: пр-о Ү.., пристеженіА: ฉ.e [I9́2], в.е; ш прилагателныхъ существителнь полагаемыхъ: пр-о д. ; $\omega$ прилагателныхъ усъченых ${ }^{4}$ : пр-о е., увьщеніе; ш родителном со именем: гл. в. [I93], w двою существителну: пр-о зे., пристеженіА: a.e, В.e, ₹.e [I94], изатіе; пр-о з., $\omega$ существителных ко чести и безчестію возносимыхъ: пр-о $\not ., \quad \omega$ существителныхъ стицаемых" чрез прилохеніе спрагаемыхъ: пр-о $\tilde{\text {. } ; ~ w ~}$ родителномъ со имены собраніе часть число и чинъ знаменующими: пр-о I. [I95], пристеженіА: a.e, в.е, ₹.e; w прилагателных родителному сочинаемых: пр-о $а$ i., w прилагателныхъ размыреніА: пр-о ві; $\omega$ разсудителныхз и превосходителных: пр-о Үi. [I96], пристеженіА: а.е, в.е, ґ.e, д.e, е.e, ふ.e [I97]; $\omega$ дателномъ со именемъ:гл. г., пр-о ді, пристеженіе; $\omega$ творителномъ со именемъ: гл. Д., пр-о еі., пристеженіе [I98],

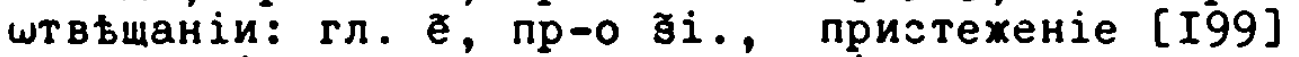

$\omega$ сочиненіи м Б с т о и м е $н$ i $A$ :

ш указателныхъ ми, ти, си: гл. а., пр-о а.e, пристеженіА: а.e [I99], в.е, Ү.e, מ.e; w возносителных:

гл. в.:ш возносителномъ и предидущем, пр-о в.е [200] пристеженіе [иже, ғахе, еже], увьщеніе:á.e [20I], в.e, пр-0 ₹.e, म.e, пристеженіе [202], увьщеніе г.e [203], w возвратителных: гл. ґ., пр-о е., пристехеніе; w вопросителных и притажателныхъ: гл. Д., пр-о 3. [205], w мьстоименіихъ существителнь употреблаемых: гл. е, пр-0 $3 ., \not{A},, \tilde{\theta} ., \mathcal{I} .[206]$

$\omega$ сочиненіи $\Gamma \pi$ a $\Gamma$ о $\pi$ a: глава $\approx .$, пр-о $а$. $\omega$ именителном со гйомъ, $\omega$ именителномъ двойственном: пр-о в., пристеженіА: ă.е, в.е, Ү.e [207], д.e, w неопредьленном в мьстш именителнагш полагаемомз: пр-о $\mathbf{r}$. $\omega$ именителномъ по гль: пр-о д., $\omega$ предидущемъ и посльдующем гіу именителном: пр-о е. [208], ш именителныхъ собирателных: пр-0 в̈; $\omega$ р $о$ д и со гломъ: гл. в., пр-о з., $\omega$ глехъ частицу не приемлющих: пр-о пр-о $\ddot{\theta} .\{209] ;$ '

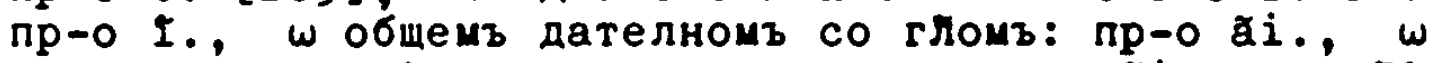
дателномъ со гломъ самостолтелном: пр-о ві., 
есмь дателному сочинаемомъ: пр-о $\mathbf{1}$.; $\omega$ в и н и-

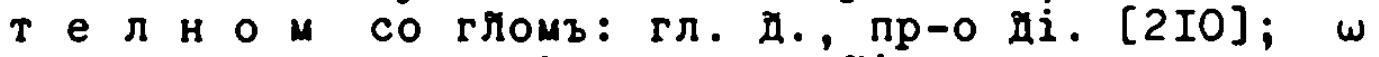
двою винителну со гломь: пр-s ё., дателномъ со глом" над винителенъ [2II]: пр-о Зі., изатіе; $\omega$ дателномъ со гломъ над винителенъ: пр-о зі.; $\omega$ з в а т е $\pi$ н $о$ м со гломъ: гл. е., пр-о

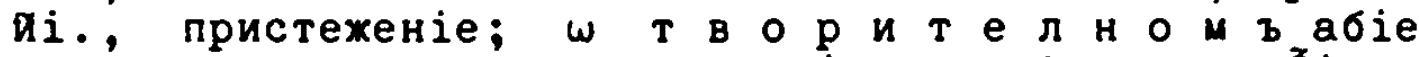
и $\omega$ гла страдателнагш сочиненіи: гл. \$., пр-о $\theta_{i}$. [2I2], пристехеніе, $\omega$ творителномъ органа вины образа цены штстолніА мьры преимьніА и шбиліА: пр-о $\tilde{R}$.

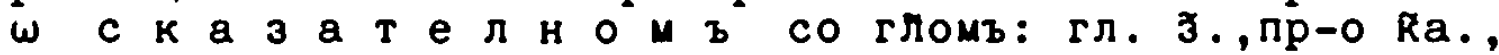
$\omega$ сказателнохъ со глом над винителенъ: гл. З., пр-о Rв. [2I3], $\omega$ сказателномъ со предлогомъ на над винителенъ: пр-о Rг.; пр-о Rд.; $\omega$ числителных и чинителныхъ именъ сочиненіи: гл. именъ градшв царствъ и проч. сочиненіи: гл. I, пр-о

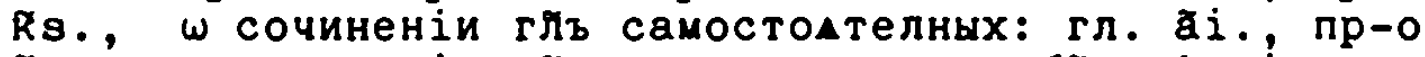

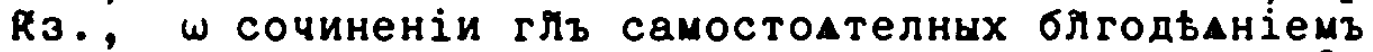
предлшгъ падеха притахущихъ: гл. ві., пр-о Ки. [2I5] w сочиненіи гль преходителных над свой им" падежъ инъ предлшгъ блгодьнніем" приемлющих: гл. ті., пр-о Rө., $\omega$ глех" дъестрадателных: гл. ді., пр-о $\omega$ сочиненіи н е о $п$ р е д ь $л$ е ны х з: гл. а., пр-о a., пристехеніА: 8.e, в.е, $\omega$ глехъ шпредъленых неопредвленым предидущих: пр-о В. [2I6], пристехеніе; $\omega$ неопредьленых подиинителнь полагаемых: пр-о భ., д., увьщеніе [2I7], $\omega$ глу имамь и хощу неопредьленым прилагаему: пр-о д., $\omega$ прилагателном со неопредъленым: гл. в., пр-о ё., ніА на мъсто: гл. Ғ., пр-о З., пристеженіе [2I9], $\omega$ прилагателномъ рода средна со неопредъленым: гл. д., пр-0 3 .

ш сочиненіи д в е $п$ р и ч а с $т$ i й: гл. а., пр-о в., в., пристехеніе, пр-о ₹., д. [220],

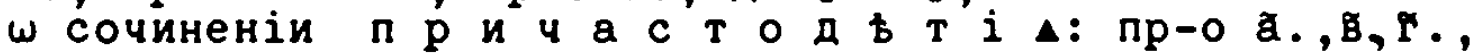
$\omega$ сочиненіи гльв $\sigma$ е 3 л и н ы $\mathbf{x}$ в дъйствителных: гл. а., пр-о a.; $\omega$ именителном со безличнымъ: гл. в. пр-о в., \$. [22i];

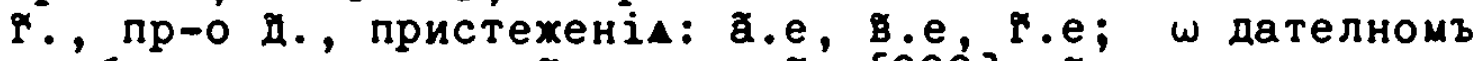
со' безличнымъ: гл. д., пр-о ё. [222], в. w сочиненіи глив $\sigma$ е $3 \pi$ и н н $x$ страдателных: гл. e., np-о Зे. ш сочиненіи п $\mathrm{p}$ и ч а с т і $\Delta$ : гл. а., пр-о а., увъщеніе, пр-о в. [223], Ү., д., е.

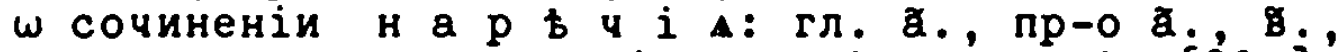
$\omega$ родителном со нарьчіи: гл. в., пр-о г. [224], д., $\omega$ разсудителныхъ и превосходителных нарьчіих: пр-о е. $\omega$ дателном со нарьчіемъ: гл. $₹$, пр-о З., ном со нарьчіемъ: гл. д., пр-о з., ш звателном со нарьчіемъ: гл. е., пр-о нарьчіемъ: гл. З., пр-о $\dot{\theta} .$, токмw точію: пр-о I.,

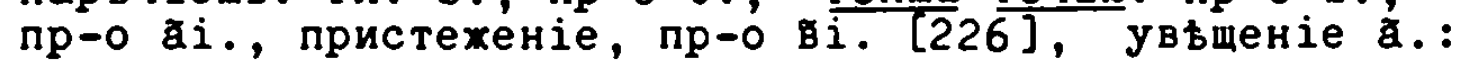
w нарьчіихъ штрицаніА никто же не, ни не, ньсть ни, не не [227], увъщеніе в.: $ш$ различіи нарьчію прежде даxе и прехде нехе.

ш сочиненіи п ре д $л$ о г a: гл. а., пр-о а. $\omega$ родителномъ со предлоги $\mathbf{y}, \underline{\omega}, \underline{\text { из" }}$, или ис, ли $\mathrm{c}^{4}$, до. 
пр-о в., $\omega$ дателномъ со предлогомъ ко или $\kappa^{*}:$ пр-о $\widetilde{I} ., \omega$ винителномъ со предлогомъ воз или вос: пр-о д. [228], $\omega$ винителномъ и творителномъ со предлоги во или в со предлогом $\frac{\text { со: }}{n p-0} \overline{\mathrm{S}}$,, с сказателном со предлогомъ при: пр-о или шбъ: пр-о $\not$ [229], $\omega$ различіи предлога по и сочиненіи егш: пр-о $\theta$., $\omega$ сочиненіи предлога за: пр-о г. [230], гл. В., пр-о а̃., ві.

ш сочиненіи с о у з а: np-о а., В., §., пристеженіе,

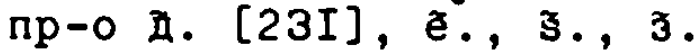

w сочиненіи ме ж д о м е т i a: np-o a. [232] пр-о В., $\mathbf{Y}$.

$\omega$ с $\vee$ н

$\omega$ просӨеси или приложеніи, $\omega$ синекдось или шб" 4 тіи,

$\omega$ синӨеси или сложеніи, $\omega$ с глличи или шсаженіи, $\omega$ проличи или предвзАтіи, $\omega$ антіптшси или мьстопадежіи, $\omega$ еналлазь или измьненіи, ш еллинісмь [234]

w ч и н

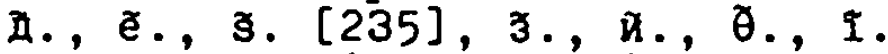

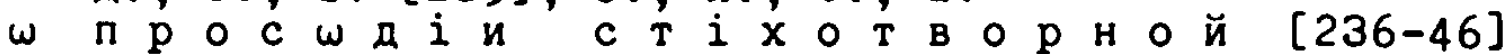
что есть просшдіa, како во познаніе стіхотвореніА прийти можемъ, $\omega$ писменехъ [236]

$\omega$ слшгъ количествь, $\omega$ раздьленіи слшгъ словомъ количества, $\omega$ раздьленіи слшгъ словом чина [237], $\omega$ познаваніи количества слшг", $\omega$ познаваемыхъ естеством", правило $\omega$ самогласныхъ естеством краткихъ е и o, пр-о $\omega$ двогласных естествомъ краткихъ ей и ой, пр-о $\omega$ самогласныхъ и двогласныхъ свойственныхъ йнесвойственныхъ естествомъ долгихъ [238], пр-о $ш$ двовременныхъ самогласныхъ $\underline{a}, \underline{i}, и \underline{v}$, пр-о $\omega$ двогласныхъ свойственныхъ

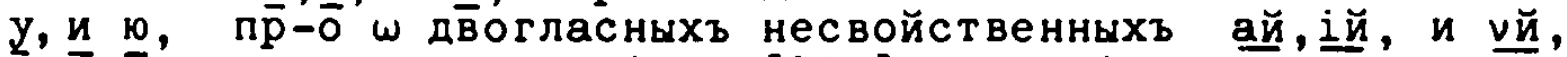
$\omega$ пооб̆наваемыхъ положеніемъ [239], изатіА: а.,в., х., д., $\omega$ познаваемыхъ наращеніемъ [240], $\omega$ приращеніих на a: пр-о, изатіе, увъщеніе, $\omega$ познаваніи шконченіемъ: пр-о, увьщеніе $\omega$ двовременну $\underline{i}, n \underline{v}:$ а.e, в.e [24I], ร.e, $\omega$ естеством долгом в" конии $a, \omega$ у увьщеніе, увьщеніе $\omega$, увьщеніе.

$\omega$ степенехъ стіхотворныа м $ы$ р,$\omega$ степени, $\omega$ числь степеней [242], двосложніи, тресложніи,

$\omega$ c $\mathrm{T}$ i c $ь$ или вьршу, колики суть стіхшвъ роди, $\omega$ родь стіха иршйскагш или шестомьрнагш, пристеженіе, [243], $\omega$ родь стіха елегійскагш или патомьрнаг $\omega, \quad и-$ ршелегійскій, $\omega$ роды стіха іамвійскагш, $\omega$ родь стіха сафійска [244], w родь стіха фалечска или единнадесатосложнаг $\omega, \omega$ роды стіха гликонска, $\omega$ роды стіха хоріамвійска асклипіадска, $\omega$ пресьченіи, $\omega$ слозь коегшждо рода посльднем [245],

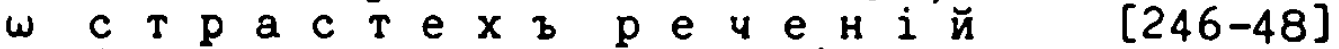

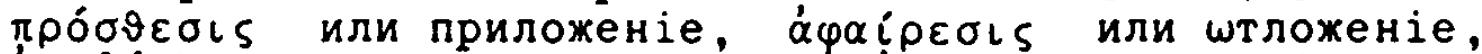
$\alpha v \alpha \delta i \pi \lambda \omega \sigma \iota s$ или усугубленіе, \&роцs или штатіе,

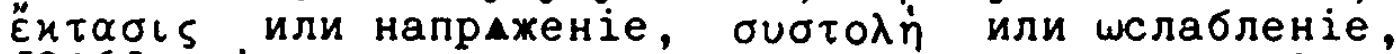

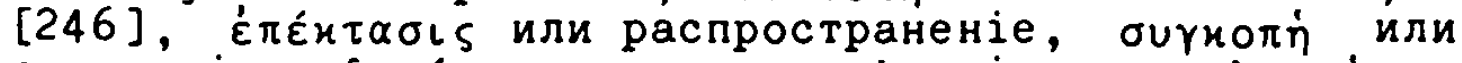

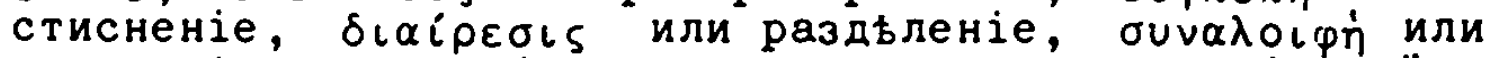

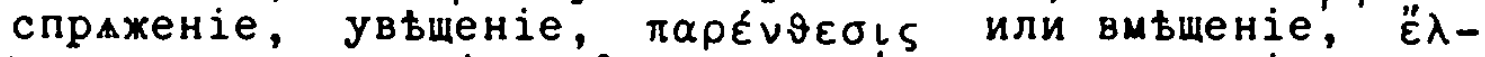
$\lambda \varepsilon \iota \psi \iota \varsigma$ или изатіе, $\delta\llcorner\pi \lambda \alpha \sigma \iota \alpha \sigma \mu о \varsigma$ или удвоеніе, $\pi \alpha \rho-$

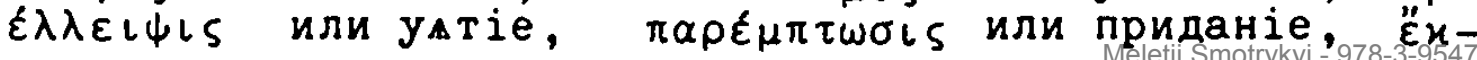




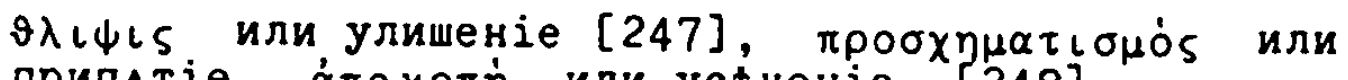

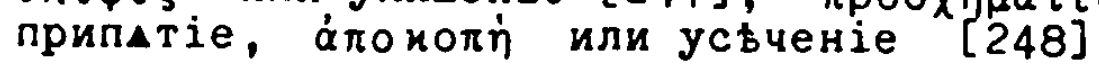

Verzcichnis der im Grammatiktext angefühten Beispiele 249-60

Verzeichnis der grammatischen und verstechnischen Terminologie bei Smotryćkyj $261-68$

Verzeichnis der identifizierten $Z$ itate aus der Bibel von Ostrih $(1,80-81)$ 


\section{SPECIMINA PHILOLOGIAE SLAVICAE}

Herausgegeben von

Olexa Horbatsch und Gerd Freidhof

1. Lavrentij 2 i 2 a $n$ i j: Hrammatika Slovenska, Wilna 1596. Herausgegeben und eingeleitet von Gerd Freidhof, Frankfurt am Main 1972; XVI, 93 S., DM 14.-

2. A d e $l \mathrm{p} h \circ \mathrm{t}$ e $\mathrm{s}$. Die erste gedruckte griechischkirchenslavische Grammatik, L'viv-Lemberg lb9l. Herausgegeben und eingeleitet von Olexa Horbatsch, Frankfurt am Main 1973; XVI, 217 S., DM 22.-

3. Gerd $F r$ i d $h$ o : Notizen und Materialien zur russistischen Linguistik. Unterlagen für die Seminararbeit, Nr. 1, Frankfurt am Main 1973; 101 S., DM 9.- (für Studenten 6.-)

4. Meletij S m o t r y ć k y j: Hrammatiki slavenskija pravilnoe syntagma, Jevje 1619. Kirchenslavische Grammatik (Erstausgabe). Herausgegeben und eingeleitet von Olexa Horbatsch, Frankfurt am Main 1974; XXII, 280 S., DM 30.- 